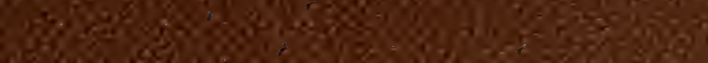

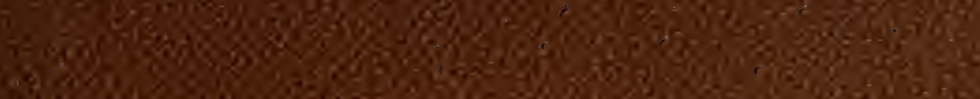

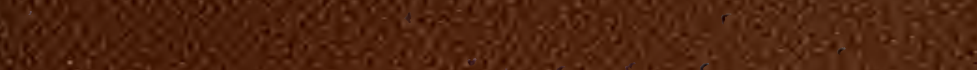

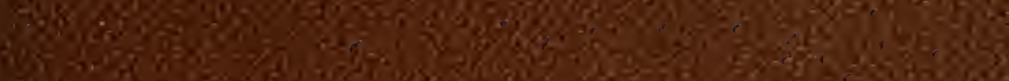
4.

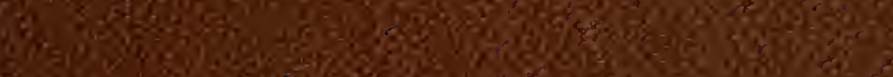
6. Q6.

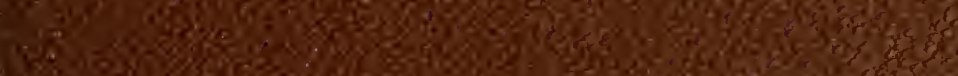
-

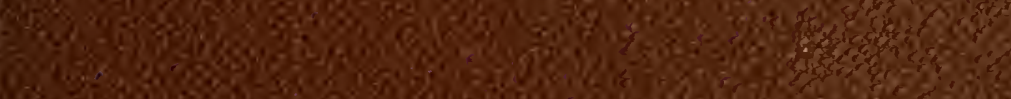

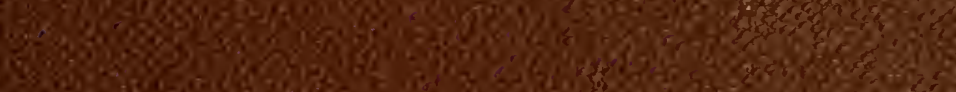
10. 18.

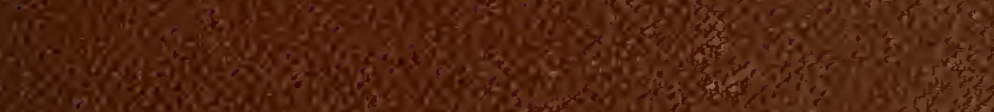

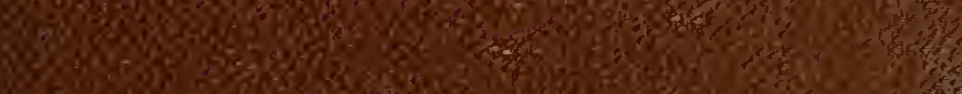

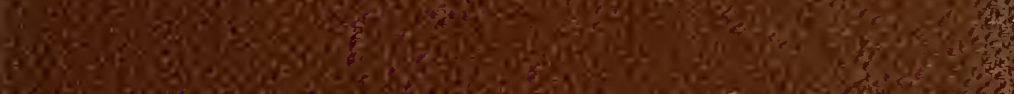

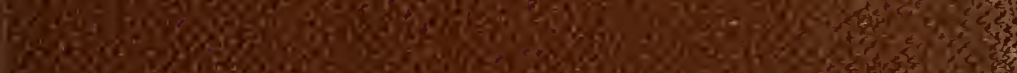

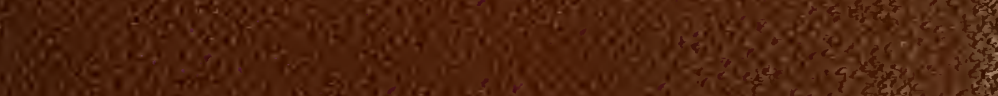

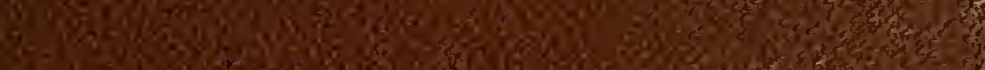

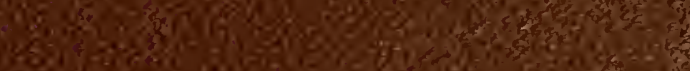

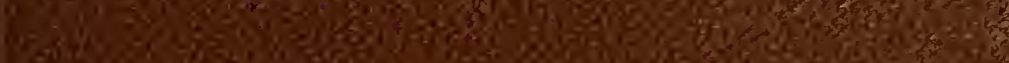
-

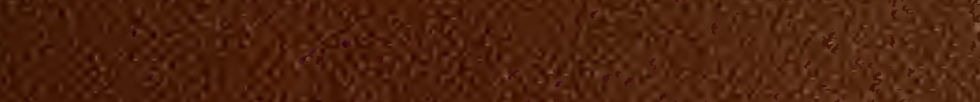

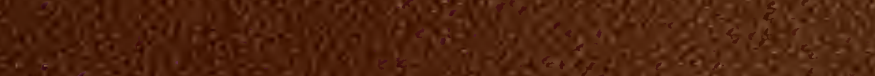

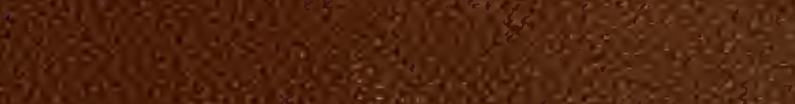

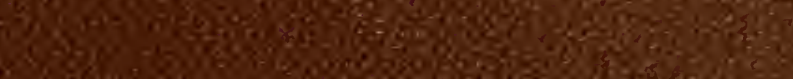

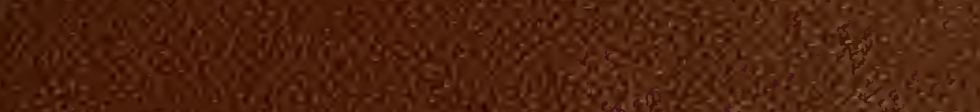

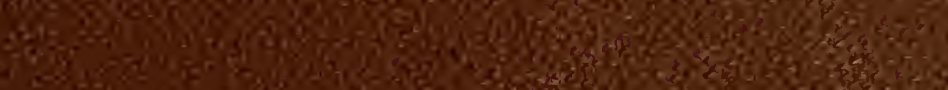

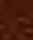

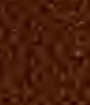

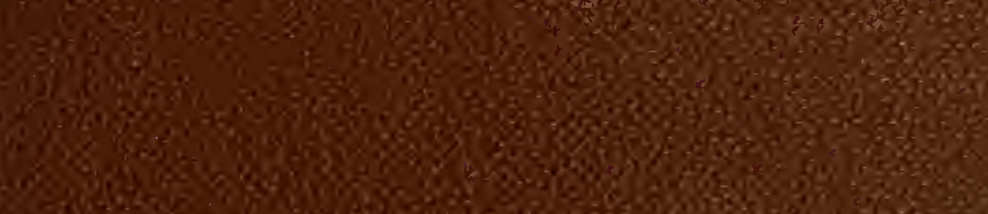

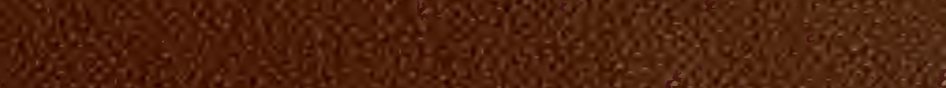
W.

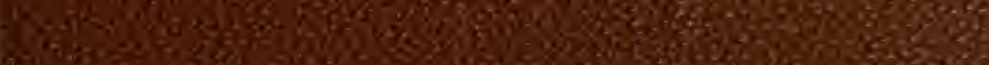

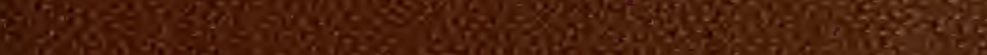
L.M. 

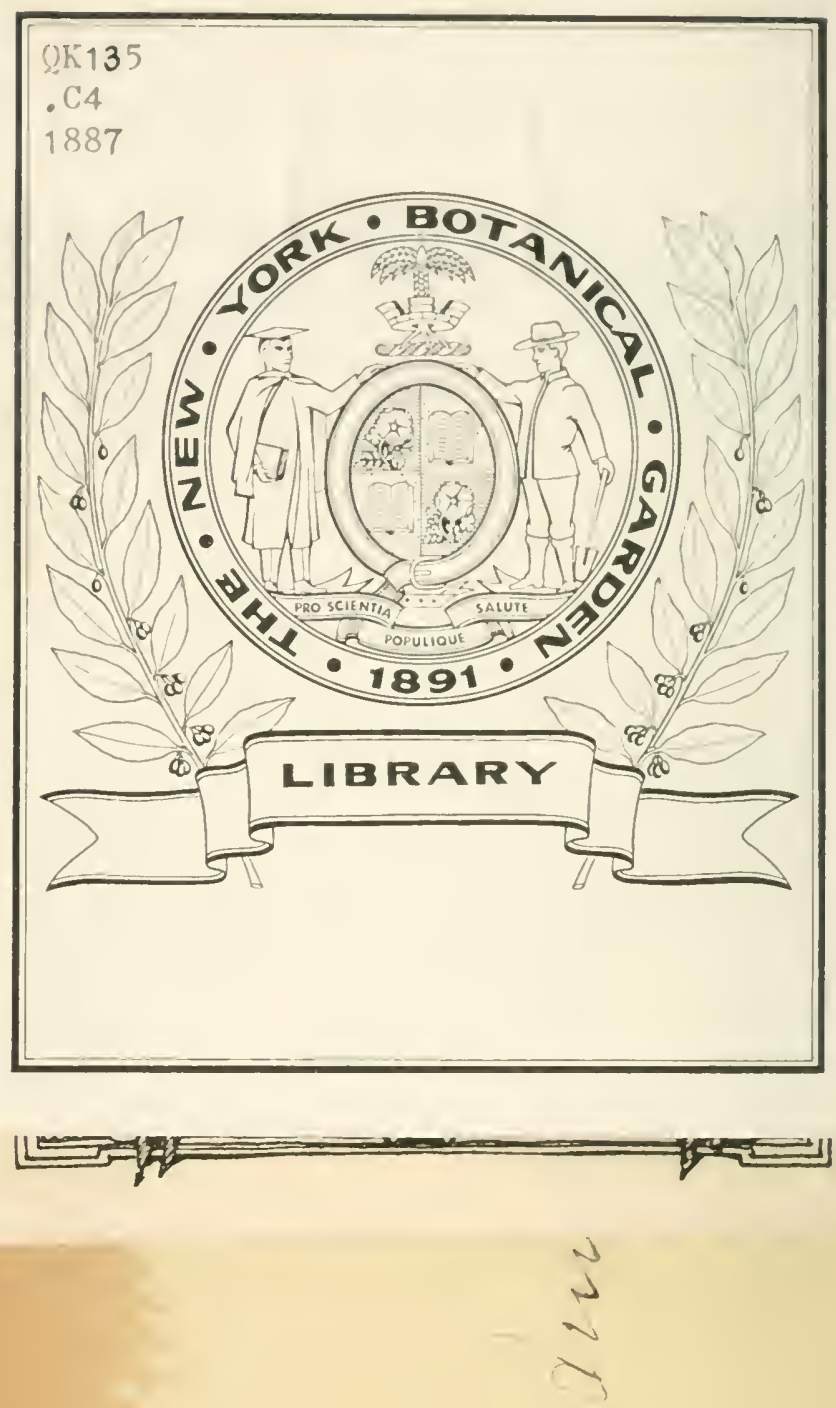



\section{F L O R A}

OF THE

SOUTHERN UNITED STATES. 



\section{F L O R A}

OF THE

\section{SOUTHERN UNITED STATES:}

CONTAINING AN ABRIDGED DESCRHPTHON OF THE

\section{FLOWERING PLANTS AND FERNS}

OF

TENNESSEE, NOR'TH AND SOUTII CAROLINA, GEORGIA, ALABAMA, MISSISSIP'PI, AND FLORIDA:

ARRANGED ACCORDING 'TO THE NATURAL SYSTEM.

BY

A. IV. CHAPMAN, M. D.

THE FERNS BY PROF. DANIEL C. EATON.

\section{LIBQARY}

Ni: W YURK

Bi: औN

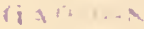

SECOND EDITION.

NEW YORK :

IVISON，BLAKEMAN，TAYLOR，\& CO. 1887. 


\section{Copyright,}

By $\Lambda$. W. Chipman, 1883. 


\section{LIHRARY \\ N'U VOOK \\ Bi' I I ICA! \\ UARDEN}

\section{PREFACE.}

WHEx the first edition of this work was issued, some portions of the country embraced within the limits assigned to it were imperfectly investigated or wholly unexplored. But the discoveries in Southern botany made during the last few years by Feay, Garber, Curtiss, and others, of tropical forms on the peninsula and keys of Florida, by Dr. Gattinger of Northern forms which extend into Tennessee and the mountains of North Carolina, and by correspondents from other States, have become so numerous that a new edition of the Southern Flora is required to embrace them.

In this edition I have concluded to incorponate these additions in the form of a Supplement to the first edition, avoiding any material alterations in it.

And now, since the different sections of all the States which are included in the limits embraced by this work have been pretty thoroughly explored, and future acquisitions will, probably, be comparatively few in number, the time seems to have arrived when the promise provisionally made in the Preface to the first edition may be at least partially fulfilled. 
It is my intention, therefore, to commence the preparation of a final edition, which shall include in their proper place all the acquisitions made to our Flora since the pulslication of the first edition, with the elanges in nomenclature introdued during that time; and I invite a continuance of the co-operation and assistance of all who are interested in the successful prosecution of the work.

Apalachiola, Flomida,

December 26, 1882 . 


\section{O N T E N T S.}

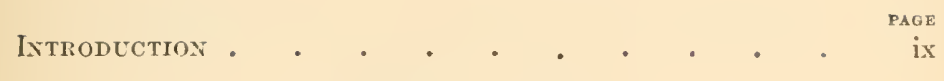

Sketch of the Elemexts of Botaxy . . . . ix

Glossary of Botamcal Terms . . . . . xvii

Abbreviations of the Names of Authors . . . xxv

SigNS USED IN THIS Work . . . . . . xxi

Directions to the Student . . . . . . xxrii

Artificial Axalysis of the Nateral Orders. . xxix

FLora. - Pilenogayoes on Flowerixg Plants . . . 1

Cryptoganous or Flowerless Plaxts . . 585

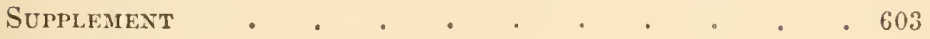

INDEX • . . . . . . . . 675

INDFX TO SUPPLEMENT • . • . . 。 • 695 



\section{N T R O D U C T I O N.}

\section{SKETCH OF THE ELEMENTS OF BOTANY.}

\section{Vegetable Tissue.}

1. Plaxts are primarily composed of minute membranous vesicles or cells, which are endowed with the power of reproduction, and through which, although elosed and destitute of visible pores or openings, the juices of the plant are readily transmittel.

2. Variously modified, these cells form the Elementary Tissues; viz. Cellular Tissue or Parenchyma, Woody Tissue or Woody Fibre, and Vuscular Tissue or Tessels and Ducts.

3. Cellular Tissue, which exists in all plants, and of which those of the lower orders are wholly composed, consists of cells aggregated together, and cohering by their eontiguous surfaces.

4. Woody Tissue is composed of slender and elongated cells, with firm and thickish walls, collected in threads or bundles.

5. Vascular Tissue is made up of larger cells, either in the form of continuous tubes, or forming sueh by the union of their extremities. In some of these, the walls are marked with dots, lines, or bands; while in others they are lined with spirally coiled fibres which are capable of being unrolled. The latter are called Spiral Vessels, and exist only in plants which bear proper flowers.

6. Of these tissues are formed the Organs of plants; viz Organs of T'egetation, consisting of the Root, Stem, and Leaves, and Organs of Reproduction, consisting of the Flower and Fruit.

\section{The Root.}

7. The Root, or Descending Axis, is that part of the plant which grows downward, eommonly penetrating the soil, from the moisture of which it imbibes nourishment. It branches indefinitely and without order, but bears no other appendages. Its ultimate branches are called Rootlets.

8. Roots which descend inmediately from the embryo are termed Primary Roots. They are called Tap-Roots, when they consist of one thick and fleshy piece; fascicled or clustered, when of several fleshy branches springing from a cominon centre; tuberous when the branches beeome greatly enlargerl and filled with starchy matter; and fibrous, when all the parts are slender and thread-like. 
9. But roots under favorable circumstances are developed from ther part: of the plunt. 'These are colleel secomlury liouts.

10. Acrial lients are those which spring from the stem or branches alove grouml. In some, as in muny Judogronous l'ants, thay proceed from the lower joints of the stem; in otlers, as the Mangroves and Fig-tress of South lilorila, they descend from the branches, and at length, penctrating the soil, form new stems in all respects similat to that of the parent tree. The tendrit-like routs of some climbing stemis are alio of this clatss.

11. Epripligtes or Air-Plents, of which the Tillaudsia and Epidendrum are examples, are those which are horne on the trunks or branches of trees, but draw their morishnent from the air.

12. I'arasites, like גir-Plants, grow on other plants; lut their roots, penetrating the substance of the supporting plant, feet upon its juices. Some, as the Mistletoc and Dorlder, fix themselves upon the trunk or branches; others, like the Bechi-drop, upon the root.

\section{The stem.}

13. The Stem, or Ascending Axis, is that part of the plant which grows upward into the air and light, bearing leaves and flowers. It exists, umler various modifientions, in all flowering plants; but in those which are said to be stemless or acaulescem, it is very short, or concealed in the ground.

14. It consists of a succession of leaf-bearing points, or Nodes, separated by naked joints, or Internodes. The growing points, which are prosected by reduced leaves in the form of scales, are called Buds. These are terminul, when they terminate the axis; axillary, when they spring from the axil of the Jeaves; that is, from the point where the upper surface of the leaf joins the stem; and adeentetious, when they are developed from any other part.

15. Simple stems grow by the developnent of the terminal bud alone; branching stems expand indefinitely from the axillary buts also. The ultimate divisjons of the branches are called brunchlets.

16. The jointerl stem of Grasses and similar plants is a Culm.

17. The thick and simple stem of the Palmetto is a Cuudex.

18. A Rhizoma, or Rootstock, is a perennial stem, commonly creeping on the ground, or beneath its surface, developing annually a lond at the apex, while the older portion decays.

19. A Tuluer is a subterranean branch, excessively thickened by the deposition of starchy matter, and furnished with minute seales, having concealed buds (eyes) in their axils.

20. $\Lambda$ Corm is a solid globular snbterranean stem, filled witl starcliy matter, with a burl at the apex and roots below.

21. A Bulb is a short subterranean stem, made up of the thickenerl hases of leares, in the form of persistent seales. It is tumicatrd or coated, when the seales are large and wrapped one within the other; and scaly, when these are sinall and imbricated. Small aerial bulbs, such as are borne in the axil of the leaves of the Tiger-Lily, and among the flowers of the Onion, are called Bullilets.

22. A Stolon is a branch which bends to the earth, strikes root, and forms a new plant. 
23. A Rumer is a thread-like prostrate branch, producing roots and a tuft of leaves at its extremity

24. Spines, or Thorns, are imperfectly developed, leafless branches, with hard tips.

25. Tendrils are the thread-like spirally coiled brauehes of weak and slender plants, by means of which they attach themselves to other and stronger oljects for support. Leaf-stalks and parts of the inflorescence are occasionally converted into tendrils.

26. Plants which die down to the ground at the close of the season, or after maturing seed, are called Herbs, or Herbaceous Plunts. Those with woody stems, lasting from year to year, when of lumble size, are called Shrubs, and when reaching an elevation of twenty feet or more, Trees.

\section{Internal Structure of Stems.}

27. The stems of Phienogamons Plants are composer of cellular tissne, woody tissue, and vessels; and upon the arrangement of the latter are founded the two divisions of Exogenous and Eudogenous Plants.

28. Fxogenous stems consist of a central column, called the Pith; an external corering, called the Bark; and a midile portion, called the Wood.

29. 'Their Pith is a mass of cellular tissue, enclosed in a thin sheath of spiral ressels, termed the Medullary. Sheath.

30. Their Wood is composed of one or more layers of woody and vaseular tissue, traversed by thin plates of cellular tissne, called the medullury rays, and annually increased, in all perenuial stems, by the addition of a new layer to the outside of that of the previons year. The new wood is called the Alburnum, or Sap-uood, and the older and harder portion, the Duramen, or Iteart-rcood.

31. The Bark, like the wood, is made up of layers. The inner bark, or Liber, is composed chiefly of woody fibre. Between it and the woorl, in the growing season, is secreted a thin mucilage, called the Cambium, in which the new layers of wood and bark are developed. Surromding the inner bark is the Green bark, consisting of cellular tissue filled with Chlorophyll, or the green matter of vegetables. Corering the whole is a thin membrane of cellular tissue, ealled the Epidermis, or Cuticle.

32. Endogenous stems exhibit no distinction of pith, wood, and bark; but are composed of threads or bundles of woody tissue, irregularly embedded in cellular tissne. They increase in diameter by the formation of new bundles, which are clicfly directed to the centre of the stem.

\section{The Leaves.}

33. Leaves are expanded appendages of the stem, developed from axillary and terminal buls. They consist of loose cellular tissue, supported by a network of woody and vascular tissue, called veins or ribs, and protected lyy the epidermis. In them the fluids received from the root, and what they imbibe from the air, through minute openings in the epidermis, called stomata, are converted into the proper food of the plant.

34. In the bud, they are folded, plaited, or coiled in varions ways. This is termed their Iernation. 
35. A complete leaf comprises the Blude, the Stall, and a pair of Stipules: lut these three parts are not always present in one leat:

36. The I3late, Limb, or Iamim, is the expanded part, and presents a great variety of forms. It is simple, when it consists of a single piree, lowever "ut or dividel; and rompenuel, when of two or more distinet pieces fleuflets), which separate ly a joint.

37. The Stalk, or Petiole, eonnects the lhade with the stem. When it is wanting, the leaf is said to he sessile. The stalk of a leaflet is called a Prtiolule.

38. The Stipules are appendagres of varions forms, placel one on eacl side at the base of the petiole. They are separate, or che united with the petiole, or with each other, when they ocrasionally form a sheath (Ochera) around the stem alove. The stipules of a leaflet are called Stipels.

39. The manner in which the veins are distributed through the leaf is called renction.

40. There are two modes of venation; viz. parallel-reined, or nerced, when several simple veins, or ribs, rmn parallel from the hase of the blade to its apex; and reticuluted, or netted-veined, when the veins divide into numerons primary and seconclary loranches (veinlets), which again unite to form a kind of network.

41. The latter node embraees both the pinnatly reined, or feather-mincd leaf, where the petiole is contimmel throngh the middle of the blade, griving off at intervals lateral veins; and the palmately veined or ribbed leaf, when it divides at the apex into three or more strong branches.

42. The manner in which leaves are divided corresponds with that of their venation.

43. A simple pimnately reined leaf becomes pimnatifid, when the incisions (sinuses) extend ahout half-way to the midrib, or contimuation of the petiole; and pinnately dicided, when they extend down to the midrib. A componnt pinnately reined leaf is, of course, pimme, with the separate leaflets arranged on each side of the eommon petiole. When this is terminated by a leaflet, the leaf is said to be odd-pinnate, or unequally pinnate, and when it is wanting, abruptly pimate.

44. So, also, the palmately veined leaf becomes palmatcly eleft or divided, when the incisions are direeted toward the hase of the blade. When the dirisions consint of separate leaflets, it becomes palmately compound.

45. Floral leaves, or those from the axils of which the flowers are developed, are called Bracts; and those which are borne on the flower-stalk, Bractlets.

\section{The FIower.}

46. A Flower consists of those parts, or organs, which are concerned in the production of seed. Like the leaf, of which its parts are a modification, it is developed from an axillary or terminal bul.

47 . The manuer in which the flowers are arranged on the stem or branches is termed the Inflorescence.

48. There are two modes of inflorescence; viz. the indefinite, or centripetal, where the flowers all arise from axillary buds, the lowest or ontermost expanding first, while the axis elongates indefinitely from the terminal bud; and the definite, or centrifugal, where the flowers arise from the terminal bud, first, of the main axis, and successively from that of the branches. 
49. When the flowers arise from the axil of the ordinary leares of the stem, they are said to be axillary; but of tener, they are disposed in a more or less obvious eluster, each arising from the axil of a greatly reduced leaf, or Bruct.

50. The stalk of a solitary flower, or of a cluster of flowers, is termed the Peduncle; or, when it proceeds from the root, a Scape; and that of each individual of a elnster is called a Pedicel. The main axis of a cluster, or that portion of the common peduncle which bears the flowers, is ealled the Rachis.

51. The indefinite infloresence includes the Spike, Ament, Spadix, Raceme Corymb, Umbel, Head, and Panicle; the definite, the Cyme and its morlifications.

52. The Spike consists of a more or less elongated rachis, with the flowers sessile, or nearly so, in the axils of the bracts.

53. The Ament, or Catkin, is the scaly deeidnons spike of the Pine and Willow.

54. The Spadix is a spike with the flowers borne on a thick and fleshy rachis. It is naked, as in the Golden-club, or enelosed in a hood, called the Spathe, as in the Indian Turnip.

55. The Raceme presents the elongated rachis of the spike, but the flowers are raised on pedicels.

56. The Corymb is a short raceme, with the lower pedicels elongated, so as to bring their flowers to the same level as the upper ones.

57. The Umbel is a modification of the raceme, but with the rachis so much contracted, that the pedicels (rays) apparently spring from a common eentre. When the umbel is compound, the partial umbets are termed Umbellets.

58. $\Lambda$ Head is an umbel with sessile flowers. The erowded bracts of this and the preceding are collectively termed the Lutolucre, and those of the umbellets, the Iniolucel.

59. When the pedicels of a raceme or corymb are transformed into branehes, either simple or snecessively diviled, the inflorescence becomes a Punicle.

60. When the further growth of the axis is arrested by a single terminal flower, and from the axils below branches are developed, each terminated by a flower, and bearing branches in the same manner, the inflorescence is said to be cymose or centrifigal. But it presents several peculiar forms, occasioned either by the imperfect development, or by the entire suppression of some of its parts. Some, as the true Cyme, are short and expanded; others are elongated, like the spike or raceme. In all, the flowers expand surcessively from the summit, downward, or from the centre, outward.

6I. The Flower consists, commonly, of one or more whorls of leaves, called the Floral Envelopes, - of which the outer one is termed the Culyx, and the inner one the Corolla, - an inner whorl of threar-like organs, called the Stamens, and one or more central organs, ealled the Pistils. These are inserted on the apex of the axis, which here takes the name of Torus, or Receptacle.

62. The Floral Envelopes are sometimes wanting; but the stamens and pistils, being the fertilizing organs, are, in all perfect flowers, always present.

63. The Calyx is composed of leaves (Sepals), usnally of a greenish eolor, which are distinet, or united by their marcins. When the floral envelopes consist of a single whorl only, it is always a ealyx. 
64. The Corolla is usually of a thimer texture than the colyx, and vnriously

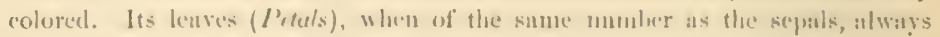
nternate with them. 'Tley are also often united lỵ their contiguous margins, ta firme u menoprtalous corulla

6.5. W'ien the calyx and corolla ure so menrly alike as not to he rembly dimtinguished, they are eollectively termed the P'rionth.

66. A flower is complete when all its parts ure present; incomplets, when the floral envelopes, or a part of them, ale wanting ; perfict, when the stanu+11s anul

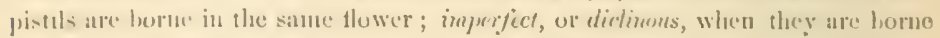
in scparate thowers; regular, when the sepuls or petals are of unifinu shepe ant size; mel irreysler, when they are mulike in shape or size.

6i. Inuperfert flowers are further distinguished inte monecions, wher these furnished with stamens (stuminute or sterile floners) and those furnished with pi-tils (pistillute or fertile flowers) are borne on the sime plant; diurious, when they are borne on separate plants; and polygrmons, when both perfect and injerfect flowers are lorne on the same or different individnals.

68. The unumer in which the parts of the floral envelopes are arranged with respeet to each other in the but is termed their. Estivation. They are valdate, whon their contignous margins meet, without overlinping; imluplicute, when these project inwardly; reduplicute, when they project ontwarclly; imbricutrel, when the margins of one overlap the adjaecnt margins of the two next within; convolute, or twistrd, when one edge of each piece covers the margin of the one next before it, and the other edge is covered lyy the margin of the one next after it; and pluited, when the parts are folded lengthwise.

\section{The Sinmens.}

69. A Stumen consists of a sac, culled the Anther, and, usually, al stalk, called the Filument, wh which it is supported.

70. They are hypogynous, when they are insurted on the receptacle; periygnons, when on the ealyx; epigynous, when on the osiry; priptulues, when un the corollis; and gynandrous, when they are united with the style. They are, al:o, often combined with each other, eitluer into one set (monadely)hous), or into two, three, or mores sets (diadelphous, triadelphons, \&c.).

71. The Anther is composed, commonly, of wo united eells, which open in rarious ways, and discharge a yellow, fertilizing powter, ealled the P'ollen. The part which connects the cells is the Comoctior.

72. It is ereft, or innate, when fixed by its base to the apex of the filanent; achuet, when fixul to the filanent by its whole length; xersutile, when fixed by the midulle to the apex of the filaments on which it turns as on a pivot; iutrorse, when it faces inwardly toward the pistils; and extrorse, when it faces outwardly toward the petals. Oecasionally, they are united into at tube (symgensious).

73. Between the stamens and the pistils is often a fleshy expansion, called the Disk:

\section{The Pistils.}

74. The Pistils oceupy the eentre of the flower. They are insirterl, singly or in a whorl, on the receptacle; or, when this is elongated or cnlarged, they cover its surface. 
75. A Pistil consists of three parts, - the Orary, the Style, and the Stigma.

76. The Ovary is the lower and hollow portion, containing the Ovules, or rudiments of seeds.

77. The Style is an extension of the ovary, commonly of its apex, which supports the stigma.

78. The Stigma is commonly the apex of the style, or, when this is wanting, of the ovary, denuled of the epidermis.

79. When the pistil is composed of a single piece, or carpel, it is simple; bnt, oftener, it is compound, consisting of two or more carpels, united by their margins, or by their sides, which then form partitions or dissepiments, that divide the pistil into as many cells as there are carpels.

80. The line next the axis, or which corresponds to the united margins of a folded leaf, is called the Ventral Suture; and that which corresponds to the midrib, the Dorsal Suture.

81. The Ventral Suture bears the orules; and the line of their attachment is called the Placenta. This is central or arile, when it occupies the centre of the pistil, and parietul, when it is borne on its walls.

82. The Ovule is connected with the placenta by a cord, called the Funiculus. It consists of a central boty, ealled the Nucleus, enclosed in two sacs, each with an opening at the apex, called the Foramen. The onter sac is termed the Primine, and the inuer one the secundine. The point where these parts unite is called the Chulaza.

83. The Ovule is orthotropous when the chalaza is next the placenta, and the apex at the opposite extremity; campylotropous, when it curves on itself, so as to bring the apex near the chalaza; amutropous, when it is inverted on its cord, to which it adheres; the true apex pointing to the placenta, white the chalaza, or true base, points in an opposite direction; and amphitropous, when it is half inverted on its cord, its axis running parallel with the placenta. The adhering portion of the cord in the last two cases is termed the Raphe.

\section{The Fruit.}

84. The Fruit is the ovary, with its contents, bronght to maturity. But during this process it sometimes undergoes important changes, either by the obliteration or abortion of some of jts cells, partitions, or ovules, or liy the formation of false partitions, or by various changes effected in its walls, or in the parts which surround them.

85. In some, the walls, or Pericurp, remain closed; in others, they open, or are dehiscent in various ways, oftener splitting regularly into separate pieces, called Valves.

86. Many terms are employed to designate the different kinds of fruit, but only the following are in general use.

87. A Follicle is a simple fruit, opcning along the ventral suture only; as the fruit of the Milkweed.

88. A Legume is a simple fruit opening at hoth sutures; as in the Pulse Family. When it is divided across into closed joints, it is a Loment.

89. A Capsule is a dry componnd fruit, opening in varions wars. When it opens at the dorsal sutures, or into the cells, the dehiscence is said to be loculicidal: 
mol septicidul, when it opens at the ventrul suture, or through the partitions. When it opens tmansersely, the upper portion falling off entire, like a lid, the dehiseence is circunseissite.

90. A silique is a slender two-valved colpsule, with two parietnl plurenta conneeted by a persistent falsc partition. $\Lambda$ short and broud silique is a silicle. These ne peculitur to the Mnstard Family.

91. $\Delta P^{\prime}$ epo is the fleshy indehiscent fruit of the Gourd Finnily, with the seeds often cmberded in the pulpy placente.

92. A Pome is the inctehiscent frut of the $\Delta$ pple or Quince tribe, where the cells are enclosed in the enlarged and He-hy tube of the calyx.

93. A Berry is an indehiscent fruit, with the secds cmbededed in soft pulp.

94. A Drupe consists of one or more hard or bony cells, estled the Putr$m e n$, covered with a fleslyy or pulyy coat, called the Surcocurp; is the Peach, Holly, \&e.

95. An Achemem is a small, dry, one-seded, indehiscent fruit, the walls of which do not adhere to the enclosed seed. When these are closely mited, it becomes a Caryopsis; or when the walls are thin and blatder-like, and open irregulatly, a Litrcle.

96. $\Lambda$ Vut is a dry, indehiseent fruit, with laard or bony walls; as the $\Lambda$ corn and Hickory-nut.

97. A Samara is a dry, indehisecnt fruit, with its walls expanded into a wing; as that of the Maple and Elm.

98. The collective fruit of the Pine is called a Cone or Strolile.

\section{The Seed.}

99. The Seed is the matured ovule, and continins the Embryo, or the rudiment of a future plant. 'The onter coat, or Integument, is called the Testa. It varies greatly in textmre, and is occusionally furnished with hairs, which either cover the entire seed, or form a tuft (C'oma) at one or both extremities.

100. The terms employed in descriling the ovule are chictly applicalle to the seel. The formen of the ovule, which is closed in the seed, becomes the $1 / \mathrm{i}$ cropyle, and is always opposite the radicle of the embryo. The scar left on the seed by the separation of the cord is the Ililum. It is sometimes cureloped in a false covering, originating, during its growth, from the cord or from the placenta. This is called the Aril.

101. The Testa includes either the embryo alone, or an additional nutritive substance, called the Albumen.

102. The Embryo consists of the Piadicle, the Plumule, and the Cotyledons.

103. The Radicle is the first joint of the stem. In germination, it elongates at one end to form the root, and at the other, from a minnte burl (Plumule), to form the stem. It is inferior when it points to the base of the pericarp, and superior when it points to its summit.

104. The Cotyledons are the seed-leares. The cmbryo of the Exogrenous Plants bears two of these, placed opposite (rarely three or more in a whorl), white that of Endogenous I'lants bears only une. Ilence the former are called dicotyledonous, and the latter monocotyledonous.

105. When the entryo is exposed to the combined influenee of air, heat, and moisture, it derelops into a growing plant. This is termed Gomination. 
106. The preceding considerations refer solely to Plrænogamous I'lants, or those which bear flowers, consisting of stamens and pistils, and produce seeds, which eontain an embryo, or a rudiment of a future plant.

107. But there are plants of a lower grade, which do not bear flowers furnished with ordinary stamens and pistils, nor seeds containing an embryo, but in place of seeds they produce minute powdery bodies, called Spores. These are termed

\section{Cryptogamous or Floverless Plants.}

108. The stems of the higher orders of Cryptogamous Plants - and these only are embraced in this work - exhibit nearly the same anatomical structure as those of Phrnogamous Plants. But they grow only from the apex, withont any perceptible increase of diameter, aud therefore are termed Acrogens or Pointgrowers.

109 The different orders presenting no common type, the habit, the mode of inflorescenee, and the process of fertilization, so far as it is known, being different in all of them, the characteristics of each are more conveniently explained in the body of the work, and need not be enumerated here.

\section{Classification.}

110. Classification consists in the arranging of plants possessing like structure, habits, \&c., into groups, designating them by proper names, and defining them by appropriate characters.

111. An assemblage of individuals which are so essentially alike as to indicato their descent from a common parent, and which preserve their characteristies when propagated from seed, is termed a Species. But circumstances connected with the growth of an individual may produce some deviation from its ordinary state, and it then becomes a Variety.

112. When the pistil of one species is fertilized by the pollen of another allied species, the result is a Irybrid.

113. An assemblage of speeies agreeing with one another in structure and appearance constitutes a Genus. In the same manner, although with fewer points of agreement, genera are collected into Orders, or Families, and these, in turn, into Clusses.

114. But each of these may include members that agree in some important points, which are not common to the others. Of such are formed the intermediate divisions of Subgenera, Suborders, and Subclasses.

115. There are two modes or systems of classification; the Artificial System of Linnæus, and the Natural System of Jussien.

116. In the Artificial System, the Classes and Orders are founded on the number, position, and comnection of the stamens and pistils, regrardless of any other relationship. In the Natural System, every part of the plant is taken into consideration; and the Orders embrace those genera which agree with each other in the greatest number of important particulars. The latter system is now in almost universal use, and is the one adopted in this work. 


\section{GLOSSARY OF BOTANTCAI TTERMIS.}

* The numbers annexed to the names, or their definition, refer to the paragraphs of tho preceding Sketch; but those preceded by "Flora, p." reter to the pages of the Flors.

Abortive: not fully developed.

Abruptly pinnate, 43 .

Accuinbent : Flora, p. 24.

Achenium, 95.

Achlanydeons: without floral envelopes. Acrogens: Flura, p. 585.

Acuminate: tapering into a slender point. Acute: pointerl.

Adlierent : growing fust to another body.

Adnate: same as Adherent.

Adnate Anthers, 72.

Aerial Roots, 10 .

A-tivation, 68.

Air-Plants, 11.

Aggregate: crowded together.

Alliunen, 101.

Alburnum, 30.

Alternate: sciltered; one after another.

Alveolate: deeply pitted.

Ament, 53.

Amentaceous: bearing aments.

Amplitropons, 83.

Anatropous, 83.

Androgynous: containing both staminate and pistillate flowers.

Angiosperma: Flora, p. 1.

Anmual: lasting only one vear.

Aunular: disposed in, or forming, a ring or circle.

Anterior: applied to that part of an axillary flower which is farthest removed from the main axis.

Anther, 71.

Apetalous: without petals.

Apiculate: tipped with a short abrupt point.

Appendage: something added to a part.

Appresser : lving near to: pressed against.

Aquatic: growing in water.

Arborescent: tree-like

Areolation: spaces between the leaf-veins.

Aril, 100

Arillerl: envered with an aril.

Armed: furnished with thorns, prickles, \&e.

Articulated : divided into joints; conneeted by a joint.
Ascenling: / curring outward and upAssurgent: ward.

Attenuated: gradually narrowed.

Auriculate: eared; bearing small lateral lobes.

Awl-shaped: narrow and shamp-pointed.

Awn: a rigid bri-tle-like aljendage.

Awmerl: bearing an awn.

Axil: the point where the upper surface of the leaf joins the stem.

Axillary: borne in the axil.

Axis: the central line of a body; the part around which others grow.

Baceate: berry-like; juicy.

Barbed: bearing rigid points which are directed back ward.

Bark, 31

Basal: belonging to the base.

Beaked: ending in a stout point.

Bearded: bearing tufts or lines of hairs.

Bell-shaped: expanding from a short and rounded base, into a spreading border.

Berry, 93.

Ridentate: two-toothed.

Jiennial: lasting two years.

Bifid: two-eleft.

Bifoliolate: bearing two leaflets.

Biglandular: bearing two glands.

Bilabiate: two-lipped.

Bipinnate: twice pinnate.

Biternate: twice ternate.

Bladders: small saces filled with air.

Blade: the expmuded portion of a leaf, \&c.

Boat-shaped: sce Carinate.

Brachiate: with pairs of opposite branches spreading at riglt angles.

Bract, 45 .

Bracted: furnished with bracts.

Bractlet, 45.

Bristle: a rigid hair.

Bristly: beset witl, or like, bristles.

Brush-shaped: divided at the apex into numerous hairs or filaments.

\section{Bud, 14}

Bulb, 21.

Bulbous: shaped like a bulb.

Bulblet, 21. 
Caducous: falling away early.

Crespitose: growing in a tuft.

Callous: thickened.

Calyx, 63. :

Cambium, 31.

Campanulate: see Bell shaped.

Campylotropons, 83.

Capillary: hair-like.

Capsule, 89.

Capsular: relating to, or with the characters of a capsule.

Carinate: keeler]; bearing on the back a sharp longitudinal ridge.

Cariopsis, 95 .

Carpel: a single pistil, or one of the parts of a compound pistil.

Carpellary: pertaining to a carpel.

Carpophore: Flora, p. 157.

Cartilaginous: liard and touglı.

Caruncle: an appendage of the hilum.

Caudate: tailed.

Caudex, 17.

Caulescent: furnisher with a stem.

Cauline: pertaining to the stem.

Cell: one of the cavities of the fruit or of the anther, \&c.

Celled: divided into cells.

Celhular 'Tissue, 3.

Centrifugal Inflorescence, 48.

Centripetal Inflorescence, 48 .

Chaff: thin seales or bracts.

Chaffy: furmished with chaff, or of the texture of cliaff.

Chalaza, 82.

Channelled: with a deep longitudinal furrow.

Character: a plirase employed to distinguish a genus, \&e. from all others.

Chartaceous: of the texture of paper.

Chlorophyll: the green matter of leaves, \&c.

Ciliate: fringed with a row of hatirs

Circinate: rolled inward at the apex.

Circumscissile, 89.

Cirrhose: bearing tendrils; tendril-like.

Clasping: enclosing by its base, as a leaf the stem.

Clavate: club-shaped.

Claw: the stalk of a petal.

Clawed: raiser on a claw.

Climbing: clinging to other objects for support.

Club-shaperl: terete and gradually thickened upward.

Chustered : crowded.

Coated Bulb, 21.

Cobwebby: bearing fine loose hairs.

Cochleate: coiled like a snail-shell.

Coherent: growing together.

Column: the axis of a compound pistil; the united stameus of the Mallow Family; the united stamens and pistil of the Orehis Family.

Commissure: Flora, p. 157.

Comose: bearing a coma, 99 .

Compound: composed of similar simple parts, 36.
Compressed: flattened.

Cone: the scaly fruit of the Pine.

Confluent: rumning together.

Conglomerate: heaped together.

Conical: cone-shaped.

Connate: growing together at the base as opposite leaves around the stem.

Connective, 71.

Connivent: brought near together.

Continuous: in one piece; rot jointed.

Contorted: twisted; bent.

Contorted astivation: see Convolute.

Contracted : narrowed; not spreading.

Convolute, 68 .

Cordate: heart-sliaped.

Coriaceons: of the texture of leather.

Corm, 20.

Corncous: liard like horn.

Corniculate: bearing a horn or spur.

Corolla, 64.

Corymb, 56.

Corymbose : branched like a corymb ; arranged in corymbs.

Costate: ribbed.

Cotyledons, 104.

Creeping: prostrate, and rooting.

Crenate: laving sharp notches on the edge separated by rounded teeth.

Crenulate: slightly crenate.

Crested: bearing an elevated ridge.

Crown: an appendage of the corolla at the base of the limb.

Crowned: bearing anything at the apex.

Crucifor In: shaped like a cros:

Crustaceous : liard and brittle, like a shell.

Cryptogamous ]'lants, 107.

Cucullite: see Hooded.

Culm, 16.

Cuneate: wedge-shaperl.

Cup-shaped: shaped like a bowl or cup.

Cuspidate : ending abruptly in a sharp point.

Cuticle 31.

Cylindrical: round and of nearly equal thickness.

Cyme, 60 .

Cymose: arranged in a cyme.

Decandrous : having ten stamens.

Decilluous: falling off at, or before, the close of the season.

Declining: leaning to one side.

Decomponnd: several times divided.

Decumbent: prostrate, but ascending at the summit.

Decurrent: with the edges extending below the main point of attachment.

Definite: few ; a number easily counted.

Definite Inflorescence, 48.

Deflexerl : bent downward.

Dehiscence: the manner in which closed organs regularly open.

Dehiscent: opening regularly.

Jeltoid: triangular.

Dentate: having sharp notches on the edge separated by coarse and spreading teeth.

Denticulate: slightly toothed. 
I)epre:sell: flattenetl horizontally.

Dercemling: ilirected chisuwaril.

Ditcle lpliuns: collecter in two sets.

Diandrous: laving two stameus.

biclilanydeous: having hoth callyx and coroll:L.

Dichotomous: forkerl.

1)ielimous, tit.

Dicotyledonons: having two cotyledons.

bidymons: twin.

bilymanous: havine four stamens, with two of them longer thin the others.

Difluse: looscly spreating.

l)igitate: when the ipex of the petiole bears fire or more leaflets.

Dimorphons: of two forms.

1)

1)iceolil: Filora, p. 184.

Disk, 73. Also the central part of the head of composite tlowers.

Dissected : divided into miny lobes.

Distichous: two-rinked ; pliced on opposite sides of the axis.

Distinct : separate.

Diraricate: widely spreading.

Divided: parted neally to the base.

Dorsal: pertaining to batek or outside.

Dorsal Suture, 80 .

Downy: bearing soft short hairs.

1)rupe, 94.

1)rupaceons: with the characters of a drupe.

Duramen, 30.

Dwarf: below the common size.

Eared: see Auriculate.

Echinate: beset with prickles.

Elliptical: in mutline twice as long as wide, broadest in the middle, and romuled at eacli end.

Elongated: umsually long; extended.

Einarginate: notched at the apex.

Eimbryo, 102.

Emersed: raised out of water.

Findocarp: the immer layer of the pericarp.

Eindogenous (stem:), 32.

Enneandrous: having nine stumens.

Fusiform: sword-shaped.

Entire: with margins not toothed or divirled.

Epigrnous, 70.

Epiphytes, 11.

Equilatera] : equal-sided

Equitint (leaves): two-ranked, with their bases clasped one within the other, and their sides ficeing the liorizon.

Frose: with the inargin irregularly scalloped, as if grawed.

Evergreen: lasting through the winter.

Fixngennus, 28.

Ex-erterl : protruding out of the surrounding parts.

Exstipulate: without stipules.

Extrorse Anthers, 72.

Faleate: scrthe-shaped.

Fannily", 113.
Fan-slupenl: folled or plaiterl like a fan.

Farinaceus: mealy.

Fiscicle: at cluster.

Funcicleul: cullecterl in a eluster.

fistigiate: rising to the same level; flattojpled.

Feathior-reined, 41

female (llowers): hearing only pistils.

Ferruginous: at the color of iron-rust.

Fertile: bearing fruit.

leibre, 4.

Fibrous likots, 8.

Fidllle-shaped : oblong in outline, and contrated in the nisldle.

Filament, 69. Auy threal-like part.

Filamentose: beiring or composed of threads.

Filiform: threarl-like.

Fimbriate : with the margin eut into a fringe.

Fistulous : hollow.

Fle-hy: soft and juiey.

Flexuous: rigzag; bent outward and inwatrd.

Floating: resting on the surface of the water.

Floccose : bearing tufts of deciduous hairs.

Flora: a systematic description of tle plants of a country.

Floral: belonging to the flowers.

Floret: one of the flower's of a cluster.

Flower, 61.

Flowering l'lants, 106.

Flowerles l'ants, 107

Foliacens: leaf-like.

Foliolate: bearing leaflets.

Follicle, 87.

Follieular: like a follicle.

Forked: divided into two branches.

Free: separate: discomnected.

Fringed : see Ciliate.

Frond: the leaf of a Fern.

Fructification: the fruiting state.

Fruit, 84.

Frutescent: shrublyy.

Furacious : continuing for a short time.

Fulvous: tawny.

Funiculus, 82.

Fumel-shaperl: gradually dilated upward from a tubular base.

Furrowed: grooved lengthwise.

Fusiform : spiulle-shajed ; broadest in the middle, and tapering at each end.

Geminate: by pairs.

feniculate: bent abruptly.

Genus, 113.

Germination, 105

Gibbous: puffetl out.

Glaluous: free from rongluness, or hairs.

Glands: small knobs or excrescences.

Glandular: bearing glandls.

Glancons: covered with a minute whitish powder.

Globose:
Globular: round; spherical.

Glomerate: collected in a close cluster. 
Glumaceous . glume-like, or bearing | Jointed : separating across into pieces ; gltumes.

Glumes: the scale-like bracts, \&c. of grasses and sedges.

Gramular: covered with grains.

Gymnospermous Plants: Flora, p. 431. Gynandrous, 70 .

Ilabit: the general appearance of a plant.

Habitat: the native situation of a plant.

IIairs: hair-like apyendages of the cuticle.

Huiry: furnished with hairs.

Itastate or Halber-shaped: dilated at the base into two spreading lobes.

Heart-shaped: ovate, with a sinus at the base.

Heptandrous: having seven stamens.

Herl, 26.

Herbaceous, 26; of the color and texture of a leaf.

Herbarium: a collection of dried plants.

Hilum, 100.

Hirsute: beset with coarse hairs.

Hispid: beset with rigid hairs.

Hoary: grayish-white.

Ilomogereous: uniform in substance.

Hooded : rolled inward or archerl.

Horn: an appendage like a horn.

Horny: of the texture of horn.

Hyaline: thin and nearly transparent.

Hybrid, 112.

Hypogynous, 70 .

Imbricated, 68 .

Imperfect (flowers), 66.

Incised: cut into notches or lobes.

Inchuded: enclosed; opposed to Exserted.

Incumbent: Flora, p. 24.

Incurved: bending inward.

Indefinite: numerons; not readily counted.

Indefinite Inflorescence, 48 .

Indehiscent: not opening.

Indigenous: native to a country.

Induplicate: folded inward.

Indnsium : Flora, p. 586.

Inferior: below, 103.

Inflated: puffed out, as if distended with air.

Inflexed: bent inwarl.

Inflorescence, 47 .

Innate (anther), 72.

Inserterl on: used in the sense of growing from a pitrt

Insertion: the mode of attachment.

Internodes, 14

Intermpted: not contimus ; not jointed.

Internptedly pimate: with smaller leaflets between the larger ones.

Intervals: Flora, p. 157

Introrse (anthers), 72.

Introducell: bronght from another country.

Inverted: turned upside down.

Involucel, 58.

Involucre, 58.

furnished with joints.

Keel: a sharp Iongitudinal ridge on the back of an organ; Flori, p. 86.

Kieeled: see Carinate.

hidney-shaped: heart-shaped, but the width greater than the length.

Labelhm: the odd petal (lip) of the Orchis Family.

Labiate: divided into an upper and lower lobe or lip.

Laciniate: divided into irregular lobes.

Lamellate: formed of thin plates.

Lamina: the blade of a leat, \&c.

Lanceolate: lance-sliaped.

Lamuginous: woolly.

Lateral: placed at, or pertaining to the side.

Leaf, 33 .

Leaflet, 36 .

Leathery: see Coriaceous.

Legume, 88 .

Lenticular: like a double-convex lens.

Liber, 31.

Ligulate: strap-shaped.

Ligula: Flora, p. 5.45.

Limb: the expanded part of a leaf, Sc.

Linear: Jong and narrow, with parallel margins.

Lip: see Labellum and Labiate.

Lobe: one of the parts of a divided body.

Loculicidal, 89.

Lumate: crescent-shaper.

Lyrate: pimnatifid, with the upper lobes enlarged.

Marginal: borne on, or pertaining to, the edge or margin.

Jednllary Rays, 30.

Vedullary Slienth, 29.

Membranous: of the texture of membrane.

Mericarp: Flora, p. 157.

Micropyle, 100.

Midrib: the prolongation of the petiole through the limb of a leaf.

Monadejphous, 70 .

Monandrous: bearing one stamen.

Joniliform: bearing short joints; like a string of beads.

Monochlamydeous: bearing only one row of floral envelopes.

Monocotyledonous, 104.

Monoecious. 67.

Monopetalous: with the petuls united into one piece.

Monosepalous: with the sepals united into one piece.

Mucronate: tipped with an abrupt slender point.

Muricate : beset with hard wart-like points.

Involute: with the margins rolled inward. Irregular (flowers), 66.

Naturalized : introduced, but propagating freely by seed. 
Necklaes-shapml: see Moniliform.

Nectary: uny laney-bearing pat.

Nervent (leaves), 40.

Nettenl-reined, 40.

Nental (flowern): without stamens and jistils.

Nobling: tuming outward or downward.

Nixles, 14.

Ninkose: knotty.

Niut, 96.

Nutlet: same ats Achenium.

Ubcordate: inversely heart-shuped.

Oblancechate: inversely lance-slajped.

Oblique: rmequal-sided.

Oblong: narower than Ellipticaf, with nenily parattel margins.

Obovate: egg-huped. with the narrow cond downwarl.

Obtuse: blunt; not pointed.

Ochreat, 38 .

Octandrous: having eight stamens.

(He-siled: bnrme one sicle of the axis.

Oparpue: diull.

Opposite : placed directly agaiust ench other, as leuves on the stem; placed before, as stimens before the petals.

()rbicular: circular.

Orguns, 6.

()rthotrujous, 83.

(O)al: satune as Eiliptical.

() vars, 76 .

Ovate: egr-shaped.

Ovoid: a solicl with an oval outline.

Ovule, 76 .

Palate : a prominence at the throat of some bilabiate flowers.

Palea : Fiora, J. 545.

l'ulmate: hami-shaped: when the Jobes or divisions spread from a common centre.

Palmately-veinel, 41.

P'anicle, 59.

Papery: of the texture of paper.

Papilionacents (flower): flura, p. 86

Papillose: studded witl minute wart-like prominences.

Pappus: the linb of the calyx of comjosite flowers.

Parallel-reinet. 40.

Parasitionl: supported and nourished by other flants.

Parictal. 81.

Parted: divided nearly to the base.

l'artial: pertaining to the parts of a compound organ.

leetinate: cut into fine parallel lobes.

l'erlate: nearly as palmate, but with the lateral lobes divided.

l'edicel. 50.

P'edicelled: raised on a pedieel.

Perluncle, 50 .

l'eduncled: raised on a peduncle.

l'eltate: fixed to the stall at a point within the margins.

Pendent: lianging, drooping.
Pendulums: somewhat drompiug.

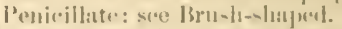

P'entamlrous: having tive stamens.

l'(epo), 91.

l'aremiand: lastiug firom yesu to year.

Perlicet Floswers, titj.

f'ertoliate: growing tursumb the stem.

P'risuth, Ge.

l'eriotrp: the walls of the fruit.

1'erigvinum: For:1, 1). 532.

l'urigumens, 70 .

l'erintent: remaining late, as opposed to decicluonis.

Personate: bearing a palate.

P(t:!1, 64.

Petalojul: petal-like: colored like a petal.

l'etiole: the stalk of at leati.

l'etioled: borne on at petiole.

l'etiolule: the stalk of a lexiflut.

l'etiolulate: raised on a petiolule.

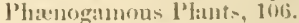

l'ifose: beset witl still'strightıt hairs.

1'inna: the primury divisiuns of a pinmately compound leat.

l'inuate, 43.

Pimately divided, 43.

P'immles: the secomblary divisions of a pirmately compoumd teaf.

l'istil, 74.

l'ith, 29.

l'itted: marked with fine indentations.

jlicenta, 81.

l'luited. 6in; folderl lengthwise.

P'lumo:e: feuthery".

p'lumu\}e, 103.

l'ollen, 71 .

Polliniat: the pollen-masses of the Milkweerl.

Polyandrous: benring many stamens.

Pofypetalou: and l'olysepulous: applied to a corolla or calyx with separate petuls or s('puls.

Polymorphous: of varions forms.

Joine. 92.

l'rickles: sharp and rigid appendages of the cuticle.

Prickly: beset with prickles.

1'rimine, 82.

l'risultic: angular, with flat sides.

l'rocess : : prominence or projection.

P'rocumbent : restiur on the ground.

l'roduced: jmolonged.

l'ruliferous: where a cluster of flowers arises out of another eluster.

Prostrate: see l'rocumbent.

P'ubescence: Hairiness in generul.

l'ubescent: hairy or downy.

pulverulent: covered witl fine powder.

P'unctite: dotterl.

pougent: ending in an abrupt lard point.

l'yramistal: pyramirt-shaped.

pyriform: peir-shiped.

Quinate: bearing five leaflets.

Riaceme, 55 .

Rachis, 50. 
Rays, 57 ; the marginal flowers a liead or cyme; the partial stalks of an umbel.

Radiate or kadiant : bearing rays ; diverging from a centre.

Radical: near or belonging to the root.

Radicle, 103.

Raphe, 83.

Receptacle, 61 .

Reclining: leaning or falling to one side.

Recurved: $\}$ bent gradually backward.

Refracted: bent abruptly backward, as if broken.

Regular: of uniform shape and size.

Reniform: see Kidney-shaped.

Repand: wavy.

Resupiuate: turned upsicle down.

Reticulate: disposed in little spaces, like network.

Revolute: rolled backward.

Rhizoma, 18.

Rlombic or Rlomboidal : diamondshaped.

Ribs, 33 ; longiturlinal ridges.

Ribbed: bearing ribs.

Root, 7.

Rootlet, 7.

Rootstock, 18.

Rostrate: beaked.

Rotate: wheel-shaped; with a short tubo and a spreading limb.

Rudimentary : imperfectly developed.

Rugose: uneven; wrinkled.

Rnminated (albumen): divided into lobes.

Runcinate: same as lvrate, but with the lobes directed backward.

Runuer, 23.

Sagittate: arrow-shaped.

Samara, 97.

Scabrous: rough.

Scales: reduced leaves, or any small and thin appendage.

Sealy: beset witl scales; of the texture of seales.

Scape, 50.

Scarious : very thin and colorless.

Scurfy: covered with minute scales.

Secund: one-sided.

Seed, 99.

Segment: one of the parts of a divided leaf, \&e.

Sepal, 63.

Septicidal, 89.

Serrate: with the margin cut into teeth like a saw.

Serrulate: finely serrate.

Sessile: not raised on a stalk.

Setaceous : bristle-like.

Sheath: the base of a leaf when it is wrapped round the stem.

Sheathing: enclosing the stem like a sheath.

Shield-shaped: see Peltate.

Slirub, 26.

Silicle and Silique, 90.
Silky: clothed with fine appressed shining hairs.

Silvery: white and shining.

Simple: of one piece.

sinuate: with the margins cut into rounded incisions (sinuses) which are separated by rounded lobes.

Solitary : standing alone.

Solus: the firuit cluster of ferns.

Spadix, 54.

spatlie, 54.

Spatulate: dilated into a broad and rounded summit, from a slender base.

Species, 111.

Specific: pertaining to a species.

spike, 52.

Spikelet: a small spike, or a branch of a spike.

Spindle-shaped: see Fusiform.

Spine, 24.

Spiny: armed with spines; spine-iike.

Spiral Vessels, 5.

Sporangia: Flora, p. 585.

spores: Flora, p. 585.

Spur: a hollow appendago of the calyx or the corolla.

Spurred: furnislied with a spur.

Squarrose : covered with spreading scales.

Stamen, 69.

Staminate: bearing stamens.

Standard: Flora, $\mu .86$.

Stellate or Stellar: radiating from a common centre.

Stem, 13.

Stemless, 13.

Sterile: unfruitful; inıperfect.

Stigma, 78.

Stigmatic: belonging to the stigma.

Stipe: the stalk of an ovary or of a fernleaf.

Stipel, 38.

Stipellate: furnished with stipels.

Stipule, 38.

Stipulate: furnished with stipules.

Stolon, 22.

Stoloniferous : bearing stolons.

Stomata, 33.

Strap-shaped: long and flat, with parallel margins.

Striate: marked with fine furrows.

Strigose: bristly witlı rigid appressed hairs.

Strobile, 98.

Style, 77.

Subulate: awl-shaped.

Suleate: marked with deep furrows.

Suspended: hanging.

Snture, 80 .

Syngenesious, 72 .

System, 115.

Tap-root, 8.

Tendril, 25.

Terete: eylindrical; round.

Ternate: of three leaflets ; three in a whorl. 
T'stu: the eovering of the seed.

Tetruneruss: in piarts of fuur.

Tetrandruts: hatugg four stamens.

Thurn, 24.

'Ihroat: the oritice of a tubular corolla, indrx, Ac.

Tomintuse: cluthed with a elose velvety pubescence.

Toutluel : see l)entate.

'Jup-slitpeal: like an inverted cone.

Turose, of Turuluse: knotted; knol,br.

Torus, 61 .

True, 26.

Triamlruss: luving three stamens.

'Tribe: : subdivision of an urder.

Trichutomous: dividing into three brinclies.

Trifoliolate: bearing three leaflets.

Trumeate: ending abruptly, as if cut off.

lube: the united part of a ealyx or corolla.

Tuber, 19.

Tuberele: a wart-like appendage; Flora, p. 504.

Tubercled : bearing tubercles, or crowned with a tuberele.

Tuberons: like a tuher.

Tubular: shaped like a tube.

Tumid: swelled; thickened.

Tunicated Bulb, 21.

Twin: in pairs; a pair united.

Twining: rising by coiling around a support.

Umbel, 57.

Timbelled: arranged in an umlel.

Umbellet, 57.

Unarmed: destitute of thorns, prickles, \&e.

Unciuate: hooked.

Undulate: wavy.

Unequally pimate, 43.

Unguieulate : clawed.
Wuifuliolute: bearing a single lonfet.

l'reeolato: urn-shated; pitcher-shaped.

letricle, 45.

l'tricular : formed like a utricle.

Valve, 85.

Valvate, 65 : opeuing by valves.

Varicty, 111.

Vascular lissur, 5.

Vinulted : archerl.

Veills, 33.

Veiny : furni-lıel with reticulated veins.

Veinlets: the ultimate branclses of veins.

Venation, 39.

Veutral Suture, to.

Ventricose : inflated.

Vermation, 34.

Versitile, 72 .

Vertical: with the elges directerl upward and lownw:ud, and the sides facing tho horizoll.

Vessuls, 2.

Vexillum : Flora, p. 86.

Villous: woolly.

Virgate: wamd-like; long and slender.

Yiscid: clammy ; glutinous.

Vitta: Flora, j. 157.

Waxy : like beeswax.

Wedge-shaped : broud at the summit, and tapering regularly to the base.

Wheel-shaped: see liotate.

Whorl: a collection of parts arranged in a ring or circle.

Whorled : disposed in a whorl

II ing: Flora, p. s6; any thin expansion.

IVinged: furnislied with wings.

Wood, 30.

Woody: of the texture of woud.

Wondy Fibre or Woody Tissue, 4.

Woolly: clothed with lung and dense sont hairs. 


\section{ABBREVIATIONS OF THE NAMIES OF AUTHORS.}

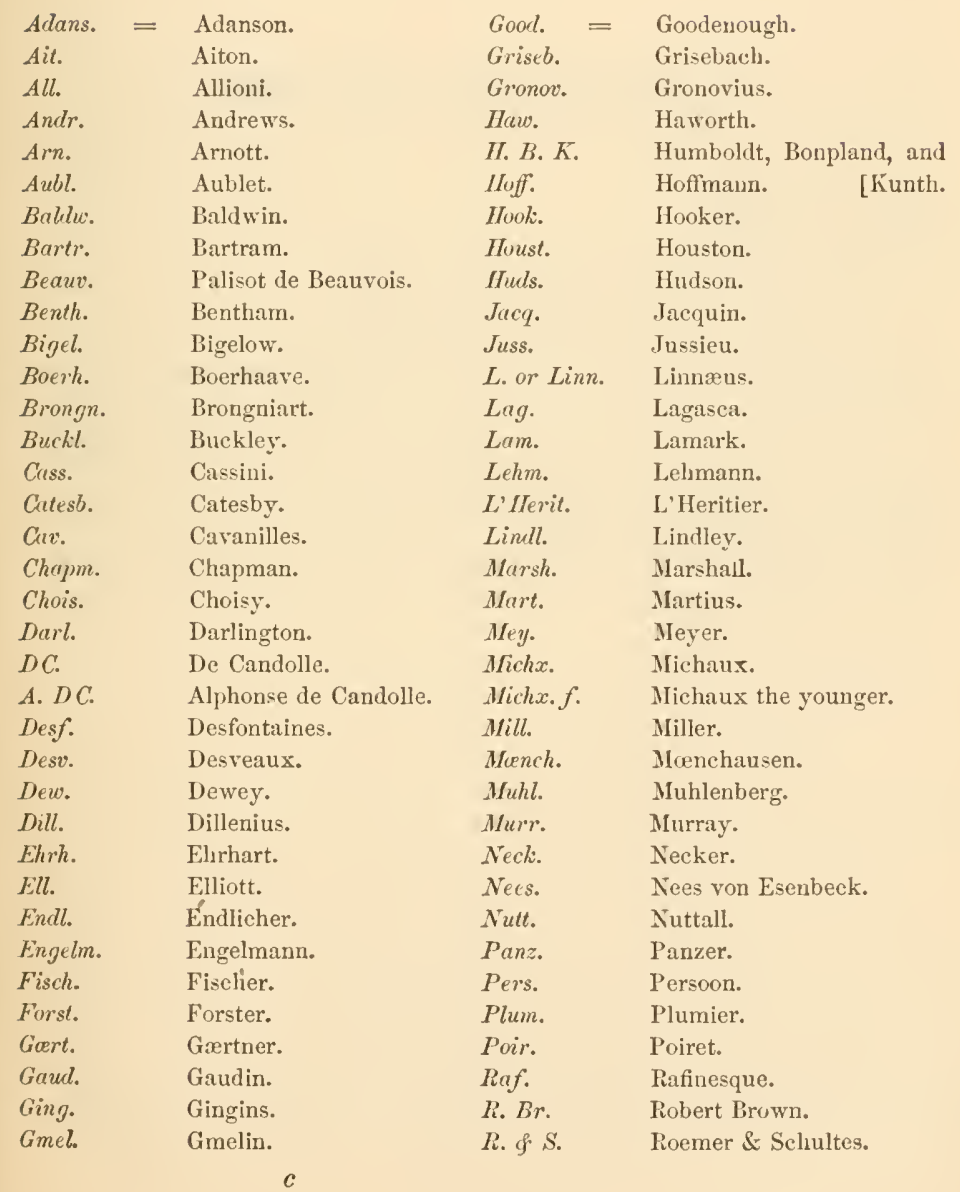




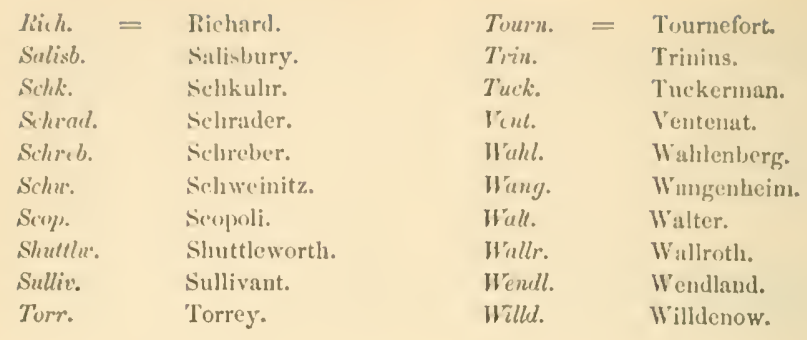

\section{SIGNS USED IN THIS WORK.}

(1) An annual plant.

(2) $\Lambda$ biennial plant.

If A peremial plunt.

- The length in feet; as, " 20 long," two feet long.

"The length in inches; as, " 2 ' long," two inches long.

"The length in lines; as, "2" long," two lines long.

(*) llaced at the end of a speeific charteter, denotes that the species is not well known.

Two adjectives connected by a hyphen denote a form intermediate between the two; as, "ovate-lanceolate," between ovate and lanceolate.

Two figures connected ly a dash, ats "stem 4 " -6 long," denote that the leugth of the stem varies from four to six feet.

n. sp. Zindicate that the species, or geuus, is new, or has not been previously n. gen. $\}$ characterized. 


\section{DIRECTIONS TO THE STUDENT.}

Havisg acquired a general knowledge of the principles of botany, and of the meaning of the peculiar terms employed in the science, the student proceeds to study or analyze plants, with a view to determine their names, and the place they oceupy in the system.

His ehief difficulty, at the outset, will be to ascertain to which one of the 164 natural orders or fanilies contained in this work the plant he may have in hand belongs. Were he to attempt to compare it with the eharacters of each order successively, the task would be tedious and discouraging.

To obviate this, and to enable him to refer any unkuown plant directly to its proper place in the Flora, some guide, such as is supplied by the following Analysis of the Natural Orders, will be necessary. One or two exanples will best explain its use.

Suppose we have in hand a flowering branch of the Linden-Tree or Basswood. Turning to the Analysis on page xxix., we compare it, first, with the Series of Pinfogamous Plants, with which we fiud it to agree in having flowers.

Then, dividing the branch across, we see if it is made up of pith, wood, and bark; if the leaves are netted-reined; and if the floral envelopes are in fours or fives. Exhibiting these peculiarities, it doubtless belongs to the Class of Dicotyledonous Plants; although, in consequence of the minuteness of the seed, we have not been able to ascertain the number of the cotyledons.

We next see if the ovules are contained in an ovary. This being elearly the ease, it comes under the Subclass of Axgiosperuous Plants. The donble floral envelopes, and the separate petals of the corolla, carry it to the PoLy PETalovs Division.

Our attention is next direeted to the insertion of the stamens and petals, whether on the calyx, or hypogynous. In our plant they are hypogynous. Then, if the stamens are more than twice as many as the petals. They are so in ours. Then, if the leaves are opposite or alternate. In onrs they are alternate. Then, if the ovaries are more than one, or solitary and 1-celled, or solitary and 2-many-celled. In ours they are solitary and 5-eelled; bringing it under the last alternative. Then, if the stamens are in any way connected 
with the petals, or free from them. In ours they are free. Iastly, whether they are unimel into a tube, or in clusters, or nere all separate. In ours they ure sre united in tive clunters, and the sepals are decilnous. This brings our plunt to the natural order, 'That iss, 59, - the number referring to the page of the Flora where the order is deseribed.

Turning to that page, and comparing our plant with the chararter of the order, we notice their agrement.

We then proceed to timl the name of the grenus. This is realily done, in this instance, ly comparing the plant with the two genera comprised in this order. With the first it will be foum to agree in every particular, and therefore we need not earry it further. We fint, then, the phant in question to be st species of ahe genus 'Tins, so named by Tournefort, and commonly called Linden or Bussurood.

Again, suppose the plant under consideration to he the common Bear-Grass. Having flowers, it is, of course, Phetnogumous. But, cutting across the stem, we find, in the place of pith, wood, and bark, a white mass of cellular tissuc, studded with minute points, which are the ends of the divided threads of woody fibre; the veins of the leaf run parallel from the base to the apex; the floral envelopes are in two rows of three each; and the embryo, if examiserl, will be found to have but one cotyledon. In these respects, our plant diflicrs widely from the Class of Dicotylerlonous Plants, and we therefore turn to its altermative, the Class of Moxocotrledoxocs Plaxts, on page xxirii. of the Aualysis, which, we observe, inclucles plants possessing these characters.

Our plant, having the floral envelopes double, and not glumaceous, falls under the sccond hearling, marked with two stars (**).

Proceeding as in the former example, and carefully comparing the plant with the analysis that follows, we sec, first, if the ovary is adherent with, or free from, the periantl. In ours it is free. 'Tlen, if the perianth is single, or clouble. In ours it is donble. 'Then, if the ealyx and corolla are alike or unlike. In ours they are alike. 'Then, if the leaves of the perianth are glume-like, or otherwise. In ours they are not glume-like. Then, if the leaves are netted-veined or parallel-veined. In ours they are parallel-veined. Then, if the eapsule is 1-celled, or 3-6-eelled. In ours it is 6-celled. Lastly, if the anthers are introrse or extrorse In ours they are introrse.

This brings us to the natural order Liliaces, described on page 480 of the Flora. It contains ten genera, belonging to three tribes, the characters of which are briefly given in the Synopsis. Our plant, hy its eapsular fruit, the separate divisions of the perianth, and leafy stem, comes under the third tribe, TrutraCE.E. Of the two sections, marked with a star (*), our plant belongs to the second; haring a Palm-like sten. No. 10, Yucea, alone remains; and to it our plant must belong.

Turning to page 485, where this genus is more fully described, we find it to embrace four species, divided into two seetions based upon the character of the stem and capsule. The short stem (exeluding the scape) and dry capsule of our plant belong to the former. It contains but one speries. Y. filamentosa, L., which we therefore find to be the botanical name of the plant in question. 


\section{ARTIFICIAL ANALYSIS OF THE NATURAL ORDERS.}

\section{SERIES I. PHANOGAMOLS OR FLOWERING PLANTS.}

Plants furnished with flowers, consisting of stamens and pistils, and producing seeds which contain an embryo plant.

\section{Class I. DICOTYLEDONOL'S OR EAOGENOLS PLANTS.}

Stem composed of bark and pith, with an interposed layer of woody fibre and ressels, and inereasing in diameter, in all perennial stems, by the annual deposition of a new laver between the wood and bark. Leaves netted-reined, commonly artieulated with the stem. Floral envelopes usually in fours or fives. Cotyledons two, rarely more.

\section{SUBCLASS I. ANGIOSPERMOUS EXOGENOUS PLANTS.}

Ovules contained in an orary, and fertilized by the action of the pollen, through the medium of a stigma. Cotyledons two.

\section{Drrisiox I. POLIPETALOUS EXOGENOUS PLANTS.}

Floral envelopes double, consisting of both caly $\mathrm{x}$ and corolla; the latter of separate petals.

* Stamens and petals free from the calyx, hypogynous or nearly so.

- Stamens more than twice as many as the petals.

Leaves opposite, entire.

Leaves dotted. Stamens separate. Stigma small.

Leaves dotless. Stamens united below. Stigma radiate-peltate.

Leares alternate.

Ovaries more than one, each 1-celled.

Stems woody. Petals 6 or more, in two or more rows.

Petals imbricated in the bud.

Anthers 4-celled. Dioecious vines.

Anthers 2-celled. Flowers perfect.

MENISPERMACE.F, 15 MAGNOLIACEA, 12

Petals valvate in the bud. Fruit pulpy. Albumen ruminated.

Herbs. Ovaries embedded in the top of the large receptacle.

ANONACEE, 14 NELUMBIACE. 18

Ovaries borne on the receptacle. Sepals and petals deciduous. RANUNCULACE. 2 Sepals aud petals persistent. CABOMBACEA, 18 
O rary kolitary, 1-celled.

l'hacenta central. Sepals 2, decidunus, Anthers introrse. sopuls 5, persistent. Anthers extrorse.

POItTUTAC.M'E.T, 43

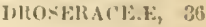

l'lacenta parictal.

(alyx persistent. Capsule 3-valved : jlacenta 3.

Caly $x$ deciduous. Juin colored. Leaves simjle, Jolvel. Juico watery. Plncenta 1. Leavea $2-3$-turnnte.

CISTACH.F, 35

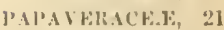

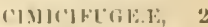
Juice watery. Placentae 2. Leaves simple or trifoliolate. CAll.AlaID.IClE. E, 31

Ovary solitary, 2-mauy-felled.

Stumens connected with the base of the jetals.

Stame'ns united in a column. Sepals valvate.

Stamens united in a ring. Sepals imbricated.

MAINACE.F, 52

C.MEIAIACH.1: 60

Stamens free from the petals.

Stamens united into a tube. Sepals perristent.

Stumens united in elnsters. Sepals deciduous.

Stamens separate. Orary 5-celled. Leares tnbular. Ovary many-celled. Leares flat.

CLISIACE.F, 42 TILIACk.F, 69 SAlRACFIACF.J, 20 NYIHI.KACE.E, 19
+ + Staments twice as many as the petals.

Oraries more than one.

Fowers diacious. Fruit a drupe. Trees, witla pinuate le:tres.

SIIIARCB.1CE.F, 67

Flowers perfect. Éruit dry, indehiseent, 1-3-seeded Aquatic berbs. CABO.JIACl.F, 18 Fruit a many-seeded follicle. Fleshy herbs. CRASSCLACE.J 199

Ovary solitary, 1.eelled.

Leaves alternate. Fruit a legume. Leares stipulate.

LEGUMHOS.I, 8;

Leares opposite.

Fruit a cipsule, with parietal placentie. Leares entire, dotted JIJERICACE. Fruit a cajsule, with a free central placenta. Leatses dotless. C.IRYOPIYIL.ACL.7, 45 Fruit a drupe. Shrubs, with trifoliolate dotted leaves.

Fruit a berry. Ilerbs, with two peltate lobed leaves.

BUUISERACHE, 67 J3EIBEI\}] ACLI, 16

Orary solitary, 2-celled

Flowers irregular: stamens monadelphous. Capsule 2-seeded.

Flowers regular: stamens separate. Capsule long, many-seeded.

Ovary solitary, 3-celled. Sbrubs, with alternate leaves.

Flowers monnecious. Fruit 3-seeded, 3-valved. Stamens united. EUPIORBiACE.E, 399

Flowers perfect. Fruit 3-seceded, 3-winged, indehiscent. Fruit many-seeded, 3-valved.

CYIJ]LACL.F, 272 ERICAC'LA, 257

Orary solitary, 4 -eelled. Stamens 8 .

St.jle single. Low fleshy root-parasites, with scale-like leares.

A slirub, with alternate leaves and bractess flowers.

Styles 4. Flowers cymose. Cap-ule 4-lobed, spreading.

Ovary zolitary 5-celled. Stamens 10.

Style single. Stamens monalelphous. Leaves alternate, pinnate.

Stamns reparate. Leaves opprite, pinnate.

Stamens separate. Leaves alternate, simple.

Styles 5 Cells of the fruit separating into 1 -seeded nutlets. Cells of the fruit uniterl. Leaves trifollolate.

Ovary solitary, 7 -celled. Anthers opening by terminal pores.

MONOTIOIE.F, 258

CYlill.A('1:. F; 27:2

CRASSULACEX, 149

CFDR RLACE.F. 62 ZYGOPHYLLACE.E. (63 P'YROLE.F, 258 GFRANIACF, GH OXAI,IDACE.E, 63 ERICACEj, 257 Ovary solitary, 10 - 12-celled. Leaves opposite, abruptly pinnate. ZYGOPHYl_LACE. 63

Ovary 1-celled. Petals 4 : stamens 6.

Sepals 2. Flowers irregular. Fmbryo minute in fleshy albumeo. Sepals 4. Flowers regular. Embryo large. Albumen none.

Orary 2-eelled.

Petals 3. Stamens 8, monadelphous. Anthers 1-celled.

Petals 4. Stamens 6. Fruit a silique or silicie.

FUMIARIACEE、 22 CAPPARIDACEE, 31

POLLOALACEF, 82 ClUUCIFERA, 23 
Ovary 3-celled. Leaves opposite.

Petals 5. Stamens 9. Leaves simple, dotted.

Petals $4-5$. Stamens 7 . Leaves palmately 7 -foliolate.

IIYPERICACEF, 38 SAPINDACE, $\mathrm{E}, 78$

Ovary 3 -4-celled. Leares alternate.

Petals 5-8. Stamens 10. Fruit indehiseent, 3-4-winged.

CYRILLACE.E, 272

Ovaries more than one.

$$
++++ \text { Stamens (the fertile ones) as many as the petals. }
$$

Flowers moncecious. Stamens united into a 5-lobed disk.

Flowers dicecious. Anthers 4-celled. Leaves simple. Anthers 2-celled. Leaves pinnate, dotted.

SCHIZAXDRE.E, 12 MEXISPERMACE.E, 15 RUTACE.E, 66

Flowers perfect. Style terminal. Orules pendulous. Style lateral. orules erect.

RANUNCULACEF; 2 SURIANACE.E, 149

Ovary solitary, 1-celled.

Flowers irregular. Fruit a legume Alhumen none.

Flowers regular. Capsule 3-ralved. Albumen fleshy.

LEGUMINOS.F, 86 VIOLACEE, 32

Flowers monøcious; the fertile ones apetalous. Fruit utricular. EUPIIORBIACE.E, 399

Flowers perfect.

Stamens opposite the petals.

Anthers opening by uplifted valves.

BERBERIDACE.E, 16

Anthers opening lengthwise.

Stamens and petals 3 . Stigmas many-parted.

CISTACE.E， 35

Stamens and petals 5 .

Leares a pair, opposite. Capsule 3 ralved, few-sceded. PORTULACACE.E, 43

Leares alternate: numerous. Capsule 2-valved.

BY'TTNERIACEE, 59

Leares at the base of a naked stem. Fruit a utricle.

Stamens alternate with the petals.

Leares opposite, dotted, exstipulate. Albumen none.

IIYPERICACE.E, 39 Leares opposite or whorled, dotless, stipulate. Albumen present. ILLECEBRE.E, 45 Leaves alternate Capsule 1-celled.

Leaves compound. Fruit a legume.

Leaves simple. Stamens with sterile ones between. Sterile stamens none.

Ovary solitar $\nabla, 2$-celled. Trees or shrubs.

Fruit a double samara. Leaves simple, opposite.

Fruit a single samara Leaves trifoliolate, al ternate.

Fruit a berry. Leaves palmately 5 -foliolate.

Fruit a drupe. Flowers perfect, racemose. Stamens 5.

Hlowers dicecious, elustered. Stamens 2.

MIMOSEE, 89

PARNASSIACE.E, 37 DROSERACEE, 36

ACERACE.E, 80 IITTACE.E, 66 VITACE.E, 70

CYRILLACE.E, 272

EUPETRACE.F, 410

GALACINEE, 268

Ovary solitary, 3-celled. Stamens united, the alternate ones sterile. Ovaries 4-celled, aggregated into a head. Diœcious.

BATIDACE.E, 411

Ovary 5-celled. Style single. Petals stalked.

Ovary 5-celled or falsely 10-celled. Styles 5. Petals sessile.

BYTTNERIACE.F, 58

LINACEE, 62

$$
++++ \text { Stamens fever than the petals. }
$$

Stamens 2. Petals 4, crueiform. Fruit a silicle.

CRUCIFER.E, 23

Stamens 2-3 Petals 5. Flowers regular. Leaves opposite.

Stamens 4. Petals 5. Flowers irregular. Leaves alternate.

* Stamens and petals inserted on the caly $x$, or on a more or less perigynous disk.

- Calyx not adherent to the ovary.

+ Stamens as many as the petals.

Stamens monadelphous around the stalk of the ovary.

PASSIFLORACEA, 147

Stamens separate, opposite the petals.

Calyx truncate Ovules 2 in each cell Woody vines.

VITACE.E, 70

Caly $x$ valvate. Orules single in the cells. Trees or shrubs.

RIIAMNACEE, 72 
Stamens suparate, alternate with the petals.

Hlerbs. Lestus alternate ('al) $x$ decillunus. ('apsule 1-celled. Ienves opposito. Calyx persistent. C'apsule 2 -4.celled.

TULYEERACF.F, 140

I. Y'TILAC'FA, 133

Trees or shrubs.

Fruit a doublo samara. Leares opposite. Styles 2.

Fruit a drupe. Ovary 1-celled. Albumen none. 0rary $2-5$-celled. Seeds with albumen. )

Fruit a capsule. Capsule tleshy. Seeds arilled.

ArVIRACF.F: 80 ANACARDIACF.F, 6

CELASTRACE.F, it Capsule 3-eelled, inflated. Leaves trifoliolate. STAPIVLFArk. Capsule 2-eelled, 2-beaked Leares simple. H:SCALLON1E.F, 151

+4 Stamens more numerous than the pelals.

Oraries more than one.

heaves alternate, stipulate.

leares alternate, exstipulate. Sueeulent herbs.

Jeares opposite, exstipulate. Sepals and petals numerous.

Orary solitary, 1-celled.

Fruit a drupe. Style arising from the base of the orary. Style terminal. Orules pendulous.

Fruit a legume. Flowers mostly irregular.

Orary solitary, $2-5$-celled.

Style siugle. Jeaves simple, opposite or whorled.

Ieares compound, dotted. l'etals ralrate.

Leares compound, dotless. P'etals imbrieated.

Styles 2. Leares alternate. Fruit a capsule.

Jeaves opposite. Fruit a double samara.

Styles 2-3, each 2-3-parted. Capsule 2-3-eelled.

Styles 3, entire. Petals elawed. Fruit a drupe.

licrbs.

+ + Calyx adherent to the otary.

Orary 1-celled. Capsule and 2-lobed ealyx cireumselssile.

PORTULACACEF, 43

Capsule 3-ralved. Caly $x 5$ parted. Leaves rough. LOASACE.F, 146

Orary $2-6$-celled.

style single. Anthers opening by a terminal pore. Lerres ribbed. IIELASTOMACET, 131 Anthers opening lengthwise. Leares ribless.

ONAGRACEF, 137

Styles or atigmas 2 or more.

Florers umbelled. Fruit dry, separating into 2 pieces.

Fruit berry-like, of $2-5$ nutlets.

Flowers not umbelled.

Flowers perfeet. Fruit eapsular. Leares alternate.

Flowers monoeious. Fruit nut-like. Leaves whorled.

Shrubs or trees.

Leares opposite.

Fruit dry, variously dehiscent, many-seeded.

Fruit indehiseent, 1-2-seeded.

Stipules between the petioles.

Stipules none. Leares dotted. Stamens numerous.

Leares dotless. Stamens 4. Orary 2-celled.

Leaves dotless. Stamens 10. Ovary 1-celled.

Leares alternate.

Flowers umbelled Leares compound.

Flowers not umbelled.

Leares stipulate. Fruit fleahy or baccate, Indehiscent.

Fruit dry; woody, 2-valred.

UNBELLJFER A, 157

ARALIACEZ, 166

SAXIFRAGACEF, 151

HALOKAGE.E, 137

IIYDRANGE,F, 151

RIIZOPIIORACE.F, 135 MYRTACEF, 130

CORNACEE, 167

COMBRETACEA, 136

ARALIACEX, 166

POME.E, 118

IIAMAYELACE.E, 156

Leares exstipulate.

Flowers dicelous. Drupe baccate. Sterile flowers apetalous. CORNACE $\mathbf{E}, 167$ 
ARTIFICIAL ANALYSIS OF THE NATURAL ORDERS. XXXii

Flowers perfeet. Ovary 3-cellect. Fruit a 2-winged nut. Ovary $2-5$-celled. Fruit a 1 -5-seeded berry. $\}$ STYRACACE. Ovary 1-celled, with two parietal placentr. GROSSULACE.F, 145 Ovary 1-celled, with sumerous placenta. CACTACE.E, 141

\section{Division II. MONOPETALOUS EXOGENOUS PLANTS.}

Floral envelopes double, consisting of both ealyx and corolla; the latter of more or less united petals.

* Calyx free from the ovary.

- Flowers regular.

+ Fertile stamens fewer than the lobes of the corolla.

Fruit a 1-seeded fleshy drupe. Evergreen shrubs or trees.

OLEACE E, 368

Fruit separating into $2-4$ nutlets.

Orary 4-lobed; the style rising from between the lobes.

LABIATE, 310

Ovary not lobed; the style terminal.

VERBENACEA, 305

Fruit a 2-eelled capsule.

Capsule eircumscissile. Leares alternate, raclical.

Capsule 2-valved. Corolla-lobes imbricated in the bud. Ccrolla-lobes twisted in the bud.

PLANTAGINACEA, 277 SCROPHULARIACE.E, 287 ACANTIIACELE, 302

++ t+ Fertile stamens as many as the lobes of the corolla and opposite them.

Herbs. Capsuie 1-eelled, many-seeded.

PRIMULACEF, 279

Trees or shrubs, rarely herbs.

Anthers introrse. Calyx plaited, glandular. Fruit a utricle. PLUMBAGINACE. 278 Calyx not plaited. Fruit a drupe. Embryo transverse. MYRSINACE.E, 276

Antbers extrorse. Ovary 1-celled. Flowers racen:ose. Ovary $3-8$-celled. Flowers clustered. THEOPHRASTACEE, $27 \%$ SAPOTACEI, 274

+++ Fertile stamcns as many as the lobes of the corolla and alternate with them.

Oraries 2 , separate.

Juice milky.

Stamens united with the stigmas into a mass.

Stameus separate aud free from the stigma.

Juice not milky. Stems creeping. Utricle 1-seeded.

Ovary solitary.

Fruit indehiscent.

Leaves opposite.

Ovary 2-celled. Drupe 1-seeded. Corolla-lobes long.

Ovary 4-celled. Drupe 4 -seeded. Corolla-lobes short.

Leares alteruate.

Flowers diøecious. Fruit baccate, $4 \sim 9-$ seeded.

Flowers perfect.

Ovary 2-celled. Corolla plaited or valvate.

ovary 4-celled. Corolla mostly imbrieated in the bud.

Fruit a capsule.

Capsule circumscissile. Flowers on a scape.

Capsule dehiscent by ralves.

Ovary 1-celled. Leaves lobed, hairy or pubescent. Leaves entire, smooth.

Ovary 2-5-celled.

Stipules membranous or annular between the opposite leaves.
ASCLEPIADACEA, 361 APOCYNACE, 358 DICHONDRE, 3 , 11

OLEACEE, 368 VERDENACE $\boldsymbol{E}, 305$

AQUIFOLIACE.E, 268 SOLANACEA, 347 BORRAGINACF.E, $32 S$

PLANTAGINACEE, 2\%

HYDROPHYLLACEE, 333

GENTIANACEA, 352

LOGANIE_E, 173 


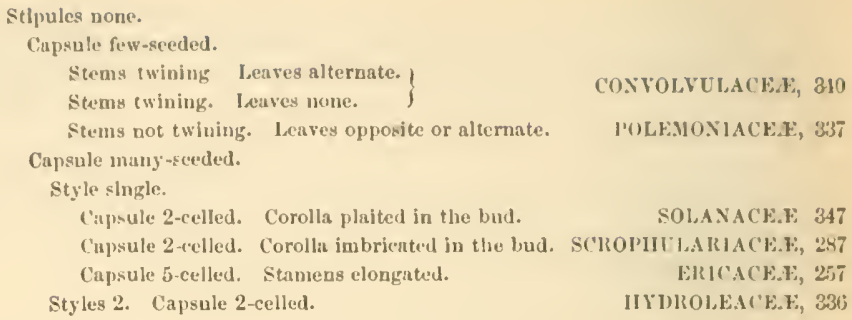

+++++ Stamens more numerous than the lobes of the corolla

Leares compound, stlpulate. Fruit a legume.

MIIJOSE.T, 88

Leaves simple.

Flowers diocious, Ovary 8-eelled, Fruit a berry.

EBENACKF, 273

Flowers perfect. Stamens numerous.

Stamens united into a eolumn. Anthers 1-celled.

IALYACE.F, 52

Stamens united in a ring or in elusters at the base.

Flowers perfect. Stamens twice as many as the corolla-lobes.

Corolla-lobes imbrieated in the bud. Capsule many-seeded.

Corolla-lobes valvate jn the bud. Drupe 1 -seeded.

ERICACE.T, 25T

OLACACEE, 61

+ Flowers irregular.

Stamens 6. Calyx or 2 sepals. Capsule 1-eelled.

FUMARIACE.F, 22

Stamens (the fertile ones) 2 or 4.

Ovary 1-celled. Stamens 2. Corolla spurred.

LENTIBULACEE, 282

Stamens 4. Fruit 1-seeded, reflexed.

PIIRYME.F, 306

Stamens 4. Fruit many-seeded. Leaves scaly. OROBA.icIICE.F, 286

Ovary 2-celled.

Albumen copious. Corolla imbricated in the bud.

SCROPIIULARIACE.E, 287

Albumen none

Pliteenta with hooked appendages. Corolla twisted in the bud. ACANTIIACEF, 302

Placentr not appendaged. Capsule large.

BIGNONIACE.E, 284

Ovary 4-celled.

Ovary 4-lobed; the style rising from between the lobes.

LAB1AT.F, 310

Ovary not lobed. Style terminal.

VERBENACEF, 305

Anthers united.

* Calyx more or less adherent to the ovary.

Anthers contorted. Vines climbing by tendrils.

CUCURBITACEE, 148

Anthers straight. Flowers in a raeeme. Fruit a many-keeded capsule. LOBELIACE E, 253 Flowers in a raceme. Fruit a $1-4$-seeded drupe. IRBIACE $E_{3} 172$ Flowers in a head. Fruit a dry achenjum. COMPOSIT 184

Anthers separate. Ienres opposite or whorled.

Leares eonneeted by stipules, or whorled.

Stipules none. Stamens as many as the lobes of the corolla.

RUBIACE.æ, 172

Stamens fewer than the lobes of the corolla.

CAPRIFOLIACE.F, 169

VALEIRIANACEE, 183

Anthers separate. Leaves alternate.

Herbs.

Corolla-lohes valvate in the bud. Capsule opening at the sides.

Corolln-lobes imbricated in the bud. Capsule ralrate.

Sbrubs. Flowers irregular. Stigma within a ciliate cup.

Flowers regular. Anthers opening by a terminal chink.

Flowers regular. Antbers opening lengthwise.

CAYPANULACEA, 256

PRINULACEF, 279

GOODEN1ACEF, 255

PACCINIE, 257

STYRACACE.E, 2T0 


\section{ARTIFICIAL ANALYSIS OF THE NATURAL ORDERS. XXXV}

\section{Division III. APETALOUS EXOGENOUS PLANTS.}

Floral envelopes single, consisting of a calyx only, or altogether wanting.

* Amentacecus trees or shrubs. Flowers monccious or diacious.

- Sterile fowers only in aments.

Leaves simple, stipulate. Involucre scaly. Secd entire.

CUPULIFER E, 420

Leares pincate, exstipulate. Involucre none. Seed 4-lobed.

JUGLANDACEA, 418

+ + Both the sterile and fertile flowers in aments.

Aments globose. Calyx none.

Fruit 2 -heaked, 2-valved, many-seeded. Sterile aments spiked. HAMAMELACE.E, 156

Fruit nut-like, 1-seeded, hairy. Aments single.

PLATANACE.E, 417

Aments oblong or linear.

Orary 1-celled. Drupe 1-seeded. Stipules none.

Capsule 2-ralved, mauy-seeded. Seed comose.

MYRICACEF, 426

SALICACEA, 429

BETULACE.E, 428

Ovary 2-celled. Fruit dry, angled or winged.

Fruit enclosed in the confluent berry-like calyx.

MORACEE, 414

* Flowers not in aments.

- Calyx and corolla none.

Ovaries 3-4, united below. Flowers perfect, spiked.

SAURURACE.E, 397

Ovary single.

Involucre none. Capsule 4-celled. Aquatic.

Involucre spathe-like. Styles 2 . Leaves alternate, parted.

CALLITRICHACE.E, 398

PODOSTEMACE.F, 399

Involucre 8-12-parted. Style one. Leaves whorled, forked. CERATOPIIYLACEA, 398

Involucre 4-5-toothed, cup-like, containing one fertile flower and

several sterile ones, each reduced to a single stamen.

ECPHORBIACE.E, 399

Ovaries more than one.

+ - Calyx herbaceous or corolla-like.

Stamens iuserted on the calyx. Leaves stipulate.

ROSACE.E, 117

Stamens hy pogynous. Stipules none.

Embryo minute.

Embryo and seeds large, curved.

RANUNCULACEE, 2 MENISPERMACE.E, 15

Ovary solitary.

Calyx adherent to the ovary.

Ovary 1-celled.

Fruit a 2-valved, many-seeded capsule.

Fruit indehiscent, 1-seeded.

Anthers (and stigna) sessile. Tree parasites.

Anthers on filanents.

Drupe berry-like. Stigma decurrent.

Drupe dry. Albumen copious

Drupe dry. Albumen none.

Ovary 6-celled, many-ovuled. Calyx tubular.

Ovary 4-celled, many-oruled. Stigma capitate.

Ovary 3-celled, 3-ovuled. Stigmas 3. Leaves dissected.

Ovary 2-3-celled. Capsule 2-valved. Leaves alternate. Fruit a berry. Leares opposite.

SAXIFRAGACEE, 151

LORANTIIACEE, 397 .

CORNACE.F, 167

SANTALACE.E, 395

COMBRETACE 136 ARISTOLOCHIACE.E, 371

ONAGRACEE, 137

HAMAMELACEF, 156 MYRTACE.E, 130

Calyx free from the ovary.

Ovary 1-celled.

Orules and seeds numerous.

Vines. Fruit berry-like.

Stems erect. Capsule circumscissile. 
Orule and seed solitary. Lenves stlpulate.

stipules sherathing. Idaves alturnate.

stipuley searious. Leaves opposite.

POLYGONACE.F, 381

stjpules not shenthing nor scurious.

Flowern perfect Aclunium 2-lobed, spiny.

II,LECEBIREF, 45

Flowers imperfect.

Lurbs. Steus twining. Leares $3-\overline{-}$-lobed.

Stems not twining. Luses serrate or entire.

PETIVEIRIE.F, 3T4

Trees or slarubs.

Juice watery. Flowers single or elustered.

Juice milky. Flowers iucluded in a tleshy receptacle.

CAXXABIXACE.F, 414

LITICAC'E.F, 411

ILIACE.F, 416

MORACE.F, 414

Orule and sced solitary. Leaves without stipules.

Stamens more numerous than the calyx-lobes.

Anthers opening by valves.

LACRACE.E, 3.13

Anthers opening lengthwise.

Caly $\times 5-6$-parted.

POLYGOSACE.K, 394

Calyx entire. Berry oval.

TIIYIEI.E.AC'L.F, 395

Stamens equalling in number or fewer than the calyx-iobes.

Flowers with searious bracts

AHARANTACL.F, 378

Flowers without searious bracts.

Caly $x$ corolla-like, plaited.

Calyx herbaceous. Styles 2.

NYCTAGISARE.E 372

CIIFOPOULACE.F, 375

Ovary 2-12-celled.

Leaves whorled

A heath-like shrub Caly $x$ of inbrieated scales.

A prostrate annual. Caly $x$ corolla-like.

F.IPETRACE.E, 410

MOLLCGINE.E， 45

Leares opposite

Fruit a single samara. Caly $x$ minute, persistent.

Pruit a double samara Calyx deciduous.

Fruit a drupe.

Flowers perfect. Stamens on the calyx.

Flowers diocious. Stumens hypogynous.

Fruit a many-seeded capsule. IIerbs.

FI.AXIXE.F, 369

ACERACE.E, 80

RIIAMNACE.E, 72

FOKESTIERE.E, 369

LYTHRACLE, 133

Leares alternate.

Orules and seeds $1-2$ in each cell.

Flowers mono-diucious. Fruit a drupe or capsule.

Flowers polygamous Capsule 3-4-winged.

EUPIORВIACE.F, 399

S.PINUACE.E, 78

Flowers perfect or polygamous.

Fruit a berry. Calyx eolored.

PIYTOLACCACE.F, 3it

Fruit a samara. Leares stipulate

Orules and seeds numerous in the cells. Capsule circumscissile.

Capsule 3-celled Flowers solitary.

LLMACE.E, 416

Capsule 5-celled Flowers cymose.

PORTLLACACE.F, 43

CRASSULACE.E, 149

\section{Subchass II. GTMNOSPERMOL'S EXOGENOL'S PLANTS.}

Orules naked (not contained in an ovary), supported by an open scale or leaf, or else terminating a branch, and fertilized by the direct application of the pollen.

Stem branching. Leaves simple.

CONIFERE 431

Stem simple, palm-like. Leaves pinnate.

CYCADACEE, 437 
ARTIFICIAL ANALYSIS OF TIE NATURAL ORDERS. XXXVii

\section{Class II. MONOCOTYLEDONOUS OR ENDOGENOUS PLANTS.}

Stem composed of cellular tissue and scattered bundles of woody fibre and ressels, destitute of proper pith, bark, or concentric layers, and increasing in diameter by the deposition of new fibrous bundles. Leaves mostly alternate, entire, and parallel-veined, commonly sheathing at the base, seldom falling off by an artienlation. Floral envelopes usually by threes. Cotyledon single.

\section{* Floral envelopes none. Flowers on a spadix.}

Stemless, floating herbs.

Plants frond-like, with no distinction of stem and leaves.

LEMNACE.E, 442

Leaves clustered, spreading. Flowers axillary.

Caulescent, leafy, rooting herbs.

Fruit a berry. Spadix enclosed in a spathe.

Fruit an achenium. Stem immersed, floating.

ARACE王, 439

Stem not inmersed, erect.

Pistia in ARACE.E, 439

NAIADACEE, 414

TYPHACFE, 443

* Floral envelopes (perianth) single or double, not glumaceous.

Ovary adherent to the perianth.

Stamens and pistil united into a column. Flowers irregular.

ORCHIDACE.E, 452

Stamens and pistil separate.

Flowers monocious or dioecious.

Flowers enclosed in a spathe in the bud. Aquatics. HYDROCIIARIDACE. 450

Flovers without a spathe. Leaves reticulate. Terrestrial vines. DIOSCOREACE.E, 474

Flowers perfect.

Ovary 1-celled. Stamens 3. Leaves minute.

Ovary 3-celled. Stamen 1. Flowers irregular.

BURMANNIACE.E, 451

CANNACE.E, 465

Stamens 3. Anthers extrorse.

IRIDACE.E, 472

Stamens 3 or 6. Perianth woolly or scurfy. HAIODORACE.E 469

Ovary free from the perianth.

Stamens 6. Perianth smooth or hairy. AMARYLLIDACE.E, 466

Perianth single (caly $\mathrm{x}$ ).

Flowers on a spadix. Ovary solitary.

Ovaries 4. Stem leafy.

ARACE, 439

NAIADACE.F, 444

Flowers on a seape, spiked. Leaves rush-like.

JUNCAGINEE, 447

Flowers on axillary peduncles. Leaves oval.

ROXBURGHIACEE, 479

Perianth double (calyx and corolla).

Caly $x$ and corolla alike, or nearly so, and glume-like.

JUNCACEÆ, 492

Caly $x$ and corolla alike, or nearly so, and not glume-like.

Leaves ribbed and netted-veined. Fruit a berry.

SMILACEE, 475

Leaves parallel-reined.

Capsule l-celled. Stamens, or the fertile ones, three PONTEDERIACE.E, 496

Capsule or berry 3- (rarely 4 or 6-) celled.

Anthers introrse (except Lilium). Style single.

Stigmas 3 , nearly sessile.

LILIACE.E, 480

Styles 3.

Anthers extrorse (except Tofieldia). Styles 3 or 1 .

Calyx and corolla unlike.

Ovaries few or numerous, forming achenia in fruit.

Ovary solitary.

Palms. Calyx tubular. Leaves fan-shaped.

Epiphytes Plants scurfy.
MELANTHACEE, 485

ALISMACE.E, $44 \overline{\%}$

PALME, 437

BROMIELIACE.E, 470 
Uerbs. Stamens 6. Leaves 3 in a whorl. Flower aingle. leaves alternate, klueathing.

TRILLIACE.E 475 COMMELYNACEF, 497 Stamens 3. Flowers perfect, solitary. Stem leafy. M.IYACACE.F, 498 Hlowers perfect, capitate. Scape leafless. XYRIDACE, Strmens 3 or 4. Flowers uouocious, capitate. Scape lealless.

ERIOCAULONACEF, 02

* Flowers glumaceous, i.e. with scale-like bracts, in place of proper floral envelopes.

Bracts single. Sheaths closed. Fruit an achenium.

Bracts by pairs. Sheatlus open. Fruit a caryopsis.

CY'ERACEN, 504, GRAJINE.k, 545

\section{SERIES II. CRYPTOGAMOUS OR FLOWERLESS PLANTS.}

Plants destitute of proper flowers, and producing, in place of seeds, minute bodies (spores) which do not contain an embryo.

\section{Class III. ACROGENS.}

Plants with a distinct stem containing woody and vascular tissue, growing from the apex only.

Fructification borne on the under side of a peltate scale.

Fructification borne on the back or margins of the leaves (fronds).

EQUISETACE.E, 285

Fructifieation borne in the axil of small leaves or bracts.

FILICES, 585

Fructification borne at the base of the luaves.

LYCOPODIACE.E, 600 HYDROPTERIDES, $60 \%$ 


\section{F L O R A}

OF THE

\section{SOUTHER U N I T E D S T A T ES.}

\section{SER IES I.}

\section{PHENOGAMOUS OR FLOWERING PLANTS.}

VEGETABLEs furmished with flowers, consisting of stamens and pistils, and usually floral envelopes of some kind, and producing seeds which contain an embryo.

Class I. DICOTYLEDONOUS OR EXOGENOUS PLANTS.

Stem composed of bark and pith, which are separated by an interposed layer of woody fibre and vessels, and increasing in diameter, in all perennial stems, by the annual deposition of new layers between the wood and bark. Leaves reticulate-veined, commonly articulated with the stem. Floral enrelopes usually in fours or fives. Cotyledons two, rarely more.

\section{Subclass I. ANGIOSPERMA.}

Orules enclosed in an orary, and fertilized by the action of the pollen, through the medium of a stigma. Cotyledons two.

Division I. POLYPETALOUS ExOGENOUS PLANTS.

Floral envelopes double, consisting of both calyx and corolla; the latter of separate petals. 


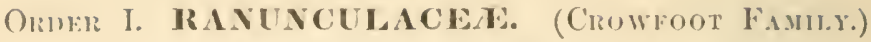

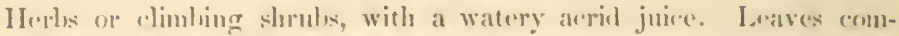
monly divielede their petjoles dilated at the base, withont stipules. Flowers recrular or imegular. Sipals $3-15$, distimet, oflen colomed.

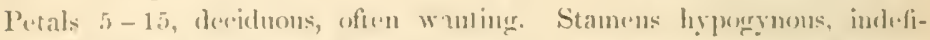

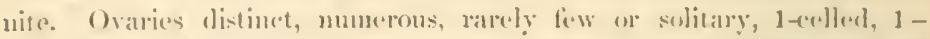
many-ovulerl. Fruit dry or baceate. Embryo minutw at the base of treshy or horny albumen.

\section{Synopsis of the Genera.}

Tribe I. CIICMATIDFA. Sepals valvate in the bud, colored. Pelfals stamen-like or none. Style elonguted, persistent. Fruit an achenium. - Chicfly vines. Leaves opposite.

1. ATIAGENE. Petals small and stamen-like.

2. CLEMATIS. Pelals none.

Trube IT. ANEMONEF. Sepals inobricated in the hul, colored. Petals none. (1vules solitiry. Fruit an achesium. - Ilerbs. Floral leares often whorled, forning :tn involucre.

3. A.EMCNi\%. Involucre leaf-like and distant from the long-peduncled flowers.

4. IIEPATICA. Involucre ealyx-like and clove to the flower.

5. TIlALICTRLy. Flowers panicled and without an involucre (except in No. 6). Achenia ribbel or inflated. Leaves compound.

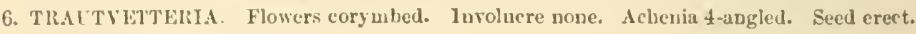
Leares simple, lobed.

Trinf III. IR A NUXCI.EA. Sepals imbricated in the bud, mostly herbaceous. Petals munifest. Ovules solitary. Fruit an achenium. - llerbs. Leaves alt rnate.

7. MYOstilis. Sepals spurred at the base. Achenia spikel. leaves radical, linear.

8. RALYCULUS. Sepals spurless. Achenia capitate. Stems leafy.

TRIBE IV. IIELLEIBOIRINA. Sepals ionbricated in the bud, colored. I'etals of various forms, or none. Fruit a 1-many-seeded follicle. Leaves alternate.

9. CALTHI Petals none. Foilicle many-seeded. Sepals yellow. Leaves simple.

10. 1SOPYruy. Petals none. Follicle few-seded. Sepals white. Leares ermpound.

11. AQV'llefil. Sepals 5, regular. Petals 5, spur-shaped, hollow. Follicle many-seeded. Leares compound.

12. DELPIIIII: Sepals 5, irregular; the outer one spurrel. Petals 4 , suall; two of them spurred, the others stalked. Follicle many-seeded. Leares loled.

13. ACONitLM Sepals 5. irregular: the outer one large, honded, and enelosing two longstalked, hookerl petals; the other petals stamen-like or wanting. Follicle many-seeded. Leaves lobed.

14. ZANTHORIIZA. Flowers reqular Sepals and petals 5; the latter 2-lobed. Follicle 1-2-seceded. Shrubby. leaves compound.

Tribe Y. CIUICIFCFF: S. Sepals imbricated in the buid, colored. Petals small and flat, or none. Fruit a follicle or berry- - Jerbs. Lenves alternate.

15 IIYDR.LSTIS. Petals none. Oviries numerous, forming a head of $\mathbf{I}-2$-seeded berries. Stems l-flowered. Leares simple, loherl.

16. ACT.FA. Petals 4-8, entire. Ovary solitary, forming a many-secded berry. Flowers in short oblong racemes. Lcaves compound.

17. CIMICIFCGA. Petals 3-5 2-cleft. Ovaries 1-8, forming many-seeded follicles. Racemes elongated. Leaves compound. 


\section{ATRAGENE, L.}

Sepals 4, colored, membranaceous, spreading, valvate in the bud, deciduous. Petals numerous, stamen-like. Stamens indefinite. Ovaries numerous, 1-ovuled. Achenia capitate, bearing the persistent styles in the form of long plumose-bearded tails. Seed suspended. - Shrubly rines, climbing by the petioles. Leaves opposite, compound, from scaly buds. Flowers solitary, showy.

1. A. Americana, Sims. Leaves in opposite pairs, ternate; leaflets stalkel, ovate, acute, entire or toothed, sometimes slightly corlate; peduncles opposite; sepals oblong-ovate. - Mountains of North Carolina and northward. April - May. - Flowers $2^{\prime}-3^{\prime}$ in diameter, purple.

\section{CLEMATIS, L. Virgix's-Bower.}

Petals none. Persistent styles naked or plnmose. Otherwise as Atragene. Herbs or shrubby vines. Leaves simple or componnd, opposite. Buds not scaly. Flowers solitary or panicled, often polygamous or dicecious.

\section{* Flovers solitary, nodding: calyx thich or leathery. - Stems erect, nostly simple, herbuceous.}

1. C. ochroleuca, Ait. Silky-pubescent; leaves ovate or roundish, entire, reticulate, nearly sessile, at length smooth above; tails of the achenia ( $1 \frac{11}{2}$ long) plumose. - Upper districts of Georgia and northward. May - June. Stens $1^{\circ}$ high. Flowers yellowish, $1^{\prime}$ long.

2. C. Baldwinii, Torr. \& Gray. Stems mostly simple, slender, slightly pubescent; leaves oblong, varying to linear-lanceolate, entire, or with three often divided lobes; perluncles elongated; tails of the achenia $\left(2^{\prime}-3^{\prime}\right.$ long) very slender, plumose. - South Florida. - Stems $10-1 \frac{1}{2}$ high. I'eduncles $8^{\prime}-10^{\prime}$ long. Flowers purple, yellowish within, the sepals woolly on the margins.

\section{+ + Stems climling, lerbuceous.}

3. C. ovata, Pursh. Smooth; stems erect or climbing; leaves broadly ovate, short-petioled, reticulate, glaucous beneath, the lowest sometimes compound or corlate; sepals orate, aeuminate, pubcscent on the margins; tails of the achenia very long, plumose. - Mountains of Georgia, Carolina, and Tennessee. - Flowers purple?, inclined. - Probably a form of the next. (*)

4. C. Viorna, L. Smoothish; leaves pinnate; leaflets 5-7, oval, or oblong-ovate, mostly acute, somewhat membranaceons, entire or 2-3-lobed, the lowest pair often ternate; calyx ovate ; sepals ovate, tapering into a short recurved point, not margined, rather longer than the stamens; tails of the achenia (1 $1 \frac{1}{2}$ long) plumose. - River-banks. May-August. - Flowers noulding. Sepals thick, reddish purple, $l^{\prime}$ long.

5. C. crispa, L. Stem sparingly pubescent; leaves pinuate; leaflets 5-7 ovate, thin, 3-lohed or ternate; those of the upper leaves entire, of the lowest lanceolate or linear; calyx campanulate; sepals lanccolate, acminate, twice as long as the stamens, the margins broad and wavy ; tails of the achenia ( $l^{\prime}$ long) rigid; silky-pubesent. (C. Walteri, Pursh. C. cylinchiea, Sins. C. line- 


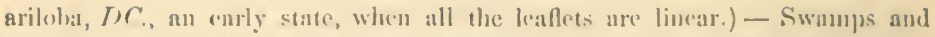
banks of rivers. Maly aml Jume. - Strms $2^{\circ}-4^{\circ}$ high, somewhat slirubby at the base. Flowers 1'- $1 \frac{1}{2}$ long, pale bluish-purple.

6. C. reticulata, Wait. Sumoth; lesves pinnate; leallets $7-9$, oval,

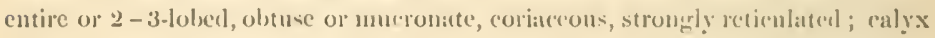
ovate; sepals ovate-lancecolate, witl spreadling tips, not margined, longer than the stamens; tails of the acheniat ( $1 \frac{1}{2}$ ' long) slemeler, phnnese. - l)ry samly soil, Florida to South Cnrolina. May - July. - Calyx downy, dull puple.

* Flowers panicled: calyx thin, spreading, uhite: stems voody.

7. C. Virginiana, L. Smootlı ; leaves ternate; leaflets ovate or cordateovate, loberl or toothed; panicle trichotomons, many-lowered, leafy ; flowers dicecious or polvganons; sepals obovate, smoothish ; tails of the achenia long, plumose. - Swanps and mealows. July. - Leallets $2^{\prime}-3^{\prime}$ long.

8. C. Catesbyana, Purslı. Pubescent; leaves hiteruate; leaflets ovate, mostly cordate, 3-toothed or lobed; panicte lenfy, many-flowered, the branclies divaricate, opposite, 3-5-flowered; flowers diacions; sepals oblong, loary ; tails of the achenia plumose. - I)ry sandy soil, near the const, Floridit to Suuth Carolina, and westward. July. - Stem climbing high. Leawes and flowers smaller than the last.

9. C. holosericea, Pursh. Silky-pubesecnt ; leaves ternate; leaflets ublong-lanceulate, entire; flowers diocious, in paniculate corynlss; sepals linear, longer than the stamens; tails of the achenia very long, plumose. - South Carolina, Walter. - Flowers small, white. (*)

\section{ANEMONE, L. WIND-FLOWER.}

Sepals 4-20, colored, imbricated in the burl, deciluous. I'etals none. Stamens inlefinite. Filaments filiform. Ovaries numerous. Ovule solitary. Achenia capitate, compressed, pointed by the short, naked or woolly, straight or hooked, persistent style. Seed suspended. - Perenuial herbs, with nakerl stems, bearing at the summit $2-3$ opposite or whorled and divided leaves, which form an involuere remote from the flower. Radical leaves lobed or divided.

1. A. nemorosa, L. (Woov Axevoxe.) Smootl or pulesent; stem 1-flowered; leaves of the involuere 3 , long-perioled, 3-parted, the divisions ovatelanceolate, lobed and toother, longer than the peduncle; s'jals $4-6$, oval, white; achenia 15-20, pointed by the hooked persistent style. -Open wools alongr the mountains and northward. March-April. - Stems $4^{\prime}-6^{\prime}$ high. Radical leaf solitury.

2. A. Caroliniana, Walt. (Cumolosi Axemoxe.) Stem slender, 1-flowered; peduncle many times longer than the small, sessile, 3-leaved, 3-toothed involucre; radieal leaves $2-3$, long-petioler, ternate, deeply parted, lohed and toothed; sepals $1+-20$, ollong, white; adhenia munerous in a cylindrical-oblong heal, woolly. - North Carolina and westward. March. - Stenis $6^{\prime}-12^{\prime}$ ligh. Flowers $1^{\prime}$ in diameter. 
3. A. Virginiana, L. (Vingrnia Axemone.) Stem hairy or woolly, at length many-flowered; peduneles elongated, the earliest one simple; lateral ones several times forking, and bearing a 2-leavel involucre and a single flower at each joint; proper involucre 3-leaved, the leaves long-petioled, 3-parted, with ovate or oblong lobed and toothed divisions; sepals 5, oval, greenish, acute; aclenia numerous, in an oblong head, woolly. - Open woods in the uprer districts, and northward. July - September, - Plant $2^{\circ}-3^{\circ}$ high. Flower $8^{\prime \prime}-9^{\prime \prime}$ in diameter. Radical leaves $3-4$, similar to the involuere.

\section{HePATICA, Dill. Liver-leaf.}

Flowers and fruit as Anemone. Involucre close to the flower, 3-leaved, resembling a calyx; its leaves sessile, ovate, entire. - A low, perennial herb, with seape-like, 1-flowered stems, and 3-lobed, long-petioled, cordate, persistent, radical leaves.

1. H. triloba, Chaix. Lobes of the leaves rounded, entire; stems hairy; flowers purplish or white; achenia oblong, hairy. - Shady woods, Florila and northward. February - March. - Stems $3^{\prime}-6^{\prime}$ ligh.

\section{ThatiCtrum, Tourn. Meadow-Rue.}

Sepals 4-10, imbrieated in the bud, colored, spreading, decidnous. Petals none. Stamens numerous. Filaments filiform, elavate or flattenel. Ovaries $3-15,1$-ovuled. Achenia sessile or stalked, furrowed or inflated, pointed by the sessile persistent stigna or short style. Seel suspended.-Peremial herbs. Leaves compound.

* Flowers polygamous or dieccious: sepuls shorter than the stamens : stigma elongated: achenia nearly sessile, ribbed: leaves alternate, decompound: involucre none: flowers small, panicled.

1. T. dioicum, L. Stems ereet; leares long-petioled; leaflets thin, roundisl, crenately $5-7$-lobed, smooth; flowers numerons; sepals greenish ; stamens and stigma filiform; achenia sessile, or (in var. stipitat U., Torr. $g^{*}$ Gray) distinctly stalked. (T. rugosum \& T. Carolinianum, $D C_{\text {.) }}$ - Mountains of North Carolina and northward. July - August. - Stem $1^{\circ}-1 \frac{1}{2}{ }^{\circ}$ high.

2. T. debile, Buckl. Stems low $\left(8^{\prime}-12^{\prime}\right)$, procumbent or aseending, much branched ; leaves long-petioled ; leaflets small, stalkel, rounded, erenately lobed, smooth; flowers few on axillary or terninal peduneles; achenia oblong, strongly ribbed, slıort-stalked, as long as the slender style. - Rich wooks, near Allenton, Wilcox County, Alabama (Buckley). March and April. - Stems brancling at the base, slender.

3. T. Cornuti, L. Radieal leaves long-petioled; sten-leaves sessile (the common petiole wanting) ; leaflets thick, oval or oblong, 3-lobed or entire, of ten cordate, smooth, or pubescent beneatlı; sepals white ; stamens and stigma slightly clavate; achenia short-stalked. (T. revolutum, LC.) - Meadows and woods, Florila and northward. June - Angust. - Stens $3^{\circ}-4^{\circ}$ high. Radical leaves very large. Leafets varying greatly in size. 
* Flouers perfict: sepuls lonyer than the stumens: stiyma short: ucliruia raissd on "stipe, influted, exiny: leuces ternate or biternute, ultermute: flowers fer, paniclel.

4. T. clavatum, J)(. Stems stender, sparingly brunched, naked below; leaves petioled, biternate; leatlets thin, romded, crenately lobed, glancous beneath; panicle corymbose, fow-many.flowered ; flowers small, white ; nheluia 5-10, somewhat cresernt-shapenl, short-pointed, long-stalked. - Mountains of North Carolina to Alubuma. July. - Stems $1^{\circ}-2^{\circ}$ highth.

5. T. nudicaule, Schwcinitz. Stem skender, naked leclow, sparingry lnanched above; radienl leaf' solitury, long-petioled, biternate; stem-leaves very small, ternate; leaflets thin, roundish, obtusely lobed, slighlitly cordate; paniclo 4-8-flowered ; flowers minute, greenish; ovaries short-stalked. - 13anks of tho Yadkin liver, North Carolina. - Stem $2^{\circ}$ high.

* * *locers perfort: sepuls longen thun the stunens: stumme inpressod: achenia sessile, ribbed: stem-leaves whortal: floreers umbrilled.

6. T. anemonoides, Michx. Radical leaves biternate, long-petioled; leaflets oval or roundish, cordate, $3-5$-lohed ; stem-leave's $2-3$, sessile, teruate; the long-stalked leaflets forming an involuce apparently of $6-9$ simple leaves; umbel 3-6-1lowered; sejuls 6-10, white. - Woods, Floridat to Misissippi, and northward. April and Mity. - Root tuberous. Stems $6^{\prime}-10^{\prime}$ high. Flow$\operatorname{crs} \frac{1}{2}^{\prime}-\frac{3}{4}$ in diameter.

\section{TRAUTVETTERIA, Fisch. \& Mey.}

Sepals 3-5, orbicular, imbricated in the bul, colored, ('alucous. Petals none. Stamens indefinite; filaments clavate. Ovaries muserous, 1-ovuled. Stignat recurved. Achenia (apitate, gilbons, 4 -sided, beaked by the looked persistent stigma. Seed ereet. - Erect, perennial herbs, witl alternate, palmately-lobed leaves, and corymbose flowers.

1. T. palmata, Fisch. \& Mey. Smooth; stem $\left(2^{\circ}-4^{\circ}\right.$ high $)$ simple or sparingly lmanched ahove; leaves uniform, reticulate, divided into 5-9 lanreolite, toothed and serrate loles ; those of the root broarl $\left(t^{\prime}-6^{\prime}\right)$, long-petioled ; eorymb many-flowered. - Margins of moutain streams, Georgia, Tennessec, and northward.

\section{MYOSURUS, L. Mouse-talL.}

Sepals 5-7, imbricated in the bud, spurred at the base. Petals $5-7$, linearspatulate. Stamens 5-20: filiments filiform. Ovaries munerous, l-ovuled. Style sululate. Achenia 3-angled, imbricated on the filiform, elongated reepptacle. Seed suspended. - Small annuls, with linear radical leaves, and small, solitary, yellowish flowers, on a naked seape.

1. M. minimus, $I_{4}$. Seapes $2^{\prime}-f^{\prime}$ long, longer than the leaves; achenia beakless. - Ingusta, Georgia (Ellott), and westward. $\Lambda$ pril. - Fruiting-spike linear, 1' -2 ' long. 


\section{RANUNCULUS, L. Crowfoot. Buttercep.}

Sepals 3-5, regular, herbaceous, concave, imbricated in the loud, deciduons. Petals 3-10, dilated, flat, furnished with a pit or scale at the narrowed base. Stamens mostly numerous. Filaments filiform. Oraries few or numerous, I-ovuled. Style short, subulate. Achenia capitate, compressed, locaked with the smooth, persistent style. Seed erect.- Ierhs. Leaves altemate, the radical ones long-petioled. Flowers axillary or somewhat corymbed, white or yellow.

\$1. Patuls whte, with a yellow pit at the luse: arheniu rugose.

1. R. aquatilis, L. Stems filiform, immersed; leaves petioled, divided into an indefinite number of eapillary segrments ; flowers axillary, remote, longpelumeled. (R. Pantothrix, $D C$ ) - Slow-flowing streams in the upper districts. July and August. 4. - Stems $1^{\circ}-2^{\circ}$ long. Leaves circular in ontline.

\section{$\$ 2$ Petals yellow, with a small scale at the base.}

* Acheniu muricute: ammuals.

2. R. parviflorus, L. Silky-pubesent; leaves small, the lower ones circular, 3-lobed, acntely-toothed ; the upper 3-parterl or entire; flowers very small; petals $3-5$, as long as the reflexed sepals; arhenia narrowly margineil, pointer with the short, recurvel style. (R. trachyspermus, Ell.) - Waste places. April am May. - Stens erect, branching from the base, $6^{\prime}-12^{\prime}$ high. Leaves rarely $\mathrm{I}^{\prime}$ wide.

3. R. muricatus, L. Nearly smooth; lower leaves 3-lobel, crenate; petals 5, longer than the calyx; achenia pointed with the broal, straight style, broally margineil. - Waste places around Charleston (Elliott). March- $\Lambda$ pril. Introduced. - Stem 12'-18' high.

\section{* * Achenie smooth: cliefly perenniuls.} - Lenes undivided.

4. R. alismæfolius, Geyer. Smooth; stems ascenling, rooting at the lower joints ; leaves lancenlate, acute, denticulate or entire; petals longer than the calyx ; achenia in glolese hearls, tumid, slender-beaked. (R. Flammula, Fyll. \&e.) - Mndely banks and ditches, chicfly in the upper districts. May-July. - Stems $10-2^{\circ}$ long. Leaves $2^{\prime}-4^{\prime}$ long. Flowers $3^{\prime \prime}-5^{\prime \prime}$ wide.

5. R. pusillus, l'oir. Smooth; stems sereral, erect; lowest leaves ovate or roundisli, the others lanceolate or linear, entire or denticulate; flowers minute; petals $1-5$, as long as the calyx; achenia in globular heats, barely pointed. (R. ohlongifolits, Ell., a broader-leaved form.) - Mully bauks, Georgia to Nortl Carolina and westward. Nareh and April. - Stem $6^{\prime}-12^{\prime}$ high. Leaves 1' long. Flowers 2" wide. Stamens 5-9.

\section{+ + Leaves (at least those of the stem) ternately lutred or divided.}

- Petals small, not exceeding the calyx.

6. R. abortivus, I. Smoth; lowest leaves orbicular, cordate, undivided, erenate, those of the stem 3-5-parted, with wedge-shaped tootlicd divisions; the uppermost sessile, 3-parted ; petals shorter than the calyx; achenia in glohose heads, pointed with a very short recurved beak. - Low grounils. March and April. - Stem $1^{\circ}-1 \frac{10}{2}$ high. 
7. R. recurvatus, Poir. Ilisute; leaves all petiolet, 3-5.loberl; the lobes wedge-shaped, sharply toothed; petals minute, shorter than the enlyx; achenia in grobose heark, pointed with a long and slender recurved leak. - Low grounds. A juil and May. - Stem 10-20 high.

8. R. sceleratus, I. Smonth; leaves 3-parter, with the divisions wedgeshaped, obtusely lobed and tootherl; the uppermost sessile; petals as leng as the calyx; achenia in oblong or 'ylindrical heads, pointless. - I)itclues and swimps, Clarlestun (Elliott). Intruluced from Europe. A pril and May. - Stems thick, 10 liigh.

9. R. Pennsylvanicus, I. Ilirsute; leaves ternate; leaflets longstalkerl, 3-parted, the divisions lancolate, acintely lobed and tootherl ; petals sloorter than the calyx; achenia in oblong heals, pointed with a broad straight beak. - Low grounds in the upper districts. June. - Stem $2^{\circ}-3^{\circ}$ hight. I'ctioles elongated, very laairy.

- Petuls much lerger than the culy.x: acheniu in glohose heads.

10. R. Purshii, Riclardon. Stem floating; immersed leaves diviled into very uunerous eapillary secrments, emersed ones reniform, 3-5-jartel, the lohes varionsly divided; sepals reflexed ; achenia pointed with a short straiglat beak. - In still watcr, North Carolina and northward. May-July- Stems $2^{\circ}-4^{\circ}$ long.

11. R. repens, L. Smooth or hairy; lenves ternate, or the earliest ones 3-lobed; leaflets 3-lobed, toothed; achenia strongly margined, pointerl with the broad and straight or slightly-rurved beak; stems crect or prostrate, often bearing long runners. - Rich soil, rhichy in the mper districts. Var. $y$ in the river swamps of the low comtry. Marels and $A$ pril.

Var. $\beta$. hispidus. Ilirsute; stem erect ; leaves ample; peluncles long, with the hairs appressed. (R. hispidus, MIx. R. Marilandirus and tomentosus, Poir: the latter a form with softer pubescence.)

Var. $\gamma$. nitidus. Smooth or nearly so; stem prostrate $\left(1^{\circ}-2^{\circ}\right.$ long); leaves and flowers smaller. (R. nitidus, M/uhl.)

12. R. palmatus, Ell. Ilirsute with appressed hairs; Jeaves small (1' wide), ternate or 3-parted, with the divisions ovate, sparingly toothed, those of the upper leaves lanceolate and entire; achenia strongly margined, straighti-beaked. (R. Carolinianus, DC.) - Swamps in the pine barrens, Middle Florida to South Curolina, rare. $-\Lambda$ pil and May. Stens 10 light.

13. R. bulbosus, L. Ilairy; stem erect $\left(1^{\circ}-1 \frac{1}{2} \circ\right.$ high $)$ from a lull--like base; leaves ternate; leaflets 3 -parted, with toothed lohes; those of the upper leaves lancelate, entirc; fowers large (1'wille); achenia pointed with a sliort recurvel beak. - Low grounds in the upper districts. Introdneed. May.

14. R. acris, I. Hairy; stem tall $\left(2^{\circ}-3^{\circ}\right)$, branched above; leaves 3-parted, the divisions deeply cut into three wedge-shaped or lanecolate, acutely. toothed lobes; the uppermost 3-parted, with linear entire lolses; arhenia pointer with a short reeurved beak. - Low waste places, sparingly introduced from Europe. 


\section{CaLtha, L. Marsi Marigold}

Sepals 4-10, regular, flat, colored, imbricated in the lud, decidnons. Petals none. Stamens numerous; filaments filiform. Ovarjes 5-15, many-ovuled. Stigma sessile. Follicles capitate or whorled, sessile, spreading, many-seeded. Perennial, smooth herbs, with cordate or reniform undivided leaves, and showy yellow flowers.

1. C. palustris, I. var parnassifolia, Torr. \&. Gr. Stem 1-leaved, 1 -flowered; radieal leaves long-petioled, broally reniform, sharply toothed; sepals oblong. (C. ficarioilles, Pursh.) - Cedar sivamps, South Carolina (Pursh), 'Tennessee, and northward.

\section{ISOPYRUM, L.}

Sepals 5-6, regular, orate, colored, imbrieated in the bud, decidnons. Petals 5 and minute, or none. Stamens numerous. Oraries 2-20. Orules few or many, in $1-2$ rows. Style short, subulate. Follicles sessile, membranaceous. Seed horizontal. - Perenuial, smooth herbs, with alternate componnd leaves, and solitary white flowers.

1. I. biternatum, Torr. \& Gr. Stem $\left(6^{\prime}-12^{\prime}\right.$ high $)$ slenter, sparingly branehed ; radieal leaves biternate, on long petioles; stem-leaves ternate, nearly sessile; leaflets ovate and obovate, obtusely 3 -lobed; petals none; oraries $1-5$; follicle 2-sceded. (Enenion biternatum, Raf.) - Sharly wools, West Florida and westward. April. - Root commonly bearing small tubers. The plant resembles Thalictrum anemonoides in general appearance.

\section{AQUILEGIA, L. Colunine.}

Sepals 5, reguliur, ovate, colored, imbricated in the bud, deciluons. Petals 5, prolonged downward into hollow spurs. Stamens iadefinite. Filaments filiform, elongated. Oraries 5, many-ovuled. Follicles sessile, connivent, many-seeded, tipped with the elongated, filiform, persistent styles. Seeds horizontal. - Erect, perennial, branching: leafy herbs, with alteruate ternately-eompound leaves; those of the root long-petioled. Flowers showy, nodding, solitary, or somewhat corymbed.

1. A. Canadensis, L. Stems $2^{\circ}$ high, smooth or slightly pubescent; radical leaves bitemate, stem-leares ternate, short-petioled; leaflets roundish or obovate, crenatcly lobed; flowers searlet, yellow within; stumens aud styles exserted. - Rocky woods, West Florida and northward in the upper distriets. April and May.

\section{DELPHINIUM, L. LaRKSPUR.}

Sepals 5, irregular, colored, imbricated in the bud, deciduons; the outermost larger, and produced hackward into a lollow spur; the others flat. Petals 4, dissimilar; the two upper with spurs which are reeeived in the spur of the sepal, the two lower stalked; sometimes (as in the annual Larkspur) all Innited. Stamens numerous, included ; filaments subulate. Ovaries $1-5$, 1-celled, many- 
ovulcil. Style sulublate. Follieles sessile, short-pointed. Serils in two rome, horizontal. - Earet lurls, with alternate petioled mod pahnately divisled leaves, and slesw flowers in termimul rawemes or panicles.

1. D. azureum, Michx. Sten mostly simple, downy: leaves 3-5-parted,

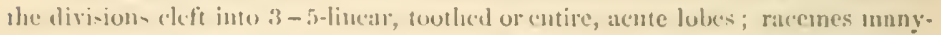

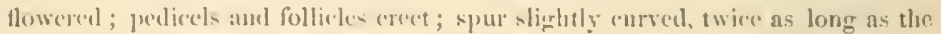
ralyx. (1), virescem, Nutt, with wider-lobel leaves, and larger greenish flow(rs.) - Rich soil, Florida and northword. May. 4. - Stems $1^{\circ}-20$ high. Leaves $2^{\prime}-3^{\prime}$ wille. Sepals sky-hlue, or sometimes whiti-h, tipeped with l,rown. Lower petals 2-cleft, learrled.

2. D. tricorne, Miels. Stem simple, slowny; leaves as in No. 1 ; rareme few flowered; judicels and follicles diverging; spmr straight, as long as the calyx - Monntains of Nortl Carolina aud northwarl. $\Lambda$ pril and May. It. - Root tuluerous. Stems 10 high. Raceme 6-12-flowererl. Sepals blue. Lower petals 2-cleft and bearded.

3. D. exaltatum, Ait. Stem tall, branching and hairy alıse; leaves Jarge, the lower 3-5-parted, the divisions cleft into 2-3-larcelate or oblong coarsely-toothel bobes, the mper 3-parted with sparingly toothed or entire lobes; racemes many-flowered; pedicels diverging; follicles erect ; spur straight, rather longer than the calyx. - Mountains of Nortl Carolina and northward. JuneAugrnst. 4. - Stem $2^{\circ}-4^{\circ}$ high. Leaves $4^{\prime}-6^{\prime}$ wide. Sejals blue. Lower petals 2-cleft and bearded, brownish.

1). Cossomins, L., the common annual Larkspur of the gartens, is becoming naturalized in some places.

\section{ACONITUM, L. Moxkshood. Wolfsixe.}

Sepals 5, irregular, colored, imbricated in the lond, decilnous; the ontermost large and helonet-shaped, the two lateral rounded, the lower smaller and ollong. letals 2 or 5, the two upper long-stalked, produced backwarl into a short incurved spur, the three lower minute or wanting. Stamens numerons; filaments short, subulate. Ovaries 3-5, 1-celled, many-orulet. Style subulate. Follicles sessile, short pointed. Seed horizontal, rugrose. - Erect ol trailiug, perennial herbs, with alternate, palmately divided leaves, and showy flowers in terminal racemes or panicles.

1. A. uncinatum, L. Stem smootl, vine-like, ereet; leaves 3-5-cleft, with the lobes ovate-lancelate, coarsely toothed; racene few-flowered ; flowers large, blue; upper sepal helmet-shaped. - Shaty banks of streams anong the mountains and northward, rare. June and July. - Stem $2^{\circ}-6^{\circ}$ long. Leares rather rigid.

2. A. reclinatum, Gray. Stem smooth, reclining ; leaves deeply $3-7$ cleft ; the lobes cuncate, acutely toothed; racemes numerous, few - many-flowered, flowers white; upper sepal elongated-conical, soon becoming horizontal. High mountains of North Carolina. July and August. - Stems $4^{\circ}-8^{\circ}$ long. Leaves thin. 
14. ZANTHORHIZA, Marshall.

Sepals 5, regular, lanceolate-ovate, colored, imbricated in the bud, decidnous. Petals 5, small, glanl-like, 2-lobed, short-stalked. Stamens 5-10: filaments short. Ovaries 5-10, 1-celled, 2-oruled. Style subulate, incurred, at length dorsal. Follicles sessile, gibbous. Seed solitary, pendulous. $-A$ smooth trailing shrub with yellow roots. Leaves pinnate, long-petioled. Leaflets 3-5, ovate and laneeolate-ovate, incisely lobed and toothed from near the acute base. Flowers small, in slender componnd raeemes, appearing before (below) the leaves, dark purple.

1. Z. apiifolia, L'Her. - Shady banks, Florida, and along the mountains of Georgia and northward. March and April. - Stems $2^{\circ}-3^{\circ}$ high.

\section{HYDRASTIS, I.}

Sepals 3, ovate, membranaccous, colored, imbrieated in the bul, eaducous. Petals none. Stamens numerous: filaments filiform. Ovaries 12-20, fleshy, 1-eelled, 2-ovuled, ripening into $1-2$ secled, capitate, lnght erimson berries. Style short. Stigma 2-lipped. - Stem ereet from a thick, knotted rhizoma, simple, 1-flowered, leafy above. Leaves broadly cordate, palmately 5-7 cleft, the lobes toothed and serrate; radieal one solitary, long-petioled. Stem-leares $2-3$, the uppernost sessile under the stalked, greenish-white flower.

1. H. Canadensis, L - Rich shaded soil along the mountains of Gcorgia and Carolina. and northward. April and May. - Stem $1^{\circ}$ high. Leaves $4^{\prime}-9^{\prime}$ wide, hairy when young.

\section{ACT无A, L. Baxererry.}

Sepals 3-5, ovate, colored, imbricated in the lud, cadueons. Petals 4-10, spatulate, entire. Stamens numerous; the filaments filiform. Ovary solitary, 1-celled, becoming a many-seeded berry in fruit. Stigma sessile, 2-lobed. Seed horizontal. - Perennial herbs. Stems simple, bearing one or two twiee or thriec ternately compound leaves, and a single oval or oblong raceme of small white flowers.

1. A. alba, Bigcl. Smooth, or nearly so ; leaves large, 2-3-ternate; leaflets thin, ovate or cordate-ovate, acutely toothed ; pedicels of the fruit very thick, red; berry white. (A. pachypoda, Ell.) - Rocky woods along the mountains of South Carolina (Elliott), and northward. May. - Plant $2^{\circ}$ high.

\section{CIMICIFUGA, L. Begane.}

Sepals 4-5, ovate or orbieular, colored, imbrieated in the bud, caducons. Petals 1-8, small, stalked, 2-lobed. Stamens very numerous : filaments filiform, elongated. Ovaries $1-8,1$-celled, hecoming nuny-secled follieles in fruit. - Perennial herbs, with large ternately compound leaves, and white flowers in elongated slender racemes.

* Ovary mostly single: stigma large, depressed: seels horizomal, smooth.

1. C. racemosa, Ell. (Bцаск Sxakeroot.) Leaves thice ternate; leaflets orate or ovate-lanceolate, sharply serrate, the terminal ones mostly 
33-lohed ; raecmes elongated, downy ; follicle broarly ovate, sessile. - Wonds in the npper livericks mul northward. Inly. - Stem $3^{\circ}-8^{\circ}$ high. Leaflets $2^{\prime}$ long. liatermes $6^{\prime}-12$ long. Flowers fetid.

* Orverics 3-8: stigma minute: serds vertical, clinfly.

2. C. cordifolia, l'ursh. Leaves twice ternate; leuflets rigril, ovate or rordate-ovate, 2-3-lobed, incisenl and sermate; racenes punicled, elonfarted; follicles ohlong, sessile. - Mountains of North Carolina. Septenuler. - Stem $3^{\circ}-4^{\circ}$ hight. (*)

3. C. Americana, Michs. Leaves thrjec ternate; leaflets thin, ovite, inciscly toothed and serrate, the terminal one 3-cleft or 3-partel ; raecones punjcleal, elongated ; follicles ohovate-ohlong, slender-stalked - Alleghany Monntains, from Gorogia northwarl. Angust and Sept. - Stems so $-4^{\circ}$ high.

\section{OrDEJ 2. MIGNOLIACEA. (MagNolia FamLY.)}

Aromatic trees or shrubs, with simple, alternate, petioled leaves, and regular, solitary, lypogynous flowers. Sepals aucl petals nostly simlar, imbricated in three or more rows in the bud. Stamens distinct or united. Anthers adnate. Ovarjes numerous, imbricated or whorled, 1-2-ovulecl. Fruit fleshy, baceate, or samara-like, distinct, or confluent in cone-like lieads. Seed dry or baceate. Embryo minute, at the base of fleslyy albumen.

\section{Synopsis.}

Scborder I. TWINTEREAE. Flowers perfect. Stamens numerous, eeparate. Ovarica in a single whorl, 1-oruled, becoming coriaccous follicles in fruit. - Ereet slirubs. Jores entire. Stipules none.

1. ILLICICI. Leaves evergreen. Flowers nodding.

SUborder IT. SCHIZANDREA. Flowers monnecious. Staunens united. Ovaries lmbricated in a heal, 2-ovuled, becoming ecattered berries in fruit. - Clinbing shrubs. J.eaves deciduous, often toothed. Stipules none.

2. SCIIZANDRA. Stamens 5, united into a 5-lobed disk.

Suborder II]. MA GNOIIEX. Flowers perfeet. Slamens numerous, separate. Ovaries imbricated in a learl, 2-ovuled. Fruit fleshy or somewlat woody, iu cone-like heads or epikes. - Chirfly trees. Leares entire. Stipules large.

3. MAGNOL:A. Fruit fleshy, dehiscent, persistent on the receptrele. Anthers introrse

4. LI:AODESDaOX. Fruit woody, indehiscent, samara-like, deciduous. A uthers extrorse.

\section{ILLICIUM, L. AXISE-TRE.}

Flowers perfect. Sepals 3 or 6 . Petals $9-30$, in rows of three, spreading. Stamens numerous, with short filanents. Anthers introrse. Ovaries 6 or more in a single whorl, sessile, l-celled, l-ovuled. Style subulate, recurved. Follicles coriacens, sureading, at length 2 -valved. Seed ascending. - Smooth anisescented slurubs. I.enves evergreen, entire, mostly elustered at the summit of the branches, petiolel. Stipules none. I'eduncles in terminal clusters, 1-flowered, nodding. 
1. I. Floridanum, Ellis. Leaves oblong-lanecolate, acuminate; petals 20-30, lanceolate and linear, widely spreading, dark purple. - Sandy swamps, Floridi and westward. May. - Shrub $6^{\circ}-10^{\circ}$ high. Leaves somewhat fleshy. Elower's flat, $\mathrm{I}^{\prime}$ in diameter.

2. I. parviflorum, Michx. Leaves lanceolate, acute; petals 6-12, ovate or roundish, concave, yellow. - Southern districts of Georgia and East Florida. May and June. - Flowers smaller than in No. 1.

\section{SCHIZANDRA, Michx.}

Flowers monocious. Sepals 5-6, ovate, coneave, greenish. Petals 5-6, obovate-oblong, crimson. Stamens 5 : filaments unitel, forning a circular, 5lobed disk: anther-cells widely separated. Ovaries numerous, 1-celled, 2-ovuled, imbricated in a head, in fruit forming 1-2-seeded berries, which are seattered on the greatly elongated filiform reeptacle. $-\mathbf{A}$ elimbing shrub ; with alternate, ob'ong, membranaceous, deciduous leaves, and small long-peduneled flowers, from axillary buds. Stipules none.

1. S. coccinea, Miclix. Leaves acuminate, long-ietioled, $3^{\prime}-4^{\prime}$ long, often somewhat toothed; uppermost flowers mostly staminate; lervies oval, red. Shady woods, Florida to South Carolina and westward. May and June. - Stem climbing high.

\section{MAgNolia, L. Umbrella-tree. Cucumber-tree.}

Flowers perfect. Sepals 3, caducous. Petals 6-9, concave, spreading, deciduous. Stamens very numerous: anthers introrse. Ovaries numerous, imbricated, 1-celled, 2-ovnled, forming in fruit a conc-like head of fleshy, 2-sceded, persistent follieles, opening on the back. Seeds berry-like, suspended by a slender cord of spiral vessels. - Aromatic trees or shrubs. Leaves alternate or clustered at the summit of the branches. Flowers large, solitary, terminal. Stipules large, adnate to the petiole, at length deciduous.

\section{* Leaves perennial.}

1. M. grandiflora, L. (MAGNoldA.) Leaves coriaccous, oblong; or obovate, smooth and glossy above, rusty-pubeseent beneath, flat or concave; petals mostly 9, obovate, coneave, clawed. - Light fertile soil in the middle and lower districts, South Carolina and westward. April and May. - A large tree. Leaves $6^{\prime}-12^{\prime}$ long. Flowers $6^{\prime}-9^{\prime}$ wide, white, ehanging to brown. Cone of fruit oval, $3^{\prime}-4^{\prime}$ long.

2. M. glauca, L. (SWEet BAY.) Leaves coriaceous, lanceolate and oblong, silky-pubescent, at length smooth alove, glancous beneath; petals 9 , obovate, concave. - Swamps, Florida and northward. May and June. - A shrub or small tree. Leaves mostly deciluous northward, $4^{\prime}-6^{\prime}$ long. Flowers z' wide, white, very fragrant. Cone of fruit oval, $1^{\prime}-1 \frac{1}{2}{ }^{\prime}$ long.

* * Leaves deciduous, acule at the base.

3. M. Umbrella, Lam. Leaves clustered at the summit of the branches, obovate-oblong, acute, downy beneath, at length smooth ; petals $\mathbf{9}$, oblong-lan- 
ceolate, armer. (M. tripetala, Mirhx.) - Rich soil in the mper clistricts. May mud fune. $-\Lambda$ small tree, with imegular branches. Letwes $1^{\circ}-11^{\circ}$ long, on short petioles. Flowers $4^{\prime}-t^{\prime}$ widle, white. Cone of fruit oblong, $4^{\prime} \ldots 6^{\prime}$ long, roserentered.

4. M. acuminata, L. Leawes seattered, oval, armunute, downyleneath; petals $6-9$, oblong-ovete, obtuse. - Upper districts, in rich shated soil. June mol July. - A large tree. Letaves $6^{\prime}-9^{\prime}$ lour. Flowers $3^{\prime}-4^{\prime}$ wide, dull yellow and greenish. Cone of fruit 'ylindrical, $2^{\prime}-3^{\prime}$ long.

* * * Lruirs decidhous, aurirulute or rordute at the lase.

5. M. cordata, Michx. Leaves orial or roumlish, slightly cordate, acute, white-downy beneath; petals $6 \cdots 9$, oblone, neute. - L plper districts in rich shaded soil. A pril and May. - A small tree. Lcaves $4^{\prime}-6^{\prime}$ long. Flowers $4^{\prime}-$ 5 wide, yellow. Cone of fruit obloner, $3^{\prime}$ long.

6. M. Fraseri, Walt. Leaves clusterel at the summit of the branches, spatulate-obovate, smooth on both surfices, cordate and 2-eares at the base, on slemeler petioles; petals oblong, olutuse, narowed and ungriculate at the base. (M. aurieulata, Lem. M. prramidata, bartr.) - Ricll woods, Floridat to T(n)nessee and westwarl. May and June. - A small tree. Leaves 8'-12' Jong. Flowers 6 ' wide, white and frawrant.

7. M. macrophylla, Michx. Leaves disterel at the sumnit of the branclies, oblongohovate, corrlate cr slightly carcel at the hase, glantous bcneatli; petals oblong, obtuse, the inuer row narrower. - Shatly woorls in lightit soil, Florida to 'Tennessec: rare. April and May. - A slorul, or sinall tree. Leaves $1 \frac{10}{2}-3^{\circ}$ long. Flowers $8^{\prime}-12^{\prime}$ wide, white, fragraut. Cone of fruit ovate.

\section{LiRiodendron, L. Tump-tree. Wirte Porlar.}

Flowers perfect. Sepals 3, reflexed. Petals 6, erect. Stamens numerons: anthers extrorse. Ovaries numerons, imbrieated, l-eelled, 2-oviled, forming in fruit a cone-like licad of samaraform, indeliserent, 1 - 2-sceded, fleciduous carpels. $-\Lambda$ large tree. Icaves angled, truneated. Stipules large, free from the petiole, rlecilnous. Flowers large, terminal.

1. L. Tulipifera, L. Le'aves smooth, on slender fretioles, mostly rounded at the hase, somewhat 3-lobed; the midelle lobe appearing as if ent off, leaving "shallow noteh; flowers bell-slaped, greenisls-yellow, striped or tinged with orange. - Low grounds, Florida amb northward. May-Junc.

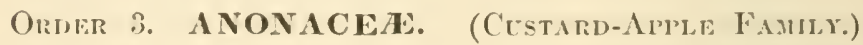

Trees or shrubs, with simple, alternate aul entire, feather-veinel leaves, and solitary, axillary, perfect, lypogyons flowers. Seprals 3 . l'etals 6, in two rows, deciluons, valvate in the bucl. Stamens munerous. Anthers adnate, extrorse, on very short filaments. Ovaries few or many, 
distinct or cohering in a mass, baceate in fruit. Seed auatropous, large. Embryo minute, at the base of ruminated albumen.

\section{Asimina, Adans. Papaw. Custard-Apple.}

Petals thick; the three outer ones larger and sprealing. Stamens very numerous, crowded on the globular receptacle. Oraries $3-15$, sessile, l-celled, few-many-ovuled, baecate in fruit. Seerls horizontal, enclosel in a thin succulent aril. - Shrubs or small trees. Leaves decituons. Flowers nodding.

\section{* Flowers appearing with or before the leaves.}

1. A. triloba, Dunal. Leaves oblong-obovate, acuminate, covered with a rusty pubescence, as also the branches when young, at length glabrous; outer petals round-ovate, diuk purple, $3-4$ times as long as the hairy sepals. (Uvaria triloha, Torr. \&. (iray.) - Banks of rivers, Florida and northward. March and April. - A shrub or small tree. Leares $8^{\prime}-12^{\prime}$ long. Flowers $1^{\prime}-1 \frac{1}{2}^{\prime}$ wille. Fruit oblong, yellow and pulpy when mature, edible.

2. A. parviflora, Dunal. Leaves oblong-obovate, abruptly pointed, and like the brauches rusty-pubeseent, at length smooth; outer petals oblong-ovate, twice as long as the ealyx. (Uvaria parviflora, Torr. \&. Groy.) - Dry sandy soil, Florida to North Carolina and westward. March and April. - Shrub $2^{\circ}-5^{\circ}$ high. Leaves $4^{\prime}+6^{\prime}$ long, thicker than those of the preceding. Flower's $\frac{1}{2}$ ' witle, rusty-puhescent, greenish-purple. Fruit oblong or pear-shaped, fleshy, fewseederl.

3. A. grandiflora, Dunal. Leaves oblong or oblong-obovate, obtuse, rigid, densely pubescent like the branches when young, becoming smoothish above; outer petals large, round-ohovate, many times longer than the sepals ; frut small, obovate, l - few-secded. (A. cuneata, Shuttl.) - Sandy pine barrens, Gcorgia and East Florida. March and April. - A small shrub Leares $2^{\prime}-3^{\prime}$ long. Outer petals two inches or more in length, yellowish-white.

* * Fiowers from the axils of present leaces.

4. A. pygmæa, Dunal. Smooth or nearly so throughout; leaves coriaceons, oblanceolate or oblong-wedge-shaped, obtuse ; outer petals oblong-obovate, many times longer than the sepals, pale-yellow, the inner ones purple within; frnit cylindrieal, pulpy, few-seeded. ( $\Lambda$. secundiflora and probably $\Lambda$. reticnlata, Shutt, the latter a pubeseent form, with smaller $\left(1^{\prime}-2^{\prime}\right)$ oblong leaves and smaller flowers.) - Dry pine barrens, Florida and the lower districts of Gcorgia. May - July. - Slunb $\frac{10}{2}-3^{\circ}$ high. Leaves $2^{\prime}-6^{\prime}$ long, rarely $1^{\prime}$ wide. Flowers $\frac{1}{2}{ }^{\prime}-3^{\prime}$ wide.

\section{Order 4. MENISPERMACEAE. (Moonseri Fanily.)}

Climbing shrubly vines, with alternate palmately veined and often lobed leaves, on slender petioles, and small polygamous or dicecious flowers, in axillary racemes or panicles. Stipules none. Sepals and petals mostly alike, in two or more rows, imbricated in the bud. Stamens 6 or 
more, lygpogyous. Antlers 2-A-ecllocl, openiug loneritudiually. Ovaries $3-8$, drupareons in fruit. Seed and embryo curved, the latter larere, in thin album(').

\section{Syuopsis.}

1. cocculat:s. Sepals, petals, and stament 6. Anthers 4-relleil.

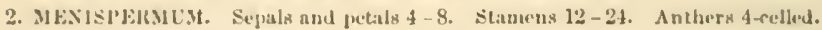

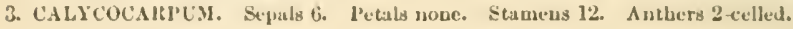

\section{COCCULUS, 1)C.}

Fluwers dicecions or polyganons. Sipals and pelals 6, each in two rows. Staneus 6: anthers 4-eelled, aloortive in the fertile flower. Ovaries 3-6, 1-celled, 1-ovulerl. Stigma subulate, recurved. Drupe bareate, enmpylotropous. Nut reniform, rugose. Seed conformed to the cavity of the unt. Embryo semicircular. - Leaves ovate or slightly cordate, entire or angularly 3-loled.

1. C. Carolinus, I)C. - Woods and llickets, Florida in North Carolina, and westwarl. Junc-Augrust. - Pubesecut. Stem twining, $10^{\circ}-15^{\circ}$ long. Leaves very arute, rather rigis. Racenes of the fertile flowers simple, of the sterile compound. Flowers white. Drupe rel.

\section{MENISPERMUM, I. MuOSEED.}

Flowers diocious. Sepals and petals 4-8. Stamens 12-24: anthers 4-celled. Ovaries 2-4. Stigma dilated, spreading. Othervise as in Coeculus. - Leaves rounded, angular or lobcd, slightly cordate and peltate at the base. Flowers white, panicled.

1. M. Canadense, L. - Banks of rirers, chicfly in the upper districts. July. - Sten twining. Sterile panicles elongatted. Drupe black.

\section{CALYCOCARPUM, Nutt.}

Flowers diacious. Sepals 6. Petals none. Stamens 12 : authers 2-celled; those of the fertile flower alortive. Ovaries 3, 1-ovuled. Stigma radiate, manycleft. Drupe oval. Nut smoolh, excavated on the inner face. Fimbry curved, foliarcous. - Jeaves round-corlate in outline, palnutely 3-5-lobed. Flowers whitish, in compound racenes.

1. C. Lyoni, Nutt. (Menispermum Lyoui, Pursh.) - Banks of the Apalachicola liver, Florida, to Tennessee. May and June. - P'ubescent. Stem twining $20^{\circ}-50^{\circ}$ high. Ieaves $4^{\prime}-7^{\prime}$ wide, with acuminate lobes, the lateral loles wavy or angled. Drupe l' long, globose.

\section{Ordir 5. BERBERIDACEA. (BARberhy FamLy.)}

Herbs or shrubs, with alternate, petiolate, mostly divided leaves, and perfect, regular hypogynous flowers. Sepals and petals in two or more rows of $2-4$ each, imbricated in the bud, deciduous. Stamens opposite 
the petals when of the same number. Anthers 2-celled, opening by uplifted valves (or lengthwise in Podophyllum). Fruit baceate or eapsular. Embryo in the axis of fleshy albumen.

\section{Synopsis.}

* Arithers opening by uplifted valves.

1. BERBERIS. Stimens 6. Leaves bristly-serrate. Shrubs.

2. CaUlophyllum. Stamens 6. Leaves eompound. IJerb.

3. DIPIILLEIA. Stamens 6. Leaves peltate, deeply 2-cleft and lobed. llerb.

4. JEFFERSONIA. Stamens 8 Seape 1-flowered. Leaves 2-parted. Herb.

* Anthers opening longitudinally.

5. PODOPIYLIUM. Stamens 12 or more. Flower solitary in the fork of the two peltate, lobed leaves.

\section{BERBERIS, L. Barbeliry.}

Sepals 6, orbicular. Petals 6, obovate, often biglandniar near the hase. Stamens 6, irritable. Stigma dircular, depressed. Fruit a 1-9-seeded berry. Seeds erect. - Sluruls with yellow wood. Leaves bristly serrate, often reduced to branching spines. Flowers racemose, yellow. Berries acid.

1. B. Canadensis, Pursh. (Aurrucax Barberry.) Smootl, spiny; leaves obovate, bristly-serrate ; racemes noddling, 6-8-fluwered ; petals notehed ; berries oval, red. - Upper districts of Georgia and nortluward. May and June. - Shub $2^{\circ}-3^{\circ}$ high, with lotted branches.

\section{CAULOPHYLIUM, Michx. Bue Conosu.}

Sepals 6, ovate-oblong. Petals 6, thick and gland-like, shorter than the stpals. Stamens 6. Style short. Stigma minute, milateral. Ovary thin, carly ruptured by the two growing seeds, withering. Seeds globose, drupe-like, stalked. Altumen horny. $-\Lambda$ smooth perennial herb, witl large ternately-compoum leaves, and small yellowisl-green flowers in a terminal racene or pauicle.

1. C. thalictroides, Michx. (Leontice thalictroiles, L.) - Mountains of South Carolina (Elliott) and northward. April. - Ilant $1^{\circ}-2^{\circ}$ high, glancous when young. Radical leaf 3-ternate, on a long petiole ; those of the stem (mostly two) sessile, the upper one liternate. Leaflets obovate-weilge-shaped, 2-3-lobed. I'anicle few Howered. Seels graucous.

\section{DIPHYLLEIA, Michx.}

Scpals 6, cadncous. Petals 6, oval, flat, larger than the scpals. Stamens 6. Stigina circular, depressed, slightly 2-lobed. Fruit baccate, 2-4-seeded. Secds erect. - $\Lambda$ smooth perennial herb, with two large, alteruate, peltate, decply 2-cleft, lobed and serrate leaves, and a terminal cyme of white flowers.

1. D. eymosa, Michx. - Margins of streans on the mountains of North Carolina. May and June. - Stem $1^{\circ}-2^{\circ}$ liggh. Lcaves often $2^{\circ}$ in diameter, the divisions 5-7-lobed. Berries bluc. 


\section{JEFFERSONIA, lantun. TWเ-LAF.}

Sepuls 4, petal-like, muluems. P'etals 8, whlong. Stamens 8. Stima nearly

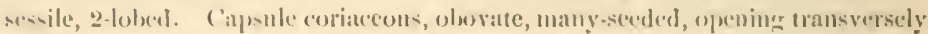

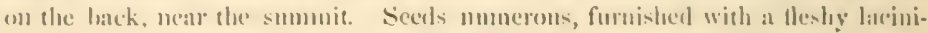

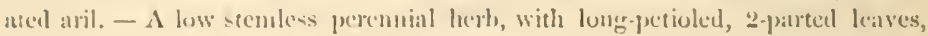
und maked scapes, lecuring a single white llower.

1. J. diphylla, l'ers. - Rieh shaly work, Tennesse and northwarl. April. - Lolnes of the leaves half-ovate, eutire or toothed. Siapes $G^{\prime}-122^{\prime}$ hight. Fluwers $\mathrm{l}^{\prime}$ wide.

\section{PODOPHYLLUM, L. Mir-APL:}

Sepals 6, eadncous. Petals 6-9, ohovate. Stamens twice as many (in our speries) as the petals. Anthers opening longitudinally. Stigma large, peleate,

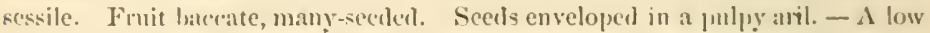
jerennial lierb, with the naked stem teminated by wo large peltate, 5 - 9 -parted, lobed and toothed leaves, with a solitury norlding flower in the fork.

1. P. peltatum, L. (MaxnRake.) - Rich wook, Florila and northwarl. April and May. - Stems $1^{\circ}$ high, the barren ones terminated ly a singrle centrally peltate leaf, smooth. Le'aves $t^{\prime}-6^{\prime}$ wide. Flowers $]^{\prime}$ wirle, ggecnish. Berry I'$^{\prime}-2^{\prime}$ long, ovoid, fellow, fragrant.

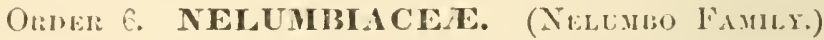

Annatic herls, with large circular centrally peltate floating leaves, and solitary hyporronons flowers on long perluncles. Serpals and petals simjlar, in several rows, mulsiwated in the bud, decidnous. Stancus indefinite, the slemler filaments prolonged above the linear, alnate, introrse antlers. Ovaries seprarate, 1-celled, 1-ovulerl, imbeliled in the flat summit of the large oleonical torus, forming large globular nuts in frut. Stigna nearly sessile, peltate. Seeds suspended. Embryo large. Albumen none.

\section{NeLUMbiUm, Jnss. Nelumo.}

Clastracters of the order.

1. N. luteum, Willi. (Water Cungeeprs.) - Lakes and still water, F!orida, near Tallahassec, and northward and westwad. Not common. July. - lihroma large, erceping. Leares $1^{\circ}-2^{\circ}$ wide, depressed in the centre. Fiowers $5^{\prime}-6^{\prime}$ wide, pale yellow. Appendage of the anthers linear.

\section{Oniner 7. CABOMBACEA. (W.thi-smat, FAMU.)}

Arpuatic perennial herbs, with peltate or dissected leaves, and solitary hypognous flowers on loug axillary peduncles. Seprals $3-4$, colored 
inside. Pefals 3-4, withering-persistent. Stamens 6-18: anflers adnate, extrorse. Ovaries 2-18. Ovules suspended. Capsule indeliscent, 1-3-seceled. Embryo minute, at the base of fleshy albumen.

\section{CABOMBA, Aublet.}

Sepals and petals: Stamens 6. Oviries 2-4. Capsule 1-3-seeded.Stems filiform, brancling. Submerged leaves opposite, diviled into numerous filiform flattened segments; floating ones peltate, entirc. Flowers small, in the axils of the floating leaves.

1. C. Caroliniana, Gray. Floating leares oblong-linear ; flowers white. (Nectris aquatica, Nutt.) - Ponds and still water, Florilia to North Carolina, and westwarl. Junc-August. - Stenis $2^{\circ}-4^{\circ}$ long.

\section{BRASENIA, Schreber. Water-sileld.}

Sepals 3-4, purple inside. I'etals 3-4, linear, persistent. Stanens 12-18: anthers exsertel. Oraries $4-18$. Capsule 1-2-seceled. - Leares all peltate and entire, alternate, oval, on long petioles. Flowers axillary, on elongated peduncles, dull purple.

1. D. peltata, Pursh. (IIydropeltis purpurea, Michx.) - Ponds and slowflowing streams, Florilia and northwarl. July-Stem, petioles, and lower surface of the leaves coated with a gelatinous, viscid exulation. Leaves $2^{\prime}-3^{\prime}$ witl.

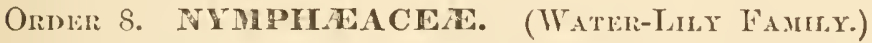

Arpatic herbs, with peltate or corlate, entire, floating leaves, aud solitary white or yellow flowers on long pedumeles. Sepals 4-6, colored inside. Petals numerous, hypogyous or perigynous, imbrieated in the bud. Stamens numerous. Ovary many-celled. Ovules numerous, inserted on the partitions. Stigmas radiate or peltate. Fruit baceate, many-sceded. Embryo included in a sac at the extremity of fininaceous albumen.

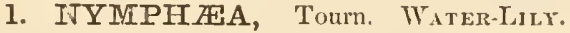

Sepals 4, green outsile. Petals ollong, inserted into the thin torus which enrelops the ovary, the inner ones passing into stamens. Stamens numerons, inserted above the petals, the outer ones petal-like: anthers aduate, introrse. Orary many-eclled. Stigmas as many as the cells, linear, radiating around a globular central glaud. Berry globose. Seed enelosed in a menbranacous aril. - Leaves orbicular, cleft at the base to the centre, floating. Flowers on elongated, often spiral peluneles.

1. N. odorata, $\Lambda$ it. (Povo-LrLr.) Rhizoma large, ereping; leaves $6^{\prime}-12^{\prime}$ wide, entire, the sinus narrow and the lobes acute, or else with an open 


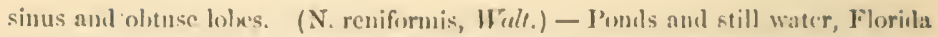
and northwart. May - June. - Flowers white, $2^{\prime}-f^{\prime}$ wisle, fragrant, expanding in the morning. l'etioles and perlundes orcusimnally villous.

\section{NUPHAR, Sulth. Yellow Watelt-Iı}

Sepals 5-6, ohorate, yellow. I'etals $10-20$, stamen-like, lypogrynous. Stamens ummerous, at length recurved, persistent. Ovary eyluniriabl, many-relled. Stigma sessile, cirenlar. Berry oblong. Seens smooth, wullout arils. - Leaves cordate or sagrittate, floating or ereet. Flowers yellow, creet.

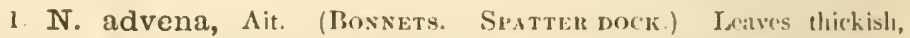
cordite, smooth or lowny beneath, often emersed and erect, on stont petioles; sepals 6, the outer ones romoled; petals mumerons, thick and flesly, truncate. In still water, common, flowering through the summer.

2. N. sagittæfolia, Pursh. I,eaves thin, floating, on slemler petioles, obJongr, sagrittate, smooth; lobes at the lase expanding; scpals 6 ; petals tramsformed into stamens. - In still water near the coast, Georgia to North Carolina; rare. June- $\Lambda$ ugust. - Leares $1^{\circ}$ long, $2^{\prime}$ wide.

\section{Order 9. SARRACENIACEA. (Putchin-Phaxt Famu.)}

Peremial marsh herbs, with hollow pitcher or trumpet-shapeel leaves, and a uaked or bracted seape, hearing few or colitary nolding lypogynous flowers. Sepals 5, colored, persistent. Petals 5, indorieated in the buel, deciluous, raroly wanting. Stamens numerous : anthers arluate, introrse. Ovary 5-celled, many-ovulerl. I'lacente central. Style single, 5-clelt, or umbrella-shaped. Capsule 5-celled, many-seceded. Embryo minute at the base of fleshy albumen.

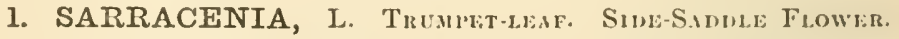

Calyx 3-lnacted. Petals obovate, drooping or incurvell. Style umbrellashaped, 5-angled; the andes emarginate, ant bearing the minute hooked stigmas beneath. Cajsule globose, rongh, loenlicidally 5-valved. - Scape bractless, 1-flowered. Flowers large, purple or yellow. Leaves 1-winged, hairy within, and usually containing water and dead insects.

\section{* Flovers purple.}

1. S. purpurea, L. (IIUxtsatax's Ctr.) Leaves slont, spreading, the tube infated, contracted at the throat, broally winged; lamina reniform, erect, hairy within, often purple-veined - Mossy swamps, Florida and northward. April and May. - Leaves $4^{\prime}-6^{\prime}$ long. Seapes 10 high.

2. S. Psittacina, Michx. (Parnot-neıken P’itcuer-Plist.) Leaves slort, spreading; tube slender, broully winged, marked witl white spots, and reticulated witl purple veins; lamina ghlobose, inflated, inenred-beakel, almost elosing the orifice of the tubc. - Pine barren swanns, Florida and Georgia April and May. - Leaves $2^{\prime}-4^{\prime}$ long. Sealpes $1^{\circ}$ high. 
3. S. rubra, Walt. (Red-flowered Trumpet-leaf) Leaves elongated, erect, slender, narrowly winged, paler above, and reticulated with purple veins; lamina ovate, ereet, beak-pointed, tomentose within; flowers reddishpurple. - Sandy swamps in the midille districts, Georgia to North Carolina and westward. May. - Leaves $10^{\prime}-18^{\prime}$ long, shorter than the seapes.

4. S. Drummondii, Croom. Leaves elongated, ereet, trumpet-shaped, narrowly winged; lamina erect, ronnded, short-pointed, hairy within, and like the upper portion of the tube white, variegated with retienlated purple veins. Pine barren swamps, Florida to the middle districts of Georgia and westward. A pril. - Leaves $2^{\circ}$ long. Scapes longer tlıan the leaves. Flowers $3^{\prime}$ wille.

$$
\text { * *locers yellow. }
$$

5. S. flava, I. (Trumpet-LeAf. WAtcies.) Leaves large, ereet, trumpet-shaped, narrowly winged; lamina yellow, erect, orbicular, slenderpointed, tomentose within, reldish at the base, or retieulated with purple veins. - Low pine barrens, Florida to Nortl Carolina and westward. April and May. - Leaves yellowish, $2^{\circ}$ long. Lamina $3^{\prime}-t^{\prime}$ wide. Scapes as longr as the leaves. Flowers $4^{\prime}-5^{\prime}$ wide.

6. S. variolaris, Michx. (Spotted Trumpet-leaf.) Leaves erect, trumpet-shaped, broadly winged, spotted with white near the yellowish summit; lamina ovate, concave, arching over the orifice of the tube, hairy and reticulated with purple veins within. - Low pine barrens, Florida to North Carolina and westward. May. - Letwes $6^{\prime}-12^{\prime}$ long, longer than the scapes. Flowers $2^{\prime}$ wide.

\section{Order 10. Papaveracez. (Poppy Fanily.)}

Herbs with colored juice, alternate exstipulate leaves, and solitary hypogynous flowers. Sepals 2-3, caducous. Petals 4-12, imbricated in the bud, deciduous. Stamens numerons. Anthers introrse. Ovary 1-celled, with parietal placentæ. Capsule many-seeded. Embryo minute, at the base of oily or fleshy albumen.

\section{ARGEMONE, L. Mexican Poppy.}

Sepals 2-3, hooded or horned. Petals 4-8. Stigmas 4- $i$, free, radiate. Capsule oblong-obovate, hispid, opening at the summit by $3-6$ valves, which separate from the filiform persistent placentæ. Seeds globnlar, crested, pitted. Glaucous herbs with yellow juice, sessile, pinnatifid, bristly leaves, and showy white or yellow flowers.

1. A. Mexicana, L Annıal ; leaves pinnatifid-lobed, bristly and prickly, blotehed with white; flowers white or yellow; calyx bristly. - Waste plaec, apparently native in South Florida. April and May. - Stem branching, 1 ¿ $^{\circ}$ high 


\section{SANGUINARIA, I. I'Ucioon. BLOOH-noot.}

Sepuls 2. I'etals 8-12. Sitignas 2. Capsule 2-valved, the valves 3eparating from the filiform persistent placentas. Sedes crested $-A$ stemless peren. nial herh, with oramge-colored juice. Rhizoma thirk. Lenves renifonm, with 5 - i wasy ar toothed lobes. Flowers white, solitary at the summit of the nakerl scalpe, fugucious.

: S. Canadensis, I. - Richl woorls, Florida and northward. March Seape $t^{\prime}-6^{\prime}$ hight. Flowers $l^{\prime}$ wide, appearing with the leaves.

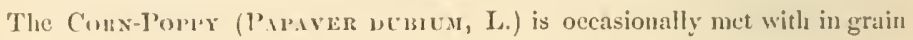
ficlds and anound dwellings.

\section{Oriner 11. FUMAIRACEA. (Fumtory Famir.)}

Smootl herbs with watery juice, alternate compound dissected leaves, without stipules, and irregular flowers. Sepals 2. P'etals 4 ; the two outer or one of them spurred or griblou: at the base; the two inner eallous at the apex, and colsering over the stigma. Stanens 6, commonly united in two sets of thee each, placed opposite the outer petals, hypogynous: a ather of the millle stamen 2-celled, of the lateral ones 1-celled. Capsule :-relled and 2-valved, with two parietal placenta, or 1-seeded and ind-riscent. Embryo minute in fleshy albumen.

\section{Synopsis.}

1. ADLCMrA, Petals united, persistent. - A tender rine.

2. DtCENTIid. F'etals connivent, deciluous; the two outer ones gibbous at the bare. - Stemless herlis.

3. CORYDALIS. Petals distiuct, deciluous, one of the outh res gibbous at the base. Caulesceut herbs.

\section{ADLUMIA, Raf.}

Sepals minute. I'ctals united, free at the summit; the two outer ones gibbous at the base, withering-persistent. Capsule linear-obloner, 4-8-secded. Seerls reniforn, not crested. Stigma 2-crested. $-A$ smooth liemnial vine. Leaves biternate, with tendril-like petioles. Flowers pale violet, in axillary and drooping pani ies.

] A. cirrhosa, Raf. (Corydalis fungosa, Tent.) - Mountains of North Carolina and northwarl. July-Septemler. - Stem $8^{\circ}-15^{\circ}$ long. Leafle:s thin, obovate, $2-3$-lobed. Corolla thick and spongy.

\section{Dicentra, Bork. Dutcmin's Breecins.}

Sepals minute. Petals conniving, lut seareely united, decisluous or withering; the two onter ones spurred or gibbous at the base. Filaments slightly mited in two sets. Stigrma 2-crested. Capsule 10-20-seeded. Seeds crested. - 
Stemless perennial herbs, with temately-eompound and dissected leaves. Flowers racemose, nodding.

1. D. Cucullaria, DC. Iihizoma granular, bulb-like; seape simple, 4-10-flowered, longer than the (1-3) long-petioled linear-lobed leaves; corolla whitish, with two divergent, wing-like spurs, longer than the pelicel; inner petals minutely crested. - Rich woods, North Carolina and northward April.Seape $6^{\prime}-9^{\prime}$ high.

2. D. eximia, DC. Rhizoma granular, sealy; raceme compounil, manyflowered, shorter than the $(3-8)$ oblong-lobed leaves; corolla rose-color, 2-gibhous at the lase; inner petals eonspicnonsly crested; stigma 2-horned at the apex.Momutain rocks, North Carolina and northward. June-September. - Scape $8^{\prime}-12^{\prime}$ high. Bracts purplish.

\section{CORYDALIS, Vent.}

Sepals minute. Petals separate, deciduous; one of the outer ones sac-like at the base. Filaments united nemry to the summit, with a gland at the lase. Stignna 2-lobed. Capsule many-seederl. Sced crested. - Caulescent, annull or liennial herbs, with bipinnate dissected leaves, and flowers in lateral and termin:il r:icemes.

1. C. aurea, Willt. Stems diffuse; racemes simple; capsule knotted, drooping; crest of the seeds scalloped; flowers yeliow. - Banks of the Apalachicola River (and as an annnal weed in gardens), Florida to Mississippi and northwarl. March and April. - Stems $66^{\prime}-12^{\prime}$ long. Leaves finely disseeterl.

2. C. glauca, Pursh. Stems crect; racemes compound; capsule cren, ereet, crest of the sects entire, flowers whitish, tinged with yellow and reddish. - Mountains of North Carolina and northwarl. May. - Plant gliucour, $1^{\circ}-\varepsilon^{\circ}$ high. Divisions of the leaves coarser than the last.

\section{Order 12. CRUCiFERAE. (Mustard Fayily.)}

IIerbs with pungent watery juice, alternate exstipulate leaves, and regular hypogynous racemose or corymbose flowers, on bractless pedicels. Fruit a silique or silicle. - Sepals 4, deciluous. Petals 4, regular, placed opposite each other in pairs, their spreading limbs forming a cross. Stamens 6 (rarely fewer), two of them shorter. Capsule 2-celled by a membranaceous partition which unites the two marginal placenta, from which the two valves separate at maturity, or inclehiscent and nut-like, or separating into 1 -seeded joints. Seeds campylotropons, without albumen, filled with the large cmbryo, which is eurved or folded in varions ways, or straight only in Leavenworthia. (The genera are distinguished chiefly by the fruit and seed; the flowers being nearly similar throughout the order.) 


\section{synojisis.}

I. SII IQIOSA. Fruit a silipue, fow-many-seeded.

- Cotyledons flattened, parallel with the partition, one edge applled to the usecudiug radicle (accumbent).

- Valves of the fruit nerveless.

1. NASTURTILI. Silique short, nearly terek. Sceds in two rowa in each cell.

2. 10DAxTIUs. Silique elongated, terete. Sieds in a single row in each cell.

3. CARDAMIXE. Silique linear, compressed. Seeds wingles, in a single row.

4. DEXIYAR1A. Silique lanceolate, c mpressed. Seeds wingless, in a single row.

5. LEATExirortill. Silique oblong. Seeds winged. Embryo straight.

- Valves of the fruit 1-nerved.

6. ARAIBIS. Silique linear, elongated: valres flittened.

- Cotyledons flat, with one edge turned toward the partition. and the hack of ono if them applied to the ascending radicle (incumbent).

7. SISYMBLILY. Silique sessile, nearly tercte.

8. WAlili.l. Silique stalked, compressed. I'etals on long claws.

II. SILTCTIOSA. Fruit a silicle.

* Siliclo eompressed parallel with the broad partition, or globular.

+ Cotyledons uerunbent.

9. DaAs.1. Silicle oral or oblong, many seeded valves $1-3$ nerved.

10. VEsicdila. Silicle orbicular, few-seeded: valves nerveless.

+ + Cotyledons incumbent.

11. CAMELINA. Siliele oboroid: ralves 1-nerved.

- Silicle compressed contrary to the narrow partition. Cotyledons incumbent, rarely aceumbent.

12. SFNEmiLrA. Valres of the silicle globular, rugose : Eceds folitary.

13. I.El']DILI. Valves of the silicle boat-shaped: seeds solitary.

14. CAPSELLA. Valves of the silicle boat-shaped : seeds numerous.

III. LOMENTACEA. Fruit separating transversely into joints.

15. CAKILE. Fruit 2-jointed.

\section{NASTURTIUM, R. Br. Water-Cress.}

Silique nearly terete, linear or oblong, or short and silicle-like, usually curved upward ; the valves nerveless. Seeds numerous, small, in two rows in each cell, not margined. Cotyledons accumbent. - Herbs. Leaves pinnately-lobed. Flowcrs white or yellow, small.

1. N. tanacetifolium, Hook. \& Arn. Smooth; stems diffuse; leaves pinnately divided, with pinnatifid or toothed lobes ; silique oblong-linear, pointed with the short style, twice as long as the pedicel. (Sisymbrium, Walt. S. Walteri, Ell.) - Damp soil, East Florida to South Carolina, and westward. March and $\Lambda$ pril. - Stems $6^{\prime}-12^{\prime}$ long. Flowers minute, ycllow.

2. N. sessiliflorum, Nutt. Smooth ; stem stout, erect, branching; leaves oblong-obovate, pinnatifid toward the base, toothed above, obtuse ; silique linearoblong, pointed with the very short and thick style, four or five times as long as the peclicel. - Banks of the $\Lambda$ palachicola River, Florida and westward. February $-\Lambda$ pril. (1) - Stem $1^{\circ}-2^{\circ}$ high. Flowers minute, yellow. 
3. N. palustre, DC. Smooth or hairy; stem erect, lrancling ; leaves clasping, pinnatiicl, with toothed lobes; silique short, ovate or oblong-ovate, pointed witlı the distinet and rather slender style, barely laalf as long as the epreading pedicel. - Wet places, North Carolina and westward. June-Angust - Stem $1^{\circ}-2^{\circ}$ high. Flowers small, yellowish.

4. N. lacustre, Gray. Smooth; stem sparingly branehed ; immersed leaves pinnately divided into very numerous capillary segments, emersed ones lanceolate, serrate; silique 1-celled, obovate, pointed with the slender style, shorter than the spreading pedicel. - Rivers and cool springs, West Florida, thenee northward and westwarl. July. - Stem $1^{\circ}-3^{\circ}$ long. Flowers conspicuous, white.

5. N. officinale, R. $\mathrm{Br}$ (W.tter-Cress.) Stems sprealing and rooting; leaves pinnate, with the leaflets roundish or oblong and nearly entire; silique linear $\left(6^{\prime \prime}-8^{\prime \prime}\right.$ long $)$, on slemder sprearling perlicels; petals white, twice the length of the calyx - Ditches, \&c., Florida and northward. Introduced.

\section{IODANTHUS, 'Torr. \& Gray.}

Silique lincar, elongated, terete; the valves nerveless. Seeds in a single row in eaclı cell, not margined. Cotyledons aecumbent. Claws of the violet-purple petals longer than the calyx. $-A$ smooth perennial, with ovate-obloug pointed and toothed leaves, the lowest sometimes Irrate-pinnatifid, and showy flowers in panicled racemes.

I. I. hesperidoides, Torr. \& Gray. (Iesperis piunatifita, Michr.) Banks of rivers, Tennessee and northward. May and Junc. Sten $1^{\circ}-3^{\circ}$ high. l'ods 1 ' or more long, curving upward.

\section{CARDAMINE, $\mathrm{L}$.}

Silique linear, flattened ; the valves nerveless, usually opening elastieally from the base. Seeds several, wingless, disposed in a single row in each cell, suspenderl by filiform stalks. Cotyledons aceumbent. - Herbs. Leaves often undivided Flowers purple or white.

\section{* Peremials.}

1. C. rotundifolia, DC. Smooth; root fibrous; stem erect, simple, soon bearing from the root or upper axils long and leafy runners; leaves oval or orbicular, of ten cordate, wavy or toothed, the lowest long-petioled and sometimes sparingly pinnatifid; silique subulate, spreading; secels oval. - Cool springs, in the upper distriets and northward. May and June. - Stem $6^{\prime}-12^{\prime}$ ligh. Runners at length $2^{\circ}-3^{\circ}$ long. Flowers conspicuous, white.

2. C. rhomboidea, DC Smooth; root tuberous; stem simple, erect, without rumners; leaves long-petioled, round-cordate, with wavy margins; the uppermost oblong-ovate, toothed, sessile; silique linear-lanceolate, pointed with the slender style; seeds rounil-oval. - Cool springs, West Florila and northward. April and May. - Stem 12'-18' high. Flowers white, larger than in No. 1 . 
* * Anmunls.

3. C. spathulata, Michx "liulieal leives petiolate, sponthulate, entire

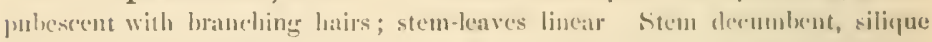
line:ar, straight, sprealing and slightity reflexch, pointed with the ses-ile stignas"

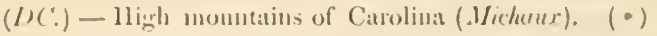

4. C. Ludoviciana, Ilook. Low; stems lusuching and hatry at the base; leares lanecolate, pinnatificl with numerous oblone or linear sparingly

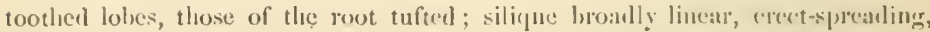
pointed with the sessile stigmal secels orbicular, margined - Waste places near dwellings, Floridat to North Carolinat and westward. Manch and $\Lambda_{\text {pril. }}$ - Steuns $4^{\prime}-6^{\prime}$ high. Flowers small, white.

5. C. hirsuta, L. Smooth or hairy; stem erect $\left(1^{\circ}-20\right.$ high $)$, hranching; leaves pinnatifid, with numerous oval or oblong sparingly tootheyl loles, those of the upper leaves linear and entire; siliçne narow-linear, crect, pointed with the nearly sessile stigma; sech oval, minute, marginless - Var. Vinasistes. (C. Virginira, Michr.) Smaller $\left(6^{\prime}-10^{\prime}\right.$ high) ; lo!es of the leaves linear or tiliform. - Wet (the variety in dry) soil, Florida and northwarl. March and A pril. - Flowers small, white.

\section{DENTARIA, L. To(rmwont.}

Silique lancelate, flattened. Secrls ovate, dispessed in a single row in each ecll, on flattened stalks, not margined. - l'erennial her's, with crepping fleshy roots, and simple stems, bearing at the summit 2-3 palmately-diviclesl leaves, and a single raceme of lauge white or purple flowers. liadical leaves on long perioles

1. D. diphylla, Michx. Root not jointed; stem-leares 2, opposite or nearIy so, ternately divided; leaftets ovate or orate-lanceolate, coarsely toothed; these of the root similar; racemes many-flowerel, longer than the leaves; flowers white. - Rich shaly woods, along the mountains and northward. $\Lambda$ pril. Stem $8^{\prime}-12^{\prime}$ jighl. Jioot jungent.

2. D. Iaciniata, Mull. lioot jointed; stem-leares mostly 3, whorled, ternately diviled; leaflets lancelate or linear, lobed and tootherl; the lateral ones 2-parter, those of the root similar or sometimes wanting; ratecunes few many-flowerel, often shorter than the leaves; flowers white or pale pmrple. Bauls of rivers in slady places, Florida and northward. Feb. - April. - Sten 4 ' 12 ' high.

3. D. heterophylla, Nutt. liont jointed; stem-Jeares 2, small, opposite, 3-parterl; leaflets linear, toothed or entire; root-leaves ternate, with larere ovate crenately-lobet and toothel leaflets; racemes few-flowerel ; flowers rather small, purple. - Shady woods, North Carolina aud northward. April. - Stem 6'-12' high.

4. D. multifida, Mnhl. Root tuberous; stem-leaves most]y 3, whorled, 2-3-ternately diviled into very narrow segments; flowers white - Shaty wools in the upper districts, A lahama and northwarl. Stems $6^{\prime}-8^{\prime}$ high. Leaves often as finely divided as those of the Carrot, sometimes approalding some of the forms of No. 2, but with smaller flowers, and longer petioles and pedicels. 


\section{LEAVENWORTHIA, Torr.}

Silique oblong or oblong-linear, compressed, often contracted between the seeds. Seeds in a single row in each cell, orbicular, flat, winged. Embryo straight or nearly so. - Small annual or liennial herbs, with short 1 -few-flowered stems, pinnatifid leaves, and yellow, white, or purplish flowers, on elongated pedicels.

1. L. aurea, Torr. Leares mostly radieal, with $4-8$ oblong toothed lobes, the terminal one larger and rounded; raceme at length 4-10-flowered; style manifest; embryo straight. - On flat rocks in the upper districts of Alabama and westwarl. - Plant $2^{\prime}-6^{\prime}$ high. Flowers yellow.

2. L. Michauxii, Torr. Leaves as in No. I; flowers mostly solitary, on radieal peduneles; style almost none ; embryo slightly eurved. (Cardamine uniflora, Michx.) - Rocks, Alabama and Tennessee. - Flowers purplish or white.

\section{ARABIS, L.}

Silique elongated, linear, flattened; valves 1-nerred. Seeds numerous, in a single row in each cell, roundish, usnally winged or margined. Cotyledons ac. cumbent. - Chiefly annual or biennial herbs. Radical leaves mostly pinnatifid ; those of the stem sessile and often cordate or sagittate at the base. Flowers white or rosecolored, in terminal racemes.

1. A. hirsuta, Scop. Rough-hairy; stems mostly simple, erect, rigid, very leafy; radical leaves oblanceolate, obtuse, mostly entire; those of the stem lanceolate or oblong, clasping, sparingly toothed; silique pedicelled, narrowlinear, erect, pointed with the sessile stigma ; seeds narrow-margined. - Rocky or sterile soil, Tennessee and northward. May. (1) - Stems $1^{\circ}-2^{\circ}$ high, often several from one root. Leares $\frac{1}{2}-l^{\prime}$ long. Flowers small, the greenish-white petals rather longer than the calyx.

2. A. patens, Sulliv. Downy with spreading hairs, erect $\left(1^{\circ}-2^{\circ}\right.$ highl $)$; stem-leaves oblong-ovate, acutish, coarsely toothed or the uppermost entire, lalfclasping by the heart-shaped base; petals (bright-white) twice the length of the calyx; pedicels slender, spreading; silique slender and curving upward, tipped with a distinct style. - Rocky banks near Nashville, Tennessec, and northward. May. - Silique $I_{2}^{\prime}{ }^{\prime}-2^{\prime}$ long.

3. A. dentata, Torr. \& Gray. Pubeseent and roughish; stems slender, diffusely branched, erect or ascending; leaves obtuse, unequally and sharply toothed, the lowest $\left(2^{\prime}-5^{\prime}\right.$ long) oblong-obovate, tapering into a slender petiole; the others smaller, oblong, clasping and auriculate at the base; racemes at length elongated; siliques seattered, narrow-linear, widely spreading, on short pedicels ; petals whitish, scarcely exceeding the calyx. - Tennessee and north ward. May. -Plant about $1^{\circ}$ high. Silique $1^{\prime}$ long.

4. A. lyrata, I. Stem smooth, branching from the base; radical leares tufted, pinnatifid, ciliate, those of the stem linear or lanceolate and entire; silique pedicclled, very narrow, erect-spreading, pointed with the short style; seeds without margins. - Mountains of North Carolina and northward. A pril - June. Stems $4^{\prime}-10^{\prime}$ high. Flowers white, the petals twice the length of the calyx. 
5. A. Canadensis, I. Stem stout, simple, nearly smonth alove; leaves thin, downy, lanceolate, sliybtly toothed, sessile by a natrow hase, the lowest coarsely or pimatificl-toothed; siliques eurved, drooping, on rough pedieds; seels winged. (A. fulcatu, .Michx.) - Dry or rocky places in the upper listricts. Mny and June. - Stems $2^{\circ}-3^{\circ}$ high. Silique $2^{\prime}-3^{\prime}$ long. Flowers white. Petals oblong-linear, not twice the length of the hairy calyx.

6. A. lævigata, I)C. Smooth und glaucous; stem ereet; leaves linear or lanceolate, entire or sparingly toothed, kagittate and clanjing at the base; pedieels short; petals (whitish) narow, slightly exserted; silique elongated, narrow-linear, recurwed-sprending; seed winged. - Rocky places, Nortl Carolina, 'Temessee, and northward. May. - Stem $1^{\circ}-2^{\circ}$ high. Silique $2^{\prime}-3^{\prime}$ long.

\section{SISYMBRIUM, L. HLDGE-MUSTARD.}

Silique linear or oblong, terete or somewhat angled, with 1-3-nerved valves. Secls in a single row in eicl cell, oblong, marginless. Cotyledons linear-oblong, incumbent. - Herbs with simple or pinnately divided leaves. Flowers in ra. cemes, small, white or yellow.

1. S. canescens, Nutt. Pubeseent and somewhat hoary; stem simple or sparingly branched; leaves liphimatifis, with small mostly toothed lobes; racemes at length elongated; silinge shorter than the spreading pedicel. (Cardilmine? multifida, DC.) - Waste ground, Florila, northwarl and westward. March and April. $\left(-\right.$ Stem $1^{\circ}-2^{\circ}$ high. Flowers small, greenish-white.

2. S. Thaliana, Gaud. Stem slender, hranehing, hairy at the base; leaves hairy, toothed or entire, the lowest obovate or oblanceolate, tufted, the others smail and seattered; siliques linear, creet-spreading, twice as long as the pedieels. - Rocks and sterile soil, Georgia and northward. Introdnced. March sund April. (2) - Stem $4^{\prime}-8^{\prime}$ high. Flowers white.

3. S. officinale, Scop. Stem tall $\left(2^{\circ}-3^{\circ}\right)$, hranching, and with the runeinate leaves pubeseent ; silique subulate, nearly sessile, appressed to the rachis. - Waste gronnds in the upper districts, and northward. Introduced. MaySept. C - Flowers pale yellow.

\section{WAREA, Nutt.}

Silique linear, flattened, long-stalked, recurved; the ralves 1-nerved. Sceds in a single row in each cell. Cotyledons oblong, flat, incumbent. - Sinooth and erect branching annuals. Leaves entire. Flowers showy, in corymb-like racemes. Petals long-clawed, white or purple.

1. W. amplexifolia, Nutt. Leaves oval and slightly elasping; petals oval, Lright-purple; silique linear. - Sand hills, Florida. September. - Stem $1^{\circ}-2^{\circ}$ high.

2. W. cuneifolia, Nutt. Leaves wedge-lanceolate; petals obovate, white or rarely purple; silique narrow-linear. - Sand hills, Florida and Georgia. September. - Stem $1^{\circ}-2^{\circ}$ high. 


\section{DRABA, L.}

Siliele oblong or oval, flattened parallel with the broad partition. Seeds numerous in two rows in each cell, compressed, wingless. Cotyledons accumbent. - Small herbs with entire or toothed leaves, and yellow or white flowers in terminal racemes.

\section{\$1. DRABA. - Petals entire.}

1. D. brachycarpa, Nutt. Annual; minutely downy ; stems leafy, simple or branched; radical leaves round-ovate, stalked, those of the stem oblonglinear; silicle oval, as long as the pedieel. - Middle districts of Georgia, in dry soil, and westward. March and A pril. - Stem $2^{\prime}-6^{\prime}$ high. Silicle $2^{\prime \prime}-3^{\prime \prime}$ long. Flowers white.

2. D. Caroliniana, Walt. Annual; stems leafy and hispid at the base, smooth above; leaves tufted, spatulate-obovate, hispid; silicle linear-oblong, two or three times as long as the pedicel. - Sandy fields, Georgia and northward. February $-A$ pril. - Stems $1^{\prime}-3^{\prime}$ high. Silicle $4^{\prime \prime}-6^{\prime \prime}$ long. Flowers white.

3. D. cuneifolia, Nutt Annual; leaves obovate, wedge-shaped, or the lowest spatulate, toothed ; raceme somewhat elongated in fruit $\left(l^{\prime}-3^{\prime}\right)$, at length equalling the naked peduncle; petals emarginate, much longer than the calyx ; silieles oblong-linear, minutely hairy, longer than the horizontal pedicels. - West Florida (Nuttall) and westward. Mareh and April.

4. D. ramosissima, Desv. Perennial; stems diffuse, pubeseent; leaves lincar-lanceolate or the lowest oblanceolate and crowded, coarsely toothed ; racenes corymbose-branched ; siliele lanecolate, flat, twisted, hairy ; style slender. - Mountains of North Carolina and northward. April and May. - Stems $4^{\prime}-8^{\prime}$ long. Flowers white.

\section{\$2. EROPHILA. - Petals 2-cleft.}

5. D. verna, L. Stems naked, slender $\left(2^{\prime}-4^{\prime}\right.$ high); leares radical, oblong; silicles oblong, smooth, shorter than the pedicels, scattered; flowers small, white. - Waste places, chiefly in the upper distriets. Introdueed.

\section{VESICARIA, Lam.}

Silicle globular and inflated, or more or less flattened parallel to the orbicular partition; the hemispherieal or convex thin valves nerveless. Seeds few or several, flat. Cotyledons accumbent. Filaments toothless. - Low herbs, pubescent or hoary with stellate hairs. Flowers mostly yellow.

1. V. Lescurii, Gray. Somewhat pubescent, but green; stems diffusely ascending from a biemnial root; leaves oblong or oval, sparingly toothed, those of the stem half-clasping by a sagittate hase; raecmes elongaterl, manyflowered; pedicels ascending; filaments inflated at the lase; style half the length of the hispid orbicular or broadly oval flattened siliele ; seeds wing-margined, one to four in each cell. - Hills near Nashville, Tennessee. A pril and May. - Flowers golden yellow. 


\section{CAMELINA, Crantz.}

Silicle oroid or pear-shaped, flattened parnllel to the broad partition; valves 1-nerved. Seeds numerous, oblong. Cotyledons incumbent. Style slender. Flowers small, yellow.

1. C. Sativa, Crantz. Leaves alternate, sagrittite; silicle large. - Fichls, North Carolini, nnd northward. Introduced.

\section{SENEBIERA, Poir.}

Siliele dilymous, compressed contrary to the narrow partition; the cells glolr ular, 1-sected, erested or pitted, indehiscent, at maturity separating from the partition. Cotyledons incumbent. - $\$$ nnual or biennial diffuse strong-seented lierbs, with pinnately lobed or divided leaves, and minute white flowers, in short racemes, opposite the leaves. Stamens 2, 4, or 6.

1. S. pinnatifida, DC. Stem prostrate; leaves deeply pinnatifid, with the numerous lolses toothed on the upper elge; silicle pitted, emarginate at hoth ends. - Waste plaees, Florida to North Carolina. March-May.-Racemes many-flowered.

2. S. Coronopus, Poir. Stem prostrate; leaves deeply pinnatifid, with the lobes emtire, toothed, or pinnatifid; silicles not emarginate, the margins crested. - Waste places. Introduced. March and $\Lambda$ pril.

\section{Lepidium, L. Peppergrass.}

Silicle rounded or obeordate, compressed contrary to the narrow partition; valves earinate: cells 1 -sceded. Cotyledons aceumbent and incumbent. Petals sometimes wanting. Stamens 2, 4, or 6. - Leaves entire, toothed, or pinnately divided. Flowers minute, in terminal racemes.

1. L. Virginicum, L. Smooth; stem erect, much branehed; leaves lanecolate, sharply toothed, the lowest tapering and mostly pinnatifid toward the base; silicle orlicular, wingless; rotyledons aceumbent; stamens mostly two. - Wastc places, very common. March-June. (1) - Stem $1^{\circ}-2^{\circ}$ high.

\section{CAPSELLA, Vent. Shepherd's Purse.}

Siliele triangular-wedge-shaped, flattened contrary to the narrow partition, many-seceled; ralies wingless. Cotyledons incumbent. $-\Delta n$ annual herb, with the ralieal leaves clustered and pimatifid; those of the stem clasping and often entire. liacemes elongated. Silicle shorter than the spreading pedicel. Flowers white.

1. C. Bursa-pastoris, Manch. - Waste ground, Florida and northward. Ifarch and April. Introluced.

\section{CAKILE, Tourn.}

Silicle 2-jointed ; the joints thick, 1-celled, 1-seeded. Seed of the upper joint ereet, of the lower suspended. Cotyledons accumbent. - Fleshy sea-side annuals, with pinnatifid or lobed leaves, and white or purple flowers in racemes op. posite the leares. 
1. C. maritima, Scop, var. æqualis. Smooth; stem much branched, prostrate; leaves oblong, irregularly toothed or pinnatifid, narrowed intc a petiole as long as the limb; flowering racenes short and eorymb-like, fruiting ones elongated; petals wedge-obovate, cmarginate; mature silicle linear, 8-ribbed, the upper joint ovate-lanceolate, slightly compressed, beak-pointed, one third longer than the eylindrical lower one; cotyledons linear, 3-angled. (C. sequalis, L'Her.) - Drifting sands along the coast. May - August. - Stems $1^{\circ}-2^{\circ}$ long. Flowers pale purple.

\section{Order 13. Capparidacere. (Caper Faintr:)}

Herbs, shrubs, or trees, with acrid watery juice, alternate, simple or palmately-compound leaves, and regular hypogynous flowers. Stipules spiny or wanting. - Sepals 4, imbricated or valvate in the bud. Petals 4 , mostly clawed. Stamens 6 or numerous. Ovary 1-celled : oviles anphitropous or eampylotropous, attached to the two parietal placentre. Fruit silique-like, and 2-valved or indehiscent. Seeds reniform, without albumen. Embryo eurved.

\section{Synopsis.}

* Caly x 4-sepalous - Ilerbs.

1. POLANisiA. Stamens $8-32$, free. Torus short. Style filiform.

2. CLEOSE. Stamens 6, free. Torus short. Stigma sessile.

3. GYNANDROPSIS. Stamens 6. Filaments partly united with the stipe of the orary.

* Calyx 4-parted. - Shrubs.

4. CAPPARIS. Stamens numerous, free. Leaves entire.

\section{POLANISIA, Raf.}

Petals clawerl. Stamens 8-32 : filaments free, unequal, filiform. Torus short, bearing a truncated or emarginate gland on the upper sile. Ovary sessile or short-stipitate. Style filiform. Capsule silique-like, many-seeded. - Annual elammy herbs, with palmately trifoliolate petioled leaves, and raccmose flowers.

1. P. tenuifolia, Torr. \& Gray. Stem slender, creet, branching; leaflets filiform, longer thin the petiole; petals oval, entire, short-clawed, inequal ; stamens 12-15; capsule linear, smooth, short-stipitate, pointed witl the persistent style ; seeds minute, circular. - Georgia (Le Conte) and South Florida (Blodyett). - Stem $1^{\circ}-2^{\circ}$ ligh. Flowers white.

\section{CLEOME, I.}

Petals long-clawed, nearly equal, entire. Stamens 6. Filaments filiform, clongated, 1 - 3 often shorter, rarely all abhreviated. Torus short, hemisplecrictl. Stigma sessile. Capsule silique-like, stipitate or almost sessile, many-seeded.Herbs with palmately $3-7$-foliolate leaves, and bracted racemose flowers. Stipules, when present, spiny. 
1. C. pungens, Willl. Clammy-pulesent; leaves 5 - 7 -foliate, long.

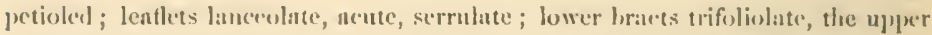
ones simple, corlate-uvate; stipules spiny; ;apsule smooth, shorter flun the clengated stipe; seeds rugrese. - Waste plares, Floridla and Westward. MayAugust. Introdued. (1) - Stem $2^{\circ}-4^{\circ}$ high. Petioles more or less spiny: Flowers showy, jurphe, changring to white.

\section{GYNANDROPSIS, ])C.}

Petals clawed, imbricated or open in the bud. Stamens 6 ; the filunerts ad. mate to the lower half of the elongated stipe of the ovary. Stimma sessile. Cansule silique-like, many-sceded. - Ilerbs with palmately 3-5-foliolute leaves, and racemose bracted flowers.

1. G. pentaphylla, I)C. Clammy-pubescent; leaves 5-foliate, the lower ones and bracts 3-foliolate; leaflets oblong-obovate, nearly entire; flowers white, open in the busl; capsules hisplid; seeds warty. - Wante places, Florida to North Caroliza. Naturalized. May-August. (1) - Stem $2^{\circ}-3^{\circ}$ high.

\section{CAPPARIS, I. Capin-tike.}

Sepals partly united, imbrieated or valvate in the but, often grlandular at the base. Petals imbricated in the but. Stamens numerous. 'Torns small. Oviry long-stipitate. Stigma scssile. Fruit fleshy, globose or silicine-like, manyseeded. - Sluruls or trees, with simple entire coriaceous leaves, spiny or minate stipules, and mostly showy flowers.

1. C. Jamaicensis, Jacy Leaves oblong, emarginate, smooth alove, the lower surface, like the flowers and flattened branclues, dotted and covered with minute seales, flowers terminal, by pairs, on short 4-iugled peiluncles; sepals ovate, valuate in the bud, scarcely shorter than the ovil white petals; filaments 20-24, long, villous at the base; cilpsule long $\left(6^{\prime}-8^{\prime}\right)$, eylindrical, torulose, downy, longr-stipitatte. (Colicodendion anceps, Shutl.) - South Florida. - Shrub $8^{\circ}-10^{\circ}$ lighl.

2. C. eynophallophora, I. I.eaves ollong, olotuse, reticulute-veinel, glabrous like the flowers and branches; peduncles t-angled, few-flowerel; sepals rounded, imbricated in the bud, much shorter than the obovate white petals; filaments very long $\left(2^{\prime}\right)$, smooth; capsule $\left(6^{\prime}-8^{\prime}\right.$ loug $)$ smooth, torulose, shortstipitate, pulpy within. - South Floridia. - Slırub $6^{\circ}-8^{\circ}$ high.

\section{Order 14. VIOLACEA. (Tholkt Famir.)}

Herbs or shrubs. Jeaves alternate, simple, involute in the bud. Stipules persistent. Flowers irrecrular, axillary, on bracted peduncles, nording. Sepals 5, persistent, imbrieated in the bud. Petals 5, hypogynous, oblicuely convolute in the buk. Stamens 5, alternate with the petals, connivent. Anthers adnate, introrse. Style single. Capsule 1-celled, loculicidally 3-valved, many-seeded: valves each bearing a placenta in the micldle. Embryo straight, in flesliy albumen. 


\section{VIOLA, Toum. Violet. Heart's-ease.}

Sepals nearly equal, produced at the base into a free appendage. Petals unequal, the lower one produeed into a sae or spur at the base. Stamens short; the broad filaments membranaceous and prolonged above the anthers; the two anterior ones spurred on the back. Stigma often beaked. - Low herbs. Peduneles 1-flowered.

1. Leaves and peduncles arising from a subterranean rhizoma, without apparent stems: perennials, flowering in early spring, the later flowers apetulous.

* Flowers blue or purple.

1. V. cucullata, Ait. Smooth or pubescent ; leares long-petioled, all undivided, varying from cordate-ovate to reniform, semate, the sides at the baso involute when young; the later ones acutish; lateral petals bearded; stigma beakless. - Low ground, conmon. - Flowers blue, often variegated with white.

2. V. palmata, L. Downy or hairy, rarely smooth; earliest leaves entire, cordate or reniform; later ones variously 3 -9-lobed, the eentral lobe always largest, lanceolate or oblong, the lateral ones spreading; flowers large, with the lateral and lower petals bearded. - Dry soil, common. - Flowers purple or blue.

3. V. villosa, Walt. Downy; leaves prostrate, short-petioled, orbicular or broadly cordate, erenate, purple-veined; peluncles mostly shorter than the leaves, flowers small. - Dry sandy or gravelly soil, Florida to North Caroliua. - Flowers pale blue.

4. V. sagittata, Ait. Smoothish; leaves cordate-oblong, aente, toothed and somewhat sagittate at the base, the earliest ones rounded, short-petioled; lateral petals bearded. - Damp pastnres in the upper districts and northward. Flowers larger than in the last, deep blue.

5. V. pedata, I. Smoothish; leaves all 7-9-parted, the divisions linear. lanceolate, entire or toothed, narrowed downwarl ; petals beardless. - Dry sandy soil in the middle and upper distriets, and northward. - Flowers large, deep blue or purple.

\section{* * Flowers white.}

6. V. primulæfolia, L. Smooth or hairy; leaves oblong, mostly acute, crenate, cordate or abruptly decurrent on the winged petiole; petals often acute, the lower ones bearded and striped with purple. - Low grounds, common. Rhizoma slender, and commonly bearing long leafy runners. Flowers small.

†. V. lanceolata, L. Smooth or pubescent ; leaves lanccolate or linear, narrowed into the long and winged petioles ; flowers beardless. - Low pine barrens. Florida and northward. - Rhizoma like the last.

8. V. blanda, Willd. Minutely puheseent; rhizoma slender; leaves small, orbicular-eordate, crenate, shorter than the peduncles; flowers small, beardless, sweet-seented, the lower petal striped with purple. - Low ground and mealows, North Carolina and northward. - Petioles slender, wingless. Leaves rarely aeute. 


\section{* * *louers yellou.}

9. V. rotundifolia, Michx. Neurly smooth; leawes liroally cordute, longer than the short petioles; lateral petsls bemrled- Mountains of North Curolina and northwart. - libizona slender, bearing rumers. Leaves flat on the ground. P'etals striped with pupple.

\$2. Leares and flouers borne on manifest stems : jorrennials.

* Stems leafy throughout.

10. V. Muhlenbergii, Tors. P'rimary stems ereet, the later ones prostrate; leaves broadly cordate or seniform, crenate and roughened with minute elevated points, the uppermost ncute; stipules fringed ; spum olituse, latf us long as the pale purple petals; lateral petals bearded. - Damp shades in the upper districts and northward.

Var. multieaulis, Torr. \& Gray. Stems all prostrate and creping; leaves smaller, roundish, obscurely crenate, jurple-reincel. - Dry rocks and hills in the lower districts. March and $\Lambda_{p}$ ril. - Stems slender, $4^{\prime}-6^{\prime}$ long.

11. V. striata, Ait. Stems ascending; leaves corkate, serrate, roughencel as in No. 10, the uppermost often acute; stipules large, fringel; spur thick, shorter than the large cream-colored petals; lateral petals bearded, the lower striped with purple. - Mountains of Georgia and northwarl. April.Stcus 10'-12' high. P'eduncles elongated.

12. V. Canadensis, I. 'Tall; leaves larore, broally corlate, acuminate, coarsely serrate, longer than the peduncles; stipules nearly entire; spur very short; petals white, extemally purplish, the bateral ones learled. - Rieh soil along the mountains of North Carolina and northwart. May-August. Stems $1^{\circ}-2^{\circ}$ ligh.

* * Stems leafy at the summit: stipules entire.

13. V. hastata, Michx. Smooth or luairy ; leaves rhombic-ovate, hastate 3-lobed, or the lower ones 3-parted (V. tripartita, Elll.), serrate and commonly acute; flowers small, yellow; lateral petals hearded, the lowest strijed with purple; spur very short. - Shaded bill-sides, Florida and nortlıward. April and May, - Stem 6'-12' high. Stipules small.

14. V. pubescens, Ait. Downy or woolly; leaves broadly cordate, roarsely servate, mostly acute; stipules large; spur very short; flowers yellow, the lower petals reined with purple, beardecl. - I)ry rocky soil in the upper districts, and northward. April. - Stems $6^{\prime}-12^{\prime}$ high. Calpsules sometimes villous.

\section{\$3. Stems leufiy: root annual.}

15. V. tricolor, L., var. arvensis, DC. Stems branching ; lowest leaves rounlish, the upper lanceolate, entire; stipnles leafy, pinnatifil ; fowers small, yellow and purple. - Cultivated gronnd. Introduecd. - Stem 6' high.

\section{SOLEA, Ging.}

Sepals not producel at the base. Petals unequal, the lowest one gibhous at the base and 2-lobed at the apex, the others smaller. Stamens with the filaments inited and produced above the anthers, the two lower ones glandular at the 
base. Style hooked at the summit. - In upright simple hairy perennia terb, with numerous ovate-lanceolate, acuminate and entire leaves, and $1-3$ shortstalked greenish nodding flowers in each axil.

1. S. concolor, Ging. - Mountains of Caro!ina and nortibward, in deep shades. June and July. (Viola conesior, $P^{3}$ ursh.) - Stem $1^{\circ}-2^{\circ}$ high. Leaves short-petioled.

\section{Order 15. Cist ACEAE. (Rock-rose Family.)}

Herbs or low shrubs, with entire leaves, and regular mostly polyandrous flowers. - Sepals 5, persistent, the two outer ones smaller, the three inner twisted in the bud. Petals unostly 5 , twisted contrary to the sepals in the bud, rarely wanting. Stamens few or numerous, distinct, hypogynous. Anthers innate. Ovary 1-celled. Style single. Capsules 3-5-valved. bearing as many parictal placentre each in the middle of the valve, few on many-seeded. Seeds orthotropous. Embryo curved, in mealy albumen

\section{Synopsis.}

1. IIELiANTII EMUM. Style none. Stigma capitate. Embryo nearly annular.

2. LECHEA. Sty e none. Stigmas plumose. Embryo nearly straight.

3. IUD OXIA. Style filiform Stigma minute. Embryo coiled.

\section{Helianthemíu, Tonn. Rock-Rose.}

Petals 5, corrugated in the bud, sometimes wanting. Stigma sessile or nearly so, capitate, 3-lobed. Capsule 3-valveil. Embryo eurved nearly into a ring. Low herbs or partly shrubly plants, with fugtcious yellow flowers.

* Flowers perfect: petals conspicuous: stamens indefinite: cripsule many-seeterl.

1. H. Carolinianum, Michx. Iirsute; leaves lancolate, denticulate, acute, short-petioled, the lowest obovate, erowled ; flowers large, solitary, horne above the axils. - Dry sanly soil, Florila to North Carolina and westward. March and April. - Stems $6^{\prime}-12^{\prime}$ high, ascending from a slirubby base. Flowers $l^{\prime}$ wide.

2. H. arenicola, sp. n. Hoary; leaves small, lanceolate, olituse, entire, with the sides revolute; flowers solitary, or 2-4 in terminal umbellate clusters, on slender pedicels. - Drifting sands near the coast, West Florida. Mareb and April. - Stems slumbby and branched at the base, all but the short $\left(2^{\prime}-6^{\prime}\right)$ flowering stems buried in the sand. Flowers $\frac{1}{2}$ ' wide.

* * Flowers of two kinds: the earliest as in the last section, the luter oncs smaller, clusterch, with small petals, or none, fewer stumens, and few-secded capsules

3. H. corymbosum, Michx. Tomentose, stems erect, slirubly at the base; leaves lancelate, obtuse, entire, hoary beneatl, with the sides revolute; flowers nearly sessile in a cymose cluster at the summit of the stem, the perfect ones long-perluneled; sepals woolly. - Dry sands ne:l' the coast, Florida to North Carolina. April. - Stems $1^{\circ}$ high. Capsule smooth. 
4. H. Canadense, Michx. Stems ereet, at first nearly simple, lowny or snuosth; Ienves lancentate, downy, or nearly smooth nhove; flowers nxillary, the perfere omes lorre, solitary, the later mpetilous ones clustered or sometimes

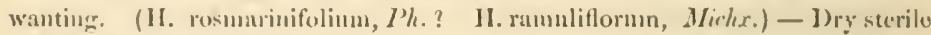
soil, Florida and northward. $\Lambda_{\text {pril. }}-$ Stems $1^{\circ}$ ligh. I'erfect flowers in inch wile.

\section{IECHEA, I.}

I'etals 3 , persistent, not longer than the sepuls. Stamens 3-12. Stigmas 3, sessile, plumose. Capsule globose, 3-valved, incompletely 3-elled, 6-seeded. Embryo slightly curved. - l'ereminal herbs, witl suall greenish flowers in racemes or panicles.

1. L. major, Michx. Villous; leaves alternate, opposite, or whorled, elliptieal, those on the prostrate radieal branches soundish; flowers on shott pedicels, densely crowded in short simple or compound axillary racemes. (L. villosa, Ell.) - Dry sterile soil, Florida and northward. July and August. - Stem $2^{\circ}$ high, branehing toward the summit. Capsules as litrge as a pin's head.

2. L. minor, Lam. Rough with appressed scattered hairs; the young branches and calyx more or less hoary; stems paniculately branched whove; leaves seattered, linear; flowers loosely racmose, on distinct, often appressed pedicels. (L. racemulosa and L. tenuifolia, Michx.) - Dry sandy soil, common. July and Angust. - Stems $\frac{10}{2}-2^{\circ}$ high. Capsules larger than in No. 1. Radieal branches often wanting.

\section{HUDSONIA, I.}

Petals 5, larger than the sepals, fugacious. Stamens 9-30. Style filiform. Stigma minute. Capsule oblong, l-elled, 3-valved, with $2-6$ erect seeds attached near their base. Embryo (oiled. - Low tufted slımbs, with minute hoary, subulate, imbrieated leaves, and yellow flowers at the sum of the branches.

1. H. montana, Nutt. Stems $2^{\prime}-4^{\prime}$ high ; leaves loosely imbrieated; peeliecls longer than the flowers; calyx campanulate; sepals acuminate. - Table Rock, North Carolina.

\section{Order 16. DROSERACEAE. (Sundew Fama.)}

Low glandular-hairy marsh herbs, with circinate tufted ralieal leaves. and regular hypogy nous white or purplish flowers, lorne on a naked scape. Sepals 5, persistent. Petals 5, withering. Stamens 5-15, distinet : anthers extrorse. Ovary 1-celled, many-ovuled, with 3 or 5 parjetal placentse. Styles separate or mited. Capsule loculicidally 3-5-valved. Seeds anatropous. Embryo minute at the base of fleshy allumen.

\section{DROSERA, I. SUNDEw.}

Stamens 5. Styles 3-5, deeply 2-parted; the divisions 2-many-lohed. Capsule 3-valved, many-seeded. - Leaves dewy with glandular hairs. Scape often forking. Flowers racemose, secund. 
1. D. flliformis, Raf. Rhizoma thick, ereeping; leaves erect, filiform, elongated, smooth at the base; scape smooth, many-flowered; flowers large, bright purple; calyx hairy ; seeds oblong, dottel. - Low pine barrens, Florida and northward. April. $4-$ Scapes $1^{\circ}-1 \frac{1}{2}^{\circ}$ high. Flowers $1^{\prime}$ or more wide.

2. D. longifolia, L. Rhizoma long and slender ; leaves linear-spatulate, gradually narrowed into the long and smooth petiole, the upper ones ereet; scupe smooth, declined at the base, 8-12-flowered; calyx obovate; seeds oblong. (D. foliosa, Ell.) - Sandy swamps, oftener in water, Florida and northward. May and June. $4-$ Scapes $4^{\prime}-6^{\prime}$ lighl. Flowers small, white.

3. D. capillaris, Poir. Rhizoma short or none; leaves spatulate, narrowed into the long and smoothish petiole; seape slender, smooth, ereet, 9-20flowered ; ealyx obovate ; seeds oval, finely furrowed and granular. (D. brevifolia, var. major, Ilook.) - Boggry ponds, Apalachicola, Florida, to Sonth Carolina (Bose.). April and May. () or $4-$ Seape $6^{\prime}-15^{\prime}$ ligh. Leaves $2^{\prime}-3^{\prime}$ long. Flowers pale rose-color.

4. D. rotundifolia, L. Rhizoma none; leaves orbienlar, abruptly contraeted into the hairy petiole; seape ereet, smootl, 6-10-flowered ; ealyx ovoid; seels corcrel with a loose membranaceous coat. - Mossy swamps, Florida and northward. May and Junc. $O$ - Seapes $6^{\prime}-9^{\prime}$ lighh. Leaves $2^{\prime}$ long. Flowers white.

5. D. brevifolia, Pursh. Glandular-puheseent thronghont ; rhizoma none; leaves short, welge-shaped; scape erect, 3-6-flowered; ealyx oval; seeds ovoid, minutely grlandular. - Low sandy pine barrens, Floridla to North Carolina. April. (1) - Seapes $3^{\prime}-6^{\prime}$ high. Leaves $\frac{1^{\prime}}{2}$ long. Flowers $\frac{1}{2}{ }^{\prime}$ wide, white.

\section{DION再A, Ellis. Fritral.}

Stamens 10-15. Styles united. Stigmas 5, fimbriate. Capsule 1-eelled, opening irregularly. Placenta at the base of the cell, many-seeded. $-\mathbf{A}$ smooth perennial herh, with the habit of Drosera. Leaves spreading, on broadly-winged, spatulate petioles, with the limb orbienlar, notehed at loth ends, and fringed on the margins with strong bristles; sensitive! Flowers in a terminal nmbel-like cyme, white, bracted.

1. D. muscipula, Ellis. - Sanly hogs in the pine barrens of North Carolina and the adjacent parts of South Carolina. April and May. - Scape $1^{\circ}$ high, 8-10-flowered. Flowers 1' wide. - For an interesting account of this remarkable plant, sce Curtis's Plants of Wilmington, in the Boston Journal of Natural History, Vol. I. 1834.

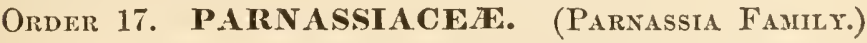

Perennial smooth herbs, with ovate or reniform chiefly radical and entire leaves, on long petioles, and large solitary flowers terminating the scape-like, 1-leaved stem. - Sepals 5, persistent. I'etals 5, ovate or obo- 
vate, veiny, inturieated in the but, deeidnons. Fertile stamens 5, alternating with the petals : anthers introrse. Sterile ones in sets of $3-15$ more or le's nuted filaments, placed opposite ear phetal. Ovary 1-eelled, with 3-t parietal placentae. Stigmas $3-1$, sossile, plared over the placentas. Capsule loculicidally 3-4-valved at the npex, mamy-seredial. Seeds anatropous, wingerl, without albumen. Bunbryostraight, cylindrical.

\section{PARNASSIA, Tourn. Grass of lirissus.}

Characters same as the oreler.

1. P. Caroliniana, Miehx. I.enves hroally ovate or eorlate-orate; camline one near the lase of the stem, clasping ; petals oval, sessile, with impressed ereenish reins; sterile stanens by thees, distinct almost to the base, $2-3$ times as long as the reenrved fertile ones. - 1)amp soil, Florida and northward. October and Nov'mber. - Stem 12' - 18' liggh. Flowers $I^{\prime}$ widle.

2. P. asarifolia, Vent. Leaves reniform; eauline one uear the millle of the stem, elasping; petals broally ovate, short-clawed; sterile stamens ly. threes. - High mountains of North Carolina. August and September, - Flow. ers larger than in No. 1.

\section{Orneis 18. HYPEIRICACEA. (Str. JoIn's-Wolt FAMLY.)}

Ilerhs or shrubs, with opposite entire dotted leaves, without stipules, and regular hypogynous, mostly yellow flowers. - Sepals $4-5$, inhluicated in the bul, presistent. Petals $4-5$, convolute or imbrieated in the hud, lecidnous. Stimens mostly numerous, and often united at the base into $3-5$ sets: anthers introrse. Styles $2-5$, often united, persistent. Capsule 1-celled, with strictly parietal placenta, or 2-5-celled hy the meeting of the placenta at the axis, septicilally $2-5$-valved. Seeds very numerous, minute, anatropous, without albumen.

\section{Synopsis.}

* Petals convolute in the bud.

1. ASCYrty. Sepals and (yellow) pretals 4.

2. IIYPERICUM. Sepals and (yellow) petals 5 . Stamens without interposed glands.

* Petals imbrieated in the loud.

3. ELOLEA. Sepals and (rose-colored) petals 5. A gland between the sets of stamens.

\section{ASCyRUM, L. St. Peter's-wort.}

Sepals 4, the two outer ones much larger (exeept No. 5). Petals 4, convolute in the bur, oblipue. Stamens numerous. Styles $2-4$, distinct or mited. Capsules 2-4-ralved, 1-celled, with 2-4 parietal placenta. - Smooth shrubs with 2-edged branches. Flowers mostly solitary, yellow.

\section{* Pedicels 2-bracted: styles shorter than the ovary.}

1. A. Crux-Andreæ, L. Leaves linear-oblong, obtuse, narowed at the base; outer sepals oval, rather obtuse, the inmer ones minute; petals oblong, 
often acute, approximate in pairs; styles 2 ; capsule as long as the sepals. Sterile soil, Florida and northward. June-September. - Shrub $1^{\circ}-3^{\circ}$ high. Leaves I' long. Branches opposite.

2. A. stans, Michx. Leaves oval-oblong, obtuse, closely sessile; outer scpals orbicular-cordate, obtuse; the inner ones lanceolate, acute; petals obovate; styles 3 or 4 ; capsule shorter than the sepals. - Var. oвovatum, Torr. \& Gray, is a dwarf state, with obovate leaves, and obtuse inner sepals. - Damp soil, Florida and northward. July-September. - Shrub $2^{\circ}-3^{\circ}$ high. Leaves and flowers larger than in No. 1 .

* *edicels bractless : styles longer than the orary.

3. A. amplexicaule, Michx. Leaves and onter sepals cordate-orate, clasping; inner sepals lanceolate, as long as the outer ones; petals olovate ; styles 3 ; (apsule oroid, barely half as long as the sepals. - Damp soil near the coast, Florida, Georgia, and westward. April-September. - Shrub $2^{\circ}-3^{\circ}$ high. Branches many times forking.

4. A. pumilum, Michx. Dwarf; leaves oblong-onorate, obtuse ; outer sepals round-ovate, the inner ones minute; petals ohorate; pedicels long and slender, refiexed in fruit; styles 2, united. - 1)ry gravelly soil, Florida, Georgia, and westward. March and April. - Stems $3^{\prime}-6^{\prime}$ long, diffuse. Leares $4^{\prime \prime}-6^{\prime \prime}$ long.

5. A. microsepalum, Torr. \& Gray. Leaves very numerous, small, oblong-linear, narrowed at the base, ohtuse ; flowers somewhat corymbose; sepals small auml equal. - Flat pine barrens, Florila and Alabama. Mareh and April. - Shrub bushy, $1^{\circ}-2^{\circ}$ ligh. Leaves $6^{\prime \prime}-9^{\prime \prime}$ long. Flowers $1^{\prime}$ wide.

\section{HYPERICUM, L. ST. Johy's-wort.}

Sepals 5, similar. Petals 5, oblique, convolute in the bud. Stamens mostly numerous, and commonly collected in $3-5$ sets, without intervening glands. Styles 3-5, distinet or united. Capsule 1-5-celled. - IIerls or shrubs. Flowers mostly eymose, yellow.

\section{\&1. Stamens numerous.}

* Capsule 3-celled : styles united: shrubs.

1. II. prolificum, L. Branches 2-edged, the barren ones clongated; leaves lance-ohlong, obtuse or nucronate, narrower at the base; eymes axillary and terminal, often few-flowered ; capsule obloner, rarely 4 -5-celled. - Varies with a more branching stem, smaller and narrower leaves, and smaller and more numerous flowers. (II. galioides, Ph.) - Swamps and banks of rirers in the nidhle and 1 pper districts. July and August. - Shrub $2^{\circ}-3^{\circ}$ high. Leaves 1'-2' longr, paler hencatl..

2. H. Buckleyi, M. A. Curtis. Low, wirly brancling from the base; leaves oblonir, obtuse, narrowel at the base, pulcr beneath; flowers solitary, terminal, on rather long and bracted pedicels; sepals oborate; style and stamens long and slender. - Mountains of Georgia and North Caroliua. - Slurub 8'-12' high. Flowers $l^{\prime}$ wide. 
* * Cupsule 3-relled: styles sqparate: minls bluck-dotud : lurls.

3. H. perforatum, I. Stin mnch branched, slightly 2-edged; eymes corymbosc, many-fluwered; leaves ellipticnl or lincar-oblong, obtne, with [x]. Incid dots; scpals lancrolate, acute, - Old ficlds, sparingly unturalizel. JuneAngust. - Stem $1^{\circ}-2^{\circ}$ highl, bearingr rumers at the base. Flowers $I^{\prime}$ wile, (leep) yellow.

4. H. maculatum, Walt. Stem tercte, sparingly banched above; leaves oblong-cordatte, obtuse, clisping, marked with pellucid dots; cymes many-flow. ered, corymlose; sepals lanceolate, arute; styles twice as long as the ovary.Dry jine harrens, Floridat to North Carolinn. Jume-August. - Stem $2^{\circ}-3^{\circ}$ high. Leaves 1'-1 l' long, rigid. Flowers small.

5. H. corymbosum, Muhl. Leares thin, oblong, slightly clasping ; sepals orate; styles as loner as the orary; otherwise nearly as the last. - Mountains of North Carolina, northward and westward. July, - Stem $11^{\circ}-20$ high. Leaves $\mathrm{I}^{\prime}-2^{\prime}$ lonis.

* * Cipsule 1-celled, or partially 3-eelleal by the introversion of the plucentec.

- Sliruls: leares everyreen.

- Cymes leujy.

6. H. faseiculatum, Lam. Lowest leaves obovate, the others narrowlinear, witl revolute margins, and numerous smaller ones chinsterel in the axils; eymes mostly 3-flowered, lateral and terminal ; sejals like the leares, mostly shorter than the ohorate one-angled petals. - Var. Asraratuotdes has very short $\left(2^{\prime \prime}-3^{\prime \prime}\right)$ and wider leates and sepals, the latter one third as long as the smaller petals. - Margins of pine barren ponds, Florida to North Carolina and westwarl. July and Angust. - Slurnb $2^{\circ}-6^{\circ}$ highl. Leares $6^{\prime \prime}-12^{\prime \prime}$ long, conspicuously rotted, gloss. Capsule oblong-linear.

7. H. galioides, Lam. Lenves linear-oblanceolate, ohtuse, tapering to the hase, glossy above, rigit ; those in the axils clustered; cymes lateral and terminal, few-flowered, or the terminal ones compoum ; sepals equal, lincar, acnte, shorter than the petals ; eapsules acute. - I'ine barrens, Florida to South Carolina and westward.

Var. ambiguum. (II. ambiguum, Ell.? Torr. \& Gray.) L Leaves oblanecolate, mucronate, pale and thin ; sepals unequal, lanceolate, narrowel at the base, longer than the petals. - River swamps, Florida. July and August. - Stems $2^{\circ}-4^{\circ}$ high. Branches often clongated. Leaves $1^{\prime}-11^{\prime}$ long.

8. H. myrtifolium, Lam. Leaves cordate-oblong and partly clasping, mostly oltuse, stancous; cymes few flowered, terminal ; sepals leaf-like, ovate, acute, as long as the obovate petals; stamens very numerous; capsule conicalovate. (II. glaucum, Michx.) - Pine barren ponds, Florida to South Carolina and westward. M:1y - September. - Shrub $1^{\circ}-2^{\circ}$ high, with spreading tereto branches. Leaves thick, $1^{\prime}$ long. Flowers $1^{\prime}$ wide.

9. H. aureum, Bartram. Leaves oblong, murronate, narrowed at the base, wavy on the margins, glaueous beneath ; flowers very lange, mostly solitary at the summit of the 2-erlged branches; sepals leaf-like, slorter than the thick and tardily deciduous petals; stamens very numerous ; capsule ovate, much smaller 
than the calyx. (II. amœnum, Pursh.) - Banks of the Flint River, Georgia to Tennessee, and westward. June-August. - Stem $2^{\circ}$ high, diftinsely branched. Leaves $2^{\prime}-3^{\prime}$ long. Flowers $2^{\prime}$ widle, with recurved orange-colored petals.

$$
\text { * Cymes leafless, bracted. }
$$

10 H. nudiflorum, Michx. Branches 4-angled ; leaves oblong, obtuse, narrowed at the base, paler bencatls ; (ymes terminal, peduncled, 5-15-flowered ; braets subulate; buds globose; petals oval, twice as long as the oval sepals; capsule ovate, longer than the calyx. - Low grounds, Florida and northward. July and August. - Shrub $2^{\circ}-3^{\circ}$ high. Leares thin, $1^{\prime}-2^{\prime}$ long. Flowers $\frac{1}{2}{ }^{\prime}$ wirle. Petals recurved.

11. H. cistifolium, Lam. Branches 2-edged ; leaves rigid, linear-oblong, sessile; cymes terminal, compound, many-flowered; bracts subulate; buds ovate; petals spreading, olovate, twice as long as the oblong, nnergnal sepals; (apsule 3-lobed, ovate, longer than the sepals. (H. rosmarinifolium, Ell.) Pine barren swamps, near the coast, Florilla to Sonth Carolina and westwarl. July-September. - Sluub $2^{\circ}-3^{\circ}$ high. Leaves very numerous. $1^{\prime}$ long. Flowers $\frac{1}{2}$ ' wide. Valves of the capsule strongly impresserl on the back.

12. H. fastigiatum, Ell. "Branches somewhat conupressed ; leaves narrow-lanceolate, very acute; corymbs terminal, many-flowered, fastigiate ; styles united. - Pine barrens of Seriven County, Georgia. May - July. - Shrnb $3^{\circ}$ high. Leaves $3^{\prime}$ long, narrowed but connate at the base. Flowers very numerous." Elliott. (*)

$$
\text { +t therls: styles distinct. }
$$

13. H. graveolens, Buckl. Stem smooth, terete, nearly simple; leaves oblong-ovate, obtuse, clasping; cymes lateral and terminal, many-flowered; petals oblong-obovate, much longer than the lancelate acnte sepals; stamens collected in three sets, as long the petuls; styles slender, twice as long as the ovary. - Mountains of North Carolina. July and August. - Stem $2^{\circ}-3^{\circ}$ high. Leaves $2^{\prime}$ long. Flowers large.

14. H. pilosum, Walt. Downy ; stem terete, mostly simple, slender; leaves small, lance-ovate, acute, erect, sessile; cymes compound; styles short. (II. simplex, Mfich.) - Wet pine harrens, Floridit to North Carolina and westward. July and Augrust. (1) ? - Stems $1^{\circ}-2^{\circ}$ high. Leaves $\frac{1}{2}^{\prime}$ long. Flowers $5^{\prime \prime}-6^{\prime \prime}$ wide.

15. H. angulosum, Michx. Smooth; stem 4-anglerl, branching; leaves ovate-lanceolate, acute, sessile; cymes leafy, many-flowered, the branches often simple; sepals ovate, shorter than the petals, longer than the ovate capsule. Varies (H. acutifolium, Ell.) with larger shining leaves, compound and nearly leafless cymes, and more crowded flowers. - Pine barren ponds (the var. in dry soil), Florila to North Carolina and westward. June - August. - Stem $2^{\circ}-3^{\circ}$ high. Leaves $6^{\prime \prime}-12^{\prime \prime}$ long. Flowers small. Styles longer than the enpsule.

\$2. Stamens 5-20: capsule strictly 1-celled: styles separate: annuals.

* Flovers in cymes.

16. H. mutilum, L. Stems slender, hranching ahove, 4-angled, leaves oblong or roundish, obtuse, clasping, 5-nerved; cymes leafy at the base; sepals 
lanceolate, mostly longer than the small petals, and equalling the (green) ovoil eapsule; stamens $6-12$. (H. parviftorm, Mull. H. quinguenervium, Halt.) - Ditches and low grounds, rommon. Jure-August. - Stem 10 hight. Branches of the erme filiform. Flowers very small, remote.

17. H. Canadense, L. Steus simple or brancherl, 4-angled; leaves linear or linear-lanceolate, the upper ones acute, seswile; sepals lancenlite, ucute, longer than the petals, shorter than the oblong (brown) cupsule. - Wet sundy places, Florida anel northward. June-Oct - Stem $t^{\prime}-12^{\prime}$ high, with the branches erect. Flowers small, copper-yellow. Stamens 5-10.

* * Foners scuttercd on the slender lranches: lcures minute.

18. H. Sarothra, Michx. Stem much hranched ; brinches erect, filiform ; leaves minute, subulate, lract-like; flowers small, seswile; sepals scarcoly laalf as long as the lanecolate pupple eapsule. - Siudy old fields. J'Jorila aul northward. June- $\mathbf{\text { ug gust. }}$ - Stems $6^{\prime}-12^{\prime}$ higgh. Stamens 5-10.

19. H. Drummondii, Torr. \& Gray Stem much branched; leaves linear or the lower ones oblong, acute, appressed; sepals barely shorter than the ovate capsule; flowers perlicelled. - 1)ry larren soil, Floricla, Sontl Carolina, and westward. July and Angust. - Stems ant branches stouter than the last. Stamens 10-20.

\section{ELODEA, Adans.}

Sepals 5. Petals 5, equal-sided, inbrieated in the bud. Stamens mostly 9, and united in sets of three, with a seale-like gland between each set. Styles 3, distinct. Capsule 3-celled, 3-valved, many-sected. Smooth perennial herbs. Flowers rose-rolor, in contracted lateral and terminal eymes.

1. E. Virginica, Nutt. Leaves oblong or oval, corlate, clasping, conspicuously dotted leneath; stamens united below the middle. - Swamps, Florida and northwurl. July aurl August. - Stems terete, $1^{\circ}-2^{\circ}$ high.

2. E. petiolata, Pursh. Ieares ohlong, narrowed at the hase, short-petioled, obsemely do:terl beneath; stamens united above the middle. - With the preceding. July and August. - Stem $2^{\circ}$ high.

\section{Order 19. CItustace. (Balsam-Tree Famit.)}

Trees or shmub, with resinous yellow juice, opposite coriaceous entire dotless leaves artienlated with the stem, and regular hypogynous flowers. Sepals 3-6. Petals 4-9. Stamens mostly numerons, distinct or varionsly mited. Ovary 1-many-celled, few - many-ovuled. Style single, often none. Fruit eapsular, baceate, or drupaceous. Seeds without albumen. Embryo straight. Cotylerlons thick, distinct or uniterl.

1. CLUSIA, I.

Calyx 2-bracted, of 6 imbricated, colored sepals. Petals 4-9. Stamens numerows, the filaments united at the base into a thick and fleshy tulbe. Ovary 
5-15-celled. Ovules numerous, fixed to a central column. Stigma large, radiate-peltate. Capsule coriaceous, globose-angled, 5-15-eelled; the valves separating from the central column at maturity. Seeds numerous, orate. - Parasitical tropical trees, with thick, opposite, entire and shining leaves, and chicfly polygamous, cymose, showy flowers.

1. C. flava, L. Leaves short-stalkel, obovate, obtuse or emarginate, fincly veined; flowers polygamous, single or by threes, on short axillary and terminal peduncles; sepals rounded ; petals 4, oral, thick, yellow and unequal; stamens short and thick; stigma about 12-rayed; capsule pear-shaped, 12-seeded, the sceds imbedded in soft pulp. - Sonth Florida. - A small tree.

\section{CANELLÁ, CORBrown. Seperate Golu}

Sepals 3, rounded, concave, imbricated in the bud, persistent. Petals 5, hypogynous, oblong, convolute in the bud, deciduous. Stamens united into a tube. Anthers 15 (21 Endl.), aldnate, linear. Orary 3-celled. Style cylindrical. Stigmas 3. Berry globose, 1-3-celled, mostly 2-sceded. Seeds globosereniform. Embryo minute, in fleshy albumen. $-\mathbf{A}$ large trec. Leaves alternate, near the ends of the branches, obovate, emarginate, glabrous, on short petioles. Racemes compound, shorter than the leaves, terminal. Pedicels 1flowered. Flowers small, purple. (The proper place of this genus is undetermined, but it lias been referred to this order.)

1. C. alba, Swartz. - South Florida. August. - Tree aromatic. Leaves 2'long. Berry black.

\section{Order 20. POrtulacacez. (Perslane Fauly.)}

Sueeulent plants, with entire leaves and regular hypogynous or perigynous flowers. Sepals 2-5. Petals $3-6$, imbricated in the bud, sometimes wanting. Stamens as many as the petals and opposite them, or indefinite. Styles 3-6, mostly united below, stigmatic along the inside. Capsule 1 -5-celled, few-many-seeded. Seeds eampylotropous, erect from the base of the cell, or attached to a central placenta. Embryo slender, eurved around mealy albumen.

\section{Synopsis.}

* Sepals 2. Petals 5-6.

1. ClaytoniA. Petals and stamens 5. Capsule 3-valved, 3-6-seeded.

2. TALINU.I. Petals 5. Stamens 10-30. Capsule 3-valved, many-seeded.

3 PORTulaCA. Petals 5-6. Stamens 8-20. Capsule circumscissile.

* * Sepals 5. Petals none.

4. SESUVIUM. Stamens $5 \cdot 60$, inserted on the calyx. Capsule circumscissile.

\section{Claytonia, L. Spring-Beauty.}

Sepals 2, free, persistent. Petals 5, hypogynous. Stamens 5 , inserted on the claws of the petals. Style 3-cleft. Capsule 1-celled, 3-valved, 3-6-seeded. - 
Smooth herbs, with a simple stem hearing two opjusite leaves, uml terminated

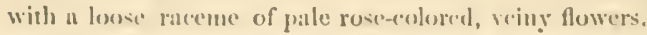

1. C. Virginica, L. Javess loner $\left(3^{\prime}-6^{\prime}\right)$, linear, arutish ; petals mostly emarerinate, but sometimes acute. - Dimup ricls soil in the upper districis. March. - Plant $4^{\prime}-10^{\prime}$ long.

2. C. Caroliniana, Michx. Leaves short $\left(\mathrm{I}^{\prime}-2^{\prime}\right)$, ovate-lanceolate or oblong, tapering at the batse, obtuse; petals obtuse. - Nountains of North Carolina and northwarel. March und $\Delta$ pril. - Sinaller than tlıc last.

\section{TALINUM, Allins.}

Sepals 2, free, leciduous. Petals 5, hypogynous. Stumens 10-30. Style 3-lobed. Capsule 3-celled at the base, 3-valved, many-seceled. - Smooth and flesly herhs, with alternate leaves and eymose flowers.

1. T. teretifolium, l’ursh. Sten thick, leafy; leaves linear-eylindrical; eymes on long peduncles; petals purple, fugacions. - Tocks, Nortl Carolina and northward. June - Augr. $4-$ Stems $2^{\prime}-4^{\prime}$ long. l'eduneles $5^{\prime}-8^{\prime}$ long.

\section{PORTULACA, Tourn. Purslane.}

Sepals 2, united and colscring with the orary below, the upper portion circumscissile and decidnous with the upper part of the capsule. Petals $4-6$, inserted with the 8-20 stamens on the calyx. Style 3-8-parted. Capsule glohose, l-eelled, many-secled. - Low, fleshy herbs, with terete or flat, mostly altemate leaves, and fugacious yellow or purple flowers.

1. P. oleracea, L. Leaves flat, cuncate, naked in the axils ; flowers yellow ; stamens 10-12.- Cultivated ground everywhere. - Stem prostrute.

2. P. pilosa, I. Leaves linear, obtuse, with a tuft of hairs in the axils; flowers jurple; stamens nbout 20. -- Key West, Florida.

\section{Sesuvium, L. Sea Plrslane.}

Sepals 5, free, united at the base, persistent, colored within. Petals none. Stamens 5, or numerous, inserted on the ealyx. Styles 3-5. Capsule 3-5celled, many-secded, circumscissile. - Prostrate and fleshy maritime plants, with nearly opposite and entire leaves, and axillary purplish flowers.

1. S. portulacastrum, L. Leaves lanccolate and oblong, acute, on winged and clasping petioles; flowers pedicelled; scpals fleshy, lanceolate, mucronate, purple within; stamens numerous, - Sandy or multly places along the coast, Florila and northward. May-December. 4 - Stems diffuse, creeping, forming mats which are sometimes $6^{\circ}$ in dianeter.

2. S. pentandrum, Ell. Icares spatulate-olsorate, obtuse, on slightly winged and elasping petioles; flowers sessile; sepals orate-lanceolate, stamens 5. - Muddy saline coves, Florida to North Carolina. May - November. (1)? - Stems (often erect) and flowers snaller than in the jreceding. 


\section{Order 21. CARYOPHYLLACEA. (Pink Famil.}

Herbs with tumid joints, entire opposite or whorled, often connate leaves, and regular hypogynous or perigynous cymose flowers. Stipules dry and scarious, or none. - Sepals $4-5$, imbrieated in the bud, persistent. Petals $4-5$, often stamen-like or none. Stamens as many as the sepals and opposite them (except Mollugo), or twice as many, or by abortion fewer. Ovary free, $1-j$-celled, with the amphitropous or eampylotropous ovules attached to a central placenta. Styles 2-5, distinet or partly united, stigmatic along the imer side. Fruit valvate or indehiseent, 1-manyseeded. Embryo curved, or forming a ring around mealy albumen.

\section{Synopsis.}

TRIBE T. ILLECEB REFE. Sepals distinct or united below. Petals often stamenlike or wanting. - Leaves wilh scarious stipules.

\section{* Fruit indehiscent, 1-seeded (utricle).}

1. PARONYCIIA. Sepals united at the base. Stamens inserted on the base of the sepals. Style long. Utricle included.

2. ANYCIIIA. Sepals distinct Stamens inserted on the base of t'se sepals. Style very short. Utricle partly exserted.

3. SIPIONYCIIA. Sepals united into a tube below the middle. Stamens inserted on the tube of the calyx. Style long.

* Fruit valvate, few - many-seeded.

+ Leaves opposite.

4. STIPULICIDA. Stem-leares minute; the lowest spatulate. Flowers in terminal clusters.

5. SPERGULARIA. Leaves all linear. Flowers solitary, axillary.

$\leftarrow$ - Leaves whorled.

6. SPERGULA. Styles 5. Stamens 5-10. Capsule 5-valved.

7. POLYCARPON. Styles 3. Stamens 3-5. Capsule 3-valved.

TribE II. MOLLUGINEAE. Stanens alternate with the sepals, when of the same number ; when three, alternate with the cells of the ovary. - Stipules none.

8. MOLLUGO. Capsule 3.celled. Leaves whorled.

Tribe III. A LSINEA. Sepals separate or nearly so. Stamens opposite the sepals when of the same number. Ovary sessile. - Stipules none.

* Valves of the capsule as many as the styles.

9. SAGINA. Styles and valves $4-5$.

10. ALSINE. Styles and valves 3.

* Valves or teeth of the capsule twice as many as the styles.

11. ARENARIA. Talres of the capsule 2-4, each soon 2-eleft. Petals entire.

12. STELLARIA. Valres of the capsule 6-10. Petals 2-cleft.

13. CERASTIUM. Capsule 8 - 10-toothed.

TRIBE IV. SILENEAE. Sepals united into a tube. Petals and stamens inserted on the stipe of the ovary. - Stipules none.

14. SILENE. Styles 3. Capsule 6-toothed.

15. SAPONARIA. Styles 2. Capsule 4 toothed.

16. AGROSTEDiMA. Sryles 5. Capsule 5-toothed. 


\section{PARONYCHIA, Tourn.}

Sepals 5, united at the base, concave and mucronate or awnerl at the apex I'etals l, ristle-like on tooth-like, alternate with the 5 stunn'ns, und inserted with them on the hase of the ealyx. Style long, 2-cleft. Ltricle included. Secd resupinate. Rndicle superior or ascending. - Low herbs, with conspieuons silvery stipules, and minute flowers in loose or compact cymes.

1. P. dichotoma, Nutt. Smooth; stems sleniler, ereet; leaves linearsubulate; those of the barren stems imbricatcd; cynes fastigiate, diffise; sepals linear, 3-ribbel, slender-pointed; petals minute, bristle-like. (Anychia argrocoma, $E / l$ ) - Rocks on the mountains of North Carolina, and westwarl. July - Nov. 4 -Stem; 6'-12' high.

2. P. argyrocoma, Nitt. Minutely pubescent; stems tufted, aseending; leaves linear, acute; eymes eapitate, the flowers concealed by the large silvery stipules; sepals lanceolate, hairy, slender-pointed; petals minute, tooth-like. Mountihins of Georgia and Nortlı Carolina. Jujy-Sept. 4 -Stems $6^{\prime}-10^{\prime}$ high. Stipules nearly as long as the leares.

3. P. herniarioides, Nutt. liough-pulsesent; stems prostrate, diffuselybramehed; leaves oval or oblong, mucrontte; flowers axillary, solitary, sessile; sepals subulate, with a short and spreading point. (Anychiat herniarioides, Michx.) - Dry sand ridges in the midhle districts, Georyia to North Carolina. July - Ott. (1)-Stems $4^{\prime}-6^{\prime}$ longr Leaves $3^{\prime \prime}-t^{\prime \prime}$ longr.

4. P. Baldwinii. Finely pubeseent; stems prostrate, diffusely-lranched; branches alternate, one-siled, filiform; leaves lanceolate or ovate-linceolate, acute, narrowed into a petiole; eymes tiffuse, nakel; sepals ohlong, 3-ribbed, ciliate, short-pointed; petals bristle-like, as long as the stumens; utricle equadliner or rather Jonger than the sepalls; style 2-cleft to the mirllle. (Anychia Baldwinii, Torr. of (iruy.) - J)ry sandy soil, Florila and Georgia. July - Oet. (1) and (2)-Stems $1 \frac{1}{2}{ }^{\circ}-3^{\circ} \mathrm{long}$. Upper leaves sometimes altcrnate.

\section{ANYCHIA, Michx.}

Sepals 5 , distinet, slightly mueronate at the apex. Petals none. Stamens $2-3$, inserted on the base of the ealyx. Style very short. Stigmas sprealing. Utriele exsertel. Seel ereet. Raclicle inferior. - An erect slender annual, with forking setaceous spreading branches. Leaves thin, oblong, obtuse, narrowed at the base. Flowers minute, solitary or clustered in the forks of the branches, greenish.

1. A. dichotoma, Michx. (Qneria Canadensis, L.) - Barren hills, Soutl Carolina and northward. July and Augrust. - Stem $4^{\prime}-10^{\prime}$ liggh.

\section{SIPHONYCHIA, Torr. \& Gray.}

Sepals 5, united to the midlle, concave and petal-like ahove, obtuse or mucronate. Petals 5, bristle-like, inserted with the 5 stamens on the throat of the calyx. Style slender, 2-cleft. Utriele included. Sced resupinate. Radicle superior. - Ereet or diffusely prostrate herbs. Cymes dense-flowered. Flowers white. 
1. S. Americana, Torr. \& Gray. Stems prostrate, diffuse, pubescent in lines; leaves lanceolate, narrowed at the base; the radical ones larger and crowded; flowers obovate, solitary in the forks of the stem, and elustered at the end of the branches; sepals rounded and incurverl at the apex, the tube bristly with hooked hairs; petals minute. (Herniaria Americana, Nutt. Paronyehia urceolata, Sluttl) - Sandy banks of rivers, Florida to South Carolina, and westward. June-Oct. (1) or (2) - Stems $1^{\circ}-3^{\circ}$ long. Leaves sometimes falcate and incrusted with brownish particles. Stipules small.

2. S. diffusa, n. sp. Pubescent; stems prostrate, diffusely-branched; leaves laneeolate, obtuse, narrowed at the base; flowers small, in compatet, rectangular cymes, terminating all the branches; sepals linear, slightly concave and mueronate at the apex, the tube bristly with hooked hairs; petals bristle-like. - Dry sandy pine barrens, Florida. June-Oct. (1) - Stems $1^{\circ}$ long. Stipu!es conspicuous, on young plants half as long as the leaves, at length 2-parted. Cymes very numerous.

3. S. erecta, n. sp. Stems smonth, clustered, erect, rigiil, nnostly simple; leaves erect, linear, acute, pubescent on the margins, those of the barren stems imbricated; cyme compound, reetangular, fastigiate, compact; sepals lanceolate, smooth, acutish, or obscurely mucronate at the apex, the tube smooth and furrowed; petals bristle-like, half as Iong as the stamens. - Sands along the west coast of Florida. June-Nor. $4-$ Root woorly. Stems $6^{\prime}-12^{\prime}$ high. Stipules hilf as long as the leaves.

4. S. Rugelii. Annual; stem erect, successively forking, clothed with a short and rather dense pubeseence, as also the leaves anil bracts; leares oblanceolate, abruptly pointed, shorter than the internodes, the upper ones linear; stipules $\frac{1}{4}-\frac{1}{3}$ as long as the leaves, soon 2-4-parted; eymes numerons, terminal, rather loosely flowered; calyx-tube short, pubescent, the linear-lanceolate divisions conspicuously mucronate, white; petals bristle-like; style includesl. (Pitronychia Rugelii, Shutt.) - East Florida. - Stems $1^{\circ}$ high, at length diffuse?

\section{STIPULICIDA, Michx.}

Sepals 5, emarginate, white-margined. l'etals 5, spatulate, 2-toothed near the base, longer than the sepals, witheringr-persistent. Stamens 3, opposite the inner sepals. Style very short, 3-parted. Capsule 1-celled, 3-valved, manyseeded. - A small perenuial, with an erect forking stem. Stem-leaves minute, subulate, with adnate pectinate stipules. Radicul leaves spatulate, clustered, growing from a tuft of bristly stipules. Flowers white, in terminal clusters.

1. S. setacea, Michx. - Low sanly pine barreus, Florilla to North Carolina. April - June. - Stem $3^{\prime}-6^{\prime}$ hight, the branches sprealing and eurving.

\section{SPERGULARIA, Pers.}

Sepals 5. Petals 5, oval, entire. Stamens 2-10. Styles 3-5. Capsule 3-5-ralved; the valves when 5, alternate with the sepals. $-\Lambda$ low maritime herb, with opposite fleshy leaves, and conspicuous searious stipules. Flowers axillary, solitary, rose-colored. 
1. S. rubra, l'ers. - Samls or inarshes along the coast, filorida and north. ward. April and Maty. (1 - Stems prostrate, much branched. Leaves linear, longer than the joints. Seed with or without a menbranaceous margin.

\section{SPERGULA, L. Sivuır.}

Sepals 5. Petals 5, entire. Stamens 5 or 10. Styles 5. Cajpule 5-vithod, the valves opposite the sepals. Embryo forming a ring around the albuncu. l.eaves whorled. Flowers eymose, white.

1. S. arvensis, L. Stem erect; leaves fleshy, narrow linear, several in a whorl; eyme loose, long-peduncled; fruiting pedicels reflexel; stanens 10 ; sceds rought. - Cultivated fields, Florida and northward: introduced. (1).

\section{POLYCARPON, I.}

Sepals 5, carinate. J'etals 5, cumarginate, shorter than the sepals. Stamens 3-5. Styles 3, very short. Capsule 3-valved. - Low ammuls, with whorled leaves, and minute flowers, in terminal cymes.

1. P. tetraphyllum, L. Stems $\left(3^{\prime}-6^{\prime}\right)$ forking, liffuse; leaves spatulate-obovate, the lower ones 4 in $n$ whorl, the upper opposite; sepals acule; stipules conspicuons. - Neir Charleston. Introducul. Jl:ty and Junc.

\section{MOLLUGO, L.}

Sepals 5. Petals none. Stamens 5 aud alternate with the sepals, or 3 and alternate with the cells of the ovary. Styles 3, short. Capsule 3-valvel, 3-celled, many-seeder. - Prostrate diffusely-braneled anuuals. Leaves whorled. Flowers white, on slender axillary peduncles.

I. M. verticillata, I. Smooth; leaves spatulate-lanceolate, uncopual, in whorls of $4-8$; fruting prefuncles reflexed; stamens $3 .-$ Cultivited ground, common. Introduced. May - August.

\section{SAGINA, I.}

Sepals 4-5. Petals 4-5, entire, or wanting. Stamens 4-10. Styles 4-5, alternate with the sepals. Capsule $4-5$-valved; the valves entire, opposite the sepals. - Small herbs, with filiform forking stems, subulate leaves, and solitary flowers.

1. S. Elliottii, Fenzl. Smooth; stems erect or ascending, tufted; peduncles erect; petals and scpals 5, equal, obtuse; st:mens 10. (Spergnolit decumLens, Ell.) - J):mp cultivated ground, common. April-June. (1 - Stens $2^{\prime}-6^{\prime}$ high. I'eluncles $2-3$ times as long as the sharp-pointed leaves.

\section{ALSINE, Tourn.}

Sepals 5. Petals 5. Stamens 10. Styles 3. Capsule 1-eelled, 3-valved, the valves entire, opposite the inner sepals. - Low siender herbs, witl linear or subulate leaves, and white cymose or solitary flowers. 
1. A. squarrosa, Fenzl. Stems tufted; leaves subulate, rigid, those of the glandular flowering stems distant, of the sterile stems imbricaterl, with spreading tips; sepals ovate, obtuse, shorter than the eapsule. (Arenaria squarrosa, Michx.) - Dry sand-hills, West Florida and northward. April and May. 4 - Stems $6^{\prime}-10^{\prime}$ high. Cymes few-flowered. Pedicels rigid.

2. A. glabra, Gray. Sinooth; stems filiform, sparingly l,ranched; leaves tender, narrow-linear, obtuse, spreading ; eyme few-flowered, spreadinor ; sepals oblong, obtuse, faintly 3-ribbed, as long as the capsule. (Arenaria glabra, Mich.r.) - Monntains of North Carolina. July. 4 ? - Stems tuftel, $4^{\prime}-6^{\prime}$ high. Cymes leafy. Pedicels setaceous. Leaves $\frac{1}{2}{ }^{\prime}-1^{\prime}$ long.

3. A. patula, Gray. Minutely pubeseent; stem filiform, diffusely branched from the base; leaves narrow-linear, spreading; cyme spreading, few-manyflowered; pedicels very slender; petals spatulate, emarginate, twice the length of the lanceolate acute $3-5$-nerved sepals. (Arenaria patula, Mlichx.) - Rocks around Knoxville, Tennessee, and northward. - Stems $6^{\prime}-10^{\prime}$ high.

4. A. Michauxii, Fenzl. Smooth ; stems tufterl, erect or diffuse, straight; leaves linear-subulate, erect, spreading or recurved, much clnstered in the axils; cymes spreading or contracted ; petals oblong-obovate, twice as long as the rigid ovate acute 3 -ribbed sepals. (Arenaria stricta, M/ichx.) - Rocks and barren soil, Georgia and northward. May and June. - Stems $3^{\prime}-10^{\prime}$ high.

5. A. brevifolia. Stems smooth, not tufted, ereet, filiform, simple, 2-5-flowered; leaves minute $\left(1^{\prime \prime}-2^{\prime \prime}\right)$, erect, lanee-subulate; sepals oblong, obtuse, as long as the expsule; petals twice as long as the sepals. (Arenaria brevifolia, Nutt.) - Rocks in the upper districts of Georgia. (1) - Stems $2^{\prime}-4^{\prime}$ long, bearing $3 \mathrm{Ol}^{4}$ pairs of leaves. Flowers small, on filiform peduncles.

\section{ARENARIA, L. SANDWorT.}

Petals 1-5, or none. Styles 2-4. Capsule opening above by as many valves as there are styles, each valve soon splitting into two pieces. Otherwise like Alsine

1. A. diffusa, Ell. Downy ; stem elongated, prostrate, alternately shortbranched; leaves lanceolate; peduncles longer than the leaves, lateral, reflexed in fruit ; petals $1-5$, shorter than the sepals, often wanting. (Stellaria elongata, Nutt. Micropetalon lannginosum, Pers.) - Shady banks, Florida to North Carolina and westward. May-October. 4 - Stems $1^{\circ}-4^{\circ}$ long.

2. A. serpyllifolia, L. Downy ; stems diffusely branched; leares small, ovate, acute, the lowest narrowed into a petiole; flowers cymose; petals much shorter than the lanceolate acuminate sepals. - Waste places, Floridia and northward. Introduced. April and May. (1) - Stems 6'-12' Jong. Leaves $\frac{1}{2}$ ' long.

12. Stellaria, L. Chickied. Starwort.

Sepals 4-5. Petals 4-5, 2-cleft, or 2-parted. Stamens 3-10. Styles 3-5, opposite the sepals. Capsule l-celled, opening by twice as many valves as there are styles, many-seeded. - Stems weak. Flowers white, on terminal perluncles, becoming lateral in fruit. 
1. S. pubera, Michs. Perennial ; stems erect or llifuse, forking, lairy in lines; leaves ohlong, antish, nurruwed at the hase, sessile; petals longer than the sepals. - Shuly rocks in the npper distriets und northwarl. $\Lambda_{\text {pril }}$ and May. - Stems $6^{\prime}-12^{\prime}$ high. Flowers showy.

2. S. media, Sunith. Anuual; stems prostrate, forking, pulesent in lines; leaves orate or oblong, acute, the lower ones petioled; jetals shorter than the sepuls. - Yards and gurdens. March and $\Lambda$ pril. Introduced.

3. S. prostrata, Ballw. Smooth or nearly so ; stems forking, prostrate ; leaves ovate, acute, all on slender petioles, the lower ones often cordate; pretuls twice as long us the sepals; seeds rough-edged. - Inimp shades, Georgiil, Florila, and westward. March und April. (i - Stems $1^{\circ}-2^{\circ}$ long. 1'etiole mostly longer than the limb.

4. S. uniflora, Walt. Smooth; stems erect from a prostrate lase; leaves remote, narrow-linear, sessile; peduncles very long $\left(2^{\prime}-4^{\prime}\right)$, ereet ; petals obeordate, twice as long as the calyx. - River swamps, South Carolina and North Carolina. May. (1) ? - Stems $6{ }^{\prime}-12^{\prime}$ high. Leaves $1^{\prime}$ long. - Perloaps a species of Alsine.

\section{CERASTIUM, I. Mouse-ear.}

Sepals $4-5$. Petals $4-5$, obcordate or 2-eleft. Sitmens 10 . Styles $4-5$. Capsule cylindriıal, 8-10-toothed, many-secderl. - IIcrbs. Flowers white, solitary or eymose, peluncled.

\section{* Petals not longer than the sepuls.}

1. C. vulgatum, I. Villons and somewhat clammy; stems aseending; leares oval, remote, the lowest obovate; eymes crowded in the bud, sprealing in fruit ; sepals lanceolate, acute, as long as the peduncles, and latf as long as the slender capsule. - Fields, Florida and northward. April amd May. ()Stems $6^{\prime}-12^{\prime}$ high.

2. C. viscosum, I. Hairy and clammy ; stems ascending ; leaves lancewhlong, obtuse, the lowest wedge-shaped; cymes loose in the bud ; sepals oblongovite, olstuse, shorter than the perluncles. - Fields, Floridia and northward. A pril and May. (1) - Flowers and capsules liarger than in Xo. 1.

\section{* Petuls longer than the sepuls.}

3. C. arvense, L. Hairy or downy; stems numerous, naked above; leaves narrowly or broally lanceolate; eymes rather few-flowered; petals ol,cordate, twice as long ns the ollong sepals. - Rocky or dry soil, chictly in the apper districts. May and June. If - Stems $6^{\prime}-12$ ' liggl. Leaves seldom $\mathbf{1}^{\prime}$ long. Elowers $\frac{11}{2}$ wide. Capsule rather longer than the calyx.

4. C. nutans, Raf. Climmy-pulsesent; stems tufted, furrowed; leares lanecolate; eymes ample, many-flowered ; petals oblong, emirginate, rather longer than the oblong sepals. - Low groumls, North Carolina and Tennessec, and northward. (1) - Stems $1^{\circ}$ high. Peluncles long. Capsule curved, three times as long as the calyx. 


\section{SiLENE, L. Catchfly.}

Sepals uniter into a 5-toothed tube. Petals 5, long-clawed, inserted with the 10 stamens on the stipe of the ovary, eommonly crowned with two scales at the base of the limb. Styles 3. Capsule I-eelled, or 3-celled at the base, opening by 6 teetl, many-seeded. - Leaves mostly connate. Flowers cymose, of.cn showy.

* Perennials : flowers showy.

+ Petals gash-fimliniate, crownless.

1. S. stellata, Ait. Leares in whorls of four, lanee-ovate, acuminate, the uppermost opposite; flowers white, in a large sprealing panicle; calyx inflated, boll-shaped. - Dry woods in the npper distriets, and nortliward. JuneAugust. - Stems $2^{\circ}-3^{\circ}$ high, downy, branching above.

2. S. ovata, Pursh. Rough-pubeseent; leaves large $\left(t^{\prime}-5^{\prime}\right)$, opposite, oblong-ovate, acuminate; flowers white, in a contracted lanceolate panicle; ealyx tubular. - Mountains of Georgia and Carolina. July. - Stems stout, $2^{\circ}-4^{\circ}$ high.

3. S. Baldwinii, Nutt. Villous; stems low, slender, bearing runners at the creeping base; leaves opposite, spatulate; the upper ones oblong, sessile; cymes few-flowered ; flowers very large, white or pale rose-color, on slender pedicels; calyx tubular, - Low shaty woods, Georgia and Florida. April and May. - Stems $6^{\prime}-12^{\prime}$ hirgli. Leaves thin. Flowers $2^{\prime}$ wide.

- - Petuls emarginate or 2-cleft, crouned.

4. S. Virginica, L. Clanmy-pubeseent; leaves abruptly pointed, the lowest ones elustered, spatnlate-obovate, on fringed petioles, the upjer small, rensote, lanceolate, sessile; eymes loosely few-flowered ; calyx tubular-elub-shaped, oblong and nodding in fruit; petals crimson, lanecolate, 2-cleft. - Rich open woods, chiefly in the upper distriets. June and July. - Stems $1^{\circ}-2^{\circ}$ high. Flowers $1^{\prime}$ widle.

5. S. regia, Sims. Viscid-pubescent and rouglish; stem tall $\left(3^{\circ}-4^{\circ}\right)$ and erect, branched; leaves ovate-laneeolate, the upper ones aeuminate; flowers large, bright searlet, short-stalked, chustered and forming a strict panicle; ealyx long, cylindrieal, striate, dilated in frnit; petals oblanceolate, generally entire; stamens and style exserted. - Prairies of Alabama and westward. July:

6. S. rotundifolia, Nutt. Hairy and viscid; stems weak, deemment, branched; leaves thin, roundish, abruptly acuminite at each end, the lowest obovate; flowers few, large, bright searlet; calyx eylindrical; petals 2-eleft, with the lobes cut-toothed. - Shady rocky banks, Tennessee and northward. June-August. - Stems $2^{\circ}$ long. Flowers showy.

7. S. Pennsylvanica, Michx. Clammy-pubeseent; stems low, elustered; lowest leaves spatulate-ohovate, the upper lance-oblong, mostly obtuse; eymes dense-flowered; (alyx elub-shaped, ereet; petals white or rose-eolor, obovate, emarginate or entire.- Roeky hills, chiefly in the upper districts and northward. March and April. - Stems $6^{\prime}-12^{\prime}$ high. 
* Ammals: flowers small, crouned, expanding at night.

8. S. Antirrhina, l. Stem slenler, smoothish, rlammy below the upper joints; leaves linear, atente, sessile, the lowest lanceolate, narrowed into a petiole; flowers panicled ; calyx smooth; petals olucordate, rose-eolored. - I)ry old fields, Florida and northwitr. May and June. - Stems $6^{\prime}-2^{\circ}$ light, simple or branched. Flowers minute.

9. S. quinquevulnera, L. Hairy; stem branching; leaves spatulate, the mpper ones linear; flowers in l-siled racemes ; alyx haty ; petals rounded, entire, piuk or crimson with a paler border, - Near Charleston. Naturalized. - Stem 10 high.

\section{SAPONARIA, I. SOAPWORT.}

Calyx tubular, terete, 5-toothel. Petals long-elawerl. Stamens 10. Styles 2. Capsule sessile or short-stiperl, 1-eelled, or 2-celled at the base, 4-toothed at the apex. - Cymes dense-flowered.

1. S. officinalis, I. Pereuninl; stems stout, ercet, smootl, leaves ovate, connate, strongly 3-ribherl; petals erowned, white or rose-color, mostly double. - Waste places. Naturalized. - Stems $1^{\circ}-20$ high.

\section{AGROSTEMmA, I. Conn-Cockle.}

Calyx tulular, with 5 elongaterl linear deciluous lobes. Petals 5, entire, crownless. Stamens 10. Styles 5. Capsule 1-relled, 5-toothed. - Annual or biemial pubescent herbs, with linear leaves, and sliowy purple flowers on elongated jeduncles.

1. A. Githago, L. Plant $\left(1^{\circ}-2^{\circ}\right.$ high) whitened with long appressed hairs; stem forking; petals ohovate, cmarginate, shorter than the lobes of the calyx. - Grain fields. Introduced. Junc and Jnly. (1) - Y'eduncles $\mathbf{4}^{\prime}-G^{\prime}$ long. Flowers $1^{\prime}$ wille.

\section{Order 22. MALVACEA. (MaL.ow Fami.)}

Mucilacrinous herbs or slurubs, with palmately reined alternate stipulate leaves, and regular monalelphous flowers on jointerl peduncles. - Sepals 5 , united at the base, valvate in the bucl, persistent, often with a calyxlike involncel. Petals 5, convolute in the bul. Stanens numerous, united into a colunn which is continuous with the claws of the jetals: anthers 1-celled, opening transversely. Ovaries uniter into a ring, or forming a several-celled capsule. Styles separate or united. Secrls kidney-shaped. Albumen searee or none. Embryo large, eurvel, with leafy cotyledons. Pubescence commonly stellate. Pollen grains hispid

\section{Synopsis.}

TRIBE I. M A LVE .E. - Carpels as many as the stigmas, 1 - few-seeded, disposed in a circle around a centrat axis, separating at maturity from the axis and from each other. Anthers borne at the apex of the column. 
* Carpels 1-seeded.

- Stigmas occupying the iuner face of the styles.

1. MALVA. Carpels beakless. No process within.

2. CALLIRRHOE. Carpels beaked, and bearing a dorsal process above the seed within.

$$
++ \text { Stigmas capitate. }
$$

3. MALVASTROM. Involucel 2-3-leaved. Ovule peritropous-ascending. Radicle inferior.

4. SIDA. Involucel none. Ovule resupinate-pendulous. Radicle superior.

* * Carpels 2 - few-seeded.

5. ABUTILON. Carpels 1-celled. Involncel none.

6. MODIOLA. Carpels transversely 2-celled. Involucel 3-leaved.

TRIBE. II. URENE E. - Carpels half as many as the stigmas, separating at maturity. Anthers borne above the middle of the column.

7. PAVONIA. Carpels 5, dry, 1-seeded. Involucel 5-15-leaved.

TRIBE III. IIIBISCE EE. - Carpels as many as the stigmas, united and forming at ma turity a loculicidal capsule. Column hearing the anthers throughout, or from above the midule.

8. KOSTELETZKYA. Cells of the depressed capsule 1-seeded.

9. HIBISCUS. Cells of the globose or oblong capsule few-many-seeded.

\section{MALVA, I. Mallow.}

Involncel 3-leaved, persistent. Petals obcordate. Styles 9-20, filiform, stigmatic on the inner face. Carpels broadly reniform, heakless, 1-seeled, indehiscent, disposed in a circle aromd the central axis, from which they separate at maturity. Embryo nearly aumulur. Radicle inferior. - ILerbs. Leaves rounded. Flowers axillary, not yellow.

1. M. rotundifolia, I. Stems several, prostrate; Ieaves long-petioled, round-cordate, crenate and crenately-lobed; flowers single or clustered, white veined with purple; carpels even. - Around dwellings. Introduced. 4.

\section{CALLIRRHOË, Nutt.}

Involueel 1-3-leaved and persistent, or none. Petals wetge-shaperl, entire, or crenate. Styles as in Malva. Carpels mmerous, with a short and naked beak, and a ligulate dorsal process below the beak within. Embryo curverl. Radicle inferior. - Perennial herbs. Leaves palmately-lobed, or angled. Flowers showy, purple or whitish.

1. C. triangulata, Gray. Rongh-pubescent; stem ascending from a perpendicular rhizoma, branching above; leaves triangular, coarsely and unequally crenate, the lowest ones long-petioled and cordate, the upper 3-5-lobed ; flowers approximate, panicled, longer than the pedicels; involucel 3-leaved, the leaves linear; carpels at length 2-valved. (Malva triangulati, Leuvenuorth.) Dry soil in the upper districts of Alabama to North Carolina and northwestivard. July. - Stem $2^{\circ}-3^{\circ}$ high. Flowers $1^{\prime}-1 \frac{1}{2}^{\prime}$ wile, purple.

2. C. Papaver, Gray. Rough with scattered appressed and rigid hairs; stems low, simple; leaves 3-5-parterl; the lobes oblong or lanceolate, toothed or entire; flowers few, solitary, axillary, long-peduncled; involncel 1-3-leaved, or none; petals finely crenate; carpels indeliscent. - Rich open woods. Georgia, 
Florida, and westwad. May-September. - Stems $1^{\circ}$ high. Flowers purple, 2: wide, on perluncles which are sometimes $1^{\circ}$ long.

3. C. alcæoides, Gray. Strigose-pubeseent; stems slender (10 high $)$; lower leaves triamerular-cordate, incised; the upper 5 - 7-parted, laciniate, the uppermost diviled into linear segments ; flowers corymbose, on slender perluncles (rose-(olor or white); involneel none; carpels obturely beaked, (rested and strongly wrinkled on the back. (Sida alcaoodes, Michx.) - Barren oak lands, Tenuessee.

\section{MALVASTRUM, Gray.}

Inrolucel 1-3-leaved or none. Styles 5-20. Stigmas eapitate. Carjels beaked or beakless, 1-seeded. Seed ascending. Embryo curred or ammlar. Radicle inferior. - Ilerbs or slirubby plants, rouglt with riggid hairs. Flowers yellow.

1. M. tricuspidatum, Gray. Perennial or slurnlbyy ; stem branchingr ; Jeaves ovate or oblong-ovate, serrate, acute, petioled ; stipnles laneeolate ; flowers in leafy spiked racemes; petals obliquely thuncated ; earpels 10-12, more or less distinetly 3-toothed or awned at tlie alex. - South Florida. - Stems 10 high. Involneel 3-leaved.

2. M. angustum, Gray. Annual ; stem crect, branching; leaves lanceolate, sparingly serrate, short-jetioled ; stipules bristle-like; flowers axillary, mostly solitury; invohecl setaceons, 2-3-leaved : carpels 5, (irenlar, awnless, at Jength 2-valved. (Sida hispida, Pursh.? Vill.?) - South Carolinal and westward. - Stems $6^{\prime}-122^{\prime}$ high. Calyx enlarged in frnit.

\section{SIDA, L.}

Involned none. Calyx angular. Styles 5-15. Stigmas capitate. Ovaries I-celled. Carpels erect, mostly 2-valved and 2-locaked at the apex, scparating at maturity from early other, and from the eentral axis. Seel resupinate, suspenderl, 3-angled. Eubryo (urved. Radiele superior. - Bramelaing herbs or shrubs, with chicfly undivided leaves, and small yellow or reddish flowers in their axils.

* Leraves, at loast the lourer ones, rordute: rurpels 5.

1. S. spinosa, L. Annual, minutely pmbescent; branches ereet; leaves oblong-ovate, acute, serrate, the shender petioles often with a fubercular spine at the base, the lower ones corlate; stipules setacenus, lailf as long as the petioles; flowers single or clnstered, on short ereet peduncles; (arjels fiuntly retienlated, each pointed with two ereet sululate spines. - Waste places, Florida and northward. July-September. - Stems $1^{\circ}-2^{\circ}$ high. Flowers $\frac{11}{2}$ wide, yellow.

2. S. supina, I'IIer. Perennial, tomentose; stems divided at the hase into slender simple ascending or prostrate branches; leaves all romi-cordate, crenate, roumlerl at the apex, hoary beneath; the slender petioles spineless at the base; stipules minute, subulate, deciduous; flowers solitary; the peduncles half as long as the petioles and reflexed in fruit; earpels downy, retienlaterl, almost beakless, opening irregularly near the membranaceous base. (S. orata, Cav. S. procumbens, Suartz.) - Sonth Florida. October. - Stems $6^{\prime}-12^{\prime}$ 
long; leaves $\frac{1^{\prime}}{2}-1^{\prime} \operatorname{long}$; the limb scarcely longer than the petiole. Flowers yellow, not half as large as in the preceding.

$$
\text { * Leaves not cordate: carpels } 7-12 .
$$

3. S. stipulata, Cav. Nearly smooth; stem erect or curving; leaves and branches distichous; leaves lanceolate and oblong, acute, unequally serrate, on short petioles; stipules linear-subulate, longer than the petioles, smooth, persistent; flowers single or elustered, on peduncles $3-4$ times as long as the petioles; carpels 10, strongly reticulated, pointed with two short and incurved spines. (S. glabra, Nutt.) - Waste places and around dwellings, Florida. June - November. (1) or $4-$ Stems $1^{\circ}-3^{\circ}$ high. Leaves $2^{\prime}-3^{\prime}$ long. Flowers 1' wide, yellow, expanding at mid-day. Petals obliquely ohcordate.

4. S. rhombifolia, L. Downy; stems erect, much branched; leaves rhombic-oblong, obtuse at each end, serrate, short-petioled, pale beneath ; stipules setaceous, longer than the petioles, calncous; peduncles solitary, more than half as long as the leaves; earpels $10-12$, even, pointed with a single subulate spine, indehiscent. - Around dwellings, Florida to North Carolina and westward. July-Oetober. (1) - Stems $2^{\circ}-3^{\circ}$ high. Leaves $2^{\prime}-3^{\prime}$ long. Flowers yellow, smaller than in No. 3.

5. S. ciliaris, Cav. Rough with appressed rigid hairs; stems prostrate; leares elliptical, obtnse at both ends, serrate above the middle, smooth above, the uppermost approximate; stipules setaceous, and like the calyx fringed with long hairs; flowers nearly sessile in the axils of the upper leaves; carpels 7 , strongly retienlated, pointed with two minute barberl spines. - Key West. 4 Stems $6^{\prime}$ long. Leaves $\frac{1}{2}^{\prime}-1^{\prime}$ long. Flowers small, red.

6. S. Elliottii, Torr. \& Gray. Perennial; stems slender, ronghish, erect, with long and straight branches ; leaves smoothish, lanceolate or linear, acnte, serrate, on short petioles; stipules setaceous; flowers large, single; peluncles longer than the petioles; carpels $10-12$, strongly reticulated, truncate or slightly 2-pointed. (S. gracilis, Ell., not of Rich.) - Open woords, Florida to North Carolina and westward. July-October. - Stems $1^{\circ}-3^{\circ}$ high. Leaves $1^{\prime}-2^{\prime}$ long. Flowers 1 'wide, yellow.

7. S. Lindheimeri, Engel. \& Gray. Stem shrubby, smooth, slender, much branched ; leaves rigid, narrow-linear, obtuse, serrate, paler and downy beneath, the short petioles spincless at the base; stipules subulate, persistent, as long as the petioles; peduncles about as long as the leaves; carpels 10, fitintly reticulated, pointed with two short and broad spines. - Key West. - Stems $1^{\circ}$ high. Leaves 1 ' long. Petals barely exceeding the calyx in length.

\section{ABUtiloN, Tonrn. Innias Mallow.}

Involneel none. Stigma capitate. Ovaries 5 or more, 1-celled, 2-9-ovuled. Carpels $1-6$-seeded, partly 2-valvel, tardily separating from each other or from the central axis. Radicle ascending. - Leaves cordate. Flowers yellow, white, or purplish.

1. A. Avicennæ, Gærtn. Tomentose ; leaves round-cordate, acuminate, crenate; peduncles axillary, $1-3$ flowered, shorter than the long petioles; car- 
pels 12-14, hairy, inflated, truncute, 3-secoled, witl two lone and spreading spines - Waste places chicfly in the mildle and upper districts. Introduerd. (1) - Stem $2^{\circ}-5^{\circ}$ high. Leares $t^{\prime}-6^{\prime}$ widle. Flowers oramere-1end.

2. A. Hulseanum, Torr. Stem hispiully pilose; leaves orbicular-ovate, ahruptly acuminate, velvety benenth with a whitish pubescenee, roughish-tomentose ahove, crenate-dentate; peduncles axillary in the upper leaves, severalflowered; styles about 12. - Tampa J3:y, Florida. - Icares 3 inches or more in diameter. Flowers $1 \frac{1 /}{2}$ in diameter, purplish ; pedicels very short.

3. A. Jaequini, I)on. Stem erect $\left(2^{\circ}-3^{\circ}\right)$, lurinching, smooth or foftdowny; leaves long-petioled, corlate or oblong-rordate, acuminatte, unequaliy erenate, velvety on hoth surfaces and hoary leneath, or ronghish alove; peeduncles solitary in the upper axils, 1-flowered, alsout the length of the petioles, or the upper ones longer; lohes of the calyx ovate or oblong, shorter than the yellow petals ; carpels $8-10$, rigill, hairy, longer than the ('alyx, ac'ute or beakel, 3-seederl. (A. peraffine, Shuth. Lavatera Americana, $L$. Sida alutiloides, Jucr. S. lignosa, $C\left(u v\right.$.) - South Floridia. - Flowers $9^{\prime \prime}-12^{\prime \prime}$ wide.

4. A. crispum, Gray. IIoary-tomentose; stem sparingly branched; leaves round-eordate, acminate, fincly erenate; pecluncles axillary, 1-fowered, elongated, filiform, refractel after flowering; earpels 10 , beakless, inflated, corrugated, hispid, 2-secded. - Key West. - Stem slender, $1^{\circ}-2^{\circ}$ high. Leaves $1^{\prime}-2^{\prime}$ long, the mpper ones nearly sessile. Peduncles as long as the leaves. Flowers $4^{\prime \prime}-6^{\prime \prime}$ wille, white.

\section{MODIOLA, Mœneh.}

Involueel 3-Icaved, persistent. Stamens 10-20. Ovaries 14-20, trinsversely 2-ectled, each cell 1-ovuled. Stigmas capitate. Carjels 2-valved, 2-seeded, separating at maturity from each other and from the central axis, each valve tipped witl a slender spine. - Prostrate herbs, with palmately divided leaves, and small axillary flowers.

I. M. multifida, Monel. Hirsute; stems diffuse; leaves long-petioled, cordate-ovate, more or less deeply 5 - 7 -parted; the divisions lobed and toothed; peduncles longer than the petioles ; carpels hispid. (Malva Caroliniana, L.) Waste places, Florida to North Carolina and westward. July-October. 4 Stems $1^{\circ}-2^{\circ}$ long. Earliest leaves orbicular, undivided. Petals red, as long as the calyx.

\section{PAVONIA, Cav.}

Inrolucel 5-15-leaved, persistent. Ovarics 5, 1-celled, 1-ovuled. Stigmas 10, capitate. Carpels indehiscent or somewhat 2-valved, naked or armed at the apex with three hispicl awns, separating at maturity. Embryo incurved. Radiele inferior. - Chiefly shrubs, with petioled stipulate leaves, and solitary flowers on axillary peduncles.

1. P. Lecontei, Torr. \& Gray. Stem much branched, roughish-pubescent; leaves ovate or somewhat sagittate, obtusely toothed, densely pubescent 
and hoary beneath, rough above, longer than the petioles; involucel of 5-6 ovate leaves, which are slightly united at the base; earpels ohovate, awnless, strongly reticulate. - South Georgia, collected by Leconte. - Stem $4^{\circ}-5^{\circ}$ high. Leaves 1 ; long. Flowers large, pale red.

\section{KOSTELETZKYA, Presl. (Hibiscus, L. in part.)}

Capsule depressed, the cells l-seeded. - Otherwise as in Hibiscus.

1. K. Virginica, Presl. Rough-hairy ; stem ereet, stout, branching; lower leaves ovate, cordate, serrate, mostly 3-lobed, the upper ones narrower and usually entire; flowers (purple) in terminal racemes. - Var. ALTIEAFOLIA. (Hibiscus althexfolius, Shuttl.) Densely stellate-pubescent and somewhat hoary; leaves all undivided, orate or ovate-lanceolate, acuminate, unequally toothedserrate ; racemes dense-flowered ; capsule hirsute. - Var. smilacifolid. (Hibiscus smilacifolius, Shuttl.) Stem more slender, smoothish below; leaves all hastate, with lanceolate serrate lobes; racemes few-flowered. - Marshes and low grounds near the coast, Florida and northwarl (the raricties near Manatee, South Florida, Rugel.). July - September. $4-$ Stem $2^{\circ}-4^{\circ}$ high. Flowers $1 \frac{1}{2}^{\prime}-2^{\prime}$ wide.

\section{HiBiscuS, L. Rose-Mallow.}

Involucel many-leaved or many-eleft, and, like the calyx, persistent. Stigmas 5, peltate or capitate. Capsule globose or oblong, 5-celled, locnlicidally 5valved, many-seeded. - Herbs, shrubs, or trees, with petioled stipulate leaves, and large showy flowers, on axillary peduneles.

\section{* Leaves of the imrolucel forked.}

1. H. aculeatus, Walt. Murieate-hispid; leaves round-cordate, divided into $3-5$ coarsely toothed and spreading lobes, the upper ones narrower and mostly entire ; flowers yellow, witlı a purple centre, short-peduncled; involucel 10-12-leaved ; eapsule hispid ; seeds smooth. - Margins of swamps and ponds, Florida to South Carolina, and westward. July. 4 -Stems $2^{\circ}-6^{\circ}$ high, Flowers $4^{\prime}$ wide.

\section{* * Leaves of the intolucel entire. \\ - Perennial herbs : stipules deciduous.}

2. H. Moscheutos, L. Tomentose; leaves broadly ovate, acuminate, toothed-serrate, mostly 3 -lobed above the middle, rounded or slightly cordate at the base, hoary beneath ; peduncles often partly adnate to the petioles; flowers white or pale rose-color with a crimson centre; seeds smooth. - Ponds and marshes, Georgia, northward and westward. July. - Stems $3^{\circ}-5^{\circ}$ high. Leaves $3^{\prime}-5^{\prime}$ long. Flowers $4^{\prime}-5^{\prime}$ wide.

3. H. incanus, Wendl. Leaves lanceolate and ovate-lanceolate, not lobed, slightly cordate, acuminate, finely serrate, hoary on both sides; flowers pale yellow with a erimson centre, often umbelled; peduncles mostly free from the petioles; capsule and seeds smooth. - Ponds and marshes, Florida to South Carolina, and westward. June and July. - Stems $2^{\circ}-5^{\circ}$ high. Leaves $3^{\prime}-6^{\prime}$ long. Flowers $6^{\prime}-8^{\prime}$ wide. 
4. H. grandiflorus, Miclix. Tomentose; leaves rouml-ovate, corlute, noitly 3-lubed, tuothed-serrate, hoary beneath ; flowers very large, pale rosecolor with a deep red centre; peduncles fre from the petioles; eapsule velvety ; secels smooth. - Marshes near the coast, Florida, Georyia, and westwatrd. July. - Stems severul from one root, $3^{\circ}-5^{\circ}$ high. Leaves $t^{\prime}-6^{\prime}$ long and nearly the sume in width. Flowers $10^{\prime}-12^{\prime}$ wile.

5. H. Carolinianus, Muhl.? Ell. Smooth; leaves corlate-ovate, art1. minate, serrate, sometimes slightly 3-lobed ; flowers purple; peduneles slighty allhering to the petioles; seeds hispiel. - On Wilmington Island, Gcorria. July .- September. - Stems $4^{\circ}-6^{\circ}$ high. Leaves $4^{\prime}-6^{\prime}$ long. Flowers $6^{\prime}-8^{\prime} w i d e .(\cdot)$

6. H. militaris, Cav. Smooth; leaves thin, on long and slenter petioles, scrate, slightly corlate, the lower ones roundish, 3-5-lobed, the upper ovatelanceolate, entire or somewhat hastate, with rounded loles; peduncles shorter than the petioles; calyx inflated ; corolla tubular-campanulate, pale rose-color witl a red centre; seeds silky. - River-banks in the upper districts, and westwark. July and A ugrust. - Stems $3^{\circ}-4^{\circ}$ high. Leaves $3^{\prime}-5^{\prime}$ long. Corolla $2 f^{\prime}$ lonig.

7. H. coccineus, Walt. Smootlı; stem gliucous; leaves long-petioled, 5-parted to the base, the lobes lanecolate, remotely toothed, with long-tapering entire tips; corolla expanding, bright searlet; petals loner-elawed; seeds pubeseent. (H. speejosus, $A$ it ) - Jeep marshes near the coast, Florida, Georgia, and westward. July and August. - Stems $4^{\circ}-8^{\circ}$ hight. Leaves $6^{\prime}-12^{\prime}$ long. Corolla $6^{\prime}-8^{\prime}$ wide. Column of stamens naked below.

\section{— + Trees or shrubs: stipules persistent.}

8. H. Floridanus, Shuttl. Hispid; leaves small, ovate, obtuse, crenate-serrate, often cordate, and slightly 3-lobed; peduncles longer than the leaves; corolla tubular-eampanulate, crimson; column of stamens exserted ; seerl woolly. (Malvariscus Floridanus, Nutt.) - South Florida. - Shrub $4^{\circ}-5^{\circ}$ ligh, branching. Leaves $\frac{1}{2}^{\prime}-1^{\prime}$ long. Stipules subulate. Flowers $1^{\prime}$ long.

9. H. tiliaceus, I. Leaves orbicular-cordate, actminate, slightly crenate, hoary-tomentose bencath; stipules large, oblong, elasping; involucel 9 10-tootherl; capsule tomentose; seeds smooth. - South Florida. - A large tree. Lenves $3^{\prime}-4^{\prime}$ long. Flowers yellow?

II. escrefstes, L. (II. Collinsianus, Nutt.?) is the garden OrRa.

II. Srriaces, I., the Altris $A$, is everywhere cultivated.

To this family belongs the Cotron-plast (Gossrpicy, $L$ ), the numerous varieties of which are now referred to two species, viz. the SHont Staple or Uplaxi (G. albua, IIam.), and the Losg Staple or Sea Island (G. NiGrux, Ilam.).

\section{Order 23. BYTtNeriacea. (Brttyeria Family.)}

Chicfly trees or shrubs differing from Malvacex in having definite stamens, of which those opposite the petals are usually sterile, 2-celled anthers, with smooth pollen-grains, and a straight embryo. - Ovary 3-5-celled, rarely 1-celled. 


\section{AYENIA, L.}

Involucel none. Calyx 5-parted. Petals on long eapillary elaws, connivent over the stigma. Fertile stamens 5, altemating with $1-2$ sterile ones, their filiments united into a pedicellate cup. Style single. Stigma 5-angled. Capsule 5-lobed, 5-celled, loculicilally 5-valved, the eells 1-seeded. - Low shrubby plants, with minute axillary flowers. Capsule rongh. Albumen none.

1. A. pusilla, L. Stems mostly simple, prostrate, downy; leaves (4" 8 "long) roundish or oblong, coarsely serrate; peduncles solitary, reflexed in fruit; eapsule depressed, muricate. - South Florida. $4-$ Stens $6^{\prime}-12^{\prime}$ long. Flowers purple.

\section{WALTHERIA, I.}

Invo'ucel 3-leaved, deeiduons. Calyx 5-cleft. Petals 5, spatulate, convolute in the bud. Stamens 5, united below. Orary 1-celled, 2-ovuled. Style single. Stigma penicillate or tuberenlate. Capsule 2-valved, 1-seeded. Embryo in the axis of fleshy albumen. - Herbs or shrubs, with alternate leaves, and small flow ers in axillary clusters.

1. W. Americana, L. Stem erect, villous; leaves ovate or oblong, acute or obtuse, serrate, plicate, tomentose on both surfaces; heads of flowers globose, stalked, or subsessile and shorter than the petioles, the upper ones often spiked; calyx hirsnte; flowers yellow. - South Florida. - Stem $2^{\circ}-3^{\circ}$ ligh, rigid. Leaves $1^{\prime}-2^{\prime}$ long.

\section{Order 24. TILIACEA. (Lindex Family.)}

Trees, rarely herbs. Icaves alternate, with deciduous stipnles. Flowers axillary or extra-axillary, hypogynous, polyandrons. Sepals 4-5, valvate in the but, decishons. Petals $4-5$, convolute or imbricated in the bud. Stamens ilistinct or mited in clusters : anthers 2-celled, the pollen grains smooth. Style singrle. Stigma 4-10-loberl. Capsule 2-5-cellerl, 1 -many-seeded. Seerk anatropous. Embryo in the axis of flesly albumen. Cotyledons flat, leafy.

\section{TILIA, Tourn. Lindes. Bisswoon.}

Sepals 5. Petals 5, imbricater in the hul. Stamens numerous, united in 5 clusters, with a p:tal-like appendage (sterile stamen) opposite each petal. Orary 5-celled, with 2 orules in each cell. Stigma 5-lohed Capsule 1-eellerl, 1-2. secded. - Trees, with cordate leaves, and several-flowered axillary peduncles, which are comnate below with a large ligulate reiny bract. Flowers cream-color.

1. T. Americana, I. Leaves smooth and green on hoth surfaces, obliquely cordate or truncate at the base, sharply serrate. - Nountains of Georgia and northward. June. - A large tree. Leaves $4^{\prime}-5$ ' wide.

2. T. pubescens, Ait. Leaves hoary-tomentose on both surfaces, becoming smoothish ahove, obliquely truncatc at the base, mucronate-serrate. - Rich soil, Florida to North Carolina, and westward. June. - Leaves $4^{\prime}-5^{\prime}$ wide 
3 T. heterophylla, Vent. Leaves lasper $\left(f^{\prime}-8\right.$ ' wille $)$ deep green above, white-tomentose beneath. - Monntains of North Carolina - June and July.

\section{CORCHORUS, I.}

Sepals 5. Petals 5, convolute in the lud. Stamens mostly numerous, separate. Style sleuder. Stigma dilated, eremlate. ('apsule mostly elongated, siliqne-like, loculicidally 2-valved, many-seeded. - Herhs ol' slorubly plants, with alternate serrite petioled leaves, and small yellow tlowers on short peduncles opposite the leaves. Stipules decidnous.

1. C. siliquosus, I. Stem much branched, hairy in lines; leaves ovate and lanceolate, sinooth; peduncles 1 -2-flowered; stamens numerous; cajsule linear, compressed, 2-celled, many-sected. - Near Mobile, Mabama, and Key West. - Stems $1^{\circ}-2^{\circ}$ high. Capsule 2' loug.

\section{Order 25. Cameletacea. (Chielda Family.)}

Trees or shrubs, with alternate exstipulate leaves, and regular hypogynous polyandrous showy flowers. - Sepals and petals 5-6, imbricated in the bucl. Stamens numerons, united at the base into a ring, or into sets placed opposite the petals, and adnate to their hases: anthers 2-celled, introrse. Ovary 2-5-celled, 2-many-ovulecl. Styles 2-5, distinet or united. Capsule 2-5-celled, mostly loculicidally dehiscent. Albumen searee or none.

\section{GORDONIA, Ellis. Lonnom. Bry.}

Sejals 5, romdish, concave. Petals 5, thick, obovate, united at the lase. Stamens united into 5 sets. Ovary 5-elled, with $4-8$ pendulous orules in each 'ell. Sty'es mitel. Capsule loculicidally 5-valved, woody. Seeds angular or winged. Flowers axillary.

1. Gordoxia proper. - Stamens short, inserted into the fleshy 5-lobed cup uthich athercs to the brese of the petals; copsule oroid, 5-ralvcd. - Leaves coriaccous, prerenmal. Flowers lono-perhuncled.

1. G. Lasianthus, I. Sepals and petals silky; leaves ohovate-oblong, narrowed into a petiole, finely servate. - Swanps in the lowecdistricts, Florida to Xorth Carolina, and westward. July and August. - A tree $20^{\circ}-50^{\circ}$ high. Flowers $2^{\prime}$ wide, white.

\$2. FrAxkuIsia. - Stamens long, distinct, inserted into the base of the petuls; capsule globose, loculicidally 5-lulved above the midelle, and septicidally 5-valved below. - Leaves deciduous.

2. G. pubescens, L'Ilerit. Sepals and petals silky; leaves obovateoblong, sharply serrate, white beneath; flowers short-peduneled. - Georgia and Florida, near the coast. - A small tree. Flowers $3^{\prime}$ wide, white. 


\section{STUARTIA, Catesb.}

Sepals 5-6, silky, 1-2-bracted. Petals 5-6, obovate, crenulate, silky. Stamens united into a ring at the base, and adnate to the base of the petals. Ovary 5-celled, with two anatropous ovules in each ecll. Styles 5, distinet or uniterl. Capsule ovoid, woody, 5-valved; the cells 1 - 2-seeded. - Shrubs, with alternate leaves, and large white or eream-colored flowers on short axillary peduncles.

$\S 1$. Stuartia. - Styles zunited: capsule globose : seeds not margined.

1. S. Virginica, Cav. Sepals 5, roundish; petals 5, ronnd-obovate; leaves oval, thin, serrulate, finely pubescent. (S. Malachodendron, L.) - Shady woods, Florida to North Carolina, and westward. April and May. - Shrub $8^{\circ}-$ $12^{\circ}$ high. Flowers $2^{\prime}-3^{\prime}$ wide. Stamens purple.

\$2. Malachodendron. - Styles separate: capsule ovate, acuminate: seeds margined.

2. S. pentagyna, L'Her. Sepals and petals 5-6, the latter obovate, with jagrged edges ; leaves oval, acute. - Mountains of Georgia and North Carolina. May-July. - Shrub similar to the preceding, the leaves and flowers rather larger, and longer stamens.

\section{Order 26. OLACACEAE. (Xmenia Famlu.)}

Trees or shrubs, with alternate entire petioled and exstipulate leaves, and regular hypogynous perfect or polygamous flowers, in axillary racemes or corymbs. - Calyx truncate or 4-5-toothed, persistent. Petals $4-5$, distinct or partly united, valvate in the bud. Stamens mostly twice as many as the petals, and inserted into their bases: anthers introrse. Ovary 1 -4-celled. Ovules few, anatropous. Style single, filiform. Fruit drupaceous, often surrounded with the enlarged ealyx, 1-celled, 1-seeded. Embryo straight in the axis of fleshy albumen.

\section{XIMENIA, Plum.}

Calyx small, 4-toothed. Petals 4, united at the base, villous within. Stamens 8. Ovary 4-celled. the cells 3-4-oruled. Drupe baceate; not enclosed in the calyx. - Thorny trees or shrubs. Leaves coriaceous. Flowers axillary, single or corymbose.

1. X. Americana, L. Smooth; leaves 2-3 together, oblong, obtuse, short-petioled; peduncles 2-4-flowered, shorter than the leaves; petals thick, lanceolate, spreading above, rusty-hairy within. - Key West. - Thorns stout, $\frac{1}{2}$ long. Leaves $2^{\prime}$ long. Flowers small, yellow. Drupe yellow, roundish, as large as a plum. Nut white, globose.

\section{Order 27. AURANTIACEA. (Orange Family.)}

The Orange, Lemon, and Lime (species of Citrus, L.) are commonly cultivated in the warmer parts of the Southern States, and the 


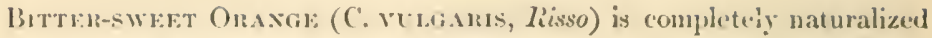
in some portions of South Florila.

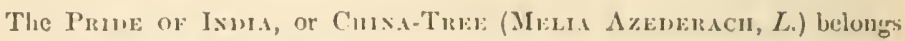
to the allied Order Merracka:

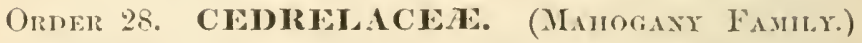

Lofty trees, with hard and colored wool, piunate exstipulate leaves, and regular hypogrnous panicled flowers. - Sepals $3-5$, often more or less unitel. Petals $3-5$, convolute in the bul. Stamens twire as many as the petak, distinct or mited into a tule, and inserted with the petals into an hypogynus disk. Ovary 3-5-celled, with few or manyovules in each cell. Style single. Capsule woorly, 3-5-celled, 3-5-valved, the valves at length separating from the thick angular or winged axis. Seed anatropous, winged. Albumen fleshy or none. Cotyletlons leafy.

\section{SWIETENIA, L. Manogaxi.}

Calyx 5-cleft. Petals 5. Stamens 10, united into a 10-toothel tube, which encloses the 10 anthers. Style short. Stigma 5-rayed. Capsule 5-eelled, 5.valved, with the numerous suspended seeds imbricated in two rows $-\Lambda$ large tree, with hard reddish-brown wood. Leaves alternate, abruptly pinuate. Leaflets 6-10, opposite, entire, ovate-lanceolate, mequal at the hase. Flowers greenish-yellow, in axillary panicles. Capsule ovate, as large as an Orange.

1. S. Mahogoni, L. South Florida.

\section{Order 29. LINACEA. (FLAX Family.)}

Chiefly herbs, with entire exstipnlate leaves, and regular hypogynous racemose or panicled flowers. - Sepals $4-5$, imbricated in the bud, persistent. Petals 4-5, convolute in the bul, deciluons. Stamens $4-5$, united at the base. Styles $4-5$, rarely united. Capsule globose, splitting into five 2-seeded earpels, which are more or less perfectly 2-celled and 2-valved. Seeds anatropous, suspended. Cotyledons flat.

\section{LINUM, L. Flax.}

Sepals, petals, staniens, and styles 5. Capsule partly or completely 10-celled, the cells 1 -seeded; seeds compressed, oily. - Stems slender. Leaves narrow and mostly altemate. Peduncle 1-flowered, bome above or opposite the leaves.

1. L. Virginianum, L. (WILD F LAX.) Leaves lanecolate, acute, the lower ones opposite and obtuse : flowers scattered in corymose racemes; sepals smooth, ovate, acute; styles distinet; eapsule depressed-globose, 10-celled. Varies with glandular sepals, larger globose-ovate capsules, and linear leaves. Sterile soil, Florida and northward. July. 4 - Stem sleuder, often much branched, $2^{\circ}$ high. Flowers yellow. 
2. I. Boottii, Planchon. Leaves linear, acute; flowers scattered in eymose racemes ; sepals ovate-lanceolate, 3 -nerved, fringell with glandular hairs ; styles united below the middle; capsule imperfectly 10-celled, globose. - Dry soil, North Carolina and northward. July, - Stems $1^{\circ}-2^{\circ}$ high. Flowers larger than in No. 1, sulphur-yellow.

3. L. striatum, Walt. "Flowers terminal; leaves subovate, alternate, the nerve and nargins deenrent on the stem ; stem branched, striate." - South Carolina, Wulter. (*)

\section{Order 30. OXALIDACEAs. (Tood-Sorret. Famly.)}

Chiefly herbs, with sour juice, alternate eompound leaves, and regular hypogynous decantrous flowers. - Sepals 5, imbrieated in the but, persistent. Petals 5, convolute in the bud, deciduous. Stamens more or less united. Styles 5, distinc't. Ovary 5-celled. Capsule 5-celled, the cells few-seeded. Seeds anatropons, pendulous. Embryo straight in the axis of fleshy albumen. Cotylerlons flat.

\section{OXALIS, L. WoOd-Sorrel.}

Capsule 5-lobed; the cells loeulicilally dehiscent on the back, l-few-seeded. Seed-coat loose and separating - Leaves 3-foliolate. Leaflets obcordate.

1. O. violacea, L. (Purple Wood-Sorrel.) Stemless; root tnberous ; seapes unbellately 4-6-flowered ; flowers purple, nodding. - Rich woods, West Florida to North Carolina, and westward. May and June. - Scapes and petioles $5^{\prime}-9^{\prime}$ high.

2. O. Acetosella, L. (Wnite Wood-Sorrel) Stemless; root creeping; scape 1-flowered; flower white, veined with red.-Mountains of North Carolina and northward. Junc. - Scape and petioles hairy, $2^{\prime}-5^{\prime}$ high.

3. O. stricta, L. (Yellow Wood-Sorrel.) Stems branehing, leafy ; peduncles axillary, 2-6-flowered, longer than the leaves; flowers yellow ; capsule elongated, erect. - Dry soil, common and varying greatly. April-December. (1) and $\$$ - O. recurva and O. fureata, Ell., and O. Lyoni, Ph., are forms of this.

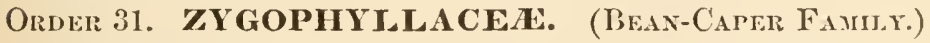

Herbs, shrubs, or trees, with hard woml, opposite pinnate dotless stipulate leaves, and regular hyporynous mostly decandrous flowers. - Sepals and petals 5-6, imbrieated or convolute in the bud. Stamens distinct, often appendaged. Ovary 2-12-eelled, witl the styles uniterl. Cajsule composed of 2-12 indehiscent earpels, which separate from each other and often from a central axis at maturity. Embryo straight. Cotyledons flat. Radicle superior. 


\section{Synopsis.}

1. TRIBULUS. ('arpels 5, transweroly few-celled, fow-sceded. Ilerbs.

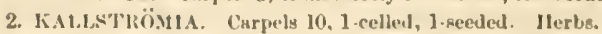

3. GUALCUM. Curpels 2-5, compressed, 1-seeded. Trees.

\section{TRIBULUS, I.}

Sepals 5, imbrieated in the lud, deciluous. Stunens 10. Ovary 5-celled, with 3-5 susjended ovules in carch cell. Carpols of the fruit 5, spiny on the back, trausversely divided juto $2-5$ onc-secled cells, separatimg at muturity, withont a central axis. Allumen none, - Prostrate lerbs. Lecaves abruptly pinmute. leduncles solitary, 1-flowered.

1. T. cistoides, L. Leaves unequal; leafets 6-16, linear-ol,long, mucronate, silky beneatı; peluncles as long as the leaves; flowers latre, yellow. Key West. - Stems $1^{\circ}-2^{\circ}$ long, hairy. Petals $2-3$ times as long as the calyx.

\section{KALLSTRÖMIA, Scop.}

Sepals 5-6, persistent, imbricated in the bud. Stamens 10-12. Ovary 1012-celled, the cells 1-ovuled. Carpels of the frut 10-12, separatiog from ench other and from the central axis. Albumen none. - IIairy lierbs, with the labit of 'Tusueves.

1. K. maxima, Torr. \& Gray. Leares nearly equal; leaftets $6-8$, obliquely oblong, mueronate, the terminal pair larger; jednncles shorter than the leaves; petals as long as the bristly calyx, yellow; carjels rugose on the back. - Kicy West and Savannalı, - Stems $10-20$ long.

\section{GUAIACUM, P!m.}

Sepals 5, deciduous. Stamens 10, with naked filaments. Ovary stalked, 2-5-cellecl, the cells 8-10-ovuled. Carpels of the fruit 2-5, compressed, 1seeded Secd-roat fleshy. Einbryo straight in barl thin albumen. - T'rees. Leaflets reticulate. Flowers bluc or purple.

1. G. sanctum, I. Branches opposite and forking, jointed, pubescent when youmg; leatfets 6 or 8 , obliquely obovate or oblong, mucronate, entire; peduncles single or clustered at the forks of the lranclies, 1-flowered, sliorter than the Jeaves; sepals and petals obtuse; flowers blue. - South Florida. $-\mathbf{\Lambda}$ sinall tree with white bark. Flowers $\frac{11}{2}$ wide. Fruit obovate.

\section{Order 32. GERANIACEA. (GRonilu Fami.r.)}

Herls or shrubby plants, with tumid joints, alternate or opposite palmately lobed stipulate leaves, and lyjogynous and ilecandrous flowers. - Sepals 5, imbricated in the bud, persistent. Petals 5, convolnte in the bud, decidnous. Stamens monadelphous at the base; the 5 exterior ones shorter and often sterile. Ovaries 5, 2-ovuled, and, with the persistent 
styles, adnate to an elongated central axis, from which they separate elastically at maturity. Sced solitary, without albumen. Eubryo convolute.

\section{GeraniUm, Tourn. Cravesmil.}

Flowers regular. Stamens perfect, the inner ones with a glanil at the base. Styles at maturity separating with the 1-seeded earpels, and coiled upwarl, the inner face nakel. - Herbs. Stems forking. Leaves palmately lobel. P'edureles 1-3-flowerel.

1. G. maculatum, I. Perennial, erect, hairy; leares 5-7-partel, the divisions acutely lobed and toothed; pednncles 1 - 2-flowered, the terminal ones often umbellate; petals large, entire, 2-3 times longer than the oblong awnerl sepals - Open woods in the upper districts and northward. April and May. - Root tuberous, very astringent. Stem $1^{\circ}-2^{\circ}$ ligglı. Flower's purple, I' wide.

2. G. Carolinianum, I. Annual, generally prostrate, pubeseent; leaves 5-7-parted, the narrow divisions obtuscly lobed and toothed; peduncles 2-flowered; petals emarginate, as long as the ovate awnel sepals. - Waste places, common. March and April. - Stems forking, 6'-18' longr. Flowers pale purple.

\section{Order 33. BALSAMINACEA. (BALSAM FAMILY)}

Smooth aml succulent annual herbs, with mulivided exstjpulate leaves, and irregular hyporyous pentandrous flowers. - Sepals 5, colored, deciduous; the two immer (and upper) ones united, the lowest large and saceate. Petals 4-5, distinct or united. Stamens 5, colierent above; Ovary 5-celled, the cells 2-several-ovuleil. Fruit capsular or drupaceous. Seeds anatropous, without albumen. Embryo straight, with thick cotyleilons.

\section{IMPATIENS, L. JEWEL-IVEED.}

Lowest sepal saceate and spurred. Petals 4, united by pairs. Filaments short, with a seale on the inner face. Capsule 5-celled, bursting elastically into 5 valves. Placenta central. persistent. - Stems brancling, somewliat pellucid. - Jeaves serrate. Peduncles axillary, 1-several-flowered. Larliest flowers fruiting in the bud.

1 I. pallida, Nutt. (PALE Tovcir-ne-sot.) Leaves ovate or oval, obtusely serrate, membranaceous; flowers pale yellow ; lower sepal slightly spotted. dilated, open, tipped with a short recurvel spur. - Wet shady places, Georgia and northward. July - Sept. - Stems $2^{\circ}-4^{\circ}$ lighlı.

2. I. fulva, Nutt. (Sиотted Touch-ме-хот.) Flowers deep orange; lower sepal conical, conspicuously spottel, tipped with a rather long recurved spur; otherwise like No 1, but with smaller flowers. - Slady swamps, Florida and northward. July-Sept. 


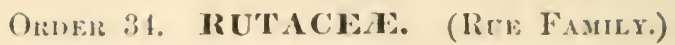

Herls, shrubs, or trees, with exstipulate simple or rompound rotter leaves, and regular hy porynous perfect or misexual flowers. - Sepals aud petals $3-5$. Stamens as many or twive as many as the sopals. Ovaries 2-5, distjuet or united, stipitate or sessile on a glamdular disk. Styles mostly united. Fruit commonly composed of scparate l-erelled 2-valved ('arpels. Embryo straight or curved, mostly in Heshy albumen.

\section{ZANTHOXYLUM, L. Р'кскLY גsı.}

Flowers monocions or diceious. Sepals and petals $3-5$. Stamens 3-5. Oviries 2-5, sessile or stipitate, 2-ovuled. Carpels 2-valved, 1-2-seeded. Seed sinootls and shining. - Trees or shrubs, commonly arned with stipular prickles. Leaves unepually pinnate, the leaflets junctate with pellucid dots. Flowers small, greenish.

1. Z. Carolinianum, Lam. (Tootuacue-Tree.) Smooth; branches amd rommouly the petioles armed with long prickles; leaves alternate, 7-9foliolate; leaftets ovate-lanceolate, crenate-serrulate, mequal-sidel, shining ahove; panicles terminal; stamens 5 ; carpels 3, nearly sessile. - Var. Fntiticosum, Gray. Sluvbly ; leaves shorter, ovate or oblong, more strongly crenate ; ovaries always two. - I)ry soil near the coast, Floricla to Nortl Carolina, and westward. June. $-\Lambda$ small tree, with the pungent bark armed with warty prickles.

2. Z. Floridanum, Nutt. (Satı-Wood.) Bruthes and petioles unarmed ; leaflets 5-7, orate-lanceolate on the fertile plant, anl clliptical, obtusc or emarginate on the sterile, slightly (renulate, and like the cymose panicle stellate-pubescent; stamens $4-5$; earpels $1-2$, ohovate, stipitate; seed solitary, obovate, black and shining. - Sonth Florilla. - Leares $1^{\prime}-2^{\prime}$ long. Cyme sessile, divild into thre primary branches. Flowers minute.

3. Z. Pterota, II. B. \& K. Smooth; branches zigrag, armed with short curvel prickles; petiole winged, jointed; leaflets $7-9$, small, ohovate, coriareous, crenate ulove the midlle, sessile; flowers in axillary clusters, which are single or by pairs, as long as the first joint of the petiole; stamens 4 ; ovaries 2; carpels solitary, glohose, pitted, distinctly stipitate. - South Florida. - Leaflets $\frac{1}{2}{ }^{\prime}-3^{\prime}$ long, thuse on the fertile plant narrower and smaller. Carpels small, dotted.

\section{PTELEA, L. IIOP.TREe.}

Flowers polycamous. Sepals and petals $4-5$, imbrieated in the bud, decidnous. Stamens $4-5$. Ovary 2-celled, with two ovules in each cell. Style short. Stigma 2-lohed. Capsule 2-eelled, 2-scederl, surrounded by a broarl cireular reticulated wing. - Unarmed slurubs, with trifoliolate leaves, and small greenish flowers in a terminal cyme.

1. P. trifoliata, L. Pubeseent; leares long-petioled; leaflets oral or ohlong, mostly acute, obscurely crenulate, paler beneath, the lateral ones unequal- 
sided; filaments $4-5$, densely villous below the middle, longer than the style in the sterile flowers, shorter in fertile ones. - Rocky banks, Florida and nortliwird. May and June, - Shrub $4^{\circ}-8^{\circ}$ high. Leaflets $2^{\prime}-4^{\prime}$ long. Fruit $1^{\prime}$ wide.

2. P. mollis, M. A. Curtis. "Laterul leaflets oval, the terminal obovate, with an abrupt acute point, the under side, with the petioles, panicles, and young branches, clothed with a soft whitish silky villus; crmes compact, with short branches; style long; filaments equalling the anthers." - Low eountry of North and South Carolina (Curtis). - Leaves smaller and more rigid than in No. 1 , the style twice as long. Stamens 4.

3. P. Baldwinii, Torr. \& Gray. Leaves very small, glabrous ; leaflets sessile, oval, obtuse, the terminal one cunciform at the base; flowers tetrandrous ; style none. - East Florida. - Shrnh $1^{\circ}$ hirh, with numerous short and scragrgy branches. Leaflets $\mathbf{l}^{\prime}$ long. Fluwers smauler than iu No. 1.

\section{Order 35. SIMARUBACEA. (Quassia Famly.)}

Trees or shrubs, with litter milky juice, pinnate exstipulate alternate and dotless leaves, and regular hypogynous perfect or polygamous llowers. - Caly x 4-5-parted or 4-5-toothed, persistent. Petals 4-5, deciluous. Stamens as many or twice as many as the petals, inserted on a hypogynous disk. Orary composed of $4-5$ distinct or united carpels, with a solitary anatropous snspended ovule in each. Fruit drupaceous, 1-seeded. Seeds with a nembranaceous coat. Albumen none. Radicle superior, included in the cotyledons.

\section{SIMARUBA, Aublet. Qcassia.}

Flowers monoecions or dicecious. Calyx $4-5$-toothed. Petals 4-5, sprealing. Stamens $8-10$, with the filaments inserted on the batek of a riliate seale. Ovaries 4-5, surrounded ly $8-10$ scale-like rudiments of stamens. Styles connirent; the stigmas spreading. Drupes $1-5$. - Trees. Leaves abruptly pinnate, with alternate and entire leaflets. Flowers small, greenis $\mathrm{h}_{\mathrm{l}}$, in lateral and terminal panicles.

1. S. glauca, DC. Smooth thronghout; flowers dioecions; stigmas 5, subulate, spreading; leaflets $4-8$, alternate and opposite, coriaccous, obovate or oblong, obtuse, paler beneath ; drupe oval, mostly solitary. - South Florida. A large tree.

\section{Order 36. BURSERACEA. (Torchi-Tood Famly.)}

Trees or slurubs, with resinons juice, unequally pinnate or trifoliolate commonly dotted leaves, and small regular flowers in axillary or terminal racemes or panicles. - Calyx free from the 1 -b-celled sessile ovary, 2-5-lobed, persistent. Petils 2-5, alternate with the calyx-lobes, and 
inserted umler an orbirulate or annular disk at the bottom of the ealyx, mostly valvate in the hul. Stamens twice as many as the petals, and inserted with them. anthers introrse. Ovules anatropons, pemdulous, mostly two in "ach coll. Stigmas $1-5$. Frnit drupareous, dry; the periearp often splitting into valves. Albumen nome. Liadicle superior.

\section{BURSERA, Jacquin.}

Flowers polygamous. Sterile 1\% Calyx 3-5-parted. Petals 3-5, valvate in the hul. Stamens 6-10. Disk crenulate. Fertile Fl. Calyx 3 parted. Petals 3. St:men; 6. Orary ovate, 3-eelled. Style short: stigma 3-lobed. Drupe oblong, 1-sected; the pericarp 3-valved. Cotyledons wrinkled.

1. B. gummifera, Jaequin. Icaves alternate, 3-9-foliolate, long-petioler, deciduous ; leaflets stalked, opposite, ovate, ar'uninate, entire, romded or slightly cordate at the base, at length smooth on hoth sisles; flowers small, whitish, in axillary racemes; drupe purplish. - South Florida. - $\perp$ large tree.

\section{AMYRIS, I. Torcir-TVuod.}

Flowers perfect. Calyx 4-parted. Petals 4, narrowed at the hase, imbricated in the but. Stamens 8, shorter than the petals, hypogynous. Oviry l-celled. Stig̣ma eapitate. Drupe grlobose, 1-seeded. Cotylerlons plano-ronvex. - Trees or shrubs. Ieaves $3-7$-foliolate, opposite, with glandular pellucid dots. Flowers paniclel, white.

1. A. Floridana, Nutt. Smooth; leaves petiolerl, trifoliolate; leaflets orate, oltuse, intire, on slender stalks; branches of the paniele opposite; drupe, like the flowers, dotterl. - Sonth Florila. $-\Lambda$ slirub or small tree. Leallets $1^{\prime}-1 f^{\prime}$ long, shining above Flowers yellowish-white.

\section{Orher 37. ANACARDIACEA. (CASHew Famly.)}

Troess or shrubs, with milky or resinons juice, alternate exstipulate dotless leaves, and perfect or polygamons recrular flowers. - Sepals and petals $4-5$, imbricated in the bud. Stamens as many as the petals, or twice as many, and inserted with them into the base of the calyx. Orary solitary, with a single ovule ascemling from the base of the cell. Style simple or 3 -cleft. Fruit drupaceous. Seeds without albuncu. liadiele curved.

\section{RHUS, I. Suмaci.}

Calyx 5-parted. Petals 5, inserted with the 5 stamens on the disk which surrounds the batse of the ovary. Stigmas 3. J)rupe dry. Raticle superior, incurved. - Slirubs or small trees. Leaves pinnate or trifoliolate, rarely simple. Flowers small, greenish, in spikes or panicles. 
* Flowers polygamous, in a close terminal panicle: drupe red, hairy: leaves pimate. (Not poisonous.)

1. R. typhina, L. Branches, petioles, and drupes villous; leaflets $17-21$, lanceolate, acuminate, serrate, smooth, pale beneatl. - Dry hill-sides, Mississippi to North Carolina, and northward. June and July. - A shrub or small tree.

2. R. glabra, L. Smooth and glaucous; leaflets $17-31$, oblongr-lanceolate, serrate, acuminate, white beneath. - Open woods in dry rich soil, West Florida to Mississippi, and northward. July. - A shrub $6^{\circ}-10^{\circ}$ high. Petioles terete.

3. R. copallina, L. (Sимасн) Branehes aud wing-margined petioles tomentose ; leaflets 9-21, lancelate or orate-lanceolate, acute or obtuse, mostly cntire, smooth above, paler and downy beneath ; panicle often large and spreading. - Margins of fields and open woods, Florida to Mississippi, and northward. July and Augnst. - A slirub or small tree.

4. R. pumila, Michx. Low, proeumbent; branches and petioles tomentose ; leaflets $11-13$, oval or oblong, acute, coarsely serrate, pale and tomentose beneath. - Pine barreus, Georgia to North Carolina. - Branches $1 \circ$ high.

* * Flowers diacious, in loose axillary panicles : drupe whitish, smooth: leaves pinnute and trifoliolate. - (.Juice poisonous.)

5. R. venenata, DC. (Poison Elder.) Snooth; leaves pinnate; leaflets $7-13$, ovate or oblong, abruptly acute or aemminate, entire ; panicles longpeduneled, narrow, erect. (R. Vernix, L.) - Swamps, Florida to Mississippi, and northward. July. $-A$ shrub $8^{\circ}-12^{\circ}$ high.

6. R. Toxicodendron, L. (Poisox OAk. Porson Iry.) Branches and petioles smooth; leaves trifoliolate; leaflets ovate or oblong-ovate; panicle small, spreading.

Var. 1. quercifolium, Michx. Stems low, erect; leaflets mostly variously lobed. - Dry pine barrens.

Var. 2. radicans, Torr. Stems elimbing by rootlets; leaflets toothed or entire, rarely lobed, more or less pubescent. - Swamps, Florida to Mississippi, and northward. July.

* * * Flowers diccious, in loose panicles : drupe oblong, smooth, scurlet : nut chartaceous: seeds arillate: leares pinnate.

7. R. Metopium, L. Smootlı; leaflets $3-7$, coriaceous, long-stalked, ovate or elliptical, acuminate, entire; panicle narrow, as long as the leaves; calyx-lohes yellowisli-white; petals and stamens 5. - South Florida. - A tree $15^{\circ}-20^{\circ}$ high.

* * * Flowers diccious, in short bracted spilies, appearing with the leaves: drupe red, luiry : leaves trifoliolate.

8. R. aromatica, Ait. Stem low, smooth; leaflets ovate, or the terminal one obovate, obtuse, pubescent when young, toothed above the middle; spikes single or elustered, spreading. - Dry open woods, West Florida to Mississippi, and northward. March and April. - Shrub $1^{\circ}-2^{\circ}$ high. Spikes $1^{\prime}$ long. - Plant aromatic, not poisonous. 
* * * * Fovers perfect, in an open panicle, the pedicels mostly abortive, dongating, anel plumose: drupe smooth.

9. R. cotinoides, Nint. Sumoth; leaves simple, meubrunarous, oval, obtuse, entire, acute at the hase, the upper ones lonur-petioled; punicle nenrly sessile, narrow, with erect hisucle': ; flowers minute. - Interior of Alabama, Buckley. Leaves, with the petiole, $3^{\prime}-4^{\prime}$ long.

\section{Order 38. VITACEAe. (Vine Fanily.)}

Climhing slırubs, with watery juice, opposite stipulate leaves, and small gronish flowers in panicled elusters opposite the leaves. - Calyx minute, trumeated. J'etals 4-5, lypogrnons or perigynons, valvate in the lud, deciluons. Stamens $4-5$, opposite the petals : anthers introrse. Ovary 2-celled, with 2 ereect collateral ovules in each cell. Style short or none: stigma slightly 2-lobed. Berry 1-4-seeded. Seeds anatropous, bony. Embryo minute at the base of hard or lleshy albumen. Radicle inferior. - Leaves simple or compound. Tendifls opposite the leaves. Flowers perfect or polygamous.

\section{VITIS, L. Vine. Graie.}

Petals distinct, or remaining united at the apex and separating at the base, inserted into a $4-5$-lohed or eup-shaped disk which surrounds the ornry.

\$1. Crssus. - Floters perfect: petals and stamens 4-5: style conspicuous: stigma minute: leaves simple or conpound.

1. V. bipinnata, Torr. \& Gray. Leaves bipinnate, smoothish; leaflets small, orate, sharply toothel; flowers somewhat eymose, on a long forking peduncle; petals $4-5$, united at the apex, separating at the base; style conical; lisk 4-5-lobel; berry $2-4$-seeded. (Ampelopsis bipinnata, Mich.x.) - Margins of swamps, Florida and northward. June and July. - Tendrils none. Leaflets l'long. Berry small, black.

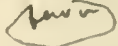

2. V. acida, I. Branches geniculate; leaves trifoliolate, thick and rigid; leaflets small, cuneate-obovate, sharply toothed at the apex; flowers in compound umbels; petals 4 , united at the apex, separating at the base; style slender; disk eup-shaped, entire; berry black, 1-seeled. - Key West. - Tendrils stout and elongated. Leaflets $\frac{11}{2}$ long. Branchlets and peduncles flattened and elongated. Leaves and parts of the panicle separating in dryiug, as also in the next speries.

3. V. incisa, Nutt. Smooth; stem climbing, warty; leaves trifoliolate, very thick and fleshy; leaflets stalked, weelge-shaped and entire near the base, the lateral ones 2-lohed, the midlle 3-lobed, all mucronate-toothed or serrate; berry (purple) globose-ovate, nodding, pointed with the conspicuous slender style, ]-seeded. - Sandy sluores of St. Vincent's Island, We'st Florida and westward. Fruiting in November. - Stem $6^{\circ}-12^{\circ}$ long. Leaflets $1^{\prime}-3^{\prime}$ long. Panicles eymose. Berry $5^{\prime \prime}-6^{\prime \prime}$ long. Flowers not secn. 
4. V. indivisa, Willd Leares simple, undivided, ovate, truncate, or cordate at the base, acuminate, toothed-serrate, pubescent; peduncles forking; petals and stamens 5 ; style slender; disk cup-shaped; berry 1 -3-seeded. - Banks of rivers, Florida to North Carolina, and westward. June. - Stem climbing high. Berry small, black.

\$2. Vitis. - Hlowers polygamons: pctals 5, colering at the top, free at the base: stamens 5 : style short: disk thick, 5-lobed: leaves simple, curdute, enture or variously lobed.

\section{* Leaves and branches woolly.}

5. V. Labrusca, L. (Fox-Grare) Leaves loroadly corlate, angularly 3-5-lobed, mucronate-serrate, very woolly when young, at length smoothish above; fertile panicles or racemes few-flowered ; berry large. - liver-swamps, Mississippi to North Carolina, and nortlwward. May and June. - Leaves $4^{\prime}-6^{\prime}$ wile. Berry $\frac{11}{2}$ in diameter, purple or whitish, pleasant-Aarored.

6. V. Caribæa, DC Leaves ronnd-cordate, with a broad and shallow sinus, entire or 3-lobel, wavy-serrate, acute or acuminate, soon smooth above, the lower surface, like the branches, petioles, and panicles, clothed with soft ashcolored down; panicles equalling or longer than the leaves; pedieels smooth. (V. coriacea, Shuttl.? a form with smaller and more rigid leaves.) - South Florida. Berry $\frac{1}{2}$ in diameter.

7. V. æstıvalis, Michx. (Summer Grape.) Leaves broadly cordate, entire or 3-5-lobed, or on young plants pinnatifid, mueronate-serrate, covered with a loose cobwebby down, at length smooth or nearly so on both sides ; panicles long, many-flowered; berry small. - Rich woods, Florida to Mississippi, and northward. June. - Stem climbing high. Leaves $4^{\prime}-7^{\prime}$ wille. Panicle $6^{\prime}-12^{\prime}$ long, compound. Berry deep blue, very austere.

\section{* * Leaves and branches smoothish.}

8. V. cordifolia, Michx. (Frost Grape.) Leaves thin, broadly cordate, entire or slightly 3-lobed, mucronate-serrate; pubeseence, when present, soon vanishing; panicles compound, many-flowered ; berry' small. - Riverswamps, Florida to Mississippi, and northward. May and June. - Leaves $3^{\prime}-6^{\prime}$ wide. Berry almost blaek, very acid. $-\mathbf{A}$ form with broader incisely lobed and toothed leaves is V. riparia, Michx.

9. V. vulpina, L. (Muscadine Bellace.) Leaves broally cordate, toothed-serrate, smooth and glossy on hoth sides, or rarely, like the lranches, pubescent, the sinus at the base broal and rounded, or narrow and acite; paniele small; berry large. (V. rotundifolia, Michx.) - Banks of rivers, Florila to North Carolina, and westwarł. June. - Stem climbing high, with pale and smooth bark. Leaves $2^{\prime}-3^{\prime}$ wide. Berry $\frac{1^{\prime}}{2}-z^{\prime}$ in diameter, purple, pleasantflavored. - A form with smaller leaves and berries, the latter very anstere, is sometimes called the Mustang Grape.

\section{AMPELOPSIS, Michx.}

Petals distinet, spreading, coneave. Disk none-Leaves digitate. Flowers clustered, in corymbose panieles. 
1. A. quinquefolia, Michx. (Vurosias Cuevrpr.) - low enrounds, Floricla mol northwarl. June.-- Sten climbung by lateral tendrils. Leaflets 5, oblong-obovate, serrate above the middle, smooth. Berry sinalt, dark-blue.

\section{Order 39. RHAMNACEAs. (Bucktholin Fambr.)}

Trees or shrubs, with simple mostly stipulate leaves, and small regular perigynous greenish or whitish flowers. - Sepals 4-5, united below, valvate in the burl. Petals alternate with the sepals, coneave or hooled, sometimes wanting. Stanens opposite the petals, and inserted with them into the margin of a fleshy disk, which lines the base of the calyx. Ovary 1-4-celled, with a solitary erect anatropous ovule in each cell. Style single. Fruit drupaceous. Embryo large, in the axis of seanty fleshy albumen. Radicle inferios.

\section{Fynopsis.}

* Drupe baccate, 1 - 2-celled. Ovary immersed in the disk.

1. SCTTIA. Pelals 5, or none. Drupe 1-celled. Calyx adnate to the base of the ovary.

2. Bkicilkina. Jetals 5. Drupe 2-celled. Caly $\mathrm{x}$ free.

* * Drupe baceate, separating into 2 - 4 nutlets.

3. SAGFretid. Leaves opposite. Nutlets 3. Flowers spiked.

4. IRIIAJNU. Leaves alternate. Seed furrowed on the back. Flnwers elustened.

5. FliNGULA. Leaves alternate. Seed not furrowed. Flowers umbelled.

* * * Drupe at length dry, separating into 3 nutlets.

6. CEANOTIIUS. Flowers corymbed. Calyx white. Nutlets 2-valved.

7. COLUBLINA. Flowers eymose. Caly $x$ green. Nutlets opening at the inner angle

8. GOUANIA. Flowers spiked. Woody vines.

\section{SCUTIA, Commers.}

Calyx-tube hemispherical or pitcher-shaped, with 5 acute lobes. Petals 5, inserted into the margin of the disk, short-clawed, sometimes wanting. Orary adhering to the disk below, 2-3-celled, with a single erect ovule in each cell. Style single, conical. Stigma 2-3-lobed. Fruit 1-telled, or separating into $2-3$ one-seeded nutlets. Seeds without albumen. Radiele very short. - Shrubs, with alternate or opposite coriaccous entire 2-stipulate leaves, and small axillary flowers in simple umbels.

1. S. ferrea, Brongn. Spineless; mature leaves coriaccons, opposite or alternate, elliptical or obnvate, emarginate, ohtuse at the base, short-petioled; stipules by pairs, ovate, minute; flowers clustered, axillary, on short pedicels; calyx-tube 5-angled, the lobes ovate; ovary immersed in the thick 5-lobed disk, 2-celled, with an ascending ovule in each cell; style very short; stigmas 2, thick, ereet; drupe 1-celled, l-seeded. (Rhamnus ferreus, Iahl. Zizyphus emarginatus, Sucartz.) - South Florida. - Branches opposite, whitish. Leaves pale, 1 'long. 


\section{BERCHEMIA, Neck. SuPPLE-J}

Calyx 5-cleft, the tube hemispherical. Petals 5, sessile, concave, as long as the calyx. Ovary fiee, 2-celled, half immersed in the fleshy disk. Styles united. Stigmas 2. Drupe oblong, 2-celled, 2-seeded. - Erect or twining shruls, with alternate pinnately-veined leaves, with minute stipules, and small greenish axillary or panicled flowers.

1. B. volubilis, DC. Stem twining; leaves oblong, acute, wavy on the margins, glossy above, the simple veins oblique; flowers in small terminal panicles; drupe purple. (Zizyphus volubilis, Willd.) - Swamps, Florida to North Carolina, and westward. June.

\section{SAGERETIA, Brongn.}

Calyx 5-cleft, the tube hemispherical, the lobes earinate within. Petals obovate, shorter than the calyx, concave. Ovary free, 3-celled. Stigmas 3, nearly sessile. Drupe baccate, composed of three even 1-seeded indehiscent nutlets. Seeds not groored. Cotyledons flat. - Slender trailing shrubs, with opposite branches and leaves, and minute whitish spiked flowers.

1. S. Michauxii, Brongn. Stem vine-like $\left(6^{\circ}-18^{\circ}\right.$ long $)$, with spinelike spreading branches; leaves ( ${ }^{\prime}$ long) nearly sessile, ovate or oblong-ovate, acute, finely serrate, smooth and shining, persistent ; spikes slender, intermpted, mostly panicled ; petals minute ; drupe dark-purple, globose. (Rhamuus minutiflorus, Michx.) - Dry sandy soil along the coast, Florida to North Carolina. September. - Drupes pleasantly acid.

\section{RHAMNUS, Tourn. Bucktions.}

Calyx 4-5-cleft, the tube urceolate, lined with a thin disk. Petals small, obovate, concare, often wanting. Ovary free, 2-4-celled. Styles united below. Stigmas 2-4. Drupe baccate, composed of 2-4 somewhat dehiscent nutlets. Seeds grooved on the back. Raphe dorsal. Cotyledons leafy, revolute. Shrubs, with alternate stipulate finely veined leaves, and small axillary clustered polygamons or diœcious greenish flowers.

1. R. lanceolatus, Pursh. Leaves oblong-lanceolate, acute, or those of the flowering branches oblong and obtuse, serrulate ; flowers elnstered, on short pedirels, with long styles, or the more fruitful ones scattered on longer pedicels, and with short styles; petals emarginate; drupe 2-seeded. - Hills and river-banks, in the upper districts, Alabama and northward. June. - A tall shrub. Drupes black, as large as a grain of pepper.

\section{FRANGULA, Tourn.}

Seeds not grooved. Iiaphe lateral. - Leaves strongly parallel-veined. Flow. ers perfect. Otherwise as in Rhamnus.

1. F. Caroliniana, Gray. (CArolina Buckthorx.) Leaves ablong, wavy and finely serrulate on the margins, the slender petioles and many-flowered short-stalked umbels pubescent; petals 5 , minute; stigmas 3 ; drupe globose, 
3-serded. (Rhammus Carolinianus, Wielt.) - Basks of rivers, Florida to North Carolina and westwarl Jume. $-\Lambda$ shrub or small tree. Leves $3^{\prime}-t^{\prime}$ long.

\section{CEANOTHUS, I. JERSY TEA.}

Calyx colored, 5-cleft, with the tube adnate to the ovary aud persistent, the lobes connivent, deciduons. Petals 5, longer than the calyx, hooled, long-clawed. Stannens exserted. Style 3-parted. Drupe dry, composed of three 2-vinlved 1-seeded untlets. Embryo in fleshy albunen. Cotyledons flat. - Shrubby plants, with altermate serrnlate minutely stipmlate 3-ribbed leaves, and small flowers in lateral and terminal corymbs or panicles.

1. C. Americanus, L. Branches pubescent; leaves decilnons, variable in size, orate or ovate-lanceolate, acute or obtuse, sharply serrate, more or less pubescent, petioled ; peduncles elongated, mostly 2-leaved ahove. - Dry woods, Florida to Mississippi, and northward. July. - Plant shrubby, $1^{\circ}-2^{\circ}$ higls. Leaves 3-ribhed, rarying from $3^{\prime}$ (C. internedius, Eill.) to $3^{\prime}$ long, often nearly smooth (C. herbacens, lieff.). Flowers and pedicels white.

2. C. microphyllus, Mids. Stem erect, diffusely much-branched; leaves peremial, small, obovate, slightly crenate, 3-ribberl, glossy above, with scattered latirs beneath; those in the axils elustered; corymbs small, terminal. - Dry harrens, Florida and Georgia, and westward. April and May. - Slırub $1^{0}-2^{\circ}$ high, yellowish. Leaves $2^{\prime \prime}-3^{\prime \prime}$ long. I'edieels and flowers white. Drupe black.

3. C. serpyllifolius, Nutt. Decumbent, diffusely branched; branches filiform; leaves very small, ovate-elliptical, serrulate, obtuse, the lower surface, as well as the petioles, strigose: peduncles axillary; flowers few, in a simple corymbose heall. - Near St. Mary's, Georgia. - Leaves $3^{\prime \prime}-5^{\prime \prime}$ long. Peduncles $12-15$-flowered.

\section{COLUBRINA, Rich.}

Calyx herhaceous, with spreading lobes. Nutlets opening at the apex and down the inner angle. Einbryo in thin albumen. Otherwise ehiefly us in Ceanothus. - Tropical slurnbs, with alternate parallel-veined leaves, and small flowers in close axillary cymes.

1. C. Americana, Nutt. Leaves coriaceons, ovate-olulong, entire, the lower surface, as also the branches and ealyx, covered witl a dense rust-colored pubescence; cyme small, shorter than the petiole; petals spatulate, emarginate, shorter than the calyx ; druge 3-lobed. - South Florida. - Leaves $2^{\prime}-4^{\prime}$ long. Drupe $4 "$ in diameter.

\section{GOUANIA, Jacquin. Craw stick.}

Calyx 5-cleft, partly adnate to the ovary, the lobes spreading. Petals 5, shorter than the calyx, and inserted into the sinuses of the 5 -lobed disk which lines its tube, hooded, und enelosing the short stamens. Orary 3-celled, 3-ovuled. Style 3-cleft. Drupe dry, 3-lobed or 3-wingerl, separating from the central axis 
into three valveless nutlets. Embryo in the axis of thin albumen. - Tropical, chiefly climbing shrubs, with alternate stipulate toothed leaves, and perfect or polygamous flowers in terminal spiked clusters.

1. G. Domingensis, L. Branches pubeseent; leaves oblong-ovate, tapering into an obtuse point, serrate, petioled ; spikes elongated, bearing a tendrit at the base; drupe globose, 3-winged. - Sontl Florida. - Leaves $2^{\prime}-4^{\prime}$ long Flowers ninute, yellow. Lobes of the disk emarginate.

\section{Order 40. CeLAstraceas. (Staff-trle: Family.)}

Shrubs, with simple stipulate leares, and small regular flowers. Sepals and potals $4-5$, imbricated in the bud. Stamens $4-5$, alternate with the petals, and inserted with them on the disk which fills the bottom of the ealyx. Ovary free, 1 -5-celled, with 1 -several erect ovules in each cell. Styles mited. Fruit "apsular or drupaceons. Seeds often arilled. Embryo in the axis of the albumen. - Flowers perfect or polygamons.

\section{Synopis.}

* Fruit a 1-2-sceded drupe.

1. MYGIND.1. Ovary 4-eelled. Stigmas 4. Drupe 1-seeded. Leaves opposite. Flowers perfect.

2. SCIIEFFERIA. Ovary 2-celled. Stigmas 2 Drupe 2-seeded. Leaves alternate. Flowers dioecious.

* * Fruit a 3-j-valved capsule : seeds ariiled.

3 ECoxym

4. CELASTRLS. Flowers polygamous, in terminal racenes. Caiy $x$ enp-shaped. Capsule globose. Leaves alternate.

5. MAYTENUS. Flowers axillary. Calyx flat. Capsule 3-angled. Leaves alternate.

\section{MYGINDA, Jacq.}

Flowers perfect. Sepals 4, united below. Petals 4, roundish. Stamens 4. Ovary 4-eclled, with a solitary anatropous ornle in each eell. Style short, 4-cleft. Drupe 1-celled, 1-sceded. Sced erect. Fmbryo in thin albumen. Cotyledons flat. Radicle inferior. - Tropieal shrubs, with small opposite coriaccons leaves, and minute white or reddish flowers on axillary forking peduneles.

1. M. Rhacoma, Swartz. Branches slender, pubeseent, angled; leares ollong, obtuse, crenate, nearly sessile, paler and often discolored beneath ; pelun. cles filiform, shorter than the leaves, cymosely 2-4-flowered; calyx-lobes round, pubescent ; petals oral, concare, ciliate ; stigmas spreading; drupe obovate. South Florida. - $\Lambda$ small shrub. Leaves $\frac{11}{2}-1^{\prime}$ long, glabrous.

2. M. ilicifolia, Lam. Branches terete, pubesent; leaves smooth, roundovate, spiny-toothed, short-petioled; peduncles shorter than the leares, umbellately 3-4-flowered; calyx 4-toothed; petals rommled; drupe obovate, pointed with the persistent style. - South Florida. $-\Lambda$ small shrub. Leaves $\frac{\lambda^{\prime}}{2}-\frac{31}{4}$ long. 


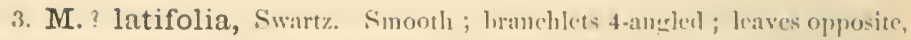
coriacens, olovate, romeled or emarginate at the aljex, narrowed at the base

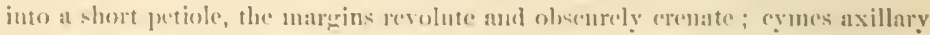
and terminal, slorter than the leaves, wislely sprealing, fow-flowerm, or in the more sterile plaut many-flowered ; sepals rounli-h, much shorter than the oblong petals; disk with four emarginate lobes alterunting with the stamens; ovary 2-celled, with a single suspended ovnle in each coll ; stigma sessile, 2-lolsed ; drupe ovoid, 1-sceded; embryo large, in thin albumen. - Sou:ls Florida. Shrub $8^{\circ}-10^{\circ}$ highlı. Leares $1^{\prime}$ long.

\section{SCH EEFFERIA, Jac!}

Flowers dicecious. Sepuls 4, harely mited at the base, roundel, 3-furrowcil. Petals t, spatulate-oblong, much longer than the calyx. Stamens 4 . Oxary 2-celled. Stigmas 2, sessile. I)rupe dry, 2-relled, 2-scerled. Immluryo in oily albumen. Radicle inferior. - Shrubs or trees, with alternate leaves and small greenish flowers in axillary chusters.

1. S. frutescens, Jater. Sumooth; leaves obovate-oblong, cutire, arute or obtuse; flowers $3-5$ in a cluster, the slender peelicels arising from a wart-like pedunele; drupe globose. - South Floritla. - A small tree with laard and closegrained wool. Leaves $1 \frac{11}{2}$ longr, pale green.

\section{EUONYMUS, I. SixDLl:-TRE.}

Flowers perfect. Calyx flat, 4-5-cleft. J'etals $4-5$, sprealing. Stamens $4-5$, very short, inserted with the petals unler the brom and fleshy disk which surrounds the ovary. Ovary 3-5-celled, with 2 erect or resupinate orules in carli cell. Style very short. Capsule 3-5-celled, loculicidilly 3-5-valved. Seed enelosed in a reil pulpy aril. - Errect or trailing shrubs, with 4-angled hranches, olprosite serrate leaves, and greenish or purplish flowers in axillary peduncled cymes.

1. E. Americanus, I. (Strawberry Besir) Flowers greenish, pentamerous; pedumeles 1-3-flowered ; eapsule warty; leaves short-petioled, varying from ovate or ohovate to linear-lanecolate, serrulate. - Low sharly woors, Florida and northward. May and June, - Shrub $3^{\circ}-6^{\circ}$ high. Leaves $1^{\prime}-2^{\prime}$ long.

2. E. atropurpureus, Jacq. Flowers purple, tetranerons; perluncles inany-flowered; eapsule smooth; leares oblong, on rather long petioles, sermlate. - River-banks, Florida and northward. May and June. - Shrub $8^{\circ}-12^{\circ}$ ligh. Leaves $2^{\prime}-5$ long. Flowers dark purple.

\section{CELAStruS, L. StafF-tree.}

Flowers somewhat dinecions. Calyx cup-shaped, 5-cleft. Petals 5, spreading. Stamens 5, inserted with the petals into the ellge of the cup-shaped fleshy disk which fills the tube of the ealyx, abortive in the fertile flower. Ovary 2-4celled, the cells 2-orulcd. Style thick. Capsule glolose, commonly 3-celled 
and 3-valved. Seeds 1 - 2 in each cell, euclosed in a fleshy searlet aril. Embryo in the axis of copious fleshy albumen. - Climbing slurubs, with alternate leaves, and small greenish flowers in axillary or terminal racemes.

1. C. scandens, I. Leaves oblong-ovate or obovate, acuminate, serrate, smooth; racemes terminating the branches, nearly simple; capsule orangecolored. - Woods and banks of streams along the mountains of Nortli Carolina, and northward. June.

\section{MAYTENUS, Juss.}

Flowers polygamous. Calyx flat, 5-cleft. Petals 5. Stamens 5, very short, inserted with the petals under the elge of the flat circular disk which envelops the ovary. Ovary 2-3-celled, with a solitary ereet ovule at the base of each cell. Style very short and thick. Stigma 2-3-lobed. Cipsule coriaceous, 1 -3-celled, loculicidally 2-3-valved, yellow within. Seeds $\mathbf{l}-3$, enclosed in a thin pulpy aril. Embryo in the axis of thin fleshy albumen. - Trees or shrubs. Leaves opposite or alternate. Flowers ehiefly in axillary elusters.

1. M. phyllanthoides, Benth. Leaves fleshy, alternate, ohlong-obovate, obscurely erenate and reticulate, glabrons; flowers minute, clustered, apparently perfect; capsule obovate, 3-angled, 1-celfed, 1-3-sceded. - South Florida. - Leares $\mathbf{l}^{\prime}-1 \frac{1}{2}^{\prime}$ long.

\section{Order 41. STAPIILEACEA. (Bladder-nut Famly.)}

Ereet shrubs, with opposite pinnate stipulate leaves, and perfect regulas pentandrous flowers. - Calyx 5-parted, colored. Petals and stamens 5, perigynous. Ovary 2-3-celled. Ovules 1-8 in each eell, attached to the eentral angle of the cell. Fruit capsular or baceate. Seeds bony, truneated at the base. Embryo straight in scanty albumen.

\section{STAPHYLEA, L. BLADDER-Nut,}

Flowers perfect. Calyx ereet, persistent. Petals obovate, creet, alternate with the sepals, imbricated in the bud. Stamens inserted with the petals into the edge of the 5-lobed disk which fills the base of the ealyx. Orary 3-celled, the cells sometimes separate above, 6-8-ovuled. Capsule 3-lobed, menbranarcous, inflated, few-seeded. - Leaflets stipellate. Flowers white, in drooping componul racemes.

1. S. trifolia, L. Leaves trifoliolate; leaflets ovate, acuminate, serrate, pubescent beneath, the teminal one long-stalkerl ; racemes lateral and terminal ; styles 3, connivent; capsule reticulated, 1-3-secled. - Danp woods, North Carolina, Tennessec, and northward. May. - Shrub $10^{\circ}$ high. Capsules $2^{\prime}$ long, $l^{\prime}$ in diameter. 


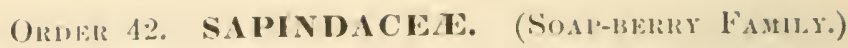

Trees or shrubs, rarely herbs, with exstipulate alternate or opposite laves, and chefly irregular and i-9-andrens fluwers, imbricated in the bul. - Calyx 4-j-lubed. P'dals 4-5, inserted with the stanens into a hyporynous or somewhat jerigrnous disk. Antluers opening lengthwise. Ovary 3-celled, the cells 1 - 2-ovuled. Seeds withut albumen. Embryo mostly curved or convolute. Cotyleelons incumbent, lleshy.

\section{Synopsis.}

Tribe I. DODONFA. - Ovules 2-3 in each cell. Embryo spiraily coilcu. Cotyledons distiuct. - Leaves alternate.

1. DODON.FA. Orules 2 in each cell. Petals none. Capsule 2-4-ringed.

Tribe II. SAPINDEF. - Orules usually solitary. Embryo curved or straight. Cotyledons distinet. - Leaves alternate.

2. IIXPELATE. Orules $2-3$ in each eell Petals $4-5$, regular. Fruit drupaceous.

3. SAPINIUS. Orules solitary. Petals 5, regular. Fruit baecate.

4. CARDIO:PERMUM. Orules solitary, Petals 4, irregular. Fruit a bladder-like capsule.

TRIBE 111. IIPPOCA ST A NEA. - Ovules 2 in each eell. Eubryo roundish. Cotyledons very thick and partly united. - Leaves opposite.

5. EsCULUS. Calyx 5-lobed. Petals 4-5, unequal. - Leaves digitate.

\section{DODON $\mathrm{EA}$, L.}

Flowers perfect or polycramous. Calyx 3-5-parted Petals none. Stamens $5-8$ : anthers thick, on short filaments. Ovary 3-4-celled, with 2 ovnles in each cell; the upper one ascending, the lower pendulous. Styles united. Capsule membranaccous, 2-4-winget, septicilally - 2 -4-valved, the cells 1 - 2-seeded. Embryo spirally coiled. - Trees or shrubs, with chicfly simple leaves, and axillary or terminal whitish or greenish flowers.

1. D. viscosa, I. Leaves viscirl, ohovate-oblong, entire, parallel-reiner ; racemes axillary and terminal, shorter than the leares; capsule 3-winged, 3seeded - South Florida. - Shrubs $6^{\circ}-10^{\circ}$ high. Flowers greenish.

\section{HYPELATE, P. Browne.}

Calyx 3-5-parted. Petals 4-5, regular. Stamens 6-10, inserted on the immer face of the cup-shaped disk which fills the hase of the calyx. Orary 2eelled, with 2-3 pendulous orules in each eell. Stỵles united. Stigma 2-lobed. Drupe globose, 1-2-sceded. Embryo erect. - Trees with alternate trifoliolate or abruptly pinnate leaves, and clustered or panicled polygamous flowers.

1. H. trifoliata, P. Browne. J,eaves trifoliolate; leaflets obovate, corialecous, glabrons, entire; panicles corymbose, slemder, axillary, longer than the leaves, few-flowered; calyx 3-4-parted, pulvescent within; petals 4, riliate; drupe black, 1-seeted. - Sonth Florida. - A small tree, with brittle branches. Leaflets 1'long, with fine oblique parallel veins. Flowers small, white. Stamens 6-8. 
2. H. paniculata, Don. Lcaves abmptly pinnate; leaflets 2 or 4 , ollong, obtuse, entire, smooth, opposite : panicles axillary and terminal, with compressed branches; flowers hoary-tomentose; calyx-lobes and petals 4 , rounded ; (ells of the ovary 2-ovuled. (Melicocea paniculata, Juss?) - South Florida. Branches purplish, dotted with white. Leaflets $2^{\prime}-3^{\prime}$ long.

\section{SAPINDUS, L. So.P-BERRT.}

Calyx 5-parted, deciduous. Petals 5, regular, with a seale at the base of each within. Stamens 8-10, inserted on the hypogynous disk. Styles united. Stin mas 3. Ovary 3-celled, the cells 1 -oruled. Fruit baceate, globose or $2 \cdots 3$ lobed, I-3-seeded. Seeds bony. Embryo ineurred. - Trees, with abruptly pinnate leaves, and small polygamous flowers in axillary or terminal racemes or panicles.

1. S. marginatus, Wild. Petioles wingless; leaflets 9-18, opposite or alternate, ovate-lanecolate, unequal-sided, strongly veined above; panicles large, dense-flowered ; fruit globose. - Georgia and Florida, near the const, and westward. - A tree $20^{\circ}-40^{\circ}$ high. Flowers white.

\section{CARDIOSPERMUM, L.}

Sepals 4, the 2 outer ones much shorter. Petals 4, irregular, each with a petal-like seale at the base within; those of the 2 outer petals entire, the others with a erested appendage on the inner edge. Stamens 8. Disk 2-glandular. Cells of the ovary 1-ornled. Style 3-cleft. Capsule 3-angled, 3-eclled, loculicidally 3-valved, inflated. Seed furnished with a cordate aril.-Herbs, climbing by tendrils. Leaves biternate.

1. C. Halicacabum, L. - Sonth Florila, apparently native, and not uncommon in cultivation. - Amuual. Stem slender. Leaflets ovate-lanceolate, incisely lobed and toothed. Capsule pear-shaped, $1^{\prime}$ in dianeter.

\section{5. 开SCULUS, L. Honsecinstrut. Beckeye.}

Calyx 5-lobed, unequal. Petals 4-5, unequal, elawed. Stamens 5-8, usıally 7 , inserted on the annular hypogynons disk. Style slender. Ovary 3-eelled, the cells 2-ovuled. Capsule coriaceous, I - 3-celled, loculieidally 2-3-valver, 1 -3-seeded. Cotyledons very large and thick, partly united. - Trees or shrubs, with opposite long-petioled digitate leaves, and showy polygamous flowers, in terminal panicles.

\section{§. 1. Esculus proper. Fruit prickly.}

1. F. glabra, Willd. Stamens almost twice the length of the ereet nearly equal pale yellow petals ; panicle oblong-ovate, loosely flowered; leaflets 5 , oval or oblong, acuminate, unequally serrulate, smooth or slightly pubesecht beneath. (A. pallida, Willd) - Banks of rivers, Tennessee and northwarl. May and June. - A small tree witl rough strong-scented bark. Flowers small.

\section{\$2. Pavia. Fruit smooth.}

2. 瓜. Pavia, L. Stamens slightly exserted; elaws of the two upper 
petuls as long as the tubulatr ealyx; paniele oblong ; leanets 5, vurying from lamwolate to wal, short-neusninate, fincly serrate, smooth, or nearly -o, ou loth sutfices - Rich soil, Florida to North Carolina, and westwarl. Mlarch-May. $-\Lambda$ slurul), or in the upper districts, a smull tree. Flowers ret.

3 死. flava, Ait. Stamens includerl; laws of the lateral petals lonerer than the tubular-campanulate calyx; paniele ohlong, pubescent; leaflets $5-$ obvate-oblong, aluminate, finely serrate, pubeseent beneath. - Rirh soil, in the midedle and upper districts of Georgia to North Carolina and nuthwart. April nul May, $-\Lambda$ slurub or small tree. Flowers pale yellow. Ar. discolor, J'ursh, is a form of this species with more strongly serrate leaflets, and flesli-colorcel or dull jurple flowers.

4. 无. parviflora, Walt. Stamens 3 times as long as the corolla ; claws of the nearly similar petals longer than the obconical calyx; panicle memose, very lonir; leaflets $5-7$, oval-ohovate, tomentose beneath. (. F malcostaclya, Mlichx.) - Upper districts of Geororia and South Carolina. April and May.Slurub $3^{\circ}-9^{\circ}$ ligh. Flowers white. Stanens 6 or 7 .

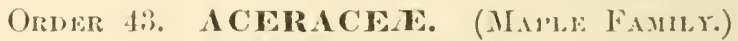

Trees or shruls, with opposite palmately lobed or pinnate exstjpulate leaves, and recular mostly polygamous or diucions flowers, with an imbicated astivation. - Calyx 4-9-lobed. P'etals as many as the lobes of the ealyx or none. Stamens 4-12, inserterl with the petals into a lyyogynous disk. Orary 2-ecelled, with 2 pendulous amplitropous wrule's in each cell, forming in fruit a double: 2-secelerl samara. Styles 2. Seeds with little or no albunen. Eimbryo folded or spirally coiled.

\section{ACER, I. MAPLL.}

Flowers polygamous. I'etals usually 5 -8, or none. Stamens 4-12. - Leaves simple, palmately lohel. Flowers vilustered or racemose.

* Flowers in terminal racemes, appraring after the toures.

1. A. Pennsylvanicum, L. (Sтmín Mlipl.) liaremes simple, droopiug ; flowers (15-25) large ; petals obovate ; leaves slighlitly cortate, with 3 acuminate finely serrate lohes ; samara large. (A. striatum, Lam.) - Banks of mountain streams, Georgia and northwarl. May. - I shrub or small tree, witl striped bark. Flowers greenish.

2. A. spicatum, Iam. (Motrtaix Mirie.) Racenes compount, erect; flowers small, very numerous; petils linear-spatulate; leaves cordate, 3-lobed, coarsely serrate; sanara small. - With the preceding. - Slurub $6^{\circ}-10^{\circ}$ ligh. Jeaves pubescent beneath.

* * Flouers on long and drooping umbellate or corymbose pedicels, developed from lateral and terminal buds.

3. A. saccharinum, Wang. (SrGar MAPLE) Leaves cordate, with 3-5 acute or atuminate sinuate-toothed lobes, paler and slightly pubescent be- 
neath ; flowers umbellate-corymbed, appearing with the leaves; calyx bell-shaped, fringed on the margin, nearly as long as the stamens; petals none. - Rich soil, ehiefly in the upper distriets, and northwind. April and Mary - A large tree. Leaves $3^{\prime}-5^{\prime}$ wide.

Var, Floridanum. Leaves truneate or slightly cordate at the base, with 3 - 5 obtnse and obscurely 3 -toothed lobes; flowers nmbellate, appearing before tho leares; ealyx short, enp-shaped, hairy, one third as long as the stamens. Upland woods, Middle Florida. March and April. $-A$ small tree. Leaves, flowers, and fruit scarcely half as large as in the ordinary form.

* * *lowers on short and crect clustered pedicels, developed from lateral buds, and appearing urfore the leaves: fruiting pedicels long und drooping.

4. A. dasycarpum, Ehrh. (SiLver MAlLe.) Leaves cordate, 3-5lobed, sharply toothed and serrate, white beneath; petals none; samara large, woolly when young. - Banks of rivers, Florida to Mississippi, and northward. February and March. $-\Lambda$ tree $30^{\circ}-50^{\circ}$ ligh, with soft wood. Flowers yellowish.

5. A. rubrum, L. (Red or Swajp Maple.) Leares 3-5-lobed, or undivided, smooth or pubescent, either cordate or rounded, or sometimes aente at the base, toothed and serrate, white beneath ; petals ol,longr or linear ; samara small, smooth. - Swamps, Florida to Mississippi, and northward February and March. - A small tree. Flowers and fruit red.

\section{NEGUNDO, Monch. Asit-leaved Mapli..}

Flowers diœeious. Calyx minute. Petals none. Stamens $4-5$, hypogynous. -A small tree, with smooth green bark. Leaves pinnately 3-5-foliolate, the leaflets ovate or oblong, lobed or toothed. Flowers sinall, greenish; the sterile ones on long and drooping chstered pedicels, the fertile ones racemose, both from lateral buds appearing with or before the leaves.

1. N. aceroides, Mcench. (Acer Negundo, L) River-banks, Florida and northward. March and April.

\section{Order 44. MALPIGHIACEA. (Malpighia Famir.)}

Trees or shrubs, with opposite simple dotless and mostly stipulate leaves, and regular racemose or corymbose fowers on usnally jointed pedicels. Calyx 5-parted. Petals 5, alternate with the calyx-lobes, nngnienlate, sometimes wanting. Stamens 10, alternate with the petals, and inserted with them into a hyporynous disk: anthers roundish. Ovary solitary, mostly 3-loberl, consisting of three more or less united carpels. Styles 3 , distinct or united. Fruit composed of one to three 1-scederl cells or carpels. Seeds pendulous, withont albumen. Cotyledons thick or leafy. 


\section{BYRSONIMA, liili.}

Calyx with 10 glands at the base without. letals 5. Stamens monadelphous at the batse. Siyles 3. Frnit drupaccous, 3-celled, 3-seceled. - Racemes terminal, simple or bruncled.

1. B. lucida, Rich. Smooth; stem much-hranched; leaves coriacrons, wedge-obovate, obtuse, entire, short-petioled, shining above, paler leneath, veinless; racemes erect, bracted, simple, twice the length of the leaves; pediecls slender, spreading; petals yellow, orbicular-eordate, wavy, lome-clawed ; drupe smooth, globose. - Sonth Florida. - I small shrub. Leaves l' long. Drupe as large as a grain of pepper.

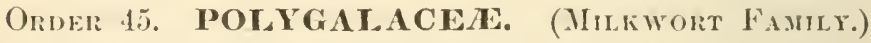

Herbs or shubs, with entire exstipulate leaves, and irregular hyporynous monadelplous or diatelphons flowers. - Antluers l-ecelled, opening by a terminal pore. (Ovary 2 -relled, with a single anatropous pendulons ovule in each cell. Seeds often carunculate. Embryo straight in scanty allumen. Radicle superior.

\section{POLYGALA, L. Mi.кWOR.}

Sepals 5, persistent, unequal; the two lateral ones (wings) larger and petal-like. l'etals 3, more or less united ; the midlle one (ked) larger, and usmally ('rested at the apex. Stamens 8, rarely 6, united into a tube, or into two equal sets, and also with the claws of the petals. Style curved, elavate. Stigma terminal or lateral. Capsule 2-eelled, 2-sected. Sechs smpended, earunculate. - Chiefly herbs. Leaves alternate or whorled. Flowers in terminal spikes or racemes, rarely axillary, or radical and imperfect.

\section{$\$ 1$. Hlowers in glolose or oblong more or less compact spikes. * Sprikes corymbose: liennials.}

1. P. cymosa, Wialt. Sten tall, simple; leaves seattered, linear, acnte, the upper bract-like, the lowest long $\left(6^{\prime}-9^{\prime}\right)$ and erowded ; corymbs simple or rompound ; wings oblong, almptly acute; seels minute, globose-olovate, smooth; carumcle none. (1'. cormbosa, Ell. P. acutifolia, Torr. \& Gray. I'. graminifolia, Poir: P attenuata, Nutt.) - Pine barren ponds, Florida to North Carolina. and westward. July. - Stens $2^{\circ}-4^{\circ}$ high. Corymbs very large and compound, or small and simple. Flowers yellow, turning dark green in drying. Plant ycllowish.

2. P. ramosa, Ell. Stem low, simple, or branching and leafy from the lalse to the summit ; leaves fleshy, lanecolate, acute, scattered, the lowest spatulate-obovate, obtuse, crowded; corrmbs compound, fastigiate; wings ovatelanceolate, acmminate; lohes of the caruncle small, rounclish, embracing the base of the minute oval hairy seel. (P'. corymbosa, Nutt. P'. eymosa, Poir.) Low open pine barrens, Florida to Misissippi, and nortluward. Jnly-Septem. her. - Stens $6^{\prime}-12^{\prime}$ high. Flowers yellow, tuming green in drying. 
3. P. Baldwinii, Nutt. Stem angled, simple; leaves alternate, lanceolate, acute, the lowest spatulate; corymbs compound ; spikes dcuse; wings oratelanceolate, tapering into a long and slenter point; secels very small, glohose, hairy; carnncle minute. - Low pine barrens, Georyia, Floricla, and westwart. July and August. - Stem $1^{\circ}-1 \frac{1}{2} 0$ high. Leaves $\frac{1}{2}{ }^{\prime}-1^{\prime}$ long. Flowers white, frugraut.

\section{* Spilies solitary: leaves alternate.}

- Flouers yellow: biemials.

4. P. lutea, L. (Yellow Bicueıor's-Buttox.) Stem simple or with spreading branches; leaves lanccolute, acute, the lowest ('hustered, spatulateobovate, obtuse; spikes dense, globose or ohlong ; wings elliptical, alıruptly pointed; lobes of the carmele nearly as long as the obovate sparse-bairy seed. - Low pine barrens, Florida to Mississippi, and northward. June-August. Stem $6^{\prime}-12^{\prime}$ high. Flowers orange-ycllow.

5. P. nana, DC. Low ; stems divided at the base into several short peIluncle-like branches; leaves chiefly radieal, clustered, spatulate or linear, ohtuse ; spikes thick, at length cylindrical, the earliest ones sessile; wings ovate-lanceolite, acuminate; lobes of the caruncle half as long as the obovate hairy seed. (P. viridescens, Nutt.) - Low sandy pine barrens, Florida to South Carolina, and westward, flowering throughout the year, - Stems $2^{\prime}-4^{\prime}$ high. Spikes $1^{\prime}-2$ ' long. Flowers yellow.

+ + Floxers purple or rosi-cutor: amuals: stems tranching.

6. P. sazguinea, L. Luives ol,iong-linear, ar`ute; spikes ovate or roundish, obtuse; flowers inlnicated ; wings broally ovate, ohtuse, sessite: lobes of the earuncle rather shorter than the pear-shaped sparse-luary seed. (I'. purpurea, Nutt.) - Low grounds, North (arolina aml northward. July - Sept. Stems 10 high. Flowers reddish-purple. Bracts persistent.

7. P. fastigiata, Nutt. Stems slenler, at first simple; leaves narrowlinear, acute; spikes ghlobose, olstuse; wings oblong-obovate tapering into a distinct claw at the base; camucle as long as the stalk of the sparse-latiry pearshaped sect. (P. sanguinea, Torr. of (fruy.) - Low pine barrens, Floridla to North Carolina, and westward. July-O(t. - Stems $10^{\prime}-15^{\prime}$ high. Leaves ereet. Flowers small, bright rose-color. Bratets deciduous.

8. P. Nuttallii, Carey. Leaves short, linear, oltuse; spikes ohlong, acute, tlense; wings short, elliptical, slightly clawed ; lobes of the caruncte collateral, one third as long as the obovate very hairy secil. (l'. sangninea, Nutt. P. ambigua, Torr. \&. Gruy.) - 1)ry santy soil, North Carolina and northwarel. Angust. - Stcm 4'-8' high, the loranches fartigiate. Spikes and greenish and purple flowers smaller than in No. 7 . Bracts persistent.

9. P. Chapmanii, Torr. \& Gray. Stems slender, at length sparingly branched; leaves seattered, unrow-linear, acute; spikes long, lauceolate, acute, loose-flowered ; wings olovite, slort-clawed; lobes of the caruncle sprealing, as long as the stalked base of the pear-slaped very hairy seed - Low pine barrens near the coast, West Florida and westward. Juse $-\Lambda$ ugust. - Stems $10-1 \frac{1}{3} 0$ high. Spikes $1^{\prime}-2^{\prime}$ long. Flowers briglit-purple. Bracts persistent. 
10. P. incarnata, I. Stem of ten simple, glancous; leaves scattered, lincar, fleshy, somerimes minute mul subulate; spikes banceolate, ardute, denseflowered; petals mited into a tule which is twice as long the the elliptical wings, conspienously crested; catrmele spongy, ns long ats the stulk of the

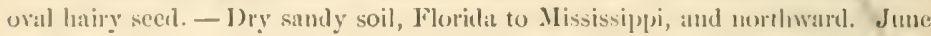
- Angust. - Stem $1^{\circ}-20$ high. Bratets deciduous. Jifowers and often the rachis purple.

11. P. setacea, Michx. Stems simple or sparingly l,anched, slender; lenves minute, seale-like; spikes oblong, dense-llowererl, andute; wings oblong, acote, as lony as the petals; (aruncle and seeds as in No. 10. - Low pine luarrens, Florita to North Carolina, and westward. May-July - Stem 10 high. Spikes $\frac{1}{2}-1^{\prime}$ long. Flowers pale rose-color or whitish. IBracts ileciduous.

* * Spikes solitary: leuves uhorled: flowers purple.

12. P. cruciata, I. Sten erect, 4-angled, simple or hranched; leaves in fours, linear or oblong-linear, thick, oltuse, the upper oncs altemate; spikes large, ovate, becomingr cylintrical, short-peduncled; wings ovate, tapering into a long subulate point; lobes of the carmele linear, collateral, as long as the smoothish oval secd. - J'ine-barren swamps, Florita to Missi-sippi, and northwarl. July-Oct. - Stem $6^{\prime}-12^{\prime}$ ligh. Spikes $l^{\prime}-2^{\prime}$ long, 3' thick. Flowers pale rose-color. IBracts persistent.

13. P. blevifolia, Nutt. Stem weak, 4-ingled, with long and spreading lranches; leaves thin, lanecolate or linear, acute, the lower ones in fonrs; spikes small, ovate, long-pedmeled ; wings lanceolate-ovate, barely pointed ; carnncle as loner as the vbovate hairy seed. - Bogs, Florida and northwarl. JulyO(t. - Stem $1^{\circ}-1 \frac{1}{2}$ long. Spikes scarrely half ats large as in the preceding. Flowers redilish-purple. Bracts persistent.

14. P. Hookeri, Torr. \& Gray. Stems short, weak, much branehed, 4angled; leaves in fours, short, linear, autish; spikes long-peduncled, ovatelancelate, acnninate, loose-flowered; wings erect, lanccolate-ovate, acute; (aruncle as long as the ovoid sparse-hairy and viscid secd. - Low grassy pine barrens, West Florida and westward. July - Sept. - Stems $6^{\prime}-10^{\prime}$ high. Leaves $4^{\prime \prime}-6^{\prime \prime}$ long; those of the branches mostly altemate. Fowers pale rose-color. IBraets persistent.

\section{\$2. Flowers in slender racemes or spikrs. \\ * Leaves alternate: perennials or biemials.}

15. P. grandiflora, Walt. P'ubeseent; stems branching; leaves lanccolate; flowers larere, erestless, seattered in long racemes; fruiting pediecls drooping; wings large, orbicular, erect; carmele enclosing the stall of the oblong latiry seerl. (l'. pulsescens, Mhll.) - Varies with smoothish lincar leaves, and sinaller flowers. (P. Habcllata, Shuttl.) - Dry light soil, Floritlat to Sonth Carolina, aud westward. July-Sept. 4 - Secm $1^{\circ}$ hight. Ravemes $3^{\prime}-6^{\prime}$ long, often lateral ly the prolongation of the stem. Flowers bright purple, turning grreenish.

16. P. polygama, Walt. Snootlı; stems numerous, simple; leaves ublong-linear, the lowest spattulate or obovate; flowers of two kinds, viz. one 
kind showy and perfect, horne in a loose terminal raceme, the other imperfect, but fruiting, in rallical (rarely axillary) spikes; wings obovate; caruncle half as long as the ohovate very hairy seed. (P. rubella, $/ h h l$.) - Wet or dry sandy barrens, Florida to Mississippi, and northward. May and June. (2) Stems $6^{\prime}-12^{\prime}$ high, very leafy. Racemes $2^{\prime}-6^{\prime}$ long. Flowers purple.

17. P. Senega, L. (Seneci Snakenoot.) Stems several from a thick wooly root, erect or ascending, simple or branching above; leaves numerous, lanceolate, the upper ones acute ( $l^{\prime}$ long); spike eylindrical, perluncled; wings round-obovate, as long as the capsule; lobes of the earuncle linear, as long as the obovate haily seed. - Var. Latifolia, Torr. \& Gray. Stem taller $\left(1^{\circ}-1 \frac{10}{2}\right)$; leaves large $\left(2^{\prime}-4^{\prime}\right.$ long $)$, orate or ovate-lauccolate, acute or aruminate at each end. - Dry rocky woods in the upper districts of North Carolina and northward; the variety in Tennessee, and northward. May and Junc. 4-Stems $8^{\prime}-12^{\prime}$ higl. Spikes $1^{\prime}-1 \frac{1}{2}$ long. Flowers greenish-white.

18. P. alba, Nutt. Stems sereral from a sonewhat wooly root, erect or ascending, antrular, at length branehed above; leares linear, narrowed towarl the base, acute, or lowest ones obtuse; spike long-peduncled, linear-lanceolate, acuminate ; flowers short-pediecled ; wings oval, rather longer than the capsule; lobes of the caruncle shorter than the ohlong-obovate very lairy seed. (P. bicolor, Kinth.) - Interior of Alabama, bukley, and westward. - Stems $\frac{1}{2}^{\circ}-10$ high. Spikes $1^{\prime}-3^{\prime}$ long. Flowers white. Bracts deciduous.

* Leares uhorled: floucers small, greenish or whute, in slender spilies.

19. P. Boykinii, Nutt. Percnnial; stems numerous, angled, simple or sparingly brancherl; leaves $4-5$ in a whorl, the lower ones obloner-ohorate, the upper lancelate and scattered; spike linear, long-peluncled ; wings obovate, as long as the capsule; caruncle half as long as the oblong-obovate curved and very latiry seed. - Rich ealeareous soil, Floridla, Georgia, and westward. May July. $\quad 4-$ Stems $1^{\circ}-2^{\circ}$ high. Leaves $1^{\prime}$ long. Spikes $2^{\prime}-3^{\prime}$ long. Flowers whitc.

20. P. verticillata, L. Annual ; stems low, 4-angled, much branelıed; leares $4-5$ in a whorl, linear, acute, the upper ones scattered; spikes lancelate; wings roundish, as long as the eapsule; lobes of the earuncle half as long as the oblong hairy scerl. - I)ry sandy soil, Florida to Mississippi, and northwarl. June - Ang. - Stem $t^{\prime}-8^{\prime}$ high. Spikes $\frac{1}{2}{ }^{\prime}-1^{\prime}$ long. Flowers grcenish-white.

21. P. leptostachys, Shuttl. Amnual ; stems filiform or setaceons, simple, or branched ahore, straight; leares remote, $4-5$ in a whorl, narrow-linear or filiform, acute; spike linear, long-peduncled; wings oval, nearly sessile, smaller than the eapsnle; carmele half as long as the smootl curvel clavateobovate seed. - Dry sand hills, Florida. May - August. - Stens $10^{\prime}-15^{\prime}$ hight. Flowers greenish.

\$3. Flowers axillary, and with imperfeet radical ones, as in No. 16.

22. P. paucifolia, I. Perennial ; flowering stems ereet, simple, leafy at the summit; leares large, orate, alternate, narrowed into a petiole, the lower ones bract-like; flowers ( $1-3)$ peduncled, erested, very large; wings obovate; 
lohes of the carmucle subulate, varying in length; seeds hairy; ralienl spikes

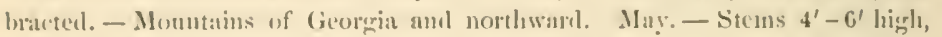
from a long prostrute bise. Flowers s.' long, purple.

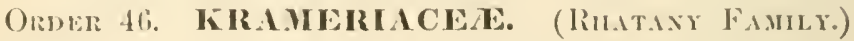

Silky-pubescent herbs wr shuls, with dilluse stems, altcruate leaves, and irregular lypoegrnous purplish flowers, on axillary 2-loratenl and jointerl

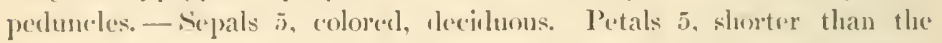
sepals; the 3 posterior ones, longrelawed, often united; the 2 anterior broal, seswile and flewhy. Stamens 4 , the posterion ones distinet or united. Anthers 2-cellerl, opening hy a terminal pose. Ovary 1-celled, 2-ovisled. Fruit l-sereded, woxly, indelisecent, amed with hispiul prickles. Albumen none. Radicle concealed in the cotyledons.

\section{KRAMERIA, Loefl.}

Characters of she order.

I. K. lanccolata, Torr. Ilerbaceous; stems slender, prostrate, mostly branching ; leaves lanceolate or linear, acute; peluncles longer than the leaves, leafy-bracted ahove the middle; claws of the posterior petals, and stamens, united; fruit globose, downy, armel with few strong spreading spines. - Tampa Bay, Sonth Florida, and westward. - Root long and woorly. Stems 10 long.

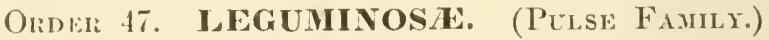

Herls, shrubs, or trees, with chicfly rompound alternate stipulate leaves, and papilionaceons or regular perigymous or hypogrnous flowers. - Srepals 5 , more or le's united. Petals 5, rawely fewer, or none. Stamens monadelplons, diarlelphous, or distinet. Ovary simple, firee, forming a legume in fruit. Secels without albumen. Icaves almost always with entire margins.

\section{Synopsis.}

Suborder I. PAPIIIONACE.E. Corolla of 5 (rarely fewer) irregular petals, inserted into the base of the ealyx, rarely perigynous, imbrieaterl in the lut, mostly papilionaceous; viz. one npper and exterior, termed the vexillum or standard; two lateral, called wings; and two lower and interior, oftener uniterl hy their contiguous margins, forming together the lieel. Stamens 10 (rarely 5), separate, monarlelphous, or diadelphous (9\& 1 , or $5 \& 5)$. Leogume 1-celled (sometimes partly 2-eelled ly the introversion of the sutures), or several-celled by transverse partitions. Style simple. Cotyledons thick.

Tribe I. LOTEX. ('orolla papilionaceous. Stamens 10 (except No. 8). Legume eontinuous (not jointed). Cotyledous leafy in germination. - Stems (except No. 12) not twining nor elimbing. 
* Stamens monadelphous : anthers of 2 forms. Leares simple, or palmately compounc.

1. CROTAlakia. Caly 5 5-lobed. Legume inflated. Lpper stipuies decurjent.

2. LUPINUS. Calyx 2-lipped. Legume flattened. Stipules not decurrent.

* Stamens diadelphous : anthers alike. Leaves trifoliolate, rarely palmate or pinuate, the earliest ones alteruate.

3. MEDICAfo. Legume membranaceous, curved or coiled, 1-many-secded. Flowers racenea.

4. MEL1LOTCS. Legume coriaccous, straight, rugose or veined,1-4-seeded. Flowers racemed or spiked.

5. TR1FOLICM. Legume smooth, membranaceous, 1 -4-seeded. Flowers eapitate.

6. IIOSACKIA. Legume straight, many-seeded. Peduncle 1-3-flowered.

* * Stamens monadelphous or diadejphous. Legume mostly 1-seeded and inde'disceut. Plants dotted with small dark glands. Earliest leaves opposite.

- Legume included in the caly $x$.

¡. PSORALEA. Corolla papilionaceous. Stamens 10, diadelphous: half of the anthers often imperfect.

8. PETALOSTEMOx. Stamens5 united into a cleft tube, and adnate to the claws of four of the nearly regular petals.

9. DALEA. Stamens 9 or 10 , the tube partly adnate to the elaws of the petals.

+ Legume exserted.

10. AyORPIA. Stamens 10 , monadelphous. Wings and keel none.

**** Staucus mostly diaulelphous. Legume 1-many-seeded, 1-celled 2-ralred. Learas pinuate.

+ Trees or shrubs.

11. ROBINIA. Legume flat and thin, margined on one edge. Trees or shrubs.

12. Wistali IA. Legume nearly terete, coriaceous, contracted between tise seeds. Twining shrubs.

$$
\text { + Herbs. }
$$

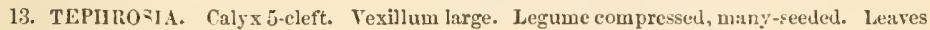
unequally pinuate.

14. IXDIGOFEliA. Caly $\mathrm{x}$ minute, 5-elcf: Texillum small. Legume terete or angled, 2 - many-seederl. Leaves unequally pinnate.

15. GLOTTIDIUM. Calyx truneate. Legume oblong, 2-secded. Leares abruptly pinnate.

16. SESBAxIA. Calyx 5-toothed. Legume very long and slender, many-sereded. Leaves abruptly pimate

***** Stanens diaclelphous. Legume 2-celled lengthwise, or 1-celled, with one of the sutures turned inward. Leaves pinnate.

17. Astragales. Stamens 10, diadelphous. Legume tumid.

Tribe II. VICIEAF. Stamens diadelphous (9 \& 1). Legume 2-ralverl, not jointed. Cotyledons thick and fleshy, remaining under ground in germination. - Climbing vines ; the petioles of the pinnate leares ending in a tendril.

18. VICIA. Style filiform, bearled at the apex, or on the side facing the keel.

19. LATIYILE. Style fiattened, bearded on the side faeing the vexillum.

TRIBE III. HEDYSAREA: Stamens monadelphous or diade'phous. Legume separating transversely iuto 1 -seeded indehiscent reticulated joiuts, or 1 -j jinted. - Stems not twining.

* Flowers yellow.

20. FSCIIYOMF. Leares pinnate. Stamens diadelphous (5 \& 5). Florers perfect

2I. ZORNIA. Leaves palmately compound. Legume 2-5-jointed. Flowers perfect.

22. STYLOSANTIES. Leaves trifoliolate. Anthers of 2 forms. Flowers uionocious.

23. CIIAPMANNIA. Leaves pinnate. Anthers alike. Flowers monoecious.

* Flowers white or purphish.

24. LESPEDEZA. Legume 1-jointed, Peduncles axillary. 


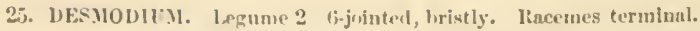

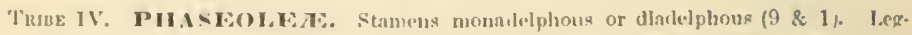
une 2 valvel, not jointed. Cotyledons thick aud fleshy ; usually rutsed aborc ground in geruniuation. - Chiclly twining vines.

- Ovary 1 - 2-ovuled.

26. RHY.Tilosia. Legume oblong. I'lowers yellow. leaves trifoliolnte.

* Ovary tew or inany-ovulexl.

- Kieel spirally twi-ted

27. Apros. Leares pinnate, not stipellate.

28. PIIASOLCS. Leaves trifoliolate, stijellate.

- + Keel straight. Leaves trifuliolate (except one species of Galactin).

+ legume terite, torulose.

29. VIGxA. Flowers yellow. Vexillum roundish. Stems twining.

30. ERYTIIRLNA. Flowers scarlet. Vexilium narrow, elongated. Steus erect.

++ + legume flattened.

$=$ Bracts opposite. Vexillum very large.

31. Clito:il. Calyx tubular, 5-tonthed. Vexillum spurless at the base.

32. CENTios EMA. Caly $\mathrm{x}$ short, 5-eleft. Vexillum epurred at the base.

$==$ Bracts alternate.

33. AMPIICARP.EA. Calyx 4-5-toothed. Flowers of two kinls. Bracts peristent.

34. GALACTIA Calyx 4-eleft. Bracts deciduous. Legume liuear.

35. CANAVALTA. Stamens monadelphous. Calyx bilabiate. Ililum linear. Legnme tbreeridged on the l,ack.

36. DOLICIIOS. Stamens diadelpluous (9\& 1). Calyx 5-cleft. Ililum oval.

Tribe V. DA IBWIRGIEA. Stamens 10, monadelplous or diadelphous. Legume intehiscent. Cotyledons thick and fleshy. - Trees or shrubs.

3i. PISCIDIA. Legume compressed, 4 -winged. Leaves pinnate.

Trine VI. SOPHOR EA:. Stanens 10, eparate. Legume not jointed. - Ereet herbs, slarubs, or trees.

* legume dehiscent.

33. BAPTISI. Stamens decilnons. legume inflited, stipitate, few-seeded. Jeares simple or trifoliolate.

39. TII:RMOPSIS. Stamens jersistent. Legume nearly sessile, flattenet, many-sceded. Leaves trifoliolate.

40. CLADIiASTIS. Stamens persistent. Legume flat, few-seeded. Leares pinnate. Tree.

* * Legume indehiscent

41. SOPHOaA. Legume moniliform. Leaves pinnate. Shrubs.

Subonden II. C.ESALPINIL.L. Corolla irregular aul somewhat papilionaceons, or almost regular, imbricated in the but $;$ the upper petal interior. Stamens separate. Embryo straight.

42. CERCIS. Flowers perfect, somenhat papilionaceous. Calyx 5-toothed. Leaves simpie.

43. CASSIA. Flowers perfect, irregular. Calyx deeply 5-parted. Anth rs dissiuilar. Leaves pinnate.

41. GLEDITSCIIA. Flowers polygamous, almost regular. Calyx 3 -5.parted. Leares pinnate and bipinnate.

Subondir III. MIMUOSE.F. Corolla regular, lypogynons, valvate in the bud. Stamens distinet or united, often very numerous, inserted with the petals. Embryo straight. - Leaves pinnate or 2-3-pmnate. Flowers polygamous. 
* Flowers perfect and staminate. Petals united.

45. MinosA. Filaments distiuct. Legume jointed, flat.

46. SCHRANKIA. Filaments distinct. Legume not jointed, echinate.

47. PITIIECOLOBIUI. Filaments united into a tube below. Legune broad and flat, mealy or pulpy withiu

* Flowers perfect and neutral. Petals distinct.

49 DESMANTIUS. Sterile filaments fliform. Legume linear, many-seeded.

49. NEPTUNiA. Sterile filaments tat or petal-like Legume oblong, few-sceded.

\section{Suborder I. Papildonacea. Pulse Family.}

\section{CROTALARIA, L. Rittle-box.}

Calyx 5-lobed. Vexillum cordate : keel falcate. Stamens monadelphons. Anthers alternately oblong and roundish. Capsule inflaterl, oblong, manyseeded. - Low herbs, with simple leaves; the upper ones with hroarl decurrent inversely sagittate stipules. Racemes opposite the leaves. Flowers yellow. Legumes rlark-purple.

1. C. sagittalis, I. Annual ; stems low, branching, shaggy with rustcolored spreading hairs; leaves nearly sessile, oral or oblong, hairy; racemes short, 2-3-flowered. - Barren sandy soil, Florida and northwarl. June and July. - Stem $3^{\prime}-6^{\prime}$ ligh. Racemes $2^{\prime}-3^{\prime}$ long.

2. C. ovalis, Pursh. Perennial; stems several, branching, prostrate or ascending, rough with appressed hairs; leaves short-petioled, oral or oblong, hairy ; racemes long, 3-6-flowered - Dry pine barrens, Floridia to North Carolina, and westward. May -July. - Stem $6^{\prime}-12^{\prime}$ ligh. Raecnes $4^{\prime}-6^{\prime}$ long. Flowers distant.

3. C. Pulshii, DC. Perennial; stems sleneler, ereet, roughened with seattered appressed hairs; leaves thick, smooth alove, the lower ones oblong, the npper linear ; racemes long, 5-10-flowered. - Flat grassy pine barrens, Florida to South Carolina, and westward. May and June. - Stem 1:- $-18^{\prime}$ highlo Ritcemes $6^{\prime}-12^{\prime}$ long. Flowers distant.

\section{LUPINUS, Tourn. Lupixe.}

Calyx 2-lipped, 5-toothed. Vexillum with the sides refiexed. Feel fuleate, acnte. Stanens monadelphous, with alteruate anthers oblong and roundish. Capsule oblong, compressed, many-seeded ; the seeds often separated by cellular partitions. - Herbs, with simple or palmatcly 5-many-foliolate leaves, and showy flowers in terminal racemes.

1. L. perennis, L. Stem pubeseent, erect; leaves palmately $\bar{z}-9$-foliolate; leaflets obovate-oblong, obtuse, more or less hairy ; stipules minute; racemes long, loosely many-flowered ; flowers purplish or purplish-blue, rarely white. - Var. gracilss (L. graeilis, Nutr.) is a more slender and hairy form, with smaller and narrower, often arute leaflets. - Dry sandy soil, Florida to Missi-sippi, and northwarl. April and May. 4 - Stem $1^{\circ}-1 \frac{1}{2}$ liigh.

2. L. villosus, Wille. - Biennial; villons and hoary ; stems thick, prostrate or ascendinır; leaves simple, lanceolate-oblong, mostly acute, long-petioled ; 
stipules lincar-subulate, clongated, adnate below to the jerioles; racemes erect densely many-flewered ; thwers pate red, the vexillum dark purple in the centre; legune very woolly - 1)ry samdy larrens, Florida to North Carolina. April. - Stems $10^{\circ}-2^{\circ}$ long. Leaves (with the pertiole) $6^{\prime}-8^{\prime}$ long.

3. L. diffusus, Nutt. P'remial; silky-tonentose and hoary ; stems postrate or ereet, murh hranched ; laves simple, oblong or obovate, obtuse, shutpetioled ; stipules short, often wauting on the branches; racemes many-flowered; flowers bhe, the vexillum lark pmrple in the eentre; leamme woolly.-- Dry

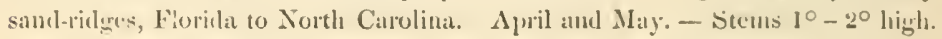
Leaves $2^{\prime}-4^{\prime}$ long.

\section{MEDICAGO, I.}

Calyx 5-cleft ; the lobes sulmuate or setaccous. Corolla decirluons. Vexillum lonirer than the partly united wings and keel. Stamens 10 , dialdplous $(9 \&$ 1), equal. Style smooth. Legume fulcate or coilerl, 1-many-seeded. - Ierbs or shrubs. Jeaves trifoliolate. Stipules alnate to the petioles, mostly inciserl. Flowers ycllow, in axillaty spikes.

1. M. lupulina, I. Pubescent ; stem procumbent; leaflets obovate, toothed ; stijules nearly entire; spikes slolose, nany-floweresl flowers mi-

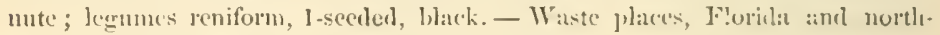
waril. Introincede. (1) - Stem $1^{\circ}-2^{\circ}$ long.

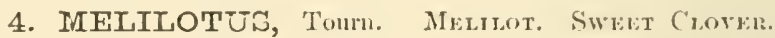

Calyx 5-toothed; the teetlı long and equal. Corollat deridnons. Wings and

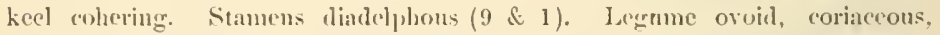
veiny or rugose, longer than the calyx, 1-4-scederl, searedy dehiscent. Smooth herls. leaves trifoliolate. Icaflets often torother. Stipules arhate to the petioles. Flowers yellow or white, in axillary racencs.

1. M. of icinalis, Wilht. Stem erect, hranthing; leuflets ohovate-ollong. tootherl; flowers yelkw; rexillum striped with lorown, as long as the keel and wins-s; lemunc obovate, rugrose. - Cultivated ground. Introduced. (1) and (5) - Stems $1^{\circ}-3^{\circ}$ hight. Legumes droopiug, 2-secelet.

2. M. alba, I.am. Stem erect, lranching; leaflets ollong, thmeate, serrate; racenes ('lonrated ; fowers white; vexillum longer than the wings and keel; Jegrumes ovate, ruggose, l-secederl. (M. leucantha, Koch.) - Cultivated grounds.

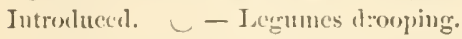

\section{TRIFOLIUM, I. Ciovi.}

Calyx s-cleft; the tecth sulmlate or setaceous. Corolla withering or persistent ; the kecl shorter than the wings, and united with them by their claws. Stainens diadelphous $(9 \& 1)$. Legrume smooth, memilranaccons, 1-6-sceded, often shorter than the calyx, searcely dehiscent. - Tufted or diffise herhs. Leaves trifoliolate, the lesflets mostly toothed. Stipules aduate to the perioles. Flowers (in our species) capitate. 
* Fruiting calyx erect.

1. T. pratense, L. (Red Clorer.) Ilairy ; stems erect; leaflets oblong.ovate or oral, often emarginate, slightly serrulate; leads large, orate; calyx-teeth setaccous, hairy ; flowers purple. - Aromel dwellings. Introduecl, hut searcely naturalized, at least in the low comntry. - Steins $1^{\circ}-2 \circ$ ligh. Leaves usually marked with a pale 3-angled spot above.

2. T. arvense, I. (R.ımit-font Crover.) Softly pubescent ; stems erect ; Jeaflets linear-oblong, minutely 3-toothed ; heads oblong; calyx-teeth setikeons. plumose; corolla white, with a purple spot on the wings. - Old fichds, chisfly in t'ae upper distriets. Introdnced. (1) - Stems $8^{\prime}-12^{\prime}$ high.

$$
\text { * * Tiniting calyx replexed. }
$$

3. T. reflexum, L. (Burraco Clovar.) P'uhescent; stems ascending; leaflets roumdish or olrordate, tuothed, the uppermost oblong; heads globose; calyx-tube very short, the subulate tecth long and latiry ; vexilhm broadly orate, purple; the wings and keel white; Jegume 3-5-secded. - Wiate places and pastures, Florilia to North Carolina, and northward. A rril and $\mathrm{Atay}_{\text {. (1) and }}$ (2) - Siens $66^{\prime}-1 \cong$ long. Ileads large.

4. T. repens, I. (Wurte Clorer.) Smooth; stens crepping; leaflets ronndish or obcordate; heads globose, long-peduncled ; ealyx-teeth short; flowers white; legume 4-seederl. - Pastures and around dwellings. Introduced. May. 4 - Stcms C'-12' long.

5. 'T. procumbens, I. P'ubeseent; stems slender, erect or procumbent ; leaflets small, thim, olovate or obcorilate, toothed, the mildle one stalked; heads small, ovate; flowers yellow; legume 1 -secded. - Waste places; more common in the upper districts. Introduced. (1) - Stems $6^{\prime}-12^{\prime}$ long.

6. T. Carolinianum, Michx. Pubeseent; stems tufted, prostrate; leaflets small, obcordate, slightly toothed ; heals roundish, long-perduncled ; flowers white, tinged with purple; vexillum acute; legune 4 -secled. - Fields and pastures, Florida to North Carolina, and westward. March ant April. \& Stems $6^{\prime}-10^{\prime}$ long; in shady places erect.

\section{HOSACKIA, Dougl.}

Calyx 5-cleft. Vexillum as long as the keel and spreading wings. Stamens diadelphous (9\& 1). Legume cylindrical or compressed, smooth, wingles, many-seedel. - Ilerbs. Leaves trifoliolate or pinnate. Stipules mostly minute and gland-like. Peduncles I-several-flowered.

1. H. Purshiana, Benth IIairy ; stem much brancher ; leaves trifoliolate, with oblong leaflets; peduncle i-flowered, longer than the leaves; keel acute; bracts simple; legume linear, nearly terete. - North Carolina. - Stem $12^{\prime}-15^{\prime}$ high. Flowers rose-color.

\section{PSORALEA, L.}

Calyx campanulate, 5-eleft, witl the lohes acute. Stamens dialelphous or partly monadelphous: half of the authers often imperfect. Legume often 
wrinkled, 1-sected, indehisent, inclumet in the ralyx. - l'eremial usually glandular berk. Stipmles cohering with the petioles. Flowers axillary or terminal, purplish or white, racemose or spiked.

\section{* Leares 1-3-foliolute.}

1. P. virgata, Nutt. Smoothish; stem virgate sparingly hranched; leaves very remote, I- (or the lowest 2-3-) foliolate; leaflets linear or oblong-linear, obtuse, the lower oues broaler and long-petioled; stipules setareons; perluncles much sloorter than the leaves; spikes dense, evlindrical ; luacts ovate, acuminate, and, like the calyx, grlamlular and hairy; corolla violet. - Near St. Mary's, Georgia, and the aljacent parts of Iilorida. July. - Stem $2^{\circ}$ high. Leaflets $2^{\prime}-5^{\prime}$ long.

2. P. melilotoides, Michx. Glandular and sparingly pubescent; leares trifoliolate ; leaflets obloner-lanceolate or elliptical ; stipuless subulate; sprikes obloner, on peduncles $2-3$ times as long as the leaves; bracts ovate, acuminatc, veiny; corolla viulét ; legume rugose. - V'ar. 1. (J'. corlaululosa, E:ll.) Glandless or nearly so ; loracts orate-lauceolate, and, Jike the calyx, villous. - Dry soil, Florida to Tennessce, and westward. May and June. - Stem $1^{\circ}-2^{\circ}$ hight. Leaflets $\mathbf{l}^{\prime}-2^{\prime}$ long.

3. P. Onobrychis, Nutt. Pubescent; leaves trifoliolate; leaflets ovate, neuminate; racemes clongated, somewhat scemd; calyx grlmdular, the teeth small, ohtuse, equal) legmme ovate, muricate, wrimkled transversely. - Near Spartanburg, South Carolina. June and July. - Stem $3^{\circ}-5^{\circ}$ high. Leaves very large.

4. P. canescens, Michx. IToary-pubescent; lower leaves trifoliolate, the npper simple, slort-petioled; leaflets obovate, slandular; racemes longer than the leaves, few-flowered ; ealyx inflated ; flowers blue, turning greenish ; lewnme even. - Dry pine barrens, Florida to North Carolina. April and May. - Stem bushy, $2^{\circ}$ high. Jescmbles a Baptisia.

\section{* Liares palmately 5 - i-foliolate.}

5. P. Lupinellus, Michx. Smooth; stem slenrler, declining, sparingly branched; leaflets filiform; racemes longer than the leaves, loose-flowered; flowers violet; legumes rugrose. (I’. Florislaua, sluttl.) - 1)ry pine barrens, Florida to North Carolina. May and June. - Stem $2^{\circ}$ longr. Leaflets $2^{\prime}-3^{\prime}$ long.

6. P. subacaulis, Torr. \& Gray. Nearly stemless; peduneles, petioles, and calyx white with spreading hairs; leaves 7 -foliolate, long-petiolel ; leaflets ohovate-ohlong, smoothish alwove, fringed on the margius and midrib beneath; pecluncles longer than the leaves, rigid ; spikes dense, ovate or oblong; bracts ovate, acuminate; (allyx-tecth obtuse. - Rocky hills, near Nashville, Tennessec. A pril and May. - Leaflets 1 long. P'eduncles $4^{\prime}-6$ long. Flowers numcrous, purple.

$$
\text { ** Leaves pinnate. }
$$

7. P. multijuga, Ell. Stem branching; leaflets numerous (9-10 pairs), oblone-lanceolate, obtuse, pubescent; spikes oblongr bracts small, memhranaceous, withont glausls. - Abbeville District, South Carolina. - Stem 10 - ${ }^{\circ}$ ligh. Leaflets small. Bracts half as long as the ealyx. Filowers violet. 


\section{PETALOSTEMON, Michx.}

Calyx nearly equally 5-toothed or 5-cleft. Petals almost regular, on filiform claws, four of them united with the tube of stamens, the fifth frec, cordate or oblong, folded. Stamens 5, united into a cleft tube. Ovary 2-ovuled. Legume indehiscent, $\mathbf{1}$-seeded, included in the calyx. - Perennial glandnlar herbs, with unequally pinnate leaves, and white or purple flowers in terminal spikes or heads.

$$
\text { * Spikes solitary. }
$$

1. P. gracile, Nutt. Stems decumbent, virgate; leaflets 5-7, oblonglinear, obtuse; spikes oval, becoming cylindrical in fruit, peduneled ; vexil!um broadly cordate - Low pine barrens, Florida and westward. Aurgust. - Stems $2^{\circ}$ long. Leaflets $\frac{1}{2}$ long. Flowers white.

2. P. carneum, Michx. Stems ercet, much branched, very leafy; leaflets $5-\boldsymbol{i}$, linear, acute; spilies oblong, long-peduncled; vexillum oblong. - Dry sandy soil. Florida and Gcorgial, westwird. - Stems $2^{\circ}-3^{\circ}$ high. Fluwers white or reddish.

$$
\text { * Spilies corymliose. }
$$

3. P. corymbosum, Michx. Stems chnstered, erect, very leafy ; leaflets $3-7$, filiform; tecth of the calyx setaceous, plumose; vexillum oblong. - VaJies with more numcrous $(11-15)$ oblong leaflets which are commonly emarginate at the apex. - Dry pine barrens, Florila to North Carolina, and westward; the variety in the low country of Sonth Carolina, C'urtis. Sept. and Oct. Stems $2^{\circ}$ high. Flowers white.

\section{DALEA, L.}

Calyx 5-cleft. Corolla imperfectly papilionaceous; petals clawed; four of them united with the tube of stamens below the middle, the fifth (vexilhum) free, cordate, and inserted into the bottom of the calyx. Stamens 10, united into a cleft tuhe. Legume $\mathbf{l}$-seeded, membranaceons, indehiscent, ineluded in the calyx. - Mostly glandular herbs, with spiked or capitate flowers.

1. D. alopecuroides, Willd. Stem erect, smooth; leaves pinnate, with numerous linear-oblong leaflets; spikes dense, cylindrical, silky-villons; corolla small, pale violet, the vexillum white-Rich soil, Alabama, northward and westward. July. - Stem $1^{\circ}-2^{\circ}$ high.

\section{AMORPHA, I.}

Calyx obeonieal, 5-toothed, persistent. Vexillum straight, concave. Wings and keel none. Stamens monulelphous at the basc, exserterl. Legume 1-2seeded, oblong, curved, ghlandular-roughened, indehiscent or nearly so. - Shruls, with unequally pinnate leaves, and numerous leaflets which are punctate with pellucid dots. Flowers blue or white, in slender racemes or spikes.

1. A. fruticosa, I. Pubescent ; leaves petioled ; leaflets 15-21, ollong, obtuse or emalrginate, sparingly dotted ; flowers racemed, blue; calyx-tectl very short, nearly equal, pubescent; legume I-2-seeded. - Banks of rivere, Florida 
to Mississippi, and nothworl. May and June. - Shrub $6^{\circ}-150$ high. Lemf.

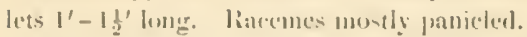

2. A. herbacea, Walt. l'ulx'sernt or glalnons; lenves slont-jetioled;

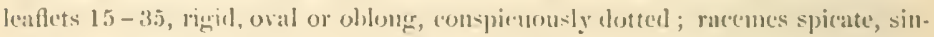

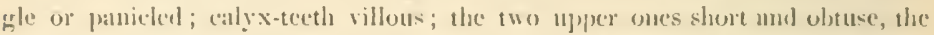

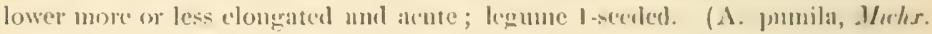
A. pulwasens, Irilld. A. Caroliniana, (ioom.) - Low pine barrens, Florida to

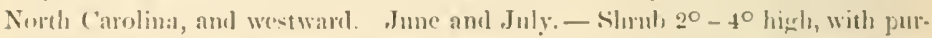
ple branches. Leaflets smaller and more crowiled than in No. 1. Flowers blue or white.

3. A. canescens, Nutt. Iloary-tomentose; leaves sessile; lenflets numerons, small, elliptical, crowelerl; spikes short, paniched, densceflowered ; calyxterth aeute, nearly expal; legume 1-secded - Neur Augusta, (icorgial, aul westward. July and August. - Shrub $1^{\circ}-2^{\circ}$ high. Flowers bright blue.

\section{ROBINIA, L. Locest.}

Calyx short, 5-toothed or 5-eleft, the two upper teeth shorter and more or less united. Vexillum large, roundish; keel ohtuse. Stamens diallelphuns (9 \&

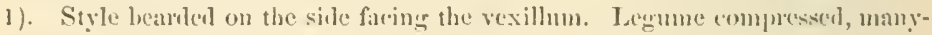
secded, the seed-bxaring suture marginerl. Secds flat. - Trees or sluruhs, often with stipular spines, unequally pimate leaves, and showy white or rose-colored fiowe's in axillary ratcemes.

1. R. Pseudacacia, L. (Loctist. Finse Acreil.) Smomhich, spines small on the older hanches, smaight; leaflets $9-17$, oblomer-ovate, ur elliptical; racemes pentulous, olhong, many-floweres ; flowers white; legune

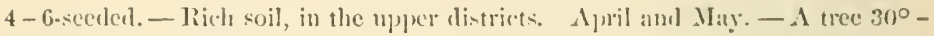
$60^{\circ}$ high, with hard and durahle woorl. Racemes $\left.3^{\prime}-5\right)^{\prime}$ long. Calyx spotted. legume smooth. Filowers frigrant.

2. R. viscosa, Veut. Braucles, petioles, perluncles, anil legumes glandularviscid ; spines very small; leaflets 11 - 2.5, orate and oblong, ohtuse or slightly cortate at the hase, paler and pulesecut beneath, tipjerl with at short bristle:

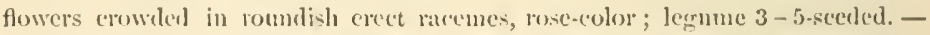
Banks of streams, on the momntans of Georgia and Carolina. May and June. $-\Lambda$ trec $20^{\circ}-40^{\circ}$ ligh. Flowers inotorous.

3. R. hispida, L. Branches, \&e. more or Jess lnistly ; stipules very slender and bristle-like, reciduous; leaflets $11-18$, smooth, ovate or oblong-ovate,

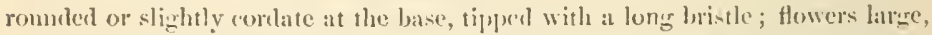
in a loose amb mostly pendulous raceme. Hrieglit ruse-evler - Mountains of Georgia and North Carolina, hoth the ordinary form and the var. 1:0<3:1, Pursh, with pubescent branches and few flowered racemes. May. - Shrub $3^{\circ}-8^{\circ}$ high.

Var. Elliottii. Branches, \&e. pubesent; stipular spines rery stout, sprearling or recurved. (R. hispida, var. wea, Ell.) - Pine barrens in the central parts of Gcorgia and sonthward. - Shrub $3^{\circ}-5^{\circ}$ highl, with thick and rigrid branches. A still smaller form, scarcely a foot high (valr. uawa, Ell.), is found nt Columbia, South Carolina. 


\section{WISTARIA, Nutt.}

Calyx eampanulate, somewhitt 2-lipped; the upper lip broad, 2-cleft, the lower 3-cleft. Vexillum large, with 2 parallel ridges at the base. Stamens diadelplou: (9\& 1). Legume coriaceous, neally terete, contracted between the seels, at length 2-valved. - Twining sluruls, with nnecunally pinnate leaves, and showy purple flowers, in a erowded raceme

1. W. frutescens, 1)C. Young leaves and branches silky-puheseent ; leuflets $9-13$, ovate-lunecolate or oblong; stipels none; racemes on short branches, dense-flowered. (Thyrsanthus frutescens, Ell ) - Marrins of swampr, Florida to North Carolina, and west to Mississippi. April and May. - Leaflets I' long. Ratcemes $4^{\prime}-6^{\prime}$ long, 2'-3' in diameter. Legmue 1 -severil-seederl. Bratcts large, callucous.

\section{TEPHROSIA, Pers.}

Calyx nearly equally 5-cleft or 5-toothed. Vexillnm large, ronndish, spread. ing or reflexed, unnally white within, and redelish or purple and silky withont keel obtuse, cohering with the wings. Stamens monalelphous or diudelphons. Style smooth or laterally bearded. Legume compressed, linear, many-seched. Perenuial herbs, with unequally pinnate leaves, with the leaflets opposite mucronate and straight-veined, and white or purplish flowers.

* Flowers single or by puirs in the axils of the leares; the uppermost often cronded in a dense ruceme.

1. T. Virginiana, Pers. (Gost's Rive) Softhairy and somewhat hoary ; stems very leafy, elustered, erect, simple ; leaflets 11-25, oblong or linear-ohlong, acute or obtnse, smoothish above; flowers yellowish-white tinged with purple. - 1)ry pine batrens, Florida to Mississippi, and northward. June and July. - Stems $1{ }^{\circ}-20$ high, from long and slender roots. Flowers showy.

* Flowers in long-peduncled rucemes opposite the leaves: rexillum pubescent extermally.

2. T. spicata, Torr. \& Gray. Hirsute or villous with rusty hairs ; stems simple or diffusely branched; leaves scattered, short-jetioled; leaflets $9-1.5$, oval or euneate-oblong, rounded and strongly mucronate at the apex, smooth. ish above; raecmes $2-3$ times as long as the leaves, 6-lo-flowered; lobes of the calyx linear-subulate; flowers large, white and purple. (T. pancifolia, Nutt. Gallega villosa, Mich.x.) Varies with linear, acnte, and reflexed leaflets, the odd one elongated. - 1) ry soil, Florida to North Carolina, and westward. June and July. - Stems $10-2^{\circ}$ long.

3. T. hispidula, Pursl. IUary pubeseent or smoothish; stems slencler, terete, creet or procumbent; petiole shorter than the lowest leaflets ; leaflets 11 15, small ( $4^{\prime \prime}-6$ " long), oblong, acute or obtuse, often smooth above; peluneles slender, terete, commonly longer than the leaves, 2-4-fowered; flowers small, purple. - Dry sandy soil, Florila to North Carolina, and westward, June and July. - Stems 6' $-18^{\prime}$ long.

4. T. chrysophylla, Pursh Prostrate, rusty pubesecnt ; stems liffusely lir:unched ; leaves sessile or nearly so, short $\left(l^{\prime}-1_{4}^{3 \prime}\right.$ long) ; leaflets (yellowish) 


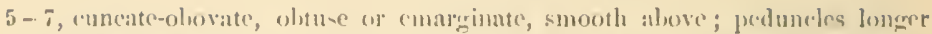

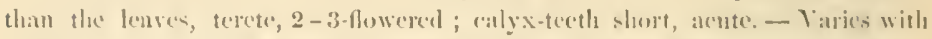
smaller (!' 2 - l' long) leaves aml flowers, the latter mosty solitary on the short

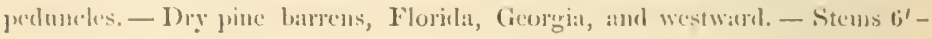
$18^{\prime}$ long.

5. T. ambigua, M. А. Curti=. IJoary-pubesent, or nearly smooth; stems

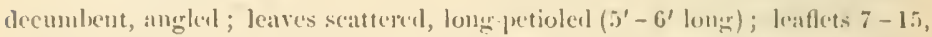
distant, wedge-oblong, truncate or conarginate at the apex, palep and oftern

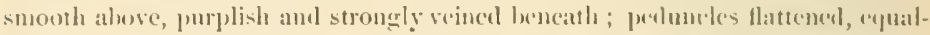
ling or exceceling the leaves, few-flowered ; aily-x-tecth short, atute; flowers white and purple. - Dry sandy soil, Floridat to North Carolinas. June and July:

6. T. angustissima, Shuttl. Smooth or nearly so througliunt; stems slender, prostrate, diffusely branched ; leaves short-petioled ; leaflets 10-15, linear, acute, mostly opposite; racemes very slender, longer than the leaves, bearing $2-4$ small seattered flowers; calyx slightly pulsescent, wats triangular-ovate aente teeth. - South Florida, lingd. - Stem 10 longr. Lcaflets $8^{\prime \prime}-12$ "long, $1^{\prime \prime}$ wide, spreading. Curulla about $3^{\prime \prime}$ long.

\section{INDIGOFERA, I. INingo.}

Calyx 5-eleft. Texillmm rommlish. Kécel with a subulate spur on each sille, often clastically reflexed. Stannens diatelphous (9\& 1). I degume 1-man!secled. Siceds usually truncaterl at each end, ofien separated ly membranaceous partitions. - Ilertss with mequally pinnate leaves, ambl white, brownish, or puplish axillary flowers. Legumes droojing.

* Rueremes longer than the leures. - Indiyenons speries.

1. I. Caroliniana, Walt. Smoothish; stem crect, tall, hranching; leaflets 10-15, ohovite or oblong; racemes many-flowered; (ally-tecth short, acute; flowers yellowish-l,rown; lagume oblong, veiny, 2-sected. - 1)ry pinc batrens, Florida to North Carolina. July and August. If - Sitem $30-50$ high. Flowers small. Legume $4^{\prime \prime}-5$ "long.

2. I. leptosepala, Nutt. Rouyl hairy ; stem decumbent; leaflets $7-9$, obovate-oblong or cuncate; meemes $6-15$-flowered; caly-tecth slemeler-subulate ; flowers pale-scarlet ; legume linear, cren, 6-9-scerlcul. - Geornia, Liftall, Sonth Florida, Blorlyett, and westward. - Stem $\Sigma^{\circ}-3^{\circ}$ long. Legunne $1 \frac{1}{2}$ long, straightit.

\section{* * Riacrmes shorter than the lan:es. - Introduced specirs.}

3. I. tinctoria, I. Stem erect; leaflets $9-11$, oval, jubescent beneath; legumo terete, torulose, curved. - Waste places. August.

4. I. Anil, L. Stem erect; leafets $7-15$, oval; legume compressell, even, thickenel at each suture. - Waste places.

These two species were formerly eultivated in some of the States, and employed in the manuficture of indigo. 


\section{GLOTTIDIUM, Desv.}

Calyx campannlate, obliquely truncate, 5 toothed. Vexillum short, reniform. Stamens diadelphous (9\& 1). Style short, incurved at the apex. Stigma acute. Legume oblong, stipitate, compressed ; the membranacous cudoearp at length separating from the coriaceous epicarp, and enclosing the two oblong seeds. $-\Lambda$ tall smooth-branching annual, with abruptly pinnate leares, and yel low flowers in axillary often compound racemes.

1. G. Floridanum, DC. (Sesbania vesiearia, Spreng.) - Damp soil, Florida to South Carolina, aud westwand. August. - Stem $2^{\circ}-8 \circ$ high. Leaflets numerous, oblong-linear. Legume 1'-2' long. Plant yellowish-green. -

\section{SESBANIA, Pers.}

Calyx 2-bracted, eampanulate, equally 5-toothed. Vexillum roundisls. Feel obtuse. Stamens diadclphous $(9 \& 1)$; the tube toothed at the base. Legume sleniter, elongated, knotted. - Iferbs or shrubs. Leaves abruptly pinnate. Leaflets numerous. Flowers yellow or redelish, in axillary racemes.

1. S. macrocarpa, Muhl. Annual, smooth ; leaflets oblong-lincar, obtuse, mucronate; racemes shorter than the leaves, I-4-flowered; legume curvel, compressed, 4-sided, many-seeded. - Swamps, Floricla to South Carolina, and restward. August and September. - Stem $5^{\circ}-12^{\circ}$ ligh. Legume $8^{\prime}-12^{\prime}$ long, pendulous. Flowers yellow and red, dotted with purple.

\section{AStragaLUS, L. Min-Vetri.}

Calyx 5-toothed; the 2 npper teeth separated. Vexillum as long as the wings and obtuse kecl. Stamens 10, diadelphous. Legume commonly turerid, few many-seeded, nsually partly or completely 2-eelled by the introversion of one or hoth of the sutures. - Herbs with unequally pimnate leares, and axillary spiked or racemose flowers.

* Legume partly or completely 2-celled by the introversion of the dorsal suture.

1. A. Canadensis, L. Tall, pubeseent ; leaflets $21-31$, oblong, obtuse; stipules ovate, elasping; peduncles as long as the leares, elosely many-flowered; ealyx-teeth subulate; legume inflater, oval, terete, 2-celled-Monutains of Georgia and Nortl Carolina, and northward. June-August. 4-Stem $2^{\circ}-3^{\circ}$ hight. Leaflets $1^{\prime}-1 \frac{1}{2}$ long. Flowers 3 ' long, pale yellow.

2. A. glaber, Michs. Sten tall, nearly smooth; leaflets 15-25, oblonislinear, pubeseent bencath; stipules minute, spreading; spikes longer than the leaves, loovely many-flowered ; calyx-teeth broal and short ; legume emred, oblong, fattened edgrewise, 2-celled.-Dry pine latrens, Florida to North Carolina. Aprit. 4-Stem $2^{\circ}$ ligh. Leaflets $6^{\prime \prime}-8^{\prime \prime}$ long. Flowers white.

3. A. obcordatus, Ell. Smoothish; stems prostrate; leaflets small, $17-25$, ohcordite; peduneles as long as the leaves, loosely 8-15-flowered; legumes creseent-shaped, compressed, veiny, partly 2-celled. - Dry santy batrrens, Florida, and the lower parts of Georgia. A pril-June. 4-Stems 6'-1 2' long. Leaflets $3^{\prime \prime}-4^{\prime \prime}$ long. Flowers pale purple. 
4. A. Tennesscensıs, Giray. Villous with white hatis; stems pros

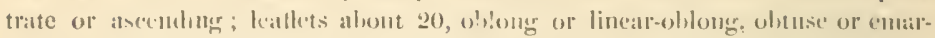
grinate, smooth alove, more or less hairy beneath; stipules ovate-lamedolate,

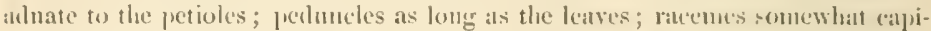
tate, 10-15-flowered; callyx-teeth subulate, much shorter than the tuhe; legrume olshong, curved, thick and theshy, reticulate-rugone when dry, 2-eelled, manysected, at length smoothish. - Ilills wear Nashrille, 'Tenmessce, Lasyumer, mul

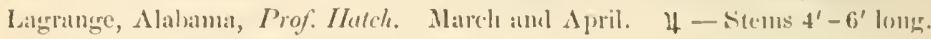
Flowers $8^{\prime \prime}-9^{\prime \prime}$ long, appurently purple.

* * Legmene 1-celled; the central suture thiclemed and sometimes slightly inflexul.

5. A. villosus, Michx. Villons and hoary; stems prontrate; leaflets ahout 13, oval or oblong, commonly emarginate; stipules lancolate, priluneles ats lomg as the leaves; ratemes ovate, tense-flowered ; alyx-teeth longer than the tube legume ol, long, curved, 3-angled, even, l-redled. (Plancal villosa, Vutt.) - Jry pine barrens, Florida to South Carolina. Aprul and May. 4 Stems $4^{\prime}-6^{\prime}$ long. Filowers small, dull yellow.

\section{VICIA, Tourn. Viten. TAlie.}

Calyx tubular, 5-cleft, the two upper teeth usually shorter. Style filiform, hairy at the apex, or on the sirle fateing the keel. Lengume $2-$ mally-seedenl, 2valved. Seels orbicular. Cotyledons thick. - Slender rlimbing lerbs. Latives pinnate; the petiole terminating in a tendril. Stipules mostly semi-sagittite. Flowers axillary.

\section{* Pelumiles shorter then the leures, 1-2-fowerrel.}

1. V. sativa, L. (Vercu or 'Tasi:) P'ubescent; stem simple; leaflets 10 - 12, varying fom obovate-oblong to linear, charginate; flowers by pairs, nearly ses-ile, prale purple; lermo linear, several-sected. - Cultivated grounds. Introdurerl. (1) - Corollat $\frac{1}{2}{ }^{\prime}$ long. Stem $1^{\circ}-2^{\circ}$ long.

2. V. micrantha, Nutt. Smooth; leaflets 4-6, linear, ohtuse or harely acute; pedumeles 1-2-floweresl ; fowers minute, pale blue; legume sabre-shaperl. 4-10-sected. - Bamks of rivers and shated places, West Floridat to North Alab:unt, and westward. A pril. (1) - Stems $2^{\circ}-3^{\circ}$ long. Seeds black.

* * Peduncles commonly longer thun the lertres, 3 - man!l-floureved.

3. V. hirsuta, lioch. IIairy; leaflets 12-14, ob!one-lincar, truneate ; [jelumeles 3-6-flowered, about as long as the latses, inlyx-teeth coptal; flowers small, bluish-white; legune short, ohlong, 2-sederl. (V. Mitrlelli, Rarf. Errom hirsutum, L.) - Cultivated grouml. Introduced. April am May.

4. V. acutifolia, EH. Sinooth; leaflets alout 4, linear or rarely olı!ong̨, arute or trmneate; peduncles $4-8$-flowered, nsnally longer tham the leaves; flowers pale bne, the keel tipled with purple; lewme linear, 4 -8-seeded. Damp, soil near the coast, Florida and Grorgia. March-May. \& - Stems angled, $2^{\circ}-4^{\circ}$ long. branching.

5. V. Caroliniana, Walt. Smoothish; leaflets 8-12, linear or lincarohlong, obtuse or barely acute; stipules small, subulate; peduncles many-flow- 
eres ; calyx-tecth shorter than the tube; flowers nearly white, the kecl tipper with blue; legune olkon, several-seded. - Dry open woorls, chicfly in the mper di-triets. A $A_{i}$ il and May. 4 - Stems $3^{\circ}-4^{\circ}$ long, branching. Flowers $t^{\prime \prime}-6^{\prime \prime}$ lonis.

\section{LATHYRUS, L.}

Style flattened, bearted on the side facing the rexillum. Ollorwise as in Vicia.

1. L. pusillus, Ell. Annual ; leaflets 2, linear-lanceolite, ac'ute; stipules sagittate; peluncles elongated, 1 -2-flowered; teeth of the calyx subulate-setareous, nearly equal; legume long, 10-15-seederl. - Near Clarleston, South Carolina, and westwarl. May. - I small aud slender vine. Flowers purple.

2. I. venosus, Muhl. Perennial ; stem stout ; leaflets 10-14, ohlongovate, obtuse; stipules lanceolite; peduncles $10-20$-flowered ; flowers linge, purple; calyx-teetl very unequal. — Shaty banks, Gorria to Mississippi, and northward. June and July. - Stem angled, $\Sigma^{\circ}-3^{\circ}$ long. Leaflets $2^{\prime}-3^{\prime}$ long. Flowers 3 -1 long.

3. L. myrtifolius, Muhl. Perennial; stem slender, 4-angled; leaflets 4-6, oblong, olntuse; stipules large, ovate, entire; peduncles 3-6-flowered ; flowers pale purple; calyx-tecth unequal - Banks of rivers, North Carolina, and northward. July and Aurust. - Stem $2^{\circ}-4^{\circ}$ long, often wingrangled. Leaflets $1 \frac{1}{2}$ long.

\section{FSCHYNOMENE, L.}

Calyx 2-lipped, 5-cleft or 5-toothed. Petals equal - vexillum romndish. Stamens diadelphous (5 \& 5). Lecume compressed, stipitate, separating transversely into 3 or more 1-seeded indehiscent joints. - Herbs or shrubs, with pinnate leaves, and axillary yellow flowers.

1. 死. hispida, Willd. Annual ; stem erect, muricate-hispid ; leaflets numerous, oblong-linear; pelluncles 3-5-flowered; legume straight, linenr, even along the upper suture, wary on the lower, 6-10-jointed, the joints nearly stquare, hispid. - Swamps, Florila to Mississippi, and northward. Angust. Stem $2^{\circ}-4^{\circ}$ ligh

2. 世. Viscidula, Michx. l'erennial; stem slender, prostrate, viscidpubescent; leaves small; leaflets $\tau-9$, obovate, reticulate-veined; peduncles 3-4-tlowered, the pedicels long and sprealing; stipules and bracts ovate; legume 2 -3-jointed, the joints half-orbicular, hispid. - Sandy places along the eonst, Florida and Georgia. August and Sept. - Stem $1^{\circ}-2^{\circ}$ long. Leaves I'long. Flowers small.

\section{ZORNIA, Gmel.}

Calyx 2-lipper, the upper lip emarginate, the lower 3-eleft. Corolla inserted into the base of the ealyx. Stameus monadelphous, alternately shorter : anther's alteruately oblong aml globose. Legume compressed, with 2 - 5 roundislı hispid joints. - Ilerbs. Leaves palmately 2-4-foliolate. Stipules sagittate. Flowers yellow, in axillary large-inateted ratencs. 
1. Z. tetraphylla, Miclix. Peremial, smooth or iluwny ; leuflets 4, lance.

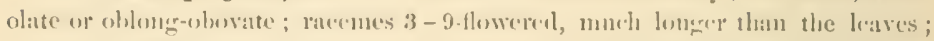

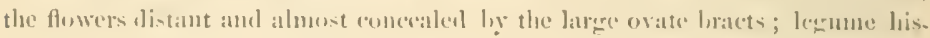

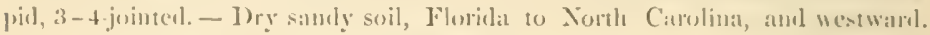
Jume - Angust. - stem 2o long, jrostrate.

\section{STYLOSANTHES, Swart\%.}

Flowers of two kimls: one kiml perfect, lut sterile; the ofich destitute of calyx, corollat, and stamens, and fertile. Caly 2-brated, 2-lipperl, 5-cheft the sube long and slender. Corollat inserted on the throst of alu: ealyx. Fiecl antire at the ajex. Stamens monadelplions, with the alternate authers linear and ovate. Style of the fertile flower hooked. Legrume veing, 1 - 2-jointer, the lower joint empty. - Low herbs. Leaves trifoliolate. Stipules unitcel with the petioles. Flowers in a short and dense terminal spike.

1. S. elatior, Swart. P'erennial ; stem mostly erect, $6^{\prime}-12^{\prime}$ high, phbescent in lines, or sonctimes hispiul; leaflets rigiu, lanerolate, strungly veincel;

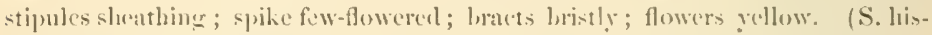
pida, Mechx.) - Samdy pine barrens, Florida and nortaward. June-Angnst.

\section{CHAPMANNIA, Torr. \& Gray.}

Flowers nearly as in Stylosanthes. Corollat inserted on the throat of the

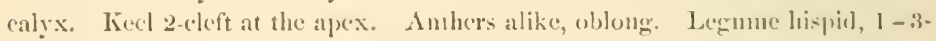
jointed. - A riscid and hirsute branching herl, with mequally pimate leaves, surall ant free stipules, and small yellow flowers in terminal racenes.

1. C. Floridana, Torr. \& Gray. - Eant Flerilit. May. - Stem slender, $2^{\circ}-3^{\circ}$ ligh. Leaflets $3-7$, oblong. liacemes often lanching, few-flowered.

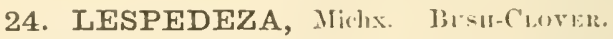

Calyx 2-bracted, 5-eleft; the teeth subulate. Cormlla inserted on the base of the calyx. Stamens diadelphoms (9\&1). Anthers aliki. Jucume small, lenticular, indehiscent, 1-seceded. - Peremial lerbs, with trifoliolate leaves, and small flowers in axillary racemes or spikes.

* Flouers of two hinds, viz. perfect, lut mosily stevile, lone in sprilies or raremes, and fertile, Int destitute of corollu and stumens; the lattor commonly in sessile clusters : corolla purple, longer than the callyx.

1. L. repens, Torr. \& Gray. Stem slender, prostrate; leafets small, oval, mostly emarginate, the petiole very short, or as long as the lateral leaflets; ratcemes few-flowered, on filiform perluncles mneh longer than the leaves; legune roundish. (I. procmubens, Mherh.) - Dry samdy soil, Florirla to Mississipji, and uorthwarl. Angust - I'lant $1^{\circ}-2^{\circ}$ jome, smooth or tomentose.

2. I. violacea, Pers. Stem eredt or spreading; leaflets viuying from elliptical to linear, pulneseent with appressed hairs brneath; fortile flowers in axillary clusters; legnme ovate, smooth, or with scattered appressed hairs, much longer than the ealyx. 
Var. divergens. (L. divergens, Pursh.) Stems diffise; leaflets oval or oblong; peduncles filiform, few-flowered, longer than the leaves, and bearing chiefly sterile flowers.

Var. sessiliflora. (L. sessiliffora, Michx. L. violaeca, Ell.) Stem erect ; leaflets oblong; flowers mostly fertile, in dense and nearly sessile clusters which are much crowderl near the summit of the branches.

Var. reticulata. (L. reticulata, Pers) Stem erect; leaves linear-oblong ; flowers clustered as in the preceding variety.

Dry barren soil, Florida to Mississipji, and northward. August. - Stem $2^{\circ}-3^{\circ}$ high. Leaflets pale berreath. Corolla twice as long as the calyx.

3. L. Stuvei, Nutt. Stem erect, branching, softly-pubescent; leatlets oval or roundish, tomentose or silky on both surfaces, or only beneath, longer than the petiole; racemes axillary, mostly longer than the leaves; flowers nearly all perfect and fertile; legume longer than the calyx, ovate, villous. - Dry sterile soil, Mississippi to North Carolina, and northward. August. - Intermediate between No. 2 and No. 4.

* * Flowers all perfect and fertile: corolle as long as the culyr, ycllouish-uhite, the vexillum spotted with purple: legume included in the culyx.

4. L. hirta, Eil. Stem ereet, pubescent or villous; leaftets oval or roundish, longer than the petiole, pubescent beneath or on hoth sides; sprikes dense, on peduncles longer than the leaves; calyx-tecth linear-lanceolate, as long as the ovate pubescent legume. - Dry barren soil, Florida to Mississippi, and nortlward. August. - Stem $2^{\circ}-4^{\circ}$ ligh.

5. L. capitata, Michx. Stem mostly simple, softly pubescent, erect; leaves short-petioled; leaflets varying from oblong to linear, silky on both sides, or only beneath; calyx hairy, longer than the oval villous legume. (L. frutescens and L. angustifolia, Ell.) - Dry or damp sterile soil, Florida to Mississippi, and northward. August. - Stem $2^{\circ}-4^{\circ}$ high.

\section{DESMODIUM, DC. (Hentsirum, L, Ell.)}

Flowers all similar and perfect. Calyx hilabiate; the upper lip emarginate or entire, the lower 3-cleft. Corolla inserted on the base of the ealyx. Stamens diarlelphous (9\&1), or more or less monadelphous. Legume flattened, 2-6jointed. - Chicfly perenni:l branching herbs. Leaves trifoliolate, petioled, stipulate; the leaflets petiolulate and stipellate. Flowers small, purple or whitish, in terminal racemes or panicles. Leguınes hispid with hooked hairs.

\$1. Stumens monadelphous belou: legumes conspicnously stipitate, 2-4-jointed, the joints half-obotate, concuve on the back.

1. D. pauciflorum, Nutt. Stem low, ascending, mostly simple, leafy ; leaves seattered, long-petioled ; leaflets thin, acute, eiliate, pale beneath, the lateral ones ovate, the terminal one rhombic-ovate; stipules minnte; racemes terminal, $4-8$-flowered, mostly shorter than the leaves. - Shaly woorls, Florida to Tennessee, and northward. August. - Stem 10 high. Leafets 1'-2' long. Corolla pale-purple or white. 
2. D. acuminatum, DC. Stem pubescert, leafy at the smmmit; leaves large, lontr-petioled ; leatlets smoothish, ovute or roundish, acominate, merme or panicle terminal, leng-peduncled, muy-llowered. - Rich shaly soil, Florialat

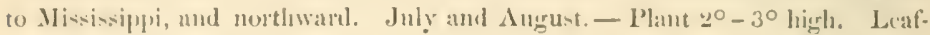
lets thin, $2^{\prime}-4^{\prime}$ long.

3. D. nudiflorum, 1)C. Sitem smooth, short, leafy at the summit ; paniele aseeneling from the base of the stem, naked, or with one or two leaves near the lass, much longer than the stem; leaves long-petioled, smooth; leaflets

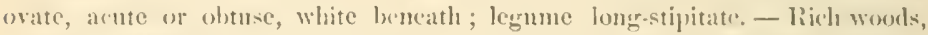
Floridal to Mississippi, and northwarl. July and Aurnst. - Stem 6'-12' high. liacemes simple or componnd, on peduncles $2^{\circ}-3^{\circ}$ hight.

\section{\$2. Stemens diadelplions: lergume sessile or short stipitute.}

* Siijules large, acate (rxirpt lo. 8), acmminate, presistent: legume 3-6-jointed, the joints contex on the ilyer suture, rounded on the louer one.

4. D. canescens, DC. Stcm tall, rough-hairy, striate; kidfets oviate, mostly acute, very rough, especially bencath; fautcle large, very laary ; bracts

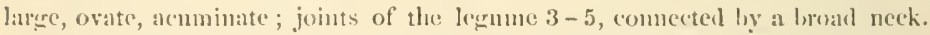

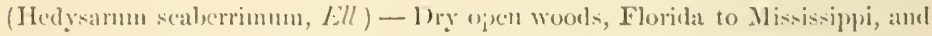
northwarl. July and Angu-t. - I'lant $3^{\circ}-5^{\circ}$ high, nuch branclied, pale green. Leatlets $1 \frac{1}{3}{ }^{\prime}-3^{\prime}$ long. Fowers larege.

5. D. molle, I) ? Sitcm tall, much hranched, softly pubeseent; leaflets rhombic or alliptical, ohtuse and often amarginatr, tomentose lencath, rough abure; racemes panicled. slender; flowers $2-3$ together, on slender pedicels; legume ncarly sessile, black; the small joints oral or rhombie, crually convex on both sutures. - Wante places, Middle Florida. Sipt. - Stem $3^{\circ}-5^{\circ}$ high. Leaflets $3^{\prime}-4^{\prime}$ loug. Lecrume I' long, penduluus. Flowers small.

6. D. cuspidatum, Torr. \& (iray. Stem smooth, erect; leaves smooth, ovate or lancelate-orate, acuminate; pandele mostly simple, elongated ; flowers and bracts large; legune $4-6$-jointerl, the joints rhombic-oblong, connerted ly a broad neck. (II. bracteosmm, Mich.r.) - Dry open woods, Florida to Mlississippli, and northwarl. July ant August, - Stem $5^{\circ}-5^{\circ}$ high. Icullets $3^{\prime}-5^{\prime}$ long. Legume $1 \frac{1}{2} \underline{2}^{\prime} \operatorname{long}$.

7. D. viridiflorum, Beck. Stem stont, tomentose, rongli alove; leaves large; leaflets orate or roumlish, ohtuse, very romgh ahove, pale and velvety bencath; stipules ovate, acmminate, rather small ; panicle large, leafles.; leamme 3-4-jointed, on a stije twice as long as the calyx, the joints half orbicular, connected by a narrow neek. - liech open woods, Florida to Missisippri, and northward. Augrut. - Stem $3^{\circ}-4^{\circ}$ lrigh. Icaflets $2^{\prime}-t^{\prime}$ long. Corolla turuing greenish.

8. D. Floridanum, n. sp. Stem short, riericl, very rough; lower leaves 1foliolate; leallets limecolate-ovate, ancute or olstuse, very rough alrove, puluseent and strongly retienlate beneath ; stipules lanec-sululate; panicle clongated, sparingly brancher, leafless; legmme 2-4-jointed, the stipe shorter than the ealyx; joints obli(jnely obsvate. - J)ry sandy soil, Apalachicolal, Florida. July and Angrust. - J'roper stem 10 hight, the panicle $2^{\circ}-3^{\circ}$. Leaflets $2^{\prime}-3^{\prime}$ long, the stipules and stipels rigid. Bracts and flowers small. 
9. D. rotundifolium, I)C. Stem long, trailing, hairy; leaflets orbicular, pubescent; stipules ovate, large, reflexed ; racemes simple, the terminal ones panicled; lobes of the ealyx longer than the tube; legume 2-4-jointed, very adhesive, the large joints half-rhombie. - Dry open woods, Florida to Mississippi, and northward. August. - Stem $3^{\circ}-5^{\circ}$ long. Flowers showy, oceasionally yellowish-white.

* * Stipules subulate, deciduous: legume 3-5-jointed, nearly straight on the uTper suture, the joints triangular, rarely rounded on the lower suture.

10. D. Canadense, 1)C. Stem erect, hairy; leaves short-petiolerl ; leaflets oblong-lanceolate, more or less hairy; panicle leafy; flowers and bracts large; legume with $3-4$ rather large obtnsely 3 -angled joints. - 1)ry wook, North Carolina, and northward. August. - Stem $2^{\circ}-3^{\circ}$ high, furrowed. L $p^{-}$ per leaves subsessile.

11. D. Dillenii, Darl. Stem erect, furrowed, hairy; leaflets oblong or orate-oblong, obtuse, smoothish abore, paler and pubeseent beneath; paniele large, leafless, rough; joints of the legrume 3-4, triangular. (1I. Marilandicum, Ell.) - Open woorls, Florida and northwarl. August. - Stem $2^{\circ}-3^{\circ}$ high. Leaflets $1^{\prime}-2^{\prime}$ long. Bracts and flowers small.

12. D. glabellum, DC. Stem erect, nearly glabrous; leaflets small, orate, obtuie, scabrons-pubeseent on both siles; joints of the legume about 4 , triangular, minutely hispicl. - In shady places, North and South Carolina. Resembles D. Marilandieum in foliage and D. paniculatum in fruit.

13. D. lævigatum, DC. Stem smooth, terete; leaflets thick, orate, ohtuse, smooth, or slightly pubescent and paler beneath; panicle leafless, rongh; joints of the legume 3-4, triangular. (II. rhombifolium, Ell.) - Dry rich soil, Florida to Mississippi, and northward. August. - Stem $2^{\circ}-4^{\circ}$ high. Leaflets $\mathbf{l}^{\prime}-2^{\prime}$ long, the lateral ones oc'asionally wanting.

14. D. paniculatum, DC. Stem slender, mostly smooth, with long and virgate lranclies; leaflets rarying from oblong to linear-laneeolate, obtuse, smooth or slightly pubeseent; legume $3-5$-jointed, the joints triangular. Shady woods, Florida to Mississippi, and northward. August. - Stem $2^{\circ}-4^{\circ}$ high. Leaflets rather rigid.

* * Stipules subulate, deciduous: legume 2-3-jointed; the joints small, oral, or obliquely-ohorutc: flourers small.

15. D. tenuifolium, Torr. \& Gray. Stem slender, erect, rough-pubescent above; leaflets linear, reticulated, obtnse, smooth above, keeled, much longer than the short petiole; panicle leafless, very rough ; flowers small ; legmine sessile, mostly 2-jointed. - Dry pine harrens, Florida to North Carolina. July and August. - Stem $2^{\circ}-3^{\circ}$ high. Leaflets $2^{\prime}-3^{\prime}$ long.

16. D. strictum, DC. Stem ereet, mo:tly simple, straight and slender, smooth or roughish; leaves on slenter petioles; leaflets narrowly linear, rather obtuse, coriaceous, reticulated, nearly smooth; panicle virgate, few-flowered ; the pedicels very slender; legume stipitate, 1 -3-jointerl. - J'ine harrens, Filorita to Mississippi, and northward. July-Sept. - Stem $2^{\circ}-4^{\circ}$ high. Leaflets $1 \frac{1}{2}-3^{\prime}$ long. 
17. D. Marilandicum, Juott Stem erect, smooth, motly simple; latfets smill, ovate or romulish, obus:, smooth, pale benenth, commonly shorter than the periole; panicle rough; legume mostly 2 jointed. - (1I. whtsimu,

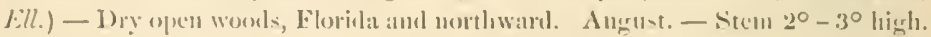
J.eatlets rarely more than I' loner, sometines ublemgr.

18. D. ciliare, ])C. Very much like No. 1\%, lut the stem and leaves rongh-hairy, and the (sometimes ane) leaflets longer than the short periofe. With the precerling.

19. D. rigidum, DC. Stem erect, bramehed. rough-pulsescent ; leaflets (pale) oval or oblong, obtuse, rough above, hairy beneath, strongly reticulated on both sisles; panicle ample, leafy below; legume mostly :3-jointed. - Dry woods, Florida to North Carolina, and northward. Angust. - Stems $2^{\circ}-3^{\circ}$ liigh. Leaflets $1^{\prime}-3^{\prime}$ long. Joints of the legume latrest of this section.

20. D. lineatum, DC. Stem prostrate, slender, smooth; Ieaflets oval or romdish, smooth; ratremes elongated, axillary and terminal, simple or paniculate, rough : leumue 2-3-jointed. - Open grassy pine barrens, Florida to North Carolina, and westward. Angust. - Stem $1^{\circ}-2^{\circ}$ long. Leaflets seldom more than $1^{\prime}$ long. liacemes $1^{\circ}-2^{\circ}$ long.

\section{RHYNCHOSIA, DC.}

Calyx 2-lipped, with the upper lip 2-eleft and the lower 3-parted, or nearly equally 4-parted. Stamens diadelphous $(9 \& 1)$. Style smooth, subulate. Legrume oblong or scymitar-shaped, mostly 1 -2-seeded. Seeds carunculate. - Frect or twining herbs or slurubs, with 1 or 3 -foliolate, mostly softly-pubeseent and resinous-dotted leaves, and axillary yellow flowers.

* Stems twining, or low and ereet: flowers in axillary racemes.

- Culyx somewhet 2-lipped, 4-cleft; the treth sulmlate, shonter than the corolla, the lowest one longest: stems twining.

1. R. minima, DC. Tomentose; leaflets small, roundish or broadly rhombic, barely acute, dotted beneath; stipules sululate; racemes filiform, much longer than the leaves, loosely 6-12-flowered ; flowers minute, reflexed; legrame scynitar-slaped. (Gilycine reflexa, Ell.) - Damp soil along the coust, liey West to Soutl Carolina, and westward. July. - Leaflets $\frac{1}{2}{ }^{\prime}-l^{\prime}$ long.

2. R. parvifolia, DC. Velvety throughout; leaflets ovite, oblong, or olovate-olulong, obtuse, or the upper ones acure, hoary and strongly reticulate heneath, longer than the petiole; stipules small, lanecolate; racemes equalling or longer than the leaves, slender, loosely 3-5-flowered; lowest tooth of the calyx nearly twice the length of the others; legume oblong, obtuse, clothed with soft down and longer hairs intermixed, 2-3-seeded. - South Florida, - Stem $10-2^{\circ}$ long. Lcaflets $1^{\prime}$ long.

3. R. Caribæa, DC. Velvety throughout; stem prostrate or twining; Jeaflets thin, ovite, acnte or slightly acuminate; stipules ovate; racemes slencler, shorter than the leaves, loosely 3-5-flowered; tceth of the ealyx short, nearly 
equal ; legume scymitar-shaped, acute - South Florida. - Stem $2^{\circ}-3^{\circ}$ long. Leatlets $1_{\frac{2}{2}}^{\prime}-2^{\prime}$ long. Racemes $l^{\prime}-2^{t}$ long. Flowers small. Legume $1^{\prime}-1^{\prime}{ }^{\prime}$ long, tapering at the base.

+ + Calyx 4-parted, nearly as long as the corolla, the lobes linear or lanceolate, nearly equal: stems twining or crect.

4. R. menispermoidea, 1)C. Stems several from one root, prostrate or twining, downy ; stipules orate-lanceolate ; leaflets solitary, reniform, tomentose; peduncles rarely as long as the petiole, with few erowded flowers at the summit ; calyx deeply parted, the lanceolate acute or acmminate lobes nearly equal ; legume oblong, acute, tomentose, 2-sceded. - Charlotte Harbor, South Florida, Blodyett. - Stems $2^{\circ}-3^{\circ}$ long. Leaflets $]^{\prime}-2^{\prime}$ in diameter.

5. R. tomentosa, Torr. \& Gray. Leaflets 1 or 3 , roundish or ovate; raecmes dense-flowered; legume oblong.

Var. monophylla, Torr. \& Gray. Pubescent; stem low $\left(3^{\prime}-6^{\prime}\right)$, crect ; leaflets mostly solitary, reniform or orbicular; racemes very short, the uppermost elustercd. (Glycine simplicifolia, Ell.)

Var. erecta, Torr. \& Gray. Velvety; stem erect $\left(1^{\circ}-1 \frac{1}{2}\right)^{\circ}$; leaflets 3 , oblong or roundish, sometimes acute ; racemes many-flowered, the terminal one often elongater. (G. erecta and G. mollissima, Ell.)

Var. volubilis, Torr. \& Gray. IJairy; stem twining, angled ; lowest leaves simple, the upper ones trifoliolate; leaflets 3 , roundish or ovate, often angular on the margins ; racemes very short, few-flowerel. (G. tomentosa, Eil.)

Dry sandy soil, Florida to North Carolina, and west to Mississippi. JuneAugust.

* * Stem tall, erect, with long virgate liranehrs : flovers solitary or by pairs, in the arils of the upper lcaves : caly.x deeply 4-cleft, shorter than the corolla.

6. R. galactoides. Stem buxhy, purplish, closely pubeseent; leaves very small, almost sessile; leaflets 3 , oval or obovate, rigicl, reticnlate, pubeseent; flowers mostly longer than the leaves, yellow, the vexillum reddish externally; legume oblong, 2-seedecl. (Piteheria galictoides, Nutt.) - Dry sand ridges, Florida and Alabama. June. - Stem $2^{\circ}-4^{\circ}$ high. Leaflets $3^{\prime \prime}-9^{\prime \prime}$ long. Legrme 3! long.

\section{APIOS, Bocrh.}

Calyx somewhat 2-lipped; the lateral teeth nearly obsolete, the lowest one longest. Vexillum rery broad, reflexed; the keel at length twisted. Stamens diadelphous (9\& 1). I Jegume nearly terete, many-seeded. - al smooth perennial twining herb, with unequally pinnate leaves, and brownish-purple flowers in dense axillary racemes.

1. A. tuberosa, Moneh. - Swamps, Florida to Mississippi, and northward. July and August. - Root bearing small edible tuhers. Stem twining high. Leaflets 5-7, ovate or ovate-lanceolate. Racemes often by pairs, shorter than the leaves. Seeds black, separated by loose cellular tissue. 


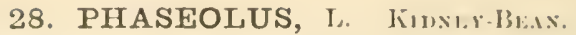

Calyx 5-tonthed, the two mpler teeth more or less miterl. Fien of the corollat

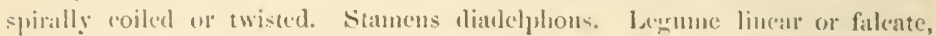
few- many-secterd. - 'Jwining or prostrate lects, with trifoliolate stipellate leaves. Flowers commonly large, racemed, or elustered at the sumnit of the axillary peduncles.

\section{* Flouers scettered in long racemes: legumes srymitur-shioped.}

1. P. perennis, Walt. Stem climhingr, pubescent; leaflets ovate, acute, (antire, membranaecons; racenes often loranching, twice as long as the leases. Low woods and margins of fields, Florida to Mississippi, and northward. July and August. 4 - Leaflets $2^{\prime}-4^{\prime}$ long. Flowers purple.

2. P. sinuatus, Nutt. Stem prostrate, smoothish; leatfets small ( $1^{\prime}$ long $)$, romelish or 3 -lobed, strongly reticulate, rather rigril ; racemes $6-8$ times as lomr as the leaves, solitary, simple. - Dry samd ridenes in the pine harrens. Florida. July and August. $4-$ Stem $8^{\circ}-120$ long. Flowers pale puple.

* * Flowers chusteral at the summit of the prehomeles: lequme lincur, narly tercte: sed scurfig. (Stromosmis: Eill.)

3. P. diversifolius, Pers. Amual; stems prostrate or trailing, roughhatiry ; leaflets ovate, entire or $2-3$-lobed ; peduncles twice as loner as the leaves. - Sandy soil, Florida to Misisipipli, and nortliwaril. June-Septenuber. Sitems $2^{\circ}-4^{\circ}$ long. Corolla purple, witlering greenislı.

4. P. helvolus, I. Perennial, smooth or luiry ; stems prostrate, leaflets varying from orate to oblong-linear, rarely 3-tobed; peduncles $3-6$ times as long as the leaves. - Woots and margins of fichls, Florida to Mississippi, amb] northward. June-September. - Corolla pale purple.

\section{VIGNA, S.Ir.}

Calyx 4-toother, the upper tooth hrouicer, entire or 2-cleft. Texillum depressedorbicular, with thickened knobs near the base. Kieel not twisted. Stmmens included in the keel, diadelplous, and with the style bent mpward. Style hairy alove, appendaged below the stigma. Legume nearly terte, somewhat torulose, the secds separated ly cellular tisone. - Twining laerbs, with trifoliolate leaves, and racemose axillary flowers.

1. V. glabra, Sirr. Annual, hirsute; leaflets orate or orate-lanceolate; racemes on stout perluncles Joneger thim the leaves; flowers yellow, erowicl; legume liriute. (Jolichos luteolus, Juer.) - Bruckish marshes, Florida to South Carolina, and west to Mississippi. July-September.

\section{ERYTHRINA, L.}

Calyx tubular-campanulate, truneate, toothless. Vexillum narow, straight, elongated. Kiecl and wings rery small. Stamens and style partly exserted. Legume stipitute, torulose, partly deliscent. - Trees, slirubs, or rarely herls, often armel with prickles. Leaves trifoliolate, the terminal leaflet longr-petiolulate. Flowers showy, scarlet, in long racemes. 
1. E. herbacea, L. Stems herbacen', several from a rery thick root, prickly, the flowering ones mostly leafless; leaves long-petioled ; leaflets ovate or somewhat hastate; rexillum lanecolate, folded ; seeds scarlet. - Light sandy soil, Florida to Nortlı Carolina, and west to Mississippi. April and May, Stems $2^{\circ}-4^{\circ}$ high. Racemes $1^{\circ}-2^{\circ}$ long. Flowers $2^{\prime}$ long. Legume opening by one suture opposite the seeds.

\section{CLITORIA, L.}

Calyx tubular, 5-toothed. Vexillum very large, spurless on the hack, ohovate, emarginate. Keel shorter than the wings. Stamens monadelphous betow. Style curred, hairy. Legume stipitate, linear-oblong, toruluse, veinless. - Pcresnial herbs, with trifoliolate leaves, and very larese purple flowers on axillary peduncles. Bracts opposite.

1. C. Mariana, L. Smootl ; stem erect or twining; leaflets orate-oblong, pale beneath; peduncles shorter thin the leaves, $1-3$-flowered ; legume $3-4$ seeded. - I)ry soil, Florida to Mississippi, and northward. July and August. Stem $1^{\circ}-3^{\circ}$ long. Flowers $2^{\prime}$ long, pale purple. Bracts shorter than the ealyx. Legume $1 \frac{1 \prime}{2}-2^{\prime}$ lonir.

\section{CENTROSEIMA, DC.}

Calyx short, 5-cleft, the 2 upper lobes more or less united. Yexillum very large, spurred on the back, orbicnlar, emaryinate. Fieel nearly as long as the wings. Stamen; monadelphous helow. Style smooth. Legume nearly sessile, linear, compressed, the sutures thickened, the ralves lined with an intra-marginal vein. - Twining herbs, with trifoliolate leaves, and very larere purple flowers on short axillary peduncles. Bracts opposite.

1. C. Virginiana, Benth. Rough with a sloot hooked pubescenee; stem very slender, much branched; leaffets oblong or linear-oblong, strongly reticulate; peduncles single or by pairs, $1-4$-flowered; calyx-teeth subulate, barely exceding the ovate luacts; rexillum allhesire; legume slender, elongated, (curvel, many-sected. (Clitoria Virginiana, Willd.) - Dry soil, Florida to Nississippi, and northward. June - September. - Flowers $1 \frac{1}{2}^{\prime}$ long. Legune $t^{\prime}-6^{\prime}$ long.

\section{AMPHICARP正A, Ell.}

Flowers of 2 kinds; those on the upper racemes perfeet, but mostly abortive, those near the base of the stem or on the prostrate branches apetalous, hut fruitful. Calyx tubulat, $4-5$-toothed. Vexillum oborate and partly enclosins the wings and keel. Stamens diadelphous, or in the fertile flowers distinet or wanting. Fertile legume olorate, fleshy, 1-2-seeded, - Twining annual or perennial herbs, with trifoliolate leaves. Flowers white or purplish, in simple or compound axillary racemes.

1. A. monoica, Nutt. IIairy; stems much lunncherl; lenflets rhomhicorate; sterile racemes single or by pairs, often compound, nodding ; lracts stri- 
ate; ralyx-tecth short, triangnlar ; fertile legumes hairy. (A. monoica and $\Lambda$

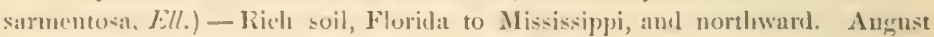
and Sept.

\section{GALACTIA, I. Browne.}

Calyx t-toothed, the upper one liroadest. Vexillum oblong or ohovate, reflexed in flower. Stamens dathphous. Legume more or less compressed, 2-valved, t'w - many-sected. - I'rostrate or twining, larely ceret, perennial licrbs, with chicfly trifoliolate leaves, and mostly small porplish or white flowers if axillary racemes. Bracts alternate and decidnous. Leaflets stipellate.

\section{* Leaves trifoliolate, with the laflets stalked: strms tuming or prostrute.}

1. G. spiciformis, Torr \& Gray. Stem twining, miuntely pubescent ; leaflets (1' longr) lhick and rigit, olshong-oval, oltuse or emarginate at both ends, smooth above, pulescent beneath; racemes spike-like, mostly longer than the leaves, the nearly sessile, mostly solitary flowers seattered on the common pedun(le nearly to its bace; corolla 2 - 3 times the length of the acuminnte hairy calyxlobes; legume roriaceous, compresined, falcate, thickened at the sutures, sprinkled with short appressed hairs, 6-10-sceded. - Varies with a stouter inore pubesent and almost villous stem, larger $\left(1 \frac{1}{2}^{\prime}-\varepsilon^{\prime}\right)$, thinner, and mostly al'ute leatlets, longer and stouter many-flowered racemes, and nearly straight legumes. (G brevistyla, Schlect.) - South Florida $\Lambda$ ug. and Sept.

2. G. pilosa, Fll. Stem twining, pulescent or smoothish, much branched ; leaflets thin, varying from oval to linear-oblong, olsuse, rounded or emarginate at hotl cruls, pulsescent and paler bencatl, often smooth above; racemes slender, commonly longer than the leaves, sometimes $4-6$ times as long; fluwers single or 2-3 together, scattered on the common peduncle, distimetly pedicelled, acuminate in the lud ; alyx sparse-hairy or smoothish, the acuminate lobes much shorter than the purple coro'la; legume nearly strajght, somewhat compresserl, covered with short appressed hairs, 10-seedel. (G mollis, Vutt. G Macreed, If. A. Curtis.) - Dry soil, Florida to Mississippi, and northward. July and August. - Stem often elongated. Leaflets $\frac{1}{2}^{\prime}-1^{\prime}$ long. Ralcemes occasionally 2-3 together:

3. G. mollis, Michx. Tillons ant somewhat hoary; stems mostly prostrate and simple; leaflets oval or oblong, olutuse or emarginate at both ends, or the upper ones acute; racemes single, ahout twice the length of the leares, the short-perlieclled flowers approximate near the summit of the stont peduncle, acute in the lond ; (alyx, like the straight 10-seeded compressed lecrume, very villous and hoary. (G. pilosa, Nutt.) - I) santy pine barrens, Florida to North Carolina, and westward. July and $\Lambda$ nqust. - Stem $2^{\circ}-3^{\circ}$ long. Leaflets $1 '$ long. Corolla redlish purple, one third longer than the acute calyx-lobes.

4. G. Floridana, Torr. \& Gray. Hoary-pubescent; stems prostrate; Jeaflets oval or oblong, rarely acute, reticulate; racemes simple or branched, often ly pairs, many-flowered, rarely longer than the leaves; flowers large, ap. prosimate, legume flat, 10-seedel - Var. microphylla every way smaller, the Jeaflets $\left(\frac{1}{2}{ }^{\prime}-g_{\mid}^{3}\right.$ long) acute or emarginate, the few flowers almost sessile in axil. 
lary (lusters. - Dry sandy pine barrens, near the west coast of Florida. JuneAngust. - Stem $2^{\circ}-4^{\circ}$ long. Leatlets $1^{\prime}-2^{\prime}$ long. Flowers largest of all.

5. G. glabella, Michx. Stem prostrate, minutely pubescent; leaflets rather rigil. on short petioles, oblong, rarely acute, smooth and shining above, slightly hairy beneath; racenes seldom as long as the leaves, 3-6-flowered; style elongated: legume slightly falcate, at length smoothish, $f-6$-seederl.Dry pine barrens, Florida to Mississippi, and northward. July and August. Stems $2^{\circ}-3^{\circ}$ long. Leaffets $l^{\prime}$ long. Flowers large, reddish-purple.

\section{* * Lcaves trifuholute, with nearly sessile leaflets: strms erect.}

6. G. brachypoda, Torr. \& Gray. Stems slender, branching, and, as well as the leares and peluncles, smoothish; leares long petioled; leaflets oblong, obtuse; flowers few, somewhat clustered at the summit of the slender peduncle; calyx woolly. - Dry sandy ridges in the pine barrens of Middle Florida. July and August. - Stems $1^{\circ}-1 \frac{1}{2}$ high. Leaflets shorter than the petiole. Flowers small, purple.

7. G. sessiliflora, Torr. \& Gray. Stem short, smooth, simple; leaflets oblong or linear-oblong, obtuse, smooth on both sides; flowers erowded in nearly sessile axillary clusters; calyx hairy. - Dry pine barrens, Florilia to North Carolina. June $-\Lambda$ ngnเt. - Stem $6^{\prime}-12^{\prime}$ high. Flowers white. Legume oblong-linear, tomentose, $6-8$-sceled.

\section{* * Leares pinnate: stems twiming.}

8. G. Elliottii, Nutt Leaflets $7-9$, elliptical-oblong, emarginate, nearly smooth and shining alove, pubescent bencath; racemes longer than the leaves, few-flowered ne:1 the summit of the pednucle; corolla white tingerl with red ; legume compresserl, villous, faleate, 3-5-sceled. - Dry soil, Florida to South Carolina, near the coast. May and June. - Plant sometimes silky throughout.

\section{CANAVALIA, DC.}

Calyx tubular, 2-lipperl ; the upper lip larger, with 2 rounded lohes, the lower entire or 2-cleft. Vexillum lurge, orbicnlar, with 2 rillges within; keel ineurverl. Stamens monadelphons. Legume oblong-linear, compressed; the valves with a longitudinal rilge near the thickened upper suture. Seels separated by interposed cellular tissue : hilum linear. - Prostrate or twining herbs, with trifoliolate leaves, and showy fowers in axillary racemes.

1. C. obtusifolia, DC. Smonthish; stem long, prostrate; leaflets thick, oval or orbicular, pointless ; raeemes stont, longer than the leaves, 6 -8-flowered ; flowers rose-color; legume 6-seerled. (C. rosea and C. miniatil, I,C.) - Samly shores of St. Tincent's Island, Florida, and sonthward. July-Sept. - Stem $10^{\circ}-15^{\circ}$ long. Leaflets $3^{\prime}$ long. Legume $4^{\prime}-5^{\prime}$ long, $1^{\prime}$ wide. Seels brown.

\section{DOLICHOS, L.}

Calyx eampanulate, somewhat 2-lipped, the upper lip of two more or less united teeth, the lower 3-eleft. Vexillum callous near the base. Keel more or less falcate. Stamens diarlelphous, the free stamen spurred at the base. Style 
hearded. Tequmo flattened. Scels compressed, with a small and oval hilum. - Twining herbs, with trifoliolate leaves, and nxillary racemose fluwers.

1. D. multiflorus, Torr. \& Gray. Percmial, pubesent; lenflets thin, barge, orbicular, abmutly nente; racemes shorter than the leaves, many aud den-ely flowered at the summut of the stout perlnnele; njper lip of the colyx entire; keel nearly straight; legume 4-5-sected. - Banks of rivers, near Milledgeville, fieorgia, and wentwarl. June and July. - Stem 50-10 long. Leaflets $3^{\prime}-6^{\prime}$ in diameter. Flowers purple. Legmme 2 ' long, $\frac{11}{2}$ wirle.

\section{PISCIDIA, I. Jıмıс. Do6woо).}

Calyx eampanulate, 5-tootherl. Keel obtuse. Vexillum ronnded. Stamens dialclphons at the base, monarlelphous above. Style filiform, smooth. Legune stipitate, linear, contracted between the seeds, furnished with four membranaceous longitudinal wings. Seeds compressed. - Tropical trees. Leaves unerpullypimate. Flowers in terminal panicles.

1. P. Erythrina, J. Yonng branches, leaves, and panicle silky and hoary, at length smoothish; leaflets 7-9, oblong or obovate, abruptly acute, straiglit-veined, distinctly petiolulate; panicles axillary and terminal, manyflowered, shorter than the leaves; upper teeth of the ealyx partly united; legume 6-sceded. - South Florida. March and $\Lambda_{\text {pril. }}-1$ small tree. Leares decilnous. Corolla white, lined with red veins. Lergume 2' long, the hroad wings wary.

\section{BAPTISIA, Vent.}

Calyx campanulate, 4-eleft; the upper lobe loroacler and mostly emarginate. Vexillum roundish, with the sides reflexed; wings and keel straight. Stamens 10, distinct, shorter than the wings, deciduons. Lerme stipitate, wal or oblong, inflated, few-seederl, pointed with the persistent style - Erect widelybramehing perennial herls. Leaves simple or palmately trifoliolate, withering. persistent. Stipmles decifuons or persistent, rarely wanting. Flowers showy in terminal racemes, rarely axillary and solitary.

\section{* Leanes simple, sessite, or prerfoliate.}

1. B. simplicifolia, Croom. Smooth; leaves large, sesile, broally ovate, olture; stipules none; racemes numerons, terminal, many-flowerel, sessile or short-perlnneled ; ovary villous and loary ; legmme small, ovatte, corlaceons, smooth. - I)ry pine harrens near Quincy, Middle Florilis. July. - Stem much branched, $2^{\circ}-3^{\circ}$ high. Leaves $2^{\prime}-4^{\prime}$ long. Flowers rather small, yellow. Plant drics hack.

2. B. perfoliata, Brown. Smooth; leaves perfoliate, oval or orbicular, glancous; stipules none; flower axillary, solitury ; legume small, ovate, coriacens. - Dry sandy soil, in the middle districts of Georgia and South Carolina. May. - Stem $2^{\circ}$ high. Leaves $2^{\prime}-3^{\prime}$ long. Flowers small, rellow ; vexillun orbicular, emarginate, shorter than the wings and keel. Ovary and style smooth. 
3 B. mierophylla, Nutt. Leaves sessile, roundish, cuneate at the base, the upper ones somewhat clasping; stipules leafy, rounded, the upper ones united witlı the leaves; flowers axillary, solitary, on short pedicels; legume roundish. Nutt. - Alabama and West Florida. - Leaves less than an inch long. Flowers unknown.

* * Leaves trifoliolate, petioled.

- Flouers yellox.

4. B. lanceolata, Ell. Pubescent when young, at lengtl smoothish ; leaves on very short petioles, the upper ones nearly sessile; leaflets varying from lanceolate to obovate, thick, obtnse, tapering at the base; stipules and bracts small and eaducous; flowers large, solitary in the axils, and in short terminat racemes, short-pedicelled ; orary villous; lecrume ovate or grlobose, coriaccous, slender-pointed. - Dry pine barrens, Florida to North Carolind, and westward. April and May. - Stem $2^{\circ}$ l:igh. Leaflets $1^{\prime}-2^{\prime}$ long. Plant turns black in drying.

5. B. villosa, Ell. I'ubesent ; leares short-petioled ; leaflets oblong anel obovate, tapering at the hase, leceoning smooth alove; lower stipules and lanceolate bracts persistent ; racenes many-flowered, deelining; ovary villous; Ieg. ume smoothish, coriaceots, ohloner, strongly beaked. - Dry sundy soil, North Carolina. May. - Stem stout, $2^{\circ}$ hight. Leaves and flowers larger tlun in No. 4, the latter on slender perlicels. I'lant turns black in drying.

6. B. megacarpa, Chujm. Stem smootl, witlt slender widely spreading branches; leaves on slender petioles; leaflets thin, elliptical or oborate, minutely pubescent and glaucons beneath; stipules and bracts calucous ; racemes numerous, terminal and opposite the leaves, few-flowered ; flowers large, pale yellow, on slender drooping pedicels ; ovin'y smooth ; lecrume large, thin, oroid, slenderpointed. - Light rich soil, Gadsden Connty, Middle Florida, and along the Flint River, netr Albany, Gcorgia. May. - Stem $2^{\circ}-3^{\circ}$ high. Leaflets $11^{\prime}-2^{\prime}$ long. Legume $1^{\prime}-1 \frac{1}{2}$ long. Plant unchanged in drying.

7. B. tinctoria, R. Brown. Smooth; branches slencler, clongated; leaves small, on short petioles, the upper ones nearly sessile; leaflets wedge-obovate; stipules and bracts minute, eadurous; racemes nnmerous, short, few-flowered; flowers small, on short and bractless pedicels; ovary smooth; legume small, roundish, slender-pointed. - Dry simuly soil, Georgia to Temessec, and northwarl. May and Junc. - Stem $2^{\circ}$ light. Leaflets $\frac{1}{2}^{\prime}-1^{\prime}$ long. Plant usually becomes lylackish in drying.

8. B. stipulacea, Ravencl. Smooth ; branches spreading; leaves small, short-petioled, 2 -3-foliolate, the upper ones mostly simple and partly clasping; leaflets round-obovate, cuneate at the base; stijules and bracts large, roundcordate, persistent ; flowers numerous, small, isillary, the upper oncs racemose, pedicels short and bractless ; ovary smooth, or slightly pubescent on the ederes ; legume small, oroid, slender-pointed. - Saud-hills, near Aiken, Soutli Carolina, Racenel. June and July. - Stem $2^{\circ}-3^{\circ}$ liggh. Leaflets $\frac{1}{2}{ }^{\prime}-3_{1}^{\prime}$ long. Plant nearly unchanged in drying. Apparently alliced to No. 3.

9. B. Lecontei, Torr. \& Grity. P'ubescent ; stem diffusely branclued ; leaves small, short-petioled; leaflets c'meate-obovate; stipules subulate and ca- 
ducous, or the lower unes larger aud persistent; racenes nunerous, short, fiwflowered, somewhat bealy at the base; bracts ovate-lanepolate, persistent;

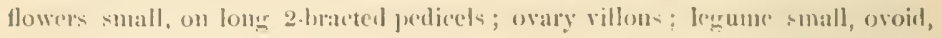
slender-pointed. - Dry sumly soil, filorila and the southern parts of (icorgia. May and June. - Stem 20 high. Leaflets $1^{\prime}$ long. I'lant unchanged in drying.

10. B. Serenæ, M. A. Curtis. Very smooth, branchingr ; leaves petiolerl;

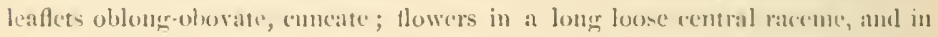
short bacemes terminating the branches; perlicels longer than the ealyx in fint ; segments of the calyx villous on the inside; legume oblomer, intlatted, the stipe Ionerer than the calyx. - Soctety Ilill, South Carolina, Curtis. Mlay and June. - Stem diffinsely brandied, $1^{\circ}-20$ highh. Leaflets $l^{\prime}$ long. Legrume $\mathrm{s}^{\prime \prime}$ long. Allied to No. $i$ and No. 11. Plant unclanged in drying.

\section{+ + Fluwers white.}

11. B. alba, R. Brown. Smooth and grlancous; branches slender, ficurons, horizontal; leaves all distinct'y jetioled ; leaflets thin, cmente-lanteolate or oljong, obtuse; stipules and bracts minnte, calucons; rateme nsually solitary, eentral, very long, those on the branches few-flowered, leymme cylindrical. Damp soil, Florula to North Carolina, aud westward. $A_{\text {pril. }}-$ Stem $2^{\circ}-3^{\circ}$ light, ofren purple. Leaflets $1^{\prime}$ long. Racemes $1^{\circ}-3^{\circ}$ long. Corolla $\frac{1}{2}^{\prime}$ long. Plant unchanged in thying.

12. B. leucantha, Torr. \& Gray. Smooth and glaneons; branches spreading, leaves short-jetioled ; leaflets oblongr and oburate, olumse; stipules lanceolate, as long as the petioles, decillwons; racenes crentral, and terminating the branches, loner, many-tlowered ; ovary smooth ; legnme large, oblong, much infated, long-stipitate. - River-hanks, Florida to Sonth Carolina, and westward. March and $\Lambda$ pril. $-\Lambda$ stouter plant than the precoling, with larger leaves and flowers, changing blackish in drying. Legmmes $1 \frac{1}{2}$ long.

13. B. leucophra, Nitt. Ilairy or smoothish; stem stont, angled; leaves slort-petioled; leaflets varying from ohlanccolate to olovale, rigill, reticulate, soon smooth above, stipules ams bracts leafy, ovate-lancelate, persistent; racemes stont, dechined, 1-sided; fowers large, yellowi-h-white, on longr and slender ereet pedicels; ovary villons, legume oroill, longr. pointed. (B bracteata, Mhhl.) - Dry rich oak woods, Wriphtshoro, Georgia, and westward. April. - Stem low, with widely spreading branches. Rascemes $t^{\prime}-12^{\prime}$ long. Flowers $l^{\prime}$ long, the vexillum spotted with brown. l'lant turns black an drying.

\section{+++ Flowers bhe.}

14. B. australis, R. Brown Smooth; leaves all short-petioled ; leaflets cuneatc-ohovate; stiputes leafy, lanceolate, twice as long as the petioles; racemes large, erect. many-flowered; flowers (indigo blun very large; bracts deciduons; legume oblong. (B. carulea, Nutt) - Binks of rivers, Georgia (Pursh), and westward. June and July. - Stem $2^{\circ}-3^{\circ}$ high. Flowers $1^{\prime}$ or more long. Legune $2^{\prime}$ long. P'lant nuchanged in drying. 


\section{THERMOPSIS, R. Brown.}

Stamens mostly persistent Legume linear or oblong-linear, nearly sessile, flattened, many-seeded. Stipules leafy, persistent. Othorwise chicfly as in Baptisia Flowers yellow.

1. T. Caroliniana, M. A Curtis. Stem stont, simple, smooth; leaves long-petioled ; leaflets memlranaceons, obovate-oblong, silky beneatls; stipules very large, ovate or oblong, clasping; racemes elongated, villous. erect. rigid, many. flowered; flowers on short pedicels; bracts ovate, deciluous ; legumes oblonglinear, erect, straight, villous and hoary, 10 -12-seeded. - Mountains of North Car olina. May - July, - Stem $3^{\circ}-5^{\circ}$ high. Raceme 6 $6^{\prime}-12^{\prime}$ long. Legume $2^{\prime}$ long.

2. T. fraxinifolia, M $\mathrm{A}$ Curtis. Stem branching, slenler, smoothish ; leaves long-petioled; leaflets oblong, narrowed at the base, often acute, smooth above, glaucous and slightly pubesceut beneath; stipules lanceolate, much shorter thin the petioles, racemes ereet, glabrous; flowers on slender spreading pedicels; bracts small, lanceolate, persistent ; legume linear, falcate, pubescent, spreading, short-stipitate, 10-seedecl. - Mountains of North Carolina. - Stem $2^{\circ}$ higls. Legunıe $3^{\prime}$ long.

3. T. mollis, M. A. Curtis. Pubescent; stem diffusely branched; leaflets oborate-oblong; stipules leafy, oblong-orate, as long as the petioles; racemes declined; perlicels shorter than the calyx and lanceolate bracts; legume linear, flat, short-stipitate. (Baptisia mollis, Mich $x$.) - Rocky woods in the midllle districts of North Carolina. April aud May. - Stem $2^{\circ}$ highl. Legume $2^{\prime}-3^{\prime}$ long, many-seeded.

\section{CLADRASTIS, Raf. Yellow-TWoo.}

Calyx 5-toothel; the nearly equal teeth short and obtuse. Vexilhum litre, roundish, reflexel, scarcely longer than the oblong wings and separate keclpetals. Stamens 10, distinct; filaments slender, incurved above. Legume shortstiphitate, linear, flat, thin, marginless, $4-6$-seeled, at lengtl 2 -valved. $-\Lambda$ small tree, with yellow woorl, pinnate leaves, and large white flowers in terminal drooping panicled racemes.

I. C. tinctoria, Raf. (Virgilia lutea, M/chx.) - Hill-silles, in rich soil, Tenuessee and Kentucky May - Leaflets 7 - 11, oval or ovate, acute, smooth, parallet veinet, $3^{\prime}-4^{\prime}$ long; the common petiole tumicl at the base. Stipules none. Racemes $1^{\circ}$ long. Flowers $1^{\prime}$ long.

\section{SOPHORA, I.}

Calyx campanulate, oblicuely truncated or 5-toothed. Stamens 10, free or ('olering at the base. Style smooth. Legume moniliform, wingless, manysceded, indeljiscent Seeds subglobose. - Trees or shrubs, with mequally pinnate leaves. Flowers in axillary and terminal racemes.

1. S. tomentosa, L. Houry-tomentose; leaflets $11-17$, obloug, coriatceons, becoming smooth above; raceme elongated ; callyx minutely 5 -toothed. - Sonth Floridia, near the const - Slirub $4^{\circ}-6^{\circ}$ high. Flower's showy, yellow. Legume stipitate, 5: long. 


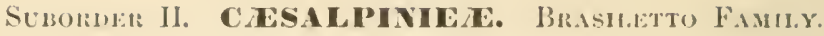

\section{CERCIS, L. RED-BUD.}

Calyx eampanulate, 5-toothet. Petals all distinct, the vexillum shorter than the wings. Stamens 10, distinct. Legumc olslong, compressed, many-seeded; the upper suture winget. - Trees, with broally-erdate simple stipulate leares, and reddistb-purple clustercd flowers alpearing before the leares.

1. C. Canadensis, L. - Rich soil, Floridla to Mississipi, and northward Fchrnary and March. - Tree $15^{\circ}-20^{\circ}$ ljigh. Flowers very numerons, from lateral buds.

\section{CASSIA, L. Sixis.}

Calyx of 5 nearly distiuct sepals. Petals 5, unequal. Stamens 5-10. Anthers mostly of allierent forms, opening by two terminal pores. Legnme many seeded. Seeds often separaterl ly aross partitions. - Ilerbs or shrubs. Leares abruptly pinnate. Flowers yellow.

* Slamens 10, unequal: jurt of the anthers abortive. sepals obtuse: stipules deriduous.

1. C. occidentalis, L. Annutal, smoothish ; stem stont, branching ; leaflets ahout 10, orate or orate-lanceolate, acute; jetiole with a globular gland at the base; racemes 2-4-flowered, the upper ones crowded. - Waste places, com. mon. - Stem $1^{\circ}-5^{\circ}$ high. Legume linear, crect, compressed, slightly curved, $3^{\prime}-4^{\prime}$ long.

2. C. obtusifolia, I. Anmual, ronghish; stem slender, leaftets 6 , cuneate-obovate, with a tooth-like gland between the lowest jair; flowers ly jairs; legume narrow-linear, 4-angled, reeurved-Waste places, Floridat to North Carolina, and westward Stem $1^{\circ}-4^{\circ}$ high. Legume $6^{\prime}-10^{\prime} \mathrm{long}$

3. C. Marilandica, L. Perennial, smoothish ; leaflets $12-18$, oblong, acute; petiole with a club-shaped gland near the base; racemes several.flowered, the upper ones erowderl, forming a compact pancle; legume linear, slighty curved. - Rich soil, Florida to Missisippi, and northward Augnst. - Stem $3^{\circ}-4^{\circ}$ bigrh. Iegume $3^{\prime}-4^{\prime}$ long

4. C. angustisiliqua, Lam.? Smontl or nearly so: stem branched; leaflets 6-10, oblong, mneronate, very ohlique at the hase, lairy at the hase beneath, with a globular gland on the petiole or between the lowest pair of leaf: lets; flowers in a terminal paniele, on slender pedicels; sepals oblong-ol,orate: petals yellow, veiny; perfeet anthers oblong, the larger one's curved; legune $\left(3^{\prime}-4^{\prime}\right.$ long) broally linear, flat, straiglit or somewhat falcate, many-seceled. - South Florila. Feb. - Leaflets 9" - 12" long. Lecgumes 4 " wide. .

5. C. biflora, I. Shrubluy leaflets 4-10, ohlong, narrowed at the base. mueronate, witl an obovoid grand between the lowest pair; ratemes $2-4$-flow. (red, often by pairs, slender, shorter than the leaves; fertile anthers 5; legume linear, flat, straight or somewhat falcate, smooth, many-seeded. - Key West. Ieaflets l'long Legume 3' longr, 2" wule. 
* * Samens 5-10: anthers all perfect: sepals acute: stipulcs persistent.

6. C. Chamæcrista, L. Armul; stem smooth or rusty-hairy; leaflets small, numerons, linear-ublong, mucronate; stipules acuminate, nerverl; flowers borne above the axils, large, elnatered, on long pelieels; anthers 10 ; style slender; legume linear, nearly straight. - Dry lamen soil, Florida to Mismissippi, and northward. July and August. - Stem $1^{\circ}-1 \frac{1}{2}{ }^{\circ}$ high. Part of the petals often purple at the base.

7. C. nictitans, L. Anmual ; jubescent ; leaflets numcrous, oblong-liuear ; stipules and bracts subulate; flowers small, $2-3$ in a cluster above the axils, on short pedicels; petals unequal; stamens 5 , near?y equal.

Var. aspera. (C. aspera, Ell.) Hirsute; stamens 7-9, rery unequal; oxary very hairy ; flowers larercr. - Dry old fields, Florida to North Carolina, and westwarl. Aumst. - Sitem $1^{\circ}$ hich, often prostrate. Leaflets about 40 , sensitive, like those of the preceding species.

\section{GLEDITSCHIA, L. Hoxer-Locrst.}

Flowers polygamous. Sepals $3-5$, united at the base, spreading. Petals as many, or less ly the mion of the 2 lower ones. Stamens 3-5, distinct, inserted with the petals on the base of the ealyx. Legume stipitate, flat, 1-many-seeded. Sceds compressed. - Thorny trees. Leaves abruptly 1-2-pinnate, with oblong serrate leaflets. Flowers small, greenish, in short spikes.

1. G. triacanthos, L. Leaflets lanceolate-oblong; thoms mostly com. pound; legume very long, many-seeded, pulpy within. - Rich woods, Floridia to Mississippi, and northward. June and July. - A large tree. Legume 12' $-18^{\prime}$ long, l' wide, twisted.

2. G. monosperma, Walt. Leaflets ovate or oblong; thorns mostly simple; legume short, obliquely oval, l-seeded, not pulpy. - Deep river swanjs, Florida to Tennessee, and westward. July. - A small tree. Legume l' long.

\section{Suborder III, MIIMOSEA. Mimosa Famil.}

\section{Mimosa, I. Sensitive-Plaxt.}

Flowers polygamons. Calyx minnte, 4-5-toothed. Petals united into a 4 -5-cleft tubular-eampanulate corolla. Stamens $4-15$, distinct, much exserted. Legume compressed, mostly jointed, 1-many-seeded; the brual ralves separating at maturity from the persistent margins. - Herbs, shrubs, or trees. Leaves bipinnate, sensitire. Flowers white or rose-color, capitate or spiked, on axillary peduncles.

l. M. strigillosa, Torr. \& Gray, Herbacens and rongl with seattered appressed rigil hairs; stem prostrate; leaves long-petioled; piuna $5-6$ pairs; leaflets 10-14 pairs, olloner-linear; peduncles longer than the leaves; heads of flowers elliptical; legume oval or oblong, 1-3-jointed, hispicl. - Bankis of rivers, liast Florida, and westward. July and Ausnst. - Flower's rose-color. 


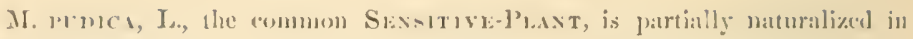
some loculities.

\section{SüRANKIA, Wilh.}

Flowers polyganons. Calyx mimute. Corolla funncl-haped, 5-eleft. Stamens 8-10, distinet, exserted. Lewme not jointed, frickly, l-celled, manyserded; the narow valves separating at maturty from the broal margins. -

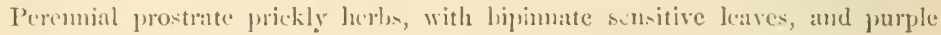
flowers in grolose axillaw peduneled heads.

1. S. uncinata, Will. Stem, petioles, peduncles, and lequnes thick!y beset with short and thick recurved prickles; pimma 5-6 pairs ; leaflets $26-30$, elliptical, reticulated with elevated reins heneatli; peduncles mostly solitary, natully shorter than the leaves; legme olbong-linear, with a short acuminate point, alout as long as the peduncle; ; seeds clliptical. - I)ry santy soil, Fiorida, and westwarl. June- $\Delta$ ngnst. - Stem $20-4^{\circ}$ long. Legme $2^{\prime}$ long.

2. S. angustata, Torr. \& Gray. Stem, \&r. armed with Eeatterel weak recurver prickles; pima $4-6$ pairs ; leaflets ahout 30 , linear-elliptical, veinless, or nearly so, on both sirles; pedunckes single or by frirs, much shorter than the leaves; legume narrow-linear, $3-4$ times as long als the peduncle, ending in a long sululite smoothish point.

Tar.? brachycarpa. Stem, \&r. as in No. 1; laffets olslongr-linear ; pelun. (les single or $2-4$ in a cluster, the upper ones longer than the feares; legumes $\left(2^{\prime}-33^{\prime}\right.$ longr) broadly linear, abrupty slender-pointed, densely armed with strong often branching frickles, about ats Jong as the peduncle - Dry pine barrens, Florila to North Carolina, and westward. June-August. - Stem $2^{\circ}-5^{\circ}$ long. lecrumes $4^{\prime}-5^{\prime}$ long.

\section{PITHECOLOBIUM, Martius.}

Flowers perfect, rarely polygamous. Calyx tulular-rampanulate, 4-5-toothed. Corolla tubular-fumel-sbajed, 4-5-eleft. Stamens 10 or more, long exserted, monadelphous near the lasse. Style filiform. Legume broully linear, compressed, contorted or falcate, transrersely partitioned, mealy or pulpy within. Seeds lenticular, - Trees or shrmh, of en amed with stipular spines. Leaves pinnate or bipinnate. Flowers chiefly capitate, axillary and ternunal.

1. P. Unguis-Cati, Benth. Unarmed or spiny; leares bipinnate; leaf. lets 4 , thin, hroadly and ohliquely obovate, the partial petioles much shorter than the common one; hearls glohose, in a loose raceme; calyxstceth short, ciliate; corolla yellowisl, smooth; stamens crisperl, twiee as long as the corolla ; ovary smooth. (Ingri Inguis-Cati, Willd.) - South Florida. - Leaflets 1'- $1 \frac{1}{2}$ ' long, light green. (Legume spirally twisted, 5-6-seeded, white, and fleshy within. McFudijen.)

2. P. Guadalupense. Unarmed; leaves lipinnate ; leaflets 4, coriaceous, obliquely oblong or olovate, the common and partial petioles nearly equall ; peduncles solitary, axillary, longer than the leaves, or the upper ones racemose; calyx and corolla pubescent ; stamens 30 or more, $3-4$ times as long 
as the corolla; ovary pubescent; legume smooth, falcate or hooked. (Inga Guadalupensis, Dest.) - South Florida. - Leaflets $\mathbf{l}^{\prime}$ long, deep green. Legune $2^{\prime}-4^{\prime}$ long. Flowers yellowish.

\section{DESMANTHUS, Will.}

Flowers polygamous. Calyx 5-toothed. Corolla of 5 oblong-spatulate petals, or tubular and 5-cleft. Stamens 5-10. Filaments of the lower flowers filiform, sterile. Legume linear, continuons, 2-valved. - Herbs or shrubs, with abruptly bipinnate leaves, and heads or spikes of white flowers borne on axillary peduncles. Leaves sensitive.

1. D. depressus, Humb. \& Bonpl. Stems slender, prostrate, sprinkled with laairs, shrubby at the base; pinnæ 2 pairs; leaflets oblong-linear, very obtuse, oblique and almost truncate at the base, hairy on the margins; peluncles 2-4-flowered, the two upper flowers (sometimes all) perfect; stamens 10 ; legume linear, many-seeded; seeds angular, compressed. — Sonth Florida. - Stems $1^{\circ}-2^{\circ}$ long. Legume $1^{\prime}-1 \frac{1}{2}^{\prime}$ long.

2. D. diffusus, Willd. Stem somewhat shrmby, prostrate; pinnæ 4-5 pairs; spikes few-flowered, eapitate; flowers pentandrous; legume narrowly linear. - Key West. - Legume 2' long.

3. D. virgatus, Willd. Stem erect, rather rigirl, smoothish, anglerl; pinnæ 1-7-pairs; leaflets numerous, oblong-linear; a rather large ovate gland below the lowest pinnæ; heads few-flowered; stamens 10 ; legune straight, linear, 10-30-seeded. (D. strictns, Bertol.) - South Florida. - Stem $1^{\circ}-2^{\circ}$ high.

\section{NEPTUNIA, Lonr.}

Sterile filaments flat, membranaceons or petal-like. Legame oblong, fowseeded ; otherwise like Desmanthus.

1. N. lutea, Benth. Stems ascending, rongh with short rigid hairs; pinnæ $4-5$ pairs ; leaflets numerous, linear-oblong, mucronate, fringed on the margins, veiny beneath; stipules ovate, acuminate; peduneles longer than the leaves, rough, mimutely bracted ; heads oval or oblong, many-flowered, nodding; petals distinet; sterile filaments $8-10$, yellow, spatulate-linear; fertile ones 10 , white ; legume 5-8-seeded. - Damp soil near the eoast, Key West to Alabama, and westward. June. \& - Stems $2^{\prime}-3^{\prime}$ long.

\section{Order 48. ROSACEA. (Rose Famil.)}

IIerbs, shrubs, or trees, with alternate stipulate leaves, and regular flowers. - Calyx of $3-8$ (mostly 5) more or less united sepals, and often with as many bracts. Petals as many (rarely none), inserted with the few or numerous distinet stamens on the edge of the disk which lines the tube of the ealyx, mostly imbricated in the bud. Ovaries 1 -several, free, or more or less united with the ealyx and with each other, $1-\mathrm{few}$ - 
ovulet. Seeds anatropons, ant, with few exerptions; withont albumen. limbryo straight, with large and thick cotyledons. Fruit varions.

\section{Synopsis.}

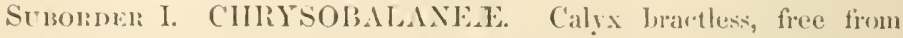
the solitary ovary. Style single, arising from the base of the ovary. Ovules creet. Frnit a drupe. - Trees or shrubs. Leares simple.

1. CIIRYSOBALANUS. Caly $x$-limb persistent. Stone grooved. Low shrubs.

Subonder II. AMYGDAlELE. Calyx bractless, free from the solitary ovary. Style single, terminal. Ovules suspended. Fruit a drupe. Leaves simple.

2. PRUNCS. Calyx-limb deciduous, Stone even, or grooved on the margins.

Suboriner III. ROSACEA. Calyx 3 -5-cleft, the lobes often alte-" nating with as many bracts, free from the 1 -several ovaries. Style lateral or terminal. Fruit a 1 -10-seceldert folliele, or a 1-seeded acheninm. - Herbs or shrubs. Leaves mostly lobed or compound.

* Fruit a 1-10-sceded follicle.

3. SPIRFI. Petals obovate or roundisb, imbricated in the bud.

5. GILLExLA. Petals linear-lanceolate, convolnte in the bud.

* * Fruit a 1-seeded achenium.

- Fruiting caly $\mathbf{x}$ dry, the lobes mostly valvate in the bud. Achcnia few, or numerous and collected into a heal.

+ Calyx-tube contraeted at the throat (except No. 4). Acheuia $1-4$.

4. Nevilsid. l'etals none. Stamens indefinite. Calyx-lobes serrate.

6. AGlilioxiA. Jetals 5. Stamens 5-15. ('alyx bristly.

7. SAxqUisolibA. Petals none. Stamens 4. Style terminal.

8. ALCIledilda. Petuls none. Stamens 1 - 4. Style lateral.

$++++\div$ Caly $\mathbf{x}$ onen, bracted. Stamens and dry achenia numerous, the iatter rarely $2-4$. $=$ Seeds erect.

9. GELI. Style persistent. Aebenia numerous.

10. WA DDSTEINiA. Style deciduous. Aeheuia 2-6.

$$
==\text { Seeds suspended or ascending. }
$$

11. POTENTILLA. Receptacle flat or convex, dry.

12. FRAGAliL. Receptacle conical, enlarged and fleshy in fruit.

++ + +4 Caly $\mathrm{x}$ open, bractless. Stamens and juicy achenia numerous.

13. RUBUS. Achenia erowded ou the conical receptacle.

+ + Calyx-tule fleshy, urn-shaped; the lobes imbricated in the bud. Achenia numerous, inserted on the receptaele which lines the iuside of the culy $x$-tube.

14. ROSA. Achenia dry and hairy. Prickly shrubs.

Sebonder IV. POMHE.T. Calyx including and eohering with the $1-5$ ovaries, very thick and fleshy in fruit.

15. CRAT EGUS. Fruit of $1-5$ bony 1 -seeded nutlets.

16. I'YliUs Fruit of 2 - 5 cartilaginous or membranaceous 2-seeded cells.

17. AMELAYCIIER. Fruit of $3-5 \mathrm{two}$-seeded cells; seeds separated by a false partition. 


\section{CHRYSOBALANUS, L.}

Calyx bell-shaped, 5-cleft, persistent. Petals 5. Stamens about 20 ; the inner ones often shorter and sterile. Orary with 2 collateral erect ovules; the style arising from its base. Drupe 1-seeded; the stone grooved. - Low nnarmed shrubs. Leaves nearly sessile, entire, with minute stipules. Flowers small, in axillary or terminal paniculate eymes.

1. C. oblongifolius, Michx. Leaves somewhat coriaceons, oblong, narrowed downwarl, mueronate, smooth on both sides, or hoary-pulsesent beneath, decidnous; eymes terminal, racemose, many-flowered; calyx pubescent ; stamens and orary smooth; drupe ovoid. - Dry sandy pine barrens, Florida, Alabama and Georgia. May. - Stems creping, the flowering branches $6^{\prime}-12^{\prime}$ high. Leares $3^{\prime}-4^{\prime}$ long. Flowers greenish-white, mostly abortive.

2. C. Icaco, L. (Coco. Plum.) Leaves short-petioled, round-ohovate, mostly emarginate, smooth, coriaccons ; cymes axillary, few-flowcred, shorter than the leaves; calyx pubescent and hoary; stamens and ovary hairy; drupe large roundish. - South Florida. - Shrub $4^{\circ}-6^{\circ}$ high, the stem and branches roughened with small white tubereles. Leaves $2^{\prime}$ long, $1 \frac{1}{2}$ wide. Dimpe yellow, purple, or black.

\section{PRUNUS, L. Plum. Cirerry.}

Calyx 5-cleft, decirluous. Petals 5, spreading. Stamens 15-30. Ovary with 2 collateral suspended orules. Style terminal. Drupe fleshy; the stone even. - Trees or shrubs. Learcs simple. Flowers white.

\$1. Prixus. (Plux) - Drupe gluncons : stone more or less compressed: leares conrolute in the bud: flowers in lateral clusters, appearing before the leaves: branches often spiny.

1. P. Americana, Marsh. Lcaves thick, ovate or somewhat olovate, acuminate, roumled or slightly cordate at the base, pubescent beneath, sliarply serrate, on glandular petioles; drupe large, globose. (P. hicmalis, Ell.) - Woods, Florida to Mississippi, and northward. March anı $A_{\text {pril. }}-\Lambda$ small tree. Leaves $2^{\prime}-3^{\prime}$ long, smooth when old. Flowers very numerons. I'lum reddish, $\frac{1}{2}^{\prime}-1^{\prime}$ in diameter, pleasantly acid, ripening in Scptember.

2 P. umbellata, Ell. Leaves thin, orate-lanceolate or oblong, acute at both ends, or the upper ones rounded at the base, fincly and sharply serrate, smooth or soft-downy beneath; calyx-teeth emarginate, pubesecut; drupe glohose ; stone slightly compressed. - Dry light soil, Florida and Alabama to Soutl. Carolina. February and March. - A slumb or small tree. Branches purple, shining. Leaves $1^{\prime}-1 \frac{1}{2}{ }^{\prime}$ long. Plum rarely $\frac{1^{\prime}}{2}$ in diameter, dark-purplish or black, sour and bitter, ripening in August.

3. P. Chicasa, Michx. Leaves thin, lanceolate or oblong-lanceolate, acute, smooth, minutely and sharply serrate, with the teeth glandulat and incurved; flowers short-peduncled; calyx smooth; dimpe yellowish-red, globose. - Old ficlds, forming thickets. March. $-\boldsymbol{\Lambda}$ shrub or small tree. Leares 
$12^{\prime}-2^{\prime}$ longr. Plum aluout $\frac{1}{2}$ in diametre, thin-skinned and of an agreenble flavor.

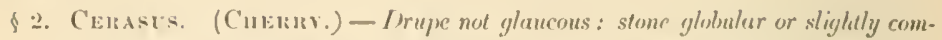

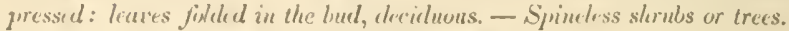

\section{* Floucers clusterct.}

4. P. Pennsylvanica, I, Lcaves thin, wate-lanceolate, acmunate, fincly

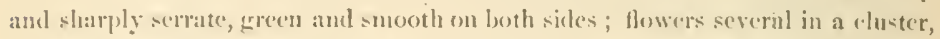
on long pedumeles; drupe globose, lightit red - liocky words, North Carolina, and northwarl. May. $-\boldsymbol{\Lambda}$ small tree. Fruit smatl and sour.

* * Floners in rucemers terminating liuf!j brenches.

5. P. serotina, liluhart. lcaves smooth, varying from oral to ovatelanceolate, mostly acute or acuminate, serrate, with the teeth eallous and appresied ; racemes long, sprealling ; drupe globose, purplisls-black. - Woorls, Floricla to Mis:issipji, and northward. A pril and May. A tree $20^{\circ}-60^{\circ}$ high.

6. P. Virginiana, I. Smonth thronglout, or the lower surface of the leaves, branches, and racemes more or less puhesceut ; leaves thin, oval, oblong or obovate, finely and sharply serrate, abuptly actute or acuminate; racenes rather short and crect ; drupe rerl. (P. hirsuta, Ell. ?) - I. ienlit samly soil, (icosgia and northward. $\Lambda$ pril. - Slurub $3^{\circ}-9^{\circ}$ higgh. Leaves $1^{\prime}-3^{\prime}$ long. Inrupe: astringent.

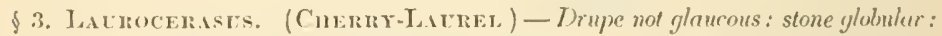
fowers in racemes from the arils of etrrygen lates.

7. P. Caroliniana, Ait. (Mock Orגisie.) Leaves roriaceous, smonth and glossy, ovate-laneeolate, acute, mostly entire; racemes slorter than the leare's, white; drupe ovoid, soon dry, black. - Janks of rivers, Floridia to North Carolina, and westward. February and March. $-\Lambda$ small tree.

3. SPIR无A, I. MEınow-Swevt.

Calyx 5-cleft, persistent. Petals 5, roundish, imbricated in the bud. Stamens 10-50. Follucles 3-12,1-10-seeded. Styles terminal. - Slırubs or perenuial herbs, with simple or conypomd leaves. Flowers white or rose-color, sometimes diweions.

\section{* Shruls : flourers perfert.}

- Flowers corymbose.

1. S. opulifolia, L. Leaves broally ovate or corlate, 3-loberl, donbly crenate-scronte, smooth; corymbs umbellate, terminating the short branches,

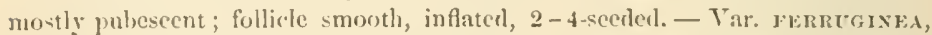
Nutt. Leaves smaller (1' long), slightly loberl, covered, like the branches, rorymbs, aud follicles, with a dense brownisl pubescence. - Banks of streams, Florisla and Alabama (the variety) to the mountains of Georgia, and northward.

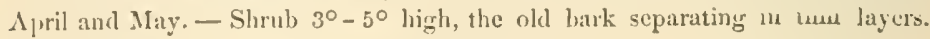
Flowers white.

\section{+- + Forcers panirled.}

2. S. tomentosa, I. Leaves simple, ovate or oblong, anrate, the lower surface, like the branches and elose panicle, covered with a densc, rust-colored 
pubescence; follicles 5, not inflated, tomentose, several-seeded. - Low grounds in the upper districts of Georgia, and northward. June and July. - Stem $2^{\circ}-3^{\circ}$ high. Flowers small, pale purple.

3. S. salicifolia, L. Smooth; panicle dense-flowered; leaves rarying from laneeolate to oblongrobovate, sharply and doubly serrate; follicles not inflated, smooth, several-seeded. - With the preeding. June and July. - Stem $2^{\circ}-5^{\circ}$ high. Flowers white.

$$
\text { * * Perennial herbs : leaves lobed or compound. }
$$

4. S. lobata, Murr. Flowers perfect, in long-pednucled panieulate cymes; leaves coarse, pinnatcely lobed, the terminal lobe very large, reniform, 7 -9-parted, with the divisions incisely toothed and serrate; stipnles reniform, persistent; follieles 6-8, 1-2-seeded. - Swamps along the mountains of Georgia and Nortl Carolina, northward. June and July. - Stem smooth, $5^{\circ}-8^{\circ}$ high. Upper leaves 3-lobed and sessile; the lowest ones on long petioles. Flowers rosecolor. Petals and sepals often in fours.

5. S. Aruncus, I. Flowers dicecions, in elongated filiform panicled racemes; learcs thrice-pinnate; leaflets thin, laneeolate-oblong, sharply and doubly serrate; stipules minnte or wanting; follieles $3-5$, several-seeded, reflexed. - Woods on the monntains of Georgiil, and northward. June. - Stem tall and slender. Flowers minute, white.

\section{NEVIUSIA, Gray.}

Calyx bractless, spreading, 5-parted, with the lobes leaf-like, incisely serrate and persistent. Corolla none. Stamens indefinite, inserted in several rows on the thin disk which lines the hottom of the calyx; filaments filiform. Ovaries 2-4, sessile: style nearly terminal, filiform. Ovule single, pendulons, anatropons. Achenia drupaceons. Cotyledons oval, flat. Embryo ineluded in thin fleshy albumen. Radicle superior, inflexed-accumbent. $-\Lambda$ shrub, with alternate leaves, free bristle-awl-shaped stipules, and single or elustered terninal flowers on slender peluneles.

1. N. Alabamensis, Gray. - Shady eliff's near Tuscaloosa, Alabama. Rev. R. D. Nevius. - Shrub $2^{\circ}-5^{\circ}$ high, with spreading branches. Leiwes short-petioled, membranaceons, ovate or oblong, donbly serrate, $1^{\prime}-2 \frac{1}{2}$ ' long. Flowers very mmerons and showy.

\section{GILLENIA, Moench. Ixpiax Pirsic.}

Calyx tubular-campaumlate, 5-toothed. Petals 5, linear-lanceolate, unequal, inserted on the throat of the ealyx, convolute in the bul. Staniens 10-20. Follieles 5, included in the calyx, 2-4-seeded. - Perennial herbs. Leaves thin, trifoliolate; the leaflets sharply and doubly serrate. Flowers white or rosecolor, in loose few-flowered corymbs.

1. G. trifoliata, Monch. Stipules small, subulate, entire; leaflets oblong, acuminate, rather coarsely serrate; lower peduncles elongated, flowers 
white - Rich wools in the northern parts of Alabama, and northward. June. - Stem $2^{\circ}-3^{\circ}$ hight.

2. G. stipulacea, Nutt. Stipules leafy, ovate, serrate; leaflets laneeolate, coarsily serrate, or the lowest incisely lebed ; flower's rose-color - Mountains of Alabana, and northward. June, - Stem $2^{\circ}-3^{\circ}$ highl.

\section{AGRIMONIA, Tomr. A; пмоху.}

Calyx 5-cheft, the tube top-shaped, contracted at the throat, amd armed with hooked briseles. Petals 5. Stamens 5-15, inserterl on the throat of the (:ilyx. Achenia 2, included in the grooved and indurated ealyx-tuhe. - I'erennial herbs, with unequally pimate leaves, leafy toothed stipnles, and small ycllow flowers in long spiked racemes. Fruit nodding.

1. A. Eupatoria, L. Stem hairy ; leafets $3-7$, with smaller ones below or intermixel, ohlong-oborate, hairy, sometines white-downy beneath, coarsely serrate; petals twice the length of the ealyx. - Jiy open woods, Florida to Mi-sissippi, and northwarl. August. - Stcm $2^{\circ}-3^{\circ}$ high.

2. A. palviflora, גit. Stem aud petioles lirsute; leatlets $9-15$, with smaller ones between, lancolate, coarsely serrate, roughish above, puheseent hemeath. - Low grount, (hicfy in the upper districts, Mississippi to North Carolina, ant northward. Angnst. - Flowers and fruit smaller than in No. I.

3. A. incisa, Torr. \& Gray. Stem, petioles, and lower surfice of the leaves elothed with soft down and long hairs intermixed; leaflets $;-9$, small (1' longr), oblong or ohovate, coarsely serrate, with smaller ones hetween; stamens 5. - Dry open woods, Floridal, Alabama, and Georgia. Angust. - Stem $2^{\circ}$ ligh. Flowers small.

\section{SANGUISORBA, L.}

Calyx 4-parted, the tube 4-angled. Petals none. Stamens 4, the filaments usnally thickened upward. Style terminal, slender. Stigma pencil-form. Achenin 1-2, included in the 4-winged indurated calyx-tube. - Herbs, with unequally pinnate lcaves. Flowers in close heads or spikes.

1. S. Canadensis, L. Smooth; leaffets numerous, stalked, corlateovate or ohlong, serrate; spikes long-peluneled, eylindrical, elongated in fruit ; stamens flattencd. - Wet mearlow, along the Alleghany Mountains, Georgia, and nortluward. September. If - Stem $2^{\circ}-4^{\circ}$ high. Lowest leaves on long petioles. Flowers white.

\section{ALCHEMILLA, 'Гоurn.}

Calyx 4-5-parted, and with as many alternate bracts; the tule olseonieal, contracted at the throat. Petals none. Stamens 1-4. Stylle lateral. Stigma capitate. Achenia 1-4, included in the persistent calyx-tuhe. - Small herbs, with palmately divided leaves, and minute greenish flowers, in corymbs or clusters. 
1. A. arvensis, L. Anuual, hairy; stem $\left(1^{\prime}-\delta^{\prime}\right.$ lighli $)$ leafy; leares $3-$ parted, the divisions wedge-shaped, 3-5-lobed ; flowers in axillary sessile clusters; fertile stamens 1-2, - Waste places, North Carolina and Virginia. Introduced. - Stem brancling from the base. Leaves $4^{\prime \prime}-6^{\prime \prime}$ long.

\section{GEUM, I. Arexs.}

Calyx campanulate, deeply 5-cleft, and usually with as many bracts at the sinuses. Petals 5. Stamens and achenia numerons, the latter erowded on the conical or cylindrical elry receptacle. Styles terminal, long, persistent, jointed and hairy, or straight and smoothish. Seeds erect. - Perennial herbs, with pin. nately divided leares. Flowers yellow, white, or purple.

1. G. album, Gmelin. Smoothish or downy; stem slender, with sprealingr branches ; radical leaves pinnate, or the earliest ones nearly simple and rounded; stem-leaves 3-parted, lobed or toothed; petals white, as long as the calyx; style jointed and bent near the middle, the smooth lower portion persistent and hooked ; receptacle and ovaries bristly-hairy. - Rich woods, Georgia and northward. April and May. - Stem $2^{\circ}$ high.

2. G. geniculatum, Michx. Hairy ; leaves pinnate, 3-parted or 3-lobed, the upper ones nearly sessile; leaflets or lobes thin, ovate and oborate, toothed and serrate; style jointed and bent in the middle, the upper portion plumose and nearly persistent, the lower pubescent, or smooth above ; heads of the hairy achenia sessile. - High mountains of North Carolina. July. - Stem $2^{\circ}-3^{\circ}$ high. Flowers white, veiny.

3. G. radiatum, Michx. Hirsnte; stem short $\left(6^{\prime}-12^{\prime}\right)$, of ten branching; lowest leares pinnate, the terminal leaflet large, reniform, olsscurely lohed, doubly toothel, the lateral ones few and small; stem-leaves scattered, small, sharply toothed, sessile; flowers large; petals obcordate, yellow; style straiglit and wholly persistent, hairy at the base; heads of achenia sessile. - Highest mountains of North Carolina. July. - Flowers I' wide.

\section{WALDSTEINIA, Willı.}

Calyx ohconical, 5-cleft, with as many alternate bracts. Petals 5. Stamena numerons, inserted into the throat of the calyx. Achenia 2-6, dry or somewhat fleshy. Style terminal, filiforn, separating from the achenium by a joint. Seeds erect. - Low perennial herbs, with ehiefly radical and roundish lobed leares, and rellow flowers on scape-like stems.

1. W. fragarioides, Tratt. Smooth or hairy; learcs long-petiolerl, trifoliolate or 3-parted, with broadly cuncate and crenately toothed leaflets ; scape as long as the leaves, bracterl, many-flowered ; achenia 4-6, minutcly hairy. Mountain-woods, Georgia aud northward. May and June.-Stem and leaves $4^{\prime}-6^{\prime}$ high. P'tals larger than the calyx.

2. W. lobata, Torr. \& Gray. Hairy ; leaves cordate, crenately 3-5-loherl; scape filiform, bracted, 4-8-flowered; aehenia mostly 2, hoary; petals rather 
shorter than the ealyx. (1)alibarda lobata, beldu.) - Banks of the Flint and Chattahoochee rivers, in the midldle districts of Georgial, not common. Man and June. - Scape and leares $t^{\prime}-8$ light.

\section{POTENTILLA, L. Criqulail.}

Calyx flat, 5-cleft, with as mumy bracts. Petals 5, obcorlate or rommlish. Stamens numerous. Style lateral or terminal, deciduous. Arlenia collected in a heal on the dry and pubescent receptacle. - Herbs or slurubly plants, with variously divided leatres. Flowers solitary or eymose.

\section{* Style terminal, or neurly so.}

1. P. Norvegica, I. Annual, hairy; stem ereet, branched; leaves palmately 3-foliolate, the leafets olowate-oblong or lancelate, coarsely serrate; flowers pale yellow, in leafy eymes; petals shorter than the calyx, - Waste places. Introducel, and sparingly naturalized. - Stem $1^{\circ}-2^{\circ}$ high.

2. P. Canadensis, I. Perennial, hairy ; stem prostrate or ascending, simple; leares palmately 5.foliolate; leaflets ohovate-oblongr, courscly serrate; flowers axillary, solitary, on long filiform peduncles; petals ycllow, ohcorlate, as long as the calyx. (1'. simplex, Mirhx.) - Neadows in the upper districts, Mississippi to North Carolina, and northward. July and $\Lambda$ ugust. - Stem $1^{\circ}-3^{\circ}$ long.

3. P. tridentata, Ait. Stem somewhat shrubby at the base, erect or ascending, pulsesent; leaves rigil, trifoliolate, ('uncate-oblong, 3-toothed at the arex ; Aowers white, in a terminal eyme. - High monntains of North Carolina. July. - Stem $5^{\prime}-10^{\prime}$ high. Achenia and receptacle very hairy.

\section{FRAGARIA, Tomm. Strawmirr.}

Flowers like Potentilla, lut the dry aeluenia borne on the enlarged, at length pulpy and scarlet receptacle. Style lateral. - I'cremnial herlss with creeping lumers. Ideaves radical, trifoliolate. Filowers white, in teminal cymes.

1. F. Virginiana, Elrhart. Hairy; leaflets oblong, coarsely serrate; seape few-flowered; fruit romudish, the achenia imberled in tle deeply pitted receptacle. - Pich woods, Florida to Mississippi, and northward. March and April. - Scapes $4^{\prime}-6^{\prime}$ hight.

\section{RUbUS, L. Brier. Bramble.}

Calyx concave or fluttish, 5-parted, without bracts. Petals 5, deciduous. Stamens numerous. Aehenia jniey, crowled on the conical or eylindrical re(eptacle. Style nearly temiual, decjouous - Perennial or shrublyy and mostiy prickly plants, with lobed or compound petioled leaves, and white or reddish flowers.

* Irrerls of achenia hemispherieul, deriduous : receptucle dry.

1. R. odoratus, L. Shrubby, not prickly; the branches, petioles, and corymbs hispid with glandular hairs; leaves large, broadly ovate, 3-lobed, or 
the lowest ones 5-lobed, the lobes aente or acuminate, toothed and serrate ; calyxlobes caudate; flowers large, rose-color; fruit redlish. - Rocky woorls on the mountains of Georgia, and northward. June-August. - Stem $3^{\circ}-4^{\circ}$ high. Flowers $2^{\prime}$ in diameter.

2. R. occidentalis, L. Glancons; stem prickly, but otherwise very smootl, bending; leaves $3-5$-foliolite ; leaflets thin, ovate, acuminate, coarsely serrate or sparingly toothed, white-downy beneath; petals white, shorter than the reflexed short-caudate loary calyx-lobes; fruit black. - Borders of woods along the mountains, Georgia and northward. May. - Stem biennial, 5० $-8^{\circ}$ long.

* * Heads of achenia oval or oblong, persistent : receptacle juicy.

3. R. villosus, Ait. Tall, shrubby; stem ereet or bending, armed, like petioles and peduncles, with stont reenrved prickles, the branches and $3-7$-foliolate leaves soft-hairy or nearly smooth; leaflets ovate or oblong, doubly serrate; racenes leafy below, bracted above; sepals acuminate, much shorter than the o'sorate white petals; fruit large, oblong, black. - Swampy thickets, common. April. - Stem $4^{\circ}-10^{\circ}$ ligh.

4. R. cuneifolius, Pursh. Shmbby, arned with stout prickles; stem erect; branches and leaves tomentose; leaves trifoliolate, with the leaflets cuneate-obovate, unequally serrate towards the summit, tomentose and white beneath ; racemes few-flowered; petals white; fruit oroid, black. - Old fields, Florida to North Carolina, and westward. April. - Stem $2^{\circ}-4^{\circ}$ high. Leaves and fruit smaller than in the preeding.

5. R. trivialis, Michx. Shrubby, and armed with stout straight or reeurved prickles and bristly hairs; stem prostrate, slender; leaves 3-5-foliolate, partly persistent; leaflets smooth, oblong ovate or obovate, acute, sharply serrate; racemes few-flowered, leafy below, mostly longer thim the leaves ; flowers large, white; fruit black. - Dry sandy soil, Florida to North Carolina, and westward. April.

6. R. hispidus, I Somewhat shrubby, and armed with weak bristle-like prickles; stem slender, prostrate ; leares trifoliolate, persistent ; leaflets obovate, obtuse, coarsely serrate, smooth; racemes many-flowered, slender, longer than the leares; flowers small, white ; fruit of few large and black achenia. (R. obovalis, Michx.) - Cold sh:tdy swamps among the mountains, Georgia and northward. May and June. - Fruit sour.

\section{ROSA, Tourn. Rose.}

Calyx 5-eleft, the urn-shaped tube becoming fleshy in fruit. Petals 5. Stamens numerous, inserted with the petals on the throat of the calyx. Oraries numerous, hairy, inserted on the thin reeptacle that lines the inner surface of the calyx-tube. Styles nearly inchded. Achenia hony.-Prickly shrulss. Leaves unequally pinnate. Stipules united with the petioles. Flowers slowy.

* Styles coltering, exserted.

1. R. setigera, Michx. Stem long, reclining, smooth; leaflets $3-5$, orate, acuminate or acute, serrate, shining above : petioles, peduncles, and calyx glan- 
dul:ur; corymb few-flowered; petals olveordate ; fruit frlohose, smooth. - Borders of swamples, Jorida to Sonth Carolina, and westwarl. Jume. - Stem $10^{\circ}-15^{\circ}$ lone. Flowers $2^{\prime}-3^{\prime}$ wide, ret.

\section{* Sigles distinnt, included: flowers red or white.}

2. R. Carolina, I. Stem erect, smooth, armed with stout recurved stipular prickles; leaflets $5-9$, oblong or elliptical, arute, fincly serrate, dull and rnoothish abore, the lower surface paler, or, like the prickly petioles and eatudate ealyx-lubes, tomentose; flowers single or eorrubose; calyx-tube am puluncles glandular-hispid. - Swamps, Florida to North Camolina, and westward. Jume. - Sten $\ddagger^{\circ}-6^{\circ}$ high, comnonly purplish. Fruit depressed-globuse, grandular.

3. R. Iucida, Flurhart. Stem low, erect, armed with bristles and stout stipular prickles; leaflets mostly 5 , elliptical or oblong-lanceolate, sharply serrate, smooth and shining alove, paler and often somewhat pubescent beneath; flowers solitary, or $2-3$ together; peduncles and ealyx glandular, the latter with foliaceous, often incised lohes. (12. parviflora, Ell.) - Florida to Mississippi, and northward, mostly in dy soil, common. May and Junc. - Stem $1^{\circ}-3^{\circ}$ lighl. A variable species. Stem sometimes smooth.

4. R. rubiginosa, L. (Eglaxtixe.) Stem erect or eurving, armed with very stout prickles; leaflets 5-7, oval or obovate, serrate, glandular beueath; flowers mostly solitary, on hispid peduncles; fruit obovate. (R. snaveolens, Pursh.) - Waste places in the upper distriets: introduced. Branches ycllowishgreen. Leaves fragrant.

5. R. lævigata, Michx. (CherokeE Rose) Stem long, trailing, smooth, the branches armed with very stont and curved prickles; leaves evergreen, mostly trifoliolate; leaflets smooth and shining, lanceolate, the midrib hisjill; stipules deciduous; flowers large, solitary, white; ealyx very bristly. Common in cultivation.

\section{CRAT ÆGUS, I. H.wт:оRx.}

Calrx urn-shaped; the limb 5-eleft, persistent. Petals 5, orbicular, concave. Stamens few or many. Styles $1-5$, distinet. Fruit fleshy, containing $1-5$ bony nutlets. - Thorny shruls or trees. Leaves simple, serrite or varionsly lobed. Flowers white, axillary and solitary, or in corymbs terninating short lateral branches. Stipules on the young brauches linear, or lunate and serrate.

* Corymbs compound, many-flouered.

- Fruit small, not larger thein a pea.

1. C. spathulata, Michx. Young hranches tomentose, otherwise nearly smooth and glandless thronghont; leaves small, spatulate, crenate at the sunmit; those on the young shoots larger and incisely lobed; calyx-loles very short; styles 5 ; fnit very small, red. - River-banks, Florida to North Carolina, and west to Mlississippi. A pril. $-\Lambda$ small tree. Corymbs sometimes slightly pubesent. Stipules lunate on the young branches. 
2. C. apiifolia, Michx Young branches, leaves, and corymbs whitened with soft hairs; leaves small, deltoid, pinnately 5-7-lobed, sharply toothed, nearly smooth when old, truncate or cordate at the base; styles $1-3$, filiform; fruit globular, red. - River swamps, Florida to North Carolina, and westward. March and April. - A small tree. Leaves $\frac{1}{2}{ }^{\prime}-1^{\prime}$ long.

3. C. cordata, Ait. Young branches, leaves, and corymbs softly pubeseent, soon smoothish; leaves large, deltoid-ovate, truncate or cordate at the base, long-petioled, 3-5-lobed and serrate ; spines slender; fruit globose, red. River-banks in the upper districts, Georgia, and northward. May and June. A small tree. Leaves $\mathbf{l}^{\prime}-3^{\prime}$ long. Styles 5 .

4. C. arborescens, Ell. Smooth; leaves thin, oval or elliptical, acute at both ends, finely serrate, sometimes obseurely toothed near the apex, on slender nearly glandless petioles; corymbs very numerous; styles 5 ; fruit ovoiıl, red.-Banks of rivers, Georgia and Florida, west to Mississippi. March and April. $-\Lambda$ small tree, with asl-colored branches. Spines stont or wanting. Leaves $1^{\prime}-2^{\prime}$ long, entire at the base, sometimes hairy in the axils of the veius beneath.

$$
\text { + + Fruit lurge }\left(\frac{1}{2}^{\prime}-\frac{3}{4} \text { ' long) ; leaves, } \& c\right. \text {. mostly glandular. }
$$

5. C. Crus-galli, L. Leaves thick, oblong-obovate, smooth, shining above, finely serrate from near the glandless base; those on the young branches sometimes slightly lobed; spines long and stont, or sometimes wanting; corymbs smooth or nearly so; styles $1-3$; fiuit pear-shaped or globose, red. - Woods, Florida to Mississippi, and northward. April and May. - A slurub or small trec.

6. C. coccinea, I. Smooth ; leaves thin, romdish-orate, with 3-5 short and sharply serrate lobes on each side, abruptly narrowed into the slender petiole, strongly straight-veined ; those on the young branches often truneate or slightly cordate at the base, and more strongly lobed; spines stont; styles $3-5$; fruit large, globose or pear-shaped, bright red. (C. viridis, L. C. populifolia, Ell.) - Open dry woods, Florida to Mississippi, and northward. April and May. A slurub or small tree. Leaves $1^{\prime}-2^{\prime}$ long, bright green.

7. C. tomentosa, L. Leaves large $\left(3^{\prime}-5^{\prime}\right.$ long $)$, broadly ovate or oval, fincly serrate, and slightly lobed above the middle, abruptly narrowed into a short margined petiole, pubeseent, especially beneath, the veins straight ant inpressed; corymbs large, tomentose; styles $1-3$; fruit pear-shaped, orange-red.

Var. punctata, Gray. (C. punctata,Jacq.) Leaves smaller and smoother, more strongly furrowed by the impressed veins, and more tapering at the base; fruit globose, dull red, dotted with white. - Woods and swampy thickets in the upper districts, Georgia and Alabama, and northward. May. $-\mathbf{A}$ shrub or small tree. Flowers and fruit large.

$$
\text { * * Corymbs simple, 1-6-flowered. }
$$

8. C. æstivalis, Torr. \& Gray. Glandless ; leaves rigid, pubeseent, becoming smooth ahove, and rusty-pubeseent on the veins beneatle, cuncateobovate, crenate above the midelle, tapering into a short petiole; corymbs 
smooth, 3-5-flowerel: styles 4-5; fruit latce, glolose, red - Varies (C. lucida, l:ll.) with smaller (1'), thimer, anel smonth feaves, which are gloss alover. - Margin of pine-larren ponds, Florida to Sonth Carolina, and westward. Mareh and $\Lambda$ pril. $-\Lambda$ small tree. Leaves $21-3)^{\prime}$ long. Fruit juie $y$, exlible.

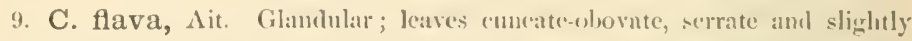
lober near the apex, smouth, tapering into a slert petiole; corymls smooth, 1-4-flowered; styles $4-5$; flowers and pear-shaped fruit larese - Shady sandy places, Florilat to North Carolina, and westward. May. - Tree $15^{\circ}-20^{\circ}$ high. Leaves 2'-3' long. Fruit greenish-yellow.

10. C. glandulosa, Michx. Branchlets, leaves, and coryubs whitened with soft hairs; leaves oparjue, cuneate, cutire or glandular-serate, tapering into a slender petiole, heconing smoothish; those on the young luanches often sparingly lobed; eorymbs 3-6-flowered, milateral ; styles 5 ; fruit small, globose, red. (C. elliptica, A At.) - Dry pine barrens, Floricia to Souh Carolina, and westwarl. April. $-\Lambda$ small tree, with coarse bark, and long reenred branches. Leaves 1 long. Fruit $3^{\prime \prime}-4^{\prime \prime}$ long.

11. C. parvifolia, Ait. Leaves obovate, scarecly petiolerl, serrate, the lower surfice, like the branchlets and calyx, pubesecut; spines numerous, long and slencler; flowers nostly solitary; ealyx-lobes large, serrate; styles 5; fruit larece, globose of pear-shalecd, somewhat latiry. - Sandy soil, Florida to Mississippi, and northwarl. April and Mlay. $-\Lambda$ much branched shrub, $3^{\circ}-5^{\circ}$ high, Leares $l^{\prime}$ long.

\section{PYRUS, I. Pear. Apree.}

Calyx urn-shaped, 5-eleft. Petals 5. Stamens mumerous. Sitles 2-5. Frnit fesly or bacate, containing 2 - 5 cartilaginous, 2 seceded carpels. - Trees or shrubs. Flowers ezmose or corymbose.

* Ifares simple, glandular : fruit depressed at the base.

1. P. coronaria, L. I.eaves on long and slender petioles, orate, roundel, or slightly cordate at the base, angled or lobed, serrate, snooth; corymbs simple, few-flowerel; flowers rose-color, very fragrant; styles woolly amel mited at the base. - Rich soil in the upper districts, Mississippi to North Carolina, and northward. A pril. - A small tree. Leaves 2'-3' long.

2. P. angustifolia, Ait. Jeaves lancelate or oblong, acute at the base, serrate, slort-prtioled ; corymls simple, few-flowered ; flowers rose-rolor, very fragrant; styles smooth, distinct. - Open woods, Florida to Miscissippi, and northwarl. April. - A small tree. Fruit very sour.

\section{* Lereres simple, the midrib glundular alwere: fruit barcate, glolose.}

3. P. arbutifolia, I, Leaves oval-ol,long or somewhat ohovate, ahruptly acnte or mucronate, smooth above, except the michib, fincly serrate; styles villon: at the lase.

Var. erythrocarpa. Stem tall $\left(5^{\circ}-10^{\circ}\right)$; hranchlets, eymes, and lower surfice of the large $\left(2^{\prime}-4^{\prime}\right)$ leaves tomentose and loary ; petals and anthers red. dish ; berries red. (Aronia arbutifolia, Ell.) 
Vir. melanocarpa. Stem low $\left(2^{\circ}-4^{\circ}\right)$; hranchlets, cymes, and leares smooth or nearly so; leaves small ; petals white; berries black. (Aronia melanocarpa, Ell.) - Swamps, Florida to Mississippi, and northward. Jiarch and April.

* * Leates unequally pimate: rymes compond : fruit bucrate.

4. P. Americana, DC. Leaflets $13-15$, lanceolate, ac'uninate, serrate above the middle, soon smooth; eymes large, dense; berry small, globose or pear-shaped, scarlet. (Sorbus microcarpa, Pursh.) - Highest mountains of North Carolina. May and June. - A shrub or small tree. Fruit acid.

\section{AMELANCHIER, Medic.}

Calyx 5-cleft. Petals 5, oblong. Stamens numerons, short. Styles 5, more or less nnited. Fruit baceate, containing $3-5$ cartilaginous 2-sceded carpels; seeds separated by a false partition. - Shrubs or small trees, with simple leaves, and white flowers in terminal racemes.

1. A. Canadensis, L, var. Botryapium, Torr. \& Gray. Branches, leaves, and racemes tomentose when young, soon smooth; leaves elliptical, al,ruptly acute, fincly and sharply serrate, often slightly cordate; racemes slender, appearing before the leases; petals four times as long as the calyx; fruit globose, purplish. (Aronia Botryapium, Ell.) - Woorls, Florida to Mississippi, and northward. February and March. - A small tree, with smooth whitish bark.

Var. rotundifolia, Torr. \& Gray. Shrubby ; leaves roundish-oval, somewhat acuminate, sharply serrate; racemes 6 -10-flowered; petals small, nalrowly oblung. (Arouia ovalis, Ell.) - Low grounds, chiefly in the upper districts, Georgia and northward. March. - Shrub $2^{\circ}-3^{\circ}$ high.

The cultivated representatives of this order are the PLum (Prexus nomestices, $L$ ): Apricot (P. Armexiaca, $L$.), Cherries (I'. Aviun and P. Cerasus, L.), Peach (Persica velgaris, Mill.), Apple (Prres malus, L.), Pear (P. comuciss, L.), Quixce (Crdoxia velankis, Pers.), and the Alyoxd (Amgilis).

\section{Order 49. CALYCANTHACEA. (CARolisd-Allspice FAMILY.)}

Shrubs, with opposite and entire leares, without stipules or pellucirl dots. - Sepals and petals numerous and alike, mited below into an olconical fleshy cup, imbricated in the bud. Stamens numerons, short, inserted within the petals, the immer ones often sterile. Anthers arlnate, extrorse. Ovaries several, enclosed in the ralyx-tule, and inserter on its imer face, becoming 1 -seceded achenia in fruit. Seeds anatropous, without albumen. Cotyledons convolute. 


\section{CALYCANThUS, L. Swlet-scerten Surun.}

Calyx-tube closed, leafy-hrarted; the lobes and petals in several rows, lanceolate, somewhat fleslyy. Stamens decilnons. Mature fruit dry, pear-haped, ewosing the larere acheniat. - Aromatic slnubs, with opposite or forkingr bramdes, slort-petioled deciduous leaves, and large brownish-purple terminal flowers.

1. C. floridus, L. Branchlets, jetioles, and perluncles hoary-pubescent ; leaves oval or oblong, mostly acute or acuminate, very rongh on the upper surfice, tomentose aud hoary beneath; seprals and petals linear-lanceulate, acute. - Banks of streaus in the upper districts, North Carolina to Mississipji. April. - Slirub $4^{\circ}-8^{\circ}$ high. Leaves $2^{\prime}-3^{\prime}$ long. Flowers $1^{\prime}$ in diameter, very fra. srrant.

2. C. lævigatus, Willd. Branchlets, petioles, and perluncles pulseseent or smoothish; leaves oblong or elliptical, mostly acute or ar'mminate, rough on the upper surface, paler und nearly smooth beneath; sepals and petals linearlanceolute, acute. (C. inolorus, Ell. leaves very rough above, but shining; flowers inorlorous.) - Banks of streans, thiefly in the low conntry, Florida, Georgia, and westward. Mardh and $\Lambda_{p}$ ril. - Shrub $4^{\circ}-8^{\circ}$ high. Lenves $2^{\prime}-$ $3^{\prime}$ long. Flowers $1 \frac{1 \prime}{2}$ in diameter.

3. C. glaucus, Willd. Branchlets, petioles, and peduncles smootli; leaves larre, orate or ovate-lanceolate, armuninate, green and ronglish on the upper surface, smootli and glaucous beneath; flowers large, the sepals and petals lanreolate, and abruptly sharp-pointed. - Low shady woods along the mountains of Georeria and North Carolina. May aud June. - Shrub $6^{\circ}-5^{\circ}$ high. Leaves rather rigid, $4^{\prime}-7^{\prime}$ long. Flowers $1 \frac{1^{\prime}}{2}-2^{\prime}$ in diameter.

The Pomegraxite (Pexica Graxatum, L.) belongs to the allicd order Graxite.e.

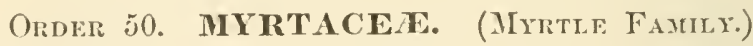

Trees or slurubs. Leaves opposite, simple, entire, dotted and commonly with an intra-marginal vein. Stipnles none. - Calyx 4-6-cleft, ralvate in the lux, the tube arlherent to the compound ovary. Petals $4-6$, inserted with the ntmerous stanens on the throat of the calyx, sometimes wanting. Filaments long, free. or varionsly combined. Anthers introrse, romulish, longitudinally dehiscent. Style solitary. Seeds without albumen, fixed to a central placenta.

\section{EUGENIA, Micheli. Alispice.}

Calyx-tube roundish, the limb 4-eleft. Petuls 4. Stamens distinct. Ovary 2-3-celled, with several orules in each cell. Fruit baecate, roundish, 1-2-celled, 1-2-seederl. Cotyledons thick and united. Radicle very short. - Flowers white, axillary, solitary, cymose, or clustered, 2-bracted. 
* Flawers in axillary cymes.

1. F. dichotoma, DC. Leaves oblong-obovate, obtuse or emarginate, rigit, and, like the branches, ronghened with appressel hairs, at length smoothish, the margins revolute; peduncles twice as long as the leares, $3-i$-flowered, the central flowers sessile; calyx-tube obeonical, 2-braeted, downy and loary, the lobes roundish, spreading; petals orbicular, ciliate; stamens numerous. South Florida. - A small tree. Leaves 1' long. Branches compressed.

\section{* Flowers solitury or umbellate.}

2. E. procera, Poir. Smooth; leaves ovate, tapering but obtuse at the apex, abruptly contracted at the base into a short petiole; peduncles solitary or $2-4$ together, filiform, not half the length of the leares, 1 -flowered; calyx-tube hemispherieal; petals orbicular, eiliate; berry globose, 1-seeded. - South Florida. May. $-A$ small tree. Leaves $1 \frac{1}{2}{ }^{\prime}-2^{\prime}$ long. Flowers conspicuous, white and fragrant. Berry as large as a grain of pepper.

\section{* * Flovers minute, in very short cluster-like racemes.}

3. E. monticola, DC. Smooth; leaves coriaceons, orate-oblong, somewhat tapering towards the apex, but obtuse or emarginate, contracted at the hase into a distinct petiole; racemes clustered, several-flowered, shorter than the petiole; stamens numerous; herry globose. - South Florida. - Slurub $4^{\circ}-6^{\circ}$ hight. Branches compressed. Jeaves 2 long. Flowers white. Berries abundant, as large as a grain of pepper, black.

4. E. buxifolia, Willd? Leaves smooth, coriaceons, olorate-oblong, rounded at the apex, short-petioled; racemes single or clustered, few-flowered, abont as long as the petiole; flowers minute; stamens few (9-12) or numerous; berry 1-3-seeded. - South Florida. - Varies much in the size of the leaves and berries, length of the petiole, and number of stamens, and probably includes two or more species.

\section{CALYPTRANTHES, Swartz.}

Calyx-tnhe obovate; the limb entire, opening across like a lit, decidnous. Petals none. Stamens nunerous. Orary 2-3-celled, with 2 orules in each cell. Berry 1-eelled, $1-4$-seeded. Seels roundish: testa smooth. Embryo curved; the long and slender radicle coiled around the distinct uncqual folded and contorted cotyledons. - Shrubs or trees. Peduneles axillary, many-flowered.

1. C. Chytraculia, Swartz. Leaves ovate and ovatc-lanceolate, aeuminate but obtuse, pubescent, becoming smooth above; peduneles lonerer than the leaves, ermose-panicled, tomentose ; flowers minute; berry dry, globose, 1 - 2. seeded. - South Florida. - 1 small tree.

\section{Order 51. MeLastomaCeA. (Melastoma Famly.)}

Ierhs, shrubs, or trees, with opposite 3-9-ribbed leaves, without dots or stipules, and showy flowers. - Calyx urn-shaped, 4-6-lcioeca, pesisient, 
colering with the ovary lelow, or with its angles. Petals 1-0, twisterl in the hul, inserted with the $1-12$ stamens on the throat of the calyx. An-

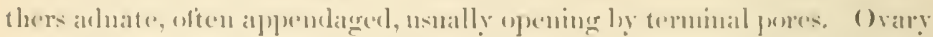

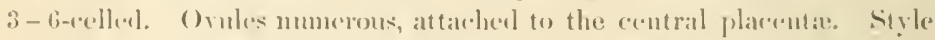
solitary. Fonit haceate and indelisisent, or capsular and loculicidally deliscent. Scerels anatronous, without albumen.

\section{RHEXIA, I. DEer-Gisss.}

Calyx-tule prolonged and narrowed alrove the orary, 4-cleft. I'ctals 4, rommish, deciluons. Stancus 8. Anthers 1-celled, opening ly a teminal pore. Capsule 4-celled, many-secded. - I'crennial herbs. Leaves 3-5-ribbed. Flower's cymose, terminal.

* Authers long, linrar, curving upu:ard, saccate ut the base, and commonly furnished with a bristle-like appenduge at the insertion of the filuments: flowers purple or whitish.

1. R. Mariana, I. Bristly ; stem brancherl, terete or 6-angled; Jeaves lanceolate, ac'ute, slort-petioled, hristly serrate; calyx mo-tly smooth, cylindri(al in flower, the neck in frut as long as the gholowe (ap)sulan portion; flowers pmole. - Varies with narrower, often linear leaves, and smaller whiti-ls flowers. (12. lanceolata, Wult.) - Swamps, Florida to Mi-isiplpi, amb northward. July - Sept. - Stem $1^{\circ}-2^{\circ}$ light. Leaves 3-ribbed. Flowers $11^{\prime}-2 t$ wide, hairy extermally.

2. R. Virginica, L. IBristly; stem 4-angled, nearly simple; Jeaves ovate and ovate-lancelate, barely acute, sessile, bristly serrate, the lowest rounded; neck of the bristly fruiring calyx shorter than the capsular portion; the lobes ovate, acuminate. - Swamps, chicfly in the upper districts, Mississippi, and norhward. July and August. - Stem 6t-12' high. Leaves 3-5-ribbed. Flowers purple.

3. R. stricta, Pursh. Stem tall, smooth, 4-winged, learled at the joints; leaves lanecolate and ovate-lanecolate, acute or acminate, 5-ribbed, bristly serrate, sessile; cyme compound; calyx smooth, urn-shaped, the lobes lancelate. - Margins of ponds in the pine barrens. Florida, Georgia, and westward. July and Angust. - Stem $2^{\circ}-4^{\circ}$ high. Leares rugose, the latteral ribs obscure. Flowers purple.

4. R. glabella, Michx. Stem terete, smooth, mostly simple; leaves lanceolate, sesile, entire or slightly serrulate, thick, smooth and glancons; calyx smooth or bristly; flowers large, bright purple. - Low pine barrens, Florida to North Carolina, and west to Mississipji. June - Augnst. - Root spongy. Stem $2^{\circ}-3^{\circ}$ high. Leaves swectish.

* * Inthers short, ablong, ereet, not appendugerl: neck of the cralyx short.

+ 1.lourrs purple: leures small, orate or roundish, bristly sermulate.

5. R. ciliosa, Nichx. Stem simple, smooth, 4-angled alove; leaves bristly on the upper surface, 3-riblued; cyme few-flowered, leafy; calyx smooth.Bogs in the pine Larrens, Florida to Mississippi, and northward. July and 
Augu-t. Stem $1^{\circ}-1 \frac{10}{2}$ high. Leares rarely $1^{\prime}$ long. Flowers $1^{\prime}-1 \frac{1}{2}^{\prime}$ in diameter.

6. R. serrulata, Nitt. Low; stem simple, 4-angled, smooth; leaves smooth above ; calyx glandular-bristly ; cyme leafy, 1 -6-flowered. - Open flat pine barrens, near the coast, Florida, Gcorgia, and westward. July and August. - Stem 2'-6' high Leaves and flowers smaller than in the preecding.

$$
++ \text { Flowers yellow. }
$$

7. R. lutea, Walt. Stem at length much lorancherl, $t$-angled, bristly; Jeaves smoothish, bristly serrulate, the lower ones obovate and obtuse, the upper lanceolate and aente; cymes numerous; calyx short and smooth; flowers snall. - Pine-barren swamps, Florida to Fortl Carolina, and westward. Julyand $\Lambda$ ugust. - Stem $1^{\circ}$ high. Petals more persistent than those of the other species.

\section{Order 52. IVTHLACEA. (Loosestrife Fayll.)}

Chiefly herbs, with opposite or whorled and entire leaves, without stipules. Flowers mostly axillary. - Calyx tubular, persistent, 4- i-tootherl, fiee from the 2-t-celled ovary. Petals as many as the teeth of the ealyx and inserted into its throat, decirluous, sometines wanting. Stamens as many as the petals, or 2-4 times as many, inserterl below the petals. Anthers short, jutrorse. Style solitary. Capsule enclosed in the ealyx, 1-t-eelled, few or nany-seeted. Placente central. Seeds anatropous, without albumen. - Sinuses of the calyx olten apjenclaged. Stigma eapitate, or rarely 2-lobed.

\section{Synopsis.}

* Calyx regular.

1. IIy poBrycula. Calyx hemispherical. Petals none. Stigma 2-lobed. Capsule 2-celled,

2. AmuxNiA. Caly $x$ campanulate. Stigma cajitate. Capsule t-celled.

3. LYTIlRLM. Caly x cylindrical, striate. ('apsule oblong, 2-cellerl.

4. NESEA. Calyx short, even. Capsule globose, 3-5-celled. Finiseus 10.

* Caly $x$ gibbous at the base.

5. CUPHEA. Caly $x$ tubular, 12-ribbed. Stamens mostly 12 . Cansule early ruptured.

\section{HYPOBRYCHIA, M. A. Curtis.}

Calyx hemispherical or campanulate, 4-loled. Petals none. Stamens 2-4. Style very short: stigma 2-lobed. Capsule globose, 2-cellet. - A submerged aquatie herb, with long filiform stens, opposite crowded pellucid linear leaves, and minute sessile axillary flowers.

1. H. Nuttallii, Torr. \& Gray. - Ponds and still water, West Florida to North Carolina, and westward. June - Ang. - Stems $1^{\circ}-2^{\circ}$ long. Leaves $1^{\prime}$ long, acute. Flowers not larger than a pin's head. 


\section{AMMANNIA, Ilouston.}

Calyx globular or eampanulate, 4-angled, 4-tootherl, the sinuses commonly furnished with a snall hom-shaped appendage. Petals 4, small, deciduous, sometimes wanting. Stamens 4, short. Stigma (apitate. Capsule globular, 4-eelled, many-seeted. - Low smooth annual herbs, with opposite leares, and solitary or clustered axillary flowers.

1. A. humilis, Michx. Stem branching from the base; leaves lanceolate, tapering into a petiole; flowers solitary ; style very short ; petals 4, purplisl. Varies with the leaves dilated and somewhat cordate at the base, and the lower flowers clustered. (A. ranosior, Mich $x$ ) - 1)itches and muddy places, Florielit to Miscissippi, and northward. August and September. - Stem 6'-12' high.

2. A. oceidentalis, I)C. Stem nearly simple, ascending, rooting at the base; leaves lanceolate, narrowed into a petiole; flowers solitary, apctalous; (alyx 8-toothed.

Yar. pygmæa. Stem very short $\left(\frac{1}{2}^{\prime}-1^{\prime}\right.$ long $)$; sinuses of the calyx appendagel, emarginate, as long as the teeth; style short. - Key Wrist, Dr. Blodyett. - Leaves obtuse. Stem 1-6-flowered.

\section{LYTHRUM, L. Loosestrife.}

Calyx eylindrical, striate, $4-7$-toothed, ustually with minute appendages in the sinuses. Petals $4-7$. Stamens as many as the petals, or twice as many, inserted on the lower part of the calyx, nearly ergual. Capsule oblong, 2-celled, many-secterl. - IIerbs, with opposite or alteruate leaves, and axillary pupple or whitish flowers.

1. L. alatum, Pursh. Smooth; stem and virgate branehes 4-anglerl; leaves lanceolate, acute at both ends, opposite, the uppermost alteruate, and shorter than the flowers ; petals and stamens 6. - Varie's with branches shorter, leaves larger ( 2 ' long), broadly laneeolate, sometimes whorled, the uppermost twice as long as the calyx. (L. lanceolatum, E/l.) - Swamps and river-banks, Floridia and northward. July-Septenuer. - Stem $2^{\circ}-4^{\circ}$ high. Flowers violet-purple.

2. L. lineare, L. Smooth; stem 4-angled, much brancherl; leaves all opposite, linear; flowers small, whitish; petals and stamens 6. - Brackish marshes, Florida and northward. August. - Stem 20-4 high. Calyx-tecth short.

\section{NES ÆAA, Commerson.}

Calyx hemispherical or eampanulate, with $4-7$ ereet teeth, and as many longer and spreading horn-like appendages in the sinuses. Petals 4-7. Stamens twice as many as the petals. Capsule glohose, 3-4-eelled. - Pereunial herbs or shrubly plants, with opposite or whorled leaves, and elusterel pedicelled flowers in their axils.

1. N. verticillata, H. B. K. Shrubby ; stems pubeseent, recurved; leaves opposite and whorled, lanceolate, tomentose beucath; peduncles sliort, 3 or 
several-flowered; petals 5, showy; stamens 10 , the alternate ones shorter. (Decodon verticillatum, Ell.) - Narshes and margins of ponds, Florida and northward. August. - Stems $3^{\circ}-4^{\circ}$ long. Flowers purple.

\section{CUPHEA, Jacq.}

Calyx tubular, 12-rihled, gibbous or spurred at the base on the upper side, 6-toothed, and usnally with as many little appendages in the simuses. Petals 6, unequal. Stamens 11-12, unequal. Ovary with a gland at the base next the кpur of the calyx. Style filiform. Stigma 2-lobed. Capsule 1-2-celled, fuwseeded. - Chiefly herbs, with branching stems and purplish flowers.

1. C. viscosissima, Jaeq. Aunual, clammy-pubescent; leares thin, opposite, ovate-lanceolate, long-petioled, rough ; flowers ncarly sessile, borne between the petioles, solitary; petals violet-purple; stanens 12. - Upper districts of Georgia, and northward. August. - Stem $1^{\circ}$ high.

2. C. aspera, n. sp. Perennial ; muricate-hispid and clanmy; leaves $3-4$ in a whorl, lanceolate, nearly sessile; peduncles longer than the leaves, horme between the petioles (whorlel) ; petals white or pale-jurple; stamens 11. - Low pine barrens, St. Joseph's, Florida. Stem $1^{\circ}-1 \frac{1}{2} \circ$ high. Leaves $1^{\prime}$ long, rigil. Root bearing small tubers.

The Crape Mrrtle (Lagerstremia Ixdica, L.), originally from Eastern Asia, is common in cultivation.

\section{Order 53. RHEZOPHORACEA. (MANgrove Faml.)}

Trees or shrubs, growing in maritime swamps, with opposite, entire, coriaceous leares, and deciduous stipules between the petioles. - Calyx unitel with the ovary, $4-12$-lobed, valvate or licl-like in the bud. Petals as many as the ealyx-lobes and alternate with them. Stamens twice or several times as many as the petals, and inserted with them on the ealyx. Ovary 2-celled with the cells 2-ovuled, or 1-celled and several-ovuled. Ovules pendulous. Fruit 1-cellerl, indehiscent. Albumen none. Radicle elongated.

\section{RHIZOPHORA, I. MAYgrove.}

Calpx-tube ohorate, the limb 4-lobed, persistent. Petals 4, oblong, emarginate, enfolding the alternate stamens in the bud, woolly on the margins. Stamens 8. Anthers linear-ohlong. Ovary 2-celled. Fruit encireled above the base by the persistent ealyx-lobes, at length perforated at the apex by the radiele of the germinating embryo. - Flowers axillary, showy.

1. R. Mangle, L. Leaves obovate-oblong; peduncles 2-3-flowered; germinating embryo elavate; flowers pale yellow. - Muddy shores, South Florida, forming dense low thickets. 


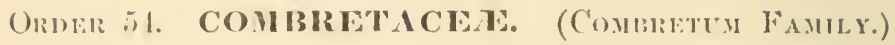

Tropical trees on shrubs, with entire exstipulate l'aves, and axillary spikerl or capitate flowers. - Calyx-tube coleerent with the 1-celled, 2- iovuled wary: the limb $4-5$-cleft, mostly decilluous. Petals $4-5$, often wanting. Stamens $4-15$, inserterl with the petals on the ealyx. Style slender: stigna simple. Fruit drupareons or baceate, or dry and intelhiscent, offen winged. Seed solitary, suspenderl, anatropous, without alluu. men. Cotyledons convolute or varjously folded.

\section{LAGUNCULARIA, Gart.}

Flowers in spikes. Calyx-tule ubconical, the limb 5-parted, ohtnse, persistent. l'etals 5, minute. Stamens 10. Style subulate; stigma capiate. Ovary 1-ecllerl, 2-orulerl. I)rupe coriarcous, euneate-obovate, rompresserl, anglerl, 1-seceled. Seeds germinating in the drupe. Cotyledons convolute. Raticle clongated. - Maritime slumbs, with opposite clliptical smonth and fleshy leaves, on biglambular petioles, and small flowers, in simple or compomol axillary and terminul spikes.

1. L. racemosa, Gart. Spikes ereet, rigit, hon'y-tomentose, the latteral ones solitary, the teminal ones in threes, simple or luranched; flowers scattered; ralyx-tube obeonical, furrowed, wing-angled in fruit. - Sonth Florilat. June to $A$ ug. $-\Lambda$ slumb or small tree, with the habit of the Mangrove.

2. L. glabriflora, Presl. Spikes spreading, slender, smooth, the lateral ones in pairs, the terminal ones in threes or fours; flowers minute, erowded, deciluous; calyx-Inbe cup-shaped, terete, even, with two opposite lnactlets appresect to silles. - Banks of the Mlanitee IRiver, South Florida, liugel. June. I'erhalys a sterile form of the preceling.

\section{CONOCARPUS, Gart.}

Flowers densely erowded in a glolular head. Calyx-tube about as long as the compressed 2-ovuled ovary; the limb 5-cleft, decidnons. Petals none. Stamens 5-10, exserted. Antluers cordate. Frnit coriaceons, seale-like, rlosely inlrieated and indehiseent. Cotyledons convolute. - Trees or shrubs, with alternate entire and somewhat flesly leaves. Heads of flowers spiked or panicled.

1. C. erecta, Jacq. Branchlets angular, smooth; leares smooth, oblong or lanceolate, acute or acuminate, narrowed into a biglandular petiole; heads of flowers sessile, or on slort and spreading pedicels; cone of fruit ovoid. - Var. sERICEA, $D C$. Branches, leaves, and panicles silky and hoary; lowest leaves mostly ohorate and obtuse or emarginate; ovary ahortive. - Sandy sea-shore, Tampa Bay, Florida, and southwarl. January and February. - A shrub or snall tree. Leaves $2^{\prime}-4^{\prime}$ long. Heads of fruit $3^{\prime \prime}-6^{\prime \prime}$ long. Flowers greenish, minute. 


\section{TERMINALIA, L.}

Flowers in spikes, often polygamous. Limb of the calyx deciduous, bellshaped, 5-cleft, witl the lobes acnte. Petals none. Stamens 10, in 2 rows, longer than the calyx. Orary 2-3 ornled. Style filiform. Drupe dry and indchiscent, 1-seeded. Seed almond-like. Cotyledons spirally convolute. Trees or shrubs, with mostly alternate leaves, which are crowded at the summit of the branches.

1. T. Catappa, L. Leares short-petioled, softly pubescent when young, at lengtl smoothish, obovate, wedge-shaped but truncated or slightly cordate at the base, with a depresser gland on each side of the midrib near the base ; spikes very sleuder, shorter than the leares, the upper flowers sterile; drupe ovate, acute, compressed, with the margins somerhat winged. - South Florida. - A large tree. Leares $4^{\prime}-8^{\prime}$ long. Flowers minute, pale green.

\section{Order 5̃. ONAGracea. (Evening-Primrose Fayily.)}

Calyx adherent to the orary, and often prodnced into a tube beyond it, 2-6-lobed, valvate in the bud. Petals as many as the lobes of the calyx, inserted into its throat, convolute in the bud, sometimes wanting. Stamens as many or twice as many, inserted with the petals. Orary 2-4-celled. Placenta central. Style solitary: stigma capitate or 2-t-lobed. Capsule loculicidally dehiscent or indehiscent. Seeds anatropous, with little or no albumen. - Chiefly herbs.

Strorder I. ONAGRACEA. Styles slender. Fruit 4-valved (indehiscent in Gaura). Seeds attached to a central placenta, without albumen.

\footnotetext{
* Calyx-tube produced beyond the orary.
}

1. GAURA. Capsule nut-like, indehiscent, 1-4-seeded.

2. (EуOTHERA. Capsule 4-valved, many-seeded.

* * Caly x-tube not produced beyond the ovary.

3. EPILOBIUM. Stamens 8. Petals 4. Seeds comose.

4. JUSSI.FA. Stamens 8-12. Petals 4-6. Capsule long. Seeds naked.

5. LUDirigiA. Stamens 4. Petils 4, or none. Capsule short, many-seeded.

6. CIRC.EA. Stamens 2. Capsule oborate, 1-2-seeded.

Suborder II. HALORAGEz. Styles rery short or none. Fruit indehiscent. Seeds suspended, solitary in each cell. Albumen thin. Flowers minute, axillary.

7. PloserpiNaCA. Flowers perfect. Stamens 3. Capsnle 3-angled.

8. MYliopHYLUM. Flowers monocious. Stamens 4-8. Capsule 4-angled.

\section{GAURA, L.}

Calyx-tube much produced beyond the ovary, the limb 3-4-Iohed, reflexed, deciduons. Petals 3-4, clawed, unequal or turned to the upper side. Stimens 
6-8. Style declined : stigma 4-lobed. Ovary 3-4-celled. Fruit 3-4-angled, mostly 1-celled, $1-4$-secelerf. - Ilerlss with alternate leaves, and white or purple flowers in a long-peduncled raceme or spilie.

1. G. biennis, I. Soft-hairy ; leaves oblong-lanceolate, acuminate, becoming smoothish, wary-denticulate on the margins; petals spatulate, white; fruit obtusely 4-ingled, acuminate at both ends, sessile. - I )ry soil, Georgia to Tenuessec, and nortliward. July and Angust. (c) - Stem $3^{\circ}-8^{\circ}$ high. Spikes compound.

2. G. angustifolia, Michx. Stem simple, or sparingly branclicl, closely pubesecnt ; leaves lanceolate, acute, coarscly-toothed, often blotehed with purple; the uppermost linear and nearly entire; fruit nearly sessile, acute at both ends, sharply 3-4-angled. - Dry old fiekls and sandy places near the coast, Florida to North Carolina, and westward. June-August. (2) - Stem $2^{\circ}-3^{\circ}$ liigh. Flowers white.

3. G. filipes, Spach. Pubescent and somewhat hoary, becoming smoothish; stem sleuder, paniculately branched; leaves linear, toothed, wary; fruit ovoid, obtuse, sharply 4-angled, on slender pedicels. - Dry pine barrens, Florido to South Carolina, and westward. July - Sept. (2) ? - Stem $2^{\circ}-3^{\circ}$ high, very leafy.

\section{ENOTHERA, L. Evening-Primrose.}

Caly-tnbe produced beyond the ovary; the limb 4-lobed, reflexed and decisluous. Petals 4. Stamens 8. Stigma 4-lobed. Capsule 4-valved, many-secledl. - Herbs, with alternate leaves, and axillary or racemose chiefly yellow flowcrs. Pollen-grains triangular, connected by cobwebby hairs.

* Capsule cylindrical, sessile: flowers expanding at night : annuals or bienniuls.

1. OE. biennis, L. Hairy, hirsute, or smoothish ; stem tall, often simple; leares lanceolate and ovate-lanceolate, acute, wary and toothed or serrate on the duargins; the carliest ones sometimes pimnatifid; spikes leafy, at length elongated ; calyx-tube longer than the lobes; flowers large. (E. nuricata, Pursh. (E. grandiflora, Ait.) - Ficlds and waste places, everywhere. June-Sept. Stem $2^{\circ}-4^{\circ}$ high. Varies greatly in pubescence and size of the flower.

2. CE. sinuata, L. Hairy or downy; stems ascending or diffuse; leares oblong, pinnately lobed, the lowest pinnatifid; flowers small, axillary; calyx and capsule hairy. Passes throngh several intermediate forms into Var. mux rFLsA, Torr. \& Gray. Stems prostrate, hoary; leaves small, lanceolate, sparingly toothed or entire. - Fields and waste places, common; the rariety in drifting sand along the coast. May-Sept. - Stems $2^{\prime}-2^{\circ}$ high.

* Cajsule obovate or clurate, furroued, and more or less peduncled: floucers expanding in sunshine.

3. CE. glauca, Michx. Smooth and somewhat glaucous; leares sessile, oblong-ovate, wary-denticulate, acute; racemes fow-flowered, leafy; flowers large; capsule ovoid-oblong, 4-winged, tapering into a short pedicel. (CE. Fraseri, Pursh.) - Nountains of Georgia, North Carolina, and Tennessec. May 
-July. 4-Stem branching, $2^{\circ}-3^{\circ}$ high. Leaves $2^{\prime}-3^{\prime}$ long. Flowers $2^{\prime}$ in diameter.

4. CE. riparia, Nutt. Stem slightly pubescent, very leafy; leaves linearlanceolate, remotely denticulate, narrowed into a short petiole; raceme short, leafy at the base, elongated in fruit ; flowers large ; capsule oblong-clavate, distinctly pedieelled, slightly 4 -winged, with 4 strong intermediate rilss. - Swamps and river-banks, Florida and northwarl. June and July. (2) - Stem $22^{\circ}-3^{\circ}$ high. Leaves $2^{\prime}-4^{\prime}$ long, pubescent on the midrib and margins. Flowers $2^{\prime}$ in diameter.

5. CE. fruticosa, L. Hairy or smoothish ; stem mostly simple; leares laneeolate, commonly wavy and remotely dentienlate on the margins; raceme at first eorymb-like, at length elongated ; flowers large ; capsule 4-winged, with intermediate ribs, oblong-clavate, longer than the pedicel. - Fields, Mississippi to North Carolina, and northward. June-Sept. $4-$ Stem $1^{\circ}-2^{\circ}$ high. Flowers $1^{\prime}-2^{\prime}$ in diameter.

6. E. linearis, Michx. Stem slender, smooth below, pubescent abore; the young branches hoary ; lowest leaves oborate; the others linear-lanceolate, entire or sparingly denticulate; raceme short, many-flowererl, leafy ; capsule oborate, 4-winged, with eonspicuous intermediate ribs, mostly shorter than the pedicel. - Dry light soil, Floridar to Mississippi, and northward. A pril-June. - Stem $1^{\circ}-1 \frac{1}{2} \circ$ high. Flowers $1^{\prime}$ in diameter.

7. G. pumila, L Low, smoothish; leares lanceolate, obtuse; raceme leafy; flowers snall; capsule oblong-obovate, 4-wing-angled, nearly sessile. Mountains of Georgia ame Carolina, and occasionally also around dwellings in the low country, from seeds introduced in Northern hay. June. - Stem $6^{\prime}-12^{\prime}$ high. Flowers $\frac{1}{2}$ in diameter.

8. CE. linifolia, Nutt. Low, smoothish; stem at length much hranehed; leaves very numerous, linear-filiform, the lowest spatulate; raceme pubescent, few-flowered ; bracts shorter than the ovary ; flowers small ; lobes of the stigma coherent into a globular head; capsule ohovate, 4-angled, nearly sessile. Gravelly hills, near Scott's mill, Waren County, Georgia, and westward. June. - Stem $6^{\prime}-12^{\prime}$ high. Flowers $4^{\prime \prime}-5^{\prime \prime}$ in diameter.

\section{EPILOBIUM, L. WILLOT-Herb.}

Calyx-tube not prolonged beyond the ovary; the limb t-cleft, decidnous. Petals 4. Stamens 8. Capsule elongated, many-seeded Seeds with a tuft of long hairs at the apex.-Pereunials, with alternate and opposite denticulate leaves, and ehiefly white or purple flowers.

1. E. angustifolium, L. Stem tall, simple, smoothish; leaves alternate, lanceolate, entire or wavy on the margins, paler beneath; racemes elongated, bracted; flowers showy; petals obovate, purple; stigma 4-lohed; capsule and calyx hoary-tomentose. (E. spicatum, Lam.) - Mountains of North Carolina and northward. July. - Stem $3^{\circ}-6^{\circ}$ high. 
2. E. coloratum, Muhl. Stem smoothi-h, murh hranchurl; leaves moctly opposite, landeolate or wrate-lanceolate, denticulnte; rucene lenfy ; flowers small,

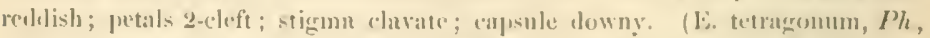
Ell.) - Swamps in the upper districts, Mississippi to North Carolina, und northwural. August. - Stem $10^{\circ}-20$ light.

3. E. palustre, I., var, lineare, Gray. Stem pulsescent, branching above; leaves linear, slightly denticulate, the lower ones opposite; raceme leafy; flowers smoll, white or rose-color; stigma clavatr; ("nj)ule boary. Mountains of North Carolina, anıl northward. August. - Stem $1^{\circ}-2^{\circ}$ high.

\section{JUSSI 屟A, I.}

Calyx-tube long, 4-angled or eylindrical, not prolonged lieyoul the ovary; the limb 4-6-lobed, persistent. l'etals 4-6. Stamens 8-12. Capsule mosty elongated, 4-6-celled, many-secded, opening irregularly at the sides. - Marsh herbs, with alternate leaves, and axillary yellow flowers.

1. J. leptocarpa, Nutt. Inairy; stem ereet, at length much hranchel; leaves lanceolate, acute; flowers small; calyx-lobes mostly 6 , as long as the petals; capsule linear, eylindrieal, much longer than the pedicel. - Marshes, Florilat, and westward. June-Sept. (1) Stem $2^{\circ}-5^{\circ}$ high. Capsule $1 \frac{1}{2}$ long, slightity curved.

2. J. grandiflora, Michx. Hairy; stem ereping at the hase; leares lanceolate, acute; flowers large; calyx-lobes 5, half as long as the petals; ovary (rarely maturing) rather shorter than the perlicel. - Marslues, South Carolina, and westward. May-August. $4-$ Stem $2^{\circ}-3^{\circ}$ long. Flowers $2^{\prime}$ in diameter. Capsule rylindrical.

3. J. decurlens, DC. Smooth; stem ereet, branched, wing-angled; leaves lanceolate, acute, sessile; flowers nearly sessile; calyx-lobes 4, nearly as long as the petals; stamens 8; apsule 4-angled, oblong-chavate. (Ludwigia decurrens, Ell.) - Ditches, \&c., Florida to North Carolina, and westward. July Sept. (1) - Stem $6^{\prime}-3^{\circ}$ high.

\section{LUDWIGIA, I. SEED-130x.}

Calyx-tube 4-angled or eylindrical, mostly short, not prolonged heyond the ovary. Petals 4, roundish or obcordate, often wanting. Stamens 4 . Style short. Stigma capitate. Capsule variously dehiscent, 4-celled, many-seeded.Perennial and mostly stoloniferous marsh herbs, with entire leares, and yellow flowers.

* Capsule cubical, indehiscent, discharging the serds through a central pore of the conver dish: calyx-lobes deciduous: petuls large: stamens and style slender: leaves alternate: flowers perdicelled.

1. L. alternifolia, L. Smoothish; stem mueh branched; leares lanceolate, short-petiolerl, acute; calyx-lobes spreading, ahout as long as the petals; capsule large, wing-angled. (L. macrocarpa, M/Chx.) - Shady swamps, Florida 
to Mississippi, and northward. Angust. - Stem $2^{\circ}-3^{\circ}$ lighli. Flowers axillary, or the upper ones somewhat racemed.

2. L. virgata, Michx. 'Tomentose; stem slender', simple, or branching from the base; leaves obtuse, sessile, the lowest oblong, the uppermost linear; flowers in elongated leafy racemes; petals twice as long as the reflexed calyxlobes; capsule strongly 4-angled. - Low pine barrens, sometimes $\mathrm{ir}_{\mathrm{r}}$ rather dry places, Florida to North Carolina, and westward. July and August. - Stem $2^{\circ}-3^{\circ}$ high. Varies considerably in pubescenee, and size of the flowers and capsule.

3. L. hirtella, Raf. Hairy; stem slender, simple or sparingly branched; leaves short, lanceolate or oblong, obtuse, sessile and rounded at the base; flowers axillary; petals twice as long as the erect or sprearling ealy $\mathrm{x}$-lobes; capsnle strongly angled. (L. pilosa, Ell.) - Flat pine barrens, Florida to Mississippi, and northward. Angust. - Stem $2^{\circ}-3^{\circ}$ high.

* * Talves of the capsule separating from the concave disk, and irreyularly from the persistent partitions and plucenta: culyx-lobes persistent: petuls small or none: stamens and style short: stems erect or ascending: laves alternate: flowers sessile.

\section{+- Petels conspicuous.}

4. L. linearis, Walt. Smooth; stem $\left(1^{\circ}-3^{\circ}\right.$ high $)$ virgately much branched; leares linear, acute; flowers small; capsule clavate-oblong, with 4 rounded angles, $2-3$ times as long as the triangular-ovate calyx-lobes. - Ditches and ponds, Florida to Mississippi, and norihward. July-Sept. - Bark at the base of the stem spongy.

5. L. linifolia, Poir. Smooth; stem low $\left(G^{\prime}-12^{\prime}\right)$, ereeping at the base, branching; lewres lincar or linear-spatulate, often obtuse; eapsule linear-eylindrical, rather longer than the lanceolate ealyx-lobes. - Ditehes and swamps in the low country, Florida to North Carolina, and westwarl. July-Sept.

\section{+ + Petuls minute or wanting.}

6. L. cylindrica, Ell. Smooth; stem angled above, often much branched; leaves long, linceolate, olseurely denticulate, acute, tipering into a petiole; petals none; capsules axillary, often elustered, cylindrical or olseurely 4 -sided, many times longer than the small calyx-lobes. - Swamps, Florila to Sonth Carolina, antl westward. July-Sept. - Stem mostly buslıy, $2^{\circ}-3^{\circ}$ ligh. Leares $3^{\prime}-4^{\prime}$ long.

7. L. pilosa, Wait. Tomentose; stem stont, terete, mueh branched; leaves sessile, lanceolate or oblong, acute; flowers in dense terminal spikes; petals mostly wanting; capsule globose - 4-sided, about as long as the spreatling calyxlobes. (L. mollis, Ell.) - Ditches and ponds near the coast, Florida to North Curolina, and westward. July-Sept. - Stem $2^{\circ}-3^{\circ}$ hight, t'ic branches spreading. Capsule whitish.

8. L. sphærocarpa, Fill. Smooth or slightly pubescent; stem sleniler, angled above, short-branched ; leaves linear-lanceolate, acuminate; flowers very small, axillary; petals none; capsule globose, pubescent, as long as the calyxlobes. - Margins of ponds, Florida to Mississippi, and northward, not common. July - Sept. - Stem $2^{\circ}-3^{\circ}$ liggh. Capsule $1^{\prime \prime}-2^{\prime \prime}$ long. 
9. L. capitata, Michx. Sumotls; stem mostly simple, sleuder, angled ubove; lave's long, lanceolate, areute, sessile, the lowest ones brouder and obtuse; flowers in a compact obloug or ovate head, the lower ones sometimes

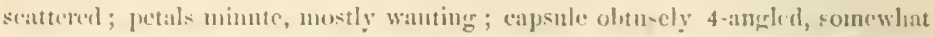
narrower at the bale, longer than the calyx-lobes. - Wet pine barrens, Florida to North Carolina. Juiy and August. - Stem $2^{\circ}-3^{\circ}$ high.

10. L. lanceolata, Fill. Smooth; stem stout, terrete, at length much branclied; leaves lanecolate, sessile; flowers very numerons, in all the axils, green; petals none; eapsule eubical, with the sides flat and the angles mar-

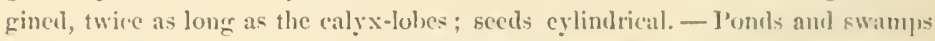
in the pine barrens, Florida and Georgia. July - Sept. - Stem $1^{\circ}-2 \circ$ higrl. Flowers small.

11. L. alata, Ell. Smooth; stem sleniler, simple or sparingly lranched near the summit, strongly angled; leaves cuncate-lancelate, obseurely denticnlate; flowers few, near the summit of the branches, white; petals none; capsule "ubicobeonical, with concare sides and winged angles, as long ats the calyxlobes; seculs ovoid, - Inrackish marshes, Flurida to North Carolina, and westwarl. July aur August. - Stem $2^{\circ}-3^{\circ}$ high.

12. L. microcarpa, Mielix. Smooth; stem low, rreping at the base, 3-angled, mostly simple; leaves spatulate-obovate; petals none; (ap)sule minute, cubic-obconical, shorter thau the calyx-lobes. - Mndily places, Florida to North Carolina, and westwarl. July aud August. - Stem $6^{\prime}-1 \cdot 22^{\prime}$ lifirl. Cap, sule searcely larger thim a pin's heak.

** * Stems creeping: leaves olmosite.

+ Petals none.

13. L. palustris, Ell. Smooth; stems diffinse; leaves ohorate, tapering

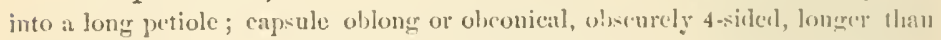
the calyx-lobes. - Ditches and mudey places, common. June-Sept. - Stems $66^{\prime}-12^{\prime}$ long.

14. L. spathulata, Torr. \& Gray. Pubeseent and somewlyat hoiry; leaves spatulate-olovate; eapsule uroiul otlerwise like the preceling. - Margins of pinc-barren ponds, Middle Florida. July amb Alugust.

\section{+ + Prlals 4.}

15. L. natans, Ell. Smooth; stems difhuse; leares ohovate, acutish, tapering into a long petiule; flowers short-pedicelled; petals roundish, as long as the lohes of the calyx; capsule olstusely 4-angled, narrowed at the hase. Marshes and margins of streans, Floridi to Nortl Carolina, and westward. July - Scpt. - liesembles No. 13, lut is every way liuger.

16. L. arcuata, Walt. Smooth; leaves lanecolate, narroverl at the hase, acute; flowers on pechincles usually longer thim the leares, 2-lsracted at the base; calyx-lobes lincur-lanecolate, shorter than the obovate petals; enjeule clavate, curved. - Nuddy margins of ponds, \&e, Florida to North Carolina. July. - Stems $4^{\prime}-8^{\prime}$ long. 


\section{CIRC无A, Tourn.}

Calyx-tube slightly produced beyond the ovary, the limb 2-eleft, decidnons. Petals 2, obcordate. Stamens 2. Style filiform. Capsule ohorate, 1-2-eelled, 1-2-seeded, bristly with hooked hairs. - Perennial herbs, with opposite petioled leaves, and small wbite or rose-colored flowers in loose terminal racemes.

1. C. Lutetiana, L. Minutely puheseent ; leaves ovate, acuminate, slightly toothed, usually longer than the petioles; bracts none; capsule hispid. Damp shades along the mountains, Georgia and northward. July. - Stem $1^{\circ}-2^{\circ}$ high, tumid at the joints. Fruit reflexed. Flowers reddish-white.

2. C. alpina, L. Smooth; stem low $\left(3^{\prime}-8^{\prime}\right)$; leaves cordate, coarsely toothed, as long as the petioles; pedicels minutely bracted; eapsule hairy. With the preceding.

\section{PROSERPINACA, L.}

Calyx-tube 3-sided, 3-lobel. Petals none. Stamens 3. Stigmas 3. Fruit bony, 3-angled, 3-celled, 3-seeded. - Herbs with pinnately disseeted leaves, and minute axillary greenish flowers.

1. P. palustris, L. Leaves lanceolate, sluarply serrate, the submerged ones peetinate. - Ponds and ditches, Florida to Mississippi, and northward. June - Augrist. - Sten $10-1 \frac{1}{2}$ long, ascending or floating.

2. P. pectinacea, Lam. Leaves all pectinate, the divisions filiform; fruit rugose. - With the preceding. - Stem $3^{\prime}-12^{\prime}$ long.

\section{MYRIOPHYLLUM, Vail. WATER-MiLfoIL.}

Flowers monnecious or polygamous. Calyx 4-parted in the sterile flowers, 4 toothed in the fertile ones. Petals 4 or none. Stamens 4 or 8 . Stigmas 4 , recurved. Fruit hony, 4-celled, 4-lobed, indehiscent. - Aquatic perennial herbs, with the submerged leaves pinnately clivided into filiform or eapillary segments, and commonly whorled. Flowers minute in the axils of the upper leaves; the uppermost sterile.

\section{* Stamens 8: fruit even or u'arty.}

1. M. laxum, Shuttl. Stem long, slender; leaves 4 in a whorl; the floral ones rerlued to minute nearly entire spatulate bracts, shorter than the flower:, which thus form an interrupted almost naked spike; fruit roughened with minute warts, with the lobes obtuse. - Ponds and lakes, Middle and West Florida. -July.

2. M. verticillatum, L. Leaves in whorls of 3-4, the floral ones linear, pectinately toothed, much longer than the flowers; fruit smooth. - Still water, Florida, and northward. July. - Stem $2^{\circ}-4^{\circ}$ long, stonter than the last.

* * Strmens 4 : fruit ridgerl and roughened.

3. M. heterophyllum, Mielıx. Stem thick; leaves $4-6$ in a whorl, the floral ones crowded, ovate or lanceolate, finely and sharply serrate; the lower 
ones pinnatifid; fruil slightly ronghened. - l'onds and ditches, Florida, and nortliwart. July.

4. M. scabratum, Michx. Stem short $\left(6^{\prime}-12^{\prime}\right)$; leaves $4-5$ in a whorl. the divisions few and capillary, the floral ones linear, pertinntely toothed; fonit strongly rilged and roughened. - Silallow ponds, South Carolina, and northwird. June auıl July.

\section{Oruel 56. CACTACEA. (Cactés Fanilr.)}

Succulent, slurubby, and commonly leafless and prickly plants, with globular, or co'umuar and angular, or flattrued and juinted strms, and solitary sessile flowers. - Sepals ancl petals similar, imbricaterl in several rows, and arlherent to the 1-cellerl ovary. Stanens indefinite, with loner filaments, juserted on the base of the petals. Style single: stigmas mimerous. Frnit bacrate. Sceds numcrous, eampylotropous, borne on several parietal placenta. Albumen suanty or none.

\section{CEREUS, II:w.}

Sepals am petals muted into an clongated tube above the ovary. Stamens inserted on the tulse. Style filiform. Stigma many-lobed. Secels witlont allumen. - Stems elongated, ribbed or angled; the angles bearing tufts of spines and showy flowers.

1. C. monoclonos, DC.? Stem tall, rolumnar, 6-8-anelcr, green; angles oltuse; spines short, lrownish. - Kery West. Stem $4^{\circ}-10^{\circ}$ liegli. Flowers $6^{\prime}$ long, the inner petals lauceolate, acuminate, white; the outer ones linear, greenish, and gradually diminishing into the scales of the tube. Stignils 10 or more, filiform, exserted. Stamens included.

2. C. triangularis, Haw.? Stem clongated, jointel, 3-sided, rooting at the joints; flowers greenish externally, white within, rery large; fruit large, naked. - Key West. - Stem climbing over bushes. Joints $1^{\circ}$ long.

\section{OPUNTIA, Tourn, Pвикит Pйл.}

Sepals and petals not united into a tube. Stamens inserted into the hase of the petals. Style eylindrical. Stigrma 3-8-loberl. Secds with thin alhumen. - Stems with flat or rarely cylindrical joints. Leaves fleshy, with tufts of bristly hairs and commonly strong spines in their axils, deeiduous. Flowers latge, yellow.

1. O. Ficus-Indicus, Haw. Stem erect, sprealing; joints oval anul obovate; beaves subulate, bristly in the axils, without spines; fruit bristly, olyovate, red within, edible. - South Florida. May. - Joints $1^{\circ}$ long.

2. O. vulgaris, Mill. Stem prostrate; joints olovate, pale; spines few and short; fiuit nearly smooth. - Dry sandy soil, Flotida and northward, near the coast. June and July. 
3. O. polyantha, Haw. Stem erect; joints oblong; spines yellow, strong, unequal; flowers numerous around the summit of the joints; stigmas 6. Key West, and waste places around Apalachicola, Florida. June.

4. O. Pes-Corvi, Leconte. Stems prostrate, diffuse; joints small $\left(1^{\prime}-3^{\prime}\right)$, 'ylindrical or somewhat fattened. easily separable, spiny; spines by pairs, unequal, elongated: sepals and petals 8-12, cuneate; stigmas 4; fruit small, fleshy, bristly, 1-2-seeded. - Barren sandy places along the coast, Florida and Georgia. May. - Stems $1^{\circ}-2^{\circ}$ long.

\section{Order 57. GROSSULACEA. (Currant Famly.)}

Spiny or unarmed slurubs, with alternate palmately veined and lobed leaves, without stipules, and with axillary racemose or clustered flowers. Calyx-tube adherent to the ovary, the limb 5-lobed. Petals 5, small. Stamens 5. Ovary 1-celled, with 2 parictal placenta. Styles more or less united. Fruit a 1-celled, many-secded berry. Seeds anatropous, with the minute embryo at the base of liard albumen.

\section{RIBES, I. Curisist. Goosebenir.}

Character same as the order.

* Stems spiny and commonly bristly: peduncles I-3-flowercd.

1. R. Cynosbati, L. Leaves on slender petioles, slightly corlate, roundish, 3-5-loled, pubescent; peduncles 2-3-flowered; stamens and single style not longer than the broad and short ealyx-tube; petals ohovate; berry mostly prickly. - Mountains of North Carolina, and northward. July. - Stem suooth or bristly. Leaves $I^{\prime}-2^{\prime}$ in diametcr.

2. R. rotundifolium, Michx. Leaves small, smoothish, roundish, 3-5lobed, often acute at the base, on slender petioles; peduncles 1-2-flowered; stamens and 2-parted style longer than the narrow-cylindrical calyx-tube; petals spatulate; berry small, smooth. - Mountains of North Carolina, and northward. - Slurub $3^{\circ}-4^{\circ}$ high, often unarmed. Leaves $\frac{1}{2}^{\prime}-1^{\prime}$ in dianeter.

3. R. gracile, Michx. Axillary spine very short; leaves on slenter petioles, pubescent on both sides, the lobes acute, incised, and acutely tootherl; peduncles long, capillary, erect, 1 - 2-flowered ; calyx smooth, tubular-campanulate. - Mountains of Tennessee.

* * Stems without spincs or bristles : racemes many-flouered.

4. R. prostratum, L'Herit. Leaves long-petioled, deeply corlate, with about 5 spreading incised and serrate lobes, smooth; racemes erect; style 2eleft ; berry glandular-bristly. - Mountains of North Carolina, and nortlewarl. May and June. - Stems reclining. Racemes $3^{\prime}-5^{\prime}$ long. Leaves $2^{\prime}-3^{\prime}$ in diameter.

5. R. resinosum, Pursh. Plant clothed in every part with resinons glandular hairs; leaves roundislt, 3-5-lobed; racemes erect; bracts linear, longer 
than the pelicels; ealyx flattish; petals obtusely rhomboidal; fruit hirsute.Mountains of North Curolina. April and May. (•)

\section{Order 58. TOASACEA: (LOASA FamiLY.)}

Herbs, commonly armed with bristly barbed and stineriner hairs. Leaves alteruate, exstipulate. Flowers solitary or asusterel. - Calyx-tube alherent to the 1-eelled ovary, the limb 5-parted and persistent. P'etals 5 or 10 , inserted on the throat of the ealyx. Stamens mostly indefinite, in several parcels, inserted with the petals. Styles united. Cagsule irregularly deliseent. Seeds firw or many, borne on 3-5 parietal placenta, commonly with scanty albumen.

\section{MENTZELIA, Plum.}

Calyx-tnbe eylindrieal or chub-shaped. Petals convolnte in the hud. Stamens commonly 30 or more, the exterior ones often dilated and sterile. Styles 3, united to the midhle. Capsule 3-valved at the summit, with 3 parietal placentre. Cotyledlons broad and flat. - Stems branching. Leares toothed of sinuate-pinnatificl. Flowers yellow.

1. M. Floridana, Nitt. Leaves deltoid-ovate, tootherl, truncate anil 2 lohed at the base; stamens abont 30 ; capsule 6-seeded. — South Floridit. Stem $1^{\circ}$ high. Flowers small, golden-yellow.

\section{Order 59. TURNERACEAL. (Turnera Famly.)}

Iteris or shrubs, with alternate simple exstipulate leaves, and solitary axillary flowers - Calyx firee from the 1-eelled owary, colored, 5-lobed, deciduous. Petals 5, inserted on the throat of the calyx, convolute in the bud. Stamens 5 , inserted into the tulse of the caly $x$ below the petals. Styles 3, distinct, simple, 2-cleft or 2-parted. Stigmas 3 or 6 , many-parted. I'lacente 3, parietal. Capsule loculicilally 3-valved, nany-sected. Seeds anatropons, arilled. Embryo in fleshy albumen. Flowers sessile, or on bracterl or jointed pedicels.

\section{PIRIQUETA, $\Lambda$ ublet.}

Calyx campannlate. Stỵles 3, 2-eleft or decply 2-parterl. Stigmas 6, manyparted. Capsule opening to the base into 3 valres. - llerbs with stellate pubescence. Flowers on jointed pedicels, yellow.

1. P. fulva. Hirsute with fulvons lairs, and stellate-tomentose; stem simple or sparingly branched; leaves lanceolate, obtuse, mostly serrate or toothed, nearly sessile; pedicels (at least the upper ones) longer than the leares, 
often bibracteolate; petals obovate; styles 2-parted. (Turnera cistoides, Ell. P. villosa, Aul.?) - Dry light soil, Florida to North Carolina. June and July. $4-$ Stem $1^{\circ}$ high. Leaves $2^{\prime}-3^{\prime}$ long, the lowest ones broader.

2. P. tomentosa, H. B. K. Stellate-tomentose thronghout; stem simple; leaves nearly sessile, oblong, acute or obmse, obscurely erenate, hoary beneath; pedicels shorter than the leaves. - South Florida. - Stem $1^{\circ}$ high. Leaves ratlier rigid, 1 ' long

3. P. glabra. Stem slender, branching, smooth; leaves smooth, linear, entire, the floral ones small and bractlike; pediecls several times longer than the leaves, and, like the calyx, stcllate-tomentose; petals spatulate; styles 2-cleft. (Turnera glabra, $D C$. ?) - Sonth Florida. - Stem $1^{\circ}-2^{\circ}$ high. Leaves $2^{\prime}$ long. Flowers $1^{\prime}$ in dianeter.

\section{Order 60. PASSIFLORACEA. (PASSion-Flower FAsHLY.)}

Climbing herbs or slirubs, witl alternate mostly stipulate leaves, and axillary often showy flowers. - Calyx of $4-5$ more or less united sepals, commonly bearing at the throat $4-5$ petals, and a crown of slender filaments in one or more rows. Staneus $4-5$, monalchplous below and enclosing the stipe of the ovary. Ovary 1-celled, with $3-4$ priretal plarentie. Styles 3-4, clavate. Fruit fleshy or baceate. Seeds nmmerous, anatropous, included in a pulpy sac. Embryo in the axis of fleshy albumen.

1. PASSIfLORA, L. Passion-Flower. MiY-Por.

Calyx tule very short. Filaments of the crown in 2 or more rows. Fruit baecate - Tendrils axillary. Peduncles jointed, l-flowered.

1. P. incarnata, L. Leaves palmately 3-lobed, acute, serrate; petioles biglandular; peduncles 3-bracted; sepals with a lorn-like point below the apex, whitish within; filaments of the crown in about 5 rows, the two outer ones as long as the sepals; berry large, oval. - In open or cultivated ground, common. June and July 4-Fruit yellowish, as large as a hen's egg. Flowers purple and white.

2. P. lutea, L. Leaves cordate, broadly 3-lobed at the summit, with the lobes rounted and entire; petioles glandless; flowers small, greenish-yellow; peduncles by pairs, bractless; filaments of the crown in 3 rows, shorter than the sepals. - Wools and thickets, Florida to Mississippi, and northward. June and July. $\quad 4$-Fruit oval, purple, $\frac{1}{2}$ in tiameter.

3. P. suberosa, L. Leaves smooth, slightly fringed on the margins, 5nerved at the base, divided above the midlle into 3 ovate entire acnte lobes, the middle lohe largest; petioles short, biglandular alhove the mildle; pedumeles rommonly by pairs; flowers greenish : petals none: filaments of the crown shorter than the sepals, purple at the base; fruit purple. - South Florida. 
4. P. angustifolia, Swart. Lower leaves mostly 3-lohed, witl the lobes lanceolate, obuse, and entire; uppero laves simple, laureolate, mul acute; petioles short, biglandular ; flowers small, solitary or ly patrs, the perlumeles short and bractess; petals none - Soutl filorida. - Stem $10-2^{\circ}$ long. Leares sometimes entire. Flowers $4^{\prime \prime}-6^{\prime \prime}$ wirle, yellowish. Berry purple, als lamge as a pra. Filaments of the crown in 2 rows. Stanens occasionally 4 . Stipules sululate.

5. P. Warei, Nutt. Juaves on short biglandular petioles; the lower ones 3-lobed, acute; the mper orate or oblong, undivided; stipules subulate; perluncles commonly by parrs, about the length of the petioles; flowers very small; segments of the crown few, filiform, shorter than the ealyx. - South Floridit. Probably identical with P'. pallida of the West Indics.

\section{Order 61. CUCURBITACEA. (Gotro FAMLs.)}

Horbs, with sueculent strms, climbing by means of lateral tendrils. Leaves alternate, palmately veined or lobed. Flowers axillary, momerious or dicecious. - Calyx 5-teothed, arlnate to the ovary. Corolla of is listinet, or more or less united petals, colierent with the ealyx. Stamens $3-5$, free or variously uniterl. Anthers long, straight or tortums, commonly commate. Ovary 1-3-relled. Stigmas 3. Fruit (pepo) fleshy or pully, 1-3-celled. Seeds compressed, anatrojous, without albumen. Cotyledons leafy.

\section{Syuopsis.}

1. BRYoxid. Petals 5, distinet, or united at the base. Ovary 3-celled. Fruit 3-seeded, smooth.

2. MEtortilif. Petils 5, united into a campanulate corolla. Ovary 3-celled. Fruit many-serded, smooth.

3. SICyos. l'etals 5 , united at the base into a rotate corolla. Ovary 1-celled. Fruit 1 seeded, hispid.

\section{BRYONIA, I.}

Flowers monercious or dinecions. Calyx 5-toothed. Petals 5, distinct, or united at the base. Stancus 5, triadelphous. anthers tortuous. Style mostly 3-cleft. Fruit ovate or globose, smooth, few-seeded.

1 B. Boykinii, Torr. \& Gray Rough-pubesent; leaves broally cordate, 3-5-lobed; the lateral lohes entire or toothed, the midlle one euspidate; sterile and fertile flowers internixed, $3-5$ in a cluster, short-pedicelled; styles united ; fruit 3-sected ; the seeds 3 -tootlied at the base. - River-banks, Georgia, and westward. June and July. - Stems elongated. Flowers greenish-white. Berry crimson.

\section{MELOTHRIA, I.}

Flowers polygamous or monocions. Calyx of the fertile fiower narrowed above the ovary; the sterile ones eampanulate. P'etals 5 , united into a campanu- 
late corolla. Stamens 5, triadelphous: anther's tortuous, connate, at length separate Style single, with a cup-shaped disk surrounding its base. Stigmas 3. Fruit oval, smooth, many-seeled.

1. M. pendula, L. Stem filiform, smooth; leaves rough, cordate, with $3-5$ angular-toothed lobes; sterite flowers in small raremes; the fertile solitary, on long peduncles; fruit oval, blaekish, drooping. - Light soil, Florida to North Carolina, and westward. May-August. - Flowers small, yellow.

\section{SICYOS, I.}

Flowers moncerions. Calyx flattish, with 5 subulate or minute teeth. Petals 5 , united below into a rotate corollis. Stamens 5, monadelphons or triadelphous. Ovary l-celled, l-ovulct. Style slenter. Stigmas 3. Fruit nembranzceous, bristly, 1-secded. - Amnull herbs. Sterile and fertile flowers mostly from the same axil.

1. S. angulatus, L. Plant hairy and clamny ; leaves thin, cordate, with $3-5$ acuminate denticulate lobes; sterile flowers racenose; the fertile ones in peduncled clusters, whitish. - River-banks, Florida, and northward. JuneAugust.

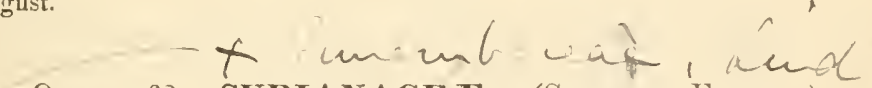

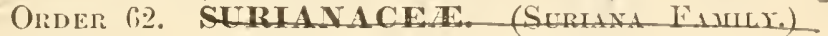

A dowry shrub, with alternate crowled exstipulate leaves, and perfeet yellow flowers, in small axillary lnacted racemes. - Calyx 5-parted, persistent; the base filled with a fleshy torus, which bears the ovaries, petals, and stamens. Petals 5, oblong-obovate. Stamens 10, hairy, the alternate ones short and sterile. Ovaries 5 , distinet, with 2 erect collateral orthotropous ovules in earlh. Styles 5 , each arising from the central angle of the ovary near the base, thickened upwarts. Carpels 1-seceled, indehiscent. Seeds without albumen. Embryo hooked.

\section{SURIANA, Plum.}

Character same as the order.

1. S. maritima, L. - Sea-shore, South Florida. - Shrub $4^{\circ}-6^{\circ}$ high. Leaves linear-spatulate, fleshy, inbrieated near the summit of the branches. Racemes shorter than the leares.

\section{Order 63. CrassumaCe. (Orpine Famir.)}

Sueculent herbs, with exstipulate leaves, and regular perfect and mostly cymose flowers. Sepals $3-20$, more or less mited at the base, persistent. Petals as many as the sepals, inserted on the base of the calyx, imlnicated in the bud, rarely wanting. Stamens as many, or twice as many, inserted 
with the petals. Ovaries as many as the sepals, separate or mited lodow. Carpels several-seded, opuning alonge the inner suture. Seeds anatropous. Embryo straight, in thin albumen.

\section{Synopis.}

1. SEur. Carpels distinet. Sepals $4-5$. Stamens $S$ or 10 .

2 JilMolil's.l. ('arpels united at the base. Sipuls 4 . Sumens 8

3. 1'ENTHOHLM. Carpels uniled above the middle. Sipuls 5 . Stanens 10.

\section{SEDUM, L. OnPINL. STOxL-crop.}

Siprals 4-5. Stamens 8 or 10. Carpels distinct, many-seeled, witl an entire seate at the base of each. - Ilerlos smooth and fleshy.

1. S. telephioides, Mirhx. Stem stont, erect or ascenting, very leafy throngliont leaves alternate, oblong-obovate, tootherl or entire; the lower ones mostly tapering into a petiole, the upper sessile; cymes compact, crect, manyflowerel; petals flen-color, ovate-lanceolate, acuminate; stamens 10; carpels acuminate, pointed with the slender style. - Dry rocks, along the mountaius, Georgia, and northwart. June - Stem $7^{\prime}-12^{\prime}$ high. Leaves $1^{\prime}-1 f^{\prime}$ long.

2. S. ternatum, Nichx. Stems low $\left(3^{\prime}-8^{\prime}\right)$, lrameling at the base, ascencling; lowest leaves crowded, spatulate or ohovate, 3 in a whorl; the upper ones scattered, oval or lanceolate; cyme composed of 3 recurved branches; stamens 8, those of the eentral flowers 10. - Mountain-rocks, Georgia, Temuessee, and northward. May and June. \& - Flowers white.

3. S. pulchellum, Michx. Stems ascending $\left(4^{\prime}-12^{\prime}\right.$ long $)$; leaves rery muncrous, alternate, linear, obtuse; cyme composed of several recurved or spreading branehes; flowers pale purple; sepals much shorter than the petals; stimens 8 , those of the eentral flowers mostly 10 ; carpels tapering into the long aud slender style. - With the precelling. May and Junc.

4. S. Nevii, Gray. Stems low $\left(3^{\prime}-5^{\prime}\right)$, ascending; leaves alternate, srattered, linear-clavate, obtuse; flowers sessile, seattered along the widely spreasling or recurved braneles of the simple eyme; lracts linear, longer than the flowers; sepals lincar-lanceolate, acutish, as long as the linceolate white petals; stamens 8, shorter than the petals; anthers purplish-brown; earpels tapering into the short subulate style - liocky cliffs at Tuscaloosa, Alabama, Rev. $R$. D. Nerius. April and May.

\section{DIAMORPHA, Nutt.}

Sepals 4, rery sliort. Petals 4, oval, coneare. St:umens 8. Carpels 4, united below the midlle, at length spreading, 4-8-secled. - $\mathbf{A}$ small $\left(1^{\prime}-4^{\prime}\right)$ succuIent biennial herb, branching from the batse. Leaves terete, fleshy. Fluwers white.

1. D. pusilla, Nutt. - On flat rocks in the upper districts, Alabama to North Carolina. March and $\Lambda$ pril. 


\section{PENTHORUM, Gronov.}

Sepals 5. Petals 5, ofien wanting. Stamens 10. Carpels 5, united into a 5-cellod capsnle, sprealing at the summit, which falls away at maturity. Sceds numerous. - Perennial (not fleshy) herbs, with alternate serrate leaves, and yellowish flowers our one side of the revolute branches of the sinple eyme.

1. P. sedoides, L. Stem erect, $1^{\circ}-2^{\circ}$ himh; letres lanceolate; petals commonly none. - Ditches and mudely places, common. July-Sept.

\section{Order 64. SAXIFRAGACEA. (Saxtfrage Famit.)}

Calyx of $4-5$ more or less united sepals, free, or more or less aclherent to the ovary, persistent. Petals as many as the sepals, rarely wanting. Stamens as many, or $2-4$ times as many, inserterl with the petals on the calyx. Ovaries 2 or sometimes $3-4$, commonly united lelow, and separate at the summit. Seets few-many. Embryo straight, in the axis of fleshy albumen.

\section{Synopsis.}

Suborible I. SAXIFlidGFE. Herbs. Petals imbricated in the burl. Stipules arlnate to the petiole, or none.

\section{* Stamens as many as the eepals.}

1. Leptropetaion. Styles 3. Capsule 1-celled, beakless.

2. Il CUCirfis. Styles 2 Capsule 1-celled, 2-beaked.

3. BorkixiA. styles 2. Capsule 2-celled, 2-beaked.

* Stamens twice as many as the sepals. - Capsule 2-celled.

4. SAXIFRAGA. Flowers perfect, Stimens 10. Leaves entire or lobed.

5. ASTILBE. Flowers polygamous. Stamens 10 . Leaves ternately compound.

6. TiARflla. Stamens 10 . Petals 5 entire.

$$
\text { + Cipsule } 1 \text { celled. }
$$

7. MitelLA. Stameos 10 Petals 5 piunatifid.

8. CiIrisosplfiviuy. Stamens 8 - 10. Petals none.

Suborder II. ESCALLONIEE. Shrubs. Petals valvate in the bud. Stipules none. Leaves altermate.

9. ITEA. Stamens and petals 5. Flowers in a dense raceme.

Suborder III. HIDRANGIE.E. Shrubs. Petals valvate or convolute in the bud. Leaves opposite. Stipules none.

10. IIYDRANGEA. Petals ralrate. Stamens $8-10$. Styles distinct.

11. DECCMIARIA. Petals valvate. Stamens 20 or more Styles united

12. PHILADELPIILS. Petals convolute. Stameus 20 or more. Styles 4. Capsule 4-valred.

\section{LEPUROPETALON, Fil.}

Calyx-tuhe turbinate, cohering with the lower portion of the orary, 5-parted. Petals 5, minute, spatulate. Stamens 5, very short. Styles 3. Capsule globu- 
lar, 1-celled, with is parietal placenta, many-sected, loculicidally 3-valved ut the

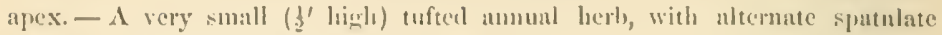
leaves, and solitary teminul white flowers.

1. L. spathulatum, Ell. - Closic dimup soil, Georgia (near Suvannuh) and South Carolinis. March aud April.

\section{HEUCHERA, I. ALriroot.}

Calyx eampanulate, coherent with the base of the ovary, 5-cleft. Petals 5, spatulate. Stamens 5. Styles 2. Capsule l-eelled, with 2 prarictal placentar, many-seederl, 2-beaked, opening between the beaks. Seeds rongh or hispid. Perennial lurbs, with crect scape-like stemss. Lenves ehiefly radical, longr-petioled, romulish cordate, lobed or toothed. Stipmles adnate to the petioles. Flowers eymose-patuicled.

\section{* Caly.x equal-suded.}

1. H. Americana, L. liongh-pubescent ; scape leafless ; leaves crenately or acutely $i-9$-lobed and toothed, the tecth mucronate; panicles long, narrow, loosely-fowerel; calyx as long as the white spatulate petals, much shorter than the stamens and rery slemder styles. - Shady rocky flaces in the middle and upper districts, Mississippi to North Carolina, and northward. April and May. - Scape $2^{\circ}-3^{\circ}$ hight, sometimes with one or two leares. Leaves $2^{\prime}-4^{\prime}$ widle. on petioles $4^{\prime}-12^{\prime}$ long.

2. H. villosa, Michx Scape bracted or somewhat leafy, and, like the petioles and lower surface of the leaves, shaggy with long sprealing rusty hairs: leaves sharply 5-7-lohed and toothed panicle loose; flowers minute; petals white, very narrow, ahout as long as the stamens; styles elongated. (II. caulescens, Pursh) - Mountains of North Carolina and Tennessee. June and July. - Scape $1^{\circ}-3^{\circ}$ high. Leaves $3^{\prime}-8^{\prime}$ wide. Flowers about a line in length.

3. H. Curtisii, Gray. Seape and petioles smooth; leaves slightly lohed; branches of the panicle long, racemose, spreading; petals purple? spatulatelanceolate, scarcely longer than the ealyx; stamens sliglitly pubescent. (II cauleseens, $\beta$, Torr. \& Gray) - Buncombe Comity, Nolth Carolina, Curtis. Flowers liarger than the last.

\section{* * Caly $x$ ollique.}

4. H. pubescens, Pur.l. Glandular-puberulent; stem (20) leafy; leaves round-cortate, acutely $5-7$-lolsed and tootherl, with the sinus closed; stipules obtuse, fringed; flowers nodling; enlyx ovoid, yellowish-green, the ovate lobes ohtuse; petals spatulate, white, nud, like the smooth stamens and styles, includcl. - Mountains of North Carolina, and northward. June anıl July.

5. H. hispida, Pursh. Iirsute or minutely glandular-pmbescent; leares 5-9-lobed, the lobes short, rounded, and numcronately toothed; panicle contracted; the short branches few-flowered; petals broadly spatulate, purjle, rather shorter than the more or less exserted starnens; styles at length much exserted. - High mountains of North Carolina. May and June. - Scape $2^{\circ}-3^{\circ}$ high, sometimes smoothish, as well as the petioles. Flowers larger than any of the preceding. 


\section{BOYKINIA, Nutt.}

Calyx turbinate, coherent with the ovary, 5-cleft. Petals deciduous. Stamens 5, short. Styles 2-3. Capsule 2-3-cellerl, with a eentral many-seeder placenta, 2-beaked, opening between the beaks. Seeds smooth. - Ereet leafy perennial herbs, with alteruate round-cordate palmately lobed and toothed leaves, and small flowers in corymbose eymes.

1. B. aconitifolia, Nutt. Glandular-hairy, or the upper surface of the long-petioled 5-7-lobed leaves smoothish; cymes fastigiate, clamny; flowers secund, white: teeth of the calyx triangular-ovate. - Mountains of Georgia, North Carolina, and Tennessee. June and July. - Stem $1^{\circ}-2^{\circ}$ high.

\section{SAXIFRAGA, L. Sixifrage.}

Calyx free, or cohering with the base of the orary, deeply 5-cleft. Petals 5, commonly deciluous. Stamens 10. Styles 2. Capsule 2-celled, 2-beaked, opening between the beaks. Secds numerous, smooth. - Lowest leaves clustered.

\section{* Stems leafiy.}

1. S. leucanthemifolia, Michx. Hairy and clammy ; leaves spatulate, coarsely toothed, tapering into a long winged petiole; the upper ones linear; paniele diffuse; petals clawed, unequal, white, the 3 larger ones spotted with yellow. - Mountains of North Carolina. July. - Stem 10'-20' high.

\section{* Stems nolied, scapre-like.}

2. S. erosa, Pursh. Leaves oblong, tapering to the base, sharply toothed; scape elammy-pubeseent ; paniele long, slender, loosely flowered ; sepals reflexed, nearly as long as the oval white petals; stigmas sessile. - Sharly banks of streams on the mountains of North Carolina, and northward. July. - Scape $1^{\circ}-3^{\circ}$ high. Leaves $8^{\prime}-12^{\prime}$ long.

3. S. Virginiensis, Michx. Pubescent; leares somewhat fleshy, obovate, crenately toothed; seape clammy ; panicle cynose, dense-flowered; sepals erect, not half as long as the oblong obtuse white petals; styles short. - Rocks on the mountains of Georgia, and northward. $\Lambda$ pril and May. - Scape $4^{\prime}-12^{\prime}$ high.

4. S. Careyana, Gray. Smooth or pubescent ; leaves broadly orate, erenately or sharply toothed, abruptly contracted into a slender petiole; seape slender; panicle loosely flowered ; sepals spreading, half as long as the lanccolateolblong, white, faintly spotted petals; filaments filiform. - Moist slatdy rocks, on the high mountains of North Carolina. June. - Plant $6^{\prime}$ hight.

5. S. Caroliniana, Gray. Glandular-pubeseent; leaves all radieal, deltoid or ovate, coarsely toothed, abruptly contracted into a margined petiole; bracts of the seape few ; panicle diffuse; petals orate, white, with 2 pale spots below the middle, twiee the length of the reflexed sepals; filaments clnb-shaped; carpels turgid, free from the calyx, at length widely spreading. - Damp sharly places on the mountains of North Carolina. May and June. - Scape 6'-12' hight. 
5. ASTILBE, Il:miltun.

Flowers polygamo-licerious. Calyx ('ampanulate, j-parted, nearly free from the ovary. L'etals 5, spatulate, whiluering-persistent. Stamens 10, exserted.

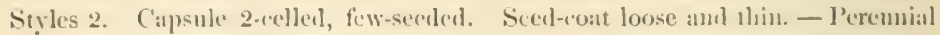
herbs, with rematcly (compound leaves, and small yellowish-white flowers, in panicled racemes.

1. A. decandra, Jon. - Banks of streams amongr the mountains of Georgia and North Curolina. Junc- $\Lambda$ ugust. - Stem $3^{\circ}-50$ hight. Leaves twice or thrice ternately componnd; the leaffets mostly cordate-ovalte, sharply lobed and toothed. Stimmas of the sterile flowers and the stamens and petals of the fertile ones smaller or rulimentury.

\section{TIARELLA, I, False Mitre-Wort.}

Calyx campanulate, nearly free from the ovary, 5-parted. Petals 5, entire. Stamens 10. Styles 2 Capsule membranaccous, 2-valved, the valves very unequal, l-celled, few-seeded. Seeds glohular, smooth. - P'erenual herbs, with scape-like stems, chiefly radical and petioled leaves, and small racemose flowers.

1. T. cordifolia, L. Leaves romnl-rortate, erenately or acntcly loberl and toothed, lairy above, pubeseent beneath, on long hairy petioles; scape ( $t^{\prime}$ 12' high) nakel, or learing $1-2$ altemate leaves above the middle; racemes simple or lrancherl, many flowered ; petals oblong, white or purplish. - Tocky woods and hanks, Mississippi, and northward along the mountins. April and May.

\section{MITELLA, Tourn. Mitre-wort.}

Calyx colerent with the base of the orary, 5-cleft. Petals 5, pinnatifid. Stamens 10. Styles 2. Capsule 2-beaked, 1-celled, 2-valved at the apex, manyseeded. Seeds smooth, horne on two parietal placentæ. - Perennial herbs, with broally cordate and lobed leaves, and small flowers in a terminal raceme.

1. M. diphylla, L. Hairy; radical leaves cordate, a(nte, coarscly serrate and slightly 3-lohed, on long petioles; stem-leaves 2 , opposite, sessile; raceme slender, lonely many-flowered. - Shady woods, on the mountains of North Carolina, and northward. May. - Stem $6^{\prime}-12^{\prime}$ high. Flowers white.

\section{CHRYŚOSPLENIUM, Tourn. Golden Saxifrage.}

Calyx-tulie coherent with the orary, 4-5-lohed ; the lobes obtuse and yellow within. I'etals none. Stamens $8-10$, very short, inserted on a conspicuous disk. Styles 2. Capsule very short, 2-lobed, l-celled, with 2 parietal placentæ, 2-valved at the apex, manr-seeded. - Smooth and suceulent herbs, with roundish leares, and axillary flowers.

1. C. Americanum, Schweinitz. Stems prostrate, forking; leaves mostly opposite, roundish, slightly lobed; flowers solitary, greenish - Cold and sliady 
streams, among the mountains, Georgia, and northward. April and May. 4Stems $4^{\prime}-6^{\prime}$ long.

\section{ITEA, I.}

Calyx campanulate, 5-cleft, free from the ovary. Petals 5, lanceolate. Sta. mens 5, shorter than the petals. Styles 2, nuited. Capsule 2-celled, 2-furrowed, septicidally 2-valved, several-seeded. - A shrub with simple oblong or oval serrate pubeseent leaves, and close mostly drooping racemes of white fragrant flowers terminating the branches.

I. I. Virginica, L. - Swamps, Florida to Mississippi, and northwarl. Niay and June. - Shrub $4^{\circ}-10^{\circ}$ ligh.

\section{HYDRANGEA, Gronov.}

Calyx-tnbe hemispherical, 8 -10-ribbed, coherent with the ovary; the limh 4-5-toothed, persistent. Petals ovate, valvate in the bud. Stamens 8-10, filiform. Capsule crowned with the 2 diverging styles, 2-celicd, many-sceded, opening at the apex between the styles. - Erect shrubs, with opposite petioled leaves, without stipules, and whitish or purplish flowers, in anple eompound eymes; the marginal flowers mostly sterile, with the calyx-lobes enlarged and showy.

1. H. arborescens, I. Smoothish; leaves orate, acute or acuminate, serrate, mostly rounded or cordate at the hase; eymes crowded, flat-topped; sterile flowers few or none. (II, vulgaris, Wichx. H. cordata, Push) - Banks of streams, Florida to Mississippi, and northward. June and July. - Shrul, $4^{\circ}-8^{\circ}$ high. Leaves $3^{\prime}-6^{\prime}$ long.

2. H. radiata, Walt. Leaves ovate, acuminate, serrate, mostly corlate at the base, white-tomentose beneath; cymes flat-topped; sterile flowers few. Rich soil, Georgia, Carolina, and Tennessee. May and June. - Shrub $4^{\circ}-8^{\circ}$ high.

3. H. quercifolia, Bartram. Young branches and leaves densely tomentose; leaves oval, sharply 5-lobed, serrate; cymes clustered, forming a close oblong panicle; sterile flowers large, numerons. - Shatly banks, Florida, Georgia, and westward. May and June. - Shrub $3^{\circ}-6^{\circ}$ high. Leaves $4^{\prime}-8^{\prime}$ long. Sterile flowers whitish, turning purple.

\section{DECUMARIA, L.}

Flowers all fertile. Calyx-tube turbinate, coherent with the ovary, $7-10$ toothed. Petals valvate in the bud, oblong. Stamens $21-30$. Styles uniterl, persistent. Stigna thick, 7-10-rayed. Capsule 10-15-ribbed, 7-10-celled, bursting at the sides; the thin partitions at length separating obliçuely into uttmerous chaffy seales. Seeds numerous, suspended. - A smooth elimbing shrub, with opposite ovate or oblong entire or serrate leaves, and numerous odlorous white flowers in compound terminal cymes.

1. D. barbara, L. - Banks of streams, Florida to North Carolinn, and westward. May and June. - Leaves shining, sometimes pubescent. Capsule, with the persistent style and stigma, urn-shaped, pendulous. 


\section{PHILADELPHUS, I. Srmisa.}

Calyx-tulse turbinate, cohering with the ovary, the limb 4-5-parted, persistent. Petals 4-5, convolute in the bud. Stamens 20-40, shorter than the petals. Styles mostly 4 , more or less uniter. Cipsule mostly 4-celled, loculi('idally 4-valved, many-seceded. - Shrubs with simple opposite 3-5-ribbed leaves, withont stipules, and large white solitary or cymose flowers.

1. P. grandiflorus, Wille. Branches and leaves pubescent; leaves ovate or ovate-ollong, acuninate, sharply serrate; flowers solitiry, or 2 or more in a terminal cyme; calyx-lobes ovate, acuminate, much longrer than the tube. lianks of streams, Florida to North Curolina. April and May. - Shrub 6 $0^{\circ}-10^{\circ}$ liggh, with lone and slencler branches.

2. P. inodorus, L. Smooth; leaves entire or nearly so, ovate or ovateoblong, acnte; calyx-lobes ovate, acute, as long as the tube- L Pper tistricts of Alabama to South Carolina. May, - Flowers smaller than in the last.

3. P. hirsutus, Nitt. IIairy; leaves sinall, orate, ac'ute, slarply serrate; flowers 1-3 together, terminal, and on short lateral branches; ealyx-lobes ovate, as long as the tube. - North Carolina and 'Tennessee. $-\Lambda$ small shrub. Leaves $1^{\prime}$ long. Flowers $\frac{1}{2}$ wide.

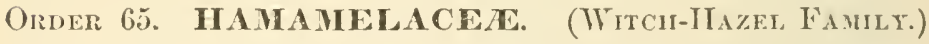

Trees or slumbs, with alteruate leaves, deciluous stipules, and chustered or spiked, often polygamous or monecious flowers. - Calyx-tule colserent witl the base of the ovary. Petals $4-5$, long and linear, or none. Stamens twice as many as the petals, with the alternate ones sterile, or nnmerous and perfert. Styles 2. Capsule wooly, 2-eelled, opening at the smmmit. Serels anatropous, lony, $1-2$ in each cell. Embryo large and straight, in searce albumen.

\section{Synopsis.}

1. HAMAMELIS. Calyx-lobes and petals 4. Fertile stamens 4. Ovules solitary in each eell, suspended.

2. Fotileigilla. Caly $\times 5$ - $i$-toothed. Petals none. Stamens numerous, all ferile. Ovules solitary, suspended.

3. LIQUIDAMBAR. Calyx and corolla none. Flowers polygamous or movœcious, eapitate. Stamens numerous. Ovules several.

\section{HAMAMELIS, L. Wiтсн-НА\%е.}

Calyx 2-3-bracted, 4-parted. Petals 4, long and linear. Stamens 8, the alternate ones short and sterile. Styles 2. Capsule loculicilally 2-valved at the apex, the outer roat separating from the immer one, which encloses the seed, but soon splits elastically into 2 valves. Scels large, bony, - Shrubs. Leares short-petioled. Flowers yellow, clustered. 
1. H. Virginica, L. - Low woods, Florida to Mississippi, and northward. November. - A large shrub. Leaves obovate or oval, oblique, crenate-toothed, pubescent; flowers appearing when the leaves are fulling.

\section{FOTHERGILLA, L.}

Calyx truncate, obscurely 5-7-toothed. Petals none. Stamens numerous, slenter, perfect. Styles 2. Capsule 2-lobed, 2-celled, 2-ralved at the apex, with a single bony seed in each cell. $-\Lambda$ shrub, with oval or obovate leaves, and white odorous flowers in terninal braeted spikes, appearing before the leaves.

1 F. alnifolia, L. - Swamps, Floricta to North Carolina. March and A pril - Shrub $2^{\circ}-4^{\circ}$ high. Leaves smooth, or tomentose beneath, toothed at the summit. Capsule hitiry.

\section{LIQUIDAMBAR, L. Sweet-Gun.}

Flowers monoeclous, in globular 4-bracted spiked heads. Calyx and corolla none. Stamens very numerous. Styles 2. Ovary 2-celled, with numerous ovules in each cell. Cajpsules united in a close heal, woody, 2-beaked, opening between the beaks, $1-2$-seeded. Seeds wing-angled. - Trees. Heads of sterile flowers sessile, erowded; those of the fertile flowers on long nodding peduneles.

1. L. Styraciflua, L. Branebes with corky wings; leaves roundish, with 5-7 acuminate serrate sprearling lohes. - Swamps, Florila to Mi-cissippi, and northwarel. March. - A large tree. The exposed juice hardens into a fragrant gum.

\section{Order 6if. TMBELLIFERAe. (Pargley Famly.)}

Herbs, with chiefly hollow and furrowed stems, alternate mostly compound leaves, with dilated or clasping petioles, and umbelled flowers. Calyx-tube colserent with the ovary; the limb 5-lobed or obsolete. Petals 5 , mostly incurved, inserted with the 5 stamens on the edge of the disk that erowns the ovary. Styles 2. Fruit composed of 2 indehiscent carpels (mericarps), suspended from a filiform axis (carpophore), and colsering by their inner face (commiswure) : each furnished with 5 primary ribs, and often with as many secondary ones; the intervening spaces (intereds:) usually containing channels (vittce), which are filled with aromatic oil. Seed solitary, suspended. Embryo minute, at the base of horny albumen. - Umbels and partial umbels (umbellets) commonly subtended by an involucre or involucel.

\section{Synopsis.}

1. Inner face of the seed flat, or neariy so.

* Ymbels simple, or one growing from the summit of another. Stems creeping.

1. IIYDiOCOTYLE. Fruit orbieular, flattened. Leaves rounded.

2. CRANTZIA. Fruit globular. Leaves linear, fleshy. 
* Comleje enpitate (flower sussile).

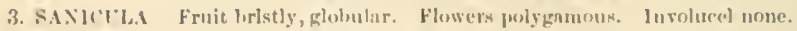

4. Ekrigitu. Fruit scaly, turbinste. Flowers perfect, liractedl. lleads iuvolucelled.

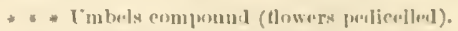

- Fruit with bristly ribs; the hri-tlas in a single row.

5 IIACUS. Fruit 9-rihbed. Leaves thely 2-3-pinnate.

+ + Fruit suooth or slightly roughened.

+ Fruit wingiess, laterally comprexsed, or twin.

6. CIC'UTA. Flowers white. Fruit subglobose. Caly $x$-limb E-toothell.

7. ChYl'Tot.kis. Flowers white. Fruit oblong. Calyx-liml, olsolete. Divisions of the leaves lanceolate.

8. LEPTOCACLIS. Flowers white. Fruit ovate, rough Calyx-limb olsolete. Divisions of the leares tiliform.

9. DIsCopleukA. Flowers white. Fruit ovoid. Calyx-limb 5-toothed. Dirisions of the leaves filiturm.

10. IIBLosc1.1DIC.II Flowers white. Fruit oblong. ('alyx-liub obsolete. Inroluere 13 leaved, or none.

11. SIUM. Flowers while. Fruit globose. Calyx-teelh minute or none, Involuere 5-6leared. Leares pinuate

12. BUPLEURCM. Flowers yellow. Fruit oroil-oblong. Leares simple.

13. Ziz1A. Flowers yellow. Fruit oroilt-oblong; the intervals witl 3 vitta.

14. THASPILY. Flowers yellow or dark purple. Fruit ovoid or ublong; the intervals with single rittæ.

15. LIGUSTICUy. Flowers white. Fruit elliptical, with sereral vitta in each interval.

++ ++ Fruit dorsally eompressed, winged on tlue margins.

$=$ Margins of the fruit double-winged. Flowers white. Leares pinnately compound.

16. AXGFI.ICA. Carpels 3-ribbed on the bick, the intervals with single vitte.

17. ARCilixfielCA. Carpels 3 -ribled on the back the intervals with 2 or more vitta.

18. CONIOSELINUM. Carpels 3 -winged on the back; the interrals with $2-3$ vitta.

$==$ Margins of the fruit single-winged.

19. TIEDEMANIIA. Fruit broadly winged. Marginal wings renote from the 3 doreal ones. Leaves simple, terete.

20. AlicllEmoli. Fruit as in No. 19. Leares pinnate or teruate.

21. IIERAClLEU. Fruit with all the ribs equidistant. Marginal flowers sterile. Plant woolly.

\$2. Inwer face of the seed concave.

22. C11.FROPHYLLTM. Fruit linear-oblong, narrowed towards the apex.

23. OsyorRIIIZA. Fruit linear-elarate, narrowed towards the base.

\section{HYDROCOTYLE, Tomn. Marsi Pexiytort.}

Calyx-tecth obsolete. Jetals not incurred. Fruit laterally compressed, orbieular. Carpels 5-ribhed, the dorsal and lateral ones often olsolete, the intermediate ones enlarged. Vitta none. - Low marsh herlss, with slender ereeping stems, and peltate or reniform leaves. Lmbels small, axillary. Flowers white.

1. H. Americana, I. Smooth; leaves orhicular-reniform, crenately 7 lohed; umbels sessile, 3-5-flowered; frnit 2-ribhed. - Mountains of North Carolina, and northward. July. - Stems stoloniferous. Leaves very thin, glossy. 
2. H. umbellata, L. Smooth; leaves orbienlar, peltate, obscurely lobed, crenate; unbels globose, on peluncles commonly longer than the petioles; fruit 2-ribbed on each side. - Wet places, Florita to Mississippi, and northward. May. - Leaves $\mathbf{l}^{\prime}$ wide.

3. H. ranunculoides, L. Smooth; leaves orbienlar-reniform, erenately 3-5-lobel; umbels few-flowered, on peduncles mueh shorter than the petioles, mostly nodding in fruit; fruit obscurely ribbed. - Springs and muddy places, Florida to North Carolina, and westward. May and Jume. - Petioles $6^{\prime}-12^{\prime}$ long. Peduncles I' long.

4. H. interrupta, Muhl. Smooth; leaves orbicular, freltate, erenate; numbels proliferons, the nearly sessile clusters forming an interrupted spike; fruit strongly ribbed. - Wet places, Florida to Mississippi, and northwart. June. - Petioles longer than the perhucles.

5. H. repanda, Pers. Pubeseent; leaves broadly ovate, truncate or slightly cordate at the base, glantular-serrate; umbels eapitate, few-flowered, shorter than the petioles; fruit strongly ribbed. - Low grounds, Florida to North Carolina, and westward. July.

\section{CRANTZIA, Nitt.}

Calyx-tecth obsolete. Petals roundish. Fruit globular. Carpels 5-ribherl, the lateral ribs thickened and corky. Vittæ single in the intervals, with 2 on the commissure. - Small creeping marsh herbs, with fleshy linear leaves, anıl small whitislı flowers in axillary umbels.

1. C. Iineata, Nutt. (Iydrocotyle lincuta, Michx.) - MIudly banks, near the coast, Fioridla to Mississippi, and northward. July. - Leaves $1^{\prime}$ long, with cross partitions, narrowed towards the base, obtuse. Involnere 5-6-leaved.

\section{SANICULA, 'Tumn.}

Calyx 5-toothed, persistent. Fruit globose, without ribs, armed with hooked prickles; the carpels not separating spontanconsly, each with 5 vitte. - Perennial erect branching herbs, with palmately-divided long-petioled leaves, and polygamous flowers in small heads, risposed in a loose expanding cyne.

I. S. Marilandica, L. Leaves $5-7$-parted, the divisions lobed and toothed; hearls many-flowered; sterile flowers numerons on slender pedicels; styles long, recnrved. - Dry woods, Gcorgia, and northward. May, - Stem $2^{\circ}-3^{\circ}$ highls.

2. S. Canadensis, L. Leaves 3-5-parted, the divisions lobet and toothed; heals few-flowered; the sterile flowers $(1-3)$ nearly sessile; styles short and straight. - Dry woods, common. May. - Stem $1^{\circ}-2^{\circ}$ high. Branches of the cyme long aud spreading.

\section{ERYNGIUM, Tourl. उuttox-Syakleot.}

Calyx 5-toothed, persistent. Styles slender. Fruit turhinate, eovered with' scales or tubereles, without ribs or vitte. - Ilerbs, with spiny or bristly mostly 
lobed or torth d leaves, und white or blne bracted flowers closely se'ssile in dense leats.

$$
\text { * Fruit sraly: stoms irect. }
$$

1. E. yuceafolium, Michx. Leaves linear, coneave, hristy or foncwhat sping on the matrons, parallel-vened ; latwes of the involuere mo-tly entire, shorter than the broally oxate head ; brats entire. - J'ine harrens, mostly in d:unp soil, Floridli, and northward. June. If - Stem $2^{\circ}-3^{\circ}$ high. leaves distant, the lowest ones $10-11^{\circ}$ long. Flowers white.

2. E. Ravenelii, Gruy. Leaves linear, elongaterl, nearly trete, greoved on the uper surface, obsurely deutieulate; leaves of the involucre 3-eleft, ats long as the hearl; brats 3-cleft, spine-pointerl, longer th:m the flowers. - Low pine harrens, near the heal-waters of Cooper river, South Carolina. Razenel. Sept. and (1)t. - Stem $12_{2}^{10}-3^{\circ}$ high. Flowers white.

3. E. Virginianum, Lam. Leares linear-lanceolate, flat; the lowest ones spiny-scrrate with the tecth ineurved, or nearly entire, veiny; the upper narrower, syiny or pinnatifid; leaves of the involucre (blue) 3-5-cleft, longer than the head; bracets 3-eleft, as long as the flowers. - Marshes, Florilla to Mississippi, and northw:trl. July. 4 or (2) - Stem $2^{\circ}-3^{\circ}$ high. Flowers blue.

4. E. præaltum, Gray. Leaves lancelate, flat, veiuy, scrate; the op)Jer ones linear, sping-toothel; leaves of the involuere $2-3$ times as loner as the heat ; bracts tricuspiclate, barely as long as the mature calyx. (L. Virginianum, Ell.) - Fresh mar-hes near the coast, Georgia to North Carolina. Aurust. - Stem $4^{\circ}-6^{\circ}$ high. Lowest leaves $1^{\circ}-2^{\circ}$ longr and $2 \frac{1}{2}^{\prime}-3^{\prime}$ wide. Fluwers white.

5. E. virgatum, Lam. Jeaves short, oblong or oblong-ovate, scrrate, the npper ones toothed or divided; leaves of the involucre entire, or with 2-4 hristly teeth, longer than the head; lnacts 3-toothel. (E. ovalifolimu, M/ich.r.) - Pinc-harren swamps, Florida to North-Carolina, and westward. August. Siem $1^{\circ}-2^{\circ}$ long. Leaves $2^{\prime}-3^{\prime}$ long, sometimes cordate. Flowers blue.

\section{* Fruit gromular: stems diffise.}

6. E. aromaticum, Baldw. Stems clusterel, prostrate, very leafy; leaves spanlate, pinnately lober, eartilaginons on the margin; the 3 upler lobes broad and spine-pointed, the lower ones scattered and bristle-hike; leaves of the involuere 3-eleft, longer than the globose lieal; loracts 3-toothed. - Dry pine barrens, Jast and South Florida. Sept. - Stems l' long.

7. E. Baldwinii, Spreng. Small, prostrate, lrandhing; leaves thin; the carliest ones ovate, sharply serrate or toothed, lone-petioled, the others 3-parted, with the middle segment laneeolate and commonly 3-toothed; leares of the involucre subulate, longer or shorter than the obloner head; bracts spatulate, obtuse, harely exeeding the calyx. - Iow sandy pine barrens, Georgia, Florida, and westward. September. (1) ? - Stens $5^{\prime}-10^{\prime}$ loner. Flowers blue.

8. E. Cervantesii, Laroch. Stems prostrate, diffusely branched; earliest leares linecolate or ohlong, entire, or sparingly toothed, lonor-petioled, the others sessile, 3-parted, with the segments linear or filiform and entire; leaves 
of the involuere subulate, as long as the hemispherical hear; braets sulublate acnte, twice as long as the ealyx. (E. filiforme, Shuttl.) - Damp sanly soil along the coast of West Florida. July and Angust. (2) - Stems $1^{\circ}-2^{\circ}$ long. Leaves somewhat fleshy. Flowers very small, blue.

\section{DaUCUS, Tourn. Carrot.}

Calyx 5-toothed. Corolla irregular. Fruit ovate or oblong; the carpels with 9 unequal bristly or prickly ribs, and a single vitta under the larger ribs. - Annual or biennial herbs, witl pinnately finely dissected leaves and involucre, and white or yellowish flowers.

1. D. pusillus, Michx. Annual; stem rongh with rigil reflexed lairs; leaves twice pinnate, with the divisions linear; bristles of the fruit barbed.Dry sterile soil, Florida to South Carolina, and westward. June. - Stem $1^{\circ}-3^{\circ}$ high. Umbels long-peduncled.

\section{CICUTA, L. Whter-Hewlock.}

Calyx 5-toothed. Fruit roundish. Carpels with 5 flattish equal ribs; the intervals with single vittæe, and 2 on the inner face. - Smooth perennial marsh herbs, with hollow stems, and twice pinnately or ternately divided leaves. Involucels many-leaved. Flowers white.

1. C. maculata, L. Stem large $\left(3^{\circ}-6^{\circ}\right.$ high $)$, purplish; leaflets oratelanceolate, acute, coarsely serrate ; umbels large, many-rayed. — Harshes, Florida to Mississippi, and northward. July. - Plant rery poisonous.

\section{CRYPTOT正NIA, DC.}

Calyx-teeth obsolete. Fruit oblong, contracted at the sirles. Carpels equally 5-ribbed, with very slender single vitte in each interval, and one under eacli rib. - $A$ smooth perennial herb, with trifoliolate leaves on long petioles. Leaflets Jarge, ovate, doubly serrate and mostly lobed. Rays of the umbel few and very unequal. Involucre none. Involucels filiform. Flowers white.

1. C. Canadensis, DC. (Chærophyllum Canadense, Prss.) - Rich shady soil, North Carolina to Mississippi, and northward. July. - Stem $2^{\circ}$ high.

\section{LEPTOCAULIS, Nutt.}

Calyx-teeth obsolete. Fruit ovate, compressed on the sides, often rough or bristly. Carpels 5ribbed, the intervals with single vittæ, and 2 on the fice. Slender smooth herbs, with fincly dissected leaves, and white flowers. Umbels few-rayed. Involucre none. Involucel few-leaved.

1. L. divaricatus, DC. Annual; stem $\left(6^{\prime}-18^{\prime}\right.$ high $)$ widely loranched; leaves 2-3-pinnatifid, with the divisions filiform; umbel 3-4-rayed. (Sison pusillum, Michx.) - Dry sandy soil, Florida to North Carolina. April. - Fruit very small, roughencd with minute scales. 


\section{DISCOPLEURA, I)C.}

Calyx-tecth subulate, jersistent. Fruit orate: the carpels etrongly 3-ribled on the batck, and with two lateral ribs united with a thick corky margin. Interrats with single vitta. - Smooth ammuls, growing in marslues deares pinnately disected, with the filifonn divisions often whorled. Involucre and involucel conspicuous. Flowers white.

1. D. capillacea, DC. Unbets 3-10-rayed; leaves of the involuere mostly 3-5-cleft ; fruit orate. (Ammi (alpillacem, Michr.) - Brackish marshes, Filorida to Mississippi, and northwart. Jume and July. - Stem $1^{\circ}-2^{\circ}$ high, much branched. Varliest leaves simple, or simply pinnite.

2. D. costata. Stem tall, manching above; leaves of the involucre $10-$ 12, many-parterl ; fruit oratte, deeply sulcate. (Ammi costitum, Ell.) - Swamps of the (Igeechee liver, Georgia. October aud November. - Stem $4^{\circ}-5^{\circ}$ highth. Firuit larger than in No. 1.

3. D. Nuttallii, I) C. Lmbels many-rayed; leaves of the involncre 5-6, entire; fruit globose. - Tampa Bay, Florida, and westward. - Stem $2^{\circ}-6^{\circ}$ ligh.

\section{HELOSCIADIUM, Kooh.}

Calyx-teeth 5, or olsolete. Fruit ovite or oblong, flattened on the sides, the earpels equally 5-ribbed. Intervals with single vitta. Flowers white.

1. H. nodiflorum, líoch. Stems prostrate or crepping; leaves pinnate; leaflets ovate-lancelate, scrate; unbels short-pedunclerl, opposite the leaves; involuce 1-2-leaved or none; involueel 5-6-lavod. (Siun nodiflornm, L.) - Jitches, \&e. around Clarleston. Introduced. $\Lambda_{\text {pril-June. }}$ Stems $2^{\circ}$ long.

\section{SIUM, L.}

Calyx-teeth small or obsolete. Fruit ovate or globular, flattened at the sides; the earpels with 5 equal eorky ribs. Intervals usually with several vitte. Marsh or aquatie perennial herhs. Leaves pinnate; the immersed ones dissected into numerots eapillary divisions. Inwolucre several-leaved. Flowers white.

1. S. lincare, Miehx. Leaflets varying from lincar to oblong, fincly and sharply serrate; calyx-tecth minute; fruit glolubir, strongly ribbed. - Alener streams, commonly in water, Florida to Mississippi, and northward. July. Stem $2^{\circ}$ ligh.

\section{BUPLEURUM, Toirn.}

Calyx-tecth obsolete. Fruit flattened at the sicles, or twin, ovate-olylong. Carpels 5-ribbel, the intervals witl ${ }_{1}$ or without vitte. - Smooth herbs, witl entire simple leatres, and yellow flowers.

1. B. rotundifolium, L. Leaves ovate, perfoliate; umbel 5-rayed ; involucre none; leares of the involucel 5, ovate, mucronate. - Fields, North Carolina. - Introducecl. 
13. ZIZIA, DC.

Calyx-teeth obsolete. Fruit ovoid-oblong, twin. Carpels 5-ribbed, the cross section nearly orbieular. Vitte 3 in each interval, and 4 on the commisinre. A smooth perennial lierb, with 2-3-ternately componnd leaves, and yellow flowers.

1. Z. integerrima, DC. Stem slender; leaflets oblong-ovate, entire; rays of the nubel long and slender; involuere none. (Smyrnium integerrimum, L.) - Rocky woods, Mississippi, and northward. May and Junc. - Sten $1^{\circ}$ $2^{\circ}$ high.

\section{THASPIUM, Nitt.}

Calyx-teeth short or olsolete. Fruit ovoid or oblong, somewhat flattish at the sides. Carpels commonly equally and strongly 5-ribbed. Intervals with single vitta. - Perennial herls, with 1 - 2-ternately-divided leaves (the lowest often entire), and yellow or purple flowers. Involuc re none.

\section{* Culyx-teeth short, obtuse.}

1. T. barbinode, Nutt. Stem pubescent at the joints; leares 1-2-ternate, more or less pubescent; leaflets cuneate-ovate, entire toward the base, toothed above, the terminal one narrowed into a long stalk; fruit oblong, the ribs mostly unequal; flowers pale yellow. - River-banks, West Florila, and northwark. May and June. - Stem branching above, $2^{\circ}-3^{\circ}$ liggh. Leaflets $\frac{1}{2}^{\prime}-1^{\prime}$ long, often 2-3-lohed.

2. T. pinnatifidum, Gray. Branches and umbels ronghish-pnberulent ; leaves 1-3-temate; leaflets 1-2-pinnatifil, the lobes linear or oblong; fruit oblong, narrowly 8 -10-winged, the intervals minutely scabrous. - Mountains of North Carolina and Tennessee. - Stem $2^{\circ}-5^{\circ}$ high.

\section{* Calyx-tecth olsolete.}

3. T. aureum, Nutt. Lcaves 1-2-ternate; the leaflets oblong-lanceolate, sliarply serrate, the lateral ones unequal at the base; fruit oral, the ribs thick or winged. (Smymium auremm, L.) - Rich soil, Florida, and northward. May. - Stem $1^{\circ}-2^{\circ}$ high. Lowest leaves sometimes cordate and undivided. Flowers yellow.

4. T. trifoliatum, Gray. Leaves crenate; the lowest ones usually simple and cordate, the ofhers trifoliolate; leaflets ovatc-lanceolate, mostly obtuse at the base; fruit roundish, ribbed or winged. (Sinyrnium cordatum, Wult. S. atropurpureum, Lam.) - Rich soil, Florida to Mississippi, and northward. June. - Stem $1^{\circ}-2^{\circ}$ high. Flowers yellow or dark purple.

\section{LIGUSTICUM, L. Noxpo.}

Calyx-teeth minute or obsolete. Fruit elliptieal, nearly terete. Carpels with 5 aeute equal and somewhat winged ribs. Vittæ numerons. Involucre short, 2-6-leaved - Perennial herbs. Leaves 1 -3-ternately divided. Flowers white.

1. L. actæifolium, Michx. Stem tall $\left(3^{\circ}-6^{\circ}\right)$, sinootl, branched; leaves 3-ternately divided; leaflets ovate, toothed; unbels very numerous, pani- 


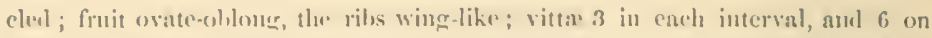

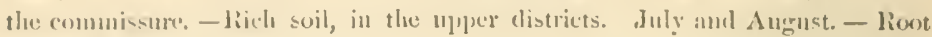
larger, aroniatic.

\section{ANGELICA, I.}

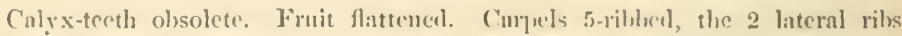
dilated into wings. Vitte simgle in eath interval, and $2-4$ on the commissme Seed allerent to the pericarp. - Chicfly geremial herbs, with compound lenves, no involucre, and white flowers.

1. A. Curtisii, Buckley. Stem smooth; leaves twiece ternate, or the di visions yuinate; leaflets thin, ovate or owate-ianceolate, often sliẹlitly (ordatu", shaply toothed; frut broully winged ; commissure with 2 vitta. - Iligh monn. tains of North Carolina. August. - Stem $3^{\circ}$ hight. Petioles large aud sheatl. ing.

\section{ARCHANGELICA, Hofim.}

Calyx-tecth short. Fruit flattened. Carpels ribher as in Angelicat. Vitte very numerous, entirely surounding the loose seel. - l'eremial herhs. Leaves 1-2-ternate, with pimate divisions. Lenflets touther. Ipjer petioles infiated. Involucre none. Involncel many-leaved. Flowers white.

1. A. hirsuta, Torr. \& Gray. Tpuer part of the stem aml umbels softly

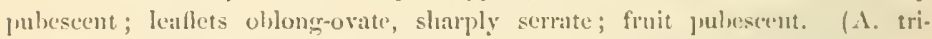

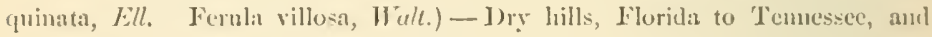
northward. July. - Stem $2^{\circ}-3^{\circ}$ ligrl.

2. A. dentata, Chrinn. Stem siender, sinooth; mmlels sligrhtly pubescent; leaflets lanceolate, stronerly veined, coarsely touthed; fruit smosth. - 1)ry pine barens, Florida. September. - Stem $2^{\circ}-3^{\circ}$ high, branching above; teeth of the small $\left(\frac{1}{2}\right)$ leaflets spreating

\section{CONIOSEIINUM, Fischer.}

Calyx-tecth obsolete. Fruit oral. Carpels somewhat flattened on the baek, 5-winged, with the lateral wings twice as broad as the dorsal ones. Vittie 2-3 in each interval, and $4-8$ on the commissure. - Smooth herls. Jeases thin, fincly 2-3-pinnately compoumb. Involuere none. Involucels subulate. Flowers white.

1. C. Canadense, 'Torr. \& Gray. I, Eflets pinnatifil, with liusar-oblong lobes, the petioles inflated; rass of the umbel slemler; finit broally ovul.Iligh mountains of North Carolina, and northwarl. Augrust. - Stem $3^{\circ}-5^{\circ}$ high.

\section{TIEDEMANNIA, IC.}

Caly'x 5-toothed. Frnit whovate, compressed. Carpels with 5 sharp and slender ribs, winged on the margins. Intervals with single vitte, aml 2 on the commissure. $-\Lambda$ smooth erect perennial herl, with terete petioles destitute of leaflets. Involncre and involucel 5-6.leaved. Flowers white. 
1 T. teretifolia, DC. (Simm teretifolium, Ell.) - Pine-loaren swamp, Florida to North Carolina, and westward. August. - Stem $2^{\circ}-4^{\circ}$ high. Petiules with eross partitions.

\section{ARCHEMORA, DC.}

Calyx 5-toothel. Fruit oval or obovate, flattened on the back. Carpels with 5 slender ohtuse rils, winged on the margins. Intervals with single vitte, and 4-6 on the commissure. - Smooth herbs, with pinnately-divided leaves, and white flowers. Involuere few-leaved or none. Involucel nuny-leaved.

1. A. rigida, DC. Leaves pimate; the leaflets $(3-9)$ varying from linear to oblong, varionsly toothed or entire. (Sinm rigilus, tricuspiclatum, and denticulatum, Ell.) - Swamps, Floricla to Mississippi, aud northward. August and September. - Stem $2^{\circ}-5^{\circ}$ highl.

2. A. ternata, Nutt. Leaves ternate, with the leaflets linear, entire and strongly nervel; the lowest ones on very long petioles. (Neurophyllum longifolium, Torr. \& Gray.) - Low or swampy pine barrens, Florida to North Carolina. November. - Stem slender, 20 high. Petioles of the lower leaves $1^{\circ}$ or more long. Root bearing tubers.

\section{HERACLEUM, L.}

Calyx-teeth minute. Fruit oval, flat. Carpels with the 2 lateral ribs distant from the 3 dorsal ones, and near the dilated margins. Vitte shorter than the earpels, single in the intervals, and usually 2 on the commissure. - Stont perennial herbs, with pinnately or ternately divided or lobed leaves on inflatel petioles, and white flowers. Involuere few-leaved. Involucel many-leaved. Marginal flowers commonly larger and radiant.

1. H. lanatum, Michx. Villous; leaves very large, ternate; leaflets lroadly cortate, deep? y lober, hoary benenth. - Mountaius of North Carolina. June. - Stem $4^{\circ}-8^{\circ}$ high, strongly furrowed.

\section{CIAROPHYLIUM, I.}

Calyx-tecth obsolete. Fruit oblong or linear, tapering at the apex, contracterl at the sides. Carpels deeply furrowel on the commissure, with 5 ohtuse equal ribs. Intervals with single vitta. - Herbs, with compound fincly lissected leaves, and white flowers. Involucre few-leaved or none. Involucel many-leaved.

1. C. procumbens, Lam. Stem weak, slightly pubescent; leaves ternately divisled; the divisions bipimnatificl, with oblong obtuse lobes; unubel sessile, of 2-3 long rays; involucel $4-5$-leaved, few-flowered; fruit oblong, abruptly pointel, finely ribbed. - Shady river-banks, Mississippi to Nortl Carolina, and northward. April and May. (1) or (2) - Stem $6^{\prime}-18^{\prime}$ long.

2. C. Teinturieri, IJook. \& Arn. More pubeseent; lobes of the leaves narrower and acute; fruit oblong-linear, more strongly ribhed and tapering at the apex; otherwise like the last. - Banks of the Apalachicola River, Florida, and westward. March and $\Lambda$ pril. - Stem erect, $1^{\circ}$ high. 


\section{OSMORRHIZA, liaf.}

Calyx-tecth cilsolete. Frnit clavate, angred. Carpels with bristly rils, fur. rowcil on the commisure. Vitte none. - l'erenuial herlss with aromutic roots latives 2-ternate, with the leatlets ovate, toothed or serrate. Limbels opposite the leaves. Involucre and incolncel 2-5-leared. Flowers white.

1. O. brevistylis, I)C. Styles very short, conical; fruit "omewhat tapering at the apex. - Momtains of North Carolina and northwart. June. Plant hairy, $1^{\circ}-1 \frac{10}{2}$ high. Leaflets thin, acuminate, pinnatifid.

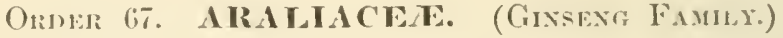

Tumbelliferons lierbs, shrubs, or trees, nearly as in the last orter; lut the flowers (chicely polygamous) with flat and sperading petals, the styles and carpels of the baceate firut nsually more than two, and the embryo at the apex of eopious fleshy albumen.

\section{ARALIA, I. Sirsal'AriLha.}

Calyx-tecth 5, or none. P'ctals, st:amens, and spreading styles 5. Berry drupaccous, 5-lohed, 5-eelled. - Ifrbs or shrubs. Teaves compound. Umbels corymbed or pauded. Flowers whitish. Berry black.

\section{* Stems herbacions.}

1. A. racemosa, L. Stem smootlı, leafy, widely bramched ; leaves ternately decompound; leaflets large, broally cordate, donbly serrate; nubels very umurons, paniclecl. - Rich woods aloug the montatins, Georgia, and northward. July. - lioot thick, aromatic. Stem $3^{\circ}-5^{\circ}$ high.

2. A. hispida, Michx. Stem leafy, somewhat shrubly at the base, hristly, leaves bipinnately compound ; leaflets lanceolate-orate, sliarply scriate; umbels in naked perduncled cormuls. - Nountains of North Carolina, and northward. June and July. - Stem $1^{\circ}-2^{\circ}$ hight.

3. A. nudicaulis, L. Stem maked, short, bearingr 3 long-peduncled umbels at the atex; Ieaf solitary, raclicil, long-perioled, ternately dividerl, the divisions çuinlte; leaflets oblong-ovate, acuminate, serrate. - Mountains of Nortle Carolinil, and northwarl. May. - Root loner and slender, aromatic. Stem 10 high, much shorter than the leaves.

$$
\text { * * Slems roodly. }
$$

4. A. spinosa, I. Stem simple, prickly; leaves very large, erowded at the sumunit of the stem, lipinnately compound; leaflets thick, orate, crenate, glancous beneath; umbels in very large houry paniches. - Swamps, Florida to Mississippi, and northward. July and August. - Stem $10^{\circ}-15^{\circ}$ high.

\section{PANAX, L. Ginsexg.}

Calyx mimutely 5-toothel. Petals and stamens 5. Styles 2-3. Berry fleshy, drujacicous, 2 - 3-loberl, 2 - 3-celled. - Low herbs, with naked stems, bearing at 
the summit a single long-perluncled umbel of greenish flowers, surrounded by a whorl of three $3-7$-fololate leaves. Berry red or greenish.

1. P. quinquefolium, L. Root fusiform; leaflets $5-7$, oblong-obovate, serrate, stalked; styles 2, berry crimson. - Rich wooks along the mountains, Georgia, and northward. July. - Stem $1^{\circ}$ high. Leaflets $2^{\prime}-3^{\prime}$ long.

2. P. trifolium, L. Root glohose; leaflets 3-5, lanceolate, serrate, sessile; styles 3 ; berry greenish. - With the last. - I'lant $4^{\prime}-6^{\prime}$ high.

\section{Orner 68. CORNACEA: (Dogwoon Famix.)}

Trees or shrubs, with simple, entire or rarely toothed exstipulate leaves, and perfect or polygamons flowers. - Calyx coherent with the 1 - 2-celled ovary, $4-5$-toothel. Petals $4-5$, valvate in the bucl, sometimes wanting. Stamens $t-10$, inserted into the margin of the lisk that crowns the ovary. Orules solitary, anatropous, pendulons. Fruit a berry-like 1-2-celled, 1-2-seeded drupe. Embryo nearly as long as the fleshy albumen. Cotyledons large and foliaceous.

\section{CORNUS, Tourn. Dogwoon. Coryer.}

Flowers perfect. Calyx 4-toothed. Petals and stamens 4. Stigma capitate. Drupe 2-celled, 2-sceded. - Shruhs or low trees. Leaves and lranches opposite (except No. 1). Flowers in naked spreading cymes, or capitate, and subtended by a colored involucre.

* Flowers white, in a loose open cyme: involucre none.

1. C. alternifolia, L'IJerit. Leares oval, abruptly acute at each end, pale and pubeseent beneath, long-petioled, and, like the greenish striped branches, alternate; drupes deep blue. - Banks of streams, Florida, and northward. May. - A widely branching slurub, or small tree.

2. C. stricta, Lam. Leaves ovate or oblong, ahruptly acute or aeminate, smooth, whitish leneath; cymes flat or depressed at the summit; drupes and anthers pale blue. - Swanıs, Florida to Nortlı Carolina, and westward. April. - A shrub or small tree. Branches lorown.

3. C. paniculata, L'Herit. I,eaves smooth, orate-lanecolate, acuminate, paler beneatlr; cymes convex at the summit, somewhat panieled, loose-flowered; drupes white, depressed-rylobose. - North Carolina and northward. May and June. - Shrub $4^{\circ}-8^{\circ}$ high. Branches gray.

4. C. sericea, L. Leaves ovate or elliptical, smooth above, the lower surface, like the purplish branches and elose depressed cyme, silky-pubescent; drupes pale blue. - Low woods, Florida to Mississippi, and northward. May. - Shrnb $6^{\circ}-10^{\circ}$ high.

5. C. asperifolia, Michx. Leaves short-petioled, lanceolate-ovate or oblong, aeute, very rough on both sides, as well as the branchlets and flat cymes; 
drupes pale lilue. - 1)ry wools, Florida to South Carolina, and westward.

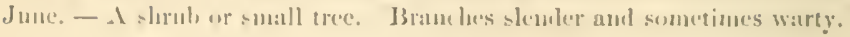

* * Flowers copitate, subtender biy a white 4-harrol involucre.

6. C. florida, I. Jestes orate-lanecolate or orate, at length sinooth on both sides; flowers greenish; drupes oroid, red. - Uak wools, common. May. - A small tree. Wood latrd and close-grained. Leaves of the involuere cmarginate and thickened at the sunmit, showy.

\section{NYSSA, I. Sorr Gey.}

l'lowers diucio-polygamons. Sterile flowers in many-flewerel heads or eymes. Calyx 5-partcrl. Stamens 5-10. Petals and pistil nome. Fertile flowers singre or few in at heal. Calyx-limb 5-toothed or olsolete. I'etals 5, nimute, or wanting. St:unens 5-10, mostly sterile. Style long, revolute. Stigua decurrent. Ovary 1-celled, 1)rupe 1-seeled. - Trees or slirubs. Leaves alternate, entire or rarely toothed, fincly reticulated. Flowers small, greenish, on axillary or lateral perluncles.

$$
\text { * Strrile flowers in loose rlustris. }
$$

1. N. multiflora, Wang. Leares oral or olsovate, mostly arute, tomentose when youmg, at length shiming above: fertile pedumcles longr ami sleniler, 3-8-flowered; dmpes ovoll, dark blue. - lich upland woods, Florida to Mississippi, and northwanl. May. $-\Lambda$ tree $30^{\circ}-50^{\circ}$ lighl, with widely spreading branches. Jeaves rather thick, dark green, $2^{\prime}-5^{\prime}$ long. Fertile peduncles $1 \frac{1}{2}^{\prime}-$ $3^{\prime}$ long. Drupe $\frac{1^{\prime}}{2}$ long.

2. N. aquatica, I. Branehes, leares, \&c. tomentose when young, at length nearly. smouth; leaves short-petioled, varying from lanceolate to orbienlar, obtuse, sometimes slightly cordate; peduncles short, the fertile ones 1-2flowerel; drupes oval, blue. - Ponds and swamps, Floridin (o North Carolina, and westwird. $\Lambda$ pril and May - $\Lambda$ large tree, or in pinc-barren swamps sometimes a mere shrub. I.eaves $1^{\prime}-2^{\prime}$ long. Peduncles $\frac{1}{2}-1^{\prime}$ long. I) mupe smaller than in the last.

3. N. uniflora, Walt. Lcaves large, long-petioled, ovate or ollong, acute, entire or slarply toothed, tomentose bencath, the lower ones often cordate; fertile peduncles elongated, 1-flowered; drujes orate-oblong, dark blue. (N. tomentosa, Mich.r. N. grandidentata, Wichx. f.) - Jeep swamps and ponds, Florida to North Carolina, and westward. April. $-\Lambda$ large tree. Leaves $4^{\prime}-6^{\prime}$ long. Drupe $8^{\prime \prime}-12^{\prime \prime}$ lonig.

$$
\text { * Sterile flowers capitate. }
$$

4. N. capitata, Walt. (OGEecirfe Lise.) Leaves large, short-petioled, oblong, oval or olovate, mucronate or acute, tomentose heneath; flowers below the leaves, the fertile ones perfect, solitary, on very short peduncles; drupe oblong, recl. - Swamps, Florida and Gcorgia, near the coast, and westward. A small tree. Leaves $3^{\prime}-5^{\prime}$ long. Drupe $1^{\prime}$ long, agreeably acid. 


\section{Division II. MIONOPETALOUS EXOGENOL'S PLANTS.}

Floral envelopes double, consisting of both calyx and corolla; the latter of more or less united petals.

\section{Order 69. CAPIRIFOLI A CEA. (Honeystekle Fauly.)}

Chiefly trees or shmbs, with opposite leaves, and no stipules. Calyxtube adherent to the ovary, the limb 4-5-toothed or loberl. Corolla tubular or rotate, $1-5$-lobed. Stamens as many as the lobes of the corolla, and alternate with them, inserted on its tube. Ovary 2-5-celled, with 1 many pendnlous ovules in each cell. Fruit mostly baceate or drupaceous. Seeds anatropous. Embryo small, in the axis of fleshy albumen.

\section{Synopsis.}

* Corolla tubular. Style slender. Stigma capitate.

1. SYMPHORICARPLS. Corolla campanulate, Berry 4-celled, 2-seeded. Erect shrubs.

2. DiERvillA. Corolla funnel-shaped. Capsule 2-celled, 2-valved, naany-seeded. Erect shrubs.

3 LONICERA. Corolla tubular. Berry 1 -3-celled. Chiefly woody vines.

4. TRIostecy. Corolla tubular. Drupe bony, 3-5-seeded. Ilerbs.

* * Corolla rotate. Stigmas 3-5, sessile. Flowers in cymes.

5. SAIBUCUS. Leaves pinnate. Berry $3-5$-seeded.

6. VIBURNUI. Leaves simple. Drupe 1-seeded.

\section{SYMPHORICARPUS, Dill. SNOWBERY.}

Calyx-tube globose, the limb $4-5$-toothed, persistent. Corolla eampanulate, nearly regular, 4-5-lobed. Stamens $4-5$, inserted on the throat of the eorolla. Ovary 4 -celled, 2 of the cells with several abortive orules, the other two with a single suspended fertile ovule in each. Berry 4-eclled, 2-seeded. Seeds bony. - Erect slirubs with entire leaves, and white or reddish flowers in axillary spikes or clusters.

1. S. vulgaris, Michx. Leaves oval, downy beneath; flowers in small axillary clusters; corolla smoothish within; herries red. (Symphorea glomerata, Pers.) - Dry soil among the mountains, Georgia, and northward. July Sept. - Shrub $2^{\circ}-3^{\circ}$ bigh.

\section{DIERVILLA, Tourn.}

Calyx oblong or cylindrieal, narrowed above, with 5 subulate teeth. Corolla funnel-shaped, 5-lobed. Stamens 5. Capsule 2-celled, septicidally 2-valved, many-seeded. - Low shrubs, with ovate or oblong acuminate serrate deciduous leares, and axillary and terminal eymose flowers.

1. D. trifida, Mœnch. Leaves ovate or oblong-ovate, distinctly petioled, pubescent, especially on the reins above; peduncles mostly 3-flowered; capsule 


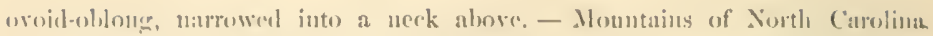
June, - Stem zo- do high. Flowers greenish-yedlow.

2. D. sessilifolia, buckley. Leaves ovate-lancelate, desely sessile aur

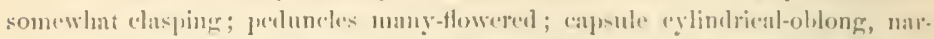
rowed into a short neck abore, - With the preceding. - Le'ases mol capsule larger than in that specirs.

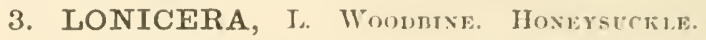

Calyx oroid, 5-toothed. Corollat tulular, 5-elleft, often lilabliate, and griblous: near the hase. Stamens 5. Ovary 2-3-redled, with sereral ovules in each eell. Berry l-3-celled, several-secded. Seeds bony. - Freet or twining sliruls, with entire, often counate leaves. Flowers by pairs or in spiked whorls.

1. L. sempervirens, גit. Sten twining; leaves ol,hng or lanceolate, pale and tomentose beneath, the upper pair shorter and comnate; spikes terminal; whorls distinet; corolla nearly equally 5-lobed, scarlet or orange without, yellow within. (Caprifolium, Ell.) - Margins of swanps, Florida, and northward. April-Sept. - Leares jeremial. Corolla 2 long.

2. L. grata, Ait. Stem twining; leaves ohovate, glamous beneath, the 2 or 3 upper pairs comnate; whorts of flowers axillary and terminal; corolla bilabiate, the tube loner and stender. - Mountains of Curolina, and nortluward. Mar. - Youm hranches often hairy. Corolla $1 \frac{1}{2}$ ' long, with a red or purplish tule and a white limb, chantring to yellow. Berry orange-red.

3. L. flava, Sims. Smosth and somewhat glaucons; stem searecly twining; leares oral or ohorate, the upper pairs comnate; whorls of flowers crowderl, terminal ; corolla slender, bilabiate. - Banks of rivers in the upper districts of Georgia and South Carolina. June and July. - Coro!la l' long, bright yellow; the t-cleft limb nearly as long as the tule.

4. L. parviflora, Lam. Smooth; stem twining; leares elliptical, glaucous beneath, all more or less connate; whorls of flowers erowded, peiluneled; corollat short, hilaliate, giblons at the base; stamens hairy below. - Momutains of North Carolina. - June. - Corolla $8^{\prime \prime}-10^{\prime \prime}$ long, yellow and purplish.

\section{TRIOSTEUM, I. Fever-Wort.}

Calyx ovoid, with 5 leafy linear-lanceolate persistent lobes. Corolla tubular, equally 5-lobed, rather longer than the ealyx. Stamens 5. Ovary 3-eclled, with a single orule in each cell. Funt a dry drupe containing 3 lony nutlets. - Perennial hairy berbs, with large leaves, narrowed but connate at the hase, and sessile axillary fowers.

1. T. perfoliatum, I. Stem soft-hairy; leaves oval, acuminate, entire, hairy above, tomentose heneath; flowers commonly clustered, brownish-purple. - Shady wools in the upper distriets. June and July. - Stem $2^{\circ}-4^{\circ}$ high. Leaves $4^{\prime}-7^{\prime}$ long.

2. T. angustifolium, L. Stem hirsute; leares lanceolate or ohlong, acuminate, hirsute ahove, pubescent beneath ; flowers mostly solitary, vellowish. - Shady rich soil among the mountains. June. - Plant smaller than the last. 


\section{SAMBUCUS, Tourn. Elder.}

Callyx-lobes minute or none. Corolla rotate, 5-lobed. Stamens 5. Fruit a globular baceate drupe, containing three 1-sceded nutlets. - Shrubs, with pinnate leaves, and white flowers, in ample terminal cymes.

I. S. Canadensis, L. Ieaflets 7-11, oblong, serrate, smoothish, acute, the lower ones often 3-parted; eymes flat, 5-parted ; fruit black. - Low grounds, common. June and July, - Stem $4^{\circ}-16^{\circ}$ high, the straight young slioots with large pith.

2. S. pubens, Michx. Leaflets 5- 7 , oblong, serrate, pubescent beneath, eymes paniculate, pyramidal; fruit red. - Mountains of North Carolina, and northward. June. - Shrub $6^{\circ}-10^{\circ}$ high. Cymes smaller than in the last.

\section{VIBURNUM, I. Haw. Slot.}

Calyx minute, 5-toothed. Corolla rotate or somewhat campanulate, 5-lobed. Stamens 5. Ovary $1-3$-celled, one of the cells containing a single ovule, the others empty. Drupe baceate, containing a single compressed bony nut. Shrubs or small trees. Leaves loberl or undiviled, the petioles sometimes winged. Flowers in terminal cymes, small, white; the marginal ones occasion ally radiant and sterile.

\section{* Sterile and radiant flowers none.}

\section{$₫$ Cymes sessile.}

1. V. prunifolium, L. Leaves thin, obovate or roundish, mostly obtuse, finely and sharply serrate, smooth and glossy, or the reins beneath and more or less dilated petioles rusty-pulseseent ; eymes large, 4-5-rayed; drupe oblong. ovoid, black. - Dry rich woods, Florida to Mississippi, and northward. April and May. - A small tree. Fruit edible.

2. V. Lentago, L. Leaves thin, orate, acuminate, fincly and sliarply serrate, smooth above, the lower surface and dilated wary petioles roughened with minute scales when young; cynes 4-rayed; frnit oval, black. - Mountains of Georgia, and northwarl. May. - A small tree.

3 V. obovatum, Wilt. Leaves small, thick, obovate, or obovate-oblong, obtuse, slightly erenate or entire, smooth; cymes 3-rayed; drupe oroid, black. (V. lavigatum, Ait.) - River-banks, Florida to North Carolina, and westward. April and May. $-\Lambda$ shrub or small tree. Leaves $\frac{1 \prime}{2}-1$ long. Cymes small.

+- Cymes peduncled.

+ Lenves palmately lobed.

4. V. acerifolium, L. Pubescent; leaves roundish or broadly orate, ronnded or cordate at the base, coarsely serrate, 3-lobed ahove the mildle; cymes 7-rayed ; fruit oval, black. - Dry open woods, West Florida to Miscissippi, and northwarl. May and June. - A slender slinb, $2^{\circ}-4^{\circ}$ high. Leaves $2^{\prime}-3^{\prime}$ wide, becoming smooth above, sometimes almost entire.

\section{+t++ Leaves undivided.}

5. V. nudum, L. Rnsty-pubescent; leaves varying from oval to lanceolate, entire or nearly so, thick, becoming smooth ahove, prominently reined be- 
neath; eymes rather short-peduncled, 5-rayed; fruit ovoid, bluc. - Swamps, common. April und May. - Shrub $80-120$ ligh.

6. V. dentatum, I. Veins of the leaves leneath with tufted huirs in their axils, otherwise smooth; leaves romblomite, slightly cordate, coursely serrate, acute, plieate by the strong impressed veins; cymes long-pedunded, irayed ; ealyx smooth, with the lolues olutuse; fruit small, romulinh, deep bluc. Rich damp soil, West Florida to Mississippi, and northward. Mardh - May. 1 large shrul.

7. V. scabrellum, Torr. \& Gray. Hairy throughout, and the leaves beneath stellate-tomentose; leaves ovate or roundish, often cordate, or rarely cuneate at the hase, rather obtusely and coarsely serrate, short-petioled; ("ilyx-lohes hairy, acute; rorolla hairy; eymes 7 -rayed ; fruit roundish, deep bhut - Swamps or rocky hills, Floridit to South Carolina, in the lower districts, and westward. May and June. - Shrub $8^{\circ}-12^{\circ}$ hirgl. Leares thick, $1^{\prime}-2^{\prime}$ long, or sometimes twice that size.

8. V. pubescens, Pursl. Leaves small, ovate or oh.ongrovate, coarsely serrate, hairy alove, tomentose bene:th, on very short petioles or the uppermost subsessile; cynes small, smoothish, i-rayed ; fruit oblong, black. - Mountains of North Carolina. June. $-\Lambda$ slurub $2^{\circ}-3^{\circ}$ high. Leaves $1^{\prime}-2^{\prime}$ long.

\section{* Marginal flowers rediant und sterile.}

9. V. Iantanoides, Michx. Stem smooth and straggling ; luanches, eymes, and lower surfice of the round-ovate, cordate, scrrate leares covered with tufted down; cymes sessile; fruit ovod, black. - Deep shades on the mountuins of North Carolina. June, - Stem $2^{\circ}-4^{\circ}$ long. Leares $4^{\prime}-6^{\prime}$ long. sterile flowers $l^{\prime}$ in diuneter.

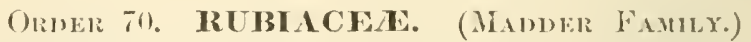

Herls, shrubs, or trees. Leaves entire, opposite and united hy interposed stipules, or whorled. - Calyx-tube adlerent to the ovary, or (in Loganice) free; the limb $4-6$-teotleed or lobed, or obsolete. Corolla 4-6-loberl, inserted on the throat of the calyx. Stimnens 4-6, inserted on the tule of the corolla, and alternate with its lobes. Ovary 2-10eplled, with 1 -several anatropous or amphitropous orules in each cell. Style mostly solitary. Albumen hard or fleshy.

\section{Synopsis.}

Suborner I. COFFEE T:. Ovules and seed solitary in the cells (except No. 7). Calyx-tube adherent to the ovary.

\$1. Leaves whorled. Stipules none.

1. GALIUM. Corclla rntate, valvate in the bud. Fruit 2-eelled. Ilerbs.

\$2. Leaves opposite, rarely three in a whorl, with stipules interposed.

* Lerbs. Mature fruit dry. Flowers axillary, single or elustered.

2. SPERMACOCE. Carpels 2, one of then closed by the partition, the other open. Flowers clustered. 
3. BORRERIA. Carpels 2, both open on the inner face. Flowers clustered.

4. DIODIA. Carpels 2-3, bony and closed. Style 2-cleft. Albumen fleshy.

5. ERNODEA. Carpels 2, somerhat fleshy, closed. Style entire. Albumen horny.

* Shrubs. Fruit dry. Flowers in globular peduneled heads.

6. CEPHALANTIIUS. Carpels 2-4, separating at the base, closed.

* * Shrubs. Fruit fleshy or pulpy. Flowers mostly axillary.

- Ovaries united, forming a compound berry in fruit.

7. MiтCHELLA. Flowers by pairs. Stamens 4. Berry 4-seeded.

8. MORINDA. Flowers numerous. Stamens 5. Berry 1-seeded.

- - Ovaries and fruit separate.

+- Albumen horny.

9. CHIocoCCA. Fruit flattened, even. Stigma entire. Seeds suspended.

10. PSYCIOTIRIA. Fruit ribled. Stigma 2-lobed. Seeds erect.

+* Albumen fleshy.

11. STRUiPfi. Corolla bell-shaped. Anthers subsessile, united Leaves whorled.

12. GLETTARDA. Corolla salver-form. Anthers subsessile, separate.

13. Elithilis. Corolla subrotate. Filaments slender.

Suborder II. CINCHONE. Ovules and seeds numerous in the cells. Calyx-tube adherent to the ovary. Leaves opposite.

* Fruit baccate, indehiscent.

14. IA MELIA. Fruit 5-celled. Stigma entire.

15. RANDIA. Fruit 2-celled. Stigma 2 -lobed.

* Fruit capsular, loculicidally dehiscent.

16. PINCFNEYA. Shrub. Flowers cymose, terminal. Seeds winged.

17. ExosteminA. Shrubs. Flowers solitary, axillary. Seeds winged.

18. OLDENLANDJA. Herbs. Capsule often free from the calyx above. Seeds wingless.

Suborder III. LOGANIEA. Ovules and seeds numerous in the cells. Calyx free from the ovary. Frnit capsular. Leaves opposite.

\section{* IIerbs.}

19. SPIGELIA. Corolla tubular. Style single, jointed.

20. MITREOLA. Corolla short, 5-lobed. Styles 2, united above.

2I. POLYPREMUM. Corolla short, 4-lobed. Style single.

* Evergreen woody vines.

22. GELSEHIUI. Corolla campanulate. Seed winged.

\section{GALIUM, L.}

Calyx-tceth obsolete. Corolla rotate, 3-4-lobed. Stamens 3-4. Styles 2, united at the base. Stigma capitate. Fruit double, separating into two l-seeded closed earpels. Albumen horny. - Slender herbs, with square stems and whorled leaves. Flowers minute. - The following species are all perennials.

* Fruit baccate peduncles 1-3-flowered: leaves 4 in a whorl.

1. G. hispidulum, Miehx. Stems much branched, slightly roughened, hairy at the joints; leaves small $\left(2^{\prime \prime}-6^{\prime \prime}\right)$, rigid, lanceolate-ovate, rough on the margins and veins beneath, acute; berry roughened, bluish-black. (knbia Brownei, Mich $x$.) - Dry sandy soil near the coast, Florida to North Carolina, and westward. May-Sept. - Stems $1^{\circ}-2^{\circ}$ long. Root yellow. Flowers greenish-white. 
2. G. uniflorum, Michx. Smooth; stems mostly simple, slender, ereet;

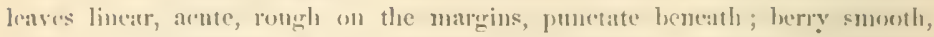
black. - 1)ry rich suil, Filorida to Sentl Carolina, nud westwarel. June and July. - Stens numerous, $1^{\circ}$ high. Flowers white.

$$
\text { * * Fruil dry: perluncles commonly 3-many-fouered. }
$$

3. G. trifidum, L. Stems slenter, weak, smowth or rongh-anglet, at lengtl difruse ; leaves $4-6$ in a whorl, unepual, varying from linur to sputulate-lanecriate, obtuse, smooth, or rough on the margins and midrih, the upper ones often opposite; peduncles 1 -3-flowered; corolla-lole's and ramens often 3 ; fruit smooth. (G. tinctorium, L.) - Wet places, Florida, and northwarl. June and July, - Stems $1{ }^{\circ}-2^{\circ}$ long. Flowers white. 1'lant dries black.

4. G. triflorum, Michx. Stems weak, lliffuse, very rough ; leaves $4-6$ in a whorl, lanecolate or elliptical, ruspidate, the mpper surface and veius beneath hispirl; pednueles mostly 3 -flowered; fruit densely uncinate-hispirl. Low sladed places, Florida to Mississippi, ant northwarl. July - Stcms $2^{\circ}-3^{\circ}$ long. Flowers grenish-white. A smoother form is G. cuspilatum, Muhl.

5. G. pilosum, Ait. Stems rigrit, hairy or ronghened on the angles, branching; leaves small $\left(t^{\prime \prime}-8^{\prime \prime}\right), 4$ in al whorl, oval, slightly printed, more or less hairy and roughenel, dotted; peduncles $2-3$ times forking; fruit pediecllerl, bristly with hooked hairs. (G. Bermudianum, Ell, apparently a discased state.) - I) ry soil, Florida to Mississippi, and northward. June-Sept. - Stem $1^{\circ}-3^{\circ}$ long. Flowers purple.

6. G. circæzans, Michx. Stems erect, smooth or nearly so; leaves large $\left(1^{\prime}-1 \frac{1}{2}^{\prime}\right), 4$ in a whorl, ovil, mostly ohtuse, 3-nerved, pubeseent; petuncles forking, then spueating and spike-like; fruit bristly with hooked hairs, nearly sessile, notding. - I)ry open woots, Florida to Mississippi, ant nortluwarel. July- - Stems several, sparingly branelied, $1^{\circ}$ high. Flowers purple.

7. G. latifolium, Michx. Stems erect, smooth; leaves thin, 4 in a whorl, ovate-lancelate, arute, smootl, 3 -nerved, dotter, minutely fringed on the mar. gins; perluneles filiform, 2-3 times forking; finit smootls. - Moumains of Nortl Carolina, and northward. July- Stems $1^{\circ}-1 \frac{10}{2}$ higrly. Lcaves $1^{\prime}-2^{\prime}$ long. Flowers purple.

\section{SPERMACOCE, I.}

Calyx 2-4-parted, persistent. Corolla salver-shaped or funnel-shaper, 4-lobed, ralvate in the bud. Stamens 4 , inserted on the throat of the corolla. Stigma simple or 2-cleft. Frut composet of two l-seeded earpels, scparating from the apex downward, one of them elosed by the partition, the other open. Seeds grooved on the inner face. - Low herbs. Leaves obliquely straight-veined, their bases connected by the bristly-fringet sheathing stipules. Flowers small, in axillary sessile clusters.

1. S. glabra, Michx. Stem 4-angled, smooth, erect; leaves lancelate or oblong, acute, roughened on the margins and reins beneath; clusters globose, 
dense, many-flowered; corollit harly longer than the lancolate calyx-teeth, white, wooly within; stamens and style inchuded; fruit olovite. - bauks of rivers, Florila and westward. June. $4-$ Stem $1{ }^{\circ}-2^{\circ}$ high.

2. S. Chapmanii, Torr. \& Gray. Stem erect, smooth, slightly angled; leaves oblong-lanceolate, acute, rongh above and on the margins; clusters fewflowered ; corolla white, hairy within, $2-3$ times as long as the calyx; stamens and slender style exserted ; fruit turbinate. - Dry soil, Florida, Georgia, and westward. July. If - Stem $6^{\prime}-12^{\prime}$ high.

3. S. tenuior, L. Stem slender, erect or prostrate, branching from the base, terete, smooth; leaves lanceolate, rough above, remote; chnsters small, mostly few-flowered; flowers minute, the smooth white corolla barcly longer than the subulate teeth of the calyx; stamens and style included; fruit ovoir, hairy. - South Florida, in dry soil. (1) - Stem $3^{\prime}-12$ long.

4. S. involucrata, Pursh. Stem alternately lranched, very hispid; leaves ovate-lanceolate, acuminate, hirsute on botlı surfaces; stipules witlı many bristles; heads terminal, involucrate; stamens exserted. - Carolina, Frazer. Ahout a foot high. Leares somewhat oblique. Flowers white with a very long tube. Pursh. (*)

\section{BORRERIA, Meyer.}

Carpels of the fruit separating from the apex downward, both opening length. wise on the inner face. Otherwise like Spermacoce, both in character and labit.

1. B. micrantha, Torr. \& Gray. Annual; stem erect, slender, simple or branched above, 4-angled, smooth; leaves remote, lanceolate, mostly ubtuse, narrowed at the base, the upper surface and margins rough, the lateral veins obseure; clusters dense, globose, axillary and terminal ; ealyx-teeth 4, subulate, longer than the minute (white) corolla; fruit ovoid, hairy. - Waste places, Florida. June-August. - Plant $6^{\prime}-18^{\prime}$ high, pale green. Leares $1^{\prime}$ long.

2. B. podocephala, DC, var. pumila. Stems low $\left(3^{\prime}-6^{\prime}\right)$. smooth, erect or ascending, branching at the base ; leaves smooth, linear, with the margins revolute, those in the axils clnstered, the floral ones mostly 4 , longer than the solitary terminal long-peduncled globose head; stipnlar bristles 2-4; fruit pubescent, ovoid, crowned with two subulate spreading ealyx-lobes; corolla somewhat funnel-shaped, mostly 3-lobed, smooth within; stigma capitate. Pine Key, South Florida, Lr. Blodgett.

\section{DIODIA, I.}

Characters chiefly of Spermacoce, but the two bony indehiscent carpels closed on the inner face, - Herbs. Corolla-tuhe often long and slender. Flowers few or solitary in the axils of the narrow leaves.

1. D. Virginiana, L. Perennial; stem and leaves smooth, pubesecnt, or hirsute; stem prostrate, 4-anirled ; leares somewhat fleshy, lancelate, acute, sessile; flowers single, or 2-6 in a cluster; corolla luairy within, the tube long 
and slender; fruit ovould, strongly rilled, crowned with the 2 (rarly 4) linear (o) linceolate ealys-tectl. (1). tetrigona, Walt. 1). hirsut:I, I'ursh.) - W't places, Flerrida to North Carolina, and westward. June - Sejt. - Stem $10-4$ o loner. Fluwers white or purplish.

2. D. teres, Walt. Anumal; stem erect, widely branelect from the base, terete, bristly or latiry; leaves lincar or lanceolate, acnte, romerh; flowers solitary or 2-3 together; corolla funnel-shaperl ; frnit olovate, "wen, crowned with the 4 short calyx tecth. (Spermacoce diodina, a/chx.) - 1) ry sauly soil, Floridia to Mississippi, and northward. July-Sept. - Stem $6^{\prime}-12^{\prime}$ high, sometimes prostrate. Flowers purplislı.

\section{ERNODEA, Swart\%.}

Calyx ovate; the limb 4-6-parted, persistent. Corollit salver-shaped, slender; the lobes $4-6$, revolute. Stamens exserted; anthers linear, erect. Style wender, longer than the stamens. Fruit obovate, somewhat fleshy, the two separable horuy carpels clocel. Seeds furrowed on the inner face. -1 somewhat shrubly prostrate and smootl plant, with rigid 3-nerved lanceolate leaves, and solitary sessile axillary flowers.

1. E. littoralis, Swartz. - Sonth Florilin, along the coast. Marel and April. \& Stems straight, rigid, t-angled, smooth. Jranches shert, alternate. Le:ives sessile, smooth, acute, the upper ones crowded. Flowers sessile in the upper axils, yellow. Fruit roundish.

\section{CEPHALANTHUS, I. Butrox-Bris.}

Calyx obconical, 4-toothed. Corolla tubular, 4-rleft, inbricated in the busl. Stamen 4. Style slender, exserted. Stịnma eapitate. Fruit dry, obconieal, separating from the bane into $2-4$ one-seedenl earpels. Seeds pendulous. Altumen horny. $-A$ cusatic shruls, with oval or lanceolate leaves, short cutire stipules, and white flowers collected into a globose long-peduncled licad. Receptatcle liairy.

1. C. occidentalis, L. Smooth, or the young branches and lower surface of the ovate-oblong arute leaves pulsesent; peduncles terminal, and in the upper axils. - Ponds and marshes, Florila, and northwarl. July and August. - Stem $4^{\circ}-12^{\circ}$ lighls. Leaves petioled, $3^{\prime}-5^{\prime}$ long, sometines 3 in a whorl. IIeals $I^{\prime}$ in dinncter.

\section{MITCHELLA, I.}

Flowers hy pairs, witl their ovaries united. Calyx 4-ioothed. Corolla funnel-shaped, 4-lobed, hairy within, valvate in the hud. Stanens 4. Style slender. Stigmas 4. Fruit composed of two 4-seeded fleshy drupes united, crowued with the 4-toothed calyx. $-\Lambda$ smooth ereeping evergreen shrub, with small lroadly-orate leaves, ninute stipules, and fragrant white terminal flowers.

1. M. repens, I. - Shady woods, Florida to Mississippi, and nortlıward. March and April. - Stem $10-2^{\circ}$ long. Leaves $6^{\prime \prime}-10^{\prime 4}$ long, mostly some what cordate, shining above, on slender petioles. Corolla $\frac{1}{2}^{\prime}$ long. Fruit red. 


\section{MORINDA, L.}

Flowers numerous, their ovaries united into a liead. Calyx obseurely toothed. Corolla fumnel-shaped, 5-lobed, valvate in the bud. Stamens 5, short. Style slender. Stigmas 2, filiform. Frnit composed of 2-4 one-sected carpels, all nnited into a fleshy head. - Trees or shrubs. Leaves opyositc or whorled. Stipules within the leaves. Flowers terminal, or opposite the leaves.

1. M. Roioc, L. Stem smooth, procumbent or elimbing; leaves smooth, lanceolate and acuminate, or obovate oblong and abruptly aente, short-petioled : stipules broad and short; flowers small, erimson. - South Florida. Mareh and April.

\section{CHIOCOCCA, Browne.}

Calyx ovate, 5-toothed. Corolla funnel-shaped, 5-lobed, valvate in the bud. Stamens 5, inserted on the base of the corolla; anthers linear, included. Style slender. Stigma obtuse. Fruit fleshy, roundish, compressed, composed of two oblong 1-seeded nutlets. Seeds suspended. - Shrnbs. Leaves smooth, petioled. Stipules connatc. Flowers in axillary racemes, white or yellow.

1. C. racemosa, Jacq. Erect; laves oblong $\left(2^{\prime}-3^{\prime}\right.$ long $)$, acnte at bot.t. ends; racemes mostly longer than the leaves, often compound, many-flowered; corolla many times longer than the ealyx-teeth, white, turning yellow. - Varies with the stems prostrate and vine-like, leaves smaller $\left(\frac{1}{2}{ }^{\prime}-33^{\prime} \operatorname{lon} \Omega\right)$, more rigirl, and longer than the few-flowered simple racemes. - South Florida. - Fruit white.

\section{PSYCHOTRIA, L.}

Calyx ovate, 5-toothed, or nearly entire. Corolla short, funnel-shaperl, 4-5lobed, valvate in the bud. Stamens 4-5. Stigma 2-eleft. Fruit drupaceous, composed of two 1-seeded carpels, mostly ribbed or angled when dry. Seeds erect. Albumen horny, - Shrubs or trees. Leaves o]posite, narrowed to a petiole. Stipules sometimes membranaceous and deciluous. Flowers mostly in terıninal corymbs or panicles.

1. P. lanceolata, Nutt. Leaves lanceolate, acuminate at each end, tho lower surface as well as the branches ferruginous-pubescent; stipules clasping, ovate, acite or acuminate, deciduous; corymbs terminal, trichotomous at the hase. - South Florida. - Leaves $2^{\prime}-3^{\prime}$ long. Fruit ovate, red.

2. P. undata, Jacq. Leares oblong, acuminate at each end, undulate, rugose, and, like the branches, smooth; stipules round, membranaceous, deciduous; cyme sessile, twice trichotomous, shorter than the leaves; corolla naked at the throat, hairy at the insertion of the filanents ; fruit (dry) ovoil, 10-ribbed.South Florida. - Leaves about $3^{\prime}$ long. Flower's small.

\section{STRUMPFIA, Jacq.}

Calyx-limb 5-parted; the lobes acute, erect. Corolla somewhat bell-shaped, deeply 5-parted, the tube very short, the lobes ereet, lanceolate, spreading at the apex. Stamens 5 , inserted on the base of the corolla; filaments very short; 
anthers thick, colering in mu woicl-ohlong 5-angled tulse. Style single, as long ths the anthers, villons; stigmin obtuse, 2-lubed. Orary 2 -4-celled with a single: wrule in each cell. Fruit a 2 -4-eelled, 1-4-secelel drupe. -1 low maritime shrub. Bratnedus romeleneal by the persistent stipules, trichotomus. Leares ternate, very rigid, linear, obtu-e, cutire, the marenins rewolute. Flowers small, in axillary racemes, shorter than the leares. Corolla pulescent. Drupe small, retl.

1. S. maritima, Jace. - South Florila, Ir. Blodlyett.

\section{GUETTARDA, I.}

(alyx-tube ovoul, the limb tubular, searcely tuothed. Corolla salver-shaped, 4-9-lobed, naked in the throat. Anthers $4-9$, sessile in the throat of the corolla. Style simple. Stimma mostly capitate. Fonit composel of 4-9 ome-seded bony carpels, unitcl. - Trees or slurubs, with orate or lanceolate leaves, and laneeolate deciduous stipules. I'eduneles axillary, forking. Flowers sessile.

1. G. Blodgettii, Shutt. Idawes membranaceons, elliptical, slighthly mucronate, futher-veined, rough above, the lower suffue, especially the weins, like the brandes and cymes, covered with appresed siky latirs; cymes shorter than the leaves, 5-10-flowered; flowers silky, termmerons (rarely trinerens); stigma entire; fruit gloluse, composed of 4 mutlets surrounded ly 8 cmpty cells; ealyxlimb truncate, che $\mathrm{ft}$ on one side. - South Floridil. - Leaves $1^{\prime}-1 \frac{1}{2}{ }^{\prime}$ long. Fruit as large as a peat.

2. G. ambigua, DC. Leases coriacens, elliptical or somewhat obovate, cordate at the base, rugose, muricate alove, the lower suffece, like the branches and ermes, rusty-iomentose; cymes longer than the leaves, several-flowered;

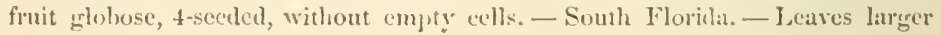
than in No. 1.

\section{ERITHALIS, Browne.}

Calyx ovoid, obseurely 4 - 10-tootherl. Corolla somewhint rotate, 4-10-prarted, with lincar sprealing lohes. Stamens $4-10$, inserted on the base of the corollas: anthers linear. Style simple. Srigma 2-lippet. Frnit grlobose, ribbed, conposed of 4-10 one-seeded hony carpels. Seeds stepended. - Smooth shrubs, with opposite petioled leaves, brond and short mucronate sheathing stipules, and axillay yanicled flowers.

1. E. fruticosa, L. I.eaves coriaceous, oblong, obtuse, shining, narrowel into a petiole; panicles about as long as the leases, many-flowererl; flowers mostly tetruncrous, sinall; fruit 5-ribbed, 6-10-celled. - South Filoridit. Leaves $2^{\prime}-3^{\prime}$ long. Flowers small, white.

\section{HAMELIA, Jaণ.}

Calyx oval, 5-toothed. Corolla tubular, somewhat 5-angled, 5-lobed. Stamens 5, inserted into the tube of the corolla: anthers linear. Style simple. Stigma oltuse. Berry ovoid, 5-furrowel, 5-celled, many-secled. Secds minute, 
compressed. - Shrubs, with opposite or whorled oblong petioled leaves, lamecoLate stipules, and orange-colored flowers, in axillary and terminal cymes.

1. H. patens, Jacq. Pnbesecut; branches angled; leaves 3 in a whori, oblong, acute; cymes terminal, perlmeled, umbellate; corolla eylindrical, the lobes coneave at the apex, and mucronate on the back. - South klorida. Leaves $3^{\prime}-5^{\prime}$ lumig. Flowers erimson. Berry black.

\section{RANDIA, Houst.}

Calyx obovate, 5-toothed. Corolla salver-shaped, 5-lobed. Anthers 5, sessile in the throat of the corollat, linear. Style simple, short. Stimmal clarate, 2-lobed. Fruit somewhat dry, 2-eelled, many-seeded. Seeds wingless. - Branching mostly spiny shrubs, with opposite leaves, and solitary stipules between the petioles. Flowers solitury or in short racemes.

1. R. aculeata, I. Spiny ; leaves small, obovate, smooth, eoriaccons; flowers solitary, axillary; corolla (white) hairy in the throat, the tube $2-3$ times as long as the calyx, the limb eonvolute in the bud. (R. latifolia, Lam.) South Florida. - Branches rigicl. Leaves $5^{\prime \prime}-10^{\prime \prime}$ long, rather longer than the subulate sprealing syines. Corolla $3^{\prime \prime}-t^{\prime \prime}$ long. Fruit ovoid, as large as a pea, about 6-seederl. Sinuses of the calyx hairy.

2. R.? clusiæfolia. Spineless; leares large, clustered at the end of the branches, oborate, smooth, mueronate; stipules larwe, orate, persistent ; racemes teminal, corymbose, slorter than the leaves; ealyx-teetli subulate; corolla smooth within, fleshy, the tube many times longer than the calyx, the limb lanceolate, convolute in the but. (Garkenia clusiafolia, Jaeq. ?) - Soutl Florida. - Leaves $3^{\prime}-t^{\prime}$ long, 2' wide, apparently somewhat fleshy, black when dry. Curolla $\mathrm{l}^{\prime}$ long.

\section{PINCKNEYA, Michx. Georgia Burk.}

Calyx oblong-obovate, 5-lobed; the lobes laneeolate, deciduons, or one of them, in the onter flowers, often transformed into a large colored leaf. Corolla tubular, hairy, with 5 linear-oblong revolnte loles, slightly imbricated in the bud. Stamens 5, exserted : authers ublong. Stigma obtuse. Capsule globose, papery, 2-celled, opening loculicidally at the apex, and at length septicidally to the base. Seels numeruus, in 2 rows, horizontal, membranaceous, winged. - A shrub or small tree, with pubescent branches. Leaves large, oval or oblong, acute, smoothish above, the lower surfice, like the terminal compound ryme, hoarypubeseent. Stipules linear, deciduous.

1. P. pubens, Michx. - Marshy banks of streams in the pine harrens, Floridla to South Camolina. May and June. - More conspicuous for its ovate pink-colored floral leaves, than for its purplish spotted corolla.

\section{EXOSTEMMA, DC.}

Calyx obovate or tubular; the limb 5-toothed, persistent. Corolla-tube very long, terete; the limb with 5 long linear recurved lobes, valvate in the bud. 
Stamens 5, exserted. Style filiform, thichenerl nhowe. Stipma olutuse or 2-lubed

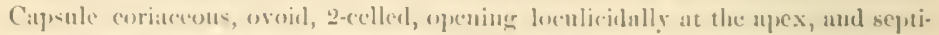

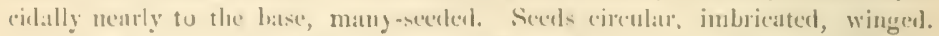
- Trees or shrubs. Icaves oppusite. Stipules sulitary. Flowers white or rerldish.

1. E. Caribæum, li. \& S. Smooth; brandles slender; l.aves ovatelaurecolate, atemuinate; perlunc!es axillary, solitary, 1-flowered ; corollat us long as

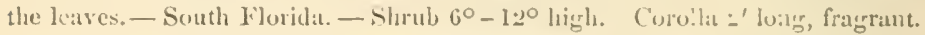

\section{OLDENLANDIA, Plum. Iห,1:s.}

Jlowers tetramerous (except No. 8). Calyx 4-toothal, persistent. Coroll:t funnel-sliaped, salver-shaped, or whed-shaped, 4 -lobed, valvate in the buil. Stanens 4. Stigna mostly 2-lobed. Capsule roundi-h or obcorditte, 2-eelled, opening loculicilally at the apex, which is often free from the calyx. Seevls few or many, wingless, - Chiefly suall lacrbs, with opposite leaves. Stipules uniterl with the petioles, sometimes fringed with bristles. Flowers small, white or purplish.

* Corolla salver-shaped. longer than the calyx, smonth: flovers dimorplious, - some of them braring exsentrd stamens and an included style, while ollurs brar induded stamens and an cxserted style: peduncles axillary, solitary: caysule broul, fice ut the apex.

1. O. ccerulea, Gray. Annual or biennial, smootlı; stems tufted, forking; leaves lanceolate, those at the laise spatulate, chustered; peduncles elongated, erect or spreading. (IIonstonia cormlea, L. II. patens, JEll.) - Muint hanks, Florida to Mississippi, and northward. February and March. - Stems $3^{\prime}-6^{\prime}$ hight. Corolla hlue or white, yellow in the shroatt.

2. O. serpyllifolia, Gray. P'erennial, smooth; stems filiform, prostrate, lranching; leaves ovate or roundish, abruptly contracted into a lour and slender petiole; feduncles elongated, terminal and in the forks of the stem. (Howstonia sejpyllifolia, Michx.) - High montains of North Carolina. - Stems 6' $12^{\prime}$ long. Peduneles $1^{\prime}-22^{\prime}$ long.

3. O. rotundifolia, Gray. Perennial; stems diffuse, creeping; leaves round or oval, fle-hy, abruptly contrated into a short petiole; peluncles most!y shorter than the leaves, recurved in fruit; flowers white. (Houstonia rotundifolia, M/ichx.) - Sandy soil near the coast, Florida to South Carolina, and westward. February and March, and bearing apetalous fruiting flowers through the year.

* * Corolla funnel-shaped: flowers dinccionsty dimorphous: capsule free at the apex: stem 4-angled: flowers in terminal cymes.

4. O. purpurea, Gray. I'ubescent; stem branching, erect; leaves ovate or lanceolate-orate, sessile, 3-5-ribbed; calyx-lobes longer than the capsule; corolla purple or nearly white, slightly hairy within; (apsule roundish. (Iloustonia purpurea, L.) - Woods, Mississippi to North Carolina, and northward. June and July. - Stems $8^{\prime}-12^{\prime}$ high. Calyx-lobes occasionally $3-4$ times the length of the capsule. 
Var. longifolia, Gray. Smooth; leares lanceolate or linear, 1-ribbed, the lowest spatulate-oblong; calyx-lobes as long as the globose (apsule. (Houstonia longifoha, Willd.) - With the preceding.

Var. tenuifolia, Gray. Branches and pedieels filiform, spreading; leaves remote, narrow-linear; flowers and capsules smaller. (Houstonia tenuifolia, Nutt.) - Mountains of North Carolina. July.

5. O. angustifolia, Gray. Smooth; root woorly; stems elustered, ereet, branching abore; leaves linear; cymes crowded, with the central flowers nearly sessile; corolla white, very hairy within; capsule ovoid, as long as the calyxtceth. (Hedyotis stenophylla, Torr. \&. Gray.) - Sandy pine barrens, Florida, and westward. June and July. - Stems $1^{\circ}-2^{\circ}$ high.

Var. filifolia. Stem slırubly at the base, diffusely branched; leaves filiform, remote; cymes scattered, 3 -flowered, the slender pedieels equal and sprending; eapsule obeordate, rather longer than the calyx-teeth, the upper balf free. South Florida. - Stem slender, $6^{\prime}-10^{\prime}$ long. Flowers and eapsules very small.

* * Corolla wheel-shaped, shortcr than the calyx-lobes: flowers axillary and terminal, sinyle or clustered, sessile: stumens and style very short: capsule enclosed in the calyr-tube: perennial: stipules fringed.

6. O. Boscii. Stems 4-angled, smooth, diffuse; leaves linear; flowers single, or 2-3 together; corolla white or purplish; apsule ovoid. (Hedyotis Boseii, $D C_{\text {. }}$ ) - River-banks, Florida to South Carolina, and westward. July. - Stems $6^{\prime}-10^{\prime}$ long.

7. O. glomerata, Michx. Stems terete, smooth or pubeseent, branching; leaves oblong or oval, short-petioled; clusters dense, many-flowered; corolla greenish-white. (Hedyotis glomerata, Ell.) - Wet plates, Florida to North Carolina, and westward. July. - Stems $10^{\prime}-15^{\prime}$ high.

* * * Corolla funnel-shaped, 5-lobed, longer than the caly $x$-teeth : flowers axillary and terminal, pentamerous: capsule top-shaped, included in the calyx-tube: annual: stipules finged.

8. O. Halei. Stem weak, diffuse, forking; leaves oval-oblong, acute at each end, somewhat fleshy; flowers solitary, or in short 3-5-flowered cymes, white. (Hedyotis Halei, Torr. \&. Gray.) - Banks of rivers, South Florida, and westward. July.

\section{SPIGELIA, L. Pinквоот.}

Calyx 5-parted; the lobes linear-subulate, persistent. Corolla tubular-funnel-shaped, 5-lobed, valvate in the bud. Stamens 5: anthers linear. Style slender, jointed, hairy above. Stigma capitate. Capsule composed of two fewseeded earpels, which at length separate at the hase and open loculicidally. Herbs. Leaves opposite. Flowers in one-sided terminal spikes, rarely solitary.

1. S. loganioides, A. DC. Stem simple, ascending, somewhat 4-angled, the upper part and joints slightly puberulent; leaves ovate or ohovate, scssile, the upper surface and margins roughish; flowers axillary, solitary, or the terminal ones three in a cluster; tube of the corolla more than twice as long as the 


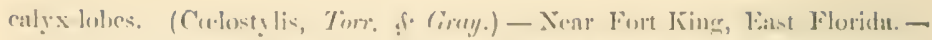
Stem 6'-10' high. Icaves $4^{\prime}-9^{\prime \prime}$ long. Corollat $4^{\prime \prime}$ longe, white.

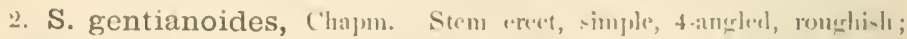

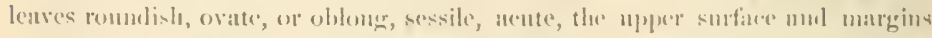

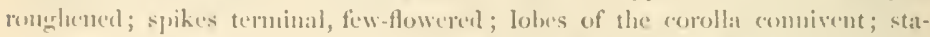
mens amel style iuduled. - Light diy soil, Went Florida. May and June. Stem 6 $6^{\prime}-10^{\prime}$ high. Corolla $6^{\prime \prime}-10^{\prime \prime}$ lones, pale roscteoler.

3. S. Marilandica, L. Stem simple, ereet, smowth, 4-anglinl; leaves wate-lancecolate, or oblong, arente, sessile, pubeseent on the wins; spukes terminal, many-fluwered, sometimes forking; corolla long, slender, the lobes sprealiner anthers and style exserted. - lich woorls, Florida to Mississippi, and northward. May and Junc. - Stem 10 $-2^{\circ}$ hight. Corolla 1 1 21 long, scarlet, yellow within. $-\Lambda$ popular vermifuge.

\section{MITREOLA, I. MiтRः-WORT.}

Calyx 5-partel. Corolla short, 5-lobed, valyate in the bud, the tube roundish, bearded in the throat. Stamens 5, inclucled: anthers ovate. Styles 2, short, united ahove. Stigma capitate. Capsule 2-parterl, mitre-shaped, many-seeded, the two lobes opening on the inner face neal the apex. Sieeds oval, concave. Smooth herbs, with opposite leaves, and small white flowers in terminal ambl axillary cymes, with the simple branches recured in the bud.

1. M. petiolata, Torr. \& Fray. Stem lwanching; leaves thin, ollong, acute, narrowed into a petiole. (Ophiorhiza lauceolata, Ell.) - Mudly lanks, Flonila to North Carolina, and westwarl. June-Sept. (I - Stem 4-anged, $1^{\circ}-2^{\circ}$ higlı. I carces $2^{\prime}-3^{\prime}$ lone.

2. M. sessilifolia, Torr. \& Gray. Stem simple, t-angled; leaves thick, ovate or roundish, strongly veined, seswile, rough on the margins; flowers and capsule very small. (Ophiorhiza Nlitreola, M/irhe.) - Varies with lanecolate obserely-veined leaves, and lareer flowers and frut. - Grassy swamps, Florida

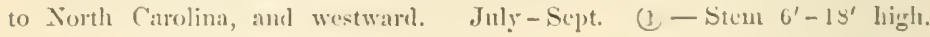
Leaves $6^{\prime \prime}-10^{\prime \prime}$ long. I'lant pale green.

\section{POLYPREMUM, L.}

Calyx deeply t-parted, persistent. Corolla whec-shaped, bearder in the throat, 4-bobed, imbricated in the buel. Stamens 4. Style single, very short. Stigma oroid, entire. Capsule ovoid, compressed, 2-celled, loculicidally 2-valved, many-secded. - A low smooth perennial herb, wish 4 -angrled forking stens, linear acute leaves, their bases nnited by the membranaceous stipules, and solitary sessile white flowers in the forks of the stem.

1. P. procumbens, I. - Waste places, Florida to North Carolina. June - Sept. - Stems $6^{\prime}-10^{\prime}$, erect or prostrate, clustercil. Llower's very small, the corolla barely longer than the ealyx-lobes. 


\section{GeLSEMIUM, Juss. Yellow Jessamine.}

Flowers dimorphons. Calyx 5-parted, persistent. Corolla funnel-shaped, 5lobed; the lobes rounded, emarginate, spreaaing, qumeuncial in the bud, the sinnses impressed. Stamens 5, inscrted near the base of the corolla: anthers oblong-sagittate, extrorse. Styles united, filiform, partly persistent. Stigmas 4, linear, spreating. Capsule oblong, compressed, 2-celled, opening septicilally to the middle, and loculieidally at the apex, each valve tipped with the persistent base of the styles. Seeds several, oval, flat, winged, obliquely imbricated in two rows. - A smooth woody vine, with opposite evergreen leaves, minute stipules, and large yellow fragrint fiowers, in axillary braeted and cluster-like racemes.

1. G. sempervirens, Ait. - Margins of swamps, and river-banks, Florida to North Carolina, and westward. Mareh and April. - Stem twining, purplish. Leaves lanceolate or ovate, acute or subcordate at the base, short-petioled. Racemes few-flowered. Pedicels scaly. Corolla $1^{\prime}-1 \frac{1}{2} /$ long.

\section{Order 71. VALERIANACEAE. (VAberiax Fambr.)}

Herbs with opposite exstipulate leaves, and eymose flowers. - Calyxtube atherent to the ovary. Corolla tubular or funnel-shaped, mostly 5lobed, imbricated in the bud. Stamens distinct, fewer than the corollalobes, and inserted into its tube. Ovary 3-celled, two of which are empty, the third containing a single suspended anatropous ovule. Style slender. Stigmas 1-3. Fruit 1-3-celled, 1-seeded. Albumen none.

1. VALERIANA, Tourn. VAleriax.

Limb of the calyx composed of screral plumose bristles, at first incurved, afterwarl spreading. Corolla gibbous at the base, 5-lobed. Stamens 3. Fruit 1-celled, 1-seeded. - Perenuials.

1. V. scandens, L. Smootls; stem climbing; leaves on slender petioles, ternately divided; leaflets ovate, entire ; eymes panieulate, diffuse, axillary and terminal ; corolla very short. - East Florida.

2. V. pauciflora, Michx. Smooth; stem $\left(1^{\circ}-3^{\circ}\right)$ erect, or decumbent at the base, simple; leaves membranaceous, toothed or serrate, the radieal ones mostly entire, orate or cordate, long-petioled, the others pinnately $3-7$-lobed; cymes terminal, in a close panicle; tube of the pale pink corolla long and slender. - Mountains of Temnessee, and northward. June and July.

\section{Fedia, Monch. Lamb-Lettuce.}

Calyx-limb toothed or obsolete. Corolla funnel-shaped, 5-lobed. Stamens 3. Fruit 3-eelled, two of the cells empty and sometimes confluent into one, the other 1-seeded. - Annual herbs, with forking stems, opposite entire or lobed leaves, and white or purplish flowers in crowded bracted eymes. 
1. F. radiata, Michx. Leaves ohloug, the npper ones clasping and toothed

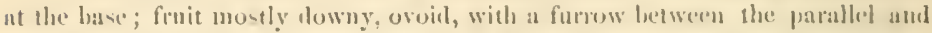
comtizuons empty cells; Howers white - liver-banks, Floridit, and northward. February and March. - Stem $6^{\prime}-12^{\prime}$ high.

\section{Onden 72. Conposit N. (Composite Fanhly.)}

Flowers clustered in a dense head upon a common feceptarle, and surroumbed by an involueve. Calyx united with the ovary; the limb (joppus: cither obsolete, or forming a cup-like or toothed border, or dividerl into chaffy scales or bristles. Corolla superior, flat or fimmel-shaped, 5(arely 4-) lobed, valvate in the bud. Stamens alternate with the lobes of the corolla, and inserted into its tube: anthers cohering in a cylinder (syngenexions). Style singre: stigmas 2. Fruit (achenimm) dry and seedlike. Seed solitary, erect, without alhumen. Radicle inferior. - Iterlss or shrubs. Leaves withont stipules. Involucre composed of short or leafy bracts (sceles of the ineolucre), arranged in 1 -many series. Rereptacle naked, or furnished with seales (chaffy). Ilearls with the flowers all tubular (discoirl), or all strap-slsaped, or the marginal ones strap-shaped or ligulate (radiate).

\section{Artificial Synopsis of the Genera.}

Suboinei: I. 'TUBCLIFLORA. Corolla of the perfect flowers tubular, equally 5- (rarely 3-4-) lobed. Ray-flowers, when present, ligulate, either pistillate or neutral.

\section{Iteads discoid.}

* Ileads with the flowers all perfect. No.

Pappus none. Leaves resinous-dotted. Flowers yellow. . . . FLAVERIA. 55 Pappus bristly or hairy.

Flowers yellow.

licceptacle pointed. . . . . . . . . . BIGELOVIA. 21 Receptate flat. . . . . . . . Nos. 1 \& 33 in SOLIDAcio. 20 Reeptacle eonvex. . . . . . . . . . . RUGELIA. 75 Flowers white, blue, or purple.

Receptacle cuaffy.

Leaves opposite. Flowers white. . . . . . . MELANTIIERA. 40 Leaves alternate. Flowers purple. . . . . . CAIRPIIEPIOILU. 8 Recrptacle bristly.

Leaves spiny, . . . . . . . . . . CIRsIIY. 78 Leaves not spiny, cordate. . . . . . . . . . LAPPA. 79

Receptacle naked.

Scales of the juvoluere in a single row.

CACALIA. 73

Scales of the involucre iu 2 or more rows.

Pappus double, the outer row very short. . . . . . VERTONiA. 1 Pappus single.

Achenia ribbed or striate.

l'appus plumose. Flowers cream-colored. . . . . . IKUIINIA. 10

Pappus scabrous. Leaves cordate. . . . . . BIICKELLIA. 11

Pappus scabrous. Leaves not cordate. . . . . . LIATRIS. 9 
Achenia not rihbed, 5-angled.

No.

Receptacle conical. . . . . . . . . CONOCLINIUM. 14

Receptacle flat. Stems climbing. . . . . . . MIKANIA. 13

Receptacle flat. Stems erect. . . . . . . EUPATORIUM. 12

Pappus scaly.

Flowers blue or purple.

Pappus a cup-shaped border of united scales. . . . . . CCELESTINA. 5

Pappus slender, almost bristly.

Pappus deciduous. Ifeads large and single. . . . . . STOKESIA. 2

Pappus persistent. Heads small, in 3-bracted clusters. . ELEPIIANTOPUS. 3

Pappus of 5 oval almost bony scales. Leaves whorled. . . SCLEROLEPIS. 7

Flowers white.

Receptacle naked.

Leaves entire, linear or lanceolate . . . . . PALAFOXIA. 5i Leares entire, ovate or cordate. . . . . . . . AGERATUM. 6 Leaves pinnately lobed. . . . . . . . . IIYMENOPAPPUS. 58

Receptacle chaffy.

Achenium top-shared. Scales of the pappus 5-6. . . . MLASIIALLIA. 63

Achenium flat. Pappus 2-awned. . . . . . ACTINOMERIS. 49

Flowers yellow. Pappus 2-4-awned.

Awns of the pappus deciduous. . . . . . . . IlELIANTIIUS. 47

Awns of the pappus persistent, hispid upwarl. . . . . COREOPSIS 50

Awns of the pappus persistent, hispid downward. . . . . . BIDENS. ¿2

* Hleads with flowers variously imperfect.

Marginal flowers pistillate. Central flowers perfect.

Pappus bristly.

Scales of the involucre in a single row. $\quad . \quad . \quad . \quad$ ERECHTHITES. 72

Scales of the involucre in $\mathbf{2}$ or more rows.

Involucre persistent. Leaves sinuate-lohed. . . . . . COxYZA. 26

Involucre persistent. Leaves entire. Anthers tailed. . . . PLUCIIEA. 28

Involucre persistent. Leaves entire Anthers tailless. . . GXAIIIALIUMI. 70

Involucre deciduous. Iteads spiked. . . . . . PTEIROLAULON. 29

Pappus not bristly, 5-lobed. • . . . . . . . TANACETUM. 67

Pappus none. . . . . . . . . . . . A ARTEMisia. 68

Marginal flowers pistillate. Central flowers staminate.

Pappus none. Style rigid, persistent. . . . . . . . SOLIYA. 69

Pappus none. Style deciduous. Heads nodding. . . . . . . IVA. 35

Marginal flowers neutral. Central flowers perfect. . . . . CENTAUREA. 77

* * lleads dioecious or mococious.

Staminate and pistillate heads on the same plant.

Fruiting iuvolucre 1-seeded, naked or tubercled. . . . . . AMBROSIA. 36

Fruiting involucre 2-seeled, armed with hooked spines. . . . XANTIIUM. 3i

Staminate and pistillate heads on separate plants.

Anthers tailed. Iloary herbs. . . . . . . . . ANTENNARIA. 71

Anthers tailless. Smooth shrubs. . . . . . . . . BACCHARIS. 27

Rays pistillate.

2. Heads radiate.

Flowers all fertile.

Receptacle naked.

Rays yellow. Leaves opposite.

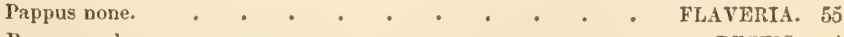

Pappus scaly. . . . . . . . . . . . PECTIS. 4

Rays yellow. Leares alternate.

Scales of the involucre in 1 row. . . . . . . SENECIO. it

Scales of the involucre in 2 rows. . . . . . . IIELENIUM. 59

Scales of the involucre in severa' rows. . . . . . . . IXUIA. 25 
liays white or purpie.

Jappus none.

l'aplus liristly.

Recritacle pitted.

lanys white or purple.

l'appus doubie. . . . . . . . . . . . . . . . . . .

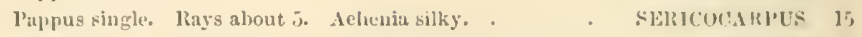

lappus single. Rays numerous. P'appus bristly. . . . . . AsTEIR. 16;

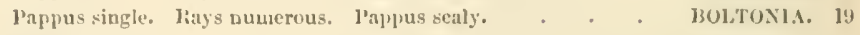

liays yellow.

l'appus double, of the ray anul disk flowers alike. . . . CIIRYsorsis. 21

Pappus double, of the ray flowers none. . . . . IIETEROTIIECA. 23

1'appus single.

Leares opposite. Ileads large, single or corymbose. . - . AliviC.. Fi;

leares alternate. Heads racemed or elustered. - . - SOLIIAfio, 20

leaves alternate IIeads panieled. . . . . . . ISUPAPPLS, 22

lieceptacle ehaff:

Involucre double, the nuter 4-leared, 4-angled. . . . . . TETRAGONOTIECA. 43

Involuere imbricated or spreading.

Maritime shrubs. Pappus 4-toothed. + . . . . BORliICIII. 3.

IIerbs.

Receptacle conical or elongated.

liays persistent. Corolla-lobes relrety. . . . . . 71XN1.1. 41

Rays deciduous. Achenia 3-4-angled. . . . IIELIOPsis. 42

lays deciduous, Achenia compressed. . . . . SPILANTIIES. 53

Tieceptacle flat.

l.eares lohed, alternate. . . . . . . . . ACIILl.k.1. 65

Leares not lobed. Pappus 2-awned. . . . . VERIBEINA. it

Leares not lobed. Pappus none. . . . . . . ECLIPT.1. 35

Flowers of the disk sterile.

Rays yellow. I’appus none. . . . . . . . . TOI,YINIA. 30 Rays yellow. Pappus a tonthed crowr. . . . . . CIIRYsogoney. 31

Rays yellow. Pappus 2-toothed or awned. Achenia wiuged. - . SILPIIlLy. 32

Rays yellow. l'appus 2-toothed or awued. Achenia wiugless. . BERLANDIERA. 33

lays white. Receptacle couical. . . . . . . . PARTIE.vily. 34

Rays neutral (without jistils).

lieceptacle naked, or nearly so.

Aehenia villous. l'appus sealy, long-amned. . . . . GAILLAIRDIA. 56

Aehenia smonth or the angles hairy. l'appus arnless. . . . LEPTOPOD. 60

Receptacle deeply pitted.

Margins of the pits entire. Perennial. . . . . . BALDiTINIA. 61

Margins of the pits toothed. Annual. . . . . . ACT1.0SPER.IU. 62

Reeeptacle ehaffy throughout.

Involuere double. Pappus 2-4-awned.

Awns of the pappus hispid uptrard . . . . . . COREOPSIS. 50

Arns of the pappus hispid domoward. Achenia beakless. . . BlDE.S. 52

$\Lambda$ wns of the pappus hispid downward. Acheula beaked. . . . Cossos. 51

Involuere simple or imbrieate.

Parpus a cup-shaped border, or none.

Chaff of the reeptaele elnagated, spine-pointed. . . . ECIINACEA. 44

Chaft of the receptacle not elongated nor spine-pointed. . . RLDBECK1A. 45

Pappus 2-4-awned.

Achenia winged. Jeares dirided. Receptacle elongated. . . LEPACHYS. 46

Achenia winged. Leaves undivided. Receptacle convex. - ACTINoyERIS. 49

Achenia wingless. Awns of the pappus deciduous. . . HELIAXTIIUS. 47

Achenla ringless. Awns of the pappus persistent. - . IIfLANTHELLA. 48

Receptacle chaffy at the apex. Achenia ribbed. . . . . . MARUTA. 64 
Stmonder II. LABIATIFLOR.E. Cornlla of the perfect flowers 2-lipped; the outer lip 3-lobed, the inner o-lobed.

Ilerb stemless. Scape 1 flowered. Flower nodding.

Siborder III. Liglifilore. Coroila of all the flowers ligulate.

Pappus none. Achenia many-rible1. . . . . . . . . APOGON. \&I

Pappus scaly and bristly.

Scales of the pappus 5 , with 5 intermediate liristles. . . . . . KRIGIA. 82

Scales of the pappus and bristles numerous. . . . . . . CTXTiLA. \&

Pappus hairy.

Pappus tawny or dirty-white.

Flowers erect, rose-color. Lcares filiform. . . . . . LYGODESMIA. 86

Flowers erect, yellow. Achenia beakless. . . . . . . IIIERACIL I. 84

Flowers erect, yellow. Achenia long-beaked. . . . . PrimiorAPPUS. 88

Flowers volding, whitish or purplish. . . . . . . NABALUS. 85

I'appus clear white (except in one Mluigedium).

Achenia conspicuously beaked.

Achenia ribbed. Stemless lierbs. . . . . . . TARAXACUM. 87

Achenia flat. Stcms leafy. . . . . . . . . LACTUCA. 89

Achenia beakless or nearly so.

Flowers blue. Achenia slightly beaked. . . . . . MULGEDIUM. 90

Hlowers yellow. Achenia beakless. . . . . . . . SONCIUUS. 91

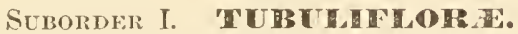

TRIBE I. TERNONIACE-is. Ifads discoid; the flowers all tublar and perfect: brunches of the style terete, filiform, hairy all over; the stigmatic lines only on the loicer prart. - Merts, with alternate leaves and purple flowers. L'Ectis alone has pistillate rays and yellow flowers.

\section{VERNONIA, Schrel. Irox-wed.}

IIeads many-flowered, the flowers all equal and tubular. Involucre shorter than the flowers; the seales closely imbricated in several rows. Receptacle naked. Achenia cylindrieal, ribbed. Pappus donble; the exterior consisting of very short seale-like bristles, the interior of copious capillary bristles. - Perennial herbs, with alternate leaves, and eorymbose purple flowers.

1. V. oligophylla, Miehx. Stem nearly naked; leaves rough above, pubeseent beneath, denticulite; those at the base large, oval or oblong, the others small, distant, lanceolate; corymb few-flowered, spreading; involucre bell-shaped, the scales lanceolate, aenminate, fringed. - Damp soil, Georgia to North Carolina, and westward. July. - Stem $2^{\circ}$ high, sparingly branched.

2. V. ovalifolia, Torr. \& Gray. Stem pubescent, very leafy, corymbosebranched ahove; leaves roughish above, pubeseenı beneath; the lowest ones oval or oblong, toothed-serrate; the upper lanceolate and entire; involuere bell- 


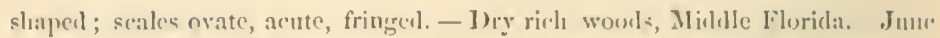
and July. - Stcm $2^{\circ}-3^{\circ}$ high.

3. V. Noveboracensis, Will. Stem uore or less pubescent, loranclued above; leaves lanceolate, serrate, mostly roughi-h abose, sunoth or pubesecent leneatlı; corymbs spreading; involucre hemispherienl, the soules fringerl, ovate, ending in a loner filiform point, or simply acute. (V. tomentesa, K\%. V. praealta, Willd.) - liver-batuks and low ground, Floridat to Mi-kisippi, and nortl. warl. July-Sept. - Stem $3^{\circ}-6^{\circ}$ Jight. Seales of the involucre purple, and usually coverel with web-like hairs.

4. V. fasciculata, Michx., var. altissima, 'Turr. \& Gray. Stem tall, and, like the lanecolate serrate leaves, smoothish; involncre small, lemisplerical; the seales ovate, acute or mucronate, fringed, appressed. (V. ultissima, Tull.) - Low groumd, Florida to North Carolina, and westwurd. September. - Stem $6^{\circ}-10^{\circ}$ ligh. Leaves $6^{\prime}-12^{\prime}$ long.

5. V. angustifolia, Michx. Stem slender, smooth or hairy, very leafy; leaves lincar or linear-lanceolate, smoothish, or pubsecnt amd roughish, the low: est ones sparingly denticulate, the upper entire, with the margins revolute; (orymlss mostly umbel-like; involucre bell-shaped; the seales lineculate, fringerl, acute or eonspicuously mucronate. ( $V$. seaberrima, Nutt) - I)ry pine bartens, Floricla to North Carolina, and westward. June-Aurnst. - Sten $2^{\circ}-3^{\circ}$ highl.

\section{STOKESIA, I'IIer.}

IIeads many-flowered; the marginal flowers much larger, decply split on the inside, and ray-like. Involucre subglobose, bracted, the outer seales prolongerl into a leafy bristly-fringed appendage, the inner ones lanceolate and entire. Receptacle naked. Achenial short, 3-4-ingled, smooth. Papplus composed of $4-5$ filiform chaffy deeidnous scales. $-\lambda$ sparingly brancherl downy-stemmed perennial. Leaves smouth, lanceolate, entire, the mpper ones sessile, and, like the bracts, fringerl at the lase, the lowest narrowed into a slender petiole. IIcarls few or solitary, large, terminal. Flowers blue.

1. S. cyanea, L'Iller. - Wet pine harrens, South Carolina, and westward, very rare. - Stems $1^{\circ}-1 \frac{1}{2} 0$ high. Heads I' wide.

\section{ELEPHANTOPUS, L. Elepinst's-root.}

Heads 3-5-flowered, crowded in terminal 3-bracterl elusters. Flowers all equal and similar. Involucre compressed; seales 8, in 2 rows, dry, oblong, acute, dotted. Receptacle naked. Corolla decply split on one side, palmate. Achenium oblong, ribhed, hairy. Pappus bristly from a dilated base, double or single. - Erect hairy corymbose-branched perennials, with alternate ample leaves, and purpie or white flowers.

1. E. Carolinianus, Willd. Stem leafy, hairy; leaves thin, oval or oblong, incurved-scrate, hairy, tapering into a petiole; bracts ovate, longer 
than the heads; seales of the involuere slightly hairy. - Damp shady soil, Florida to Mississippi, and northward. July and August. - Stem $1^{\circ}-2^{\circ}$ high. Leares $3^{\prime}-6^{\prime}$ lons, $2^{\prime}-4^{\prime}$ wide. Flowers purple.

2. E. tomentosus, L. Rougli-hairy; stem nearly naked; radical leaves sprealing, ohovate-oblong, narrowed into a petiole; stem-leaves (1-2) small, lanceolats; bracts ovate or cordate, usually shorter than the lieads; scales of the involuce very hairy. (E. nudicaulis, Ell.) - Dry sandy soil, Florida to North Carolina, and westward. June-August. - Stem $1^{\circ}-2^{\circ}$ high. Radical leaves $4^{\prime}-10^{\prime}$ long, $2^{\prime}$ wide, spreading on the ground. Flowers pale purple.

\section{PECTIS, L.}

Heads sereral-flowered, radliate. Rays pistillate. Disk-flowers somewhat 2lipped, perfect. Involuere cylindrical. Scales 5-8, in a single row. Receptacle naked. Branches of the style short, obtuse. Achenium linear. Pappus composed of abont five uneqnal bristle-pointed scales. - Chicfly ammals. Leaves opposite, glandular-dotted, bristly on the margins. Flowers small, yellow.

1. P. linifolia, L. Stem diffusely branched $\left(6^{\prime}-12^{\prime}\right.$ high $)$; leaves linear, connate; lieads snall, on long and slender bracted peduncles; seales of the involuere slightly prodnced at the base; achenia hairy. - South Floricla.

TrIBE II. EUPATORIACE.E. Ileads discoill; the flowers all tubular and perfect: Iranchrs of the style, usually clongated, club-shaped, minutely pubescent; the stigmatic lines obscure. - Flowers white, blue, or purple.

\section{COFLESTINA, Cass.}

Heads many-flowered. Inrolucre nearly hemisplerical; the seales numerous, imbricated. Receptacle naked or chaffy. Achenia 5-angled. Pappus cupshaped, truncate or more or less prominently toothed. - Leaves opposite, toothed. Heads in elose corymbs. Flowers blue or purple.

1. C. maritima, Torr. \& Gray. Stem diffuse, somewhat shrubby at the base, smooth ; leaves ovate, abruptly contracter into a slender petiole; corymhs few-flowered; receptacle naked; pappus a whitish truneated margin. - Sonth Florida. - Stem $1^{\circ}-2^{\circ}$ long. Flowers blue.

\section{AGERATUM, L.}

Receptacle always naked. Pappus composed of 5-10 distinct seales. Otherwise like Coelestina.

1. A. conyzoides, L. Leaves orate, rhombic, or cordate, on rather long petioles; scales of the pappus 5 , slightly serrate, awn-prointed from a loroal base. - Wet places near Savannab, Georgia. May. - Pubeseence and form of the leaves variable. Flowers white or blue. 


\section{SCLEROLEPIS, Cisss.}

Heals many-foweresl. Seales of the involucre linear, imlricated in two rows, equal. Reereptacte naked. Curolla 5-terotherl. Arlunia 5-angred. Srales of the paptur 5, almost horny, oval. -1 smouth angatic prerennial herb, with whorled linear leaves, and $1-3$ beads of purple flowers, terminuting the stem or peduncle-like branches.

1. S. verticillata, Cass. (Sparganoplorni verticillatus, Mrir.r.) - Slaıllow ponds, Filorida to Missisipjpi, and northwarl. July. - Stems ascending, $1^{\circ}$ high. Ieares $5-6$ in a whorl. Ileads 2̇ $^{\prime}$ wide.

\section{CARPHEPHORUS, Cass. (Tiıtris, Fill.)}

Ileals many-flowerel. Seales of the involucre imbricated in $3-5$ rows, ovate or lanceolate, appresscol. Rieceptarle chafly. Achenia 10-riblect. L'appus of numerous une(pisl bearderl bristles. - Ereet perennial herbs. Leaves altemate. Heads corymbed. Flowers purple.

1. C. Pseudo-Liatris, Cass. Jubescent and somewhat hoary; stem simple, rigil ; leaves linear, appresed, the lowest (rowded, clongaterl; corymb small, dense, mostly simple; pediecels luacted; seales of the involucre laneeolate, acute, hairy. - Open gralay pine harrens, WW storida. September. Stem $6^{\prime}-18^{\prime}$ high. Ileals larely labemose.

2. C. tomentosus, Torr. \& Gray. Stem simple, tomentose; leares smooth or hairy, ghand-pointed ; the lowest oblong or lanecolate, 3-ribbed, narrowed into a long elasping petiole, the others numerons, small, ohlong or oval, sesile; corymb loose-flowered; seales of the inwolucre very tomentone, the onter ones slort, orate, the inner oblong, acte. (L. Walteri, Ell ) - Low pinc ballrens, North and South Carolina. September. - Stem $2^{\circ}$ bigh.

3. C. corymbosus, Torr. \& Gray. Stem tall, hairy; leaves smootls or more or less hairy; the lowest cuncate-lanceolate, obtuse, 1- or obscurely 3ribbed; the others numerons, small, oblong, sessile; heads ahont 20, (doscly corymbed; seales of the involucre nearly smooth and efual, oval, very obtuse, bronlly margined. (L. tomentosa, Ell.) - Margins of swamps, Florida 10 North Carolina. September. - Sten $2^{\circ}-4^{\circ}$ high.

4. C. bellidifolius, Torr. \& Gray. Smooth; leares spatulate-lanceolate, 3-ribbed, obtuse; heals few in a loose corymb; scales of the involucre oblong, obtnse, sparingly fringed on the margins; pappus slightly plumose. Dry sancl-hills, Wilmington, Nortl Carolina. September- Stens several from the same root, $12^{\prime}-18^{\prime}$ high. Heads sometimes panicled.

\section{LIATRIS, Sclireb. Ветток-Sхлкекоот.}

Heads few-or many-flowered, the flowers all similar and perfect. Seales of the involucre inbricated. Receptaclé naked. Corolla 5-lobed. Achenia nearly terete, narrowed at the base, about 10-ribled. Pappus of numerous plumose or bearded bristles. - Perenuial berbs (rarely shrubby), with mostly tuberous roots 
and simple stems. Leaves alternate, usually entire. Flowers purple, often valrying into white, eommonly dotted with resinons particles.

$\$ 1$. Root tuberous: leaves very numerous, linear or lanceolate, the loutest brouder and tapering at the base, the upper sessile: heads in spikes or racemes: uchenia hairy: pappus plumose or bearded: stems simple, or in more vigorous plunts sometimes branching below the spikes, and bearing fewer-flowered heads.

* Scales of the incolucre with petal-like or leafil tips: jappus plumose.

1. L. elegans, Willd. Heads very numerous in a cylindrieal raeeme, $4-$ 5-flowered; imer seales of the involucre petal-like, purple; stem tomentose; leaves smooth, the lowest lanceolate. - Dry piue barrens, Florida to Sonth Carolina, and westward. Angust. - Stem $2^{\circ}$ high. Ileads showy.

2. L. squarrosa, Willd. Hearls few or nunerous, large, many-flowered, eylindrical; seales of the involnere with leafy spreading tips; stem pubescent; leares smoothish or hairy, long, linear, rigid, 3-5-ribbed. - Dry sandy soil, Florida to Mississippi, and northward. July and August. - Stem $1^{\circ}-1 \frac{1}{2}{ }^{\circ}$ high. Heads l' long, sessile or terminating short branchlets. Corolla Lobes hairy.

* Scales of the involucre not appendaged.

+ Heuds 3-6-flowered: pappus conspicnonsly plumose.

3. L. Boykinii, Torr. \& Gray. Nearly smooth; stem slender; leaves linear, dotted ; heads 3-4-flowered, rather closely spiked; seales of the involuere smooth, lanecolate or linear, acuminate and spreading at the apex, as long as the pappus. - Near Colnmbus, Georgia. August and September. - Sten $1^{\circ}-2^{\circ}$ high. Spike $6^{\prime}-10^{\prime}$ long.

4. L. tenuifolia, Nutt. Smooth; stem tall and slender; leares narrowlinear or filiform, the lowest long and crowled ; beads 5-flowered, in a long and close raxceme; scales of the involucre barely pointed, smooth, purple. - Dry pine barrens, Floridla to North Carolina, and westward. September. - Stem $2^{\circ}-4^{\circ}$ high. Racemes often 1 -sided.

\section{+ + Heads 3-many-flowered: pappus densely bearded.}

5. L. pauciflora, Pursh. Stem pubeseent, declining; leares linear, short, smooth; heals 4-5-flowered, in a long 1 -sided raceme; scales of the involucre oblong-lanceolate, acnte, smooth, or pubescent on the margins. ( $\mathrm{L}$. secunda, Ell.) - Dry sandy ridges in the middle districts. Alabama to North Carolina. September. - Stem $2^{\circ}-3^{\circ}$ long.

6. L. Chapmanii, Torr. \& Gray. Stem tomentose; leaves smooth or pubescent, linear, rather obtuse; the uppermost very short and lraet-like; heads mostly 3 -flowered, cylindreal, densely spiked ; seales of the iuvolucre lanecolate, acuminate, smooth; the outer ones much shorter and hroarler; corolla and very hairy achenium large. - Dry sandy ridges, Florida. July-Sept. Stem $1^{\circ}-2^{\circ}$ high.

7. L. gracilis, Pursh. Stem tomentose and somewhat hoary; leaves smooth or nearly so, the lowest lanceolate, olutuse, long-petioled, the others lincar, appressed or spreading, short; heads small, 3-7-flowered, sessile or on slender tomentose and braeted pediecls; seales of the involnere oblong, rather 
obtuse or mucronate, more or less pubesent; the ed ges not margined and $\mathrm{cmm}$

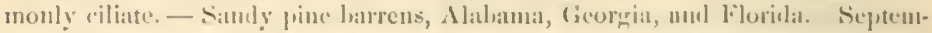
ber. - stem $1^{\circ}-2^{\circ}$ lighli. Varies greatly in the length and direction of the perlicels.

8. L. graminifolia, Willt. Stem nsually smooth, and striped with greener lines; leaves more or less hairy on the upper surfare, and fringed near the hase; the lowest lanceolate or lincar-lancelate, clongated, the "1per linear; heats in spikes or racemes, often rery numerons; involucre lowally obroniral, i-14-flowered; the seales ollong-spatulate, rounded at the apex, narrowly marginerl. (I. gracilis, Ell., a more slender form, with the fewer-flowered heads on longer pedicels.) - Light dry soil, Florida to Mississiplpi, and northward. Scptember. - Stem $2^{\circ}-6^{\circ}$ high.

9. L. spicata, Willu. Smooth; stem very leafy; leaves linear, erect; the lowest very long, obtuse, 3-5-ribhed; the uppermost small and lract-like; hearls sessile, eylimlrical, 8-12-flowered, crowded in a long rylindrical spike; scales of the involnere smooth, obtuse, narrow-marginel, furp)le. (L. resinosia, Nutt., a small form witl 5-flowered hearls.) — Swamps, Floricla to Mississi]pri, annl nortlwarl. Arroust and September. - Sten rigid, $2^{\circ}-5^{\circ}$ highl. Sjike's sometimes $2^{\circ}-3^{\circ}$ long. Styles elongated.

10. L. pilosa, Willd. More or less pubescent with long seattered hairs; stem sturst ; Javes linear or linear-lanceolate, clongated, hairy ; leads in a Joose simple raceme, 10-15-flowered; seales of the turbinate or campanulate involucre glalbrons, not prunctate, with slight scarjous margins, the exterior narrowly oblong, short, very ohtuse; the innemost linear; achenia pubescent, nearly as long as the densely bearded (almost plumose) pappus. - Henilerson County, North Carolina, Curtis. $-\Lambda$ stout plant, with the heads $8^{\prime \prime}-10^{\prime \prime}$ longr.

11. L. scariosa, Wilh. Stem sturt, pubescent ; leaves mo:tly pubeseent, the lowest large, ublong or lanccolate, obmse, the upper linear, acute; hearls large, 15-40-flowered, romdish, sessile or pedicelled; seales of the involuere spatulate or oberate, rounded at the apex, usially with broal and rolored margins; the outer ones with spreacling tips. (L. spheroidea, J/che.) - Dry light soil, Floridat to Mi ississippi, and northward. September. - Stem $3^{\circ}-6^{\circ}$ high. Ileads sometimes l' wide.

12. L. heterophylla, I3rown. Leaves lanceolate, smooth; the upper ones linear-lanecolate and much smaller; heads alout 10, roundisli, spiked, erowhlerl, 15-16-fowered; seales lanceolate, with pointed spreading tips. - Georgia to North Carolina, not common.

\section{\$2. Root not thberous: leures oborate or oblong: lieuls feu-flouered, corymbed or panicled: pappes minutely bearded.}

13. L. odoratissima, Willd. (Hovxu's Toxgre.) Stem herbacens, smooth; Jeaves smooth and of ten glancous, oltuse; the lowest spatulate-obovate, 3-5-ribbed, the upper oval or ohlong, small, sessile; heads 7 -- 8-flowered, llisposed in an ample spreading corymb or panicle. - Flat pine harrens, Florila to North Carolina, and westwarl. September. - Stem $2{ }^{\circ}-3^{\circ}$ high. The withering leaves exhale the odor of vanilla. 
14. L. paniculata, Willd. Stem riscid-pubeseent; leaves smooth; the lowest spatulate-lanccolate, the upper lanceolate, sessile, small ; heatls mostly 5 flowered, in small lateral and terminal corymbs, forming a dense oblong panicle. - Damp pine barrens, Florida to North Carolina, and westward. Sept. and Oct. - Stem $1^{\circ}-2^{\circ}$ high.

15. L. fruticosa, Nutt. Stem shrubby, smooth; branches naked above; leaves ohovate, not ribbed, the lowest ones opposite; heads corymbose, 5-flowered; scalcs of the involucre lanceolate, acute, dotted. - East Florida. _ Leaves I'long.

10. KUHNIA, L.

Heads 10-25-flowered. Flowers all similar and perfect. Seales of the involucre few and loosely imbricated in $2-3$ rows. Receptacle naked. Corolla slcnder, 5-toothed. Achenimu eylindrical, many-striate. Pappus a single row of strongly plumose bristles. - A perennial herb, with lanceolate or linear dotted leaves, and heads of yellowish-white flowers in panjeled corymbs.

1. K. eupatorioides, L. Stem puhescent, or somewhat viscid, mostly branched; leaves toothed or entire, pubescent, or smoothish beneath, the lower ones sometimes opposite; corymbs loose or crowded. (K. Critonia, aud Ki. glıtinosa, Ell.) - Light and dry soil, Florida to Mississippi, and northward. Sept. - Stem $2^{\circ}-4^{\circ}$ high.

\section{BRICKEIIIA, Ell.}

Heads few- or many-flowered. Seales of the involuce linear, imbricated, the outer ones shorter. Receptacle flat, naked. Corollin 5-toothed. Achenia eylindrical, 10-striate. I'appus a single row of bearded bristles. - Perennial herbs, with dotted opposite 3-ribbed leares, and large heads of pale purple flowers, in terminal corymbs.

1. B. cordifolia, Fll. Stem erect, tomentose, mostly branching; leaves ovate, serrate, mostly corlate, petioled, the upper ones often alternate; heads large, 30-40-flowered; achenia nearly smootl. - Jight rich soil, Western Georgia and Elorida, and westward. Aug. - Stem $2^{\circ}-4^{\circ}$ high. Flowers showy.

\section{EUPATORIUM, Toun. Thonolghwort.}

Heads 3-many-flowered. Involncre eylindrical or bell-shaped, the seales in a single row, or imbrieated in 2-sereral rows. Receptate flat, naked. Corolla 5-toothed. Achenia 5-angled, the sides smooth and eveu. I'ippus a single row of slender rough bristles. - Perennial and mostly resinous-dotted herbs, with opposite or whorled leaves, and white or purplish flowers.

\section{\$1. Heatls corymbed.}

* Scales of the cylindricel involucre munrous, closely imlnirated in several rous, the outer ones shorter: heads feu-or muny-fouered: lenes chirgly opposite.

1. E. ivæfolium, L. Herbaceous; stem (;0-50) erect, terete, roughhairy, at length much branched; leares laneeolute, acute at each end, nearly 
sessile, 3-newed, sparingly semate; coryubs dense; heads 15-20-fowerwl; scales of the involucre very ohtuse, strongrly striate. - Near Natchez, Mississippi, and south Florila. July-November. - Flowers lilur.

* * Scules of the involucre purplish, scurious, abluse, imbricated in sevcrul rou's, the outer ones much shorter: licures uhorlal: fiouers purplish.

2. E. purpureum, I. Smooth or pulsesent; stem simple, tall, of ficm spotted or clotted; leaves petioled, 3-6 in a whorl, varying from lamerolate to ovate, coarsely serrate, roughish ; corymbs large, rompomul hearls 5-10-flowered. - Swanjs, rarely in dry woods, Florida to Misissippi, and northward. Anr. - Sept. - Stem $3^{\circ}-10^{\circ}$ high, solid or hollow, even or grooved. A variable speeies, including F. ternifolium, F. maculatum, and E. verticillatmm, E:ll.

** * Scals of the involucre (grem or white) imbricuted in 2-3 rous, the outcr ones shorter: heuds 5-20-flowered: leaves, uchenia, de. dotted with resinous glunds: flowers white.

- Ilauls 5-floured: leares underided, spssile or narroued into a stalk-like base (ехеслt No. 13.)

3. E. hyssopifolium, L. Puheserut; leaves opjosite, the upper ones alternate, lanceolate or ovate-lanecolate, coarsely serrate or toothed, 3-ribbed at the base; seales of the involnere lanceolate, obtuse, nucronate, shorter than the flowers. (F. linearifolium, Wall.) - Varies with the leaves narrow-lineat and entire, the lower ones 4 in a whorl, and numerous smaller ones in the axils. Low ground, Florida to Mississippi, and northward. Sept. - Stem $2^{\circ}-3^{\circ}$ high. Leaves rigill, sometimes all alteruate.

4. E. cuneifolium, Willi. I'ubescent; Jeaves short, obovate-ollong, sparingly serrate near the summit, or entire, 3-ribbed, mostly very obtuse; seales of the involucre obtuse, shorter than the flowers. (E. glaucescens, Ell.) - Rich shaded soil, Florida to Sonth Carolina. Sept. - Stem $2^{\circ}-3^{\circ}$ high. Leaves $1^{\prime}$ loner, pale and somewhat grlancous on both siles.

5. E. leucolepis, Torr. \& Gray. Stem simple, virgate, mimutely pubeseent and rougliened; leares somewhat remote, lanceolate or linear-lanceolate, acute, serrate, rery rough on both sides, obscurely 3-ribbed; corgmls ample, loary; scales of the involuere lanecolate, acuminate, white and scarious at the apex, as long as the flowers. - Flat pine barrens, Florida and northward. Sept. - Stem 20 high. Leaves $1^{\prime}-2^{\prime}$ Joug.

6. E. parviflorum, Ell. Tomentose; stem slender, simple or branched above; leaves alternate, opposite, or whorled, lanecolate, aneute, strongly scrate, 3-ribbed near the base, tapering into a petiole; corrmbs large; scales of the involncre lanceolate, olstuse, shorter thin the flowers, seareely longer thin the mature achenial. - Margins of ponds and wet places, Floridat to North Carolina, and westward. Sept. - Stem $2^{\circ}$ litigh. Leaves $2^{\prime}$ long, strongly reined. Flowers smallest of all.

7. E. scabridum, Ell.? Stem stont, tomentose; leaves opposite, oratelaneeolate, acute at both ends, thickly and unequally serrate, rough above, tomentose and somewhat glancous beneath, 3-ribbed from near the base; corymb; 
ample, dense; scales of the involucre lanceolate, cuspidate, shorter than the flowers. - Low pine barrens, Middle Florida to South Curolina. August. Stem 20 high. Leaves $1 \frac{1}{2}$ long.

8. E. rotundifolium, I. Stem puhescent, mostly simple; leares short, broadly ovate or roundish, obtusely serrate, roughish, mostly truncate at the base, 3-ribbed and somewhat rugose ; corymbs large; scales of the involnere latuceolate, acute, shorter than the flowers. - Low pine barrens, Florida to North Carolina, and westward. August. - Stem $2^{\circ}$ ligh. Leaves $1^{\prime}$ long.

9. E. teucrifolium, Willd. Rough-pubesent; leares ovate or oblongovate, coarsely serrate and sometimes toothed near the base, 3-ribbed; the uper ones small and remote; corymbs dense, depressed in the centre; scales of the involnere lanceolate, mueronate, shorter than the flowers. (E. verbenafolium, Michx.) - Damp soil, Florida and northward. S'jt. - Sten virgate, $2^{\circ}-3^{\circ}$ ligeh. Leaves $1^{\prime}-1 \frac{1}{2}$ long, the base rounded or truncate. Branches of the corymb alternate.

10. E. album, I. Rough-pubescent or hairy ; leaves oblong or lanceolate, marrowed at the base, toothed-serrate, strongly veined; corymbs dense; scales of the involucre lanceolate, smooth, or the outer ones pubescent, longer than the flowers, the acuminate or mucronate tips white and searious. - Dry sancly soil, Florida to Mississippi, and northward. Sept. - Stem $1^{\circ}-2^{\circ}$ high. Leaves $2^{\prime}$ long.

11. E. altissimum, L. Stem tomentose; leaves opposite, laneeolate, acute, pubcscent, strongly 3-jibbed, sharply serrate alove the millle, narrowed at the base; coryml, dense, hoary; scales of the involucre shorter than the flowers, linear-oblong, olstuse. - Sterile soil, North Carolina and westward. Sept. - Stem $3^{\circ}-7^{\circ}$ high. Leaves $3^{\prime}-4^{\prime}$ long.

12. E. sessilifolium, L. Smooth; leaves long, lanceolate, acuminate, serrate, rounlexl and closely sessile at the base; corymb tomentose; scales of the involnere oblong, ohtuse. (E. truncatum, Eil.) - Open woods, in the upper districts, Alabama and northward. Sept. - Stem $2^{\circ}-4^{\circ}$ high, mostly branching abore. Leaves $3^{\prime}-6^{\prime}$ long, thin and veiny.

13. E. mikanioides, 11. sp. Stem aseending from a ereeping base, branching and tomentuse above ; leaves opposite, long-petioled, deltoid, glandılar-serrate or toothed, truneate or abruptly acute at the base, resinous-dotted above, pubescent on the veins leneath; the petioles somcwhat connate; corymb ample; scales of the involucre alout 10, lanceolate, acute; anthers slightly exserted ; achenia 5-angled, glandular. - Low sandy places, on St. Vincent's Island, West Florida. Sept. - Stem $1^{\circ}-2^{\circ}$ highl. Leaves $1^{\prime}-1 \frac{1^{\prime}}{2}$ lon $r$, somewhat fleshy.

+ + Ileads 6-15-flowered: leaves opposite.

+ Leaves sessile or perfoliute.

14. E. pinnatifidum, Ell. Pubescent; leaves lanceolate, jinuately lobed or pinnatifid, the uppernost linear and entire, the lowest ones whorled; heads 6 -9-flowered ; seales of the involucre lanceolate, acute. - Dry soil, Florilla to North Carro!ina. Sept. - Stem $2^{\circ}-3^{\circ}$ high. 
15. E. perfoliatum, J. Pubeseent or liairy; leaves lanecolate, arumi-

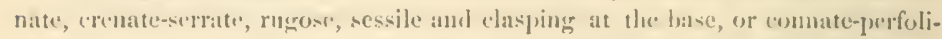

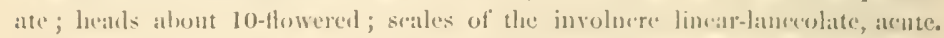
- Low gromel, Floridat and northward. Sept. - Stem stomt, $2^{\circ}-3^{\circ}$ high. Le'ives $G^{\prime}-8^{\prime}$ long.

\section{$\rightarrow+$ Leaters prtioled.}

16. E. serotinum, Michx. I'ubescent; stem tall, mostly hranching ;

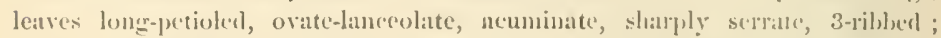
heats 1.2-15-flowered; seales of the involuce linear-oblong, obtuse; acheniat smooth. - Rich soil, Florilia to North Carolina, and westward. Sept. - Stem $3^{\circ}-6^{\circ}$ high. Leaves $4^{\prime}-9^{\prime}$ long.

17. E. villosum, Swart\%. Stem tomentose, brunching; leaves slortpetioled, ovate, ohtuse or moneronate, rusty-pubesent, dentirulate or entire, 3ribled; corymb dense; heads $10-15$-flowered; seales of the involure about 10, equal, linear, obtuse, shorter than the flowers; anthers slightly exscrted; achenia hispicl; pappus shorter than the flowers. - South Florida. - Leaves rigid, $1^{\prime}-1 \frac{1}{2}$ ' long.

* * * * Scales of the imolucre (grecn) rqual, in a single row: heatls 8 -30-flutcred: leeres, arheria, $f c$, not resinous-lotted: leares on slender pretioles.

18. E. ageratoides, I. Smooth; leaves thin, ovate or slightly corlate, acuminate, coarsely and sharply serrate, 3-ribbel ; heals $10-20$-flowered ; siales of the involucre lincar, arutish, slightly pubeseent; achentia mooth. - Rich sharled soil, Florirla to Mlississippi, and northward. Scpt. - Stem commonly Iranching, $2^{\circ}-3^{\circ}$ high. Leaves $3^{\prime}-5^{\prime}$ long. Flowers white.

19. E. aromaticum, I. J'ubeseent; leaves thickish, orate, or the lowest corlate, crenate-serrate, roughish, on short petioles, barely alcute; leanls 815-flowered; scales of the involucre lincar ; achenia smooth. (E. ceanothifulium, Willd.) - 1)ry open woods, common. Sept. - Stem $2^{\circ}$ ligh. Leaves $1^{\prime}-2$ ' long. Flowers white.

20. E. incarnatum, Walt. Pubescent ; stem sleuder, reclining, diffusely branched; leaves on long petioles, deltoid, acuminate, truncate or corlate at the base, coarsely serrate; corymbs numerons, small; heads alout 20-flowered; scales of the involucre linear, acute, 2-ribbed; achenia hispicl. - lich shated soil, Florilla to North Carolina. Sept. - Stem $2^{\circ}-4^{\circ}$ long. Leaves $1^{\prime}-2^{\prime}$ long. Flowers pale purple.

\section{\$2. Heats in panicled racemes: leaves pimately dividert.}

21. F. fœniculaceum, Wild. Stem tall, pulseseent, pauiculately much brauched; divi-ions of the leaves filiform, smooth; heals 3 - 5 -flowered; seales of the inrolucre smooth, margined, notched at the apex, unucronate; achenia smooth. - Chiefly in old ficlds, Florida to North Carolina, and westward. Sept. and Oct. - Stem $3^{\circ}-8^{\circ}$ high. Flowers white.

22. E. coronopifolium, Willı. Pubeseent; stem panieulately branched; divisions of the leaves linear ; hearls crowled, 5 -flowered; scales of the involucre mueronate, pubeseent, margined; achenia smooth. - Dry sandy soil. Florila to North Carolina. Sept. and Oet. - Stem $2^{\circ}-4^{\circ}$ ligh. Flowers white. - l'robably a broaler-leaved form of the preceding. 


\section{MIKANIA, Willd.}

Heads 4-flowered. Scales of the involucre 4. Receptaele naked, flat. Anthers partly exserted. Corolla, achenia, \&c. as in Eupatorium. - Cliefly climbing herbs, with opposite mostly cordate leaves, and whitish flowers.

1. M. scandens, Willd. Smooth or pubescent; leaves on slender petioles, acuminate, toothed or entire; corymbs numerous, on short axillary branches or peduncles; seales of the involucre linear, actute; achenia mimtely glandular. (M. pubescens, Muhl.) - Swamps, Florida and nothward. Aur. and Sept. Stem twining.

\section{CONOCLINIUM, DC.}

Ileads many-flowered. Scales of the involucre nearly equal, imbricatcil in 2-3 rows. Receptacle conieal, naked. Corolla 5-toothed. Anthers included. Achenia angled, smootlı. - Perennial herbs, with opposite petioled serrate leaves, and heals of purple or blue flowers in a terminal corymb.

1. C. cœlestinum, DC. Snoothish; leaves deltoitl-ovate, the lowest often cordate, acuminate, coarsely serrate; hearls $30-60$-flowered ; flowers bluisli-pnrple. (Enpatorium exelestiuum, L.) - Rich soil, Florida and northwarl. Sept. - Stem $2^{\circ}$ high.

Trпne III. ASTEROIDE.F. ITeads disroid or radiate; the retys pistillate: branches of the style, in the perfect flower, futtened, lincar or lanceolate, equally pubscent abve on the ontside; the conspicuous stigmatic lines tominuting where the exterior pubescence commences.

\section{SERICOCARPUS, Nees.}

Ifeads 12-15-flowered; the ray-flowers ahout 5, white, pistillate; those of the disk tubular and perfect. Involucre somewhat eylindrical or (lub-shaped; the scales cartikiginous, whitish, closely imbricated in several rows, with greenisll and more or less spreading tips. Receptacle pitted, toothed. Achenia short, obpyramidal, silky. Pappus simple, composed of numerons capillary bristles. - Perennial herbs. Leaves alternate. Heads erowded in a dense corymb. Disk-flowers yellow.

1. S. conyzoides, Nees. Stem slightly puhcscent, corymbose above; nearly terete; leaves ciliate on the margins, otherwise smooth, the lower ones spatulate-oblong, serrate alove the middle, the upper oblong or lanceolate and entire; involucre top-shaperl ; pappus rust-color. (Aster conyzoides, Willd.) Dry gravelly or sundy soil, in the middle and upper districts, Georgia and northward. Angust. - Stem $1^{\circ}-2 \circ$ high.

2. S. solidagineus, Nees. Smooth; stem angled; leaves lanceolite or linear, obtuse, entire, the lowest spatulate; involucre top-shuped ; pappus white. (Aster solidaginoiles, Willd.) - Low gromel in the upper districts. August. Stem slender, $2^{\circ}$ high. Heads smaller tham in the last. 


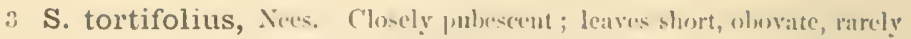

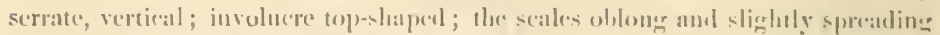

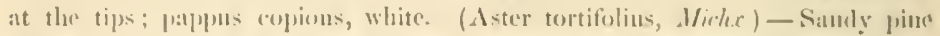
harrens, Filerida to North Carolina, and westwarel. Augunt. Stem $10-2^{\circ}$ high. Leaves I' long.

\section{ASTER, 'Tumr. Aster. Srarworr.}

Ileals many-flowered; the rays (white, blue, or purple) in a single series, pis. sillitie. Serales of the involnere more or less imbricited, mostly with herhaceons or leafy tips. lieceptacle flat, pitted. Achenia usually compreseced. Pappos a single row of numerous rongh eapillary bristles. - I'eremial (rarely ammua!) herbs. Leaves alternate. Disk-flowers yellow, often clanging to purple.

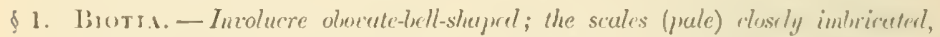

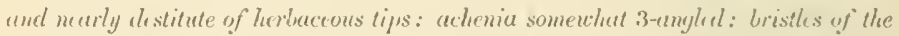
pappus rigirl: leaves large; the lower ones cordete: luouls corymbet.

1. A. corymbosus, $\Lambda$ it. Stem sleniter, smoutlı; leaves on slender petioles, thin, coarsely serrate, ar uminate; the lower ones cordate, the upper oblome; imvoluere shorter than the lisk, the seales uhtuse; rays $6-9$, white. - Shaty woods in the upper distriets, Georeria and northwarl. Sept, and Oct. - stem $10-2^{\circ}$ high. Leares $2^{\prime}-t^{\prime}$ long. Corymbs loose.

2. A. macrophyllus, L. Stem stunt, rough-pubeseent; leaves large, rather thick, rough, mucronate-serrate, areute; the lowest broally corlate, on slender naked petioles; the npper ovate, on short and winged petioles; insolucre nearly as long as the disk; the exterior seales rigid, with spreading fringed

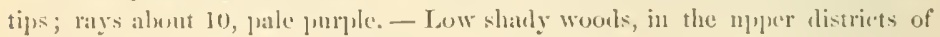
Georgia, and alone the mountains, northwarl. Sejt. - Stem $1 \frac{1}{2}{ }^{\circ}-2^{\circ}$ high. Le'are's $4^{\prime}-6^{\prime}$ loner, $2^{\prime}-4^{\prime}$ widc.

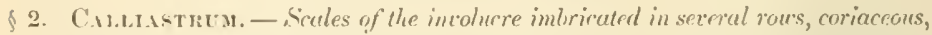

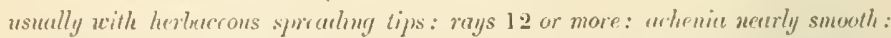

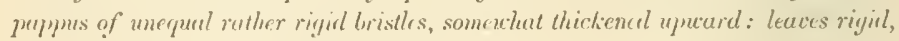
none of them corelute: houls larye amb shoury.

3. A. mirabilis, Torr. \& Cray. Rough-pubescent ; stem corymbosely branched above; leaves urate, mucronate-serrate, sessile; the lowest abruytly narrowerl into a petiole; involucre hemi-pherical; the scales ol,long-linear, ol)tuse and recrirved at the summit; achenia nearly smootl, striate. - Columbia, South Carolina, Prof. Ciillors. Sept. - Stem $1^{\circ}-2^{\circ}$ hight - Stem-leaves $1^{\prime}-\dddot{u}^{\prime}$ long. Rayss alout 20, bue or vislet, clongated.

4. A. spectabilis, $\Lambda$ it. Stum corymbose anil glundular-puloescent ahove; Ieaves oblonir-lanceolate, rough on the mper surface, sessile and entire; the lowest tapering into a jetiole, aul sparingly serrate; houls not numerous, single, terminating the branches; involncre nearly hemisplerical, as long as the disk; the seales linear-olblong, with olotuse and spreading glandular tijs. (.1. surenlosus? Ell., witl ohovate-oblongr, mostly serrate leaves, and broater scales of the involucre.) - I'ine barrens, Florisli and northward. Sejt. aud Oct. - IRhizoma slender. Stem $1^{\circ}-2^{\circ}$ high. Leures $2^{\prime}-4^{\prime}$ long. Heads $\frac{1}{2}^{\prime}$ in dianeter. Raiys abont 20, l' lomer, deep violet. 
5. A. gracilis, Nutt. Stem slender, slightly pubescent, corymhose at the summit; leaves rough, oblong, partly clasping, entire ; the lowest obseurely crenate and narrowed into a petiole; heads corymbose; insoluce (whiti-s) obconieal, as long as the disk; the seales very unequal, acute, the lower ones much shorter, green and slightly spreading at the tips. - North Carolina and Tennessee. Sept. - Stem $1^{\circ}-2^{\circ}$ high. Leaves $1^{\prime}-2^{\prime}$ long. Heads smallest of this group. Rays about 12, violet.

6. A. surculosus, Michx. Stems several from a creeping cantex, slender, pubescent above: leares lanceolate or linear-limceolate, acute, smooth, the margins rough and sometimes sparingly serrate, clasping; the lowest narrowed into a petiole; heads solitary, or $3-5$ in a simple corymb; involucre broally top-shaped, nearly as long as the disk; the scales linear-spatulate, with abruptly pointed spreading herbaceous tips; the outer ones lanceolate and leaf-like. Margins of swamps, North Carolina. Sept. - Stems $\frac{10}{2}-1 \frac{10}{2}$ ligh. Lowest leaves $4^{\prime}-6^{\prime}$ long. Heads $\frac{1}{2}$ wide. Ray's nnmerous, violet.

7. A. paludosus, Ait. Stem slightly roughened; leaves linear, rigrid, acute, entire, partly clasping, often fringed near the base; heads $3-8$, racemed or corymbed; involncre hemispherieal, as long as the disk; the seales nearly equal, linear-spatulate, with mucronate green and spreading tips. - Low pine larrens, Florida to Nortlı Carolina. Sept. and Oct. - Stem $1^{\circ}-2^{\circ}$ high. Leaves $2^{\prime}-4^{\prime}$ long. Hearls $\frac{1}{2}-3{ }^{\prime}$ wide. lays numerous, deep blue.

8. A. spinulosus, n. sp. Rhizoma tnherous; stem rigid, sprinkled with white jointed hairs; leaves rigil, nurrow-linear, pungent, appressed, the margins fringed with bristly hairs; the lowest ones very mumerons and elongated; heads $4-8$ in a simple spike; involucre bell-sliaperl, rather shorter than the disk; seales equal, lanceolate-subulate, rigid, erect, spine-pointed, bristly near the base; achenia strongly ribbed. - Damp pine barrens, West Florida, near the coast. June - Angust. - Stem 10'-15' high. Lowest leaves 6'-12' long. $1^{\prime \prime}-3^{\prime \prime}$ wide; the upper ones $l^{\prime}$ loug. IIeads $\frac{\lambda^{\prime}}{3}$ wide. Rays $12-15$, jaic blue. Pappus tawny.

9. A. eryngiifolius, Torr. \& Gray. Rhizoma tulerons; stem rigid, sprinkled with jointel hairs; leaves lanecolate-linear, pungent, the lowest mostly entire; the others ereet, and fringed with spiny teeth ; heads very large, solitary or $3-4$ in a loose raeeme; involucre hemispherical, shorter than the disk; scales very numerous, herbaceous, rigid, lanceolate, tapering into a long and slender reeurved tip; achenia short, oblong. - Low pine barrens, Florida. June-August. - Stem $1^{\circ}-2^{\circ}$ high. Lowest leaves $4^{\prime}-6^{\prime}$ long. IIeads $l^{\prime}$ or more in diameter. Rays numerous, white.

\$3. Aster proper. - Scales of the involucre imlnicated in varions deyrees, with herbacpons tips: rays numerous: achemia fluttened: pappus of soft cupillury bristles, not thickened uprard: autumnal plants.

* Leaves uniform, small, sessile, entire, silky or silvery on both silles, mucronate: scales of the involucre imbricated in 3-severul rous: ruys violct-purple.

10. A. sericeus, Vent. Stem with numerous branches, bearing the large heads (single or 3 in a eluster) at their summits; leares oblong-lancenlate, sil- 
very; scales of the insolucre leafy and sprealing; arbenia sinooth. - A Western species, a form of which, with narrower and less silvery lenves mul sales. grows

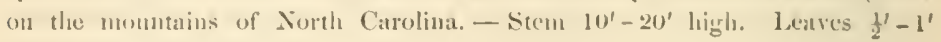
long. Ileads showy.

11. A. concolor, L. Stem mostly simple, slenter, hearing towarks the

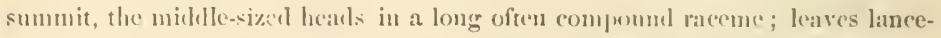
olate, silky when young; the lowest ones oblong; seales of the obovoil involucre lanceolate, appresserl, the subulate tips sprending; uchenia silky. - Jry sauly soil, Florida and northward. - loot sometimes tuberous. Sitem $1^{\circ}-3^{\circ}$ lighr. Leaves erect $\frac{1}{2}^{\prime}-1^{\prime}$ long.

* * Ifares rough, all sessile or clasping and entire: heads chiefly solitury, terminat-

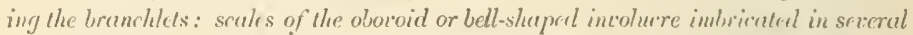
rous, coriuceous, with herbaccons slightly spreuding tips: rays purplish-bluc: achenia hairy.

+- Itares very small, sessile: leads smull: scules of the inrolucre sputulate.

12. A. squarrosus, Walt. Stem slenter, cliflise; leares ohlong or triangular-ovate, reflexerl, very rough, seswile; the lowest spatulate, - 1)ry suil, Floridat to Xortly Carolina. - Stem $1^{\circ}-2^{\circ}$ high. Lowese leaves $\frac{1}{2} l$ long, the other's $2^{\prime \prime}-3^{\prime \prime}$ long.

13. A. adnatus, Nutt. Stem with the sleniter branches erect; leaves oblong, very rough, the mislrit, partly alnate to the stem, free at the alex; the luwest werlere-obovate, free. - Sandy barrens, Florida and Alabanıa. - Stem $1{ }^{\circ}-2^{\circ}$ hight. Heals smaller than in the preceding.

+t t- Leaves all clasping and auricled at the base: hads large: scales of the imrolucre linear.

14. A. patens, Ait. Stem pubescent, loosely panirled above; leaves ovate-oblong, with very rongh and wary margins; those on the slender and spreading lrauchlets very small. - Var. Iru Logiforits. Leaves larger, thinner, and less roughened, contracted below the midhle; heals often racemose on the short lateral branches. - Dry soil, chicfy in the upper districts. - Stem $1^{\circ}-3^{\circ}$ ligh. Leaves $1^{\prime}-2^{\prime}$ (in the var. $3^{\prime}-6^{\prime}$ ) long. Hends showy.

* * Lerves (und stems) smooth: the lowest tapering into a petiole, the olliers sessile or clusping: lecads michlle-sizd, shony: scales of the oborvid imolncre uthitish, the short green tips seurcely sprcuding: rays bright blue: achenia mostly smooth.

15. A. læevis, L. Very smooth and ofen glaucous; stem rigid, panicled above, bearing the showy licads on short rigill branchlets; leaves oblong or lin(colate, coriaceus, mostly entire and rough on the margins; the npper ones sessile or clasping; scales of the involucre rigid, appressed, with albruptly pointed herbaceons tips. - Open woods in the upper clistricts. - Stem $2^{\circ}-3^{\circ}$ ligh.

16. A. gracilentus, Torr. \& Gray. Very smooth; stem slender, loosely panicled alrove, bearing the heads at the end of sleuder leafy branchlets; leaves linear, elongated; the lower ones coarsely toothed ahove the micklle, the upper slightly clasping and entire; seales of the involucre much shorter than the disk, 
lanceolate, acute, appressed. - Lincolnton, North Carolina, Curtis. - Stem purple, $2^{\circ}-3^{\circ}$ high. Lower leaves $5^{\prime}-6^{\prime}$ long, $3^{\prime \prime}$ wide. Heads smaller than those of the preceding.

17. A. virgatus, Ell. Stem rers smooth, straight, bearing the heads in a single raceme at the summit of the long and slender branches; leaves linearlanceolate, entire, rough on the margins, partly clasping, the lowest broader and narrowed at the base; scales of the involucre lanceolate, acnminate; the nuter ones spreading. - Western districts of Georgia, and westward. - Stem $3^{\circ}-4^{\circ}$ high. Lower leaves $3^{\prime}-6^{\prime}$ long; those of the branches small and numerous.

18. A. concinnus, Willd. Stem nearly smooth, somewhat loosely corymbose; the branches virgate, dichotomous-paniculate; leaves lancelate, partly clasping, remotely and sharply serrate, with scabrous margins; those of the branchlets oblong, entire; scales of the involucre lincar, acute, closely imbricated. (A. cyaneus? Ell.) - Florida to North Carolina. - Stem $2^{\circ}-3^{\circ}$ high. Achenia pubescent.

**** Lower leares large, cordate, on long petioles: heads middle-sized or smail, racemed or panicled: scales of the incolucre someuhat membranaccous, with short green tips : rays ulue or violet.

- Leaves entire, or nearly so.

19. A. azureus, Lindl. Stem roughish, rigid, racemose-compound at the summit, the branches slender; leaves rigid, rough; the lowest ovate-lanceolate or oblong; the upper lanceolate or linear, sessile; those of the branches subnlate, appressed; scales of the obconical involucre closely imbricated, abruptly acute. - Dry soil in the upper districts of Georgia and northward. - Stem $2^{\circ}-$ $3^{\circ}$ high. Rays bright blue.

20. A. Shortii, Hook. Stem smoothish, slender, racemose-panicler at the summit; leaves nearly smooth, ovate-lanceolate, acute; those of the stem all on slender petioles, and obtuse or cordate at the base, commonly entire; those of the branches oblong, sessile; scales of the bell-shaped involncre linear, closely imbricated, rather obtuse, shorter than the disk. - Mountains of Georgia and westward. - Stem $2^{\circ}-4^{\circ}$ high. Rays violet-blue.

21. A. undulatus, L. Pubeseent ; stem racemose-panicled above; leaves varying from lancelate to broadly ovate, often wary or slightly serrate on the margins, roughish on the upper surface; the lowest on long and slender petioles, which are dilated and clasping at the base; the upper on broadly winged petioles, or sessile and clasping; scales of the obovoid involncre linear, appressed, acute. (A. diversifolius, A. sagittifolius, and A. scaber, Ell.; the last with smaller leares, and very rough on both sides.) - Woods, common and very variable. - Stem $2^{\circ}-3^{\circ}$ high. Heads small. Rays pale blue.

22. A. asperulus, Torr. \& Grar. Ronghish; stem racemose-panicled above, or simple; lowest leaves oblong-ovate, obtuse or slightly cordate at the base, sparingly serrate, on slender (not clasping) petioles; the upper oblong, narrowed at the bace, sessile or on short winged petioles; those of the branches minute; hearls loosely racemed or panicled, small; scales of the hemispherical involucre lanceolate, acute. - Dry gravelly soil, West Florida, Georgia, and westward. - Stem $2^{\circ}$ high. Rays pale blue. 


\section{+ + Louest leares ronspicuonsly serrute: houels smull.}

23. A. cordifolius, L. Stem commonly smonth, racenone-panicicd alıore;

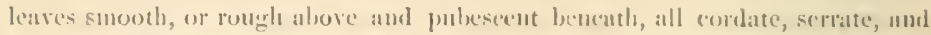
slemeler-petioled, or the "1permo-t on short wiugerl petioles, or sosile and entire;

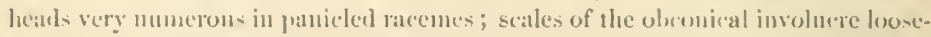
Iy imbricatetl, with obtuse or slightly peinted green tijs. - (1) wen worls, in the upper distriets. - Stem $1^{\circ}-3^{\circ}$ ligh. Leaves commonly thin. Ralys pale violet.

24. A. sagittifolius, Willel. Stem nearly smooth, racenose-branclud alove; leaves orate-lanceolate, acuminate, pulsescent; the lowest corlate, on long and mostly margined petioles; the upper alsuptly contrincted intes at winged petiole; those of the branches lauceolate, acute at both ends, entire; headi in deuse compound racemes; seales of the ollong involuere rather loosely imbircated, linear-subulate, the tips green and spreading. (A. paniculatus, Fill.) lich woods, Florida and nortlaward. — Stem $2^{\circ}-3^{\circ}$ high. Ileads more crowded than those of the preceding. Rays purple.

* * * * Leures lineur or lancolate, entire, scssile; radical onrs spatulate-lanron-

late, serrate: heads small asd numerous, racemed: stales of the incolucre in seicrul rous, rigiel, with spreading or recurved green tips.

25. A. ericoides, 1. Smooth; stem much branched ; leares linear-lanceolate, acute at eateh end; those of the branehes subulate; heads racemose, mostly on one sile of the sprearling hranches; scalcs of the involucre broalest at the lyase, with acute or subulate tips. - Var. VIl.toses, Stem and broader leaves rongh-

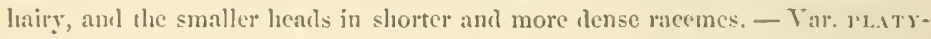
jurules. Stem $\left(3^{\circ}-4^{\circ}\right)$ and larger leaves clothed with soft white hairs; licals larger. - Dry soil, Floridla, and northward. - Stem $1^{\circ}-2^{\circ}$ high. Iaays white or jale blue.

26. A. multiflorus, Ait. Whitish-pubeseent; stem rery leafy, and much branched; leaves linear, obtuse at each end, often briste-pointed, sprealling or recurved, the upper ones sessile or somewhat clasping; heads deusely racemose ou the short and very leafy branches, or sometimes solitury at their summits; scales of the inroluere broadest at the apex, oltuse or slort-pointerl. Dry sterile soil, in the upper districts. - Stem $1^{\circ}-2^{\circ}$ high. Leares about $1^{\prime}$ long. Jays white.

****** Leaves lincar, lanecolute, or ollong, sessile, usually narrourd at the luse: heads small or middle-sized: scales of the ineolucre membranaccous, with appressed or slightly spreading tips: rons palc purple or white.

\section{- Ilcads small.}

27. A. racemosus, Eill. Rough-pubeseent; stem much branelsed, hearing the sinall head; in a spiked raeeme near the summit of the slender erect branches; leaves lincar, sessile, rigricl scales of involucre smooth, linear-subulate; the inner ones as long as the disk; rays rery short. - Danj rich soil, Paris Island, South Carolina. - Stem $2^{\circ}$ lighh. Rays pale purple.

28. A. Baldwinii, Torr. \& Gray. Rougl-pubeseent; stem slender, panicled above, bearing the solitary or loosely racemose heads on the slender branchlets; leaves very rough, entire; the lowest ovate, on slender margined petioles, 
the others sessile or partly clasping; the uppermost very small, ereet; scales of the involncre in 3-4 rows, linear, acute. - Dry pine barreus, Florida and Georgria. - Stem $1^{\circ}-2^{\circ}$ high. Lowest leares $1^{\prime}$ long, the npper ones $2^{\prime \prime}-3^{\prime \prime}$ long, similar to those of No. 33 .

29. A. dumosus, L. Smoothish; stem slender, raecmose-panicled, bearing the small heads chiefly on slender and very leafy branchlets; leaves linear, entire, spreading or reflexed; the lowest spatulate-lanceolate, serrate; those of the branches short, linear-oblong, and mostly obtuse: seales of the involuere closely imbrieated in 3-6 rows, with obtuse green tips. (A. foliolosus, Ell.) Dry or damp soil, common, and running into several rarieties. - Stem $2^{\circ}-3^{\circ}$ high. Rays jale purple or white.

30. A. Tradescanti, L. Stem slender, pubescent, racemose-branched; leaves long, linear-lanceolate, sparingly scrrate, tapering into a long and slender point ; the uppermost entire; heats in elose racemes along the spreading branches; scales of the involnere narrow-linear, acute, imbricated in 3-4 rows. - Var. FRAGILIS. Leaves mostly entire ; heads fewer, often solitary on the branchlets. (A. tenuifolius, Ell.) - Low ground in the upper districts. - Stem $2^{\circ}-3^{\circ}$ liigh. Rays pale purple or white.

31. A. miser, L. Pubescent or hairy; stem simple, and bearing the small heads in a long and leafy compound raceme, or diffusely branched, with the lieads scattered along the branches, or in short few-flowered racemes; leaves varying from linear-lanceolate to wedge-obovate, acute at each end, sharply serrate in the middle; the lowest spatulate, the uppermost entire; seales of the involucre linear, acute. - Low grounds and banks, conmon and very variable. - Stem $1^{\circ}-4^{\circ}$ long. Rays white or purplish. A. diffusus, A. divergens, and A. pendulus, of Aiton, are forms of this.

\section{+ + Ileads midlle-sized.}

32. A. simplex, Willd. Stem smooth or pubescent in lines, corymbose or racemose-branched; heads in short racemes; leaves lanceolate, acute or acuminate at both ends, smooth, rongh on the margins, the lower ones sharply serrate; seales of the involnere linear-subulate, loosely imbrieated. - Low ground, Florida, and northward - Stem $3^{\circ}-6^{\circ}$ high, sparingly or diffusely branched. Leaves $2^{\prime}-4^{\prime}$ long. Rays pale blue.

33. A. tenuifolius, L. Nearly smooth; stem paniculately hranched; the rather small heads disposed in panicled racemes; leaves long, narrow-lanceolate, tapering to a long and slender point ; the lower ones commonly serrate in the middle; seales of the involncre numerous, linear-sulsulate, appressed. Low ground in the upper distriets, Gcorgia, and northward. - Stem $2^{\circ}-3^{\circ}$ high. Leaves $3^{\prime}-6^{\prime}$ long. Ray's short, pale purple or white.

******* Leaves lancelute or oblong, sessile, the upper ones more or less clasping: heads large or middle-sized: scrles of the incolucre nearly equal, with spreading green tips: rays mostly large and numerous, blue or purple.

34. A. Novi-Belgii, L. Nearly smooth ; stem stout ; leaves oblonglanceolate, pale or somewhat glaucous, serrate in the middle, acute or tapering at each end; scales of the involucre rather closely imbricated, with broadish 
acute herlacenus tips; rays pale lhe or purplish. - Georria und South Carolina. - Stem $1^{\circ}-4^{\circ}$ high. Leaves thickish, the lowest $5^{\prime}-6^{\prime}$ longr. IIeads sometimes $\mathrm{I}^{\prime}$ in diancter.

35. A. longifolius, Iam. Stem nearly smooth, corymhose-panicled ahove; leaves long, lanceolate, acuminate, shining ahove, the howest narrowed at the batse, and serrate in the middle, the upjer sessile or partly clasping; heads solitary or few on the rigid branclulets; scales of the iurolucre linear, with green and subulate, or broaler and abruptly pointed sprealing tips ; rays purplis 1 l,Inc. - Swampe, Gcorgiil, and northward. - Stem $1^{\circ}-3^{\circ}$ high. Leaves $3^{\prime}-6^{\prime}$ long. Heads showy.

36. A. Elliottii, 'Torr. \& Gray. Stem stont, smooth, very leafy, corym. lose-branchel; the branches short and pubeseent in lines; leaves large, oblonglancelate, acnte, scrmate, narrowed toward the base, and partly clasping; the lowest spatulate-oblong, obtuse, crenate; hearls corymbed at the ends of the branches; scales of the involucre subulate, with long and spreading tips; rays pale purple. (A. puniceus, Ell.) - Swamps, Florida to North Carolina. Stem $2^{\circ}-3^{\circ}$ high. Icaves $4^{\prime}-6^{\prime}$ long, or the lowest $1^{\circ}$ long.

37. A. puniceus, I. Stem lispirl, panicled above; leaves lanceolate or oblong-lanceolate, acuminate, sharply serrate, very rough ahove, amiculate and clasping at the base; scales of the involucre linear-subulate, in about two rows; rays numerous and showy. - Swampy thickets along the mountains of North Carolina, and northward. - Stem $3^{\circ}-5^{\circ}$ ligh, commonly purplish. Rays violet-purple.

3. A. prenanthoides, Muhl. Stem pubesent in lines, corymbose at the summit; leaves ovatc-lancelate, acuminate, sharply servate in the iniddle, contracted into a broally winged petiole, which is dilater and clasping at the base, rough above; scales of the involucre narrow-lincas, imbricated in 3-4 rows, with spreading green tips. - Dump woods, North Carolina, and northward. - Stem $1^{\circ}-3^{\circ}$ high. Leaves thin, $5^{\prime}-6^{\prime}$ long. Rays palc purple.

******** Leaves lancealate or oblong, entire, sessile or clusping: heads

large, in corymls or racemes: scrles of the imvolurre numerous, with spreading green summits: rays numerous, shoury.

39. A. grandiflorus, L. Sten rigid, rough with bristly hairs, sparingly branched; leaves small, linear-oblong, sessile, hispid, commonly reflexed ; heads very large, solitary, terminating the branches; scales of the involucre rigid ; the outer ones with olstuse spreading tips, the inner erect, acute; rays violet. (A. ciliatus, Walt. ?) - Dry soil in the upper districts. - Stem $2^{\circ}-3^{\circ}$ high. Leaves $1^{\prime}-2^{\prime}$ long. Heads $1^{\prime}$ in diameter.

40. A. Curtisii, Torr. \& Gray. Smooth throughout; stem simple, slender; leaves memhranaceous, lanccolate, entire or slightly serrate, acuminate, sessile; heads in a simple or slightly compound terminal raceme; scales of the involucre lincar-spatulate, coriaceous, the green and spreading tips barely acute; rnys purple. - Mountains of North Carolina. - Stcm $2^{\circ}-3^{\circ}$ high. Leaves $3^{\prime}-4^{\prime}$ long Heads $\frac{1}{2}-3{ }^{\prime}$ in diametcr. 
41. A. Carolinianus, Walt. Stem long and trailing; the branches and leaves closely pulescent; leaves short, oblong, acnte, abruptly contracted into a short auriculate-clasping petiole; heads single, or somewhat racemose at the ends of the branches; scales of the involucre narrow-linear, with recurved subulate tips; rays slender, pale purple. - River-swanps, Florida to South Carolina. - Stem $4^{\circ}-10^{\circ}$ long. Leares $1^{\prime}-2^{\prime}$ long.

42. A. Novæ-Angliæ, L. Stem hairy or hispid, corymbose above; leaves lancelate, acute, pubescent, scarcely narrowed at the auriculate-clasping base; heads corymbed; scales of the involucre linear-subulate, loosely imbricated, viseid; rays violet-purple. - Upper districts, in low ground, and northward. - Stem $2^{\circ}-4^{\circ}$ high, mostly purple. Leaves $2^{\prime}-3^{\prime}$ long. Ileads $\frac{1}{2}^{\prime}$ or more in diameter, numerous and showy.

\$4. ORthoneris. - Scales of the involucre regularly imbricated, scarious on the margins, without herbuceous tips: pappus soft-hairy.

43. A. acuminatus, Michx. Pubescent; stem erect, corymbose above; leaves large, oblong-lanceolate, acuminate, coarsely serrate, tapering at the base; heads corymbed, on slender naked peduncles; scales of the involnere linearlanceolate; rays white. - Mountains of North Carolina, and northward. Sept. - Stem $1^{\circ}-1 \frac{1}{2} \circ$ high. Leaves thin, $3^{\prime}-5^{\prime}$ long, strongly reined.

\$5. Oxxtripoliva. - Scales of the involucre without herbaceous tips, scarious on the margins: pappus soft-hairy: stems smooth und slender: leuvcs nurrow, entire, mostly fleshy.

* Perennial: scales of the involucre imbricated in several rows: rays conspicuous.

44. A. Chapmanii, Torr. \& Gray. Stem erect, straight, branched above; lower leaves long $\left(3^{\prime}-9^{\prime}\right)$, linear, spreading, the upper seattered, subulate, crect; heads large, solitary, terninating the slender branches; scales of the involucre lanecolate, rigid; rays slowy, purple; achenia smooth, many-ribbed. - Pinebarren swamps, West Florida. Oct. - Stem $2^{\circ}-3^{\circ}$ high.

45. A. flexuosus, Nutt. Sten mostly reclining, flexnous, sparingly branched; leaves fleshy, narrow-linear; heads few, scattered, terminal, small; seales of the involucre narrow-linear, very acute, the lower ones smaller and passing into bracts; achenia slightly hairy, 5-ribbed. - Salt marslies, common. Oct. - Stem $1^{\circ}-3^{\circ}$ long. Rays white or pale purple.

* * Annual: scales of the involucre in $2-3$ rous : rays short.

46. A. Iinifolius, L. Stem paniculately much branched ; leaves linearlanceolate, tapering at each end ; those of the branches linear or filiform, sessile; heads small, very numerous, in leafy racemes; scales of the cylindrical involucre linear-subulate, smooth; rays in two rows, not longer than the disk; achenia somewhat hairy, 5-ribbed. - Wret places along the coast, Florida, and northward. Oct. - Stem $2^{\circ}-3^{\circ}$ high. Lowest leaves sharply serrate.

47. A. divaricatus, Nutt. Stem diffusely branched; leaves linear-subulate; the lowest ones linear, tapering at the base; heads small, loosely panieled, on spreading peduncles; scales of the involucre lincar-sulualate, smooth; rays in a single row, longer than the disk; achenia 4-ribbed, hairy. - Salt marshes, 
Florida to South Camolina. Sejt. - Stem $1^{0}-3^{\circ}$ ligh. Lowest leaves oval or lanceolate, toothed; those of the branches short and bract-like. Rays blue.

48. A. exilis, Fill. Very glabrous; stem sleniler, tall, spaningly hrandued; leaves very long, linear-subulate; heads in racemes; seales of the involuere linear-lanceolate, half ns long as the rays. - Damp soil, in the Weatern districts of Goorgia. Sept. and Det. - Stem $4^{\circ}-5^{\circ}$ high. Low'st leares $4^{\prime}-6^{\prime}$ long, l" wide. Rays pale purple. Achenia pubescent.

\section{ERIGERON, I. FLEAmAx.}

IIcads mostly hemispherical, many-flowered. Rays very numerous, pistillate. Scales of the insolucre nearly equal, in $1-2$ rows. lieecptacle flat, nakesl. Achenia compressed. I'appus a single row of capillary bristles; or with an outer row of short chaffy scales or bristles. - Herbs. Leaves alternate. Iays white or purplish.

\section{* P'uppus doulle.}

1. E. strigosum, Muhl. Anuual, rough-puhescent; stem slenier, corymbose-panicled above; leaves entire or sparingly serrate, the lowest oblong, tapering into a slender petiole, the upper laneeolate or linear, sessile, distant; heads small, corymbose-panicled ; rays white or rose-color; outer pappus short and chaff. - Dry old ficlds, common. June. - Stem $2^{\circ}$ high.

$$
\text { * * Pappus single. }
$$

\section{+ Annual: rays shorter than the disk.}

2. E. Canadense, I. Hirsute or smoothish : stem much branched; leaves linear-lanceolate; heads very numerous, in panicled racemes, small, eylindrical; rays white; disk-flowers 4-toothed. - Old ficlds, common. MaySept. - Stem $1^{\circ}-3^{\circ}$ high.

\section{- + Perennial : rays conspicuous.}

3. E. Philadelphicum, I. Hairy; stem corymbose-branched ahore; leaves thin, toothed or entire; the lowest spatulate-oblong; the upjer olulongJanceolate, elasping; rays very numerous and narrow, purplish. (E. quercifolium, Lam., with the lowest leaves pinnately toothed) - low ground, Florida, and northward. May. - Stem $2^{\circ}-4^{\circ}$ high.

4. E. bellidifolium, Muhl. Hairy or villous; stem simple; lowest leaves spatulate or obovate, toothei above the millile; the upper oblong, sessile and entire; heads large, solitary or corymbose ; rays broadly linear, bluislt-purple. - Open woods and banks in the upper districts. March and $\Lambda_{\text {pril. }}-$ Stem 10 high, stoloniferous.

5. E. vernum, Torr. \& Gray. Smooth or nearly so; stem simple, seapelike; rarlical leares clustered, thick, spatulate or obovate, entire or slightly toothed; the others small and remote; heads rorymber ; rays (about 30 ) white. (E. nulieaule, Michx.) - Pinc-barren swamps, Florida to North Carolina, and westward. March and $\Lambda$ pril. - Rhizoma thick. Stem $1^{\circ}-2^{\circ}$ high.

\section{DIPLOPAPPUS, Cass.}

Heads many-flowered. Rays $8-12$, pistillate. Seales of the involucre imbricated, without herbaceous tips. Receptacle flat, alveolate. Pappus of capillary 
bristles in two rows, the outer row much shorter. - Perennial erect herbs. Leaves alternate. Heads single or corymbose. Rays white or purple.

\section{* Rays purple.}

1. D. linariifolius, Hook. Stem rigid, simple, closely pubescent; leaves numerous, linear, spreading, the margins very rough ; heads solitary or somewhat racemose; seales of the involucre inbricated in several rows, linear, appressed; achenia silky. - Dry open woods, West Florida to Mississippi, and rorthward. September. - Stem $1^{\circ}$ ligh. Leaves $1^{\prime}$ long.

$$
\text { * Rays while. }
$$

2. D. cornifolius, Darl. Stem pubescent ; leaves elliptical, tapering at each end, hairy on the margins and veins beneath; heads few, on slender spreading peduncles; achenia smooth. - Upper districts of Carolina, and northward. Angust. - Stem $1^{\circ}-2^{\circ}$ high. Leaves $2^{\prime}-4^{\prime}$ long.

3. D. amygdalinus, Torr. \& Gray. Stem roughish and corymbose above ; leaves oval or oblong, acute at each end, nearly smooth; heads numerous, corymbed ; scales of the involucre obtuse ; achenia hairy. - Swamps, Florida, and northward. September. - Stem $2^{\circ}-4^{\circ}$ high ; the branches spreading. Leaves $1 \frac{1}{2}{ }^{\prime}-2^{\prime}$ long.

4. D. umbellatus, Torr. \& Gray. Stem smooth, corymbose above; leaves lanceolate, acuminate; seales of the involuere acutish ; achenia hairy. Swamps in the upper distriets. September. - Stem $3^{\circ}-6^{\circ}$ high. Iranches erect. Leaves $3^{\prime}-5^{\prime}$ long.

5. D. obovatus, Torr. \& Gray. Closely pubescent; stem simple, sealy at the base; leaves oblong, sessile, strongly veined; heads large, corymbed, on long and naked (whitish) peduncles; scales of the involucre acute; achenia hairv. (Aster obovatus and $\Lambda$. dichotomus, Ell.) - Low pine barrens, Florida to South Carolina. May - July. - Stem $1^{\circ}-2^{\circ}$ ligh. Leaves $1^{\prime}-2^{\prime}$ long.

\section{BOLTONIA, I'IIer.}

Heads many-flowered. Rays pistillate. Seales of the hemispherieal involucre imbricated in two rows, not longer than the disk. Receptacle hemispherical or conical, obscurely alveolate. Achenia flattened, obovate, wing-margined. Pappus composed of several short chaffy seales; that of the disk-flowers mostly with 2-4 longer awns. - P'erenuial herbs, resembling Asters.

1. B. diffusa, Ell. Stem with long and slender branches; leaves linear, entire; heads small, terminal ; achenia narrowly murgined, hairy ; pappus very slort, 2-awned. - Damp soil, Florida to North Carolina, and westward. Sept. and Oct. - Stem $3^{\circ}-4^{\circ}$ high. Rays purplish.

2. B. glastifolia, L'Her. Stem paniculate; leaves rigid, lanceolate, sparingly serrate; the upper ones linear, entire; heads rather large; achenia broadly margined ; pappus of few short bristles, and 2-4 long awns. - River swamps, Florida, and northward. July - Sept. - Stem $3^{\circ}-5^{\circ}$ high. Rays white. 
3. B. asteroides, L'IIer. Stem panimulate, the lianches slort; leaves lanccolate, cutire; achenia smoeth, narrow-mangined ; pappus very short, withont awns. - Swampls, North Carolina. Stem $2^{\circ}-3^{\circ}$ liggh. Ilearls intermediate in size between the two preceding.

\section{SOLIDAGO, L. Golnex-ron.}

Ilcads few of many-floweresl. Rays $1-16$, rarely wanting, pistillate. Diskflowers tubular, perfect. Seales of the involucre imbricated, rarely with sprearling tips. Beceptacle flat, mostly alveolate. Achenia terete, many-ribled. Pappus simple, of numerous seabrous mostly capillary bristles. - l'eremial (rarely shrubby) erect plants, with alternate leaves, and small heads of yellow flowers.

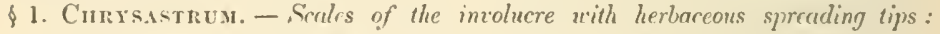
bristles of the pappus uncyul, some of them thicliend upuard: racemes short, forming a long and narrow leafy panicle.

1. S. discoidea, Torr. \& Gray. Pubescent or hairy; stem simple or branclied; leaves ovate, acinte, abruptly uarrowed into a petiole, the lower ones coarsely serrate ; racemes composed of $3-6$ large $10-15$-flowered heads ; rays none; achenia smooth. (Aster? discoilleus, Fll.) - Iich woods, Florila, Georgia, and westward. September. - Flowers yellowish-white. Stem $3^{\circ}-5^{\circ}$ hiph.

2. S. squarrosa, Muhl. Stem stont, simple, pubescent above; leaves large, smoothish, oblong, acute, serrate, the lower ones tapering into a long winged petiole; the upper sessile and entire; racemes shorter than the leaves, composed of 3-6 ilustered leads; rays 12-16, showy; achenia smooth. Mountains of Georcria, and northwart. September, - Stem $2^{\circ}-4^{\circ}$ high. Lowest leave: $6^{\prime}-8^{\prime}$ long. Heads $16-24$-flowered.

\$2. Virgaxrea. - Scales of the inelucre appressed: rays mostly, four than the disk-flouters, rarely wanting: ruremes racemose, corymbose, or panicled.

* Tiacemes not l-sided; leates fiather-veined.

- Racemes axillary, cluster-like, usually shorter than the leares: the uppermost often crouded and racemose: leaves uniform, serrate.

3. S. pubens, M. A. Cwrtis. Stem simple, slender, pubescent; leares thin, oval-lanceolate, aenminate at each end, coarsely serrate, pubescent; raeemes dense, the upper ones racemose; heads $8-14$-flowered ; rays $4-7$; seales of the involuere obtuse, villous-pubescent; achenia hoary. - Upper and mountainous parts of North Carolina, Curtis. August. - Stem $2^{\circ}-3^{\circ}$ ligh. Leares $3^{\prime}-5^{\prime}$ long.

4. S. Buckleyi, Torr. \& Gray. Villons-pubescent ; leaves oblong, acute at each end, coarsely serrate, smoother above; racemes loose, all separate and much shorter than the leaves; heads $15-20$-flowered ; rays $4-6$; seales of the involucre rather acute, nearly smooth; achenia short and smooth. - Interior of Alabama, Buclley. Oetoher - Stem 20 ligh. Leaves $3^{\prime}$ long.

5. S. latifolia, L. Stem smootl, simple, angled; leaves oval or ovate, acuminate, abruptly contracted at the base, unequally toothed-serrate, mostly 
pubescent bencath; racemes roundish or oblong, much shorter than the leaves, the upper ones more or less racemose; heads about 10-flowered; rays $3-4$; seales of the involucre smoothish, obtuse; achenia silky-pubescent. (S. flexi(aulis, Ell.) - Shady woods in the upper distriets. September. - Stem $1^{\circ}-2^{\circ}$ high, often flexwous. Leares $3^{\prime}-5^{\prime}$ long, $2^{\prime}-3^{\prime}$ wide. Racemes sometimes longer than the leaves.

6. S. cæsia, L. Stem slender, often branehing, smooth and glancous; leaves smooth, lanecolate, acuminate, sessile, sharply serrate; racemes all distinct, roundish, much shorter than the leares; the lowest rarely elongated; heads about 10-flowered; rays $3-4$, large, bright yellow; seales of the involuere smooth, obtuse; achenia pubescent. - Damp shady woods and banks, Florida and northwarl. September. - Stem $2^{\circ}-3^{\circ}$ high, often purple. Leaves $3^{\prime}-5^{\prime}$ long, $\frac{1}{2}^{\prime}-1^{\prime}$ wide. Racemes in all the upper axils.

7. S. Curtisii, Torr. \& Gray. Smoothish; sten tall, not glaneous, straight and mostly simple, striate-angled; leaves lanceolate or obovate-lineeolate, acuminate at each end, sharply scrrate above the middle, sessile; meemes lense, much shorter than the leaves; hears 8-12-flowered; rays 4-6; scales of the involucre oblong-linear, obtuse; achenia hoary-pubescent. - Mountains of North Carolina and Tennessee. September. - Stem $2^{\circ}-3^{\circ}$ high. Leaves $5^{\prime}-6^{\prime}$ long.

8. S. monticola, Torr. \& Gray. Smoothish; stem terete, simple and slender, puberulent above; leaves very thin, oblong-lanceolate, acuminate, slightly serrate; the upper ones small and bractlike; racemes sessile, the uppermost approximate and nearly as long as the leaves; heads about 15-flowererl; scales of the involucre linear, aeute; achenia smooth. - Mountains of North Carolina, Curtis. September. - Leaves and flowers smalier than the last.

9. S. lancifolia, Torr. \& Gray. Smooth ; stem tall, simple, angled ; leaves long.lanceolate, acuminate, finely serrate, sessile ; raeemes approximate, peduncled, somewhat compound ; the upper ones longer than the reduced leaves; heads nearly sessile; seales of the involuere oblong, very obtuse, minutely granular; achenia hairy. - Mountains of North Carolina. September. - Stem $3^{\circ}$ high. Leaves $4^{\prime}-5^{\prime}$ long. Heads large.

+ + Racemes crouded in racemose or pyramidal terminal panicles, longer than the leaves (except No. 15): loutest leuves larye, commonly tapering into a petiole, the uppermost small, sessile and entive.

10. S. bicolor, L. Pubeseent; stem simple, or branching above ; lowest leaves spatulate-oblong, serrate; the upper lanceolate; panicle racemose, the lowest racemes shorter than the leaves; heals about 20 -flowered; rays $7-9$, short, whitish; scales of the involnere obtuse. - Dry soil in the upper distriets, and northward. Septenber. - Stem $1^{\circ}-2^{\circ}$ high. Radical leaves $2^{\prime}-5^{\prime}$ long.

11. S. puberula, Nutt. Minntely pubeseent ; stem simple, virgate; lowest leaves spatulate-oblong, serrate above the millle; the upper liunceolate; panicle dense, racemose or pyraniclal ; hearls about 30 -flowered ; rays about 10 ; scales of the involucre subulate; achenia smoothish. (S. pubescens, Ell.) - Dry simdy soil, Mississipji, and northward. 
Var. pulverulenta. Upper leaves shorter, oblongrolovate; seales of the (20 - 2.5-flowered) involnere linear-lanecolate; achenia smooth. (S. pulverulenta, Nutr.) - Damp pine barrens, Florikla to North Carolina. Sept. and (Bct. - Stem $2^{\circ}-4^{\circ}$ high, often purplish. Lowest leaves $2^{\prime}-4^{\prime}$ long. Flowers middlesized, brigrht yellow.

12. S. petiolaris, Ait. Minutely pulveseent ; stem mestly simple, straight, very leafy; leaves oblong-lanneolate or elliptical, acute, rough on the margits, all but the lowest entire, and nearly sessile; panjele racemose or oblong ; heads large, 20-25-flowered; rays about 10, showy ; scales of the involucre linear, pmbescent ; the outer ones more or less spreading ; achenia smoothish. (S. clata? Ell ) - I)ry sandy soil, Florida to North Caroliua. Sept. - Stem $2^{\circ}-3^{\circ}$ ligh. Leaves 1 ' -2 ' lung.

13. S. speciosa, Nutt. Stem stont, mostly simple, smooth below, pulies(ent above; leaves smooth, the lowest large $\left(5^{\prime}-8^{\prime}\right.$ loug, $1 \frac{1}{2}^{\prime}-2^{\prime}$ wide), serrate; the upper ones lancelate; panicle compact, pyramilal; heads rather large, erowdel, 15-20-flowered; rays 6-8, showy; scales of the involucre lanecolate, ohtuse; achenia smooth. - Varies, with the stem and lower surface of the loroader $\left(2^{\prime}-3^{\prime}\right)$ leaves villous; the fewer, larger, and more seattered heads abont 30-flowered (S. petiolaris, Ell.?); or every way smaller; the short racenes forming a narrow racemose panicle (S. erecta, Ell.). - 1)ry suil, Florida to Mississippi, and northward; the first variety only in the mpper distriets. Sept. and Oct. - Stem $3^{\circ}-5^{\circ}$ high, often purplish.

14. S. verna, Curtis. Closely pubeseent and somewhat hoary; stem simple, or panicled above; leaves thin, ronghish, the lowest oblong, abruptly narrowed into al long and slender petiole, the npper ones sessile and entire; racemes rery stender, spreatling, forming an open somewhat corymbose panicle; heads rather large, scattered, about 30 -flowered; rays narrow; seales of the involuere linear; achenia pubeseent. - Pine barreus, near Wilunington, North Carolina, Curtis. May and June. - Stem $2^{\circ}-3^{\circ}$ high. Luwest leares $3^{\prime}-5^{\prime}$ long.

15. S. glomerata, Miehx. Smooth; stem stout. simple; leaves large, oblong-lancolate, acuminate at each end, sharply serrate, the lowest tapering into a petiole; racenes cluster-like, much shorter than the leares; the upper ones approximate and racenose; leads very large, $30-40$-flowered; rays $10-$ 12 ; scales of the involucre acute, smooth; achenial pubescent. - High mountains of Nurth Carolina. Sept. - Stem $1^{\circ}-2^{\circ}$ high. Leaves $4^{\prime}-9^{\prime}$ Iong.

\section{+++ Riacemes corymbose.}

16. S. rigida, I. Rongh-pulsescent and somewhat hoary; stem stout; leaves rigit, oval or oblong, serrate, sessile; the lowest narrowed into a petiole; corymb compact; heads very large, $30-35$-flowered; rays $7-10$; scales of the involucre ollong, obtuse; achenia smooth. - Mountains of Georgia and northward. Sept. - Stem $3^{\circ}-4^{\circ}$ high. Lowest leares $6^{\prime}-9^{\prime}$ long.

17. S. corymbosa, Ell. Stem ereet, snuoth; the branches rough-bairy; lower leaves oblong-lanceolate, the upper orate; all fleshy, rigid, smooth, but very rough and fringed along the marein; racemes corymbose, the lower rerurved; rays long. - Mitllle districts of Georgia. Sept. and Oct. - Stem stout, 
$4^{\circ}-6^{\circ}$ high. Lower leaves $4^{\prime}-6^{\prime}$ long. Scales of the involucre oval. Rays about 10. (*)

18. S. spithamæa, M. A. Curtis. Stem low $\left(8^{\prime}-12^{\prime}\right)$, rigitl, soft-lairy ; leaves oblong-lanceolate, smooth, slrarply serrate, acute; the lowest tapering into a petiole; corynb dense, compound; heads 25-30-flowered, rays $6-7$, slrort; seales of the involisere lanceolate, acute; aclienia pubesecnt. - On the summit of Roan and Hanging Rock Monntains, North Carolina, Curtis. Sept. - Stems tnfted. Leaves $1^{\prime}-3^{\prime}$ long.

* Racemes 1-sided, mostly compound, spreading or recurved (in Nos. 20 and 21 often erect), commonly disposed in a pyremidul panicle.

- Smooth species, growing in marshes: stems virgate: leaves very numerous, more or less fleshy; the lowest clongated and tapering into a margined petiole; the upper small and passing into bracts: heads middlc-sized: achenia pubescent.

19. S. flavovirens, n. sp. Smooth throughont; stem stout, simple; leaves oblong, obtuse or mucronate; the lowest serrate, on winged petioles, the upper entire, narrowed at the base; panicle pyramidal; heads 10 -12-flowered; rays mostly 3, showy; scales of the involucre lanceolate, acutislı. - Brackish marshes, Apalachicola, Florida. Sept. - Whole plant yellowish-green. Sten $2^{\circ}-6^{\circ}$ high. Lowest leaves $5^{\prime}-10^{\prime}$ long, somewhat fleshy, obscurely ribbed. Heads rather large.

20. S. virgata, Michx. Smooth; stem slender, rarely branched; leaves somewhat fleshy, entire; the lowest oblong-spatulate, sometimes slighily serrate, veiny ; the upper very small, lanceolate, appressed; panicle racemose, erect, or pyramidal, with the lower racemes 1-sided; heads 12-16-flowered; rays 5-7 ; seales of the involncre lanceolate, acute. - Pinc-barren swamps, Florida to Mississippi, and northward. Sept. - Stem $3^{\circ}-5^{\circ}$ high.

21. S. angustifolia, Ell. Smooth; stem slender, simple, or branched above; leaves fleshy, entire, the lowest lanceolite, the upper linear and acute; panicle racemose or pyramidal, lower racemes spreading and 1-sided; heals rather small, about 10 -flowered; rays 5 , narrow; scales of the involucre linear, obtuse. - Salt marshes, Fiorida to North Carolina. Oet. - Stem $2^{\circ}-4^{\circ}$ ligh.

22. S. sempervirens, I. Stem simple, or branched alove; lowest leaves lanceolate-oblong, entire, fleshy, long-petioled; the upper lanceolate, acute, sessile or partly clasping; panicle contracted or pyramidal ; heads rather large; rays $7-10$; seales of the involucre linear, acutish. (S. limonifolia, Pèrs.) Salt marshes, Florida, and northward. Sept. and Oet. - Stem $3^{\circ}-8^{\circ}$ light. Leaves varying in thickness, the lowest $6^{\prime}-12^{\prime}$ long.

+ + Stems (smooth) commonly branching: leaves not fleshy, serrate, veiny; the lowest ample, tapering into a maryined petiole: panicles pyramidal, or racemose. on the spreading branches.

23. S. patula, Muhl. Stem stout, strongly angled ; leaves large, ovate or oblong, acute, very rough above, smooth beneatls; panicles dense, leafy ; peduncles puhescent ; rays $6-7$; arhenia sparsely pubescent. - Swamps, Georgia, and northward. - Leaves $6^{\prime}-12^{\prime}$ long. 
Tar. strictula, Torr. \& firng. Stem simple, or with fuw elongated ronghpulescent luanches; leaves smaller; racemes slort, forming a loug and slemeler compond meme. (S. salitin:t, lill.) - Swamps, Florida, and northwarl. Sept. and Oct. - Stem $4^{\circ}-6^{\circ}$ high.

24. S. arguta, Ait. Smooth; leares sharply serrate, acute or acuminate at each end, the lowest elliptical or lanceulate-olshong, somewhat 3-ribbed, on winged and ciliate petioles; the mper sessile; panicle dense, somewhat corymbo:e; heads small, crowdel, 18-20-fluwered; rays 8-12, small; scales of the involuere obtuse; achenia nearly smooth. (S. juncea, Ait., a form with uarower and less strongly serrate leaves, the upper ones entire.) - Rich soil in the upper districts. Sept. - Stem $2^{\circ}-4^{\circ}$ high.

25. S. Boottii, Hook. Stem smooth, or pubescent alove; leaves linceolate or oblong, acute or acuminate at each end, appresscul-serrate, smusth or more or less pubescent; panicle open, oblong or pyramidal; leauls alout 12 flowered; rays 5 ; seales of the involncre obtuse; arhenia nearly smoth. - Varies, with tonger, narrower, and more sharply serrate leaves, and sleuler racemose panicles towarls the summits of the spreading branches. (S. juncea? Ell.) Sandy soil, Florida to North Carolina. Sept. - Stem $2^{\circ}-3^{\circ}$ highl, often purplish. Ileads larger and leaves more rigid than in the last.

26. S. gracillima, Torr. \& Gray. Smootlı; stem slender; lowest leaves spatulate-lunceolate, obtuse, serrate near the apex; the others linear and entire ; heads rather large, 9-12-flowered, forming a narrow compound racene at the sumnit of the stem and branches; rays mostly wanting; seales of the involuere oblong, obtuse; achenia pubescent. - Dry pine barrens, Midule Florida. Oct. - Stem $2^{\circ}$ light.

+- + + Leaves very numerous, grudually dimimishing in size upuard, veiny, sessile, or the louest narroued into a short petiole: heads small.

27. S. altissima, L. Stem hirsute; leaves orate or oblong, acute, serrate, rough above, pubescent, especially on the veins beneath, often rugose, prominently veined; panicle leafy, often narrow and elongated; the racemes slender and recurved ; seales of the 10-15-flowered involucre linear; rays 6-9, snall ; achenia pubeseent. (S. rngosa, S. ulmifolia, and S. aspera, Ell.) - Low thickets, Florida, and northward. Sept. and Oet. — Stem $2^{\circ}-6^{\circ}$ high, commonly branching. Leaves variable in texture and pubesence, being thin and smoother in shady places, and more rigid, rougher, and often rugose in places more exposed.

28. S. ulmifolia, Muhl. Stem smooth, or softly pubescent alove; leaves orate-lanceolate, acuminate, scrate, smooth on the npper surface, paler amd pubescent on the veins beneath; paniele loose, spreading; heads alout 10-flowered; rays $4-5$; scales of the involnere acutish ; achenia nearly smooth. - Low ground in the upper distriets of Alabama, and northward. Sept. - Stem $2^{\circ}-3^{\circ}$ high. Leaves thin, $2^{\prime}-3^{\prime}$ long.

29. S. Elliottii, Torr. \& Gray. Smooth; stem mostly simple; leaves oblong-lanceolate or elliptical, sessile, acute, fincly serrate, the upper often entire; racemes crowded, forming a prranidal panicte; scales of the 13-20- 
flowered invcluere linear, obtnse; rays 5-7; achenia minutely pubescent. (S. elliptica ? Ell.) - Damp soil wear the coast, Georeria to North Carolina. Sept. - Stem $3^{\circ}-6^{\circ}$ high. Leaves very mumerous, $2^{\prime}-3^{\prime}$ long.

30. S. pilosa, Walt. Stem hirsute, simple, or branching above; leaves very numerous, oblong-lanceolate, slightly serrate, mucronate, rough above, pubescent on the veins beneath; racemes numerous, slender, forming a pyramidal or soinewhat corymbose panicle; heads narrow, 12-15-flowered; rays 7-10, small ; seales of the involucre linear; achenia slightly pubescent. (S. pyramidata, Pursh. S. villosa, Ell.) - Low ground, Florida, and northward. Sept. and Oct. - Stem $2^{\circ}-8^{\circ}$ high. Leaves $2^{\prime}-3^{\prime}$ long.

31. S. odora, Ait. Stem mostly simple, pubeseent in lines; leaves entire, varying from linear-lanceolate to oblong-ovate, smooth on both surfaces, rough on the margins, punctate with pellucid dots, often reflexed; panicle pyramidal, mostly one-sided ; heads 5-7-flowered; rays about 3, showy; achenia hairy. (S. retrorsa, Michx.) - Dry soil, Florida and northward. Oet. - Stem $2^{\circ}-3^{\circ}$ ligh. Leares $1^{\prime}-2^{\prime}$ long. - Plant anise-seented.

32. S. tortifolia, Ell. Sten straight, simple or branched, rough-pubescent above; leaves small, linear, entire, or the lowest slightly serrate, often twisted, pubescent on the margins and midrib; panicle dense, pyramidal ; heads small, 6-9-flowered ; rays 3-4; scales of the involucre linear, obtuse ; achenia slightly pubescent. - Dry sandy soil, Florida to North Carolina. Sept. - Stem $2^{\circ}-3^{\circ}$ high. Leaves very numerous, $1^{\prime}-2^{\prime}$ long.

33. S. brachyphylla, Chapm. Stem slender, pubescent, sparingly branched; leaves smooth or pubescent on the reins, finely serrate, the lowest spatulate, the upper oval or orbicular; racemes short, forming a compound raceme toward the end of the spreading branches; scales of the 3-5-flowered involuere rigid, ohtuse; rays none; achenia pubescent, as long as the rigid pappus. - Dry light soil, Georgia, Florida, and westward. Sept. - Sten $2^{\circ}-3^{\circ}$ ligh. Leaves $1^{\prime}-2^{\prime}$ long.

++++ Lowest leaves cordate, on long petioles: heads in simple or compound racemes, 8-10-flouered: pappus rigid, equalling or shorter than the hairy achenia.

34. S. amplexicaulis, Torr. \& Gray. Pubescent and roughish; stem slender, sparingly branched above; leaves sharply serrate, acute, the lowest broadly cordate; those of the stem ovate, abruptly contracted into a broadly winged and clasping petiole, the uppermost small, sessile, and entire; racemes slender, often simple; rays 1-3; pappus as long as the achenium. - Dry open woods, West Florida, and westwarl. Oct. - Sten $2^{\circ}-3^{\circ}$ high.

35. S. cordata, Short. Pubescent; stem sparingly branclied above; leaves acute, on wingless petioles; the lowest large, coarsely serrate, cordate, the others ovate, sharply serrate, on short petioles; the uppermost entire, sessile; racemes compound, terminating the sprealing branches, composed of crowled clusterlike racemes; the lower ones scattered; scales of the 8-10-flowered involucre rigid, obtuse; rays 5-6; pappus inuch shorter than the achenium. (Brachychæta, Torr. \& Gray.) - Mountains of Georgia and Nortl Carolina, and northward. Sept. - Stem $2^{\circ}-3^{\circ}$ ligh. Lowest leaves $3^{\prime}-5^{\prime}$ wide. 


\section{++++ Ienres more or kess prominonly 3-riblud.}

36. S. nemoralis, $\Lambda$ it. J'aut grayiah, minutely jubeserent and rongh enel; stem mostly simple; leaves olssemrely 3-riblued; the lowest spatulateollong or lancelate, scrmate; the upper lanceolate, nente, narrowed toward the lase, mostly entire; panicle thense, oblong or pyranilal, rereurved; lesals 10 12.fowered; mys $6-7$; achenia huiry. - Uld fields und open woods, common. - Stem $1^{\circ}-2^{\circ}$ hight.

37. S. Leavenworthii, Torr. \& Gray. Stem simple, minutely pubescent and roughish; leaves very numerous, smooth, lincal-lancenlate, cutire; the low. est sparinorly scrrate; pauicle pyramiltal; heads ratlur large; rays $10-12$; achenia pulesecent. - Damp soil, Florilat to Somth Carolina. Oct. - Stem $2^{\circ}$ $3^{\circ}$ high. Leaves $2^{\prime}-3^{\prime}$ long, $3^{\prime \prime}-4^{\prime \prime}$ wide, faintly ribled.

38. S. Canadensis, I. Stem pubeseent and of en rough ; leaves laneenlate, acute or acuminate, shapply serate, Jough alwe, pubescent beneath ; panicles pyramidal, dense; leads small; ruys rery short; achenia pulwecnt. Varies (S. procera, Ell.), with a more hairy stem, less serrate leaves, the upper entire, and larger heads and rays. - Margins of fields, \&c. Florida, and northward. Oct. - Stem $3^{\circ}-8^{\circ}$ highl.

39. S. serotina, גit. Stem smooth, often purple; leaves lanceolate, acuminate, serrate, rourh alove, pubescent on the reins beneath; panicle pyrumiclal, of numerous recurvel racemes; mys short; mature achenia smooth. - Low ground, Florida, and northwarl. Oct. - Sten stout, $4^{\circ}-8^{\circ}$ ligh. Heads larger than in the last, but smaller than those of the next species.

40. S. gigantea, Ait. Stem smooth; leaves smooth, lanccolate, acuminate, sharply scrrate, rough on the margins; panicle large, pyramidal, pubescent; rays snall; achenia pubescent. - Marrins of ficlds, \&e., Mlabamit, and northwarl. Sept. and Oct. - Stem $2^{\circ}-6^{\circ}$ high.

\$3. Cnrrsoma.- Stem shrubly: leares impressed-punctate, veinless: rays 1-3: receptacle conical, naked.

41. S. pauciflosculosa, Michx. Stcm, leaves, and involucre riscid; leares spatulate-lanceolate or linear, obtuse, entire, the lowest seale-like; panicle 1 -sided; the clusters erect, on naked peduncles; heads $4-7$-fluwered ; scales of the involncre olstuse; achenia pubescent. - Sandy banks and shores, Florida to South Carolina. Oct. - Stem $1^{\circ}-2^{\circ}$ high. Leaves $1^{\prime}-2^{\prime}$ long. Rays large.

\$4. EvтимmA. - Merbaccous: leaves narrow, entire, 1-5-nerved: heads corymbose: rays more mumerous than the disk-flowers: receptacle bristly: involucre riscid.

42. S. lanceolata, L. Stem pubescent above, corymbose; leaves linearlanceolate, roughish on the upper surface, pulsesecut on the veins heneath, 3-5nerved; heads olx onical, mostly sessile, in dense elusters; rays $15-20 .-$ Damp soil, Georgia, and northwarl. - Stem $2^{\circ}-3^{\circ}$ high.

43. S. tenuifolia, Pursh. Nearly smooth; stem corymbosely much branched; leaves linear, 3-nerved, glandular-dotted; heads few in a cluster, 
often pedicelled, top-shaped; rays about 10. - Low sandy places, common. Oet. - Stem $2^{\circ}$ high. Heads smaller than those of the preceding.

\section{BIGELOVIA, DC.}

Heads 3-4-flowered; the flowers all tubular and perfect. Involuere cylin. drical-elub-sluaped, as long as the flowers; the scales linear, rigid, appressed, somewhat viscid. Receptacle narrow, cuspidate. Achenia terete, striate, hairy: Pappus simple, of numcrous scabrous capillary bristles. Styles searcely exserterl. - $\mathbf{A}$ smooth erect percnnial herb, with narrow obtuse and entire leaves, and small heads of yellow flowers, disposed in a compound corymb.

1. B. nudata, DC. Stem nostly simple, virgate; lowest leares spatulatelanecolate, obseurely $3 \cdot$ nerved; the others seattered, linear. (Chrysocoma nudata, Michx.) - Var. ViRGATA. Lowest leaves linear-spatulate, 1-nerved; the others narrow-linear or filiform; hcads larger. - Low pine barrens, Florida, and northward. Sept. - Stem $2^{\circ}$ ligh.

\section{ISOPAPPUS, Torr. \& Gray.}

Heads several-flowered. Rays 5-12, pistillate. Involucre cylindrical-campanulate; the scales lanceolate-subulate, imbricated in 2-3 rows, appressed. Receptacle alreolate. Achenia terete, silky. Pappus a single row of nearly equal capillary bristles. - Biennials. Stems paniculate. Leaves alternate, nar1. Heads seattered, on slender peduncles. Rays yellow.

1. I. divaricatus, Torr. \& Gray. Hispid and glandular; stem erect, the slender branches sprcading; leaves linear-lanceolate, sparingly toothed; involucre soft-hairy; rays 5-8. (Chrysopsis divaricata, Nutt.) - Sandy fields and woods, Florila, Georgia, and westward. Sept. - Stem $1^{\circ}-4^{\circ}$ high. Panicle large. Heads 15-20-flowered.

\section{HETEROTHECA, Cass.}

Heads many-flowered. Rays pistillate. Seales of the involuere imbricated in few rows, linear. Receptacle alveolate, bristly. Achenia of the rays oval, destitute of pappus, those of the disk-flowers oborate, compressed, hairy, with a double pappus; the outer one short and chaffy, the inner bristly. - Biennial rough-hairy branching herbs, with irregularly toothed or entire altcrnate leaves, and corymbose-panicled heads of yellow flowers.

1. H. scabra, DC. Lcaves oblong, toothed, eommonly sessile or clasping; the lowest petioled, obtuse or somewhat cordate at the base; inrolucre thick, shorter than the brownish inner pappus. (Chrysopsis scabra, Nutt.) Dry sandy plaees along the coast, South Carolina, and westward. Sept. - Stem rigid, $1^{\circ}-2^{\circ}$ high. Leaves $1^{\prime}-2^{\prime}$ long.

\section{CHRYSOPSIS, Nutt.}

Pappus of the ray and disk-flowcrs alike, double; the exterior row chaffy, or of ehaffy bristles, the interior longer, capillary; otherwise like Heterotheca. - 
I3iennial or perennial hairy or silky herbs, with linear or oblong inostly entire leaves. Heads mostly corymbet. Flowers yellow.

* Locues narrow, nered, entire: achrnia oblong-linear, narroucd at cach end, pubescent : prennials.

1. C. graminifolia, Nutt. Stem leafy, white with appressed silky shining hairs, as also the linear leaves; heads numerous, rather small, on slender and more or less glandular peduncles; involuere top-slatped, the linear seales glandular. (C. argentea, Nutt.) - Sandy pine barrens, common. Sept. - Stem $1^{\circ}-2^{\circ}$ high. Lowest leaves $4^{\prime}-8^{\prime}$ Jong.

2. C. oligantha, Chapm. Stem nearly naked and glandular above, the lower part, like the linear or lancelate leares, silky with appressed shining hairs; heads $1-4$, on long erect glandular peduncles, mather large; involuere bell-shaped, the seales glandular-pubescent - Low pine-barrens, Florida. April and May. - Stem $1^{\circ}$ high. Stem-leaves clasping; those of the root clongaterl.

3. C. pinifolia, Ell. Smooth; stem rigid; leares linear, crowded, ricrid; corvub large; scales of the involucre woolly at the summit. - High sancl-hills in the Western rlistricts of Georgia, Elliott. - Stem $1 \frac{1}{2}^{\circ}-2^{\circ}$ high. Stem-leares $4^{\prime}-6^{\prime}$ long, the uppermost filiform. Heads large. Exterior pappus somewlat chaffy.

* Leaves veiny, oblong or lanccolate: the lowest narrowed at the base, the upper sessile: achenia oborate, compressed.

4. C. Mariana, Nutt. Perennial; stem simple, corered with Joose silky deridnous hairs; lowest leaves spatulate-oblong, entire or slightly serrate; the upper ones lanecolate, sessile, entire; corymb small, nostly simple and umbellate, cone-like in the loud; peduneles and involuere glandular. - Sandy pinebarrens, Florida, and northward. Sept. - Stem $1^{\circ}-2^{\circ}$ highl.

5. C. trichophylla, Nutt. Biennial; stem very leafy, mostly branching, villous with loose silky hairs; leaves oblong or lanecolate, the earliest ones crowded, obtuse and densely villous, the upper mostly acute and often smoothish ; corymb large, compound; peduncles and involucre smoothish. - Var. HYssopifolia (C. hyscopifolia, Nutt.) has narrow-linear aud smooth leaves, except the tuft at the hase. - Dry pine barrens, Florida to North Carolina. Sept. Stem $2^{\circ}-3^{\circ}$ high, commonly ascending. Leaves $1^{\prime}-2^{\prime}$ long.

6. C. gossypina, Nutt. Biennial, densely villous and hoary throughout; leaves oblong, obtuse, entire; the lowest spatulate, the upper sessile; corymb simple. (C. dentata, Ell., leaves larger, the lowest sinuate-toothed.) - Dry sandy soi], Florida, and northward. Sept. - Stem $1^{\circ}-2^{\circ}$ ligh.

7. C. scabrella, Torr. \& Gray. Pulvernlent-scabrous throughont; stem ftont, corymbosely branched above; leaves oblong-lanceolate, mucronulate, entire, equally somewhat glandular-scabrous on both silles, sessile, the lower ones narrowed at the hase; heads numerons, in a compound corymb); peduncles and lanccolate obtuse scales of the involucre puberulent-glandular. - Pine woods, Florida. Sept. and Oct. - Stem $2^{\circ}$ high. 
8. C. villosa, Nutt. Rough-hairy and somewhat hoary throughout; stem rixid, very leafy; leaves lanceolate, acute, entire or sparingly serrate; the npper ones sessile, the lowest narrowed into a petiole; heads large, in a simple corymb. - Dry soil, Alalama, and westward. Sept. - Sten $1^{\circ}-2^{\circ}$ high. Leaves $l^{\prime}$ long, fringed near the base.

9. C. decumbens, n. sp. Stems decumbent, simple, silky-rillous; leaves villons, laneeolate-oblong, obtuse, entire, sessile, leafy in the axils; the lowest spatulate-oblong, clustered; lieads large, in a loose corymbose panicle; the pecluncles and involucre glandular-pubescent; rays abont 25, showy; arhenia hairy, furrowed; exterior pappus bristly. - Sandy shores on St. Vincent's Island, West Florida. Oct. and Nov. (2) - Stems $2^{\circ}-4^{\circ}$ long. Upper leaves $\frac{1}{2}^{\prime}-1^{\prime}$ long, the lowest $3^{\prime}-4^{\prime}$. Heads largest of all.

\section{INULA, I. Elechupane.}

Heads many-flowered. Rays pistillate. Seales of the involnere imbricater in sereral rows. Receptacle flat or convex, naked. Anthers bieaudate at the base. Pappus single, of eapillary slightly seabrous bristles. - Perennial herbs. Flowers yellow.

1. I. Helenium, L. Stem stout ; Icaves large, orate, denticulate, tomentose beneath; the lowest ones petioled, the npper clasping; heads very large, somewhat corymbose; outer scales of the involuce broadly orate, leafy; rays numerous, narrow; achenia 4-sided, smooth. - Mountains of North Carolina. Introduced.

\section{CONYZA, L.}

Heads many-flowered; the exterior flowers pistillate, fertile, in several rows ; the corollat filiform, 2-3-toothed; a few of the central flowers staninate, with a tubular, 5-toothed corolla. Seales of the involucre in several rows. Iiceptacle punctate. Pappus a single row of capillary bristles. - Branehing herbs, with toothed-lobed leaves, and heads of yellow flowers in corymbs or panicles.

1. C. ambigua, DC. Rongh-hairy; lower leaves oblong-lanceolate, lobed, the upper entire, linear; heads panieled. (C. sinuata, Ell.) -Around Cliarleston. Introduced. April - July. - Stem $2^{\circ}$ high.

\section{BACCHARIS, L.}

Ifeads diœcions, many-flowered; the flowers all tubular. Corolla of the sterile flowers 5-eleft; of the fertile ones filiform, nearly entire, without antliers ; style exserted. Seales of the oblong or hemisplerieal involucre inbricated in several rows. Reeptacle naked or somewhat chaffy. Achenia ribbed. Pappus of the sterile flowers capillary, in a single row, as long as the involuere; of the fertile flowers in 1 -several rows, commonly much longer than the involuerc. Smooth and resinous shrubs. Leaves alternate. Flowers white.

1. B. halimifolia, L. Branches angled; leaves obovate, or oblong-ohovate, toothed above the middle, the uppermost lanceolate, entire; heads pedun- 
(led, the terminal ones cluctered; pappus of the furtile flowers $3-4$ times as

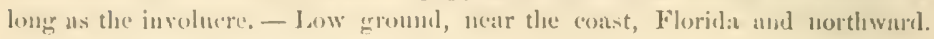
Sept. and Uct. - Shurub $20-12^{\circ}$ high.

2. B. glomeruliflora, l'ers. IBranehes angled; leaves werlere-obovate,

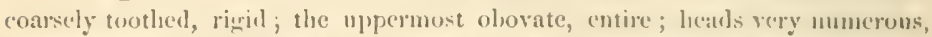
in dense sessile axillary clusters; pappus of the fertile flowers twiee as long as the involucre. (B. sessiliflorn, M/chx.) - Swamps along the coast, Florida to North Carolina. November, - Shrub $6^{\circ}-12^{\circ}$ high.

3. B. angustifolia, Miclx. Branches umerous, angled ; leaves linear, entire ; heads single, or $2-4$ in a terminal eluster; achenia smootl. - Saline marshes, Florida to Nortl Carolina. Oct. - Slırub $4^{\circ}-8^{\circ}$ higho. IIcuds small.

\section{PLUCHEA, Cass.}

Heads many-flowered; the central flowers mostly perfeet, but sterile, with the corolla dilated and 5 -cleft; the others pistillate, slender, slightly toothed. Anthers bieaudate. Scales of the involucre imbricated. Receptacle flat, mostly naked. Achenia grooved or angled. l'appus a single row of eapillary slightly scabrous bristles, - Odorous mostly pubescent and glandular herbs, with alternate ovate or oblong serrate leaves. H(ads of purplish flowers corymlose.

1. P. bifrons, DC. Stem simple, or sparingly branched ; leaves oblong, acute, denticulate, strongly reticulated and rugose, cordate and clasping; heads clustered; involucre pubescent and viseid. (Conyza bifrons, Ell.) - Margins of pine-barren ponds, Florida to North Carolina. September. - Stem $1^{\circ}-2^{\circ}$ high. Flowers pale purple or white.

2. P. fœtida, DC. Minutely pubescent and glandular; leaves large, membranaccous, orate-lanceolate, acuminate, serrate, tapering into a petiole ; corymbs axillary and terminal; heads rather small, numerous, on slender pedicels; involucre smoothish, often purplish. (Conyza Marylandica, Ell.?) Damp soil, Florida, and nortlward. September. - Stem $2^{\circ}-5^{\circ}$ ligh. Leaves $5^{\prime}-8^{\prime}$ long, resinous-dotted. Flowers purple.

3. P. camphorata, DC. Minutely pubeseent and glandular-riscid; leaves ovate-lanceolate or oblong-ovate, acute, denticulate, nearly sessile ; heads rather large, in a dense corymb, on short and stout pedicels; scales of the involucre pubescent, the inner ones long-acuminate. - Salt marshes, Florida to North Carolina. Septemher. - Stem $1^{\circ}-2^{\circ}$ high; the branches fiw and ereet. Leaves $2^{\prime}-3^{\prime}$ long. Flowers light purple.

4. P. purpurascens, DC. Tomentose and glandular; leaves ovatelanceolate, acute or acıminate, sharply and somewhat erosely serrate, on slender petioles; heads rather small, on slender pedicels, loosely corymbose; scales of the involuce pubescent, the inner ones lanceolate, acnte. - Swamps and low ground, Florida. September. - Stem $1^{\circ}-2^{\circ}$ high, with numerous spreading branches. Leaves $2^{\prime}-4^{\prime}$ long. Flowers bluish-purple. 


\section{PTEROCAULON, Ell.}

Heads and flowers chicfly as in Pluchea. Scales of the involucre laneeolate, imbricated in several rows, caducous. Receptacle mimutely hairy. Achenia angled, pubescent. Pappus of numerous equal capillary bristles, longer than the involucre. - Perennial herbs. Leaves lanceolate, densely tomentose and hoary beneath, the margins broally decurrent on the stem. Heads compactly spiked.

1. P. pycnostachyum, Ell. Stem rarely branched, $1^{\circ}-2^{\circ}$ high ; leaves wavy, smooth above; spike thick, woolly ; flowers white. - Damp pine barrens, Florida to North Carolina. June and July.

Tribe IV. SENECIONIDEA. ITcads discoid or radiate: branches of the style, in the perfect flowcrs, linear, concex externally, hairy or brush-shaped at the apex, and truncate, or produced into a conical or hispid appendage; the stigmatic lines terminating at the appendage, not confluent.

\section{POLYMNIA, L.}

Hearls many-flowered ; the rays pistillate, in a single row; those of the disk tubular, 5-toothed, sterile. Seales of the involucre in two rows; the onter leafy, spreading; the inner smaller, membranacens, clasping the olovoid fertile achenia. Receptacle chaffy. Pappus none. - Coarse branching perennial herbs, with angular or lobed leaves, and heads of yellow flowers in corymbose panicles.

1. P. Canadensis, I. Yiseid-pubescent ; lowest leaves opposite, petioled, pinnatifid ; the upper alternate, angled or lobed; outer seales of the involucre acuminate, hairy and viscil ; rays shorter than the involuere. - Mountains of North Carolina. July and August. - Stem $2^{\circ}-5^{\circ}$ high. Heads small, Rays pale yellow.

2. P. Uvedalia, L. Stem smooth, or rough-pubescent; leaves broadly ovate, $3-5$-lobed, coarsely toothed, rough above, pubescent beneath, abruptly contracted into a simnate-winged petiole; outer scales of the involuere ciliate, obtuse; rays much longer than the involucre. - Rieh soil, Florida, and northward. July and August. - Stem $3^{\circ}-6^{\circ}$ high. Rays bright yellow.

\section{CHRYSOGONUM, I.}

Heads many-flowered; the rays 5, pistillate. Disk-flowers tubular, 5-toothed, sterile. Scales of the involnere in 2 rows; the exterior oblong, leafy; the interior roundish, clasping the oval compressed 4-angled fertile achenia. Receptacle flat, chaffy. Pappus a slightly lohed cup-shaped crown, divided on the inside to the base. - A low hairy stoloniferous perennial herb, with oval or spatulateoblong opposite crenate leaves, and single heads of yellow flowers borne on a long peduncle.

1. C. Virginianum, L. - Jry open woods, Florida to North Carolina. February - April. - Plant at first simple, producing from a tuft of radical leaves a single peduncled head, afterward stoloniferous and branehing. 


\section{SILPHIUM, L.}

Heads many-ftowered; the rays numerons, pistillate, fertile, in a single row. Disk-flowers cylindrieal, sterile; tho stylo undivilet. Scales of the involucro leafy, imbricated in several rows; the innermost smallest, chall-like. Receptacle small, with linear acutish chaff. Fertile achenia in 3-4 rows, round or obovate, flat, broally winged, 2-toothed or emarginate at the apex; the sterile ones slen. der. Palpus none, or represented hy the two teeth of the achenia. - Tnll resinous herbs, with alternate opposite or whorled leares, and large leads of yellow flowers in corymbose pauicles.

* Stems tercte, nearly ualied: leates aiternate; the lourst large, serrate or variously lobed, long-petioled; the others small and scutterwl.

1. S. laciniatum, I. Stem hispid or smooth; leaves very rough or hispid, on clasping petioles, pinnately parted; the divisions oblong or linceolate, acute, lobed or toothed ; heads large, spicate or racemose; scales of the involucre ovate, tapering into a long and spreading point, ciliate; achenia roundobovate, emarginate. - Varies with the more numerons seswile and rlacping leaves less deeply parted. (S. gumnmiferum, Ell.) - Prairics of Alabama, am westward. July and $\Lambda$ ugast. $-\mathrm{Stcm} 6^{\circ}-8^{\circ}$ high. Lowest leares $1^{\circ}-2^{\circ}$ loug. Heads $1 \frac{1^{\prime}}{2}-2^{\prime}$ in diameter.

2. S. terebinthinaceum, L. Stem snooth, naked above; leaves rough. hairy, undivided, cordate-oral or oblong, coarsely serrate, on slender petioles; heads small, loosely panicled; seales of the involucre oval or obovate, obtuse, smooth; achenia obovate, emarginate or 2-toothed. (S. pinnatificum, Ell., l'aves pimatiful.) - Open woods in the western districts of Georgia, and westward. July-Sept. - Stem $4^{\circ}-8^{\circ}$ higl. Radical leaves $2^{\circ}$ long. Heads $I^{\prime}$ wide.

3. S. compositum, Michx. Smooth; leaves cordate-ovate or reniform, angularly toothed or varionsly lobed, long-petioled; heads small, corymbosely panicled; scales of the involucre obovate or oblong, obmse; achenia roundish, deeply emarginate; rays 6-10. (S. terebinthinaceum, Ell, leaves reniform, anfularly toothed or lobed.) - Var. Micuacxi, Torr. \& Gray. Leaves deeply pinnatifid or ternately divided; the divisions lobed or toothed. - Var oratıFoLIUn, Torr. \& Gray. Leaves ovate, angularly toothed. - Sandy open woods, Florida to North Carolina. July $-\mathrm{Sept}-\mathrm{Stem} 3^{\circ}-6^{\circ}$ high. Leaves $6^{\prime}-12^{\prime}$ long. Heads $\frac{1}{2}$ ' in diameter.

* Stems leufy: leaves undivided, alternate, opposite, or whorled. + Stems terete.

4. S. trifoliatum, L. Stem snooth; leaves rongh, lanceolate, slightly serrate, on short bristly petioles; the upper ones alternate or opposite; the lower $3-4$ in a whorl ; heads small, loosely panicled ; seales of the involucre ovate or oral, fringed on the margins; achenia oblong-olovate, 2-tonthed. (S. ternatum and $\mathrm{S}$. atropurpureun, Willd.) - Open woods along the mountains of Georgia, and northward. July - Sept. - Stem $4^{\circ}-6^{\circ}$ ligh. Leaves $4^{\prime}-6^{\prime}$ long.

5. S. Asteriscus, I. Stem smooth or hirsute; leaves rongh, opposite or alternate, or the lower ones sometimes 3 in a whorl, lanceolate or oblong, toothed, 
on short hirsute petioles; the upper ones sessile and commonly entire; heads somewhat corymbose, rather large; exterior scales of the involucre ovate, acute, short-ciliate; the interior oblong, obtuse; achenia broadly obovate, 2 toothed. - Var. Dentatur. Lower lcaves on rather long petioles, sometimes incisely toothed; achenia slightly cmarginatc at the apex. (S. dentatum, Ell) - Dry open woods, Florida to North Carolina. July-Scpt.-Stem $2^{\circ}-4^{\circ}$ ligh. Leaves $3^{\prime}-5^{\prime}$ long. Rays showy.

6. S. lævigatum, Ell. Smooth; leaves thick, lanceolate-oblong, acute at each end, opposite, coarsely scrrate, on short petioles; the upper nearly sessile; heads small, loosely corymbose; scales of the involucre ovate, obtuse, spreading; achenia oval-obovate, narrowly winged, emarginate and slightly 2-toothed at the apex. - Western districts of Georgia and Alabama. July - Sept. - Stem $2^{\circ}-3^{\circ}$ high. Lowest learcs $6^{\prime}-8^{\prime}$ long.

7. S. scaberrimum, Ell. Stem rough-hairy; leaves mostly opposite, ovate, acute, serrate, rigid, very rough on both sides, on slort petioles; heads corymbose; scales of the involncre ovate, ciliate; achenia nearly orbicular, broadly winged, deeply notched at the apex. - Western distriets of Georgia and Alabanı. Angust and Sept. - Stem stout, $3^{\circ}-4^{\circ}$ high, becoming smoothish. Leares $3^{\prime}-4^{\prime}$ long. Heads larger than in the last.

$$
\text { +- Stems square. }
$$

8. S. perfoliatum, L. Stem and branches smooth or hairy ; leaves large, opposite, ovate or ovate-olblong, coarsely toothed, rough on hoth sides, or pubescent or hairy beneath, their bases, or winged petioles, united; the uppermost commonly cntire, simply serrate ; corymb trichotomons ; the central heads longpeduncled; scales of the involucre ovate, obtnse; achenia broadly oborate, emarginate. (S. connatum, L. S. integrifolium, Ell.?) - Banks of streams along the monntains of Georgia, and northward. July-Sept. - Stem $4^{\circ}-6^{\circ}$ high. Leaves $6^{\prime}-12^{\prime}$ long. Heads large.

\section{BERLANDIERA, DC.}

Heads many-flowered. Ray-flowers few, pistillate; those of the disk tubnlar, 5-toothed, sterile. Scales of the involucre in three rows, the innermost largest, membranaccons, adberent to the fertile nehenia. Receptacle chaffy; the chaff dilated upward, obtuse, hooded, partly embracing the sterile achenia ; the inner oncs grarlually nartower. Fertile achenia in a single row, obovate, flattened, wingless, pubescent on the inner face, the apex entire.-Perennial downy or hoary herbs, with alternate leaves, solitary or corymbose heads, and yellow rays.

1. B. tomentosa, Torr. \& Gray. Stem leafy, hoary-tomentose; leaves oblong-ovate, crenate, hoary beneath, elosely pubescent above; the lowest taperingr into a petiole; the upper cortate, sessile ; hearls at length nmmerous, corymbose-panicled. (Silphim pumilum, Michx.) - Iry pine barrens, Florida to North Carolina, and westward. June-August. - Stem $1^{\circ}-3^{\circ}$ high. Leaves $2^{\prime}-3^{\prime}$ long. 
2. B. subacaulis, Nutt. liourgl-puleseent nut sumewhat hoary ; leaves

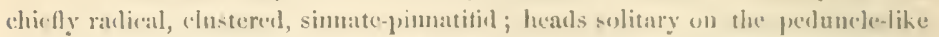
stem, or fiw on the peduncle-dike branches of the short and uearly labless stem.

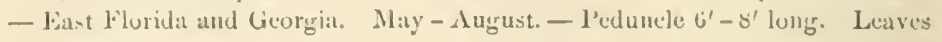
$3^{\prime}$ long.

\section{PARTHENIUM, I.}

Heads many-flowered; the ray-flowers 5 , in a single row, short, obeordate, pistillate; those of the disk tulular, 5-toothed, sterile. Anthers slightly mited. Seales of the involnere in two rows, orate or rumdish. lieceptnele conical, ehatly; the elatf dilated upward. Achenia smooth, comprescell, thick-margined. Pappus of two awn-like or roundish scules. - Herbs. Leaves alternate. Flowers white.

1. P. integrifolium, L. lerennial; stem ereet, simple, rough; leaves mudivided, ovate or oblong-ovate, serrate; the lowest narrowed into a long petiole; panicle dense, corymbose; involucre hoary; pappus minute, awn-like. - Dry soil among the momtains, Alabana, and northward. August. - Stem $1^{\circ}-2^{\circ}$ ligh. Lowest leaves $4^{\prime}-6^{\prime}$ long. Ray's conspicuous.

2. P. Hysterophorus, I. Annual, pubescent ; stem diffuse; leaves pinnatifid, with linear toothed lobes; heads loosely panicled ; seales of the papjus oval. - Waste places, East and South Florida, and westward.

\section{IVA, I.}

Heads few- or many-flowered; the flowers all tubular; the marginal ones (1-5) with a slort corolla, pistillate and fertile; the ecentral ones 5-toothed, sterile. Antlers nearly distinet. Seales of the involuce $3-5$, in a single row, oval or olsovate, distinct or partly united, or 6-9 and imbricated. Chaff of the small receptacle linear or spatulate. Achenia biconex, obovate. Palplus none. - Branching lrerbs or shrubs, with opposite or (the upper) alternate mostly flesly leaves, and small axillary nodding leads of whitish flowers.

* Scales of the intolucre $3-5$, in a single row.

1. I. frutescens, I. Slirnbby; leaves lanreolate or oblong, sharply toothed-serrate, 3-ribbed, smoothish; seales of the involucre 5, orlicular; fertile flowers 5. - Saline marshes, Florida, and northward. $\Lambda$ ur. and Sept. - Shrub $4^{\circ}-8^{\circ}$ high.

2. I. microcephala, Nutt. Annual, rongh with ricrid appressed hairs; stem slewser, much branched; leaves narrow-linear, entire; heals minute, 6 12-flowered; seales of the involuere $4-5$, ohovate, ciliate; fertile flowers $1-3$. - Dry barren soil, Florida to South Curolina. Aug. and Sept. - Stem $1^{\circ}-2^{\circ}$ high.

* * Scales of the inrolucre $6-9$, imbricated in $2-4$ rours.

3. I. imbricata, Walt. Somewhat slurubby, smooth; leaves fleshy, lanceolate, the lower ones slightly serrate and 3-ribbed, the upper alternate and entire; heads many-flowered; outer seales of the involucre orbicular ; the inner oborate, 
toothel-margined; fertile flowers 2-4, the short corolla 5-parted. - Varies with sinaller and fewer-flowered heads, and the corolla of the fertile flower truneate. - Driftingr sands along the coast, Florida to North Carolina. Ang, and Sept. - Stem $1^{\circ}-2^{\circ}$ high. Leaves $1^{\prime}$ long.

\section{AMBROSIA, Tourn.}

Heads monocions, in racemes or spikes; the upper ones sterile, nodding; the lower pistillate and fertile. Involucre of the sterile flowers hemispherical, composed of 7-12 united scales, 5-20-flowered. Receptaele naked or with slender chaff. Corolla 5-toothed. Involucre of the fertile flowers 1-flowered, ovoid or turbinate, entire, closed, pointed, commonly with a row of tubereles or spines near the apex. Corolla and stamens none. Achenia globose or ovoid. Pappus none. - Herbs. Leaves nostly pinnately lobed. Fertile flowers single or elustered at the base of the sterile spike, or in the axils of the upper leaves, bracted. Flowers whitish.

\section{* Leaves undivided or 3-5-lobed, opposite : receptacle naked.}

1. A. trifida, L. Stem tall $\left(6^{\circ}-10^{\circ}\right), 4$-sided, rough-hairy; leaves rough, palmately 3-5-lobed, with the lobes ovate-lanceolate and serrate, or all undivided; fruit oborate, 6-toothed around the base of the conically beaked apex, clustered. (A. integrifolia, Muhl.) - River-banks and rich soil, Florida and northward. Aug. and Sept.

\section{* Leaves pinnately lobed; the upper ones mostly alternate: receptacle commonly cluifity.}

2. A. crithmifolia, DC. Stem prostrate and shrubby at the base; the mranches velvety pubescent; leaves bipinnatifid, thickish, softly pubescent; spikes few, the terminal one elongated ; fruit downy, unarmed. - Sandy shores at Key West, forming large clusters.

3. A. artemisiæfolia, L. Annual, erect, hairy or smoothish ; leaves bipinnatifid, with linear lobes; the upper often entire; spikes single or panicled; furtile flowers single, elustered, or sometines spiked ; fruit nearly globose, armed with six short teeth. (A. elatior, L. A. paniculata, Michx., spines of the fruit obsolete.) - Cultivated ground, everywhere. July - Sept. - Stem $1^{\circ}-4^{\circ}$ high.

4. A. hispida, Pursh. Hispid and hoary throughont; leaves bipinnatifid, with toothed lobes; racemes terminal, somewhat panfeled. - South Carolina, Catesby. - Stem $1^{\circ}$ high. Heads larger than in No. 1. (*)

\section{XANTHIUM, Toirn, Соскцевет.}

Heads monocious, spiked; the upper ones many-fowered, sterile, with the scales of the involucre separate, in a single row; the receptacle oblong, chaffy, and the short corolla 5-toothed; the lower ones furtile, consisting of two pistillate flowers, enclosed in a 2-celled oblong elosed involucre, which is armed externally with numerons hooked spines or bristles, and terminated by one or two stout beaks. Corolla filiform. Achenimn ohlong, solitary in each cell - Coarse annual herbs. Leaves alternate, lobed and petioled. 
1. X. strumarium, I. Stem spineless, rongh, brunched; leares large, broally cordnte, $3-5$-lubed ; the lobes inothed, acute and rongl on both siles; fruit oval, pointed lỵ two straight and smooth leaks. - Var. I.chisstos. Leaves ohtnoe, less strongly lobed the incorved leaks and spines of the larger $\left(t^{\prime}\right)$ fruit luintly - Cultirated ficlds and waste places, common. July - Sept. Stem $10-10$ high oftein spotterl.

2. X. spinosum, I. Stem armerl with triple spines, mnch branched; Ieaves lancrulate, entire or 3-lubed, hoary-tomentose beneath; fruit pointed by a single beak. - Waste places aromol the larger seaports, and sparingly in the intcrior. Introduced. Ang. and Sept. - Stem $2^{\circ}-3^{\circ}$ high.

\section{ECLIPTA, L.}

Heads many-flowered; the ray-flowers short, pistillate, in a single row; those of the disk tubular, 4-toothed, perfect. Seales of the involucre $10-12$, in 2 rows. Leceptacle flat, with bristly chaff. Achenia 3-4-angled, hairy at the npex. Pappus none. - Rough branching annuals, with opposite lanceolate leaves. Heats small, axillary, on peduncles of varying length. Flowers white.

1. E. erecta, I. Stem ereet or diffuse, terete, tmuid helow the joints, sprinkled, like the leaves, with appressed rigid hairs; leaves ollong-lancrolate, acute, serrate, narrowed into a petiole; peduncles single or $2-3$ together. (F. procumbens, and E. brachypoda, Michx.) - Wet places, Florida, aud northward. Sept. and Oct. - Stem $6^{\prime}-3^{\circ}$ long.

2. E. longifolia, Schrud. Stem erect, rough-lairy; leaves lancelate or oblong-lanceolate, acuminate, serrate, sessile and clasping; peductes longer than the heads. - Wet places, Apalachicola, Florida. Sept. - Stem $1^{\circ}-2^{\circ}$ ligh. Leaves $4^{\prime}-6^{\prime}$ long.

\section{BORRICHIA, Adans.}

Heads many-flowered; ray-flowers pistillate, in a single row; those of the disk tubular, 5-toothed, perfect. Scales of the hemisplerieal involure imbricated; the exterior ones leafy. Receptacle flat, with rigid persistent ehaff. Achenia somewhat wedge-shaped, 3-4-angled. Pappns a 3-4-toothed horder. - Fleshy maritime slurubs. Leaves opposite and slightly connate. Heads solitary, peduncled. Flowers yellow.

1. B. arborescens, DC. Smonth, or the young branches pulhescent; leares spatulate-lanceolate, aluruptly pointed, entire; scales of the imvolucre as long as the disk; the inner ones and chaff of the reseptacle olstuse. - Key West. Dec. - Shrub $5^{\circ}-10^{\circ}$ ligh.

2. B. frutescens, DC. Branches and leaves hoary-tomentose; leaves varying from spatulate-linear to obovate-sblong, entire or toothed near the base; scales of the involucre shorter than the disk, the inner ones and chaff of the receptacle spine-pointerl. (Buphthalmum frutescens, $L$ ) - Saline marshes, Florida to North Carolina. June - Oct. - Sten $10-2^{\circ}$ high. 


\section{MELANTHERA, Rohr.}

Heads many-flowered; the flowers all tubular and perfect, 5-eleft. Scales of the involurre imbricated in 2 rows. Chaft of the convex receptacle rigid, persistent, partly sheathing the flowers. Achenia 4-angled, short, truneate at the upex. Pappus of 2-several rough rigid deciduons awns or bristles, - Rough perennial herbs, with branching 3-4-angled stems, opposite undivided or 3lobed serrate petioled leares, and seattered heads of white flowers, on long peduncles. Anthers black.

1. M. hastata, Michx. Stem commonly spotted; leaves varying from lanceolate to ovate, entire, or more or less hastate-3ㄱobed, serrate; seales of the involucre linceolate, acute; (haff of the receptacle spine-pointed. - Light rich soil, Florida to South Carolina. Ang. and Sept. - Stem $3^{\circ}-6^{\circ}$ high.

2. M. deltoidea, Michx. Leaves deltoid-ovate, undivided; scales of the involucre ovate; chaff of the receptacle obtuse, mucronate. - South Florida.

\section{ZINNIA, L.}

Heads many-flowered; the ray-flowers pistillate; those of the disk perfect, tubular, with 5 velvety lobes. Scales of the involucre imbricated, oval or roundish, margined. Chaff of the conical receptacle elasping the disk-flowers. Rayflowers oblong, rigid persistent. Achenia of the disk compressed, with a $1-2$ awned pappus; those of the rays 3 -angled, destitute of a pappus. - Annual herbs, with sessile entire 3-ribbed leaves, and solitary heads, on long inflated peduncles.

1. Z. multiflora, I. Stem erect, hairy, branching; leaves oblong-lanceolate; chaff of the receptacle obtuse ; pappus of the disk-flowers 1-awned; rays red or purple. - Waste places, Florida to North Carolina. Introduced. July Sept. - Stem $1^{\circ}-2^{\circ}$ high. Rays sometimes fading into yellow.

\section{HELIOPSIS, Pers.}

Heads many-flowered; the ray-flowers pistillate; those of the disk tubular, perfect, 5 -toothed. Scales of the involuere in 2-3 rows; the exterior longer, leafy. Chaff of the conical receptacle lanecolate, partly clasping the smooth 4angled truncated achenia. Pappus none. - Perennial herbs with the habit of Helianthus. Rays yellow.

1. H. lævis, Pers. Smooth; stem slender, lranching; leaves ovate or ovate-lanceolate, acute or aeuninate, sharply serrate, 3-ribbed at the hase, on slender petioles; peduncles elongated; scales of the involucre obtuse; rays decidnous. - Dry open woods, Florida, and northward. Aug. and Sept. Stem $2^{\circ}-3^{\circ}$ high. Leaves $2^{\prime}-3^{\prime}$ long, sometimes scabrous.

\section{TETRAGONOTHECA, Dill.}

Hearls many-flowered ; the ray-flowers $(6-9)$ pistillate; those of the disk tubular, 5-toothed, perfect. Involucre double, 4-sided; the exterior of 4 vvate 
Ieaves partly united lelow; the interior of about 8 small chasty scales. Chatf of the conical receptacle lanceslute, acute. Achenin obsovid, uenty terete, trmeated. l'appus none. - A low hairy and clammy jeromial herb, with large sesile or connatr, oval or oblong, coarsely toothed leaves, and large solitary liends we yellow fluwers, on longr peduneles.

1. T. helianthoides, I. - Dry samly soil, Filorila to Nortı Carolina.

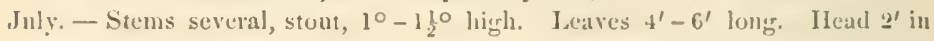
dimeter.

\section{ECHINACEA, Moneb.}

IIeads many-flowered; the ray-flowers pistillitte, but sterile, drooping; those of the disk tubnlar and perfect. Scales of the involure lanecolate, imbricated in three or more rows, spmealingr. Receptacle at length conical. Chaff of the reecptacle rigit, spine-pointed, longer than the disk-fluwers. Achenia short, 4-sided, crowned with a cup-shaped toothed pappus. - J'cremial sparingly branched herbs, with alternate modivided 3-5-ribbed leaves, and large heads terminating the peduncle-like summit of the stem or branches. Rays red, purple, or white.

\section{* Tiays clongated, purple or ulite.}

1. E. purpurea, Maneh. Stem simple, or with pednncle-like branches, smooth or hairy ; leaves ovate-lanceolate, serrate, rough ; the lowest ones ovate, on lone petioles; scales of the involuere imbrieated in $3-5$ rows, ciliate; rays alout 12, lanceolate, purple. - Varies with the stem and leaves smooth; rays strap-shaped, white, - Rich woorls in the upper districts. June-August. Stem $2^{\circ}-5^{\circ}$ higrh. Rays $2^{\prime}-3^{\prime}$ long.

2. E. angustifolia, DC. Hirsute; stem simple; leares lancelate, entire, 3-ribbed; the lowest tapering into a long periole; scales of the involncre inbrieated in $2-3$ rows; riys $12-15$, narrow, pale purple. - I'rairies and low harrens, Alabama, and westward. May-Jnly, - Stem $1^{\circ}-3^{\circ}$ high. Lowest leaves $\frac{10}{2}$ long.

$$
\text { * Rays short, durl red. }
$$

3. E. atrorubens, Nutt. Smooth, or rongh throughout with white appressed hairs; stem simple, furrowed ; leaves rigid, entire, shining; the lowest linear-lanecolate, narrowed into a petiole, 3-riblusl; the upper few and remote, linear, sessile; scules of the involuere in three rows; rays about 9 , wedge-shaped, shorter than the ovate dark purple disk ; "haff of the reeppticle short-cuspidate, alout as long as the disk-flowers; pappus 4-toothed - Low pine barrens, Georgria and Floridla. June-August. - Stem $2^{\circ}$ hirh. Lowest leaves $\frac{10}{2}$ long. Heads $\frac{1}{2}^{\prime}$ in diancter. Plant turns black in drying.

\section{RUDBECKIA, I.}

IIeads many-flowered; the ray-flowers neutral; those of the disk tubular, perfect. Seales of the involucre in about two rows, leafy, spreading. Receptacle conical or cylindrical; the ehaff not rigid, and mostly shorter than the diskflowers. Achenia smooth, angled, truncated. Pappus a narrow border, or none. 
- Perennial or biennial herbs, with altemate simple or lobed leares, and showy heads terminating the stem or branclues. Rays yellow or party-colored. Disk dark purple or yellowish.

\section{* Disk orate or glubose.}

\section{+ Leares undivided: stem simple or sparingly branelied.}

1. R. hirta, L. Hirsute; stem and branches naked at the summit; leaves 3-ribbed, lanecolate or oblong, serrate, the upper ones sessile, the lowest narrowed into a petiole; disk roundish, purplish brown; chaff of the receptacle acute, hairy at the apex; appendages of the style subulate. - 1)ry soil, Florida to Mississippi, and northward. July and August. - Stem rigid, $1^{\circ}-2^{\circ}$ high. Rays longer or shorter than the involucre.

2. R. fulgida, Ait. Hairy ; stem simple or sparingly branchel, naked at the summit ; leaves 3-ribbed, mostly serrate ; the lowest ovill or oblong, on slender petioles; the upper ones spatulate-oblong or lancolate, slightly clasping ; rays commonly longer than the involuere; disk roundish, lark purple; cliaff of the receptacle smoothish, rather obtnse; appendages of the style slort-conical. (R. discolor, Ell. R. spathulata, Wichx., a smoothish montain form, with spatulate mostly entire leares, and smaller heads.) - 1)ry soil, Florida, and northward. August and September. - Stem $1^{\circ}-3^{\circ}$ high. Rays of ten turning rethlish at the base in withering.

3. R. mollis, Ell. Stem hirsute-villous, branchingr; leaves oblong, obscurely serrate, sessile and partly clasping, soft-tomentose on both sides; the lowest soincwhat spatulate; scales of the involncre numerons, linear-lanceolate, villous, reflexel, half as long as the $(12-20)$ rays; disk brownish; chaff of the receptacle rather obtuse, tomentose at the apex. - Western districts of Georgia. August - Oetoher. - Stem $2^{\circ}-3^{\circ}$ high.

4. R. Heliopsidis, Torr. \& Gray. Rlizoma prostrate; stem pubeseent, with few peduncle-like branches at the summit; leaves ovate or oval, slightly serrate, obtuse, smoothisb, 5-ribbed, petioled ; scales of the involucre oblong, shorter than the lrownish-purple subglobose disk, and (10-12) oblong-lincar rays ; chaff of the receptacle oltuse, pubeseent at the apex; achenia of the rays 3-angled, as large as those of the disk. - Pine barrens near Columbus, Georgia, and Alabama. Atugnst and Septenber. - Stem $2^{\circ}$ high.

\section{+ +- Leavrs divided: stem paniculately or corymbosfly branched.}

5. R. triloba, L. Biennial, rongh-hairy; stem much branched; lowest leaves long-petioled, ovate or oral, simple, or with two small lateral lobes, serrate ; lower stem-leaves 3 -lobed; the npper simple, sessile, often entire; heals small, numerous; seales of the involucre narrow-lanceolate, shorter than the rays; disk almost black; (haff of the receptacle awl-pointed, smooth, as long as the flowers. - Var. Prxxatilob., Torr. \& Gray, is smaller and more slender, and the lower stem leaves pimately lobed. - 1)ry soil, West Florila and northward. August and September. - Stem $2^{\circ}-5^{\circ}$ highl. Leares sometimes all undivided. Rays about 8 .

6. R. laciniata, Y. Stem smooth, tall $\left(4^{\circ}-6^{2}\right)$, branching; leaves rough ; the lowest pinnately divicled, the divisions lanceolute or oblong, lobed or 
piunatifis ; the middle ones 3-5-parted; the uppermost of en undivided, toothed: disk yellowish, ovate or conicul ; rays large, drouping; chatf of the receptacle truncate, pubescent at the apex, about as long as the 3-angled anchenia. (R. digit:ata, Mill. R. lavigata, Pursh.) - Swanps, Florida, and northward. July und Augunt. - Leaves linge. liays $1^{\prime}-2^{\prime}$ long.

7. R. heterophylla, Torr. \& Gray. Pubescent ; stem corymbose alove; leaves coarsely serrate, rough above, tumentose beneath; the lowest orbicularcordate or 3-5-parted, on long petioles; the midlle ones 3-lolerl; the nppermost ovate, sessile and entire; disk globose, yellowish; rays droopling ; chaff of the receptacle acute; achenia 3 -sided. - Swamps, Middle Florida. August. Stem $3^{\circ}-4^{\circ}$ high. Leaves and heads much smaller than in the preceding.

* * Disk colummar, elongated : stems tall, simple.

8. R. maxima, Nutt. Smootlı; leaves large, unemhranaceons, oval or oblong, slightly toother or entire, feather-veined, the lower ones petioled, the upper clatping; head solitary, longrpeduncled; lays large, drooping. - Wet pine barrens, West Florida and westward. Angust. - Stem $4^{\circ}-9^{\circ}$ high. Lowest leaves $8^{\prime}-12^{\prime}$ long. Ray's $2^{\prime}$ long.

9. R. nitida, Nutt. Smooth and shining; stem tall, nakerl above; leaves rigid, oblong-lanceolate, slightly toothed or entire, 3-5-ribbed ; the lowest longpetioled; the upper partly clasping, small; rays large, drooping; lisk lrown. - IBorders of swampy thickets, Georgia, Florida, and westward. July. - Stem $3^{\circ}-5^{\circ}$ high. Lowest leaves $4^{\prime}-6^{\prime}$ long.

* * * Lower leates opposite: disk orate, yellow: chaff of the recrptarle cuspidate, ribued: achenia biconver, striate, huiry, rounded at the apex: pripus none.

10. R.? Porteri, Gruy. Rough with short scattered hairs; stem paniculately branched; leaves lancelate, entire, narrowed at each end, fringed at the base; exterior scales of the involucre linear, as long as the disk; the interior shorter, resembling the chaft of the reeptacle; rays $;-9$, longer than the disk. - Stone Mountain, Georgia. - Stem $2^{\circ}-3^{\circ}$ high.

\section{LEPACHYS, Taf.}

Scales of the involucre few and small. Chaff of the oblong or columnar receptacle truneate and thickened at the apex. Achenia fattened and margined. Pappus 2-toothed or none Otherwise like Rudbeckia. - Percnuials. Leaves pinnately divided. Rays large, drooping, yellow.

1. L. pinnata, Torr. \& Gray. Rough with short appressed hairs; stem spariugly branched; divisions of the leaves $3-7$, lanceolate, acute, serrate or entire; disk yellowish, oval or ohlong, shorter than the rays; pappus obscerely 2-toothed. (Rudbeekia tomentosa, Ell.) - Dry soil, West Florida, Georgia, and westward. July-Sept. - Stem $3^{\circ}-4^{\circ}$ ligh. Rays $2^{\prime}$ long.

\section{HELIANTHUS, L. SUNFlower.}

Heads many-flowered; the ray-flowers neutral; those of the disk tubular and perfect. Scales of ahe involucre imbricnted in 3 or more rows, with or without 
leafy spreading tips. Receptacle flat or convex, chaffy. Achenia 4-angled, usually compressed. Pappus of 2 (rarely $3-4$ ) cadncous chaffy scalcs or awns. Annual or perennial herbs, with opposite or alternate, commonly 3-ribbed, undivided leaves. Heads solitary, terminating the stem or branches. Disk yellow or dark purple. Rays yellow.

* Annual: dish dark purple: chaff of the receptacle 3-tcothed: leaves on long and slender petioles: achenia pubescent.

1. H. debilis, Nutt. Roughish; stem slender, decumbent, branching; leaves rarely opposite, deltoid-ovate, acuminate, wavy-serrulate; heads small; sciales of the involucre narrowly lanceolate, slender-pointed; pappus 2-iwned. - Shores of East Florida. - Stem $1^{\circ}-2^{\circ}$ long. Rays $10-14$.

2. H. præcox, Gray \& Engeln. Rough with seatterel rigit hairs, viilons when young; stem erect, panjeulately branched, somewhat spotted; leaves thin, coarsely serrate, acuminatc, undulate, the lowest deltoid-ovate, cordate, opposite, the upper ones ovate-lanceolate; scales of the involucre lanceolate-subulate; rays 15 - 20. - Sandy shores, West Florida, and westward. Ju?y - Sept. — Stem $2^{\circ}-3^{\circ}$ high.

$$
\begin{aligned}
& \text { * Peremial: disk dark purple. } \\
& \text { + Rays minute or wauting. }
\end{aligned}
$$

3. H. Radula, Torr. \& Gray. Stem simple, ascending, leafy and hirsute towards the base, naked and smoothish above; leaves thick, entire, rugose, hirsute, the 4 radical ones large, romdish or rhombic; spreading; the lower ones obovate, opposite; the uppermost small, linear; seales of the involucre oblongovate; rays mostly wanting; chaff of the receptacle acuminate. - Low sandy pine barrens, Georgia, Florila, and Alabama. Oct. - Stem $2^{\circ}$ high. Heads rather large.

$$
+ \text { + Rays conspicuous. }
$$

4. H. angustifolius, L. Stem rough-hairy or smoothish, panienlately branched; leaves linear, elongated, entire, with the margins revolute; the lowest ones opposite; scales of the involucre lanceolate, acuminate; chatf of the receptacle 3-toothed; rays $12-18$, showy. - Varies, with broader leares, and the disk at first yellow. - Low ground, Florida to Mississippi, and northward, common. Oct. - Stem $2^{\circ}-6^{\circ}$ high. Leares $3^{\prime}-6^{\prime}$ long.

5. H. heterophyllus, Nutt. Hirsute or hispid; stem slender, mostly simple, naked above ; leaves opposite, thick, entire; the lower ones lanccolate or oblong, tapering into a petiole; the others linear, remote; seales of the involucre lanceolate, acuminate, ciliate; claft' of the receptacle 3-tootlicd, the middle tooth cuspidate; rays 15-20, elongated. - Pine-barren swamps, Florila to Nortl Carolina, and westward. Scpt. aud Oct. - Stem $2^{\circ}-4^{\circ}$ high. Lowest leaves $2^{\prime}-6^{\prime}$ long. Rays $1 \frac{1}{2}$ long.

6. H. atrorubens, L. Hirsute or hispid; stem sparingly branched and somewhat naked above; leaves opposite, oval, serrate, the lowest large and longpetioled ; the upper small, sessile, distant ; seales of the invohere oval or oblong, obtuse; chaff of the receptacle acute; rays about 12 ; achenia pubescent at the apex. (HI. sparsifolius, Ell ) - Dry soil, Florida to North Carolina. Sept. and Oet. - Stem $2^{\circ}-5^{\circ}$ ligh. Lowest leaves $4^{\prime}-6^{\prime}$ long. IIeads rather sinall. 
7. H. rigidus, Desf. Stem leafy, stont, mostly simple, rongh; lenves oblong-lancenlate, slight]y scrate or entire, thick nnd rigrid, wery rough on hoth sieles, narrowed into short commute petioles ; seales of the involucre ovute, nente, appressed; chaff of the receptacle obtuse ; rays 20-25. (II. scalserrimus, Fill.) - Western districts of Georgia, Ellioll, mul westwatl. Sept. - Stem $1^{\circ}-3^{\circ}$ high. Ileads showy.

\section{* * * Perennial: disk yellou': hrads larye or middle-sizrl.}

8. H. læetiflorus, Pers. Stem stout, roush, l,amehing; leaves oval-lancewhte, acuminate, serrate, rigid, very rongh on both sides, on short pecioles; the uppermost often altemate; heads solitary or corymbose, on naked peduncles; scales of the involucre ovate-lanceolate, acnte, riliate, appressel; chaff of the receptade somewhat 3-toothed or entire; rays $12-16$, elongated. (II. tric'uspis, Ell., with the leaves all nearly eutire; (hafl' of the receptacle 3-toothed.) - J)ry soil, in the Westem districts of Georgial, and westward. Sept. - Stem $3^{\circ}-4^{\circ}$ high. Leares $5^{\prime}-8^{\prime}$ long. Rays $11_{2}^{\prime \prime}$ long.

9. H. occidentalis, Ridicll, var. Dowellianus, 'Torr. \& Gray. Nearly smooth; stem lanched allove; leaves triple-nervenl, sather thick, slightly dentate, on margined petioles, and with a short scattered pulsescence; the lowest ones opposite, large, broadly ovate, subcordate, obtuse ; the npper alteruate, oblong-orate; peduncles long and slender; seales of the involuere lanceolate, anenminate, slightly ciliate, sliorter than the disk, appressed; rays $1.2-15$. - Macon Comnty, North Carolina, Curtis. Aug. and Sept. - Stem $4^{\circ}-5^{\circ}$ high. Lower leaves $7^{\prime}-8^{\prime}$ loner, $5^{\prime}-6^{\prime}$ wide. Ralys $l^{\prime}$ longe.

10. H. mollis, Lam. Villous or tomentose and somewhat hoary; stem mostly simple; leaves ovate or oblong-ovate, acute, slightly serrate, cordate and chasping; the npper ones often alternate; heals few, on short peduncles; scales of the involucre lanceolate, acute; chaff' of the receptacle cntire; rays $15-25$. (H. pubesecns, EVll.) - Dry open woods in the upper rlistriets of Georgia, and westward. Sept. - Stem $2^{\circ}-3^{\circ}$ high. Leares $2^{\prime}-3^{\prime}$ long. Heads thick.

11. H. giganteus, I. Stem hirsute, rough, lranching alove; leaves lanceolate, acuminate, scrate, nearly sessile, rough alove, paler aml rough-hairy beneath, slightly 3-nerved at the base, all lint the lowest ones alternate; scales of the involucre linear-lancelate, spreading, lirsute; ray's 15-20. - Low ground in the upper districts, and northward. Sept. - Stem $3^{\circ}-10^{\circ}$ high. Leaves $2^{\prime}-5^{\prime}$ long. Rays I' long.

12. H. tomentosus, Michx. Stem stout, hirsute, hranching; leaves all alternate, or the lowest ones opposite, very rough above, tomentose beneath, slightly serrate; the lowest large $\left(6^{\prime}-12^{\prime}\right)$, ovate, on short winged petioles; the upper ones oblongr; heads large; scales of the involncre numerous, lauceolate, acuminate, villons, spreading; rays $15-20$. (II. spathulatus, Ell., with the leaves all opposite, scales of the involncre shorter.) - Open woods, and margrins of ficlds, Florida to North Carolina. Sept. - Stem $4^{\circ}-8^{\circ}$ hight. Rays 1'- $1 \frac{1}{2}$ ' long.

13. H. doronicoides, Lam. Stem tall, branched, smooth below, hirsute above; leares opposite, ovate or ovate-lanceolate, acuminate, serrate, rough 
above, pubescent beneath ; the lower ones often slightly cordate, on short winged petioles; scales of the inrolucre lincar-lanceolate, hirsute, about as long as the disk; rays $12-15$. - Southern States, Torr. \&. Gray, and westward. Sept. Stem $5^{\circ}-8^{\circ}$ high. Lowest leaves $6^{\prime}-12^{\prime}$ long. Heads large. liays $1 \frac{1}{2}^{\prime}$ long.

14. H. strumosus, L. Stem simple or branched, rongh above, smooth below; leaves varying from lanceolate to ovate-lanceolate, acuminate, slightly serrate, short-petioled, very rough above, paler and smooth, or roughish, or sometimes softly pubescent beneath; seales of the involucre lanceolate, acuminate, as long as the disk, sprearling; rays 8-10. (H. mollis, Ell.) - Dry soil, common. Sept. - Stem $2^{\circ}-4^{\circ}$ ligh, sometimes glaueous. Leaves $3^{\prime}-4^{\prime}$ long.

15. H. decapetalus, L. Stem branched, smooth below, rough above; leaves thin, opposite, ovate, acuminate, coarsely serrate, rough on the upper surface, smooth or roughish beneath, abruptly short-petioled; scales of the involucre lanceolate-linear, spreading; the exterior ones longer than the disk; ratys 8-10. (H. strumosus ant H. tenuifolius, Ell.) - Mountains of Georgia, and northward. Sept. - Stem $2^{\circ}-5^{\circ}$ ligh. Leaves $3^{\prime}-6^{\prime}$ long, obtuse at the base.

16. H. hirsutus, Raf. Stem hirsute, simple or forking at the summit; leaves opposite, short-petioled, tapering from the broad and rounded, sometimes slightly cordate base, acuminate, serrate, very rough above, paler and roughhairy beneath; scales of the involnere ovate-lanceolate, acuninate, appresserl, as long as the disk; rays about 12. (H. diversifolius, Ell, with the leaves broader; the upper oval, and nearly entire.) - 1)ry soit in the upper distriets. Sept. - Stem $2^{\circ}-5^{\circ}$ high. Leaves $3^{\prime}-5^{\prime}$ long.

17. H. divaricatus, L. Stem smooth, simple, or corymhosely branched at the summit; leaves opposite, sessile, ovate-lanceolate, serrate, rounded or truncate at the base, very rough above, smooth or rough-pubescent beneath; heads few, on short peduncles; scales of the involucre lanceolate or linear-lanceolate, spreading, as long as the disk; rays 8-12. (H. truncatn;, Ell.) - Dry woods, Florida, and northward. Sept. - Stem $2^{\circ}-3^{\circ}$ high. Leaves $3^{\prime}-5^{\prime}$ long.

\section{* * * * Perennial: disk yellow : heads small : leaves narrow.}

18. H. microcephalus, Torr. \& Gray. Stem smooth, much branched; leaves opposite, or the upper ones alternate, laneeolate or ovate-lanceolate, acute, sparingly serrate, rough ahove, paler and tomentose beneath, on short petioles; lieads numerous, on pubescent peduncles ; scales of the involucre orate-lanceolate, appressed ; rays $5-8$. (H. divaricatus, Ell.) - Dry woods, Florida, and northward. Sept. - Stem $3^{\circ}-5^{\circ}$ high; the branches forking. Leares $3^{\prime}-10^{\prime}$ long.

19. H. Schweinitzii, Torr. \& Gray. Stem hispis, hranching above; leaves lanceolate, acuminate, sparingly serrate, nearly sessile, very rough ahove, hoary-tomentose liencath ; the lower ones opposite, the upper altemate and entire; scales of the involucre lanceolate, aente, with spreading tips; rays about 8. - Upper districts of North Carolina, Curtis. - Stem $3^{\circ}-5^{\circ}$ higlh. Leaves $3^{\prime}-$ 5 ' long.

20. H. Iævigatus, Torr. \& Gray. Stem smooth and glancous, the branches forking; leares smooth or both sides, opposite, or the uppermost alternate, ob- 
lone-lanecolnte, acute, entire or scrrulate, obscurely 3-riblud, nearly sesfile, scales of the involucre ovate, acute, appressed with sprealing tips; rays $6-8$. - North Carolina, Curtis. - Stem $4^{\circ}-5^{\circ}$ high. Ileads twice as large as those of No. 18.

21. H. longifolius, Pursh. V'ery smooth throughout; stem slender, branching: lares mostly olpo-ite, linear-lanceolate, sessile, entire; the lowest tupering into slender petioles and sparingly serrate; heads fow; seales of the involucre orate-lanceolate, as long as the disk; rays ahout 10. - Damp rich soil in the Western districts of Feorgia, Elllott. - Stem $3^{\circ}-4^{\circ}$ high. Leaves $6^{\prime}-$ $8^{\prime}$ long. Rays small. - Reseubles an aquatic Coreopsis.

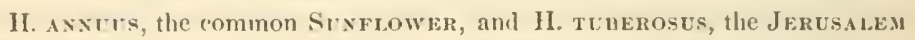
Articuoke, are commonly cultivatel species.

\section{HELIANTHELLA, Torr. \& Gray.}

$\Lambda$ chenia 4-angled, compressed, slightly winged, erowned with a ciliate horder, or the andes prolonged into persistent, often lacerated, 'haffy seales; otherwise like IIclianthus. - Slender perennial herbs, with nurrow leaves, and showy heads of yellow flowers.

1. H. grandiflora, Torr. \& Gray. Hirsute; stem simple; leaves alternate or opposite, lanceolate-linear, entire; scales of the involucre lanceolate, appressed; ['appus of two obtuse lacerated scales. - East Florida. - Stem $3^{\circ}-$ $4^{\circ}$ lighl. Leaves $\mathbf{1}^{\prime}-2^{\prime}$ long. Rays nearly $2^{\prime}$ long.

2. H. tenuifolia, Torr. \& Gray. Ilirute; stem simple, or corymbose at the suinmit; leaves narrow-linear, entire, the lower ones opposite or whorled; the upper alternate; seales of the involuere lanceolate-subulate, spreading; pappus of 2-4 acute awns.-Dry sandy pine barrens. West Florida. June and July. - Sten $1^{\circ}-2^{\circ}$ high. Rays $1^{\prime}-1 \frac{1}{2}$ long.

\section{ACTINOMERIS, Nutt.}

Heads many-flowered; the ray-fowers $4-14$, neutral, or wanting. Seales of the involucre in $1-3$ rows, leafy. Receptacle convex or conical, chaffy; the claff embracing the outer edge of the laterally compressed ohovate mostly winged achenia. Pappus of two persistent awns (obsolete in No. 5). - Perennial herbs, with ovate or lanceolate serrate ofien decurrent leaves. Flowers yellow or white.

\section{* Stems tall, branching: pappus 2-awned.}

1. A. squarrosa, Nutt. Stem pubeseent, winged above; leares alternate or opposite, rougl, ovate-lanceolate, acuminate at each end ; heads corymbose; scales of the involucre in 2 rows, linear-spatulate, spreading; achenia broadly obovate, winged; awns of the pappus rigid, spreading; rays $4-12$, yellow. River-banks, Florida to North Carolina. Sept. - Stem $4^{\circ}-8^{\circ}$ high. Lowest leaves 10 long.

2. A. alba, Torr. \& Gray. Stem smonth, or pubescent and often slightly winged above; leaves ulternate, rough, lanceolate; heads looscly corymbose; 
scales of the involucre in a single row, lancelate-subnlate; achenia mostly broadly winged; awns of the pappus slender; flowers white ; rays none. - Rich soil, in the lower districts, Georgia and South Carolina, and westward, rare. Sept. - Stem $4^{\circ}-8^{\circ}$ ligh. Leaves $5^{\prime}-8^{\prime}$ long.

3. A. helianthoides, Nutt. Stem hirsute, strongly winged; leaves alternate, orate-lanceolate, sessile, rough-hairy above, downy and hoary beneath; heads few, corymbose; scales of the involucre in $2-3$ rows, broadly lanecolate, appresscd; rays 8-14, yellow; achenia slightly winged; awns bristle-like. Near Louisville, Georgia, and westward. July. - Stem $2^{\circ}-3^{\circ}$ high. Leares $3^{\prime}$ long. Rays $1 \frac{1}{2}$ ' long.

4. A. nudicaulis, Nutt. Hirsute; stem wingless, somewhat naked and corymbose above; leaves opposite, oblong, sessile, barely acnte, the nppermost small and mottly alteruate; heads corymhose ; scales of the involucre short, in $2-3$ rows; rays $7-12$, yellow ; achenia obovate-oblong, mostly wingless; awns short. (Helianthus? aristatus, Ell.) - Dry sandy woods, Georgia, Alabama, and Florida. Aug. and Sept. - Stem $2^{\circ}$ high. Leaves $2^{\prime}-3^{\prime}$ long.

* * Stems low, simple: pappus obsolete: rays none.

5. A. pauciflora, Nutt. Stem wingless, simple, smooth below, naked and rough above; leaves opposite or alternate, lanceolate or elliptical, sessile, rigid, obtuse, strongly reticulate, rough with short rigid hairs; heads solitary or $2-3$ torrether, terminal; scales of the involucre in 2 rows, lanceolate, appressed; flowers orange-yellow; the marginal ones abortive; achenia oblong-obovate, narrowly winged, with a cup-shaped lisk ; pappus winting. - Low pine barrens near the coast, West Florida. June and July. - Stem $1^{\circ}-2^{\circ}$ high. Leaves $2^{\prime}$ long. Involucre, chaff, and achenia dark brown.

\section{COREOPSIS, L. TICKSEED.}

Heads many-flowered; the ray-flowers commonly 8 , neutral, rarely wanting. Involucre double; each row of about 8 scales; the outer ones narrow and spreading; the inner membranaccous and appressed. Receptacle flat, chaffy. Chaff membranaceous, mostly deciduous with the achenia. Achenia compressed, often winged, not narrowed nor beaked at the apex, awnless, or with a pappns of two upwardly hispid or serrulate awns or scales. - Herbs. Leares entire or pinnately divided. Heads solitary or corymbose. Disk dark purple or yellow. Rays yellow, rarely rose-color.

\section{* Rays none.}

1. C. discoidea, Torr. \& Gray. Smooth; stem diffusely branched; leaves long-petioled, 3-parted, with ovate-lanceolate coarsely serrate divisions; the uppermost often simple; heads small, on short peduncles; exterior involucre foliaceons, longer than the heads; achenia narrowly werlge-shaped, hairy. - Swamps, North Carolina, and northward. July-Sept. - Stem $1^{\circ}-2^{\circ}$ high.

\section{* Rays entire, or emarginate at the apex, yellow.}

- Leaves petioled: achenia narrouly wedge-shaped, 2-toothed or awned: scules of the involucre equal, the outer ones separute.

2. C. aurea, Ait. Stcm smooth, much branched; leaves smooth or slightly pubescent, 5-7-parted; the divisions oblong or lanceolate, serrate, toothed or 
lobed, or all linear and entire ; exterior seales of the involuce line:ur-spatulate ; achlenia smoothish, with two short triangular tecth. (C. mitis, Michx. C. nrguti, Pursh.) - Swamps, Floridal to North Carolina, aul wentwarl. Aug. - Oct. Stem $2^{\circ}-4^{\circ}$ high. Leaves polymorphous; the uppermost commonly undivided. hays sliowy.

3. C. trichosperma, Michx. Smooth ; stem somewhat 4-anrled, branching; leaves pinnately 5-7-patrted the divisions lancelate or linear, sharply scrrate or toothed; the upper ones 3 -5-eleft; exterior scales of the involucre linear, obtuse; nchenia hispid ahove, crowned with two trianenlar hispisl tectls. - Swanıs, South Carolina, and northward. Sept. - Stem $1^{\circ}-2^{\circ}$ hight. $\Lambda$ chenia twice as large as in the preceding.

+ + Leaves petioled: achenia elliptical or obocate, emarginate, aumless: exterior scalcs of the involucre shorter than the interior.

4. C. tripteris, L. Stem smooth, branching ; leaves smooth, or rough alove; the upper and lower ones entire, the mildle ones 3- (rarely 5-) parterl, with the divisions lanceolate and entire; exterior seales of the involucre 5-6, obtuse, united at the base; achenia elliptical, smooth, ineurved, narrowly winged. - Woods and margins of field-, Florida to North Carolina, and westward. Aug. and Sept. - Stem $3^{\circ}-6^{\circ}$ high.

5. C. latifolia, Michx. Smooth or somewhat pubescent; stem tall; leaves undivided, ovate-oblong, acuminate, coarscly scriate, smooth above, paler beneatls; heads small, corymbose; seales of the involucre $4-5$ in each row; the exterior ones short, not united below; rays $4-5$; achenia obovate-oblong, wingless. - Hight monntains of Georgia and North Caroliua. Aug. - Lowest leaves 6 ' long.

+ + + Leaves sessile, 3-parted to the base, seemingly 6 in a uhorl; the dirisions entire or varionsly divided: scales of the involucre equal; the exterior ones linearoblong, united below: achenia oblong, narrouly winged, naked or minutely 2-toothed at the apex.

6. C. senifolia, Michx. Pubescent; stem 4-angled below, branching; divisions of the leaves oval-lanecolate, entire, the uppermost leares often simple; disk yellow; achenia ninutely 2-toothel. (C. stellata, Nutt, with the stem more slender and leaves narrower.) - Dry sandy woods, Florida to North Carolina, and westward. Aug. - Stem $2^{\circ}$ high. Leaves $1^{\prime}-2^{\prime}$ long. Rays $6^{\prime \prime}-9^{\prime \prime}$ long.

7. C. delphinifolia, Lam. Smooth or slightly pubescent; divisions of the leaves entire or $2-3$. (the middle one sometimes 5-) parted, linear-laneeolate, rather rigid; rlisk brownish; achenia obovate-oblong, minutely 2-toothed. (C. verticillata, Ehrh, Ell.) - Dry soil in the upper districts. Aug. and Sept.Stem $1^{\circ}-2^{\circ}$ high.

8. C. verticillata, L. Smooth ; stem branching, slender; divisions of the pinnately or bipinnately divided leaves linear or filiform; disk yellow; achenia minutely 2 -toothed at the apex. (C. tenuifolia, Ell.) - Low ground, in the upper districts. Angust, - Stem $1^{\circ}-3^{\circ}$ high. 


\section{* * * Rerys 3-5-toothed or lohed.}

+ Rays yellow: achenia orbicular, broadly winged, warty, and with a tulerste at each end on the inside, 2-toothed: sculs of the imolncre nearly equal: hurds long-peduncled.

9. C. auriculata, L. Stem erect, pubescent, commonly branched; upper leaves oblong or ovate-laneeolate, mostly entire, nearly sessile; the lower petioled, oval or roundish, entire, or with $2-4$ small lateral lobes; exterior seale; of the involucre lanceolate; rass 4-tootherl. (C. pubescens, Ell ) - Rich slarled soil, West Florida to the momntains of North Carolina. June-Sept. - Stem $1^{\circ}-4^{\circ}$ high. Leares $1^{\prime}-4^{\prime}$ long, variously divided on the sane plant. Fiays sliowy.

10. C. grandiflora, Nutt. Stem slender, smooth, ascending; leaves elongated; the lowest linear-spatulate, on long ciliate petioles; the upper ternately or 1-2-pinnately parted, the divisions linear; exterior scales of the involnere ovate-lanceolate; rays large, $4-5$-tootheil. - Dry soil, Florida and Georgia, and westward. April-June. - Stem $8^{\prime}-12^{\prime}$ higl.

11. C. lanceolata, I. Smoothish; stem short, ascending; leaves undivided, thick; the lowest spatulate-oblong on long ciibate petioles; the uper lanceolate sessile; exterior scales of the involucre ovate-lanecolate; rays large, strongly 4-5-toothed. (C. crassifolia, Ait., stem and leaves hairy or woolly.) Dry rich soil, Florida to North Carolina. May and June. - Stem 6 $6^{\prime}-12^{\prime}$ long.

+- Rays yellow: acheniu nrarly straight, ollong, 2-awnd, the margins with a serrulute or pectinate wing (excrpt 10. 12): cxterior scales of the incolucre shorter than the interior : disli dark merple.

12. C. Leavenworthii, Torr. \& Gray. Smooth ; stem dichotomous abore; leaves opposite, lincar, entire, or with two lateral lobes; rays 3-toothed; achenia with a broad whitish entire wing, conspicuously 2-toothel. - Tampa Bay, East Florida. - Stem slender, $1^{\circ}-2^{\circ}$ highl. Lower leaves $3^{\prime}-4^{\prime}$ long, $1^{\prime \prime}$ wide. Rays $5^{\prime \prime}-6^{\prime \prime}$ long.

13. C. gladiata, Walt. Smonth; sicm terete, naked abore, simple, or with $f$ :w peduncle-like hranches ; leaves flesly, alteruate, cutire, or rarely 3 -lobed ; the lowest ones spatulate-ollong, on long petioles; the upper small, linear; heads large; exterior scales of the involucre small and roundish; rays showy, 4-toothed; wings of the achenia pectinately toothed. - Low pine barrenc, Floricla to North Carolina, and westward. Sept. and Oct. - Stem $2^{\circ}-3^{\circ}$ high. Lowest leaves $S^{\prime}-10^{\prime}$ long. Rays wedge-shaped, $1^{\prime}$ long.

14. C. angustifolia, Ait. Smooth; stem slender, 4-angled, dichotomonsly branched above; leaves opposite or alternate, linear, obtuse, entire; the lowest ones spatulate-lanceolute ; heads small, corymbose ; rays 3 -toothed ; wing. of the achenia pectinately toothecl. - Pine-barren swamps, Florida to North Carolina, and westward. Sept. and Oet. - Stem $2^{\circ}-3^{\circ}$ high. Leaves somewhat fleshy. R'y $\frac{1}{2}{ }^{\prime}$ long.

15. C. integrifolia, Poir. Smooth; stem terete, corymbosely branched above; leaves opposite, petioled, entire, orate or ollong, ohtuse, the margins scarious and roughish; heads few, on long peduncles; exterior scales of the 
involncre oblong-linear; rays wedpre-slapeol, palmately 3-lobed; ovary wingless, with lisppid margins, - River-hauks, South Carolina und Georgia. Septembrr. - Stem $2^{\circ}-3^{\circ}$ hight.

$$
+++ \text { Jians purple or rose-rolur. }
$$

16. C. nudata, Nint. Snooth; stem slender, forking uhove; leaves alternate, distant, terete, and ru-h-like; rays brighlit purpgle, 3-toothed ; achenia with lacerated wings, 2-awned. - I'ine-barren ponds, Florida and fiecroria, near the coast. $\Lambda_{\text {plril. }}$ Stem $2^{\circ}$ high. Lowest deaves 10 long. liays $l^{\prime}$ long.

17. C. rosea, Nutt. Smooth; stem low, branching; leaves opposite, linear; heads small; rays sliglitly 3-tootled; achenia wingless, unawned. Swanps, Georgia, Nuttall, and northward. July and Angust. - Stem $8^{\prime}-12^{\prime}$ high. liays rose-color.

18. C. Emleri, Ell. Leaves broad-lanceolate, sessile, acute at each cnol, cutire; peduncles axillary and terminal, dichotomonsly corymbose. - Collected near the junction of the Broad and Saluda livers by Mr. (Emler. Elliott. Stem $2^{\circ}-3^{\circ}$ high, angrular, smooth. Leaves connate by a small memlorane. Heatls small. Rays about 8, entire. Achenia wedge-shaped, slightly 2-toothed and margincd. (*)

\section{COSMOS, Cav.}

Seales of the involnere more or less mited. Achenia tercte or 4-angled, narrowed or beaked at the apex, and crowned with $2-4$ downwarlly barbed or lispid deciduous awns. Otherwise like Coreopsis. - Leaves opposite, pinnately dividerl. Disk yellow. Rays purplish.

1. C. caudatus, Kunth. Smooth; leaves hipinnately diviled, with the divisions lanccolate and entire; achenia ( $1^{\prime}$ long) tapering into a very long rongh beak, 2-awned ; rays short, 3-cleft, rose-color. - Kiey West, Florida.

\section{BIDENS, L. Beggar-ticks.}

Chiefly like Coreopsis; but the exterior involncre often long and leaf-like; the achenia compressed, or 3-4-angled, (not narrowed at the apex, ) and crowned with 2-4 persistent downwardly barbed or hispid awns. - Leaves serrate, or pinnately divided, opprosite. liays yellow or white, often wauting. Disk yellow.

\section{* Acheniu flattened, narrorly uedge-shaped.}

1. B. frondosa, L. Stem tall, branched; leaves thin, long-petioled, pinnately 3 -5-divided; the divisions ovate or ovate-lanceolate, acmuinate, sharply serrate; heads discoid; exterior scales of the involnere large, leafy; achenia 2-awned. - Low gromud, Florida and northward. July - Sept. (1) - Stem $2^{\circ}-5^{\circ}$ high. Marrins of the achenia upwardly ciliate.

2. B. connata, Mulı. Stem low, branched; leaves ohlong-lanceolate, acuminate, conrely serrate, tapering and connate at the base, the lowest often 3-parted; heads discoid; exterior involncre leafy; achenia 2-4-awned, with downwardly hispid margins. - Western districts of Georgia and westward, in damp soil. July-Sept. (1) - Stem $1^{\circ}-2^{\circ}$ high. 
3. B. chrysanthemoides, Michx. Smooth; stem erect or ascending; leaves undiviled, oblong-lanceolite, obscurely serrate, connate; heads radiate, showy ; athenia 2-4-awned. - Wet places, Florida to Mississippi, and northward. Sept. and Oct. (1) - Stem thick, $1^{\circ}-2^{\circ}$ ligh.

* * Achenia 3-4-angled, linear: heads rudiate: scales of the involucre nearly equal.

4. B. leucantha, Willd. Stem low, 4-angled; leaves pinnately 3-5divided; the divisions orate or lanecolate, serrate; the lowest ones undivided; outer scales of the involucre obtuse, spreading; the imner ones acute; rays 5,

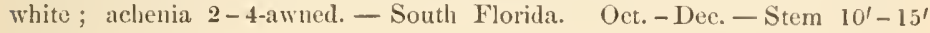
lighl.

5. B. bipinnata, L. Stem tall, 4-angled, much branched; leaves bipinnate, the dhisions small, orate or linceolite, acute; heads small; rays $2-3$, yellow; achenia 3-4-awned. - Cultirated grounds, common. Aug. and Sept. (1) - Stem $2^{\circ}-5^{\circ}$ high.

\section{SPILANTHES, Jacq.}

Heads many-flowered; the ray-flowers often wanting. Scales of the involnere in 2 rows, appressed, shorter than the disk. Ricceptacle convex or elongated; the membranaceous chaff embracing the flowers. Achenia of the disk compressed, mostly ciliate on the margins, naked at the apex, or with $1-3$ bristly awns; those of the rays 3 -angled. - Chiefly ammal and acrid herbs, with opposite undivided leares, and solitary heads of yellow flowers on long peduncles.

1. S. repens, Michx. Stem branching, slightly pubescent, decumbent and rooting at the base; leaves orate-lanceolate or lanceolate, slightly serrate, natrrowed into a petiole; heads small, ovoid, becoming oblong-conical; achenia awnless, not ciliate ; rays 12. (Acmella repens, Pers.) - Mnddy banks, Florida to South Carolina. Sept. and Oet. 4 ? - Stem $66^{\prime}-12^{\prime}$ long.

2. S. Nuttallii, Torr. \& Gray. Villons-pubescent or smoothish; stem diffusely branched, ascending ; leares ovate or oblong, coarsely serrate, abruptly petioled; heads ovoid, at length oblong-conical; achenia awnless or with $1-\mathbf{2}$ minute awns, ciliate on the margins; rays 10-12. - Inundated places, East Florida, Aug. - Oct. - Stem $1^{\circ}-2^{\circ}$ long.

\section{VERBESINA, I.}

Heads many-flowered; the ray-flowers few, sometimes wanting. Scales of the involuce imbricated in 2 or more rows. Receptacle flat, or somewhat convex; the chaff' coneave. Achenia laterally compressed, wingless, 2-awned. - P'erennial herbs. Stems mostly winged by the decurrent serrate or lobed leaves. Heads corymbose. Flowers white or yellow.

1. V. Siegesbeckia, Michx. Stem 4-winged, branching; leaves opposite, ovate or ovate-lanceolate, acuminate, sharply serrate, 3-ribbed; corymlss trichotomons; rays $1-5$, yellow; achenia wingless. - Waste places, roal-sides, \&c., Mississippi to North Carolina. Sept. - Stem $4^{\circ}-6^{\circ}$ high. 
2. V. Virginica, I. Stem 3-winged; the branches mostly wingless, tomentese; leaves ovate or ovate-lanceolate, irregralarly serrate or sinuate-lobed, silpering into winged petioles, rongh alove, downy lnewett ; coryuls cymose; rays 3-4, oval, white; achenin winged. (V. siunata, Lll.) - Dry open woods, Florida and northward. Sept. - Stem $2^{\circ}-6^{\circ}$ high.

\section{FLAVERIA, Juss.}

lieads few-flowerel, discoid, or with a single pistillate ray. Involuere of $3-5$, oblong nearly equal scales. lieceptacle naked. Achenia oblong or chub-shaped, smooth, striate. Pappus none. - Tropical herbs, with opposite leaves, and densely clustered heads of yellow flowers.

1. F. linearis, Lagasea. Stem somewhat prostrate at the lase, branched ahove, smorthish ; lenves fleshy, linear, eomute, entire; eroryb dance; ecales of the involucre mostly 5 ; ray often wanting. - Key West. - Stem $1^{\circ}-2^{\circ}$ liigh.

\section{GAILLARDIA, Fong.}

Heats many-flowered; the rays nentral, decidnons. Scales of the involuce in 3 rows, acute, sprearling above. Receptacle convex or hemispherical, naked or fimbrillate. Rays wedge-shaper, palmately 3-lubed. Corolla of the disk with subulate lobes. Achenia top-slaped, hairy. I'alpms of 6-10 membranaceons 1-nerved awned scales. - Pubescent branching herlss, with alternate leaves, and solitary hends of yellow or purple flowers terminating the branches.

1. G. lanceolata, Michx. Stem $\left(1^{\circ}-2^{\circ}\right)$ with long and sleuder branches; leaves narrow-lancenlate, mo:tly entire, sessile, the lowest narrowed at the base; rays yellow, sometimes wanting; disk-fowers pmrple ; receptacle naked; scales of the pappus $7-9 .-$ Dry pine barrens, Florida to South Carolina. Juig - Sept.

\section{PALAFOXIA, Lagasca.}

Heads many-flowered; the ray-flowers pistillate, or none. Scales of the obconical involucre in 2 rows, membranaceous at the summit. Receptacle flat, naked. Achenia slender, 4-angled, taperinir at the base. Pappns of 6-12 membranaccous denticulate scales, pointed by the prolonged rigid midrils. Herhs or shrubs, with narrow entire leaves, and heads of white or purple flowers in a terninal corymb.

1. P. integrifolia, Torr. \& Gray. Stem ( $2^{\circ}$ high) branched abore, smoothish; leares lanceolate, rongh; the lower ones often opposite; rays none; flowers purplish; scales of the pappus 8-9, linear-subulate. (Polypteris integrifulia, Nutt.) - Dry pine barrens, Georgia and Florida. July-Sept.

\section{HYMENOPAPPUS, L'Herit.}

Heads many-flowered; the flowers all tubular and perfect. Seales of the involncre 6-12, oval or oborate, membranaceons, white. Receptacle naked. Corolla slender. Achenia top-shaped, f-angled. Papjus of $12-20$ short obtuse 
thin scales. - Hoary or woolly herbs, with alternate pinnately lobed or divided leaves. Heads corymbed. Flowers commonly white.

1. H. scabiosæus, L'Herit. IIoary-tomentose ; stem corymbosely branched; leaves pinnatifid or the lowest bipinnatifid, with lanceolate or oblong divisions; scales of the involucre broadly obovate, longer than the disk; pappus minute. - Light dry soil, Florida to Sonth Carolina, and westward. April and May. - Stem $2^{\circ}$ high. Leaves at length smoothish above.

\section{HELENIUM, L.}

Heads many-flowered, radiate; the rays pistillate, wedge-shaped, 3-5-cleft. Seales of the inrolucre in 2 rows; the outer ones linear or subulate, spreading, the imner fewer and chaffy. Receptacle naked, convex, globose, or oblong. Corolla of the disk 4-5-toothed. Achenia top-shapel, furrowed, hairy. Pappus of 5-8 membranaceous pointed or awned l-nerved scales. - Erect branching herbs, with the stem winged by the alternate decurrent leaves. Heads terminating the branches. Flowers mostly yellow.

\section{* Disk glolose : corolla of the disk mostly 5-cleft.}

1. H. autumnale, L. Smooth or minntely pubeseent; leaves lanceolate or oblong, serrate, strongly decurrent; seales of the involuere linear-subulate; scales of the pappus orate-lanceolate, denticulate, awn-pointed ; rays 3-5-cleft, longer than the disk. - Damp soil, Floricta, and northward. Aug. and Sept. Stem $2^{\circ}-4^{\circ}$ high. Aehenia hairy.

2. H. parviflorum, Nutt. Smootlı; leaves lanceolate or oblong-laneeolate, sparingly serrulate, searcely decurrent; seales of the involucre filiform; rays 3-cleft, narrow; achenia smooth; pappus awned.-Georgia, Nuttall. Ifeads smaller than the last.

3. H. tenuifolium, Nutt. Smooth; stem slender, very leafy; leaves narrow-linear, entire; heads on long and slender peduncles; scales of the involucre subulate; seales of the pappus orate, entire, abruptly awned ; achenia villous. - Road-sides, West Florida, and westward. Septenber. - Stem $1^{\circ}-2^{\circ}$ high. Branches erect.

\section{* * Disk conical or ollong: corolla mostly 4 -cleft.}

4. H. quadridentatum, Iabill. Smoothish; lowest leaves oblong, pinnatifid ; the upper ones lanecolate, entire ; rays slorter than the oblong disk ; scales of the pappus roundish, ohtuse. - River-banks and damp soil, North Carolina, and westward. (1) - Stem mnel branched, $1^{\circ}-3^{\circ}$ high.

\section{LEPTOPODA, Nutt.}

Heads many-flowered, radiate; the rays nentral, 3-4-eleft. Disk-flowers 4-5-toothed. Scales of the involuere in 1-2 rows, spreading; the exterior leafy, numerous; the interior slort and chaffy. Receptacle conieal or hemispherieal, naked. Achenia slort, truneate at each end, striate. Pappus of 6-12 searious toothed or fimbriate scales. - Perennial herbs. Stems mostly simple, naked above. Leaves alternate. Heads solitary. Flowers yellow or purple. 
* Slems commonly simple, diluted under the heud: disk-flourers yollow: rongs 20 or more. - delennia smensth.

1. L. Helenium, Nutt. Smooth or nearlyso f leaves entire or obscurely serrate, lancenlate or linear, the lower ones decurrent, the lowest tapering inte a petiole; rays $20-30$ in a single row; scales of the papjus lacrate, ami mosty lristle-pointed; achenia smooth. (1. decomens, l:ll.) - Margins of pinc-barren ponds, Floridis to South Carolina, und Wentward. $\Lambda_{\text {pril }}$ and May. - Stem $1^{\circ}-2^{\circ}$ ligh.

2. L. incisa, Torr. \& Gray. Smooth; leaves lanceolate, ratlucr olutuse, sessile, not decourent, sinnate-pinnatifit or incised ; seales of the papplus laterate, or sliglutly fimbriate at the summit; rays ahout 40 , in $2-3$ rows. - Low pine barrens, Georgia and westwarl. - Rescmbles No. 4.

++ Arhenia hariry on the angles.

3. L. fimbriata, Torr. \& Gray. Stem smooth, sometimes branching, the peduncle slightly pubeseent; leaves linear-lancelate, acute, entire or olscurely serrate, decurrent; scales of the pappus fimbriate. - Low pine barrens, Florida, und westwarl. April and May.-Stem $1^{\circ}-2^{\circ}$ high.

4. L. puberula, Machride. Closely pubesent; leaves somewhat fleshy, linear-lanceolate, sessile but not deemrent, dentienlate; the lowest spatulatelanecolate, toothed or pinnatifid; scales of the pappus obtuse, with slightyly lacerated margins. - Wet pine barrens, Florida to North Carolina, and westward. April and May. - Stem $2^{\circ}$ high.

5. L. brevifolia, Nutt. Stem pubescent above, often sparingly branched; l'aves ('ntire, more or less decurrent, the upper ones lanceolate, the luwest spatularte-oblong, obtuse; seales of the pappus obtuse, slightly lacerate at the apex.Wet phaces, Alabama to North Carolina. May and June. - Stem $1^{\circ}-3^{\circ}$ high. Hearls large.

* * Stems branching, leafy: heads corymbose: rays 8-12: Aloxers of the disk purple.

6. L. brachypoda, Torr. \& Gray. Stem jubeseent ; leares lanceolate, entire or nearly so, decurrent; seales of the piljpus ovate, slightly dentienlate, abruptly awn-pointed; achenia hairy on the angles. - River-bank-, Fiorida to North Carolina. Nay and June. - Stem $1^{\circ}-2^{\circ}$ high.

\section{BALDWINIA, Eill.}

Heads many-flowered, globose in fruit; the ray-flowers $20-30$, neutral, 3-toothed at the apex; tube of the disk-flowers dilated and indurated. Seales of the involuere short, fleshy, imbricated in abont 4 rows. Receptacle deeply alveolate; the 5-6-angled cells with entire margins, enclosing the slender obconical hairy achenia. Pappus of $7-9$ oblong nerveless (haffy scales, as long as the achenia. $-\Lambda$ n erect puberulent mostly simple perennial herh, with alternate fleshy entire linear or (the lowest) spatulate leaves, and a solitary head of yellow flowers on a long peduncle.

1. B. uniflora, Ell. - Low pine barrens, Florida to North Carolina, and westward. September. - Stem $2^{\circ}-3^{\circ}$ high. Ifeads large. - Dr. Curtis finds a form with the disk-flowers dark-purple. The rays are also sometimes tubular. 


\section{ACTINOSPERMUM, Ell.}

Scales of the involucre in about 2 rows, lanceolate, setaceonsly acuminate. Margins of the cells of the reeptacle cuspidate-toothed. Achenia radiate at the summit. Pappus a row of 12 short roundish entire seales. Otherwise like Baldwinia. - A slender branching annual. Leaves alternate, linear, fleshy. Heads of yellow flowers showy, terminating the peduncle-like summit of the branches.

1. A. angustifolium, Torr. \& Gray. (Baldwinia multiflora, Nutt.) Dry sandy ridges in the pine barrens, Florida and Georwia. Sept. - Stem $1^{\circ}-2^{\circ}$ high, smooth. Leaves very numerous, sprinkled with jointed hairs.

\section{MARSHALLIA, Sehreb.}

Heads many-flowered; the flowers all tubular and perfect. Corolla pubeseent, with linear spreading lobes. Scales of the involnere oblong-linear or laneeolate, in 1-2 rows. Chaff of the convex or conical receptacle narrow-linear, rigid. Achenia oblong, narrowed downward, 5-angled, mostly hairy. Pappus of 5-6 ovate or triangular acmminate entire membranaceons seales. - Perennial herbs, with simple and seape-like or branching stems, smooth entire 3-nerved alternate leaves, and a solitary head of white or purplish flowers terminating the stem or branches. Anthers blue.

1. M. latifolia, Pursh. Stem leafy, simple or sparingly branched above; leaves ovate-lanceolate, acuninate; seales of the involuere linear-lanceolate, acnte; achenia smooth. - Dry soil, in the ujper districts. May and June. Stem $1^{\circ}$ high.

2. M. lanceolata, Pursh. Stem naked above, simple, pubescent; leaves lanceolate, obtuse; the lowest spatulate; seales of the involucre oblong-linear, obtuse; achenia pubescent. - Var. Platrinylla, Curtis. Stem leafy to the mildle; leaves longer and broader; the lowest $\left(5^{\prime}-6^{\prime}\right)$ on long and slender petioles. - Dry open woods, Florida to North Carolina, and westward; the variety in the upper districts. April - June. - Stem $6^{\prime}-12^{\prime}$ high. Leares $2^{\prime}-3^{\prime}$ long.

3. M. angustifolia, Purslı. Stem simple or branched, leafy below, puberulent above; leaves linear, acute, the lowest spatulate; seales of the involucre linear and acute; disk at length ovate or oblougr achenia with hiciry angles. - Low pine barrens, Florida to North Carolina. July and Aug. - Stetn $2^{\circ}-3^{\circ}$ high.

\section{MARUTA, Cass. MiY-WEed.}

Heads many-fowered; the ruys neutral. Scales of the hemispherieal involucre imbrieated in few rows, shorter than the disk. Receptacle conical, elaffy thronghout, or ouly at the summit. Achenial obovoid, ribbed, smooth. Pappus none. - Branching annuals. Leaves alternate, thrice pinnately divided. Ifeads solitary, terminal. Rays white.

1. M. Cotula, I)C. Stem $1^{\circ}$ high ; divisions of the leaves linear; scales of the involucre with scarious margins; disk yellow. (Anthemis Cotula, L.) Waste places. Introduced. May and June. 


\section{ACHILLEA, L. Yannow.}

Ileals many-flowered the rays pistillate, few and short. Senles of the involucre imbrieated. Receptacle flat or clongated, chally. Arhenia oblong, compresseal, mangined. I'appus none. - l'eremial herbs. Leaves altemate, commonly pinnately divilded. Ileals small, corymbose.

1. A. millefolium, I. Stems $\left(1^{\circ}\right.$ high $)$ simple, pulsesent, tufterl ; leaves: lanceolate, bipinnatifit, the dirisions linear, 3-5-cleft; corymbs dense, compound; rays $4-5$, white. - Old fields and around dwellings. Introduced. May - Sint.

\section{LEUCANTHEMUM, Tourn. Ox-erE Disx.}

Ileads many-flowered; the rays numerous, pistillate. Scales of the involuere inlrricated, lroad, rounded, with scarions margins. Receptacle that or convex, nakcd. Arhenia nearly terete. P'appus none. - P'erennial lierbs. Leaves alternate, toothed or pinnatifid. Heads solitary, terminating the stem or branches. Raỵs white.

1. L. vulgare, Ian. Stem $\left(6^{\prime}-12^{\prime}\right.$ high $)$ simple, nakcil above; leaves pinnatifid; the lowest spatulate-obovate; the upper lancenbate; leads showy. (Chrysanthemum Leucanthemun, L.) - Fields. Introduced. Mily and June.

\section{TANACETUM, I. TAxs.}

Ileads many-flowered, discoill ; the flowers all fertile: the marginal ones chicfly pistillate, 3-5-toothed. Scales of the involuere imbrieated, dry. Receptacle convex, naked. Achenia angled or ribber. l'appus a narrow border, or none. - Herhs with alternate dissected leaves, and solitary or corymbose heals of yellow flowers.

1. T. vulgare, L. Stem smootb, crect; leaves bipinnately divided, the lobes serrate; heads corymbose, numerons; pappus 5-lober. - Common in gardens, and sparingly naturalized in North Carolina. 4 - Stem $1^{\circ}-2^{\circ}$ high.

\section{ARTEMISIA, L. Wom WоOD.}

IIeads few-or many-flowered, disereicl; the central flowers perfect, 5 -toothed (sometimes abortive), the marginal ones pistillate, 3-toothed. Scales of the involucre inbricated, mostly with scarious maryins. Rereptacle convex, naked or villons. Achenia obovoid. I'appus none. - Aromatic herbs or shrubs. Ietaves alternate, pinnately divided. IIeads small, in panicled spikes or racemes.

1. A. caudata, Michx. Smooth; stem slender, hranching; lowest leaves 2 -3-pinnately divided, the upper ones pinnate, with the divisions filiform ; leads grlohular, in small racemes, forming an clongated panicle. - Dry open woods, West Florida, and nortluward. Sept. (2) - Stem $2^{\circ}-6^{\circ}$ high. Receptacle nakel. Disk-flowers abortive.

\section{SOLIVA, Ruiz \& Pavon.}

Ileads many-flowered, monocions ; the fertile flowers in sereral rows, apetalous or nearly so; the staminate few in the centre, with a $3-6$-toothed corolla. 
Sea!es of the involncre 5-10, in a single row. Receptacle flit, naked. Achenia compressed, with winged or thickened margins, armed with the persistent rigid style. Pappus none. - Small depressed herbs, with petioled pinnately divided leaves, and small sessile or rarely pedunculate heads.

1. S. nasturtiifolia, DC. Very low and depressed ; leaves on short petioles, pinnately parted ; the loles $3-4$ on each side, obtuse, entire; heads sessile; achenia cuneiform, villous at the apex; the eallous margin tuberenlate-rngose throughout. (Gymnostylis stolonifera, Nutt.) - South Carolina, around Charleston. Introduced. Feb.-May.

\section{GNAPHALIUM, L. EverLasting.}

Heads many-flowered, discoid ; exterior and pistillate flowers very slender, mostly in several rows; the central ones perfect. Scales of the involucre inbricated, appressed, scarious. Receptacle flat, naked. Achenia terete or more or less flattened. Pappus a single row of eapillary bristles. - Woolly or downy herbs. Leaves alternate, undivided. Heads in erowded spikes or corymbs. Involucre colored.

1. G. polycephalum, Michx. Stem woolly, white, branching above; leaves linear, sessile, undulate, white beneath; heads corymbose; scales of the involuere white, obtuse. - Old fields, common. Sept. and Oet. (1) - Stem $2^{\circ}$ bienh. Perfect flowers few.

2. G. purpureum, L. Woolly or tomentose and housy throughout; stems branching at the hase, ascending, simple; lowest leaves spatulate-lanceolate, the upper ones linear; heats in erowled spikes. - Cultivated ground, very common. April - June. (1) - Stems 4'-12' high.

\section{ANTENNARIA, Gret. Everlastixg.}

Heads many-flowered, dicecions, discoid; the corolla of the sterile flowers 5eleft; of the pistillate ones filiform. Scales of the involucre imbrieated, scarious, colored. Receptacie convex or flat. Achenia nearly terete. Pappus a single row of eapillary loristles, which, in the staminate flowers, are thickened at the alex - Perennial downy or woolly herbs, with alternate entire leaves, and corymbose rarely single beads.

1. A. margaritacea, R Br. Stem corymbose above, woolly; leaves linear-lanceolate, with revolute margins, tomentose; heads corymbose; involurre white. - Upper distriets of North Carolina, and northward. Sept. and Oct. - Stem $1^{\circ}-2^{\circ}$ high.

2. A. plantaginifolia, Hook. Stoloniferons; stenus scape-like; radical leaves spatulate or obovate, lroary, becoming smooth above, 3-ribbed ; those of the stem f'w, linear or lanceolate; heads small, in at terminal eluster, sometimes single and larger; involncre white or purplish. - Sterile soil, Florida, and northward. Marth - May. - Stcin $6^{\prime}-12^{\prime}$ hight. 


\section{ERECHTHITES, Raf. Fm:w:1.}

Heads many-flowered, discoid ; the maryinal flowers pistillate, very slender, 2-3-tootherl; the others perfiect, $4-5$-tootherl. Seales of the cylindrical involu(') in a single row, linemr, acute, bracted. Beceptacle naked. Achenia oblong, striate. Jappus of copiuns soft hairs. - Erect ammul herbs, with ulternate simple leaves, and corymbose heads of greenisly flowers.

1. E. hieracifolia, liaf. Stem mostly branched, smooth or hairy ; leaves lanceolate, sessile, sharply serrate or toothed; the upper somewhat clasping; bracts snbulate, minute; pappus white. (Senecio hicracifolius, L.) - Rich soil, common. July $-\mathrm{Se}$ )t. - Sten $1^{\circ}-5^{\circ}$ high.

\section{CACALIA, L.}

Heads 5-many-flowered; the flowers all tulutlar and perfect, 5-cleft. Scales of the involnere $5-30$, in a single row. Receptacle flat, naked, or with at tubercular prominence in the ecentre. Achenia oblong, smooth. J'alpus of numerous capillary bristles. - l'eremial, mostly smooth and tall herbs, with altemate entire or lobed leaves, and corymbose heads of white flowers.

\section{* Rerepharle flat: involucre about 12-leated, 25-30-flocered.}

1. C. Suaveolens, L. Smooth; leares ovate, hastate, acute, toothedserrate, on winged petioles; the nppermost sessile; brikets filiform. - Low ground, West Florida, and northward. Sept. and Oct. - Stem $3^{\circ}-5^{\circ}$ high.

* * Rereptucle tubercular in the centre: scules of the inrolucre and flourers 5.

2. C. reniformis, Muhl. Stem angrled ; leaves not grlancous, angularly toothed, on slender petioles; the lowest large, reniform, the upper ones roundish; corymb (ompound. - 1)imp soil in the monntains of North Carolina and Tennessec. July and Aug. - Stem $4^{\circ}-9^{\circ}$ high. Radical leaves sometmes $2^{\circ}$ in diameter, the teeth mneronate.

3. C. atriplicifolia, L. Stem terete, corymbosely branched above; leaves glaucous bencath, ancularly loberl, the lobes mostly entire, mucronate; the lowest ones reniform; the upper rhomboid ; corymbs compomal. - Woods and moist banks, Florila, and northward. - Aug. and Sept. - Stem $4^{\circ}-8^{\circ}$ high. Leaves smaller and thicker than the last.

4. C. diversifolia, Torr. \& Gray. Stem angled; leaves not glaucons, petioled ; the lowest broadly cordate or eordate-ovate, obtnsely toothed, the npper 3-5-lobed. - Muldy banks of the Chipola River, Mariana, West Florida. May - Aug. - Stem $2^{\circ}-3^{\circ}$ high.

5. C. ovata, Walt. Stem terete; leaves glaueons beneath, 3-5-nerved, ovate or oral, obtuse, entire or wary-toothed ; the lowest long-petioled; the upper ones sessile; corymbs open. - Swamps, Georgia, Florida, and westward. July and Ang. - Stem $3^{\circ}-4^{\circ}$ high. Lowest leaves $5^{\prime}-8^{\prime}$ long.

6. C. tuberosa, Nint. Stem furrowed, angled; leares not glancous, oval or lanecolate-oblong, strongly 5 - 7-nerved, entire or slightly toothed ; the lowest long-petioled; corymlss dense. - Swamps, Georgia, Florida, and westward. Aug. and Sept. - Stem $3^{\circ}-5^{\circ}$ high. Leaves thick. 
7. C. lanzeolata, Nutt. Stem teretc; leares rather fleslyy, lanceolate or linear-lanccolate, entire, 3-nerved, somewlat glaucous; the lowest tapering into a long petiole, the upper sessile. - Brackish marshes, Georgia, Florila, and westward. Aug. and Sept. - Stem $3^{\circ}-5^{\circ}$ high. Lowest leaves $1^{\circ}$ or more long.

\section{SENECIO, L. Grovidsel. Butter-weed.}

Heads many-flowered; the flowers all tubnlar and perfect, or with pistillate rays. Scales of the involucre in a single row, often bracted. Receptacle naked or alveolate. Achenia not beaked nor winged. Pappus of copions soft hairs. - Herls, with entire or pimnately divided leares. Heads corymbose. Flowers yellow. Pubescence mostly webby and deciduous.

\section{* Anmul: heads radiate.}

1. S. lobatus, Pers. Smooth ; stem furrowed, hollow ; leaves tender, lyrate-pinnatifil, with rounded tootherl lobes; the earliest orbieular, long-petioled; rays about 12. - Low ground, Florida to North Carolina, and westward. March and A pril. - Stem $1^{\circ}-3^{\circ}$ high. Lobing of the leaves variable.

* * Peremial: heads radiate: lorrest lectes petioled, undivided; the others pinnately lobed or toothed; the uppermost sessile.

2. S. aureus, L. Smooth, or more or less woolly when young; stem $\left(2^{\circ}\right.$ high) slender; radical leaves long-petioled, round-cordate, crenate; the others lanceolate or oblong-lanceolate, pinnatifid; rays 8-12; achenia smooth. Moutains of North Carolina. July.

Var. fastigiatus. Stem stout $\left(2^{\circ}-3^{\circ}\right.$ ligh $)$, stoloniferous; petioles of the larger ( $2^{\prime}$ wide) leares, as also the involucre, densely woolly at the base. River-banks, Florida.

Var. Balsamitæ. Rarlical leaves spatulate-lanceolate or obovate ; lower part of the stem often densely woolly; achenia hairy. - Dry open woods in the upper districts. May and June, - A polymorphous species.

3. S. tomentosus, Michx. Woolly and hoary throughout; the leaves becoming smoothish; lowest leares oblong, crenate, obtutse; stem-leares few, scattered, lanceolate, acute, serrate or toothed ; rays $12-15$; achenia hairy. Damp soil, Florida to Nortl Carolina. April and May. - Stems mostly simple, $2^{\circ}-3^{\circ}$ high. IIeads rather large.

4. S. Elliottii, Torr. \& Gray. Smoothish; leares chicfly radical, thick, ohorate or roundish, erenate, on short winged petioles; those of the stem small, pinnatifid ; heads erowded; ratys 9-12; achenia smooth. (S. obovatus, E/l. in part.) - Rocky plares, West Florida to North Carolina. April and May. Stem $1^{\circ}$ high. Radical leaves $2^{\prime}-3^{\prime}$ wide.

$$
\text { * * * Perennial : heads radiute : leaves ull bipinnately dissceted. }
$$

5. S. Millefolium, Torr. \& Gray. Woolly when young, at lengtl nearly smooth; stems tufted, corymbose ahove; leares lanceolate, with the divisions linear and toothed, the lowest ones petioled; heads crowded; rays 9 - 12. Mountains of North Caroliua, Buckley. Jume. - Stenıs $1^{\circ}-2^{\circ}$ high. 


\section{RUGELIA, Shutt.}

Heads many-flowered, the flowers all tulualar and perfeet. Seales of the campamulate involnere lancelate, equal, in a single row. Recrptacle convex, naked. Corolla 5-cheft. Style lutbous at the base, the long lranches trmocated at the apex, and beset with rigid reflexcel hairs. Achenia terete, striate. P'appus of numerous rather righil rough bristly hairs. $-\Lambda$ peremial herl, with alternate unliviled leaves, and latre heads in a simple corymbose raceme.

1. R. nudicaulis, Slunttl. Minutely pubescent; rhizona creping; stem simple, erect ; leaves ovate, acute at each end, dentienlate; the lowest ones large $\left(2^{\prime}-t^{\prime}\right)$, erowded, on loug margined petioles, the others small, seattered, and nealy sessile; heads on long bracted peduncles. - Smoky Monntains, Tennes. see, lingel, Buckley. - Stem 10 high.

\section{ARNICA, I.}

Heads many-flowered, raliate; the rays pistillate. Serales of the eampanulate involnere lamecolate, equal, in ahont two rows. Reeptacle flat, hairy. Achenia terete, narrowed downward, somewhat ribbed. l'alpus a single row of rough lnistly hairs. - l'eremial herbs. Leaves opposite, undivided. Heads singrle or corymbose.

1. A. nudicaulis, Ell. Hirsnte; radieal leaves spreading, oval or obovate, obtuse, $3-5$-ribbed, serrate or entire; the others (2-3 pairs) distant, oblong, sessile; heads eorymbose, showy ; achenia smoothish. - Wet pine balrens, Florida, and northward. $A_{p}$ ril and May. - Stem $1^{\circ}-2^{\circ}$ high, simple, or with few opposite branches.

Tunze Y. CYNARE.E. Heads discoid; the flowers all tubulur ; the exterior ones sometimes enlarged and ray-like: style thickend at the summit; the stigmatic lines extending to the summit of the branches, without appenduges.

\section{CENTAUREA, L. Star-TustuE.}

Heads many-flowered; the marginal fiowers mostly large and sterile. Seales of the involncre imbricated. Receptacle bristly. Achenia compresed. Pappens of rough bristles in one or more rows, sometines wanting. - Herbs. Leaves alternate. Hearls solitary.

1. C. Calcitrapa, I. Stem diffusely branched, hairy; leaves pinnately lobed; the lubes linear, toothed; heads sessile; involucre spiny; pappus none. - North Carolinat. Naturalized-Flowers purple.

\section{CIRSIUM, Tourn. Tuistle.}

Heads many-flowered, discoid; the flowers all similar and perfect. Seales of the involucre imbrieated in many rows, all but the imnermost ones usually spinepointed. Reepticle hristly. Achenia obloner, compressed, smooth. Pappus of numerous plumose hairs. - Herbs, with alternate sessile or decurrent inostly pinnatifid and spiny leaves. Heads large, subglobose. Flowers purple or whiti-h. 


\section{* Leares decurrent.}

1. C. lanceolatum, Scop. Stem hairy, branched; leares pinnatificl, spiny, hirsute above, woolly heneath; scales of the involucre webby, tipped with strong creet spines; flowers purple. - Banks of the Savannah River at Angusta to North Carolina, and northward. Introduced. Sept. (2) - Stem $2^{\circ}-3^{\circ}$ high.

$$
\text { * * Leaves sessile. }
$$

- Scales of the involucre tipped with spreading spines.

2. C. discolor, Spreng. Stem tall, hirsute, the branches leafy to the summit; leaves deeply pinnatifid, smoothish, or with scattered hairs above, hoarytomentose beneath; the divisions $2-3$-lobed, pointed with a spine, and ciliate on the margins; scales of the involucre narrow, webby, tipped with a very slender spreading spine; flowers purple, - Margins of fields, \&c. in the npper districts. July-Sept. (2) -Stem $3^{\circ}-6^{\circ}$ high. Lower leaves $6^{\prime}-12^{\prime}$ long. Heads about $l^{\prime}$ in diameter.

3. C. altissimum, Spreng. Stem tall, pubescent; the branches leafy to the snmmit; leaves rongh-pubescent above, hoary-tomentose beneath, fringed with fine prickles; the lowest petioled, pinnatifid; the upper sessile, entire or pinnately lobed; heads bracted; scales of the involucre webhy when young, tipped with a weak prickle; flowers purple. - Fields and thickets, Mississippi to North Carolinat, and northward. Aug. and Sept. - Stem $3^{\circ}-10^{\circ}$ ligh. Heads abont $\mathrm{l}^{\prime}$ in diameter. Involucre somewhat viscid.

4. C. Nuttallii, DC. Stem angled, paniculately brancher, smooth or hairy ; the branches naked at the summit; leaves clasping, soft-hairy, becoming smoothish above, pinnatifid; the nunıerous spreading lobes lanecolate, 3-toothed, tipped with strong spines, and ciliate on the margins; heads numerons, small, bractless; scales of the involncre appressed, riscid, tipped with a short, at length spreading prickle; corolla white or pale purple. (Cnicus glaber, Ell.) - Dry light soil, Florida to Sonth Carolina. July and Aug. - Stem $3^{\circ}-8^{\circ}$ high. Heads $8^{\prime \prime}-10^{\prime \prime}$ in diameter.

5. C. Virginianum, Michx. Stem slender, simple or sparingly branchal, hoary-tomentose ; leares linear, or lincar-lanceolate, rigid, smooth ahove, hoary heneath; the margins revolute, toothed or pinnatifid, and spiny; seales of the involucre viscid, spiny; flowers purple. - Pine-barren swamps, Florida, and northward. Aug. and Sept. - Stem $2^{\circ}-3^{\circ}$ high. Heads $\frac{1}{2}^{\prime}$ in diameter.

+ + Scales of the involucre spineless, or the outer ones spine-pointed.

6. C. muticum, Michx. Stem tall, branching, commonly hairy; leaves with scattered hairs above, pubescent or at length nearly smooth bencath, bristlyciliate on the margins, decply pinnatifid; the lobes lanceolate, 2-3-toothed, spiny; seales of the involucre unarmed, webly, viscid; flowers purple.Swamps in the upper districts. Aug. and Sept. - Stem $3^{\circ}-8^{\circ}$ high. IIeads $\mathbf{I}^{\prime}$ in diameter.

7. C. Lecontei, Torr. \& Gray. Stem simple, or with 1-3 nearly naked branches, hoary-tomentose; leaves lanecolate, smootl above, hoary beneath, entire, the margins fringed with bristly hairs, and spiny; the earliest ones pin. 
natifil ; scales of the imoluere ençirlate, viscid, not wehlyy ; fowers purple. Pine-haren swanps, Florida, Georria, and westward. July and dugr. - Stem $2^{\circ}-3^{\circ}$ high, rirgil. Ileads $l^{\prime}$ in diameter.

8. C. repandum, Michx. Wehby throughont when young; stem simple, very leafy; leaves oblong-linear, clasping, the margius undulate and closely fringed with bristly spines; heals mostly solitary; flowers purju. - Iry pine barrens, Florida to North Carolina. June and July. - Stem $1^{\circ}-2^{\circ}$ high.

9. C. horridulum, Miclix. Webhy when young, at length smoothish; stem thick, loranching; leaves clasping, pinnatifil, armed with long and stout spines; heads large, surrounded by a whorl of linear pectinate spiny bracts; scales of the involucre linear-subulate, spine-pointerl flowers purpte or vellowish. - Samly soil, Florida, and northward. April and May. - Stem $1^{\circ}-3^{\circ}$ high, often purple.

\section{IuAPA, Tonr. Burdock.}

Heals inany-flowered, discoil ; the flowers all perfect and similar. Seales of the globose involucre imbricatch, coriaccous, with subulate spreading hooked tips. Receptacle flat, bristly. A chenia ollong, compressed, transversely rugose. Pappus of numerous short caducous bristles. Anthers caudate at the lase. Biennial branching herbs, with large cordate petioled leaves. Heads small. Flowers purple or white.

1. I. major, Gxrt. Leaves undulate on the inargins, pubesent beneath; the uppermost ovate; leads corymbose; involuere smooth or webby. - Waste places, North Carolina. Introdnced from Europe.

\section{Suborder II. LABITTILORR.}

TRInE VI. MUTISIACE.L. Meads with the flowers dissimilar or rarely dicxcious; the marginal ones pistillute or neutral, ligulate or bilabiate: style as in Tribe $\mathrm{V}$.

\section{CHAPTALIA, Vent.}

IIcads many-flowered, radiate. Ray-flowers pistillate, in two rows, the onter ones ligulate, the inner ones ligulate or 3-5-toothed and filiform. Disk-flowers perfect but sterile, bilabiate, the outer lip 3-cleft, the inner 2-cleft. Anthers candate. Seales of the eylindrical involucre lanceolate, acute, imbricated in few rows. Receptacle naked. Fertile achenia oblong, smooth, narrowed at each end. Pappus of numerous bristly hairs. - Stemless perennial herbs; the simple scape bearing a single head of white or purplish flowers. Leaves smooth above, white tomentose beneath.

1. C. tomentosa, Vent. - Low pine barrens, Florida to North Carolina. Fcb. $-\Delta$ pril. - Scape tomentose, $6^{\prime}-12^{\prime}$ high. Leaves spatulate-lanceolate or oblong. Heads nodding. 


\section{Suborder III. IIGULIFL,ORT.}

Trine VII. CICHORACEA. Style rylindrical above and pubescent, like the rather oltuse lranches; the stigmatic lines terminating below or near the middle of the lranches. - Plunts with milky juice: leaves alternaie.

\section{APOGON, Fil.}

Heads 10-20-flowered. Seales of the involncre mostly 8, somewhat in two rows, nearly as long as the corolla, connivent in fruit. Receptacle naked. Achenia ovoid-oblong, terete, ribbed and transversely striate, smooth. Pappns none. $-\Lambda$ low smooth and branching annual, with lanccolate entire or toothed leaves, and single or umbellate heads of yellow flowers, borne on slender peduncles.

1. A. humilis, Fill. - Florida to Sonth Carolina. April and May. Stem-leares elasping; the uppermost mostly opposite. - I'lant $6^{\prime}-12^{\prime}$ high.

\section{KRIGIA, Schreb.}

Heads 15-30-flowered. Scales of the involucre 6-15, somewhat in 2 rows, equal. Receptacle naked. Achenia top-shaped, 5-angled. Pappus double; the outer of 5 broad chaffy seales; the inner of 5 rough bristles. - Small annual herbs, branching at the base, with naked peduncle-like stems, each terminated by a small head of yellow flowers. Leaves chiefly radieal, mostly lyrate or toothed.

1. K. Virginica, Willd. Proper stem short, simple or forking; scapes at length several, slightly pubescent, elongated in fruit; leaves somewhat glancous; the lowest rounded, entire; the others spatulate-oblong, pinnatifir. (K. dichotoma, Nutt.) - Dry sandy soil, Florida, and northward. March - May. Seapes at length $1^{\circ}$ high.

2. K. Caroliniana, Nutt. Stem short; seapes pubeseent or somewhat hispid near the apex; leaves linear-lanceolate, acute at each end, entire or sparingly toothed, or the upper ones variously lobed. (K. leptophylla, $D C$.) - Dry sandy places, Florida to North Carolina. Feb. and March. - Scapes $3^{\prime}-12^{\prime}$ high.

\section{CYNTHIA, Don.}

Heads many-flowered. Seales of the involncre 12-15. Achenia slort, ohlong or top-shaped, obscurely 4 -angled, not beaked. Pappus double; the onter of numerous, very small chaffy scales; the inner of numicrous bristles. - Perennial nearly smooth herbs, bcaring single heads of yellow flowers on long more or less glandular peduncles or scapes. Leaves alternate, entire or pinnatifid.

1. C. Virginica, Don. Root fibrous ; stem branched above, bearing 35 heads on slender umbellate peduncles; radical leaves oval or spatulate-oblong, toothed or pinnatifid; the upper ones clasping and entire; achenia oblong. Sandy soil in the upper distriets. May - July. Stem $1^{\circ}-2^{\circ}$ high.

2. C. Dandelion, DC. Stemless or nearly so; roots hearing small tubers; scapes several, bearing single heals; lowest leaves spatulate-oblong; the 
others linear, clongraterl, entire or tontluesl ; achenia sonewhlat top-shaped. -

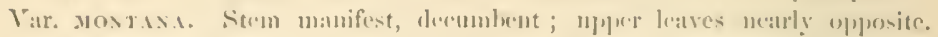

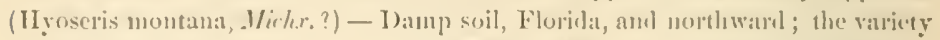
on the mountains of North Carolina. March - May - Scapes $f^{\prime}-12^{\prime}$ ligh.

\section{HIERACIUM, Tourn.}

Heads many-flowered. Seales of the involuce imbreated, or in 2 rows; the onter row short. Receptacle nearly naked. Achenia not leaked, commonly terete or spindle-shaped, ribhed. Pappus a single row of presistent lowmishwhite hairs. - Perennial herlos with altemate entire or tootherl leaves, and single, corymbose, or panicled heads of yellow fluwers. - Involuere, in our species, in 2 rows, the onter short and bract-like.

1. H. scabrum, Midix. Stem stont, leafy, hirsute below, rough alove; panicle somewhat corymhose; leaves oral, sessile; the lowest spatulate-oblongr, hirsute; peduncles and involuere tomentose and glandular-hispiri ; achenia "ylindrical. (II. Marianum, E:ll.) - Open woods in the uplur. distriets. Aug. and Sept. - Stem $1^{\circ}-3^{\circ}$ ligh. Heads large, many-flowered.

2. H. Gronovii, I. Stem leafy and hirsute below, naked and smootlier ahove; leares entire or denticulate, hirsute; the lowest sputulate-oblongr ; the upper smali, sessile; panicle narrow, clongaterl achenia narrowel upwarl. -Dry sandy soil, Florida, and northward. Sept. and Oct. - Stem $1^{\circ}-2^{\circ}$ higgh. Lowest leaves spreading on the ground.

3. H. venosum, L. Stem slender, nearly leafless, smootlı; lowest leaves oblong-obovate, smooth, or lirsute on the veins beneath, often veiued with purple; the others $(1-3)$ small and remote; heads small, in a spreading eorymhose panicle, smoothish; achenia linear. - Shady soil in the upper distriets. May - July - Stem $1^{\circ}-2^{\circ}$ high.

4. H. paniculatum, L. Stem slender, leafy, villous below; leaves thin. lanecolate, dentieulate, aeute, smooth ; panicle divaricate; heads small, 12-20. flowered; involucre smooth; achenia short, not narowed upwart. - Open wooks along the mountains, Georgia, and northward. Aug. and Sept. - Stem $2^{\circ}-3^{\circ}$ highh. Peduneles filiform.

\section{NABALUS, Cass.}

Hearls 5-20-flowered. Involuere cylindrical, eomposed of 5-14 linear seales, and several short exterior ones. Receptacle naked. Achenia lincar oblong or cylindrical, furrowed, glabrous, not narrowed upward. Pappus of numcrous straw-colored or brownish bristly hairs. - Perennial herls, with bitter tuberous roots, entire or variously lohed leaves, and nodding heads of yellowish white or purplish flowers, in short racemes or clusters.

1. N. albus, Hook. Smooth; stem paniculate, purplish; leaves acutish, angled, toothed, or variously 3 -5-lobed or parted; the lowest petioled; the uppermost nearly sessile; racemes short, spreading; involucre purplish, of about 
8 scales, 8-12-flowered; pappus light brown; flowers white or cream-color. Open woods in the upper districts of Georgia, and northward. Sept. - Stem $3^{\circ}-4^{\circ}$ high.

2. N. altissimus, Hook. Smooth; stem simple or sparingly branched above; leaves thin, ovate or cordate, petioled, acuminate, denticulate, or the lower ones palmately $3-5$-cleft or parted ; heads in small axillary and terminal clusters, forming a long panicle; involnere slender, greenish, of about 5 scales, 5-6-flowered; pappus dirty white or straw-colored. - Varies with the wavytoothed leaves, deltoil ; the lowest hastate-3-angled or parted. (Prenanthes deltoidea, Ell.) - Woods along the mountains, Georgia, and northward. Sept. - Stem $3^{\circ}-5^{\circ}$ high. Flowers yellowish, or greenish white.

3. N. Fraseri, DC. Smooth or slightly pubescent; stem corrmbosely panicled above; leaves deltoid, mucronate, pinuately 3-7-lobed, on winged petioles; the upper lancelate, often entire; clusters small, terminal; iurolnere greenish, smooth or hairy, of about 8 scales, 8-12-flowered; pappus strawcolor. - Varies with the lanceolate or oblong leaves mostly sessile, or the uppermost elasping; the 12-15-flowered involucre hirsute with long purplish hairs. (Prenanthes crepidinea, Ell.) - Dry sterile soil, Florida, and northward. Scpt. - Stem $1^{\circ}-4^{\circ}$ ligh.

4. N. virgatus, DC. Smooth; stem simple, virgate; leares lanceolate, acute, sessile or partly elasping; the uppermost small, entire; the lowest deeply pinnatifid, on margined petioles; elusters of heals small, racemose; involucre smooth, purplish, of ahout 8 scales, 8-12-flowered ; pappus straw-color. Damp soil, Florida, and northward. Sept. - Stem $2^{\circ}-4^{\circ}$ high. Flowers purplish.

5. N. crepidineus, DC. Smoothish; stem tall, corymbosely panicled; leaves oblong-ovate or somewhat hastate, acute, mequally toothed, the lowest on winged petioles; involucre brown, hairy, of 12-14 seales, 20-35-flowered ; pappus light brown. - Mountains of North Carolina and Tennessee. Sept.Stem $5^{\circ}-8^{\circ}$ high. Lower leaves $8^{\prime}-12^{\prime}$ long. Flowers yellowish-white.

\section{LYGODESMIA, Don.}

Heads 5-10-flowered. Involucre elongated, cylindrieal, of 5-8 linear scales, and a few short extcrior ones. Receptacle nakel. Achenia linear, elongated, smooth, striate, not narrowed upward. Pappus of copious smoothish white hairs in several rows. - Perennial smooth herbs, with linear or filiform leaves. Heads solitary. Flowers rose-color.

1. L. aphylla, DC. Stem simple or forking; lowest leaves filiform, elongated ; the others remote, small, and hract-like; heads showy. (Prenanthes aphylla, Nutt.) - Dry sandy pine barrens, Georgia and Florida. April and May. - Stem $10-2^{\circ}$ ligh.

\section{TARAXACUMI, IIaller. DANDElios.}

Heads many-flowered. Involucre double; the exterior of small sprearling scales; the interior erect in a single row. Reeptacle naked. Achenia oblong, 
ribbed or angled, muricate on the ribs; the apex abruptly producesl into a lon:heak. Jappus of copious white hairs. - Stemless peremnial luerhs. Sicapes hot low, hearing a single heal of yellow flowers. Latves all radical, oblong or lancerolate, entire or jiunatifil.

1. T. Dens-leonis, Desf. Leaves pinnatifid, the lobes arute, toothed; heads showy. - Jamp soil, sparingly naturalized.

\section{PYRRHOPAPPUS, DC.}

Heads many-fowered. Involucre doulle, of mumerous subulate seales; the imer ones erect and partially united, often with a callous appendage at the apex. lieceptacle flat, nakerl. Achenia oblong, nearly terete, 5-furrowed; the apex narrowed into a longr filiforn leak. I'appus of copious soft redelish or brownish latirs. - Simootl anmul lıerbs. Leaves ohlong or lanecolate, commonly toothed or pinnatifid. Heads solitary, terminating the naked stem or peduncle-like branches. Flowers yellow.

1. P. Carolinianus, DC. Stem brancling ; leaves lanecolate, mostly toothed or pinnatifirl achenia shorter than the filiform beak. (Borklansia, Eill.) - Fields, Florida to Mississippi, and northward. April-July. - Stem $1^{\circ}-2^{\circ}$ higrh.

\section{LACTUCA, I. LetTres.}

Ireads few- or many-flowered. Scales of the eylindrical involucre imbrieated ; the outer ones short. lieceptacle maked. Achenia eompressed parallel to the s(ales, smooth, alumptly narrowed into a filiform heak. Pappus of copions soft white hairs. - Tall herbs, with eutire or pimatifid leaves. Ileads paniculate. Flowers white, purple, blue, or yellow.

1. L. elongata, Muhl. Smooth or nearly so; stem tall $\left(4^{\circ}-8^{\circ}\right)$, simple or panienlate; leaves clongated, lameolate, sessile or partly clasping ; the upper ones mostly entire; the lower pinnatifid ; panicle long, leafless; flowers yellow. - Var. ixtrgrifolus. Leaves all undivided, or the lowest pinnatifid ; flowers yellow or purplish. - Var. GRaminifolia. Smaller $\left(2^{\circ}-3^{\circ}\right)$, leaves linear or linear-lanceolate, rather rigid, all entire, or the lowest ones sparingly toothed or pinnatifid; flowers purple. - Dry soil, Florida, and northward. July-Sept.

\section{MULGEDIUM, Cass.}

Heads many-flowered. Seales of the involuere imbricated, the outer ones short. Receptacle naked. Achenia smooth, laterally compresserd, narrowed into a short beak, which is expanded into a ciliate disk at the ajex. Pappus of eojious white or tawny hairs. - Tall herbs. Leaves pinnatifid or undivided. Flowers mostly blue.

\section{* Pappus white.}

1. M. aeuminatum, DC. Smootlı; stem panieled ahove; leaves orate or orate-lancelate, neuminate, toothed, on winged petioles, the lowest sometimes sinuate-lobed; heads racemed, on spreading peduncles. (Sonchus, Ell) 
- Margins of fields, \&c., Florida, and northward. Sept. (2) - Stem $3^{\circ}-6^{\circ}$ high. Leaves $3^{\prime}-6^{\prime}$ long, often hairy beneath. Flowers blue.

2. M. Floridanum, DC. Smooth; stem panicled ahove; leaves all pinnatifil and toothed, with the terminal lobe larger and 3-angled, or the uppermost lanceolate, sessile or clasping; lıcads racemose-panicled; flowers blue. Rich soil, Florida to Norch Carolina. Aug. and Sept. - Stem $3^{\circ}-6^{\circ}$ high.

\section{* Pappus tawny.}

3. M. leucophæum, DC. Smoothish; stem panicled above; leaves numerous, irregularly pinnatifid, with coarsely-toothed lobes; the terminal lobe 3-angled, or in the upper leaves often linear and entire; racemes panieled. Mountains of North Carolina. Sept. (2) - Stem $3^{\circ}-12^{\circ}$ high. Leaves $6^{\prime}-$ $12^{\prime}$ long. Flowers pale blue.

\section{SONCHUS, L.}

Heads many-flowered. Seales of the involucre imbricated. Receptacle naked. Achenia compressed, ribbed, not leaked nor narrowed at the apex. Pappts of copious soft white hairs. - Annuals. Leaves entire or pinnatifid. Heads somewhat umbelled. Flowers yellow.

1. S. oleraceus, I. Smooth ; stem branching; leaves pinnatifid, with spiny-toothed lobes, clasping; the lowest petioled; achenia transversely roughened. - Waste places. Introduced. June-Ang. - Stem $1^{\circ}-2^{\circ}$ highl.

2. S. asper, Vill. Smooth, or the upper part of the stem and peduncles hispid; leaves entire, clasping, fringed with weak spines; the lowest oblongobovate, the upper lanceolate; achenia smooth. - Fields, Florida, and northward. June - Aug. - Stem $2^{\circ}-3^{\circ}$ high.

\section{Order 73. TOBETIACEA. (Lobelia Famlly.)}

Chiefly herbs, with milky juice. Leaves alternate, without stipules. Flowers irregular, - Calyx 5-lobed, the tube adherent to the 2-celled ovary. Corolla unequally 5-lobed, valvate in the bud; the tube split on one side to the base. Stamens 5 , inserted on the calyx; the anthers, and commonly the filaments, united into a tube. Style solitary: stigma 2lobed, surrounded with a ring of hairs. Fruit baeeate and indehiscent, or capsular and 2-3-valved, many-seeded. Seeds anatropous. Embryo straight in fleshy albumen. - Acrid poisonous plants.

\section{LOBELIA, I. Lobela.}

Corolla bilahiate; the upper lip small, erect or reflexed, 2-patted, the lower spreading, palmately 3-cleft; the tube straight. Anthers, or at part of them, bearded at the apex, curved. Capsule 2-celled, 2-valved at the apex, manyseeded. - Stems erect. Lcaves umdiviled; the serratures glandular Flowers blue, white, or scarlet, in terminal racemes or spikes. 


\section{* Finurers scarlet.}

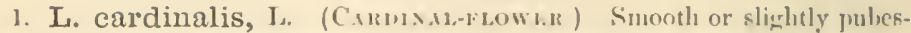
cent; stem stout, simple; laves lauceolate, denticulate; loracts leafy; ftumens

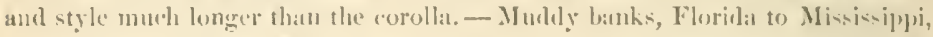
anel nortlawarl. July-Scjet. 4-Stem $2^{\circ}-3^{\circ}$ hiph. liaceme many-flowered. Flowers very showy.

$$
\text { * * Houcers blue and ullite. }
$$

+ Sinuses of the calyx with deflexed appenduges.

2. L. syphilitica, I. Ilairy ; leaves thin, laureolate, arute at cach end, ('oarsely serrate; Jaeemes leafy, many-floweert; calyx lairy; the lanceolate denticulate lobes half as long as the large (1'long) light hlue corolla.-Swamps along the mountains, Gcorgia, and northward. Aug. and Sept. 4-Stem $1^{\circ}-$ $3^{\circ}$ high.

3. L. puberula, Michx. Softly pubescent or villous, or sometimes neurly smooth; leaves thickish, mostly ohtnse, lanceolate or olyong, glandular-denticnlate; spikes mostly 1-sided; calyx top-shaped, the linear lobes nearly as long as the tube of the bright blue eorolla. - Swamps and low ground, Florida to Mississipli, and northward. Ang. and Sept. $\downarrow$-Stem $1^{\circ}-2^{\circ}$ high. Corollat half as large as in the preceling. Appendages of the calyx oltuse.

4. L. leptostachys, A. DC. Closely puhesent; stem slender, simple; leaves oblong-lanceulate, obtuse, denticulate; flowers small, crowderl in an elongrated spike; appendages of the calyx 10, subulate, as Jong as the tube. - South Carolina aud northward. July and Ang. 4-Stem $1^{\circ}-1 \frac{1}{2}{ }^{\circ}$ high. Corolla $3^{\prime \prime}-4^{\prime \prime}$ Jonin.

5. L. brevifolia, Nutt. Stem thick, virgate, angled, smooth or pubescent; leaves short ( $4^{\prime \prime}-12^{\prime \prime}$ longr), fleshy, ol,long-linear, obtuse, touthed, sprealing or reflexerl; the lowest werlge-shaped; ealyx hirsute, the ovate-lanceolate lobes strongly toothed, the 5 appendiges obtuse; corolla pale blue. - Damp open pine barrens, Florida, Alabama, and westwarl. Oct. 4-Stem $1^{\circ}-1 \frac{1}{2} \circ$ high. Leaves very numerous.

\section{+ + Simuses of the crly $x$ without appendagrs.}

6. L. amœna, Michx. Smooth or rough-pubeseent; leaves scattered, oblong, obtuse, denticulate, the lower ones tapering into a long petiole, the uppermost nearly sessile; racemes 1-sided, many-flowered; ealyx-lobes linearsubulate, mostly glandular; corolla (1'long) bright blue. - Swamps, Florida to South Carolina, and westward. Sept. and Oct. 4 - Stem $2^{\circ}-4^{\circ}$ high. Lowcst leaves $3^{\prime}-6^{\prime}$ long. Bracts small.

7. L. glandulosa, Walt. Smootl or pubescent; stem mostly simple, nearly leatfess above; leaves thick, linear or linear-lanceolate, glandular-denticulate, sessile, the uppermost scattered and loract-like; racemes 1-sided, 3-9flowered, the flowers distant; calyx smooth or hirsute, with linear glandular lobes, corolla $\left(8^{\prime \prime}-10^{\prime \prime}\right.$ long) pale blue. - Pinc-baren swamps, Florida, North Carolina, and westward. Oct. 4-Stem $2^{\circ}-4^{\circ}$ long. Lower leares $2^{\prime}-4^{\prime}$ long.

8. L. inflata, L. Pubescent or hairy; stem leafy, hranching from the base; leaves oblong, ohtuse, toothed, sessile; racemes leafy below ; corolla small, 
pale blue ; mature capsule ovoid, inflated. - Dry sterile soil in the upper districts, and northward. Aug. and Sept. (1) or (2) - Stem $1^{\circ}-1 \frac{1}{2}^{\circ}$ high. Corolla $2^{\prime \prime}-$ $3^{\prime \prime}$ long.

9. L. spicata, Lam. Closely pubeseent; stem slentler, simple; lowest leaves obovate or oblong, obtuse, denticulate; the upper ones small, lanceolate, seattered; flowers small, in a long and dense raceme, on short pedieels; corolla pale blue. (L. Claytoniana, Michx.) - Dry soil in the middle and upper districts, Mississippi, and northward. Aug. and Sept. (2)? - Stem $1^{\circ}-2^{\circ}$ high. Corolla $4^{\prime \prime}-5^{\prime \prime}$ long.

10. L. Nuttallii, R. \& S. Stem very slender, mostly simple, roughish; leaves small, entire; the lowest elustered, spatulate or obovate; the others distant, linear; flowers small, scattered in a long and slender ruceme, on filiform perlicels which are longer than the bracts. (L. Kalmii, Ell.) - Low pine barrens, Georgia, and northward. Ang, and Sept. - Stem $1^{\circ}-1 \frac{1}{2}^{\circ}$ high. Corolla $3^{\prime \prime}-4^{\prime \prime}$ long, pale blue.

11. L. Boykinii, Torr. \& Gray. Smooth; stem slender, ereeping at the base, sparingly branched above; leaves small ( $6^{\prime \prime}$ long), subulate, seattered, the lowest seale-like; racemes loosely many-flowered, the filiform pedicels and slender ealyx-lobes spreading; corolla $\left(3^{\prime \prime}-5^{\prime \prime}\right.$ long $)$ bright blue. - Margins of pinebarren ponds, Florida and Georgia. July - Sept. - Stem $2^{\circ}$ high.

12. L. paludosa, Nutt. Smooth; stem mostly simple, nearly leafless; ralical leaves fleshy, spatulate-lanceolate or linear, oltuse, erenulate; the others small, linear and remote; racemes slender, loose; braets minute; corolla small, white or pale blue. - Pine-barren swamps, Florida to Mississippi, and northward. May-Aug. 4-Stem $2^{\circ}-4^{\circ}$ high. Lowest leaves $3^{\prime}-9^{\prime}$ long. Corolki $\frac{1}{2}{ }^{\prime}$ long.

\section{Order 74. GOODENICEA. (Goodenta Famu.)}

Herbs or shrubs, with watery juice, alternate exstipulate leaves, and irregular flowers. - Calyx tubular, 3-5-lobed or entire, more or less adherent to the 1-4-celled ovary. Corolla irregular, unerpually 5-lobed, induplicate in the bud; the tube split on one side, or 5-parted. Stamens 5 , free from the corolla, the filaments and anthers rarely united. Style commonly single: stigma thick, surronnded with a cup-shaped mostly ciliate membrane. Fruit capsular or drupaceous. Embryo straight, in the axis of tleshy albumen.

\section{SC开VOLA, L.}

Calyx 5-toothed. Corolla villous within, 5-lobed, with the lobes nearly equal and winged; the tube split on one side. Filaments and anthers free. Drupe 1-4-eelled, the cells l-seeded. - Ilerbs or shrubs. Leares alternate. Peduncles axillary, dichotomons. Nlowers blue or white. 
1. S. Plumicri, Vahl. Shrubly, fleshy, smooth; leaves obloneroborate, entire, beareled in the axils; peeluneles shorter than the leaves; (alyx tubular,

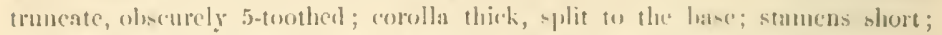
ovary 4 oruled ; drupe 2-celled, 2-secded. - Se:i-sliore, South Florila.

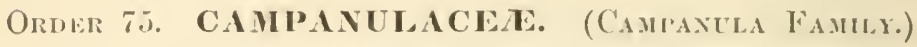

IIcrbs, with milky juice, alternate leaves, and rerrular mostly blue flowers. - Calyx 3-5-lobed, adherent to the ovary. ('orolla 5-luberl, valvate in the bud. Stamens 5, free from the corolla, the loroal filat ments and anthers distinct. Style single, hairy abore. Stigmas 2 or mose. Capsule 2-sereral-eclled, many-seeded, splitting at the ajex, or opening by lateral valves or lobles. Embryo straight in fleshy albumen.

\section{CAMPANULA, I. Bellflowir.}

Calyx 5-lobed. Corolla 5.lobed, mostly bell-shaped. Filaments dilated at the base. Stigmas 3, slemeler Cilpsule short, 3-celled, openiug by lateral valres, - Flowers spiked or pamieled.

* Flowers pumcled, on slender spreading pedicels: corolle small (3"-4"), bell-shaped.

1. C. aparinoides, I'ursh. Stem weak, reclining, the angles, as also the margins and midrib of the linear nearly entire leaves, hispid backward; panicle few-flowered; (alyx-lobes triangular; corolla white. (C. erinoiles, Muhl.) Swamps anoug the mountains, Georgia, and northward. July and August. Stem $1^{\circ}-1 \frac{10}{2}$ high. Lowest leaves narrowly obovate.

2. C. divaricata, Michx. Smooth; stem terete, pauiculate above; the branches somewhat naked, spreading; leaves stattered, ovate-lanceolate, acuminate at cach end, coarsely serrate; calyx-lobes subulate; style slightly exserted ; corolla blue, nodding. - Monutains of Georgia and Carolina. July and August. - Stem $1^{\circ}-2^{\circ}$ high.

3. C. flexuosa, Michx. Branches ereet; leaves lanceolate, the upper ones approximate; otherwise like the preceding. - Momntains of Carolina. Michaux. (*)

* *lowers spiked, single or 2-3 togrther: corolla large, somewhat whcel-shaped.

4. C. Americana, L. Stem tall, smooth or hairy, mostly simple; leaves ovate-lanceolate, acuminate, serrate; spike elongated, leafy; corolla (1' wille) blue. (C. acuminata, Mich.x.) - Dry rocky soil, Florida to Misissippi, and northward. Aug. and Sept. - Stemn $2^{\circ}-4^{\circ}$ high. Spike $1^{\circ}-2^{\circ}$ loug. Style exserted.

\section{SPECULARIA, Heist.}

Calyx 3-5-lobed. Corolla wheel-shaped, 5-lobed. Stamens free; the filaments inemlranaceous, hairy, shorter than the anthers. Stigmas 3. Capsule prismatic, 3-celled, opening by 3 lateral valves. - Low annuals. Flowers axillary. Corolla blue. 
1. S. perfoliata, A DC. Pubescent; stem angled, simple or branched; leaves round-corlate, erenate, clasping ; the lowest narrowed at the base ; flowers single or elustered, sessile, the lower ones apetalous. (Campanula, L.) - Fields, Florida to Mississippi, and northward. May - Aug. - Stem $1^{\circ}$ high.

\section{Order 76. ericaces. (ILeath Famly.)}

Shrubs or small trees, rarely herbs, with undivided alternate exstipulate leaves, and regular flowers. - Calyx 4-5-parted. Corolla 4-5-parted or toothed, or 4-5-petalous, imbrieated in the bud. Stameris free from the corolla, and as many or twice as many as its divisions: anthers 2-celled, often varionsly awnerl, opening commonly by terminal pores. Style 1: stigma entire or 3-lobed. Fruit 3-10-celled. Seeds anatropons, attached to a eentral placenta. Embryo small, in fleslyy albumen.

\section{Syllopsis.}

Suborder I. VACCINIEE. Calyx-tube adherent to the ovary. Corolla superior. Anther-eells prolonged into a slender tube. Fruit a berry. - Shrubs. Corolla monopetaluns.

1. GA Y LUSSACIA. Berry 8-10-eelled; the cells 1-seeded. Anthers awnless.

2. VACCiNicy. Berry 4-5-celled, or partially 8-10-celled by false partitions, manyseeded.

Strorder II. ERICINEA. Calyx free from the ovary. Corolla hypogynous. Fruit a eapsnle. - Shrubs or small trees.

Tribe I. ANDROMEDEA. - Capsule loculieidally dehiscent.

* Anther-cells opening lengthwise. Corolla monopetalous.

3. EPIGEA. Corolla salver-shaped. Leares cordate.

* * Anther-cells opening at the apex. Corolla monopetalous

4. GAULtieria. Caly $x$ beeming berry-like in fruit. Authers 4 -awned at the apex.

5. LEUCOTHOE. Caly $x$ iubricated in the bud. Valves of the capsule entire.

6. CASSANDRA. Calyx imbricated in the bud. Pericarp separating into two layers; the outer oue 5-valrei, the inner 10 -ralved.

7. ANDROMEDA. Calyx valvate in the early bud. Capsule globular. Seeds pendulous.

8. OXYDEXuruI Caly $x$ valvate in the bud. Capsule pyramidal. Seeds ascending.

* * Anthers inverted in the bud, opening by terminal pores. Corolla 5-jetalous.

9. CLETIRA Stamens I0. Style 3-cleft. Capsule 3-celled,3-ralred.

TRIBE II. RIODORER. - Capsule septieidally dehiseent.

* Corolla monopetalous.

10. KALIIA. Corolla wheel-shaped, with 10 eavities in which the anthers are lodged.

11. MENZIEsiA. Corolla (small) oroid, 4 toothed Stamens 8 , ineluded.

12. RliododexDroy. Corolla (large) funnel or bell-shiped, 5-lobed. Stamens 5 or 10, exserted.

* Corolla of 5 or 7 separate petals.

13. LEIOPIY LLUM. Corolla 5 petalous. Anthers opening lengthwise.

14. BEJARIA. Corolla $T$-petalous. Anthers opening at the apex. 


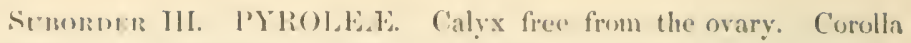

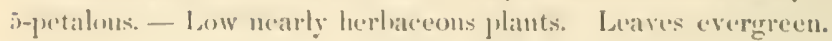

- Capsule 5-celled.

15. JYROLA. Flowers racemose, on scape-like stems. Style filiform, elongated.

16. CIIIIIIIIIA. Flowers umbellate. Style very short, top-bhaped.

* Capsule 3 -criled.

17. SlloRTis. Flower solitary, terminatiug the scape-like seuly steu.

Suborints IV. MONOTROPlis. Calyx of $+1-5$ seale-like or bratctlike sepals. Corolla j-boberl or j-petalons. Siceds very minute. - Fleshy scaly lectss, parasitic on roots, and destitute of green foliage.

18. SCIIEINITZIA Corolla monopetalous, bell-shaped, 5-lobed. Anthers 2-celled. 19. MOsOTroP.1. Corolla $4-5$-petalous. Authers liduey-shaped, opening across the top.

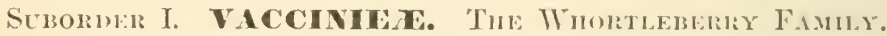

\section{GAYLUSSACIA, himth. II" кLEmerir.}

Corolla tubular, ovoid, or bell-shaped, j-cleft. Stamens 10 : anthers awnless. Fruit a berry-like drupe containing 10 seed-like nutlets. - Low hranching mostly resinous-dotted shrubs, with white or reddish nodding flowers, in lateral bracted racemes.

1. G. frondosa, Torr. \& Gray. Leares entire, ollong or obovate, obtuse, rugose, glausous, and, like the spreading branches, slightly pulsescent; corolla small (2"), slost-bell-shaped, reddish; berry depressed-globose, bluc, grlancons; bracts small, ollong. (Vaccinium frondosum, lill.) - Low ground, Florida to Mis:sisipli, and northward. April. - Slurub $1^{\circ}-2^{\circ}$ high.

2. G. dumosa, Torr. \& Giray. I3ranches and racemes pubsecent; leaves thick, oblome-obovite, scrmlate, mucronate, soon smooth and shining; corolla (t"long) bell-shapred, angled, white; bracts orate, leafy ; berry globose, smooth, back. (Vacciniun dumosum, Ell.) - Vatr. mutrul.1. Stem taller $\left(1^{\circ}-2^{\circ}\right.$ high) ; brancles, leaves, and herries hirsute or hairy. - Low sandy pine barrens and swampe, Florilla to Mississippi, and northward. April and May.- Shrub $6^{\prime}-12^{\prime}$ high. Berry $4^{\prime \prime}-6^{\prime \prime}$ in diameter.

3. G. resinosa, Torr. \& Giray. Stem much brameherl leaves oblong or oborate, entire, roated, like the hranchlets, \&e., with resinons viscid globules; raremes few-fowered; lnacts small, deciluons; corolla small, ovoid or cylindrical, reddish; berry blatek, smooth. (Vaceinium resinosum, Ell.) - Sandy woods in the upper distriets of Georgia, and northward. April and May. - Shrub $2^{\circ}-3^{\circ}$ high.

4. G. ursina, Gray. Leaves large $\left(2^{\prime}-3^{\prime} \operatorname{lon} g\right)$, thin, lanceolatc-oblong, acute, emire; the reins, like the branches, rusty-tomentose; raecmes remotely few-flowered; luacts minute; corolli bell-shaped; herry black. (V'accinium ursinum, .1. A. Curtis.) - Mountains of North Carolina. - Shrub $2^{\circ}-3^{\circ}$ high. 


\section{VACCINIUM, L. Hickleberry. Blekberry.}

Corolla cylindrical, ureeolate, or eampanulate, 4-5-toothed or parted. Stamens 8-10: anthers awuless, or 2-awned on the back; the cells prolonged into a tube, and opening at the apex. Berry $4-5$-eelled, or by false partitions $8-10$ celled, many-seeded. - Shrubs. Flowers nodding, solitary, clustered, or racemed, white or reddish. Pedicels 2-bracted.

\$1. Oxrcoccus. - Ovary 4-celled: corolla 4-parted, the narrow divisions recurced: stamens 8: anthers aunless: pedicels axillury, solitury.

1. V. macrocarpon, Ait. Stems slender, ereeping; leaves evergreen, small ( $\frac{1^{\prime}}{2}$ long), oblong, obtuse, pale or whitish beneath, perlicels longer than the leaves; corolla rose-eolor ; berry large, red. - Cold nossy swamps, North Carolina, and northward. July. - Stems $1^{\circ}-2^{\circ}$ long. Berry very sour, $\frac{1}{2}^{\prime}$ in diameter.

2 V. erythrocarpon, Mirhx. Stem crect $\left(2^{\circ}-4^{\circ}\right.$ high) $)$ leaves deciruous, oblong-ovate, aemminate, serrulate, hairy beneath; pedicels shorter than the leaves; flowers pale rose-color; berry small, red.-High mountains of North Carolina. July. - Branches flexuous. Berry insipid.

\$2. Vitrs-IDAs. - Orary 4-5-celled: corolla eylindrical or globose-campanulate, 4-5-tootherl: stamens 10: anthers awnless: flowers in short bracted racemes: leaves persistent.

3. V. crassifolium, Andr. Smooth; stems $\left(1^{\circ}-2^{\circ}\right)$ filiform, proeumbent; leaves small $\left(3^{\prime \prime}-7^{\prime \prime}\right)$, short-petioled, oval or obung, thick and shining, the revolute margins entire or slightly serrulate: racentes short, cluster-like, fewflowered ; corolla small, globose-eampanulate, 5 -tomherl; berry black. (V. myrtifolium, Michx.) - Sandy pine-barren swamps, Georgia to North Carolina. April. - Corolla white or rose-color.

\$3. Batonendoon. - Orary more or less 10-celled by false partitions: corolla bell-shaped, 5-cleft: stamens 10, hairy: anthers 2-auned on the back: fiowers in leafy racemes, seemmgly axillary.

4. V. stamineum, I. Tomentose; leaves deciduous, orate or oblong, obtuse or shoghtly cordate at the base; often whitish beneath; anthers exserted; berry greenish, glohose or pear-shaped. - J)ry woods, Florida, and northward. May and June. - Shrub $3^{\circ}-10^{\circ}$ high. Branches spreading. Corolla short, drying purplish.

5. V. arboleum, Michx. Arborescent, smoothish; leaves deeiduous, oval or obovate, shining above; the veins beneath more or less pubescent ; corolla large, angled, white; anthers inchuled; berry globose, black. - Open woods, Florida to North Carolina. May. - Stem $8^{\circ}-15^{\circ}$ high. Flowers very numerous. Berry mealy, ripening in the winter.

\$4. Craxococius. - Ovary more or less 10-celled by false partitions: corolla cylindrical, urceolate or obovate: stamens 10, hairy: unthers awntess: flowcrs in short small-bracted racemes or clusters.

* Leanes evergreen, smull.

6. V. nitidum, Andr:? Smooth and shining thronghout; stem much branched; leaves obovate or oblong-obovate, acute, glandular-seriulate, punctate 
beneatl, ealyx-tecth obtuse, and, like the pedicels and broally oral bracts, reddish; corollat ovoid or obwate, white; berry somewhat peatr-shaped, black, Low pine larrens, Georgia and Flurida. March and $\Lambda_{\text {pril. }}-\mathrm{Stem} 1^{\circ}-20$ high. Leaves $\frac{1}{2}$ longer.

¡. V. myrsinites, Michx. Stem much brancher, puleserent; leaves lanccolate, oblong, or ohovate, bristly-serrulate, shining nbove, paler heneath, glancons when young; calyx-tecth ache, redeli-h, like the perlicels and oblung lonets; corolla cylindrical or ohovate, white, purplish in the but ; berry globose, blue. - Sandy pine barrens, Florida to North Carolina, and westward. March and $\Lambda_{\text {pril. }}$ - Slarub $6^{\prime}-18^{\prime}$ light. Leaves $\frac{1^{\prime}}{2}-1^{\prime}$ long.

\section{* Ierues decidnous.}

8. V. tenellum, Ait. Stem much brincled; the spreating greenish lramches jubescent; leaves oblong-obovate or oblancelate, mucronate, ante at the hase, slightly serrulate near the apex, pulleseent when young ; corolla oblong, white; calyx-tecth obtuse; bracts oblong-linear; berry globose, black or with a blue bloom. - Varies with the branches and lenves more pubescent, almost villons, and the calyx-tecth narrower ant acute. (V. galezans, $\left.1 / 1 / h x_{0}\right)$ - Margins of pinc-barren swamps, Florila to North Carolina, and westwarl. April. Shrub $1^{\circ}-3^{\circ}$ high. Leaves $\frac{1}{2}^{\prime}-I^{\prime}$ long, commonly thin and deciluous, but along its sonthern limits mostly coriaceous and persistent.

9. V. Elliottii. Stem tall, slender, with spreading branches; leaves distichous, orate-lanceolate, very acute, bristly serrulate from the obtuse or rounded base, pulpescent on the veins; elusters sessile, 2-4-flowered; corolla reddish, cylindrical, short-pedieclled; calyx-tecth triangular; leery mostly solitary, small, glohose, llack. (V. myrtilloides, Ell, not of Mfickx.) - Ihiver-swamps, Florila to Sonth Carolina. Mirch. - Shrnb $4^{\circ}-8^{\circ}$ high; the branches smooth and mostly flexuous. Leares $\frac{11}{2}-3 /$ long.

10. V. corymbosum, L. Stem tall $\left(4^{\circ}-10^{\circ}\right)$; leaves varying from ovate-lanecolate to broadly oval, entire or nearly so, pubeseent when young, be'oming smoothish especially ahove $\left(1^{\prime}-2^{\prime}\right.$ loner $)$; racemes or "Insters numerons, mostly on leafless branches; corollit cylindrical or oblong; berry globose, black or blue. - Margins of pouts and swanıs, Flerida, and northward. Feb. to April. - Varies greatly in the thickness, pubeseence, and form of the leaves, and includes several nominal species.

11. V. Constablæi, Gray. Stem low $\left(1^{\circ}-3^{\circ}\right)$; leaves oval, pale, glaucous, glandular-mncronate, entire or obscurely serrulate, ciliate; racenes very slort, sesvile; rorolla short-cylindrieal; berry blue. - On the summit of Roan Mountain, Nortl Carolina, July. - Leaves $1 \frac{11}{2}-2^{\prime}$ long. Racemes 5-10flowered.

12. V. hirsutum, Buckley. Hirsute throughout; stem low $\left(1^{\circ} \mathrm{high}\right.$, much branched ; leaves ovate, entire, slightly inucronate, racemes short, corolla oblong, contracted at the apex, the teeth short; berry globose. - Monntains of Cherokee County, North Carolina. Buckley. 


\section{Suborder II. ERICINEAE. The Heati Family.}

\section{EPIG止A, L. Grouxd Laurel.}

Calyx deeply 5-parted, colored ; the lobes acuminate. Corolla salver-shaped, 5-eleft. Staneus 10: anthers oblong, awnless, opening lengthwise. Capsule depressed-glohose, 5-celled, many-seeded. - A prostrate slırubhy plant, lispid with rust-colored hairs. Leaves evergreen, cordate-oval, entire, reticulated. Flowers in dense bracted racenes, white, fragrant.

1. E. repens, L. Dry santly soil, Florilla, and northward. Feb. and March. - Stem 6' $-12^{\prime}$ loug. Racemes shorter than the leaves.

\section{GaULtheria, Kalin. Wintergieen.}

Calyx 5-lobed, becoming berry-like in fruit. Corolla ovate, 5-toothed. Stamens 10: anther-cells 2-awned at the apex, opening by a terminal pore. Capsule enclosed in the berry-like calyx, depressed-globose, 5-celledl, 5-valved, many-seeded. - Shrubs, with alternate leaves, and white or red flowers.

1. G. procumbens, L. Smooth; stem creeping; the short $\left(3^{\prime}-5^{\prime}\right)$ branches erect, naked below; leaves oval or obovate, serrulate, shining; pedicels axillary, l-flowered, nodding; fruiting calyx bright red. Shady woods and banks, especially among the mountains, North Carolina and northward. June. - Whole plant aromatic.

\section{LEUCOTHÖ̈, Don.}

Calyx deeply 5-parted, imbricated in the bud, unchanged in fruit. Corolla ovate or cylindrical, 5-toothed. Stamens 10: anthers awnless, or the cells 1-2-awned at the apex, opening by a terminal pore. Stigma capitate. Capsule depressed-globose, not thickened at the sutures, 5-celled, 5-valved, many-seeded. Seeds pendulous. - Shrubs, with alternate leaves, and white flowers in axillary or terminal one-sided racemes.

* Anthers awnless or nearly so: racemes axillary, shorter than the evergreen leaves.

1. L. axillaris, Don. Leares oval or oblong, abruptly acnte, spinuloseserrulate toward the apex, on short petioles; racemes short, dense-flowered; calyx-lobes ovate, acute; anther-cells 2-horned. (Andromeda axillaris, Lam.) - Sandy swamps, and banks of streams in the lower districts, Florida to Nortl Carolina, and westward. Feb. and March. - Stem and branches curving. Leaves $2^{\prime}-4^{\prime}$ long.

2. L. Catesbæi, Gray. Leaves orate-lanceolate, aenminate, spinuloseserrulats thronghout, on conspicuons petioles; racemes dense-flowered; calyxlobes ovate-oblong; anther-cells not horued. (Andromeda spinulosa, Pursh.) Banks of streams along the mountains, Georgia and North Carolina. March and April. - Stem $2^{\circ}-4^{\circ}$ high.

3. L. acuminata, Dnnal. Sten tall, with straight and hollow branches; leaves orate-lanceolate, acuminate, nearly cntire; corolla cylindrical; anthers 
gribluns near the bake. - Margins of swanpu, East Floridat to South Carolina, l:lliot, and mommans of North Catrolina, Curtis. A pril. - Shrub $3^{\circ}-120$ highl. Lemess reticulated.

\section{* Anther-cells 1-2-aund at the aper: rasmes terminal, lonysr than the serrulate julvescent deciduous lates: calyx brartul.}

4. L. racemosa, fray, Jranches and racemes straight; leaves oratelancerlate, acute, soon smooth; racemes long, single or somewhat paniculate; corolla cylindrical-ovate; antherecells 2-awned; eapsule not lobed (A. racemosa, $\left.L_{.}\right)$- Margins of ponds and swamps, Florida to Mississippi, aml northward. $\Lambda$ pril and May: - Shrub $4^{\circ}-10^{\circ}$ high.

5. L. recurva, Gray. Branches and racemes recurved; leaves ovate, acuminate, pulescent on the veins; raeemes long, single; corolla cylindrical; anther-eells 1-awned; capsule 5-lobed. (Andromeda recurva, Buckl.) - Mountains of North Carolina, Lucktey. $\quad$ p pril. - Shrub $3^{\circ}-4^{\circ}$ high.

\section{CASSANDRA, Don.}

Calyx deeply 5-parted, imbrieated in the but, 2-bmeted. Corolla cylindrical(ollong, 5-toothed. Stamens 10 : antlers awnless, opening by terminal pores. Capsule depresied, 5-cellew, many-seeded; the pericarp separating at maturity into 2 lavers, the onter one 5-valved, the inner 10-ralved. $-\Lambda$ small slomb, with evergreen serrulate leaves, and solitary axillary nodeling flowers.

1. C. calyculata, Ion. Leaves oblong, mucronate, paler and scurfy heneath, the floral ones oval; flowers in the axils of the upper leaves, small, white; (alyx-loles ovate, arute. (Andromeda calyculata, $L$.) - Varies with the leaves and calyx-lobes narrower. (Andromeda angustifolia, Pursh.) - Swamps in the momtains of South Carolinit, and northward. April - Slirub $2^{\circ}-3^{\circ}$ high. Leaves l' long.

\section{ANDROMEDA, L.}

Calyx deeply 5-parted, valvate in the early bud. Comlla 5-toothed. Stamens 10: anther-eclls opening by a terminal pore. Capsule 5-celled, 5-ralved, manyseeded. Seerls pendulous or sprealing. — Shlubls. Leaves altemate. Flowers in lateral and terminal raeemes or clusters, nodding.

* Flowers in racemes: rorolla ovoid or urn-shuped: anther-crlls 1-awned on the luck: leaves coriaccous, everyreen.

1. A. floribunda, P'ursh. Young lranches, leaves, and racemes hirsute; leaves ovate-lanccolate, areute, bristly-sermate ; racemes dense-flowered, crowded in a terminal panicle; calyx-lobes ovate, acute. - Damp soil along the mountains. A pril. - Shrub $3^{\circ}-10^{\circ}$ ligh. Flowers very numerous.

2. A. phillyreæfolia, IIosk. Smooth; stem alternately leafy and bracted; leaves oblong or lanecolate-olilong, olituse, glamblular-serrate near the apex; racenes solitary, axillary, loosely 4-12-flowered; (alyx-lobes lanecolate; corolla ovoid ; eapsule depressed-ghobose. - Shallow ponds in the pine harrens, chiefly near the coast, West Florida. January - March. - Shrub $1^{\circ}-2^{\circ}$ high. 
* Fiowers in umbel-like clusters: capsule more or less ribbed at the sutures, the ribs separating at maturity.

- Corolla orate, cylindrical, or somewhat bell-shaped: anthers or filuments aumal: capsule ocate, truncate: shrubs smooth throughout.

3. A. nitida, Bartr. Branches 3-angled; leaves evergreen, orate or oblong, entire, shining; clusters axillary, very numerous, 6-12-flowered; sepals lanceolate-ovate, spreading; corolla cylindrical-orate, gibbous at the base ; filaments 2-awned at the apex. - Low pine harrens, common. March-May. Shrub $2^{\circ}-6^{\circ}$ liggh. Corolla white, red, or purple, odorous.

4. A. Mariana, L. Leaves deciduous, oblong, obtuse or acute, entire; flowering stems commonly leafless; calyx-lobes lanceolate, acute, half as long as the large $\left(\frac{1}{2} /\right.$ long) cylindrical white corolla; filaments 2-awned near the apex. - Damp soil near the coast, Florida, and northward. April and May. Stem $2^{\circ}-4^{\circ}$ high, often simple. Leaves $2^{\prime}-3^{\prime}$ long.

5. A. speciosa, Michx. Leaves decidnous, oblong or elliptical, obtuse, serrate, often whitish beneath; flowering stems mostly leafless; calyx-lobes ovate, sereral times shorter than the large bell-shaped white corolla; anthercells 2-awned at the apex. - Low pine barrens, Florida to North Carolina. Shrub $3^{\circ}-4^{\circ}$ high.

+ + Corolla small, nectrly globular, scurfy: anthers and filaments aunless : capsule globose: shrubs pubescent, or scurfy.

6. A. ferruginea, Walt. Branches and young leares scurfy; leaves evergreen, obovate or lanceolate-obovate, rigid, at length smooth above and whitish beneath; the margins mostly rerolute; chsters few-flowered. (A. rigida, Pursh.) - Low sandy pine barrens, Florida to South Carolina, and westward. - A low shrub or small tree. Branches very leafy, rigid. Leaves $\frac{1{ }^{\prime}}{2}-1^{\prime}$ long.

7. A. ligustrina, Muhl. Leaves deciduous, oblong or oblong-oborate, serrulate, acute, pubescent like the branches, paler beneath; clnsters few-flowered, disposed in compound more or less leafy panicled racemes; filaments hairy, awnless. (A. frondosa, Pursh, with racemes more leafy and the filaments slightly awned at the apex) - Margins of swamps, Florida to Mississippi, and northward. May. - Shrub $3^{\circ}-4^{\circ}$ high. Leaves $2^{\prime}$ long. Flowers very small.

\section{OXYDENDRUM, DC. Sorr-woon. Sorrel-tree.}

Calyx 5-parted. Corolla ovate, 5-toothed. Stamens 10: anthers awnless, opening by terminal chinks; the cells acuminate. Capsule conical, 5-angled, 5-celled, many-seeded. Seeds aseending - A small tree, with deciluous oblong serrulate acuminate leaves, on slender petioles, and white flowers in long and slender 1 -sided terminal panicled racemes.

1. O. arboreum, DC. (Andromeda arborea, $L$ ) - Rich woods, Florida to Mississippi, and northward. April and May. - Tree $15^{\circ}-40^{\circ}$ high. Leaves $4^{\prime}-6^{\prime}$ long, sour. Corolla pubesecnt. 


\section{CLETHRA, l.}

Calyx 5-parterl, imbrieated in the bul. Corolla 5-prtalous. Stamens 10: anthers olncorlate, inverted in the lnsl, opening ly terminal pores. Style slender, 3-cleft. Caprule 3-celled, 3-valved, nauy-seriled — Slornhs or small trers. Leaves nlternate, oblong or obovate, sermte, deciduons. Flowers white, in terminal racemes, stamens and style exserted.

1. C. alnifolia, I. Shrulby ; lranches aul racemes tomentose; leaves slort-petioled, obovate or wedge-oblong, acute, sumoth on both sidl-s; racemess simple or panicled; style and filaments smooth; luacts partly persistent. (C. paniculata, Pursh.) - Varies, with the leaves hoary beneath, rongh ahove (C. tomentosil, Lam ), or on loth sides (C. scalbra, P'r.rs.); style hairy; braets caducous. - Swamps, Filorida to Mis-isippi, and northward. July- - Shrub $4^{\circ}-8^{\circ}$ light. Loaves $2^{\prime}-3^{\prime}$ long. Flowers fragrant.

2. C. acuminata, Midix. Arboresent; brawehes and racemes whitetomentose; leaves thin, smooth, ovate or ovate-laneeolate, acuminate, on slender petioles ; racenes solitary ; style smooth ; filuments hairy - Mountains of North Caroliua. July and Ang. - Leaves $3^{\prime}-4^{\prime}$ long. Bracts caducous.

\section{KALMIA, I. LATREL.}

Calyx 5-parted. Corolla depressed-eampanulate or rotate, 5-lolsed, with 10 cavities at the silles in which the anthers are lodgerl. Filaments elastic. Style single. Stigma capitate. Capsule globose, 5-celled, 5-valved, many-secded.Shrnbs, with entire alternate opposite or whorled evergreen leaves, and showy white or rose-colored flowers.

\section{* Flowers in corymbs.}

1. K. latifolia, L. (Csurco-BLsh.) Branches smonth; leaves mostly alternate, petioled, elliptical, acute at each end, green on both silles; corymbs terminal, viscid; corolla large, varying from white to deep rose-color. - Sliady hanks, Floriela, and northward. May and June. - Shrub $4^{\circ}-10^{\circ}$ ligh. Leaves shining.

2. K. angustifolia, I. (SnEeP LAcrec.) Branclies smooth; leaves petiolcd, oppusite or three in a whorl, narrowly oblong, ohtuse, pale or glaucous bencath; corymbs lateral, glandular; flowers small, deep rose-color. - Barren hills, chiefly in the upper distriets. April and May. - Slirub $2^{\circ}-3^{\circ}$ high. Leaves and flowers smaller than those of the preceding.

3. K. cuneata, Michx. Branches pubescent; leaves sessile, alternate, wedge-oblong, pubescent beneath, bristle-pointed; corymbs lateral; flowers white. - Swamps, South and North Carolina, not conmon. - A small shrub.

\section{* * Flowers solitary, axillary.}

4. K. hirsuta, Walt. (Wr small ( $\frac{1}{2}$ long), oblong or ovil, mostly obtuse and alternate, the margins revoLute; caly-lobes leafy ; flowers numerous, approximate, pale or deep rose-color; pedicels slender, longer than the leaves. - Flat pine barrens, Florida and Georgia. June to Sept. - Shrub 6 $-18^{\prime}$ high. 


\section{MENZIESIA, Smith.}

Calyx 4-toothed. Corolla ovoid, 4-toothed. Stamens 8, included: anthers awnless, opening by terminal pores. Stigna obtuse. Capsule woody, 4-eelled. 4-valved, opening septicidally, many-seeded. - Shrubs, with entire alternate membranaccons leaves, and nodding greenish-white flowers in terminal clusters, appearing with the leaves.

1. M. globularis, Salisb. - Mountains of North Carolina. July. - A straggling slurub, $3^{\circ}-6^{\circ}$ high. Leaves deciduous, oblong, acute, hairy, glaucous beneath, glandular-pointed.

\section{RHODODENDRON, L. Rose-BaY. Hoxexsuckle.}

Calyx mostiy minute, 5-toothed. Corolla bell-shaped or funnel-shaped, usually somewhat irregular, 5-lobed. Stamens 5 or 10 , mostly declined: anthers opening by terminal pores. Style single, elongated : stigma capitate. Capsnle 5-celled, 5-valved, many-seeded. Seeds minute, seale-like. - Shruhs or small trees. Leaves alternate, entire. Flowers showy, in terminal clusters from large scaly buds.

\$1. Azatea. - Corolla funnel-shaped, mostly glandular-viscid externally: stamens 5: the long filuments and style exserted: leaves deriduous.

* Flowers appearing with or before the leaves.

1. R. nudiflorum, Torr. Branchlets hairy; leaves ohovate or oblong, pubescent, soon smoothish above; calyx-lobes minute; tube of the corolla finely pubeseent, rather longer than the lobes ; corolla white, varying to deep rose-color, or sometimes yellow. - Swamps and banks of streams, Florida to Mississippi, and northward. April and May. - Shrub $4^{\circ}-6^{\circ}$ high. There are many varieties.

2. R. calendulaceum, Torr. Branchlets hairy; leaves oblong or obovate, hairy; calyx-lobes conspieuous; tube of the corolla hairy, shorter than the lohes. - Woods on the mountains of Georgia, and northward. May. Slirub $3^{\circ}-10^{\circ}$ high. Fiowers flame-color, very sliowy.

* * Flowers appearing after the leaves.

3. R. viscosum, Torr. Branchlets bristly; leaves coriaceous, obovate, with the margins and veins beneath hirsute, green on both sides ol glancous beneath; corolla glandular-viscid, white; calyx-teeth minute, rounded. Swamps, Florida to Mississippi, and northward. July and Aur, - Shrub $4^{\circ}-$ $6^{\circ}$ high. Capsule hispid.

4. R. arborescens, Torr. Branchlets sinooth; leares smooth, ohorate, ciliate on the marrins, pale beneath; corolla glandular-viscid, rose-color; ealyxlobes conspicuous, aente. - Mountains of Georgia, and nortlaward. Junc.Shrub $3^{\circ}-10^{\circ}$ high. Flowers fragrant.

\$2. Ruododespron. - Corolla bell-shaped, snooth: stamens 10: leaves coriaccous, everyreen.

5. R. maximum, I. Leaves obovate-oblong, abruptly aente, smooth and green on both sides; calyx-lobes conspicuous, rounded; corolla white or rose- 
color, spotted within with yellow or green. - Sharly lanks of strenus on the nountains of (icorpin, and northwarl. July. Stem $6^{\circ}-20^{\circ}$ high. Lecures $4^{\prime}-10^{\prime}$ loner. Corolla $1^{i}$ in liameter.

6. R. Catawbiense, Michx. Leares (-lliptic-ol,long, olstuce at each enul, mucronate, smooth; the young ones and bramchlets tomentone; ealyx-lobex

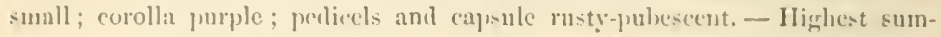
mits of the monntains of North Carohina. June. - Shrub $3^{\circ}-6^{\circ}$ high. Leaves $3^{\prime}-5^{\prime}$ long.

7. R. punctatum, Andr. Leares elliptical, acute at eacl end, glalrous; the lower surface and dense corymbs thickly intterl with resinous globules; calyx-lobes small, rounded; corolla somewhat fumcl-shaped, rose-color, spotted within, longer than the pedicels; capsule elongated. - Varies with smaller $\left(1^{\prime}-1_{\frac{1}{2}}^{\prime}\right)$ oral or obovate obtnse leaves, mimute calyx-lobes, and shorter capsule $\left(t^{\prime \prime}-5\right)^{\prime \prime}$ long). - Mountains of Georgia and North Carolina; the variety in the samdy pine harrens of West Florida. May and June. - Shrub $4^{\circ}-6^{\circ}$ high. Leaves $2^{\prime}-3^{\prime}$ long.

\section{LEIOPHYLLUM, Pers.}

Calyx 5-partel. Corolla of 5 spreading petals. Stamens 10, exserted: anthers opening lengthwise. Style filiform. Capkile 3-eelled, 3-ralved, unanyseeded. - A low, smooth, mueh branched sluruh, with very numerous thick, oval, entire evergreen leaves, and small white flowers in terminal clusters.

1. L. buxifolium, Ell. - Sandy pine baryens, and on the mountains of Carolina. Mray. - Shrub $6^{\prime}-10^{\prime}$ high. Leaves $\frac{1}{2}$ l long, alternate or opposite, glossy.

\section{BEJARIA, Mutis.}

Calyx 7 -lobed or $i$-toothed. Corolla of 7 oblong spreading petals. Stamens 14 : anthers versatile, opening by terninal pores. Style elongated : stigna depressed. Capsule depressed-globose, 7-eelled, 7-ralred, many-seederl. - Shrubs, with alternate entire coriaceons leaves, and white or purple flowers in racemes or corymbs.

1. B. racemosa, Tent. Branches rough with seattered rigid hairs; leaves orate-lanecolate, smooth; racemes terminal, elongated; calyx 7 -toothed. - Dry sandy soil, Georgia and East Florida. June and July. - Shrub $3^{\circ}-4^{\circ}$ high. Flowers white, showy.

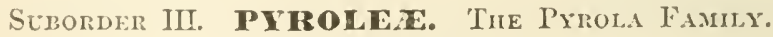

\section{PYROLA, I.}

Calyx 5-parted. Petals 5, coneare, deciduous. Stamens 10: anthers somewhat 4-celled, opening by terminal pores, inverted in the bud. Style long, mostly declined : stigma 5-lobed or 5-rayed. Capsule globose, 5-eelled, 5-valved, opening through the cells from the base upward; the sutures pubescent. Sceds 
very minute, numerons. - Smooth perennial herbs, with creeping rots, and evergreen radical leaves. Flowers commonly white, nodding, in a simple raceme at the summit of the nearly naked seape.

1. P. rotundifolia, L. Leaves orbieular, thick, nearly entire, shorter than the petioles; raccmes many-flowered; stigma 5-erenate. - Dry woods in the mountains, Georgia, and northward. June and July. - Seape $1^{\circ}$ high.

\section{ChimaphilA, Pursh. Prixce's Pine.}

Calyx 5-eleft. Petals 5, spreading, deciduous. Stamens 10, the filaments dilated in the middle: anthers somewhat 4-celled, opening by terminal pores, inverted in the bud. Stigma broad, 5-erenate, nearly sessile. Capsule globose, opening from the apex downward; the sutures naked. - Low creeping evergreens, with erect branches, lanceolate serrate whorled leaves, and whitish umbellate nodding flowers on long peduncles.

1. C. umbellata, Nutt. Leares wedge-lanceolate, narrowed at the base, scrrate above the mildle, not spotted ; umbels $4-7$-flowererl; filaments smooth. - Open woods, North Carolina, and northward. June. - Branches $6^{\prime}-10^{\prime}$ high. Leaves glossy.

2. C. maculata, Pursh. Leaves lanceolate, broad at the base, toothedserrate throughout, blotehed with white; umbels $2-5$-flowered ; filaments villous below. - Dry open woods in the middle and upper districts, Mississippi, and northward. June. - Smaller than the preceding.

\section{SHORTIA, Gray.}

Calyx 5-sepalous, scale-like, imbricated in the bud. Capsule shorter than the calyx, nearly globose, 3-celled, loculicidally 3 -ralved. Placenta large, central. Seeds small, numerous. Emlryo terete, straight, shorter than the albumen. Style filiform, somewhat persistent. Corolla and stamens unknown. $-\Lambda$ smooth perennial nearly stemless herb. Leares roundish, subcordate, crenate. serrate, long-petioled. Scape sealy-braeted towards the summit, 1-flowered.

1. S. galacifolia, Gray. - High mountains of Carolina, Michaux.

\section{Suborder IV. Honothopera. The Indan-Pipe Fauily.}

\section{SCHWEINITZIA, Ell.}

Calyx of 5 sepals, persistent. Corolla persistent, bell-shaped, 5-lobed. St:1mens 10: anthers shorter than the filaments, fixed near the apex, awnless; the cells opening at the apex. Style short and thick: stigma large, 5-angled. Capsule oroil, 5-celled. Seeds very numerous. - Stem low $\left(3^{\prime}-4^{\prime}\right)$, smooth, brownish, sealy. Spike several-flowered. Flowers flesh-colored, odorous.

1. S. odorata, Ell. - Shady woorls, North Carolina, and nortlıward, rare. April. - Parasitic on the roots of herbs. Flowers nodding. 


\section{MONOTROPA, 1. INmin-I're.}

Calyx of 2-5 deciduous sepals. (corolla $4-5$-petalous, giblous at the hase, deciluous. Stamens $8-10$ : anthers reniform, opening aross the apex. Stigna brond, 4-5-payed. Capsule ovoid, 8-10-furowed, 4-5-celled. Seeds very numerous, minute. - Stems low, fleshy, white or reddish, senly. Flowers solitary or racemose, nodling. Capsules encet. Ilerbs parasitic on routs, or decayed vegetable matter.

\$ 1. Moxotror., Nintt. - Stem 1-flowered: sepals 2-4: protals 5: anthers opening by 2 chinks: style short and thick:

1. M. uniflora, L. - Slatly woods, Florida to Mississippi, and northward. Ang. and Sept. - Stem smooth, $4^{\prime}-10^{\prime}$ high, white, turning black in drying. Flower sliowy.

\$2. Hrpopitrs, Dill. - Stem sereral-flowerd; the upper foucer commonly with 5 petals and 10 stamens; the athers with 4 petuls and 8 stamens: sepals as many as the petuls: anthers opening by 2 unerual valves; the smaller one erect: style longer thun the ovury.

2. M. Hypopitys, L. (M. lanuginosa, Michx.) - Sluarly wooda, Florida to Mississippi, and northward. Aug. - Stems $4^{7}-8^{\prime}$ high, pubescent, reddish.

\section{ORnER 77. GALACINEA: (GALAX FAMIL.)}

Calyx small, 5-sepalous, persistent. Petals 5, hypogynous, obovatespatulate, decidnous. Stamens hypogynous; the filaments united into a 10 -toothed tube; those opposite the petals sterile, the 5 alteruate ones shorter and learing a roundish 1-celled anther, which opens across the top. Style short: stigna 3-lobed. Capsule ovoir, 3-celled, loculicidally 3-valved. Seeds numerous, fixed to the central plarenta. Embryo straight, in fleshy albumen.- A smooth perennial stemless lierb, erect from a creeping scaly rhizoma. Leaves all radical, evergreen, roundcorlate, crenate, petioled. Seape $\left(1^{\circ}-2^{\circ}\right.$ high $)$ simple, bearing a long spiked raceme of small white flowers.

\section{GALAX, L.}

Characters of the order.

1. G. aphylla, I. - Open wools on the mountains of North Carolina. June and July. - Jhizoma deep red.

\section{Order 78. AQUIFOLIACEA:. (IIOLly Faimly.)}

Trees or shrubs, with alternate simple leaves, and small white or greenish flowers. - Calyx 4-9-toothed. Corolla hypogynous, rotate, 4-9- 
parted, imbricated in the bud. Stamens 4-9, alternate with the lobes of the corolla, and inserted on its base: anthers opening lengthwise. Ovary free from the calyx, 4-9-celled. Stigma lobed, nearly sessile. Drupe berry-like, composed of 4-9 one-seeded nutlets. Seeds anatropous, suspended. Embryo minute, in fleshy albunen.

\section{ILEX, L. Holly.}

Flowers perfeet or diœecionsly polygamous, of $4-9$ parts. Drupe containing 4-9 nutlets. - Leaves evergreen or deciuluous. Fertile flowers commonly solitary on the young branches, the sterile ones mostly in sessile or peduncled clusters or cymes.

\$1. AQU1FOLIUM. - Parts of the flower 4: drupe red: nutlets ribled or veiny on the back: leaves evergreen.

1. I. opaca, Ait. (Holly.) Simooth; leaves oval, coneave, wavy and spiny on the margins; sterile flowers cymose, on slender peduncles; calyx-lobes acute. - Sandy soil, Floriclin to Mississippi, and northward. April and May.$\Lambda$ small tree.

2. I. Dahoon, Walt. Young branches, lower surfuce of the leaves, and clusters more or less pubescent; leaves varying from obovate to oblong-linear, acute or obtuse, mucronate, entire, or sharply serrate above the mirldle, on short petioles; sterile peduncles many-flowered, the fertile oues shorter, and mostly 1 flowered; ealyx-teeth acute; untlets 3-ribbed on the back. (1. laurifolia, Nutt. I. ligittrina, Ell.) - Var. MrRtrifoli. Leaves small $\left(\frac{1}{2}{ }^{\prime}-1^{\prime}\right)$, linear-oblong, entire, or, on the young branches, sharply 2-4-toothed toward the apex. (I. myrtifolia, II'clt.) - Margins of swamps and pine-barren ponds, South Florida to North Carolina, and westward. April and May. - A handsome shrub or small tree. Leaves $2^{\prime}-3^{\prime}$ loug.

3. I. Cassine, L. (Yaupox ) - Teaves small ( $\left(\frac{1}{2}-l^{\prime}\right.$ long), oval or oblong, obtuse, erenate; elusters very numerous, nearly sessile; calyx-lobes minute, obtuse. - Light sandy soil along the coast, Florida to North Carolina. April. - Shrub $8^{\circ}-12^{\circ}$ light, slender, the short spreading branches often spine-like. Firuit elustered, albuniant.

\$2. Prixondes. - Parts of the flower 4-6: drupe red or purple: mutlets 4-6, ribled on the back: shruls: leares dreiduous.

4. I. decidua, Walt. Leaves lanceolate or oblong, obtusely serrate, pubescent on the veins beneath, tapering into a short petiole; flowers on short pedicels, in sessile elusters; calyx-teeth smooth, acute. (1. prinoides, Ait.) Varies with the leaves smooth on both sides, and the flowers on longer pedicels. - River-swamps, Florida to Mississippi, and northward. April and May. $-\mathbf{A}$ large shrub. I.eaves thin, $1^{\prime}-2^{\prime}$ long. Drupe red.

5. I. ambigua. Branches slender; leaves oval or oblong, aente or sornewhat acuminate, finely and sharply serrate, smooth on both sides, or rarely, like the branchlets, softly pubescent; pedicels of the sterile flowers clustered, longer than the petioles; those of the fertile ones very short, solitary; ealyx-tecth ob- 
tuse, ciliate. (I. inouticola, (royy?) - Sandy margins of swamps, Florida, and northwarl. April. $-\Lambda$ shrub or small tree. Leave's $1^{\prime}-4^{\prime}$ long.

6. I. Amelanchier, M. A. Curtis. I.caves ollong, harely acute at each end, serrulate, pubesecnt and finely reticulate beneath ; fruiting pedicels solitary, as loug as the petioles; drupe latree, red ; nutlets stromyly 3-ribbet on the back; (alyx-tecth acute. - Swamps, Society [Iill, South Carolina, Curtis. - Leaves abont $2^{\prime}$ long, $1^{\prime}$ wicle. 1)rupe $3^{\prime \prime}-4^{\prime \prime}$ in dianeter.

\$3. I'lixos. - Parts of the flower mostly 6-9: nutles smooth and eirn on the bark.

* Leaces deciduous: drupe red.

7. I. verticillata, Gray. Leares (thick) oval, obovate, or wederc-lancenlate, acuminate, rather coursely serrate, paler and pubese'ent beneath; flowers all cheterel, 6-parted, on slort pedicels; frnit abundiunt. (I'rinos verticillatus, L.) - Low ground, West Florida, ant northward. $\Lambda$ pril. $-\Lambda$ large shrub. Leaves about 2' long. Perlicels shorter than the petioles.

8. I. lanceolata. Lcaves lanceolate, fincly and remotely scrrate, acute at cach end, smooth on both sides, membranaceous; fertile flowers scattered generally in pairs, 6-parted ; sterile ones clnstered, triandrons; drupes small. (Prinos lanceolatus, Pursh.) - Lower districts of Georgia and South Carolina, Pursh. June.

\section{* Leaves smooth, evergreen: drupe black.}

9. I. glabra, Gray. Leaves werlge-oblong or obovate, crenately 2-4toothed near the apex; sterile peduncles many-flowered; the fertile, 1-flowered; flowers all 6-9-parted. (Prinos glaber, L.) - Low pine harrens, Florida to Mississipji, and nortluward. May. - Shrub $2^{\circ}-4^{\circ}$ high.

10. I. coriacea. Leaves oval or oblong-obovate, entire or with sharp scattered tectl, viscid when young; peduneles 1 -flowered, the sterile ones mostly clustered, the fertile solitary ; flowers 6-9-parterl. (I'rinos roriaceus, Ell.) Wet thickets, Florida, Georgia, and westward. May. - Shrub $4^{\circ}-8^{\circ}$ high.

\section{Order 79. S'TYRACACEA. (Storax Faumr.)}

Trees or shrubs. Leaves alternate, without stipules. Flowers perfect. - Calyx 4-8-toothed, or entire, fiee, or adherent to the 2-5-celled ovary. Corolla hypogynous, or inserted on the calyx, 4-8-lohed or 4-8petalous. Stamens inserted on the base of the corolla, twice as many as its divisions, or nore numerons, separate, or monadelphons or polyadelphons at the base. Style single. Fruit capsular or drupaceous, 1-5cellerl. Seeds anatropous, mostly solitary in each cell. Embryo nearly as long as the albumen. Cotyledons flat. Radicle slender.

Tribe I. STYRACEA. Calyx 4-8-toothed, or entire : stamens $2-4$ times as many as the dirisions of the corolla: ovules partly erect or spreading, and partly pendulous : pu. bescence stellate.

1. STYRAX Fruit capsular, 1-celled. Ovary free from the calyx, or parlly adherent.

2 IIALESIA. Fruit drupaceous, 2-4-wlnged, 2-4 celled. Ovary wholly united with the calyx. 
Tribe II. SY MPLOCINEA. Calyx 5-cleft: stamens indefinite : ovules pendulous: pubescence simple.

3. SYMPLOCOS. Flowers in sessile clusters. Fruit baccate.

\section{STYRAX, Tourn. Storax.}

Calyx 5-8-toothed, free, or partly adherent to the 3-celled ovary. Corolla deeply 5-parted, with spreading or reflexed lobes, hypogynous or perigynous. Stanens 10, free or adnate to the tube of the corolla. Style filiform. Ovary completely or partly 3-celled. Capsule globose, 3-valved, 1-seeded.- Shruhs, with a downy or scurfy stellate pubescence. Leaves entire or toothed. Flowers white, in leafy racemes.

1. S. pulverulentum, Michx. Leaves small (1'-1 $\frac{1}{2}^{\prime}$ lorig), elliptical or obovate, entire or toothed, the lower surface and branches scurfy; racemes lateral, 3-7-flowered, often by pairs, hoary; calyx-teeth subulate. - Pinebarren swamps, Florida and Georgia. April and May. - Shrub $2^{\circ}-12^{\circ}$ high. Racemes $1^{\prime}-2^{\prime}$ long. Flowers fragrant.

2. S. grandifolium, Ait. Leaves large $\left(22^{\prime}-4^{\prime}\right.$ long $)$, oval or obovate, aeute, mostly entire; the lower surface, like the branches and many-flowered racemes, hoary; calyx furrowed, with triangular acute teeth. - Rich woods, Florida to North Carolina, and westward. April and May. - Shrub $4^{\circ}-6^{\circ}$ high. Racemes $3^{\prime}-5^{\prime}$ long.

3. S. Americanum, Lam. Leaves thin, obovate, or oblong-obovate, aeute, smooth ; racenies scurfy, not hoary, 4-6-flowered, terminal; calyx-teeth short, subulate. (S. glithrum and S. leve, Ell.) - Banks of streams, in the middle and upper districts, Mississippi to North Carolina. May. - Shrul $4^{\circ}-8^{\circ}$ high. Leaves $1^{\prime}-2^{\prime}$ long. liacemes $1^{\prime}$ long.

\section{HALESIA, Ellis. Sxownrop-Tree.}

Calyx obconical, slightly 4-8-toothed, adnate to the 3-4-celled ovary. Corolla inserted on the calyx, 4-lobed or 4-petalous. Stamens 8-16, separate or united below, free from the corolla : anthers linear. Ovules 4 in each cell, 2 of them erect, and 2 pendulous. Drupe dry, 2-4-winged, $1-3$-seeded. Secds cylindrical. - Shrubs or small trees, Leaves ample. Flowers in short lateral racemes, appearing with the leaves, white, drooping.

* Ovary 3-celled: corolla 4-petalous : stamens mostly 8, distinct: drupe 2-wingcd.

1. H. diptera, L. Leaves oval, consely serrate, pubescent, $4^{\prime}-^{\prime} 5^{\prime}$ long; racemes 2-4-flowered, the flowers on long pedicels; corolla $1^{\prime}$ loug; anthers spreading; drupe compressed, 1' long. - lich woods, Florida and Georgia. March and April.

* * Ocary 4-celled: corolla 4-lobed: stamens mostly 12, united below the middle: drupe 4-winged.

2. H. tetraptera, L. Leaves oblong, finely serrate, at length smonthish, $2^{\prime}-4^{\prime}$ long; flowers $2-4$ in a cluster, $8^{\prime \prime}-10^{\prime \prime}$ long; anthers erect. - River. banks, Florida to North Carolina, and westward. March and April. 
3. H. parviflora, Miclix. Leaves ovate-oblung, acnte, pulescent on both sides, glancous beueath, slighlity toothed, when young cutire; ranemes somewhat componnd, 4-5-flowered, leafy; pedicels longer than the flowers; ralyx tomentose; the tecth ovate, aleute; corollit small, tomentose, 4-piarted ; stamens 8 ; drupe slightly and unequally winged. - In Florida, Michux. - Jecures 2 long. Corolla $10^{\prime \prime}$ long. (*)

\section{SYMPLOCOS, Jneq.}

Calyx 5-cleft, more or less allherent to the 2-5-eelled orary. Corollat 5-10petalons. Stamens 15 or more, montulelphous or polyadelplions, inscrted at the hase of the corolla: anthers roundish. Ovinles $2-4$ in each cell, suspended, anatropous. Style slender: stigua entire or 3-5-parted. Berry 1-5-seeded. - Trees or shrubs. Leaves alternate, serjate. Flowers axillary, iu racemes or clusters.

1. S. tinctoria, L'Her. Lcaves smooth, corinceous, ol,long, partly persistent; clusters sessile, 6-12-flowered; calyx smooth, top-shajerl, the lobes obtuse; corolla yellow; stamens in 5 sets; stigma entire, berry 1 -seeded.Low woorls and hanks of streams, Florida to North Carolina, and westward. Marcls. - $\Lambda$ small tree. Leaves $3^{\prime}-4^{\prime}$ long, swcetish. Fluwers very numerous.

\section{Order 80. CYTILLACEAs. (Crrmua Famir.)}

Trees or shrubs, with alternate evergreen leaves, without stipules, and perfeet white flowers in lateral or terminal racemes. - Calyx of $4-5$ sepals. Petals 5-8, hypogynous, imbricated in the bud. Stamens 5-10, inserted with the petals: anthers introrse, opening lengthwise. Ovary 2-4-celled, with a single suspended ovule in each cell. Stigma entire or 2 -4-lobed. Fruit 2-4-seecled. Embryo straiglit in the axis of fleshy albumen. liadicle superior.

\section{CYRILLA, Garden.}

Calyx small, 5-sepalous, persistent. Corolla 5-petalous, spreading, deciduous. Stamens 5, opposite the sepals, subulate, spreading: anthers oval. Style persistent: stigma 2-lobed. Drupe ovate, 2-e'elled, 2-seeded; the pericarp spongy. $-\Lambda$ smooth slirub or small tree. Leaves entire. Racemes clustered at the base of the branches of the season, rigid, spreading. Flowers small, on short 2-bracted pedicels.

1. C. racemiflora, Walt. Leaves oblong or obovate-oblong $\left(2^{\prime}-4^{\prime}\right.$ long), on short petioles; racemes straight, many-flowered; drupe dry, ovate, tipped with the conspicuous slender style, mostly 1-seeded. - Varies with smaller $\left(1^{\prime}-1 \frac{1}{2}^{\prime}\right)$ oblanecolate and more rigid leaves, and the nearly grlobose drupe tipped with the short and thick style. - Shady banks, and (the variety) in pine-barren ponds, Florida to North Carolina, and westward. July. - Racemes $3^{\prime}-6^{\prime}$ long. 
2. CIIFTONIA, Banks. Tit1.

Calyx minute, composed of 5-8 scale-like persistent sepals. Petals 5-8, obovate, concave, sliort-clawed, spreading. Stamens mostly 10 , in 2 rows; the filaments ereet, thick, contracted alove the mildle; those opposite the petals longer: anthers round. Stigma sessile, 3-4-lobed. Drupe dry, 3-4-winged, 3-4-celled, with a single linear seed in each cell. $-A$ shrub or small tree. Leaves oblong, smooth, and somewhat glaucous. Racenes termiual, manyflowered, with leafy deciduous bracts. Drupes nodding.

1. C. ligustrina, Banks. (Mylocarium, Willd.)-Pine-barren ponds and swamps, Florida, and the lower districts of Georgia, westwarl. March and April. - Leaves $2^{\prime}$ long. Racemes $2^{\prime}-4^{\prime}$ long. Flowers white, fragrant.

\section{ELLIOTTIA, Muhl.}

Calyx minute, 4-sepalous. Petals 4, oblong-linear, slightly adhering at the base. Stamens 8 , included: anthers sagittate, thickened at the apex. Style slender, slightly exserted : stigma capitate. Ovary 4-celled, the cells manyovuled. Fruit unknown. - A smooth shrub, $4^{\circ}-10^{\circ}$ high. Leaves ellipticallanccolate, acuminate at each end, glaucous beneath. Racemes terminal, bractless, simple or compound.

1. E. racemosa, Muhl. - Near Waynesboro', Georgia, Elliott. - June.

\section{Order 81. EBENACEA. (Eboxy Fayily.)}

Trees or shrubs, with watery juice. Leaves alternate, entire, without stipules. Flowers polygamous; the sterile eymose; the fertile ones larger, solitary. - Calyx free from the 3-12-celled ovary, persistent, 3-7-lobed. Corolla 3-7-lobed, convolute in the bud, deciluous. Stamens mostly 16, inserted on the base of the corolla, often united by pairs; the filaments short and hairy : anthers introrse. Ovules $1-2$ in each cell, anatropous, suspended. Styles distinct, or united below. Fruit baceate, roundish, few-seeded; the seeds large, compressed. Embryo in the axis of hard albumen. Radicle superior.

\section{DIOSPYROS, L. Persimuon.}

Calyx 4-6-lobed: Corolla bell-shaped, 4-6-cleft. Stamens in the sterile flower mostly 16 ; in the fertile 8 , with the anthers sterile. Styles 2 or 4 , uniter 1 below. Ovules solitary in the cells. Berry 4-8-seeded.

1. D. Virginiana, L. Leaves ovate-oblong, mostly smooth, petioled; calyx 4-parted ; rorolla 4-cleft; styles 4, each 2-lohed ; ovary 8-celled. - Woods and old fields, Florida to Mississippi, and northwarl. May and June. - A small tree. Flowers greenish. Berry eatable when fully ripe. 


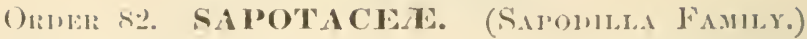

'Jrees or shruls, with milky juice, alteruate entire exstipulate shortpetioled leares, and regular perfiect (small) llowers, commonly in sessite axillary clusters. - Calyx fice from the 3-12-celled wary, 4-8-parted, persistent. Corolla hyporyous, $4-8-r$ left, mostly with one or two appendages between each lobe. Fertile stannens as many as the lobes of the corolla aud oppesite them, alternating with as many scale-like or petallike sterile ones, inserted on the tube of the corolla: anthers extrorse. Ovules anatropons, single, suspended from the central angle of each cell, or asrending from its base. Fruit a drupe or berry. Secels few. Albumen fleshy or oily, or none. Limbryo straight.

\section{Synopsis.}

* Calyx 5-parted.

+ rorolla with a single appendage between the lobes.

1. SIDEROXYLON. Sterile stamens none. Fruit a druje. Albumen copious.

++ Corolla with two appendages between the lobes.

2. UIPIIOLIS. Seed with copious albumen. Sterile slamens finbriate. Ovary smooth

3. BI MELIA. Seed without albumen. Sterile stamens entire. Uvary hairy.

* * Calyx 6-8-parted.

4. MiMUSOPS. Appendages of the corolla two between the lobes. Stamens 6-8.

\section{SIDEROXYLON, L.}

Calyx 4-parted. Corolla 5-eleft, with a single appendage between the lobes. Stamens 5, the sterile ones none. Orary hairy, 5-eelled. Drupe mostly 1-celled, 1-seeded. Albumen copions. - Tropical trees. Flowers chistered.

1. S. pallidum, Spreng. Smooth; leaves membranacens, elliptieal, obtuse, wavy on the murgins, on slender petioles; clusters fuw-flowered ; drupes purplish, oroid. - Sónth Florida. - Leaves $5^{\prime}-6^{\prime}$ long. Drupe $9^{\prime \prime}$ long.

\section{DIPHOLIS, A. DC.}

Calyx 5-parted. Corolla 5-eleft, with two toothed apjendages between the lobes. Stamens 5, each alternating witls an ovate-lanceolite fimbriate sterile one. Ovary smooth. Berry juiceless, 1-seeded. Allumen eopious, fleshy. $-\Lambda$ small tree, with silky branches. Leaves smooth, ollong-lanceolate, obtuse, narrowed into a short petiole. Flowers elustered, on short pedieels.

1. D. salicifolia, A. DC. - Sonth Florida, Dr. Blodgctt. Leares $2^{\prime}-3^{\prime}$ long. Calyx silky. Drupe small, oblong.

\section{BUMELIA, Swartz.}

Calyx 5-parted. Corolla 5-eleft, with two appendages between the lobes. Stamens 5, each alternating with a petal-like sterile one. Ovary 5-celled, hairy 
Berry oroid, 1-seederl. Albumen none. - Spiny shrubs, with hard wood. Leaves decilnons, oblong, narrowed into a petiole. Flowers clustered, white or greenish.

1. B. Iycioides, Gært. Leaves obovate-oblong, smooth on hoth surfaces; elusters miny-flowered, smooth; pedicels twice as long as the flower, rather shorter than the petioles; corolla nearly twiee the length of the ealyx.River-banks, Florida to Norih Carolina, and westward. June and July. A large shrub or small tree. Leaves $2^{\prime}-4^{\prime}$ long. Flowers greenish. Berry ovoid.

2. B. tenax, Willd. Leaves oblanecolate or olorate-oblong, thin, the lower surfice, like the branchlets and many-flowered clusters, covered with silky brown hairs; pedicels three times as long as the flower, shorter than the petioles; corolla white, barely longer than the calyx. - Dry soil, South Carolina, and westward; not common. - Leaves $1 \frac{1}{2}^{\prime}-2 \frac{1}{2}^{\prime}$ long. Berry oval.

3. B. lanuginosa, Pers. Leaves obovate-oblong or obovate, coriaceous, the lower surface, like the branchlets and many-flowered clusters, covered with a dense rusty villons puhescence; corolla white, twice as long as the calyx. - Dry sandy soil, Florida to Sonth Carolina, and westward. June and July. - A slırub or small tree. Leares $2^{\prime}-3^{\prime}$ long. Berry small, ovoill.

4. B. reclinata, Vent. Snootlı; branches diffuse; leaves obovate, often emarginate; clusters few-flowered. - Varies with the branchlets, leaves, and elusters sprinkled with appressed silky fulvons hairs; flowers smaller. - Riverbanks, Florida to South Carolina. June and July. - Shrub $3^{\circ}-4^{\circ}$ high. Leaves $1^{\prime}-2$ long. Flowers white. Berry globose.

5. B. parvifolia, $\Lambda$. DC. Smooth throughout; lateral branches slort and spinc-like; leaves small, eoriaceous, lanceolate-spatulate or oblong-obovate, obtuse, clustered ; flowers few in a eluster, on short pedicels; calyx-lobes ovate, obtuse, the two onter ones smaller; corolla yellowish-white; berry large, oblong. (B. angnstifolia, Nutt.) - South Florida. - A small tree. Leaves $1^{\prime}$ long. Berry $3^{\prime \prime}-4^{\prime \prime}$ long.

\section{MIMUSOPS, L.}

Calyx 6-8-parted; the lobes in two rows. Corolla 6-8-eleft, with 2 appendages between the lobes. Stamens 6-8, with as many 2-lobed sterile ones interposed. Ovary 6-8-celled, hirsute. Berry globose, 1-2-celled. Albumen fleshy. - Trees or shrubs. Leaves coriaceous, elustered at the sumnit of the branches. Flowers axillary, white.

1. M. Sieberi, A. DC. Branches short, thick, tubercular; leaves rigid, smootl, ohlong, emarginate at the apex, obtuse at the base, on stout pretioles; pedicels as long as the petiole, reenrved ; calyx-lobes coriaceons, orate-lanceolate, pubeseent, as long as the corolla. - South Florida. - Leaves $2^{\prime}-3^{\prime}$ loug; the midrib stout, the lateral veins obscure. 


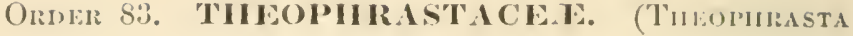

$$
\text { F.1.11,Y.) }
$$

Trees or shrubs, whth watery juice. 1, daves eoriaceous, often resiususdotted, withont stipules. Flowers perfeet, thick, white, oringer, or recl. - Calyx 5-parted. Corolla 5-cleft, with a single appendare leetween the lobes. Stamens 5, fertile, opposite the lobes of the corollat anthers extrose, 2-cellet, the thickened connective prolungerl above the redls. Ovary free, 1-celled, many-ovuled. Placenta central, grlobose. Stigma capitate. Fruit globose. Seerls few, enclosed in gelatinous pulp. Einbryo in the axis of eopious albunen. Radicle inferior.

\section{JACQUINIA, L.}

Calyx-lobes obtnse. Corolla bell-shaped, with orate obtuse appendages. Stamens inserted on the base of the corolla: filaments broal and flat. Style cylindrical from a conical base: stigma eapitate, 5-angled. Berry pointed, 310-secded. Albumen hard. - Leaves entire, short-petioled. Flowers in racemes.

1. J. armillaris, Jaeq. ? Branches pubcrulcont; leates wedge-oborate, smooth, enarginate, 3-nerved, punctate, slort-petioled, the margins revolute; racemes chiefly terminal, somewhat fleshy, many-flowerer, rather longer than the leaves; loricts ovate; pedieels ereet, club-shajed ; corolla short, bell-slaiped, flesly, the tube shorter than the rounded lobes; stamens short; the filaments dilated and romnate at the hase, lining the base of the corolla ; fruit subglobose. - South Florida. - Leaves $1^{\prime}-1 \frac{1}{2}^{\prime}$ long. Fruit $5^{\prime \prime}$ in diameter, orange-red.

\section{Order 84. MIRSINACEA. (Mrrsine Fanily.)}

Trees or shrubs, often glandular-dotted, with alternate exstipulate mostly entire leaves, and regular, often monœerious or diœcious, white or rosi-colored flowers. - Calyx 4-6-parterl. Corolla 4-6-cleft. Stamens 4-6, opposite the lobes of the corolla: antlers 2-cellerl, introrse. Orary mostly free, 1-celled, smooth: ovules 1-many, imbedded in the cavities of the central placenta. Style simple. Fruit drupaceous, globose, somewhat lleshy, commonly 1-seedel. Seeds roundish, concave at the base. Embryo transverse, in hard albumen.

\section{MYRSINE, I.}

Flowers polygnmo-dicecions. Calyx 4-5-parted. Corolla 4-5-cleft, imbricated in the bud. Stamens $4-5$, inserted on the base of the corolla : anthers longer than the filaments, opening from the base upwark. Style short: stigma capitate. Orules 4-5, amplitropons. Drupe globose, 1-secied. - Leares coriaceons. Flowers small, iu axillary elusters, on short pedicels. 
1. M. Floridana, A. DC. Smooth; leaves obovate-oblong, entire, on short petioles; clusters fiew-flowered; lobes of the ealyx and corolla 5 ; drupes small, longer than the pedicels. - South Florida. - Leaves $2^{\prime}-3^{\prime}$ long. Drupes $l^{\prime \prime}$ in diameter.

\section{ARDISIA, Swartz.}

Flowers perfect. Calyx 5-parted. Corolla 5-cleft, convolute in the bud. Stamens 5 ; the anthers mostly longer than the filaments, opening from the apex downward. Ovary l-celled, many-ovuled. Style slender: stigma acute. Drupe globular, 1-seeded - Leaves coriaceous. Flowers in terminal racemes or panicles.

1. A. Pickeringia, Torr. \& Gray. Smooth ; leaves oblong-obovate, obtuse, entire, narrowed into a short petiole, pale beneath; panicles terminal, short; corolla dotted with minnte black globules. - Sonth Florida. July. - Leaves $2^{\prime}$ long. Drupe $1 \frac{1}{2} "$ in diameter, shorter than the pedicel.

\section{Order 85. PLAntaginacez. (Plantain Family.)}

Chiefly stemless herbs, with radical mostly ribbed leaves, and small whitish spiked or capitate flowers, borne on a naked scape. - Calyx of 4 imbricated sepals, with scarious margins. Corolla salver-shaped, 4-parted, withering. Stamens 2-4, included or exserted, inserted on the tube of the corolla, and alternate with its lobes: anthers 2-celled, deciduous. Style slender. Ovary free, 2-4-celled. (apsule 2-celled, few-many-seeded, opening transversely. Seeds attached to the deciduous partition. Embryo straight in fleshy albumen.

\section{Plantago, L. Plantain.}

Cliaracters same as the order.

\section{* Flower perfect.}

1. P. major, L. Leares ovate or oval, smooth or pubescent, 5-7-ribbed, mostly toothed, narrowed into a broad concave petiole; scape pubescent ; spike long-cylindrieal, densely many-flowered ; braets orate; capsule many-seeded. Low gromnd around dwellings. Introduced. May-Aug. - Scape $6^{\prime}-12^{\prime}$ high. Leaves $4^{\prime}-6^{\prime}$ long.

2. P. cordata, Lam. Smooth; leaves broadly ovate or cordate, toothed, 7 -9-ribbed, on long flat petioles; spike long-cylindrical, rather loosely flowerer; bracts roundish; capsule 2-4-seeded. - Low ground, in the upper districts of Georgia, Tennessee, and northward. April-June. $4-$ Scape $1^{\circ}$ high. Leaves $3^{\prime}-8^{\prime}$ long.

3. P. Rugelii, Decaisne. Leaves smooth or pubescent, oblong, entire or obscurely dentieulate, 3-5-ribbed; spike cylintrical, rather loosely flowered; bracts acute, shorter than the smooth calyx; capsnle coniral, 4-seeded. - Hills ncar Decatnr, Alabama. Ringel. - I'lant small. Scape slender. 
4. P. lanceolata, I. Sinooth or pulsescent; leaves lanceolate, acute, denticulate, 3-5-riblucl, longr-petioled; spikes dense, ovate or oblong ; rapsule 2-sected. - l'antures und waste ground. Introduced. - Scapes $1^{\circ}-20$ high. Spikes 1'- 2' lung.

5. P. sparsiflora, Michx. Leaves smooth, lauceolate, tuothed or entire, narrowed into a long petiole; scipe much longer than the leaves, pubescent below; spike longr, loosely flowered; bracts ovate; ealyx-lubes oltuse; rapsule 2-secded. (P'. intermuta, Lam.) - Moist pine barrens, Georgia and South Carolina. June-Sept. - Spikes $6^{\prime}-9^{\prime}$ long.

\section{* * Flouers diccious: annuals.}

6. P. Virginica, I. Iubescent ; leares lanceolate or oblong, toothed or entire, 3-5-riblecl, on rather short petioles; spike eylindrical, densely-flowered; stamens 4 ; capsule 2-4 secded. (I'. purpuraseens, Nutt.) - Low sanly soil, very rommon. April-June. - Scapes 1' (and then 2-4-flowered) - 10 light. Leaves $\frac{1}{2}^{\prime}-6^{\prime}$ long.

7. P. heterophylla, Nutt. Smooth or jubescent; leaves somewliat flesly, linear, entire, or with scattered spreadiug teeth; spikes linear, clusely flowered; the lower flowers seattered; stamens 2, exserted; eapsule manyscerled, twice the length of the calyx. - Waste places and ficlds, Florida and northward. April and May. - Scape $2^{\prime}-6^{\prime}$ high, commonly longer than the lares.

P. pusilua. Nutt. (which may be found within our limits) differs from No. 7 in having the oroid 4 -sceded capsule scareely longer than the caly $\mathrm{x}$.

\section{Order 86. PI,UMBAGINACEAE. (Leadwort Family.)}

Herbs or shrubs, with seattered or radical and clusterel leaves. Calyx tubular or funnel-shaped, 5-toothed, plaited, persistent. Corolla salver-shaped, 5-lobel or 5-petalous, with the 5 stamens opposite the lobes or petals, and inserted on their claws or on the rereptacle. Styles 5 , listinct or united. Ovary 1-celled, with the solitary anatropous orule suspended from the apex of the filiform corl which arises from the base of the cell. Fruit utricular or eapsular, variously dehiscent. Embryo straight, ix mealy albumen.

\section{STATICE, i. MLrem Rosemary.}

Calyx hracted; the limb scarions, 5-lobed. Petals 5, distinct, or united by their claws. Stamens 5, inserted on the claws of the petals. Styles separate or nearly so: stigmas slender. Utricle varionsly dehisent. - Peremnial herbs, growing in saline marshes, with fleshy chicfly radical leaves, and scape-like stems.

1. S. Caroliniana, Walt. Leares ohlong or obovate, tapering into a long petiole; seape sealy, widely branching; flowers mostly single, in 1-sided 
sprealing spikes; calyx funnel-shaped, smooth, the lobes of the searious limb alternating with 5 smaller ones. - Sult marshes, Florila, and northwarl. Aug. and Sept. - Seape $2_{2}^{10}-2^{\circ}$ high. Lcaves $3^{\prime}-6^{\prime}$ long. Flowers bluc.

\section{PLUMBago, Tomn. Leamwort.}

Calyx tubular, 5-ribbed, 5-toothed. Corolla salver-shaped, 5-lober. Stamens 5, inserted on the receptacle. Styles mited. Stigmas linear. Utriele splitting into valves from the base npwarl. - Icrbs or shrubs, with alternate cntire mostly clasping leaves, and blue or white flowers in terminal spilics.

1. P. scandens, L. Shrubby ; leaves ovate-lancelate, acute, narrowed into a clasping petiole; calyx glandular-viscid, half as long as the tube of the corolla; lobes of the corolla ovate, white; style smooth. - South Florida. Leares $2^{\prime}-3^{\prime}$ long. Spike elongated.

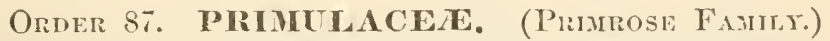

Herbs, with simple alternate or opposite leaves, and recular fowers. Calyx 4-5-lobed, persistent. Corolla 4-5-loberl. Stamens 4-5, opposite the loles of the corolla, and inserted on its tube. Orary free, or partly adherent to the calyx, 1-celled, many-ovulerl. J'acenta central, globose. Style single. Capsule 1-cellerl, many-seeded, valvate or circumscissile. Seeds anatropous or amphitropous. Embryo straight in fleshy albumen.

\section{Synopsis.}

* Ovary free from the ealyx. - Capsule opening by valres or teeth.

1. IIOTTONIA. Corolla salrer-shaped. Leaves pectinately dissected.

2. LYsIMACIIA. Corolla wheel-shaped. Stems leafy. Leaves opposite, entire.

3. DODECATIIEON. Corolla wheel-shaped. Stemless. Leaves radical.

+ - Capsule opening transversely.

4. ANAGAllis. Parts of the flower 5. Leares opposite. Stamens bearded.

5. CENTuxculus. Parts of the flower 4. Leaves alternate. Stamens beardless.

* * Ovary partly adherent to the calyx.

6. S.IJOLLS. Stamens 5, with sterile filaments interposed. Capsule valvate.

\section{HOTTONIA, I.}

Calyx 5-parted. Corolla salver-shaped, 5-lobed. Stamens 5. Style slender. Capsule globose, at length splitting into 5 valves, which cohere at the hase and apex. Seerls fixed by the base, anatropous. - Aquatic perennial herbs, with pectinately dissected leares. Flowering stems mostly clustered, nearly leafless, inflated, bearing at the joints whorls of small white flowers.

1. H. inflata, Eill. Flowering stems 3 - several in a terminal cluster, much inflated ; upper stem-Ieaves erowded, with filiform divisions; bracts entire. Ponds and ditehes in the upper districts, Mississippi, and northward. June. 


\section{LYSIMACHIA, I. H.แBsisturk.}

Calyx 5-parted. Corolla whecl-shupeel, 5-loluel. St:mens 5 ; the filaments often monadelphous at the base, and commonly with the rusliment of $\mathrm{n}$ sterile one imerposed. Style slender. Capsule globose, 5-10-vilverl, few - many-

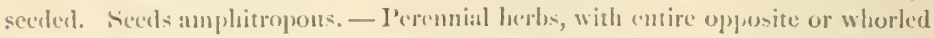
leaves, und axillary or racenose yellow llowers.

\section{* Flowers in terminal rarcmes or panicles.}

1. L. strieta, $\Lambda$ it. Stem smooth, erect, brunching; leaves very mumerous, (1) pre-ite, dotted, lanecolate, acute at each end; racemes long, leafy at the hase; pediecls slender; lobes of the corolla hanceolate-oblong, obtuse, entire, marked witlı dark lines; filanents monulelphous, uncyual ; stcrile ones none; capsule 5-valved, 3-5-sected.-Var. AxGrstitola. Leaves linear-lincolate, obtuse; lobes of the corolla lanceolate, arute. (I. angustifolin, Michx. L. Loomisii, Torr, corolla-lulses lroaler.) - Low grouml in the millile and upper districts. July. - Stem $1^{\circ}-2^{\circ}$ high. Leares $2^{\prime}$ long. Flowers small.

2. I. Fraseri, I)uby. Stem glandular-pubescent at the snmmit, ercet; leaves opposite, ovate or cordate-ovate, acuminate, narrowed into a sliort petiole; flowers in a leafless panicle; calyx bell-shaped, the lohes fringed on the margrins; lobes of the corolla ovate-lanceolate, obtuse, entire; filaments monadelphons, uneynal; sterile ones none. - South Carolina. Froser.

3. I. Herbemonti, Ell. Stem erect, smooth, simple; leaves (and flowers) four in a whorl, ovate-lanecolate, sessile, dotted ; flowers racemose, or short perlicels, the upper ones scattered; lobes of the corolla oblong-lancelate, rlotted; filaments monadelphons at the base. (L. aspernlafolia, Poir :) - Near Columbia, South Carolina, Elliott. North Carolina, Curtis, Croom. - Stem $2^{\circ}$ high. Leaves faintly 3 -5-nerved.

\section{* Flovers axillary.}

4. I. quadrifolia, L. Stem pubescent, simple; leares $4-5$ in a whorl, orate-lanceolate, actite, dotted, sessile; peduncles filiform; lobes of the corolla ovate-obloug, dotted, filaments monadelplious. - Sliady woods in the upper dis. tricts, and nortluward. July. - Stem $2^{\circ}$ high.

5. I. ciliata, L. Stem mostly branching, smooth; leaves opplo-ite, lanceolate-ovate, acute, cordate or rounded at the base, on ciliate petioles; corolla longer than the calyx, with broadly ovate or roundish dentieulate lobes; peduncles opposite. - Varies (I. hybrida, Wichx.) with the leares lanceolate or ovatelanceolate, narrowed into a short petiole; the uppermost, like the perluncles, often whorled; or (I. heterophylla, M/ichx.) with the lowest leaves ohovate, the others long, lanecolate; or (I. angustifolia, Lam.) with linear nearly sessile leaves, and a more slender stem, and smaller flowers. - Woods and thickets, chicfly in the upper districts, Mississippi, and northward. July and Aug. Stem $1^{\circ}-2^{\circ}$ high. Leaves $2^{\prime}-4^{\prime}$ long.

6. I. radicans, Hook. Smooth throughout; stem long, prostrate; the slender branches often rooting at the apex; leaves opposite, orate-lanccolate, acute, on long and slender petioles; peduncles longer than the leaves; corolla 
as long as the calyx. - Swamps and marshy banks of streams, in the upper districts. July. - Stem $2^{\circ}-3^{\circ}$ long. Flowers smaller than iu any form of the preceding.

7. L. longifolia, Pursh. Smooth; stem erect, mostly simple, 4-angled; leaves linear, obtuse, sessile, with the margins revolute, the lowest ones spatulate; corolla large, with roundish abruptly acute lobes. - Wet banks, South Carolina, and northward. July to Sept. - Stem $1^{\circ}-3^{\circ}$ high. Leaves $2^{\prime}-4^{\prime}$ long, rather rigid. Corolla $8^{\prime \prime}-9^{\prime \prime}$ in diameter.

\section{DODECATHEON, L. American Cowsip.}

Calyx 5-cleft, the lobes reflexed. Corolla-tube very short, the 5-parted limb reflexed. Stamens 5, the filaments monadelphous at the base: anthers long and linear, erect. Capsule oblong-ovate, 5-valved at the apex, many-seeded. - Stemless herbs. Leaves radical, clustered, spatulate or oblong. Flowers umbellate, terminating the naked scape, white or purple.

1. D. Meadia, L. Smooth; leaves entire or obscurely crenate; umbel bracted, many-fluwered; flowers showy, nodding. - Woods, North Carolina and Tennessee. May and June. 4-Scape $1^{\circ}$ ligh. Leares $4^{\prime}-6^{\prime}$ long.

\section{ANAGALLIS, L. Pimpernel.}

Calyx 5-parted. Corolla wheel-shaped, 5-parted, longer than the calyx. Stamens five: filaments bearded. Capsnle globose, opening transversely, manyseerled. - Low herbs, with opposite or whorled leaves, and axillary peduncled flowers.

1. A. arvensis, L. Stem branching, spreading, 4-angled; leaves ovate, sessile; pedıneles longer than the leares, nodding in fruit; flowers red. - Fields and pastures. Introduced. July. (1)-Stem $6^{\prime}$ long.

\section{CENTUNCULUS, L.}

Calyx 4-parted. Corolla bell-shaped, 4-cleft, shorter than the calyx. Stamens 4, bearlless. Capsule globose, many-seeded, opening transversely. Small annuals, with alternate leaves, and minute nearly sessile axillary white flowers.

1. C. minimus, L. Stem 3-angled, ascending, mostly branched; leares obovate, acute; flowers often clustered. (C. lanceolatus, Michx.) - Low ground near the coast, Florida to North Carolina, and westward. March and April. Stem $1^{\prime}-6^{\prime}$ long.

\section{SAMOLUS, L.}

Calyx 5-eleft; the tube adherent to the base of the ovary. Corolla salvershaped, 5-parted, commonly with slender filaments interposed. Stamens 5, includcl. Capsule 5-valved at the apex, many-seeded. - Smooth and somewhat fleshy marsh herbs, with alternate entire leaves, and small white flowers in terminal racemes. 
1. S. floribundus, liunth. Stem at length morh brancherl; lenves ohovate, the lowest tufecl, spreading, the others seatterel; racemes many-flowered; pedicels long, filiform, minutely lracted in the midhle; (ap)sule glohose, longer than the calyx; flowers minute. - Brackish marstes, Florida to Mississippi, and nurthward. May-July, (2) - I'lant 6'-12' ligh, pale greecu.

2. S. ebracteatus, Kunth. Stem simple or spuringly branched, naked above; leaves spatulate-obovate; racemes few-flowered; perlierls luactless; (ap) sule shorter than the ealyx ; flowers conspienous, - Suline marshes, Florida, and westward. Maly and Junc. - Stem $1^{\circ}-2^{\circ}$ high.

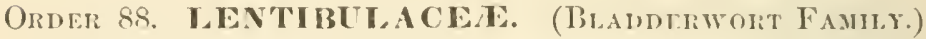

Aquatic or marsh herbs, with entire or dissected leaves, and irregular flowers. - Calyx 2-lipped. Corolla 2-lipped, personate, spurred at the base. Stamens 2, short, included: anthers 1-celled. Ovary free, oroid, 1-eelled. Orules numerons, anatropons, inserted on the free central glolose placenta. Style short : stigma 2-lipped. the luwer lip larger and covering the anthers. Capsule globose, many-seeded, opening irregularly. Embryo straight and thick. Albumen none.

\section{UTRICULARIA, L. Blinnerwort.}

Lips of the calyx entire. Throat of the corolla nearly closed br the projecting palate; the lips entire or slightly lobed, the lower one with an apf,ressed or depending spur at the hase. - Herbs, floating in still water by means of small air-bladders attached to the finely dissected leaves (or roots), or rooting in damp earth, with entire leares, and few or no air-bladders. Scapes or peduneles 1 - many-flowered.

* Sten flouting: upper leaves whorled, on inflated petiolcs; the others scuttered and fincly dissecled: flowers yellow.

1. U. inflata, Walt. Scape 5-10-flowered; corolla large $\left(9^{\prime}\right.$ wide); the lower lip 3-lobed, twice as long as the appressed conical notehed spur, the upper coneave, nearly entire; fruit nodding. - Var. susor. Every way smaller; scape 2-flowered. - Ponds and ditches, Florila to North Carolina, and westward. April and May. - Stem $2^{\circ}$ long. Seape $6^{\prime}-12^{\prime}$ high.

* * Stem flonting: leaves all scattered and fincly dissected: flouers y llow.

2. U. vulgaris, L. Leaves decomponnd; scape scaly, 5-12-flowered; throat of the corolla closed by the prominent palate; the lobes nearly entire, with reflexed margins, Innger than the conical obtuse somewhat spreading spur; fruit nodding. - Ponds nul still water, Mississippi to North Carolina, and northward. May - July. - Stem $2^{\circ}-3^{\circ}$ long. Scapes $6^{\prime}-12^{\prime}$ high. Corolla $\frac{1}{2}$ 'wide.

3. U. striata, Leconte. Leares decompound; seape slender, sparingly braeted, 5-6-flowered; lips of the long-pedicelled corolla nearly equal, 3-lobed; 
the upper one concave, striate in the middle, the lower with reflexed margina, as long as the linear nearly appressed notched spur; palate dotted with brown; fruit erect. (U. fibrosa, Ell.) - Still water, Florida, and northward. Sept. Scapes $10^{\prime}$ high. Corolla $\frac{1^{\prime}}{2}$ wide.

4. U. fibrosa, Walt. Small; leaves short, sparingly rlivided, root-like; scape 1-3- (mostly 2-) flowered, almost bractless; lips of t'de small $\left(4^{\prime \prime}-5^{\prime \prime}\right)$ corolla equal, roundish; the upper one slightly 3-lobed; the lower entire, rather shorter than the subulate appressed spur; palate globose, 2-lobed; fruit erect, on stont pedicels. (U. longirostris, Leconte. U. biflora, Lam.?) - Ponds, Florida to South Carolina. May and Junc. - Stem $4^{\prime}-6^{\prime}$ long, with clustered liranches. Scape 2'-4' high.

5. U. gibba, L. Stem short, with clustered branches; leaves sparingiy divided; scape 1-2-tlowered; lips of the corolla ncarly equal, longer than the gibbons obtuse appressed spur; fruit erect. (U. fornicata, Leconte.) - Shallow pourls, South Carolina, Elliott, and northward. June. - Stem $2^{\prime}-3^{\prime}$ long. Scape $1^{\prime}-3^{\prime}$ high.

* * * Stem floating: leares vhorled, finely dissected: flovers purple.

6. U. purpurea, Walt. Stem long, filiform; scape mostly 1-flowered; upper lip of the corolla truncated; the lower 3-lobed, with the lateral lobes sac-like, longer than the subulate spur. - Shallow ponds, Florida to Missisippi, and rorthward. June. - Stem $1^{\circ}-2^{\circ}$ long. Scape $2^{\prime}-3^{\prime}$ high. Corolla $4^{\prime \prime}$ wide.

**** Stemless : scape rooting, scaly: lcaves linear and entire, or none: airbladders few or none: flowers yellow.

7. U. cornuta, Michx. Scape $2-4$-flowered; pedicels short, as long as the calyx; lips of the large ( 39 ' wide) corolla ohovate, unequal; the lower one larger, abruptly pointed, entire, as long as the horn-shaped acute depending spur, the margins strongly reflexed. (U. personata, Leconte, the more numerous $(4-12)$ and scattered flowers mach smaller.) - Swamps, Florida, and northward. JulySept. - Scape 10 ligh.

8. U. subulata, I. Scape setaceous, 3-9-flowered; pedicels much longer than the calyx; lower lip of the small $\left(3^{\prime \prime}-4^{\prime \prime}\right)$ corolla 3-lobed, longer than the appressed conical green-pointed spur; leaves, when present, linear, fugacions. (U. setacea, Michx.) - Wet sanly pine barrens, Florida to North Carolina, and westward. Feb. - May. - Scape $2^{\prime}-8^{\prime}$ light.

9. U. bipartita, Ell.? Scape filiform, 1-3-flowered; pedicels long and slender; upper lip of the corolla slightly 3-lohed; the lower entire, as long as the conical obtrse spur; lower lip of the calrx sometimes 2-cleft ; fruit crect. Miry margins of ponds near. Tallahassec, Florida, to South Carolina. Sept. Scape $4^{\prime}-6^{\prime}$ high. Corolla $6^{\prime \prime}-8^{\prime \prime}$ wide.

\section{PINGUICULA, Toum. Butterwort.}

Upper lip of the calyx 3-lobed, the lower 2-lobed. Corolla somewhat 2-lipped; the upper lip 2-lobed; the lower 3-lobed, spurred at the base; 
palate lairy. - Stemless herhs. Teaves nll radicul, clusterenl, entire, with the margins commonly inolute. Sinpe naked, commonly viscill.

\section{* Flourers yellou.}

1. P. lutea, Walt. Clammy-pubescent ; laves oblong-olovate; corolla

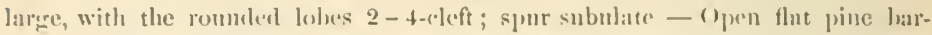
reus, common. F(b) $-A$ pril. - Plant yellowish. S('upe $G^{\prime}-12^{\prime}$ high. Corolln $1^{\prime}-1 \xi^{\prime}$ wide, norllingr.

$$
\text { * * Flouers purple, offen clanging to white. }
$$

2. P. elatior, Mirhx. Jeaves clammy-puhestent, spatulate-orate; seapes villous near the base; lohes of the corolla 2-cleft, romded; spur obtuse - Margrins of ponds. Florida to Nurth Carolina. March and $\Lambda$ pril. - Scapes $8^{\prime}-12^{\prime}$ bigh. Corolla 1' wille.

3. P. australis, Nutt. Smoothish; leaves lanceolate or olılong, flat; corolla 5-parted, the wedge-ohovate lobes 2-eleft, acutish; spur sac-like, obtnse. Shallow ponds, West Florila, near the coast. Mardh. - Scapes $1^{\circ}$ high. Corolla $1^{\prime}$ wide.

4. P. pumila, Michx. Clammy-pubescent; leaves romdish or ohovate; lobes of the corolla obcorlate; spur somewhat sac-like, obtuse. - Jow sandy pine barrens, Georgia, Florida, and westward. March and April. - Scape 2'$6^{\prime}$ hight. Corolla $\frac{1}{2}{ }^{\prime}-4$ wide.

\section{Orint 89. Hignoniches. (Bignonia Famiz.)}

II erbs, shruls, or trees, with simple or componnd leaves, anıl regular or somewhat irregular showy flowers. - Calyx 2-lipperl, 5-lobed, or truncate and entire. Corolla tubular or bell-shaped, mostly 2-lipped. Fertile stamens 2, or 4 and didynamoms, inserted on the corolla: anther-ells diverging. Ovary 2-celled, many-ovuled; the base surrouneled with a glandular disk. Style filiform: stigma 2-lipped. Capsule 2-ralved, 2- or 4-celled, many-seeded. Embryo flat. Albumen none.

\section{Synopsis.}

Suborder I. BLGNONIE.E. Trees, shrubs, or wooly vines, Capsule 2-celled, the ralves seprarating from the partition. Seeds flat, winged. Cotyledons notched at each enl. - Leaves opposite.

1. BIGXONIA. Valves of the capsule parallel with the partition. Leares compound.

2. TECOMA. Valves of the capsule contrary to the partition. Leares compound.

3. CATALPA. Valves of the capsule contrary to the parlition. Leares simple.

Stborder II. SESAMEZ. IJerbs. Capsule 4-celled. Seeds wingless. Cotyledons thick, entire.

4 MARTYXIA. Capsule woody, beaked. Leaves simple, al ternato or opposite. 


\section{BIGNONIA, Toum. Cross-vine.}

Calyx cup-shaped, truneate or slightly 5-toothed. Corolla tubular-bellshaped, 5-lobed. Fertile stamens 4, didynamous; anthers smooth. Valves of the capsule flattened parallel with the partition, and separating from it at maturity. Seeds flat, winged. - Climbing woody vines. Leaves opposite, compound.

1. B. capreolata, L. Leaves erergreen; the short petiole terminated by 2 cordate-oh! ng entire stalked leaflets, with a branched tendril between; pedi cels clustered, axillary, elongated. - Woods, Florila to Mississippi, and nortlward. A pril. - Stem climbing high. Leaflets $3^{\prime}-6^{\prime}$ loug. Corolla $2^{\prime}$ long, red witlout, yellow within. Capsule $\frac{1}{2}$ long.

\section{TECOMA, Juss. Trumpet-Flower.}

Calyx bell-shaped, 5-toothed. Corolla funnel-shaped, 5-lobed. Fertile stamens 4, dillynamous. Valves of the capsule convex, contrary to the partition. Seeds winged. - Shrubs or woody vines. Leaves opposite, compound, decidnous.

1. T. radicans, Juss. - Stem climbing by rootlets; leaves pinnate, more or less pubescent; leaflets $9-11$, ovate or ovate-lauceolate, acute or acuminate, serrate; racemes terminal, few-flowered. (Bignonia radieans, L.) - Woods and margins of fields, Florida to North Carolina, and westwarl. May and June. Corolla $2^{\prime}-3^{\prime}$ long, searlet without, yellow within. Capsule $4^{\prime}-5^{\prime}$ long.

2. T. stans, Juss. Stem erect; leaves smooth, pinnate, long-petioled; leaflets 7 , lanceolate, acute, finely serrate; racemes many-flowered; calyx tubular; stamens 5, the fifth bearing an abortive anther. - South Florida. Mareh - May. - Stem $3^{\circ}-4^{\circ}$ high. Corolla $1 \frac{1}{2}$ long, yellow.

\section{CATALPA, Scop.}

Calyx 2-lipped Corolla bell-shaped, somewhat 2-lipped, 5-lobed. Fertile stamens 2. Valves of the eylindrieal capsule contrary to the partition. Seeds flat, with fimbriate wings. - Small trees. Leaves simple opposite. Flowers in terminal panicles.

1. C. bignonioides, Walt. Leaves large, corlate, entire or angularly lobed, acuminate, long-petioled, pubeseent; panicle trichotomous, m:my-flowered;'calyx purple; corolla white, variegated with yellow and purple within, the lobes undulate; capsule slender, elongated, pendulous. (C. cordifolia, Ell.) - River-banks, Georyia, Florida, and westward. May. - Corolla 1' long. Capsules $1^{\circ}$ long.

\section{MARTYNIA, L. Unicorn-Plant.}

Calyx 5-eleft, 2-3-bracted. Corolla irregular, tubular-bell-shaped, unequally 5-lobed. Fertile stamens 2 or 4 . Capsule woody, falsely 4-celled, ending in two long recurved horns, and opening between them. Seeds wingless. - Viscid 
branching anmals. Leaves petioled, entire, roundish, the upper ones alternate. Flowers ratemed.

1. M. proboscidea, Glox. - Stems thick, at length prostrate; leaves

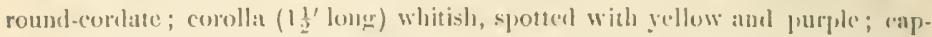
sule erested on one side, shorter than the beaks. - IViste places. Introduced. July and Aug.

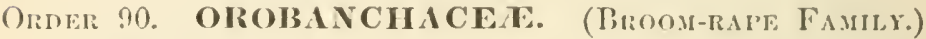

Jow, leafless, sealy herbs, parasitic on roots, with bilabiate dirlynamous flowers. - Calyx 4-5-toothed or parterl. Corolla witheringrepesistent, tubular, the upper lip 2-elett or entire, the lower 3-lobed. Stanens inserted on the tube of the corolla: anthers persistent. Ovary free, ]-cellenl, with 2-4 parictal placentx. Style simple, curvel at the apex: stigma thick, 2-luberl. Capsule 2-valved, many-secelel. Serls very small, anatropous, with the minute embryo at the base of transparent albumen. Flowers perfect or polygamous, solitary or spiketl.

\section{Synopsis.}

1. ElPIPfics. Flowers polygamous, spiked; the lower ones fertile, the upper sterile. Can ly 2 -lineted, 5-toothed. Stem branching.

2. Coxopliot,s. Flowers perfeet, spiked. Calyx 2-bracted, cleft on the lower side. Stem simple, thick and fleshy.

3. APllYilox. Flowers solitary, perfect. Calyx bractless, 5-eleft. Corolla aearly equally 5 -lobed.

\section{EPIPHEGUS, Nutt. Benchimora.}

Flowers polygamons; the upper ones slender and sterile, the lower abbreviated and fertile. Calyx 5-toothed. Capsule 2-valved at the apex, with 2 placenta on earh vilve. - Stem smooth, slender, mueds branched, puplish. Flowers small, in loose slender spikes. Corolla jurplish.

1. E. Virginiana, Bart. - Under Beech-trees, in deep shades, Florida to Mississippi, and northward. Aug. - Stems $6^{\prime}-12^{\prime}$ high. Flower's scuttered. Corolla of the sterile flowers $4^{\prime \prime}-6^{\prime \prime}$ long, 4-toothed, curved.

\section{CONOPHOLIS, Wall. SqUAW-ROOT.}

Flowers perfeet, densely spiked. Calyx 2-bracted, tubular, 4-toothed, eleft on the lower side. Lpper lip of the corolla areling, notelbed; the lower short, 3toothed. Stamens exscrted. Capsule 2-valved, with 2 pliacentae on cach valve. - $A$ thick and feshy whitish simple herb, covered with imbricated scales. Flowers yellowish, spreading.

1. C. Americana, Wallr. (Orobanche, L.) - Shady woods, Florida to Mississippi, and nortluward. April. - Stems clustered from matted roots, $4^{\prime} \cdot 6^{\prime}$ high, $\frac{1}{2}$ ' thick. 


\section{APHYLLON, Mitchell.}

Flowers solitary, perfect. Cillyx 5-cleft, bractless. Corolla tubular, eurved, nearly equally 5-lobed. Stamens included. Capsule 2-valved, with 4 equidistant plicentx. - Stemless or nearly so. Flowers purplish, on a long seape or peduncle.

1. A. uniflorum, Torr. \& Gray. - Stem very short and sealy ; peduncles l-scveral, $3^{\prime}-5^{\prime}$ high, pubescent; calyx-lobes lanceolate-subulate. (Orobanche uniflora, $L$ ) - Woods, Florida, and northward.

\section{Order 91. SCROPHULARIACEA. (Figwort Famly.)}

Cliefly herbs. Leaves commonly opposite, without stipnles. Calyx 4-5-cleft or parted. Corolla 4 -5-lobed, regular, or bilabiate; the lobes imbricated in the bud. Fertile stamens 4 (sometimes 2, rarely 5), mostly didynamons, inserted on the tube of the corolla: anther-cells often separate, opening lengthwise. Ovary free, z-celled, many-ovuled. Placentx central. Style simple or 2-cleft. Capsule 2-celled, many- (rarely 1-few-) seeded. Seeds anatropous. Embryo small, in copious albumen.

\section{Synopsis.}

\$1. Upper lip of the corolla exterior in the bud (except Mimulus). Capsule commonly repticidally dehiscent.

* Stamens 5, all perfect. Corolla regular.

1. VERBASCUM. Corolla wheel-shaped. Filaments, or a part of them, bearded. Leaves alternate.

* Fertile stamens 4 ; the fifth sterile or rudimentary. Flowers cymose. Leaves opposite.

2. SCROPIIULARIA. Fifth stamen scale-like. Corolla globose or oblong; four of the lobes short and erect.

3. CIIELONE. Fifth stamen shorter than the others. Corolla tubular, inflated, contracted at the throat. Seeds winged.

4. PENTSTEMON. Fifth stamen as long as the others. Corolla dilated upward. Seeds wingless.

* * Fertile stamens 4 : sterile ones none. Flowers axillary or racemed.

5. LINARIA. Corolla spurred at the base. Capsule toothed at the apex.

6. MinuluS. Caly $x$ tubular, 5-angled, 5-toothed. Corolla large.

7. IIERPESTIS. Calyx 5 parted, the three onter lobes much larger. Corolla short.

**** Fertile stamens 2 : sterile ones 2 or none.

8. GRATIOLA. Caly $x$ 5-parted. Sterile filaments entire, included. Capsule ovate or globose.

9. ILYSANTIIES. Caly 5 5-parted. Sterile filaments 2-cleft, exserted. Capsule oblong.

10. IICRANTHEMUI. Caly $x$ 4-parted A scale-like appendage below the filaments.

\$2. Upper lip of the corolla interior in the bud. Capsule commonly loculicidally debiscent.

* Corolla regular or slightly 2-lipped; the lobes nearly equal.

1- Stamens 2, distant. Capsule mostly obcordate.

11. AMPIIANTIIUS. Style 2-cleft. Flowers solitary, terminating the central scape and in the axils of the tufted radical leaves.

12. VERONICA. Style simple. Flowers in leafy racemes or spikes.

- Stamens 4 - 5, equal. Peduneles axillary, 2 or more together.

13. CAPRARIA. Corolla bell-shaped, 5-cleft. Capsule loculieidal. Leaves alternate.

14. SCOPARIA. Corolla wheel-shaped, 4-cleft. Capsule septicidal. Leares opposite or whorled 
- + - Stamens 4 Flowers meemed or spikinl.

t+ Anthers 1-celled.

15. Brolixiza. Corolla nalver-shaped. Stamens didynamoun. Tlowers apiked.

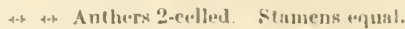

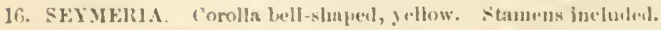

Ji. HAC'RANTILRA. Corolla tubular, omage. situmens long-exnerted.

$\leftrightarrow+4$ Anthers 2-celled. Stamens didy namous.

15. OTOPIILLA. Anthers unequal. Corolla bell-shaped. Cpper leares 2 -eared at the base

19. DAsistoyA. Anthers eijual, awned at the base. Corolla funnel-shaped, yellow. Leaves mostly pinmatificl.

20. GERARDIA. Anthers equal, pointed at the base. Corolla bell-shaperI, purpie. Leaves narrow, entire.

- Corolla tubular, 2-lipped; the upper lip arebing and enclosing the 4 didynamous stauens.

- Anther-cells unequal.

21. CASTILI.EIA. Anther-cells separate. Leares alternate, the floral ones eolorer.

+ - Anther-cells equal.

22. SCIIWAIBEA. Calyx 10-12-ribhed, the upper tecth smaller. Capsule oblong, manyseeded. Leaves entire, alteruate.

23. PEDICULALIS. Capsule sword-shaped, few-seeded. Leares pinnatifid.

24. IELAMIYICM. Caly $x$-cleft. Capsule flat, 1-t-seeded. Upper leaves bristly-tootlied at the base.

\section{VERBASCUM, L. MulleiN.}

Calyx 5-parted. Corolla rotate, 5-lobed; the lobes nearly equal, roundish. Stamens 5, declined, all, or a part of them, bearded. Stigna simple. Capsule globose, many-sceded. - Tall biennial herbs. Leaves alternate. Flowers in racemes.

1. V. Thapsus, L. Woolly throughout; stem stout, simple; leaves slightly erenate, rugose; the lowest large, oblung, petioled, the others broudly decurrent on the stem; raceme spike-like, dense, cylindrical; flowers yellow. Olel fields and waste ground. Introduced. - Stem $2^{\circ}-5^{\circ}$ high. Lowest leaves $1^{\circ}$ long. Raceme rigid, $1^{\circ}-2^{\circ}$ long.

2. V. Blattaria, L. Stem smooth below, pubeseent above, sparingly branclsed or simple; leaves smooth. oblong, acute, serrate or pinnately lobed; the lowest petioled; the upper clasping; racemes elongated, glandular, the flowers scattered; corolla bright or pale yellow; filaments all bearled with purple hairs. - Waste ground, chiefly in the upper districts. Introluced. Stem $2^{\circ}-3^{\circ}$ high.

3. V. Lychnitis, I. Plant mealy-white; stem branching and angled above; leaves ovate, acute. sessile; the lowest narrowed into a periole, greenish above; flowers in a pyranidal panicle, yellow; filaments bearded with whito hair:- In Carolina, Muhlenberg. Introduced.

\section{SCROPHULARIA, L. Figwort.}

Calyx 5-parted. Corolla globose or oblong, 5-eleft ; the 4 upper lobes ereet, with the two uppermost longer; the lowest spreading. Stamens 4, declined; the fifth sterile and scale-like, placed near the orifice of the tube of the corolla : 
anther-cells transverse and confluent into one. Capsule many-secded. - Tall herbs, with opposite leaves, and greenish-purple flowers in loose cymes, forming a narrow panicle.

1. S. nodosa, L. Smooth; stem 4-sided; branches elongated, spreading; leaves ovate or oblong, or the uppermost lanceolate, acute, serrate, rounded or cordate at the base; flowers small. (S. Marilandica, L.) - Shady banks and thickets, Florida to Mississippi, and northward. Sept. - Stem $2^{\circ}-5^{\circ}$ high.

\section{CHELONE, Tourn. STake-HEAD.}

Calyx 5-parted or 5-sepalous, braeted. Corolla inflated-tubular, contracted at the throat, bilabiate; the upper lip coneave, emarginate; the lower obtusely 3-lobed, woolly in the throat. Stamens 4 , with the filaments and cordate anthers woolly, and a fifth sterile one shorter than the others. Seeds inbricated, broadly winged. - Smootl perennial herbs, with opposite serrate leaves, and large white or purple flowers in short dense bracted spikes.

1. C. glabra, L. Stem simple or branched, 4-sided; leaves laneeolate or oblong, acute or acuminate, on very short petioles; spike terminal, imbricated, nearly sessile, simple or branched; bracts and sepals orate; corolla white or rose-color. (C. obliqua, L.) - Wet banks of streams, Florida and northward, rare in the lower districts. Sept. - Stem $2^{\circ}$ high. Leaves $2^{\prime}-4^{\prime}$ long, some. times pubeseent beneath. Corolla $1^{\prime}-1 \frac{1}{2}^{\prime} \mathrm{long}$, coneave beneatl.

2. C. Lyoni, Pursh. Stem simple or branchel; leaves orate or ovateoblong, rounded or eordate at the base, acuminate, serrate, conspicuously petioled, mostly pubescent on the veins beneath; spike sessile, simple or branched; bracts and calyx-lobes ovate, eiliate; flowers purple. (C. latifolia, Muhl., leaves acute at the base.) - Mountains of North Carolina. Sept. - Stem $2^{\circ}-3^{\circ}$ high. Leaves $4^{\prime}-6^{\prime}$ long, thinner, and the flowers smaller than in the preceding.

\section{PENTSTEMON, L'Her.}

Calyx 5-parted. Corolla inflated-tubular, or somewhat bell-shaped, open at the throat, bilabiate; the upper lip rounded, concave, emarginate or 2-lobed; the lower 3-lobed. Stamens 4, deelined at the base, and a fifth sterile one as long as the others, and commonly bearded above. Cipsule 2-valved, manyseeded. Seeds wingless. - Erect perennial herbs, with opposite leaves, and white or purple flowers in axillary and terminal cymes, forming a close or open narrow terminal paniele.

\section{* Leaves pinnately devided.}

1. P. dissectus, Ell. Smootl or minutely pubeseent; divisions of the leaves linear, obtuse, entire or sparingly lobed ; eymes few-flowered, long-peduneled; corolla somewhat bell-shaped, with rounded and nearly equal lobes; anther-cells smooth, spreading; sterile stamen bearded at the apex. - Dry soil in the middle districts of Georgia. - Stem $2^{\circ}$ high, slender. Calyx-lobes small, acute. Corolla $9^{\prime \prime}-10^{\prime \prime}$ long, purple. 


\section{* * Iseres renelivirlad.}

2. P. pubescens, Solimler. I'uixesent or smuoth; leaves lanceolnte, acute, scrate or entire, sessile or clasping; the lowest os ate or oblong, tapering into a slender petiole; rymes sprending, few-flowered ; tule of the corollat gradnally dilated above the middle; the lower lip longer thim the upper; sterile stanen bearded down one side; anthers suowtl. (P. lacrigatus, Soland., a smooth form.) - Dry open woods and fence-rows, Florida to North Carolina, nud westwad. Jume and July. - Stem $2^{\circ}$ high. Lowest leares $3^{\prime}-5^{\prime}$ long. Corollit l' long, pale purple.

3. P. Digitalis, Nutt. Smooth or nearly so: stent-leaves ovate-lancelate, serrate or entire, clasping; the lowest ollong, narrowed into a petiole; cymes fiw-flowered, sureading, forming a narrow panicle; tube of the corolla alsuptly ditated near the base; the lips neary equal; sterile stamen bearded down one side. - Dry soil, Georgia, Florida, and westward. July. - Stem $2^{\circ}$ high. Corolla $9^{\prime \prime}-12^{\prime \prime}$ long, white or pale jurple.

Var. multiflorus, Benth. Larger $\left(3^{\circ}-4^{\circ}\right.$ lijul) ; leaves thicker; cymes many-flowered, forming a large spreading panicle; corolla smaller. - l'ine barrens, Florida.

\section{IINARIA, Juss. Tonit-Fix.}

Calyx deeply 5-parted. Corolla personate, spurred at the base; the upper lip emarginate or 2-lolexl; the lower 3-lobed; the throat commonly closed by the prominent palate. Stamens 4, didynamous. Capsule grlolose or ovoid, opening at the apex, with few or sereral tooth-like valves, many-seeded. - Herhs, with alternate or (on the radical branches) opposite or whorled leaves, and axillary or racemose flowers.

* Stems with prostrute Inunches at the luse, zchich bar broader opposite or uchorled leares.

1. L. Canadensis, Spreng. Smooth; stem erect, stenter, mostly simple; leaves linear, fat, scattered; those on the radical branclues ohlong; racemes straight ; jedicels creet, as long as the calyx; lobes of the surall $\left(3^{\prime \prime}-4^{\prime \prime}\right)$ blue and white corolla rounderl; spur filiform, emred, as bongr as the pedicels. (Antirhinum Canadense, $L$ ) - Cultivated ground, common. April and May. (2) - Stem $10-20$ hight.

2. L. Floridana, n. sp. Stem smooth, ascending, panicnlately much branched; Jeaves scaltered, fleshy, terete, lincar or ("lub-shaped; those on the radical branches ohovate; racemes elongated, flexuous glandular-hairy ; pelicels sprealing, 3-4 times as long as the (alyx ; lobes of the small (2") blue corolla truncate or emarginate; spur very short. - Drifting sands near the const, West Florida. April ambl May. (2) - Stem $3^{\prime}-12^{\prime}$ highl.

\section{* * Prostrute branclies none.}

3. L. vulgaris, Miller. Smooth; stem ereet, simple or branched; Ieaves alternate, linear or linear-lanecolate, crowiled ; raceme dense; flowers large (1' long), yellow ; spur subulate; sectl flattened, marginct. - Waste places, North Carolina, and northward. Naturalized. Aug. $4-$ Stem $1^{\circ}-3^{\circ}$ higgh. 
4. L. Elatine, Miller. Inairy; stem prostrate, slender, branching; leaves small, ovate and hastate; the lowest sometimes opposite and toothed; pedicels axillary, filiform, commonly longer than the leaves; flowers small, yellow and purplish ; calyx-lohes lanccolate, acute. - Waste places, North Carolina. Naturalized. (1) - Stem $4^{\prime}-12^{\prime}$ long.

\section{MIMUULUS, L. Moxíx-Fowk.}

Calyx tubular, 5-angled, sharply 5-toothed. Corolla bilabiate; the upper lip 2-lobed, ereet or reflexed; the lower 3-lobed, spreading. Stamens 4, dirlynamous : anther-cells somewhat confluent. Stigma orate, 2-lipped. Capsule loculicidally 2-valwed, many-seeled. - Erect smooth perennial herbs, with opposite leaves, and axillary purple flowers.

1. M. ringens, L. Stem compressed, 4-anglerl, the angles wingless; leaves oblong or lauceolate, denticulate, cordate ant ciajping at the base; peduncles longer than the flowers. - Swamps in the upper districts. Aug. - Stem $1^{\circ}-2^{\circ}$ high. Leares thin, $2^{\prime}-4^{\prime}$ long. Corolla showy, the palate greenish and puheseent.

2. Mr. alatus, Ait. Stem square, with winged amgles; leaves oblong-ovate, aeuminate, serrate, tapering at the base into a petiole; peduneles shorter than the flowers. - Swamps, Florida, and northward. July and Ang. - Stem $2^{\circ}$ high. Leares $2^{\prime}-5$ long. Calyx-tecth small.

\section{HERPESTIS, Gærtn.}

Calyx 5-parted; the 3 outer lobes, especially the upper one, broader. Corolla bell-shaped, 5-lobed or bilabiate, with the upper lip 2-lohed or emarginate, the lower 3-lohed. Stamens 4, didynanous: anther-cells contignous or divaricate. Style dilated and flittened at the apex. Capsule 2-valved, many-seeded. - Low herbs, with opposite leaves. Flowers opposite, axillary, or in leafy terminal racemes.

\section{* Stems 4-tungled: leaves serrate: peduncles 2-bracted at the base : exterior calyx-lobes oblong: corolla uhite.}

1. H. nigrescens, Benth. Smooth; stem ereet, simple or lranched; leaves oblong or olslong-obovate, rather obtuse, serrate above the mildlle; lower feduncles as long as the leaves, the upper much longer; tube of the corolla striped with bite; the upper lip rounded. (Gratiola acuminata, Wall.) - Low ground, Florida to North Carolina, and westward. Ang and Sept. - Stem $1^{\circ}$ $-1 \frac{1}{2}$ liigh. Leaves $1^{\prime}-2{ }^{\prime}$ long.

2. H. peduncularis, Benth. Smooth; steın decumbent, diffuse, creeping near the hase; leaves small, ohorate-oblong, entire near the base; peiluneles filiform, 3-4 rimes as long as the leares. - Key West. - Stems $6^{\prime}-12^{\prime}$ long Leaves $4^{\prime \prime}-6^{\prime \prime}$ long. Flowers smaller than in No. 1. 
* * Stems lerite, succulent, crecping: leaves orate or roundish, entire: cxterior culyx.

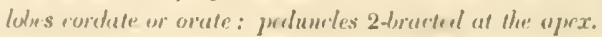

3. H. Monnieria, limuth. Snooth; stems diflise, (recping; leaves fleshy, wedge-obovate, eutire or obscurely erenate; corolla bell-shajeel, with the romuled lobes nearly equal; peduncles as long as the flowers; exterior calyxloles ovate. (1I. cuncifolia, Pursh.) - Jitches and mully banks along the coast, Florila to North Carolina, unl westward. Jume - Scept. 4-Stem 10 $-2 \circ$ long. Leaves 1 ' long. Corolla white or prale blue.

4. H. amplexicaulis, Pursh. Stem villons, ascending from a crepping lase; leaves smoothish, ovate, cordate and clasping, obtuse; jerluncles slorter than the flowers; exterior calyx-lobes cordate; hase of the ovary surroumled hy a 12-toothed disk. (H. rotumlifolia, Ell., not of P'ursh.) - P'ine-barreu pomls, Florida to North Carolina, and westwarl. July - Sęt. \& - Flowering stems $6^{\prime}-8^{\prime}$ light. Leaves $\frac{1}{2}$ long, crowded. Flowers bluc. Plant udorous.

\section{GRATIOLA, L. Hene-Hrssor.}

Calyx 5-parted, the lobes nearly epnal, narrow. Corolla bilabiate, with tho upper lip entire or emarginate, the lower 3-cleft. Fertile stamens 2, included, the anterior ones sterile or wantiugr. Stigma 2-lipped. Capsule 4-valved, manyseeded. - Jow perennial herbs, with opposite leaves, and solitary axillary white or yellow flowers. Calyx mostly 2-bracted.

* Connective of the anthers diluted, the cells transverse: stems tender: flowers priluncled.

+ Sterile stamens minute or none.

1. G. Virginiana, L. Stem branching from the base, glandular-pubescent above; leaves lanecolate, acute, sparingly serrate, scssile, the lower ones narrowed at the base; petuncles slender, the upper ones longer than the leaves; corolla white, with the yellowish tube twice as long as the ealyx; calpsule ovate, acnte. - Mudly banks and ditches, Florida to Mississippi, and northward. $A$ pril and May, - Stem $6^{\prime}-12^{\prime}$ high. Leaves $1^{\prime}$ long. Corolla $5^{\prime \prime}-6^{\prime \prime}$ long, hairy within.

2. G. Floridana, Nutt. Stem simple or lrancherl, smooth ; leaves laneeolate or oblong, ubtuse, entire or nearly so, narrowed at the base, sessile, the lowest slightly petioled; peduneles filiform, longer than the leaves; lohes of the corolla emarginate. white; the slender yellowish tube three times as long as the ealyx. - Muddy hanks of the Chipola River, West Florida. April. - Stem 10 high. Leaves $1^{\prime}$ long. Corollia $8^{\prime \prime}$ long. Capsule globose.

3. G. sphærocarpa, Ell. Smooth ; stem thick, ascending, branching at the base; leaves oblong or lance-obloner, surrate ahove, narrowed and entire towards the base, sessile, the lowest mostly ohovate; peduncles thick, shorter than the leaves, sometimes shorter than the caly'x ; corolla white, the tube twice as long as the calyx; capsule glohose. - Springs and branches, Florida to South Carolina, and westward. March-May. - Stem $4^{\prime}-12^{\prime}$ ligh. Leaves 1' long. Corolla $\frac{1}{2}$ long. 


\section{+ - Sterile stamens manifest.}

4. G. viscosa, Schwein. Viscil-pubescent; stem ascending, simple or sparingly branclıed ; leaves orate-lanceolate, acute, sharply serrate, clasping, 3-nerved; pedumeles as long as the leaves; lobes of the corolla white, emarginate, the tube yellowish and bearded within; calyx-lobes lanceolate, much longer than the small globose capsule. - Ditches aud muddy places in the upper districts, Mississippi to North Carolina. June-Ang. - Stem 6'-12' high. Leares $\frac{1}{2}$ long. Corolla $5^{\prime \prime}-6^{\prime \prime}$ long. Bracts wider than the calyx-lobes.

5. G. Drummondi, Benth. Viscid-puberulent; stem decumbent at the base, ascending; leaves lanceolate, acute, sparingly serrate, 3-nerved, clasping; bracts and calyx-lobes subulate, much longer than the capsule. - In Georgia, Boykin, and westward.

6. G. quadridentata, Michx. Pubeseent and somerwat viscid; stem decumbent at the base, ascenling, simple or branched ; leaves lanceolate, sessile, 4-toothed; peduncles mostly longer than the leaves; corolla ycllowish-white; eapsule small, globose, mnch shorter than the linear unequal calyx-lobes; bracts minute. - Margins of pine-barren ponds, Florida to South Carolina, and westward. June - Aug. - Stem $4^{\prime}-6^{\prime}$ high. Leaves $\frac{1}{2}^{l}$ long. Corolla $5^{\prime \prime}$ long.

7. G. aurea, Muhl. Smooth; stem decumbent, creeping, the flowering branches ascending, 4-angled; leaves sessile, oblong-lanceolate, slightly serrate; peduncles as long as the leaves, or the upper ones longer; bracts as long as the ealyx; corolla bright yellow. - Wet pine barrens in the lower districts of Georgia and Sonth Carolina. April-June. - Steuı $1^{\circ}-2^{\circ}$ long. Lcaves $\frac{1^{\prime}}{2}-1^{\prime}$ long. Corolla $6^{\prime \prime}$ long.

8. G. officinalis, L. Smooth ; stem ereet, 4-angled above; leaves laneeolate, serrulate or entire, slightly clasping; peduncles shorter than the leaves; corolla pale yellow, striped with red, bearded with yellow hairs within; capsule aeute, as long as the calyx. - Swamps, in the Soutbern States, Leconte. Stem $1^{\circ}-2^{\circ}$ high. Corolla $8^{\prime \prime}-10^{\prime \prime}$ long.

* * Connective of the anthers not dilated; the cells vertical: stems rigid, hairy: flowers sessile: sterile stamens manifest.

9. G. pilosa, Michx. Hirsute; stem ercet, simple or branching at the base; leaves ovate or roundish, sparingly toothed, sessile or slightly clasping; corolla tubular, white, seareely longer than the calyx. - Low ground, Florida to Mississippi, and northward. June-Aug. - Stem $8^{\prime}-16^{\prime}$ ligh. Leaves $\frac{11}{2}$ long. Corolla $t^{\prime \prime}$ long.

10. G. subulata, Baldwin. Shrubby, hispid ; stem mach branched, mostly prostrate; leaves lincar, entire, the margins revolute; calyx-lobes subulate, unequal; corolla salver-shaped, somewhat persistent, the upper lip romisht, the lower 3-parted; the slender eurved tube three times as long as the calyx, hairy within; lobes of the stigma emarginate; capsule acute. - Low santy pine barrens, Florida, near the coast. July - Sept. - Stem $3^{\prime}-6^{\prime}$ long. Leaves $3^{\prime \prime}-6^{\prime \prime}$ long. Corolla $6^{\prime \prime}$ long. 
9. ILYSANTHES, liıf.

Calyx 5-parted, bractless. Cowlla bilabiate; the upper lip short, crect, 2-cleti; the lower langer, spreading, 3-cleft. Jiertile stunces 2, incluted; the two anterior enes sterile, 2-lobed, with one of the bobes tiplpeel witls a gland, the other smooth, areute. Capsule ovate or oblomer as lone ns the calyx - Sinooth

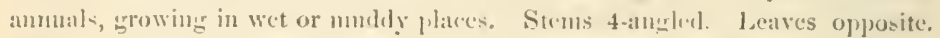
I'eluncles axillary, often reflexel in fruit. Flowers small, purplish.

1. I. grandiflora, Benth. Stem ereeping, very leafy"; leares roundist, entire, nervelen, partly claspingr peduncles $2-3$ times ns lomer as the leaves; sterile stamens lohed at the midelle. - In Georgia, Vuttull. - Icares $3^{\prime \prime}-4^{\prime \prime}$ long. Corolla larger than in the next.

2. I. gratioloides, Benth. Stem ereet, at length difinsely manched; leaves lanceolate, oblong, or ovate; the lowest narrowed into a periule, the upper sessile, alcute, olsecurely toothed or entire; lower peduncles mostly shorter than the leaves, the upper much longer, spreadine; corolla pale bluce, twice als lomer as the ealyx; (a)psule oblong. acute, scarecly longer than the calyx. (Limdernia dilatata and aftenuata, Ell. Gratiola anagalliclea, Mich.x. G. tetragrona, Ell.?) - Springs and rivulets, common. May-Sept. - Stem $6^{\prime}-12^{\prime}$ long. Lcares $\frac{1}{2}$ - 1' long. Corolla $3^{\prime \prime}-4^{\prime \prime}$ long.

3. I. refracta, Benth. Stem erect, very slender, forking; radieal leaves tufted, oblonir, obtuse, entire, narrowed at the base; the others remote, small, lanceolate, sessile; perluncles filiform, many tımes longer than the leaves, reflexel in fruit; corolla pale blue variegated witl purple; (apsule oblongr-linear, twice ats loner as the calyx. (Lindernia montienla, Nuth.) - Springs and mudly banks of rivulets in the middle and upper elistrirts, Misisiplpi to North Carolina. July - Scpt. - Stem $6^{\prime}-12^{\prime}$ high. Riadical leares $1^{\prime}$ long. Corolla $3^{\prime \prime}-4^{\prime \prime}$ long.

4. I. saxicola. Stems clustered, leafy, simple or sparingly branched; leaves oblong, cutire, obtuse, sessile; the radical ones densely tufted, narrowed into a petiole; peduncles rather stout, $3-4$ times as longe as the leaves, willely spreading or reflexed in fruit; rorolla liae, variegated ; (alysule oroid, rather longer than the calyx. (Lindernia saxicola, M. A. Cintis.)-On rocks at Tolula Falls, freorgia, and Cherokee, Yorth Carolina, Curtis. Aug. 4 ?Stems $3^{\prime}-5^{\prime}$ higgh. Stem-leaves $2^{\prime \prime}-t^{\prime \prime}$ long. Corolla $4^{\prime \prime}$ long.

\section{MICRANTHEMUM, Michx.}

Calyx 4-parted, or 4-cleft. Corolla somewhat bilabiate; the upper lip shorter, entire; the lower 3-lobed, with the mildle lobe lonerer. Stunens 2, incluberl; the flaments with a gland-like appendage at the lase: anther-eclls diverging. Style short: stigna eapitate. Capsule 2-valverl, few-secded; the delicate partition vanishing at maturity. Seeds oblong, reticulate. $-\Lambda$ small smooth perennial herb, with diffuse ereeping stems, roundish opposite entire leaves, and minute nearly sessile axillary white flowers. 
1. M. orbiculatum, Miehx. (M. cmarginatum, Ell. IIemianthus mi(ranthemoides, Nutt. Herpestis micrantha, Ell.? not of Pursh.) - Muddy banks, Florida to North Carolina, and westwarl. June-Oet. - Stem 6'-12' long. Leaves $3^{\prime \prime}-5^{\prime \prime}$ long, sometimes emarginate. Corolla not longer than the minute $\left(\frac{1}{2}{ }^{\prime \prime}\right)$ ealyx.

\section{AMPHIANTHUS, Torr.}

Caly 5-parted. Corolla somewhat funncl-shaped, 4-cleft; the upper and lower lobes rather longer. Stamens 2: anther-cells distinct. Style minutely 2-cleft at the apex, acute. Capsule obcorlate, compressed, loenlicidal. Seeds oblong, rugulose. - A very small annual, with the linear obtuse leaves clustered at the summit of the short stem, and minute white flowers, some of which are borne on short naked recurved peduncles from the axils of the leaves, and others on a slender ( $1^{\prime}$ long) terminal 2-bracted seape.

1. A. pusillus, Torr. - In shallow cxcarations of flat rocks, Newton County, Georgia, Di. Leurenworth. Mareh and April.

\section{VERONICA, L. SPEedwell.}

Calyx 4-5-parted. Corolla wheel-shaped, or salver-shaped, 4-5-lobed. Stamens 2, one cach side of the npper lobe of the corolla. Stigma capitate. Capsule compressed and obcordate, or oblong and obtuse, septicilal or loculicidal. Seeds few or many, flattened or eoneave on the inner face. - Chiefly herls, with the stem-leares opposite or whorled, the floral ones alternate. Flowers small, axillary, racemed or spiked, blue or white.

\section{* Leaves whorled: corolla tubular: capsule oblong.}

I. V. Virginica, L. Perenuial, smooth or pubescent; stem tall, erect; leares $4-7$ in a whorl, lanceolate, serrate, short-petioled; flowers very numerous, crowded in axillary (whorled) and terminal spikes; stamens long-exserted; corolla white or purple. (Leptandra, Nutt) - Mountain-meadows, Georgia, and northward. June - August. - Stem $2^{\circ}-4^{\circ}$ high. Leaves $2^{\prime}-4^{\prime}$ long.

* * Stem-leuves opposite: corolla uheel-shaped: capsule obcorclate.

+ Flowers in dense axillary racenes.

2. V. officinalis, L. Perennial, pubesecut; stem prostrate, rooting at the base; leaves obovate-elliptical, or wellge-oblong, obtuse, serrate, short-petioled; raeemes alternate, many-flowered ; corolla blue. - Mountains of North Carolina, and north ward. July. - Stem $6^{\prime}-12^{\prime}$ long. Racemes $2^{\prime}-4^{\prime}$ long.

+ + Flowers scattered, in leafy terminal racemes.

3. V. serpyllifolia, L. Perennial, smoothish; stem ascending, diffusely branched ; leaves oval or roundish, crenate, short-petioled, the floral ones lanceolate and entire; pedicels as long as the calyx ; corolla blue. - Low pastures in the upper districts. May - Sept. - Stem $4^{\prime}-6^{\prime}$ long. Leaves $4^{\prime \prime}-6^{\prime \prime}$ long.

4. V. peregrina, L. Annual, smooth; stem erect, simple or branched; leaves sessile, oblong, toothed; the lowest narrowed into a petiole; the floral 
mes cutire; priduncles slorter than the ralyx; corolla white, minnte. - Cultivated ground, very common. April-Jume-Stem 2'-12' high. Leaves $j^{\prime}-l_{1}$ lomir.

5. V. arvensis, I. Anmual, hairy; stems ascending, loranclied at the base; leaves orate, obmes, crenate, petioled; the floral omes laureolate, entire, ses-ile; flowers me:try sessile; rorolla pale hlue. - Cultivated ermuml. Introdured. Niy and June. - Stems $6^{\prime}-12^{\prime}$ light. Jucaves $f^{\prime \prime}-6^{\prime \prime}$ long.

6. V. agrestis, I. Annual, puluescent; stems prostrate, diffisely brancliel; leaves all petioled, ovate, coarsely serrate; peluncles much longer than the ealyx, recurved in fruit; corolla blue, striate. - Cultivated grouml. Introducedl. Fel. - May. - Stem 6'-12' long. Leaves 6" $-9^{\prime \prime}$ long. Fruiting calyx much enlarged.

\section{CAPRARIA, L.}

Calyx 5-parted, equal. Corolla bell-shaperl, equally 5-Jobed, smootls within. Stamens 4-5: anthers sagittate. Style slender: stigmat thick, ovate, at length 2-lolvel. Capsule coriaceous, ovate, septicilally 2-valved, the valves 2-reft at the apex. Secds numerous, reticulate. - Perennial herbs, or slurublyy plants. Leaves alternate, serrate. Peduncles axillary, single or by pairs, mostly 1flowered.

1. C. biflora, I. Shrubby, smooth or puheseent; stem erect, branching; leaves lanceolate or oblong, sharply serrate, narrowed and entire below the middle; peduncles filiform, mostly by pairs, shorter than the leaves; calyxlobes linear; corolla deeply 5-eleft; stamens 5, included. - South Florida. Nov. - Stem $2^{\circ}-3^{\circ}$ high. Leares $1^{\prime}-1 \frac{1}{2}^{\prime}$ long. Flowers white?

\section{SCOPARIA, L.}

Calyx 4-5-parted. Corolla wheel-form, 4-cleft, hairy in the throat. Stamens 4. Style club-shaped at the apex. Capsule septicidally 2-valved, the valves inembranaceous, entire. Seeds numcrous, reticulate. - Herbaceons or slumbly plants, with opposite or whorled leaves. Peduncles axillary, commonly by pairs, l-flowered.

1. S. duleis, I. Annual, smooth; leaves ovate or oblong, toothed, mostly three in a whorl, much longer than the perluneles; ealyx-lobes oblong; flowers small, white. - South Florida. - Stem $1^{\circ}-3^{\circ}$ high. Leares $\frac{1}{2}^{\prime}-1^{\prime} \frac{1}{2}^{\prime}$ long.

\section{BUCHNERA, L.}

Calyx tubular, 5-toother. Corolla salver-shaped, 5-lobed, the lobes wedgeobovate. Stamens 4, didynamons, included: anthers 1-cellel. Style simple, club-shaped at the apex. Capsule coriaceous, straight, loculicidally 2-valved, the ralves entire. Sceds numerous, reticulate. - Rough herbs, turning black in withering. Leaves opposite, toothed or entire; the uppermost small, and passing into the braets of the many-flowered spike. Flowers blue. 
1. B. elongata, Swartz. Rough with short rigid hairs; stem mostly simple; leaves entire or slightly toothed, 1-nerved, or obscurely 3-nerved; the lowest obovate or obovate-oblong, obtuse, the lower stem-leaves narrowly lanceolate; the uppermost distant, acute; spikes interrupted, long-peduncled; flowers opposite or alternate. - Low pine barrens, Florida, Georgia, and westward. July abd Aug. -- Stem $1^{\circ}-2^{\circ}$ high. Corolla $4^{\prime \prime}-5^{\prime \prime}$ long.

2. B. Americana, L. Very rough, with bristly hairs; stem often branching above; leaves prominently 3-nerverl, mostly toothed ; the lower ones ollong, obtuse, the others lanceolate, acute; calyx-tecth acuminate. - Low pine barrens, Florida to Mississippi, and northward. July and Aug. - Sten $2^{\circ}-3^{\circ}$ high. Corolla $6 "$ - 7"long.

\section{SEYMERIA, Pursh.}

Calyx 5-parted. Corolla bell-shaped, 5-lobed, the lobes oblong. Stamens 4, equal, the filaments woolly: anthers ollong, opening at the apex, awnless. Style simple, obtuse. Capsule ovate, flattened above, loculicilally 2-valved. Seeds numerous, covered by the loose hyaline testa. - Chiefly annuals. Stems erect, branching. Leaves opposite, pinnately divided. Flowers yellow, in terminal leafy-bracted racemes.

1. S. tenuifolia, Pursh. Smooth or nearly so; stem with elongated erect-spreading branches; leaves pinnate, the entire or lobed divisions filiform; capsule smooth, acute at the base, shorter than the pedicel. - Low pine barrens, Florida to North Carolina, and westward. Aug. and Sept. - Stem $2^{\circ}-4^{\circ}$ high.

2. S. pectinata, Pursh. Viscid-pubescent; stem with ascending branches; leaves pinnatifid, the entire obtuse divisions oblong-linear; capsule hairy, obtuse at the base, as long as the pedicel. - Dry sandy soil, Florida to South Carolina, and westward July-Sept. - Stem $6^{\prime}-18^{\prime}$ high.

\section{MACRANTHERA, Torr.}

Calyx 5-cleft, the lohes elongatcd. Corolla cylindrical, 5-toothed; the teeth reflexed. Stamens 4, equal, long-exsertcd, woolly : antliers large, oblong, approximate. Style simple, filiform, elongated: stigma minute, flat. Capsule ovate, loculicidally 2 -valved, many-seeded. $-\Lambda$ tall bicnnial, with pinnatifid opposite leaves, and showy orange-colored flowers, in terminal leafy racemes.

1. M. fuchsioides, Torr. Smoothish; stem branching, 4-sided; earliest leares ovate-oblong, entire; those of the stem lyrate-pinnatifid, with the lobes denticulate; the uppermost toothed-serrate; pedicels slender, recurved, tho upper ones longer than the floral leaves; flowers erect; calyx-lobes lanceolate, denticulate, rather shorter than the corolla. - Var. Lecoster has the shorter and narrower lobes of the calyx entire. (M. Lecontei, Torr) - Marshy banks of pine-harren streams, Georgia, Florida, and westward. Sept. and Oct. - Stem $3^{\circ}-5^{\circ}$ high. Earliest leaves $6^{\prime}-8^{\prime}$ long; those of the stem $2^{\prime}-4^{\prime}$ long. Co rolla $9^{\prime \prime}-12^{\prime \prime}$ long. - The plant turns black in drying. 
18. OTOPHY亡ニА, IBml.

Calyx deply 5-eleft; the lobes leafy, mexpral. I'nhe of the corollat lilated

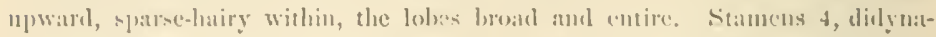

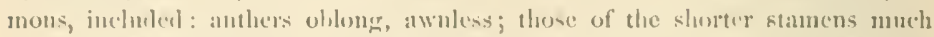
smaller. Style clomerated, dilated and flattened at the apex, entire. Capsule sub-rglubose, loculiciclally 2-valved, many-seeded.

1. O. Michauxii, Benth. Hairy: stem erect, simple; leaves opposite, lanecolate, entire, sessile; the upper ones mostly 2-eared at the base; fluwers opposite, in a leafy spike. (Gerarlia anriculatil, Mi.hx.) - Low ground, Ien. nessce, North Carolina, and northwarl. Angr. (1)?-Stcum rigid, zo ligh Leaves $1^{\prime}-2^{\prime}$ long. Corolla $9^{\prime \prime}-12^{\prime \prime}$ long, purple.

\section{DASYSTOMA, Raf. Jille Foxetore.}

Calyx bell-sliajed, 5-cleft, the loles often toothed. Corolla tulular-hellshaped, woolly within, 5-lobed, the lobes ronnded. Stamens 4, didynamons : anthers oblong; the cells parallel and awned at the bise. Style filifim, thickcued and stightly 2-lobed at the apex. Capsule orate, acute, loculicidally 2valved, many-seded. - Tall herbs, with opposite ovate or oblong mostly pinnately diviled or lobed leaves, and large yellow flowers in a leafy raceme. Fi]aments woully.

1. D. pubescens, Benth. Pubeseent; leaves ublong, ohtuse, entire, or the lowest ones pinnatificl : ealyx longer than the pediecl, with oblong obtuse lobes. (Gerardia flima, L.) - Dry woods in the upper districts, Georgia, and northward. July - Sept. 4 - Stem $2^{\circ}-4^{\circ}$ higl, mostly simple. Lcares narrowed into as short petiole. Corolla $1 \frac{1}{2}$ long.

2. D. quercifolia, Benth. Smooth and glancons; stem simple or branched; lowest leaves twice-pinnatifie ; the others pimatifid, or the uppermost lanceolate and entire; ealyx shorter than the pedicel, with lanecolite or subulate acute lobes. (Gerardia quereifolia, Pursh.) - Rich woods and river-banks, Florida to Misissippi, and northward. July - Sept. If - Stem $3^{\circ}-6^{\circ}$ high. Iobes of the leaves toothed. Corolla 2' long, the tube nore slender and with smaller lobes than the preceling.

3. D. pedicularia, Benth. Smooth or somewhat puleseent; leares ovate-lanceolite, pimnatifid; the lobes finely toothed; flowers opposite; calyx shorter than the pedicel; the toothed lobes as long as the tube. (Gerardia pedicularia, L.) - Dry sandy soil, chicfly in the upper districts, Mississippi to North Carolina, and northward. July and $\Delta u g$. Sten $2^{\circ}$ hifrl, much branched. Leares about $2^{\prime}$ lone, the lohes numerous and short. Corolla 12" $-15^{\prime \prime}$ long, with a lather slender tube und short lobes.

4. D. pectinata, Benth Puhcseent or somewhat villous; leares lanceolate or ovate-lanceolate, fincly pinnatifid and toothed; the earliest ones entire; flowers aternate, scattered on the ontside of the ascending hranches; calyx longer than the pedicel; the pinnatificl lobes innger than the tulse. - Dry sandridges in the pine barrens, Florida to North Carolina. Aug. and Sept. (2)- 
Stem $2^{\circ}-4^{\circ}$ high, widely branched. Corolla $1_{2}^{1}$ long, witl a wider tube and larger lobes than in No. 3 .

\section{GERARDIA, I.}

Calyx bell-shaped, 5-toothed; the teeth short, acute, entire. Corolla tubularbell-shaped, 5-lobed, the lobes rounded, spreading; the throat oblique. Stamens 4, didynamons, the longer ones commonly woolly: anthers woolly, connivent in pairs; the cells diverging and pointed at the base. Style slender, dilated, and flattened upward. Capsule ovoid or globose, smooth, loculieidal. Seeds numerons, angled, reticulated. - Chiefly slender branching aunuals. Leaves opposite, or rarely alternate, narrow, entire. Flowers in the axils of the upper leaves, showy, purple; the tube of the corolla mostly dotted witl red and yellow, ofter woolly at the throat.

\section{* Perennial.}

1. G. linifolia, Nitt. Smooth; branches elongated, ereet; leaves erect, linear; peduncles as long as the leaves, or the uppermost longer; calyx truncate, with minute teeth; lobes of the corolla nearly equil, fringed on the margins; capsule large ( $3^{\prime \prime}$ wide), globose, one third longer than the calyx. - Low pine barrens, Florida to North Carolina, and westward. Sept. - Stem $2^{\circ}-3^{\circ}$ high. Leaves $\mathbf{l}^{\prime}$ long. Corolla $\mathbf{l}^{\prime}$ loug, pubescent.

\section{* * Annnals. \\ - Corollu snall, the 2 upper lobes short, truncate and erect.}

2. G. divaricata, n. sp. Stem $6^{\prime}-12^{\prime}$ high, smooth, widely branehed from the base; leaves all opposite, spreading or reflexed, filiform, roughish on the margins. 3 long; the uppermost minute; pedicels all opposite, setaceons, spreading, the upper ones $4-5$ times as long as the leaves; calyx-teeth subulate, one third as long as the tube; corolla $\frac{1}{2}$ long, the lobes ciliate; capsule ovoid, twice as long as the calyx. - Low sandy pine barrens. West Florida. Sept.

3. G. filicaulis. Stem $6^{\prime}-12^{\prime}$ long, filiform, reclining, smooth and glaucous; hranches alternate, setaceous; leaves minute, l" long, subulate, rough; Howers few, terminal ; ealyx-teeth triangrtar, oue fourth the length of the tube; corolla $4^{\prime \prime}-5$ "l long, compressed, the lobes slightly fringed; eapsule globose, one third longrer than the calyx. (G. aphylla, var. filicaulis, Benth.?) - Low grassy pine barrens, West Florida. Sept.

+ + Lobes of the corolla nearly equal, spreading.

- Pedicels as long, or twice as long, as the caly.x, shorter than the leaves.

4. G. aphylla, Nutt. Stem $2^{\circ}-3^{\circ}$ high, smooth, 4-angled, sparingly branchel near the sunmit; leaves minute, l" long, subulate, appressed; flowers mostly alternate, on one side of the spreading branehes; perlicel as long as the calyx; calyx-teeth minute, obtuse; corolla $\frac{1}{2}$ long, hairy within, the upper lobes reflexed ; capsule globose, $2^{\prime \prime}$ longr, twice as long as the calyx. - Low sandy pine barrens, Florida to North Carolina, and westward. Sept.

5. G. purpurea, L. Stem $1^{\circ}-3^{\circ}$ high, smooth, the branches elongated; leares opposite, broally or narrowly linear, rough above, $1^{\prime}-1 \frac{1}{2}$ long; flowers opposite or nearly so, the stout pedicels as long ats the ealyx, calyx-tecth con- 
spicuous, triangular, sometimes lalf as lome ns the tulo, spreacliner; corolla 8 "

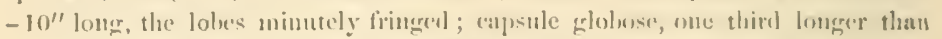
the ralyx - law ground, Florida to Mis-issippi, and northward. Sipt.

Var. fasciculata. Stcm taller $\left(3^{\circ}-5^{\circ}\right)$, much hranclued alowe, rough; leaves rongh on loth sides, elusteret, the uppermust, like tlue flowers, alternate; calyx-tecth more pointed ; corolla larger. (G. fisciculatti, E:ll.) - Irackish soil, along the const, Floriula to Soutl, Carolina.

6. G. maritima, laf. Smooth; stem $s^{\prime}-16^{\prime}$ higel, 4-angled, with numerous short and leafy branclies near the hase; leuves fleshy, lincar, obtuse, opjosite, the upper ones small and remute; pedicels as long as the calyx and the fioral leaves; calyx-teetls short, obtuse; comlla $6^{\prime \prime}-8^{\prime \prime}$ long, slightlly ohlique at the throat, the upper lobes fringed, and villons within ; eapsule grobose, twice as long as the calyx. - Salt marshes, Florida, and northwarl.

Var. major. Stem 20 ligh, much branchet ; leaves flat, acute; floral leaves longer than the peslicels; culyx-teeth trianıular, acute; corolla and capsule larer. - Brackisla marshes, A palachicola, I'lorida. - Corolla l' long.

․ G. setacea, Ell. Very smooth; stem $1^{\circ}-2^{\circ}$ high, much lunehel, slender; leaves l' long, setacens, opposite; pedicels stout, club-slapecl, three times as long as the calyx, mostly alternate, or terminating the setaceous peduncle-like hranchlets; calyx-tecth short, subulate; corolla I' long, woolly within, the rounded lohes thickly fringed; capsule ovoil, barely execeling the ealyx. (G. Plukenetii, Ell.?) - Damp or dry sandy pine barrens, Florida to South Carolina. Sept.

++ +r Pedicts much longer than the cally.r, commonly longer then the Lraves.

8. G. tenuifolia, Vahl. Stem smooth, $1^{\circ}-1 \frac{10}{2}$ high, much luanehed; leaves linear, smooth, or rough on the marrins, $1^{\prime}-1 \frac{1}{2}$ long; pedicels filiform, ahout as long as the leaves, opposite; (alyx-tecth loroadly subulate, $f$ as long as the tube ; rorollat $\frac{1}{2}$ ' long; capsule glohose, as long as the ralyx. - Var. Futrorms. Stem and pedicels rough; leaves filiform, clustered; corolla larger

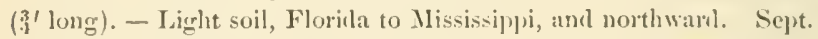

9. G. filifolia, Nutt. Stem $1^{\circ}-2^{\circ}$ high, much hrancherl, smooth; leaves very numerous, all alternate and clustered, smooth, fleslyy and somewhat clubshaped: pedicels alternate, twice as long as the leaves; ealyx-tecth subulate, one fourth the length of the 5-ingled tube ; corolla $3_{1}^{3}$ loner; (apsule ovoid, as long as the ralyx - Low sandy piue barrens, Gorgia and Florila. Sept.

10. G. parvifolia. Stem rongh, striate, $12^{\prime}-18^{\prime}$ ligh, the slender bramelses erect; leaves $4^{\prime \prime}-6^{\prime \prime}$ long, opposite or alternate, linear, very rough, rather obtuse; pedicels filiform, $2-4$ times as long as the minute floral leaves; calyxteeth minute, obtuce; corolla $\frac{1}{2}$ long, pale puple or white. (G. setncea, var. parvifolia, Benth.?) - Grassy margins of ponds, Florida, and westward. Sept. - Unlike the other species, this remains unchanged in drying.

\section{CASTILLEIA, I.}

Calyx tubular, compressed, cleft at the sunimit; the lohes entire or 2-cleft. Tube of the corolla included in the calyx; the upper lip long, narrow, curved, 
laterally eompressed, and enclosing the four dirlynamous stamens; the lower lip short, 3-loled : anther-cells oblong-linear, uneinal; the onter one fixed by the middle, the inner pendulons. Capsule loculicidal, many-seeded. - Herhs, with alternate entire or incisely-lobed leaves, the uppermost colored. Flowers in leafy spikes or racenıes.

1. C. coccinea, Spreng. Stem hairy; ralical leaves clustered, nearly entire; those of the stem pinnatifid, with the lobes linear; the floral ones 3 lohed, bright scarlet at the sunmit; corolla greenish-yellow. - Damp soil in the upper districts. June-Ang. (2) - Stem $1^{\circ}-1 \frac{10}{2}$ high.

\section{SCHWALBEA, L.}

Calyx tubular, oblique, 10-12-ribbed, 4-toothed, the upper tooth very small, the lowest elongated, 2-cleft. Corolla bilabiate; the upper lip oblong, arehed, enclosing the four didynamous stamens; the lower rather sliorter, obtusely 3-lobed: anther-eells parallel, equal. Capsule oblong, acnte, locnlicidally 2-valved, many-seeded.

1. S. Americana, L. - Sindy pine barrens, Florida to Mississippi, and northward. May and June. 4-Stem simple, $1^{\circ}-1 \frac{1}{2} 0$ high, pubescent. Leaves alternate, lanceolate, entire, sessile; the lower ones oblong, the uppernost linear, small. Flowers in a spiked raceme. Corolla l' long, yellow and purple.

\section{PEDICULARIS, L.}

Calyx tubular, more or less eleft at the apex, varionsly 2-5-toothed. Corolla bilabiate; the upper lip compressed, eurved and bearded at the apex, cnclosing the 4 didynamous stamens; the lower lip 2-crested above, 3-lobed, with the lateral lobes larger and romded: anthers transverse. Capsule ovate or lanceolate, compressed, the upper portion empty. - Herbs, with finely and pirnately divided leaves. Flowers in leafy racemes or spikes.

1. P. Canadensis, L. Stem simple, hairy $\left(6^{\prime}-9^{\prime}\right.$ high $)$; leaves alternate, smooth, oblong or lanceolate, pinnatifid; the lobes oblong, simply or doubly crenate; spike dense, capitate, elongated in fruit; eorolla pale yellow and purple; the upper lip hooked, 2-awned under the apex ; capsule lanceolate, exserted. - Shady woods and banks, Florida to Mississippi, and uorthward. March and April. 4 - Stem bearing slender leafy and rooting runners. Fruiting spike $3^{\prime}-5^{\prime}$ long.

2. P. lanceolata, Michx. Stem tall $\left(1^{\circ}-3^{\circ}\right)$, smooth, simple or sparingly branched; leaves nearly opposite, lanceolate, pimnately toothed, the teeth erenate; spike dense; corolla pale yellow, the upper lip enrved, awnless, the lower erect; capsule ovate, searcely exserted. - Swamps on the mountains of North Carolina, and northwarl. Aug. and Sept.

\section{MELAMPYRUM, Tourn.}

Calyx bell-shaped, with 4 subulate teeth. Corolla bilabiate; the tube dilated above; the upper lip short, eompressed, obtuse, straight; the lower rather longer, 
spreadinu, bicomwex, will three short lobes. Stamens 4, dislynamons, muler the upper lip: anthers upproximat, olilong, hairy; the (wlls nearly c(pual, slightly fointed at the base. Orury with 2 ovnles in each rell. Capsule compressedl,

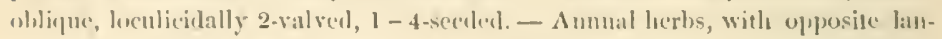
recolate or linear leaves, and solitary axillary flowers.

1. M. Americanum, Michx. Stem naked luelow, leafy and commonly branched above the middle; leaves lanecolate, entiw, short-pretioled; the upper ones broader and sharply toothed at the base; flowers greenish-yellow. - J ry woods along the mountains, Georgia, and northward. Aug. - Stem 6 $6^{\prime}-12^{\prime}$ highl. Leaves $2^{\prime}$ long. Flowers $4^{\prime \prime}-5$ "long.

\section{Ounli 92. ACANTHACEA. (Acanthes FamLx.)}

Chiefly herbs, with opposite (rarely alteruate or chustered) undividerl exstipulate leaves, and bracted, often showy flowers. - Calyx 5-parterl. Corolla more or less bilabiate. 5-lobed, twisted in the busl. Furtile stamens 2 or 4, inserted on the tube of the corolla: anthers 2-eelled. ()vary free. Style single: stigma entire or 2-lobul. Capsule lorulicibally 2-valved. 2-eelled, 4-several-sected, opening elastically. Sereds anatropous, flat, rounled, without albunen, mostly supported by eurverl appendages of the placentre. Radicle inferior. - Stems commonly swollen between the joints.

\section{Syuopsis.}

- Capsule oblong, bearing the seeds at the base. Appendages of the placenta none.

1. ELYTRARIA. Spike borne on a closely-braeted scape. I.eaves radieal.

* Capsule club-shaped, bearing the seeds abore the base, appendaged.

2. DIP'TERACANTHCS. Corolla nearly regular. Stamens 4. Flowers axillary, solitary or clustered.

3. DIANTIERA. Corolla bilabiate. Stamens 2. Cells of the antliers plaeed one lower than the other. Flowers in long-peduneled axillary spikes.

4. DICLIPTERA. Corolla bilabiate, resupinate. Stamens 2 . ('ells of the anthers plaeed one behind the other. Flowers in leafy-bracted heads or elusters.

\section{ELYTRARIA, Valil.}

Calyx 4-5-parted, the lateral lobes narrower. Corolla salver-shaped or bilabiate, 5-lobet. Fertile stamens 2, the 2 anterior ones sterile: anther-cells parallel. Stigma 2-eleft. Capsule sessile, about 8-seeded; the secils fixed near the base of the eapsule, without appendages. - Low herbs. Leaves all radical, elustered. Scape eovered with imbrieated bracts. Flowers spiked, 2-bracted.

1. E. virgata, Michx. Leaves oval or oblong, narrowed downward, entire or wary on the margins, smooth or pubescent; hracts of the seape alternate, rigill, lanceolate, acuminate, clasping; those of the spike ovate; corolla white, salver-shaped, the lobes nearly equal; capsule cylindrieal Banks of rivers, Florida to South Carolina. Aug. 4 - Scapes 6'-12 high Leaves $2^{\prime}-4$ ' long. 


\section{DIPTERACANTHUS, Nees.}

Calyx 2-bracted, 5-parted, with linear or bristle-like lobes. Corolla funnelshaped, 5-lobed; the lobes equal, romded. Stamens 4, didynamons, included: anthers sagittate. Style simple, or 2-cleft at the apex. Capsule narrowed below the middle, fattened contrary to the partition, 4-12-seeded. Seeds borne above the middle, supported ly curved appendages of the placentx. - Perennial herbs, with tumid joints, entire opposite leaves, and axillary solitary or clustered nearly sessile flowers. Corolla white, blue, or purple.

\$1. Calophanes. - Anther-cells pointed at the base: style simple: capsule 4-seeded.

1. D. oblongifolius. Pubeseent and somewhat hoary; stem 4-angled, erect from a creeping base, simple or sparingly branched; leaves nearly sessile, oval or obovate, obtuse, the upper ones narrower and often acute; flowers solitary or $2-3$ in a cluster; calyx-lobes subulate-setaceous, as long as the oblong bracts, and tube of the spotted purple corolla. (Ruellia oblongilolia, Michx.) Dry saudy pine barrens, Florida to Sonth Carolina, and westward. JuneAngust. - Stem $6^{\prime}-12^{\prime}$ high. Leaves $\frac{1^{\prime}}{2}-1^{\prime}$ long. Corolla $1^{\prime}$ long, rather exceeding the leaves.

2. D. riparius, n. sp. Stem minutely pubescent, erect from a creeping base, simple, slender; leaves smooth, membranaceous, oblong, obtuse, slightly crenate, tapering into a long and slender petiole; flowers clustered, sessile; calyx-lobes subulate-setaccous, shorter than the spatulate-oblong bracts; corolla white, 3-4 times shorter than the leaves. - Shady banks of Little River, Middle Florida June and July, - Stems $1^{\circ}-1 \frac{1}{2} \circ$ high. Leaves $1^{\prime}-1_{\frac{1}{2}}^{\prime}$ long. Corolla $\frac{1}{2}$ long.

3. D. humistratus. Stem smooth, diffuse, creeping; leaves oblong-oval, entire, narrowed into a petiole; flowers nearly sessile, solitary or 2-3 in a eluster; bracts oblong-spatulate, shorter than the setaccous calyx-lobes; eapsule lanceolate, smooth. (Rucllia lumistrata, Mfich $x$.) - Grassy places, Florida to South Carolina. - Plant small. Leaves $\frac{1}{2}$ ' long.

4. D. linearis, Torr. \& Gray. Small, rougli-pubescent ; stem prostrate, diffuse, very leafy; leaves oblong-linear, entire, narrowed toward the base, obtuse ; calyx-lobes setaceous, hairy; bracts similar to the leaves; capsule oblong, 4-anglerl, at length 4-valved, 2-4-seeded. - South Florida, - Stem $66^{\prime}$ long. I.eaves $4^{\prime \prime}-6^{\prime \prime}$ long.

\$2. Dipteracaxtics. - Anther-cells pointless : style 2-cleft at the apex: capsule 8 - 12 -seeded.

5. D. ciliosus, Necs. Ilirsute with white hairs; leaves oval or ovateollong, nearly sessile; flowers solitary or $2-3$ in a cluster; tube of the corollis twice as long as the setaceous calyx-lohes, and much longer than the short funnel-shaped throat; eapsule smooth. (Ruellia ciliosa and R. lybrila, Pursh.) - Dry soil, Georqia, near Savannah, Pursh., and westwarl. July and Aug. Stem rarying from a few inches to $3^{\circ}$ light. Leaves $1^{\prime}-2^{\prime}$ long. Corolla $2^{\prime}$ long, pale blue. 
6. D. strepens, Nees Smonih, pubesecut, or hairy ; leaves varying from lancenlate to orhicular, mo-dly narrowed into a petiole; flowers sesile or perluncled; tube of the corolla barely longer than the linear or linear-lanceolate bairy

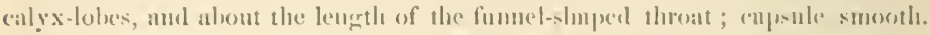
(liuellia strejens, L.) - Dry rich soil, Florida, and uorthward. June-Sipt. Stem $2^{\prime}-3^{\circ}$ lighla. Leares $1^{\prime}-4^{\prime}$ loug. Corolla $1^{\prime}-2^{\prime}$ lomg, blue or purple. id polynorphons species. Latter flowers sometimes fruiting in the lud.

¡. D. noctiflorus, Nees. Closely puhescent; stem simple, rigril; leaves oblong or lanceolate, sessile, eutire or slightly toothed ; flowers solitary, priluncled ; corolla large; the elongated tube twiee as long as the linear hairy calyxloles; capsule pubeseent. - Low grasy pine barens, Florila, Georgia, and westward. July and Aug. - Sten $1^{\circ}$ highl. Corolla $2^{\prime}-4^{\prime}$ long, white.

\section{DIANTHERA, Gronov.}

Calyx 5-parted. Corolla bilahiate; the upper lip emarginate; the lower 3loled, rugose or veiny in the middle, sprearling. Stamens 2 : anther-sells sepurated, one placed lower down than the other. Stigmia simple, ar'ute. Capsule flattened, narrowed downward, bearing the seeds above the mirldle. Seeds monty 4, supported by the appendages of the platentax. - lerennial smooth herlss, with opposite entire leaves, and short-bracted mostly alternate flowers in long-peduncled axillary spikes.

1. D. Americana, L. Stem tall, anglerl ; leares long, linear-lanceolate; spike's oblong, dense or somewhat capitate, on perlmeles as lour as the leaves. (Justicia cnsiformis, Ell.? J. pedunculosa, Michx.) - In slow-flowing streams, South Carolina, and northward. July and Aug. - Stem 20 hight. Leaves and pednncles $4^{\prime}-6^{\prime}$ long. Spike $\frac{1}{2}$ long. Flowers pale purple.

2. D. ovata, Walt. Steun low $\left(4^{\prime}-8^{\prime}\right.$ high $), 4$-ingled ; leaves ovate-lanceolate, rather acute, nurrowed into a short petiole; the lowest small, lanceolate; spikes 3-4-flowered, on simple pedumeles shorter than the leaves; corolla small, pale purple, the lower lip striped with deeper lines. (Justicia humilis, Michr.) Mnddy bauks of streams, Florida to South Carolina. - Leaves 2' -4 ' long, $I^{\prime}-1 \frac{1}{2}$ wide.

Var. lanceolata. Stem taller $\left(1^{\circ}-1 \frac{1}{2}^{\circ}\right)$; leaves smaller, lanceolate, acnminate, nearly sessile; peduncles longer than the leaves; spikes many-flowered, 1-silled, often branching. - Rirer-banks, Floricla. July.

Yar. ? angusta. Leaves linear or linear-lanceolate, reflexed, the lower ones rery remote; peduncles as long as the leaves; spikes several-flowered, the lower flowers often opposite, - Pine-harren ponds, Florida. Maly. - Stem 10 light. Leaves $1^{\prime}-2^{\prime}$ long. Corolla $4^{\prime \prime}-5^{\prime \prime}$ long.

3. D. crassifolia, n. sp. Stem rigid, angled; leares fleslyy, linear, channelled, acute; the lower distant, small aud obtuse; peduncles stont, erect, longer than the leaves, exceding the stem; spike few-flowered; corolla large, bright purple; the lower lip striped with deeper lines; capsule 2-seeded; secds circular,

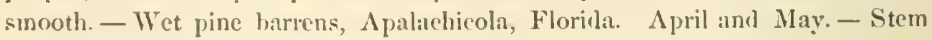
$6^{\prime}-12^{\prime}$ high. Leaves $4^{\prime}-6^{\prime}$ long. 1'eduncles $4^{\prime}-9^{\prime}$ long. Corolla and capsule I' long. 


\section{DICLIPTERA, Juss.}

Calyx 5-parted, mostly leafy-hracted. Corolla hilabiate, mostly reversed; the lower lip 3-lobed; the upper 2-cleft or entire. Stamens 2: anther-cells equal, one placed behind the other. Calpsule oblong or oval, bearing 2 or 4 seeds below the middle ; the partitions at length free from the valves. - Herbs, with simple leaves, and purple, scarlet, or white flowers in axillary and terminal heads or spike-like eymes.

1. D. brachiata, Spreng. Smooth or nearly so; stem 6-angled, with numerous spreacling branches; leaves thin, oblong-ovate, acuminate, abruptly contracted into a long and slender petiole; spikes solitary or 2-3 together, interrupted, mequal ; bracts oblong, mucronate, narrowed at the base, at length inflated; corolla small, purple. (Justicia brachiata, Pursh.) - River-banks, Florida to North Carolina. July and Aug. - Stem $1^{\circ}-2^{\circ}$ high.

2. D. Halei, Ricldell. Stem tomentose, mostly simple; leaves ovate-lianceolate, aeuminate but rather obtuse, tapering into a petiole, sprinkled on the upper surfice and veins beneath with very short hairs; the lower ones smaller and obtuse; spikes axillary and terminal, short-peduncled, leafy at the base, compact, few-flowered; braets oblong or oval, mueronate, short-stalked, and, like the lincar-spatulate bracteoles, and subulate calyx-lobes, fringed with long hairs; capsule oral, 4 -seeded. (Justicia laterirens, Buckley? Rlyytoglossa viriliflora, Nees.) - Shady banks of rivers, Florida, and westward. JuneSeptember. - Stem $\frac{10}{2}-2^{\circ}$ high. Leaves $2^{\prime}-4^{\prime}$ long. Corolla $4^{\prime \prime}-5^{\prime \prime}$ long, white.

3. D. assurgens, Juss. Smooth or minutely pubeseent; stem angled, much branched; leaves elliptical, acute, on slender petioles; flowers mostly single, scattered in 1 -sided spike-like eymes; bracts small, unequal, the interior ones subulate, the exterior larger and somewhat spatulate; calyx-lobes subulate, unerual ; corolla (scarlet) curred, nearly equally 2-lipped ; the upper lip entire, the lower minutely 3-toothed; anthers slightly exserted ; style hair-like, elongated. - South Florida. - Stem $1^{\circ}-2^{\circ}$ high. Leaves $1^{\prime}-2^{\prime}$ long. Corolla $9^{\prime \prime}$ $-12^{\prime \prime}$ long.

\section{Order 93. VERBENACEA. (Vervain Fanily.)}

Chiefly herbs or shrubs, witl 4-angled mostly rough stems, and opjosite and exstipulate leares. Flowers spiked, eapitate, or cymose. - Calyx 4 -5-cleft or parted, free. Corolla regular and salver-shaped, or more or less bilabiate, 4-5-lobed. Stamens $4-5$, inserted on the tube of the corolla: anthers 2-cellerl. Orary entire, 1-8-celled, with 1 or (in Avicennia) 2 orules in each eell. Style simple, terminal. Fruit dry or baceate, 1 -s-eellerl, commonly separable into as many 1-seeded indehiseent nutlets. Albumen scarce or none. Embryo straiglit. 


\section{Synopsis.}

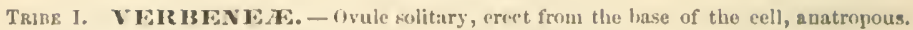
liadiclo pointing downward. Flowers in spikes or heuds.

- Herbs. Fruit dry.

1. Plili. Stamens 4. Fruit of 2 two-eellow nutlets, enclosed in the iuflated ealyx.

2. VERBENA. Stamens 4. Fruit of 4 one-relled nutlets. Fruiting caly $x$ not inflated.

3. StAchYTARPIIA. Stauens 2. Fruit of 2 one-celled untlets, imbedd $d$ in excavations of the thickened rachis.

4. LIPl'L. Stamens 4. Fruit of 2 one-eelled nutlets. Flowers ext]itate.

* Shrubs. Fruit fleshy or pulpy.

5. I.INTANA. Fruit of 2 one-relled nutlets. Flowers eapitate.

6. Citharf.xtull. Fruit of 2 two-celled nutlets surrounded by the eup-shaped calyx. Flowers spiked.

i. DURANTA. Fruit of 4 two-celled nutlets enclosed in the beaked ealyx.

Trube JI. VITEAS. - Orule solitary, suspended from the inner angle of the cell, amphitropons. Radicle pointing downward. Flowers in cymes. Fruit baccate.

8. CALLICAliPA. Fruit of 4 separate l-eelled nutlets. Shrubs.

Tribe 11. A VICENNIAE.- Orules by pairs, suspended from the apex of the cell. amphitropous. Fadicle pointing downward. Flowers in imbricated spikes or heads. Fruit capsular.

9. AVICExid. Embryo large, germinating within the eapsule. Trees.

TRIBE IV. PIIRYMEA. - Ovule solitary, erect from the base of the 1-celled orary, orthotropous. Radicle pointing upward. Cotyledons convolute arouud their axis. Flowers in elongated slender spikes. Fruit a earyopsis.

10. PHRYMA. Corolla bilabiate. Stauens 4, didynanıous. Fruit reflexed.

\section{PRIVA, Adans.}

Calyx tubular, 5-toothed. Corolla salver-shitped, 5-cleft. Stamens 4, didynamons, included. Ovary 4-eelled. Style persistent. Fruit dry, separating into two 2-celled spiny-angled nutlets, and included in the infated membranaceons calyx. - Perennial herbs, with serrate petioled undivided leaves, and minute flowers in a loose slenderspike.

1. P. echinata, Juss. Smootl or hispid ; stem branching; leares cordateovate, acute, coarsely serrate; flowers alternate; fruiting calyx bristly with hooked hairs, ovoid ; finit orate, 4-angled, the angles arned with tubereular spines, pointed by the persistent hent style. - South Florida. - Leaves $\mathbf{l}^{\prime}-2^{\prime}$ long. Spikes $6^{\prime}-9^{\prime}$ long, terminal and in the forks of the stem.

\section{VERBENA, L. Vervin.}

Calyx tubular, 5-ribbed, 5-toothed. Corolla salver-shaped, bearded in the throat; the limb somewhat bilabiate, 5 -lobed. Stamens 4 , didynamous, included. Stigma 2-lobed. Oviry 4-eelled. Fruit of 4 separate 1-seeded nutlets. - Herbs, with serrate or pinnately divided leaves, and mostly small flowers in lengthening slender spikes. 
* Anthers of the longer stamens tipped with a gland-like appendare: flowers showy.

1. V. Aubletia, L. Hairy; stem creeping at the base, ascending, forking; leaves ovate-oblong, 3-eleft, with the lobes toothed, narrowed into a slender petiole; the lower ones smaller, ronnded, toothed; spikes terminal and in the forks of the stem, long-peduneled, closely flowered; calyx long. slender; the unequal teetls subulate; eorolla showy, purple.-Dry light soil, Florida to South Carolina, aud westward. May - August. - Stem $6^{\prime}-12^{\prime}$ higrh. Corolla $\frac{1}{2}$ long.

\section{* * Anthers without appendages : flowers sinall.}

t- Leaves undivided.

2. V. urticifolia, L. Rough-hairy; stem tall, branehing; leares ovateoblong, acute or acuminate, mucronate-serrate, contracted at the base into a long petiole; spikes very long, filiform, axillary and terminal f flowers minute, white or pale blue. - Low ground, Florida to Mississippi, and northward. Aug. - Oet. - Stem $2^{\circ}-5^{\circ}$ high. Leaves very rough, $2^{\prime}-6^{\prime}$ long.

3. V. hastata, L. Rough-hairy ; stem branching; leaves oblong-lanceolate, acuminate, eoarsely and sharply serrate, tapering into a long petiole; the lowest broader, and often hastate-loberl at the base; spikes linear, short, closeflowered; flowers violet. (V. paniculata, Lam.) - Low ground, in the upper distriets, Mississippi, and northward. July - Sept. - Stem $2^{\circ}-3^{\circ} \mathrm{high}$. Flowers larger than in No. 2.

4. V. angustifolia, Michx. Rough-hairy; stem simple or branched above; Jeaves lanceolate or linear-laneedate, rather obtuse, coarsely serrate, tapering from near the apex to the sessile base; spikes linear, terminal, closeflowered; flowers purple. - Dry woods, Florida to Mississippi, and northward. July - Sept. - Stem $6^{\prime}-12^{\prime}$ high. Flowering spikes $2^{\prime}-3^{\prime}$ long.

5. V. Caroliniana, Michx. Rough with short rigid hairs; stem simple, aseending; leaves oblong, or the lowest oblong-obovate, aeute or obtuse, sharply and doubly serrate, entire toward the narrowel base, sessile; spikes $1-3$, elongated ; flowers flesh-eolor. - Dry pine barrens, Florida to South Carolina, and westward. Aug. - Stem $4^{\prime}-6^{\prime}$ ligh, shorter than the spikes. Leaves $1^{\prime}-2^{\prime}$ long. Nutlets tardily separating.

\section{+ + Leaves pinnatifid.}

6. V. officinalis, L. Stem smoothish, ereet, branehing; leaves lanceolate or oblong, pimately lobed or toothed, narrowed and entire near the lase, sessile, pubescent beneatl, spikes linear or filiform, panicled; bracts shorter than the calyx; flowers purple. (V. spuria, L.) - Waste ground, chiefly in the upper distriets. Introdueed. July and Aug. - Stem $1^{\circ}-3^{\circ}$ high.

7. V. canescens, Kunth? Hirsute and hoary; stems numerons, prostrate, diffuse; leaves small, pinnately toothed or lobed, oblong, narrowed into a petiole; spikes terminal, dense; bracts linear, entire, spreading, much longer than the flowers, the lower ones recurved; flowers purple. - Strects of Apalachieola, Florida, and along the Central Railroarl in the middle distriets of Georgia. Aug. - Stems $4^{\prime}-6^{\prime}$ long. Spikes $3^{\prime}-6^{\prime}$ long. Leaves $6^{\prime \prime}-9^{\prime \prime}$ long. 


\section{STACHYTARPHA, Vuhl.}

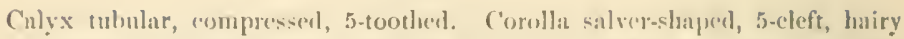
in the throit. St:mens 4, dielyamons, the upjer juir stcrile. Ovary 2-celled.

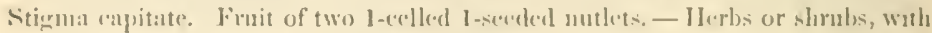
4-angled forking stems, and opposite undivided leaves. Flowers in struight and rigid spitic's, imbededed in excavations of the thickened rathis, and corered by the imbricatcel luatets.

1. S. Jamaicensis, Valıl. Ilerbaceous, smoothislı; strms ascending; leaves oblong, coarsely serrate, tapering into a slember margined putiole; spikes linear, terete, elongated ; bracts lanceolate, al'uminate, appresscel, with scarious rough margins; flowers small, blue. - South Florida. - Icaves 2'-4' longr. Spikes $8^{\prime}-12^{\prime}$ long.

\section{IIPPIA, L.}

Calyx tubular, memlsanaceons, 2-4-toothed. Corolla subular-fumel-shaperl, somewhat lilabiate, 5-cleft. Stamens 4, diclynamous, includcal. Ovary 2-celled, 2-ovuled. Style short: stigua ohliqgucly capitate. Fruit of two 1-seeded scparable mutlets. - II (rils, with 4-angled stems, opposite or whorled simple leaves, and small flowers in dense spikes or heals.

1. L. nodiflora, Michx. Stem ereeping, finely pubescent, the flowering branches erect; leaves obovate, oblong, or lanceolate, rough, tapering and entire bclow the middle, serrate alıre; heads dense, globose in flower, oblong or cylindrical in fruit, on axillary pedunctes which are 2-3 times as long as the leaves; flowers white or purple. (Kapania nodiflora, Lam.) - Jamp sandy soil near the coatit, Florida to Mississippi, and northward. May-Sept. Flowering stems $6^{\prime}-12^{\prime}$ high. Leares $l^{\prime}$ long.

\section{LANTANA, L.}

Calyx minute, slightly 4-toothed. Corolla bilabiate; the upper lip notehed or entire; the lower 3-lobel. Stannens 4, didynamous, included. Style short : stigma obligue. Fruit flesly or berry-like, of two mostly rugose or tnberenlate l-seeded nutlets, enelosed in the cnlarged membranaceons ealyx. - Shrubs, with simple rugose serrate leaves, and axillary peduncled capjutate bracted flowers.

1. L. involucrata, L. Var. Floridana. Stem much branched, pubescent; leaves small $\left(1_{2}^{\prime}-1^{\prime}\right)$, oval or olovate, crenate, ronnded at the apex, densely pubescent when young, at length rough alove, contracted into a slender petiole; peduneles $2-3$ times as long as the leaves, the upper ones corymbose; heads small; bracts ovate, as lonir as the tulo of the sinall $\left(2^{\prime \prime}-3^{\prime \prime}\right)$ white? corolla ; the outer ones empty and narrower, involucrate - South Florida.

2. L. Camara, I. Stem pubescent, hirsute, or spiny; leaves ovateoblonø, acuminate, crenate, short-petioled, very rough above, pubescent beneath; peduncles as long as the leares; bracts laureolate, lialf as long as the tulue of the yellow corolla; involucre none. - St. Mary's, Gcorgia, Elliott. June-Nov. Shrub $2^{\circ}-4^{\circ}$ high. Leaves $2^{\prime}$ long. 


\section{CITHAREXYLUM, L}

Calyx cup-shaped or somewhat tubular, slightly 5-toothed. Corulla salvershaped, 5-lobed, the throat pubesecut. Stamens 4-5, included: anthers sagittate. Orary 4-celled. Style thickened upward: stigma notehed. Drupe juicy, of two 2-secled bony nutlets, partly ineluded in the enlarged indurated calyx. Trees or shrubs, with entire mostly glandular-petioled leaves, antl small flowers in slender spikes or racemes.

1. C. villosum, Jacq. Branches 4-angled, hairy or tomentose ; leaves somewhat coriaceous, oblong or ollong-obovate, obtuse, entire, tomentose and pale beneath, roughened and shining above, narrowed into a short biglandular petiole; spikes declining, loose-flowered; corolla smooth externally, the tuhe as long as the calyx, the lobes rounded or notched; stamens 4 ; drupe globose, half incluked in the enlarged calyx. - Sonth Florida. - Leaves $2^{\prime}-5^{\prime}$ long. Spikes $2^{\prime}-4^{\prime}$ long. Corolla $2^{\prime \prime}$ long. Drupe $4^{\prime \prime}$ in diameter. Fídoce ur ve

\section{DURANTA, I.}

Calyx tubular, 5-ribbed, 5-toothed. Corolla somewhat bilabiate, pubescent in the throat; the upper lip 2-lobed; the lower 3-lobed. Stamens 4, included. Ovary 8-celled. Style short : stigma oblique. Drupe baccate, of four 2-seeded bony wutlets, included in the enlarged beak-pointed calyx. - Slirubs. Leaves opposite or whorled, entire, dotted. Flowers showy, in axillary and terminal racemes.

1. D. Plumieri, Jacq. Spineless or spiny ; branches and racemes pubescent; leaves oblong or obovate, obtuse, entire, or serrate near the apex, tapering into a slender petiole; racemes curving, loose-flowered; lower bracts leafy; drupe glohose. - South Florida. - Leaves 1'-2' long. Corolla $5^{\prime \prime}$ long, lilac. Drupe yellow.

\section{CALLICARPA, L. Frexch Melberry.}

Calyx small, eup-shaped, 4-toothed. Corolla funnel-shaped, 4-cleft. Stamens 4, equal, exserted. Orary 4-eelled. Style slemler; stigma capitate. Drupe baceate, of four separate 1-seeded nutlets. - Shrubs, with a glindular or seurfy mo:tly stellate pubescence. Leares opposite, undivided, serrate, petioled. Flowers in axillary forked cymes.

1. C. Americana, L. Branches and leaves scurfy ; leaves ovate-oblong, acute at each end, erenate-serrate, rough above, hoary beneath, becoming smoothish ; cymes many-Howered, as long as the petioles; corolla blue; drupe purple. - Dry open woods, Florida to North Carolina, and west to Mississippi. Juue and July. - Shrub $3^{\circ}-8^{\circ}$ high. Leaves $4^{\prime}-6^{\prime}$ long.

\section{AVICENNIA, L.}

Calyx of 5 imbricated coneave sepals. Corolla bell-shaped, 5-lobed. Stamens 4, equal, exserted: anthers 2-eelled. Ovary 2-celled, with two collateral amphitropous suspended ovules in each cell. Style short or none. Capsule 
ovate, coriacens, indchiseent. Emblovo Inrge, naked, germinating within the

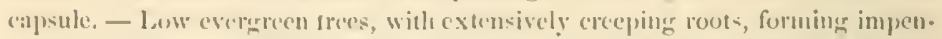
"trible thickets on the numbly shores of the sea. Jataves opposite, rntire, strooth nhove, homy and velvety beneath. Flowers in dense heads, on axillury and teminal pedunctes.

1. A. oblongifolia, Nutt ? Tomentose Itronghtout, exeptt the upy̨er surface of the rigid ublung olstuse short-petiuled leaves; peduncles thee together, terminal, shorter than the leaves; heads ovil ; sepals and bracts orhicular; corollat tomentose on lroth sides; stgle exscrted. - Kicy West. Oct. - Branches tercte. Leares $2^{\prime}-3^{\prime}$ long. P'duncles 4-angled. IItads $\frac{1}{2}$ long. Corollit $3^{\prime \prime}$ long.

2. A. tomentosa, Jaeq. Leaves olovafertliptical, very ohtuse, tapering into a petiole, sulooth ahove, white-tomentose beneath; spikes short, the lower flowers mostly scattered; corolla-lohes trumeate, silky below, smooth above; stigma nearly sessile. - Suuth Florida. Nuttall. - Leaves $3^{\prime}$ long. Corollis white.

\section{PHRYMA, I. LOPSEED.}

Calyx tnbular, bilabiate; the npper lip of 3 bristle-pointed teeth; the lower shorter, 2-eleft. Corolla bilabiate; the npper lip notehed, the lower longer, 3 . lobed. Stamens 4, didyuanous, included. Style slender. stigma 2-cleft. Fruit oblong, pointed by the persistent style. $-\Lambda$ perennial branching pubescent lerb, with opposite ovatte or oblong coarsely-serrate long-petioled leaves, and small opposite purplish flowers in a slender terminal spike. Fruit reflexed.

1. P. leptostachya, L. - Rich shaded soil, Florida to Mississippi. and northwarl. July and Aug. - Stem $1^{\circ}-3^{\circ}$ high, tumid above the joints. Leaves $3^{\prime}-5^{\prime}$ long.

\section{OrDER 94. IABI ATA. (MiNT FaMLY.)}

llerbs or shruhs, with opposite 4 -angled hramehes, and olposite exstipulate leaves. Flowers oppowite, solitary, or oftener in close axillary spiked or eapitate eymes (whorls). Calyx $3-10$-cleft or toothel. Corolla wore or less bilatiate, 4-5-hobed. Stamens inserted on the tule of the corolla, diandrous or dilynamons. Orary 4-cleft or 4-parted, the loles surromuling the base of the single style. Ovule solitary, erect, anatropıons. Fruit of $1-4$ one-serded nutlets. Albumen searce or none. Embryo straight or (in Scutellaria) curved. Radicle short, inferior. - Plants iommonly dotter with minute glands, which are filled with an aromatic volatile oil.

\section{Synopsis.}

TRIBE I. OCIMOIDER. - Stamens 4, didynamous; the lower pair longer, reclining on the lower lobe of the corotta. Anthers 2-celled. Nutlets smooth, distinct.

1. Ocisuy. Upper lobe of the caly $\mathrm{x}$ broal, decurrent Lobes of the corolla nearly equal

2. HYPTIS. Catyx-teeth nearty equal. Lowest lobe of the corolla longest, saceate, bent downward. 
TRIBE 11. SATUREIERE. -- Stamens 2 or 4, straight and sprealing, or connivent undet the upper lip; the upper pair shorter, or abortive. Anthers 2-celled. Nutlets smooth, distinct.

* Corolla-lobes nearly equal. Stamens distant.

3. MENTIA. Fertile stamens 4. Whorls spiked. Nutlets obtuse.

4. LYCOPUS Fertile stamens 2. Whorls axillary. Nutlets truncate.

* Corolla 2-lipped. Stamens straight, distant, spreading.

5. CUNiLA. Stamens 2. Caly $x$ equally 5 toothed, hairy in the throat.

6. PYCNANTIEMIU. Stamens 4. Caly $x 2$ lipped or 5 toothed, naked in the throat.

i. COLlixsoniA. Stamens 2 or 4. Calyx 2-lipped, the upper lip truncate, 3-toothed. Corolla fimbriate.

* Corolla 2-lipped. Stamens ascentling and spreading above, or counivent under the upper lip.

- Fertile stamens 2, the two sterile ones snall.

S. HEDEOMA. Calyx 13-nerved, 2 lipped; the lower lip hispid.

+ + Fertile stamens 4. Caly $x$ 13-nerved.

9. MICROMERIA. Calyx-teeth nearly equal. Flowers solitary. Low lierbs.

10. CALAMINTIIA. Calyx 2-lipped. Flowers in cymes. Anthers awnless. Chiefly shrubs.

11. DICERANDRA. Caly x 2-lipped. Anther-cells awned Branching annuals.

12. MELISSA. Caly $x$ tubular-bell-shaped, flattened on the upper side. Tube of the corolla curved upward.

TribE III. MON A R DEA. - Stamens 2, ascending and parallel. Anthers 1-celled, or with 2 confluent cells. Calyx and corolla 2-lipped. Nutlets smooth, distinct.

13. SALVIA. Counective of the anther elongated, oblique; the upper cell fertile; the lower abortive or wanting.

14. MONARDA. Anther 2-celled, the cells confluent. Calyx-teeth equal.

15. BLEPIILIA. Anther 2-celled, the cells confluent. Caly $x$ 2-lipped; the upper teeth amned.

Tribe IV. NEPETEXE.-Stamens 4, the upper pair longer Nutlets smooth, distinct.

16. LOPIIANTHUS. Upper stamens curving downward; the Iower ascendiug. Auther-cells parallel.

17. NEPETA. Stamens all ascending. Anther-cells diverging.

18. CEDRONELLA. Stamens ull ascending. Anther-cells parallel.

Tribe T. STACHYDEA. - Stamens 4; the lower pair longer, parallel, ascending Upper lip of the corolla concave or keeled. Calyx 3-10-toothed or lobed. Nutlets smooth, distinct.

* Caly x 2-lipped, closed in fruit.

15. BRCXELLA. Iips of the caly $x$ toothed. Flowers 3 in a rluster, spiked.

20. SCUTELLAlifA. Lips of the calyx entire; the upper one appendaged. Flowers single, opposite.

* *alyx not 2-lipped ; the teeth or lobes spineless.

21. MACBRIDEA. Caly $\times 3$-lobed. Flowers capitate, in crowded 4-flowered whorls.

22. PIISostegiA. Calyx 5-toothed. Flowers opposite, spiked. Nutlets 3 angled.

23. LAMIUM. Caly $x$ 5-toothed. Flowers in axillary cymes. Nutlets truncated.

* * * Caly $x$ not 2 -lipped; the teeth rigid or spiny.

24. MARRUBICM. Calyx-teeth 10, nearly equal. Stamens included. Ilerbs woolly.

25. LEONOTIS. Calyx-teeth 8-10, rery unequal. Stamens exserted. Whorls globose.

26. LEONURUS. Calyx-teeth 5. Nutlets obtuse, not truncate. Leaves incisely lobed.

27. STACIIYs. Calyx-teeth 5. Nutlets truncate, sharp-angled. Leaves undivided.

Tribe VI. AJUGEF.-Stamens 4, ascending, parallel, exserted. Nutlets reticulated and nitted, their bases partially united within.

* Stamens barely exserted, nearly equal.

23. ISANTHUS. Lobes of the corolla and caly x nearly equal. Peduncles 1 -3-forered. 
- Sinmena Inng-axerted, dliynnmous.

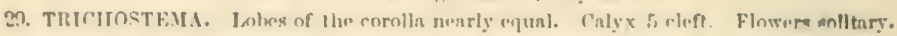

30. TELClill M. Lower lube of the corella lungest. Culy $x$ f-luothed. Whorle erowded.

\section{OCIMUM, I. BisiL.}

Calyx ovate or bell-shaped, 5-toothed, angled, deflexed in fruit; the upper tooth roundish, with the margins decourent. Corollat nearly equally 2-lipperd; the upeer lip 4-cleft; the lower entire, fitt. Stamens 4, dislynamous; the lower pair longer, resting upon the Jower lip of the corolla. Siyle s-eleft at the apex.

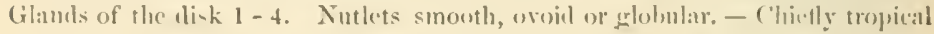
herles or shrubs. Whorls 6-flowered, in a terminal brated spike of raceme.

1. O. Campechianum, Miller. Stem branehed, pubeserent, ('xpecinlly at the joints; leaves ovate and ovate-lancenlate, acute, fincly serrate, narrowed into a slenile pubesent petiole, paler and pubeseent on the reins beneath, dotted; raceme many-flowered, pubescent ; bracts ovate ; caly $\mathrm{x}$ hispid on the ueres, the lower teeth awned; corolla small, slightly exserted; stamens smooth. - South Florida. - Stem $6^{\prime}-12^{\prime}$ high. Leaves $1^{\prime}-2 \prime$ long. Flowers purple.

\section{HYPTIS, Jarq.}

Calyx tubular, with 5 equal subulate teeth. Corolla 5-bobed; the four upper lohes short, spreadling or reflexed ; the lowest longer, saceate, aluruptly deflexerl, thickened at the base. Stanens 4, didynamons, included in the bud in the lower lobe of the corolla. Nutlets smooth, ovoid.

1. H. radiata, Willd. Herbaceons; stem ereet, mostly simple, pubeseent ahove; leaves orate-lanceolate, serrate or toothed, tapering into a petiole, smooth; hearls peduncled, in the axils of the upper leaves, globose, surrounded by an involnere of several lanceolate whitish bracts, puthesecnt; corolla small, white, lotted with purple. - Low ground, Florida to North Carolina, and westward. July-Sept. - Stem $2^{\circ}-4^{\circ}$ higl.

\section{MENTHA, L. Mist.}

Calyx tuhular, nearly equally 5-toothed. Corolla equally 4-lohed, the upper lohe notehed or entire. Stamens 4, equal, distant, straight: anther-cells parallel. Style 2-eleft at the apex. Nutlets smooth, obtuse. - l'ungent aromatic herbs. Whorls (in our species) approximate, forning a dense or interrupted terminal spike.

1. M. viridis, L. Stem and leares smooth; leares ovate-lanceolate, uncqually scrrate, nearly sessile; bracts leafy, and, like the calyx, snooth or hairy; spike eylindrical, interrupted below; calyx-teeth linear-subulate. (M. tenuis, N/ich.r.) - Damp soils. Introduced, and sparingly naturalized. July - Sept. Stem $1^{\circ}-2^{\circ}$ high. Flowers pale bluc.

2. M. rotundifolia, L. Soft-hairy; stem erect; leaves roundish, rugose, crenate, sessile, hoary beneath; spikes oblong, interrupted; bracts lanceolate; 
fruiting calyx ronndish, the teeth short and acute. - Near Wilmington, North Carolina. Introduced - Stem $1^{\circ}-2^{\circ}$ high. Corolla whitc.

3. M. piperita, L. Smooth; stem creeping at the base, ascending, branched; leaves orate-oblong, acute, sharply scrrate, rounded at the base, short-petioled; spikes slender, interrupted; bracts mostly longer than the whorls, the upper ones linear; calyx-teeth hairy. - Low ground. Introdueed. July - Sept. - Stems $1^{\circ}-2^{\circ}$ high. Flowers white or blue.

\section{LYCOPUS, L.}

Calyx bell-shaped, equally 4-5-toothed, naked at the throat. Corolla bellshaped, exserted, equally 4-cleft. Fertile stamens 2, exserted; the upper pair sterile, included or wanting: anther-cells parallel. Style 2-cleft at the apex. Nutlets 3-angled, truneate at the apex, narrowed at the hase. - Marsh or aquatic herbs, with long runners at the base. Leaves mostly toothed or pinnatifid. Whorls dense, axillary。 Flowers small, sessile.

1. I. Virginicus, L. Stem smoothish; leaves ovate-lanecolate, toothedserrate, acute or acuminate at each end, roughened above; calyx-tceth 4 , ovate, obtuse; corolla small, exserted; sterile stamens minute.-Ponds and ditches, Florida? and northward. Sept. - Stem $1^{\circ}-2^{\circ}$ high. Leaves $1^{\prime}-2^{\prime}$ long. Flowers white.

2. I. sinuatus, Ell. Stem smooth, much branched; leaves pinnatifidtoothed, ovate-oblong, tapering at each end; the upper ones narrower; calyxtecth 5, laneeolate-subulate, acute; corolla twicc as long as the calyx; sterile stamens minute or none. (L. exaltatus, Pursh.)

Var. intermedius. Closcly pubescent or tomentose; stem simple or branched, very leafy; leaves ovate-lanceolate, acuminate at each cnd, coarsely serrate, pale beneath; whorls dense; calyx-teeth subulate, pubescent, ncarly as long as the corolla; seeds pitted.

Var. angustifolius, Benth. (L. angustifolius, Ell.) Pubescent ; stem simple or sparingly branched; leaves sessile, lanceolate or linear, toothedserrate or entire, resinous-dotted; calyx-tecth subulate. - Ponds and ditehes, Florida to Mississippi, and northward. Aug. - Oct. - Stem $2^{\circ}-4^{\circ}$ high. Leaves $2^{\prime}-4^{\prime}$ long. Flowers white.

\section{CUNILA, L. Dittaxy.}

Calyx tubular, 10-nerved, equally 5-toothed, hairy in the throat. Corolla 2-lipped; the upper lip notched or entire, the lower 3-cleft. Stamens 2, distant, exserted : anther-cells parallel. Style 2-cleft at the apex. Nutlets smooth.Perennial herbs. Flowers small, in corymbose or crowded whorls.

1. C. Mariana, L. Sinooth; stem slender, much branchel ; leaves ovate, scrrate, acute, rounded or cordate at the base, subsessile; cymes loose, axillary and terminal, pedunclerl, mostly shorter than the lenves, corymbose ; calyxtecth laneeolate, acute. - Dry soil along the mountains, Georgia and northward. July-Sept. - Stem $l^{\circ}$ high. Leares $l^{\prime}$ long. Flowers purple. 


\section{PYCNANTHEMUM, Michx. HuRsi-MiNT.}

Calyx tubular, 13-atervenl, naked in the thront, equnlly 5-toothed, or slightly 2-lippeal. Corolla 2-lipped; the upjer lip nothed or entire, the lower 3-elleft. Stunens 4, nearly equal, straight, spreading, commonly "xserterl: unther-eclls parallel. Style 2-cleft at the apex. Nutlets smooth. - Perential mostly pmbeseent or hoary herbs, with erect branching stems. Floral leaves often whitetomentose. Cymes mosty terminal, bracted. Corolla small, white or purplish - Plants aromatic mud pungent.

* Caly $x$ more or less 2-lipped, the sululute terth offen hearded with urul jointrd hairs: cymes mostly terminal, widely spreading in fruit: lracts longer than the floucers: leaces pubscent, the uppermost uhitend.

1. P. incanum, Michx. Stem densely pulescent and hoary; leaves ovate or oblong-ovate, acute, sharply serrate, short-petioled, hoary-tonentose beneath ; calyx-teeth sulmlate, and, like the bracts, commonly bearderl with weak hairs (1'. Loomisii, Nutt.) - Var. Telua. (P. Tullia, Benth.) Leaves smaller and smoother; eymes larger and more expanded; calyx-teeth longer. - Var. A1nescess. ( $I^{\prime}$. albeseens, (iray.) Leaves orate-lanecolate, oltuse, smooth ahove, hoary beneath; (alyx-tecth triangular lanecolate, obtuse, not bearled. - Dry woods and fence-rows, Florida to Mississippi, and nortloward. Aug and Sept. Stem $2^{\circ}-4^{\circ}$ ligh. Leaves $1^{\prime}-2^{\prime}$ long. Flowers white.

2. P. dubium, Gray. Stem villous-pubescent; leaves lanceolate, aeute at each end, smooth or nearly so, entire; cymes hoary, dense-flowered, shortpeduncled; calyx-teeth subulate, tipped, like the lracts, with a tuft of weak hairs; the 2 lower ones shorter. - Mountains of North Carolna. Aug and Sept. - Stem $2^{\circ}-3^{\circ}$ high. Leaves $2^{\prime}-3^{\prime}$ long.

* Calyx-tefth nearly equal.

- Caly.x as long as the corolla; the teeth subulate and awn-pomtcd, like the rigid bracts: cymes dense-flowered

3. P. aristatum, Michx. Tomentose and hoary, or sometimes hairy; stem branched ; leaves ovate or oblong, acute, sparingly serrate, rounded at the base, short-petioled, the uppermost somewhat whitened; eymes mostly terminal; ovary bearded. - Var, urssopifolidy, Gray. Stem simple or enrymbose above; leaves rigid, linear-oblong, obtuse, entire. - Low ground, Fiorida to Mississippi, and northward. Aug. and Sept. - Stem $1 \frac{10}{2}-3^{\circ}$ high. Leaves l' $^{\prime} 2^{\prime}$ long.

+ + Culyx-teeth beardless and aunless: cymes cupitate, mostly termmal: Uructs shorter then the flowers: leaves subsessile.

4. P. pilosum, Nutt. Softy pubescent or villous; branches short, erect, leaves lanceolate, entire, acute at each end, none of them whitened; eymes small, compact, corymbose; calyx-teeth ovate-lanceolate, acute, and, like the bracts, hoary-tomentose, or, in var. Levtovos, Gray, subulate and villons. Upper districts of Gcorgria, and northward. Aug. and Sept. - Stem $2 \circ$ high. Leaves $1^{\prime}-2^{\prime}$ long. 
5. P. muticum, Pers. Smooth or tomentose; stem corymbosely branched; leaves ovate or ovate-lanceolate, acute, scrrate, romded or slightly cordate at the base, sessile or short-petioled, the uppermost whitened; cymes suall, com. pact, corymbose, minutely hoary-tomentose; calyx-teeth short, triangular-ovate, obtuse. - Dry soil, Florida to Mississippi, and northward. Aug. and Sept. Stem $1^{\circ}-2^{\circ}$ high. Leaves $1^{\prime}-2^{\prime}$ long.

++ + Cymes capitate, in compact corymbose clusters: bracts shorter than the flowers: stem and rigil entire leaves smoothish.

6. P. lanceolatum, Pursh. Stem branched; leares lanceolate or linearlanceolate, acnte, rounded at the base; cymes numerous, pubescent; bracts orate-laneeolate; calyx-teeth slort, triangular. - Dry soil in the upper districts. Aug. and Sept. - Stem $2^{\circ}$ highl. Leaves $1^{\prime}-2^{\prime}$ long.

7. P. linifolium, Pursh. Stem branched; leaves rery numerons, linear, sessile; cymes smoothish ; lracts linear, acute; ealyx-teeth lanceolate-subulate, rigid, acute. - Dry soil, Florida to Mississippi, ancl northward. Aug. and Sept. - Stem $2^{\circ}$ ligh.

8. P. nudum, Nutt. Smooth; stem simple or corymbose at the summit, straight; leaves sessile, ovate-oblong, ohtuse, rounded at the base; cyme's smooth; exterior bracts narrow-lanceolate, the inner short, subulate; calyxteeth short, triangular-lanceolate, and, like the corolla, pubescent. - Low pine barrens, Dalc Comnty, Alabana, to the mountains of Nortli Carolina. Aus. ant Sept. - Stem $2^{\circ}$ high. Leares $\frac{1}{2}^{\prime}-1^{\prime}$ long.

+++ Cymes axillary and terminal, large, dense-flowered: Urcuts ciliate.

9. P. montanum, Michx. Stem slender, smooth, simple or branched; leaves smooth, orate-lanceolate, serrate, acute, tapering into a short petiole, the lowest rounded at the base; cymes globose, the upper ones closely sessile; bracts numerous, ciliate; the exterior ovate, very acute, as long as the flowers, the inner ones linear; calyx-teeth short, acute; ovary bearded. - Mountains of North Carolina. July and Ang. - Stem $1^{\circ}-3^{\circ}$ high. Leaves $2^{\prime}-3^{\prime}$ long.

\section{COLLINSONIA, L. HoRse-B.im.}

Calyx ohovate, enlarged and deflexed in fruit, 2-lipped; the upper lip flattened, truncate, 3-toothed, the lower 2-eleft. Corolla funnel-shapel, 2-lipped, dilated at the throat; the four upper lobes equal, the lowest larger, declining, toothed or fimbriate. Stamens 2 or 4, long-exserted, spreading: anther-cells diverging. Nutlets smooth. - Strong-scentel perennial herbs. Leaves large, coarsely serrate, dotted beneath. Flowers yellowish, solitary, opposite, in racemes or panicles. Petioles tunid at the base.

\section{* Fertile stamens 2.}

1. C. Canadensis, L. Nearly smooth; leaves ovate or oblong-orate, acuminate, sharply serrate, acute, rounded or cordate at the base, long-petioled, the uppermost smaller, sessile; panicle elongated; bracts minute, very acute; flowering ealyx very small, the upper lip much shorter than the lower, with 
sulunlate treth; corolla 4 times as long as the calyx, yollowish. - Kirh shatded soil, Floridn to Mississippi, nud northward. S'pt. - Sten $20-4 \circ$ highl. Lenves $4^{\prime}-y^{\prime}$ long. Corolla $3^{\prime \prime}-5$ " long.

2. C. scabriuscula, Ait. Sim smoothish; leares petioled, ovate, arute, dentate, roumled at the base, smooth above, the uppermo-t sescile; bracts small, subulate-acuminate; panicle elomgatted, leafy at the lase; ralyx-tecth short, neute; stamens included or exserted. - lich wools, Florida, P'ursh, to South C'arolina, Ellliott. Sept._- Stem $3^{\circ}$ high. Leaves 2' $3^{\prime}$ long, on short petioles. Corollat half as larere an in the preceding, the lowent lobe jurpule.

3. C. punctata, Ell. Stemn puliescent; leaves wate-lanccolate, acuminate, mucronate-serrate, pubesent and dotted beneatli ; puluicle pulieseent, leafy at the base; bracts ovate, acute or acuminate; calyx-teeth large, lanceolate, acute, nearly equal, $\frac{1}{2}-\frac{1}{3}$ as long as the yellowish corolla; sterile stamens included, capitate. - Rich shady woods, Florida to North Carolina. Sept. Stem $2^{\circ}-4^{\circ}$ high. Leares $4^{\prime}-6^{\prime}$ long. Corolla $4^{\prime \prime}-6^{\prime \prime}$ long, hairy within.

4. C. ovalis, Pursh. Stem slender, pulueseent above; leaves ovate or round-ovate, acute, smooth, with few very course mucronate tectl, the lowe ones harely longer than the rery slender petiole, the upper sessile; racemes panicled; calyx pubeseent, with unequal subnlate teetlı; bracts orate, acuminete. - Mountains of North Carolina. - Stem $2^{\circ}$ high. Leares (excluding the petiole) $2^{\prime}$ longr, $1 \frac{1^{\prime}}{2}$ wide.

\section{* * Frtile stamens 4.}

5. C. verticillata, Baldw. Stem simple, smooth below; leaves 4 , membrimaccons, elliptical, acute, rather fincly serrate, acnte or obtuse at the base, short-petioled, approximate, the lower surfice, like the simple long-peduneled raceme, viscid-pubescent; lower flowers whorled, the upper opposite; bracts minute; caly-tecth linear-submate, half as long as the corolla - Light shaded soil, Georgia, elicfly in the upper districts. Sept. - Stem $1^{\circ}$ high. Corolla yellow or purplish.

6. C. anisata, Pursh. Viscid-pubeseent; stem stout, simple or hrauched; leaves larre, oval or ovate, acute, mucronate-crenate, mostly rounded or coriate at the hase, the uppermost sessile; panicle many-flowered; bracts ovate; calyxlolses large, ovate-lanceolate, nearly equal ; corolla large, yellow. - Dry shaded soil, Georgia, Alabama, and Florida. Aug. and Sept. - Stem $1^{\circ}-2^{\circ}$ high. Leaves $4^{\prime}-8^{\prime}$ long. Corolla $\frac{1^{\prime}}{2}-3^{\prime}$ ' long.

\section{HEDEOMA, I'ers.}

Calyx tubular, somewhat gibhous under the hase, equally 5-toothed or bilabiate, with the upper lip 3-tootheel, the lower 2-rleft, hairy in the throat. Corollat 2-lipped ; the upper lip notched or entire, the lower 3-cleft. Stamens 2, ascending : antler-cells diverging. Nutlets smooth. - Iterbs, with small leaves, and axillary few-flowered 'ymes.

1. H. pulegioides, Pers. Annual, pubescent, much branched; leares oblong-ovate, obtuse, sparingly serrate, pale beneath, contracted into a slender 
petiole; whorls 6-flowered, shorter than the leaves; lower lip of the ealyx hispid. - Dry hills in the upper districts. June-Sept. - Stem $1^{\circ}$ high. Leaves $1^{\prime}$ long. Corolla small, pale blue.

\section{MICROMERIA, Benth.}

Calyx tubular, 13-nerved, nearly equally 5-toothed, mostly lairy in the throat. Corolla 2 -lipped; the upper lip flat, notched or entire, the lower spreading, 3lobed; the straight tube commonly shorter than the ealyx. Stamens 4, didynamons, arehing inward: anther-cells parallel, or at length diverging Nutlets smooth. - Herbs, with the small white or purple flowers solitary, or few in a whorl, chiefly axillary.

1. M. Brownei, Benth. Smooth; stem prostrate or ascending, mostly simple; leaves round-ovate, obtuse, crenate or entire, short-petioled ; flowers solitary, opposite, on widely spreading peeluncles, exceding the leaves, ereet, purple. - River-banks, Florila. July and Aug. - Stem $6^{\prime}-12^{\prime}$ long. Leaves $4^{\prime \prime}$ $-6^{\prime \prime}$ long.

\section{CALAMINTHA, Benth.}

Calyx tulular, 13-nerved, 2-lipped; the upper lip spreading, 3-toothed, the lower 2-cleft, bearded or naked in the throat. Corolla 2-lipped, open at the throat; the ujper lip notelied or entire, the lower 3-lobed, the tube commonly exsertel. Stamens 4, dielynamous, arching inward: anther-cells at length diverging. Nutlets smooth. - Herbs or shrubby plants, with white, searlet, or purple flowers

\$1. Calanintia. Irerbs: cymes peduncled, compound, small-bracted; the upper ones forming a 1-sided compound raceme: flowers small.

1. C. Nepeta, Link. Villous; stem mueh branched, aseending; leaves small, ovate, obtuse, serrate, petioled; eymes numerous, dichotomons, looseflowered; calyx bearded in the throat, half as long as the purple corolla. Waste places and road-sides, Georıia to North Carolina, introduced. July Sept. - Stem $1^{\circ}-2^{\circ}$ long. Leaves $\frac{1}{2}^{\prime}$ long.

\$2. Calonelissa. Shrubs: cymes nearly sessile, axillary, few-flowered, often leafy-bracted: pedicels elongated: throat of the calyx bearded: Alowers shoury.

2. C. Caroliniana, Sweet. Stem much brancherl, elosely puhescent; leaves rigid, smooth, oval or oblong, obtuse, erenate, finely dotted, narrowed into a sleneler petiole; axillary leaves small and elustered; eymes 6 -flowered, the lower bracts leafy; corolla white or purple, spotted. - Samly or rocky banks, Florida to North Carolina. Aug. and Sept. - Shrub $1^{\circ}-2^{\circ}$ high, the flowering branches simple. Leaves $I^{\prime}-1 \frac{1}{2}$ long. Corolla I' long.

3. C. coccinea, Benth. Smooth or minutely pubescent; leaves obovateoblong, obtuse, entire or obscurely crenate, tapering into a short petiole; flowers solitary, or in 3-flowered bracted eymes; corolla large, scarlet. - Sandy shores of St. Andrew's Bay, West Florida. Oet. and Nov. - Stem $2{ }^{\circ}$ high, the outer bark loose and shredly. Leaves $\frac{1}{2}$ long. Corolla $1 \frac{1}{2}$ long. 
4. C. dentata, u. sp Demedy tumentose; stcu diffusely branchul ; leaves small, obuvate or weelge-shnjed, roumled and 2 - 4 -texthed ut the apex, weurly sessile; fluwers solitary or 3 terederer (alyx smosth, the upper lip emanginate

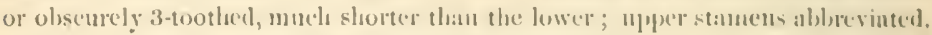
sterile. - Samd ridges near Aspaliagal, Florida. Sept. and (Wet. - Stem 20 lighl. Leates very numerous, $\frac{1}{2}$ long.

5. C. canescens, Torr. \& Gray. Hoary-tomentose; stem diffuscly branched ; laves linear, entire, obtuse, with the margins revolute; cynes very numerous, 1-3-flowered; inlyx suooth or hairy, the upper lip obtusely' 3-twothed ; corolla hairy, white or purple, dotted in the throat ; anthers hairy. - Dry sands along the west coast of Florila, flowering throngliout the year. Stem $1^{\circ}-20$ light. Leaves $\frac{1}{2}-\frac{3}{4}$ long. Corolla ${ }_{2}^{\prime}$ long.

\section{DICERANDRA, Benth.}

Calyx tubular, 33-rerved, 2-lipped; the upper lip entire or minutely 3-toothed. the lower scarecly longer, 2-cleft, the throat bearled. Corolla 2 -lipped; the upper lip erect, the lower spreading, 3-cleft. Stancens 4 , didymanoms, spreading, exserted: anther-cells distinct, diverging, awned at the apex Nutlets smooth. - Smooth annuals, with narrow leaves. Cymes loose, spreading, several-flowered, forming a leafy terminal raceme. Flowers purple.

1. D. linearifolia, Benth. Stem mostly branching, erect; leaves linear or lanceolate, serratte or entire, obtuse, scssile; cymes peduncled, 3-9-flowered ; calyx purple, declined in fruit. (Ceranthera linearifolia, Ell.) - Dry sandy pine barren;, Florida, Georria, and westward. Oct. and Nor. - Stem 10 high. Leaves I' long. Flowers very numerous, purple, dotted. Style hairy.

2. D. densiflora, Benth. Stem loosely branclued ; leaves oblong-laneeolate, or the uppermost linear; cymes sessile, 5-10-fluwerel. - East Florida, Bentham. - Cymes more compact, calyx smaller, and the awns of the anthers shorter, than in No. 1.

\section{MELISSA, L. B.ı..}

Calyx tulular-bell-shaped, 13-nerved, 2-lipped; the upper lip flattish, 3-toothed, tle lower 2-(deft, beardless in the throat. Corolla-tube renrred-aseendingr, 2-lipped; upper lip ereet, the lower 3-cleft, spreadiug. Stamens 4, curved and connivent under the upper lip: anther-cells at length diverging. Nutlets smonth. - Ilerbs, with few-flowered 1-sided axillary eymes, and white or yellow flowers.

1. M. officinalis, L. Stem erect, branching; leaves nvate, crenate, truncate or corlate at the base; cymes 3-6-flowercd, witl orate bracts. - North Carolina, and northward. Introduced.

\section{SALVIA, L. SAGE.}

Calyx tuhular or bell-shaped, 2-lipped; the upper lip entire or 3-toothed, the lower 2-cleft, beardless in the throat. Corolla 2-lipped; the upper lip entire or 
notehed, the lower sprealing, 3-lohed, with the middle lobe larger, entire or notehed. Stamens 2, short: anther-cells linear, widely separated by the elongated oblique comnective; the upper one fertile, the lower imperfect or wanting. - Cymes in spikes, racemes, or panicles.

\section{* Lpper lip of the caly.r entire: lower anther-cell wanting.}

1. S. azurea, Lin. Smooth; stem simple or branched; leaves lanceolate or linear, obtuse, entire, or the lower ones serrate, tapering at the base; racemes elongated; whorls nearly sessile, 6-12-flowered; calyx longer than the pedicel, the teeth ovate, acute; corolla $2-3$ times as long as the calyx, white or bluc; style bearded. - Dry light or sandy soil, Florida to South Carolina, and wesiward. July and Aug. - Stem $2^{\circ}-4^{\circ}$ high. Leaves $1 \frac{1}{2}^{\prime}-3^{\prime}$ long. Corolla $6^{\prime \prime}$ $-8^{\prime \prime}$ long.

2. S. urticifolia, L. Stem $\left(1^{\circ}-2^{\circ}\right)$ mostly simple, villous-pubescent and somewhat viscil; leaves thin, rhombic-orate, acnte, serrate, ahruptly contracted into a winged petiole, the upper surface and veins beneath sparse-hairy ; racemes terminal; bracts ovate, acmminate, calucous; whorls 6-12-flowered, remote; calyx bell-shayed, longer than the pedieel, broadly 3 -toothed, about half as longr as the blue and white corolla ; style bearded.

Var. major. Leaves rigid, narrower, acuminate, crenate, with longer and broader-winged petioles; the lower surface, like the taller $\left(4^{\circ}-6^{\circ}\right)$ branching stem, hoary-tomentose ; racemes axillary and terminal ; flowers smaller. - Dry soil in the upper districts of Georgia, and northward: the variety in Middle Floridia. July - Sept. - Leares $2^{\prime}-4^{\prime}$ long. Corolla $4^{\prime \prime}-5^{\prime \prime}$ long.

3. S. serotina, I. Stem tomentose, branclingr ; leaves ovate, mostly acute, crenate-serrate, tomentose, paler beneath, cordate or truncate at the base, petioled; racemes many-flowered; whorls mostly 6-flowered, the lower ones rather distant, the upper much crowded; calyx glandular, longer than the pedicel, aeutely toothed, the upper lip purple; corolla small, twice as long as the calyx; style beardless; the lower lohe spatulate, acute, the upper short, subulate, reflexed. - South Florida. Nov. - Stem rigid, $1^{\circ}$ high. Leaves $1^{\prime}$ long, twice as long as the petiole. Corolla blue and white, $3^{\prime \prime}-4^{\prime \prime}$ long.

4.' S. Blodgettii, n. sp. Stem much lranched, shrubhy at the base; branches erect, filiform, jubescent; leaves small, thin, oval or ovate, slightly crenate, rounded at the apex, acute at the base, about as long as the very slenfler petiole; racemes filiform, few-flowered; whorls distant, 2-6-flowerel ; calyx somewhat ghamilular, acutely toothed, slightly inflated in fruit; corolla very small; lower lobe of the style spatulate obtuse. - South Floritit. - Stem 6' 12' high. Leaves $6^{\prime \prime}-9^{\prime \prime}$ long. Flowers blue, smaller than in No 3.

\section{* U Uper lip of the calyx lroad, 3-toothed: lower anther-cell pollen-learing, but sterile.}

5. S. Iyrata, L. Hairy ; stem erect, sparingly branched; leares chiefly radical, spreading, lyrate-pinnatifid, mostly discolored; sten-leaves 2 or 4, smaller; the upper pair lanceolate and entire; raceme many-flowered; whorls 6-flowered, distant in fruit, longer than the ovate-lanceolate bracts; upper lip of the bell-shaped calyx truneate, with short erect tecth; corolla-tube elongaterl, 


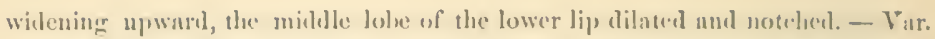

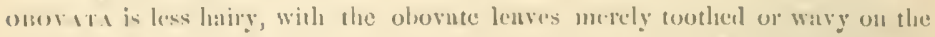
namprins. (S. wovita, Ell.) - Samly soil, Florila to North Carolina, and westwarl. April and May, - Stem 10 high. Laves $3^{\prime}-6^{\prime}$ lonar, commonly purple treneath. lianemes in fruit $6^{\prime}-12^{\prime}$ long. Corullat $9^{\prime \prime}-12^{\prime \prime}$ long, blue, whitespetted in the throat.

6. S. Claytoni, lill. Ifaves cordate-ovate, sinuate, toothed, rugose; treth of the mper lip of the enlyx connivent. - 1)ry samly pastures, around Beanfort, South Civolina, Filliot. Norts Carolina, Curtis; flowering through the summer. - Root thick, perennial. Stem 10 hight. Leaves pubescent on the veins and marcrins. Bracts cordate-ovate, acuminate, tuuthel.

S. offucixalas, L., is the common Garuex Sage.

S. coccrst. L., is common in gardens, and occasionally spontaneous around dwellings.

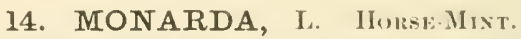

Calyx tubular, elongated, 15-nerved, nearly equally 5-toothed, bearied in the throat. Corolla nearly equally 2-lipped; the upper lip notehed or entire, the lower 3-toothed. Stumens 2, ascending under the upper lip, and oftener exserted: anther-eells linear, divereringr, confluent. Nutlets smoth. - Herbs. Leares undivided. Whorls large, dense-flowered. Bracts colored.

\section{* Cipper lip of the corolla linatr, acute.}

1. M. didyma, L. Stem smoothish; leaves orate-lanceolate, acuminate, serrate, rounded at the base, petioled, smooth or hispid; whorls mostly solitary, terminal ; ealyx smooth, inenrved; corolla large, bright red. - Mountains of North Carolina, and northward. Aug. and Sept. - Stem ereet, 20 high. Leaves $2^{\prime}-3^{\prime}$ long. Bracts lanceolate, red. Corolla $\mathbf{l}^{\prime}$ Jong.

2. M. fistulosa, I. Sten branching, more or less pulescent, comnonly hairy at the joints; leaves petioled, ovate-lancelate, acute, sharply serrate, mostly rounded or truncate at the base ; whorls terminal ; ealyx slightly incurved, hispid in the throat; corolla slender, rose-color. (M. Clinopodia, and M. mollis, L.) - Mountains of Georgia, and northward. Aug. and Sejt. - Stem $2^{\circ}-5^{\circ}$ high. Leaves smoothish, tomentose, or lhispiu, $1^{\prime}-3^{\prime}$ long. Bracts pale purple.

* * Lpper lip of the corolla brouder, notched.

3. M. punctata, L. Closely and finely pulesecut; sten much branched; leaves laneeolate or oblong, acutish, slightly serrate, narrowed into a petiole, whorls lateral and terminal; bracts ovate or oblong, purple; corollit yellowish; the lower lip dotted with brown, the upper keeled; stamens not exserted. - Dry santly soil, Florida to Mississippi, and northward. Aug. - Uet. - Stem $1^{\circ}-3^{\circ}$ high. Leaves $1^{\prime}-2^{\prime}$ long.

4. M. gracilis, Pursh. Very smooth; whorls lateral and terminal ; exterior bracts linear, ciliate; corolla short ; leaves linear-lanccolate, acuminate, serrate. - Mountains of Carolina, Lyon. - Stem obtuse-ingled. Whorls small, naked. Calyx pubescent, ciliate. Corolla very sleuder, smooth, yellowish. white. (*) 


\section{BLEPHILIA, Raf.}

Calyx ovate-tubular, 13-nerved, beardless in the throat, 2-lipped; the upper lip with three awned teeth, the lower 2-cleft, awnless or short-awned. Anthers 1-eelled. Utherwise like Monarda. - Stem erect. Whorls several, lateral and terminal, the upper ones crowded.

1. B. ciliata, Riff. Stem hirsute; leaves nearly sessile, ovate-lanceolate, fincly scrrate, smoothish ahove, paler and tomentose beneatl, whorls globose, crowded, or the lower ones distinct; bracts ovate-lanceolate, long-ciliate; calyx and corolla hairy. (Monarda ciliata, L.) - 1)ry soil, in the npper districts of Gcorgia, and northwark. July and Aug. - Stem $2^{\circ}-3^{\circ}$ high. Leaves $2^{\prime}-3^{\prime}$ longe Corolla $\frac{1}{2}$ long, blue.

2. B. hirsuta, Benth. Stem hirsute; leares long-petioled, ohlong-orate, serrate, smooth or hirsute; whorls globose, distinct, or the upper ones crowded, the lower axillary; bracts linear-subulate, lone-ciliate; corolla slightly pubescent. (Monarla hirsuta, Pursh.) - Damp woods on the mountains of North Carolina, and northward. July and Aug. - Stem $2^{\circ}-3^{\circ}$ high, branching. Leaves thin, $3^{\prime}-4^{\prime}$ long. Corolla pale blue.

\section{LOPHANTHUS, Bentl.}

Calyx tutular, 15-nerved, slightly incurved, with the mouth oblique, and unequally 5-toothed. Corolla 2-lipped; the upper lip deeply notched, the lower spreading, 3-cleft, with the middle lobe crenate. Stamens 4, distant or spreading, the upper pair longer: anther-cells parallel. Nutlets smooth. - Erect peremial herbs Whorls numerous, crowded in a cylindrical spike.

1. L. scrophulariæfolius, Benth. Stem puleseent, leares petioled, ovate or ovate-lanceolate, acmininate, serrate, lairy bencath; spike interrupted at the base; calyx-teeth whitish, lanceolate, acute. - Momtains of Georgia, and northward. Aug. - Stem $3^{\circ}-4^{\circ}$ high. Spikes $4^{\prime}-15^{\prime}$ long. Bracts orate. Corolla purplish.

2. L. nepetoides, Benth. Smooth; leaves petiolerl, ovate or oblong, acute, serrate; spike interrupted at the base; calyx-teeth green, ovate, barely aeute. - Woods, North Carolina, and northward. Aug. - Stem $4^{\circ}-6^{\circ}$ high. Bracts ovate. Corolla greenish-yellow.

\section{NEPETA, L. CitхIי.}

Lower lip of the corolla 2-cleft or entire. Stamens ascending : anthers approximate by pairs, the cells diverging. Otherwise like Lophanthus. - Corolla blue or white.

I. N. Cataria, I. Erect, hoary-pubeseent; leaves petiolate, corlate-ovate, acute, coarsely serrate; whorls many-fowered, the upper ones crowdel in a thick dense raceme, the lower axillary; bracts as long as the pedicel; ialyxteetl lanceolate-subulate, the upper ones longer; corolla sinall, white. - Waste grounds, introduced. - Stem $2^{\circ}-3^{\circ}$ high. 
2. N. Glechoma, I3entl. Stem prostrate or ereeping, pubesent; leaves

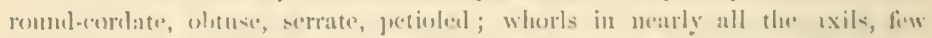

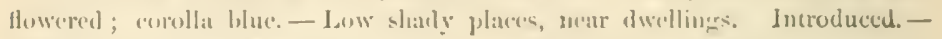
Stem $t^{\prime}-12^{\prime}$ long. Letaves $2^{\prime}-1^{\prime}$ long. Anthers forming a cross.

\section{CEDRONELLA, Mnnch.}

Calyx licll-shaped, nearty equally 5-trothed; the month ohlique. Corolla dilated at the throat, 2-lipped; the upper lip stmight, 2-cheft, the lower 3-cideti, with the miclule lobe largest. Stamens 4 , ascending, the mper puir lonerest anther-cells jarallel. Nuthets smooth. - Flowers in a terminal spike or raceme.

1. C. cordata, Benth. Stem low, pulsecent, learung loug rumuers; leaves long-jetiolel, corilate, crenate, smoothish; the floral ones ovatte; raneme fewHowered, 1-sided; cymes 1-3-flowered; calyx and pulc-bluc corolla large. (1) racocephalum cordatum, Nutt.) - Shady banks, un the monntains of North Carolina. May aml Junc. - Stem $\frac{1}{2}$ high, creeping at the basc. Laares l' $^{\prime}$ lonir. Corollat 1 $\frac{1}{2}$ long. Plant pleasamt-scented.

\section{BRUNELLA, Tourn. SELF-HiAl.}

(alyx tubular-hell-shaped, lo-nerved, fat above, 2-lipped; upper lip broad, truncated, 3-toothed, the lower 2-eleft. Corolla-tube slightly inllated under the throat, 2-lipped; the upper lip ronndish, arching, entire, the lower 3-lobed, with the middle lobe rounded, concave, erenate. Stamens 4 , exserted, the smouth filanent prolonged above the anther: anther-celts spreading. - IIerbs, with 6-flowered densely-spiked whorls. Floral leaves orbicular, imbricated, persistent.

1. B. vulgaris, L. Pubesent or smoothisl ; ftem crect, mostly simple; leaves orate or oblong, servate, petioled; spike's oblong or eylindrical; flowers purple. - Low grounds, Florila, and northward. Introduecd. - Stem 6'-12' lighl. Spikes thick, lateral and terminal.

\section{SCUTELLARIA, I. SKrLlcar.}

Calyx bell-shaped, 2-lipped, entire and closed after flowering; the upper lip furnished with a helnet-shaped appendage on the back, and fatling away at maturity, the fower persistent. Corolla-tube rentred-isecending, dilated at the throat, 2-lipped ; the upper lip arehing, entire or notehed, with the small lateral loles united with its siles, the lowest lobe large and iprealing. Stamens 4, ascending : anthers ciliate, alproximate by pairs, those on the shorter filaments 1-celled, on the longer ones 2-celferl, cordate. - Perennial mo-tly inodorous hrrbs. Flowers opposite, solitary, in the axils of the upper, mostly bract-like leaves, rarely in lateral racemes. Corolla blue or white.

\section{* Flowers in terminal raremes.}

- Leaves cordute, oxate or oblong, crenate, petiold; the floral ons shorter than the flowers, entire.

1. S. versicolor, Nutt. Softly pubeseent; stem stout, brancherl above; leaves large, long-petioled, all broadly cordate, rugose and reticulate; the floral 
ones ovate, sessile; racemes terminal and axillary, many-flowered, viscil ; ealyx hatry; laterul lobes of the corolla conspicuous. (S. cordifolia, Muhl.) - Dry open woods in the upper districts. July - Sept. - Stem $2^{\circ}-3^{\circ}$ high. Leaves $2^{\prime}-4^{\prime}$ long. Racemes $3^{\prime}-6^{\prime}$ long. Corolla $6^{\prime \prime} \ldots 8^{\prime \prime}$ long, blue and white.

Var. minor. Snall $\left(6^{\prime}-12^{\prime}\right)$; leaves tomentose, fincly crenate ; the lowest ones orbicular, the upper orate-lanecolate, truncated at the base $\left(\frac{1}{2}{ }^{\prime}-l^{\prime}\right.$ long $)$, the floral ones narrower. (S. saxatilis $\beta$ ? pilosior, Benth.?) - Dry woods, near Washington, Wilkes County, Gcorgia. August.

2. S. arguta, Buckley. Stem somewhat procmmbent, pubescent; leares ovate, cordate, coarsely erenate, on long pubeseent petioles, nearly smooth; racemes axillary and terninal; flowers small. -- Back Monutain, North Carolina, Buckley. July and Aug. - Stem $8^{\prime}-12^{\prime}$ long. Leaves $1 \frac{1}{2}^{\prime}-2^{\prime}$ long, paler leneath, shorter than the petioles.

3. S. canescens, Nutt., var. ? punctata. Stem ereet, tomentose, branched above; leaves ovate or oblong-ovate, arute, smoothish, paler and strongly veined beneath, resinous-dotted on hoth sides, short-petioled, the lower ones cordate, the npper and foral ones lancelate, tapering at the hase; racenes simple, axillary and terminal, pubescent, many-flowered; corolla b]ne and white. - Dry open woods, Fiorida and Georgia. Jnly and Ang. - Stem $2^{\circ}$ high. Leaves $12^{\prime \prime}-2^{\prime}$ long, $2-3$ times as long as the pubesent petioles. Corolla $8^{\prime \prime}-9^{\prime \prime}$ long.

4. S. serrata, Andr. Smooth; stem erect, branched; leaves ovate, acute, smooth and green on both sides, decurrent into the margined petiole, the floral ones small, lanceolate; racemes short, simple, few-flowered, l-sided; calyx mostly lairy ; corolla large, blne. - Dry woods, Nurth Carolina. - Stem $20-3^{\circ}$ - lighr. Leaves $1^{\prime}-1 \frac{11}{2}$ longr. Corolla $I^{\prime}$ Jong.

5. S. pilosa, Michx. Ilairy; stem simple or sparingly branched; leaves distant, ovate, obtuse, coarsely erenate; the lowest rounded at the base, the upper ones albruptly short-petioled, the floral ones spatulate, obtuse; racemes short, few-flowered ; corolla pale bluc. - Dry sandy soil, Flonida to Mississippi, and northward. July and Aug. - Stem $1^{\circ}-2^{\circ}$ high. Leaves $1^{\prime}-2^{\prime}$ long. Corolla $8^{\prime \prime}-9^{\prime \prime}$ long.

6 S. villosa, Ell. Stem erect, brancling, villous; leaves large, laneco. late, acute at each end, coarsely toothed, villons beneath, hispirl above; racemes paniculate, with the flowers crowded. - Georgia, between the Ocmulgee and Flint Rivers, Elliutt. May - July. - Stem $2^{\circ}-3^{\circ}$ highh. Leaves $3^{\prime}-4 \frac{1}{2}$ loner, on petioles $\frac{1}{2}$ long. (*)

+- Ulper and floral lcaves alike, entire, nearly scssile; the lower lroader, petioled, and mostly crenate.

7. S. integrifolia, L. Pubescent thronghont; stem mostly simple $\left(6^{\prime}-\right.$ $12^{\prime}$ highl) ; leares small $\left(\frac{1}{2}{ }^{\prime}-1^{\prime}\right.$ long), lanceolate, obtuse, entire, tapering downwarl, sessile; the lowest ovate or ohovate, short-petioled, erenate or entire, the lower floral ones sonctimes longer than the flowers; racemes leafy, few-manyflowered. - Dry sandy soil, Florida to North Carolina, and westward.

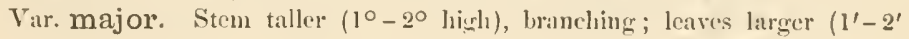
long); the upper oblong, entire, tapering iuto a betiole, the lower ovate or col- 
date, coarsely erenate, lonar-petioled, romuled at the njex. - Swamps, Florila,

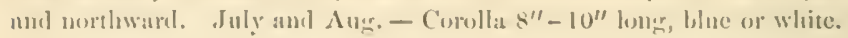

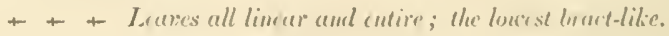

* S. Floridana, n. sp. Miuntely pubesent ; strul slensler, branclingr; leares lincar, oltuse, entire, sessile, with rewolute murgur ; the lowest minute and loractlike, the flural ones shorter than the flowers; racenes loose, fewfluwereal; corollat hare, much dihterl at the throat, the nearly "enal lips hroad mul obnse, filaments hairy at the base. - Pine-barren swamps ncar the const, West Florida. July- Stem 10 high. Leaves 1 long, $2^{\prime \prime}-I^{\prime \prime}$ wirle. Corolla I' long, deep blue, the lower lip white in the middle.

* *louers smull, in axillary racemes.

?. S. lateriflora, T. Smooth; stem elongated, diffuscly branched; leaves petioled, ovate-lanceolate, coarsely serrate, actuminate, the lower rombled at the base; racemes slender, 1-sided ; corolla bhe. - Shady swamps, Florida to Missisippi, and nortluward. July - Sept. - Stem $2^{\circ}-3^{\circ}$ high. Lcaves membratnaceous, $2^{\prime}-3^{\prime}$ lung. Corollia $2^{\prime \prime}$ long.

*** Flowers solitury, in the axils of the upper leares.

10. S. galericulata, C. Stem erect or ascenling, simple or branehed, smooth or pmbesent; teaves short-petioled, ovate-lanceolate, acute, slightly crenate, rounded or subcordate at the base, paler aud pubescent heneath; flowers nearly sessile, turned to one side. - Wet shaded places, North Carolina, nud northwarl. July and Aur. - Stem $1^{\circ}-2^{\circ}$ light. Leares $1^{\prime}-1_{2}^{1}$ long. Corolla $i^{\prime \prime}-8^{\prime \prime}$ long, blue, the lower lip white in the midele, spotted with blue.

11. S. parvula, Michs. Stem low, pubescent; leaves oratc or romdish, obtnse, mostly entire, nearly sessile, strongly veined f flowers small, periuncled. Rocky wouds, West Florida to Mississippi, and northward. July and Ang. Fibres of the root often bearing small tubers. Stem $6^{\prime}-9^{\prime}$ lighl. Leaves $4^{\prime \prime}-6^{\prime \prime}$ long. Corolla blue, $2^{\prime \prime}-3^{\prime \prime}$ long.

\section{MACBRIDEA, Ell.}

Calyx tubular-bell-shaped, 3-lohed; the upper lobe lancelate, entire, the two lower ones oblong, notched or entire. Corolla inflated, 2-lipped; the upper lip arehing, coneare, the lower broally 3-lobed, spreading. Stamens 4, ascending umler the upper lip. Filaments hairy : anthers approximate by pairs, the cells diverging, hairy within, denticulate on the margins. Nutlets smooth. - Erect mostly simple perennials. Whorls erowded in a dense cone-like terminal head. Corolla large, white or purple.

1. M. pulchra, Ell. Smooth or hairy; leaves lanceolate aeute, sermlate, Ilotted; the lower ones narrowerl into a petiole, the upper sessile, the floral ones ovate, acute; whorls 4-flowered; calyx striate, the lobes entire; corolla purple, the tube striped with purple and white, the upper lip entire. - Pine-barren swamps, Georgia to North Carolina. Aug. and Sept. - Stem $1^{\circ}-1 \frac{1}{2}{ }^{\circ}$ liggh. Corolla $1 \frac{1}{2}$ ' long. 
2. M. alba, n. sp. Smooth or hirsute ; leaves wedge-lancelate or oblong, toothed, rounded at the apex narrowed to the sessile base; the lowest oblong, tapering into a slender petiole; the floral ones ovate or orbicular, obtuse; whorls 4-flowered; calyx nerveless, with the two larger lobes noteherl; curolla white, the upper lip emarginate. - Low pine barrens, West Florida, near the coast. July and Aug. - Stem $1^{\circ}-1 \frac{1}{2}{ }^{\circ}$ high. Leaves $2^{\prime}$ long, or the rarlical ones $4^{\prime}-5^{\prime}$ long, and, like the calyx and corolla, thick and somewhat fleshy.

\section{PHYSOSTEGIA, Benth.}

Calyx tubular-bell-shaped, inflated in fruit, nearly equally 5-toothed. Corolla tubular-funnel-shaped, 2-lipped; the upper lip erect, concave, entire or notehed, the lower spreading, broadly 3-lobed. Stamens 4, ascending under the upper lip: authers approximate, with the cells parallel, ciliate. Nutlets smooth, acutsly 3-angled. - Smooth perennial herbs, with erect mostly simple stems, and opposite showy purplish flowers, in terminal spikes or racemes.

1. P. Virginiana, Benth. Leaves large $\left(6^{\prime}-9^{\prime}\right.$ long $)$, oblong, sharply serrate, the lowest narrowed into a petiole; spikes thick, dense-flowered; ealyxteeth acute; corolla l' long. (Dracocephalum Virginianum, L.) - Varies through several intermediate forms, including Dracocephalum variegatum, Vent., and D. obovatum, Ell., into var. Dexticulata, with lanceolite or linear denticulate or entire leaves, and smaller ( $6^{\prime \prime}-9^{\prime \prime}$ long) flowers in a long loosely fowered spike. - Low gromel and swamps, Florila to Mississippi, and northward. JuneAug. - Stem $2^{\circ}-4^{\circ}$ high. Racemes simple or compound.

\section{LAMIUM, L. Dead-Nettle.}

Calyx tubular-bell-shaped, 5-nerved, nearly equally 5-toothed, the teeth subulate, not spiny. Corolla slender, dilated at the throat, 2-lipped; the upper lip ovate or oblong, narrowed at the base; the lateral lobes small, at the margins of the throat; the lowest lobe large, notched, contracted at the base into a short stalk. Stanens 4, ascending under the upper lip : anther-cells at length spreading. Nutlets 3-angled, truneate at the apex.-Herbs. Leaves incised; the lower ones petioled, the floral ones sessile, longer than the dense whorls.

1. L. amplexicaule, L. Leaves orbienlar, inciscly crenate-lobed; the floral ones clasping, the others long-petioled; tube of the corolla straight, the lateral lobes truneate; anthers hairy. - Cultivated gronnd and waste places, common. May. (1) - Stems $4^{\prime}-12^{\prime}$ high. Corolla sniall, purple, often imperfectly developed.

\section{MARRUBIUM, L. HoREmound.}

Calyx tubular, 5-10-nerver, nearly equally 5-10-toothed; the teeth spiny, mostly spreading in fruit. Corolla-tube included in the calyx, 2-lipped; the upper lip ereet; the lower 3-lobed, with the middle lobe largest. Stamens 4, included: anther-cells diverging. Lobes of the style short, obtuse. Nutlets obtuse at the apex. - Chiefly tomentose or woolly perenuial herbs, with rugose leaves, and axillary whorls. 
1. M. vulgare, Y. Woolly; stems luancling at the base, ascending; leaves petioled, ovite or romulish, crenate, the floral ones smaller, lut longer than the enpitate many-flewered whorls; (alyx-tecth 10, recurved-spreacling ; corolla small, white. - Waste ground anil road-xides. Introduced. - Stems $1^{\circ}-2^{\circ}$ ligh.

\section{LEONOTIS, R. HHow:.}

Calyx tubular, 10-nerved, incurved, unequally 8-10-toothed; the teeth straight, sping, the upper one largest. Corolla slender, 2-lipperl; the upper lip long, arching, entire, the lower very short, 3-choft, spreading. Stamens 4, atscending under the upper lip: anther-cells diverging. Nutlets 3-angled, trunrate. - Tall herbs, with very large globose whorls in the axils of the upper leares Flowers yellow or scarlet.

1. I. nepetæfolia, R. Br. Anmual; stem tomentose, simpile or lranched; leaves remote, long-petioled, broadly ovate, erenate, the floral ones lancelate; whorls 1 -screral ; calyx 8-tootherl; corolla villons, scarlet. - Wraste grounds, Georgia and Florida. Jine $-\Lambda$ ug. Introduced. - Stem $1^{\circ}-6^{\circ}$ high. Whorts $\mathbf{l}^{\prime}-2^{\prime}$ in diameter. Corolla ' $^{\prime}$ long

\section{LEONURUS, I. Motherwort.}

Calyx top-shaper, 5-nerved, 5-toothed, the teeth spiny and at length sprearing. Corolla 2-lipped; the upper lip entire, the lower spreading, 3-lobed, with the miditle lobe obcordate. Stamens 4 , aseending: anther-cells parallel, naked. Nintlets 3-ingled, tuncate. - Herbs, with inciscly lobed leaves; the floral ones longer than the dense whorls. Bracts subulate.

1. L. Cardiaca, L. Stem $\left(2^{\circ}-4^{\circ}\right.$ high $)$ square, pulbescent; leaves longpetioled, the lower ones round-cordate, palmately lobed and toothed; the floral ones wedge-shaped, 3-eleft toward the apex; whorls distant, 6-15-flowered; corolla villous, purplish, spotted with lrown in the throat. - Waste places. Introduced. June-July.

\section{STACHYS, L. Henge-Nettle.}

Calyx tubular-bell-shaped, 5- or 10-nerved, 5-toothed; the teeth equal, or the upper one larerer, more or less spiny (in our species), spreading in fruit. Corolla hairy within, 2-lipped; the upper lip erect, the lower sprearling, 3-lobed, with the middle lolie much larerer. Stamens 4, ascending: anthers 2-celled. Nuthets not truneate. - Cliefly hairy or hispid herls, with few-flowered whorls in terminal racemes.

\section{* Perennial.}

1. S. aspera, Michx. Stem erect, with the angles rough with recurved hristly hairs, rarely smoothish; leaves short-petioled, ovate-oblong or ovatelanceolate, acute, serrate, rounded at the base, smooth, or sprinkled with hairs above; the floral ones longer than the ealyx; whorls 6 - 10-flowered, the lower oues distant; ealyx-tecth spinc-pointed. (S. hispida, P'ursh. S. tenuifolia, Willd.) 
- Swamps, South Carolina, and northward. June-Aug. - Stem $1 \frac{10}{2}-2^{\circ}$ high. Leaves $2^{\prime}-3^{\prime}$ long. Corulla purple.

2. S. hyssopifolia, Miehx. Smooth or nearly so; stem erect, slender; leaves sessile, lanceolate or linear, obtnse, entire or sparingly serrate; raceme short, of few 4-6-flowered whorls; calyx smooth, with spiny spreading teeth, $\frac{1}{3}-\frac{1}{2}$ as long as the smooth violet eorolla. - Wet pine barrens, in the middle districts of South Carolina, and northward. June- Ang. - Stem $1^{\circ}-1 \frac{1}{2}^{\circ}$ high. Leares $1^{\prime}-2^{\prime}$ long.

\section{* * Annual.}

3. S. Floridana, Shuttl. Smooth or hirsute; stem slender, erect; leaves lanceolate or oblong, petioled, or the upper ones sessile, acute or obtuse, serrate, truneate, or the lowest subeordate at the base; whorls few or numerous, distant, 6-10-flowered ; calyx pubescent, with lanceolate-subulate rigid teeth; corolla twice as long as the calyx, purple. (S. annua, Walt.?) - Low gromds, Middle and Sonth Floricla. Ju!y. - Stem $10^{\prime}-15^{\prime}$ high. Leaves $1^{\prime}$ long, the lowest shorter thim the petiole.

\section{ISANTHUS, Michx.}

Calvx bell-shaped, 10-nerved, 5-cleft. Corolla bell-shaped, equally 5-lobed. Stamens 4, incurved-ascending, exserted: anthers 2-eelled. Nutlets obovoid, inpressed-reticulated, laterally cohering at the base. - An annual pubescent and somewhat viscid branching herb, with laneeolate entire or sparingly toothed aeute leaves, and small pale blue flowers, on $1-3$-flowered axillary peduncles.

1. I. cœruleus, Miehx. - Dry soil in the upper districts. July - Aug. Stem terete, $1^{\circ}-1 \frac{1}{2}^{\circ}$ high. Leaves $1^{\prime}-1 \frac{1}{2}^{\prime}$ long, 3-nerved below t'se midllle.

\section{TRICHOSTEMA, L. Blue-Curls.}

Calyx short, reverser, oblique, 5 -toothed; the 3 lower teeth long, connate: the 2 upper ones very short. Corolla slender, nearly equally 5-cleft. Stancus 4, long-exserted, partly coiled: anther-cells diverging. Nutlets pitted, nuited at the base. - Brancling annuals, with entire leaves, and solitary blue flowers on lateral peduncles.

1. T. dichotomum, I. Pubescent and somewhat viscid, or nearly smooth; stem much branched, obscurely 4-angled; leaves oblong or lanceolate, obtuse, narrowed into a petiole. (T. lincare, Nutt. is a smoother form, with linear leares.) - Dry sandy soil, Florida to Mississippi, and northward. Augr. and Sept. - Stem $1^{\circ}-2^{\circ}$ high.

\section{TEUCRIUM, L, Germaxnen.}

Calyx tubular or bell-shaped, 5-toothed. Corolla 5-lobed; the 4 npper lobes short, the lowest large, oblong or rounded, coneave. Stamens 4, dirlynamous, the lowest pair longest, exserted hetween the 2 upper lobes of the corolla: anther-cells confluent. Nutlets rugose. 
1. T. Canadense, I. Stem tomentose, ereet, simple ol liranehed; Iraves

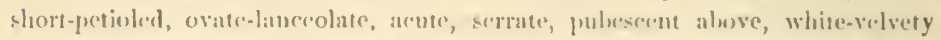
beneath; flowers mostly altruate, in a long loary spiked rareme, longer than the subulate lracts; ealyx bell-shuped. ('T. Virginieun, L, - Swamps and

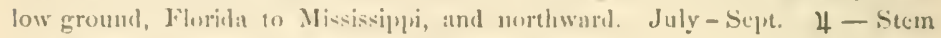
$2^{\circ}-3^{\circ}$ high. Leare's $2^{\prime}-6^{\prime}$ long. Elowers purplish.

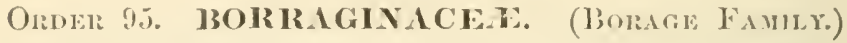

II entire exstipulate mosty rough-lairy leaves. Flowers usually in 1-siled spikes or racemes, which are coiled in the luml. - Calyx free, j-cluff or 5-parted, valvate in the lund, persistent. Corrlla regular (exrept No.6),

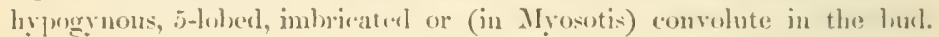
Stamens 5, wpual, inserted on the mbe of the comolla and alteruate with its lobes. (Oray d-elled, with a single ovule in earh crell. Style single. Fruit various. Allumen siaree or noue. Cotyledons flat or folded. Radicle superior.

\section{Synopis.}

Tribe I. CORDIEA. Orary undivided. Style terminal, twice 2-lobed at the apex. Firuit a 4-celled drupe. Cotyledons folded. Albumen none. - Shrubs. Flowers in hetds or spikes.

1. CORDIA. Caly $x$ opening regularly, not eircumscissile.

Tribe II. EHRETIEA. Ovary undivided. Style terminal, 2-lobed at the apex. Fruit a 4-seeded berry. Cotyledons flit. Albumen seanty. - Shrubs.

2. EIllETiA. Style slender. Flowers corynbose

3. TOULXEFonTiA. Style short. Flowers ey mose or spiked.

Tribe III. HELIOTROPEAs. Otary undivided. Style terminal, simple. Fruit separating into 2 or 4 nutlets. - Cliefly luerbs.

4. IIELL10TROP'lty. Fruit spparating into 4 nutlets, each 1 -sceded.

5. HELIOPIIYTCy. Fruit separating into 2 uutlets, each 2 -seeded.

Tribe IV. BORIRAGEF. Otary deeply 4-parted, enclosing the base of the simple style. Fruit of $1-4$ one-seeded nutlels. - Herbs.

* Throat of the corolla naked. Nutlets not bispid.

- Corolla irregular.

6. ECHICY. Corolla funnel-shaped, unequally lobed.

- Corolla regular.

7. Oxoswodicy. Lobes of the carolla erect, acute. Nutlets smooth and stony.

8. LITIIOSPERMLII. Lobes of the corolla rounded. Nutlets smooth or rugose.

9. METREXSIA. Lobes of the corolla rounded. Nutlets somewhat fleshy.

10. MYSOTIS. Lobes of the corolla convolute in the bud. Nutlets smooth.

* Throat of the corolla elosed with scales. Nutlets hispid.

11. Cyxoglosscy. Corolla funnel-shaped. Nutlets depreseed. 


\section{CORDIA, Plum.}

Calyx orate or bell-shaped, 4 -5-toothed, not cireumscissile. Corolla funnel or salver form, 4-5-lobed. Stamens 4-5. Ovary entire, 4-celled. Style terminal, twice 2-cleft, mostly exserted. Drupe ovate or globose, pulpy, I-4seeded, commonly enclosed in the enlarged calyx. - Trees or shrubs. Leares toothed or entire. Flowers spiked or capitate, white.

1. C. bullata, I. Rough throughout with white bristly hairs; leaves oblong-ovate, serrate-toothed, rugose, paler beneath, abruptly petioled; flowers capitate, on peduneles which are shorter than the leares, and nearly terminal, but elongated and lateral in fruit; caldy oroid, the subulate bristly teeth spreading; corolla short, hairy in the throat; stigmas club-shaped ; drupe 1-seeded. South Florida. - Leares $\frac{1}{2}{ }^{\prime}-1 \frac{1}{2}{ }^{\prime}$ loner. Heals $4^{\prime \prime}-5^{\prime \prime}$ in diameter

\section{EHRETIA, L.}

Calyx tubular, 4-5-toothed. Corolla salver-form or wheel-shaped, 5-lobed. Stamens 5: anthers ovate. Orary entire, 4-celled. Style terminal, 2-cleft at the apex. Berry composed of 2 more or less separable 2-seeded nutlets. Tropical shrubs. Leaves entire. Flowers corrmbose, white.

1. E. Beurreria, L. Smooth; leaves petiolate, obovate or oblong-obovate, entire, mucronate, obtuse, or notched at the apex, paler beneath; corymb many-flowered, diwaricate; ealyx leathery, the teeth acute, pubescent on the margins; stigmas depressed; nutlets t, apparently 2-eelled, l-seeded, fincly furrowed on the back. - South Florida. - A small tree. Leaves $1 \frac{1}{2}^{\prime}-3^{\prime}$ long, actute at the base. Flowers white and fragrant.

2. E. Radula, Poir. Stem smooth; leaves ohorate, entire, rounded or notehed at the apex, tapering at the base into a short petiole, smooth beneath, very rough and at length white-spotted above; corymb few-flowered; pedieels minutely braeted and sparingly hispid; calyx 4 --5-toothed; the teeth ovate, acute, pubescent on the margins; lobes of the corolla rounded, wavy; stigmas peltate, depressed in the centre; berry ovate, separable into 4 one-seeded nutlets. - South Florida. - Leaves $1^{\prime}-1 \frac{1}{2}$ long. Corolla $6^{\prime \prime}$ long.

\section{TOURNEFORTIA, L.}

Calyx 5-parted. Corolla salver-form or wheel-shaped, 5-lohed. Stamens 5, includer. Style short, terminal; stigma conical. Berry composed of two 2-sceded nutlets, which are either united or separable, or loy abortion 1-2-seederl. - Erect or twining shrubs, with entire leares, and white or yellowish flowers, in 1 -sided bractless often eymose spikes.

* Fruit ovate, separable into two 2-secded nutlets: corolla-lobes orate, plicate.

1. T. gnaphalodes, R. Br. White-silky throughout; stem thick, ereet; leaves very numerous and imbricated, linear, obtuse, fleshy, tapering to the base; peduncles axillary; spikes 2-4-parted, dense, reeurver; calyx-lohes oblong, obtuse; corolla fleshy; anthers ovate; berry deeply excarated at the base. - 
Sen-shore, Sout'. Floridil. - Shrub $2^{\circ}-t^{\circ}$ high. Leaves $z^{\prime}$ longr. Corollat -mull, white.

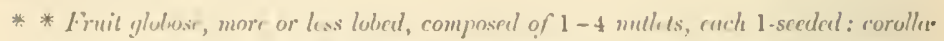
lobes nurrou', urutr.

2. T. volubilis, I. Stem twining, and, like the lower surface of the lewes and spikes, tomentuse; leaves ovate or oblong-ovate, petioled, roughish ahove, paler beneath; spikes lateral and terminal, very slemder, cymose, shortpeduncled, spreading; tule of the corollar eontracted in the midlle, the lohes linear-subulate; anthers connivent; berry small, 1-3-secded. - South Florida. - Leaves 1'- I' long. Corolla 2" long.

\section{HELIOTROPIUM, Tourn.}

Calyx 5-parterl, persistent. Corolla salver-form, open at the throat, folded between the 5 lobes. Filaments and style very short. Stigma somewhat conieal. Fruit separable into four 1-seeded mutlets. - Herts or shrubly plants. Leares rarely opposite. Spikes 1 -siled. Flowers white or l, lue.

1. H. Curassavicum, I. Annual, smooth, fleshy; stems at length prostrate and diffuse; leares altemate or opposite, lanceolate or linear, obtuse, narrowed at the base; spikes peduneled, simple or 2-parted, coiled in the bud; flowers small, sessile, white, bractless; untlets smooth. - Saline mar.hes, Florida to North Carolina. June - Aug. - Stem $6^{\prime}-18^{\prime}$ long. Leaves $1^{\prime}-2^{\prime}$ long. - Plant drice black.

2. H. myosotoides, n. sp. Ammunl stem ereet, branched, rough with rigid white appresed hairs; the young branches hoary ; leares oblong or lanceolate, obtuse, hispid on both siles, marrowed to the base, the lower ones opposite; spikes filiform, elongated, 1-sided; flowers short-pedieclled, some of them leafybracted, others hractless; exterior calyx-lohes larger ; corolla ninute ( $\frac{1}{2}$ " long), white; anthers hairy at the apex; nutlets united, hispid at the apex, with the silles concave. - South Florida. - Stem $4^{\prime}-6^{\prime}$ high. Leaves $\frac{1}{2}$ lung. Corolla slightly hispid.

\section{HELIOPHYTUM, DC.}

Throat of the corolla bearded, or closed by 5 inflexel folds. Fruit separating into two 2-celled nutiets. Otherwise like Heliotropium.

1. H. Indicum, DC. Annual ; stem erect, rough-hairy; leaves oblongovate, often cordate, toothed or wavy on the margins, rugose, slightly roughish, decurrent into a long petiole; spikes hairy, coiled, at length elongated; corolla blue; mutlets spreading - Wiste plates, Florida to North Carolina. June Oet. - Stem $1^{\circ}-2^{\circ}$ ligh. Lenres $2^{\prime}-4^{\prime}$ long. Fruiting spike $6^{\prime}-9^{\prime}$ long.

2. H. parviflorum, DC. Perennial, hirsute; stem erect, hranching; leaves lanecolate or oblong, obtuse, entire, tapering into a slender petiole, the lower ones mostly opposite; spikes slender; corolla white, bearded in the throat; nutlets uneven, united. - Sonth Florida - Stem shrubby at the hase, 6'-18' high. Leaves nembranaceous, $1^{\prime}-2^{\prime}$ long. Corolla $1^{\prime \prime}$ long. Spikes $2^{\prime}-4^{\prime}$ long. 


\section{ECHIUM, Tourn.}

Calyx 5-parted. Corolla fumel-form, unequally 5-lobed, naked at the tirroat. Stamens 5, unequal, mostly exserted. Style filiform. Nutlets 4 , closed at the base, uneven or rough. - Herbs, with altemate leaves, and blue or purple flowers in spiked often panicled racemes.

1. E. vulgare, L. IHispid with bristly spreading hairs; stem simple, erect $\left(1^{\circ}-2^{\circ}\right.$ high); leaves linear-lanceolate, sessile; flowers large, in slort axillary raccmose spikes; corolla purple, pubeseent, twice as long as the lanceolate ealyx-tecth, shorter than the stamens and style. - Fields, Noril Carolina. Introduced, Junc-Ausg.

\section{ONOSMODIUM, Miehx.}

Calyx 5-parted, the lobes linear and acute. Corolla ovate-tubular, naked in the throat, with five aeute, connivent lobes. Anthers nearly sessile, sagittate, inclurled. Ovary 4-parted. Style smooth, exserted. Nutlets 1-4, ovoir, shining. - Erect hispid herbs, with entire somewhat ribbed sessile leaves, and greeuish flowers in a terminal bracted raceme or spike.

1. O. Carolinianum, IC. Rough with spreading white rigicl hitirs; stem stout, branched; leaves oblong-ovate; lobes of the corolla ovate, lairy; anthers oblong; calyx-lohes searcely twice as long as the dnll white nutlets. Dry soil in the upper districts. June. 4-Stem $3^{\circ}-4^{\circ}$ high. Leaves $2^{\prime}-3^{\prime}$ long. Racemes leafy.

2. O. Virginianum, DC. Rough with appressed bristly hairs; stem slender, sparingly branched; leaves lanecolate or oblong-lanceolate, obtusc or acute; lobes of the corolla lanceolate-subulate, bristly ; calyx-lobes $3-4$ times as long as the white polished nutlets. (O. hispilum, Michx.) - Dry pine barrens, Florida, and northward. May and June. 4-Stem $1^{\circ}-2^{\circ}$ high. Leaves $2^{\prime}$ long. Corolla twice as long as the calyx. Racemes leafy.

\section{LITHOSPERMUM, L. GROMWEL.}

Calyx 5-parted, the lobes equal. Corolla funnel or salver form, obtusely 5-lobed, smonth, gibbous or hairy in the throat. Anthers ohlong, nearly sessile, included. Stigma capitate, somewhat 2-lobed. Nutlets $1-4$, ovate, stouy, truncate at the basc. - Chiefly rongh-hairy herbs, with red roots, alternate entire leaves, and variously colored flowers in leafy-bracted racemes or spikes.

\section{* Annual: mutlets roughened.}

1. L. arvense, L. Rough with appressed hairs; stem nearly simple, or branched from the base; leaves lanceolate; the upper ones sessile and acute, the lower obtuse, tapering at the base; flowers scattered ; corolla yellowish-white, about as long as the linear-subulate lobes of the calyx; nutlets 4. - Cultivated grounds and waste places, Florida, and northward. Mareh and April. Introluced. - Stem $6^{\prime}-18^{\prime}$ high. Leaves $1^{\prime}-2^{\prime}$ long. 
* Perennials: mulets smomth, white.

2. L. tuberosum, lingel. Ilicpicl with seattered rigill laairs; stem erect, branching above; leaves sonewhat 3 -ncred ; radimal ones larege $\left(f^{\prime}-6^{\prime}\right.$ loner $)$,

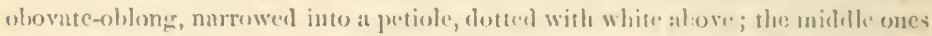
oblong, sessile; the florat ones ( $1^{\prime}$ long) elliptical ; (alyx-lobes linear, as longe as the tube of the small yeltuwish-white corollat, and twice as long as the mosty

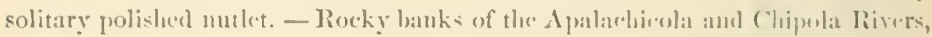
Florida. March and April. - l'lant $6^{\prime}-10^{\prime}$ light, increasing in fruit to $2^{\circ}$ or more. lioots bearing oblong tuluers.

3. L. hirtum, Jchnn. IIispill with rigid glossy hairs; stem mostly sinple, erent; leaves linear-laneculate, obtuwe, sessile; the lowest scale-like; the floral ones ovatc-lanecolate; cololla large, yellow; the tule hairy at the lase within, rather longer than the linear calyx-lobes; nutlets ovate, polisherl. (Batschia Gmelini, Michx.) - I)ry pine harrens, Florida to South Carolinat. April and May. - Stem $1^{\circ}-1,0$ l.i.h. Leaves $1^{\prime}-2^{\prime}$ long. Corollat $6^{\prime \prime}-8^{\prime \prime}$ long.

4. L. canescens, Lchm. Stem villous, ereet, nearly simple; leates lanccolate, sessile, obtuse, somewhat silky with alpresued glon. liairs; the lowest small and scate-like; corolla larere, yellow; the tube $2-3$ times as long as the calyx. - Dry soil in the mprer districts. $\Lambda_{1}$ ril and May. - Stem $6^{\prime}-12^{\prime}$ high. Corolla smaller than in the preceding.

\section{MERTENSIA, loth.}

Calyx 5-parted. Corolla funnel-shaped, 5-lobet, nakerl, or witl 5 folls in the throat. Stamens partly exserted. Style filiform. Nutlets somewhat fleshy, not flattened at the base. - Smooth or soft lairy peremuial l:erls, with eutire leaves, and showy purplish-blue flowers in corymbed or panicled racemes, the upper ones bractless.

1. M. Virginica, DC. Smooth; stem erect, simple; leaves membranaccous, clliptical or oborate-ohlon: the lower ones narrowed into a petiole; raremes colynulose; corolla large, waked and expanding at the throat, shightly loled; the tube 4 times as long as the ealyx, villous at the hase within; filameuts longer than the anthers. (P'ulmonaria Virginiea, L.) - River-bauks and along mountain strcams, Soutl Carolina to Tennessee, and northward. May. Stem $1^{\circ}-2^{\circ}$ high. Leaves $2^{\prime}-3^{\prime}$ or the lowest $4^{\prime}-6^{\prime}$ long. Corolla $1^{\prime}$ long, sometimes white.

\section{MYOSOTIS, L. FoRgET-ME-хOT.}

Calyx 5-cleft. Corolla salver-form, 5-lobed, convolute in the hnd; the tube as long as the calyx, with 5 obtuse appendages in the throat. Stamens very short, included. Nutlets 4, elliptical, compressed, smooth, with a minute scar at the base. - Low hairy herbs, with entire alternate leaves, and snill white or blue flowers in terminal bractless racemes. 
1. M. laxa, Lehm. Smooth, or slightly roughened with appressed scattered hial's; stem weak, slender, creeping at the base, branching; leaves lanceolate, obtuse, the lowest spatulate; racemes elongated in fruit; flowers distant, on widely spreading pedicels; calyx hispid with straight hairs, the tecth equal and obtuse; corolla pale blue. - Low grounds, Florida to Mississippi, and northward. May. (1) - Stem $1^{\circ}$ ligh. Leaves $1^{\prime}-1 \frac{1}{2}$ long.

2. M. Velna, Nint. Hirsute with rigid spreading hairs; stem erect $\left(4^{\prime}-\delta^{\prime}\right.$ high), branching above; leaves lanceolate, sessile; the lower ones spatulate, obtuse; calyx longer than the appressed pedicel, hispirl, with the hairs near the base hooked; the teeth mequal, acute. - Var. MACRosperus is every way larger $\left(1^{\circ}-1 \frac{1}{2}^{\circ}\right.$ high $)$; ealyx with all the hairs hooked, the lower tectl twice as long as the upper ones. - Dry places in the upper districts, and northward; the variety, Elorida, and westward. March and April. (1)-Corolla white or pale blue.

\section{CYNOGLOSSUM, Tourn. Houxd's-Toxgue.}

Calyx 5-parted. Corolla funuel-form, with the throat closed with 5 obtuse scales. Stamens included. Nutlets 4 , fixed near the apex to the base of the style, corered all over with barbed or hooked bristles. - Racemes with the lower flowers commonly bracted, the upper ones bractless.

1. C. officinale, L. Villous; stem leafy, branched above; leaves lanceolate or oblong, acute; the upper sessile, the lowest tapering into a long petiole; racemes hoary, nearly bractless; nutlets flattened anteriorly and slightly margined ; corolla reddish-violet. - Waste grounds, North Carolina, and northward. Introrluced. - Stem $1 \frac{1}{2}^{\circ}-2^{\circ}$ high.

2. C. Virginicum, L. Hispid; stem simple, stont, naked above; leares oval or oblong; the lowest petioled, the upper auriculate and elasping; racemes single or corymbose, bractless; pedicels slender, recurved in fruit; nutlets rounded anteriorly; corolla pate blue. - Dry soil, Florida to Mississippi, and northward Mity and June. - Stem $2^{\circ}-3^{\circ}$ high. Lowest leaves $6^{\prime}-9^{\prime}$ long. Nutlets 1-4.

3. C. Morisoni, DC. Hairy ; stem erect, rather slender, widcly branehed ; leaves lanceolate-oblong, aente; the lowest tapering into a petiole; racemes numerons, slender, villous, bracted; pedicels short, recurved in fruit; corolla small, about as long as the calyx, white or pale blue. (Myosotis Virginiana, Pursh.) - Dry woods in the upper districts of South Carolina and northward. June and July. - Stem $2^{\circ}-3^{\circ}$ high.

\section{Order 96. HYDROPHYLLACEA. (WaterleaF Fanilit.)}

Herbs, with alternate or (the lowest) opposite palmately or pinnately divided leaves, and regular flowers, either solitary in the axils, or in 1-sided recurved spikes or racemes. - Calyx 5-partenl, persistent; the 


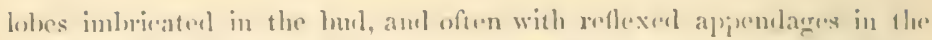
sinuses. Corolla obtuscly 5 -loberl, convolute on imbricaterl in the luml. Stamens 5, inserterl into the hase of the corollat, aud alternate with its

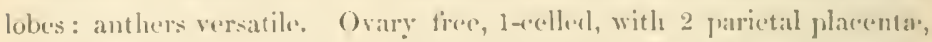
cach bearing 2 or more amphitropous ovoles. Style slemeler, 2-cleft. Capsule grlubose or oblongr, loculicidally 2-valved. Seeds retirulated. Eumbryo sulall in the axis of hard albment.

\section{Synopsis.}

* Lobes of the corolla conrolute in the biul.

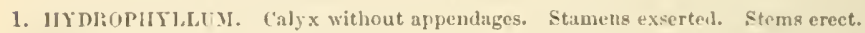

2. NEMoplitad. Calyx appeudaged at the siunses. Stamens included steus prostrate.

* Lobes of the corolla imbricated in the buil.

3. PIIACELIA. Caly $x$ wilhout appendages. Capsule $t$-many-serded.

\section{HYDROPHYLLUM, I. WITER.F.}

Calyx 5-parted, the lohes subulate; withont appendlanes. Corolla broatly tuhular, 5-eleft, about as long as the calyx, with 5 linear appenlages on the tube within, opposite the lobes. Stamens and style exserted : anthers linear. Ovary hicpid. Ilacenta 2, thick and fleshy, comected with the pericarp at the base and apex; earh 2-ovuled. Style filiform, 2-cleft. Capsule glohose, 2-valved, 1-4-secdel. - Erect perenuial mostly hairy herbs, with long-petioled pinnately or palmately divided leares, and white or blue flowers in peduncled eymes, withont bracts.

1. H. Virginicum, L. Stem leafess below, sprinkled, like the leaves, with rigid hairs; leaves jimnately divided into 5 - 7 ovate eleft or toothed lobes, paler leneath; pednueles forking, longer than the petioles; cymes dense; calyxlobes linear, hispil ; filaments slightly hairy. - Low woods along the mountains, Georgia, and uorthward. June. - Stem $1^{\circ}-2^{\circ}$ high.

2. H. Canadense, I. Smoothish; leares orbicular-cordate, palmately j-7-loberl, slarply tootherl; cymes dense, on forking peduncles which are shorter than the petioles; calyx-lobes sparingly hispirl; filaments densely hearded. - Mountains of North Carolina, Tennessee, and northward. June.Stem $1^{\circ}$ high. Leaves $3^{\prime}-5^{\prime}$ in diameter. Corolla white.

\section{NEMOPHILA, Nutt.}

Calyx 5-parted, with reflexed appendages in the sinuses. Corolla tubular or short lell-shaped, with 10 scale-like appendages at the base of the filaments. Stamens includel : anthers ovoid. Orary hispid, 2-12-ovuled. P'lacenta large, lining the walls of the periearp. Style 2-parted. Capsule globose, 1-2-seeded. - Tender prostrate annual herbs, witlı divided leaves, and solitary long peduncled flowers opposite the leaves.

1. N. microcalyz, Fisch. \& Meycr, Pubeseent, or at length smoothish; stem filiform, diffuse; leaves thin, long-petioled, alternate, 3-lobed; the lobes 
obovate or ivedge-siaped, crenately toothel; the lowest ones mostly opposite, and 3-5-lobel ; flowers minute, white, on slender spreading peduncles, which are shorter than the petioles; ovary 4-ovuled; capsule 1-2-seederl. - Shady woods, Florida, Georgia, and westward. April - June. - Stem $3^{\prime}-1^{\circ}$ longr. Leaves $\frac{1 \prime}{2}-1$ long. Corolla $1^{\prime \prime}$ long. Seeds bony.

\section{PHACELIA, Juss.}

Calyx 5-parted, not appendaged in the sinuses. Corolla bell-sliaped, 5-lobed, imbricated in the burl. Stamens included or exserted : anthers ovoid or oblong. Ovary 2-many-oruled; the 2 narrow placente often projecting inwards, and forming an imperfect partition in fruit. Style 2-cleft. Calsule 2-valved, 4many-sceded. -- Jow cliefly annual herbs, with alternate mostly pinnately divided leaves, and white or blue flowers in one-sided racemes.

\$. Prickina. - Ovules and seeds 4: corollu variously appendeged within, the lobes entire.

1. P. bipinnatifida, Michx. Hairy ; stem erect, much branched ; leaves long-petioled, 3-5-lobed, with the lohes oblong-ovate, acutely toothed; the lower ones short-stalked, the upper confluent; racemes loosely many-flowered, glandul:ar; pedicels slender, recurved in fruit; calyx-lobes linear, lisplid; stamens bearded below, equalling or longer than the corollit. - Shaded binks, Alabama to North Carolina. May and June. - Stem $6^{\prime}-12^{\prime}$ high. Corolla blue, $\frac{1}{2}{ }^{\prime}$ wide.

\$2. Cosmaxтисs. - Otules and seels 4: corolla not appendugrd within, the lobes fimbriate: filaments lairy belou:

2. P. Purshii, Bucklcy. Stems erect or ascending, clnstered, smooth or hairy, branched ; leaves hirsute; the lower ones petioled, almost pinnate, the upper clasping, pinnatifil, with the lobes acute ; racenes many-flowered ; ealyxlohes lanecolate-linear, bristly-eiliate; corolla bIue. (P. finloriata, Pursl.) Shady banks, North Carolina, Tennessee, and northward. May and June.Stem $8^{\prime}-12^{\prime}$ high. Corolla $\frac{1}{2}$ wide.

3. P. fimbriata, Michx. Smoothish or slightly hairy; stems sprearling or ascending; leaves few, the lowest petioled, with $3-5$ ronndish leaflets; the upper ones pinnately 5 - 7 -lobed, with the lobes obtuse; racemes 3 - 10 -flowered ; alyx-lobes linear-oblong, obtuse; corolla white. - High mountains of North Canolina, Michaux, Burliley. May. - Stems 5 - -8 long.

\$3. Eutoci. - Orules more than 4: corolla usually with minute appendages within, the lobes entire.

4. P. parviflora, Pursh. Pnbescent; stems sereral, spreading, branching; leaves petioled ; the lowest 3 - 7 -lobed, the upper 3 -parted ; racemes loosely 5 15-flowered; pedicels sleneler, much longer than the ealyx; ealy-x-lobes linearohlong, bristly-ciliate; corolla small. jalc-bhe or white. - Shaty loanks, North Carolina, and northward. A pril and IIay. - Stems $3^{\prime}-8^{\prime}$ high. Corolla $3^{\prime \prime}-$ $4^{\prime \prime}$ wide Capsule few-seeded.

5 P. pusilla, Buckley. Pubescent and somewliat glancons; stems ascending, branclied; leaves sessile, pinnatifiel, the segments obovate, abruptly 


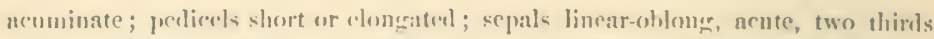
the length of the pate hilue or white corolla; stamens exserted - L'ruirics of Alabimua, Buckley. April.

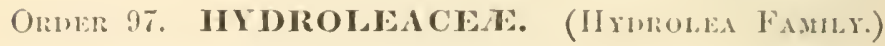

Cilandular-pubesent or luistly herbs, with entire alternate leaves. Flowers renular, axillary and solitary or clustered, or in terminal corymbs or coilerl luracterl spikes. - Cialyx 5-parted. Corolla somewlat luellshaped, 5-lobed, imbricated in the luml. Stamens 5. inserterl on the tube of the corolla, and altemate with its lobes, the filanents oftener hairy. Styles 2, separate: stimas capitate. Orules numerous, anatropous. Capsule many-seeded, more or less a-celled by the meeting of the 2 parietal placentie, 2- or rarely 4-valved, opening through the midelle of the cells, or at their margins. Embryo straight, in fleshy albumen.

\section{HYDROLEA, L.}

Calyx 5-parted. Corolla short, bell-shaperl, 5-cleft; the lobes sprearling. Stanens somewhat excerted, with the filanents dilated at the lase: anthers sagittate. Styles 2 (rarely 3), separate. Capsule globose, 2-celled, or imperfectly 4-eelled by the introversion of the placenta, 2-valved. - llerts, wrowing in water or mully places, with 'ntire leares, often with spines in their axils, and blue axillary or corymbose flowers.

1 H. corymbosa, Ell. Spineless; stem erect, hirsure, and branching above; leares ovate-lancedate, sessile; the reins aud marmins slightly pubescent ; flowers in a close terminal corymb; calrx-lubes lanceolate, acute, hispid, $\frac{1}{3}$ as long as the corolla. - Pine-barren ponds, in St. Stephen's, South Carolina, Ellint. July and Aug. - Stem 20 high, creeping at the hase. Leaves $1^{\prime}-12^{\prime}$ long. Corolla "azure, with yellowish reins and 5 white spots near the base." Capsule 2-valved.

2. H. quadrivalvis, Walt. Spiny; stem ascending from a creping base, lispirl, mostly simple; leaves lanceolate, acute, pubeseent on the veins, tapering into a petiole; flowers axillary, the lower ones clntered, the upper solitary, short-peduncled; calyx-lobes linear, nearly as long as the corolla ; stamens inctuded: (aj) sule almost 4-eelled, by the introversion of the placenta, 2-ralvel. - Pools and muddy banks of streams, Florila to North Carolina, and westward. July and $\Lambda$ ug. - Stem $1^{\circ}-3^{\circ}$ long. I.caves $3^{\prime}-4^{\prime}$ long.

\section{NAMA, L.}

Calyx 5-parted. Corolla tubular-funnel-shaped, 5-cleft. Stamens included, the filaments equal : anthers reniform. Ovules numerous, anatropous, pendulous. Styles 2, distinct. Capsule oblong, many-seeded, seemingly 2-relled by the meeting of the placentx at the axis, 2 or at length 4-valved. Secds pitted. - 
Difuse, hairy herbs, with alternate, entire leaves, and axillary and terminal singrle, clusterel, or 'ymose purple or white flowers.

1. N. Jamaicensis, L. Pubescent ; stems prostrate, diffusely branched, angled or slightly winged ly the decurrent leares; leaves spatulate-obovate, obtuse, tapering imo a petiole; flowers solitary or $2-3$ together, short-peduncled; calyx-lobes linear, ciliate, as long as the corolla; capsule oblong, splitting loculicidally into 2 valves, and at length septicidally into 4 valves, liaving the 2 placentæ free. - South Florida. - Stem 12'-18 long. Leaves $\frac{1}{2}^{\prime}-1^{\prime}$ long. Corolla small, purple, ciliate. Capsule 4-angled, smovit.

\section{Order 98. POLEMONI ACEA. (Polemoxilu Family.)}

Chiefly herbs, with opposite or alternate leaves, and regular solitary or cymose flowers. - Calyx 5-cleft or 5-parted, with membranaceous-margined lobes, imbricated in the bud. Corolla 5-lobed, convolute or (in No. 4) imbricated in the bud. Stamens 5, inserted on the tube of the corolla. Ovary 3 -celled, with 3 - many amplitropous orules attached to the central placenta. Style 3-cleft. Capsule 3-celled, loculicidally 3-valved. Seeds angular. Embryo straight in the axis of eopious albumen. Cotyledons leafy. Radicle inferior.

\section{Synopsis.}

Tribe I. POLEMIONIEA. - Lobes of the eorolla convolute in the bud. Anther-cells parallel, opening length wise.

1. PIILOX. Corolla salver-form. Filaments unequally inserted on the tube. heaves entire.

2. GILIA. Corolla tubular-funnel-shaped. Filaments equally inserted near the throat of the corolla. Leaves pinnately divided.

3. POLEMonIU.r. Corolla short-bell-shaped. Filaments inserted ou the throat of the corolla. Leaves pinnate.

TRIB II. DIA PEN SIEA. - Lobes of the corolla imbricated in tle bucl. Anther-eells opening transversely.

4. PYXIDANTHERA. Anther-cells awned at the base. Leaves eutire. Fiowers solitary.

\section{PHLOX, L.}

Calyx cylindrical or bell-shaped, 5-eleft. Corolla salver-form, witlı a long and slender tube, and obovate or roundish lobes. Stamens 5 , included, nnequally inserted on the tube. Style filiform. Ovules solitary in the cells. Capsule ovoid, 1-3-seeded; the valves at length separating from the central placenta. Seeds ereet. - Mostly perennial herbs, with opposite or (the npper) alternate entire leaves, and showy purple or white flowers in terminal pauicled eymes.

\$1. Stems herbaceous, erect or ascending.

* Style long, filiform : calyx-teeth lanceolute-subulate, not aun-pointed (except in $\mathrm{V}_{0}$ 1) - lobes of the corolla entire.

1. P. paniculata, L. Smooth; stem tall, branched above; leaves ovatelanceolate, acute or acuminate, the upper ones often corlate; cymes numerous, 
close-flowercl, forming a corymberse or pyramilal panicle; enlyx-teeth long, bristle-pointed; loles of the corolla romelobovate. (l'. undulatil, Pursh. l'.

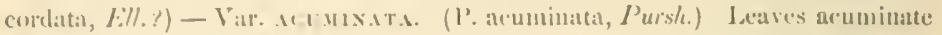
ut each and, the lower surface, like the stem, pubescent ; calyx-lobes shorter. Jich woots in the upper districts of Georria, and northwart. June and July. - Stem $2^{\circ}-4^{\circ}$ hight. Leares $2^{\prime}-4^{\prime}$ long, thin, strongly veined beneath, the primary veins uniting within the mareins. Corollat parple or white.

2. P. maculata, L. Stem ereet, pubesecnt and ronghish, especially above,

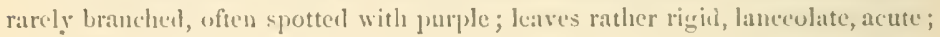
the lowent oftent linear and clongited, the npper broater and resunted at the base, rougl on the margins; rymes closely many-flowered, lateral am twminal, forming an oblong or pyramidal panicle; calyx-lobes straight, acute; whe of the corollat slender, enred; the lobes ohorate. (I'. pyramidalis, Simith. P. suavenlens, .lit.) - Var. ximnd. (P'. nitida, Ell.?) Stem rigrid, rough; leaves unmerous, uniform, ovate-oblone, mo-tly cordate at the latse; calyx-lobes acuminate. - Low woods, Florida to Mississippi, nud northward. June and July. - Stem $2^{\circ}-3^{\circ}$ highl. Icares $2^{\prime}-t^{\prime}$ long. Corolla purple or occasionally white.

3. P. Carolina, L. Smooth ; stem (10 high) erect or astending, sparingly branched ; leaves rarying from ovate to lanccolate, acute or acuminate, the upper ones often rounted or slightly cordate at the base; panicle corymbose, few-flow. eresl; calyx-lobes lanceolate, short-aeuminate. (P. triflora, .Wichx.?) - North Carolina, Bentham.

4. P. glaberrima, L. Smooth ; stem erect or ascending, sparingly brancherl above; leaves linecolate or lincar, acute, the lower tapering to the hase, the upper broader and rounded at the base; cymes usially 3 , terminal, few-flowered; caly.x. lobes lanreolate, acnte; corolla large, with the lolses wedge-obovalte. - Momn. tains of Xorth Carolina and 'Tennessec, and northwarl. July. Stem $1^{\circ}-2^{\circ}$ high. Leaves $3^{\prime}-4^{\prime}$ long. P'culicels as long as the calyx. Corolla $1^{\prime}$ long, pale purple.

5. P. reptans, Miehx. Pubesent or smoothish; stem low, skrnder, simple, learing long runners at the base. Stem-leaves few, distant, laneolate, rather obtuse; the radical ones and those on the runners larger, spatulate or ohovate, petioled ; cyme terminal, few-flowered ; calyx-lobes linear-subulate, mnch shorter than the spreading or recured pediecls; corolla-lobes obovate, shorter than the slender straight tube; antliers slightly exserted. - Damp sharly woods near Washington, Wilkes Co, Creorqia, and northwad aloner the mountains. May amel June - Stem $6^{\prime}-10^{\prime}$ high. Leaves $6^{\prime \prime}-8^{\prime \prime}$ long, the radieal ones $I^{\prime}-3$ long. Corolla l' longr, purple.

* * Style stort, scarcely longer thun the orary: calyx-teeth lonent-subulate, tapering into an awn-like pout: lobes of the corollu often notched: stems pubescent.

6. P. divaricata, I. Softly pubesent snd more or less glaurlular; stems ascending from a decumbent hase, simple; leawes distant, lanceolate or ovatelanceolate, rather acute, mostly rounded at the base; cynes rorymbose, loosely. flowered; lohes of the corolla obovate, notched or entire, as long as the tube, and twice as long ats the calyx. - Woods and banks, Florida to Mississippi, and 
northward April and May. - Stem $1^{\circ}$ ligh. Leaves $1^{\prime}-1 \frac{1}{2}^{\prime}$ long. Corolla $6^{\prime \prime}-9^{\prime \prime}$ long, pale bluish-purple.

7. P. Walteri. Softly pubescent or villous; stem low, ascending, simple; leaves linear-lanceolate, rather acute, sessile, erect; the lower ones approximate, the upper distant and often alternate; eymes terminal, compact, leafy-bracted; corolla-tube longer than the obovate lobes, and twice as long as the straight barely awned ciliate calyx-tecth. (P. pilosa, var. Walteri, Gray. P. pilosa, Walt, Ell. P. glutinosa, Buckl.?) Dry gravelly hills and pine barrens, Florida, and northward. April and May, - Stem $6^{\prime}-12^{\prime}$ ligh. Leaves $1^{\prime}$ long. Corolla bright purple, sometimes white, the tube $6^{\prime \prime}-8^{\prime \prime}$ long.

8. P. pilosa, L. Pubescent or villous; stem erect, mostly branching; leaves linear, or linear-lanceolate, spreading, distant, acute, the uppermost rounded at the base; cymes corymbose, loose-flowered ; calyx-teeth $\frac{2}{3}$ as long as the tube of the corolla, prolonged into long and spreadiug bristle-like points, hairy (P. aristata, Mich.x.) - Dry woods, Florida, and northward. April and May. - Stem rather sleuder, $1^{\circ}-1 \frac{1}{2}$ h high. Leaves $2^{\prime}-4^{\prime}$ long. Corolla $\frac{1}{2}{ }^{\prime}$ long, purple.

9. P. Floridana, Benth. Stem erect, simple, closely pubescent; leares uniform, linear-lanceolate, acute, spreading or recurved, the upper ones often alternate; cymcs crowled or corymlose ; calyx-teeth spreading, somewhat bristlepointed, glandular-pubescent, $\frac{1}{3}-\frac{1}{2}$ as long as the tube of the large corolla. Dry open woods, Middle Florida. May. - Stem $1 \frac{10}{2}-2^{\circ}$ high. Leaves $2^{\prime}-3^{\prime}$ long. Corolla l' broad, pale purple, the lobes round-oborate and entire.

\$2. Stems shrubliy, tufted, creeping: leaves subulute, rigid, leafy in the axils: style short.

10. P. subulata, L. Pubescent; flowering stems erect; leaves very numerous, the upper ones linear and mostly alternate; calyx-teeth subulate, erect, spiny-pointed ; lobes of the corolla notehed or entire. (P. setacea, $L$. P. Hentzii, Nutt.) - Sandy pine barrens, Florida to Mississippi, and northward. April and May. - Stems $4^{\prime}-12^{\prime}$ long. Leaves $4^{\prime \prime}-6^{\prime \prime}$ long. Corolla $\frac{1}{2}{ }^{\prime}-\mathrm{I}^{\prime}$ broud, parple or white.

P. Drummondr, Mook, is an annual species, conmon in gardens.

\section{GILIA, Ruiz and Pavon.}

Calyx tubnlar or bell-shaped, 5-eleft. Corolla funnel-shaped, 5-lobed. Stamens inserted equally near the mouth of the corolla. Ovules commonly numerous in the cells. Capsinle oblong or obovoid. Seeds angled or compressed. Herbs, with finely divided leaves, and showy flowers.

1. G. coronopifolia, Pers. Stem tall, simple, pubescent or hairy, very leafy; leaves pinnately divided into many filiform very acute segments; flowers scarlet, crowded in a long compound raceme or narrow panicle ; corolla tulunlarfunnel-shaped, with the oval-oblong obtuse lobes about $\frac{1}{3}$ as long as the tube; stamens exserted. (Cantua Floridana, Nutt ?) - Dry sandy soil, Florida to South Carolina, and westivard. July. $\left(2-\right.$ Stem $2^{\circ}-4^{\circ}$ high. Corolla $1^{\prime}$ long, yellow and spotted with red within. 


\section{POLTMONIUM, I,}

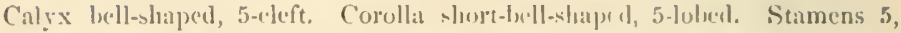
deelineel, inserted engally on the throat of the corollas, with a hatiry appendage at the base of the tilaments. Orules numerons in the cells. Capsule ovoisl. Seerls angled. - Herbs, with alternate pimately divided leares, and blue or white flowers in a nearly bractless corymb.

1. P. reptans, L. Smooth; stem weak, diffusely hranched; leaves petioled, pinnate, with 5-13 lanceolate or elliptical entire leaflets; (orymlss jeclun(lecl, few-flowered ; flowers norlding ; calyx-lobes ovate, ache; corolla blue; anthers white. - Shatly mountain woods, South Carolina, anct northwarl. April and May. $\quad 4-\mathrm{Stem} \frac{10}{2}-1^{\circ}$ high. Leaflets $\frac{11}{2}-1 \frac{1}{2}$ long. Calyx enlarged in fruit.

\section{PYXIDANTHERA, Michx.}

Calyx 3-bracted, 5-sepalous. Corolla hell-shaped, 5-lobed; the lobes rounded, imbricated in the bud. Stamens lroad, adnate to the tube of the corolla : anther. eclls rounclish, awned at the bise, opening ly a transwerse line. Ovules 5-8 in each cell. Capsule few-seeded. - A small creejing shrub, with ascending very leafy branches. Leaves evergreen, linear, hearded at the base, the upper ones alternate. Flowers solitary, teminil. Sepals oblong, obtuse, ciliate. Corolla small, white.

1. P. barbulata, Michx, (Diapensia, Ell.) - Dry pime barrens, North Carolina, and northward. April and May. - Stems $3^{\prime}-6^{\prime}$ long. Leaves $2^{\prime \prime}-$ $3^{\prime \prime}$ long.

\section{Oronk 99. CONVOL VULACEA. (Convolvulus FAMILY.)}

Chiefly twining or prostrate herbs, with alternate exstipulate leaves, and regular mostly showy and fingaceons flowers. - Calyx 5-sepalons, imbricated. Corolla bell-shaped, funmel-shaped, or salver-form, 5-plaited or 5-lobed, convolute in the but. Stamens 5, inserted on the tube of the corolla: anthers 2-celled, sagittate. Ovary fiven, single or innble, 1-4celled, with 1-2 erect anatropons ovules in each cell. Styles 1 or 2 , entire or 2-reft. Stigmas rapitate, ovate, or acute. Capsule 2-6-seceded. Embryo large, coiled or curved in mucilaginous albumen.

\section{Synopsis.}

TRIBE I. CONVOLVUI, F. - ovary single. Fmbryo with leafy cotyledons. Capsule opening by valves. - Flowers axillary. single or cymose.

* Style single. Stigmas globose.

1. QUAMOCLIT. Capsule 4-eelled, 4-seeded. ('orolla (red) salver-shaped. Stamens exserted.

2. BATATAS. Capsule 4-celled, 4-seeded. Corolla bell-shaped. Stamens included. 
3. PII.IRBITIS. Capsule 3-celled, the cells 2-seeded. Corolla bell-shapel.

4. IPOMIEA. Capsule 2-eelled, the cells 2 -seeded. C'orolla bell-or funnel-shaped. Stamens uostly included.

$$
\text { * * Style single. Stigmas ovate or eylindrical. }
$$

5. JACQUEMONTIA. Capsule 2 celied, 4 -sceded. Stigmas ovate, flattened.

6. CALYsteglA. Capsule imperfectly 2 -celled, 4-seeded. Stigmas cylindrical. Calyx ineluded in the membrauaceous braets.

* * Styles 2, separate or partly united. Ovary 2-celled.

7. Evolvulus. Siyles separate, 2-parled or 2-cleft.

8. STYLISIIA. Styles separate or partly united, entire.

Tribe 1I. DICHONDREA.- Orary double. Embryo with cotyledons. Capsule utricular, 1-seeded. - Stems creeping.

9. DICHONDRA. Corolla bell-shaped. Stigmas thiek. Peduncle 1-flowered.

Tribe 1II. CUSCUTER. - Ovary single. Embryo destitute of cotyledons. Capsule closed.

10. CUSCUTA. Twiuing parasites, with scale-like leaves. Styles 2.

\section{QUAMOCLIT, Tourn. Cripress-Vixk.}

Sepals 5. Corolla salver-form, 5-plaited, with the tube elongated. Stamens inserted at the base of the tube, dilated at the base, exserted. Ovary 4-celled. Style single : stigma globular, 2-lobed. Capsule 4-valved, 4-seeded. - Twining annual herbs, with cordate entire or pinuatifid leaves, and red flowers, on axillary peduncles.

1. Q. coccinea, Mœnch. Leaves petioled, cordate, acuminate, angled at the base; peduncles as long as the petioles, $3-5$-tlowered; sepals awned; corolla slightly lobed, scarlet. (I pomeil coccinea, L.) - Cultivated gromd, in the middle and upper districts, and northward. July and Ang. - Corolla $\mathrm{l}^{\prime}$ long, sometintes yellowish.

2. Q. vulgaris, Chois. Leaves pinnatifid, with long and linear segments ; peduncles $1-3$-flowered, the pedicels much thickened upward; sepals ovate or oblong, awnless. - Spontaneous near gardens. July-Oct.

\section{BATATAS, Chois.}

Sepals 5 Corolla bell-shaped, the limb 5-plaited, spreading. Stamens slightly dilated at the base, included. Ovary 4-celled. Style simple: stigma globular, 2-lobed. Capsule 4-celled, 4-seeded. - Trailing or twining herbs, with entire or lobed leaves. Peduncles axillary, 1 -several-flowered.

1. B. littoralis, Chois. Smooth and fleslyy; stem prostrate, creeping; leaves oval or oblong, cordate, notehed at the apex, entire or hastate-lobed, the lateral lobes entire or 2-cleft; peduncles as long as the petioles, l-flowered; bracts subulate; sepals olblong, mucronate; corolla obscurely lobed, white, the tube yellowish. (Convolvulus obtusilobus, Michx.) - Drifting sands along the coast, Florida to South Carolina. May - Sept. 4 -Leaves $\ell^{\prime}-2^{\prime}$ long. Corolla 2' long.

B. Enulis, Chois., includes the different kinds of the eultivated SweET 户отато. 


\section{PHARBITIS, Clois. Inmixi-(imor.}

Sepals 5. Corella luell-shuped or fummel-nlatpral, 5-plated. Stamens dilated

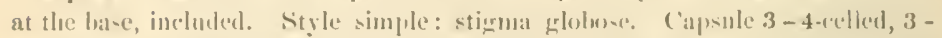
4-sulved, 6-8-serded. - Twining luebs, with petioled cordate entire or lobed leaves, mal single or cymose blue or purple flowers, on axillary bracted peduncles.

1. P. hispida, Chois. Annual; stem gl:undular-roughened and latiry; leaves cutire, rombl-corlate, acuminate; perluncles mostly longer tham she leaves, 3-5-Ilowered; scpals ovate-lanceolate, acute, mostly hairy ; corolla showy, hluc, jurple, or variegated. (Convolvulus purpureus, L.) - Around dwellings. Introiluced. Jume-sept.

2. P. Nil, Chois. Aunual, latiry ; leaves membranaceous, broadly corlate, 3-lobed, the lobes acuminate; perluneles shorter than the leaves, 2-3-flowered; sepals denscly hispid, ending in a long subulate point; bracts linear; corolla purple. (Convolvulns Nil, L.) - Cultivated grouncl, Florida, and northward. July - Sept. - Corolla $1 \frac{1^{\prime}}{2}$ lon $\underline{2}$,

\section{IPOMAEA, L. MonNixg-GionY.}

Sepals 5. Corolla bel-shaped or funnel-shaped, 5-plaited. Stamens dilated at the hase, included (exeept No. 8). Orary 2-eclled, rarely imperfeetly 4-celled. Style simple: stigma capitate, 2-lobed. Capsule 2-iclled, 2-4-valved, 4-secded, or, by abortion, $1-3$-sceded. Seeds smooth or liairy. - Twining or trailing rarely ereet herbs, with cordate or sagittate entire or varionsly lobed lawes, and slowy white or purple flowers on axillary pedunctes.

* Flowers crowded in a leafy-bracted capitate cyme : corolla small, bell-shapued.

1. I. tamnifolia, L. Hairy ; stem erect or twining; leaves cordate-ovate, acuminate, somewhat plicate with impressed parallel veins ; perluncles longer than the petioles; lower bracts longer than the many-flowered heads; sepals subulate, bristly, nearly as long as the blue corolla; stigmas distinct; ('al):ule depressed, somewhat 4-sided. - Cultivated ground, Florida to South Carolina, and westward. July-Oct. (1)-Stem $1^{\circ}-4^{\circ}$ long. Corolla $\frac{1}{2}$ long.

* * Flowers solitary, or fure in an open cyme.

+ Corolla bell-shapal: leaves orbicular : stems prostrate.

2. I. Pes-Capræ, Sweet. Smooth and fleshy; stem prostrate; leaves petioled, orlicular, or slightly notelied at the apex, parallel-reined; pedurcles I-3-flowered, the ovate bracts minute; sepals oval or oblong. obtuse, mucronate; tulie of the corolla very short. (I. orbieularis, Kill.) - Drifting sands along the coast, Florida and Georgia. Aug. - Oct. 4-Leaves 2' long. Corollat $2^{2}$ long, purple.

+ + Corolla (mostly small) bell-siaped: rapsule leairy: secds sumooth or nearly so: stems slender, twining: leaves petioled, cordute, entire or 3-lubed: stumens includid.

3. I. commutata, R. \& S. Stem pubescent or hairy; leaves thin, cordate, acuminate, entire, angled or 3-lobed, the lateral lobes aeute or sometimes 
2-cieft, sprinkled with hairs on both sides; peduucles 4-angled, about as long as the filiform petioles, $1-5$-flowered; bracts small, subulate ; corolla purple, $4-5$ times as long as the ovate-lanceolate aemminate ciliate sepals; capsule globose, 4-valved, shorter than the calyx. (I. trichocarpa, Ell.) - Margins of swamps, and cultivated grounds, Florida to North Carolina, and westward. Aug. - Oct. -Leaves $I^{\prime}-1 \frac{1}{2}^{\prime}$ long. Corolla $1 \frac{1}{2}^{\prime}-2^{\prime}$ long.

4. I. triloba, L.? Stem slender, hairy ; leaves cordate, abruptly attenuated, but obtuse at the apex, entire or hastate-lobed, with the lateral lobes rounded, smooth below, slightly hairy above; peduncles 3-flowered, longer than the leaves; bracts subulate; corolla small, purple, twice as long as the oblong, aeute, hairy sepals ; capsule globose ; seeds slightly pubescent on the angles. South Florida. - Leaves $1^{\prime}-1 \frac{1^{\prime}}{2}$ long. Corolla $\frac{1^{\prime}}{2}$ long.

5. I. lacunosa, I. Stem and leares smoothish; leaves cordate, obtuse or acuminate, entire or 3-lohed; peduncles 1 -3-flowered, shorter than the leaves, often shorter than the petioles; corolla small, white, twice as long as the oratelanceolate acuminate ciliate sepals; capsule globose, slightly hairy. - Low grounds, in the middle districts of Georgia, and westward. Ang. - Oct. - Calyx and corolla commonly longer than the preceding.

+ + + Corolla large, funnel-shaped, the tube elongated: capsule smooth: seeds often woolly: stems elongated: leares cordute, petiolcd, entire or 3-lobed.

6. I. pandurata, Meyer. Stem twining, smoothish ; leaves cordate, acuminate, but scarcely acute, entire or fiddle-shaped, more or less pubescent above, paler and smooth beneath; peduneles commonly longer than the petioles, $1-6$ flowered; bracts minute; scpals smooth, oblong-ovate, obtuse, mucronate, the two outer ones shorter; corolla white, with pointed lobes, the tube purple within. - Var. instata. Stem mostly prostrate; leaves hastately 3 -lobed, the lateral lobes rounded; peduncles mo tly 1 -flowered, longer than the leaves; inner sepals acute. - River-banks and margins of swamps, the var. in sandy pine barrens, Florida to Mississippi, and northwarl. Aug.-Oet. \#-Root tuberous, very large. Corolla $3^{\prime}$ long. Capsule globose. Seeds woolly on the angles.

7. I. Michauxii, Sweet. Stem pubescent, stont ; leaves membranaceous, deltoil, cordate but decurrent on the petiole, obtuse, plaited by the strong impressed veins, wary on the margins, slightly roughened above, hoary-pubesecnt beneath; peluncles 1-5-flowered; sepals thick, oblong, obruse, tomentose; corolla pubescent, white tinged with purple, notched at the angles of the limb, and bright purple on the tube within; capsule ovate, pointed, 2-valved; seeds very silky. (I. mactorhiza, Wichx.) - Light sandy soil, Florida to South Carolina, along the coast. July - Sept. 4-Root very large. Leaves $3^{\prime}-5^{\prime}$ long, oceasionally 3-lobed. Corolla $3^{\prime}-4^{\prime}$ long, opening at night. Ovary imperfectly 4-celled.

8. I. Bona-Nox, L. Smooth ; leares membranaceons, cordate, acuminate, entire, long-petioled; peduncles very stout, 5 - 7 -flowered, longer than the leaves; sepals ovate, obtuse ; the 2 outer ones prolonged in a long filiform appendage; corolla white, almost salver-form; the tube very long and slender; stamens and style partly exserted; capsule orate, pointed with the conical per 
sistent liase of the style. (Calonyetion spreciosum, Chois.) - Sonth Florida. Stem sometimes prichly. Leatres $2^{\prime}-3^{\prime}$ long. 'Tube of the corollat $3^{\prime}-4^{\prime}$ long, $1^{\prime \prime}-2^{\prime \prime}$ in lianeter.

9. I. sagittifolia, Bot. Reg. Smooth and somewhit fleslyy ; stem slemer; leaves sagittate, lanceolate or linear; the lateral lobes long, spreading, acute; peduncles 1 - 3-flowered, chul-shaped, shorter than the leaves, minutely loracted; sepals oval, rounded and purple at the ajex, shorter than the ovate 4-valved pointed capsule; seeds silky on the angles; corolla bright purple. (C. sagrittifolius, Mirhx.) - Salt mashes, Florida to North Carolina. July-Sept. 4Stem commonly $2^{\circ}-3^{\circ}$ lung. Corolla $3^{\prime}$ long.

10. I. fastigiata, Sweet? Smooth; leaves cordate, 3-loherl, with the Jobes anuminate; peduncles ahout as long as the petioles, 3-sereral-flowered, with leafy lancelate bracts; sepals lancelate, terminating in a long sululate point, on pecliecls shorter than the bracts; tube of the corolla greenish, the expamling acutely lobed border purjole. - South Florida. - Leaves $1 \frac{1}{2}$ ' -2 ' long. Corolla 3 ' long.

$$
++++ \text { Corolla bell-slutped: leares pedately } \text { i-parted. }
$$

11. I. sinuata, Ort. Stem very long, shrublyy at the hase, the branches muricate, hairy; leaves smooth, with the divisions lanceolate, sinuate-toothed; perbneles shorter than the leaves, 1 - 2-flowered ; pedicels flattened, dilated upwarl, nodlding; sepals ovate-laneeolate, acutish, smooth, half as long as the corolla, widely spreading in fruit; corolla white, purple in the throat; capsule glohose; seeds smooth. (Convolvnlus dissectus, Michx.) - Sonth Florida. July-Oct. 4 - Stem sometimes $40^{\circ}$ long. Leares $4^{\prime}-6^{\prime}$ wide. Corolla $1 \frac{1}{2}$ loing.

\section{JACQUEMONTIA, Chois.}

Sepals 5, unequal. Corolla bell-shaped, 5-plated. Style single : stigmas 2, ovatte or oblong, flattened. Ovary 2-celled, 4-ovuled. Cajsule 2-celled, 2-4valved, 4-secled. - Hahit of Ipomoea.

1. J. violacea, Chois. Stem smoothish, twining; leaves petioled, oblongovate or ovate-lanceolate, acuminate, pubeseent, the lower ones slightly cordate; pedumeles longer than the leaves, many-flowered; scpals ovate, acmuinate, the 2 outer ones larger; corolla small, purple; stigmas oblong, diverging; capsule smooth, 4-valverl, shorter than the ealyx. - South Florida. - Stem $1^{\circ}-3^{\circ}$ long. Leaves $1^{\prime}-2^{\prime}$ long. Corolla $\frac{1}{2}$ long. Seeds roughish.

\section{CALYSTEGIA, R. Brown.}

Sepals 5, included in the two large membranaceous bracts. Corolla bellslapped. Style single: stigmas 2, oblong or eylindrical. Capsule imperfectly 2-celled, 4-sceded. - Leaves petioled, eordate or sacrittate. Peduneles 1-flowered.

1. C. sepium, R. Br. Smooth; stem twining; leaves broadly sagittate, acnte, the wicle lateral lohes obliquely truneated and often toothed; peduneles 4-angled, as long as the petioles; bracts cordate-ovate or oblong, strongly keeled 
on the back; sepals aeute; corolla white or rose-rolor. (Convolvulus sepium, L.) - Varies with the stem and shorter peduncles pubescent; leaves smaller and narrower. (C. Catesbeiana, Ph.?) - Rich soil, Florida (the rar.), and northward. Aug. and Sept. 4 - Leaves $2^{\prime}-4^{\prime}$ long. Corolla $1 \frac{1}{2}^{\prime}-2^{\prime}$ long. Stigmas oblong-ovate. Stamens dilated and flattened below.

2. C. spithamæa, Pursh. Pubescent; stem ereet, rarely twining at the summit : leares orate or oblong-ovate, cordate, the upper ones acute; perluncles longer than the leaves, terete; braets ovate-lanecolate; corolla white. - Dry soil, Florila, and northward. May-Sept. If -Stem $1^{\circ}-2^{\circ}$ high. Leaves $I^{\prime}-2^{\prime}$ long. Corolla $1_{2}^{1 /}-2^{\prime}$ long.

3. C. paradoxa, Pursh. Stem prostrate, tomentose; leares oblong, eordate-sagittate, aente; peduncles longer than the leaf; braets remote from the flower, linear; sepals naked, smooth, aenminate; corolla large, white. In Carolina or Virginia, Pursle. (*)

\section{EVOLVULUS, I.}

Sepals 5. Corolla bell-shaped or somewhat wheel-shaped, mostly hairy. Stamens included. Styles 2, distinct, 2-eleft or 2-parted: stigma obtuse. Capsule 2-eclled, 4-seeded.-Small perennial herbs, with ehiefly silky or hairy prostrate stems, entire leaves, and small flowers un axillary peduncles. Capsules nodding.

\section{* Common peduncle very short or none; the pedicels shorter than the lenves.}

1. E. sericeus, Swartz. Silky with appressed hairs throughout, exeept the upper surface of the leaves; stem diriding at the base into numerous prostrate or ascending simple filiform lranches; leaves sessile, linear or linear-lan. ceolate, acute at each end, ereet; peduncle almost wanting, l-flowererl, rarely $2^{\prime \prime}-3^{\prime \prime}$ long and $2-3$-flowered ; sepals orate-lanecolate, aenminate, $\frac{1}{2}$ as long as the white wheel-shaped corolla. - Varjes with shorter $\left(4^{\prime}-6^{\prime}\right.$ long) and more rigid stems, ancl oblong or elliptieal and obtuse leaves. - Damp soil, Florida, Georgia, and westward. June-Oet. - Stems $6^{\prime}-12^{\prime}$ long. Leaves $6^{\prime \prime}-9^{\prime \prime}$ long. Corolla $4^{\prime \prime}-5^{\prime \prime}$ in diameter.

\section{* Peduncles longer than the leares.}

2. E. glabriusculus, Chois. Stem ereeping, simple, sprinkled with appressed hairs ; leaves rigid, elliptieal-obovate, mucronate, nearly sessile, smooth above, pubescent on the veins beneath; peduncles bristle-like, rather longer than the leares, $1-3$-flowered; sepals ovate-laneeolate, aente, hairy, as long as the pedicel ; corolla very small. - South Florida. - Stem $l^{\circ}$ long. Leaves $4^{\prime \prime}-6^{\prime \prime}$ long. Corolla $2^{\prime \prime}$ wide.

3. E. diffusus, n. sp. Silky with long spreading hairs; stems very numerons, filiform, diffuse; leaves oborate or oblong, mueronate, short-petioled; peduneles bristle-like, often by pairs, 3-4 times as long as the leaves, $1-3$ flowered; sepals ovate-laneeolate, aeuminate, shorter than the pedicels; corolla wheel-shaperl, styles parted nearly to the base. - South Florida. - Stems $1{ }^{\circ}$. $2^{\circ}$ long. Leaves $4^{\prime \prime}-6^{\prime}$ long. Corolla $2^{\prime \prime}$ wide. 


\section{STYLISMA, litf.}

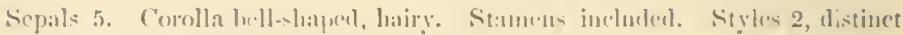

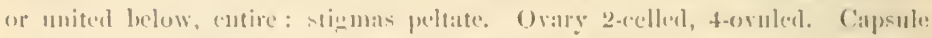
1 - 4-scedeel. - I'erennial prostrate pubesent heris, with entire leaves, and small fluwers on axillary perluncles which are longer than the leaves.

1. S. humistrata. Hairy and roughish; leares petioled, ollong, slighlitly: corilate, obtuse or entreginate at the apex, mueronate; perduncles filiform, $1-7$. flowered ; sepals ovate, acute, smonth, fringed on the margins; (appule smooth, noddling; luacts minute; corolla white; filaments hairy; styles mited below. Varies with linear or lanecolate, often acute, nearly sessile leates, sliorter and uniformly l-fluwered peiluncles, and more pubescent sepals. (Convolvulus humistratus, II alt. C. tenellus, Ell.) - Dry sandy pine barrens, Florida to South Carolina, and westward. July-Sept. - Stems $2^{\circ}-3^{\circ}$ long. I.eaves $1^{\prime}-3^{\prime}$ long. Corolla $10^{\prime \prime}$ long. Capsule orate, commonly 1-secilerl, crowned with a tuft of hairs when young.

2. S. aquatica. Silky-pubescent and somewhat hoary; leares linear-chlong. obtuse, mucronate, trumcate or slightly cordate at the hase, short-petioled; peduucles $1-7$ (mostly 3-)-flowered; sepals orate-lanceolate, acunninate, very silky; capsule ereet, pubesecnt ; lyracts subulate, as long as the pedicels; corolla purple; filaments smooth; styles distinet. (Couvolvulus aquaticus, Wult.) Margins of ponds, Florida to North Carolina, anıl we-tward. July-Sept Stems $2^{\circ}-3^{\circ}$ long. Leaves $\frac{1^{\prime}}{2}-1^{\prime}$ long. Corolla $5^{\prime \prime}$ long.

3. S. Pickeringii, Gray. Soft-pubescent or villons; leaves linear, oltuse, narrowed at the nearly sessile hase; peduncles 1 - 3 -flowered ; bracts linear, as long as the flower; sepals ovate-lanecolate, very hairy, longer than the perlicel ; corolla small, white; styles united nearly to the apex; stamens slightly exserted. - Sandy pine barrens, North Carolina, and northward. July-Sept. - Stems $2^{\circ}-3^{\circ}$ long. Leaves $12^{\prime \prime}-15^{\prime \prime}$ long. Corolla $5^{\prime \prime}$ long.

\section{DICHONDRA, Forst.}

Calyx 5-parted, with the lobes oborate. Corolla somewhat whecl-shaped, 5-parted, shorter than the calyx. Stamens included. Oraries 2, distinet, 2-ovuled. Styles 2: stigmas capitatc. Utricles 2, one-sceded. - Low pubescent ereeping herbs, with broadly cordate petioled leaves, and solitary bractless flowers on axillary peduncles.

1. D. repens, Forst., var. Carolinensis, Chois. - Iow grousds, Florida to North Carolina, and westwarl. March-Oct. 4-Stems filiform, $6^{\prime}-12^{\prime}$ long. Icares $\frac{1^{\prime}}{2}-1 \frac{1}{2}$ in diameter, on petioles $1^{\prime}-4^{\prime}$ long. I'eduncles shorter than the petioles. Calyx silky. Corolla minute, greenish white.

\section{CUSCUTA, Tourn. Donner.}

Calyx 4-5-cleft, or 4-5-sepalons. Corolla glolsular-urn-shaped, bell-shaped, or somewhat tubular, 4-5-eleft. Stamens 4-5, with fimbriate mostly confuent scales at the base. Ovary 2-celled, 4-oruled. Styles 2 : stigmas capitate (in 
our species). Capsule 4-sceded. Embryo filiform, coiled around fleshy albumen. Cotyledons none.- Twining parasites, germinating in the ground, but early decaying at the root. Stems filiform, yellow or redilish, withont leaves, or with minute seales in their place. Flowers white, small, varionsly clustered.

* Flowers pedicelled, with few and distant bracts: culy $x$ 4-5-cleft : corolla bellshaped, pristent at the base of the capsule.

1. C. arvensis, Beyrich. Low ; flowers small, 5-parter, in loose umbellike cymes; lobes of the corolla lanccolate, acuminate, spreading or reflexed, longer than the tube; scales ovate, often partly exserted ; capsule globose, thin, yellowish — Fields and sterile soil, on small herbs, Florida to North Carolinia. June and July. - Steins $1^{\circ}$ high. Flowers the smallest of our species.

2. C. Gronovii, Willd. Stem climbing high; flowers mostly 5-cleft, in loose paniculate cymes; lobes of the corolla ovate, obtuse, spreading, mostly shorter than the tube; scales large, confluent at the base; capiule globose, brown. (C. Americana, Pursh., I)C.) - Low shady places, on coarse herbs, Florida, and northward. Aug. - Oct.

3. C. neuropetala, Engelm. Stem branching; flowers rather large, 5-parted, in smooth unbel-like cymes; lobes of the calyx ovate-lanceolate, acute; lobes of the corolla ovate, acuminate, crenulate, 1-nerved, spreading, as long as the tube; scales ovite, incurved, as long as the tube. - Damp soil, Florida, and westward. May.

4. C. rostrata, Shuttl. Stem twining high; flowers large, 5-parterl, in umbel-like cymes; lobes of the calyx ovate, obtuse ; lobes of the corolla ovate, obtuse, spreading and at length reflexed, half as long as the tube; scales connate at the hase; capsule large, acute. - Shaded moist places on tall herbs, on the monntains of North Carolina, and northward.

* * Flowers scssile, in compact clusters: culyx of 5 separate sepals, surrounded by seceral similur bracts: corolla persistent at the apex of the capsule.

5. C. compacta, Juss. Stems climbing high; hracts and sepals orbicular, concave, denticulate, imbricated; tube of the corolla equalling or longer than the calyx, the oblong obtuse lobes spreading; scales confluent at the base; capsule globose-ovate. - Damp shady places, Floricla, and northwarl. July - Oct. - Clusters often continuous, and spirally coiled around herbs and shrubs.

\section{Order 100. SOLANACEA. (Nightshade Family.)}

Herbs or shrubs, with colorless juice, alternate leaves, and regular axillary or supra-axillary flowers. - Calyx 4 - $i$-cleft, or $t$ - 7 -toothed, persistent, often inflated in fruit. Corolla 5-10-lobed, plaited and ralvate, eonvolute, or imbrieated in the bud. Stamens 4-7, inserted on the tube of the corolla : anthers 2-celled, opening lengthwise or by terminal pores. Style and stigma single. Fruit a 2-eelled (rarely $3-5$-celled) many- 
sereled capsule or berry. P'lacentas aluate to the partilion and projecting

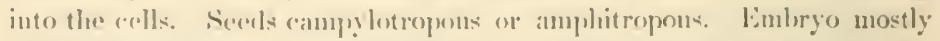
slender and carved in fleshy allumuen. - Chicfly narcotic proisons.

\section{Synopsis.}

3. Fruit a berry.

- Corolla wheel-shaped or sliort bell-shaped.

- Anthers connivent. Calyx unchanged in fruit.

1. SOLAXCM. Anthers opening by terminul pres. Berry juicy.

2. CAl'sICLy. Anthers opening lengthwise. Berry juiceless.

+ + Anthers geparate, opening lengthwise. Fruitiug ealy $x$ inflated.

3. PIISALIS. I rry juicy. Caly $x$ rutire at the base.

4. NICANDR.1. Ferry dry. Calyx 10-toothed at the base.

* Corolla funnel-sbaper.

5. LYCICy. Anthers opening lengthwise, Jerry juicy. Shrubs.

6 2. Fruit a eapsule.

6. DitURA. Calyx prismatic or terete, circuuscissile. Capsule spiny.

\section{SolanUm, L. Nightshane.}

Calyx 5-toothed or 5-eleft. Corolla wheel-shaped, 5-lobed, valvate, with the margins turned inward. Stamens 5, inscrtel on the throat of the corolla, exserted; the filaments very short: anthers opening by 2 terminal pores, connivent. Stigma obtuse. Berry juicy, 2-celled, mauy-secded. - Herbs or slurubs, often armed with prickles. Leaves alternate or in pairs. Flowers opjposite the axils, or above them.

\section{* Unarmed: cymes or racemes corymbed: corolla 5-jarted.}

1. S. nigrum, L. Herbaceous, mostly pubeseent with simple hairs; stem erect, branching; the branchlets wing-ingled, and more or less toothed; leaves petioled, oblong-ovate, toothed or entire; flowers somewhat umbelled, drooping, small, white; berry black. - Dimp soil, Florida to Mississippi, and northward. July - Sept. - Stem $1^{\circ}-3^{\circ}$ ligh, diffuse. Leaves $2^{\prime}-t^{\prime}$ long, when in pairs, uncqual. Corolla $4 "-6$ " wide. Berry $2^{\prime \prime}-3^{\prime \prime}$ in diameter.

2. S. Radula, Vilhl. Shrubby, and very rough throughout with slort rigid rusty stellate hairs; leaves oblong, entire, acute, tilpering into a slort petiole; cymes slender, long-peduncled, once or twice forking, many flowered, longer than the leaves; flowers small, linear in the bud ; corolla white, deeply parted, the lohes linear-lanceolate, obtuse; anthers hairy, - South Florida Leares $2^{\prime}-3^{\prime}$ long. Cymes $3^{\prime}-4^{\prime}$ long. Corolla $5^{\prime \prime}$ wide.

3. S. verbascifolium, L. Shrubby, and hoary throughout with dense soft stellate hairs; leaves large, orate-oblong, acute at each end, entire; eymes on long and very stout peduncles, forkina, rompactly many flowered ; flowers globoseohovate in the bud; calyx-lobes orate, acute; co:olli-lobes oblong, obtuse, anthers oblong, twice as long as the slender filaments; ovary woolly. South Florida. Uct. - Dec, - Shrub $4^{\circ}-5^{\circ}$ high. Leares $6^{\prime}-9^{\prime}$ long. Co. rolla $\frac{1}{2}$ wide 
4. S. Blodgettii, n. sp. Stem slirubby? smooth, the branches, like the up. per surface of the leaves, roughened with a close stellate (greenish) pulsescence; leares oblong, obtuse, entire, narowed into a short petiole, hoary-tomentose beneath, like the rather short-peduneled many-flowered forking eymes; calyx small, obconical, with short rounded tecth; corolla purple? deeply parted, $3-4$ times as long as the ealyx, with lanceolate acute lobes; anthers nearly sessile, linear, narrowed at the apex, shorter than the style. - South Florida. - Leaves $3^{\prime}-4^{\prime}$ long. Flowers $\frac{1}{2}$ ' in di:meter.

\section{* * Prickly: flowers racemed: corolla mostly angularly lobed.}

5. S. Carolinense, L. Hirsute with stellate hairs; stems ereet; leaves orate-oblong, angularly loberl or toothed, abruptly eontracted into a short petiole; the reins and petiole, like the stem, armed with straight yellow prickles; racemes simple, slender, 3 -sereral-flowered ; calyx-lobes acuminate. - Var. F LoRiDANA (S. Floridanum, Dunal) is less hairy; stems ascending from a creeping base; leaves narrower, sinuate-lobed or toothed, with more numerous and stronger prickles. - Nry waste places, Florida to North Carolina. June-Sept. $4-$ Stem $1^{\circ}-1 \frac{10}{2}$ ligh. Leaves $3^{\prime}-5^{\prime}$ long. Corolla $9^{\prime \prime}-12^{\prime \prime}$ wide, blue or white.

6. S. aculeatissimum, Jacq. Plant heset throughout with bristly hairs and stout prickles; stem diffusely branched; leaves petioled, orate or oval, membranaceons, acute, rounded or corrlate at the base, acutely lober or toothed; racemes lateral, slender, 2-5-flowered, shorter than the petioles; corolla-lobes laneeolate, acute, white; anthers acuminate; berry globose, yellow. - Waste places, Florida to North Carolina. I'robably introduced from Mexico. June Sept. (1) - Stem $1^{\circ}-2^{\circ}$ high. Leaves $3^{\prime}-6^{\prime}$ long. Corolla $6^{\prime \prime}-9^{\prime \prime}$ wide, the lobes recurvel.

7. S. mammosum, L. Pubesent with stellate hairs, and the stem, petioles, and nerves of the leaves armed with stout flattened prickles; stem stont, erect; leaves larege, ovate, sinnate-lobed, slightly cordate; racemes cymose, long-peduncled, many-flowered; corolla large, purple, with ovate sprealing lobes; berry conical-ovate. - Road-sides, and waste ground, Florisla and Genrgia. July - Sept. (1) - Stem $2^{\circ}-3^{\circ}$ high. Leaves $6^{\prime}-9^{\prime}$ long. Corolla $1 \frac{1}{2}{ }^{\prime}$ wide. Anthers narrowed upwarl, on slender filaments. Calyx unarmell.

8. S. hirsutum, Nutt., not of Dunal. Dwarf, hirsute; leaves hroadly ohorate, very obtuse, nearly entire, narrowed at the base, prickly on the midrib; racemes 3-flowered; peduneles filiform. - Milledgeville, Georgia. - Roots profusely creeping. Stem a span high, beset with yellowish hairs. Calyx very rough. Flowers purple? (*)

S. Pseldo-Capsicur, L., the Jerusalem Cherry, is sometimes spontaneols near dwellings.

S. turerosca, L., is the Irisu Potito, as it is here called; S. Melonfesa, L., the Egri-Plant; and S. Lrcopersicus, L. (Lycopersicum eseulentum, Mill.) the Tomato. 


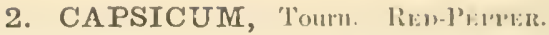

Calyx enp-shaped, 5- i-touthed. Corolla whec-shaped, 5-7-eleft, plated. Stamens $5-7$, inserted on the throat of the coroflal, exserted allhers comnivent,

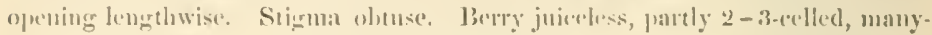

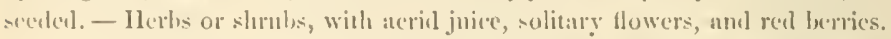

1. C. frutescens, I. Slmubly, smooth; stem loranching; leaves ohlongr ovate, ohtuse, cutire, achte or rounderl at the bave, petioled, often by pairs; calyx obsemely toothed, long-pelnneled, ereet ; bery ohlong, shorter than the perluncle. - South Floridla. - Stem $1^{\circ}-2^{\circ}$ high. Leatse's $1^{\prime}$ long. Flowers in the forks of the branches. Berry $t^{\prime \prime}-6^{\prime \prime}$ long.

\section{PHYSALIS, I. Grovin-Curnir.}

Calyx 5-tootherl, inflated in fruit, and enclosing the juiey berry. Corolla short-bell-shaped, plaiterl, 5-lobed or 5-anglet. Stamens 5, inserterl on the tube of the corollat : anthers separate, opening lengthwise. Stigma obtuse. Seeds flat, kidney-shapet. - Diffusely branching herbs, with alternate petioled leaves, which are often by pairs, and solitary nodding flowers in their axils, or in the forks of the branches.

* Perennial: peduncles commonly longer than the petiole: rorolla $8^{\prime \prime}-10^{\prime \prime}$ in cliameter, spotted in the throat with broun or purple.

1. P. viscosa, L. Prbescent or hairy; root slender, elongated; stems erect, at length diflusely brancherl, angled; leaves ovate, entire or angularly toothed, acite or obtuse, rounded or cordate at the base; ealyx hairy, with triangular-ovate loles; corolla pubescent, yellow, with 5 large brown spots in the throat; style and filaments purple; anthers ycllow; fruiting calyx oblongovate, sharply 5-angled, concave or truneate at the base; berry globose, viscitl. (P'. heterophylla, Ners. P. l'ennsylvani(":l, L.) - Dry light or samly soil, Floridla to Mississippi, and northward. July-Ott. - Stems $1_{2}^{\circ}-2^{\circ}$ high, sometımes purple; the pubescence of ien viscil, jointed, or rongh. Leares $1^{\prime}-2^{\prime}$ long, the $n_{j}$ permost rarely acute and unequal at the base. Corolla obsenrely lobed. Fruiting calyx $1^{\prime}-1 \frac{11}{2}$ long.

2. P. lanceolata, Michx. Pubescent; leaves orate-lanceolate or oblong, obtuse, lut often attenuate at the apex, entire, wary, or coarsely and obruscly toothed on the margins, acute and commonly very unequal at the base; calyx pubescent, the lobes long-acmninate from an ovate base; corolla 5-lobed, or sonewhat 10-lubed or toolhed, yellow in the throat ; fruiting calyx orate or glohoseorate, 5-angled. (1'. Elliottii, Kunze. P. maritima, M. A. Curtus?) - Dry sancly soil, Florida to Aorth Carolina. Jnly - Oct. - Stem $1^{\circ}$ high, erect or difiuse Leaves $1^{\prime}-3^{\prime}$ long. Fruiting ealyx $l^{\prime}-1 \frac{1^{\prime}}{2}$ long, smooth or hairy.

3. P. angustifolia, Nutt. Smooth; stem low, erect or at length diffuse, 3-4-angled; leaves linear or lanceolate, oltuse, entire, narrowed grarlually at the base into a winged petiole; calyx lobes short, triangular-ovate, obtuse, tomentose on the margins; corolla ycllow, brownish purple in the throat, 
5-lobed, fruiting calyx oblong-ovate, wing-angled, depressed at the base. Low sandy places along the coast, West Florida. July-Sept. - Stem 6'-12' high. Leaves $2^{\prime}-5^{\prime}$ long, equal at the hase, somewhat fleshy. Corolla soructimes $I^{\prime}$ in diameter. Fruiting calyx $9^{\prime \prime}-12^{\prime \prime}$ long. Anthers yellow.

* Annual: pcduncles shiorter than the petiole: corolla $4^{\prime \prime}-6^{\prime \prime}$ in diumeter, yellow, spotted in the throut with green or brown.

4. P. angulata, L. Smooth throughont; stem sharply 4 -angled, erect or at length diffusely procumbent; leaves oblong-ovate, acuminate, sharply toothed, long-petioled, slightly unequal at the bise, the lower ones often somcwhat cordate; calyx-lobes triangular-lanceolate, as long as the tube; corolla pale-yellow, 5-toothed, spotted with green in the throat; filaments smooth; antliers purple; fruiting calyx globose-ovate, equally 10-angled, reticulated with purple reins, depressed at the base. - Fields and waste ground, Florida, and northward. July-Oct. - Stem $1^{\circ}-4^{\circ}$ long. Leares $2^{\prime}-3^{\prime}$ long. Fruiting calyx I' long.

5. P. pubescens, I. Tomentose or villous with soft often viscid hairs, rarely smoothish; stem diffusely branched, 4-angled, with one side rounded; leaves long-petioled, mostly acute, obtuscly toothed, wavy-margined, or entire, ovate, and mostly slightly corlate and unequal at the base; calyx-tecth subulate, twice as long as the tube; corolla bright yellow, 5- or somewhat 10-toothed, brown in the throat; filaments lairy; antliers pmplish; fruiting ealyx oblongovate, sharply 5-angled, truncate at the base. (I'. hirsuta, Lunal. I'. pruinosi, Ell. P obscura, Michx.) - Fields and waste grounds, common. July-Oct.Stems $1^{\circ}-3^{\circ}$ long. Leaves $1^{\prime}-2^{\prime}$ long.

\section{NICANDRA, Adans.}

Calyx 5-parted, inflated, 10-toothed at the base. Corolla bell-shaped, plaited, obscurely 5-loled. Stamens 5: anthers separate, opening lengthwise. Berry juiceless. - A smooth erect branching annual, with ovate-oblong toothed or lobed petioled leaves, and solitary axillary nodding purple flowers.

1. N. physaloides, Gart. - (Atropa physaloides, L.) - Waste and cultivated ground. Introduced. July-Sept. - Stem $1^{\circ}-3^{\circ}$ high, with angled branches. Leaves $2^{\prime}-5$ long, decurrent on the petiole. Corolla white in the timoat. Fruiting calyx 5-angled, enclusing the globose berry.

\section{LYCIUM, L.}

Calyx 4-5-rleft. Comlla funnel-shaped, 5-10-eleft or toothed. Stamens 4-5. anthers opening lengthwise, separate. Stigna capitate. Berry uot enrlosed in the calyx. - Ereet or twining often sping shrubs, with entire alternate or clustered leaves, and axillary or terminal flowers.

1. L. Carolinianum, Michx. Stem erect, spiny, much branched ; leaves sinall, clnstered, club-shaped, fleshy; flowers solitary, axillary, purple ; calyx and corolla 4-cleft; stamens 4, exserterl. - Salt inarshes, Florida to South Carolina. July - Sept. - Shrub $3^{\circ}-5^{\circ}$ high. Lcaves $1 \frac{1}{2}$ long. Corolla small, hairy withis. Berry red. 


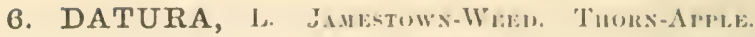

Calyx tulular, terene or angled, 5-cleft, selanating mar the base, the mper

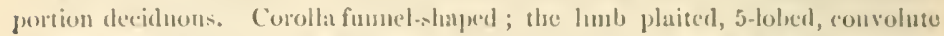
in the but. Stamens 5. anthers opening lengtlowise. Capmule spiny, imper-

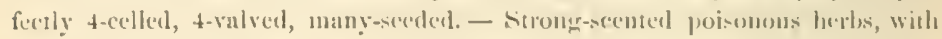
petioled ublong or ovate mostly toothed leaves, and large sulitaly flowers in the furks of the brauches.

1. D. Stramonium, I. Smooth; stem stont, forking; leaves ovate or oblung-ovate, acme, simate-toothed; corolla sharply 5-teothed, white, twice as long as the 5-angled calyx; capsule erect. - Var. "TAтria. Larger; lenves often cordate; stem and corollib pupli-1, - Waste gromul, very rommon. June - Oct. - Stem $1^{\circ}-3^{\circ}$ high. Leaves $4^{\prime}-8^{\prime}$ loug. Corolla $3^{\prime}-4^{\prime}$ long.

2. D. Metel, L. Pubescent; stem stout, brauching; leaves ovate, entire or slightly toothed; corolla white, lu-tootherl calyx loose, terete; mpanle noddiner. - North and Souh Carolina, Curtis. Inroduced. - Stems $3^{\circ}-4^{\circ}$ high. Leaves $6^{\prime}-8^{\prime}$ loug, Corolla $6^{\prime}$ long.

The Petuxia, Nignt-Brommixg Jissamine (Cestrem), and Tobacco (Nicotiaxi), beloug to this fimily.

\section{ORDER 101. GENTINNACE. (GENTIAN FamLY.)}

Chiefly smooth and bitter herls, with eolorless juice, opposite entire partly sheathiner exstipulate leaves, and regular often showy flowers. Calyx 4-12-parted, or 4-12-cleft. Corolla 4-12-lobed, ronvolute, rarely valvate or inbricated, in the bud, hyporgnous. Stamens alternate with the lobes of the corolla, aul inserted on its tule: anthers 2-celled. Ovary singl', witl numerous anatropous ovules. Stigmas 1-2. Capsule 1celled, or imperfectly 2-4-celled by the introversion of the marcrins of the valves, septiciclally 2-valverl. Placente parictal. Seeds numerous. Embryo minute, in the axis of fleshy albumen.

\section{Synopsis.}

* Corolla convolute, or (in Obolaria) imbriented in the bud. Testa membranaceous. - Leares sesisile.

1. SABBATIA. Style conspicuous, deciduous. Stigmns linear, twisted. Corolla wheelshaped, 5-12-parted.

2. EUstoyA. Style conspicuotw, persistent. Stigmas roundisb, flat. Corolla tubular, 45. partecl.

3. Gevtraxa. Stigmas sessile, flat, persistent. Corolla bell-shaped or funnel-form, $4-j-$ lobed, mostly with plaited appendages between the lobes.

4. BARTONiA. Caly $x$ and corolla 4-lobed. Stigmas sessile. Leaves srale-like.

5. OBOLAlitA. Calyx 2 -leavel Corolla 4 -lobed, imbricated in the bud.

6. FRASERA. Corolla wheel-shaped, 4-parted, the lobes witl a large depresed gland in the niddle.

* Corolla follied in the bud. Testa woody. Petioles elongated.

7. Limsantinemuy. Leaves floating, cordale. Flowers clustered on the petiolo. 


\section{SabBatia, Adans. Americay Centalry.}

Calyx 5-12-parted. Corolla wheel-shaped, 5-12-partel, withering-persistent. Stamens 5-12, inserted on the throat of the corolla: anthers sagittate, mostly recurved. Style conspicuous: stigmas linear or oblong, twisted. Capsule glohose, l-celled, 2-valved, many-seeded. - Annual or biennial branching herbs, with cymose or panicled white or purple slowy flowers.

\section{* Calyx and corolla mostly 5-parted.}

- Flovers in corymbose cymes, white, turning yellowish: branches opposite.

1. S. lanceolata, Torr. \& Gray. Stem tall, terete below, 4-angled and corymbosely branclied ahove, the branches opposite; leaves ovate or roundish, 3-5-nerved, acute or obtuse, elasping; the upper ones llistant, lanceolate, and very acute; cymes large, loosely many-flowered ; lobes of the corolla (often 6) obovate-oblong, twice as long as the filiform ealyx-lobes. (S. corymbosa, Baldw.) - Wet pine barrens, Florida to North Carolina. July. - Stem $2^{\circ}-3^{\circ}$ high. Leaves $1^{\prime}-1 \frac{1}{2}^{\prime}$ long; the lowest minute. Corolla $10^{\prime \prime}$ wide, turning yellowish in drying.

2. S. paniculata, Pursh. Stem virgate, wing-angled throughout, commonly much branched from the base; leaves elasping, lanceolate, 3-nerved, mucronate, the upper and floral ones linear, the lowest tufted, oblong-obovate; cymes very numerous, densely few-flowered, leafy; lobes of the corolla oborate, one third longer than the linear calyx-lobes. - Low grassy meadows, Florida to North Carolina. August. - Stem $9^{\prime}-18^{\prime}$ high. Leaves $\frac{1}{2}^{\prime}-1^{\prime}$ long. Corolla $\frac{1}{2}$ wide.

3. S. macrophylla, Hook. Glancous; stem terete, corymbosely branched above; the branches opposite ; leaves thick, erect, ovate-lanceolate, acute, clasping, 3-5-nerved; cymes large, flat-topped; corolla small, the lobes thrice as long as the very short bristle-like calyx-lobes. - Wet pine barrens, Florida, and westward. July and Aug. - Stem rigid, hollow, $2^{\circ}-21_{2}^{\circ}$ high. Leaves $1 \frac{1}{2}{ }^{\prime}-3^{\prime}$ long. Corolla $5^{\prime \prime}-6^{H}$ wide.

+ + Flowers in panicled cymes, purple: branches opposite.

4. S. angularis, Pursh. Stem square, wing-angled, erect, paniculately much branched, often from near the base, the branches opposite; leaves numerous, ovate, elasping, 3-5-nerved, often as long as the joints, the upper ones acute; lobes of the corolla oblong, about twice as long as the linear calyx-lobes.Low rich grounds, Florida, and northward. Aug. - Stem $1^{\circ}-2^{\circ}$ high. Leaves $1^{\prime}-1 \frac{1}{2}^{\prime}$ long. Corolla $1^{\prime}$ wide.

5. S. brachiata, Ell. Stem erect, terete, paniculately lranched near the summit; the branches opposite, spreading; leaves sessile, lanceolate, the upper ones linear, acute, the lowest clisterel ; flowers in small loose peduncled cymes, terminating the branches, and forming an oblong or pyramilal panicle; lobes of the corolla narrowly oblong, twice as long as the linear calyx-lobes. - Low grounds in the midrle and upper distriets, and northwart. July and Aug. - Stem $2^{\circ}$ high. Leaves l' long. Corolla l' wide. 


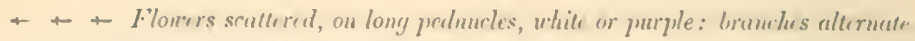

6. S. Elliottii, sienul. Stem low, terete, fanjenlately much branthed

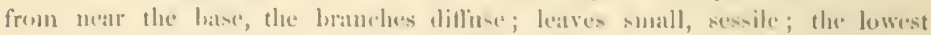

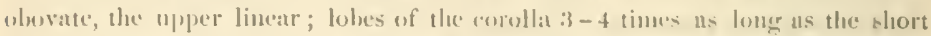

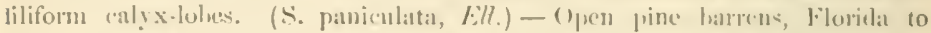
South Corolina. Ang. and Sept. - Stuns $3^{\prime}-12^{\prime}$ high. Lataves $3^{\prime \prime}-6^{\prime \prime}$ longr. Corulla $8^{\prime \prime}-10^{\prime \prime}$ wille.

7. S. gracilis, Pursh. Stem slightly t-ingrled, crect or reclining, diffuse, the branches 1-3-flowered ; leaves linear or olshendinear, the uppermost almost filiform ; flowers terminating the short loranchlets; lobes of the corollat obovateoldong, rather longer than the filiform calyx-lobes. - - Low grassy pine barrens and mearlows, Florida to Mississippi, and northwarl. July and Am. - Stem slemeler, $1^{\circ}-11^{10}$ long. Leaves $1^{\prime}-1 \frac{1}{2}^{\prime}$ long. Corolla $12^{\prime \prime}-15^{\prime \prime}$ wille.

8. S. stellaris, Pursh. Stem ulscurely t-angled, slender, paniculately branched, the branches elongaterl ; leaves somewhat fleshy, the lowest lanceolate or oblong, olitue, the upper linear, arnte; flowers on very long peduncles; fobes of the corollat oblong, longer than the filiform calyx-lobes. - Salt marshes, Florida, and northward. Aug. and Sept. - Stem $1^{\circ}-3^{\circ}$ Jight. Lealves $1^{\prime}-2^{\prime}$ loug. P'eluncles $1^{\prime}-4^{\prime}$ Jong. Corolla $1 \frac{1}{2}^{\prime}$ wide.

9. S. calyeosa, Pursh. Stem low, terete; leaves thin, laneeolate or oblong, obtuse, marrowed at the base, the lowest petioled ; flowers few ; corolla white, 5 - 7 -lolerl, shorter than the lanecolate leafy caly-lobes. - River swamps, Florida to Nortl Carolina, and westward. July and Aller. - Stem 6 $6^{\prime}-12^{\prime}$ high, rigid. Leaves $1^{\prime}-1 \frac{1}{2}^{\prime}$ long. Corolla $8^{\prime \prime}-10^{\prime \prime}$ wide.

\section{* *alyx und corolla 7 -12-parted: flowers purple.}

10. S. chloroides, l'ursh. Stem erect, terete, simple, or 1-2forking, 1-5-flowered ; leaves lanecolate, sessile, miform, on the lowest spatulate-oblong and the upper linear, acute; corolla larege, 8-12. (mostly 10-) parterl, commonly more than twiec as long as the linear or subulate calyx-lobes. - Margins of pine-harren ponds and swamps, Florida, aud northward. July and $A$ ug. Stum $1^{\circ}-1 \frac{10}{2}$ high. Leaves $1^{\prime}$ long. Corolla $1 \frac{1}{2}^{\prime}-3^{\prime}$ witle.

11. S. Boykinii, Gray. Stem mostly simple, somewhat angled; leaves l:uncelate-oblong, or the lowest elliptical ; Howers single or $3-7$ in a terminal capitate cluster, sessile and 2-bracted; corolla 8-9-parted, much fonger tham the oblong-lanceolate ealyx-lohes. - Midhle Georgia, Ir. Boykin. - Stem $1^{\circ}$ high. Leaves $1^{\prime}-2^{\prime}$ long. Corolla $1 \frac{1}{2}$ ' wide.

12. S. gentianoides, kill. Stem erect, simple, slender; lowest leaves lanceolate or oblung, narrowed at the base; the others long, linear, sessile; flowers large, in axillary and terminal chusters, or terminal and solitury; corolla $8-10$-parted, $2-3$ times as long as the sululate calyx-lolus; antliers straight. - Low pine barrens, Georgia, Floriłla, and westwarl. July and $A$ g. $-\operatorname{Stcm} 1^{\circ}-2^{\circ}$ high. Leaves $1 \frac{1}{2}-3^{\prime}$ long. Corolla $2^{\prime}$ wide. 
2. EUSTOMA, Don.

Calyx bell-shaped, 4-5-parted, sharply 4-5-angled; the lobes subulate, kecled. Corolla tubular, $4-5$-lobed, membranaceous at the balse, witheringpersistent; the lobes ereet, lanceolate-oblong, acute. Stamens 4-5, partly exserted, inserted on the middle of the tube of the corolla: anthers sayittate, introrse, opening lengthwise. Style conspicuous, erect, persistent: stigmas round-ovate, thick, at length sprealing, with the margins revolute. Capsule oblong, obtuse, l-celled, the margins of the valves slightly inflexed. Placenta spongy, sutural. Secds minute, globose, sessile. - Herbs, with oblong glaucons elasping leaves, and panicled showy purple or blue flowers.

1. E. exaltatum, Griseh. Stem $\left(2^{\circ}-3^{\circ}\right.$ high $)$ terete, glaucous, paniculately forking above; leaves mucronate, deeurrent at the base, the upper ones lanceolate; flowers long-peduncled, terminating the branches, blue; ealyx-lobes as long as the tube of the corolla, dilated and membranaceous at the base. South Florila. (1) - Corolla 12" $-15^{\prime \prime}$ long.

\section{GENTIANA, Toum. Gextix.}

Calyx 4-5-parted. Corolla bell-slaped or funnel-shaped, 4-5-lobed, often with plaited toothed appendages between the lobes. Stamens $4-5$. Stigmas 2, sessile, compressed, persistent. Capsule 1-celled, 2-valved, many-sceder; the seeds sutural, or covering the inner fice of the valves. - Flowers showy, solitary or elustered, axillary and terminal.

* Annual: corolla fumel-shuped, destitute of appendages: anthers versatile: capsule sessile: seeds wingless.

1. G. quinqueflora, Lam. Stem 4-angled, slender, branching; leaves orate or ovate-lanceolate, acute, cordate and slightly clasping at the base, 3-5-nerved; flowers $3-5$, temminating the short branches; corolla blne, rather slender, naked in the throat; with ovate bristle-pointer entire lobes, mueh longer than the subulate calyx-lobes. - Dry soil along the monntains, Georgia, and northward. Ang. and Sept. - Stem $1^{\circ}-2^{\circ}$ light. Leaves $1^{\prime}$ long. Corolla $l^{\prime}$ long.

2. G. crinita, Frel. Stem terete below, the upper portion and branches 4-angled; leaves lancelate, acute, closely sessile, the lowest narrowed into a petiole; flowers terminal, on long angnlar peduncles; calyx-lobes 4, ovatelanceolate, acute, strongly keeled, as long as the tule of the corolla; lobes of the corolla 4, rounded, fimbriate, nearly as long as the tube; sceds sealy.Damp soil along the montains, Georgia, and northward. Oct. and Nov. Stem $1^{\circ}-2^{\circ}$ high, often much branched. Leares $1^{\prime}-2^{\prime}$ long. Corolla blue, $1 \frac{1}{2}^{\prime}-2^{\prime}$ long.

* * Perennial : corolla bell-shaped, with plaited inn'led appendages hetwern the lobes: anthers erect, mostly connizent: capsule pedecelled: secels commonly winged.

3. G. ochroleuca, Frol. Stem low, smoothish; leaves oblong or obovate-oblong, narrowed at the base, the npper ones narrower and ateute; flowers in a dense mostly terminal eluster ; corolla open, yellowish-white, $\frac{1}{2}-\frac{1}{3}$ longer 
than the erect linenr-lanecolate calyx-foles; the ovate lobes twice as long as

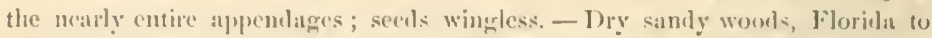
Nortl Carolina. Sept. and Oet. - Stcm $6^{\prime}-12^{\prime}$ high. Corolla $12^{\prime}$ long, striped within with green and purple veins. Anthers sepmate.

4. G. Elliottii. Stem rough and slightly pubescent ; leaves lanceolate or lincar-lanecolate, rough-margined; clusters axillary and terminal; calyx-lubes linear-laneeolate, twice as long as the tule; corollat large, open, bright-l,ue, lined within with yellow and fleeper bluc, the erect or spreading ovate acute lobes twiee at long as the 2-cleft fimbriate nppendages; seeds lanceolate, narrowly winged, covering the entire inner face of the valves. (G. Catesber, E:ll.) - Bamks of streams and ditches, in the luwer amb mildle districts. Oct. - Stem $1^{\circ}-1 \frac{10}{2}$ high. Curolla $1 \frac{1}{2}^{\prime}$ long. Flowers rarely solitary.

Var. parvifolia. Stem tall ( $2^{\circ}$ high), slender; l(aves short ( $2_{2}^{\prime}-1^{\prime}$ long), sessile, ovate or oblongrovate, ronnded or cordate at the base, rigid; ; "alyx-lubes erect, lanceolate, twice as long as the tube; appendinges of the corolla broak, unequally 2-cleft, fimbriate. - l'inc-baren swamps near the coast, Georgia and Florili:. - Corolla $2^{\prime}$ long.

Var. ? latifolia. Stem low $\left(6^{\prime}-12^{\prime}\right.$ high $)$, rigrid ; leaves $\left(2^{\prime}-3^{\prime}\right.$ long $)$ memhranaccons, oblong or ovate-oblong, acute at each cod; calyx-lobes linear, shorter than the tube, spreading; appendages of the corolla equally divided into two slender bristle-pointed nearly entire lolx.s. - River-banks, Middle Florida. Curolla $1^{\prime}-1 \frac{1}{2}^{\prime}$ loug.

5. G. Saponaria, I. Stem smooth; leaves ovate-lanceolate or oblong, narrowed at the lase, rongh-margined ; ealyx-lobes linear or spatulate, acute, half as long as the corolla; corolla light blue; the lobes short and broad, obtuse, ereet, or converging, longer than the 2-eleft minutely-toothed appendiges; seeds acute, narrowly winged, covering the valves. (G. Catesbei, Wult)-Moist woods on the mesuntains of North Carolina, and northward. Sept. and Oct. Flowers ilustered.

6. G. Andrewsii, Griseb. Stem smooth $\left(1^{\circ}-2^{\circ}\right.$ high $)$; leaves oratelanceolate, acute, narrowed at the base; flowers elustered, axillary and terminal; calyx-Jobes uvite, spreading, shorter than the tube; corolla (1'long) elul)-shaped, inflated, elosed ; the broal and rounded lobes shorter than the slightitly toothed appendatges; ('ajsuste at length part) y exserted; seerls broally winged. (G. Saponaria, Frol.) - Mountains of North Carolina, and northward. Sept. and Oct.

7. G. angustifolia, Michx. Stem low, smooth, 1-flowered; leaves linear, fleshy; calyx-lolses linear, erect, half as long as the corolla ; corolla large, bright blue, the lobes orate, twiee as long as the broad toothed appendages. - Varies with the corolla, green withont and white within. - Low pine barrens, Florida to Nortl Carolina. Nov, and 1)ee. - Stem $4^{\prime}-10^{\prime}$ ligh. Corolla $2^{\prime}$ long.

\section{BARTONIA, Mul].}

Calyx 4-parted. Corolla 4-parted. Stamens 4: anthers small. Stigmas sessile. Cansule 1-celled, 2-valved, septicidal. Seeds covering the inner surface 
of the valves. - Small annual herbs, with erect filiform stems, scale-like sululate leaves, and white flowers.

1. B. verna, Muhl. Stem $\left(2^{\prime}-6^{\prime}\right.$ high) simple or sparingly branched, succulent, few-flowered; calyx-lobes lanceolate-subulate, one third as long as the oblong or obovate obtuse spreading white lobes of the corolla ; anthers oblong; capsule roundish. (Centaurella verna, Michx.) - Dimp pine barrens near the coast, Florida to North Carolina. Feb. - April.

2. B. tenella, Muhl. Stem $\left(6^{\prime}-12^{\prime}\right.$ high $)$ braucher ; the branches, like the leaves, opposite or alteruate, many-flowered; calyx-lobes subulate, as long as the tube of the greenish-white corolla; lobes of the corolla erect, acute; anthers globose ; capsule oblong-lanceolate. (Centaurella janiculata, Michx.) Swamps, Florida to Mississipyi, and northward. Sept. and Oct. - Flowers much smaller than in No. 1.

\section{OBOLARIA, L.}

Calyx of 2 spatulate liact-like sepals. Corolla bell-shaped, 4-cleft, imbricated in the bud. Stamens 4: anthers round-cordate. Style short: stigma 2-lipped. Capsule ovoil, 1-celled. Seeds numerous, covering the valves. - A low sparingly branched perennial herb, with opposite wedge-obovate leaves, and single or clustered axillary and terminal purplish flowers.

1. O. Virginica, L. - Rich shady woods, South Carolina, and northward. March and April. - Plant smooth, purplish, $3^{\prime}-8^{\prime}$ high. Branches generally 3-flowered.

\section{Frasera, Walt. Auerican Columeo.}

Calyx 4-parted. Corolla wheel-shaped, 4-parted, the lobes each with a depressed fringed gland on the upper face. Stamens 4 : anthers nodding. Style persistent : stimmas spreading. Capsule compressed. Seeds few, large, winged, borne on the margins of the valves. - Tall and smooth perennial herbs, with whorled or opposite sessile leaves and branches, and cymes of greenish-yellow flowers, disposed in a large terminal paniele.

1. F. Carolinensis, Wait. Stem $\left(3^{\circ}-8^{\circ}\right.$ high $)$ erect ; leaves and branches mostly four in a whorl, lance-oblong, the lowest spatulate; panicle nyramidal; corolla-lobes oblong, mueronate, dotted with purple. - Rich soil in the upper districts of Georgia, and nortliward. July. - Lowest leaves $1^{\circ}$ long. Corolla I' wide. Root large and bitter to the taste.

\section{LIMNANTHEMUM, Ginel.}

Calyx 5-parted. Corolla wheel-shaped, 5-parted, the lobes infolded in the bud, ciliate, and glandular-crested at the base. Stamens 5. Style short or none: stigma 2-fobed, persistent. Capsule 1-celled, opening irregularly. Seeds few or many. Testa woody. - Perennial aquatic herbs, with floating circular or cordate spongy leaves, and white peduncled Howers clustered near the summit of the long petiole. 
1. L. lacunosum, firiscl. Icaves $\left(1^{\prime}-2^{\prime}\right.$ wisle) rorlate, entire, smooth;

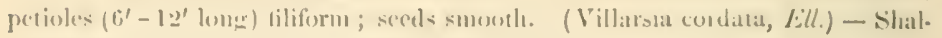
low ponds, Jlorida, amd northward. June and July.

2. L. trachyspermum, (iray. Leaves $\left(3^{\prime}-5^{\prime}\right.$ wilc) circular, crenate,

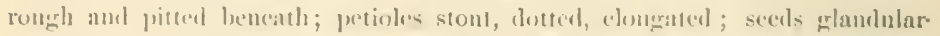
ronglenet. (Villarsia tratelyesema, fill.) - l'onls in deep water, Florida to North Carolinit, and westward. $\Lambda_{\text {pril-June. }}$

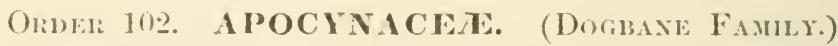

II rebs or shruls, with acriel milky juice, mostly opposite entie exstipulate leaves, aud regular cymose or panicled flowers.s. Calyx frees, 5-parted,

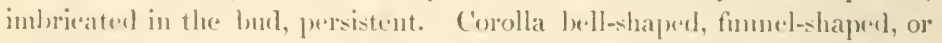
salver-form, s-lobed, convolnte in the buel. Stamens 5, distinet, inserterl on the tube of the corolla: anthers mostly sagittate, erect, introrse. Pollen granular. Ovaries 2, distinct, tleeir styles unitul. Fruit few-manyseceded. Seeds anatropous or amphitropous. maked, or bearing a tuft of down at the apex (comost). Embryo straight in searce albumen.

\section{Synopmis.}

* Fruit a many-sceded follicle.

- Seeds comose. Leares opposite.

1. APOCYXUM. Corolla bell-shaped, with seale-like appendages at the base of the lobes. Jlerbs.

2. FORSTERoxiA. Corolla funnel-shaped. Stamens inserted at the base of the corolla. Twining slirubs.

3. ECIIITES. Corolla funnel- or salver-shaped. Stamens inserted above the base of the corolla.

+ + Sueds nakeu. Leares opjosite or alternate.

4. A.rsoxiA. Corolla funnel-shapeil. Flowers pauicled. Leaves alternate.

5. VINCA. Corolla salver-shaped. Flowers axillary. Leares opposite.

* Fruit a few-seeded drupe.

6. VAlLSIA. Corolla salver-shaped. Leuves alteruate. Flowers in cymes.

\section{APOCYNUM, Tourn. Ixmay IIEmp.}

Calyx 5-parted. Corolla leell-shaped, 5-lohed, with seale-like appendages at the base of the lubes. Stamens inserted on the base of the corolla: anthers sagritate. Stigma sessile, 2-lohed. Follicles long and slemer. Seeds mumerous, oberoid, comose. - Perennial ereet branching herbs, with opposite oval or ollong mneronate petioled leaves, and small white flowers in lateral and terminat cymes.

1. A. cannabinum, I. Stem smonth, with erect branches; leaves oval or ohlong, mucronate, pubesecnt beneath ; (ymes terninal, elose-flowered, shorter than the leaves; ealyx-lobes lanceolate, as long as the tube of the greenish-white corolla; lobes of the corolla creet. (A. pubeseens, Ri. Br.) - Var. glablrk- 
yu 3. Smooth throughont; leaves narrower, often acute at each end. -- Dry or damp soil, Florida, and northward. July and Aug. - Sten $2^{\circ}-3^{\circ}$ high. Leaves $2^{\prime}-3^{\prime}$ long. Corolla $2^{\prime \prime}$ long.

2. A. androsæmifolium, L. Stem smooth, with spreading branches; leaves oval or orate, smooth, or pubescent beneath ; cymes axillary and terminal, long-peduncied, commonly exeeding the leaves, loose-flowered; calyx-lobes ovate, shorter than the tube of the white or pale rose-colored corolla; lohes of the corolla spreading or revolnte. - Rich soil, North Carolina, and northward. June and July. - Stem $2^{\prime}-3^{\prime}$ high. Corolla twiee as large as in No. 1.

\section{FORSTERONIA, Meyer.}

Calyx 5-parted, mostly glandular at the base within. Corolla funnel-shaped, 5-cleft, without appendages. Filaments slender, inserted on the base of the corolla : anthers lincar-sagittate. Nectary of 5 distinct or partly united thickish glands. Stigma simple or 2-lobed, 5-angled. Follicle slender. Seeds lincaroblong, comose. - Twining shrubs, with opposite petioled leares, and small flowers in lateral and terminal eymes.

1. F. difformis, A. DC. Leares ovate-lanecolate, lanceolate or linear, acuminate, narrowed into a petiole, smooth, or, like the branchlets, pubescent when young; cymes spreading, as long as the leaves; flowers greenish. (Echites difformis, Wralt.) - River-banks, Florida to North Carolina. May-Aug. Stem twining, $10^{\circ}-15^{\circ}$ high. Leaves $2^{\prime}-3^{\prime}$ long. Corolla $4^{\prime \prime}$ long. Follicles $6^{\prime}-9^{\prime}$ long.

\section{ECHITES, P. BrowNe.}

Calyx 5-parted, with $3-5$ glands at the base within. Corolla salver- or funnel-shaped, 5-lobed; the tube mostly elongated, and dilated above the insertion of the stamens. Filaments very short: anthers sacgittate, bearing the pollen, and adhering to the stigma in the middle. Nectary of 5 distinct or partly united glands. Style simple: stigma thick, with a spreading membranous appendage at the base. Follicles long and slender. Seeds linear-oblong, comose or plumose. - Erect or twining slurubs, with opposite leaves, and cymose axillary and terminal mostly fragrant flowers.

1. E. umbellata, Jacq. Smooth; stem twining; leaves distant, oval, mueronate, slightly cordate, short-petioled, parellel-veined; peduncles shorter than the leaves, $3-7$-flowered; calyx-lobes ovate, acuminate; corolla salverform, the cylindrical tube $\left(2^{\prime}\right.$ long) slightly dilated above the insertion of the stamens, four times as long as the rounded spreading lobes, pubescent within ; anthers awnless ; stamens inserted near the middle of the tube. - South Florida. - Leaves $1 \frac{1}{2}{ }^{\prime}-2^{\prime}$ long, recurved and folded. Flowers white?

2. E. Andrewsii. Smooth; stem low, erect or twining; leaves approximate, oval or oblong, mucronate, acute or rounded at the base, the margins revolvte; peduneles axillary, 3-5-flowered, shorter than the leaves; calyxlobes lanceolate-subulate; tube of the corolla much dilated above the insertion 
of the stamens, lell]-shaperl, scaredy longer than the ovate sprealing lobes; muthers taperiug into a long bristle-like awn; glamb of the nectary 5 , roumberl, as loner as the ovaries. (E. sulcereta, Audr. Neriandra suberecta, A. $I / C$.) Simly shores, South Florilit. - Stem $1^{\circ}-20$ high. Leares $1 \frac{1}{2}^{\prime}-2^{\prime}$ long. 'Tulo of the corollat l' long, $\frac{1}{2}$ wirle.

\section{AMSONIA, Walt.}

Calyx small, 5-parted. Corolla funnel-fom, 5-lobed, bearded within. Stamens inserted ahove the middle of the tube: anthers oblong, obtuse. Stigma grlobose, surromded ly a ('up)-shaped memlnane. Foflicles slender. Sceds in a single row, terete, truncated at cach enrl, naked. - Erect lramching permuial lerbs, with altenate leaves, and small pale blue flowers in a terminal panicle.

1. A. Tabernæmontana, Walt. Stem smooth, branching alove; leaves ovate, ovate-limecolate, or lanc(o)ate, acute or acuminate at each encl, glancrous beneath, short-petioled; tulse of the corolla slemler; smooth, or woolly alove, many times longer than the ninnte ealyx; follieles spreadiner. (A. latifolia, Michx. A. salicifolia, Pursh.) - Swamps and wet banks, Florilin to Mississippi, and northward. May and June. - Stem $2^{\circ}$ high. Leaves $1^{\prime}-4^{\prime}$ loner, often slightuly pubesent beneath. I'aniele open or contraeted. Follicles $4^{\prime}-6^{\prime}$ long.

2. A. ciliata, Walt. Stem hairy, at length much branched alove; leares very numcrous, lincar or linear-lanceolate, acute at each eml, fringed on the margins; corolla smooth. - Dry sandy soil, Florida to North Carolina. A pril and Naty. - Stem at length $2^{\circ}-3^{\circ}$ high. Leaves $1^{\prime}-2^{\prime}$ long. Corolli palo bhe or white. Follieles more slender than those of the preceding.

\section{VINCA, L. Peirixizle.}

Calyx 5-parted. Corolla salver-form, 5-lobed, thickened or angnlar at the throat, the narrow tube hairy within. Anthers oblong, longer than the filaments. Glands 2, altemating with the ovarics. Style slender: stigma thick, with an inverted eup-shaped membrane at the base. Follicles 2, lincar, erect. Seceds ollong, rough, naked. - Herhs or sluruby plants, with epposite short-petioled leares, and axillary mostly solitury showy flowers.

1. V. rosea, L. Shrubhy, pulseseent; stem ereet, branching; leaves oblong, rounded at the apex, inueronate; flowers solitary or by pairs, nearly sessile; lobes of the corolla white or pale rose-color, obliquely ohovate, mucronate, shorter than the downy tube; a row of laiirs at the throat and another on the tubs below. - South Florida, and in the streets of Apatachicola, probably introduced. Flowering through the summer.

\section{VALLESIA, Ruiz and Pavon.}

Calyx 5-parted. Corolla salver-shaped, 5 lobed. Stamens inserted on the throat of the corolla: anthers cordate-ovate, longer than the slender filaments. Nectary noue. Ovaries 4-ovuled. Stigma club-shaped. Drupe mostly solitary, 
oboroill, 1 -2-seeded. Seeds naked, club-shaped, furrowerl. Radicle thick, inferior. - Shrubs. Leaves alternate. Cymes long-peduncled, opposite the leaves.

1. V. chiococcoides, Funth. Smooth; leares laneeolate-oblong, acute at ench end, short-petioled; eymes forking, spreading, as long as the leaves, many-flowered; lobes of the eorolla linear, shorter than the tube, hairy within; style slender; stigma 2-lobed, globose below the apex. - South Florida. Leaves $1 \frac{1}{2} \prime-2^{\prime}$ long. Corolla $3^{\prime \prime}$ long. Drupe $4^{\prime \prime}$ long, 1-seeded.

\section{Order 103. ASCLEPIAdAEA. (Milkweed Fauml.)}

Erect or twining herbs or shrnbs, with milky juice, entire commonly opposite leaves without stipules, and umbellate or cymose flowers. - Calyx 5-parted, persistent. Corolla 5-parted, mostly valvate in the bud, hypogynous, deciduous. Stamens 5, inserted on the base of the corolla, the filaments united in a tube (gynostegium) which encloses the ovaries, and bears appendages of various forms, which are collectively termed the stamineal croun. Anthers erect, 2-4-eelled, expanding above into a thin membrane. Pollen united in flattened waxy pear-shaped masses, which are equal in number to the cells of the anthers, and fixed to the five angular processes of the stigma by a slender stalk, pendulous or horizontal. Styles 2, the thick and fleshy stigma common to both. Fruit a follicle. Seeds anatropous, imbricated on the thick and at length free placenta, and commonly bearing at the hilum a tuft of hairs (coma). Enbryo straight in thin albumen. Cotyledons leafy.

\section{Synopsis.}

Tribe I. A SCLEPIA DEAE. - Pollen-masses 10, fixed by pairs to the cleft proeesses of the flat or conieal sligma, pendulous.

* Stamineal erown single, 5 -leaved.

- Lobes of the corolla reflexed or spreading.

1. ASCLEPIAS. Leaves of the crown enclosing a horn-like appendage.

2. ACERA TES. Leaves of the erown without appendages.

++ Lobes of the corolla ereet.

3. PoDostifuid. Stigma long-pedicelled. Corolla smooth wary. Stem ereet.

4. MEIASTELMA. Stigma sessile or pedicelled. Corolla downy within. Stems twining.

* Stanineal crown single, 5-lobed.

5 SEUTERA. Stigua conical. Crown deeply 5-parted.

6. CYyocronul. Stigma flat. Crown crenately 5 lobed.

* * Stamineal crown double.

7. SARCostemis. Outer crown annular; the inner one 5-leaved.

Tribe II. GONOLOBEAE. - Pollen-masses 10, fixed by pairs at the augles of the depressed stigma, horizontal.

8. GONOLOBUS. Crown simple, annular. Stems twining. Leaves cordate. 


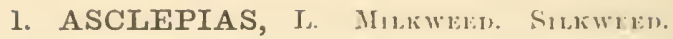

Calyx 5-parted. Corollis whech-shapued, depply 5-parted, reflexed. Crown composed of 5 hooded leaves, each containing an incurved hom-like appendage.

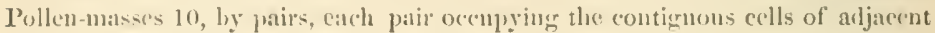
anthers, and suspented by a sender stalk from the projerting augles of the stigma. Follicle many-secded. Seeds olovate, flat, usually comose. - I'crennial lecrls, with mostly simple (not twining) stems, and opposite alternate or whorled leaves. Flowers in lateral (between the leaves) and terminal umbels.

\section{\$1. Stems herbacrous: seeds comose.}

* Follicles spiny: leuves opposite.

1. A. Cornuti, Decaisne. Softly pubescent; stem stout, ereet, obscurely 4-ancled ; leares oval-oblong, short-petioled, inneronate, soon smooth above, the lowest somewhat cordate; umbels numerous, many-flowerer, long-perluneled; corvllat greenish-purple, one fourth as long as the predicels; leaves of the crown pale purple, ovate, obmse, longer than the incurved horn; follicle ovate-obleng, woolly, armed with soft spines. (A. Syriaca, $\left.L_{\text {.. }}\right)$ - Fields and roal-sides, New Berne, North Carolina, Croom, and northward. June and July. - Stem $3^{\circ}-4^{\circ}$ high, sonetimes branclsed. Leaves $4^{\prime}-8^{\prime}$ long. Pedicels $1^{\prime}-1_{2 .}^{\prime}$ long, purplish. Corollat $\frac{1}{2}$ wide.

$$
\text { * Follicles spineless. }
$$

- Leaves opposite, oval or oblong, narrowed into a petiole.

2. A. phytolaccoides, Pursh. Stem tall, smooth; leuves ovate or orate-lanceolate, tapering at each end, paler and minutely pubesecnt beneath, mensbranaceous; umbels long-peduncled, many-flowered; pedicels filiform, drooping, nearly as long as the peduncle; corollat pale greenish; leaves of the cruwn white, truncated, 2-toothed, shorter than the subulate ineurved horn.Low grounds along the mountains, and northward. June and July. - Stem $3^{\circ}-$ 50 high. Leaves $6^{\prime}-9^{\prime}$ long. Pedicels $2^{\prime}-3^{\prime}$ long.

3. A. purpurascens, L. Stem smooth; leares ovate-oblong, arute, short-petioled, paler and pubescent beneath; umbels $1-2$, termin.l, peduncled, many-flowered; pedicels lialf as long as the peduncle, and twice as long as the dark purple corolla; leares of the crown oblong, abruptly contracted above, twice as long as the incurved horn and nearly sessile gynostegium. - Thickets and borders of woods, Tennessee, North Carolina, and northward. June and July, - Stem $2^{\circ}-3^{\circ}$ high. Lueaves $4^{\prime}-7^{\prime}$ long. Pulicels $g^{\prime \prime}-15^{\prime \prime}$ long, pubescent.

4. A. variegata, I. Stem stout, leafless below, pubescent in lines; leaves oval, oblong, or obovate, cuspidate, smooth on both sides; nmbels $3-5$, pubescent, closely flowered, the upper ones corymbose; pedicels erect, as long as the peduncle; corolla white; leaves of the crown roundish, longer than the purplish gynostegium, equalling the thick awl-pointed incurved horn. (A. niven, Pursh.) - Dry open woods and borders of fields, Florida to Mississippi, and northward. Mar and June - Stem $2^{\circ}-3^{\circ}$ high, purplish. Leaves 1'uther thick, $2^{\prime}-3^{\prime}$ long Peduncles $9^{\prime \prime}-12^{\prime \prime}$ long. 
5. A. incarnata, I., var. pulchra. Hairy; stem ereet, branching; leaves oblong or oblong-lanceolate, acute, nearly sessile; umbels numerous, somewhat corymbose, long-pednueled, often compound; pedicels erect, much shorter than the peduncle; corolla small, reddish-purple; leaves of the crown flesh-color, ovate, as long as the slender incurved horns, and twiee as long as the short-stalked gynostegium. ( $\Lambda$. pulchra, Willd.) - Swamps in the upper distriets, Georgia, and northward. June and July. - Stem $3^{\circ}-t^{\circ}$ high. Leaves $4^{\prime}-6^{\prime}$ long.

6. A. tomentosa, Ell. Pubescent or villous; stem stout, very leafy; leaves oblong or oblong-lanceolate, cuspidate, undulate, somewhat hoary bencatl, abruptly short-petioled; umbels $4-10$, alternate, nearly sessile, many-flowered ; pedicels three times as long as the large greenish corolla; leares of the crown obovate, truncated, shorter than the gynosteginm and the broad abmptly pointed erect horn. (A. aceratoides, $\boldsymbol{H}$. A. Curtis.) - Dry sandy pine barrens, Florida to North Carolina. June and July. - Stem $1^{\circ}-4^{\circ}$ high. Leaves $2^{\prime}-3^{\prime}$ long, thiek, on rather slender petioles. Pediecls $1^{\prime}$ long. Corolla $\frac{1^{\prime}}{2}$ wide. Follicles lanceolate, tomentose, $4^{\prime}-6^{\prime}$ long.

7. A. obovata, Ell. Tomentose; stem stout, rery leafy; leaves thick, oblong-oval or obovate, cuspidate, undulate; the midrib, like the short (2" long) petiole, very thick and prominent ; m mbels nearly sessile, closely $10-1$ t-flowered; the stout pedicels barely twice as long as the large ycllowish-green corolla; leaves of the crown purplish, twice as long as the gynostegium, and equalling the incurved horn; folliele tomentose. - Dry gravelly or sandy soil, Georgia, Florida, and westward. June and July. - Stem $1^{\circ}-2^{\circ}$ high. Leaves and flowers as large as those of the preceding.

$+\div$ Leares opposite, lanceolate or linear, narroved into a petiole.

8. A. cinerea, Walt. Stems ereet, slender, pubescent in lines; leares long, narrowly linear, distant, spreading; umbels $3-6$, commonly longer than the leaves, 5-7-flowered, the slender drooping pelicels longer than the peduncle; flowers small, purple withont, ash-color within; leaves of the crown obliquely truneated, 2-toothed at the inner angle, shorter than the gynostegium, longer than the thick horn; follicle smooth, linear. - Flat sandy pine barrens, Florida to South Carolina. June-Aug. - Stem $1^{\circ}-2^{\circ}$ high. Leaves $2^{\prime}-3^{\prime}$ long, $1^{\prime \prime}$ wide, somewhat glaucous; the uppermost often minute. Corolla $3^{\prime \prime}-4$ " wide. Follicle $3^{\prime}-4^{\prime}$ long.

9. A. viridula, n. sp. Stem slender, pubescent in lines; lcaves linear, erect; umbels shorter than the leaves, 6-12-flowered, the ereet or spreading pedicels as long as the peduncle; corolla small, yellowish-green; leaves of the crown oblong, spreading at the apex, rather longer than the erect subulate horn, and twice as long as the gynostegium ; follicle smooth, linear. - Pinc-barren swamps, West Florida. June and July. - Stem 10'-15' high. Leaves $2^{\prime}$ long. Corolla $3^{\prime \prime}$ wide. Follicle $3^{\prime}$ long.

10. A. paupercula, Michx. Stem smootl, tall; leaves elongated, linear or linear-lanceolate, acuminate, rough-margined, the upper ones small and remote; umbels 2-5, corymbose, 6-10-tlowered; pedicels pubescent, about as 
long as the peduncle; corolla deep red; leaves of the crown obloug, erent, bright orange, more than twice as long as the sululate incurved hom and the short-stalked gynostegium ; follicle lancelate, minutely pubeseent. - Marshes, Florida, and northworl. June and July. - Sten $2^{\circ}-4^{\circ}$ high. Leaves $6^{\prime}-12^{\prime}$ long. Corolla $3^{\prime \prime}-t^{\prime \prime}$ long.

11. A. Curassavica, I. Stem somewhat sluruhly, branching, slightly pulsesecent, leafy to the summit; leaves thin, lanceolate, acuminate, smooth; umbels corymbose, long-peduneled, 8-10-flowerel, pubescent; perlieels much shorter than the perluncle; corolla scarlet; leaves of the erown bright orange, olhong, erect, longer than the stalked gynostegium, shorter than the thick incurved horn; follicle ovate-lanceolate, velvety, - South Floriula. A pril-Nov. - Stem $1^{\circ}-2^{0}$ hight. Leaves $3^{\prime}-4^{\prime}$ long. Corolla $3^{\prime \prime}$ long.

+ + + Leaves opposite, oncte or oblong, more or less cordate, nearly sessile.

12. A. rubra, L. Smooth; stem simple, naked at the summit; leaves ovate or ovate-lanceolate, acmunate, rounded or slightly cordate at the base, very short-petioled; umbels $1-3$, terminal, sessile, few-flowerd ; lohes of the corolla lanceolate, acnte, reddish-purple; leaves of the crown oblong, acute, purplish, barely longer than the subulate ineurved horn, amb twiec as long ats the short-stalked gynostecriun ; follicle smooth. (A. laturifolia, Mickx.) - Wet pine barrens, Gcorgia, and northward. June -July. - Stem $2^{\circ}-4^{\circ}$ high. Leaves $2^{\prime}-4^{\prime}$ long.

13. A. obtusifolia, Michx. Smooth and somewhat glancons; stem ereet; leaves oblong, undulate, mucronate, cordate and partly clasping at the base; unbels $1-3$, lateral and terminal, long-peduncled, many-flowered; corolla errecnish-purple; leaves of the erown truncated and somewhat toothed at the apex, Jather longer than the gynosteginm, much shorter than the subulate incurved horn; follicle smootl. - Sandy soil, Florida, and northwarl. JuneJuly. - Stem $2^{\circ}-3^{\circ}$ high. Leares $2^{\prime}-3^{\prime}$ long, the midrib very broad. Corollnlobes $3^{\prime \prime}$ long. Pedicels pubesecnt.

14. A. amplexicaulis, Michx. Smooth and ghlaucons; stem declining, very leafy; leaves large, fleshy, ovate, obtuse, cordate and clitspiug at the base, veined witl white; nmbels $3-6$, lateral and terminal, many-Howerel, the smooth and slender pedicels shorter than the pedunele; corolla anh-eolor; leares of the crown oval, obtuse, white, longer than the gynostegium, and the nearly straight horn. - Dry sandy pine harrene, Florila to North Carolina. April and May. - Stems several, $1^{\circ}-2^{\circ}$ long. Leaves $4^{\prime}-5^{\prime}$ long, the midrib broad and prominent.

\section{+ + + + Eiper and lower leares moslly opposite, the middle ones whorled.}

15. A. quadrifolia, Jaeq. Somewhat pubescent; sten slender, simple; leares thin, ovate or ovate-lanceolate, acuminate, contracted into a petiole, pale beneath; umbels 2-5, inany-flowered, the slender peduncle longer than the pedicels; corolla pale-pink; leaves of the crown white, oblong, obtuse, twice as long as the gynostegium and stout horn. - Mountains of Carolina, and northward. June - Aug. - Stem $1^{\circ}-1 \frac{1}{2}$ high. I.caves $2^{\prime}-3^{\prime}$ long. 
16. A. verticillata, I. Stem slender, branching, pubescent; leaves narrowly linear, with the nurgins revolute, $4-5$ in a whorl; umbels several, small, the peduncle and pedicels nearly equal; corolla greenish; leaves of the crown white, romdish, haif as long as the slender incurved horn. - Open woods and fence-rows, Florida, and northward. July-Sept. - Stem $2^{\circ}-3^{\circ}$ high. leaves $1^{\prime}-2^{\prime}$ long. Follicle smooth.

$$
++++ \text { Leaves alternate, or the lowest opposite. }
$$

17. A. tuberosa, L. Hirsute; stem erect or declining, widely branched above, very leafy; leaves varying from linear to oblong, acute, short-jetioled; umbels numerous, corymbose; corolla yellowish-orange; leaves of the crown briglit orange, erect, oblong-lanceolate, twice as long as the gynostegium, and rather longer than the slender incurved horn. - Light dry soil, common. June and July. - Stem $1{ }^{\circ}-2^{\circ}$ long.

18. A. Michauxii, Decaisne. Pubescent ; stems several, short, prostrate; leaves linear, erect, the lower ones mostly opposite; nmbels $1-3$, terminal, sessile or peduncled; flowers gray and purple; leaves of the crown ovate, spreading, as long as the subulate horns, and longer than the gynostegium; follicle long, linear-lanceolate, tomentose. (A. longifolia, Ell., Michx. iu part.) - Low sandy pine barrens, Florida to Sonth Carolina. April-May. - Stems $6^{\prime}-12^{\prime}$ long. Leares $3^{\prime}-4^{\prime}$ long. Follicle $4^{\prime}-5^{\prime}$ long. Flowers fragrant.

\$2. Stem slirublyy: seeds mostly naled.

19. A. perennis, Walt. Stem branched, pubescent in lines, shrubby at the base; leaves thin, lanceolate or oblong-lanceolate, tapering at each end, paler beneath; umbels $5-\boldsymbol{i}$, long-peduncled, pubescent, the upper ones corymbose ; corolla small, white; leaves of the crown spreading, half as long as the needle-shapel, erect horn; follicle ovate-lanceolate, smooth. (A. parviflora, Pursh. A. debilis, Michx.) - Mruddy banks of rivers, Florida to Sonth Carolina. June-Aug. - Stem $1^{\circ}-2^{\circ}$ high. Leaves $2^{\prime}-4^{\prime}$ long.

\section{ACERATES, Ell.}

Leaves of the crown destitute of a horn-like appendage. Otherwise like Asclepias.

\section{* Leares opposite.}

1. A. viridiflora, EIl. Pubescent; stem stout, simple; leaves varying from oval or obovate to lanceolate, acute, obtuse, or emargiuate, undulate, shortpetioled; mmbels lateral and terminal, nearly sessile, densely many-flowered; flowers small, greenish; leaves of the erown oblong, erect, as long as the sessile gynostegium. - Dry sterile soil, Florida, and northward. June and July. Stem $1^{\circ}-1 \frac{1}{2} \circ$ ligh. Leaves $1 \frac{1}{2}^{\prime}-2 \frac{1}{2}^{\prime}$ long.

2. A. connivens, Decaisne. Stem stout, simple, pubescent ahove; reares nearly sessile, erect, mueronate, the lower ones approximate, oblong or oblongobovate, the upper more distant, smaller and lancolate; umbels 3-6, 6-9flowered, the stout peduncle and pedicels nearly equal, pubescent; flowers large, greenish; leares of the crown oblong, incurved, twice as long as the gynoste- 
gium, with their rounded summits connivent oree it - Wet pine barrens, Florilis and Georgia. Jume and July. - Stem $1^{\circ}-2^{\circ}$ high. Leaves $1^{\prime}-2^{\prime}$ long, some what fleshy, Corolla $8^{\prime \prime}-10^{\prime \prime}$ wisle.

\section{* Leaves allernate.}

3. A. paniculata, Decaisne. Closely pubesent; stem angular, often branching; leaves oblong or lanec-oblong, arute or obtuse at each curl, shortpetioled; umbels corymbose, often compoume ; corolla large, greenish, spread ing or nearly erect; leaves of the crown oblong, obtuse, ascending. shorter than the nearly sessile gynostegium. (Podostigna viridis, Ell.) - Dry pine barrens, Florida to South Carolinat. July. - Stem $1^{\circ}-1 \frac{1}{2}$ high, leafy to the summit. Leares $3^{\prime}-4^{\prime}$ long. Corolla 1 ' widle.

4. A. longifolia, Ell. Pubescent; stem terete; leaves linear and linearlanceolate, acute at each end, slightly petioled, rough-margined, the lowest commonly opposite, sometimes whorled; umbels pubeserit, slender-peduncled, many-flowered, alternate, opposite or whorled; flowers small, pale purple; corolla reflexed; leaves of the crown deep purple, oval, shorter than the gynostegium, and adnate to its stalk; folliele lanceolate, tomentose. (A. longifolia, Michx. in part.) - Low pine barrens, Florida, and northward. July. Stem $1^{\circ}-1 \frac{1}{2}^{\circ}$ high. Leaves $3^{\prime}-6^{\prime}$ long. Corolla $4^{\prime \prime}$ wide.

\section{PODOSTIGMA, Ell.}

Calyx 5-parted. Corolla 5-parted, with the lobes erect. Leaves of the crown destitute of a horn, ascending, incurved-beaked at the apex, mitcd with the base of the long and slender gynostegium. Stigma small, depressed. Sceds comose - A low pubescent simple-stemmed perennial herb, with opposite lanceolate sessile leaves, and few-flowered umbels on lateral peduncles.

1. P. pubescens, Ell. - Low pine barrens, Florida to North Carolina June-Oct. - Root tuberons. Stem $6^{\prime}-12^{\prime}$ high. Lcares erect, $1^{\prime}-2^{\prime}$ long. Umbels of 4-6 orange-colored flowers. Corolla $4^{\prime \prime}-5$ "long, as long as the pedicel, longer than the short peduncle, the oblong lobes wary on the margins Follicles linear-lanceolate, tomentose, $4^{\prime}-6^{\prime}$ long, many-secded. Seeds oval, winged.

\section{METASTELMA, R Brown.}

Calyx 5-parted. Corolla bell-shaped, the lohes mostly hoary-pubescent within Crown 5-leaved, inserted on the base or on the summit of the gynostegium. Stigma flat. Follicles slender, smooth. Secls comose. - Twning shrubs, with smooth leaves. Umbels few-flowered. Flowers small, white.

1. M. Schlectendalii, Decaisne. Branches pubesecnt; leaves oblong or obovate, cuspidate, rather acute at the basc, on slender petioles; peduncles 3-6-flowered, as long as the petiole, shorter than the pedicels; sepals obtuse, ciliate; lobes of the corolla ovate-lanceolate, incurved, densely pubescent within; leaves of the erown oblong, inserted on the summit of the slender gynostegium, as long as the stigma. - South Florida. - Leaves $\frac{1}{2}^{\prime}-1 \frac{1}{2}^{\prime}$ long, the margins rev olute. Corolla 2" long. Gynosteginm 5-winged at the base. 
2. M. parviflorum, R. Brown. Herbaceous? stem very slender, pubescent in lines; leaves smooth, linear-lanceolate, faleate, aeuminate, rounded at the base, short-petioled, drooping ; umbels sessile or short-peduncled, 4-6-flowered ; sepals smooth, acute; lobes of the corolla linear, incurved at the apex, very pubescent within ; leaves of the erown insertect on the base of the sessile gynustegium, linear, ereet, exceeding the stigma. - South Florida. - Leaves $6^{\prime \prime}-8^{\prime \prime}$ long. Corolla $\mathrm{l}^{\prime \prime}$ long.

3. M. Fraseri, Deeaisne. Branches slender, pubeseent in lines; leaves oral or round-orate, mucronate; umbels sessile; pedicels short, smooth; Jobes of the corolla ovate, acute, thickish, pubeseent on the margins; leares of the erown linear, as long as the corvlla, longer than the gynostegium. - In Carolina, Fraser. (*)

\section{SEUTERA, Reich.}

Calyx 5-parted Corolla somewhat wheel-shaped, 5-parted, with narrow acute smooth lobes. Crown sumple, deeply 5-parted. inserted on the base of the sessile gynostegium; the lobes ovate, flattened. Stigma conical, longer than the anthers. Follicles smooth. Seets comose - A slenter partly shrubly twining vine, with fleshy linear drooping leaves, and long-peduncled umbels of greenish flowers.

1. S. maritima, Decaisne. (Lyonia, Ell.) - Salt marshes, Florida to North Carolina. July and Ang. - Stem shrubby at the base; the branches twining around rushes and saline grasses. Leaves $2^{\prime}$ long. Peduncles eommonly longer than the leaves, many-flowered. Lobes of the corolla lanceolate, imbricated in the bud. Lobes of the erown obtuse, as long as the stigma.

\section{CYNOCTONUM, Meyer.}

Calyx 5-parted. Corolla wheel-shaped, 5-parted. Stamineal erown simple, enclosing the base of the sessile grnostegium, 5-lobed or 5-erenate. Anthers membranaceous at the apex. Stigma flattish. Follieles linear, spreading or reflexed. Seeds eomose - Perennial or shrubby twining plants. Leares mostly cordate. Umbels lateral.

1. C. ${ }^{2}$ scoparium. Stems much branched, pubescent in lines, shrubly at the base; leaves thin, linear, euspidate, tapering into a petiole, smoothish ; umbels nearly sessile, few-flowered, slıorter than the leaves; ealyx-lobes ovate, obtuse, pubescent like the pedicels; corolla smooth, the spreading lobes laneeolate, obtuse; crown erenately 5-lobed, shorter than the gynosteginm; follieles very slender, widely spreading; seeds linear, wingless. (Cynanchum scoparium, Nutt.) - Dry rich soil, near the coast, West Florida to Key West. - Leaves $\frac{1}{2}^{\prime}-\mathbf{1}^{\prime}$ long. Flowers green, less than a line long. Follicles $\mathbf{I}^{\prime}$ lung.

\section{SARCOSTEMMA, R. Brown.}

Calyx 5-parted. Corolla wheel-shaped, 5-parted. Crown donble; the exterior forming a ring at the base of the eorolla; the interior longer, 5-leaved Stigma pointed, notched. Follıcles slender, smooth. Seeds comose. - Ereet or 
twining slumbs. J, aves of en cordate. Jilowers yellow or whic, in lateral unilsels.

1. S. crassifolium, I)ecaisne. Stem smooth and wining; leaves nearly sessile, oblong, mucronate, romuled at the batse ; pedumeles stomt, 8-12-flowered, $2-3$ times as long as the leaves and pediecls ; lobes of the corolla ovate, obtuse, ejerealing; the outere surface, like the ealyx and pedicels, puleserent; leaves of the inner crown oval, rather exceenling the stigma and anthers. - Somb Florida. - Leaves somewhat fleshy, 9" 1 12" long. Corolla $3^{\prime \prime}$ wide. Ovary villous.

\section{GONOLOBUS, Michx.}

Calyx 5-parted, sprealing. Corollat wheel-slaped, 5-parted, the lobes spreading, twistel in the bud. Crown a way-lobed ring at the throat of the corolla. Gynostegium flattened, depressed. Antlers opening transersely. Pollen. masses lorizontal. Follicles inflated, angled, and often armed witls soft spines. Seeds comose. - Twining herbs, with olposite periolate cordafe leares, and yellowish or purplish flowers, in lateral corymbs or unbels.

1. G. macrophyllus, Michx. Ilairy; leares oblongovate, corlate, abruptly acuminate; nmbels peduncled, several-flowered; pedicels spreading, unequal, shorter than the petioles; corolla dull-purplish, conical in the hurl the lanecolate obense lobes more or less pubescent within, green at the apex; follicle strongly ribberl. - Low thickets, Florida, and northwarl. July and Aug. Leares $2^{\prime}-6^{\prime}$ long.

2. G. flavidulus, Chapm. IIirsute; leaves round-ovate, cordate, abruptly acute; umbels about as long as the petioles; corolla yellowish-green, orate in the bul, the ovate obtuse lobes pulsescent withont ; follicles armed with soft spines. - Light rieh soil, Florida, ant norkhward. - Leares $4^{\prime}-6^{\prime}$ long.

3. G. prostratus, Baldw. Stem dividing at the base into many divaricate branches, $6^{\prime}-12^{\prime}$ long, hairy; lower leares often reniform, the upper corlate, generally acute, all slightly hairy on both sides, and ciliate; mubels axillary, 3-floweresl; flowers small, jurplish; petals ovate, obtuse; follicles oval, smooth. - Sand-hills near the Altamalıa River, Georgia, Buldwen. (*)

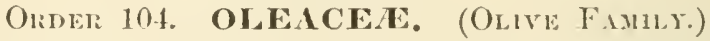

Trees or slıruls, with opposite entire or pinnate exstipulate leaves, and perfect polyeamons or dicecious flowers, - Calyx 4-toothed. Corolla 4-lobed or 4-jetalous, valvate in the bul, sometimes wanting. Stamens 2-7. Ovary 2-celled, with 2 suspended anatropous orules in earli cell. Style single or none. Fruit 1 -2-seeded. Embryo straight, in hard albument.

\section{Symopsis.}

Tribe I. OLEINEAE. Fruit a drupe or berry. Flowers with both calyx and corolla Leaves simple, entire

1. OLEA. Flowers polygamous. Corolla salver-shaped, with short lobes.

2. CHIONANTIIUS. Flowers perfect. Corolla wheel-shaped, with elongated lobes. 
Trlbe II. FRAXINEAE. Fruit a samara. Flowers dioecious, apetalous. Leaves pinnate.

3. FRAXINUS. Flowers in lateral and terminal panicles. Caly $x$ minute or rarely wanting. Trees.

TRIBE III. FORESTIEREA. Fruit a drupe. Flowers diocious or perfect, apetalous. Leaves simple.

t. FORESTIERA. Flowers mostly diacious, from scaly axillary buds. Shrubs.

\section{OLEA, Toum. Olive.}

Calyx 4-toothed. Corolla short-salver-form, 4-lobed. Stamens 2. Style short. Stigma globose or 2-lobed. Drupe mostly 1-seeded, oily. - Trees or shrubs, with opposite coriaccous entire leaves, and small white fragrant flowers, in axillary racemes or panieles.

1. O. Americana, L. Snooth; leaves oblong or obovate-oblong, narrowed into a petiole; racemes compound, shorter than the leaves; flowers polygamo-diøcions, bracted ; drupe ovoil, dark purple. - Light soil, near the coast, Florida to North Carolina. March and April. - A shrub or small tree, with whitish bark and evergreen leaves. Drupe as large as a pea, bitter and astringent.

\section{Chionanthus, L. Frixge-Tree.}

Calyx smalt, 4-eleft. Corolla wheel-shaped, 4-parted, with long and linear lobes. Stamens 2-4, included. Style very short: stigma notched. Drupe fleshy, I-seeded. - A shruh, with ohlong entire deciduous leaves, and delicate white flowers in slender axillary panicles, appearing with the leaves.

1. C. Virginica, L. - Light soil, Florida, and northward. April and Mar. - Shrub $6^{\circ}-10^{\circ}$ high. Leaves smooth or pubeseent, narrowed into a petiole. Panicles longer than the leaves, leafy-bracted. Flowers on slender drooping pediecls. Corolla-lobes linear, $1^{\prime}$ long. Drupe ovoid, purple.

\section{FRAXINUS, Tourn. Asir.}

Flowers dioecious and (in our species) apctalous. Calyx 4-lobed or toothed, minute, sometimes wanting. Stamens 2-4: filaments shorter than the large anthers. Stigma 2-eleft. Fruit (samara) dry, winged above, 1-2-seeded. Cotyledons elliptical. Radicle slender. - Trees. Leaves petioled, odd-pinnate, deciduous.

* Fruit naked and terete or barely margined and 2-edged at the base, winged above: leaflets $7-9$, stulked.

1. F. Americana, L. (Wntте Asu.) Branches and petioles smooth; leaflets ovate-oblong or lanceolate-oblong, aeuminate, entire, or slightly serrate above, smooth on the upper surface, pubescent or glaucous beneath; fruit terete, striate, dilated at the apex into a cuneate-linear or lanceolate obtuse or notched wing. (F. acumiuata and F. juglanlifolia, Lam ) - Swamps, Florida to Mis- 
siscipji, aul morthwarl. A pil. -1 large tree. Isatlets $2^{\prime}-4^{\prime}$ long. Fruit $1 \frac{11}{2}$ long.

2. F. pubescens, Lam. (RED Asu.) liranhlets and petioles velvetypulusent; leaflets oblong-ovate or ovate-lanecolatte, graclually acuminate, lright arreen aluve, pale and more or less pubeseent beneatl ; fruit acute at the base, llattisla and somewhat 2-edzed, gradually dilated mpwards into a long lanceolate and ofter noteled wing. (F. tomentosa, M/chx.) - Swamps, Floriela and northwarcl. March and $\Lambda$ pril. $-\Lambda$ small tree.

3. F. viridis, Míhx. (Grkex Asu.) Glabrous throughout; leaflets ovate or oblemer-oviate, more or less tootherl, smouth and green hoth siles; fruit as in No. 2, of which it may be a varicty. - Swamps, Florida to Mlississippi, and northward. March and $\Lambda$ pril. $-\Lambda$ small tree.

* * Fruit winged all round the sect-bearing portion: leaffets $5-9$, short-stallird.

4. F. quadrangulata, Michx. (Bule $\Lambda$ sir.) Branchlets square, smooth : leaflets oblongr-ovate or obloner, acmunate, sharply serrate, when youngr pubescent beneath; fruit linear-oblong, obtuse at both ends. - Temessee, and northward. May.

5. F. platycarpa, Miehx. (W.ıт:R Asu.) Branchlets terete, smooth or pulxescent; leathets ovate or elliptieal, serrate or almost cutire, often pubesrent bencath; fruit broadly winged, oblong-ohovate or oblong with a tapering and acute base, sometimes 3-winged. (F. triptera and F. panciflora, Nutt.) Deep river-swamp, Florida to Mississippi, and northward. Mareh and $A$ pril. $-\Lambda$ small tree.

\section{FORESTIERA, Poir. (A)ELA, Jichx.)}

Flowers diøeious or polygumous, from axillary sealy buds. Corolla none. Calyx minute, 4-lobed. Sterile flowers single or 3 together in the axils of imlnicated sealy braets. Stamens 3-7. Fertile flowers pedmueled. Styles slender. Stigma capitute. Orary 2-eelled. Inupe oroid, 1-secded, blaek or blue. Shrnbs. Leaves opposite, petioled, scrrulate. Flowers minute, greenish, prereding the leares.

1. F. porulosa, Poir. Leaves corinecons, smooth at matmity, nearly sessile, ovate-lancelate or oblong, obmse, entire, punctate underneatl, the margins entire and revolute; druje short-ovoil. - Coast of East Florida, Michanx, Leitner.

2. F. ligustrina, Poir. More or less pubeseent; the branchlets roughened with tine tubercles; leaves rather menbranaceus, obovate or obovateoblong, mostly ohtuse, serrulate ( $I^{\prime}$ long), contracted at the base into a distinet petiole; drupe oval-oblong. - Roeky banks, Florida, Georgia, and westward.

3. F. acuminata, Poir. Glabrous or slightly pubeseent when young; branchlets sonctimes spinescent; leaves membranaceons $\left(2^{\prime}-3^{\prime}\right.$ long), ovatelanecolate or orate and tapering-acuminate at hoth ends, sonewhat sermlate, slender-petioled ; drupe elongated-ol] ong, mostly pointed when young. - Wet grounds, Georgia to Tennessee, and northwestward. 


\section{DIVIsION III. APETALOUS EXOGENOUS PLANTS.}

Floral envelopes single, consisting of a calyx only, or altogetler wanting.

\section{Order 105. A RISTOLOCHIACE. (BIRTHWORT FAMILY.)}

Herbs or woorly vines, with alternate petioled mostly corlate and entire leaves, and solitary peduncled dull-colored flowers. - Calyx arlherent to the 6-celled ovary, tubular, valvate in the bud. Stamens 6-12, more or less united with the styles: anthers adnate, extmrse. Fruit 6-celled, few - many-seeded. Seed anatropous. Embryo minute, at the base of fleshy albumen.

\section{ASarum, Tomm. Asarabicca.}

Calyx regular, 3-lohed. Stamens 12 , the filaments partly nnited with the style, and nsually prolonged beyond the anthers. Capsule fleshy, globose, opening irregularly - Aromatic perennial herbs, with creeping stems, long-petioled cordate or kidney-shaped leaves, and axillary pelmoled flowers.

\$1. Asirux. - Caly.x bell-shaped, admate to the ovary, 3-parted: filaments free or nearly so: stigma 6-lobed. - Leaves deciduous.

1. A. Canadense, I. (Wild Grxger-root.) Pubeseent; leaves 2, kitney-shapel; calyx-lobes acuminate; filaments as long as the style. - Mountains of North Carolina, and northward. A pril and May. - Flowers short-peduncled, purple within.

\$2. IEterotrora - Calyx inflated, nearly fiee from the ovary, 3-cleft: filaments united with the ovary: styles 6 : stigmas 2-cleft. - Leaves evergrcen, smooth, mottled.

2. A. Virginicum, L. Leaves round-cordate; calyx inflated-bell-shaped, with romded lohes; stigmas deeply 2-cleft. - Rieh shady woods in the upper districts, Georgia, and northward. April and May- - Ieaves single or $2-3$ together, $2^{\prime}$ long. Flowers $8^{\prime \prime}-9^{\prime \prime}$ long, nearly sessile at the base of the petioles, greenish withont, dult purple within

3. A. arifolium, Miehx. Leaves oblong-cordate; calyx piteher-shaped, with ronnded lobes; stigmas slightly 2 -cleft. - Shady woods in the lower districts, Floricla to North Carolina. Mareh and April - Leaves $3^{\prime}-4^{\prime}$ long, amrienlite at the base, long-petioled. Calyx $1^{\prime}$ long, distinctly peluucled, contracted above the middle, dark purple within.

\section{ARISTOLOCHIA, Tonm. Birthwort.}

Calyx tubnlar, eommonly bent and inflated above the ovary. Anthers 6, sessile, adnate to the $3-6$-lobed or angled stigma. Capsule 6-valved. - Lirect or 
twinine loclis or shrnhs. I,eaves altcrnate, corilate at the base. Flowers longpeduncled, axillary, or near the base of the stem.

\section{* Low herbs.}

1. A. Serpentaria, L. Stems single or chistered, pulsescent, zigzag and leafy alone; leaves shore-pertioled, varying from ovate to hincar-lanceolute, cordate or latstate at the base; flower's mear the basce of the stem, on bracted spread-

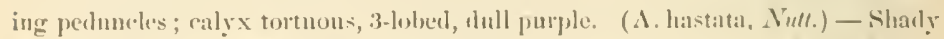

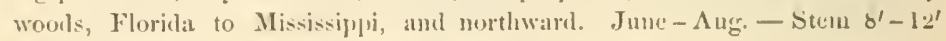
high. Leares $2^{\prime}-4^{\prime}$ long. Calyx shaped like the letter $S$.

* * IToody vines : capsule oblong, six-angled, $3^{\prime}-4^{\prime}$ long.

2. A. Sipho, L'Iler. Stem smootluish; leaves large, orlicular-eordate, slightly pubescent beneath; pedmeles slender, solitary, with a roundish clissping bract near the base; calyx curring upward, with the broal sprealing brownishpurple horder obscurely 3-lobed. - Rich woods along the monntains, Georgia, and northwarl. May, - Stem elimbing high. Leaves $66^{\prime}-12^{\prime}$ broad. Calyx shaped like a Dntch pipe, $1 \frac{1}{2}$ ' long.

3. A. tomentosa, Sins. IIoary-pubescent; leaves cordate; peduneles opposite the leaves, bractless, woolly; calyx bent in the midhlle, the greenish rugose unequally 3 -lobed border reflexed, thickened and dark brown at the nearly closed throat. - River-banks, Floridat, to the mountains of North Carolina, and westwarl. May. - Stem very long. Leaves $3^{\prime}-5^{\prime}$ long. Calyx similar in shape to the preceding, but smaller.

\section{Order 106. NYC'TAGINACEA. (Folróloock Famly.)}

Herbs or shruls witl tumid joints. Leaves mostly opposite, simple, petioled, withent stipules. - Calyx colored and resimbling a corolla, tubular-bell-shaped or funnel-shaped, free from the 1-celled and 1-oruled ovary, plaited in the lud, contracted in the middle, with the upper portion decidnons. Stamens 1 -several, hypogynous: antluers 2-celled, roundisl. Ornle crect. Style simple: stigma simple or branched. Achenium enclosed in the indurated, mostly ribled, often glandular hase of the calyx. Embryo eniled on filded around copious mealy albumen. Cotyledons leafy. Radicle inferior.

\section{Synopsis.}

* Fintrers surrounded by a ealyx-like involuere.

I. OxYBAPICS. Involucre open, membranaceous, 5 lobed. Jerbs.

* * Flowers without an involucre.

2. ROFRIIAATIA, Flowers perfect. Embryo eoiled Ilerbs.

3. PISONIA. Flowers dioecious. Embryo straight. Shrubs.

\section{OXYBAPHUS, Vahl.}

Flowers perfect, 1-5 in a cluster, surrounded by an open eup-shaped 5-lobed involuere. Calyx-tube very short; the bell-shaped limb 5-lobed, deciduous. 
Stamens 3, exserted. Style slender: stigma eapitate. Achenium enclosed in the indurated ribbed persistent base of the calyx. - Ereet herbs, from thick perennial roots. Leaves opposite. Flowers terminal, purple or rose-color.

1. O. angustifolius, Sweet. Stem smoothish, branching above; leaves linear-laneeolate, smooth, obtuse at the sessile base; the upper ones distint, acute; flowers loosely panicled; involuere with rounded hairy lobes, at length enlarged and strongly nerved, 3-flowered; base of the calyx villons. - South Carolina, and westward. - Stem $3^{\circ}-4^{\circ}$ high. Leaves $2^{\prime}$ long. Calyx $4^{\prime \prime}-5^{\prime \prime}$ long, whitish, veiny.

2. O. albidus, Sweet. Stem erect, 4-angled, furrowed, glanilular, pubescent; branches opposite; leaves oblong-laneeolate, rouglish; peduncles opposite, the lower ones solitury, the npper elustered; involuere lairy; base of the calyx 5-6-angled, almost hispid. (Allionia albida, Ell.) - Near Columbia, S. C., Elliott.

\section{BOERHAAVIA, L.}

Flowers perfeet. Involucre none. Calyx-tube eylindrieal or obconical, 5ribbed; the limb colored, funnel-shaped, 5-Iobed, deciduous. Stamens 1-4: anthers minute, roundish. Style slender: stigma obtuse. Embryo follerl. Annual herbs, with diffinse branching stems, and opposite ovate or rounded leaves. Flowers small, in solitary or panicled elusters.

1. B. erecta, L. Stems ascending, branclied from the base, smooth, turnid at the joints ; branches alternate; leaves ovate or romdish, acute or mueronate, of ten more or less cordate, wavy along the margins, whitened and minutely dotted with black beneath; elusters 3 -5-flowered, in ample panicles; stamens 2 ; fruit smooth, obconical, truncate, strongly ribhed. - Cultivated ground, Florida to Sonth Carolina. July-Sept. - Stem $1^{\circ}-3^{\circ}$ long. Leaves rather thick, $2^{\prime}-3^{\prime}$ long Flowers small, purple.

2. B. hirsuta, Willd. Stem diffise, alternately branched, minutely pubescent, hirsute above ; leaves ovate or oblong-ovate, mucronate, obtuse at the base, undulate, smooth, and similarly colored on both sides, eiliate on the margins; clusters 3 - 6 flowered, forming a loose spreading paniele; flowers minute ; calyxlimb hairy at the apex ; frnit obeonical, rounded at the apex, with the ribs glandular-viseid. - South Florida. - Stem stout, $2^{\circ}-3^{\circ}$ long. Leaves $1^{\prime}-2^{\prime}$ long.

3. B. viscosa, Lag Viseid or minutely pubeseent; stem terete, straight ; branehes opposite; leares ovate-oblong or ovate-laneeolate, mueronate, aeute at the base, smooth, whitish beneath, slender-petioled; peduncles solitary, axillary, 2-eleft, mostly shorter than the leaves; flowers capitate, minute; stamens 3 ; fruit elub-shaped, acutish, with the ribs glandular. - South Florida. - Stem $2^{\circ}-$ $3^{\circ}$ long. Leaves $1^{\prime}-1 \frac{1}{2}^{\prime}$ long.

\section{PISONIA, PJum.}

Flowers dincrions. Involucre none. Calyx 5- or 10-toothed, funnel-shaped in the sterile flowers, tubular and persistent in the fertile. Stamens $6-10$, exserted: 
anther-eclls distinct. Style inostly lateral : stigmn many-cleft. Fruit terete or

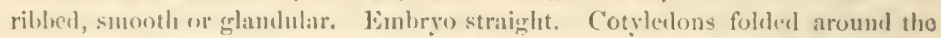
nlbumen. - 'Trees or shrubs, with opposite or alternate leaves, and mostly rosecolured fluwers in corymbose eymes.

1. P. aculeata, I. Spiny; stem smonth; hruncles willely spreading; leaves alternate, short-petioled, ovate or ellipticnl, acute or obtuse, smouth; cymes terminal, peduncled, pulsescent, many-flowered; ealyx of the sterile flower 10-toothed; stmmens 7 ; fruit elub-shaljed, 10-striate, and beset with 5 rows of shining viscid glanels. - South Jiloridat. - Shrub $5^{\circ}$ high; the spines short and recurverl. Leaves $l^{\prime}-2^{\prime}$ long.

2. P. obtusata, Swart\%. Smooth, spineless; leaves oblong, rounded at the apex, tapering at the base, short-petioled, revolute on the matrgins, rigid; cymes long-peduncled, many-flowered, the branches lorizontal; fertile culyx 5-cleft, with the lobes narrow and acute; stamens 7 ; fruit oblong, many furrowed, glandless; eapsule truncite. - South Floridit. - Leaves opluosite, 1'-2' long, light brown beneatli. Flowers $1^{\prime \prime}-2^{\prime \prime}$ long. Pigen cenc $x$, /3uf the

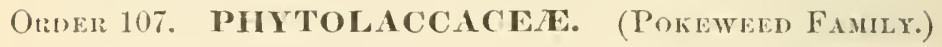

IIerbs or shrubs, with alternate entire leaves, anul apetalous 3-bracted racemed or spiked flowers. - Calyx composed of $4-5$ mearly enual sepals, more or less united at the base, unchanged in fruit. Stanens hyjogryous, as many ats the sepals and alternate with them, or nunerous, fiee, or united at the base; sterile ones nome: anthers 2-celled, introrse. Ovary simple or componnd. Ovules amphitropous or campylotropons, solitary, erect. Styles as many as the ovaries. Fruit of 1 -many earpels. Abumen copious or none. Embryo annular, rarely straight. Radicle inferior.

\section{Synopsis.}

Sumorder I. PETHERIEA. Fruit simple. Cotylerlons convolute. Leaves stipulate.

I. PETIVERIA. Fruit an achenium with refiexed sjines at the apex. Embryo straight iu seanty alliumen.

2. RIVINA. Fruit a berry. Embryo forming a ring around the albumen.

Sumorner: II. PHYTOLACCE.E. Fruit compound. Cotyledons flat. Leaves exstipulate.

3. PIIYTOLACCA. Fruit a berry, composed of numerous carpels arranged in a circle.

\section{PETIVERIA, T'lum.}

Calyx 3-bracted, 4-parted, herbaceous. Stamens 4-8: anthers linear. Ovary simple, l-celled. Ovule single, ereet, anphitropous. Stigma manyeleft. $\Lambda$ chenimn wedge-shaped, compressed, 2-lubed at the apex, each lobe 
armed with 2-3 reflexed spines. Allumen almo-t none. Embryo straight. Cotyledons unequal, convolute. - Shrubby tropical plants, with entire stıpulate leaves, and small greenish flowers in an elongated and slender spike.

1. P. alliacea, L. - Sonth Florida. - Sten $2^{\circ}-3^{\circ}$ high, closely pubescent. Leaves $3^{\prime}-4^{\prime}$ long, oblong or obovate, obtuse, narrowed into a short petiole, pubeseent beneath. Spikes filiform, single or by pairs, $6^{\prime}-12^{\prime}$ long. Calyx-lobes linear, incurred at the apex. Stamens 4-5. Achenia erect, appressed to the rachis, with two spines at each lobe. Stipules subulate, minute.

\section{RIVIIṼA, Plum.}

Calyx remotely 3-bracterl, 4-parted, colored. Stamens 4-8: anthers ovate or oblong. Ovary simple. Ovule solitary, amplitropons. Stigma capitate or many-cleft. Berry nearly globose, at length dry. Embryo forming a ring around the copious albumen. Cotyledons somewhat leafy, convolute. - Shrubs, with alternate minutely stipnlate petioled leaves, and small white or rose-colored flowers in axillary and terminal racemes. Bracts decidnous.

1 R. humilis, L. Closely pubescent; stem with spreading branches, leaves oblong-ovate, rounded at the base, tapering but obtuse at the summit, on long filiform petioles; racemes slender, longer than the leaves; calyx-lobes obovate, pale rose-color; berry rounded, compressed. - South Florida. - Shrub $1^{\circ}-2^{\circ}$ high. Leaves $1^{\prime}-3^{\prime}$ long. Flowers and berries $1^{\prime \prime}-1 \frac{1}{2}^{\prime \prime}$ long.

\section{PHYTOLACCA, Tomm. Pokewen.}

Calyx 3-braeted, 5-parted; the lobes petal-like, rounded. Stamens 5-2.5, the filaments subulate: anthers elliptical. Ovary compound. Styles 5-12, short, distinet, recurred at the apex, stigmatic within. Fruit a depressed globose berry, containing 5-12 one-seeded indehiscent carpels united in a circle. Embryo forming a ring around the central albumen. Cotyledons linear. - Ereet branehing herbs, with entire petioled leaves. Flowers in raccmes opposite the leares.

1. P. decandra, L. Smooth; stem very stout $\left(2^{\circ}-12^{\circ}\right.$ high $)$; leares ovate-lanceolate, acute; racemes many-flowered, as long as the leaves; flowers white, turning purplish; stamens, styles, and earpels 10. - Margins of ficlds and uncultivated ground, Florida, and northward. Ju'y-Sejt. 4-Root large. Berry black.

\section{Order 108. CHENOPOdACEA. (Goosefoot Famlt.)}

Unsightly herbs, with exstipulate leares, ineonspicuous flowers, and the character's mostly of the preceding family; but the green calyx often becoming succulent in fruit, 5 (rarely $1-2$ ) stamens opposite the sepals, a solitary ovary forming an achenium or utricle in fruit, two short and spreading styles, a horizontal or vertical lenticular seed, and the embryo forming a ring around the albumen, or spirally coiled with little or no albumen. 


\section{Syuopis.}

Trabe I. CYCLOLOIBT.:- Kmbryo curved like a ring around the albumen.

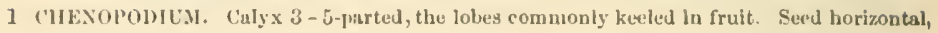
rarely vertical.

2. ATIIPLlix. Flowers monocious. Calyx of the sterile fiowers 5-parted, of the fertile llower nome. Ovary enclosed in a pair of separate at length coriaceous bracts. Radiele inferior.

3. OBLONE. Bracts of the fertile flower unifed. Radiele superior.

4. SAlICORIIA. Flowers 3 together, lodged in excavatious of the thiekened joints of tho leafless stem.

TRIBE 11. SPIROLOBEA. - Embryo spirally coiled, with little or vo albumen. Sced horizontal.

5. CIIExOPODINA. Calyx 5-parted, not keeled. Lenves terete, fleshy.

6. SALSOLA. Culy $x$ at length Iransversely winged. Leaves spiny.

\section{CHENOPODIUM, L. Pigwein. Goosfroot.}

Calyx 5- (rarely 3-4-) parted, lractless, the lohes mostly keeled. Stamens 5, the filaments filiform. Styles 2-3, distinct, or mited at the lase. Utricle depressed, enclosed in the glohose or 5-ingled eaiyx. Seed horizontal (rarely vertical), lenticular. Embryo forming a more or less perfect ring aromm the copious mealy albumen, - Glandular or powlery-coated herls, with altemate leaves, and clusters of small greenish flowers disposed in panicled spikes.

\section{* Annuals.}

1. C. Boscianum, Moq. Stem ercet, with angular hranches; leaves small, spreading, lanceolate-linear, very aeute, entire, or the lower ones somewhat toothell, more or less mealy and whitened beneath; spikes loose, leafy; seed acute on the margins, slightly roughened, shining, enclosed in the acuteangled calyx. - Carolina, Bosr. - Stem slender, $2^{\circ}$ high. Leaves $5^{\prime \prime}-12^{\prime \prime}$ long, on petioles $2^{\prime \prime}-3^{\prime \prime}$ long. Calyx-lobes elliptical-orate, acutish.

2. C. album, L. Stem erect, branched, slightly furrowed; leaves ascending, rhombic-ovate, acnte at the base, tootherl; the upper ones lanceolate and entire, more or less couted with a white powder; spikes panicled; the small clusters seattered or erowded, nearly leafless; seed enclosed in the 5-angled ealyx, acute on the margins, smooth and shining. - Varics (C viride, L.) with nearly entire and less mealy leaves, and the larger elnsters more senttered. Cultivated gronnds, Florida, and northward. July - Sept. - Stem $2^{\circ}-6^{\circ}$ high. Petioles long and slender.

3. C. murale, I. Stem ascending, branched; leaves long-petioled, oraterhombic, acute, unequally and sharply toothed, bright green on both sides; spikes slender, sprealing, corymbose, scarcely exceeding the leaves; secl not shining, acute on the margins, nearly enclosed in the slightly angled calyx. - Waste places, Florida, and northward. - Stem $6^{\prime}-18^{\prime}$ high.

4. C. Botrys, L. Stem erect, branched; leaves ohlong, somewhat pinnatiffl-lohed, with the lobes obtuse and glandular-pubescent, the upper ones minute; racemes numerous, axillary, spreading, cymose; secds with rounded 
margins, not wholly included in the open and even calyx. - Waste places, Columbia, South Carolina, Ellott, and northward. - Stem 6'-12' high.

\section{* * Perennial.}

5. C. Anthelminticum, L. (Wori-SeEd) Stem stout, erect, branching; leaves oblong or laneeolate, acnte at each end, sharply toothed; flowers in narrow panieles terminating the branches; seeds with obtuse margins, smooth and shining, included in the even calyx. - Waste grounds, Florida, and northward. - Stem $2^{\circ}-3^{\circ}$ high.

\section{ATRIPLEX, L. Oriche.}

Flowers monœcious or diœeious, either similar to those of Chenopodinm, or the fertile flower destitute of a calyx, and enclosed in two ovate or rhombie separate or partially united bracts. Sced vertieal, lentieular. Embryo forming a ring aronnd the copious mealy albumen. Radicle inferior. - Herls, commonly coated with seurfy or silvery seales. Leaves alternate or opposire, oftener hastate or angled. Flowers in dense spikes.

1. A. hastata, L Stem angled, diffusely branched ; leaves petioled, commouly nearly opposite, hastate or triangular, somewhat toothed, and, like the branches, nore or less seurfy; fruiting bracts triangular-ovate or rhomboidal, enture or toothed below, smooth or muricate within. (A. patula, Ell.) - Seashore, Sonth Carolina, Elliott, and northward. June-Sept. - Stems $1^{\circ}-2^{\circ}$ long

\section{OBIONE, Gærtn.}

Chiefly as Atriplex, both in character and habit; but the two indurated bracts more or less mnited, often toothed on the edges and erested on the sides, and the radicle superior

1 O. arenaria, Moquin Plant coated with silvery seales; stem branehing from the base, aseending; lowest leaves opposite, obovate, entire, tapering into a petiole, the others alternate, nearly sessile, lanceolate or oblong, aente, wary and slightly toothed; sterile flowers in elose terminal spikes; the fertile ones in axillary clusters; bracts 3 -toothed at the summit, and with two mostly toothed knobi at the sides. (Atriplex arenaria, Nutt.)-Drifting sands along the coast, Florida, and northward. July-Sept. (1)-Stem $1^{\circ}-2^{\circ}$ high. Leaves $I^{\prime}-1 \frac{1}{2}{ }^{\prime}$ long.

2 O. cristata, Moquin. Plant seurfy, green; stems diffusely branched; leaves oblong, mucronate, petioled, denticulate, green ahove, palcr beneath; braets roundish, acute, somewhat spiny-toothed on the margins, and with $2-4$ romolish knols at the sides. - Sandy shores, South Florida. - Stem $1^{\circ}-1 \frac{10}{2}$ high. Leaves $\frac{1}{2}^{\prime}-1^{\prime}$ long. Flowers elustered.

\section{SALICORNIA, Tourn. SAMPHIRE.}

Flowers perfeet, lodgred in exeavations of the thickened upper joints of the stem, spiked ; calyx thin, with a dentieulate border, at length spongy, and sur 
roumled at the apex by a cirrular wing. Sianens 1-2. Styles mited helow. Ltricle included in the calyx. Embryo coiled, or bent inte a ring. - Sinnoth and sucenkent saline plants, witls jointedl leafless stems. Fluwers three togethere the lateral one's sometimes sterile, minute.

1. S. herbacea, I. Anmial ; stem erect, much branclied; the joints thickencel upwarl, olotusely 2-toothed at the apex; spikes long, tapering to the summit. - Salt marshes along the const, Georgia, and northward. Aurgust. Stem 6 $6^{\prime}-12^{\prime}$ high.

2. S. ambigua, Michx. Stem surulhy, prostrate or ereeping; the loranches herbalecous, erect; joints truncate, dilated upward, slightly 2-tootbed ; spikes cylindricul, ohtuse, the uppermost approximate, sessile, the lateral ones perluncled. - Sandy marshes along the const, Florida, and northward. Aug. - Stem $2^{\circ}-3^{\circ}$ long, the branches $4^{\prime}-6^{\prime}$ high.

\section{CHENOPODINA, Moqnuin.}

Flowers perfect, bracted. Calyx 5-parted, fleshy, inflatel aud berry-like in fruit. Stamens 5. Stigmas 2-3, spreading. Itricle depresserl, enclosed in the calyx. Sced horizontal, lenticular. Embryo flat-spiral, dividling the scanty albumen into 2 portions. - Smooth saline plants, with flesby terete alternate leaves, and axillary clustered flowers.

1. C. maritima, Moquin. Annual; stem diffusely much brancherl ; leaves linear, acute; calyx-lobes obtuse, keeled; stamens exserted. - Low sandy pliness along the coast, Florida, and northward. Sept. - Stem $1^{\circ}-3^{\circ}$ high. Leaves $1^{\prime}-2^{\prime}$ long. Flowers ninute.

\section{SALSOLA, I. SAltwort.}

Flowers perfect, 2-bracted. Calyx 5-parted, the lobes at length transwersely winged. Stamens 5, slightly mitel at the base. Style slenter: stigmas 2. Utricle flattenerl at the apex, encloser in the persistent calyx. Fmbryo conicalspiral. Allumen none. - Saline plants, with alternate and fleshy leaves, and axillary flowers.

1. S. Kali, I. Smooth; stem spreading, ascending; leares subulate, spinepointed, like the ovate bracts; flowers solitary; calyx-lobes commivent, with the dilated, memliranaceons wing rose-colored. (S. Caroliniana, W'alt.) - Sandy shores, Georgia, and northward. Aug. (1) - Stem $1^{\circ}-1 \frac{10}{2}$ high.

\section{Ordir 109. A MARANTACEA. (AMaraxth Famig.)}

Chiefly herbs, with simple exstipulate leaves, and inconspicuous scarionsbracted flowers, which are commonly crowded in spikes or heads. - Sepals $3-5$, free, or united at the base, searious, imbricated in the bud. Stamens $3-5$, hyporynous, opposite the sepals, free, or uniterl below, often with 
sterile filaments interposed: anthers 1 - 2-celled, introrse. Ovary single, ovate, compressed, 1-many-ovuled. Stigmas 1-3. Utricle closed or circumscissile. Embryo eoiled into a ring around the central albunen.

\section{Synopsis.}

TribF. T. CELOSTEA. Anthers 2-eelled. Otary many-ovuled.

1. CELOSIA. Stamens united at the base. Utricle eircumscissile.

Tribe II. ACHTRANTHEA. Anthers 2-celled. Ovary 1-ovuled.-Leares alternate. Stamens free. Sterile filaments none.

* Itricle circumscissile.

2. AMARANTUS. Flowers monocious, Sepals $3-5$.

* Etricle indebiscent.

3. EUyOLUS. Flowers all alike, monocious, sessile. Sepals $3-5$.

4. AMBlogrNa. Flowers monøeious. Calyx of the staminate flower 3-sepalous, of the pistillate flower 5 -parted, funnel-shaped.

5. SCLEROPLS. Flowers monoeious. Sepals 5. Stamens 3. Fruiting pedicels judurated and deciduous with the fruit.

6 ACXIDA. Flowers diocious. Scpals of the staminate flower 5, of the pistillate none. Stamens 5 .

Tribe III. GOMPHRENEAE. Anthers 1-celled. Ovary 1-ovuled. Leaves opposite. Stamens united below.

7. IRESINE Calyx 5-sepalous. Stamens united into a short cup. Sterile filaments none.

8. ALTERNANTIIFRA. Calyx 5-sepalous. Stamens united into a cup. Sterile filaments minute, tooth-like.

9. TELANTIIERA. Calyx 5-sepalous. Stamens united into a tube. Sterile filaments cleft or fimbriate at the apex.

10. FRELICIIIA. Calyx 5-cleft. Stamens wholly united. Anthers sessile. Sterile filaments entire.

\section{CELOSIA, I.}

Flowers perfect, 3-bracted. Sepals 5. Stamens 5, united at the base into a cup. Sterile filaments none. Anthers 2-celled. Style short or elongaterl. Stigmas 2-3, reeurred. Utriele many-seeder, circumscissile. - Smooth herbs or shrubs, with alternate petioled leaves, and glossy flowers, crowded in axillary and terminal spikes or panicles.

1. C. paniculata, L. Stem shrubby, erect; leaves deltoirl-ovate, acute, abruptly petioled; spikes eylindrieal, simple or branched, mostly shorter than the leares; sepals oblong, rigid, several times longer than the hracts; stigmas 3 ; utricle many-seeded. - South Florida, Dr. Blodyett. Leaves 2 long. Secds niuute, lenticular, shining.

\section{AMARANTUS, Tourn. AMaraxtr.}

Flowers polygamo-monœcious, 3-bracted. Sepals 5 , rarely 3 , smooth, erect. Stamens 5 or 3, free. Sterile filaments none: anthers oblong, 2-eelled. Style none: stigmas $2-3$, slender, spreading. Utriele 1 -seeded, ovate, 2-3-toothed at the apex, circumscissile, commonly included in the calyx; periearp mostly membranaceous. Radicle inferior. - Unsightly annual herbs, with erect or dif- 
fuse stems, alternate mostly petioled entire mucronate leaves, and greeni-h or purplish flowers, erowded in axillary and terminal spikes or clusters. Bracts Jonger than the sejals.

* Flowers in small axillary rlusters: sepals and stamens 3.

1. A. albus, I. Stem erect, branching from the base, smooth; leaves small, long-petioled, oblong-obovate, very obtuse or emarginate, wary at the margins; clnsters shorter than the petioles; sepals awl-pointed, much shorter than the subulate spine-pointed spreading bracts, and half as long as the rugrose utricle. - Cultivated grounds, Florjda, and northward. May-Sept. - Stem $1{ }^{\circ}$ high. Leaves $\frac{1 \prime}{2}-1^{\prime}$ long.

* * Flowers (green) crowded in terminal and axillary spilies: sppals and stamens 5 : leaves long-jetioled.

2. A. chlorostachys, Willd. Stem erect, furrowed, pubescent; leares ovate or rhombic-ovate, obmse, or the npper ones acute, short-mucronate, the veins beneatl, like the petiole, pubescent; spikes very mumerons, formingr a long leafy and more or less dense panicle; sepals lanceolate, acute, scarecly half as long as the subulite bracts, shorter than the rugose utricle. - Cultirated gromols, common. Aug. and Sept. - Stem $2^{\circ}-4^{\circ}$ high. Leaves $2^{\prime}-4^{\prime}$ long, twice as long as the petiole.

3. A. hybridus, L. Smooth or ncarly so; stem creet, branching; leaves thin, ovate or ovate-oblong, obtuse, notched, or tapering at the apex, long. inucronate, the pale reins prominent beneath; spikes numerous, panicled, the terminal one elongated, the lower axillary ones short and roundish, sepals ob. long, acuninate, rather shorter than the subulate bracts, and equalling the slightly rugose unicle. - Cultivated gronnds, Florida, and northward. Aug. and Sept. - Stem $2^{\circ}-3^{\circ}$ high. Leaves $2^{\prime}-5^{\prime}$ long.

4. A. spinosus, L. Smooth; stem stout, suceulent, often purplish; leares ovate or ovate-oblong, obtusc or emarginate, long-petiolecl, often blotehed with purple, spiny in the axils; terminal spike elongatel, bending, the lower axillary ones short and roundish; sepals, bracts, and rugose utricle nearly equal. Ficlds and waste places, Florida, and northward. July-Oct. - Stem $1^{\circ}-3^{\circ}$ high.

\section{EUXOLUS, Raf.}

Charaeters chicfly of $A$ marantus; but the somewhat fleshy utricle indehiscent, and the (grcen) sepals longer than the bracts.

1. E. lividus, Moquin. Stem erect, branched, succulent, green, red, or purple; leaves long petioled, ovate, obtuse or notehed at the apex; spikes dense-flowered; the terminal one longest, acute, with severul shorter ones crowded near its base, the lowest axillary ones much shorter than the petiole; sepals 3 , shorter than the roundish acute rugose ntricle, and 3 tumes as long as the bracts. (Amarantus lividus, L.) - South Florida to South Carolina July-Sept. (1) - Stem $1^{\circ}-3^{\circ}$ high. I,eaves, with the petiole, $3^{\prime}-6^{\prime}$ long 
2. E. pumilus, Raf. Stem low, somewhat fleshy; leaves small, mostly crowded near the end of the branches, ovate, obtuse, short-petioled; flowers in small axillary clusters; sepals 5, half as long as the ovate obscurely 5-ribbed utricle. (Amarantus punilus, Nutt.) - Sandy sea-shore, South Caroliua, and northward Aug. and Sept.

\section{AMBLOGYNA, Raf.}

Flowers monnecinus. Staminate flowers 3-sepalous, triandrous. Pistillate flowers round-fumel-shaped, 5-eleft, with spreading spatnlate scarious lobes, enclosing the indehiscent utricle. Otherwise like Amarantus.

1. A. polygonoides, Raf. Stem slightly pubescent, slender, branching from the base; leaves small, rhombic-orate or ohovate, obtuse, notehed, tapering into a slender petiole; flowers erowded in axillary clusters, shorter than the petiole; bracts subulate; calyx of the pistillate flowers twice as long as the bracts, with a finely ribhed tube, and a sprealing white border; utricle orate, rugose above, 3-cleft at the apex. - South Florida. (1) - Stem $1^{\circ}-1 \frac{1}{2}^{\circ}$ long. Leaves $\frac{1^{\prime}}{2}-1^{\prime}$ long.

\section{SCLEROPUS, Schrad.}

Flowers monœcious, 3-bracted, trinndrous. Calyx 5-sepalous. Utricle indehiscent. Staminate flowers solitary, sessile in the upper axils. Pistillate flowers clustered in the lower axils, on flattened pedicels which become indurated, and fall aw:y with the mature fruit. Otherwise like Amarantus and Euxolus.

1. S. crassipes, Moquin. Smooth; stem erect, branching; leaves obovate, obtuve, notchel, tapering into a slender petiole; chusters shorter than the petiole; sepals much longer than the strongly keelerl bracts, spatulate, ohtuse, enclosing the granular-ronghened utricle. - South Florida. (1)-Stem $1^{\circ}-2^{\circ}$ high. Leaves $1^{\prime}$ long.

\section{ACNIDA, Mitchell.}

Flowers dicecions, 3-bracted. Calyx of the staminate flower 5-sepalous. of the pistillate flower none. Stamens 5 , free. Sterite filaments none: anther-cells united only in the middle. Stigmas 3-5, spreading, shorter than the 1-ovuled ovary. Utricle fleshy, 3-5-angled, indehiscent. Seed obovate. Rarlicle inferior. - A smooth marsh annual, with long lanceolate alternate entire leaves, and thin scarious white flowers in axilliry and terminal panicles.

1. A. australis, Gray. - Marshes and river-banks, Florida, and northward. Aug. and Sept. - Stem stout, branched, $2^{\circ}-8^{\circ}$ high. Leaves longpetioled, $3^{\prime}-6^{\prime}$ long, obtuse or acuminate. Spikes cylindrical, panicled. Sepals pointed. Bracts of the pistillate flowers subulate.

\section{IRESINE, Browne.}

Flowers perfect or diøcions, 3-bracted. Sepals 5. Stamens 5, united into a cup at the base. Sterile filaments none: anthers 1-celled, ovate. Style very 
short: stigmas 2-3, slender. ['tricle romdish, l-sceded, indehisecnt, included in the calyx. Seed vertical, lenticular. Ladicle ascending. - Chicfly lierbs, with opposite petioled leates, and scarious gloss flowers, disposed in single or panicled spikes or lieads.

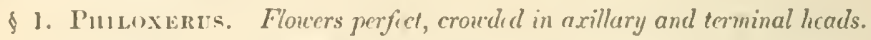

1. I. vermicularis, Moqnin. Smooth; stem much branclied, prostrate or ereeping; leaves club-shaped, fleshy, semi-terete; heads mostly sessile, ovate or globose, at length oblong or eylindrical, obtuse ; flowers white; sepals obtuse, longer than bracts, the two exterior ones woolly at the base. - Sandy sea-shores, South Florida. - Stems $1^{\circ}-2^{\circ}$ long. Leaves $\frac{1}{2}^{\prime}-1^{\prime}$ long. Heads $3^{\prime \prime}-8^{\prime \prime}$ long, mostly terminal and solitary.

\$2. Iresinastrim. Florrers dircious, disposed in loosely-panicled spities.

2. I. diffusa, II. \& B. Stem erect, somewhat 5-angled, smooth; leaves petioled, orate, acmuninate, slightly denticulate-ciliate on the margin, smooth; panicle narrowly pyramidal, much branched ; spikelets orate, obtuse, straw-color; sepals 3-nerved, smooth, acute, twice as long as the ovate bracts; rachis slightly pubescent. (I. celosioides, Ell.?) In Florida, Mhchaur. Saline marshes, South Carolina, Elliott. - Stem $2^{\circ}-3^{\circ}$ high. Leaves $1_{\frac{1}{2}}^{\prime}-2^{l}$ long, the upper ones lanceolate. Branches of the panicle alternate.

\section{ALTERNANTHERA, Mart.}

Flowers perfect or dixcious, 3-hracted. Sepals 5, smooth or villous. Stamens 5, united into a short cup at the hase. Sterile filaments minute, tooth-like: anthers 1-celled. Style short: stigma capitate or 2-lolsed. Utricle indehiscent, 1-seeded. Seed vertical, lenticular. Radicle ascending.-Herls. Leaves opposite.

* Floxers dierrious: licads or spilies loosely pamicled: stigma 2-lobed.

1. A. flavescens, Moquin. Stem erect, smooth, furrowed, simple or sparingly branched ; leaves ovate-lanceolate, acute or acuminate at each cut, ronghish with short seattered hairs, short-petioled; panicle oblong, the branches alternate, nearly leafless; spikes oblong, lengthening, straw-color; sepals of the staminate flowers oblong, acute, nerreless, smootl, twice as long as the ovate persistent bracts; those of the pistillate flowers ovate, 3-nerved nearly to the apex; the pedicels clothed with long white wool. - Margins of fields; Middle Florida. July - Sept. (1) - Stem $2^{\circ}-3^{\circ}$ ligh. Leaves $2^{\prime}-4^{\prime}$ long, the uppermost alternate and lanceolate. Panicle $8^{\prime}-12^{\prime}$ long. Sterile filaments toothlike, minute.

* * Flowers perfect: heads mostly axillary, solitary or clustered: stigma capitate: stems prostrate.

2. A. Achyrantha, R. B1: Stems forkıng, pubeseent; leares smoothish, oval or ohovate, narrowed into a petiole; heads dense, oval, white; sepals lanceolate, spine-pointed, woolly with harbed hairs on the back, the two inner ones much smaller; sterile filaments subulate from a dilated and obseurely denticulate 
hase, as long as the fertile ones. (Achyranthes repens, Ell.) - Along roads and places much trodden, Florida to South Carolina. June-Oct. 4-Stems 6'12 ' long. Leaves $l^{\prime}$ longr.

\section{TELANTHERA, R. Brown.}

Flowers perfect, 3-bracted. Sepals 5, erect. Stamens 5, united into a tube below the middle. Sterile filaments elongated, flattened, fimbriate at the apex: anthers l-celled, oblong. Style short: stigma capitate. Utricle indehiscent, 1 -seeded, included in the calyx. Seed vertical. Radicle ascending. - Herbs or shrubs, with opposite leaves. Flowers capitate.

* Culyx sessile, the 3 exterior sepals longer: heads sessile or nearly so.

1. T. polygonoides, Moquin. Stem erect or prostrate, pubescent; Ieaves oblong-obovate, hairy; heads sessile, roundish, single or $2-3$ together, axillary and terminal; sepals thin, ovate-lanceolate, twice as long as the bracts, the outer ones 3-nerved, woolly at the base; sterile filaments as long as the fertile ones, 3-4-cleft at the apex. - On the coast of South Carolina, Moquin.

2 T. maritima, Mocuin. Smooth and fleshy; stem prostrate, branching, angled; leaves wedre-ohovate, very ohtuse, mueronate; heads roundish or oblong, axillary and terminal, dull straw-color, rigid; flowers crowded, 3-angled; sepals smooth, rigid, ovate, acuminate, 5-ribbed, with the margins membranaceous, one third longer than the ovate keeled bracts; sterile filaments longer than the fertile ones, $4-6$-eleft at the apex. - South Florida. - Leaves $1^{\prime}-2^{\prime}$ long. Heads $4^{\prime \prime}-6^{\prime \prime}$ long.

* * Calyx raised on a short 5-angled pedicel; the sepals nearly equal, cylindrical, hairy: heads long-peduncled.

3. T. Floridana, n. sp. Shrubby; stem slender, elongated, forking, remotely jointed; the young branches and leaves roughened with appressed seattered hairs; leaves distant, fleslyy, oblong-lanceolate or obovate, aente or acuminate, tapering into a short petiole; peduncles terminal and in the forks, 4-6 times as long as the leaves; beals white, ovate; sepals Ianceolate-oblong, acute, $3-5$-nerved, lairy, $2-3$ times as long as the ovate acute bracts; sterile filaments longer than the fertile ones, 5 -6-cleft; utricle crowned with a narrow toothed margin. - South Florida, along the coast. - Stem $2^{\circ}-4^{\circ}$ long Leaves I' long.

4. T. Brasiliana, Moquin. Herhaceons, rough-hairy; the young leaves and branchlets hoary; stem erect, forking; leaves thin, orate-lanceolate, acuminate, tapering into a short petiole, longer than the internodes, rather shorter than the sleuder peduncles; lieads and flowers as in No. 3; utricle erowned with a narrow entire margin. - South Florida. - Stem apparently tall. Leaves $2^{\prime}-4^{\prime}$ long.

\section{FRGELCHIA, Monch.}

Flowers perfect, 3-bracted. Calyx tubular, 5-cleft, indurated and spiny-crested in fruit. Stanens 5, united into a long tube. Sterile filaments entire anthers 
sessile. Stigma capitate or many-rleft. Utricle indehisernt, l-scederl, included in the calyx. Secel rertical. Radicle ascendiug. - Woosly or hairy anmuals. Leaves opposite. Spites ofposite, and terminating the natked peduncle-like summit of the stem.

1. F. Floridana, Moquin. White-tomentose or woolly : stem ereet, simple or branched ; leaves varying from linear to ollong ; spities uvate or ublong, lengrthening with age; bracts mostly blackish, shorter than the wonlly calyx; style short; stigma capitate; fruiting calyx round-ovate, compressed, toothed aloug the margios, and mimtely tubereled at the base. (Oplotheca Floridana, Nutt.) - 1)ry sandy places, Georgia, Florila, amd westward. July-Sept. Stem $\frac{10}{2}-3^{\circ}$ high. Spikes solitary, few, or numerous.

\section{Ordir 110. POI ÍGONACEAs. (Beckwinat Fanmy.)}

Ilerbs, shrubs, or (tropical) trees, with simple mostly alternate and stipulate leaves, and perfect or diøecions llowers - Calyx 3-b-cleft, on 3-6-sepralous, persistent. Stanens $4-12$, inserted on the base of the ealyx : anthers 2-celleel. Ovary single, 1-reelled, with the solitary orthotropous ovnle erect from the hase of the eell. Styles $2-3$, distinct or partly united. Fruit (achenium) lenticular or 3-angled, rarely ovoisl. Fmbryo mostly on the outside of mealy albumen. Radicle pointing upward. - Stipules sheathing, annular, or wanting.

\section{synopsis.}

Suborner I. POLTGONE.E. Involuere none. Calyx 5-cleft or 5)-sepalous. Stamens 4-9 (mostly 5-8). Ovules sessile. Einbryo curved on the outside of the albumen, rarely straight in its centre. Stijules sheatling.

* Caly x 5-sepalous, the inner sepals erect, mostly enlarged in fruit.

1. IICMKX. Calyx green, often grain-bearing. Stigmas many-cleft.

2. POLYGoxella. Caly $\mathrm{x}$ corolla-like. Stigma entire.

* Caly $x 5$-sepalous, the sepals alt ereet, unchanged in fruit, free from the achenium.

3. POLYGoxuI Sepals entire. Embryo curred on the outside of the albumen.

4. TIISAXELLA. Inuer sepals fimbriate. Embryo straight at the side of the albumen.

* * Calyx 5-parted, the lube enlarged and fleshy in fruit: and partly uuited with the achenium.

5. COCCOLOBA. Achenium oroid or globose. Trees.

Suborder II BRLXNICIIFA. Involuere none. Calyx 5-parted, the tube enlarged and indurated in fruit. Stamens 8. Ovule borne on a slender stalk. Embryo at the margin of the allsumen. Stipules none.

6 BRUNNICIIA. Pedieels winged in fruit. Climbing surubs. 
Suborder III. ERIOGONEE. Flowers surrounded by an involucre. Calyx 6-parted. Stamens 9. Orule sessile. Embryo included in scarce albumen. Stipules none.

7. ERIOGONUM. Involucre 5-toothed. Woolly or silky herbs.

\section{RUMEX, L. Dock.}

Flowers perfect or dicecions. Calyx herbaceous, 6-parted, the 3 outer lobes spreading or recurved, the inner ones (valves) mostly enlarged in fiuit, and enclosing the 3-angled achenium, often bearing grain-like prominences on the outside. Stamens 6: anthers erect. Styles 3: stigmas many-cleft. Achenium 3-angled. Embryo curved on the outside of the albumen. - Herbs, witl alternate leaves, smooth truncated sheaths, and small green flowers in racemed or panicled clusters.

\section{* Flowers perfect or polygamous.}

- Valves entire.

1. R. crispus, L. Smooth; leaves lanceolate, wavy-crisped, acute at both ends, or the lowest truncate or slightly cordate at the base, and long petioled, the uppermost linear; panicle leafy at the base; whorls crowded in fruit; valves broadly cordate, obtuse, one or all grain-bearing. - Waste ground around dwellings, Florida, and northward. June and July. $\quad 4-$ Stem $2^{\circ}-3^{\circ}$ ligh. Lowest leaves $1^{\circ}$ long.

2. R. verticillatus, L. Smooth; lowest leaves oblong, obtuse or corlate at the base, flat, the others lanceolate, acute at each end ; panicle naked, looseflowered; pedieels slender, thickened upward, reflexed in fiuit; valves ovate, obtuse, rugose-veined, each bearing a large grain, which is half as wide as the valve. (R Britannicus, E/l) - Swamps and ditches, Florida, and northward. May and June $4-$ Stem $1^{\circ}-2^{\circ}$ high. Lowest leaves $1^{\circ}-1 \frac{1}{2}$ long.

3. R. Floridanus, Meisner. Smooth; stem stout, branching; leaves lanceolate, acute at each end; panicle naked, dense-flowered; pedicels about twice as loug as the valves, thickened upward, reflexed in fruit; valves deltoidovate, obtusely pointed, each bearing a narrow grain, which is much narrower than the reticulate valve. - 1)eep river-swamps, West and Sonth Florida. June. $4-$ Stem $2^{\circ}-3^{\circ}$ high. Leaves $\frac{1}{2}^{\circ}-1 \frac{1}{2}^{\circ}$ long.

4. R. sanguineus, L. Lowest leaves oblong, corlate, acute or obtuse, the upper lancelate, acute, obtuse or corlate at the base, wavy-margined ; panicle leafless; lower whorls distunt; pedicels very short; valves oblong, longer than the pedicel, one only prominently grain-learing. - Around Charleston, Elliott. New Berne, Croom. Introduced. June and July. $4-$ Stem $2^{\circ}-3^{\circ}$ high. Lowest leaves large, variegated with red veins.

$$
\text { +- + Valves toothed or bristly on the margins. }
$$

5. R. obtusifolius, L. Stem ronghish ; lowest leaves large, ovate-oblong, cordate, mostly obtuse, the midlle ones oblong, the upperinost linceolate, alcute at each end; panicle large, leafy below; lowest whorls scattered, the upper somewhat crowded; valves triangular-ovate, toothed near the base, nearly as 
long as the stenler recurved pediecels, one or all more or lexs prominently grain-

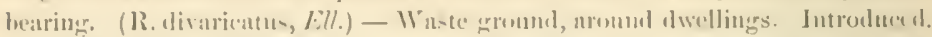
June - Ang. If - Stem $2^{\circ}-3^{\circ}$ high. I dowest leares $1^{\circ}-11^{\circ}$ long, $6^{\prime}-9^{\prime}$ wide, slirlitly crenate, and way on the matrins.

6. R. pulcher, L. Brauches rigirl, spreadinge; lowest leaves cordateobloner, somewhat fiddle-shajued, the npper lanceolate, ancute; whorls renote; valves lourer than the thick perlicels, wate-obleng, rigid, strongly tootherl, more or less prominently grain-bearing. - Aromed Charleston, S:llivet. Introdnecel. June ancl Jnly.

7. R. maritimus, I. Pubescent ; stem Iow, diffitely l,runched ; leares lanceolate, wayy-maryined, the lower ones somewlat cordate or latitate at the hase, the upper linear; whorls compactly (onweded in leafy spikes; valves small, britly on the margins, nearly covered by the large arain. (li persicarivides, L.) - Sus-shores, Norts Carolinat, and northward. Aug. and Sept. (1) - Stems $6^{\prime}-12^{\prime}$ light. Spike's yellowish.

\section{* * Houers diccious. Iterls will sour juice.}

+ Cialyx not enlaryod in fruit.

8. R. Acetosella, L. Root erecpiur ; stems low, erect or ascendiner: leaves ublong, lanceolate, or linear, entire or hastate-lobed : panicle slender, leafless; whorls scattered, few-flowered; valves ovate, grainless, appressed to the achesimm. - Ohl fichds and sterile soil, common. June and July. 4-Stens $6^{\prime}-1$ ? long. Leares and flowers small.

\section{+ + Inner caly,r-lobes diluted in finit.}

9. R. hastatulus, Baldw. Stems clustered, erect; leaves glauenus, lanceolate or linear, or the lowest oblong, entire or hastate-lobed ; whorls few-thwered, seattered, or the upper ones crowdinl; valves romul-cordate, entire, membranaceons, resicnlated, red or white, grainless. - J)ry sands, along the coast and in the middle districts, Florida to Sonth Carolina. May and June. - Stem $1^{\circ}-1 \frac{1}{2} 0$ high. Leaves $1^{\prime}-2^{\prime}$ long, the uplere one's mostly entire.

\section{POLYGONELLA, Michx.}

Flowers perfect or dixecionsly polyenmons. Calyx corolla-like, deeply 5-parted or 5-scpalous; the three inner sepals mustly colarenging and cnelosing the 3-angled achenium, glandless. Stamens 8 : inthers romulish. Stigmis 3, capjitate. Embryo straight, or nearly so, in the centre, or at one side of the mealy allumen.Sinooth ame commonly glancons herbs or shrnbs, with slender branching stems, small altermate leaves, and small flowers in spiked racemes. - Sheaths smooth. Bracts imbricated, top-sbaped, novtly l-flowered. Pedicels nodding in fruit.

\$1. Ei morrosizla. Filuments all alilie, sululute: stigmas nearly sessile: Fluners dinciously polygamous: cmlryo in the centie of the albumen.

1. P. parvifolia, Michx. Shmbly and diffusely branched at the base; leaves wedge-shined or linear-spatulate, vertical ; those on the sterile shoots imbricated; sheaths obliquely truncate, pointless; racemes short, very numerous, somewhat erowded in an oblone or corvmbose pusicle; bracts truncate; llowers 
white, Jellowish, or rose-eolor; exterior sepals recurved; valres orbicular, equal. longer than the orate achenium. - Dry sandy soil, near the coast, Florida to North Carolina. Aug. and Sept. - Stem $1^{\circ}-2^{\circ}$ high. Leaves $\frac{1}{2}^{\prime}-1^{\prime}$ loug. Racemes $\frac{1^{\prime}}{2}-1^{\prime}$ long.

2. P. gracilis, Meisner. Annual; stem tall and slender, paniculately brancher ahove; leaves remote, wedye-oblong, obtuse, often wanting; sheaths truncate, pointless: racemes slender, scattered, forming a large and sprealing panicle on the sterile plant, more erowded on the fertile; bracts truneate; flowers white or pale rose-color, the fertile ones greenish; sepals all ereet; valves oval or elliptical, nnequal (the interior longer), shorter than the ovate-lanceolate acuminate acheninm. (Polygonum gracile, Nutt.) - Dry sand ridges in the pine barrens, Florida to South Carolina. Sept. and Oct. $-5 t e m 2^{\circ}-5^{\circ}$ high. Leaves $1^{\prime}$ long. Racemes linetr, $\mathbf{I}^{\prime}-3^{\prime}$ long.

3. P. brachystachya, Meisner. Shrubly; branches slender; leaves linear, tapering from the obtuse apex to the base; sheatlus obliqnely truneate, somewhat pointed; panicle conpound, leafy ; racemes short, ollong, nearly sessile; bracts truneate; exterior sepals keeled, reflexed; valves oval, strongly 1-nerved, longer than the rhomboidal achenimm, nearly equal. - South Floridi. Branches straight, $1^{\circ}-1 \frac{1}{2}{ }^{\circ}$ long. Leaves $3^{\prime \prime}-5^{\prime \prime}$ long. Racemes $\frac{1}{2} f$ long.

4. P. Croomii, n. sp. Stem shrubby at the hase; branches stender ; leaves very small, narrowly lincar, obtuse, erowded or imbricated on the sterile shoots; sheatlis obliquely truncate, subulate-awned; racemes slender, scatterer in an open oblong panicle; brats of the filiforn rachis obliquely tmueate, pointed; flowers minute, white; exterior sepals recurved; valves unequal, the 2 exterior roundish, the interior oblong, longer than the rlombie-ovate achenimm. - In Carolina or Georgia, probably in the mildle districts, Croom. - Stem apparently $1^{\circ}-1 \frac{1}{2}^{\circ}$ high. Leaves $2^{\prime \prime}-3^{\prime \prime}$ long. Racemes $3^{\prime \prime}-5^{\prime \prime}$ or the sterile ones at length 9 "long.

5. P. ciliata, Meisner. Stem herbaceous, nearly simple; leares subulate, very acute, sheaths fringed at the throat with a few long bristles; panicle sinple, short, leafy at the base; spikes nearly sessile, filiform ; bracts minute, pointed; pedicels very short; sepals oblong, obtuse, spreading longer than the achenium. - South Florida, near the Manatee River, Rugel. - Stem 2o high, slender. Leaves $1^{\prime}-1 \frac{1}{2} \cdot$ long.

\section{\$2. Goxoryum. Filaments unlike, the 3 interior dilated at the bres: styles} manifest: flowers perfect: embryo at one side of the allumen.

6. P. Meisneriana, Shuttl. Stem slurubly, much branched; leares minute, filiform, obtuse ; sheatlss truncate, pointless ; racemes long, forming small punicles at the end of the branches; bracts loose, oblique, with the points spreading ; exterior sepals reeurved; valves equal, roundish, often emarginate, longer than the ovate acuminate achenium; three interior filaments inversely sagittate below the midlle. - Alabama, Ruyel, and near Macon, Georgia. - Stem $1^{\circ}-2^{\circ}$ high, with filiform branchlets. Leaves numerous, $2^{\prime \prime}-3^{\prime \prime}$ long. Fruiting spikes rigid, $\mathrm{l}^{\prime}-2^{\prime}$ long. Valves largest of all. 
7. P. articulata, Meisucr. Annual ; stem nuch liranched, slender; leaves narrowly linear, olutue, decilnous; shenths truncute, pointless; racemes unucr.

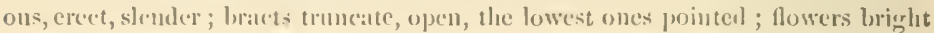
rose-tolor; sepals oval or romblish, nearly equal, unchangerl in fiut; interior filaments rhombic-ovate at the base. (l'olygonmu articulatum, L.) - I)ry samely soil, Georgia, and northward. Aug. - Stem $6^{\prime}-12^{\prime}$ high. Leaves $t^{\prime}-8^{\prime}$ long. Racenes $1^{\prime}-3^{\prime}$ long.

\section{POLYGONUM, L. KNotwen.}

Flowers perfect. Calyx 5- (rarely 4-) parted, corollit-like, the lobes nearly cypul, erect and mehomered in frut. Stamens 3-9: anthers romelish. Styles 2-3, distinct or partly united : stigmas entire. Acheninu 3-angled or lenticulas, anclosed in the persistent ealyx. Embryo corverl on the outside of the allumen. Radicle slender. - Iirerls, with alternate, simple leaves, and sheathing stipules. Flowers commonly white or rose-color, variously disposetl.

\$1. Anurgogoson. Flouers in closely-bracted spilies: stumens 7 : slyle 2-cleft: achenium lenticular: cotyledons incumbent : allnmen maly.

1. P. orientale, L. Ilairy ; stem tall, lranclunge leares ovate, acuminate, petioled; sheatls loose, salver-form; spikes panicled, crlindrical, dense, nortlinge; brats ovate; flowers large, bright rose-color. - Around dwellings, eseaped from cultivation. Junc-Sept. - Stcm $3^{\circ}-5^{\circ}$ high. Spilies $2^{\prime}-3^{\prime}$ long.

\$2. Persicaria. Flouters in closely-bracted spilies: stamens 4-8: styles 2-3, or 2-3-cleft: actenium 3-angled or lenticular: catyledons accumbent: albumen horny: sheuths cylindricul, truncate.

* Sheaths maleal: style 2-cleft or 2-parted: acherium lenticuler.

2. P. incarnatum, Eill. Stem smooth below, the smmmit of the branches, peduncles, and calyx sprinkled with glandular dots; Jeares lamecolate, long. acuminate, petioled, rough on the margins and veins; sheatlis slender, appressed; spikes racemed, linear, nodding; bracts spreading, acnte, longer than the pedicels; flowers small, flesh-color. Stamens 6, style 2-panted; achenium ovate, with the sides concave. - Ponds, ditehes, \&e., South Carolina, and westward July-Oct. (1) Stem $2^{\circ}-3^{\circ}$ high. Leares $6^{\prime}-8^{\prime}$ long. Spikes $1^{\prime}-2^{\prime}$ long.

3. P. densiflorum, Neisner. Stem stont, smooth, tumid at the joints, brameling above; leaves lanecolate or oblong-lanecolate, tapering at the summit, but rather obtuse, rough on the margins and reins; spikes racemed or somewlat panicled, linear, ereet, dense-flowered, the peluncles minutely glanclular; bracts ubliquely trmucate, obtnse, shorter than the perlicels; stamens mostly 6 ; style 2-cleft; achenium round-ovate, black and shining, with the sides convex - Mudly banks, Florila, and westward. Sept. and Oct. (1)Stem $3^{\circ}-4^{\circ}$ high Leaves $6^{\prime}-10^{\prime}$ long. Spikes $2^{\prime}-4^{\prime}$ long. Flowers white.

4. P. Pennsylvanicum, L Stem smooth below, the branches and peduncles roughened with short glandular hairs; leares short-petioled, lanceolate, 
rongh on the margins and reins; spikes ereet, oblong, obtuse, close-flowered; flowers rose-color; stamens mostly 8, exserted; style 2-cleft; achenium orbicular, with the sides concave. - Wet places, Georgia, and northward. JulySept. (1) - Stem $1^{\circ}-3^{\circ}$ high, sometimes nearly smooth. Leaves $2^{\prime}-4^{\prime}$ long. Spikes $1^{\prime}-1 \frac{1}{2}{ }^{\prime}$ long. Flowers much larger thim those of the two preceding species.

\section{* * Sheulls fringal with bristly hairs: achenium 3-angled, or (in No. 5) sometimes lenticular: stumens mostly 8 .}

5. P. Persicaria, L. Stem smooth, branching from the base, erect or diffuse; leaves lanceolate or oblong, obtuse or acutish, the margins and veins ronghened; sheaths short, nearly smooth, fringed with a few short bristles; spikes short, oblong, obtuse, dense-flowered; flowers rose-color; stamens $6-7$; style half 2-cleft; achenium lenticular or 3-angled, smooth and shining. - Low places around dwellings and along roads, Florida, and northward. Introduced. July. (1) - Stem $1^{\circ}-1 \frac{1}{2}{ }^{\circ}$ high. Leaves $2^{\prime}-4^{\prime}$ long, often with a dark triangrular spot in the middle. Spikes $\frac{1}{2}^{\prime}-\mathbf{l}^{\prime}$ long.

6. P. acre, Kunth. Stem slender, smooth, creeping at the base; leaves lanecolate, rough on the margins and reins, and, like the white ealyx, dotted with pellueid glands; sheaths smoothish, long-fringed at the throat; spikes 1-3, filiform, loose-flowered; stamens 8; stỵle 3-parted; achenium 3-angled. (P. punctatum, Ell.) - Ditelses and margins of ponds, Fiorida, and northward. July - Sept. $4-$ Stem $1^{\circ}-3^{\circ}$ long. Leaves $2^{\prime}-4^{\prime}$ long, very acrid. Spikes $2^{\prime}-3^{\prime}$ long.

7. P. hydropiperoides, Michx. Stem slender, smooth, ascending from a fluating or erecping base; leaves linear or lanceolate, roughened with short rigid hairs on both sides, or only on the margins and veins; sheaths hispid, long-fringed ; spikes 2-3, linear, rather close-flowered; ealyx pale rose-color, ant, like the leaves, glandless; stamens 8 ; style 3-cleft; achenium 3-angled. (P. mite, Pers.) - Ditches and muddy banks, Florida, and northward. JulySept. $\quad 4$ - Siem $2^{\circ}-3^{\circ}$ long. Leaves $2^{\prime}-4^{\prime}$ long, not acrid. Spikes $1^{\prime}-2^{\prime}$ Jong.

8. P. setaceum, Baldw. Stem ereet, sparingly branehed, smooth below, the upper portion, like the peduncles and lanceolate glandless leaves, rongh with appressed laairs ; stipnles appressed-hirsute, copiously fringed with long bristles ; spikes filiform, by pairs, loose-flowered; flowers white, glandless; stamens 8 ; style 3-cleft; achenium 3-angled. - Low ground, Georgia and Florida. July Sept. $\quad 4-$ Stem $2^{\circ}-3^{\circ}$ high. Leaves $3^{\prime}-5^{\prime}$ long. Spikes $1^{\prime}-2^{\prime}$ long.

9. P. hirsutum, Walt. Stern ereet, densely hirsute with spreading fulvous hairs; leaves lanceolate, nearly sessile, rounded at the base, hirsute, particularly on the veins and margins; sheatls hir'sute, copjously fringed; spikes $2-3$, lincar, erect, rather elose-flowered; jeduneles smooth above; braets naked ; flowers white, glaudless; stamens 8; arhenium 3-angled. - Pine-barren pronds, Florida to North Carolina. July-Sept. \& - Stem $2^{\circ}-3^{\circ}$ highl. Leaves $2^{\prime}-3^{\prime}$ long. Spikes I' long. 


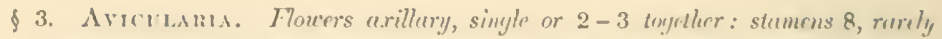

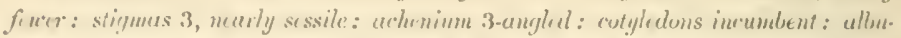

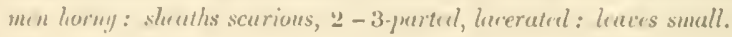

10. P. avieulare, I. Steu prostrate, diffisse, short-jointert; leaves sessile (1) long), ohlong-linear or lancrolite, obtuse, longer tham the 3-r.feft sheaths; flowers clnstred, nearly sessile, greenish-white, longer than the lull aldenium; stamens moitly 5. - Waste places and along roads, common. - Vat. likictex. (l'. erectum, I..) Stem stouter, erect or asending, leaves larecer (1'- I $\frac{1}{2}$ lung $)$,

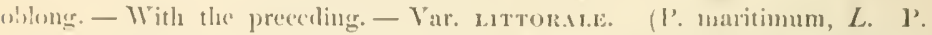
grlaucutu, Nutt.) Stem long $\left(1^{\circ} .2^{\circ}\right)$, prostrate, rigill, short-jointed; leaves small $\left(t^{\prime}-6^{\prime \prime}\right)$, oblong-linear, glatucons; the uppermo-t imbrieated and scarcely longer than the more conspicuous silvery sheaths; (alyx rechlish-white, shorter thin the smooth achenium. - Scarcoast sands, Georgial, and nosthward.

11. P. tenue, Michx. Smooth; stem erect, branched, sharply angled, slender; leaves scattered, linenr, acute; sheaths small, fringed ; fluwers mustly solitary, grecnish-white; achenimm smooth and shining. - Dry rocks in the upper districts. July - Sept. (1) - Sten $6^{\prime}-8^{\prime}$ lighl. Leares $6^{\prime \prime}-12^{\prime \prime}$ long.

\$4. Tovisis. Flowers scuttered in a lony und stemeler spilie: culy.x 4-perted: stamens 5, inchedel: styles 2, exsertul, persistent: achenimm lentucular: cotyledons acerumbert.

12. P. Virginianum, I. Stem erect, smooth below; the upper portion, like the leaves and spikes, more or less hairy ; leaves larese, ovate or ovite-lanceolate, acute at cach enl; sheaths cylindrieal, hairy, fringed ; flowers grecuish, curvel; styles at length hooked at the apex. - Dry rich soil, Floridla, and nortliwarl. Aug. and Sept. It - I'lant $2^{\circ}-4^{\circ}$ liggli. Leaves $3^{\prime}-5^{\prime}$ longr, $3 \frac{1}{2}^{\prime}-2 \frac{1}{2}^{\prime}$ wisle. Spike $6^{\prime}-12^{\prime}$ long.

\$5. Fenisorstux. Flowers in terminal clusters: culy.x 4-5-parted: stumens 6 or 8: styles 2-3: achenizun lenticular or 3-engled: cotyledons accumbent.Stems weak, branching, armed on the ungles, petioles, f.c. with recurcal prickles.

13. P. arifolium, I. Leaves lastate, acuninate, membranaceous, minutely detted and hairy, long-petioled, the lobes acute; peduncles rather short, bristly; fluwers white, somewhat spiked; stamens 6; styles 2; achenimm lenticular. - Riec fields and wet places, South Carolina, and northward. June(). (1) Stems $2^{\circ}-3^{\circ}$ long. Leaves $3^{\prime}-4^{\prime}$ loug. Calyx often 4 -parted.

14. P. sagittatum, I. Leaves small, sagittate, acute, short-petioled, smooth; peluncles elongated, smooth; flowers white, capitate; stamens 8; styles 3 ; aclicuinu 3-angled. - Wet places, Floricla, and northward. JuneOct. (1) $-\operatorname{Stcm} 1^{\circ}-3^{\circ}$ long. Leaves $1^{\prime}-2^{\prime}$ long.

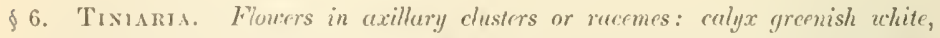
5-parterl, the outer lobes keeled or wingrd on the buck: stumens 8: styles 3, rery short: achenium 3-angled: cotyledons accumbent. - Amuals, with twining stcms and cordate leaves.

15. P. Convolvulus, L. Stem roughish, prostrate or twining, or when small erect ; leaves long-petioled, sagittate-cordate, acnminate, the lobes aeute or 
obtuse ; sheaths naked ; flowers in axillary elusters, or forming long interrupted and leafless racemes ; fruiting calyx ovate, minutely puberulent, closely investing the dull black achenium, the outer lobes keeled. - Cultivated ground. Introduced. July-Sept. - Stems $1^{\circ}-3^{\circ}$ long.

16. P. cilinode, Michx. Minutely pubescent; stem twining; leaves ovate, cordate or somewhat hastate at the base, acuminate, petioled ; sheaths with a row of reflexed hairs at the base; flowers in loose simple axillary and panicled racemes; fruiting calyx smooth, nearly including the smooth and slining achenium, the outer lobes slightly keeled. - Dry rocks on the mountains of North Carolina, and northward. July - Sept. - Stem $3^{\circ}-9^{\circ}$ long.

17. P. dumetorum, L. Smooth; stem twining; leaves ovate, acuminate, long-petioled, cordate or somewhat sagittate at the base; sheatls naked; flowers in long axillary more or less leafy racemes; fruiting calyx somewhat spatulate, emarginate, much longer than the smooth and shining achenium, the outer lobes winged and decurrent on the pedicel. (P. scandens, L.) - Low margins of fields and thickets, Florida, and northward. June-Sept. - Stem $6^{\circ}-12^{\circ}$ long.

\section{THYSANELLA, Gray.}

Flowers polygamous. Calyx corolla-like, deeply 5-parted, unchanged in fruit; lobes erect, unequal; the 2 outer ones cordate at the base; the inner ones smaller, pectinate-fimbriate. Stanens 8 , the filaments filiform. Styles 3, filiform : stigmas entire, obtuse. Achenium ovate, 3-angled, nearly included in the persistent calyx. Cotyledons on the outside of the albumen. - An erect smooth and branching annual, with long linear acute leaves, truncate cylindrical sheaths, fringed with long bristles, and white or rose-colored flowers in closely bracted spikes.

1. T. fimbriata, Gray. (Polygonum fimbriatum, Ell.) - Dry pine barrens, Georgia and Florida. Sept. and Oct. - Stem branching abore, $2^{\circ}$ high. Leaves $1^{\prime}-2^{\prime}$ long. Sheatlus smooth, adnate to the leaves, not longer than the fringe, the lower ones imbricated. Spikes $2^{\prime}-3^{\prime}$ long, panicled, erect, the upper ones pistillate, the lower staminate. Bracts pointed with a long and slender awn. Outer calyx-lobes oblong, entire in the staminate flowers, fimbriate, like the inner ones, in the pistillate ones.

\section{COCCOLOBA, Jacq.}

Flowers perfect. Calyx herbaceous, 5-parted, the tuhe enlarged and more or less fleshy in fruit. Stamens 8 . Filaments suhulate. Styles 3 : stigmas entire. Achenium nearly globose, included in and partly united with the persistent calyx. Embryo straight in the axis of mealy albumen. - Trees or shrubs, with alternate leaves, truncate sheatls, and small greenish flowers in axillary and terminal racemes.

1. C. uvifera, Jaeq. (SeA-Grape.) Smooth; leaves short-petioled, coriaceous, orbicular-cordate or reniform ; racemes terminal, rigid, creet; pediecls 


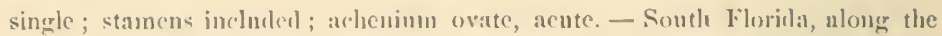
(oalst, $-\Lambda$ slorul, or smatl tree, with rieriel spreading branches. Leaves $3^{\prime}-5^{\prime}$ wiske, very thick. liacemes 6 long.

2. C. Floridana, Meisner. Sinontlı; leares petiolerl, somewhat coriareons, clljptical, obuse at each end; racemes slemeler, terminal and on short laternl branches, recurved; predicels $2-3$ together, ahout the length of the calyx; stanen exserted; achenimm oroin, obtuse. - Sonth Florida. $-\Lambda$ small tree. Leaves $2^{\prime}-3^{\prime}$ long. Slieaths loose, brown. Racemes $2^{\prime}-3^{\prime}$ long. Aclenium $4^{\prime \prime}-5$ "l long. Pincere pium.

\section{BRUNNICHIA, Banks.}

Flowers perfect. Calyx bell-shaped, 5-parted, the tube enlarged in fruit and enclosing the free achenium. Stamens 8 or 10 . Sityles 3 , slender: stigmas entire. Orule horne on a sleusler cord from the base of the ovary, pendulous. Achenium obtusely 3 -angled. Seed 6 -furrowed. Embryo in one of the angles of the mealy allommen. $-A$ smooth vine, climbing by terminal tendrils. Leaves ovate or cordate-ovate, petiolerl, acute, deciluons. Sheaths olselete. Flowers greenish, in axillary and terminal racemes, on slender pedicels, which beconce indurated and flattened in fruit.

1. B. cirrhosa, Banks. - River-luanks, Florida to South Carolina. A pril and May, - Stem shrubly, $10^{\circ}-20^{\circ}$ long. Leaves $2^{\prime}-3^{\prime}$ long. Racemes $3^{\prime}-$ $6^{\prime}$ long. Bracts ovate, acinminate, $3-5$-flowered. Frniting pedicels curved.

\section{ERIOGONUM, Michx.}

Flowers perfect or polygamons, surrounded by an involuere. Calyx deeply 6-cleft. Stamens 9. Ovary free, 3-sided. Styles 3: stigmas eapitate. Achenimm 3-angled or 3-winged. Embryo straight in the axis of the albumen, or more or less curved. - Downy or woolly lerbs. Leaves altcrmate, opposite or whorled. Slreaths none. Inflorescence rarious.

1. E. longifolium, Nint. Stem erect, tomentose, corymbose above, lenfy below ; leaves smooth or villons ahove, white-tomentose beneath, the lowest clustered, oblong-linear, long-tapering at the lase, the upper seattered, the uppermost bract-like; involucre stalked, many-flowered, obtusely 5-toothed; calyx herbaceons, epual, woolly without. - Sand ridges, East Florida. $4-$ Stem $2^{\circ}-3^{\circ}$ higls. Lowest leaves $3^{\prime}-5^{\prime}$ long.

2. E. tomentosum, Michx. Stem erect, tomentose, corrmbose alonve, leafy throughont; leares smooth above, white tomentose benenth, the lowest clustered, olovate-oblong, long-petioled, the others in whorls of $3-4$; elliptical, sessile; involucre sessile, obtusely 5 -toothed; ealyx white, unequal, wonlly without - Dry pine barrens, Florida to South Carolina. July-Sept. 4 -Stem $2^{\circ}-3^{\circ}$ high. Lowest leaves $4^{\prime}-6^{\prime}$ long. Flowers very numerous on one side of the spreading branches. 


\section{Orier 111. LaUiaceac. (Latrel Famly.)}

Aromatic trees or shrubs (except Cassyta), with alternate simple ninutely dotted leaves, without stipules, and perfect or polygamous clustered flowers. - Calyx 6 -9-parted, imbricated in 2 rows. Stamens 6 or more, in $1-4$ rows: anthers adnate, $2-4$-cellerl, opening by lid-like valves. Orary free, 1-celled, with a solitary anatropons suspended orule. Style simple, thick : stigma obtuse. Fruit a drupe or berry. Seed without albumen. Embryo large. Radicle superior.

\section{Synopsis.}

Tribe I. L A URIN EA. Fruit naked. - Trees or shrubs.

* Flowers perfect. Stamens 12, the 3 inver ones sterile.

1. PERSEA. Anthers 4-celled, 4-valved. Trees with evergreen leaves.

* Flowers diocious. Stamens 9 , all fertile.

2. SASSAFRAS. Involucre none. Anthers 4-celled.

3. BENZOIN. Involucre 4-leaved. Anthers 2-celled.

4. TETRANTIIEliA. Involucre 2-4-leaved. Anthers 4-celled.

Trme II. CASSYTEAE. Fruit enclosed in the fleshy calyx. - Leafless trining parasites.

5 CASSYTA. Flowers perfect. Stamens 9. Anthers 2-celled.

\section{PERSEA, Gærtn. Red-BAY.}

Flowers perfect. Calyx deeply 6-parted, persistent. Stamens 12, in 4 rows, the inner ones sterile and gland-like. Filaments pubescent, the inner fertile ones biglandular. Antlers 4-celled, those of the two onter rows introrse, of the inner row cxtrorse. Stigma disk-like. Drupe ovoid. - Trees or slurnbs, with evergreen entire petioled leaves, and grecnish or white flowers, in axillary peduncled elusters or panicles.

1. P. Carolinensis, Nees. Branehlets smoothish ; leaves oblong or laneeolate-oblong, smooth and deep green above, glaucous beneath, obscurely veined; flowers silky, in eymose clusters, on peduneles shorter than the petioles; calyxlobes unequal, persistent; drmpe blue. (Laurus Carolinensis, L.) - Rich shady woods, Florida to North Carolina. July. - A tree $20^{\circ}-40^{\circ}$ high. Leaves $2^{\prime}-$ $3^{\prime}$ long.

Var. palustris. Shrubby; the branchlets, lower surface of the leaves, and flowers densely tomentose; leaves strongly veined, pale green, varying from oral to laneeolate; peduneles longer than the petioles. - Ponds and pine-barren swamps. July. - Shrnb $4^{\circ}-10^{\circ}$ high. Leaves $3^{\prime}-6^{\prime}$ long. Flowers larger than the preceding form.

2. P. Catesbyana. Smooth; leaves lanecolate-ohlong, acute or ohtnce, retieulate, shining, on short margined petioles; flowers minute, in narrow axillary panicles which are commonly shorter than the leares; ealyx white, puheseent within, the nearly equal lobes deciduous; filaments very slort, the innermost 


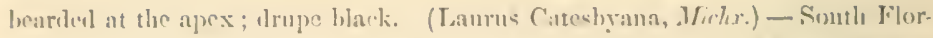
illa. - Shrub $6^{\circ}-9^{\circ}$ hirglo. Leaves $3^{\prime}-5^{\prime}$ long. Fruiting jediccls club-shaperl.

\section{SASSAFRAS, Nies.}

Involucre none. Flowers diceciously polygamons. Calyx roparterl, sprearing. Stancus of the sterile flowers 9 , in 3 rows, all fertile, the 3 inner ones biglandular at the base; those of the fertile flowers 6 , sterife: anthers linear, 4-eelled, 4-valved, introrse. Style subulate: stignual rist-like. I)rupes blue, on thick red perlicels. - Trees, with entire or 2-3-lohed decilnous leaves, and greenish flowers in elustered racemes, ippearing hefore the leares.

1. S. officinale, Nees. Leaves ovate, entire or 2-3-lolerl, smonth or pulesecnt; racemes slort, silky; flowers sometimes white. (Laurus Sassafra4, L.) - Dry open woods anel old fields, Florida, and northward. March. $-\Lambda$ small iree, with spicy bark.

\section{BENZOIN, Nees. Srice-Busu.}

Involuere 4-leaved. Flowers diuecionsly polygamous. Calyx 6-jarted. Stamens of the sterile flowers 9 (more muncrous and rudimentary in the fertile flowers), in 3 rows: filaments slender, the inner ones lobed and glandular at the hase: nuthers orate, 2-celled, 2-valved, introrse. Style short. Drupe ohovoid, red, the pedicels not thickenerl. - Shruls, with entire decirluous leares, and dull yellow flowers in lateral sessile clusters, appearing before the leaves.

1. B. odoriferum, Nees. Branches slender, smooth; leares oblong-obovate, acute at the base; paler and pubeseent bencath, soon smootlı; clusters numerous, smooth. (Laums Benzoin, $L$ ) - Banks of streans and low woorl, Florida, ancl northward. Feb. and Mareh. $-\mathrm{A}$ shrub $6^{\circ}-10^{\circ}$ high, with spicy bark. Lcares $3^{\prime}-5^{\prime}$ long.

2. B. melissæfolium, Nees. Leaves ollong, short-petioled, obtuse or slightly cordate at the base, silky on both sides, as also the branchlets and clusters, at lenerth smooth above; drupes obovois. (Lamms melissæfolia, Walt.) - Mitroins of ponds, West Florilla to North Carolina. Feb. and March. $-A$ shuub $2^{\circ}-3^{\circ}$ high. Leares $1^{\prime}-2^{\prime}$ long.

\section{TETRANTHERA, Jicq .}

Involuere 2-4-Jeared. Flowers diøccions. Calyx 6-parted, deciduous, Stamens of the sterile flowers 9 , in 3 rows; those of the fertile flowers nuncrous and rudimentary : anthers 4-celled, 4-valved, introrse. Stirma peltate. J)rupe glohose. - Trees or shrubs, with entire leaves, and sinall flowers in clustered umbels.

1. T. geniculata, Nees. Branchlets smooth, zigzag, spreading; leaves small, oval or oblong, soon smooth, decidnous; in rolucre $2-4$-flowered; flowers yellow, appearing hefore the leares; drupe red. (Laurus geniculata, Walt.) Shallow pine-barren ponds, Florida, and northward. Fcb. and March. - A 
karge shrub, with numerous spreading and forked branches. Leaves somewhat coriaceous, $\frac{1}{2}{ }^{\prime}-1^{\prime}$ long.

\section{CASSYTA, L.}

Flowers perfect. Calyx 6-eleft, persistent, the exterior lohes minute. Stamens 12, in 4 rows, the inner row sterile: anthers 2-celled, the inner ones extrorse, the onter introrse. Style very short: stigma disk-like. Fruit enclosel in the fleshy persistent tube of the calyx. $-\Lambda$ leafless parasitic plant, with twining filiform stems, and spiked flowers.

1. C. filiformis, Miller, - South Florida. - Spikes 2-4-flowered. Calyxlobes thick, triangular, acute. Anthers oval, obtuse.

\section{Order 112. THYMELEACEA. (Mezereun Family.)}

Slurubs, with aeril juice, tough bark, simple entire dotless leaves, without stipules, and regular perfect flowers, with a tubular or bell-shaperl 4-5-cleft rarely entire calyx. Stamens commonly twice as many as the (alyx-lobes, in 2 rows: anthers 2-eelled, opening lengthwise. Style simple: stigma capitate. Drupe with a single suspenrled anatropous seerl, containing little or no albumen. Cotyledons plano-convex. Radicle superior.

\section{DIRCA, L. Leatherwood.}

Calyx bell-shaped, entire, or obscurely 4-toothed. Stamens 8, unequal, exserted. Style filiform. Albumen none. - A low branching shrub, with alternate petioled oblong or obovate at length smooth and deciduous leaves, and light yellow flowers, from hairy buds, appearing before the leaves.

1. D. palustris, L. - Shady banks of streams, Florida, and northward. Feb. and March. - Shrub $2^{\circ}-3^{\circ}$ high, with pale sprealing jointed branches. Leaves $2^{\prime}$ long, silky when young. Flowers three in a cluster, on short pedicels. Drupe small, red.

\section{Order 11\%. SANTALACEA. (Sandawoon Family.)}

Herlos, shrubs, or trees, with simple entire exstipulate leaves - Calyx tubular, 4-5-cleft, valvate in the bud, the tube colierent with the ovary. Stamens 4-5, opposite the lobes, and inserted on the fleshy disk at their base. anthers introrse, opening lengthwise. Ovary 1-cellerl, with $2-4$ anatropous ovules suspended from the apex of the free central placenta. Style single. Fruit 1-seeded. Embryo small, at the apex of copious albumen. Cotyledons cylindrical. Radicle superior. 


\section{Synopis.}

- Flowers perfert.

1. contaxnR.1. Anthors connectel with the calyx-lobes by a tuft of hairs. Leaves ab terunte.

* Flowers dioccious. Shrubs.

2. DARBYA. Calyx 4-5-eleft. Anthers connected with the calyx-lobes by a tuft of hairs. Leaves opposite. Flowers umbelled.

3. PYRULARIA. Calyx 5-eleft. Stamens 5. Anthers free. Albumen oily. Leaves alternate. Flowers spikel

4. InCliLFI. Calyx-linb dnuble, each 4-lohed. Stamens 4. Anthers free. Albumen tushy. Leaves uearly opposite. Flowers terminal.

\section{COMANDRA, Nutt.}

Flowers perfect. Calyx hell-shaped, 5-cleft, the persistent lohes alternating with the lobes of the disk. Stamens 5 : anthers connected with the calyx-lobes by a tuft of hairs. Stigna capitate. Fruit mut-like, 1-seeded. - Smooth perennial herbs, with alternate leaves, anil small greenish-white flowers, in axillary and terminal unbel-like peduneled rlusters.

1. C. umbellata, Nutt. Stem branching above; leaves sessile, laneeolate or oblong; peduncles several, corymbose, 3-5-flowered, mostly longer than the leaves; style slender; fruiting ealyx urn-shaped. (Thesium umbellatum, L.) Dry soil in the upper distriets of Georria, and northward. April and May.Stem $8^{\prime}-10^{\prime}$ hirgh. Leares $\frac{1^{\prime}}{2}-1^{\prime}$ long.

\section{DARBYA, Gray.}

Flowers diwcious. Sterile flowers top-shaped, 4-5-eleft, the lobes ovate, spreading. Stamens $4-5$, inserted into the sinuses of the erenately $4-5$-lobed disk : filaments short : anthers connected with the calyx-lolses by a tuft of hairs. Frnit 1-elled, 1-seeded. Fertile flowers unknown. $-\Lambda$ small shrub, with opposite oral membranaceous short-petioled leaves, and small greenish flowers in axillary peduncled umbels.

1. D. umbellulata, Gray. - Near Milledgeville and Mason, Georgia, Ir. Boykin, Prof. Darly. Lincolnton, North Carolina, Curtis. - Shrnb $10-1 \frac{1}{2}{ }^{\circ}$ high. Leaves $1^{\prime}$ long, smooth. Peduncles 3-8-flowered, shorter thun the leaves.

\section{PYRULARIA, Michx. OıL-Nut.}

Flowers diocions. Calyx 5-eleft, the lohes recurved. Disk composed of 5 roundish glunds. Stamens of the sterile flowers short, alternate with the grlands. Fertile flower pear-shaped. Style short and thick: stigma depressed-capitate. Drupe pear-shaped, fleshy. Albumen oily. - A low branching shruh, with alternate deciduous leaves, and small greenish flowers in a short terminal spike.

1. P. oleifera, Gray. (Hamiltonia oleifera, Mfull) - Shady hanks on the mountains, Georgia, and northward. May. - Leaves petioled, obovate-oblong, acute at each end, pubescent, $3^{\prime}-4^{\prime}$ long. Drupe $l^{\prime}$ long. 


\section{BUCKLEYA, Torr.}

Flowers diœcious. Calyx club-shaped, the limb double, each 4-parted; the exterior lobes linear, leafy, somewhat persistent, the interior triangular-ovate, slightly imbricated in the bud, deciduous. Stamens of the sterile flower 4 . Disk of the fertile flower 4-lobed, fleshy. Style short: stigma 4-lobed. Drupe oblong, compressed, furrowed. Embryo slender, in the axis of copious fleshy albumen, - An erect shrub, with straight and slender branches. Leaves scarcely petioled, nearly opposite, distichous, lanceolate, acute, pubescent. Flowers terminal, greenish, the sterile ones umbellate, the fertile solitary.

1. B. distichophylla, Torr. - Mountains of Nortlı Carolina, Buckley.Shrub $6^{\circ}-7^{\circ}$ high. Leares thin, $1^{\prime}-1 \frac{1}{2}$ long. Calyx-tube $4^{\prime \prime}-5^{\prime \prime}$ long, scarcely longer than the exterior spreading lobes, much longer than the inner ones. Drupe $\frac{1^{\prime}}{2}$ long.

\section{Order 114. LORANTHACEA. (Mistletoe Famil.)}

Parasitical shrubby plants, with evergreen almost veinless leaves, without stipules, and perfect or diœeious flowers. - Calyx of $2-8$ sepals, distinct or united into a tube, valvate in the bud, sometimes wanting. Stamens as many as the sepals and opposite them. Ovary 1-celled, commonly with a single suspended ovule. Style simple or none. Fruit berry-like. Seeds anatropous. Embryo longer than the fleshy albumen.

\section{PHORADENDRON, Nutt. Mistletoe.}

Flowers diœcious, in short jointed spikes. Calyx of the sterile flower globular, 2-4-lobed. Anthers sessile at the base of the lobes, transversely 2-celled. Calyx of the fertile flower adnate to the ovary. Stigma sessile. Berry globose, pulpy, 1-seeded. - Evergreen shrubs, growing on the branches of various trees, with brittle jointed stems, thick persistent leaves, and small flowers in axillary spikes.

1. P. flavescens, Nutt. (Viscum flavescens, Pursh.) - Florida to Mississippi, and northward. April and May. - Plant yellowish, $2^{\circ}-3^{\circ}$ long. Branches opposite or whorled. Leaves obovate, fleshy. Spikes shorter than the leaves. Berry white, glutinous.

\section{Order 115. SAURURACEA. (Lizard's-tatl Family.)}

Perennial marsh herbs, with jointed stems, alternate entire leaves, with sheathing stipules, and perfeet flowers in bracted spikes or racemes. Calyx and corolla none. Stamens few or many, hypogynous: anthers introrse, opening lengthwise. Ovaries 3-5, move or less united. Orules few, orthotropous, ascending. Embryo minute, corlate, container in a eavity at the apex of the albumen. Fruit follicular, 1 -few-seeded. 


\section{SAURURUS, I, II\%Am'S-TAII.}

Stamens 1-8, with long clul-sluped filaments. Fruit sornewhat fleshy, composerl of $3-4$ partly united $1-2$-secoled carpels, prointed with as many stigmas - Flowers white.

1. S. cernuus, I, Stem ereet, branehing; leaves petiolerd, cordate-ovate, or oblong-ovate, ar'unimte; spikes white, ferminal, nodding at the apex; flowers numerons, each from the axil of a small bart. - Marshes and muldy hanks, Florida, and northward. May- $\Delta$ ug. - Rhizonla crecpinge. Stem $1^{\circ}-2^{\circ}$ high. Spikes $4^{\prime}-6^{\prime}$ long.

\section{ORDER 116. CERATOPUYIA ICIA. (IIORNWORT}

$$
\text { FAMIL.) }
$$

Submerged aquatic herbs, with filiform jointed and branehing stems, finely disserted whorled leaves, and small axillary monnerious flowers, destitute of floral envelopes, but surrounded by an involure of 8 -12 linear leaves. Anthers 12-2t, ollong, 2-3-tontherl, sussile. Ovary solitary, simple, with a single suspended orthotropous ovule. Achenium compressed, pointed with the slender persistent style. Allumen none. Cotyledons 4. Plumnle conspicuous. - Consisting of the single genus

\section{CERATOPHYLLUM, I. Iorwwort.}

1. C. demersum, I. Leares rigid, 6-9 in a whorl, once or twice forking, with the lohes spiny-toothed; achenium oral, compressed, tnlereular-1oughened on the sides, and arned near the base with 2 lateral widely-spreading slender spines. - In still water, Florida, and northwarl. Sept. anul Oct. - Stems $1^{\circ}-$ $4^{\circ}$ long. Leaves near the end of the bramches much erowded.

2. C. echinatum, Gray? Leaves weak, $9-12$ in a whorl, $3-4$ times forking, the nltimate secrments bristly-toothed; oraries warty, unarmed; achenium oblong, tuberculatr-lourhened on the sides, the edges margined and armed with $5-7$ strong and spreading spines. - Shallow ponds, on St. Vincent's Islunt, West Florida. May.-Stems $6^{\prime}-12^{\prime}$ long.

3. C. submersum, L. Leaves lair-like, $3-4$ times forking, bristlytoothed; achenium oblong, slightly compressed, tubereular-roughened, with rounded margins, unarmed, - South Florida, $D_{r}$. Blodyett. - Stems $6^{\prime}-12^{\prime}$ long.

\section{Order 11\%. CAMTITRICIICEAS. (WATEli-STARWORT} FMILY.)

Small aquatic annuals, with opposite entire leaves, and solitary axillary polygamous flowers without floral envelopes. Stamen mostly solitary, 2bracted in the sterile flower. Filament slender: anther reniform, the 
cells confluent. Styles 2, slender: stigmas aeute. Capsule 4-angled, 4celled, with a single suspended anatropous seed in each cell, indehiscent. Embryo straight, in copious fleshy albumen. Radicle long, superior. Consisting of the single genus

\section{CaLLitriche, L. Water-Starwort.}

1. C. verna, L. Floating leaves spitulate or obovate, crowded, the lower ones distant, lincar; fruit nearly sessile, 2-bracted, keeled on the back. (C. heterophylla, Ell.) - Var. TerRestris. Smaller $\left(2^{\prime}-3^{\prime}\right.$ long); stems much branched, creeping on lamp earth ; leaves ( $1^{\prime \prime}-2^{\prime \prime}$ long) all linear. - Ditches and shallow water, Florila, and northward. March and April. - Stems several, $6^{\prime}-12^{\prime}$ long. Leaves $\frac{1}{2}^{\prime}$ long.

\section{Order 118. POdostemacea. (River-weed Family.)}

Moss-like aquatic plants, with minute flowers, from a spathe-like involucre, and destitute of floral envelopes. - Stamens 5-12: anthers 2-celled. Capsule 2-3-celled, and pointed by as many persistent styles. Sceds numerous, on a thick central placenta, destitute of albumen.

\section{PODOSTEMON, Michx. River-weed.}

Spathe 2-leaved. Flowers pedicelled. Filaments elongated, borne on one side of the stalk of the ovary, united below, and bearing only a single anther. Styles 2, simple. Capsule ribbed, 2-celled, 2-valved. Seeds imbricated. Submerged aquatic plants, attached to rocks and peblbles by disk-like expansions of the stem. Leaves 2-ranked, divided into filiform segments.

1. P. ceratophyllum, Michx. Leaves rigid, sparingly divided, sheathing at the base ; flowers solitary, on slender pedicels ; capsule oval, 8-ribbed. Rocky plaees in rivers, Georgia, and northward. July. - Plant olive-green, $\mathbf{l}^{\prime}-4^{\prime}$ long.

2. P. abrotanoides, Nutt. Leaves much divided, with hair-like scrments; flowers 2-3 together, on short pedicels ; capsule oblong, 10-ribbed. Gravelly places in the Chattahoochee River, Nuttull. - Plant larger than the last.

\section{Order 119. EUPHORBIACEA. (SPURge Fumly.)}

Plants commonly with acrid milky juice, and monorious or diocious often petalous flowers. - Calyx 2-8-lobed, mostly valvate in the bud, sometimes wanting. Stigmas 2-several, simple or divided. Fruit of $2-$ several (mostly 3) 1-2-seeded earpels united around a central axis, separating at maturity, rarely 1 -celled or indehiscent. Sceds suspended, anatropous. Embryo in fleshy albumen. Cotyledons flat. 


\section{Synopsis.}

f 1. Orules and seeds solitary In the cells. Flowers monneious.

- Flowers without l]oral euvelopes, enclosed In a conmon cup-kluped involurro

1. EUPIORIBIA. Fertile flower solitiry in the 4.5 -toothed involucre. Sterile flowers ser pral, each reduced to a single stamen.

- Howers in bracted spikes or racemes; the upper ones sterile, the lowest fertile.

- Flowers apetalous.

++ Stigmas and cells of the causule $6-7$.

2. HIPloyANE. Carpels woody, indehiscent. Spikes terminal. Staninate flowers elus tured.

4t +4 Stigmas and cells of the dehiscent eapsule 3 .

3. STILITXgiA. Calyx 2 -3-toothed. Anthers ereet. Staminate forrers elustered.

4. EXC(ECARIA. Calyx 3-parted. Anthers pendulous. Staminate flowers single.

5. ACALYPIA. Stiguas many-parted. Flowers spiked. Bracts of the pistillate flowers leafy, toothed.

6. TRAG1A. Stignas 3, simple. Flowers racemed. Bracts small, entire.

+ + Staminate flowers (except No. 1 in Croton), or the pistillate also furnished with petals.

7. CROTON. Plstillate flowers apetalous, or with minute petals. Stanens 6 or more, distinct.

8. CROTONOPSIS. Pistillate flowers apetalons. Capsule 1.eelled. Stamens 5 , distinct.

9. AlloRA. Pistillate and staminate flowers 5-petalled. Capsule 3-celled. Stamens 10 monadelphous.

* Flowers cymose or panieled, apetalous.

10. CNIDOscolus. Flowers cymose. Calyx white, corolla-like.

11. RICINUs. Flowers in crowded panicles. Calyx herbaceous.

12. Ovules, and commonly the seeds, 2 in the cells.

* Flowers monocions, apetalous. Ovary 3-celled. Ilerbs.

12. PIIYLANTIIUS. Flowers axillary. Calyx 5-6-parted. Stamens 3, monadelphous.

13. PACIIYSANDRA. Flowers spiked. Caly 4 -yartud. Stamens 4 , distinct.

* Flowers dicecious, a petalous. Ovary 2-celled. Shrubs.

14. DRYPETES. Flowers in axillary elusters. Fruit drupaceous, 1.celled, 1-seeded.

\section{EUPHORBIA, L. SPURGE.}

Flowers monecious, destitute of calyx and corolla; the single pistillate, and several monandrous staminate ones included in a eup-shaped or top-shaped $4-5$. toothed involuere, which has commonly thick and often colored glands between the tecth. Styles 3, 2-cleft. Capsule exserted, 3-celled: earpels 2-valved, 1-secded. - A polymorphous genus of plants with acrid milky juice.

\section{\$1. Leaves wathout stipules.}

* Stem erect, umbellately branched alove: involucres solitary, terminal and in the forks of the branches: leaves of the stem alternate, those of the branches opposte or whorled.

- Glands of the involucre 5, with whte petal-like appendages: leaves entire: perennials.

1. E. corollata, L. Stem smooth or pubescent; lranches 4-6, twice or thrice forking, mostly short and fastigiate; leaves thick, oblong or oval, obtuse, pale and mostly hairy beneath; involucres pedicelled; appendages of the (green) 
glands orlbicular, showy ; capsule and seed smooth. (E. paniculata, Ell.) - Var. ANGUSTIfoliA, Ell. Stems slender; braneles mostly 3, forking, elongated, spreading; leaves varying from linear to obovate; involueres small, seattered; appendages of the glands transversely oblong. - Dry rich soil, Florita to Mississippi, and northward; the var. in sandy pine barrens. July - Sept. - Stem $1^{\circ}-2^{\circ}$ high.

2. E. discoidalis, n. sp. Smooth or pubescent; branches commonly 2, divaricate, forking; leaves linear, obtuse, with the margins revolute; involucres on slender pedicels; glands deep red, bordered by the narrow appendages; seeds ohovate, pale, minutely pitted. - Dry sandy pine barrens near the coust, West Florida. Ang. - Oet. Plant $6^{\prime}-18^{\prime}$ high ; the stem mueh shorter than the branches. Leaves $2^{\prime}-3^{\prime} \operatorname{long}, 1^{\prime \prime}-2^{\prime \prime}$ wide. Involueres seattered.

3. E. Curtisii, Engelm. Snıoth; stems filiform; branches mostly 3 , ereet, sparingly divided; leaves thin, linear or linear-oblong, obtuse, short-petioled, spreading or recurved; involueres minute, seattered, on long eapillary pedicels; glands green, nıargined by the white erenate appendages; capsule erect, short-stalked, round-angled; seed globose, smooth.-Low pine barrens, Florida to North Carolina. Aug. - Plant $6^{\prime}-9^{\prime}$ high, sometimes branching from the base. Leaves $\frac{1}{2}^{\prime}-1 \frac{1}{2}^{\prime}$ long.

$+\leftarrow$ Glands of the involucre 5, without appendages.

+ Annuals.

4. E. commutata, Engelm. Smooth; stems erect or ascending, umbellately or alternately branehed; leaves thin, obovate, entire, the lower ones petioled, those of the branches round-kidney-shaped, sessile; involucres nearly sessile, shorter than the floral leaves; glands crescent-shaped or 2-horned; capsule smooth, round-angled; seeds oroid, pitted. - Dry soil, Aspalaga, Florida, and probably elsewhere, previonsly confounded with E. Peplus, $L$, which has a wing-erested capsule. - Stem $6^{\prime}-12^{\prime}$ high. Leaves $\frac{1^{\prime}}{2}-1^{\prime}$ long. Plant pale green.

5. E. obtusata, Pursh. Smooth; stem erect; branches 3-5; leaves sessile, serrulate, obtuse; those of the stem wedge-oblong, of the branches ovate; involucre nearly sessile; glands oval; capsule round-angled, warty; seeds smooth. (E. Helioscopia, Ell.?) - Shady woods, South Carvinia, aud northward. July - Sept. - Stem $1^{\circ}$ high. Leaves $1^{\prime}$ long.

\section{« Perennials.}

6 E. Darlingtonii, Gray. Stem tall; branches 5-8, forking; leaves entire, slightly pubescent beneath; those of the stem oblong, of the branches oval or roundish, obtuse, truneate at the base; involueres nearly sessile; glands obliquely oval, capsule obseurely warty; seeds smooth. - Mountains of North Carolina, and northward. July. - Sten $2^{\circ}-4^{\circ}$ high.

7. E. Floridana, n. sp Smooth; stem erect; branches 3-4, forking; leaves entire, sessile; those of the stem linear or linear-lanceolate, mostly acute, reflexed ; of the branches cordate-ovate, clasping, acute ; involucres short-pedieelled, green, with the ovate lobes nearly entire, much shorter than the truncate crenate stalked glands; eapsule acute-angled, and, like the seed; smooth. - Dry 
fine harrens, Middle Florila. June $-\Lambda$ nge - Stem $1^{\circ}-2^{\circ}$ highl. Branches of the more sterike plants successively forking and widely spreading. Leaves $1^{\prime}-2$ ' long.

8. E. inundata, Torr. Smonth; $\mathrm{st} \mathrm{sm}$ ereet, 3-hranched or alternately brancherl from mear the base, few-flowerel; leaves erect, lancolate, entire, acute, sessike; thuse of the branches oblong-ovate, clispping ; involuere long-peduncled, redilish, the pubesecnt lobes 3-toothed ; glauds orbicular, peltate, entire; capsules acute-angled, smootl, like the globose seed. - L'ine-harren swamps, Florida. April-June. - Stems $6^{\prime}-12^{\prime}$ high, from a thick woody root. Leaves $2^{\prime}-3^{\prime}$ long.

9. E. telephioides, n. sp. Smooth and somewhat fleshy : stem thick; branches 3 , short, forking; leaves of the stem large, oblong-obovate, obtuse, ereet, with membranaceous margins; those of the brauches small, ovate, clasping ; involucre purple, slenier-stalked, the lobes ovate, entire, ciliate, incurved; glands peltate, roundish, entire; cupsule acute-angled, smooth : seeds smooth. Low sandy pine harrens near the coast, West Florida. May and June. - Plant light-green, $2^{\prime}-5^{\prime}$ lighli. Stem-leaves $2^{\prime}-3^{\prime}$ long, often longer than the branches. Floral leaves $4 "-6$ " long.

* * Stem erect, successirely forking : leaves commonly opposite : involucres in the forks dark purple: glands 5, without appendages : perennials.

10. E. Ipecacuanhæ, L. Stems several from a long perpendienlar root, slender, commonly forking from near the base; leares of the stem and branehes similar, opposite, or the lowest rarely alternate, entire, obtuse, varying from linear to round-obovate, short-petioled; pedincles slender, mostly longer than the leaves; involucre small; eapsnle slender-stalked, nodkling, round-angled; seeds minutely pitted. - I)y samly soil, Florida to Mississippi, and northward. May and June. - Stem $2^{\prime}-12^{\prime}$ high. Leaves $\frac{1}{2}^{\prime}-1^{\prime}$ long.

11. E. nudicaulis, n. sp. Simooth; stems slender, forking above; leaves minute ( $\frac{1}{2}$ "long), oval or obovate, the lowest alternate, those of the branches opposite; involueres minute, on short peduneles; glands top-shaned. - Low pine barrens, near St. Joseph's, West Flurida. June. - Stems $1^{\circ}$ high. Capsule and seeds unknown.

*** Branches and leaves alternate: involucres terminal, clustered or single: glands without appendages.

12. E. cyathophora, Jacq. Anmual, smootlı; stem creet, branching from the base; lranchies elongated, leafy at the summit; leaves petioled, oblong, fidde-shinped, toothed or entire, the uppermost deep red at the base; involueres elustered, short-stalkel, with 5 incised lobes and a single gland; ('apsule smooth; seeds globose, warty. - Var. graminifolia (E. graminifolia, . Vich. all linear and entire. - South Florida, and around dwellings, applarently introduced. May-Oct. - Stem $1^{\circ}-2^{\circ}$ high. Leaves $2^{\prime}$ long.

13. E. trichotoma, II. B. K. Shrubby; stem irregularly much branched, very leafy; lenves small, imbricated, oblong-obovate, acnte, obscurely crenate, sessile; involucre solitary, top-slıped, sessile ; glands 5 , peltate ; capsule smooth, short-stalked. - South Florida. - Stem low. Leaves $3^{\prime \prime}-4^{\prime \prime}$ long. 
\$2. Leaves stipulate, all oprosite: glands of the involuere 4 : annuals. * Stems erect or ascending: secds 4-angled, transversely rugose.

14. E. hypericifolia, L. Smooth throughout; stem $\left(\frac{1}{2}^{\circ}-1^{\circ}\right.$ high) ereet; branches alternate, 2-ranked; leares $\left(\frac{1}{2}-1^{\prime}\right.$ long) petioled, lanceolate-oblong, oblique and obtuse or acute at the base, equally serrulate on both margins; stipules reflexed; invohneres in dense lateral long-peduncled cymose clusters; appendages of the glands white, kidney-shaped; eapsules rather acntely angled, smooth; seed minute, reddish. - South Florida. - Var. consurss, Engelm. Stem often pubescent, ascending $\left(1^{\circ}-1 \frac{1}{2}^{\circ}\right.$ ligh $)$; leaves oblong or lanceulate, obtuse or cordate at the base, often blotched with red, sharply serrate on the lower margin, entire below the middle on the upper; clusters terminal; appendages of the glands rounded, entire; capsule round-angled, smooth ; seeds larger, nearly black. - Cultivated grounds, Florida and northward. Aug. and Sept.

15. E. pubentissima, Michx. "Perennial, ereet, very pubescent; stem somewhat dichotomous; leaves opposite, sessile, oval, slightly cordate, obtuse; peduncles solitary; interior segments of the involuere (glands) white." Michaux. - "Pine barrens in the mildle districts of Georgia and Carolina. Leaves nearly $\mathrm{l}^{\prime}$ long. Flowers in the forks; peduneles nearly as long as the leaf." Elliott. (*)

16. E. glabella, Swartz? Stem stout, smooth, ascending, alternately branching or forking from the base, purple; leaves very numerous, somewhat fleshy, nearly sessile, oblong-orate, cordate, acute, entire, with the margins invoInte, the uppermost crowded ; involucres in dense terminal elusters ; glands peltate, orbicular, bordered by a white appendage; eapsule smooth, acute-angled; seed bluish, faintly rugose. - Sandy sea-shore, South Florida. - Stem $1^{\circ}$ high. Leares $3^{\prime \prime}-5^{\prime \prime}$ long. Stipules fringed.

17. E. pilulifera, L. Pubescent; stem ereet, forking from the base; leaves short-petioled, ohlong-ovate, oblique, acute at each end, serrate; involucres minute, in dense terminal short-stalked clusters; glands without appen. dages; capsule acute-angled, hairy; seeds faintly rugose. - South Florida. Stem $4^{\prime}-6^{\prime}$ ligh. Leaves $5^{\prime \prime}-8^{\prime \prime}$ long.

* * Stems prostrate, diffuse: leaves small: inwolucres small and mostly crouded near the summit of the branches.

18. E. maculata, L. Pubescent; leaves oblong, serrate, obliqne at the base, petioled, often blotched with purple; stipules 2-parted; capsule aeuteangled, hairy; appendages of the glands transversely oblong, white; seed 4angled, smooth, faintly wrinkled or pitted on the concave sides. (E. depressa, Torr.) - Cultirated ground and waste places, very common. June-Oct. Stens $6^{\prime}-12^{\prime}$ long. Leaves $3^{\prime \prime}-4^{\prime \prime}$ long.

19. E. inæquilatera, Sonder. Smooth; leaves oval or obovate, oblique and acute or obtuse at the base, obscurely serrulate, petioled; stipules ovate, entire or sparingly short-fringed; appendages of the glands white, transversely oblong; capsule smooth, acute-angled; seed 4-angled, granular-roughened and faintly wrinkled on the sides. - South Florida. May-Oct. - Stems 6'-12' long. Leares $2^{\prime \prime}-5^{\prime \prime}$ lung. 
20. E. cordifolia, Iill. Smooth; leaves petioled, oval or roumlish, entire, obtuse, cordate or truncate und oblique at the batse; stipules slender, decply parted into long capillary segrnents; appendages of the glands conspicuous, oblong or roundish, white; cupsule smooth, acute-ingled ; sced 4-ingrled, smouth and even. - Sandy pine barrens, Florida to south Carolina, and westward. July - Sept. - Stems $6^{\prime}-18^{\prime}$ long. Leaves $4^{\prime \prime}-6^{\prime \prime}$ long, pale green.

21. E. polygonifolia, L. Smooth and somewhat fleshy; leaves oblong or linear-oblong, cntire, oblique, obtuse or sliphty cordate at the base, petioled; stipules ly pairs, 2-3-parted ; glands of the involucre slightly margined by the narrow appendages, rather slorter than the subulate olstuse lobes; capsule smooth, acute-ingled; seed large, ohovate, not angled, smooth and even. Drifting sands along the coast, Florida, and northward. July-Oct - Stems $4^{\prime}-12^{\prime}$ long. Leaves $\frac{1^{\prime}}{2}$ long. Involueres densely bearded withiu. Seed whitish.

\section{HIPPOMANE, I.}

Flowers monocions, apetalous, in thick cylindrient spikes. Sterilo flowers clustered in the axil of a broad entire bract. Calyx top-shaped, 2-lobed. Stameus 2, exserted: anther-cells separate. Fertile flower solitary at the base of the spike. Calyx 3-parted, many-bractel. Orary sessile, 6-7-eclled. Style short and thick: stigmas $6-7$, acute, spreading. Fruit fleslyy, of few woody 1-seeded indehiscent carpels. $-\Lambda$ small tree, with milky poisonous juice, and short and thick branelies. Leaves alternate, stipulate, petioled, ovate, serrulate, acute or acuminate, smooth, approximate at the summit of the branches. Petioles biglandular at the apex. Spikes greenish.

1. H. Mancinella, L. - South Florida. - Branehes roughened with the scars of the decidnons leaves. Leaves $1^{\prime}-2^{\prime}$ long. Spikes $2^{\prime}$ long, terminal, solitary. Clnsters of flowers with a gland-like bract ou each side. Frut resembles an apple.

\section{STILLINGIA, Gard.}

Flowers monoecious, apetalous, spiked. Sterile flowers elustered, cup-shaped, $2-4$-toothed or erenate. Stamens $2-3$, exserted : anthers erect. Fertile flowers few at the base of the spike. Calyx 3-lobed. Style short : stıgmas 3, entire, spreading. Capsule roundish, of three 1-celled 1-seeded 2-valved carpels. Smootls herbs, shrubs, or trees, with milky juce. Leaves alternate, stipulate. Bracts with a fleslyy gland on each side.

1. S. Sylvatica, L. (Queen's Delicur) Iterbaceous; stems clustered, erect or ascending from a thick wooly root, umbellately branched : leaves sonewhat crowded, nearly sessile, thickish, varying from linear lancelate to obovate, obtuse or acute, crenate-serrulate; spikes yellowish, terminal, and in the forks of the stem, longer than the leaves; glands cup-shaped; stamens 2. eapsule roughish; seed globose. - Yight dry soil, Florida to North Carolina, and westward. April-Sept. - Stems $1^{\circ}-3^{\circ}$ lughl. Leares $1^{\prime}-2^{\prime}$ long. Spukes $2^{\prime}-3$ long. 
2. S. aquatica, n. sp. Shrubby; stem single, ereet fiom a fibrous spongy root, unbellately or alternately branched above, thickened near the base; leaves lanceolate, mostly aeute, tapering at each end, short-petioled, sharply serrulate, the uppermost yellowish; stipules bristly; spikes mostly slorter than the leaves, terminal and in the forks of the stem; glauds peltate; stamens 2; capsule smooth ; seels globose, pitted, silvery-coated. - Pine-barren ponds, Florida to South Carolina. May - Sept. - Stem $3^{\circ}-6^{\circ}$ high. Leaves $2^{\prime}-4^{\prime}$ long.

3. S. ligustrina, Miehx. Shrubby; branches alteruate, slender; leaves petioled, ovate-laneeolate or oblong-ovate, mostly obtuse, narrowed at the base, entire; stipules ovate; spikes short, often by pairs, shorter than the leaves, lateral and terminal ; stamens 3 ; eapsule and oval seed smooth. - River-swamps, Florida to North Carolina, and westward. May-Aug. - Duruu $6^{\circ}-12^{\circ}$ bigl. Branches spreading. Leaves $\mathbf{I}^{\prime}-3^{\prime}$ long.

4. S. sebifera, Mielıx. Arborescent; leaves long-petioled, rhomboidal, aeuminate, entire; spikes terminal, densely flowered ; sterile flower's pedicelled; calyx t-toothed; stamens 2; capsule roughish; seeds white.-Georgia and South Carolina, near the coast; introduced from China. June and July. $-\mathbf{A}$ tree $20^{\circ}-40^{\circ}$ high.

\section{EXCOEARIA, I.}

Flowers monœeions or diceious, apetalous. Sterile flowers in eylindrical spikes, sessile. Calyx 3-parted. Stamens 2-4, partly monadelphous: anthers pendulous. Fertile flowers few or solitary at the base of the sterile spike, sessile or peduneled. Calyx 3-sepalous; style 3-parted: stigmas entire, spreading. Capsule of three 1-eelled, 1-seeded, 2-valved earpels. - Shrubs or trees, with milky juice, and alternate serrate or erenate leaves.

1. E. lucida, Swartz. Smooth; leaves coriaceous, pctioled, obovate or oblong, obtuse or emarginate, crenate; fertile flowers solitary or by pairs, longpeduneled, nodding; eapsule round-angled, smooth, like the ovoid seed. - South Florida. - Tree $30^{\circ}-40^{\circ}$ high. Leaves $1^{\prime}-1 \frac{1}{2}{ }^{\prime}$ long.

\section{ACALYPHA, L.}

Flowers monœeious, apetalous, in axillary and terminal spikes. Staminate flowers clustered, minutely braeted. Calyx 4-parted. Stamens 8-16, with the filaments unitel at the base; anthers pendulous. Pistillate flowers at the base of the staminate ones, or on separate spikes, surrounded by a leafy toothed bract. Calyx 3-parted. Styles 3, many-cleft. Capsule roundish, of three 1-celled, 1-seeded, 2-valved carpels. - Herbs, with watery juice, and alternate serrate leaves.

* Staminate and pistillate flowers on the same spike.

1. A. Virginica, L. Annual, smoothish or hairy ; stem ereet, branehed; leaves thin, long-petioled, rhombie-ovate or oblong-ovate, acute, coarsely serrate above the middle; staminate spikes few-flowered, mostly shorter than the large 5-9-lobed bracts, with $1-3$ pistillate flowers at the base ; eapsule pubeseent. - 
Fields and around dwellinge, Florida, and northward. July - Sept. - Stem $10-20$ high. Leaves, witlı tle petiole, $4^{\prime}-5^{\prime}$ long.

2. A. gracilens, (iray. Amual, downy ; stem slemder, erect or ascending; leaves slort-petioled, lanceolate, ohseurcly serrate or entire; staminate spikes mostly many-flowered and louger than the ovate-serrate or toothed loracts, with $1-3$ pistillate flowers at the base; capsule laairy. - Sterile soil, Florida, and northward. July - Sept. - Stem $6^{\prime}-18^{\prime}$ high. Leaves $1^{\prime}-1 \frac{1^{\prime}}{2}$ long.

3. A. corchorifolia, Willd. Peremnial; stems several from a thick and woody root, prostrate, pulescent, simple or sparingly loranclied; leaves shortpetioled, ovate and oblong, obtuse, crenate, hairy ; pistillate flowers numerous, crowded at the base of the slender staminate spike, each surrounded by a roumd-ovate hairy toothed bract; causule bristly; seed ovoid, smonth. - South Florida. - Stems $4^{\prime}-6^{\prime}$ long. Leaves rigid, $6^{\prime \prime}-8^{\prime \prime}$ long. Spikes mostly terminal.

$$
\text { * * Staminate and pistillate flowers on separate spikes. }
$$

4. A. Caroliniana, Walt. Annual; stem ereet, much branched, pubes('ent; leaves thin, smooth, corlate-ovate, sharply serrate, Jong-petioled; staminate spike lateral, small, the minute white flowers pedieelled; pistillate spike terminal, stout, many-flowered; bracts cut into several subulate lobes; eapsule bristly; seeds silvery, pitted. - Cultivated ground, Florida to Mississippi, and northward. July - Sept. - Sten $1^{\circ}-2^{\circ}$ light. Leaves $2^{\prime}-3^{\prime}$ long.

\section{TRAGIA, Plım.}

Flowers monœeious, apetalous, in slender racemes. Sterile flowers few or numerous, caducous. Calyx 3-4-parted. Stanens 2-4, with short and separate filaments. Fertile flowers few or solitary at the base of the raceme. Calyx 5-8-parted. Style 3-cleft: stigmas entire. Capsule bristly, of three globose l-celled, l-seeded, 2-valved carpels. - Pubeseent or bristly herbs, with watery juice. Leaves alternate. Racemes opposite the leaves and termual. Bracts small, entire, persistent. Flowers minute, greenish.

1. T. urens, I. Low, downy or hairy; stem at length much branched; leaves nearly sessile, varying from loroadly ovate or oblong-ovate, and serrate or toothed throurhont, or only at the apex, to linear and entire, obtuse, paler beneath; racemes shorter than the leaves and few-flowered, or clongated and many-flowered. ('T. linearifolia, Ell., the narrow-leaved form.) - Dry sandy soil, Florida, and nortlward. May-Aug. 4-Stem 6'-12' high. Leaves $1^{\prime}-2^{\prime}$ long.

2. T. urticifolia, Michx. Bristly, with stinging hairs, stem erect, sparingly branched; leaves petioled, deltoid-ovate or ollong, coarsely serrate, truncate or cordate at the broad base, pale beneath, racemes shorter than the leaves, the sterile flowers somewhat crowded; capsule very bristly - Dry soil, Florida to North Carolina, and westward. June-Sept. 4-Stems $1^{\circ}-2^{\circ}$ high Leaves $1^{\prime}-2$ ' long. 


\section{CROTON, I.}

Flowers monœcions, in spikes or racemes. Calyx of the sterile flowers 4-6. cleft or $4-6$-parted. Petals $4-6$ (wanting in No. 1). Stamens $5-20$, distinct : anthers erect, introrse. Glands as many as the calyx-lobes and opposite them. Fertile flowers at the base of the sterile spike. Calyx 5-8-cleft or 5-8-parted. Petals minute or wanting. Styles $2-3$, once-thrice 2-cleft. Capsule of 3 (rarely $1-2$ ) 1-celled, 1 -seeded, 2-valved carpels. Glands as many as the calyxlobes or none. - Herbs or shrubs, with watery juice, stellate pubeseence, and alternate petioled leaves. Flowers terminal, and at the divisions of the stem.

* Styles very short: stigmas 18-20: petals none: stamens mostly 12: capsule 3-celled.

1. C. maritimum, Walt Herbaceous; whole plant covered with a rough scurfy stellate and somewhat hoary pubescence; stem stout, bushy, umbellately branched; leaves thick, long.petioled, ovate, obtuse, entire, rounded or slightly cordate at the base, hoary beneath; spikes long-peduncled, capitate, few-flowered, the sterile and fertile ones mostly separate; calyx 5-cleft, with orate-obtuse lobes; capsule much longer than the calyx; seeds oroid, mottled. - Drifting sands along the coast. Florida to North Carolina. July - Oct. - Stem $2^{\circ}-3^{\circ}$ high. Leaves $2^{\prime}-3^{\prime}$ long. Flowers oecasionally polygamous.

* * Styles 3, twice 2-parted or 2-cleft: stigmas 12: petals of the sterile flowers 5-6, of the fertile none: stamens 8-15: capsule 3-celled.

2. C. balsamiferum, Willd. Shrubby; stem smooth, whitish; branches stellate-pubescent, ronghish; leaves slender-petioled, ovate, acute, crenulate, sprinkled with rigid stellate hairs, hoary when young; spikes woolly, at length elongated; sterile flowers numerous, the fertile ones few; calyx of the sterile flower 5-parted, longer than the woolly-margined petals; style twice 2-parted; the divisions long, filiform; stamens about 15; capsule much longer than the calyx; seed oroid, smooth. - South Florida. - Shrub $1^{\circ}-2^{\circ}$ high. Leares thin, $1^{\prime}-1 \frac{1}{2}$ ' long.

3. C. Elliottii. Annual, stellate-tomentose thronghout; stem slender, erect, umbellately much branched; leaves short-petioled, lanceolate or oblong, entire, obtuse at each end, green above, pale beneath, the lowest scattered, the others mostly crowded at the divisions of the stem and summit of the branches; sterile flowers few, minute; calyx 5-parted, unequal, longer than the petals; stamens 8-10; fertile flowers several, clustered; calyx 5-8-parted, with oblong obtuse lobes, as long as the capsule; style twice 2-parted; seeds oval, smooth, flattener on the inner face. (C. elliptieum, Ell.) - Pine barrens, Florida to South Carolina. July - Sept. - Stem $2^{\circ}-3^{\circ}$ high. Leaves $1 \frac{1}{2}^{\prime}-2^{\prime}$ long.

4. C. argyranthemum, Mieldx. Herbaceous, perennial, covered througlout with stellate silvery seales; stem erect, umbellately branched; leaves obovate or oblong, obtuse, entire, silvery beneath, narrowed into a petiole; racemes sessile, oblong, obtuse; the fertile flowers numerous and crowded; calyx $5-6$. parted, with the lobes acute; stamens 10-12, hary, styles long and slencier, 4-cleft at the apex; capsule much longer than the calyx - Dry sandy pine 
laurens, Grorgia and Flotida. June-Sept. - Stem $6^{\prime}-12^{\prime}$ high. Leares 1'- 1! long.

* * * Styles 3, 2-cleft: stigmas 6 : petals of the sterile flowers longer than the calyx, of the fertile ones minute, sutulate: stamens 8: copsule 3-celled.

5. C. glandulosum, L. Annual, rongly with bristly hairs; stem umbellately brancheal ; leares oblong, ohtuse, coursely serrate, mostly croweled at the divisions of the stem mol summit of the branches; the slender petiole biglandular at the apex; spikes small; sterile flowers minute, white; calyx 4-parted; petals 4 ; furtile flowers few, with the calyx 5-parted - I)ry waste places, Florida to North Carolina, and westward. Ju'y - Sept. - Stem 6' - $18^{\prime}$ high.

**** Styles 2, 2-parted: stigmas 4: petals 5 in the sterile flowers, none in the fertile: stamens 5-10: copsule 1 - 2-rellcd.

6. C. monanthogynum, Michx. Annual; stem erect, twice or thrice umbellately branched, the spreading forking branches, like the leaves and meemes, stellate-tomentose; leaves on slender petioles, ovate or oblong, entire, obtuse, whitish beneath; racemes in the forks of the hranches, few-flowered; the sterile flowers corymbose; the fertile (1-2) nodding. - Dry sterile soil, South Florida to North Carolina. June-Sept. - Stem $1^{\circ}$ hight. Leaves $1^{\prime}$ long.

\section{CROTONOPSIS, Michx.}

Flowers monœcious, in terminal and axillary clusters. Calyx of the sterile flowers 5-parted. Petals and stamens 5. Filaments separate, dilated upward. Fertile flowers below the sterile. Calyx 3-5-parted. I'etals none. P'etal-like glands 5, opposite the calyx-lobes. Ovary 1-eelled, 1-ovuled. Stigmas 3, each 2-cleft. Fruit glohose, indehiscent, 1-seederl. - A low and slender branelning annual. Leaves linear or lanceolate, short-petioled, entire, green and hairy ahove, the lower surface, like the branches, covered with silvery seales. Flowers minute.

1. C. linearis, Michx. - Dry sandy soil, Florida to North Carolina. A isg. - Sept. - Stem $6^{\prime}-12^{\prime}$ high, alternately branched or forking. Leaves $\frac{1}{2}-1^{\prime}$ long, alternate or opposite.

\section{APHORA, Nutt.}

Flowers monocious, in axillary spikes. Sterile flowers few, Calyx 5-parted. Corolla of 5 spatulate petals alternating with 5 flattened glands, as long as the calyx. Stamens $10-12$, in 2 whorls of 5-6 each, monadelphous below. Fertile flowers like the sterile, but the petals shorter than the ealyx. Style 3-parted, the divisions 2-cleft. Capsule of three 1-celled, 1-sceded, 2-valved carpels. Shrubs, or lıerls, with watery juice.

l. A. Blodgettii, Torr. Branches smonthish; leares alternate, oval or oblong, mostly acute, sharply sermalate, smooth, or sprinkled with simple appressed hairs, abruptly short-petioled; sterile thuwers $3-5$, fertile mostly solitary ; 
calyx-lobes lanceolate, acute; petals greenish-white; capsule rough-hairy; seed globose, wrinkled. - South Florida. - Shrub $1^{\circ}-2^{\circ}$ high. Leaves $1^{\prime}-2^{\prime}$ long.

\section{CNIDOSCOLUS, Pohl.}

Flowers monceious, apetalous, cymose. Calyx corolla-like. Calyx of the sterile flower salver-shaped, 5-lobed. Stamens 10, the 5 inner ones with monadelphous filaments. Fertile flowers intermingled with the sterile ones. Calyx of 5 sepals, convolute in the bud. Styles 3, many-parted. Capsule of three 1-celled, 1-seeded, 2-valved carpels. - Herbs or shrubs, with alternate leaves, and white flowers.

I. C. stimulosus, Gray. Herbaceous, bristly with stinging hairs; stem erect, simple or branched; leaves long-petioled, rouncl-cordate in outline, palmately 3-5-lobed or parted, the divisions toothed, pinnatifid, or somewhat bipinnatifid, often discolored; calyx showy; capsule oblong; seed oblong, smooth, spotted. (Iatropha stimulosa, Michx.) - Dry pine barrens, Florida to North Carolina. April - Sept. 4 -Stem $\frac{10}{2}-20$ high. Flowers sometimes diceious.

\section{Ricinus, Tourn. Castor-oil Plaxt.}

Flowers monœcious, apetalous, in a dense oblong panicle, the upper ones fertile. Calyx 3-5-parted. Corolla none. Stamens numerous; the filaments much branched: anther-cells distinct, pendulous. Styles 3, 2-parted. Capsule spiny or bristly, of 3 oblong 1-celled, 1-seeded, 2-valved carpels. - Herbs, or (tropical) shrubs or trees, with petioled peltate lobed leaves. Panicles lateral and terminal.

1. R. communis, L. Stem large, glaucous; leaves orbicular in outline, palmately 7-9-lobed; the lobes oblong or ovate, acuminate, unequally serrate, smooth; petioles glandular; panicles in the forks of the stem, and opposite the leaves, dense, glaucous. Capsules oblong, spiny. - Waste places. Introduced. June-Oct. (1) - Stem $3^{\circ}-10^{\circ}$ high. Leaves $1^{\circ}$ in diameter. Stipules large, deciduous. Panicle $6^{\prime}-12^{\prime}$ long.

\section{PHYLLANTHUS, Swartz.}

Flowers monœcious, apetalous, axillary. Calyx 5-6-parted. Stamens 3, monadelphons. Glands 5-6. Ovary 3-celled, with two ovules in each cell. Styles 3, 2-cleft. Capsule globose, of three 1-celled, 2-seeded, 2-valved carpels. - Smooth herbs, with 2-ranked leaves and branches. Flowers small, greenish.

1. P. Carolinensis, Walt. Annual; branches erect-spreading; leares ohlong, oval, or ohovate, entire, short-petioled; flowers mostly by pairs, one sterile, the other fertile, on short nodding pedicels; calyx 6-partal, the lobes oblong, obtuse, strongly l-nerred, membranous on the margins; capsule smooth; seed semicireular, 3-angled, striped with lines of uninute raised points - Low ground, Florida, and northward. Aug. - Sept. - Stem $8^{\prime}-16^{\prime}$ higl. Leaves $\frac{1}{2}-1^{\prime}$ long. 
2. P. Niruri, L. Annual? luandhes short, very slender, recorved ; leaves (rowiled, oval (2" 4 " long); calyx 5-partel; seed white, smooth, 6-furrowed on the back and 3-furrowed on the sudes; otherwise mostly like No. 1. - South Florid:ı. - Stem $6^{\prime}$ highl.

\section{PACHYSANDRA, Michx.}

Flowers monocions, apetalons, spiked. Culyx bract-like, 4-parted. Sterile flowers numerons. Stamens 4, with elub-shuped exserted filanents. Fertile flowers few, at the base of the sterile spike. Ovary 3-eelled, with two ovules in cach cell. Styles 3, thick, recurved. Capsule of three I-cellerl, 2-seeded, 2-valved carpels. - A pubescent erecping perennial herl), with erect simple branches, bearing at the summit several large ovate toothed alternate abruptly long-petioled leares, and near the base several thick bracted spikes.

1. P. procumbens, Michx. - West Florida, and westwarl, in rich shady woods. Feb. and March. - Flowering stems $1^{\circ}$ high. Leares $3^{\prime}-4^{\prime}$ long, often discolored. Flowers odorous.

\section{DRYPETES, Valsl.}

Flowers diecious, apetalous, in axillary clusters. Calyx 4-6-parted, lined in the centre with a wavy-lohed di.k. Stamens $4-10$, inserted under the disk: anther-cells distinet. Ovary resting upon the disk, 2-celled, the cells 2-ovuled. Styles 2, short, spreading. Fruit drupaceous, 1-2-celled, 1-2-sceled. - Tropical trees or shruhs, with alternate coriaccous entire smooth petioled leaves, and minute inany-bracted flowers.

1. D. crocea, Poit. Branches smooth; leaves oblong, acute at each end, somewhat coriaccous, finely veined; elusters many-fluwered, slorter than the petioles; calyx 4-parted, and like the ovary and slightly 4-angled l-secded drupe, tomentose ; stamens 4, exserted; styles thick, obtuse. South Florida. - A small tree. Lcaves $3^{\prime}-t^{\prime}$ long, smooth and slining. Flowers greenish-white.

2. D. glauca, Tahl. Branches whitish, warty; leaves glaucons, oblong, obtuse or gland-pointed, coriaccous; clusters few-flowered, as long as the petioles; calyx 5-parted; stamens 10 ; drupes oval, tomentose. - South Florida, Dr. Blodgett. - Leaves $2^{\prime}-3^{\prime}$ long.

Euplorbia Ihtmyres and saromata, Dr. Curtis informs me, are naturalized in North Carolina, and Mereurials Axxua is spontancous around Charleston.

\section{Order 120. EMPETRACEE. (Crowberty Famly.)}

Shrubs. with evergreen linear alternate or whorled leaves, without stipules, and small dinecious or polygamous flowers. - Calyx bract-like, of $2-3$ sepals, imbricated. Corolla of $2-3$ petals similar to the calyx, hypogynous. Stamens $2-3$, alternate with the petals, exserted: anthers 
2-celled, extrorse. Ovary 2-9-celled, the cells 1-oruled. Style short or none: stigma lobed or incised. Drupe berry-like, globose, of $2-9$ oneseeded nutlets. Seeds ereet. Embryo in the axis of copions fleshy albumen.

\section{CERATIOLA, Michx.}

Calyx bracted, of two fringed sepals. Corolla 2-petalled. Stamens 2: anther-cells globose. Ovary resting on a fleshy disk, 2-celled, 2-ovuler. Style short: stigma many-cleft. Drupe 2 -seeded. - A heath-like erect verticillately much branched slurub, with small linear shining whorled leaves, and axillary (whorled) reddish flowers.

1. C. ericoides, Michx. Dry barren sands, Florida to South Carolina. November. - Shrub $2^{\circ}-5^{\circ}$ high, the young lranches pubescent. Leaves 3 in a whorl, $4^{\prime \prime}-6^{\prime \prime}$ long, the margins revolute. Petioles yellowish, appressed. Drupe yellowish, somewhat persistent.

\section{Order 121. BATIDACEA. (Batis Famis.)}

Represented only" by

\section{BATIS, P. Browne.}

Flowers diœecious, in axillary fleshy conical spikes. Bracts of the sterile flowers round-cordate, persistent. Calyx cup-shaped, somewhat compressed, unequally 2-lipped. Petals 4, rhombic-ovate, clawed. Stamens 4, alternate with the petals, partly exserted: anthers oblong, introrse. Fertile flowers consolidated. Braets deciduous. Calyx and corolla none. Ovary 4-celled, with a single ereet anatropous orule in each cell. Stigma sessile, broad, obseurely 2-lobed. Drupe 4-seeded. Seed oblong, without albumen. Cotyledons flesly. Radicle inferior. - A smooth maritime shruh, with the habit of Salicornia. Leaves opposite, fleshy, club-shaped, semi-terete. Stipules none. Petals white.

1. B. maritima, L.- Salt marshes, Apalachicola, and southwarl. JuneSept. - Plant pale green, strong-scented. Stems prostrate, $2^{\circ}-3^{\circ}$ long, the short branching flowering stems erect. Leaves 1 l long. Spikes $3^{\prime \prime}-5$ "l long.

\section{Order 122. URT ICACEA. (Nettle Fanuly.)}

Herbs, with watery juice, often armed with stinging hairs. Leaves undivided, stipulate. Flowers monœcious or diøecious, apetalous, clustered, eymose, spiked, or panicled. - Calyx of the sterile flower 4-5-parted or $4-5$-sepalous. Stamens as many as and opposite the sepals. Filaments inflexed in the bud, expanding elastically: anthers 2-celled, introrse. Calyx of the fertile flower $2-4$-sepalous. Ovary sessile, free, 1-celled, 
with a single crect orthotropens ovole. Stigma simple or tufted. Ache-

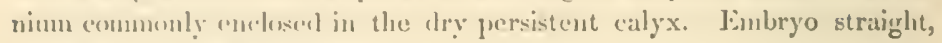
in the axis of the-lyy allumen.

\section{Syuopsis.}

* Plnnts armed with stinging latirs.

1. Ulitict. Stamens 4. Stigma tufted. Acheninm straght.

2. LAPOLTEA. Slamens 5. Stigma subulate. Arfruium ohlique.

* I'lints destituto of stinging hairs.

- Flowers in cymose elusters.

3. PII.F.l. Clusters naked. ('alyx-lobes unequal. Leaves opposite.

4. 1.iRIFTARIA. ("lusters involucrate. Calyx-lobes equal. Leaves alternate.

- Flowers in spiked clusters.

6. BomitiriA. Stigmas subulate, leaves opposite or alteruate.

\section{URTICA, Tourn. Nittı..}

Flowers monacions or dixcions. Calyx of the sterile flower 4-parted. Stamens 4, inserted around the ahortive orary. Calyx of the fertile flower 4-sepatlous, unequal; the inner ones dilated in frnit, aus cuclosiug the arhenimu. Stigma sessile, tufred. Achenium straight, ovale, smooth, ('ompressed. - Herls, with stinging hairs, opposite leaves, and greeni-h flowers, in panicled spikes or close chisters.

\section{* Fiowers in panicled or simple spilies.}

1. U. gracilis, Ait. Stem tall, 4-angled, smoothish, slender; leaves longpetioled, ovilte-lanecolate, coarscly serrate, acute, rounded at the base, 3-5nerved, smoothish, the petioles bristly; spikes very slender, loosely panicled. (L. procera, Willd.) - Low ground in the upper districts, and northward. July and Aurg. $4-$ Stem $3^{\circ}-4^{\circ}$ hitgh, mostly simple. Leaves thin, $4^{\prime}-6^{\prime}$ long.

2. U. dioica, L. Hispil throughont; stem 4-angler, puhescent abore, brancling ; leaves rather slont-petioled, ovate, corlate, acuminate, coarsely serrate, pulescent beneath; spikes much branched; flowers often dicecious. Waste places. In Carolina, Pursh. Introduced. June-Aug. 4-Stem $2^{\circ}-$ $3^{\circ}$ ligh. Leaves $3^{\prime}-4^{\prime}$ long, thicker than in No. 1, and flowers larger.

3. U. capitata, Willd. Stem 4-angled, roughish; leaves large, longpetioled, rough, oblong-ovate, sliglitly cordate, coarsely scrate, 3-nerved; thoso on the branches alternate; spike solitary, leafy at the summir. - VTet shaded jliares, North and South Carolina, Curtis, Elliott. July ant Aur. - Stem $3^{\circ}-$ 50 high.

$$
\text { * * Foucers in simple clusters shorter than the petioles. }
$$

4. U. urens, L. Stem 4-angled, hairy; leares ovate, coarsely serrate, 5-nerved, hairy; (lusters by pairs in each axil, loose, peduneled. - Damp soil. Introdnced. Dee, $-\mathrm{Feb}$. (I - Stem $1^{\circ}$ high.

5. U. Chamædryoides, Pursh. Stem smooth; leaves small, nearly sessile, ovate, coarscly serrate, hairy beneath, hairy and bristly above; elusters nearly sessile, globose, dense; ealyx hairy, - St. Simon's Island, Georgia Elliott. Feb. and March, - Stem $\star^{\prime}-6^{\prime}$ high. 


\section{LAPORTEA, Gaudich.}

Flowers monceious or dicecions. Calyx of the sterile flowers 5-parted. Stamens 5, inserted around the abortive ovary. Calyx of the fertile flowers 4-sepalous, the 2 inner ones larger. Stigma subulate, hairy on one side. Achenium oblique, tubereular-ronghened. - Herbs, with stinging hairs, alternate long-petioled serrate leaves, and minute flowers in spreatling cymes.

1. I. Canadensis, Gaudiclı. Stem hispid; leaves ovate, acuminate, rounded or cordate at the base; the veins and petioles hispid; cymes very slender, single or by pairs, the upper mostly fertile, the lower sterile. (Urtica Canadensis and U. divaricata, L.) - Low shaded places, Florida, and northward. July and Aug. I - Stem $2^{\circ}-4^{\circ}$ bigh.

\section{PILEA, Lindl.}

Flowers monœcions or diœcious. Calyx of the sterile flower 3-4-parted. Stamens 3-4. Calyx of the fertile flowers 3-lobel, the lobes tunequal or nearly equal, commonly with an inflexed seale-like sterile stamen at the base of each. Stigma sessile, tufted. Aclreuium ovate, compressed, straight. - Low herbs, destitute of stinging hairs. Leaves npposite, long-petioled. Flowers in axillary cymose clusters.

1. P. pumila, Gray. Stem angnar, simple, smooth, pellurcid; leaves membranaceous, ovate or elliptieal, acuminate, coarsely serrate, 3-nerved, slightIy hairy abore; cymes much shorter than the petiole. .(Urtica pumila, L.) Wet shaded plaees, Florida, and northward. July-Sept. (1) - Stem $6^{\prime}-12^{\prime}$ high. Upper leaves $1^{\prime}-2^{\prime}$ long, the lower not longer than the petiole.

2. P. herniarioides, Lindl. Stems erect or ereeping, branehed, tender, pellucid ; leaves small, round-obovate, entire, opaque, transversely marked on the upper surface with white raised lines; clnsters shorter than the petiole; flowers minute. - Shader moist places, Key West. November. - Stenıs $2^{\prime}-4^{\prime}$ long. Leaves $1^{\prime \prime}-2^{\prime \prime}$ long, rather longer than the petiole. Achenimn very minute, oblong, terete.

\section{PARIETARIA, Tourn. Pellitory.}

Flowers polygamons, in axillary cymose clnsters, supported by a bract-like involuere. Callyx of the sterile flowers $4-5$-sepalous. Staniens $4-5$, inserted around the abortive ovary. Calyx of the fertile flowers 4-parted. Stigma tufted. Ovary surrounded by four sterile, or sometimes pericet, stamens. \ehenimm ovoid - Weak downy herhs, withont stinging hairs. Leaves alternate, entire, long-petioled. Flowers minute, greenish.

1. P. Pennsylvanica, Muhl. Pubescent with straight hairs; stem simple or sparingly branched; leaves thin, oblong-lanceolate, obtuse, roughened with minute elevated dots; clusters dense; flowers shorter than the involucre. - Shaded roeks in the upper districts. May - July. (1) - Stem $4^{\prime}-12^{\prime}$ high. Leaves $6^{\prime \prime}-9^{\prime \prime}$ long. 
2. P. debilis, loort. Inbesient with straightit and hooked hairs inter. mixed ; stem much loranched, pellucid; leaves osute, mosty aldminate, but

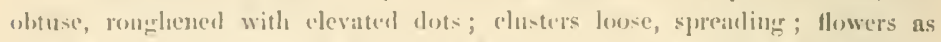

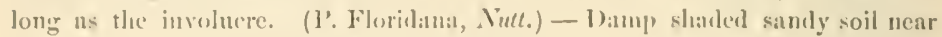

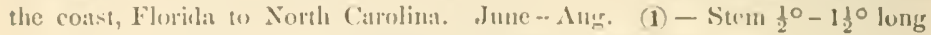
Leaves $6^{\prime \prime}-9^{\prime \prime}$ long, about the lengel of the stemler petiole.

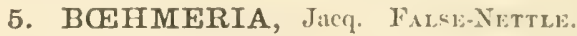

Flowers monacious or rliecions, in spiken rhsters. Culyx of the sterile flowers 4-5-cleft. Stamens 4-5. Calyx of the fertile tlowers tubular, 4-5toother or entire. Stirma subulate, hairy. Achenium elliptical, enclosed in the persistent calyx. - Rongh herlss with alternate or opposite petioled leaves.

1. B. cylindrica, Willd. Pubescent and rough witl straight and hookerl hairs; leaves opposite and altermate, orate and ovate-lanceolate, acuminate, serrate, rommled and 3-nerved at the hase, on long or short petioles; spikes axillary, mostly leafy at the summit, the fertile ones compactly flowered, sliort; the sterile interrupted, and sometimes longer than the leaves. (13. lateriflora, Mhull.) - Swanpy thickets, Florid:a, and northward. July-Sept. I -Stem $1^{\circ}-3^{\circ}$ highl, mostly simple. Leaves $2^{\prime}-5^{\prime}$ long.

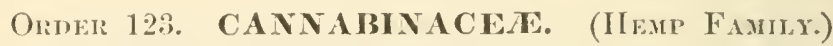

Erevet or twining berbs, with opposite incised or loberl and stipulate leaves, and dicerious flowers. Sterile flowers racemose or panicled. Caby 5-sepalous. Stamens 5, opposite the sepals, not inflexed in the burl. Fertile flowers in bracted spikes. Calyx 1-leaved, embracing the 1-celled ovary. Ovule solitary, erert. Stimmas 2, sululate, pubescent. Fruit indehiscent. Albumen mone. Embryo coiled or eurved.

\section{HUMULUS, I. IIor.}

Sterile flowers panicled. Fertile fowers in short axillary and solitary spikes. Bracts leafy, imbricated, 2-flowered, forming in fruit a membranceous cone. Calyx enlared in fruit. Embryo spirally coilct. - A rongh perennial twining herb, with cordate 3-5-lobed leaves, and greenish-yellow flowers.

1. H. Lupulus, L. - Low grounds along the mountains, Georgia, and northward. June and July. - Stem $6^{\circ}-10^{\circ}$ high. Lcaves petioled, serrate. Achenium eoverel with resinous yellowish odorous grains.

\section{Order 124. MORACEA. (MUlberry Family.)}

Trees or shrubs, with milky juice, alternate leares, with large deciduous stipules, and monccious or direcious flowers, erowded in spikes or 
heads, or enclosed in the fleshy receptacle. - Calyx of the sterile flowers 3-4-loberl. Stamens 3-4, inserted on the base of the calyx. Filaments inflexed in the bud, elastie. Calyx of the fertile flowers $3-5$-sepalous. Ovary 1-2-celled, 1-2-ovuled. Styles 2. Aehenimm 1-seeded. Embryo curved, in fleshy albumen.

\section{MORUS, Tourn. Mulberry.}

Flowers monœcious, spiked; the sterile and fertile flowers in separate spikes. Calyx 4-parted. Stamens 4. Ovary 2-celled. Styles filiform. Achenium ovate, compressed, covered by the suceulent berry-like ealyx. - Trees, with rounded leares, and axillary spikes.

1. M. rubra, L. Leaves cordate-ovate, acuminate, serrate, petioled, rough ahove, white tomentose beneath, on young shoots 3 -5-lobed; stipules linear; sterile spikes slender, drooping; the fertile ones ovoid or oblong, resembling a blackberry in fruit. - Rich woods, Florida, and nortlwwarl. March. - A small tree.

2. M. alba, L. Leaves cordate-ovate, acute, serrate, oblique at the base, smooth and shining, sometimes lobed; fruit whitish. - Around dwellings. Introduced. - A small tree.

\section{FICUS, Tourn. Fig.}

Flowers monœecions or diœcious, lining the insile ot the fleshy closed receptacle. Calyx of the sterile flowers 3-parted. Stameus 3. Calyx of the fertile flowers 5-cleft, pedicelled. Styles lateral, slender. Achenium fragile. Embryo hooked. - Trees or shrubs, with entire or lobed leaves, and large convolute stipules. Flowers axillary.

1. F. aurea, Nutt. Branches pale, smooth, furrowed; leaves smooth, coriaceous, oblong, entire, narrowed but obtuse at eaclı end, stout-petioled; receptacle orange-yellow, globose, bracted, on short and thick pedieels. - South Florida. - A small tree. Leaves $3^{\prime}-4^{\prime}$ long. Fruit about $4^{\prime \prime}$ in diameter.

2. F. pedunculata, Willd. Branebes terete, uneren; leaves ovate or oval, coriaceous, entire, smootls, obtuse, rounded or slightly cordate at the base, slender-petioled; receptacle yellowish, globose or obovate, slightly braeted, as long as the slender pedicels. - South Florida. - Tree $20^{\circ}-40^{\circ}$ high, multiplying by means of aerial roots. Leaves $2^{\prime}-2 \frac{1}{2}^{\prime}$ long, $1 \frac{1^{\prime}}{2}$ wide. Receptacle rather smaller than in No. 1.

3. F. brevifolia, Nutt. Branches smooth; leaves cordate-ovate, entire, obtuse, smooth, on short petioles; receptacle purplish-red, depressed-globose, single, short-peduncled, with 2-cleft bracts. - South Florida, Dr. Blodgett. - A small tree. Leaves 2 long, with impressed veins.

F. CArica, L., is the commonly eultivated Fig.

Broussonetia papyrifera, Vent, the Paper Mulberry of our yards, belongs to this fimily. 


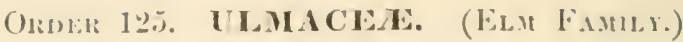

Trees, with watery juine, alteruate mulivided stipulate leaves, and per-

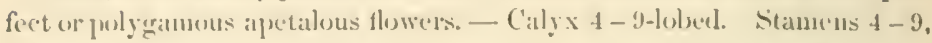
inserted on the base of the calyx, ereet in the bud. ()vary 1-2-enled. Orules solitary, suspended. Styles 2, spreadiner. Fruit membranaceous or chupaceons. Embryo straight or curved, without albuneu. Cotyledons leaty.

\section{Synopsis.}

- Fruit dry. Anthers extrorse.

1. ULMt'S. Flowers perfect. Ovary 2-celled. Fruit wingel.

2. PlAdElid. Flowers polygauons. Ovary 1-eelled. Fruit wingless.

* Fruit a drupe. Anthers introrse.

3. CELTIS. Flowers polygamous. Ovary 1-celled. Cotyledons curved.

\section{ULMUS, I. Ely.}

Flowers perfect. Calyx bell-shiped, $4-9$-eleft. Stamens $4-9$, slender, exserted : anthers extrorse. Ovary 2-celled. Styles short. Fruit l-celled, 1-seceled, surrounded by a broal membranaceons wing. Gimbryo straight. - Trees. Leaves short-petioled, musty oblique, donbly scrate, straiglit-veiued. Stipules deciduous. Flowers greenish or puplish, clustered, appearing before the leaves.

1. U. fulva, Michx. (Shrperr lis.s.) Branchlets pubescent; leaves thick, ovate-oblong, acuminate, hroadly serrate, slightly obliçue at the hase, very rough above, pubeseent beneath; ealyx and short pedicels pulnescent; fruit orbicular, pulsesecent on the sides, smooth on the mareins, with the oftuse teeth erect; expanding luds rusty-tomentose. - lich wookls, West Florida, and northwarl. Feb. and Matuch. $-\Lambda$ small tree. Leaves $4^{\prime}-8^{\prime}$ long. Fruit $8^{\prime \prime}-9^{\prime \prime}$ wiıle. Inner bark very mueilaginous.

2. U. Floridana, u. sp. Branchlets smooth; leaves thiek, ohlong-ovate, acute or sliglitly accuminate, broally serrate, oblique at the base, smooth above, more or less pulescent beneath; pedicels very slender, somewhat racemose, and, like the ealyx, smooth; fruit orbicular, fringed on the margins, with the short and broal tecth erect. - Banks of the Chipola River, at Miariana, West Florida. Feb. and Mareh. $-\Lambda$ tree $30^{\circ}-40^{\circ}$ high, with brittle hranclses. Leaves $3^{\prime}-4^{\prime}$ long. Fruit $2^{\prime \prime}-3^{\prime \prime}$ in diameter. Bud-scales downy on the margins.

3. U. Americana, I. (Es.s.) Branchlets amel buds suooth; leaves thin, obovate-oblong, or oval, ohlique at thé hase, sharply scrrate, almuptly aeuminate, smooth above, pulsescent, or at length smooth beneath; perlieels clustered, slender, smooth, like the culyx; fruit oval or obovate, downy on the margins, with the sharp teeth comivent. - Low gromels, Florida, and northward. Feb. and March. $-A$ large tree, with spreading branches. Leares $2^{\prime}-4^{\prime}$ long. Fruit 6 "l long.

Var. ? aspera. Leaves larger $\left(3^{\prime}-6^{\prime}\right)$ on shorter petioles, oval-olylong, aeuminate, very oblique or half-eordate at the base, very rough above, pubesecnt 
bezeath; pedicels and calyx smaller. - Swanps of the Apalachicola Rirer, Florida. Jan. and Feb. - A small tree.

4. U. alata, Michx. (Wninoo) Branches corky-winged; leaves small, ovate-lanceolate, acute, sharply serrate, commonly even and rounded at the base, rough nbove, pubescent beneath, nearly sessile, flowers clustered, on slender pedicels; fruit oval, downy on the marrins. - Rich soil, Florida to North Carolina. - A small tree. Leaves $\mathrm{l}^{\prime}-1 \frac{1}{2}^{\prime}$ long.

\section{Planera, Gmel. Planer-Tree.}

Flowers polygamous, clustered. Calyx bell-sliaped, 4-5-clcft. Stamens 4-5: anthers extrorse. Ovary l-celled. Styles short. Fruit unt-like, coriaceous, wingless. Embryo straight, without albumen. - Small trees, with the foliage of the Elm.

1. P. aquatica, Gmel. Leaves ovate, slort-petioled, acutc, serrate, roughish ; flowers in small roundish clusters, appearing before the leaves; wut ovate, rovered with warty seales. - River-swamps, Florida to North Carolina. Feb. and March $-A$ tree $20^{\circ}-30^{\circ}$ high. Leaves $1^{\prime}-1 \frac{1}{2}^{\prime}$ long.

\section{CELTis, Tourn. Nettle-Trek.}

Flowers perfect or polygamous, apetalous. Calyx of five sepals. Stamens 5 : anthers introrse. Ovary 1-celled. Styles 2, slender, pubescent. Drupe globose. Embryo curved around scanty gelatinous albuncn. Cotyletons wrinkled. Trees Leares petioled, commonly oblique at the base. Flowers axillary, solitary, or few in at cluster, greenish.

1. C. occidentalis, L. Young leaves and branchlets silky; leaves $\left(2^{\prime}\right.$ long) ovate, acuminate, sharply serrate, abmptly contracted at the base, soon smootl, fermgineons beneath ; fertile flowers mostly solitary, on drooping peduncles; the sterile ones $2-4$ in a cluster; drupe dark purple, with a thin swect pulp - Rich soil, Georgia, and northwarl. March. - A trec $40^{\circ}-60^{\circ}$ high. Var. ixtegrifoli. (C. integrifolia, Nutt.) Leaves ovate or ovate-lanceolate $\left(2^{\prime}-3^{\prime}\right.$ long), acuminate, entire, rounded, or the lower ones corlate at the base, ronghened with minute elevated points. - Sandy soil, Apralachicola, Florida (perhaps introduced), and westivard. $-\Lambda$ small tree. Branches and leaves 2-ranked. - Var. 1'UM1LA. (C. pumila, Pursh.) Shrubby; leaves $\left(1^{\prime}-1 \frac{1}{2}{ }^{\prime}\right.$ long) ovate, acute, scrate. obtuse at the basc, pale beneath, very rough above; drupe glaucons. - Sharly woods, Florida to North Carolinit. March and $\Lambda$ pril. - Stem $5^{\circ}-10^{\circ}$ high.

\section{Order 126. PLATANACEA. (Plane-tree Famly.)}

Large trees, with alternate palmately-lobed petioled stipulate leaves, and monocious flowers, in axillary long-peduncled globose heads. - Calyx and corolla none. Anthers on short club-shaped filaments, numerous; 
2-relled, adnate to the truneated connective. Ovaries numerous, olxonical, hair! at the base. Ovules 1 - 2, orthot mopons, premlulens. Style subulate. Nitt 1-seceled. Sered cylindrieal. Embryo in the axis of searee fleshy allumenc - Flowers intermixed with copious club-shaped seales. Consisting of the single genus.

\section{PIATANUS, I. Plaxe-Tree. Sycamole.}

1. P. occidentalis, [. - Lcaves $\left(4^{\prime}-9^{\prime}\right.$ witke) rouml-cordate, angularly lobed and toothed, covered when young with deuse whitish down, soon smooth; stipules toothed; heads perdulous $\left(8^{\prime \prime}-1 \cdot 2^{\prime \prime}\right.$ in diameter $)$ - River-banks, Flor ida, and northward. Alarch and $\Lambda$ pril. $-\Lambda$ large tree, with the white bark separating in thin plates.

\section{OrDER 127. JUGLANDACEA. (WANTT FAMHY.)}

Trees, with alternate olf-pinnate exstipulate leaves and monuerious apetalous or minntely petalled flowers. Sterile tlowers in pendulous aments. Calyx 2-6-parterl, the stanens few or mumerous. Firfile flowers single or clustered. Calyx 3-5-parted, the tube adliesent to the incompletely 2-1-eelled ovary. Fruit drupraceous, with a bony endocarp. seed 4-lohed, without allsumen, orthotropous. Cotyledons oily, 2-lobed. Raclicle slort, sujerior.

\section{CARYA, Nutt. IIckory. Pignut.}

Aments of the sterile flowers mostly three together, on a common pedunele, lateral. Calyx mequally 3-parted. Stamens 3-6. Furtile flowers terminal. Calyx 4-parterl. Petals none. Stigma large, 4-lohel. Nut smooth, $4-6$-angled, incompletely 4-celled; the cortaceous epicarp (husk) partly or completely 4-valved. - Trees, mostly with sealy buds. Leaflets serrate. Frunt roundislı.

\section{* Epricarp very thick, 4-valved: seed thick, cdible.}

1. C. alba, Nutt. (Sueldadis Iheкоrx.) Leaflets 5-7 (mostly 5), lanceolate-obloner, of the upper ones ohovate-oblong, acumninate, pubescent be neath ; fruit depresserl-globose ; nut roundish, thin-shelled, compressed, 4-anghter, slightly pointed. - Rich woods in the upper districts, Georgia, and northwarl. March and $A$ pril. $-\Lambda$ large tree, with shaggy and scaly bark

2. C. sulcata, Nutt. Leaflets $7-9$, obovate-oblong, acumiuate, pubescent bencath; fruit oval, 4-angled ahove; nut oblong, thick-shelh il, conspicuously pointed, slightly rompressed. - Rich wools in the upper distriets of Carolina, Elliot, and northwarl. Mareh and $\lambda_{\text {pril. }}$ - A large tree, with scaly bark.

3. C. olivæformis, Nutt. (PEctx-xut) Leaflets 13-15, lanecolateoblong, serrate fateate, aluminate; nut olive-slaped, smooth, thin-shelled, some. what 4-angled. - River-hottoms, Mississippi, northward and westward. $-\Lambda$ large tree with smoothish bark. 
* * Epicarp protly 4-valved: sced thin: bark not scaly.

4. C. tomentosa, Nutt. (Hickorr.) Leaflets 7-9 (mostly 7), large, oblong-obovate, aeute, pubescent bencath ; sterile aments tomentose; fruit large, globose; epicarp thick, coriaceous, parted nearly to the lase; mut thick-shelled, oval, somewhat 6-angled. - Rich soil, Florida, and northward. March and April. - A large tree with rough bark.

5. C. glabra, Torr. (PIG-Nut.) Leaflets 5-7 (mostly 7 ), ovate-lancelate, acuminate, smooth ; fruit obovate, obeordate, or pear-shaped; cpicarp thin, parted to the middle, corialecons; nut thick-shelled, sometimes angled. (C. porcina, Nutt.) - Woods, Florida, and northward. Mareh and April. - I large tree with smoothish bark.

6. C. microcarpa, Nutt. Leaflets $5-7$, oblong-lanceolate, smootl, glandular bencatlı, acuminate; aments smooth; frnit roundish; cpicarp thin ; nut thin-shelied, slightly 4-angled. - Mountains of North Carolina, and northwart. April and May. - $\Lambda$ large tree. Fruit ${ }_{4}^{3 \prime}$ in diameter.

7. C. myristicæformis, Michx. "Leatlets 5, ovate-lanceolate, acnminate, smooth, the terminal one sessile; fruit oval, rugose, rough; nut ovial, slighttly acuninate, furrowed, very hard." - Sonth Carolina, at Goose Creck, Michaux. Berkeley District, Ravent. Nints resembling nutmegs.

8. C. amara, Nutt. (Bıттек-хит.) Leaflets 9-11, oblong-lanceolate, acute, smoothish; fruit globular; epicarp thin, parted to the middle; nut thinshelled, obcordate; seed much wrinkled. - Low ground, Florida, and northward. March and April. $-\Lambda$ tree of moderate dimensions, with smooth bark, and very bitter and astringent seeds.

9. C. aquatica, Nutt. Leaflets $9-13$, lanceolate, acuminate, slightly serrate, smooth ; fruit roundish, 4-ribberl ; epicarp thin, 4-pasted to the base; nut compressed, thin-shelled, 4-angled; seed much wrinkled. - River-swamps, Florida to South Carolina. March and $A$ pril. $-\Lambda$ small tree with rough bark. Seeds very bitter and astringent.

\section{JUGLANS, L. Waliet. Butternut.}

Sterile aments lateral, solitary. Calyx 5-6-parted. Stamens numerons. Fcrtile flowers terninal. Calyx 4-cleft. Petals 4, minute. Stigmas 2, long, recurved. Fruit oblong or globose. Epiearp indehiscent. Nut incompletely 4-celled, furrowed or sculptured. - Trees with naked buds. Leaflets serrate.

I. J. nigra, I. (Bцаск Wilsut.) Leaflets 11 -21, ovate-lanceolate, pubcseent bencash, acuminate, slightly cordate at the base, or oblique; fruit glohose, rough-dotted; nut furrowed. - Rich woods, Florida, and northwarl. March and April. $-A$ tree $30^{\circ}-50^{\circ}$ high.

2. J. cinerea, L. (Butrervit.) Leaflets 15-19, ovate-lanceolate, acite, rounded at the base, pubescent ; the petioles, fruit, \&c. viscid ; fruit oblong; nut deeply sculptured, acute. - Rocky woods in the upper districts. March and April. - A tree $30^{\circ}-40^{\circ}$ hight. 


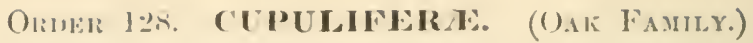

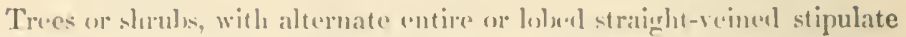
leaves, and monocions aputalous fluwers. Sterilo fluwers in pendulous

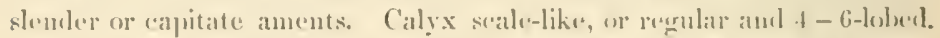
Stamens few. Fortile flowers single or clustered, furnisluel with an invo-

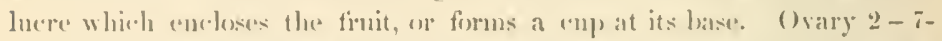

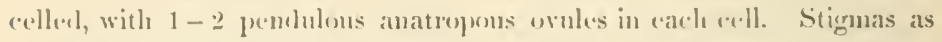
many as the cells. Frnit 1-celled, 1-seceled. Albumen none. Cotyledons thick and llesly. Radicle superior.

\section{Synopsis.}

* Fertile flowers single, or few in a cluster.

1. QCERCLs. Nut solitary, with the base enclosed in a sealy involuere.

2. C.IST.1.EA. Nuts $1-3$, enclosed iu a 4 -ralved spiny jnvolucre; slerile aments elongated, erect.

3. FAGLS. Nuts 2, 3-anglm, enclosed in a somewlat spiny 4-valved involucre: sterile aurents capitate, pendulous.

4. CokiLts. Nut solitiry, buny, enclosed in a leafy lacerated involucre.

* Fertite flowers spiked.

5. CAlipixts. Nuts $1-2$, in the axil ot an open leafy involucte.

6. Ostri. Nut solitary, enclosed ju a membranaceous in thated intolucre.

\section{QUERCUS, L. OAK.}

Sterile ament slender, bractless, pendulous. Calyx unequally $6-8$-parted. Stanens 6-12, slemer : anthers 2-celled. Fertile flowers axillary, solitary, or few in a cluster. Calyx 6-cleft or denticulate, adnate to the 3-4-eclled ovary. Orules 2 in each cell. Stigmas obtuse. Nut (Acorn) oblong or hemispherical, partly (rarcly wholly) enclosed in the emp-shaped scaly involncre. Cotyledons very thick, plimo-convex. - 'Trees or shrubs, with simple entire or lobed leares. Stipules eaducous.

\section{Fruit biennial.}

* Leaves entire, short-prtioled; those on vigorous shoots often lobed or toothed.

1. Q. Phellos, L. (WhLow-O.k.) Leaves (2'-3' long) linceolate or linear-lanecolate, brislle-awned, scurfy, like the branchlets, when young, becominer smooth on both sides; fruit small, sessile; cup flattish, enclosing the base of the hemispherical nut. - Margins of swamps and streams, Florida to Missis. sippi, and northwarl. $-\Lambda$ skiuler trec, $40^{\circ}-50^{\circ}$ high.

Var. laurifolia. (Q. laurifolia, M/chx.) Leaves larger $\left(3^{\prime}-4^{\prime}\right.$ long), olsong-lanceolate; cop deeper and more pointed at the base. - Light uplands, Floricla to Nortlı Carolina. - A tree commonly larger than the preceding.

Var. arenaria. (Q myrtifolia, Willd ?) Slurubby $\left(4^{\circ}-80\right.$ high); leaves small ( $\frac{1}{2}^{\prime}-1 \frac{1}{2}^{\prime}$ lon $\left.x\right)$, rigil, oblong or olovate, oltuse or barely pointed, with the margins revolute. - Dry sand ridges, along the roast of Florida and Georgia.

2. Q. imbricaria, Mirhx. (Surgtz-().к.) Leaves lancelate-oblong, acute or obtuse at each end, mucrouate, pale and downy beneath, deciduous; 
fruit middle-sized ; cup narrowed at the base, enclosing one half or one third of the nearly hemispherical nut, the broad and whitish scales clusely appressed. Monntains of North Carolina, and northward. - A tree $40^{\circ}-50^{\circ}$ high. Ledves $3^{\prime}-5^{\prime}$ long.

3. Q. cinerea, Michx. (Higm-Grodxd Willow-OAк.) Leaves perennial, oblong-lanceolate, obtuse or acute, mucronate, white tomentose benealh; firuit small, sessile; cup shallow, narrowed at the base, pale, enclosing one third of the hemispherical nut. - Dry sandy pine barrens, Florida to North Carolina. - A small tree, fruiting abundantly. Leares $2^{\prime}-3^{\prime}$ long, scurfy, like the branchlets, when young.

Var. pumila, Michx. (Q. pumila, Wult.) Shrublyy $\left(1^{\circ}-3^{\circ}\right.$ high); branches slender; leaves lanceolate, wary, at length smooth on both surfaces. - Flat or dry pine barrens, Florida to Nortlı Carolina. - Roots ereeping.

4. Q. virens, Ait. (Lrve Oıк.) Branchlets tomentose; leaves coriaceous, percnuial, oblong, obtnse, somewhat rugose, smooth and shining alove, hoary-tomeutose beneath, the margins revolute; fruit long-peduncled; cup topshaped, hoary, enclosing the base of the oblong chestnut-brown nut. - Dry or wet soil, in the lower districts, Florida to North Carolina. - Commonly a large tree with spreading brauches. Leaves $2^{\prime}-4^{\prime}$ long.

Var. maritima. (Q maritima, Willd.) Shrubby $\left(4^{\circ}-10^{\circ}\right.$ high); leares smootl, lanceolate, concare, mostly acute; fruit larger. - Sand ridges along the coast, Florida to South Carolina.

Var. dentata. (Q. nana, Willd?) Dwarf $\left(1^{\circ}-2^{\circ}\right.$ high $)$; earliest leaves flat, wedge-obovate or obovate-oblong, mueronate, toothel, at length smooth, the others lanceolate and entire; fruit sessile or short-peduncled, often clustered. - Flat pine barrens, Florida. - Leaves nearly sessile.

\section{* * Leaves 3-lobed at the summit, bristle-awned.}

5. Q. aquatica, Catesb. (WATER-OAK.) Leaves perennial, short-petioled, obovate-oblong or wedge-shaped, smooth on hoth sides, obtusely 3-lobed at the sumnit, often entire, or on young sloots pinnatificl-toothed or lobed, mostly awnless when old; fruit small, mostly sessile; cup shallow, flat, enclosing the base of the hemispherical downy nut. - Swamps and wet banks, Florida, and northward. - A small tree, with smooth bark. Leaves $2^{\prime}-3^{\prime}$ long, with tufts of down in the axils of the veins when young.

Var. hybrida. Smooth, with ash-colored branchlets; leares oblong or wedge-oblong, entire, emarginate, or 3-lobed at the sunımit, tapering or abruptly contracterl into a short petiole; fruit very sınall, closely sessile; cup shallow, flattened, enclosing the base of the ovate nut. - Rocky banks of Schurlock's Spring, West Florida, and of the Flint River at Albany, Georgia. - A lofty tree. Leaves $3^{\prime}-4^{\prime}$ long. Fruit $4^{\prime \prime}-5^{\prime \prime}$ long.

6 Q. nigra, L. (Вцаск JАск.) Leaves short-petioled, coriaccous, broadly wedge-shaped, rounded at the base, nostly 3 -lobed at the summit, bristle. awnerl, smooth ahove, rusty-pubescent beneath, deeidnous; fruit middle-sized, on short and thick perluncles; cup top-shaped, with coarse truneate seales, enclosing one third or one half of the oblong-orate nut. (Q. ferruginea, Michx.) 
- Dry gravelly or sandy suil, Florida on Misciscippi, and northwarl $-\Lambda$ small tree. Leares $t^{\prime}-y^{\prime}$ loug. Internediate forms between this and No. 7 are not uneommun.

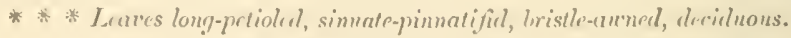
- Cecurs smouth or norly so.

․ Q. Catesbri, Michx. ('Truxy-Osk.) Leaves somewhat coriaccous, broad, nurrowed into a short fetiole, deeply pinmatifil ; the lobes very acute from a loroal base, spreadling, mostly fillate and entire; fruit rather large, shortperluncled; cup thick, turlinate, with brosul obtuse seales, enclosing latf of the orobil nut: the upper seales inflexel and lining the inner colge of the eip. 1) $y$ pine barrens, Florida to North Carolina. $-A$ small tree. Leaves $6^{\prime}-9^{\prime}$ lont.

8. Q. tinctoria, Bartr. (Busk (OKK) I.eaves ubovate-oblong, with decp or slallow open simuses, and about 6 sharply-toothed lobes, olutuse or truncate at the lase, puleserent when young, at leugth only in the axils of the veins beneath; en] top-shapeel, with broad scales, enclosing about half of the roundish depressed mut. (Q discolor, Ali.) - 1)ry woods, chicfly in the upper districts, and northward. - $\Lambda$ large tree, with the onter bark dark-brown, the inner thick and yellow. Leaves turning light-brown after frost. Nuts $6^{\prime \prime}-8^{\prime \prime}$ long.

9. Q. coccinea, Wang. (Scrncet O.K.) Leares long-petioled, oral or oblong, with decp and broal sinuses, and $6-8$ entire or sparingly toothed lobes, truncate at the base, smooth and shining on both sides; rup top-shaped, with coarse scales, enclosing one half or one third of the oroid nut. - Dry woorls, Florida, and northwarl; more abundant in the npper distriets. - A large tree, not easily ditingnisher from the preceling, and probably only a form of it. Leaves turning bright searlet after frost.

10. Q. rubra, L. (Riv OkK.) Leaves oblong, witl open shallow sinuses, and 8-12 eutire or sharply toothed lobes, smooth on both siles, paler beneath; fruit larece, cup shallow, flat, with fine seales, enelosing the base of the ovate or ollong mut. - lioeky wook-, Florida, and northward. - I large tree. Leaves turning dark red afier frost Nint $1^{\prime}$ long.

11. Q. Georgiana, M. A. Curtis. Shrullyy; leaves small, very smooth, somewhat olrovate, wedge-shaped at the base, with deep or shallow open sinuses, and 3-5 triangular-lanceolate entire acute or uhtuse lobes; fruit short-peduneled; cup suooth and shining, sancer-shaped, enclosing one third of the ovalglohose nut. - Stone Momntain, Georgia, liavenel. - Shrul, $6^{\circ}-8^{\circ}$ high, growing in clusters. leares $3^{\prime}-t^{\prime}$ long. Fruit aluudant. Nint $\frac{1^{\prime}}{2}$ long.

\section{+ + Leares tomentose benfalh.}

12. Q. falcata, Miclix. (Sraxisir OAx.) Leaves ohlong, rounded at the base, $3-5$-lobed ; the lobes entire or sparingly toothed at the apex, the terminal one commonly namow and elongated; fruit rather small; (up somewhat topshaped, with coarse seales, enclosing half of the glohular nut. - Var. l'sGoneFolı, Ell., has larger leaves, with $11-13$ nearly opposite and spreading lobes. - Dry woods, Florida, and northward. $-A$ large tree. Leaves $4^{\prime}-5^{\prime}$ long, entire near the base. Nut $\frac{1}{2}$ long. 
13. Q. ilicifolia, Wang. (Betr-O.k.) Shrubby; leaves obovate, with 3 - 5 angular or slort and broal mostly entire lobes, acute at the base, whitetumentose, like the branchlets, when young, at length smooth and dark green abore; fruit short-peduneled; cup shallow, saucer-shaped, with coarse scales, enelosing about one third of the ovate nut. (Q. Banisteri, Michx.) - Barren soil in the npper distriets, Georgia, and northward. - A shrub $3^{\circ}-4^{\circ}$ ligh. Leaves $3^{\prime}-5^{\prime}$ long. Fruit abundant.

\section{\$2. Fruit unnual: leaves awnless, deciduous. \\ * Leaves sinuate-lobed.}

14. Q. obtusiloba, Michx. (Post-OAk.) Leares with $5-7$ broad rounded or notehed lobes separated by wide open sinuses, narrowed at the base into a short petiole, pubescent beneath; cup hemispherical, enclosing one third or one half of the oval nut. - Cold elayey soil, Florida, and northwarl. - A tree $40^{\circ}-50^{\circ}$ high. Nut $\frac{1}{2}$ long. Leaves $4^{\prime}-6^{\prime}$ long.

Var. parvifolia. Leaves smaller ( $1 \frac{1}{2}{ }^{\prime}-3^{\prime}$ long), oblong, obtuse, cntire or sinuate-toother, nearly smooth on both sides, rusty-puhescent, like the branchlets, when young; nut larger. - Saud-ridges near the coast, West Florida. - 1 shrub or small tree.

15. Q. alba, L. (White O.ı.) Leaves oblong or obovate-ohlong, with 7-9 mostly obtuse and entire narrow lobes separated by narrow sinuses, narrowed into a petiole, densely tomentose, like the branchlets, when young, at length smooth or glaucous bencath ; fruit large, nearly sessile; cup hemispljerical, enc.osing one third of the olylong-ovate nut. - Damp woorls, Florida to Mississippi, and northward. - A large tree with white bark. Leaves $4^{\prime}-6^{\prime}$ long. Nut abont $\mathrm{l}^{\prime}$ long.

16. Q. macrocarpa, Michx. (Mossx-ctp OAк.) Leaves thin, obovateoblong, pubescent or pale beneath, acnte at the base, short-petiolesl, slightly or strongly fer-many-lobed; the lobes rounded, entire or obtusely toothed; fruit large; scales of the cup thick, the upper ones produced into long awns; nut ovoid, included, or half enclosed in the eup. - Woods and river-banks, North Carolina, and northward. - A middle-sized trec. Leares $6^{\prime}-15^{\prime}$ long. Nut $1^{\prime}-1 \frac{1}{2}$ ' long.

17. Q. Iyrata, Walt. (Orer-crp O.K.) Leaves crowred at the end of the branehlets, oborate-oblong, acute at the hase, 7-9-loberl, white-tomentose beneath, or at length smoothish, shining above, the lobes triangnlar, acute, and entire; fruit sessile: cup round-ovate, with rugged scales, almost eorering the roundish nut. - River-swamps, Florida to North Carolina. - A large tree. Leares $5^{\prime}-8^{\prime}$ long, short-petioled. Fruit $\mathrm{l}^{\prime}$ long.

\section{* * Leares toothed.}

18. Q. Prinus, L. (Swame Cuestivit-Oak.) Leaves oblong or obovate-oblong, obtuse, with rounded teeth, smooth and shining ahore, pale and pubeseent beneath, acute at the base, short-petioled ; fruit large, short-peduncled; cup hemispherical, rugged with tubercular scales, enclosing the base of the roundish or oblong-ovate nut. - Low grounds, Floricla to Mississippi, and northward - A large tree. Nut about 1 'long. 
Vir. monticola, Michx. (Rock Cukstsit-OAк.) (Q. montuma, Willd.)

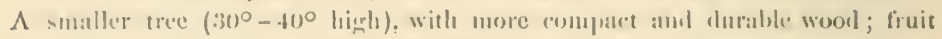
smaller; mut ohlong. - liochy wools along the monntains.

Var. Michauxii. (Q. Mirhauxii, Nutt.) Lenves sualler ( $t^{\prime}-5^{\prime}$ longr), rather ritril, velvety bessenty, often olituse or slightity cordate at the base; unt wate ( 1 'l' loner). - Low gromd, Floridat to South Carohna, - A large tree.

Var. discolor, Miclix. Lcaves obvate, ante at the base, coarsely aud oltusely touthed or somewhat lobed, dark-green alove, white-tomentose beneatl; fruit long.jechuncled, cup tubercular, hemisplierical; nut oblong-ovate ( $1^{\prime}$ long). ( $($. bicolor, Willd.) Swamps along the mountains. - A large tree.

19. Q. Castanea, Willl. (Cиеsтхст.ОАк.) Leaves oblong, varying to lanceolate, acuminate, sharply tootherl, with the points incurred, mostly acute at the base, smooth nbove, paler and minutely pulescent or glaucous beneatl; fruit small, sessile or short-peduncled; cup hemisplicrical, with flut seales, enclosing one thitrl of the oblong nut. - Rocky woods. W'st Florida to Mississippi, and northward. - A large or middle-sized tree. Leaves $3^{\prime}-6^{\prime}$ long. Nut 7" -9 "long.

20. Q. prinoides, Will. (Cunquapis-O.к.) Shrubly; leaves lanecdate-oblong, ante at each cud, acutely toothed, smooth above, white-tomentose hencath; finit small, mostly sessile; cup hemispherical, with flat scales, enclos. iner alout one half of the round-orate mut. (Q. Chinquapin, Pursh.) - Barren soil in the upper districts, and nortlaward. - Slurub $2^{\circ}-6^{\circ}$ high. Leaves $3^{\prime}-4^{\prime}$ long. Nut $8^{\prime \prime}-9^{\prime \prime}$ long.

\section{CASTANEA, Tourn. Cnestrit.}

Stcrile flowers in separate clusters, in long erect cylindrical aments. Calyx 5-6-prated. Stamens 8-15: anthers 2-celled. Fertile flowers 1-3, enclosed in the licll-shaped, at length globose, 4 -valved and rery prickly involuere. Calyx 5-6-lobed, superior. Alortive stamens 5-12. Ovary 3-6-celled. Ovules single or ly pairs in each cell. Stigmas $3-6$, bristle-like, spreading Nuts 1-3, roundish, compressed, or plano-ronvex. Cotyledons very thick. - Trees or shruls:, with oblong petioled sharply-serrate straight-veined leaves.

1. C. vesca, I. (Cirestivt.) Leaves oblong-lancelate, acuminate, coarsely scrrate, smooth on hoth silles; nuts mostly 3 , the middle one flattened, the 2 outer oncs plano-('onvex, dark brown. - Dry woods, West Florida, and northward. April. - A large tree. Leaves $6{ }^{\prime}-i^{\prime}$ long.

2. C. pumila, Michx. (Curquarix.) Leares oblong, acute, or obtuse, finely scriate, houry-tomentose beneath; nuts solitary, nearly globular. (C nana, Muld., a form with larger leaves and nuts.) - Dry sandy soil, Florida, and north. ward. A pril - May. $-\Lambda$ large shrub or small tree. Leaves, involucre, and nut smaller than those of the preceding.

\section{FAGUS, Tourn. ВеЕси.}

Sterile flowers capitate, on long and drooping peduncles, with deciduous bracts. Calyx bell-shaped, 5-6-cleft. Stamens 8-12: anthers 2-celled. Fertile flow- 
ers solitary or by pairs, peduncled, surrounded with numerous lincar bracts and a 4-lobed involucre. Calyx of $4-5$ subnlate lohes. Ovary 3-celled, with two ovules in each cell. Styles 3 , filiform. Nuts commonly 2 , acutely 3 -angled, enclosed in the soft-spiny 4-ralved inrolncre. Cotyledons thick and fleshy. Trees, with whitish bark, and straight-reined leaves expanding with the flowers.

1. F. ferruginea, Ait. Leaves oblong-ovate or rhombic, acute, fincly serrate, silky on both sides when young, when old only on the veins heneath; spines of the involnere short, recurved. - Damp sandy soil, Florida, and northWurd. April. - A large tree, witl widely spreading branches.

\section{CORYLUS, Tourn. HAZEL-NUT.}

Sterile flowers in cylindrical pendulous bracted aments. Calyx 2-cleft, partly united with the bract. Stamens 8 : anthers 1-cellcrl. Fertile flowers clustered. Ovary 2-celled, 2-ovuled. Stigmas 2, filiform. Involucre tuhular at the base, leafy and lacerated at the summit, enclosing a single bony (cdible) nut. - Shrubs, with broadly cordate doubly serrate petioled leaves. Flowers appearing before the leaves.

I. C. Americana, Walt. (Hazel-vet.) Branchlets glandular; leaves round-cordate, coarsely serrate, acuminate, pubescent; involncre roundish at the base, dilated and flattened alove the nut, glandular hairy ; nut roundish, somewhat flattened. - Rich soil along the margins of woods and thickets, West Florida, and northward. Feb. and March. - Shrub $5^{\circ}-6^{\circ}$ ligh, tough and flexible. Leaves $4^{\prime}-6^{\prime}$ long.

2. C. rostrata, Ait. (BeAked Hazel-yut.) Branchlets smooth; leaves ovate or oblong-ovate, slightly cordate, acuminate, finely serrate, rather thin, pubescent; involucre bristly, prolonged into a tube above the nut, 2-cleft and toothed at the summit; fruit nearly globular. - Rich soil in the upper districts, and northward. March - April. - Shrub $4^{\circ}-6^{\circ}$ high.

\section{CARPINUS, L. HoRxbeam.}

Flowers destitute of floral envelopes, supported by scale-like bracts. Sterile flowers in drooping cylindrical aments. Stamens 8-14: filaments slort : anthers 1-celled, hairy at the apex. Fertile flowers spikerl. Bracts 2-flowered, deciduous. Ovary 2-celled, 2-ovuled. Stigmas 2, filiform. Nut solitary, angular, sessile in the axil of an open 3-lobed leaf-like involuere. - Trees, with simple orate or oblong straight-veined deciluous leaves, folded in the bud. Flowers expanding before the leaves.

1. C. Americana, Michx. (Hornbesm.) Branchlets smooth and slender; leaves oblong-orate, acute or slightly acuminate, sharply and donbly serrate, rounded at the base, more or less pubescent. Fertile spikes terminal, long-peduncled, 6-12-flowered; involucre unequally 3-loberl, the middle lobe longer and serrate on one side; nut small, ovate, compressed, 8-ribbed. - Rich woods, Florida, and northward. March. $-\Lambda$ small tree, with hard and closegrained wood. 


\section{OSTRYA, Micheli. 11np-II)m:mian.}

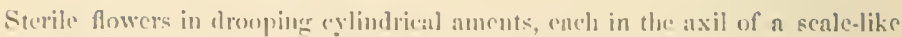
luact, distitute of at calyx. Stancus with the filancuts imperularly mited. Fertile flowers in a short terminal croweded spitie, ench enclosed in a membranaecons iuvoluce. Wrary 2-eelled, 2-ovuled, bearded at the apex. Stigmas 2, filiform. Fruting involuce inflated, nerved, hairy or bristly at the hase, enciosing the solitary pointed nut. - Small trees, with ovate or oblong serrate short-petioled deciluous leaves. Flowers appearing with the leaves.

1. O. Virginica, Willi. (How-Homxa.un) Leaves ovate-oblong, slarply and simply scrrate, aruminate, roundet or slightitly cordate at the lase, pulsescent; fertile spitic cone-like, slort-peduncled ; the imbricated involucres oblong, mucronate, bristy at the base. - Rich woors, Florida, and northward. March. - A small tree, with hard and close-grained wood.

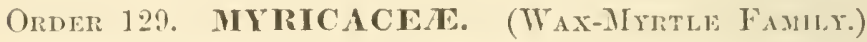

Chiefly shrubs, with simple alternate leaves, with or without stipules, and monecions or dicecious flowers, disposed in aments, destitute of calyx or corolla, each in the axil of' a simple bract. Stamens $2-10$; the short filaments free or partly united: anthers 2-celled. Ovary solitary, 1-celled, surrounder at the base with a row of seales. Ovule solitary, orthotropous or amphitropous. Involucre none. Stigmas 1-2, elongated. Fruit a dry 1-seed d drupe. Albumen none. Cotyledons fleshy. Radicle superior.

\section{Synopsis.}

* Seed orthotropous. Plants dotted with resinous glands.

1. MYRICA. Flowers dicecious. Filaments united below. Leaves serrate or entire. Stip . ules none.

2. Comp'TON1A. Flowers monocious. Filaments forking. Leares pinnatifa. Stipules half-cordate.

* Seed amphitropous. Plant destitute of glands.

3. LEITyeria. Flowers diocious. Filaments distinet. Stigma solitary. Leares entire. Stipules none.

\section{MYRICA, L. Wax-Myrtle. Bayberry.}

Flowers in short axillary aments, diøcious, cach in the axil of a scalc-like bract. Calyx and corolla none. Stamens $2-10$, with the filaments united below. Ovary cnclosed in a cup of $3-5$ rounded scales. Orule orthotropous. Stigmas 2 (rarely 4), flattened on the inner face, widely spreading. Nut glo. hosc, covered with waxy grains. - Shrubs or small trees, dotted with minute resinous and orlorous glands. Branclies clustered. Lcaves short-petioled, serrate or entire. Stipules none.

1. M. cerifera, L. (WAX-MYrtue. Baymerry.) Branchlets pubescent ; leares lanccolate or oblong-lanccolate, mostly obtuse, entirc, or with a few sharp 
serratures near the anex, smooth, or pubeseent on the veins beneath, tapering into a petiole; sterile aments very numerous, oblong; bracts welge-shaped; stamens 4; fertile aments small; bracts rounded, obscurely 3-lobed; seales of the ovary 4, ciliate; stigmas 2 ; fruit abundant, white - Margins of swamps, mostly near the coast, Florida, and northward. March and April. $-\Lambda$ shrub or small tree. Leares persistent along our southern limits, but northwardly deciduous, $1 \frac{1}{2}-4^{\prime}$ long.

Var. media, Michx. Branchlets smooth or hairy; leaves larcer, obovateoblong, entire, or slightly serrate near the apex, mostly rounded or emarginate at the summit ; aments and nuts larger; seales of the sterile flower roundish. Wet pine barrens. - Slirub $2^{\circ}-4^{\circ}$ high. Leaves mostly deciduous.

Yar. pumila, Michx. Low $\left(1^{\circ}-2^{\circ}\right.$ high $)$, much branched; leaves smaller $\left(\frac{1}{2}-2\right.$ ' long), persistent, varying from wedge-obovate to wedge-lanceolate or linear-spatulate, coriaceous, obtuse, mostly toothed near the apex; aments ininute, ovoid, few-flowered. - Sandy pine barrens.

2. M. inodora, Bartr. Smooth; leaves perennial, coriaceous, oblong. obtuse, very entire, tapering into a petiole, with the margins revolute; sterile aments oval or oblong, with the roundish bracts transversely ridged on the back; stamens about 10, monadelphous; fertile aments small, elongated in fruit; stigmas 2 or 4 ; seales of the ovary 5 ; unts large, black, commonly solitary. - Margins of pine-barren ponds and swamps, Florila, common near the coast. Feb. - Marcl. - A shrub or small tree, with whitish bark. Leaves about $2^{\prime}$ long, sparingly dotted. Nuts ovoid, $3^{\prime \prime}$ long.

\section{COMPtonia, Solander. Sweet-Ferx.}

Flowers monœcious. Sterile ament cylindrical, with kidney-shaped acum1nate bracts. Stamens 3, forked. Fertile ament globular, bul-like. Ovary surrounded by 5-6 long and slender persistent scales; orule orthotropous. Stigmas 2, spreading. Nut ovoid-oblong, smooth. - Low shrubs, with narrow pinnatifid leaves, and small semicordate stipules.

l. C. asplenifolia, Ait. Leares thin, short-petioled, lincar-lanceolate, with nuncrous rounded lobes, deciduous; fertile aments at the base of the sterile, appearing before the leaves. - Dry woods, North Carolina, and northward. April. - Plant $1^{\circ}-2^{\circ}$ high, aromatic when bruised. Leaves $3^{\prime}-4^{\prime}$ long, resembling those of a fern.

\section{LEITNERIA, N. Gen.}

Flowers in aments, diccious, each in the axil of a seale-like bract. Calyx and corolla none. Sterile ament many-flowered, cylindrieal, elongated; bracts ovate, acuminate, imbricated, staminiferous at the base, hairy, the lower ones empty; stainens 5-10, frec: anthers 2-celled, introrse. Fertile ament fewmany-flowered, narrowly eylindrical, short, in fruit elongated ; braets ovate, approximate, at length seattered, the lower ones empty. Ovary ovoid, nearly smooth, with the hase snrronnded by a enp of 4 minute ovate toothed seales. Ovule solitary, anphitropous. Stigma solitary, thiek, elongated, channelled. 
Drupe oblong, oltuse, narrowed at the hase: cpienrp thick, enriasenus, smooth: endocarp ('onstaceons. Albumen mone. Jimbryo large, filling alie acll. Cotylodous oval, compressed. Rarlirle superior. $-\Lambda$ stont slurub, $2^{\circ}-6$ lighl, with soft wood mul smooth lighlt-hrown latk, without resinens dots. Branclies short

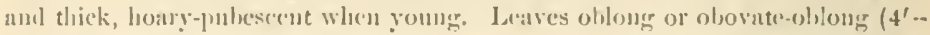
(i' long), acute at each end, cutire, smooth and shining alove, honry-tomentose beneath, straighti-veined, on long spreading or recurved houry petioles, deciduous. Stipules none. Aments developed before the lenves, from the uxils of the preceding year, the sterile ones $1^{\prime}-1 \frac{1}{2}^{\prime}$ loug, the furtile $6^{\prime \prime}-8^{\prime \prime}$ long. Drupe $\underline{1}^{\prime}$ long, green, slightly curved.

1. L. Floridana. - Salt or brackish marshes, Apalachicola, Florida. Feb. and March.

\section{Orimer 130. HETULACEA. (Brrch Famir.)}

Trees or shruls, with alternate simple straight-reined leaves, deciluous stipules, and monecious amentaceous flowers, placed $2-3$ together in the axil of a 3-lobed bract. Stumens 4 : fifaments distinct. Ovary 2-celled, with a single suspencled anatropous orule in each coll. Stigmas 2, elongated. Frnit a winged on angled 1-celled 1-seeded nut, forming, with the imbricated persistent bracts, a cone-like spike.

\section{BETULA, Tourn. Brrer.}

Sterile aments drooping. Bracts 3-flowered, 2-bracteolate, peltate. Calyx seale-like. Stamens short: anthers 1-celled. Fertile aments oblener or erlindrical. Bracts 3.flowered. Calyx none. Stigmas filiform. Nut broadly winged. Cotyledons oblong. - Trees or shrubs, witl the outer lauk of en separable into thin papery shects. Leaves petioled, serrate. Fruiting bracts membranaccous.

1. B. nigra, L. (BLACк Brincur.) Leares rhombicovate, acute, doubly scrrate, smooth above, loary-tomentose beneath, like the short petioles and branchlets, becoming rusty or smoothish; sterile aments long and drooping; the fertile oncs oblong, short-peduneled, with the woolly tracts ('left into three linear-oblong nearly equal lobes. (B. rulura, Mlichx.) - Banks of rivers, Florida, and northward. March. $-\Lambda$ middle-sized tree, with reddish-brown bark, and long spreading branches.

2. B. excelsa, Ait. (Yelrow Brren.) Leaves ovate or oblong-ovate, acuminate, unequally and loubly scrrate, pubescent, like the bunclilets, when young, at length smooth on hoth sides, on short pubescent petioles; fruiting aments oral-oblong; lobes of the braets nearly equal, slightly spreading and hairy, acute. (B lntea, Michx.) - Mountains of North Carolina, and northward. March and $A$ pril. $-\Lambda$ tree $40^{\circ}-60^{\circ}$ high, with yellowish bark. Leaves $2^{\prime}-3^{\prime}$ long.

3. B. lenta, L. (Crenry Bırcu.) Branchlets smooth; leaves orate or oblong-ovate, acute, cordate, finely and doubly serrate, silky wlen juung, at 
length on?y or the petioles and reins beneath; frniting aments oblong; lobes of the bracts widely spreading, acnte, smooth. - Cool shady lanks in the upper parts of Georgia, and northward. ivarch. - A middle-sized tree, with dark brown rugged bark, and close and fine-grained wood. Young twigs spicy and aromatic.

\section{ALNUS, Tourn. AlDER.}

Sterile aments elongated, drooping. Bracts peltate, 5-braeteolate, $1-3$-flowered. Calyx 4-parted or (in No. 2) seale-like. Stamens 4: anthers 2-eelied. Fertile aments short, erect. Bracts fleshy, 2-flowered. Calyx of four minute scales, adherent to the bracts. Braets of the fruiting ament woody, persistent. Nut angled or winged. - Shrubs or small trees. Leares petioled, serrate, the stalked buds covered with a single scale. Fertile aments racemed.

1. A. serrulata, Ait. Leaves ohovate, obtuse or abruptly pointed, serrulate, commonly pubescent beneath, acite at the base, short-petioled; stipules oval, obtuse ; fruiting aments ovoid, slort-peduneled; fruit ovate, wingless. Banks of streams, Florida, and northward. Jan. - March. - Shrub $3^{\circ}-12^{\circ}$ high. Leaves $2^{\prime}-4^{\prime}$ long, thickish, and partly persistent at its southern limits. Calyx of the sterile flowers 4-parted.

2. A. viridis, DC. Leaves oval, rounded at both ends, slightly oblique at the base, finely and sharply serrate, softly pubeseent on the lower surface, or only on the veins and petiole, stipules ovate; calyx of the sterile flowers seale-like; fruiting aments oroid, long-peduncled; fruit winged. High mountains of North Carolina, and northward. April. - A low much branched shrub. Lcaves $2^{\prime}-2^{\prime}$ long.

\section{Order 131. SALICACEA. (Whlow Famly.)}

Trees or slrubs, with soft wood, alternate simple stipulate leaves, and diœcious amentaccous flowers, destitute of calyx and corolla, each solitary in the axil of a simple bract. Stamens 2-many. Ovary 1-celled or imperfectly 2-celled, with numerous erect anatropous ovules in each cell. Styles 2, very short, more or less united: stigmas 2-lobed. Fruit a 2 -valved many-seeded capsule. Seeds minute, clothed with long silky hairs. Albumen none. Cotyledons elliptical, flattened. Radicle pointing downward.

\section{SALIX, Tourn. Willow.}

Bracts of the aments entire. Flowers each with 1-2 small glands. Stamens 2-6, free, or their filaments cohering at the base. Stigmas short, 2-lobed. Leaves commonly narrow, short-petioled. Stipules scale-like and deciduous, or leafy and persistent. Buds covered with a single scale. Aments mostly erect, appearing with or before the leaves. 
- Aments small, stswile: arary silliy: stamens 2. - Iow cancscent shrubs, with small lears. Aments developed bu jore the laves.

1. S. tristis, Ait. Leaves very mumcrons, lanceolate, obtuse or acute, entire or wayy, at least on the margins, tapering at the hase, nearly sessile, covcred with a grayish down, at lougth smoothish above; stipules mimute, caducous; flowering aments small, glohular; the ovnl bracts hairy on the margins; style short; orary slender, long-beaked. - Dry barren soil, in the "pper distriets of Georgia, and northward. Marcls and $\Lambda$ pril. - Shrub $1^{\circ}-2^{\circ}$ high. Leaves $1^{\prime}-2^{\prime}$ long.

2. S. humilis, Marshall. Leaves lanceolate, obtuse or abruptly pointed, narowed into a petiole, smoothish above, grayish-pubeseent beneath, often slightly serrate near the summit; stipules small, seni-cordate or lunate, entire or toothed ; flowering aments ovoid or oblong, often drooping, with the lanceslate bracts villous; style conspicuons; ovary slender. (S. conifera, M/ull. S. Muhlenbergiana. Willd.) - Barren soil in the upper districts, and northward. March. - Shrub $2^{\circ}-4^{\circ}$ high, often bearing cone-like excrescences.

3. S. rosmarinifolia, I. Leaves linear-lanceolate, nearly entire, flat, pubescent alove, silky beneuth; ovary lanceolate, villous; styles clongated. Swamps and low ground, Florida? and northward. - Slurub $2^{\circ}-4^{\circ}$ high. Branches silky. Leaves $1^{\prime}-2^{\prime}$ long. Stipules subulate. Bracts oblong, obtuse, hairy on the margins.

* * Aments large, cylindrical, sessile, silky-villous, developed br fore the leaves : ovuries woolly. - Lurye shrubs.

4. S. discolor, Mubl. Branchlets jubescent; leaves oblong, petioled, acute at cach end, scrrate in the niddle, smooth and shining ahove, glancous bencath; stipules semi-lunar, tootherl; aments wooliy, with glossy hairs; stamens 2; ovary white-silky, sessile. - Low ground, Carolina, Pursh, and northwarl. April. - Shrub $8^{\circ}-10^{\circ}$ high. Leaves $2^{\prime}-4^{\prime}$ long. Aments $1^{\prime}-1 \frac{1}{2}$ long

* * Aments large, cylindricul, on leafy peduncles or branclilets, appearng with the leaves: oturies smooth, stallied.

5. S. Floridana, n. sp. Leaves ovate-lanecolate, acute, smooth above, glaucous beneath, fincly serrate, ronuded at the hase, the petioles pubescent; stipules small, calucous; fruiting ament oblong, dense: capsule ovate-lanceolate, smooth. - Rocky lanks, West Florirla, fruiting in April. - Shrub $8^{\circ}-12^{\circ}$ highl. Leaves thin, $2^{\prime}-3^{\prime}$ long. Fruiting ameuts $2^{\prime}-3^{\prime}$ long, $1^{\prime}$ in dameter, enveloped in the copions wool of the seeds. Flowers not seen.

6. S. nigra, Marshall. Leaves lanceolate, arute at each ('nd, scrrate, petioled, pubescent when young, becoming smoothish and green on both surfaces; stipules small and calducons, or sometimes lunate, toothed, and persistent; anents elongated, the fertile ones slender, loose-flowered ; bracts decidnous ; stamens 3-6, hairy below; capsule orate, acuminate, pointed by the conspieuons style. (S. Honstoniana, Pursh.) - Swamps and muddy banks of rivers, Florida, and northward. A slirub or small tree, with brittle branches. Leaves $2^{\prime}-3^{\prime}$ 
long, sometimes pubescent at maturity, like the branchlets. Fertile aments $3^{\prime}-4^{\prime}$ long.

The Weeping-Willow (S. Babylonica, Tourn.), and the Yellow Willow or Golden Osier (S. vitellina, Smith), are introduecd species.

\section{POPULUS, Tourn. Cotton-Wood. Poplar. Aspen.}

Bracts of the aments toothed or lobed. Flowers from an oblique cup-shaped disk. Stamens few or numerous, with the filaments free. Stigmas elongated, 2-parted. - Trees. Leares ovate or roundish, on long and often laterally compressed petioles. Buds corered with imbricated, often resinous-coated scales. Aments slender, drooping, appearing before the leaves.

1. P. angulata, Ait. Branches thick, smooth, and sharply angled; leaves large, smooth, deltoid-ovate, acute or slightly acuminate, truncate at the base, obtusely serrate with incurved teeth; the conspicuous veins and compressed petiole yellowish. - Banks of rivers, Florida, and northward. March and April. - $A$ large tree. Leaves $6^{\prime}-8^{\prime}$ long, longer than the petiole.

2 P. grandidentata, Michx. Branches terete; leaves round-ovate, acute, sinuate-toothed, hoary-tomentose when young, like the branchlets, at length smooth, seareely longer than the slender compressed petiole; fruiting aments elongated, pubescent. - Low woods in the upper districts, and northward. March and April. - A middle-sized tree, with smooth gray bark. Leaves $3^{\prime}-5^{\prime}$ long, and nearly of the same width.

3. P. heterophylla, L. Branches terete; leares ovate, mostly obtuse, serrate, with obtuse, ineurved teeth, rounded or with a small sinus at the base, loary-tomentose on both sides when young, like the nearly terete petioles and branchlets, at lengtl only on the veins beneath; fruiting aments smooth. River-swamps in the middle and upper districts, Mississippi to North Carolina, and northward. March and A pril. $-A$ large tree. Leaves $3^{\prime}-5^{\prime}$ long.

The Lombardy Poplar (P. dilatata, Ait.), and the White Poplar (P. alba, L.), are introduced species.

\section{Subclass II. GYMNOSPERMI.}

Ovules naked (not enclosed in an orary), commonly supported by an open seale or leaf, and fertilized by the direct application of the pollen. Cotyledons often more than two.

\section{Order 132. Conifera. (Pine Family.)}

Trees or shrubs, with branching stems, composed of glandular or diskbearing woody tissue without ducts, resinous juice, linear or needle-shaped 
mostly persistent leaves, and monereions or dicedous anchtaceons flowers. Calyx and rorolla none. Orules ortlostropuns. Fruit a cone or drupe, Embryo in the axis of the albumen. Cotyledons 2 or more.

\section{Synopsis.}

Sumorner I. AlBETINE.E. Fertile flowers consisting of numerous bracted inbricated earpellary scales, bearing two collateral inverted orules at their base, and forming a cone in fruit. Busls scaly.

1. PIXUS. Leaves $2-5$ in a cluster, mostly elongated, sheathed at the buse.

2. ABIIS, leares single, short, destitute of a sheath.

Sumorder II. CLPRESSINEA. Fertile flowers consisting of few bractless mostly peltate carpellary seales, bearing one or several erect ovules at their base, hecoming fleshy or indurated, and forming in fruit a drupe or cone. I3uds naked.

3. JUxIPERUS. Fruit a drupe. Leaves minute, imbricated.

4. CUPRESSUS. Fruit a globular cone, with peltate scales. Leaves imbrieated, persistent.

5. TAXonuy. Fruit a globular cone, with peltate seales. Leaves spreading, on slender deciduous branchlets.

6. TIIUJA. Fruit an oblong cone, with imbrieated oblong seales. Leaves minute, imbricated on the flattened branches, persistent.

Suboriner III. TAXINEA. Fertile flower solitary, without a carpellary scale. Fruit a diupe. Buds sealy.

7. TA.IUS. Drupe surrounded by a fleshy cup. Albumen homogeneous.

8. TORREYA. Drupe naked. Albumen ruminated.

\section{PINUS, Tourn. PINE.}

Flowers monœcions. Sterile aments spiked or clustered. Stamens numerous on the axis, with very short filanents: anthers with a scale-like connertive, 2-celled, opening lengthwise. Fertile aments terminal, single or chustered. Carpellary scales in the axils of deciluous bracts, each bearing two collateral inverted orules at the bise, indurated in fruit, and forming a cone; the apex commonly thickened, angular, and spiny. Seeds nut-like, lodged in an excavation at the base of the seale, and furnished with a thin decilnous wing. Embryo in the axis of oily albumen. Cotyledons $3-12$, linear. - Trees. Icaves evergreen, needle-shaped, $2-5$ in a cluster, their bases enclosed in al thin scarious sheath.

\section{* Leaves turo in each sheath.}

1. P. pungens, Michx. (Thmle-Mocrtaix Pine.) Leaves from a short sheath, crowderl, short and rigid ; cones large, commonly $3-4$ in a whorl, ovate, sessile, the thick scales pointed at the apex, and armed with a very stout spine, which on the upper scales is incurved, on the lower ones recurved. - Mountains, rarely west of the Blue Ridge, Georgia to North Carolina, and northward. - A 
tree $40^{\circ}-50^{\circ} \mathrm{hi}_{g} h$, with sigil and irregular branches. Leares about $2^{\prime}$ long. Cones $3^{\prime}$ long, yellowish-brown. Buds resinous.

2. P. inops, Ait. (Jersey or Scrub Pixe.) Branchlets smooth and glaucous; leaves from short sheaths, scattered, short and rigid, flat on the inner face; cones solitary, conical-oblong, mostly reflexed, slıort-peduncled; scales armed with a ciraight sululate rigid spine. - Dry sandy or gravelly ridges in the middle districts, South Carolina, and northward. - A tree $15^{\circ}-30^{\circ}$ high, with rough blackish bark, and spreading or recurved flexible branches. Leaves $1^{\prime}-2^{\prime}$ long, dark green. Cones light brown, about $2^{\prime}$ long, opening at maturity.

3. P. glabra, Walt. Branches and branchlets smootl, whitislı; leaves slender, scattered ; cones generally solitary, somewhat relindrical; spincs nearly obsolete. - In close rich soil, near Black Oak, South Carolina, Ravenel. $-\Lambda$ tree $40^{\circ}-60^{\circ}$ lighl, with smoothish bark and soft white wood, blanching from ne:tr the gromul. Leaves $3^{\prime}-4^{\prime}$ long. Cones about $2^{\prime}$ long. "Wings of the seed lighter colored, more tapering, longer and less gibbons than those of $\mathrm{P}$. mitis." This specics of Walter, long overlooked, but lately revived by Mr. Ravenel, is, if I mistake not, not uncommon in the low lummocks of this State, and is distinguished liere, as in South Carolina, as the Spruce-Pine.

4. P. mitis, Michx. (Shont-Leaved Pixe.) Leaves from a long sheath, crowded, very slender, concave on the inner face, dark green; cones small, mostly solitary, oval or conical-oblong; the thin scales flattened at the apex, and armed with a weak incurved spine. (P. variabilis, Pursh.) - Light clayey soil, Florida, and northward. - A large tree, with rough bark, and fine-grained valuable wood. Leaves $3^{\prime}-5^{\prime}$ long, sometimes three in a sheath. Cones light brown, about $1 \frac{1}{2} /$ long, opening at maturity. Wings of the secd reddish.

$$
\text { * * Leaves thrce in each sheath. }
$$

5. P. rigida, Miller. (Pıтcu-Pixe) Leaves crowded, from a very short sheath, rigid, flattened on the inner face; cones single or clustered, sessile, orate, the scales armed with a short and rigid recurved spine. - Sandy barren soil in the upper distriets, and northward. $-\Lambda$ small or middle-sized tree, with thick blackish rugged bark, and hard resinous wood. Branches numerons, rigid, rough with the persistent bases of the leaf-bracts. Leaves $3^{\prime}-5^{\prime}$ long. Cones $2^{\prime}-3^{\prime}$ long, light-brown.

6. P. serotina, Michx. (Poxp-Pine) Leaves somewhat crowded, from a short sheath, elongated; cones mostly opposite, round-ovate, sessile; the scales rounded at the apex, and armed with a very small and weak spine.Borders of ponds and swamps in the lower districts, Florida to North Carolina. - A sniall tree, witl rongh bark and sappy valueless wood. Leaves $5^{\prime}-8^{\prime}$ long. Cones $2^{\prime}-3^{\prime}$ long.

7. P. Tæda, L. (Loblolly or Old-fueli) Pine.) Branches scaly; leaves from a long sheath, slender, elongated; concs larçe, solitary, oblongconical, with the scales armed witl a slıort and rigid straight spine. - Light 
sul mostly damp soil, Florida to North Carolina. - Commonly a lofty tree, with very thick and furrowed batr, and valuable, but spmringly resinons wood; but in old fielels low, with spreading branches. Leaves $6^{r}-10^{\prime}$ long, rarcly 2 or 4 in a slieatio, dark green. Cones $3^{t}-5^{\prime}$ Jong.

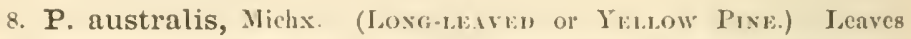
very long, from long sheaths, erowded nt the summit of the thick and very sealy branches; cones large, cylindrient or conieal-oblong, lie thick sentes armed with ushort recursed spine. (1’. palustris, $L$., the prior but inappropriate name.) Sandy soil, constituting almost the entire growth of the l'ine Barrens. $-\Lambda$ lofty tree, with thin-scaled lark, aud very valuable resinons wood, dividing near the summit into few spreading hranches. Leaves $10^{\prime}-15^{\prime}$ longr. Leaf-bracts scatrions, fimbriate. Cones $6^{\prime}-10^{\prime}$ long.

\section{* * Leures five in cach sheath.}

9. P. Strobus, L. (Wuit: l'sx.) Leaves slemder, from a very short and deciduous sheath; cones long, cyliudrical, recurved, with the loosely imbrieated seales neither thickened nor spiny at the apex. $-A$ tree of moderate dimensions on the mountains of Georgia and North Carolina, lut northward one of the loftiest of trees, and greatly valued for its soft white wood. Leaves $3^{\prime}-4^{\prime}$ long. Cones $4^{\prime}-6^{\prime}$ long.

\section{ABIES, Tourn. Sirece. Fir.}

Chiefly as in Pimus, but the aments mostly solitary; antluers opening lengthwise or transverscly; scales of the cone not thickened at the apex, nor spiny; wings of the seed persistent. - Leares single, short.

* Cones lateral, erect; with the scules deciduous at maturity: anther-cells opening transversely.

1. A. Fraseri, Pursh. (Silver or Bursin Fir.) Leaves somewhat distichous, linear, flattened, obtuse or emarginate, whitened beneath, the lower ones somewhat recurved, the uppermost erect ; cone oblong-ovate; braets long, oblong-wedge-shinjed, short-pointed, reflexed at the summit. - High mountains of North Carolina, and northward. $-\Lambda$ small tree. Leares $6^{\prime \prime}-8^{\prime \prime}$ Jong. Cones $1^{\prime}-2^{\prime}$ long.

* Cones terminal, pendulous, with the scales persistent: anther-cells opening lenythurise.

2. A. Canadensis, Michx. (IEmlock-Sprucen) Leaves distichous, flat, linear, obtuse, dark green above, whitened beneath; cones small, oval or oblong, with the few scales smooth and entire. - lligh mountains of North Carolina, and northward $-A$ linge tree with the horizontal branches gradnally diminishing upward, forming a pyramidal spire. Leaves $\frac{1}{2}$ long. Cones $\mathbf{8}^{\prime \prime}-$ $9^{\prime \prime}$ long.

3. A. nigra, Poir. (BLACK Sprver.) T.enves scattered on all sites of the branches, needle-shaped, 4 -sided, erect, dark green; cone ovate or ovate- 
oblong; the scales with a thin wavy or denticulate margin. - Iligh monntains of North Carolina, and northward. - A tall but slender tree. Leaves $\frac{1}{2}$ long; rigid. Cones $1^{\prime}-1 \frac{1}{2}^{\prime}$ long.

4. A. alba, Michx. (Wuite Spruce.) Leaves inserted on all sides of the branches, needle-shaped, 4 -sided, incurved, light green; cones oblong-cylindrical, with the scales entire. - High mountains of North Carolina, and northward. - A small tree, with more slender and less crowded leares than those of the preceding. Cones $I^{\prime}-2^{\prime}$ long.

\section{JUNIPERUS, L. JUNIPER.}

Flowers mostly diœcious. Aments lateral and terminal, small, few-flowered. Stamens several: anther-cells $3-6$, inserted heneath the peltate scale, opening lengthwise. Carpellary scales 3-6, I-3-ovnled, partly united, fleshy, and forming in fruit a berry-like drupe containing $1-3$ erect bony seeds. Cotyledons 2, oblong. - Trees, with subulate or scale-like persistent leares.

1. I. Virginiana, L. (RED CEDAR.) Branches terete; leaves opposite or by threes, ininute, rhombic-ovate, closely imbricated, depressed on the back; those on young shoots subulate and spreading; drupes small, blue, 1-2-secled. - Dry, rocky, or even wet soil, Florida, and northward. March. - A small tree, with redaisl, fine-grained, durable, and odorous wook, and spreading branches. Leaves dark green.

\section{CUPRESSUS, Toum. Cypress.}

Flowers monøecious. Aments terminal, few-flowered. Anther-cells 2-4, inserted under the lower edge of the peltate scale, opening lengthwise. Carpellary scales peltate, bearing several erect ovules on their stalks, l,ecoming woody in fruit, and forming a globular dehiscent cone. Sceds winged at each end. Cotyledous 2-3, obtuse. - Trees, with minute imbricated leaves.

1. C. thyoides, L. (White Cedar.) Branchlets compressed, crowded, distichous; leaves ovate, imbricated in 4 rows, with a roundish gland on the back; anther-cells two under each scale; cones small. - Swamps, Floridi, and northwarl. April. - A middle-sized tree, with fibrous bark, and light durable wood Branches spreading. Cones $3^{\prime \prime}-4^{\prime \prime}$ in diameter, borne on short scaly stalks.

\section{TAXODIUM, Richard. Cypress. Bald-Crpress.}

Flowers monœcious. Sterile aments small, in a Jong drooping spiked panicle. Scales peltate. Anther-cells 2-5, opening lengthwise. Fertile aments single or by pairs, with the peltate scales 2-ovuled. Cone globular. Scales very thick, angular, slender-stalked, separating at maturity. Seeds 3 -angled, wingless. Cotyledons 6-9, linear. - Trees, with distichous decidnous leaves.

1. T. distichum, Rich. Leaves alternate, opposite, or whorled, on very numerous short and slender deciduous branchlets, linear, acute, 2-ranked or im 
bricated. (Cupressus di-ticlat, L.) - Ponds nud deep swompe. Florida, and

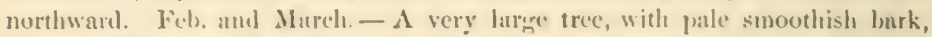
light duruble weot, und few fastigiate branches at the smomit. Ideaves $4^{\prime \prime}-6$ " long. Cones $\xi^{\prime}-l^{\prime}$ in diameter. Attacled to the roots are liollow conical knobs called Cypress-linees.

\section{THUJA, Tourn. Arnor-Vits.}

Flowes inomerions. Aments small, terminal. Antherecells \&, with a sealelike connective. Carpellary seales imbricated in four rows, with two erect orules at the base. Cone oblone, the few scales imbrieated, expanding at maturity, persistent. Sced winged. Cotyledons 2, oblong. - 'Trees or slurubs, with sealelike imbricated persistent leaves.

1. T. occidentalis, I. (Arnor-Vutev) Branclies flat, disticluons; leaves owate, obtuse, with a gland on the back, imbricated in four row's ; rones oblong, nodding, with the outer scales oblong, obtuse; seeds broally winged, emarginate at each cull. - Rocky bauks on the mountains of Carolina, and northward. $\Lambda$ small or middle-sized tree. Cones $\frac{1}{2}$ long.

\section{TAXUS, Toum. Yiw.}

Flowers diocions, axillary; the sterile ones in grobular few-flowered aments. Anther-cells $3-8$, inserted under the peltate scale. Fertile flowers solitary, sculy-bracted, consisting of a singrle orule on a cup-shaped disk, which becomes lare and bery-like in fruit, and surounds the nut-like seed. Embryo in the axis of nealy albumen. - Trees or slurubs, with seattered branches, lincar rigid distichous leaves, and sealy buds.

1. T. Floridana, Nutt. Leaves narowly linear, mucronate, conspicuously petioled (abont $9^{\prime \prime}$ long), the onter margin revolute; frut abundant; the fleshy disk of the seed bright resl. - Banks of the $\Lambda$ palachicola liver, Midule Florida. $-\Lambda$ sinall tree, $10^{\circ}-20^{\circ}$ high.

\section{TORREYA, Arnott.}

Flowers dicerious, axillary; the sterile ones in givbose or oblong aments $\Lambda$ nther-cells 4, inserted under the peltate scale. Fertile flowers solitury, con. sisting of a solitary oriule surrounded with imbrieated persistent scales. Disk none. Seed large, oroid, naked. Embryo at the apex of hard ruminated albumen. Cotyledons 2 , linear. - Trees, with whorled branches. Leaves distichous, rigid, persistent. Buls sealy.

1. T. taxifolia, Arn. Branchlets opposite, 2-rankel ; lenves linear, spinypointed, nearly sesile, light green; sterile aments yellow, rowded; sect ovoid, drupe-like. - Rieh soil, along the east bank of the Apalachicola River, Middle Florila. March. $-\Lambda$ midlle sized tree, with duralle strong-seented wood, and horizontal hanches. Leaves very rigid, and pungent, l' long. Sced smooth and gliueous, similar in shape and size to a nutmeg. 


\section{Order 133. CYCADACEAs. (CrCas Famhy.)}

Trees or shrubs, with simple trunks, inereasing by a terminal bud, like the Palms, and composed of a large pith, mixed with woorly bumlles or plates, enclosed in a cylinder of woody fibre and spiral vessels. Leaves pinnate, coiled in the bud, like Ferns. Flowers diocious, destitute of calyx and corolla. Sterile flowers consisting of 1-celled anthers inserted under the peltate scales of a cone-like ament. Fertile flowers consisting of naked ovules inserted under the scales like the sterile flowers, or on the margins of contracted leaves. Seed nut-like. Embryo in the axis of the albumen. Iadicle ending in a long spiral cord. Cotyledons 2.

\section{ZAMIA, L.}

Flowers in cone-like aments, with the peltate seales inserted on all sides of the common rachis. Anthers numerons. Orules by pairs, pendulons. Seed roundish, drupe-like. - Leaflets thickened at the base and articulated with the petioles, with numerous simple veins.

1. Z. integrifolia, Willl. (Coosxue.) Stem short, globular or oblong; leaves petioled, spreading, with the numerous lanceolate or lineir-lanceolate leaflets entire, or serrate near the apex; aments oblong, obtuse, short-peduncled. Low grounds, Sonth Florida. - The stem abounds in starch, from which the Florida Arrowroot is obtained.

\section{Class II. MOTOCOTYLEDONOUS OR ENDOGENOUS PLANTS.}

Stems composed of cellular tissue and seattered bundles of wooly filure and ressels, destitute of proper pitl, bark, or eoneentric layers, and inereasing in diameter by the deposition of new fibrous bundles. Leaves mostly alteruate, entire, and parallel-reined, commonly sheathing at the base, seldom falling off by an articulation. Floral envelopes usually by threes. Cotyledous single.

\section{Order 134. PALMLE. (Paliss.)}

Chiefly trees, with a thick wooly stem (caudex), growing by a terminal bud, pinnate or fan-shaped leaves, which are plaited in the bud, and a sparlix of small perfect or polygamous flowers. Sepals and petals 3 , free or more or less united, persistent. Stamens mostly 6, hyporynous or perigynous: anthers 2-celled, introrse. Ovary 3-celled, commonly with a 
single crect orthotropous or anatropous orule in each cell. Styles 3, mostly mited: stigmas cutire. Fruit a drupe or berry. Embryo 'ylindrical, platerel in a cavity of the hard allmmen, near the circumference of the secel. - Stems ereet or ereeping. Jeaves long-petioled. Spadix axillary.

\section{SABAL, Alans. Palmito.}

Flowers perfect, sessile, brated. Calyx cup-shaped, 3-cleft. Corolla 3petallet. Stamens 6, hyporynous; the filaments subulate, dintinct. Anthers cordate ovate, horizuntal. Orary 3-celled. Styles united, 3-angled: stigma capitate or obtue. Fruit a l-seeded irnpe. Embryo dorsal. Albumen homorrencous, horny. - Stens simple or branched, erect or ereeping. Ideaves fin-shaped, lone-petiolet, with the divisions 2-eleft at the apex and often with long threal-like filaments interposed. Spadix long, branching, with sheathing spatle's at the joints. Flowers small, whitish, rigikl. Drupe oblong or globose. Slueatlis of the leaves commonly composed of try interlaced fibres.

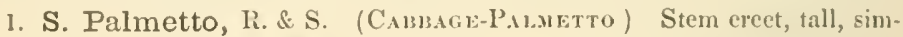
ple, leafy at the summit; leaves large, cordate in ontline, finnatifid-fan-shaped, recurved at the summit, mostly shorter than the smooth eoneave petiole; the very numcrous divisions decply eleft, and with thread-like filaments at the sinuses; spatix smooth and spreading, commonly shorter than the leaves; petals slightly united at the bate; style thiek; drupe globose. (Chanorops Palmeto, Michr.) - Sanrly soil along the coast, Florida to North Carolina. June. Stem $20^{\circ}-40^{\circ}$ high. Leares $5^{\circ}-8^{\circ}$ long, their bases long-persistent. Drupe black, $4^{\prime \prime}-5$ " in diameter.

2. S. serrulata, R. \& S. (SAw-PAlмetтo.) Stem creeping, branthing; leaves cireular in outline, fun-shaped, bright-green, shorter than the slenter plano-convex more or less spiny-edged petiole; the numerous $(15-30)$ erect divicions slightly cleft at the apex, and without thread-like filanents in the sinuses; spudix densely tomentose, much shorter than the leares; petals searcely united; style slender; druje oroid.oblong. (S. minima, Nutt.? Chamarops, Pursh.) - Sandy soil in the lower districts, Florida to South Carolina. June. - Stem $4^{\circ}-8^{\circ}$ long. Leaves $2^{\circ}-4^{\circ}$ high. Drupe black, $8^{\prime \prime}-9^{\prime \prime}$ long.

3. S. Adansonii, Gnerns. (Dwarf P.nmetro.) Stem short, buried in the earth; leares cireular in outline, glancous, fan-shaped, slightly pinnatifid, longer than the stont concave smooth-cluged petiole; the numerons $(20-30)$ divi-ions slighlty eleft at the apex. sparingly filanentose at the sinuses; spadix erect, smooth, slender, much longer than the leaves; petals united at the bave; style thick; drupe glohose. (S. pumila, Ell.) - Low grounds in the lower districte, Florida to North Carolina. June and July. - Leaves $2^{\circ}-3^{\circ}$ high. Spadix $3^{\circ}-6^{\circ}$ high. Drupe $4^{\prime \prime}$ in cliameter, black. Nut hemispherieal.

\section{CHAM无ROPS, Is.}

Flowers polygamous, bracted. Calyx 3-cleft. Corolla 3-petalled. Stamens $6-9$, with the filaments connate at the base : anthers oblong. Ovaries 3 , more 
or less united. Stigmas acute, stigmatie on the inner face. Drupes $1-3$, one. seeded. Embryo dorsal, in horny somewhat ruminated albumen. - Low palms, with fan-like long-petioled leaves, destitute of thread-like filaments. Sheaths soon dry and net-like. Spadix dense-flowered, branching. Spathe 2-4-leaved. Flowers yellowish. Drupe globose or ovoid.

1. C. Hystrix, Fraser. (Bute Paluetro.) Stem short, proliferous; leaves circular in outline, with numerous $2-4$-toothed divisions, on triangulal rongl-erlged petioles; sheaths persistent, composed of oblique fibres interwoven with numerous ereet strong spines; spadix small, short-peduncled; spathes about 4, oblong, woolly, acntely 2-lipped; petals oroir ; drupe oroid. - Low shady woods in the lower distriets, Florjda to South Carolina. June and July. - Stem $2^{\circ}-3^{\circ}$ long, ereet or ereeping. Leaves somewhat glaneous, $3^{\circ}-4^{\circ}$ high. Spadix $6^{\prime}-12^{\prime}$ long. Partial spathes none. Drupe $6^{\prime \prime}-9^{\prime \prime}$ long.

\section{Order 135. ARACEA. (Arum Famex.)}

Acrid chiefly stemless herbs, from tuberous or ereeping rootstocks, with entire or divided often veiny leaves, and perfect or monœcious flowers borne on a spadix, and commonly enclosed in a spathe. - Calyx and eorolla wanting, or the former with seale-like sepals. Stamens short, hyporynous: anthers extrorse, commonly sunk in the thick conneetive. Ovary 1 -several-celled, with 1 - several ovules in each cell. Stigma sessile. Fruit fleshy, indehiseent. Embryo straight. Albumen mealy or fleshy, sometimes wanting.

\section{Synopsis.}

* Calyx and corolla none. Spadix enclosed in a spathe. Flowers monocious.

- Fertile flowers numerous. Spadix frec.

1. ARIS EMA. Spathe thin, convolute at the base, arching above. Spadix barren above. Leaves 3 - several-lobed.

2. PELTANDRA. Spathe (green) thick, convolute throughout, wavy on the margins. Spadix flowering throughout. Leaves sagittate.

3. Xaviliosoria. Spathe convolute at the base, open and white above. Spadix flowering throughout. Leaves sagittate.

+ + Fertile flower solitary. Spadix adnate to the spathe.

4. PISTIA. Free-floating aquatics. Fertile flowers solitary.

* * Calyx manifest. Flowers perfect.

- Spadix enclosed in a spathe.

5. STMPLOCARPUS. Spathe thick and fleshy, convolute, pointed. Spadix globular. Sepals and stamens 4.

++ Spadix naked.

6 OROYTIUM. Spadix terminating the elub-shaped white-topped scape.

7. ACORUS. Spadix attached to the side of the flattened leaf-like scape.

\section{ARIS ÆMA, Mart. Indian Turnip.}

Spathe convolute below, dilated and commonly arehed above, withering. Spadix covered below with monœeious flowers (the lower ones fertile), clon- 
Fated amd naked alove. Calyx and corolla none. Stamens 4 in $n$ whorl, very short: unther-cells 2-4, distinct, opening at the top. Orary l-eelled, with 5-6 creet orthotropous oruhes. Stigma sessile. Fruit a 1-few-seculerl scarlet berry. Ismbryo in the axis of mealy albumen. - Ront tuherons. l'etioles of the commonly divided and veing leaves elongated and sheathing the seape. Frnit-clusters milicd.

1. A. triphyllum, Torr. (Wakle-lions.) Leaves two, trifoliate; leafIcts sessile, oblong-ovate, acuminate; spathe tulualar, dilated, flattened and ineurved above, acuminate, green, or variegated with white and pmple, lomger than the club-shaped ohtuse often diecious spadix. (Arum triphyllum, L.) Low rich wooks, Florida, and northward. March. - l'lant $1^{\circ}-1 \frac{1}{2}$ liggh. Ieaflets $3^{\prime}-6^{\prime}$ loutr. Root depressed, magose, intensidy acrid.

2. A. polymorphum. Leaf solitary, 3-5-foliohte; leaflets rarying from cublomer to obovate, acite or slightly acuminate, nearly sessile, the hateral ones cntire, 2-lobed or 2-parted to the base; spathe, \&e. as in tho preceding. (Arum polymorjplumn, Buckly. A. quinatum, Nutt.?) - Mountains of North Carolina. - Plant $1^{\circ}-1 \frac{10}{2}$ ligh.

3. A. Dracontium, Schott. (Drisos-root.) Ieaf solitary, pelately 9-13-foliolate; leaflets petioler, entire, lanceolate or oblong, actminite; spathe tubular (green), coneare and erect ntrove, much shorter than the very slender spadix. (Arum Dracontium, L.) - Rich woods, Florida, ant northward. Mardl and A pril. - Plant $1^{\circ}-1 \frac{1}{2}{ }^{\circ}$ highl. Berries numerous on the flat rhachis, 1 - 3-scederl.

\section{PELTANDRA, Raf. Arrow-Artis.}

Spathe clongated, fleshy, convolute througlout, wavy on the margins, curved at the apex, persistent at ilse base. Spadix long, wholly covered by the monoccions flowers. Calyx and corolla none. Anther-ells 5-6, imbedided in the thick peltate connectire, opening by a terminal pore. Orary l-celled, with several orthotropons orules. Berry 1-3-seeded. Seed gelntinous, without albunen. Eumbryo large. Plumule conspicuons, curred. - I flesly stemless marsh herh, from a ereeping rhizoma. Leaves sagittate, with the petiole sheathing the base of the thick scape. Frnit-clusters enclosed in the fleshy persistent base of thic spathe.

1. P. Virginica, Raf. Leaves scveral, ohlong, acute, fincly veined, and with $2-3$ intramarginal nerves, the lobes obtuse; seapes shorter than the leaves recursed in fruit; spathe lanceolate, acute, longer than the eylindrical sparlix, both early decaying ahove the fertile flowers; berries green, in a globose cluster, 1-secded. (Arum Virginieum, L.) - Marshes and wet places, Florida, and northward. April and May. - Plant $1^{\circ}$ high. Spatbes $2^{\prime}-4^{\prime}$ long.

\section{XANTHOSOMA, Schott.}

Spathe convolute at the hase, straight. Spadix sterile in the middle. Calyx and corolla none. Anther-cells numerous, adnate to the conical truncate 
connective, opening at the apex. Ovaries numcrons, crowded, somewhat 4-eclled, with numerous horizontal ovules in each ecll. Style short and thick: stigma broad, depressed, lobed. Berry red, many-secded. - Herbs. Petioles of the sagittate leaves sheathing the base of the scape.

1. X. sagittifolium, Schott. Stemless; leaves glaucous, hastate-cordate, acuminate, the lobes oblong, obtuse ; spathe hooded at the summit, oval-linceolate, white, longer than the spadix. - Marshes and springy places, near Savannals, Elleott, and Wilmington, Curtis. May and June. If - Root tuberous. Petioles $12^{\prime}-15^{\prime}$ long. Leaves $5^{\prime}-7^{\prime}$ long, the lobes somewhat sprearling and gencrally obtuse. Scape as long as the petioles.

\section{PISTIA, L.}

Spathe tubular at the base, spreading above, united with the spadix. Flowers few, moncecious, the upper ones staminate and supported by a eup-shaped involuere; the fertile solitary. Calyx and corolla none. Anther-eells 3-8, opening transversely. Ovary 1-celled, with several erect orthotropous ovules. Siyle thick : stigma disk-like. Berry few-many-seeded. Eumbryo at the apex of the albumen. - Sinall frec-floating aquatic herbs, with fibrous roots, and entire elustered spreading leaves, with the flowers in their axils.

1. P. spathulata, Michx. Leaves arranged in a circle, round-obovate, abluptly contracted into a sliort petiole, with the nerves projecting beneath (lamelliform); roots numerons, elongated ; spathe short-peduncled, white. - In still water, East Florida, and westwad. - Leaves $l^{\prime}$ - ㄹ' long.

\section{SYMFIOCARPUS, Salisb. Skexk-Cabbage.}

Spathe hooded-shell-form, acminate, fleshy, early decaying. Spadix pedunclel, globose, corered with the perfect flowers. Sepals 4 , hoorled, berry-like in fruit. Corolla none. Stamens 4 : anthers 2-eelled, opening lengthwise. Ovary 1-celled, l-ovuled. Style pyramidal, 4-angled; stigma minute. Berries with the sepals united in a mass. Seeds globose, without albumen. Embryo thick and fleshy. - Perennial garlic-scented herbs, from a lleep and thick rhizoma, with large stout-petioled veiny leaves, and nearly sessile spathes, appearing before the leares.

1. S. fœtidus, Salish. I,eaves thin, oval, cordate, short-petiolel; spatho ovate, incurved, spotted with purple and yellow; spadix dull-purple, much shorter than the spathe, enlarged in fruit. (Pothos foetidus, Mich. $x$.) - Bogs and swamps, North Carolina, and northward. Feb. and March. - Leaves $1^{\circ}-2^{\circ}$ long. Spathe $2^{\prime}-4^{\prime}$ long. Spadix in fruit $2^{\prime}-3^{\prime}$ in diameter. Seeds about the size of a pea.

\section{ORONTIUM, L. Goldex-CuUb.}

Spathe none. Spadix cylindrical, covered with the yellow perfect flowers. Sepals and stamens $4-6$. Authers 2-celled, opening lengthwise. Ovary l-eelled, 
with a single amphitropous orule. Stigma minnte, sessile. Fruit green. Sted without albumen. imblryo thick and flesly. $-\Lambda$ peremuial nquatie licrb, with oblung lone-petioled leaves, and a yellow erect spadix terminating the clubshaped scape.

1. O. aquaticum, L. Rhizoma deep, fleshy; leaves acute, nerved, on stont terete petioles; seape tercte, thickened upwarl, whice beneath the spadix, sheathed below, commonly curved. - Ponds amel slow-flowing streams, Florjda, and northward. Miarch and $\Lambda$ pril. - Leares about $1^{\circ}$ long. Scapo $1^{\circ}-2^{\circ}$ long. Spatdix 1'-2' long; the upper flowers mostly tetrandrous.

\section{7. acorus, I. Calants. Sweet Frag.}

Seape fattened, leaf-like, with the lateral sessile sparlix covered with the perfeet flowers. Spathe none. Sepals aud stamens 6. Corollat none. Filaments slender: anthers kilney-shaped, I-celled, opening transversely. Ovary 2-3celled, with several orthotropous suspended orules in each cell. Stigma minute. Fruit dry, gelatinous within, 1 - few-sceded. Embryo in the axis of the albumen. - P'rennial herbs, from a ereeping aromatic rhizoma. Icaves erect, long, flattened, 2-edged. Seaje leaf-like, elongated ahore the spadix.

1. A. Calamus, L. - Wet places, Florida, and northward, apparently introduced. April. - Rhizoma rather slender, pungent. Leaves $1^{\circ}-20$ high, linear-lanceolate. Scape narrower than the leaves. Spadix cylinitrical, yellowish, $2^{\prime}-3^{\prime}$ long; spreading.

\section{Order 136. IEMNACEE. (DeckWeed Faumy.)}

Minute aquatic floating plants, witl lentieular proliferous stems (fronds). and usually simple roots, pendent from beneath. Flowers monocious, mostly from a marginal cleft of the stem. Spathe membranaceous, pitcher-shaped, bursting into two une fual lobes, soon vanishing, commonly enclosing two sterile flowers, which are reduced to single slender filaments bearing a 2-celled inther, and a single sessile 1-celled ovary, which forms in fruit a 1-i-seeded utricle. Embryo straight, in the axis of fleshy albumen.

\section{LEMNA, L. DUCKWEED}

Spathes marginal, 3-flowered. Anthers opening transversely Stigma funnelform. Orules erect from the base of the eell, anatropous or half-anatropous. Sterns inereasing by lateral buds. Roots terminating in a calyperelike appendage. - The flower's of these plants are seldom seen.

1. L. minor, L. Stems pale, round-olıvate, fattened, single or variously chustered ; root siugle ; ovule solitary, half-anatropous; seed horizontal. - Pools, ditches, \&e., Florida, and northward; commion near the coast, and probably intermixed with $L$. perpusilla, Torr - Stems $1 "-2^{\prime \prime}$ long. 
2. L. polyrhiza, L. Stems roundish or obovate, flat and paic above, convex and dark purple beneath, clustered ; roots numerous, clustered ; ovules 2 . - Ponds, Florida, and northward - Less common than the preceding. Stems $2^{\prime \prime}-4^{\prime \prime}$ long.

\section{Order 137. TYPHACEA.. (CAT-tail Famly.)}

Simple-stenmed marsh herbs, with elongated strap-shaped nerved leaves, and monocious flowers, on a globular or eylindrical spadix, destitute of floral envelopes, but enveloperl in copious pappus-like hairs or seales. Spathe bract-like or none. Anthers single or 2-4 together, on long and slender filaments. Ovary 1-celled, with a single suspended anatropous ovule. Style slender. Fruit nut-like. Embryo straiglt in copious albumen. - Sterile spadix placed above the fertile, continuous or distant.

\section{TYPHA, Tourn. Cat-TaIL.}

Flowers densely erowded on a long cylindrieal terminal spadix, enveloped in copious pappus-like hairs; the sterile ones sessile on the upper part of the spadix, the fertile on slender stalks. Style filiform : stigma lateral. Embryo eylindrical, in the axis of fleshy albumen. - Stems straight, from a thick rhizoma, clothed below with the sheathing hases of the elongated linear leaves. Spathes bract-like and deciduous, or none.

1. T. latifolia, L. Stem terete, jointed below; leaves nearly as long as the stem, erect, flat, reticulated and somewhat glaucous; sterile and fertile portions of the spadix contiguous, cylindrical. - Margins of ponds and rivers, Florida, and nortliward. July and Aug. - Stem $4^{\circ}-6^{\circ}$ high, scape-like above. Leaves about $1^{\prime}$ wide. Spadix ahout $1^{\circ} \operatorname{long}$. $-T$. angnstifolia, $L$., if found within our limits, may be known by narrower leaves which are channelled near the base, and by the interval which separates the sterile and fertile portions of the spadix.

\section{SPARGANIUM, L. BUR-REED.}

Flowers densely crowded in glolunlar lieads, surrounded by several seales like a calyx; the upper heads sterile, naked, the lower fertile and commonly bracter. Ovary sessile, pointed by the short persistent style. Stigma lateral. Fruit nutlike. Embryo eylindrieal, in the axis of fleshy albumen. - Marsh or aquatic plauts, with erect stems, and long strap-shaped sessile leaves, the lowest ones sheathing. Heads of flowers scattered.

I. S. ramosum, Huds.? Leares flat, obtuse, the upper ones gradually shorter, coneave and clasping at the base, the lower sheathing and elongated; heads $5-9$, disposed in axillary and terminal interrupted spikes; the lowest one larger and pistillate, the others wholly staminate; scales wedge-shaped; stigma subulate, simple. (S. Americanum, Ell.) - Lagoons and ditches, Florida, and northward. July. - Stem $2^{\circ}-3^{\circ}$ high. Leaves as long as the stem, $8^{\prime \prime}-12^{\prime \prime}$ wide. Heads of fertile flowers $8^{\prime \prime}-10^{\prime \prime}$ in diameter. 


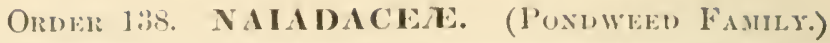

Aquatic herhs, with slembler jointed leafy immersed stems, aml jerfect muncerious or dieceions flowers, destitute of floral envelopes, or with

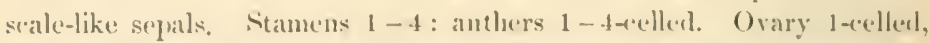
forming a 1-seeted arleninm in firuit. Stignas $1-1$. Sexd without albumen. Embryo straight, curverl, or coiledl. - Lceaves sheatling, or with sheathing stipules. Flowers commonly enclosed in a spathe.

\section{Synopis.}

* Flow rs monocious or dinecious.

1. NAIAS. Stigmas $2-4$. Flowers naked. Leaves opposite or whorled.

2. 7.0STERA. Stigmas 2. Flowers enclosed in a spathe. leaves alternate.

3. ZAXXICIELliA. Stigma single, peltate. Ovaries 4 , from a cup-like iorolucre.

* Flowers perfect.

4. RUPPIA. Fruit long-pedunelet, umbellate. Caly $x$ and corolla noue.

5. POTAMOGETON. Fruit sessile, spiked. Calyx 4-leared.

\section{NAIAS, L.}

Flowers monœeious or diøcions, axillary, sessile, destitute of calyx and corolla. Sterile flower monandions, enelosed in a spathe. Anther 4-celled, oprening at the apex, the filament lengthening. Fertile flower naked; the sessile ovary pointed with the slender style. Stigmas 2-4, subulate. Orule erect. Achenium minute. Embryo straight. Radicle inferior. - Stems filiform, forking. Leases opposite or whorled, linear, dilated into a short slieath at the base Flowers solitary, minute.

1. N. flexilis, Rostk. Stem immersed $\left(1^{\circ}-2^{\circ} \mathrm{long}\right)$; leaves 3 in a whorl. narrow-linear, menbranaceous, spreading, minutely denticulate on the margins, the lower ones often remote; stigmas 3-4; achenium elliptical, acute, smooth, yellowish. (Caulinia flexilis, Willd.) - In ponds and still water, South Carolina, and northward. July and Aurr. - Leaves about $\mathbf{1}^{\prime}$ long.

Var. ? fusiformis. Stem $\left(6^{\prime}-12^{\prime}\right.$ long) almost eapillary, very leafy throughout ; leaves opposite, approximate, spreading or recurved ( $2^{\prime \prime}-4^{\prime \prime}$ long); achenim narrowly spindle-shaped, finely reticulatel, brownislı. - Brackish water along the coast. West Florida. July and Aug.

\section{ZOSTERA, L. FEL-GRASS.}

Flowers monocious, naked; the sterile and fertile ones alternately arranged on the anterior edge of a flattened membranaccous spadix, and encloserl in the sheath-like base of the leaves. Anthers oblong, l-celled, filled with fine filaments instead of pollen-grains. Orary fixed near the apex, containing a single pendulous orthotropous ovile, and pointed with the subulate persistent style. Stigmas 2, capillary. Utricle hursting irregularly. Seeds striate. Cotyledons inflexel-eurved, received in a longitudinal cleft of the embryo - Marine herbs, with creeping stems, and narrowly linear obtuse and elongated sheathing leaves. 
1. Z. marina, L. Stem slender, terete, jointed; leaves thin and tender, faintly 3-5-nerved; flowers in two rows on the linear spadix. - Deep saltwater coves. West Florida, and northward. Aug. aud Sept.

\section{ZANNICHELLIA, L.}

Flowers monœcious, axillary. Sterile flower consisting of a solitary naked filament bearing a 2-4-celled anther. Fertile flower from the same axil, composed of 2-6 sessile 1-celled ovaries, surrounded by a cup-shaped involucre, and pointed with the slender style. Stigma obliquely peltate. Ovule suspended, orthotropons. Achenium oblong, stalked. Embryo sleniler, coiled. - Submerged aquatic plants, with filiform branching stens, and very narrow and entire alternate leares, witlı sheathing stipules.

1. Z. palustris, L. Stems tufted, filiform, alternately branched; leav's narrowly linear, entire, acute, 1-nerved; anther 2-celled, on a long and slender filament; achenia 3-6 in a cluster, commonly raised on a short common peduncle, each stalked, linear-oblong, somewhat compressed and curved, smooth and wingless, about one third longer than the persistent style. - Fresh or brackish water, West Florida, and northward. May-Aug. - Stems $1^{\circ}-3^{\circ}$ long. Leaves $1^{\prime}-2^{\prime}$ long.

\section{RUPPIA, L. Ditch-gRass.}

Flowers perfect, naked, two or more on a slender spadix, enclosed in the spathe-like sheaths of the leaves, but soon long-exserted. Stamens 2, closely sessile : anther-cells large, distinct. Ovaries 4, sessile, containing a single suspended campylotropous ovule. Stigma peltate. Achenium stalked, obliquely ovate. Embryo pointed by the short plnmule. - Salt-water lierbs, with filiform branching stems, and altemate linear or bristle-like sheathing leares.

1. R. maritima, L. - In shallow water, along the coast, Florida, and northward. May - Aug. - Stems immersed, $1^{\circ}-3^{\circ}$ long, mostly creeping at the base. Leaves filiform, $1^{\prime}-3^{\prime}$ long, with dilated membranaceous sheaths. Fruiting peduncles $1^{\prime}-4^{\prime}$ long. Acheninm pointed.

\section{PotamogetoN, Tourn. Pondwed.}

Flowers perfect, spiked. Sepals 4, roundish, valvate in the bud. Stamens 4, opposite the sepals: filaments short: anthers 2-celled. Ovaries 4, sessile. Orules aseending, campylotropous. Style short or none: stigma peltate. Achenia 1-4, compressed. Embryo curved or coiled. - Aquatic herbs, with immersed slender and jointed stems. Leaves stipulate, alternate and opposite, either all immersed and commonly membranaceous, or the upper ones floating and more rigid. Spikes peduneled, axillary and terminal.

\section{* Leaves all immersed and alike.}

+ Lear'es filiform.

1. P. pectinatus, L. Stem slender, fexuous; the branches diffusely forking; distichous ; leaves long, thickish, sliglitly channelled, approximate on 
the branches; stipules small, muiterl with the long and slieathing liase of the leaves; spikes sleniler, interrupted, on long filiform peduncles; arheniun ohovate, smooth, slightly compresied, kected on the latek. - Fresh or hrackish wner, Went Florirla, and northwarl. June-Aug. - Stcms $2^{\circ}-3^{\circ}$ long. Leaves $3^{\prime}-$ 4' long. Spikes 1'-2' long.

2. P. pauciflorus, Porsh. Stem very slender, flattened, sparingly brancherl; leaves seatterel, thin, 3-nerved, sessile; stipules fre from the leaves, connate, sheathing; spikes short-perluncled, 4-6-flowered, glolose in fruit; arheniun rouncl-ohovate, short-pointed, kecled and sinuate-toothed on the back. - Shallow ponels, Georgia, ant northward. July and $\Lambda$ ug. - Stem $1^{\circ}-2^{\circ}$ long. Leures $1^{\prime}-2$ ' long. Peduncles $\frac{11}{2}-1^{\prime}$ long.

+- + Lenves lanceoiate or cordute: stipules free, shrathing.

3. P. perfoliatus, L. Stem terete, branching, very leafy ; leaves orate, cordate, clasping, obuse, many-nerved, those at the branclies and peduncles opposite; spikes lateral and terminal, oblong, densely many-flowered, on stont peduneles $2-3$ times as long as the leaves; achenium obliquely ohovate, roumled on the bark, short-pointed. - Fresh or brackish water, West Florila, amb northward. July-Sept. - Stems $1^{\circ}-2^{\circ}$ long. Leaves $6^{\prime \prime}-8^{\prime \prime}$ lung.

4. P. Iucens, I.? Stems sparinerly branched; leaves lanceolate, acute, contracted and sessile at the base, pellucid, 5-9-nerred, wary on the margins; stipules (white) connate, roumbel on the back; spikes cylintrical, many-flowered, on stont perinncles shorter than the leaves; achenium (immature) oval, compressed, roumlerl on the lack, short-pointed. - Fresla water, A palachicola, Florida. Aug. - Stems $2^{\circ}-3^{\circ}$ Jong. Leaves $2^{\prime}-3^{\prime}$ long, equalling the spikes.

* * Leuves of two forms; the immersed ours thin the pullucid, the fioating oncs longpetioled and somerthat coriuceous.

5. P. fluitans, Roth. Stem sinple; leares many-nerverl; the floating ones varying from oblong-lanceolate to orate, acute at each end, or obtuse or cordate at the base; the others large, oblong, gradually or abuptly shortpetioled, undulate; stipules connate aml keeled on the biack; perluncles stont, t!eckened upwarl; spikes long, 'ylindrieal, dense-flowered; achenium smooth, 1-3-kecled on the back. - Fresli-water ponds and streams, Florida, and northwarl. June $-\Lambda$ ug. - Leaves $2^{\prime}-9^{\prime}$ long.

I'. xitsxs, I. probalsly oceurs within our limits, but I have not seen epecimens. It may be known by longer-petioled $\left(t^{\prime}-12^{\prime}\right)$ leares, more slender pelinncles, and rounded stipules and achenia.

6. P. heterophyllus, Schreher. Stem slender, lranching; floating leares small, thin, elliptical or oblong-linear, on filiform petioles; immersed leaves long, sessile, linear or lanceolate; stipules connate, 2-riblbel; petuncles thickened npward; spikes narrowly eylindrical; achenium smooth, slightly keeled on the hack. - Shallow jonds, North Carolina, and northward. July. - Floating lcares 1'$2^{\prime}$ long. Immersed leaves $t^{\prime}-6^{\prime}$ long.

7. P. hybridus, Michx. Small; stems rery slender, branched; floating leares lanceolate or elliptical, commonly acute at cach end, shining and strozgly 
impressed-nerved, longer than the filiform petioles; immersed leares filiform, scattered; spikes oval or oblong, short-pedıncled; achenium nearly eireular, concave on the sides, rugose or tuberculate, and 1-3-ridged on the back; embryo coiled. (P. setaceus, Pursh. P. heteroplyyllus, Ell. ?) - Shallow ponds, Florida, and northward. June - Aug. - Floating leaves $6^{\prime \prime}-8^{\prime \prime}$ long, commonly 5-nerved.

\section{Order 139. alismacez. (Water-Plantain Family.)}

Marsh herbs, usually with creeping runners or rootstocks, nerved and reticulated sheathing leaves, and scape-like stems, bearing the perfect or monœcious flowers in spikes or whorled racemes. - Sepals and petals 3, or the latter sometimes wanting. Stamens few or numerous: anthers 2celled. Ovaries 3 or many, with 1 - 2 anatropous or campylotropous erect ovules. Style short or none. Achenium coriaceous, 1-2-seeded. Embryo straight or curvel, without albumen.

\section{Synopsis.}

Suborder I. JUNCAGINEF. Sepals and petals (when present) greenish. Ovule auatropous. Embryo straight.

1. TRIGLOCHIN. Leaves rush-like. Flowers in spiked racemes.

Suborder II. ALISMEA. Petals white, deciduous. Ovule campylotropous. Eubryo curved or hooked.

2. ALISMA. Flowers perfect. Achenia whorled. Racemes compound.

3. ECIIINODORUS. Flowers perfect. Aehenia clustered in a head.

4. SAgitTaria. Flowers monœeious. Achenia clustered in a head.

\section{TRIGLOCHIN, L.}

Flowers perfect, in a spiked raceme. Sejals 3. Petals 3, and greenish, like the sepals, or none. Anthers 3-6, nearly sessile, oval. Ovaries 3-6, united around a central axis, from which they separate at matırity, l-oruled. Stigmas plumose. Embryo straight. - Leaves rush-like, fleshy, 2-ranked. Flowers small, braetless.

1. T. triandrum, Michx. Leaves erect, linear-sıbulate, semi-terete, dilated at the base and sheathing the base of the terete seape; flowers very numerous, on short pedicels; sepals oval, deciduous; petals none; anther's and ovaries 3 ; fruit globose-triangular, pointless, when dry 3-winged by the compressed 3-ribbed achenia ; embryo oblong. - Salt marshes along the const, West Florida to North Carolina. Aug. - Sept. - Scape and leaves $\frac{1}{2}^{\circ}-10$ liggl.

\section{ALISma, L. Water-Plantain.}

Flowers perfect in a whorled paniele. Sepals 3. Petals 3 , involute in the bud, deciduous. Stamens 6-12. Ovaries numerous in a simple whorl. Style 
short. Achenimm 1-siceled, 2-3-kecled on the back. - liouts fibrons. Leaves sustly oval or cordite, nerved, shorter than the seaje. Flowers white

1. A. Plantago, L. Lases lour-petioled, ovnte or vhloner, mente, rounded or cordate at the batse, 3-9-nerved ; panicle larere, lax, the whorled hranches and elongated filifurm pediecls braeted at the base; achenia ohtuse, 15-20 in a

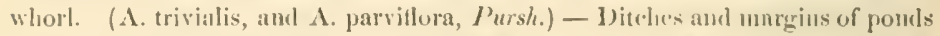
in the upper listricts, Georgia, and northward. July and Ang. - Leatves $2^{\prime}-4^{\prime}$ long. l'auicle $1^{\circ}-20$ long.

\section{ECHINODORUS, Richard.}

Flowers perfect, mostly in whorled racemes. Sepals 3. Petals 3, imbriented in the but, witlering. Stamens few or numerous. Oraries few or many, imbrieated, forming ribbed achenia in fruit, watully beaked with the persistent style. - Herbs, with petioled nerved leaves. Hethls mostly bur-like.

1. E. parvulus, Engrehm. Small ; leaves linceolate or spatulate, mostly acute, fincly nerved and somewhat pinnately-veined, commonly shorter than the single or elistered 1-6-flowered scapes; flowers mostly clustered or umbelled, on long bracter pedicels which are recurved in firnit, stamens 9 ; achenia few, shorter than the ovate sepals, obovate, flattend at the sides, and suroumded with 5 prominent ribs, heakless. - Margins of shallow ponts, Mlidlle Floribla, and westward. July and Aug. - Seapes $1^{\prime}-t^{\prime}$ high. Achenia black and shining.

2. E. rostratus, Engelm. Leaves varying from lanceolute to ovate, acnte at each emi, or romided or cordate at the base, 5-nerved, about as long as the petiole; scape rigid, erect, longer than the leaves; whorls few; pedicels ereet or spreading; sepals ovate, many-nerved, shorter than the oval hur-like lieat ; stamens 12; style longer than the ovary; achenia unmerous, strungly 3-ribhed on the back, with fanter lateral and intermediate ribs, beaked with the long persistent style. - Soutl Floricla, and westward. - Scape simple, $3^{\prime}-8^{\prime}$ high, or oc'asionally $2^{\circ}$ ligh and paniculately branclied. Leares $1^{\prime}-2^{\prime}$ long. Flowers 5 " wide.

3. E. radicans, Engrem. Leaves large, long-petioled, ovate, cordate or truncate at the base, obtuse, 7 - 9-ribled ; scape elongated, prostrate, rooting and proliferous; whorls several, remote; pedicels slender, spreadine, or recurved; stamens ahout 20 ; style shorter than the ovary; heals grlobose, longer than the many-nerved sepals; achenia very numerous, short-beaked, ribbed and slightly denticulate on the back. (Alisma radieans, Nutt.) - Swamps, Florida to North Carolina, and westward. July - Sept. - Seape $2^{\circ}-4^{\circ}$ long Leaves $3^{\prime}-8^{\prime}$ long. Flowers $8^{\prime \prime}-12^{\prime \prime}$ wide.

\section{SAGitTaria, L. Arrow-grass.}

Flowers monacious, in a whorled raceme, the upper ones sterile. Sepals 3, persistent. Petals 3 , imbricated in the bud, withering. Stamens few or many. Ovaries crowded in a grobular head. Achenia flat, membranaceous, winged. Marsh or aquatic herbs, with seape-like stems, and variously-shaped nerved and 
reticulated sheathing leaves, which are often without a blade. Flowers white, commonly 3 in a whorl from the axils of persistent bracts.

* Filuments long and slender.

1. S. falcata, Pursh. Tall; leares ereet, rigid, broadly lanceolate, acute at each end, pinnately nerved, on long and stout petioles; scape longer than the leaves, of ten branching above; pedicels of the sterile flowers slender, longer than those of the fertile ones; bracts and sepals orate, obtuse, granular-roughened; stamens numerous, with hairy tilaments; achenia obliquely obovate, wing-keeled, strongly beaked. (S. lancifolia, Mich $x$.) - Lakes and rivers, Florida to South Carolina, and westward. June - Sept. - Scape $2^{\circ}-5^{\circ}$ high. Leaves $1^{\circ}-2^{\circ}$ long. Flowers $1^{\prime}-1 \frac{1}{2}^{\prime}$ wide.

2. S. variabilis, Engelm. Leaves mostly sagittate, acute or obtuse, varying from linear to broadly ovate, smooth, or rarely, like the scape, bracts, and sepals, pubescent; bracts acute; flowers mostly large; pedicels of the sterile flowers twice as long as those of the fertile ones; achenia obovate, beaked; filaments smooth. (S. sagittifolia, hastata, pubescens, \&c. of authors.) - Marshes, ditches, \&c., Florida, and northward. July-Sept. - Seape $1^{\circ}-3^{\circ}$ high, angled. Leaves $2^{\prime}-12^{\prime}$ long.

\section{* Filaments short, thickened at the base.}

3. S. heterophylla, Pursh. Scape weak; leaves linear or laneeolate, and acute at each end, or elliptical, and obtuse or sagittate at the base ; bracts obtuse; sterile flowers on long and slender pedicels; the fertile ones nearly sessile; achenia narrowly obovate, long-beaked. - Margins of ponds and streams, Florida, and northward - Leaves $2^{\prime}-4^{\prime}$ long. Seape few-flowered, the lowest whorl only bearing fertile flowers.

4. S. simplex, Pursh. Scape slender, commonly prostrate in fruit, simple or branched; leaves linear or lanceolate, acute at each end, 3-nerved, erect, the earliest mostly destitute of a blade; bracts membranaceous; flowers small, all on long filiform pedicels; stamens 10-12, hairy at the base; achenia obovate, wing-keeled, beakless. (S. graminea, Michx.) - Shallow pontls in the pine barrens, Florida, and northward. May - Oet. - Scape $10^{\prime}-15^{\prime}$ high, usually longer than the leaves

5. S. natans, Michx. Small; leaves floating, ovate-oblong or elliptical, obtuse at each end or the lowest slightly cordate, $5-7$-nerved, alout as long as the few-flowered scape; bracts membranaceous, acute; pedicels of the fertile flowers stonter than those of the sterile ones, recurved in fruit; stamens 7 or 8 : achenia obovate, 3-ribbed on the back, short-beaked. - Shallow ponds and streams, Florida to South Carolina. June - Scpt. - Scapes $3^{\prime}-6^{\prime}$ long. Leaves $1^{\prime}-2$ ' long.

Var. lorata. Leaves strap-shaped, obtuse, without a blade, nerveless ; scapes floating or erect; flowers sometimes diweious; achenia conspicuously beaked, pimpled. - Brackish water, along the west coast of Florida. May-Sept. When growing in deep water the floating scapes are $2^{\circ}-3^{\circ}$ long; when on muddy lanks, only $3^{\prime}-5^{\prime}$ high, and the short leaves bear much resemblance to those of Crantzia lineata. In this state it is probably S. pusilla, Pursh. 


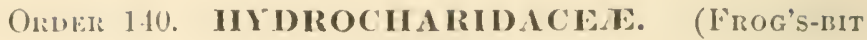
Fint1L.)

Aquatic herhs, with monnecious or dicerious flowers, from a membranaceons spathe. Sepals and petals 3 , or the latter wanting, distinct in the sterile flower, united into a tube in the fertile, and coherent witl the 1 -9celled ovary. Stamens 3-12. Ovules numerous, ascending, ortliotropous. Stignas 3-9. Fruit indehiseent, many-seeded. Embryostraight, witlout albumen.

\section{Synopsis.}

* 0vary 1-eelled. Stigmas 3.

1. ANACItARIS. Flowers polygamouliocious. Spathe sessile. Stamens 9. Leaves short, opposite ormhorled.

2. VAlLlsikilA. Flowers liocious. Spathe peduncled. Stamens 3. Leaves long, linear. * Cells of the ovary and stigmas $6-9$.

3. L13xовıLy. Flowers mouacious. Stamens 6-9, monadulphous. Leares cordate, petioled.

\section{ANACHARIS, Rirh.}

Flowers diceionsly polygamous, enclosed in the bud in a 2-cleft axillary sessile spathe. Sterile flowers minute. Sepals and petals 3. Anthers 9. Fertile flowers pistillate or perfect. Sepals and petals uniterl into a very long and slender 6-parted tube. Stanens 3-6, perfect or sterile. Ovary l-celled, with three parictal placenta, few-ovuled. Style capillary, alnate to the tube. Stigmas 3, each 2-lobed, exserted. Fruit oblong, coriaceous. - Perennial herbs, with elongated filiform brancling immersed stems, and small and very numerous opposite or whorled leaves. Fertilization effecterl by the sterile flowers breaking away from the stem, and expanding at the surfuce anong the floating stignaıs.

1. A. Canadensis, Planch. Stem much branched; leares $3-4$ in a whorl, sessile, varying from linear to elliptical, 1-nerverl, pellucid and minutely serrulate. (Clor:a Canadensis, Nutt.) - In slow.flowing streams and ponds, Cherokee, Nortl Carolina, Curtis, and northward, July and Aug. - Leures $3^{\prime \prime}-6^{\prime \prime}$ long.

\section{VALLISNERIA, Mieheli. Tape-grass.}

Flowers diocions Sterile flowers numerons, minute, crowded on a spadix, which is enclosel in an ovate 3-leaved short-stalked spathe. Calyx 3-parted. Corolla none. Stamens 3. Fertile flowers solitary, enclosed in a tulublar spathe, and borne on a very long and mostly spiral scape. Sepals and small petals 3 , united and coherent with the eylindrical l-celled many-oruled ovary. Stigmas 3, each 2-lobel. Secels numerous, fixed to three parietal placentix. - Syntitic herbs, with creeping stem", and elongated strap-slatped leaves. Fertilization effected mostly as in Anacharis. 
1. V. spiralis, L. - Slow-flowing streams and ponds, Florida, and northward. July-Sept. If - Plant creeping, proliferous. Leaves strap-siaped, obtuse, 5 -9-nerved, sharply serrulate, $1^{\circ}-3^{\circ} \operatorname{lon} q, 6^{\prime \prime}-12^{\prime \prime}$ wide. Scape of the sterile flowers $1^{\prime}-4^{\prime}$ long, of the fertile ones $2^{\circ}-5^{\circ}$ long. Fruit $1^{\prime}-3^{\prime}$ long, often curved.

\section{LIMNOBIUM, Richard.}

Flowers monœcious, from a membranaceous mostly sessile spathe, peduncled. Sterile spathe entire, 2-3-flowered; the furtile 3-leaved, 1-flowered. Sepals and petals 3 , united in the fertile flower, and coherent witi. the ovary. Stanens 6-12, monadelphous : anthers linear. Ovary $6-9$-celled, with as many central placentæ, forming a many-seeded berry in fruit. Stigmas 6-9, each 2-parted. - $A$ floating aquatic herb, with copious pendent roots, long-petioled roundcordate and many-nerved leaves, and small white flowers.

1. L. Spongia, Richard. Stems extensivcly proliferons; leaves purplish beneath, and with air-cells near the base; sterile peduncles tender, soon vanishing ; the fertile ones commonly short and thick, recurved in fruit; petals oblong, alternating in the fertile flower with a pair of minute sterile filaments. (Hydrocharis spongiosil, Busr.) - Still water, Florida, and northward. July and Aug. 4 - Leares $2^{\prime}-4^{\prime}$ wide.

\section{Order 141. BURMANNIACEA. (Burdaxid Famby.)}

Small herbs, with filiform stems, seale-like leaves, and regular perfeet flowers. - Sepals and petals united to form a tubular unecually 6-eleft corolla-like perianth, with the tube colerent with the 1 or 3-celled manyoruled ovary. Stamens 3 or 6 , inserted on the tube of the perianth: anther-cells separate, 2-lobed, opening crosswise. Style slender: stignas 3, dilated. Placente 3, central or parietal. Capsule many-seeded. Seeds minute, with a loose or reticulated testa.

\section{BURMANNIA, L.}

Tube of the perianth mostly 3-angled or 3-winged, 6-cleft, withering-persistent; the three interior lobes smaller. Stamens 3 , very short, inserted opposite the interior lobes of the perianth. Orary 3-celled, with three thick 2-lobed central placentæ. Stigmas glubose, dilated or 2-lobed. Capsule splitting at the apex into 3 valves. - Radical leaves crowded and grass-like, or none; those of the stem minute, scalc-like. Flowers racemose or clustered.

1. B. biflora, L. Stem simple, or forked above, I-several-flowered; leaves subulate, scattered; perianth blue, broadly 3-winged, the exterior lobes erect, ovate, acute, the interior linear and incurred; seeds ublong, striate. (Tripterellia coerulea, Michx.) - Grassy or mossy margins of swamps and ponds, Florida to North Carolina. Sept. - Nov. - Stem $l^{\prime}-5^{\prime}$ high. In this and the following species the seeds escape through irregular fissures at the sides of the capsule. 
2. B. capitata. Stems setaccons, simple; leaves sululate, scattered; flowers several in a terminal cluster, white, tinged with blue; perianth 3-angled, wimgless, the interior lubes linear, erect; seeds linear-obleng, spirally striate. (Tripferella capitata, Miehx.) - Low or swanpy pine barrens, floridat to Nurals Carolina. Stept. - Nov. - Stems $2^{\prime}-6^{\prime}$ high.

\section{APTERIA, Nutt.}

Perianth terete, tubular-be[l-shinged, 6-eleft, with the 3 interior Iobes smaller. Stanens 3, very short, opposite the interior lubes of the perianth, the filaments flat and orlhieular at the apex : anthers rlosely alhering to the globose stigmas. Ovary l-eelled, with there 2-winged parietal placentas. Capsule obovate, splitting from the base into three valves, which remain attached to the ayex of the persistent placenta. Seeds ovoid. - A small perennial herb, with subulate bract-like leaves, and seattered nodding flowers.

1. A. setacea, Nitt. Deep shady woods, along the margins of swamps, Florida, Georgia, and westward. Sept. and Oet. - Stem creet or aseending, purple, filiform, simple or lnasehed, $2^{\prime}-8^{\prime}$ higrl. Leaves scattered. Fluwers few, distant, on nodding pedicels. l'urianth white, 5 "long.

\section{Order 142. ORCHIDACEA. (Orchis Fanim.)}

Perennial herbs, witl simple stems, from thick fibrous or tuberous roots, nerved leaves, and irregular often showy flowers. - Perianth 6-parted, mited below with the 1-celled ovary; the three onter divisions (calyx) and commonly two of the inner ones (petals) similar in form; but the third, posterior, or, by the twisting of the ovary, anterior one (Labellum or Lij) differs from the others in form, and often bears a spur or prominence at the base beneatl. Staumens 3, united with the style into a column, one or (in Cypripedium) two unly bearing a 2-resled anther. Pollengrains rolering in 2, 4, or 8 waxy or powlery masses (Polliniu). Capsule with three parietal placente, splitting at the sicles into thre valves. Seeds very mumerons, mimute, covered with a loose membranareous testa. Albumen none. - Plants mostly smooth and more or less sueculent. Leaves almost always altemate, sheathing and entire. Stems leafy or seape-like. Flowers bracted, solitary, spiked, or racemed, and remarkable for their various and singular forms.

\section{Symopsis.}

I. Anther solitary, fixed to the apex of the column like a lid, deciduous.

TRIBE I. MA I.AXIDEA. - Pullen in smooth waxy masses, without stalks or connect. ing tissue. - Roots tuberous.

* Stems leafy.

1. MICROSTYLIS. Lip corlate or sagiltate. Colnmn minute, 2 -toothed at the apex.

2. LIPARIS. Lip entire. Column elongated, incurved, margined at the apex. 
* Stems sheathed.

3. CORALLORHIZA. Spur of the lip short and adnate to the ovary. Root branching, toothed.

4. APLECTRU.I. Lip spurless. Root of two solid connected tubers, hearing a single leaf.

Tribe II. FPIDENDIREA. - Polleu in smooth waxy masses eonueeted by elastic tissue.

5. EPIDENDRTM. Pollen-inasses 4. Claw of the spurless lip adnate to the column.

6. TIPularia. Pollen-masses 4. Lip free, spurred. Stem sheathed.

7. BLETIA. Pollen-masses 8. Lip free, hooded, spurless.

Tribe III. A RETHUSE EL. - Pollen in loose powdery masses. Lip crested.

8. CALOPOGON. Pollen-nmasses 2. bipartible. Column incurved, winged at the apex.

9. Pogonia. Pollen-masses 2. Column wingless, elub-shaped.

10. ARETHUsA. Polleu-masses 4. Column petal-like. Root a solid tuber.

II. Anther solitary, adnate to the column, ereet, persistent.

TRIBE FV. OPHRYDEE. - Anther adnate to the apex of the eolumn, the cells separate. Pollen eohering in numberless waxy grains, which are eollected by elastic tissue into a large mass, and attached to a gland of the stigma by an elastic stalk. Lip spurred.

11. ORCIIIS. Anther-cells eontiguous, parallel. Glands of the stigna covered with a common hood-like fold of the stigma.

12 GYINADENIA. Anther-cells contiguous, parallel. Glands of the stigma naked.

13. PLATANTHERA. Anther-cells diverging from the base. Glands of the stigma naked.

14 HABENARIA. Anther-eells diverging. Glands naked. Throat of the stigma furnished with variously shaped appendages.

Tribe V. NEOTTIEA. - Anther attached to the back of the column, parallel with the stigma ; the cells approximate. Pollen powdery.

* Pollen-masses 2.

15 SPIRANTIIES. Lip nearly entire, clasping the column, obtuse.

16. GOODYERA Lip sessile, entire, contracted above the middle, slender-pointed.

17. LISTERA. Lip 2-cleft. Stem with a pair of ovate opposite leaves.

* * Pollen-masses 4 .

18. PONTIIEVA. Claws of the petals and lip adnate to the eolumn.

III. Anthers two, fixed beneath the lateral lobes of the eolumn.

Tribe VI. CYPIR PEDIEA. - Column appendaged by the petal-like sterile stamen.

19. CXPRIPEDIUM. Lip large, inflated. Leaves large, plaited.

\section{MICROSTYLIS, Nutt. ADver's-Movth.}

Sepals oblong, sprealing. Petals filiform. Lip corlate or sagittate, entire or nearly so, sessile. Column mimute, 2-toothed at the apex. Anther lid-like. Pollen-masses 4, eollatcral, united by pairs at the apex. - Low herbs, from bulbous roots. Stem 1-2-leaved, sheathed below. Flowers racemed or spiked, minute, greenish.

1. M. ophioglossoides, Nutt. Leaf solitary near the midalle of the 5-angled stem, orate, clasping; raceme short, with the unexpanded flowers crowded in a globular head, elongated in fruit; pedieels slender, mueh longer than the flowers; lip aurieled at the base, 3-toothed at the apex. (Malaxis ophioglossoides, $1 /$ uhl.) - Low shady woods, Florida, and northward. July and Aug. - Stem $4^{\prime}-8^{\prime}$ high. Leaf $1^{\prime}-2^{\prime}$ long. Flowers $\frac{1^{\prime \prime}}{2}$ wide. 
2. M. Floridana, п. sp. Leaves 2, near the hatse of the 3-angled stem, uncpual, ovite, or elliptical, mostly acute, sleathing; raceme stemler, aente, ('lemerated in fruit, many-flowered; perlicels longer than the flowers; sepals obloner, spreadine, with the margins revolute; petals filiform, reflexed, twi-ted ; lip round-auriculate-cordate, abruptly narrowerl aud entire at the apes, depressed at the simus; capisule oblong or obovate. - Wet sharly woorls, A palatelicola, Florilla. July and Aug. - Stem 6'-12' high. Leaves $1^{\prime}-4^{\prime}$ lung. Flowers $1^{\prime \prime}$ wile.

\section{LIPARIS, Richard. TWмYLAne.}

Sepals spreading. Petals linear or filiform, spreading or reflexed. Lip entire, flat, often with two tubercles above the base. Column long, semi-terete, incurved, marginel at the apex. Pollen-masses 4 , collateral, united ly pairs at the apex. Low herbe, from hulhons roots. Leaves ", sheathing the base of the scape-like stem. Flowers racened, greenish or purplish.

1. L. liliifolia, Richard. Leaves elliptieal, olnuse, sheathed at the lase; seape 3-angled, 10 - 20-flowered, longer than the leaves; sepals linear, whitish; petals fitiform, reflexed, yellowish; lip large, wedge-obovate, concave, aloruptly pointed, brownisli-purple. (Malaxis lilifolia, Surerlz.) - Low slarly woods and banks in the "pper distriets, Georgia, and northward. June and July. - Scape $5^{\prime}-10^{\prime}$ ligh. Leares $2^{\prime}-4^{\prime}$ long. Lip $\frac{1}{2}$ long.

\section{CORALLORHIZA, Haller. Coral-root.}

Sepals and petals alike, olslong or lanceolate, connivent. Lip clasping the base of the straight 2-edged colunn, spreading and concave alove, 2-rilged near the base, spurless, or with the spur adnate to the orary. Anther lid-like. Pollen-masses 4 , incumbent. - Low dull-colored leafless herbs, with coral-like roots, sheathed stems, and racemose flowers.

1. C. odontorhiza, Nutt. Root pinnately brancled and toothed; stem tumisl at the base, slender ahove; sheaths 3, clongated ; racemes 10-15-flowered; sepals and the rither shorter spotted petals erect, lanceolate, obtuse; lip entire, longer than the sepals, distinctly elawed, the spreading limb oval, concave, 3-nerred, witl two tooth-like ridges in the throat, white spotted with purple; the margins erenulate below the iniddle and involute ahove; margins of the column thickened and ineurved at the base; eapsule oval, nodding - Shady woods, Florida, and nortlowarl. Feb. and March. - Stem $s^{\prime}-16^{\prime}$ ligh. Lip $4^{\prime \prime}$ long.

2. C. micrantha, n. sp. lioot toothed; stem low, rigil; sheaths 2, abruptly pointel ; raceme 6-12-flowered ; flowers very small (1" - $1 \frac{1}{2} "$ long), erect; sepals and petals nearly epral, linear, erect ; lip short-clawcel, entire, oval, concave, denticulate on the margins, without teeth or ridges, slorter than the scpals, white spotted with purple; capsule ohovate, norlling. - Shady woods, Florida and Georgia. Ang. and Sept. - Stem $3^{\prime}-6^{\prime}$ high.

3. C. innata, R. Brown. Root branching; stem slender; sheaths 3 ; the upjer one elongated and often leaf-like at the apex; raceme 5-12-flowered; lip 
somewhat hastate, 3-lobed above the base, with two distinet ridges on the fice, white spotted with crimson ; sepals and petals ollong-lanceolate, brownish ; capsule oval or elliptical - Dimp shaly woods, Georgia, and northward. Sept. and Oct. - A vernal species in the Northern States.

\section{APLECTRUM, Nut. Putty-Root.}

Sepals and petals alike, linear-oblong, erect. Lip spurless, short-clawed, 3-lobed and 3-ridged at the throat. Column straightish, cylindrical. Anther lid-like, slightly lateral. Pollen-masses 4.- Root tuberous, proliferous, very glutinous within, first bearing a single large plaited and petioled leaf, which is persistent throngh the winter, and afterward a 3 -sheathed seape, with a raceme of yellowish flowers at the summit.

1. A. hiemale, Nutt. (Corallorhiza hiemalis, Ell. Limodorum trifidum, Michx.) - Rich woods, chicfly in the upper districts, and northward. A pril and May. - Leaf oval, many-nerved, $4^{\prime}-6^{\prime}$ long. Scape $12^{\prime}-15^{\prime}$ high, $10-15$-flowered. Sepals and petals yellowish, tipped with brownish purple. Lip whitish, spotted, the middle lobe rounded and crenulate on the margins. Capsule reflexed.

\section{EPIDENDRUM, L. TREE-ORCHIS.}

Sepals and petals nearly equal and alike, widely spreading. Lip with the claw wholly or pattly adnate to the elongated margincd or winged column, entire or parted, mostly rigid or tubercled on the face. Spur none, or adnate to the ovary. Column prolonged at the apex into a toothed or fimbriate cup. Anther lid-like, somewhat 4-celled. Polien-masses 4, lenticular, stalked. Stemless herbs, from a tuberous or creeping rhizoma, elinging to the bark of trees by thick and matted roots. Leaves sheathing, rigill, perenuial. Scape sheathed or bracted, bearing a raceme of greenish and purplish flowers.

1. E. conopseum, Ait. Scape few-many-flowered; leaves 1-3, coriaceous, lanceolate, acute, spreading ; bracts subulate, the lowest somewhat leafy; sepa's spatulate, obtuse, with revolute margins; petals linear-spatnlate, obtuse; lip 2-tubercled at the base, 3-lobed, the lateral lobes rounded and crenulate, the middle one notched at the apex, the claw wholly adnate to the slightly margined colnmn. - On various trees, but chicfly on Magnolias, Florida to Sonth Carolina. Aug. - Scape $2^{\prime}-8^{\prime}$ high. Leaves $1^{\prime}-3^{\prime}$ long. Fluwers $4^{\prime \prime}-5^{\prime \prime}$ long, green tinged with purple.

2. E. venosum, Lindl. Scape tumid at the base, 5-7-flowered; leares 2 , linear-lanccolate, abruptly pointed; bracts short, orate; sepals and petals spatulate-lanceolate, acute; lip 3-parted, 2-crested in the middle; the lateral lobes oblong, acute; the middle one wedge-shaped, notehed at the apex, the claw partly adnate to the 2-winged column. - South Florida, Dr. Blodyct. Scape $1^{\circ}$ high, invested with numerous short whitish sheaths. Leaves $4^{\prime}-5^{\prime}$ long. Flowers $8^{\prime \prime}$ long. 


\section{TIPULARIA, Nint.}

Sepals and petals oblentr, spmenling. Lij) long-spured, 3-fobed, the latern lobes short aud triamenlar, the midelle lobe linear. Sjur filiform, ascending. Colmm slender, wingless. Anther lid-like. Pollen-masses t, stallerl, waxy. lioot tuberons, proliferons, first producing a single orate leaf, on at sheathed petiole, afterwarl a slender sleathed seape, ending in a long racene of numerous greenisli fluwers.

1. T. discolor, Nntt. - Sharly banks, Florida, and northwarl. Aur. Scape about $1^{\circ}$ high. Leaf $l^{\prime}-2^{\prime}$ long, arente, smmewhat plated and manynerved, purple beneatl. Flowers suall, nodding, bractless. Spur about $1^{\prime}$ long.

\section{BLETIA, Ruiz and Pavon.}

Sepals and petals alike and nearly equal, spreading. Lip spurless, jointed, 3-lobed, erested on the face. Column free, elongated, semi-terete. Auther lid-like, fleshy. Pollen-masses 8, by pairs, with a stalk to each pair, waxy, becoming powdery. - Scape fiom tuberous rootstocks, sheathed or senly, manyflowered. Leaves slueathing the base of the seape, narow, plaited, sometimes wanting. Flowers spicate or racemose, mostly showy.

1. B. aphylla, Nutt. Lenfless; scape stout, terete, tapering into the many-flowered spike; sheaths several, short, the upper ones passing into the ovate aeuminate bracts; flowers spreading, l,rownish, striped with purple; sepals and petals oblong-lanecolate, oblique; lip concave, emargiuate, with a 6-ridged erest along the middle, the lateral lobes ereet. - Rich sharled soil, Florida to North Carolina, and westward. July and Aug. - Root consisting of horizontal, jointed tubers. Seape $1^{\circ}-1 \frac{1}{2}{ }^{\circ}$ high. Perianth $3^{\prime}$ long.

2. B. verecunda, Swartz. Scape leafy at the base, many-flowered; leaves lanceolate, plaited, strongly nerved; petals and sepals greeni-h, the former connirent; lip saceate, wary and furrowed, emarginate. - Open pine barrens, Middle and East Florida. July. - Seape $1^{\circ}-1 \frac{1}{2}{ }^{\circ}$ high. Leaves $6^{\prime}-9^{\prime}$ long.

\section{CALOPOGON, R. Brown.}

Sepals unequal, the two lateral ones broader and oblique. Lip (hy the untwisted orary) brought to the upper or inner side of the flower, dilated at the apex, bearded on the face, and narrowed into a linge-like claw. Column long, ineurved, winged at the apex. Anther terminal, lid-like, sessile. Pollenmasses 2, powdery. - Seape ereet from a solid tuber, sheathed at the base, bearing below the middle a single narrow sheathing leaf, and terminated with a loose spike of showy flowers.

1. C. pulchellus, R. Br. Scape 2-8-flowered; leaf linear-lanceolate, erect, keeled, many-nerved; flowers large, mostly approximate, bright purple; lateral sepals obliquely ovate, abruptly pointed, shorter than the lanccolate obtuse petals; lip broadly obcordate, acutely 2-eared at the base; filaments of the erest decurrent on the claw, the lower ones purple and united; orary 
straight, 2-3 times as long as the laneeolate-subulate bracts. - Swamps, Florida, and northward. June. - Seape $1 \frac{10}{2}-2^{\circ}$ high. Leaves $6^{\prime}-12^{\prime}$ long. Flowers $1^{\prime}-1 \frac{1}{2}^{\prime}$ wide.

2. C. pallidus, n. sp. Scape 10-20-flowered; leaf linear, erect, keeled, few-nerved; flowers seattered, white tinged with purple; lateral sepals obliquely oblong, shorter than the linear-lanceolate acute petals; lip werlge-obovate, abruptly short-pointed, obtusely 2-eared at the base; filaments of the erest mostly united and purple at the base; ovary straight, scarcely longer than the subulate bract. - Wet pine barrens, West Florirla, near the coast, to North Carolina. May. - Scape $1^{\circ}-1 \frac{1}{2}$ o high. Leaves $6^{\prime}-9^{\prime}$ long. Flowers $9^{\prime \prime}-12^{\prime \prime}$ wide.

3. C. parviflorus, Lindl. Scape 3-6-flowered; leaf' linear, concave, appressed to the scape; flowers approximate, bright purple; lateral sepals oblong, curved, acute, longer than the oblong-lanceolate, obtuse petals; lip wedge-obovate, emarginate, winged at the base; filaments of the crest all yellow and distinet; ovary curved, four times as long as the ovate-acuminate bract. (C. pulehellus, var. graminifolius, Ell.) - Wet pine harrens, Florida to North Carolina. March and April. - Scape $6^{\prime}-12^{\prime}$ high. Leaves $3^{\prime}-5^{\prime}$ long. Flowers $8^{\prime \prime}-10^{\prime \prime}$ wide.

4. C. multiflorus, Lindl. Scape 7-14-flowered; leares mostly two, linear, rigid, concave, erect; flowers approximate, deep purple; lip wedgeshaped, pointed, winged at the base, bearded in the middle with uniform, filiform hairs; sepals and petals orate, acute. - South Florida. - Plant $1^{\circ}$ high. Leaves $3^{\prime}-5^{\prime}$ long. Flowers of the size of the preceding.

\section{POGONIA, Juss.}

Sepals and petals alike, or the former narrower and elongated. Lip mostly crested and 3-lobed. Column club-shaped, wingless. Anther lid-like, stalked. Pollen-masses 2, powdery. - Stems exect from thick fibrous or tuberous roots, sheathed at the base, few-leaved, 1-or few-flowered. Leares alternate or whorled. Flowers nodding, showy.

* Sepals and petals nearly alike, erect.

1. P. ophioglossoides, Nutt. Root fibrous; leaves 2, sessile, lanceolate, the upper one terminal and smaller; flower mostly solitary, terminal, sessile, pale rose-color; sepals laneeolate, as long as the oval or oblong petals; lip spatulate, flat, yellow-crested, fimbriate on the margins, longer than the petals, and twice as long as the thick column. - Swamps, Florida, and northward. A pril and May. - Stem $6^{\prime}-12^{\prime}$ high. Flowers $\frac{1}{2}$ long.

2. P. pendula, Lindl. Root tuherous; leaves several, short, alternate, ovate, clasping; flowers $3-7$, axillary, long-peduncled, drooping, whitislı ; sepals and petals lanceolate, acute; lip spatulate, somewhat 3-lobed, roughened but not crested, rather shorter than the petals, longer than the column. (Triphora pendula, Nutt.) - Rich shady woods, Millle Florida, and northward. July and Aug. - Stem $4^{\prime}-8^{\prime}$ high. Leaves $6^{\prime \prime}-9^{\prime \prime}$ long. 
* * Sepuls (lirown) linear, spreading, much longer than the crect preals : lip cresiect, 3-lobed.

3. P. divaricata, R. Ir. Jcares 2, sessile, lanceolate, one near the mistlle of the stem, the other smaller and bract-like at the hase of the solitary terminal flower; sepals purplish-brown, broadly linear, and, like the fleshcolored lanceolate petals, recurved at the apex; lip half-cylindrical, wavy and crenulate on the margins, 3-lobed at the apex, greenish veined with purple; crest beardless. - Swamps, Florida to North Carolina. May, - Stcm $1^{\circ}-2^{\circ}$ high. Leares $2^{\prime}-5^{\prime}$ long. Sejals $1^{\prime}-1 l^{\prime}$ long.

4. P. verticillata, Nutt. Leaves 5, olovate-oblong, abruptly pointer, whorled at the base of the solitary reddisl-brown flower; sepals linear, spreading, 3 times as long as the crect oblong yollowish petals, and yellowish 3-lobed wary lip. - Low shatly woods, Florida, and northward. May. - Stem 10 high. Leaves enlarged in fruit. J'lower peduneled. Sepals $2^{\prime}$ long.

\section{ARETHUSA, Gronov:}

Sepals and petals alike and nearly equal, cohering at the basc, arching and connivent orer the column. Lip adnate to the basc of the colmmn, dilated and bent downwarl ahove the middle, crested within. Column incurved, expanded and petal-like at the apex. Anther terminal, Jicl-like, with the cells approximate. Pollen-masses 4, powlery. - Scape erect from a solid globular tuber, sheathed, bearingr a singrle large terminal flower.

1. A. bulbosa, L. - Bogs on the mountains of Carolina, Michaux, and northward. May. - Scape $6^{\prime}-9^{\prime}$ high. Sheaths $3-4$, the uppermost enclosing a linear late-developed leaf. Flower $1^{\prime}-2^{\prime}$ long, 2-bracted, bright purple and fragrant.

\section{ORCHIS, L. Orcuis.}

Sepals and petals nearly equal, arching and connivent over the column, or the lateral sepals spreading. Lip adnate to the base of the column, depending, spurred at the basc. Anther terminal, crect, the cells contiguous and parallel. lollen-masses 2, waxy, stalked, and, with the two distinct glands, cnelosed in a common sac or fold of the stigma. - Stem mostly scape-like, leafy at the base. Flowers showy, spiked.

1. O. spectabilis, L. Lcares 2, ohovate-oblong, about as long as the 3-5-flowered 5-angled scape; bracts lanccolate, leafy, mostly longer than the flowers; scpals and petals connivent, oblong, purple ; lip white, obovate, entire, crenulate, as long as the club-shaped spur. - Rich sharly woods in the upper districts, and northwarl. May, - Root of thick clustered tibres. Scape $4^{\prime}-6^{\prime}$ high. Flowers $6^{\prime \prime}-8^{\prime \prime}$ long.

\section{GYMNADENIA, R. Brown.}

Sepals and petals nearly equal, the lateral scpals spreading, the upper, with the rather shorter petals, arehing and connivent over the short column. Lip 
adnate to the $b_{d}$ ss of the column, spurred at the hase. Antlace crect, the cells contignons and parallel. Pollen-masses naxy, fixed by a stalk to the naked glands of the stigma. - Stems leafy. Flowers small, spiked.

\section{* Ovary twisted; the lip therefore anterior.}

1. G. flava, Lindl. Stem slender ( $1^{\circ}$ high); lowest leaf $\left(4^{\prime}-6^{\prime}\right.$ long) lanceolate, sheathing, the others $(6-8)$ small, the uppermost passing into the subulate braets of the slort $\left(1^{\prime}-2^{\prime}\right.$ long) oblong densely many-flowered spike; flowers orange-yellow; lip ovate, slightly erenate; spur filiform, depending, shorter than the ovary. (Orehis flava, Nutt, not of Linn.) - Open grassy swamps in the pine barrens, Florida, and northwarl. July and Ang.

2. G. tridentata, Lindl. Sicm $\left(9^{\prime}-12^{\prime}\right.$ high $)$ scape-like above; lowest leaf $\left(t^{\prime}-6^{\prime}\right.$ long) lancelate-oblong, tapering into a sheathing base, obtuse, the others small, scattered, passing into the bracts; spike (1'-2' long) loosely $4-$ 12-flowered; flowers yellowish-green ; lip truncate, 3-toothed at the apex, longer than the petals; spur slender, club-shaped at the apex, curving upward, longer than the ovary. (Orchis clavellata, Mich $x$.) - Low shady woods in the upper districts, Mississippi to North Carolina, and northward. July.

$$
\text { * Ocary straight : lip posterior. }
$$

3. G. nivea, Gray \& Engelm. Stcin slender $\left(1^{\circ}-1 \frac{1}{2}^{\circ}\right.$ high $)$; leaves numerous, one or two of the lower ones lincar $\left(4^{\prime}-8^{\prime}\right.$ long), the others small and bract-like; spike $\left(2^{\prime}-4^{\prime}\right.$ long) cylindrical, loosely many-flowered ; flowers white; lateral sepals orate, slightly eared at the base; petals and entire lip linear-oblong; spur filiform, ascending, as long as the white rouglish ovary. (Orchis niven, Nutt.) - Pine-barren swamps, Florida, Georgia, and westward. July.

\section{PLATANTHERA, Richarl.}

Sepals and petals nearly equal, the lateral sepals mostly spreading or reflexed. $\mathrm{Lip}$ entire or variously lobed or divided, spurred at the base. Colımn short. Anther-cells diverging. Stigma without appendages, with the glands naked. Root composed of thick fleshy fibres. Stems mostly leafy. Florvers spiked or racemed, commonly showy.

\section{* Lip entire, neither tonthed nor fringed.}

1. P. orbiculata, Lindl. Leaves two, at the base of the seape-like bracted stem, large, orbicular, fleshy, spreading on the ground, silvery beneath; flowers greenish-white, in a narrow and loose raceme, longer than the bracts; lateral sepals obliquely orate, spreading, the upper orbicular; petals narrower; lip' linear-spatulate, entire, recurved ; spur very long, club-shaped, curved. - Shady woods on the mountains of North Carolina, and northward. July and Aug. Scape $1^{\circ}-1 \frac{10}{2}$ high. Leaves $5^{\prime}-8^{\prime}$ in diameter.

$$
\text { * * Lip 3-toothed or 3-lolicd: flowers spiked: stem leafy. }
$$

2. P. flava, Gray. Leares $3-4$; the two lower ones lanceolate or oblonglanceolate $\left(4^{\prime}-8^{\prime}\right.$ long), the others sinall and bract-like; flowers small, brownish green, in a loose and slender many-flowered spike; sepals and petals oval; lip oblong, hastate-3-lobed, the lateral lobes short and rounded, the middle one 
crenulate at the apex and liearing a tontli-like appendage at the throat; spur club-shaped, mostly shorter than the short orary. (Orehis flava, $L$. O. fures(ens, and (). billentata, Jill.) - Low sludy lanks, Florila, and northwarl. July and Ang. - Stem 10 high. Flowers $2^{\prime \prime}$ in diameter.

3. P. bracteata, Torr. Lower leaves obovate, the others sinaller, lanceolate; flowers small, greenish; scpals and narrow petials ereet; lip oblong-linear, slightly 3-toothed at the tip, longer than the obtuse sac-like spur. (Orchis viridis, Pursh.) - Hirgh mountains of Carolina, Pursh. - Sten low. Bracts large, conspicuons.

\section{* * Lip undirided, fringed: flowers spiked: stems leafy.}

4. P. ciliaris, Lindl. Ieares numerous, the lower ones $\left(t^{\prime}-12^{\prime}\right.$ long $)$ lanceolate or oblong, the upper small and bract-like: spikes oval or oblong, rither loosely flowered; flowers large, bright yellow; lateral sepuls roundohovate, reflexel; petals lanceolate, incised or slightly fringed at the apex; lip clawed, roundish in outline, longr-fringed ; spur filiform, commonly longer than

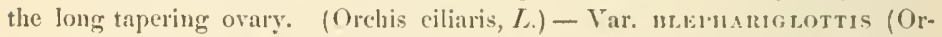
(his blephariglottis, Willd.) hats white flowers, and shorter fringe of the lip. Swamps and bogs, chiefly in the pine barrens, Florila, and noptlurarl. Ang. Stem $1 \frac{1}{2}^{\circ}-2^{\circ}$ ligh. Spike $1^{\prime \prime}-2^{\prime}$ in diameter. Ovary $9^{\prime \prime}-15^{\prime \prime}$ long. Flowcrs $6^{\prime \prime}-8^{\prime \prime}$ wide.

5. P. cristata, Lindl. Leaves numerous, the lower ones $\left(4^{\prime}-8^{\prime}\right.$ long $)$ lanceolate, the uppermost bract-like; spike oblong or cylindrieal, densely flowered ; flowers small, yellow ; hateral sepals rounded, spreading, concave; petals ol.ong, incised at the apex; lip sessile, ovate in outline, pinnatifid-fringel ; spur filiform, half as long as the tapering ovary. (Orchis cristata, M/ich $x$ ) - Bogs and swamps, Florida, and northwarl. Aıg. - Stem $1^{\circ}-2^{\circ}$ high. Spike $1^{\prime}$ in diameter. Ovary $5^{\prime \prime}-6$ "long. Flowers $2^{\prime \prime}-3^{\prime \prime}$ wide.

**** Lip 3-parted, fringed or denticulate: flowers in spiked vacemes : stem leafy.

- Flowers yellowish-white.

6. P. lacera, Gray. Stem slenier; lower leaves oblong, the uppermost small, passing into the lanceolate bracts ; raceme oblong, loosely flowered ; petals oblong-linear, entire; lip pendent, the wedge-shaped lobes deeply divided into few spreading capillary filaments; spur as long as the ovary. (Orchis lacera, Michx.) - Swamps and low ground in the upper districts, and northward. July. - Stem $1^{\circ}-2^{\circ}$ high. Lower leaves $3^{\prime}-6^{\prime}$ long Raceme $3^{\prime}-5^{\prime}$ long.

\section{++ Flowers purple: lip clawed.}

7. P. psycodes, Gray. Stem stout; lower leaves lanceolate or oblong, the upper small, passing into the linear-subulate bracts; flowers pale purple, crowded in a dense oblong raceme; lateral sepals roundish, obuse; petals oborate, minutely denticulate at the apex; lip nearly twice as long as the sepals, spreading, the wedge-shaped lobes bordered with a short fringe. (Orchis psycodes, L.) - Swamps and shaded banks, Nortlı Carolina, and northward. July. - Stem $2^{\circ}$ high. Lower leaves $3^{\prime}-6^{\prime}$ long. Flowers very numerous. Lip $2^{\prime \prime}-3^{\prime \prime}$ long. 
8. P. fimbriata, Lindl. Stem stont; leaves oval of olblong, obtuse, a fow of the upper ones small aud lanceolate like the bracts; raceme oblong, rather loosely flowered; flowers large, pale purple; lateral sepals ovate, acutish ; petals oblong, denticulate on the margins; lip twice as long as the sepals, spreading, the broad wedge-shaped lobes long-fringed; spur longer thitn the ovary. Wet ineadows, North Carolina, and northward. June. - Stem $2^{\circ}-3^{\circ}$ high. Leaves $4^{\prime}-6^{\prime}$ long. Flowers not numerous on the raceme. Lip $6^{\prime \prime}-9^{\prime \prime}$ long.

9. P. peramœna, Gray. Stem stont; lower leaves oblong, obtuse, the upper lanceolate like the briets; raceme oblong, rather loosely flowered; flowers large, violet-purple; lateral sepals broad-ovate; petals round-obovate, minutely denticulate; lip spreading, the wedge-shaped lobes finely toothed, entire, or the middle one 2-lobed; spur longer than the ovary. (Orchis fissa, Pursh.) - Mountains of North Carolina, and northward. July.-Stem $2^{\circ}-4^{\circ}$ ligh. Iip $9^{\prime \prime}$ long.

\section{HABENARIA, Willd.}

Sepals nearly equal, the lateral ones reflexed. Petals entire or 2-3-parted. Lip pendent, entire, or 2 - 3-parted, spurred. Anther-cells erect, separate, diverging. Stigma bearing two varions-shaped appendages. Glands naked. Pollenmasses 2, waxy, stalked. - Ierbs with tuberous roots, leafy stems, and spiked flowers.

1. H. repens, Nutt. Root a creeping tuber ; stem erect or ascending, rery leafy; leaves lanceolate, acute or acuminate, 3-ribbed ; spike slender, many-flowered; bracts lanceolate, the lower ones longer than the flowers; lateral sepals oblong, acute, the upper one ovate, erect; petals unequally 2-parted, the lower lobe capillary, longer than the linear upper one; lip 3-parted, barcly longer than the sepals, the lateral lobes capillary, the middle one filiform; spur as long as the ovary; appendages of the stigma tubereular. - Swamps and ditches in the lower districts, Florida to North Carolina, and westward. Ang. and Sept. - Stem $1^{\circ}-$ $2^{\circ}$ long. Leaves $6^{\prime}-12^{\prime}$ long. Spikes $\frac{1}{2}^{\circ}-1^{\circ}$ long. Flowers small, greenish.

2. H. Michauxii, Nutt. Root a glohnlar watery tuber; stem erect; leaves oval or oblong, mostly acnte, many-nerved, the upper sinaller, and similar to the orate-lanceolate clasping bracts; spike slender, loosely few-flowered; lateral sepals oblong-ovate, acnte, the upper one ovate, erect; petals unequally 2-parted, the lower lobe capillary and twice as long as the lanceolate upper one; lip twice as long as the sepals, 3-parted, the capillary lateral lobes longer than the linear middle one; spur twice as long as the ovary; appendages of the stigma tubercular. - Dry sandy or gravelly soil, Florida, to South Carolina. Augnst. Stem $6^{\prime}-18^{\prime}$ high. Leares $2^{\prime}-3^{\prime}$ long. Spike $3^{\prime}-5^{\prime}$ long. Flowers white, twiec as long as those of the preceding.

\section{SPIRANTHES, Richard. Twisted Orenis.}

Sepals and petals nearly equal; the lateral sepals diverging, dilated at the hase, the upper one connivent with the petals. Lip clawed, concave, furnished with two callosities near the base, clasping the short columu below. Stigma ovate, 
beakel. Anther attached to the hack of the colmun. Pollen-masses 2, obovate, 2-cleft, fixed to u common glamd of the stigmu, powdery. - Root composed of few dlustered tubers or fleshy filires. Stem leafy at the base, shenthed whove. Fluwers small, white, in a regnlan l-sided or spirally twisted spike.

$$
\text { * Foners on all sides of the mutuisted spilie. }
$$

1. S. cernua, Tichard. Stem smooth below, the upper portion and thick crowded spike pubescent; lowest leaves long, linear-lanceolate, the others lractlike and sheathing; loracts orate-lanceolate, acuminate, longer than the cansule; flowers recurved; lip longer than the sepal-, contracted alove the middle, wary ut the recurved ohtuse apex, 2-toothed at the base. - Grassy swamps and meadows, Florida to Mississippi, and northward. October. - Stem $6^{\prime}-12^{\prime}$ ligh. I.eaves $4^{\prime}-8^{\prime}$ long. Flowers yellowish-white, $3^{\prime \prime}-4^{\prime \prime}$ long.

* * Spites tuisted, bringing the flowers into a single struight or spirul rov:

2. S. brevifolia, n. вp. Stem pubescent alore; leares all bract-like and sheathinir, or the lowest expanding into a short $\left(1^{\prime}-2^{\prime}\right)$ lanccolate or linear early withering blade; flowers all on one side of the rachis or sparingly spiral, horizontal, pulsescent; bracts ovate, acute, scarcely longer than the ovary : sepals and petals equal; lip oblong or elliptical, very entire, wayy on the margins, recurved at the acute or obtuse apex, and with two tooth-like prominences at the base. - Open grassy swamps in the pine barrens, Apalachicola, Florida. Oet. and Nor. - Root of 3 fleslyy fibres. Stem $1^{\circ}$ ligh. Flowers $10-20,3^{\prime \prime}-4^{\prime \prime}$ long, white.

3. S. odorata, Nutt. Stem stont, leafy; lower leaves oblongr-Ianceolate, acute, the orhers diminishing upward and passing into the large lanceolate acuminate lraets; spike thick, pubescent, densely flowered, spiral; braets much longer than the orary, the lower ones as long as the recurved flowers; sepals and petals equal; lip entire, recursed, oblong, dilated and erenulate at the apex, and with two tooth-like hooked prominences at the base. - Muddy banks of rivers, near Marianna, Florida to North Carolina, and westwarl. Octolser. Stem $1^{\circ}-2^{\circ}$ high. Lowest leaves $9^{\prime}-15^{\prime}$ long, $1^{\prime}-2^{\prime}$ wide. Flowers yellowish-white, $\frac{1}{2}$ long, fragrint.

4. S. tortilis, Willd. Stem tall and slcnder, pulesecnt above; lowest leaves linear, the upper small and lract-like; spike slender, pubeseent, spiral; bracts ovate-lanecolate, acuminate, longer than the orary; lip oblong, entire, recurred and crenulate at the apex, scarcely longer than the jetals, with two gland-like prominences at the throat. - Low or marshy pine barrens, Florida to North Carolina. May. - Stem $1^{\circ}-2^{\circ}$ ligh. Leaves $6^{\prime}-10^{\prime}$ long. Flowers $3^{\prime \prime}$ long, white.

5. S. gracilis, Bigelow. Stem very slender, smooth throughont, scape-like; lowest leaves (early withering) lanceolate or elliptical, spreading; spike very slender; flowers minute, on one side of the rachis or sparingly spiral, smooth; braets ovate-lanceolate, clasping, shorter than the capsule; lip fincly crenulate on the margins, recurved and acute at the apex, with two raised ear-like prominenees at the base; anthers 4-cleft. - Damp soil, Florida, and northward. April and May. - Stem sheathed, $6^{\prime}-12^{\prime}$ ligh. Lowest leaves $1^{\prime}-2^{\prime}$ long. Flowers $1^{\prime \prime}$ long. 


\section{GOOdYera, R. Brown. Rattlessake Playtaix.}

Sepals and petals nearly equal, the two lateral sepals including the base of the sessile lip, the upper one connivent with the petals. Lip concare or sac-like, contracted above the middle into a recurved and channelled point. Anther attached to the dorsal apex of the short and frec column. Pollen-masses 2, entire, powdery. - Stems leafy or scape-like, from a słender crecping rootstock, bearing a spike of small white flowers.

* Stem scape-like, bracted: lip spurless: column manifist: anther round, bealiless, rudical leaves clustered.

1. G. pubescens, R. Brown. Scape pubescent; radical leaves thick, ovate, discolored and reticulated above, contracted into a spreading petiole; spike lanceolate, densely many-flowered, pubescent; bracts lanceolate; sepals and petals roundish; lip sac-like, ending in a slort, ovate point ; stigma ronnded. - Deep shady woods, Florida, and northward. August. - Seape $1^{\circ}$ high. Leaves $2^{\prime}$ long. Spike $2^{\prime}-4^{\prime}$ long.

2. G. repens, R. Brown. Low; scape slender, pubescent; radical leaves ovate or oblong-ovate, retienlated; spike slender, loosely few-flowered, 1-sided or somewlrat spiral; bracts linear-lanceolate; lip sac-like, ending in an oblong point; stigma 2-toothed. - Shady woods, on the mountains of North Carolina, and northward. Angust. - Scape 5'-8' high. Leaves $\mathbf{l}^{\prime}$ long.

* * Stem leafy: lip spurred: colunn inconspicuous: anther ovate, beaked.

3. G. quercicola, Lindl. Stem ascending; leaves thin, ovate or oblongovate, acute, on slender petioles, which are dilated, membranaceous, and sheathing at the base; spike short, oblong, densely flowered; bracts searious, oblongovate, mostly shorter than the flowers; sepals and petals oblong, obtuse; lip concave, ending in a broadly-ovate acuminate and recurred point ; spur ponchlike, shorter than the ovary; stigma 2-lobed. - Low shady woods, Florida, and westward. August. - Plant tender, $6^{\prime}-12^{\prime}$ high. Leares and spike $1^{\prime}$ long.

\section{LISTERA, R. Brown.}

Sepals and petals alike, spreading or reflexed. Lip longer than the sepals, 2-cleft. Column short. Stigma with a rounded beak. Anther ovate, attached to the dorsal summit of the column. Pollen-masses 2, powdery. - Steins low, from clustered fibres, bearing two opposite sessile leaves, and a loose raceme of small greenish flowers.

1. L. australis, Lindl. Leaves ovate or oblong-ovate, closely sessile; raceme smootlish, few - several-flowered; bracts minute; lip linear, $3-4$ times as long as the sepals, deeply 2-cleft, the divisions filiform; column very short. Wet shady woods, Florida, and northward. July. - Stem $4^{\prime}-8^{\prime}$ high. Leares $\frac{1^{\prime}}{2}-1^{\prime}$ long.

2. L. convallarioides, Hook. Leaves broadly corlate or roundish; raceme puheseent, few-flowered; hracts half as long as the pedicels; lip oblongobovate, 2-lobed at the apex, and 2-toothed at the base, twice as long as the se- 
pals; column matnifint. - I):mup mossy wools, on the mountains of North

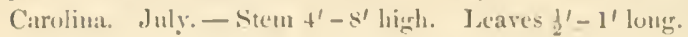

\section{PONTHIEVA, li. l3rown.}

Scpals and petals nearly alike, the two onter sepals spreading, the upper one connivent with the petals. I'etals, like the lip, atuate to the midlle of the colnmn. Lip posterior, clawer, orate, concare, spreading. Colnmn 2-lobed, beaked. Anther dorsal, lincar, stalked, 4-celled. Pullen-masses 4, linear, powdery. - Low herhs, with chustered roots, chiefly broad radical leares, and greenish flowers on a pubescent scape.

1. P. glandulosa, R. lirown. Leaves many-nerved, oblong, spreatiną, narrowed into a short petiole; seape slender, many-flowered; bracts lanceolate; lateral sepals flat. (Cramichis multiflora, Nutt. Ophrys pubera, Michx.) - Low shady woods, Florida to North Carolina. Sejt. and Oct. - Scape $1^{\circ}-1 \frac{1}{2}$ lhight.

\section{CYPRIPEDIUM, L. LADX'S SLIPER.}

Sepals 3, the two lower ones mostly united into one under the lip, spreading. Petals narrower. Jip liuge, inflated, and sac-like. Column short, 3-loled, the two lateral loles each bearing a 2-celled anther on the under side, the mildie one (stcrile stanen) petal-like. Pollen granular. Stigma thick, triangular. - Root fibrons. Leaves large, plaitcd, sheathing. Flowers large, mostly solitary, leafybracted, nodding.

* Stem lenfy: sepals and petals longer than the yellow lip, the letter linear und turisted.

1. C. pubescens, Willl. Pubeseent; stem slieatled at the base; leaves $4-6$, ovatc-oblong, acute or acuninate; flowers $1-3$; sepals yreenish, striped with deeper lines, lanceolate, acuminate, the lower sometimes 2-eleft at the apex; petals linear, spirally twisted; lip large $\left(1^{\prime}-1 \frac{1}{2}^{\prime}\right.$ long $)$, laterally flattened, spotted within; stigma triangular, obtuse. - Rich woods in the upper districts, and northward. May and Jume. - Stem $10-1 \frac{10}{2}$ high. Leares $4^{\prime}-6^{\prime}$ long. Flowers inolorons.

2. C. parviflorum, Salisb. Very near the preeenling, but every way smaller; lip lualf as large, depressed above; stigma triangular, acute; flowers fragrant. - Rich woods in the upper districts. May and Junc.

** Stem lenfy: sepuls and petals uhite, flat, obtuse, not lonyer than the lip.

3. C. spectabile, Swartz. Pubesent; leaves $6-7$, oval, aeute; sepals oval or oblong, rather longer than the lanceolate petals; lip ( $1 \frac{1}{2}$ longr) much inflated, white tinged with purple, ahout as long as the sepals. - Mountains of North Carolina, and northward. May and Junc. - Sten $2^{\circ}$ high, commonly 2-flowered. Leaves $4^{\prime}-6^{\prime}$ long. Flowers very showy.

\section{*** Scape naked, 1-flouered, 2-leared at the lintse.}

4. C. acaule, Ait. Pubescent; leaves ohlong, ohtusc; sepals greenish, oblong-lanceolate, acute, nearly as long as the lincar prtals, much shortcr than the large $\left(2^{\prime}\right.$ long) obovate purple and veiny lip. - Dry wouls in the upper distriets, and northward. May and June. - Scape $8^{\prime}-12^{\prime}$ high. Leaves $\frac{10}{2}$ long. 


\section{Order 143. CANNACEAs. (CANya Fanily.)}

Perennial herbs, destitute of aroma, with alternate sheathing leaves, the very numerous nerves parallel, and diverging from the strong midrib, and superior irregular monandrous tlowers. Sepals 3. Corolla 6-parted; the three exterior divisions alike; the three interior ones very unequal, and often varionsly inperfect. Stamen and stigma mostly petal-like. Anther 1-celled. Ovary 1-3-celled, with 1-many anatropous or eampylotropous ovules. Embryo straight or hooked, in hard albumen. - Rhizoma often tuberous, and abounding in starrh.

\section{THALIA, I.}

Calyx minute. Corolla tubular; the three exterior divisions similar and equal ; the interior unequal ; the anterior one broal and hooded, the interior lateral one elongated and clawed, the exterior lateral one furnisherl with two bristles on one side, and partly adnate to the slunder stamen on the other. Style thick, spiral : stigma perforated, 2-lipped, the lower lip long and pendent. Capsule utricular, 1-celled, 1-seeded. Seed ovoid, ereet, campylotropous. Enbryo hooked, in hard allumen - Stemless herbs from fibrous roots. Seape elongated. Petioles terete, dilated and sheathing at the base. Flowers in bracted panicled spikes, commonly two together, and included in a 2-valved spathe.

1. T. dealbata, Roscoe. Plant dusted over with a minute white powder, -therwise smooth; leaves distichous, loner-petioled, corclate-orate, acute; scape terete, reed-like; panicle erect, dense, smooth, the branches not longer than the lanceolate decidnous bracts at their base; spikes ereet; valves of the spathe unequal, ovate, coriaceous; flowers small, purple. - Ponds and marshes, South Carolina, and westward. June-Sept. - Stape $3^{\circ}-5^{\circ}$ hight. Leaves $6^{\prime}-9^{\prime}$ long, on petioles $1^{\circ}-2^{\circ}$ long.

2. T. divaricata, n. sp. Plant not powdery; leaves oblong-ovate, acute, rounded at the base, long-petioled; panicle lange, divarieate, the branches much longer than the linear deciduous bracts, hairy at the joints; spikes $6-10$-flowered, zigzag, pendulous ; valves of the spathe unequal, oblong, membranaceous, hairy; flowers small, purple, seel ovoid, enclosed in a loose membranaceous periearp. - Ponds, Apalachicoli, Florida. Sept. and Oct. - Seape $5^{\circ}-10^{\circ}$ high. Leaves $1^{\circ}-2^{\circ}$ long. Panicle $2^{\circ}-4^{\circ}$ wide, purplish.

\section{CANNA, L. Ixmax-Shot.}

Sepals 3. Corolla 6-parted; the three exterior divisions equal; the interior bilabiate, with the upper lip 2-3-parted, or sometimes wanting, the lower entire. Filaments petal-like. Anther marginal. Ovary 3-celled, many-ovuled. Style petal-like. Stigma marginal. Capsule covered with a dense bristly coat, 3-celled, loculicidally 3-valved. Placentæ central. Seeds globose, anatropous. Embryo straight in horny allumen. - Stems leafy. Leaves nitrowed into a sheathing petiole. Flowers spiked, showy. 
1. C. flaccida, Roine Stem stout, very leafy luelow; leaves ovate-lunceolate, nemuinate, umrowed into al long and sheathing prtiole; spike fi'w-fowercd; scpals grecen, lancenlate, acute, hall" ats long as the tube of the corolla; corolla funne-shuped; the exterior divisions similar to the sepals, rellexed; the three in. terior ones yellow, very thin, olloner-olovinte; two of them collateml and adnate below; stamens petal-like, obovate, thickened below, very thin and expanding above, one of them bearing the linear muther on its margin, the other two larger and united into one; style admate to the tube of the corolla ; stigma thirk, spatulate, embracing the antler in the hul; capsule ovil, 3-augled, few-seerled, men. branaceous at maturity, and bursting irregularly ut the sides; secels black, borne on al spongy cort. - Miry swamps, Florida to South Caroluna, near the coast. Junc- Aug. - Stem $2^{\circ}-4^{\circ}$ high. Leaves $9^{\prime}-15^{\prime}$ long. Corolla $3^{\prime}-4^{\prime}$ long.

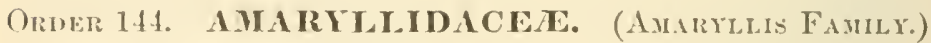

Chintly stemless smooth aul succulent herbs, with linear leaves, and smonth (not seurly ow wolly) often showy flowers. - Seprals and petals united to form a 6-parted corolla-like perianth, imbricated in the bucl, the thle arnate to the 3-celled wary. Stamens 6 : anthers introrse. Ovules anatropous, attacherl to the e'ntral plarentie. Style single. Fruit 1-3relled, valvular or indehisent. Embryo straight in fleshy albumen, the radicle resting on the umbilicus.

\section{Syuopsis.}

* Root luulbous.

1. AMARYLLTS. Tube of the perianth short, crownless. Stigmas 3.

2. PANCRATILY. Tube of the perianth elongated. Stanens connectel with a cup-shaped crown. Stigun entire.

3. C'RIXUM. Tube of the jerianth elongated. crownless. Stigma entire.

$$
\text { * Rinot tuberous. }
$$

4. AGATH. ('apsule 3-valved. Flowers spiked. Jeaves thick and fleshy.

5. IIYPOXYS. Capsule circumscissile. Flowers umbelled. Leares grass-like.

\section{AMARYLLIS, L.}

Perianth corolla-like, bell-shaped or funnel-shaped, 6-parted, spreading above, naked at the throat, the tube short or wanting. Stamens fice antlers versatile. Style elongated, declining: stignat 3-eleft. Capsule 3-valved, many-seeded. Seeds black, comjressed or angled. - Scatpe erect from a coatted bull, ending in a 1 -2-leaved one- or many-flowered spathe.

1. A. Atamasco, L. (Atumasco Lily) Scape terete, somewhat lateral, 1-flowered; leaves linear, concave, fleslyy; spathe 1 leaved, 2-cleft; perianth short-stalkerl, bell-shaped, white tinged with purple; style longer than the stamens; seeds angled. - Rich damp soil, Florida, and northward. Mareh and April. - Scape 6'-12' high, commonly shorter than the glossy leaves. Flower $2^{\prime}-3^{\prime}$ long. 


\section{PANCRATIUM, $\mathrm{I}$.}

Perianth corolla-like, 6-parted; the narrow divisions spreading; the tube slender and elongated. Stamens nnited below with a cup-shaped or fumelshaped variously toothed crown, exserted : anthers versatile, linear. Style elongated, declining. stigma entire. Capsule membranaceons, 3-eelled. Seeds often bulb-like. - Scape from a coated bu'b, compressed or 2-edged, bearing the large and fragrant leafy-bracted flowers in a cluster at the apex. Leaves strap-shaped.

\$1. Paxcrativir. Tube of the perianth dilated and funnel-shaped at the apex: crown almost uholly udnate to the tube, the border divided into six 2-clejt teeth, alternating with the stamens: capsule many-seedul, loculicidally 3-rulved.

1. P. maritimum, L. Leaves glaucous, ereet, longer than the slightly compressed many-flowered scape; divisions of the perianth linear-lanceolate, shorter than the slender $\left(3^{\prime}-4^{\prime}\right)$ tube, greenish without; stamens short. (P. Carolinimum, L.) - Salt marshes, Sonth Florida to South Carolina. July-Sept. - Scipe $1^{\circ}-1 \frac{10}{2}$ highl.

\$2. Hrmexocallis. Tube of the periantin straight, not dilated at the apex: crom fice, fannel-shaped or saucer-shaped, the border irregularly toothed: capsule 1-3seeded, bursting at the sides.

2. P. rotatum, Ḱer. Bulb bearing rumners; leaves flat above, coneave toward the base; scape 2-edged, 2-6-flowered, glaucons; divisions of the perianth white, linear, spreading or recurved, longer than the green tube; crown saucer-shaped or somewhat funnel-shaped, with the border irregrularly toothed. (P. Mexicanum of authors ) - Low banks and swamps, Florila to North Carolina. April and May. - Scape and leaves $1^{\circ}-2^{\circ}$ high.

3. P. coronarium, Leconte. Bulb withont runners; leaves linear-strapshaped, flat above, half-eylindrieal near the base; scape solitary, green, 2-edged, 4-flowered; divisions of the periunth linear, spreading, white; crown large, funnel-shaped, with six truncate lobes at the stamens, and several fine teeth at the sinuses. - Rocky islets in the Savannah River at Augusta, and in the Congaree at Columbia, Leronte. - Seape and leaves $2^{\circ}$ long.

4. P. occidentale, Leconte. Bulb without runners; leaves linear-strapshaped, obtuse, coneave, and, like the 2-edged 6-flowered scape, glaucous; divisions of the perianth white, linear, spreading and recurvel at the apex; crown funnel-shaped, with six toothed lobes alternating with the filmments; capsule many-secled. - Lpland meadows, in the western distriets of Greorgia, Leconte. - Stem and leaves $2^{\circ}$ long.

\$3. Is uExe. Tube of the periunth curved, dilated at the throut: crown nearly free, somewhat 12-toothed: capsule few-seeded.

5. P. nutans, Gwal. Leaves long, strap-shaped, sheathing; scape 3-4flowered, solitary, 2-edged; flowers nodding; divisions of the perianth lanceolatelinear, white, longer than the green tube; stamens ineurvel, searcely longer than the crown. - South Carolini, IIerbert. - Leaves $2^{\circ}$ Ioncm. 


\section{CRINUM, L.}

'Tuhe of the perianth erownless at the apex. Otlacwise like Pancrutiun both in (hanacter and hathit.

1. C. Americanum, L. Leaves strap-shaped, roneave, obtuse, remotely denticulate, sprenling; scape compressed, with rounderl edges, 2-4-fowered; hracts lancelate recurved; ovaries sessile, with a linear loractlet at the hase of each; flowers large, fragrant; leaves of the perianth white, laneeolate, shorter than the green tube; filaments and style purple ahove; stigma tmurcate, cntire; ovules 3 in each cell, erect ; rapsule globose, membranaceous, indelisecnt; 1 -6seeded, pointed with the long persistent tube of the perianth; seed large, cormlike; cmbryo oblong, in the axis of copions fleshy albumen; ralicle inferior. River-swamps, Florida, and westward. May-Sept. Scape $1^{\circ}-2^{\circ}$ high. Perianth $6^{\prime}-8^{\prime}$ long.

\section{AGAVE, L.}

Periantlı corolla-like, funnel-shaped, 6-parted, persistent. Stamens exsertel: anthers linear, versatile. Style filiform, exserted: stigma 3-augled or 3-lobed. Canssule cortiacens, 3-lohed, 3-eclled, loculicilally 3-valverl, many-seded. Sects flat, black and shining, attached to the central placente. - Seape bracted. Leaves fleshy, syiny or cartilaginons on the margins. Flowers in simple or panicled spikes, bracted.

1. A. Virginica, L. Lcaves lanecolate, thick and rigid, spine-pointed, denticulate on the margins; serue simple, smooth; flowers small, yellowish, scattered in a simple spike; perianth strongly nerved; filaments and style spotted. - Sterile soil, Florida, and northwarl. July. - Seape $3^{\circ}-5^{\circ}$ high. Leaves $6^{\prime}-12^{\prime}$ long. Capsule globose, 3-lobet.

\section{HYPOXYS, I. StAR-gRASS.}

Perianth 6-parted, persistent, the spreading divisions colored within. Stamens short, mequal : anthers ereet. Ovary 3-eelled, witl the numerons amplitropous ovinles attached to the central placente in two rows. Style short and thick: stigmas 3. Capsule top-shaped, many-seeded, opening transversely netIr the summit, the upper portion, with the withered perianth, falling off like a lisl Seculs grlobular, with a beak-like projection near the base. Radicle inferior Low pulesent herbs, from a tuberous root, with grass-like leaves, and a naked seape, bearing the few yellow flowers in a terminal bracted umbel.

1. H. erecta, I. Hairy; leaves linear, elannelled; seapes $1-4$, filiform, 2-4-flowered ; bracts subulate, much shorter than the slemler unequal pedicels; divisions of the perianth oblong, greenish and hairy without, yellow withn; cap sule 8-eellecl. - Varies, with the more rigid leaves nearly smooth, the $2-3$-flow ered scape flattened, and the bristle-like brats longer than the nearly sessile almost woolly perianth. - Low gromd, Florida, and northward. March and April. - Scapes $2^{\prime}-9^{\prime}$ long. Leares at length much longer than the seape. Flowers 8 " wide. 
2. H. juncea, Smith. Sparingly hairy ; leaves filıform ; scapes $1-3$, filiform, 1-2-flowered; bracts bristle-like, shorter than the villous pedicels; divisions of the periunth oblong, the three exterior ones greenish and hairy without; partitions of the capsule vanishing at maturity ; seeds black, minntely pitted. (H tilifolia, Ell.) - Low pine barrens, Florida and the lower districts of Georgia, and westward. March and April. - Scape $4^{\prime}-9^{\prime}$ long, at length proeumbent. Flowers $9 "-12^{\prime \prime}$ wide.

\section{Order 145. HEMODORACE.T. (Bloodwort Family.)}

Perennial fibrous-rooted herbs, with leafy or scape-like stems, mostly equitant and sword-shaped leaves, and regular woolly or scurfy flowers. - Perianth tubular, 6-cleft, more or less cohering with the 3-celled ovary. Stamens 3 or 6 : anthers adnate, introrse, 2-celled. Ovules mostly few, anatropous or amphitropous, attached to the central placente. Styles 3, united, decidnous, or persistent and separating: stigma entire. Capsule enclosed in the persistent perianth, loculicidally 3-ralved at the apex. Embryo small, in hard albumen.

\section{Synopsis.}

1. LACHNANTHES. Perianth woolly: stamens 3: style deciduous: flowers eymose: stem lexfy.

2 LOPIIOLA. Perianth woolly: stamens 6: style persistent: flowers corymbose: stem leafy.

3. ALETRIS. Perianth scurfy : stamens 6 : style persistent : flowers spiked : stem seape-like.

\section{LACHNANTHES, Ell.}

Perianth woolly withont, 6-lobed; with the exterior lobes smaller; the tule adnate to the ovary. Stamens 3, slender, exserted, opposite the interior lobes of the perianth: anthers linear. Style filiform, deelinerl, decidnous : stigma entire. Capsule glohose, 3-angled. Sceds amphitropons, few, thin, orbieular, eoneave, fixed by the middle to the thick globose placente. - A leafy-stemmed plant, with orange-colored juice.

1. L. tinctoria, Ell. Root red, fibrous; stem mostly simple, villous above; leares linear-sword-shtped, smooth, the lower ones erowded and equitant, the others smaller and remote; flowers 2-ranked, crowded in lateral and terminal compound woolly cymes, yellow within; exterior lobes of the perianth linear; values of the capsule separating from the placente; seeds black. - Ponds and ditches, Florida, and northward. July-Sept. - Stem $2^{\circ}-3^{\circ}$ high. Leaves $1^{\circ}-1 \frac{1}{2}^{\circ}$ loug. Flowers $\frac{1}{2}$ long. Bracts linear.

\section{LOPHIOLA, Ker.}

Perianth woolly without, and at the throat within, nearly equally 6-lobed, spreading; the tube adnate to the lower half of the ovary. Stamens 6 , slender : 
anthers ollong. Style sulmlate, erect, persistent and sepmrable: stigma entire Capsule ovate, corlitcous, 3-ribbed and 3-furrowed. Siceds anatropous. few, lincar-oblomer, curved, tixed ut the batse.

1. L. aurea, Ker. Stem erert, finely pubescent ahove, mostly simple; lowest leaves linent-sword-shaped, acnte, equitant, the others diminishing upward, remote; flowers small, yellow within, in elose or open rorymbose woolly racemes. (Conostylis Anericuna, I'ursh) - Wet pine barrens, Florida, and northward. July. - Stem $2^{\circ}$ high, ereeping at the batse. Leaves $t^{\prime}-12^{\prime}$ long. Flowers $3^{\prime \prime}$ long, nodding in the bud.

\section{ALETRIS, I. StiR-Griss.}

l'erianth tubular, scurfy and viscid without, smooth within, 6-cleft, the tube aduate to the base of the ovary. Stamens 6, very short, includel: anthers sagrittate. Style mbulate, erect, persistent, and separable: stigmas 3. Capsule ovate, coriaceous. Seeds ovate, ribled, fixed at the lasice. - Perennial herbs, witl slender scape-like linear-bracted stems, bearing at the base al cluster of flat spreading leaves, and at the summit numerous small white or yellow flowers in at spiked raceme.

1. A. farinosa, L. Leaves lanecolate, very aente, sessile; spike short $\left(3^{\prime}-12^{\prime}\right)$, rigid; Howers apuroximate or crowed ; perianth white or ycllow, nearly sessile, cylindrical, with nurrow and spreading lobes; style slender, subulate, 3-cleft ; capsnle ovate-lanecolate, longer than the perianth. - l'ine-barren swamps, Florida to North Carolini. May and June. - Seape $2^{\circ}-3^{\circ}$ high. Leaves $3^{\prime}-6^{\prime}$ long. Perianth $4^{\prime \prime}$ long.

2. A. aurea, Wralt. Leaves ovate-laneeolate, very acite, narrowed at the base; raceme elongated $\left(1^{\circ}-2^{\circ}\right)$, slender; flowers scatterel; periantl white or yellow, short-stalked, globose-ovate, with broal and comnivent lobes; style short, somewhat eonical, obscurely 3 -cleft; capsule ovate, as loug as the perianth. Low sandy soil, Florida to North Carolina. May and June. - Seape $2^{\circ}-3^{\circ}$ high. Leaves $2^{\prime}-4^{\prime}$ long. Perianth $2^{\prime \prime}-3^{\prime \prime}$ long.

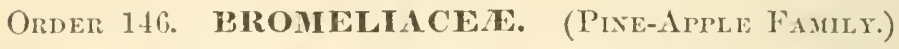

Clicfly scurfy epiphytes, with fibrous roots, rigid leaves, and regular conspienonsly bracted mostly spiken flowers. - Perianth free, or more or less adnate to the 3-eelled ovary, 6-parted, imbricated, the three outer divisions calyx-like. Stamens 6 . anthers 2 -erlled, introrse. Ovules numerons, anatropous, erect or pendnlous. Placente eentral. Style single: stigmas 3. Frnit berry-like, or 3-celled, 3-valvel capsule. Seeds stalked. Embryo small, at the base of copious mealy albumen.

\section{TILLANDSiA, I. Loxg Moss. Air-Plaxt.}

Sepals rigid. Petals imbricated and tube-like below, spreading above. Stameus filiform, lypogynous. Ovary free. Style sleuder. Capsule linear or 
finear-oblong, cartilaginous, septicidally 3 -valved, each valve separating into 2 plates. Seeds erect, elub-slıaped, pointed, raised on a long and lairy stalk. Radical leaves nostly crowded, imbricated. Petals fugacions.

* Stem rigzd, erect: flouers spilied, blue.

1 Lraies broad at the base, gradually narroued uparad.

1. T. utriculata, Leeonte. Leares seurfy and grlaucons, subulate and recurvel at the summit, very much dilated, concare and imbrieated at the base, shortcr than the rigil mostly brancling stem; the uppermost small and sheathing; flowers seattered ; sepals oblong-linear, obtuse, longer than the oblong pubeseent membranaceous bracts, much shorter than the capsule; petals pale blue, twice as long as the sepals, slightly sprearling at the apex; stamens exserted. South Florida. June and July. - Stem $2^{\circ}-3^{\circ}$ high. The dilated and iubricated bases of the leaves form a kind of cup which commonly contains a considcrable quantity of witer.

2. T. bracteata, n. sp. Leaves scurfy, concave, gradually narrowed upwarl, subulate and erect at the apex, the uppermost reluced to ovate pointed bracts; stem branched, longer than the leaves; spikes eompressed, 2-edged; bracts ovate, coriaccous, smooth, closely imbricated in two rows, keeled on the back, longer than the linear acute keeled sepals. - South Floridia - Stem $2^{\circ}$ high. Leaves $1^{\circ}-1 \frac{1}{2} 0$ long.

3. T. bulbosa, Hook. Small, very scurfy ; leaves broal and clasping at the hase, concare, imbricated, nearly equal, spreading above, shorter than the spike; spike simple, few-flowered; bracts oblong, scurfy, imbricated in two rows, longer than the sepals, and half as long as the capsule. - South Florida. - Stem stont, $4^{\prime}$ high. Spike $3^{\prime}-4^{\prime} \operatorname{long}, 6-7$-flowered. Leaves $3^{\prime}-4^{\prime}$ long Corolla jurplish blue.

\section{+- + Leaves linear or filiform, from an almuptly dilated base.}

4. T. juncea, Leconte. Stem slender, leafy; leaves seurfy, linear, concave, recurved, longer than the stem, the lowest ones imbricated, the upper sheathing; spikes branched, few-floweres ; bracts imbricated, smoothish, acute, longer than the sepals; petals deep bluc, three times as long as the sepals, recurved at the apex. - South Florida. - Stem $1^{\circ}$ high. Spikes $2^{\prime}-4^{\prime}$ long. Leaves $1^{\circ}-1 \frac{1}{2}^{\circ} \mathrm{long}$.

5. T. Bartramii, Ell. Stem slender, leafy ; leaves smootl, erect, filiform, straight and rigid, as long as the stem, the upper ones short and sheathing; spike brancherl, few-flowered; bracts scurfy, imbricated, longer than the sepals, nearly as long as the capsule, the lower ones awned; petals blue, spreading at the apex. - Southern districts of Georgia, Elliott, to South Florida. - Stem $1^{\circ}$ high. Spikes $3^{\prime}-4^{\prime}$ long. Leares bristle-like at the summit.

6. T. cæspitosa, Leconte. Stems low, clustered; leaves reddish, longer than the stem, scurfy, hristle-awl-shaped, erect, semi-terete, coneave at the base, the upper ones scale-like; spike 3 -4-flowered; bracts imbricated; petals blue, longer than the bracts, recurred at the apex. (T. pinifolia, Leconte?) - East Florida, Leconte. - Plant reddish, $4^{\prime}-5^{\prime}$ high, growing in large roundish clusters on the trunks of trees. 


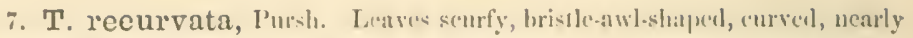

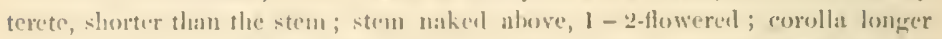

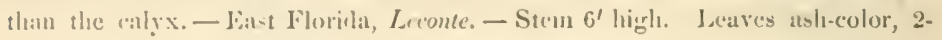
ranked, narrowly chamenellecl.

\section{* * Stems filiform, pendent: fouers solitury. yrron.}

8. T. usneoides, T. (Lusw Muss.) Sumfy and hoary; stums $\left(1^{\circ}-2^{\circ}\right.$ long) l,andhing; leares 2-ranked, linear-awl-shaped, recurved; flowers sessile at the summit of the loranches, small; sepals lonerer than the bracts, half as long as the linear recurred green petals. - Humiel situations in the lower districts. Floricla to North Carolina, and westwastl. June-S'pt.

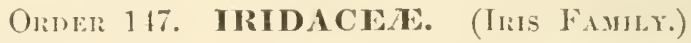

Herls, with linear or sword-shaped equitant nerved leaves, and fugacious often showy flowers from a 2-leaved spathe. - l'erianth (j-parterl, the divisions spreading and equal, w' the inner ones smaller, convolute in the bud. Stamens 3, distinct or mited : anthers extrorse. Ovary aduate to the tube of the perianth, 3-celled; the numerous anatropons orules fixed to the central placentax. Style single: stigmas 3. Capsule loculieirlally 3-valved. Embryo in the axis of Jleshy albumen.

\section{Syuopsis.}

1. IRIS. Stigmas petal-like, corering the stamens : eapsule angular.

2. SISIRINCIILM. Stigmas filiform : eapsule globular : stem flat.

3. NE.IASTYLIS. Stigmas filiform, 2-parted: stem terete.

\section{IRIS, L. BLte Flag. Flower-hit-Lare.}

Perianth crolla-like, 6-parted, the exterior divisions recurved, and often rrested or bearded within, the interior mostly smaller and crert. Stamens 3, opposite the outer divisions of the perianth, concesled by the dilated petal-like 2-lipped spreatling stigmas. Style 3-angled. Capsule 3-6-ingled. Seed ntmerons, flattened, packed in 2 rows in the cells. - Perennial herhs, with creeping or tuberons rootstocks, simple or branched stems, linear or sworl-shaped leaves, and showy flowers from a scarions spathe.

\section{* Stems tall, leafy: dirisions of the perianth unerpual.}

1. I. versicolor, I. Stem nearly terete, simple or branched; leaves sword-shaped; flowers terminal, single or spiked, crestless; perianth pale blue, variegatel with white, yellow, and purple, the inflated tube shorter than the obtuscly 3-angled orary; stigmas 2-toothed at the base, with the lips entire, or slightly crenate; capsule oblong, obtusely 3-angled. - Wet places, Florida, and northwart. April and May. - Stem $1 \frac{1}{2}{ }^{\circ}-2^{\circ}$ high. Lowest leares $1 \frac{1}{2}{ }^{\circ}-2^{\circ}$ Jong, $1^{\prime}-1 \frac{1^{\prime}}{2}$ wide. Perianth $2^{\prime}$ long.

2. I. hexagona, Walt. Stem terete, simple; leaves linear-sword-shaped; flowers axillary and terminal, solitary, crested; perianth deep blne, variegated with white, yellow, and purple; the eylindrieal angular tube longer than the 
6-angled oyary; stigmas much longer than the anthers, nearly as long as the interior perianth, the large lıps cut-toothed ; capsule oblong-cylindrieal, 6-angled. - Swamps, Fiorila to South Carolina, near the coast. April. - Stem $2^{\circ}-3^{\circ}$ ligh. Lowest leaves $2^{\circ}-3^{\circ}$ long Flowers $4^{\prime}$ long.

3. I. cuprea, Pursh. Stem simple, furrowed and 1-angled below; leaves linear-sword-shaped; flowers axillary and terminal, single or by pairs, erestless, dull yellow; tube of the perianth somewhat inflated, as long as the 6-angled ovary; stigmas scarcely longer than the anthers, abont half as long as the petals, the lips nearly entire; capsule tumid, 6-angled. - Swamps in the lower districts of Georgia, Elliott, and westward. April and May. - Stem $3^{\circ}$ high. Leaves $2^{\circ}$ long. Flowers $2^{\prime}$ long.

4. I. tripetala, Walt. Stem terete, simple, or with pelunele-like branches; leaves rather short, sword-shaped, glaucous; flowers terminal, solitary, crestles,, blue, variegated with yellow and purple; inner divisions of the perianth very short, wedge-shaped, abruptly pointed; stigmas 2-toothed at the base, and with toothed lips; ovary 3-angled, longer than the short terete tube of the perianth; capsule oral, 3-ancrled. - Pine-barren swamps, Florida to North Carolina. June and July. - Stem $1^{\circ}-2^{\circ}$ high. Leaves $1^{\circ}$ long. Flowers $2^{\prime}-3^{\prime}$ long, sometimes by pairs. Limb of the sepals roundish.

5. I. Virginica, L. Stem slender, simple; leaves elongated, grass-like; flowers 2-6, terminal, on a long and slender peduncle, crestless, blue and white; ovary 3 -angled, 2 -furrowed on the sides, much longer than the very short tuhe of the perianth; capsule 3-angled, acute at each enil. - Swamps, North Carolina, Tennessee, and northward. June.- Stem and lower leaves $2^{\circ}$ long. Flowers $1 \frac{1}{2}$ long.

* * Stems low, with sheath-like leares : divisions of the perianth nearly equal.

6. I. verna, L. Stem very short, concealed by the short spathe-like leaves, 1.flowered; proper leaves linear-sword-shaped, glaucous; perianth pale blue, crestless, the divisions about as long as the filiform partly concealed tube; capsule 3-angled. - Pine barrens of the middle districts, mostly in dry soil, Alabama to North Carolina. April - Leaves $5^{\prime}-8^{\prime}$ long. Limb of the perianth $\mathrm{l}^{\prime}$ long.

7. I. cristata, Ait. Stem 1 -3-flowered ; leaves lanceolate $\left(3^{\prime}-5^{\prime}\right.$ long); outer divisions of the periantl crested, much shorter than the filiform tube; capsule acutely 3 -angled; otherwise like the preceding. - Mountains of North Carolina. May.

\section{SISYRINCHIUM, L BLUE-ETED GRASs.}

Perianth corolla-like, 6-parted, the divisions nearly equal, spreading Stamens 3, monadelphous: anthers sagittate. Style short: stigmas 3, simple, filiforn and involute. Capsule and seeds roundish. - Grass-like herbs, with fibrous roots, and scape-like 2-edged stems Flowers small, in an umbellate cluster, successively developel from a rigid 2-leaved spathe. 
1. S. Bermudiana, I. Leaves lincur, ereet ; stem simple or spariugly

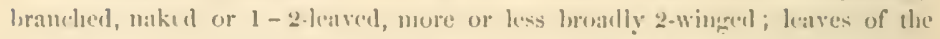
Epathe equal and shorter thun the flowers, or the lower one much longer than the flowers; perianth blue, yellow in the centre; the divisions noteled ant loriste-awned at the apex. (S. mueronutum, Mehr.) - Grassy metalows, or sometimes in dry soil, Floridil, and northward. July and Aug. - Stem $6^{\prime}-18^{\prime}$ high. Icaves mostly shorter than the stem. Flowers $t-6$ ill a spathe, $\frac{1}{2}$ wide, opening in the evening.

\section{NEMASTYLIS, Nut.}

Perianth 6-parted, the divisions nearly equal and spreading. Stamens 3, distinet, with the subulate filaments much shorter than the elongated lincar antlers. Style short, 3-lohed, with the lohes 2-parted, each division produced into filiform radiating stigmas. Capsule oblong, truneated. - Herhs with coated hullons roots, linear plicate leaves, and very fugacious flowers from a 2-leaved spathe.

1. N. cœlestina, Nutt. Bulb small, roundish; radical leaves few, clongated, slieatling; those of the stem diminishing upward, the uppermost bractlike; flowers mostly solitary, terminal ; divisions of the perianth oblong-obovate; eapsule oltusely 3-angled; seels angular, brown. (Ixia colestina, Bartrain) l'ine barrens, Florida to South Carolina, and westward. May and June. - Stem $1 \frac{10}{2}-2^{\circ}$ high. Flowers bright bluc.

\section{Order 148. DIOSCOREACER. (Yair Famlr.)}

Twining berls, with tuberous roots, ribbed and reticulated leaves, and small regular diecions flowers, in axillary spikes or panicles. - Perianth 6-parted, the tube (in the fertile flower) adherent to the 3-celled ovary. Stamens 6: anthers 2-celled, introrse. Orules anatmolous, 1 - 2 in each cell. Styles 3, more or less united below. Fruit mostly capsular, 3-6seeded. Embryo minute, in liard albumen.

\section{DIOSCOREA, Plum. Yau.}

Tube of the perianth 3-wingel. Stamens inserter at the base of the limb. Capsule 6-sected, membranaceous, 3 winged, opening septicidnlly throngh the wings. Sceds flat, broarlly winged. - Leares petioled, mostly cordate and entire. Petioles tumid at the base.

1. D. villosa, I. Stem smooth $\left(10^{\circ}-15^{\circ}\right.$ long $)$; leaves alternate, oppo. site, or whorled, broadly cordate, acuminate, 7 -9-nerved, smooth, or pubescent beneath, mostly longer than the slender petiole; flowers very small, whitish; the sterile ones in seattered clusters on the very slender branches of the axillary panicles, the fertile in a simple spike; stigmas notehed at the apex; capsule oval or obovate, strongly 3 winged, nodiling (D quaternata, Walt.) - Margins of swamps, Florida, and northward. July. 


\section{Oider 149. SMILACEA. (Surtax Famy.)}

Herbs or climbing shrubs, not essentially listinet from the Lity Family, but with ribbed and veiny reticulated leaves, and separate styles or stigmas. - Leaves not sheatling, often bearing tendrils. Fruit baccate.

Suborder I. EUSMILACE. (Smilax Family.) Flowers dinecious, in axillary and mmbel-like clnsters. Anthers 1-celled. Stigmas $1-3$, sessile or nearly so. Ovules $1-2$ in each cell of the ovary, orthotropous, suspended. - Tendril-bearing vines. Flowers small. Leaves alternate.

1. SMILAX. Cells of the orary 1-oruled. Woody rines.

2. CoprosyantiIus. Cells of the ovary 2-ovuled. Climbing herbs.

Suborder II. TrilliderE. (Trimlum Family) Flowers perfect, terminal. Anthers 2-celled. Styles or stigmas 3. Ovules several in each cell of the ovary, anatropous, horizontal. - Erect herbs. Leaves whorled.

3. TRILLIUM. Exterior leaves of the perianth calyx-like, persistent Stem 1-flowered. Leaves 3 in a whorl, terminal.

4. MEDEOLA. Leaves of the perianth alike, deciduous. Stem few flowred. Leaves $3-i$ in a whorl, lateral and terminal.

\section{SMILAX, Tourn. Chisi Brier.}

Flowers dicecious. Perianth bell shaped, 6-leaved, the leaves nearly equal and alike, deciduous. Stamens 6, inserted on the base of the perimth: anthers erect, I-celled. Ovary free from the perianth, 1 -3-celled, with a single orthotropous pendulous ovule in each cell. Stigmas $1-3$ (mostly 3 ), sesile or ncarly so, slender, spreading, or recurved. Berry 1-3-celled, 1-3-secded. Sceds globnlar or angled. Embryo minute, in horny albumen. - Woody and cominonly thorny or prickly vines, climbing by means of a pair of tendrils attached to the petioles. Leaves alternate, ribbed, and reticulate-veined, mosily smooth and shining. Flowers snall, greenish, in stalked axillary clusters.

* Peduncles longer than the petioles or podicels.

+ Peduncles flattened: berry black.

1. S. tamnoides, L. Stem scurfy when young, armed with stout subulate prickles; hranches mostly unarmed, compressed -4-angled ; leaves deltoid-ovate, or hastate-3-lobed, truncate or slightly cordate, rarely acute at the base, $5-7$ ribbed, often discolored; the margius, ribs, and petiole smooth, or fringed with fine prickles ; peduncles about twice as long as the petioles ; stigmas $1-3$, mostly solitary; berry commonly 1 -seeded. (S. Bona-Nox, hastata, hederæfolia, \&e. of authors.) - Swamps and thickets, Florida, and northward. May.

2. S. Pseudo-China, I. Lower part of the stem beset with numerous black needle-shaped prickles; branches unarmed, slightly angled; leares ovate or round-ovate, often contracted in the middle, rounded or cordate at the base, 
abmotly printed, more or less hristy-riliate om the mar,ina, 5-nerved, peduneles

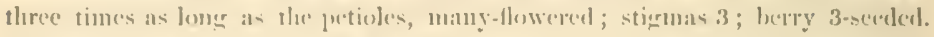
(S. panduratus, J'ursh.) - Woods and thickets, Florida, and northwarl. April atul Mny.

3. S. glauca, Walt. Stem armed with few and scattered prickles, very slender; hranches terete, marmed; leares orate or wall, entire, olitusc, mucronate, ronnded or slightly corlitte at the basc, white bencath, 3-5-ribised, the margins cutire; pedmeles very slender, $2-3$ times as long as the petiole, few-

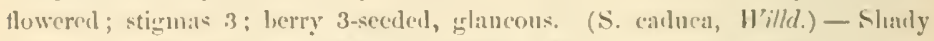
margins of swamp; Florida, and northward. May. - ldaves $2^{\prime}-4^{\prime}$ long.

\section{+ + Peduncles terete: berry whitish.}

4. S. pumila, Walt. Sofily pubescent; stem low $\left(1^{\circ}-3^{\circ}\right.$ high $)$, terete, $u n-$ armed; liaves urate or oblong, cordate, mueronate, persistent, mostly discolored and at length smooth ahove, pale beneath, 5-ribbed; pedinneles about twice as long as the petioles, rigrid, dense-flowered; stigma sinerle; bery ovoid, whitish, 1-secded. (S. pubera, Miche ) - Mry sandy soil, Florila to Sintl Carolina, in the lower districts. October, - Routstock creeping. I.caves $2^{\prime}-4^{\prime}$ long.

* Peduncles not longer than the ptioles.

- Berries red.

5. S. Walteri, Pursh. Stem low, arncel with a few scattered prickles near the base, otherwise unarmed; branches obseurely 4-angled; leaves deciduous, membranaccous, varying fiom oblong-lanceolate to oval, mueronate, at'ute, roundcl or rarely slightly cordate at the base, 5-ribled ; peduncles flattened, as long as the petiules and pedicels; perianth rather large ( 3 "long), brownish; stigmas 3 ; herry (acuminate, Wult.) glohular, 3-secded. (S. caduca, Ell.) - Pine-harren ponds and swamps, Florida to North Carolina. March and April. - Rhizona crecping. Stem seldom more than $6^{\circ}$ long. Leaves $2^{\prime}-4^{\prime}$ long.

6 S. lanceolata, I. Stem tall, mostly unarmed; branches terete; leaves evergreen, rather thin, varying from lanecol:tte to ollong-ovate, acute at each cnd, 5-ribbed, paler beneath; peduncle terete, as long as the petiole, many-flowered; stigmas 3 ; berry globular, 3-secled. - Rich woods and margins of swamps, Florida to Nortl 1 Carolina. August. - Stem sometimes $20^{\circ}-30^{\circ}$ long. Rootstock tuberous. Leares $3^{\prime}-4^{\prime}$ long.

\section{++ Berries liack.}

7. S. laurifolia, I. Stem stout, armerl with strong prickles; branchlets 1-angled, unarmed; leaves evergreen, coriaccous, varying from ovate to lanceolate, obtuie, mucronate, 3.nerred; peduncles shorter th:un the pedicels; stigma solitary ; berry globular, 1-sceled. (S. alha, Ph.?) - Swamps and margins of ponds, Florida to Jorth Carolina. July and Ang. - Stenı climbing high. Leaves $3^{\prime}-5^{\prime}$ long. Berries maturing in the fall of the succeding year, very abundant.

8. S. auriculata, Wait Stem commonly low and straggling, slender, armed with short prickles; lranches flexuous, 4 -angled; leaves evergreen, rigid, small, strongly 3-ribbed, varring from lanceolate to orate, entire or hastate-3-lohed. acute at each end; peduncles shorter than the pedicels, many-flowered; stigmas 
2-3; berry small, globular 2-3-seeded. (S. ovata, Pursh? Ell.) - Dry sandridges along the coast, Florida to North Carolina. Mity and June. - Stem trailing, or covering small bushes. Leaves $I^{\prime}-2^{\prime}$ long, strongly reticulated. Flowers small, very fragrant.

9. S. rotundifolia, L. Stem climbing high, armed with scattered prickles; branehlets 4-angled; leaves thin, ovate or round-ovate, entire, abruptly pointed, mostly rounded or slightly cordate at the base; peduncles few-flowered, rather longer than the pedicels, flattened; berry globular, 3-seeded, blue-black. (S. caduca, L. S. quadrangularis, Mfuhl.) - Swamps in the middle and upper districts, and northward. June. - Plant yellowish green. Leaves $2^{\prime}-4^{\prime}$ long.

\section{COPROSMANTHUS, Torr.}

Cells of the ovary 2-ovuled. - Stems herbaccous, unarmed. Peduneles and petioles elongated. Berry blue-black. Otherwise like Smilax.

1. C. herbaceus, Irunth. Stem erect $\left(1^{\circ}-3^{\circ}\right.$ high $)$, mostly simple, leafy above; leaves few, oblong or oval, mucronate, pubescent, 5-nerved, the upper ones whorled, the lower bract-like; peduncles few $\left(3^{\prime}-4^{\prime}\right.$ longr $)$, below the leares; berry 2-3-seeded. (Smilax herbacea, L.) - Dry furtile soil, Florida to North Carolina. June. - Flowers fetid.

2. C. peduncularis, Kunth. Stems curving or climbing $\left(3^{\circ}-5^{\circ}\right.$ long $)$, branched, leafy ; leaves alternate, round-cordate, acuminate, smooth ; peduncles numerous, axillary ( $t^{\prime}-6^{\prime}$ long) ; berry 6 -seeded. (Smilax peduncularis, Muhl.) - Rich soil in the upper districts, and northward. June. - Flowers fetid.

3. C. tamnifolius, Kunth. Stems erect or climbing; leaves hastate, cordate, obtuse, mueronate, 5-nerved, smooth, the upper ones narrower; peduncles longer than the petioles; berry 2-3-seeded. (Smilax tamnifolia, Michx.) - Pine barrens, South Carolina, and northward. July.

\section{TRILLIUM, I.}

Flowers perfect. Perianth 6-leaved, the three exterior leaves calyx-like, persistent, the interior withering. Stamens 6 , inserted at the base of the perianth. Filaments short: anthers adnate, linear, 2-celled. Ovary 6-ribbed, 3-celled, with numerous anatropous horizontal ovules in each eell. Styles or stigmas 3, slender, stigmatic within, jecurved, persistent. Fruit a roundish 6-sided manyseeded purple berry. - Low perennial herbs, with tuberous rootstocks, and simple stems, which are sheathed at the base, and terminated with a whorl of three broad leaves and a single sessile or peduncled showy flower.

\section{* Flower sessile, erect.}

1. T. sessile, L. Rootstock horizontil; stems slender, commonly two or more in a cluster; leaves sessile, broadly oval, widest in the niddle, abruptly short-pointed, narrowed at the base, $3 \cdots 5$-nerved, variegated above with paler and deeper green; petals dark purple, lanceolate, ereet, mueh longer thin the lanceolate spreading sepals - Rich shady woods, in the upper districts, and 
northwarl. March and $A$ pril. - Stems $C^{\prime}-12^{\prime}$ high. Iowaves $b^{\prime}-3^{\prime}$ long. Petnls $1 u^{\prime \prime}-15$ "long.

2. T. discolor, Wray? Roststock tuberous, vertical ; stem stout, solitary; leaves sessile, varying from crate-lanceolate to broatly watte, tapering from near the base to the apex, 3-7-nerved, sariegnted above with green and lowow or thark purple; petals erect, obloug, obuse, narrowed below, dark purple varying into green, rather lunger than the lanceolate, spreading sepals; filaments very short, purple. - Kich woods, in the mirlde and lower districts, Florida to Sonth Carolina. F(d). and March. - Sitem 6 $6^{\prime}-12$ high. Leaves $3^{\prime}-5^{\prime}$ long. 1'ctals $1 \frac{1}{2}-2$ ' long.

\section{* * Fouer on an erect or declining pedunde.}

3. T. pusillum, Michx. Stem slender; leaves sessile, lanecolate or ohlong, obtuse, 3-nerved; peduncle ereet, shorter than the spreading flower; petals lanceolate, pale flesh-color, acntish, one third longer than the lanceolate obtuse sepals; filaments slender, as long as the anthers; stigmas united below into a slender style, longer than the filaments. - I'ine harrens in the low country of Carolina, Michanx. North Carolina, Cutis. - Stem $6^{\prime}-8^{\prime}$ high . Leaves $1 \frac{1}{2}^{\prime}-$ 2' long. Flower $8^{\prime \prime}-10^{\prime \prime}$ long.

4. T. erectum, L. Stem solitary; leares sessile, hroadly rhomboidal, abruptly armininate, acnte at the lase; peduncles longer than the spreading flowers $\left(1 \frac{1^{\prime}}{2}-3^{\prime}\right.$ long), at lengtl declined ; petals oval or oblong, obtuse or acutish, dark-purple, rather longer than the lanceolate-ovate acute sepals; filaments shorter than the authers, or the slort and distinet stignas. ('T. rhomboidemm, Mich.r.) - Varies with smaller white or yellowish flowers. - Shaty woorls, on the mountains of North Carolina, and northward. May. - Stem 10 high. Leaves $3^{\prime}-5^{\prime}$ long, and of the same width. Flowers $1^{\prime}-1 \frac{1^{\prime}}{2}$ long, fetid.

5. T. grandiflorum, Salisb. Stem solitary; leaves rhombic-orate, abruptly acuminate, nearly sessile; peduscle louger than the erect-spreading flower, erect or slightly declined; petals ohovate, white, much longer and broader than the lanceolate acutish sepals; filaments slemler, shorter than the unthers, nearly equalling the short recurved stigmas - Shady wooks on the momtains of Carolina, Elliott, and northward. May - Stcm $1^{\circ}-1 \frac{1}{2}{ }^{\circ}$ ligh. Leaves $3^{\prime}-5^{\prime}$ long Petals $2^{\prime}$ long, changing to rose-('olor.

6. T. erythrocarpum, Michx. Sten solitary; leaves orate, longacuminate, rounded at the base, short-petioled; jeduncle $\left(1^{\prime}-2^{\prime}\right.$ long) erect, longer than the widely-spreading flower; petals ohlong, acutish, way, mueh longer than the lanceolate sepals, white, striped with purple at the base; stigmas slender, longer than the anthers; berry red. - Rich shady woods in the upper districts, Georgia, and northward. $\Lambda$ pril and May. - Stem $1^{\circ}$ high. Leares $3^{\prime}-5^{\prime}$ long. Flowers $9^{\prime \prime}-12^{\prime \prime}$ long.

\section{* * * Flocer on a recurerd peduncle.}

7. T. cernuum, L. Stems $2-3$ together; leares broadly rhomboidal, abruptly aruminate, short-petioled; peduncle mostly shorter than the small flower; petals white, oblong-ovate, acute, wavy, recurved, rather longer than 
the lanceolate sepals; stigmas short, distinet, exceeding the short erect anthers. - Slady woods in the upper districts, Georgia, and northward. April and May. - Stem $1^{\circ}-12^{\circ}$ high. Leaves $2^{\prime}-6^{\prime}$ long, and nearly as broal. Petals $8^{\prime \prime}-12^{\prime \prime}$ long.

8. T. stylosum, Nutt. Stem solitary, slender; leaves oval or oblong, acute, short-petioled; peduncle shorter than the large flower; petals rose-color, oblong, obtuse or abruptly pointed, wary, spreading, much longer and broader than the laneeolate sepals; stigmas slender, united below the middle, much shorter than the long recurved antliers. (T. nervosum, and T. Catesbæi, Ell.) - Low shady woods in the upper districts, Georgia to North Carolina. April and May. - Stem $1^{\circ}-1 \frac{1}{2}^{\circ}$ high. Leaves $4^{\prime}$ long. Petals $1 \frac{1}{2}^{\prime}-2^{\prime}$ long.

\section{MEDEOLA, Gronov.}

Flowers perfeet. Leaves of the perianth 6 , similar, deciduous. Stamens 6 , erect, hypogynous: anthers linear-oblong, fixed near the base, introrse. Ovary globose, 3-celled, with six anatropons ovules in eneh cell. Styles 3, slender, recurved, stigmatic within. Berry globose.

1 M. Virginica, L. Rhizoma horizontal, tuberons ; stem simple, slender, clothed with loose deciduous wool, bracted below, bearing above the middle a whorl of $6-8$ oblong-lanceolate acute leaves, and at the summit a smaller whorl of $3-4$ ovate leaves, whieh surround the $2-8$ small greenish nodling flowers; styles red. - Shady banks, Middle Florida, and northward. June. Stem $2^{\circ}$ high.

\section{Order 150. ROXBURGHIAEA. (loxburghit FAMILY.)}

Herbs or twining shrubs, with petioled parallel-nerved reticulated leaves, and perfect axillary racemose flowers. - Perianth 4-leaved or 4-parted. Stamens 4, hypogynous: anthers 2-celled, introrse. Ovary free, or united with the base of the perianth, 1-celled. Stigma sessile. Orules few or numerous, anatropous. Placenta parietal. Capsule 2-valved. Seerls fixed to hairy or fibrillous corls, erect or pendulous. Embryo minute or slender, in fleshy albumen.

\section{CROOMIA, Torr.}

Perianth deeply 4-parted, persistent, the spreading nerveless oval divisions imbricated in the bud. Filaments separate, thick, ereet, inserted on the base of the perianth opposite its lobes: anthers short, oblique, with the connective minute or wanting. Ovary glohose-ovate, sessile. Stigma 2-lobed. Ovules 4-6. Fruit follicular, beak-pointed, at length 2-valved. Seeds 1-4, obovate, suspended from the apex of the nerve like, at length free placenta, nearly eovered by the fibres of the cord. Embryo minute, olovate. $-\boldsymbol{A}$ Icw perennial herb, 


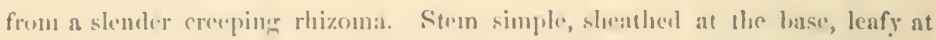

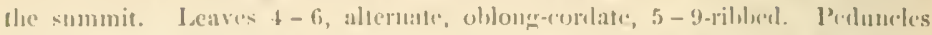
few-llowered. Flowers small, greenish, on jointed nodling pedieck, which aro thickened upward.

1. C. pauciflora, Torr. - Sharly woods, Florida, Groroia, and Alabama. April. - Stem 6 $6^{\prime}-12^{\prime}$ high. Leaven $2^{\prime}-4^{\prime}$ longr, thin, spreading.

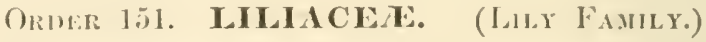

('biefly herbs, with sexile or sheathing parallel-nervel leaves, and perfert fluwers. - l'ejianth corolla-like, 6- (rarely 4-) leaved or Iobed, fiee

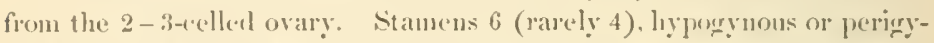
nous: anthers introrse (exeept in No. 9). Styles miterl. Sigmas 3, distinct or united. Finit a eapinle or berry, few - many-seeded. Feneds anatrojous on amplitropous. Embryo small, in fleshy or liard albumen.

\section{Syuopsis.}

TRIBE T. ASP IR A GEA. Fruit a berry. Divisions of $t^{\prime}$ e perianth more or less united (except No. 4). - Leaves brond.

1 posfgonatia Flowers axillary. Perianth tubular. Stems leafy.

2. SMLLACINA. Flowers in a terminal mome. Perianth spreadiug. Stems leafy.

3 (1) NYALJALIA. Flowers racemed. Perianth 6-lobed. Seape naked.

4. Chistosid. Flowers umbelled. Periauth 6-leaved. Scape naked.

TRIBE II. ASPHODELEA. Fruit a capsule. Divisions of the perianth united at the base. - Stems scape-like. Leaves linear, rarely linceolate.

* Root a coated bulb.

5 AILICM. Flowers umbelled, from a scarious spathe. Seeds smooth and black.

6. SOLJNA. Flowers racemed, white. Stigmas 3 . Sech roughened, brown.

* Root a tuberous rhizoma.

7. ScImitolimox. Flowers ricemed, white. Seeds smooth and blaek. Leares equitant.

Trub III. TEIAPACEA. Fruit a capsule. Divisions of the perianth distinct, decidnous. - Stems leafy.

* Bulbous-rooted herbs. Seeds pale.

8. ERITIRoNity. Seeds ovoid, with a membranaecous appendage at the apex. Stem 2 - Insed.

9. LIJlty. Seed flat, winged, not appendaged. Sten many-leared.

* l'alm-like arlorescent plant. Seeds black.

10. ICCCA Stigmas 3, pearly sessile. Capsule dry or pulpy. Leares spiny-pointed.

\section{POLYGONATUM, Desf.}

Perianth tubular, 6-eleft. Stamens 6, inserted on the middle of the tube, inclucled: anthers sagittate, fixed at the base. Ovary 3-celled, with $3-6$ ovules in each cell. Style slender: stionma obuse. Berry few-seeded. - Rhizoma ereeping. Stem simple, leafy. I,eaves oral or oblong. Peduncles axillary, 1 - few-flowered. Flowers drooping, on bractless pedicels. 
1. P. biflorum, Ell. Stem terete or furrowed, smooth, curving above; leaves 2-ranked, sessile or slightly clasping, oblong, 3-7-nerved, smooth, or pubescent beneath; peduncles much shorter than the leaves, 1-4-flowered; flowers greenish; filaments granular-ronghened; berry dark-blue. (P. pubescens, and P. multiflormm, Pursh.) - Shady banks, Florida, and northward. May. - Stem $1^{\circ}-2^{\circ}$ high, naked below. Leaves $3^{\prime}-4^{\prime}$ long, acute or obtuse. Flowers $4^{\prime \prime}-5^{\prime \prime}$ long.

\section{SMILACINA, Desf. Solomon's Seal.}

Purianth 4- or 6-parted, spreading, deciduous. Stamens 4 or 6 , inserted on the base of the perianth anthers ovate. Ovary 2-3-celled, with two ovules in each cell. Style short and thick: stigma obsenrely 3-lobel. Berry globular. l-2-seeded. - Stems simple, ereet, leafy. Flowers small, white, in a terminal raceme or panicle.

\$1. Sunteina. Dieisions of the perionth and stamens 6. Ovary 3-celled.

1. S. racemosa, Desf. Pulbeseent; rhizoma thick; stem flexuous, eurving and leafy above, leaves numerous, 2-ranked, oblong, acuminate, nearly sessile, strongly ribbed ; flowers numerons, in a close raceme or paniele; berry red, spotted. - Rich soil in the upper distriets, and northward. June and July. - Stem $1^{\circ}-2^{\circ}$ high. Leaves $3^{\prime}-5^{\prime}$ long.

\$2. Manaxtmenum. Divisions of the periunth and stamens 4. Orary 2-celled.

2. S. bifolia, Ker. Smooth; rhizoma slender; stem low, erect, 2-leaved above; leaves ovate, cordate, sessile or elasping, finely nerved; raceme simple, few-flowered; herry red, spotted - High mountains of North Carolina, and northward. June. - Stem $3^{\prime}-6^{\prime}$ high. Leaves $1^{\prime}-2^{\prime}$ long.

\section{CONVALLARIA, L. Lily OF tile VAtLey.}

Perianth bell-shaped, 6-eleft, deciduous. Stamens 6, inserted on the base of the periantl, included : anthers fixed at the base. Ovary 3-eelled, tapering into the thick style. Ovules 4-6 in each eell. Stigma truneate. Berry globose, few-seeled. - A perennial stemless herb, with a creeping rhizoma, and white racemose flowers.

1 C. majalis, L. - High mountains of North Carolina. May. - Smooth. Rhizoma slender Leaves two, oblong, their long petioles convolute, one within the other. Scape semi-terete, bearing a l-sided raceme of fragrant nodding tiowers. Berry red.

\section{CLINTONIA, Raf.}

Perianth hell-shaped, 6-leaved, decidnons. Stamens 6, inserted on the base of the periantl. Filaments filiform; anthers linear-oblong. Ovary 2-3-celled, with two or more orules in each cell. Style elongated: stigma obtuse. Berry 2 - many-seeded - Stemless herbs, with creeping rootstocks, large radical sheath- 
ing leares, and an umbel of white or greenish flowers terminating the maked seaple. Berrices lilue.

I C. umbellata, Torr. Leaves $2-4$, ohlong, riliate on the kecl and

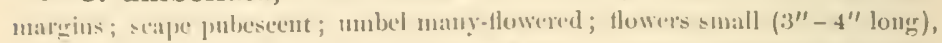
white spotted witl green or purple; ovnles 2 in each well. (Sinilacimn unbellatu. lest.) - Shady woods on the monntains, Georgia, and northward. June. - Sicape $s^{\prime}-12^{\prime}$ high, rather longer than the leaves.

2 C. borealis, liaf. Ieaves obovate-obloner, ciliate on the margins, acnte; senpe and $2-i$-lluwered umbel pulescent; fowers $\left(6^{\prime \prime}-9\right.$ "long) greenish yellow; orules mmerous. - Cold swanps on the high momitains of North Carolina, and northward. June. - S(al)e and leaves $8^{\prime}-10^{\prime}$ ligh.

\section{ALLIUM, L. Oxiox.}

Perianth 6-jarted, spreading, persistent. Stamens 6, inserted on the base of the perianth, Filaments subulate, the interior ones more or less dilated at the basc. Uvary 3-rellerl. Sityle filiform: stigma entire. Capsule loculicidally 3-valved. Ścels antropous or campylotropous, single or few in cacls ccll, angled, l,ack. - Strong-secnted stemless herbs, with lublbons roots, and a nakerl scape, ending in an muled of small flowers, from a $2-3$-leaved spathe. - Flowcrs sonetimes elianged into bulblets.

\section{* Orules solitury in the cells.}

1. A. tricoccum, Ait. Leaves lanceolate-oblong, acute, flat, long-tapering toward the lase, early withering ; mubel small, dense, many-floweret, ereet; leaves of the periantls oblong, olituse, longer than the stanens. - Monntains of Nortls Carolinit, and northward. July. - Bull,s chustered. Scape $1^{\circ}$ high. Flowers white.

* Oivles 2 in cach coll.

2. A. cernuum, Roth. Leares linear, eliannelled; seape angled; umbel many-flowerel, nodding ; leaves of the perianth acute; stamens exserted ; ovary 6-toothed - Mountains of South Carolina, and northward. July. - Scape $10-12^{10}$ hight. Fluwer's rose-color, on slender pediecls.

3. A. Canadense, Kalm. Lenves narrowly linear, concave; scape terete. umbel erect, bearing a cluster of bulbets, intermingled with a fuw stalkel rosecolorel flowers; spathe 1-2-leaved; leaves of the perianth obtuse, as long as the stanens; ovary 6-toothed. - Banks of rivers, Florida, and northward June. - Se:ipe 10 highr. Outer coats of the bulb white and scarious.

4. A. mutabile, Miehx. Icaves very narrow, roneave; seape terete, umbel ereet, many-flowered; spathe 3-leaved; leaves of the perianth acute, as loner as the stamens, white clanging to rose-color - Dry sandy soil, Florida to North Carolina Mity and June, - Scape $1^{\circ}$ high. Outer coats of the bulb composed of a network of fine fibres.

\section{* * Oeviles sereral in cach cell.}

5. A. striatum, Jacq. Leaves linear, concave; umbel erect, 3-10-flowered; spathe 2-leaved; perianth longer than the stamens, white, the exterior 
leaves green on the keel. - Low pine barrens, Florida to North Carolina. March and A pril. - Scape 6 $6^{\prime}-12^{\prime}$ high. Pulicels $1^{\prime}-2^{\prime}$ long. Flowers $5^{\prime \prime}$ long. Leaves streaked on the back.

6. A. Carolinianum, Red. Scape naked; leaves linear, even beneath; spathe 2-leaved; umhel fastigiate; leaves of the perianth oblong, obtuse; stamens subulate, twice as long as the perianth; capsule many-seeded. - In Carolina. - Bullus clusterel. Flowers white, rose-color without. $(*)$

\section{NOLINA, Michx.}

Perianth 6-parted, spreading, withering-persistent; the dirisions similar, oblonglanceolate, 1-nerved. Stanens 6 , inserted on the base of the perianth ; filanents subulate: anthers cordate. Style very short, persistent: stigmas 3, recurved. Ovary 3-angled, 3-celled, with two anatropous collateral ascending ovules in each cell. Cajsule membranaceous, obovate, wing-angled, 3-valved, mostly l-seeded. Seed oblong-obovate, dull brown and ronghish, slightly incurved; longitudinally grooved on the inner face. Embryo slender, straight, shorter than the fleshy albunen. - Root large, bulbous. Leaves numerous, all radical, very long and narrow, recurved, keeled, rough on the margins. Scape branching above. Flowers small, white, crowded in long bracted racemes. P'edicels jointed, reflexel in fruit.

1. N. Georgiana, Michx. - Dry sand-hills in the middle districts of Georgia and South Carolina. April and May. - Bulb very large. tunicated. Scare $2^{\circ}-3^{\circ}$ high, with a fiw seales near the base. Leave's $1^{\circ}-2^{\circ}$ long, dry and harsh.

\section{SCHCENOLIRION, Torr.}

Perianth 6-parted, spreading, withering-persistent; the divisions 3-5-nerved. Stamens 6, inserted on the base of the perianth: filaments subulate: anthers cordate-sagittate, introrse. Style subulate, persistent: stirma njinutely 3-lobed. Ovary globose, 3-celled, with two anatropous ascending ovnles in each cell. Capsule coriaccous, broadly obovate, obtusely 3-lobed, loculicidally 3-valverl, 1-6-seeded. Seeds globose or angular, smooth, black, and shining. Embryo straight, as long as the fleshy albumen. - Peremial herbs. Root a tuberous rlizoma. Scape branching alove. Radical leaves smooth, equitant, sheathing, linear, coneave, rounded on the back, the others small and bract-like. Flowers small, white, in loose bracted racemes. Pedieels spreading, jointed.

1. S. Michauxii, Torr. Pedicels 2-4 times the Iength of the bracts; divisious of the perianth oblong, the nerves somewhat distant. (Phalangiun croceum, Michx. Ornithogalum crocemn, Ell.) - Swamps, cliefty in the pine harrens, Georgia, Florida, and westward. May and June. - Ihizoma cylindrical. Scape $2{ }^{\circ}$ high, slender. Leaves $1^{\circ}$ long.

\section{ERYTHRONIUM, I. DOG'S-TOOTI VIOLET.}

Perianth eorolla-like, with six sprealing or recurved decidnons separate leaves; the three inner ones grooved and 2-toothed at the base. Stamens 6 , 


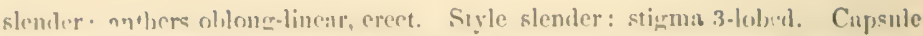

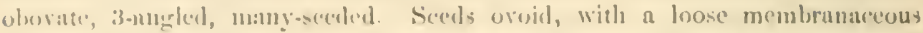
npurendage at the apex - Low herhs from a scaly bulb. Strme low, scape-like, learing mar the mifille a pair of oblong spotted sheuthing leaves, and at the mpex as singre nodling flower.

1. E. Americanum, Sinith. liullis deep, the younger ones bearing only at single leaf; leaves lanecolate or oblong, tapering ints the shoathing base, vatributed with pale and deep green; flowers (1' long) yollow, sponted near the

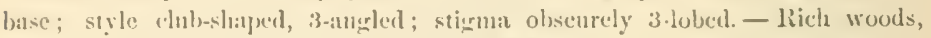
Middle Florida, and northward. Feb. and Mareh.

\section{LILIUM, J. IILY.}

Perianth corolla-like, 6-Je:1ved, decidnous, the leaves spreading or recurved abore, sessile or chwed, with a nectariferons groove near the biase. Stamens 6 , elongated; anthers lincar, extrorse in the bud, sersatile. Style tiliform, elongated; stigna 3-lobed. Capjsule oblong, many-seceled. Seeds flat, membranam ceous, horizontal, erowded in the cells. - Leafy herbs, from scaly bullus. Leaves scattered or whorled, sessile. Flower's larre, erert, or nordding.

* Flowers crect: leacrs of the perianth sprating, clawed.

1. L. Philadelphicum, I. Leaves lanecolate, the upper ones whorled; flowers $1-3$, reldish-orange spotted with pupple; leaves of the perianth lancelate, abruptly pointed. - Mountains of Nortlı Carolina, and northward. July. - Stem $1^{\circ}-2^{\circ}$ ligh. Flowers $2^{\prime}$ long.

2. L. Catesbri, Wralt. Leares linear-lanceolate, all scattered and erect; flower solitary, terminal, scarlet, variegated with rellow and purple; leares of the perianth lanecolate, acuminate, with the margins of the elaws involute; the three inner ones broader and ribbed on the back: capsule oblong, nearly terete. - Low pine barrens, Florida to North Carolina. Aug. and Sept. - Stem $1^{\circ}-2^{\circ}$ high. Leaves $l^{\prime}-2^{\prime}$ long, obscurely nerved. Flowers $3^{\prime}-4^{\prime}$ long.

* *lowers nordding; leaves of the perianth recuved, sessile.

3 L. Canadense, I. Stem commonly few flowered; leaves in remote whorls, lanceol:ate, 3-nerved, hairy on the nerves leneath; flowers long-peduncled; leaves of the perianth reeurved, rellow spotted with purple. - Mountain-meadows, Georgia, and northward. June and July. - Stem $2^{\circ}-3^{\circ}$ ligh. Leares and flowers $2^{\prime}-3^{\prime}$ loug.

4. L. superbum, I. Stem commonly many-flowered; leaves smooth, lanceolate, 3 nervel, the lower ones whorled, the npper seattered; leaves of the perianth revolute, rather obtuse, oranere spotted with purple. - Ricli soil in the mildle and upper districts, Gorgia, and northward. June and July. - Stem $3^{\circ}-6^{\circ}$ high. Flowers, when numerons, disposed in a pranilal raceme.

Var. Carolinianum. (I. Carolinianmm, Michx.) Leares often all seattered, broaler, more tapering at the base, faintly nerved; flowers $1-3$; leares of the perianth acute. - Swamps in the lower districts. July. - Stem $2^{\circ}-3^{\circ}$ high. 


\section{YUCCA, L. Spanisil BaYonet.}

Perianth cup-shaped, corolla-like, 6-leaved. Sepals and petals nearly alike, late-deciduons. Stamens 6, with rhick granular club-shaped filanents: anthers small, oval Ovary 3-celled, 3-sided, grooved at the angles. Stigmas 3, nearly sessile, oblong, concave, 2 -cleft. Ovules numerous, in two rows, the rows separated by a false partition. Capsule oblong, 6-celled, pulpy and indehiscent, or dry and loculieidally 3-valved at the apex. Seeds numerous, flat, horizontal, smooth and black - Plants with thick palm-like leafy stems (candex), numerous rigid and spine-pointed leaves, and white showy panieled flowers.

\section{* Stem short: capsule diy, 3-zalved.}

J. Y. filamentosa, L (Besr-Grass) Stem short and leafy; leaves rather rigid, spreading or recurved, varying from linear to broad-lanceolate, green or glaucons, with thread-like filaments on the margins; scape elongated, branching and pubescent above; lewes of the perianth ovate-lanceolate, white tinged with yellow or purple; capsule whth 3 rounded angles, loculicidal ab the apex, and at length separating at the inflexed sntures into three 2-celled carpels. (Y. puberula and Y. glancescens, Haw.) - Light or sandy soil, Florida to North Carohna, and westwarl. June. - Stem rarely more than a foot above the ground. Leaves $1^{\circ}-2^{\circ}$ long Scape $4^{\circ}-6^{\circ}$ high.

\section{* Stem tall: capsule pulpy, 6-angled, indehiscent.}

2. Y. gloriosa, L. Stem mostly simple, leafy at the summit; leaves linear-lanceolate, rigid, smooth on the margins; panicle large, smooth, pyramidal, short-peduncled; flowers white, single or clusterel ; leaves of the perianth lanccolate, acute. - Drifting sands along the coast, Florida to North Carolina, and westward. May and June. - Stem $2^{\circ}-4^{\circ}$ high. Leaves $1^{\circ}-1 \frac{1}{2}$ long. Panicle $2^{\circ}-3^{\circ}$ long

3 Y. aloifolia, L. Stem mostly branching, leafy ahove; leaves linearlanecolate, very rigid, strongly spine-pointed, very rongh on the margins, the lower ones reflexed ; paniele short, smooth, densely flowered, nearly sessile; divisions of the perianth ovate-lanceolate, white tinged with purple. (Y. Draconis, L. Y. serrulata, IIaw.) - Sands along the coast, Florila to North Carolina. May and June. - Stem $4^{\circ}-8^{\circ}$ high. Leaves and panicle $1^{\circ}-11_{2}^{\circ}$ long.

4 Y. recurvifolia, Salisb. Leaves linear-lanceolate, recurved, with the margins sometimes filamentose; interior leaves of the perianth wider than the exterior - On the sea-coast of Georgia, Elliott. July and Aug. - Stem about $3^{\circ}$ high. Flowers white, tinged occasionally with green and purple (*)

\section{Order 152. MELANTIIACEA. (Colchicum Famir.)}

Perennial herbs, with parallel-nerved leaves, and reçular flowers. Periantl of 6 nearly equal divisions, free from or eoherent with the base of the 3-celled ovary. Stamens 6 (in Pleea 9-12), inserted on the base of the perianth: anthers extrorse (except in Tofiellia and Pleea). Styles 
3, dislinet or more ar less milerl. Fruit a eiplesule or berry. Seceds

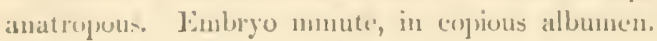

\section{synopsis.}

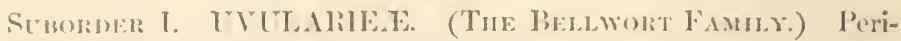

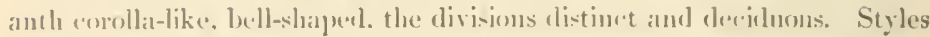
party or wholly united. Fruit a few-sereded rapsule or berry. - Stems forking and leafy alove, shenthed bedow. Leares orate or lanceolate, sescile or clisplung. Flower's perferet, solitary, nodeling.

1. ViLL.LlLA Fruit a 3-lobed Ineulicidal capsule. Flowers on short lateral hranches.

2 pliosalíts. Fruit a 3-6-seeded lerry. Flowers terminal, on straight perluneles.

3. STREPTOPUS. Fruit a many-seeded berry. Flowers nxillary, on bent peduncles.

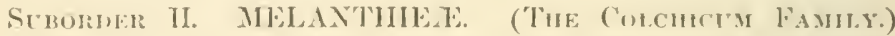
Perintle spreading; the divisions mostly distinct, often rlawerl, witheringpersistent. Styles separate. liruit a 3-rellerl capsule. - Stems leafy at the lase, simplo or lranched. Flowers in racemes or panicles, sometimes polygamous or diaciuns.

* Anther-celts confluent.

- Leares of the periantl biglandular near the base.

4. MELAXTIIU, Flowers polygamous. Filaments parily adhering to the elaws of the perianth.

5. ZIGADlivis. Flowers jerfect. Filaments free from the perianth.

+ + Leaves of the perianth glandless.

6. STEXINTIIIM. Leares of the perianth lanceolate, acute, colnerent with the base of the ovity, longer than the stamens

7. VExATIIy. Leaves of the periunth oblong or obovate, free from the ovary, longer than the stamens and short styles. Flowers polygamons.

8. AMIANTIIIUIL. Leaves of the frerianth obovate, free, sliorter thin the stamens and slemeler styles. Flowers perfeet, racemed.

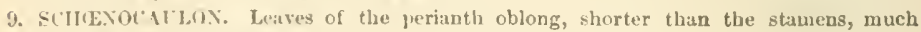
louger than the very short styles. Flowers perfert, spiked.

$$
\begin{gathered}
\text { * Anther-cells distinct. } \\
\text { - Capsule loculicidal. }
\end{gathered}
$$

10. Xikopiyluty. Flowers perfect. Tapsule 6-seeded. liadical leares grass-like.

11. CIAMIfIJRIU.I. Flowers diocions. Capsule inany-seeded. liadieal heaves oborate.

- + Capsule septicidal. Leaves equitant. Anthers introrse.

12. PLFE.L. Stumens 9-12. Anthers rersatile. Bracts spathe-like.

13. TOFIELDLA. Stamens 6 . Anthers ereet. Bracts short.

\section{UVULARIA, L. Bellwort,}

Perianth l,cll-shaped, corolla-like, the divisions distinet, grooved at the base within, deciduous. Filaments short: anthers linear, adnate. Style deeply 3 . cleft: stigmas sprearling. Capsule 3-lobed or 3-angled, loculiedially 3-valved at the apex. Seeds few, ohovoid, half encireled by the tumid raphe. - Low herbs, 
from a slender, creeping rhizoma. Leaves sessile or perfoliate. Flowers nodding, solitary, lateral ur at the apex of a 1-leaved branch, yellow.

* Leaves rounded at the base, perfoliate.

1. U. perfoliata, L. Leares ovate or oblong, glaucous beneath, the sides revolute when young; leaves of the perianth lanceolate, acute, granular-roughencd within, pale yellow; capsule obovate, truncate. (U. flava, Smith.) Woods and thickets, Florida, and northwart. April. - Stem 8'-12' high. Leaves $1 \frac{1}{2}{ }^{\prime}-2 \frac{1}{2}$ long. Flowers $1^{\prime}$ long.

2. U. grandiflora, Smith. Leares oblong, pale or closcly pubescent beneatl, the young ones revolute on the margins; leaves of the perianth linearlanceolate, acute, smooth within, greenish yellow; anthers obtuse; capsule oborate. - Woods and thickets, in the upper distriets of Georgia, and northward. April - Larger than the preceding. Leaves $2^{\prime}-5^{\prime}$ long. Flowers $1 \frac{1}{2}{ }^{\prime}$ long.

$$
\text { * * Laves narrowed at the base, sessile. }
$$

3. U. sessilifolia, L Smooth, leaves lanceolate-oblong, glancous beneath; flowers on short naked perluncle-like branches, opposite the leares; leares of the perianth lanceolate, obtuse, barely longer than the 3-eleft style; anthers obtuse; capsule ohovate, stalked. - Rich soil in the middle and upper distriets, and northward. April. - Stem $6^{\prime}-12^{\prime}$ high. Leaves $1^{\prime}-1 \frac{1}{2}^{\prime}$ long. Flowers 8 "l long.

4. U. Floridana, n. sp. Smooth; leaves oblong, slightly clasping, glaucous beneatlı; flowers on a slender l-leaved branch; leaves of the perianth linear-lanceolate, acuminate, twice as long as the 3-cleft style; antliers pointed. - Low sharly woods, Middle Florida, March. - Stem $4^{\prime}-6^{\prime}$ high. Leaves thin, $\mathbf{l}^{\prime}$ long. Flowers $8^{\prime \prime}$ long, pale yellow.

5. U. puberula, Michx. Slightly pubescent ; leaves green on both sides, oval, rounded at the base and somewhat clasping, rough on the margins; style 3-parted nearly to the base, as long as the short-pointed anthers; capsule ovate, sessile. - Mountaius of North Carolina. - Flowers yellowish-white.

\section{PROSARTES, Don.}

Perianth bell-shaped, corolla-like, the divisions distinct, decidnous. Filaments filiform, much longer than the linear-oblong obtuse anthers. Styles united: stigmas spreadning. Berry oroid, acute, 3-6-seeded. - A low forking herb. Peduncles termınal, not bent nor twisted.

1. P. lanuginosa, Don. (Streptopus lanuginosus, Mich x.) - High mountains of North Carolina. June. - Leaves $2^{\prime}-3^{\prime}$ long, sessile, ovate-oblong, acnminate, oblique or slightly cordate at the base, 5-nerved, pubescent. Peduncles $1-2$, terminal, slender, pubescent. Leaves of the perianth $\frac{1}{2}^{\prime}$ long, lauceolate, acuminate, 3-nerved, greenish. Style smooth Berry red.

\section{STREPTOPUS, Michx.}

Perianth bell-shaped, corolla-like, with the divisions distinct, deciduous, the inner ones keeled. Anthers sagittate, fixed near the base, entire, or 2-ponted at 
the apex, longer than she filanents. Styles uniterl: stigma 3-elcft or entire.

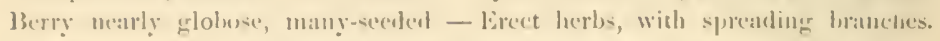
leaves clasping. Pedundes opposite the leaves, bent or twisted in the middle.

1. S. roseus, Michx. Stem much branched, with the branches flexuous and sprinkled with hatirs; leaves ovate, or the mpermost lanceolute, nemminate, sliphtly clasping, ciliate on the margins, 5-7-nerved ; flowers mostly solitary, smatl, rose-color, noddling; anthers 2-pointed ut the apex; stigma 3-eleft. Shany wools on the mountains of Georgia, and northwarl. May. - Stem 20 high. Leaves $2^{\prime}-4^{\prime}$ long, green on both sides. Flowers $3^{\prime \prime}-4^{\prime \prime}$ long.

\section{MELANTHIUM, I.}

Flowers moncecionsly polygamous. Divicions of the perianth spreading, long-clawed, somewhat cordate or liastate and biglandular at the base; the filaments partly adhering to their claws: anthers reniform, becoming peltate, the cells confluent. Styles 3 , subulate. Capsule membranaceous, 3-lobed, the eefls separating and opening down the inner suture, several-seceded. Seeds flat, winged. - Stems tumicl at the base, rough-pubesecnt above. Leaves long, linear. Flowers panicled, crean-color, turning brownish.

1. M. Virginicum, L. Stem tall, simple, the upper portion, like the loose panicle, pubescent and somewhat hoary, lowest leaves long, broally linear and elasping, the upper small and sessile ; flowers shorter than the pedicels, the upper ones perfect; leaves of the perianth oblong or roundish, often acute, the sleuder claw adnate to the lower half of the filanents; glands conspicnous. (M. hybridum, Walt., the claws concave and aduate to the filaments below the middle; glands conuivent or obscure.) - Swamps, Florida, and northward. July and $\mathrm{Aug}$. - Stem $3^{\circ}-4^{\circ}$ high. Lowest leaves $1^{\circ}-1 \frac{1}{2}^{\circ}$ long.

\section{ZIGADENUS, Michx.}

Flowers perfect. Leaves of the perianth ovate or oblong, spreading, sessile or nearly so, 1-2-glandular at the base. Filanents free from the perianth, and of equal length: anthers broadly cordate, becoming peltatc. Styles 3 , slender, spreading. Capsule membranaceous, 3-angled, septicidal at the apex, many. seeded. Seeds oblong, wingless, or slightly margined. - Stems smooth and simplc. Lowest leaves crowded, linear. Flowers white, in crowded panicles.

1. Z. glaberrimus, Michx Stem rigid, leafy; lowest leaves broadly linear, clongated. glatucous beneath, the upper small and seattered; panicle small, rigirl; bracts ovate; leaves of the perianth oblong, short-clawed, often with a white callus on one or hoth sides at the base; glands prominent; stamens and styles subulate; seeds oblong - Pine-barren swamps, Florida to North Carolina. June and July. - Stem $2^{\circ}-3^{\circ}$ high. Jowest leaves $1^{\circ}-1 \frac{10}{2}$ long. Panicle $6^{\prime}-12^{\prime}$ long, commonly dense. Flowers $l^{\prime}$ in drameter, as long as the pedicels.

2. Z. leimanthoides, Gray. Stem slender, somewhat naked above; leaves narrowly linear, green on both sides; panicle slender; bracts lanceolate; leaves of the perianth oval or obovate, sessile, the glands obscure or wanting; 
stamens and styles filiform; seeds narrowly margined, winged at the apsx. (Helonias graminea, Ell.) - Mountain swanps, Georgia, and northward. July and Aug. - Stem $2^{\circ}-4^{\circ}$ high. Lowest leares $1^{\circ}-2^{\circ}$ long. Panicle $8^{\prime}-12^{\prime}$ long. Flowers $4^{\prime \prime}$ in diameter, much shorter than the slender pedicels.

\section{STENANTHIUM, Gray.}

Flowers perfect or polygamous. Leaves of the perianth I anecolate, acuminate, united at the base, and adnate to the base of the orary, longer than the stamens. Glands none. Anthers roundish, becoming peltate. Styles short, subulate: stigmas minute. Capsule ovate, membranaceons, septicidal at the apex, severalseeded. Seeds nearly wingless. - Stem smooth, slender, tumid at the base. Lowest leaves elongated, channelled. Flowers small, greenish-white, in a simple panicle.

1. S. angustifolium, Gray. (Veratrum angnstifolinm, Pursh.) - Shady woods and banks, Florida, and northward. June and July. - Stem $2^{\circ}-3^{\circ}$ high. Lowest leaves $1^{\circ}-2^{\circ}$ long. Paniele $1^{\circ}-2^{\circ}$ long, composed of simple spiked racemes; the lower flowers often sterile. Perianth about $4^{\prime \prime}$ in diameter, nearly sessile, twice as long as the stamens.

\section{Veratrum, Tourn. False Hellebore.}

Flowers polygamous. Leaves of the perianth spreading, distinet, oblong or obovate, narrowed at the base, free from the ovary, glandless, longer than the stamens. Styles short, subulate. Capsule oblong, membranaceous, 3-pointed, the cells opening above at the inner suture. Seeds few, flat, broadly winged. Stems leafy, tumid at the base, pubescent. Leaves oral or oblung, plaited. Flowers in ample panicles, green or purplish-brown.

1. V. viride, L. Stem stout, leafy throughout; leaves broadly oval, acute, strongly plaited, clasping, pubescent beneath ; panicle pyramidal, composed of numerous dense racemes; divisions of the perianth oblong, smooth, ycllowish green, longer than the pedieels and twice as long as the stamens. - Mountain meadows, Georyia, and northward. April and May. - Stem $3^{\circ}-7^{\circ}$ high. Lower leaves $1^{\circ}$ long. Flowers large. - The plant is possessed of active, but deleterions properties.

2. V. intermedium, n. sp. Stem slender, leafy; lowest leaves nearly smooth, lanceolate or oblong, acute, narrowed into a long sheathing petiole, strongly plaited, the upper ones small, lanceolate, scattered, pubescent beneath ; panicle large, composed of long and slender loosely-flowered racemes; leaves of the perianth spatulate-oblong, dark brown within, hoary pulscrulent without, as long as the pedicels, rather longer than the stamens; ovary woolly; lohes of the capsule winged; seeds linear-oblong, broadly wingerl. - Rich shady hummorks, Middle Florida. Jnly. - Stem $3^{\circ}-5^{\circ}$ high. Lower leaves $1^{\circ}$ long. Flowers $6^{\prime \prime}-8^{\prime \prime}$ wide. Intermediate between V. Woodii, Robbins, and the next, of wlich it may prove to be a variety.

3. V. parviflorum, Miehx. Stem slender, naked ahove; leaves rarying from lanceolate to oval, smooth, slightly plaited, narrowed into sheathing peti- 
oles; panicle slenter, longr and spreading, leuncly fowered; leares of tho peri-

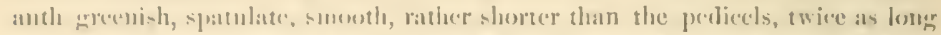
as the stamens; ovary smouth. - Mountains of North Carolina. July, - Stem $2^{\circ}-5^{\circ}$ high. Lowest leaves $9^{\prime}-12^{\prime}$ long. Flowers $4^{\prime \prime}-5 \prime \prime$ wide.

\section{AMIANTHIUM, Grav. Fu-Pusox.}

Flowers perfert. I,eaves of the perianth oblong or obovate, sessile, sprealing, glandless, shorter than the slender stamens. Anthers kidney-shuped, beromine peltate. Styles slemler: stigmas minute. Calpsule membranaceous, 3-luberl, the cells separating and opening down the inner suture, few-secled. Seets oblong or linear, wingless. - Stcms simple, smooth, tumil or bulbous at the base, scape-like above. Lowest leaves long and erowded. Flowers white, in a simple raceme.

1. A. muscatoxicum, Gray. Stem lunhons at the base, somewhat angled; lowest leaves strap-shaped, oltuse, chamnelled, the uppermost small and bract-like; raceme eylindrical, densely flowered ; leaves of the perianth oblong, nearly equalling the stamens; styles spreading; sects ovoid, redl. (Helonias erythrosperma, Michx.) - Rich woods, Florida, and northwaril. May and June. - Stem $1^{\circ}-2^{\circ}$ high. Flowers small, tuming greenish.

2. A. angustifolium, Gray. Stem tumicl at the base, slender, terete; lenves linear, acute, ehamelled, somewhat glaurous, the lowest rery long, the uppermost small and bract-like; raceme oblong, mostly densely flowered; leaves of the perianth oral, slorter than the stanıens; styles erect; seeds linear. (Ilelonias angustifolia, Mich.r.) - Low pine barrens, Florida to North Carolina. May and June. - Stem $2^{\circ}$ high. Flowers turning purple.

3. A.? aspericaule, Gray. Stem and flowers pnlverulent-roughened; stem-leares linear-lanccolate, flat; flowers in a small ( $2^{\prime}$ long) spikc-like panicle, composed of spiked racemes. - Near Colımbia, South Carolina, Curtis. - Plant imperfectly known.

\section{SCHCENOCAULON, Gray.}

Flowers perfeet. Leaves of the perianth somewhat spreading, linear-oblong, grandless; filaments sulmlate, at length twiee as long as the perianth: anthers kidney-shajed, becoming peltate. Ovary 6-8-ovnled. Styles very short: stigmas minute. Capsule and seeds unknown. - Seape very slender, hulbous at the base. Leaves all radical, very long and narrow, dry, ehannelled. Flowers small, pale green, crowded in a slender spike.

1. S. gracilis, Gray. (Helonias? duhia, Michx.) - Dry sands, Georgia and Floriln. April and May, - Leaves $1^{\circ}-2^{\circ}$ loug, scarcely $1^{\prime \prime}$ wide. Scape $2^{\circ}-3^{\circ}$ high, rush-like. Spike $3^{\prime}-4^{\prime}$ long.

\section{XEROPHYLLUM, Michx.}

Flowers perfect. Icaves of the perianth widely spreading, sessile, oval, as long as the subulate filaments. Anthers round-ovate, 2-eelled. Styles filiform: 
stigmas decurrent within. Capsule roundish, 3-lobed, loculicidally 3-valved. Sceds 2 in each cell, collateral, oblong, wingless. - Stem bulbous at the base, simple, leafy. Leaves lry, rigid, rough on the margins, very narrow, dilated at the base; those of the stem very numerons and needle-shaped. Flowers white, in a simple dense raceme.

1. X. asphodeloides, Gray. (Helonias asphodeloides, L.) - Dry sandy soil, North Carolina, and nortlward. May and June. - Stem $3^{\circ}-5^{\circ}$ high. Radical leares spreading, $1^{\circ}$ or more long, very slender-pointed. Flowers $2^{\prime \prime}$ long. Stamens dilated below.

\section{CHAM ÆLIRIUM, Will.}

Flowers dinecious. Leaves of the perianth linear-spatulate, shorter than the filiform filaments. Anthers 2-celled, roundish. Styles club-shaped: stigmas decurrent. Capsule ovoid, 3-angled, loculicidally 3-valved, many-sceded. Sceds linear-oblong, winged at the ends. - Stem simple, from a thick rhizoma, leafy. Lowest leares spatulate or ohovate, the others linear or lanceolate. Flowers small, white, in a simple spiked racene.

1. C. Iuteum, Gray. (IIelonias dioica, Pursh.) - Low grounds, Florida, and northward. May and June. - Stem $1^{\circ}-2^{\circ}$ high, furrowed. Rarical leaves clustered, $2^{\prime}-4^{\prime}$ long, spreading; the uppermost small and bract-like. Racemes $6^{\prime}-12^{\prime}$ long, the sterile ones slender and drooping at the summit; the fertile rigid and erect. Perianth inconspicuous.

\section{PLEEA, Michx.}

Flowers perfect. Leaves of the perianth sessile, widely spreading, lanceolate, rigid. Stamens $9-12$, shorter than the perianth : filaments slenler: anthers linear, introrse, 2-cleft at the base, versatile. Styles short, subulate. stigmas simple. Capsule coriaceous, ovate, 3-lobed, many-seeded; the cells opening down the inner suture. Seeds oblong, bristle-pointed. - Stems smooth and slender, from clustered rootstocks. Leaves chicfly radical, very narrow, 2-edged, equitant. Flowers few in a simple raceme, white. Bracts spathe-like, clasping.

1. P. tenuifolia, Michx. - Pine-barren swamps and bogs, Florida to North Carolina. Oct. - Stem rush-like, $2^{\circ}$ high. Radieal leaves erect, rigid, perennial, $6^{\prime}-9^{\prime}$ long. Raceme rigid, 6-9-flowered, the erect pedicels enelosed in the rigid clasping bracts. Flowers $1^{\prime}$ wide, grecnish without.

\section{TOFIELDIA, Hudson.}

Flowers perfect. Leaves of the perianth spreading, sessile, oblong or obovate. Filaments subulate anthers innate or introrse, 2-celled. Styles subulate : stigmas terminal. Capsule 3-angled, septicilally 3-partible, many-seeded. Seeds oblong. - Stems simple, scape-like, from creeping rootstocks. Leares linear, 2-edged, equitant. Flowers small, whitish, in spikes or racemes. Pedicels commonly minutely 3 -braeted under the flower. 
\$1. 'Tofirinia proper. Racemes simple, the flouers surcessively opening from the lase upururd (centripctul): anthers introrse: secds without uppenduges. Sinooth herls.

1. T. glabra, Nutt. Stem leafy at the base, and sparingly above; leaves linear; rucemes densely flowered; stamens slighlitly exserterl; styles very short. ('T. glalserrima, dfacbride.) - Low pine barrens, in the mirldle and lower districts of North and South Carolina. Uet. - Stem $1^{\circ}-2^{\circ}$ high. Raceme $2^{\prime}-4^{\prime}$ long. Flowers white.

\$2. Trustux. Racemes compound; the fouers suressively opening from the apex douneurd (centrifugal): unthers innute: seeds with tul-like appendages at cach end. - Pubscent herbs.

2. T. pubens, Ait. Stem and pedicels rongh-pubernlent; leaves long, linear; racemes $\left(3^{\prime}-6^{\prime}\right.$ long) loosely flowered; pedicels mostly three in a cluster, longer than the greenish-white flowers; capsule as long as the perianth. Low juine barrens, Florida to North Carolina, and westward. Sept. - Stem $1{ }^{\circ}$ $-1 \frac{1}{2} 0$ high. Leares $6^{\prime}-12^{\prime}$ long.

3. T. glutinosa, Willd. Stem and pedicels clammy-pubescent; leaves short, linear-sword-shaped; racemes ( $1^{\prime}$ long) dense-flowered, pedicels $3-5$ in a cluster, sliorter than the yellowish flowers; eapsule longer than the perianth. Mountains of North Carolina, and northward. June. - Stem $1^{\circ}-1 \frac{10}{2}$ high. Leaves $t^{\prime}-6$ ' long.

\section{Order 153. JUNCACEA. (Resil Family.)}

Tough grass-like herbs, with naked or leafy and jointed stems, flat or terete leaves, and regular eymose-clustered or panicled flowers. - Perianth of six nearly equal calys-like persistent divisions. Stamens 3 or 6 , inserted on the base of the sepals: anthers 2-celled, introrse, fixed at the base. Ovary free fiom the perianth, 1-3-celled, 3-many-ovuled. Style single: stigmas commonly 3, hairy. Capsule loculicillally 3-valved. Seeds anatropous. Embryo ninute at the base of the albimen.

\section{Synopis}

1. LUzUL.1. Capsule 1-celled, 3-seeded, Leaves mostly hairy.

2. JUNCLS. Capsule many sceded; the placentx separating with the partitions. Smooth herbs, with alternate leares.

8. CEPIIALOXYS. Capsule many-seeded; the placentre united into a 3-winged central column. Stem-leaves nearly opposite.

\section{LUZULA, DC. Wood-Resir.}

Sepals flat. Stamens 6. Style very short: stigmas filiform, villous. Capsulc 1-celled, 3-valved, 3-seeded. Secds erect from the base of the cell. - Perennial herbs, with flat mostly hairy leaves, and umbellate or spiked fowers. 
1. I. campestris, DC. Stem leafy; leares linear, hairy; flowers in dense ovoid umbellate spikes; capsule roundish; seeds with a conical appendage at the base. (Juncus eampestris, L.) - Dry woods and banks, Florida, and northwart. March and April. - Stems elustered, $1^{\circ}$ ligh.

2. I. pilosa, Willd. Stem leafy; leaves linear or lanceolate-linear, hairy; flowers single, umbellate; capsule orate; seeds with a curved appendage at the apex. - Monntains of North Carolina, and northward. May. - P'lant $6^{\prime}-9^{\prime}$ high.

\section{JUNCUS, L. Rusir.}

Onter sepals kecled. Stamens 3 or 6 . Style rery short: stigmas villous. Capsule 3-celled, or imperfectly 3-celled; the partitions adherent to the valves, and bearing the placentæ at their inner edges. Seeds numerous, often appendaged, horizontal. - Chiefly perennial. Leaves alteruate, often knotted by cross partitions. Flowers mostly green, elustered, cymose, or panicled.

\$1. Stems scape-like, jointless, sheathed or leafy at the base: stumens 6 or (in No. 1) sometimes 3 .

* Panicles lateral: stem sheathed at the base.

I. J. effusus, L. Stem soft and spongy; sheatls dark brown; panicle diffuse or contractel ; flowers single; sepals lanceolate, as long as the ohovate obtuse obscurely 3-angled light brown eapsnle. - Bogs and swamps, Florida, and northwarl; common. May-Sept. - Stems tufted, $2^{\circ}-4^{\circ}$ high.

$$
\text { * * Panicles lateral: stem leafy at the base: leaves terete, pungent. }
$$

2. J. setaceus, Rostk. Stem and leares slender; sheaths light brown; panicle simple, few-flowered; flowers single; scpals rigid, lanceolate-orate, rather longer than the globose pointed green capsule.- Low grounds and swamps, Florida, and northward. May-July. - Stems growing in small tufts, $1^{\circ}-3^{\circ}$ high. Capsule coriaccous.

3. J. maritimus, Lam. Stem and leaves stout and rigirl, hard-pointed; panicle compound; flowers small, $4-8$ in a cluster; sepals lanceolate, as long as the small obovate obtuse dark brown capsule. (J. acitus, 1/Wh/.) - Brackish marshes along the coast, Florida, and northward. A pril and May. - Sten $4^{\circ}-$ $5^{\circ}$ ligh.

* * * Panicles terminal, forking: leaves channelled or gronvcd; the upper ones forming an involucre under the panicle.

4. J. tenuis, Willd. Stens tough, not tumil at the base, several-leared; leaves narrowly linear, channelled; involucre longer than the panicle; flowers single; sepals lancolate, very acute, one third longer than the ovoid capsule. Low grounds, Florida, and northward. May and June. - Stem $6^{\prime}-12^{\prime}$ high. Panicle small, the flowers mostly on one side of the branches. Capsule light green.

5. J. dichotomus, Ell. Stem tumid at the base, 1-3-leaved; leaves filiform, nearly terete, slightly grooved on the inner side; involuere mostly shorter than the eymose panicle; flowers single; sepals rigid, ovate-laneeolate, 
very actite, as long as the glohose ilark green eajesule. - Iow grounds, Florida to North Curolina. May and June. - Stem $1^{\circ}-3^{\circ}$ hight. Panicle dense or clongatcel.

\section{\$2. Stoms jointed, Irafiy: slusters or panicles torminal.}

* Learss levete or someuthat fluttrud, linutled: stamens 3.

6. J. scirpoides, Iam. Rigid; stem stont, ereet; leaves terete, paniclo erect, contrancted, the few large glohose green or brownish heads composed of several more or less distinct smaller ones; repals lanceolate-sulullate, as long as the lanceolate taper-pointed 3-insted eapsule; seed ovoid, retieulated, without appendages. (J. echinatus, Ell.) - Varies with the smaller nure numerous and erowded licals conspicuously lohed by the more distinct elusters, and with broader and shorter sepals and (apsules. - Sandy swamps, Floridat to North Carolina. July-Sept. - Stem $2^{\circ}$ high, from a thick and crepping rhizoma. IIeads $4^{\prime \prime}-i$ " in diameter.

7. J. polycephalus, Ell, Michx. in part. Stem tall, slender, compressed near the base; leaves long, flattened, and often somewhat sword-shaped; panicle large, witlely spreading, the numerons globose miny-flowered pale heals sessile, or on long diverging peduncies; sepals linear-sululate, shorter than the lanceolate-subulate 3-ingled capsile; seeds oblong, striate, barely pointed. - Ponils and iniry margins of streatns, Florida to North Carolina. July-Sept. - Stem $2^{\circ}-4^{\circ}$ long. Leares weak, $1^{\circ}-2^{\circ} \mathrm{long}$, sometimes $\frac{1}{2} w^{\prime}$ wille.

Var. ${ }^{2}$ depauperatus, Torr. Stem and leaves more slender; heads smaller and fewer-flowered; sepals lanceolate, shorter than the oblong capsule - Wet places, Georgi:t, and nortlwarl. - Roots fibrous. Stems often decumbent and rooting.

8. J. paradoxus, Merer. Stem rigid, erect, terete; leares terete; panicle erect; heads pale, 8-15-flowered, ses.ile, and on short erect peduncles; sepals lanceolate-sulublate, rigril, shorter than the oblong 3-angled abruptly pointed rapsule; seeds with a loner and slender appendage at each end. - Wet places, South Carolina, Curtis, and uorthward. July - Sept. - Stem $1{ }^{\circ}-2^{\circ}$ high.

9. J. acuminatus, Michx. Stem erect, terete, like the slender leares; panicle mostly simple, ereet; heads $\left(2^{\prime \prime}-3^{\prime}\right.$ long $) 3-8$-flowered; sepals linearlanceolate, half as long as the lanceolate-oblong abruptly pointed 3-angled light brown capsule; seets with a short appendage at each end. - Sandy wet places in the midalle districts of Georgia, and northward. July - Sept. - Stem $8^{\prime}-15^{\prime}$ liigh. Root fibrous. Capsule 2" Jong.

10 J. Elliottii. Stem slender, nearly terete; leares terete, grooved near the base within ; panicle erect, simple or compound; heads ( $1^{\prime \prime}-2^{\prime \prime}$ long) $5-8$ flowered; sepals ovate-lanccolate, as long as the ovoid obseurely angled obtuse deep chestnut eapenle ; secds oblong, striate, without appendages. (J. acuminatus, Ell., not of Llfichx.) - Bogs and ditches, Florida to North Carolina. June Ang. - Root fibrous, often hearing small tubers. Stem $10-2^{\circ}$ high. Heads commonly very numerous. Capsule $\mathbf{l}^{\prime \prime}$ long, shining. 
* * Liares terte, linotted: stamens 6 : flowers clustered.

11. J. caudatus, n. sp. Rigid throughout; stem stout, from a thick and creeping thizoma; leaves commonly 3 , short and pungent; panicle erect, compound, mostly contracted; clusters numerous, more or less crowded, $2-4$-flowered; sepals lanceolate, acute, unequal, the inner ones half as long as the oblong obtuse-angled acute capsule; seeds with a long and tail-like appendage at each end, white and shining. - Pine-barren swamps and bogs, Mildle and West Florida. Augr and Sept. - Stem $2^{\circ}$ high. Leaves $2^{\prime}-6^{\prime}$ long, strongly knotted. Capsules light brown, turning almost black.

* * Leaves terete, obscurely knotted: stumens 6 : fiouers solitary, in slender 1 -sided cymose pranicles, often trunsformed into a tufi of rudimentary leaves.

12. J. abortivus, n sp. Rhizoma ereepine, thick and woody; stems slender $\left(1^{\circ}-2^{\circ}\right.$ high $)$, terete; leaves filiform, rather rigid; panicle compound, diffuse, the branches almost hair-like ; flowers minute, scattered ; sepals oblong, the inner ones obtuse, with membranaceous margins, as long as the (immature) subulate capsule; style slender. - Grassy margins of ponds, near the coast, West Florid:t. July - Sept. - Plant deep green. Flowers all alsortive or budlike.

13. J. Conradi, Tuckerm. Rhizoma creeping, filiform; stems slender $\left(6^{\prime}-10^{\prime}\right.$ ligh $)$; leaves filiform, tender; panicle compound, diffuse; the small flowers somewhat seattered; sepals acutish, shorter than the oblong tiper-pointed capsule; seeds without appendages. - Sandy margins of ponds and swamps, South Carolina, and northward. July. - Leares more slender, and the divisions of the panicle shorter and more rigil than those of the preceding species.

$$
\text { * * * Leanes knotless, cuncare or flattened. }
$$

14. J. marginatus, Rostk. Stems flattened $\left(1^{\circ}-2^{\circ}\right.$ high $)$; leaves linear, flat or concave; panicle mostly simple; heads few-many-flowered, rarely solitary or by pairs; flowers triandrous; exterior sepals lanceolate or ovate-lanceolate, awn-pointed ; the interior oblong, obtuse, broadly margined, about as long as the globular dark brown capsule; seeds oblong, acnte at each end. (J. aristulatus, Michx. J. cylindricus, Curtis, the many-flowered heads cylindrical.) Var. Biflores. (J. biflorus, Elll.) Stems taller $\left(2^{\circ}-3^{\circ}\right.$ high $)$ : panicle decomjound, diffuse; heads very numerous, 2-4-flowered; seeds narrower and more jointed. - Ditehes and low grounds, Florida, and northward. July - Sept. The variety is confined to the pine barrens of the lower districts.

15. J. bufonius, L. Annual; stems low $\left(2^{\prime}-8^{\prime}\right.$ high $)$, tufted ; often branched ; leaves very narrow; paucles forking; flowers solitary or $3-6$ in a cluster; sepals whitish, lanecolate. acute, longer than the oblong obtuse pule capsule. - Dainp cultivated ground, apparently introduced. April and May.

\section{CEPHALOXYS, Desv.}

Flowers as in Juncus. Stamens 3. Capsule many-seeded, 3-eelled, the partitions separatiug from the valves at maturity, and forming, with the united placentre, a free 3-winged central column. Seeds ovoid, without appendages. - 
A smonth Jerl, with fibrons roots, flat and loranching stems, short sword-shaped cųnitant leares, and clustered greenis! Howers.

1. C. flabellata, Jesv. Stems mo-tly creeping or floating; leaves linearsword-shaped ; those of the stem neirly opposite; heads rymose, seattered, topshaped, several-flowered; scpals rigid, lanceolate-subulate, tender-pointed, the exterior ones strongly keeled, and as long as the linear-ohlong olutuse capunle, much shorter thun the flat interior ones; tilanents exserted. (Juncus repens, Mich.r.) - Miry banks of streans and ponds, Florida to North Carolina. July. - Stems $1_{2}^{\circ}-3^{\circ}$ long.

\section{ORDER 154. PONTEDERIACRA. (PICKEIRL-WEED FinILY)}

Perenuial aquatic or marsh lerks, witlı perfect mostly irregular flowers from a 1-leaverl spathe. - Periauth corolla-like, mecpually 6-refter 6parted, imbricated in the bud, withering-persistent. Stamens 3-6, more or less unequal, and unequally inserted on the throat of the perianth: anthers 2-eelled, ereet, introre. Ovary free. Style single: stigrma 3-6loberl. Capsule 1-3-celled, 1-many-seeded. Seeds anatropous. Embryo slemeter in mealy alloumen.

\section{PONTEderia, L. Whapee. Pickerel-weed.}

I'erianth funnel-shalped, 2-lipped, with the upper lip 3-lobed, the lower 3-parted, the curred tube fle-hy and coiled in fruit. Stamens 6, unepually inserted; the three lower ones exsertel, the three upper short amel ofen imperfect: anthers oval, blue. Orary 3 -eelled, two of the cells empty, the other with a single suspended orule. Style slenter. Capsule (utricle) 1-seerlet. - Rhizoma thick and creeping. Stem ereet, bearing above the mildle a single short-petioled leaf, and at the summit a hairy sjike of blue flowers, from a l-leaved spathe. Radical leaves longr-petioled, sheathing.

1. P. cordata, I. Stem and terete petioles ereet $\left(2^{\circ}-3^{\circ}\right.$ high $)$; leaves $\left(3^{\prime}-8^{\prime}\right.$ long $)$ varying from round-corlate to lanee-ollong, obtuse, fincly nerred; spike dense, eylindrical $\left(2^{\prime}-4^{\prime}\right.$ long), the periuncle enclosed in the convolute spathe; upper lobe of the hairy perianth spotted with yellow, the tube 6-ribled. (P. lancifolia, ITuhl., and P. angustifolia, Pursh, are narrow-leavel forms.) Miry margins of ponds and rivers, Florida, and northward. July-Sept.

\section{SCHOLLERA, Schreb.}

Perianth salver-form, nearly equally 6-lobed, the tube elongated and filiform. Stamens 3, nearly equal: filaments subulate: anthers sagittate-oblong, yellow. Style long and slender. Capsule ollong, l-celled, Joculicidally 3-valved, with three parietal placenta many-sected $-\Lambda$ small aquatic herb, with slender branching stems, linear sessile leaves, and a small terminal yellow flower. 
1. S. graminea, Willd. Stem submerged, forking, leaves thin, pellueid; flowers expanding at the surface of the water; spathe convolute; lobes of the perianth linear, spreading. (Leptanthus, Michx.) - In flowing water, North Carolina, and northward. July and Aug. - Stems $1^{\circ}-2^{\circ}$ long. Leaves $3^{\prime}-6^{\prime}$ long. Tube of the perianth $1 \frac{1}{2}^{\prime} \mathrm{long}$.

\section{Order 155. COMMELYNACEA. (Spiderwort Famly.)}

Herbs, with chiefly fibrous roots, jointed and leafy stems, and perfect or somewhat polygamous often irregular flowers. - Perianth of three herbaceous or colored persistent sepals, and three fugacious petals. Stamens 6, hypogynous, perfect, or a part of them sterile: anthers 2-celled, often of two forms. Styles single: stigma entire. Ovary free from the perianth, 2-3-celled, with 1 -several orthotropous ovules in each cell. Capsule loculicidally 2-3-valved, 1-several-seeded. Embryo pulley-shaped, placed in a cavity of the albumen opposite the hilum. - Plants somewhat succulent. Stems often branching. Sheaths of the leaves entire or open.

\section{COMMELYNA, Dill. DAY-FLOWER.}

Flowers irregular. Sepals mostly colored. Petals fugacious, two of them kidney-shaped and long-clawed, the other smaller. Stamens unequal, three of them fertile, the others with 4 -lobed sterile anthers : filaments bearlless. Capsule 1 - 3-celled, the cells $1-2$-seeded, or one of them frequently enupty. - Stems branching. Leaves flat, oblong, or lanceolate, on slieathing petioles; the floral ones cordate and spathe-like, folded, and enclosing the few-flowered peduncle. Flowers blue.

1. C. communis, L.? Stem smooth, filiform, and ereeping; leaves short $\left(1^{\prime}-2^{\prime}\right.$ long $)$, ovate-lanceolate, obtuse; sheaths fringed at the throat; spathes nearly crescent-shaped, obtuse at the base, lateral and terminal; peduncles by pairs; one of them bearing 3-4 small fertile flowers, which are inchuded in the spathe; the other long-exserted, filiform, I-flowered; odd petal lanceolate, sessile; seeds reticulated - Low grounds, Georgia to North Carolina. Jnly - Sept. (1)? - Stem $1^{\circ}-2^{\circ}$ long.

2 C. Virginica, L. Pubescent; stem erect; sheaths hairy; leaves $\left(4^{\prime}-\right.$ 6' long) oblong-lanceolate, acuminate, thin, rougl above; spathe (when opened) round ovate, contracted at the base; sterile perlunele included; petals large, the odd one lanceolate; ealpsule 2-3-seeded. (C. erecta, Ell.) - Varies (C. angustifolia, Mfch.e.) with the stems smooth, ascending; leaves nurrowly lanceolate, rither rigid. and, like the sheath, nearly smooth; flowers smaller, seeds pulrerulent. - Light or sandy soil, Florida, and northward. May-Sept. 4 - Stem $1^{\circ}-2^{\circ}$ high The spathes contain a viscid secretion until the seeds mature.

3. C. erecta, X. Stem stont, erect; leaves $\left(3^{\prime}-5^{\prime} \operatorname{long}\right)$ lanceolate or oblong, acute, very rough above, the sheaths fringed with brown lairs; spathes 
rowded, short-stalked, hooderl, narrowed at the base; sterile peduncle included, petals neitrly ntike, the orlel one smatler; seeds transsersely oblong. (C. hirtellal,

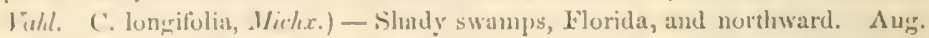

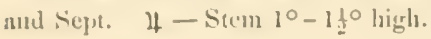

\section{TRADESCANTIA, T. Sirumwort.}

Flowers recrular. Sepals herluteroms. I'etals sinilar, ovate, fugacions. Stamens all fertile, the filuments hairy : anthers kilney-shaped. Ovary 3-celled, with two ovules in each eell. Calpsule 2-3-ecllerl, the cells $1-2$-seeded. P'ereunial lects, with narrow kecled leares, hoth the floral ones and those of the stem. Flowers in mulel-like clusters, axillary and terninal, exjanding in the morningr. Fruiting pedicels recurved.

1. T. Virginica, L. Smooth, or villous with glaniless hairs; leaves linear, broadest at the lase, mostly purple-veined; (dnsters axillary and terminal, sessile, many-flowered; flowers closely packed in 2 rows in the lud, each with an wate searions bract at the base; pettils blue, like the style and densely learded filanents, twiee as long as the lanceolate-ovate sepals. - Dry sandy soil, Florilit, and northward. Mareh-May. - Stems $2_{2}^{10}-2^{\circ}$ high. Flowers $l^{\prime}$ in diumeter.

2. T. pilosa, Lelım. Stem often branched, and, like the sheaths, villous or nearly smooth; leaves oblong, narrowed at the base, pubeseent on both sides; rhsters axillary and terminal, sessile, elense, many-flowered; the pedieels and ohlong sepals villous with glandulay hairs; seeds transversely oblong, pitted on the back; petals blne. - Light soil in the npper distriets. May-July. - Stem $1^{\circ}-1 \frac{1}{2}{ }^{\circ}$ hich Leares $1^{\prime}-1 \frac{1}{2}$ wille. Fluwers $31^{\prime}$ in diameter.

3. T. rosea, Vent. Stem simple, slender, smootls; leaves linear-lanceolate, fringer on the margins; elaters solitary or by pairs, on long $\left(3^{\prime}-6^{\prime}\right)$ terminal perluncles, few-flowered; petals bright rose-eolor, three times as long as the ovate-lanceolite sepals. - Light fertile soil, Gergia to North Carolina. JuneAug. - Stem $6^{\prime}-8^{\prime}$ liigh. Flowers $\frac{11}{2}$ in diunneter.

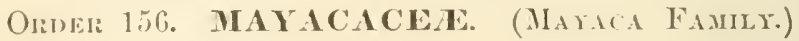

Creeping moss-like marsh herlss. with very ummerous narrow and pellucill leaves, and solitary axillary flowers. Represented only by

\section{MAYACA, Aublet.}

Flowers regular, perfect. Sepals 3, lanceolate, lerhaccons, persistent. Petals 3, obovate, deciluous or witliering-persistent. Stamens 3, free, inserted on the base of the sepalc, persistent - anthers erert, spoon-shaped, imperfertly 2-eelled, emarginate at the apex, introrse. Orary l-celled. Ornles few, orthotropons, fixed to three parietal plarente. Style single, terminal, persistent: stigma minutely 3 -lubed. Capsule rngose, 3-valved; the ralves bearing the placenta in 
the middle. Seeds globose, furrowed and pitted, pointed at the ap. Embryo minute at the apex of the albumen. - Stems braneling, tender. Leaves alternate, linear, emarginate. Flowers white or purple.

1. M. Michauxii, Sehott \& Endl. Fruiting peduncles longer than the leaves, recurved; eapsule few-seeded; flowers ( $3^{\prime \prime}-4^{\prime \prime}$ wide) white or pale purple. (Syena fluviatilis, Pursh.) - Springy places, Florida to North Caroliua. June and July. - Stems $2^{\prime}-6^{\prime}$ long. Leares $3^{\prime \prime}-t^{\prime \prime}$ long.

\section{Order 157. IYRIDACEAE. (Yellow-eyed Gizass Fayily.)}

Perennial stemless marsh herbs, with fibrous roots, sword-shaped equitant leaves, and perfect irregular fugacious flowers, collecterl in a dense imbricate-bracted spike. Sepals 3 ; the two lateral ones glumaceons, keeled, persistent; the inner one lyaline, enfolding, in the bud, the petals and carlueous stamens. Petals 3, rounded, distinct, or united by their long claws. Stamens 3, and inserted on the summit of the claws of the petals, or 6 , and the alternate ones sterile, hypogynous, and commonly bearded with jonted hairs: anthers erect, 2-celled, extrorse. Ovary free, 1-3-celled. Style single, s-parted. Capsule 3-ralved, many-seederl. Seeds minute, orthotropous. Eubryo minute, at the apex of the albumen. - Seape commonly twisted or spiral, 2-edged near the summit, with a spathe-like sheath at the base. Spikes mostly solitary.

\section{XYRIS, T. Tellow-eyed Grass.}

Petals distinet. Stamens 6, the alternate ones hypogynous, sterile, enmmouly bearded at the summit, and slightly eoheriug with the elaws of the contiguous petals. Stigmas entire. Capsule 1-eelled, 3-valved, the valves bearing the placentæ in the middle. Sceds very numerons, finely ribbed. - Spikes ovoid or oblong. Bracts coriaceous or somewhat ernsticeous, rounded, elosely imbricatel, convex and discolored on the lack; the lower ones empty. Kiecl of the lateral sepals mostly winged and varionsly lacerated. Flowers yellow.

\section{$\$ 1$. Shath of the scape longer than the leaves. Biennials?}

1. X. brevifolia, Mielıx. Seape netrly terete, smooth; leares narrowly linear, smooth on the edges; spike globose, light brown, few-flowered; bracts soon lacerated at the apex; lateral sepals lanceolate, rigul, crenulate on the wingless keel; petals obovate, rounded; sterile filanents sparingly beardeil.Low sandy pine barrens, Filoridat to Nortlı Caroina. April and May. - P'lant light brown. Seape $6^{\prime}-12^{\prime}$ lighl, clustered. Leaves $1^{\prime}-3^{\prime}$ long. Spike $2^{\prime \prime}-3^{\prime \prime}$ long. Petals $2^{\prime \prime}$ long.

2. X. flabelliformis, n. sp. Seape filiform, smooth, terete below, sliglitly compressed above; leares very short, linear-lanceolate, smooth, spreading like a 
fan, laterally curved ; spikes oblong, mostly acute, few-flowered, angulur; braets light brown, entire; lateral sepabls bunceblate, short-fringerl on the wingless kerel; jetils ohovate; sterile filiments often beardless, - Low pine barrens, near the coast, Went l'lorida. $\Lambda$ pril aud May. - Scape $t^{\prime}-12^{\prime}$ high. Leaves $2^{\prime}-1^{\prime}$ long. Spikes $2^{\prime \prime}-4$ " long. P'etals $2 "$ long.

$\$ 2$. Sheuth of the seape shorter than the leares. Perenniuls.

* Sirrile filaments bearded: sepals included.

- Lateral sepals fringal on the liat.

3. X. ambigua, l3cyr. Scape righil, fincly furrowed, rongh, 2-edged above, 1-angled below; leaves linear-lanceolate, rough on the edges; spike ovate-lanceolate or oblong, even, often aceute, many-flowered; bracts lighlit brown, oval, not erowded on the spike; lateral sepals lanecolate, tapering at each end, shining, narrowly winged; petals round obovate; seeds wroid. - Open grassy pine barrens, Floricla to North Catrolina. July - Sept. - Scape $2^{\circ}-3^{\circ}$ high, mostly solitary. Leaves $6^{\prime}-122^{\prime}$ long. Spikes $9^{\prime \prime}-15^{\prime \prime}$ long. Petals $\frac{1}{2}$ long.

4. X. strieta, п. sp. Seape flattened and broally margined, rough-edged ahove, smooth and 1-2-angled helow, slightly striate; leaves long, linear, smooth; spikes oblong or cylindrical, oltuse, many-flowered; macts dark brown, orlicular, crowded on the spike; lateral scpals broatly winged above the middle, narrowed below; petals snall, wedere-obovate; seeds ovoillShallow pouds in the pine barens, West Florida. July-Sept. - Seapes slender, clustered, $2^{\circ}-3^{\circ}$ liigl. Leaves $1^{\circ}-1 \frac{1}{2}^{\circ}$ long. Spikes $9^{\prime \prime}-12^{\prime \prime}$ long. Petals 2" long.

5. X. flexuosa, Muhl. Somewhat hulbous; scape smooth, 2-clyed above, nearly tercte below; leaves linear, smooth; spikes globose, few-flowered ; lateral sepals lanecolate, wingless. (X. hulbosa, Kunth.) - Swanps in the upper districts of Georgia, and northwarcl. Ju!y-Sept. - Seape $6^{\prime}-12^{\prime}$ liggh. Leaves $4^{\prime}-8^{\prime}$ long. Spike $3^{\prime \prime}-5^{\prime \prime}$ long.

\section{+ + Lateral sepals broadly winged, and rariously toothed or fimbriate.}

6. X. Elliottii. Seape slender, flattened and 2-edged thronghout, or 1edged helow, ronghish and mostly spiral; leaves narrowly linear, sharp-edged, twisterl ; spike few-flowered, elliptical, obtuse; lateral sepals linear, the wing cut-toothed above the midelle; petals ohovate. (X. brevifolia, Ell. ex descr.) Wet grassy pine barrens, Florida to South Carolina. July. - Scape $1^{\circ}-1 \frac{1}{2}$ o high. Leaves $6^{\prime}-9^{\prime}$ long. Petals $3^{\prime \prime}$ long.

7. X. difformis, n. sp. Scapes (lusterel, slender, smooth, widely 2-edged above, terete or 1 - 2-angled helow; leaves thin, lineur-lanceolate, smooth; spikes many-flowered, orate, acute, even, often 2-4-cleft; lateral sepals lanccolate, with the broadly winged keel incised-fimbriate; petals oborate; secels elliptical, smooth. - Swamps near the coast, West Floridu. July. - Scapes $1^{\circ}-1 \frac{1}{2}$ h high. Leares $9^{\prime}-15^{\prime}$ long. Spikes $6^{\prime \prime}-9^{\prime \prime}$ long. Petals small.

8. X. selotina, n. sp. Scapes elnstered, twisted and mostly spiral, roughangled and 2-edered above, striate; leaves linear-lanceolate, rigid, rongh on the elges; spikes many-flowered, ovoid, obtuse, dark brown, even; bracts round. 
obovate, elosely imbricated; lateral sepals linear, narrowly winged above, fimbriate and at length incised; petals small, obovate; seeds ovoid, pulverulent. Varies with shorter leaves $\left(2^{\prime}-3^{\prime}\right)$, and smaller globose or ovate heads. - P'inebarren swamps, West Florida. Sept. and Oct. - Scapes $1^{\circ}-1 \frac{10}{2}$ high. Leaves $8^{\prime}-12^{\prime}$ long. Spikes $6^{\prime}-9^{\prime}$ long. Petals $2^{\prime \prime}$ long.

9. X. elata, n. sp. Scapes elongated, slemler, smooth, terete below, 2-edged above; leaves long, linear, smooth; spikes rugose, oblong or oval, often acute, many-flowered; scales dark brown; lateral sepals linear-lanceolate, sparingly toothed on the narrowly winged keel; petals wedge-obovate; seeds elliptical, smooth. - Sandy swamps near the coast, West Florida. July and Aug. Seapes $3^{\circ}-4^{\circ}$ high. Leaves $1 \frac{1}{2}^{\circ}-2^{\circ}$ bigh. Spikes $\frac{1}{2}^{\prime}-1^{\prime}$ long. Petals $2^{\prime \prime}$ long.

10. X. Caroliniana, Walt. Scapes several, smooth, rigid, 1-2-angled below, compressed and 2-edged above; leaves linear or linear-lanceolate, smooth ; spikes rugose, oblong-ovate, obtuse, many-flowered; bracts light brown, thick, the margins thin and soon lacerate; lateral sepals linear-lanceolate, acute, the narrowly-winged keel cut-fringed above the mildle; petals obovate; seeds ovoid. - Shallow pouds and swamps, Florida, and northward. July and Aug. Scapes $1^{\circ}-2^{\circ}$ high. Leaves $6^{\prime}-15^{\prime}$ long. Spikes $6^{\prime \prime}-12^{\prime \prime}$ long.

11. X. iridifolia, n. sp. Rigid, smooth and slining; scape stout, terete or 1-angled below, dilated and 2-edged above; leaves long, strap-shaped; spikes oval or oblong, obtuse, rngose, many-flowered; braets dark brown, very thick, strongly eonvex; lateral sepals linear, membranaceous, the keel fimbriate and at length incised throughout; petals round-obovate; seeds lanceolate, angled, pulverulent. - Shallow ponds, Apalachicola, Florila. Aug. - Oct. - Scape $2^{\circ}$ $-3^{\circ}$ high, $2^{\prime \prime}-3^{\prime \prime}$ in diameter. Leaves $2^{\circ}-2 \frac{1}{2}$ long, $\frac{1}{2}^{\prime}-1^{\prime}$ wide. Spikes $1^{\prime}$ long. Petals $3^{\prime \prime}$ long.

12. X. platylepis, n. sp. Seapes mostly twisted and spiral, angular below, 2-edged above, roughish; leaves linear and lanceolate, twisterl, smooth; spikes large, oblong or cylindrical, obtuse, many-flowered; bracts pale brown or whitish, orbieular, thin, closely imbricated; lateral sepals linear, the keel narrowly winged, fimbriate towarl the apex; petals small ; seeds elliptical, smooth. (X. flexuosa, Ell.) - Low sandy places, Florida to Sonth Carolina. July Sept. - Scape $2^{\circ}-3^{\circ}$ high. Leaves $9^{\prime}-15^{\prime}$ long. Spikes ${ }_{1}^{3}-1 \frac{1}{2}^{\prime}$ long.

$$
\text { * * Sterile filaments bearded: sepals exserted. }
$$

13. X. fimbriata, Ell. Not bulbous; scape tall, furrowed, rongh, 2-erged above; leaves long, strap-shaped, smooth; spikes ovate, acnte, many-flowered; lateral sepals long-fimbriate alove the middle; petals small. - Ponds and miry plaees, Florjla, and northward. Sept. and Oct. - Scapes $3^{\circ}-4^{\circ}$ high. Leaves $1 \frac{1}{2}{ }^{\circ}-2^{\circ}$ long. Spikes $9^{\prime \prime}-12^{\prime \prime}$ long. Petals $3^{\prime \prime}$ long.

14. X. torta, Smith. Bulbons; scape nearly terete, l-erlgerl. smooth, mostly spiral ; leaves linear, rigirl, concave, with romded edges, mostly spiral; spikes pale, lanceolate or cylindrical, acnte; lateral sepals winged and fimbriate above the middle; petals large, roumd-obovate. - Sanily, often dry soil, Florida, and nortliward. July - Sept. - Scape $1 \frac{10}{2}-2^{\circ}$ high. Leaves few, $6^{\prime}-12^{\prime}$ long, 
fumid and dark bown ut the hase. Spiters a' I!' loner. Petals 9" long, ex. punding at mishlay.

* * Serrile filuments benralless: leures filifurm.

15. X. tenuifolia, n. sp. Smooth; scape slenter, terete or 1-nnengled; lenves filifim or bristle-like, (ompressed; spikes ovoid, few-flowered; lateral sepals lamecolnte, the narrowly winged keel cut-serrate; pretals obosate; secels linearoblong, sinouth. - Open grassy pine-baren swamps, Florida to North Carolina. July - Sept. - Siapes clustered, 10'-12' liggh. Leaves $4^{\prime}-6^{\prime}$ long. Spikes $2^{\prime \prime}-4$ "lung. Petals 3 "lomg.

16. X. Baldwiniana, R. \& S. (X juneea, Baldke) "Rot perennial; seape terete, sheathed at the base, $6^{\prime}-12^{\prime}$ high ; leaves $4^{\prime}-8^{\prime}$ long, terete, hollow, acente; heal oval; bracts nearly remul ; calyx about as long as the bracts, the kect slightly toothed, filaments maked." Bulduin in l:ll. - Damp pine barrens, near St. Mary's, Georgia. May and June. (*)

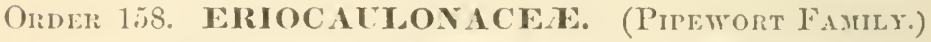

Peremial chicfly stemless marsh lictbs, with narrow tufted leaves, and mimte monderens on diceions flowers, collected in a dense hairy chaflybracterl hearl. - Stam. F\%. Śepals 2-3. Corolla tuluular, bilabiate or 3-tootherl, or sometines wanting. Stamens 2-6: anthers introrse. I'ist. Fl. Sipals and petals 2-3. Ovary 2-3-eedlecl, with a single orthotropous wrule in each cell. Style 2 -3-parterl. Capenle loculicidally 2 -3-valverl, 1 -3-seceded. Embryo minute at the apex of the albmen. - Leaves concave and partly clasping at the base. Srape furrowed and rommonly twisterl, with a spathe-like sheath at the base. Exterior seales broader, ('mpty, and involucrate. Flowers finged with white dub-shaped hairs. Corolla white.

\section{Synopsis.}

1. ERIOCAULOx. Stamens 4. Anthers 2-celled. Style 2-parted. Corolla 2-lipped.

2. P.FIALATTICS. Stamens 3 Anthers 2-celled. Style 3-parted, the lobes entire.

3. LACHXOCALLOX. Stamens 3. Anthers 1-celled. Styje 2-3-parted, the lobes entire, or 2. cleft.

\section{ERIOCAULON, I. PIPEWORT.}

Flowers monnecious, each in the axil of a scalc-like bract. Sepals 2-3. Corolla of the staminate flowers tubular, 2-lipped or 3-lobed; of the pistillate flowers 2-3-petalous. Stamens 4 or 6 : anthers 2-eelled. Style 2-3-parted : stigmas 2-3. Capsule 2-3-celled, 1-3-seeded. - Serpes single or numerous, mostly from a short and villous rootstock. Lobes of the corolla furnished with a blarkish gland on the inner face, commonly bearded with clul-shaped hairs. The following species are all tetrandrous, with a 2-parted style and a 2-celled capsule. 
1. F. decangulare, L. Leaves mostly rigid, varying from lanceolate to linear-subulate, coneare, obtuse ; scapes commonly several from a thick and creeping rootstoek, stont, smooth, $10-12$-furrowed; head $\left(2^{\prime \prime}-7^{\prime \prime}\right.$ in diameter $)$ compact, hemispherieal, at length globose; seales of the involucre numerous, small, oblong, acutish, closely imbricated, straw-colored, or light chestnut, passing into the linear-spatulate acuminate bearded bracts, which are longer than the flower. (E. gnaphalodes, Ell., not of Michx.) - Boggy places, Florida, and northward. July - Sept. - Scapes $2^{\circ}-3^{\circ}$ high. Leaves $4^{\prime}-12^{\prime}$ long, $2^{\prime \prime}-6^{\prime \prime}$ wide.

2. E. gnaphalodes, Michx. Leaves lanceolate-subulate, flat, very acute, rigid, or the immersed ones thin and pellucid; scapes few or single, slender, $9-$ 11 -furrowed; heat hemispherical $\left(4^{\prime \prime}-8^{\prime \prime}\right.$ wide); scales of the involucre few, oblong or roundish, very obtuse, turuing lead-color; bracts shorter than the flower, spatulate, their broad and bearded summit obtuse or more or less mucronatepointed, turning blackish. (E. compressum, Lam.) - Swamps and shallow ponds, Florida, and northward. April -June. -Scapes $1 \frac{10}{2}-2^{\circ}$ high. Leaves $2^{\prime}-6^{\prime}$ long, concave at the base.

3. E. Ravenelii, n. sp. Smooth throughout; root fibrons; leaves linear or linear-lanceolate, very acute, flat, thin, and pellueid; scapes low and slender, clustered, slightly furrowed; heads small $\left(1^{\prime \prime}-2^{\prime \prime}\right.$ in diameter), globose, few or many-flowered; scales of the involucre few, in one or two rows, oblong, very obtuse, whitish, pellucil, longer than the immature head, and, like the oblong obtuse or barely pointed dark brown scales, beardless; flowers naked, or with few hairs at the base, dark brown, shorter than the bracts; style oceasionally simple; secds minutely pubescent. - Wet places, St. John's (Berkeley) Parish, South Carolina, H. W. Ravenel. - Scapes weak, $1^{\prime}-6^{\prime}$ high. Leaves $1^{\prime}-2^{\prime}$ long.

\section{P开PALANTHUS, Martius.}

Flowers monœcious. Staminate Fl. Sepals 3. Corolla tnbular, 3-toothed. Stamens 3: anthers 2-eelled. Pistillate Fl. Sepals and petais 3. Style 3parted, the divisions entire: stigmas 3 . Capsule 3-celled. - Habit of the preceding.

1. P. flavidulus, Kunth. Leaves short $\left(1^{\prime}-2^{\prime}\right.$ long), subulate, smooth, or sparingly pubescent; scapes numerous, filiform, 5-furrowed, and like the sheatls hairy; heals hemispherical, yellowish-white; seales of the involucre oblong, acute, smooth and shining; flowers slender, pedicelled; sepals linear, acute; corolla of the staminate flowers funnel-shaped; of the pistillate flowers composed of 3 slender petals, cohering above the ovary; stamens and styles exserted. (Eriocaulon flavidulum, Michx.) - Low sandy pine barrens, Florida to North Carolina, and northward. A pril and May. - Scapes 6'-12' high.

\section{LACHNOCAULON, Kunth.}

Flewers monocious, Staminate Fl. Sepals 3, equal. Corolla none. Stamens 3, with the filaments united below into a club-shaped tube: anthers 1celled. Pistillate Fl. Sepals 3, equal. Corolla none, or reduced to tufted hairs. Style club-shaped, 2-3-parted, the divisions entire or 2-cleft : stigmas 2-6. Cap- 
sule 2-3.relled. - Habit of the two preceding. IBracts and sepals blackish. fringed with club-shnped latirs.

1. L. Michauxii, kunth. I'aves linear $\left(1^{\prime}-2^{\prime}\right.$ long $)$, hairy, becoming smoothish; s(apes slender, hairy, 4 furrowed $(10$ high); heads glolose; lracts und scpals sparmlnte, olumere, fringed with white hairs; divisions of the style 3 ,

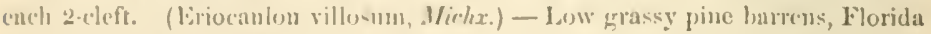
to North Carolina. Dlig and Juse, growing in tufts. - Jleals $2^{\prime \prime}$ wide.

2. L. glabrum, liorvicke. l,aves liuear, smooth (1'long); seapes numerous, smooth, 5-furrowed $\left(3^{\prime}-5^{\prime}\right.$ high $)$; heals glolose, becoming oblong, dark brown; bracts und sepals spatulate-ohovare, obtne, slightly fringed with slort hrowniwh hairs; divi-ions of the style 3 , entire. - Sandy springy places, St. $\mathbf{A n}$ drews Bay, West Forida. Oet. - Seapes 30 or more in a cluster. Heads $3^{\prime \prime}$ long, not unlike those of Eleocharis obtusa.

\section{Order 159. CYPERACEA. (Sedge Family.)}

Slender herbs, with simple solid mostly 3-angled stems (culms), and grass-like leaves, with closed sheaths. Flowers spiked, each in the axil of a single (rarely 2-4) scale-like bract (scale). l'erianth composed of lypogrnous scales or bristles, or none. Ovary 1-celled, with a single crect anatropous ovule, forming in fruit a lenticular or 3-angled achenium (nut), which is often crowned with the persistent jointed base of the style (mbliercle). Stamens 1-12: antliers erect. Style 2-3-cleft or parted. Embryo minute at the base of the albumen.

\section{Synopsis.}

Trine I. CYPER EF, - Flowers perfect: epikelets 1-many-flowered: ocales one to each flower, imbricaled in 2 rows: perianth bristly, or none.

* Perianth none: aut beakless.

1. CYPERCS. Spikelets few-many-flowered: Inflorescence terminal.

2. Fillidila. Spikelels 1-flowered : inflorescence terminal, eapitate.

* Perianth bristly: nut beaked.

3. DULICIIUM. Spikes lateral and terminal : spikelets many-flowered.

TRDE II. IIPOC A RPI H. A. - Flowers perfect : spikes many-flowered : scales 2-4 to each flower; the exterior ones imbricated in many rows: perianth none.

4. If IIICARPIIA. Inner feale 1 : involucre mostly 1-jeared, erect.

5. LIPOCARI'IIA. Inner seales 2 : leaves of the involucre 2 or more, spreading.

TRIBE III. SCIIEP EX. - Flowers perfect : spikes commonly many-flowered : scales one to each flower, imbrienled in several (rarely 2) rows, all fruitful, or the lowest empty: perianth brislly, hairy, or wanting.

- Perianth of 3 bristles, alternating with 3 stalked scales.

G. FUIREsA. Nut polnted: scales of the clustered axillary and terminal spikes awned.

* Perianth bristly, occasionally wanting.

7. ELEOCIIARIS, Nut tubercled: culms leafless, sheathed at the base, bearing one terminal spike. 
8. SCIRPCS. Tubercle none: culms mostly leafy at the base or throughout: spikes commonly few or muay : perianth of $3-6$ bristles.

9. ERIOPIIORUM. Perianth of numerous long and woolly hairs : otherwise like Scirpus.

*** Perianth none: style tumid at the base.

+ Scales imbricated in several rows : spikes terete.

10. FIMBRTSTYLTS. Style deciduous: stigmas 2 ; nut lenticular or globose.

11. TRICIIELOSTYLIS. Style deciduous: stigmas 3 : nut 3 -angled.

12 ISOLEPI s. Style persistent at the base: stigmas 3 : nut 3 -angled.

- + Scales imbricated in 2 rows: spike compressed.

13. ABILDGAARDIA. Style 3-cleft, jointed to the 3-angled nut.

TRIBE IV RHYNCHOSPOREA. - Flowers perfect or polygamous: spikelets commonly few-flowered : scales one to each flower, imbricated in few - several rows, the lower ones enpty, the upper mostly sterile: perianth bristly, or none.

* Perianth bristly (occasionally wanting in Rhynchospora).

14. RHYNCHosporA. Style 2-cleft, dilated and persistent at the base: nut lenticular or globose.

15. CERATOSCIIENUS. Style entire or minutely 2-cleft, the lower half persistent : nut flat.

16. CHATOSPORA. Style 3 -cleft, deciduous : nut 3-angled : spikelets terminal.

** Perianth node.

17. PSIJOCARYA. Spikes terete, many-flowered, cymose: flowers perfect.

18. DICIIROMIENA. Spikes compressed, eapitate : most of the flowers imperfect.

19. CLADIUMI. Spikes few-flowered, only the uppermost flower perfect: nut globose.

TRIBE V. SCI.ERIE AE.-Flowers monocious: sterile spike many-florered : scales one to each flower, imbricated in few rows: fertile spike 1-flowered, with two or more scales: perianth none.

20. SCLERIA. Style 3-clcft, deciduous. Nut bony, globose or 3-angled.

TRIBE VI. CA RICEA. - Flowers monœcious, very rarely dioecious : sterile and fertilo flawers on the same spike, or on separate spikes: scales one to each flower, imbricated in few-many rows : nut enclosed in a sac : perianih none.

21. CAREX. Bristles within the sac none. Spikes axillary and terminal.

\section{CYPERUS, L.}

Spikelets 2-many-flowcred, commonly flat or compressed. Scales imbricated in two opposite rows, often decurrent on the jointed rachis, deciduous. Perianth none. Stamens $1-3$. Style 2-3-eleft, deciduous. Nut lenticular or 3-anglcd. - Culms 3-angled (rarely terete), jointless, leafy or occasionally sheathed at the base. Spikelets numcrous (rarely 1-2), disposed in single or umbellate heads or spikes, and surrounded with a leafy involucre. Rays sheatlred.

\$1. PYCREUS. Style 2-cleft: nut lenticulur: spikes more or less umbelled. Annuals: spikelets linear or lineur-oblong, flat, many- (10-40-) flowered: rachis narrowly mamined: scales compressed-kceled, 5-nerved.

\section{* Spikelets clustered on the common rachis.}

1. C. flavescens, L. Umbel sessile or of 2-4 ravs, shorter than the spikelets; spikelcts 3 -several in a cluster, oblong-linear, acute, spreading, 20 30 -flowered; scales yellowish brown, ovate, obtuse, appressed; rachis margined; stamens 3 ; nut orbicular, black, smooth and shining; culms clustered, $4^{\prime}-10^{\prime}$ 
light ; leaves am 3-leaved involuce narmwly linear. (C. facciculatus, Ell. ?) Low grounds, Filoridis, and norelıwarl. duly and Ang.

2. C. rivularis, kinuts. Limbel of $3-4$ rays, one or two of them longer than the spikeless; spikclets $3-6$ in a cluster, oblong-lincar, acnte, muny-fluwered; scales pale straw-('olor, ovate, obtuse, appressed ; rachis inargined; stamens 2 ; nut round-ohovate, transversely ronghened, black and slining; culms 6'-12' high, slender; leaves and 3-leaved inrolucre linear. - Marshy banks of streams, Georecia, Florida, and westwatrd. Aug.

3. C. diandrus, Torr. Lmbel of $2-5$ short and unequal rays, the longer ones longer than the spikelets; spikelets lanceolate-oblong, acute, brownish or dark brown, sprealing; seales ovate, obtuse, alpuressed, green on the keel; rachis margined; stamens 2 ; nut oblong-oborate, roughish, dull grray. - Wet places, North Carolina, and nortluward. Aug. - Culms $4^{\prime}-10^{\prime}$ high. Involuce 3-leared. This and the preceding are probably only diandrous forms of No. 1.

$$
\text { * * Spilielets scattered an the common rachis (spilird). }
$$

4. C. Nuttallii, Torr. Limbel sessile or of $3-6$ rays, $1^{\prime}-2^{\prime}$ long ; spikelets numerous on the rays, spreading, linear-lanccolate, aeute, light or yellowish brown, 12-20-flowered, the lower ones commonly eompound; seales rigid, oblong-ovate, acute or mucronate, appressed; stamens 2; mut oblong-obovate, very obtuse, grayish and minntely pitted; culns clustered, 3-ingled, $4^{\prime}-15^{\prime}$ high ; leaves and involucre narrowly linear. (C. flaveseens, Ell. C. holosericeus, Limk:?) - Salt or brackish soil, Florida, and northwart. July-Sept. - l'lant commonly ycllowish and glossy throughout. Spikclets rarely erowded in a terminal liead.

5. C. flavicomus, Michx. Umbel compound, many-rayed; spikelets very numerous, crowded, lincar, acute, 12-30-flowered; seales loosely imbricated, yellowish, round-ohorate, cmarginate, with broad and scarious margins, at length spreading; rachis broadly margined; stamens 3 ; nut oborate, black, smooth and shining, barely shorter than the seale; (nlms thich, obtuse-angred, $1^{\circ}-3^{\circ}$ high; leaves broadly linear, glaueous heneath, as long as the culm. - Low grounds and ditclies, Gcorgia and South Carolina. May-Sept. - Involucre 3-5-leaved. Spikelets $6^{\prime \prime}-9^{\prime \prime}$ long.

6. C. microdontus, Torr. Umbel of $4-8$ rays, simple or somewhat compound; spikelets numerous, crowded, linear, acute, 15-25-flowered, pale brown; scales thin, ovate, acute, eloscly imbricated ; rachis slightly margined; stamens 2 ; nut linear-oblong or somewhat club-shaped, short-pointed, grayish and minutely pitte ; enlms filiform, 3-angled, $6^{\prime}-12^{\prime}$ licklı ; lenves and elongated involnere very narrow. - Margins of ponds and streams, Florida to North Carolina. July - Sept. - Rays $1^{\prime}-2^{\prime}$ long. Spikelets $4^{\prime \prime}-7 "$ long.

8 2. CYPERL'S Provir. Style 3-cleft: nut 3-angled: joints of the ruchis winged by the adnute decurrent scales, rarely uingless.

1. Sprcatr. Umbel simple or compound: spikelets few-many-flowered, distinct, spreading, forming loose or compact spites at the summit of the rays: scales rigid, 7-11-nerved: joints of the rachis commonly conspicuously uinged: stanens 3. 
* Spikelets approximate or crowded on all sides of the common ruchis, forming oldong or cylindrical spilies.

7. C. strigosus, L. Umbel large, $4-$ - S-rayed, simple or compound, much shorter than the involucre; involucels bristly, shorter than the dense oblong spikes; spikelets yellowish, lincar, acute, compressed, 6-10-flowered; scales somewhat scattered on the very slender rachis, oblong-lanceolate, acute, elosely appressed, much longer than the linear-oblong acute minutely dotted dull mut; culms $\left(1^{\circ}-3^{\circ}\right.$ high) tumid at the base, as long as the broally lincar leaves. Swamps and damp soil, Florida, and northward. July - Scpt - Rays $4^{\prime}-6^{\prime}$ long. Spikelets $\frac{1}{2}{ }^{\prime}-{ }_{4}^{3}$ long. Sheath of the rays bristle-pointed.

8. C. stenolepis, Torr. Umbel simple or compound, 6-9-rayed, sliorter than the 3-6-lcaved involnere; sheaths of the rays truneate; involuccls bristly, shorter than the orate compact spikes; spikelets yellowish, lincar, acute, compressed, 5-8-flowered; scales linear-lanceolate, acute, involute, spreading, much longer than the oblong-linear acute dull and minutely pitted nut; culms smooth $\left(2^{\circ}-3^{\circ}\right.$ high $)$; leaves very rough on the margins, whitish beneatl. - Swamps and wet places, Florida to North Carolina. Aug. and Sept. - Stem rather slender, longer than the leaves. Spikelets $6^{\prime \prime}-8^{\prime \prime}$ long.

9. C. Michauxianus, Schultes. Umbel compound, 4-6-rayed; rays short with the sheaths pointed; spikes loose, mostly shorter than the leafy involucels; spikelets spreading or reflexed, linear-subnlate, tercte, 10-12-flowered; scales seattered on the short-jointed broadly-winged rachis, oblong, obtuse, f:intly nerred, appressed; nut oblong, compressed-3-angled; culms slender, obtuse-angled; involucre 4-6-leaved. (C. speciosus, Vahl ?) - Swamps and ditches, Florida, and northward. Aug. and Sept. (1) - Culm $2^{\circ}-3^{\circ}$ higlı. Spikclets $6^{\prime \prime}-8^{\prime \prime}$ long, flexuons in fruit.

Var. ? elongatus, Torr. "Culm tall and slender; rays elongated; spikelets subulate, obtnsely quarlrangular ; scales lanceolate, acute." Torr. - North Carolina, Curtis. - Rays $3^{\prime}-5^{\prime}$ long. Spikelets crowded, 6-8-flowered.

10. C. tetragonus, El1. Umbel simple or compound, of 6-12 slender rays; spikes cylindrical, loose; spitikelets horizontal, short (2" $-3^{\prime \prime}$ long), oblong, 4-augled, 4-6-flowercd; scales ovate, mucronate, appressed, 9 - 11 -nerved, twice as long as the oblong dull nut; culms mostly slender, $1^{\circ}-2^{\circ}$ high, acutely rough-angled at the summit, as long as the green rough-edged leavcs; involucre many-leaved. - Dry sandy soil, along the coast, Florida to North Carolina. Aug. and Sept. If - Spikes $1^{\prime}-1 \frac{1}{2}^{\prime}$ long, $5^{\prime \prime}$ wide, those on the longer rays commonly compound. Rays $3^{\prime}-5^{\prime}$ long. Joints of the rachis broadly winged.

11. C. ligularis, L. Uinhel compound, of $4-6$ rays; spikes ovate or ohlong, dense; spikelets spreading ( $4^{\prime \prime}$ long), linear-lanceolate, compressed-4-angled, 8-10-flowered, acute; scales oblong-orate, acnte, spreading, 9-11-nerved, thrice the length of the ohlong-olovate pointed blackish nut; culms obtuseangled, shorter than the $\left(3^{\circ}-4^{\circ}\right.$ long) whitish long-tapering leaves. - Sandy shores at Key West. Oet. $4-\mathrm{Culm} 2^{\circ}-3^{\circ}$ high. Leaves rough-edged. Rays $2^{\prime}-3^{\prime}$ long. Spikelets light brown. Joints of the rachis broadly winged. 


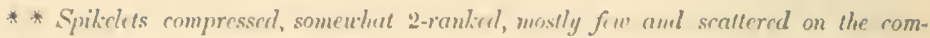
mon rachis: preremials, with cropping tulor-buring roststorks: flours mosily abortive.

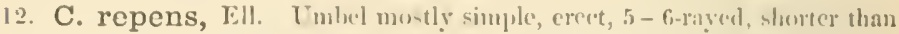
the 3-5-leared insolnce; spiliclets lincar, spending, 12-24-flowerel, the lower ones often chustered; scatles oblong, olutuse or short mucromute, compresced-keelerl, thin-matrined, spreating at the apex, yellowish brown; nut oblomg, trifuetrons, acute. - Sandy soil near the roast, lilorida, and northword. July - Sept. - Culms $1^{\circ}-1 \frac{1}{2}$ high, acnte-ingled, lonerer than the erect smooth leares. Rays $2^{\prime}-4^{\prime}$ long. Spikelets $6^{\prime \prime}-8^{\prime \prime}$ long. Whole plant yellowish.

13. C. lutescens, Torr. \& IIook. Umbel simple, large, 5-7-riyed, shorter than the 3-5-leaved involncre; spikelets horizontal, flat, linear, 30-40-flowcred, the lowest $2-3$ in a eluster; scales light brown, ulsong-linnecolate, acute, rounded on the bark, slightly spreading at matmity; nut olovate-ol,long; enlms stont $\left(2^{\circ}-3^{\circ}\right.$ high), acute-angled, shorter than the lroally linear leaves. - Kicy West. Nov. - Leares $3^{\prime \prime}-6^{\prime \prime}$ wide, very smooth. Rays $4^{\prime}-8^{\prime}$ lung. Spikelets $\mathbf{l}^{\prime}$ long, $1 \frac{1}{2}^{\prime \prime}$ wide, serrate, the lower ones with a bristly involucel.

14. C. rotundus, I. Umbel simple or componnl, 3-8 rayed, mostly longer than the 3-leaved involuere; spikes composed of 3-9 seattered linear flat 20-30-flowered spikelets; seales oblong, obtuse, appressed, 7 -nerved on the green keel, the membranaceous sides dark chestnut; nut obovate ; culms smooth, slender, longer than the broadly linear erowded sprearling rongle leaves. (C. IIydra, Michx.) - Sandy soil, along the coast, Florida to North Carolina. Aug. and Sejt. - Culm $9^{\prime}-18^{\prime}$ lighh. Rays slender, $2^{\prime}-t^{\prime}$ long. Spikelets $\frac{1}{2}^{\prime}-1^{\prime}$ long.

2. Sparsifiont. Limbel compound: spiliftets compressed, mamy-fowerd, scattercel in loose spilies at the filiform summit of the rays: scales thin, 5-nerred, separate: joints of the rachis slightly margined: stamens 2 .

15. C. Iria, L. Imbel 6-8-rayed, crect, shorter than the 3-4-leaved involucre; spikelets erect-spreading, ollong-linear, 12 -24-flowered; scales sprearling, nearly orbicular, obtuse or emarginate, short-mucronate, 5-nerved on the green $\mathrm{kecl}$, the thin whitish sides minutely pitted ; nut oblong-obovate, abruptly pointed; style very short; culms $\left(1^{\circ}\right.$ high) slender, acute-ingled, longer than the smooth narrow leaves. - Santec Canal, South Carolina, Ravencl. Probably introducel from Eastern Asia.

3. Palmaty. Uinbel compound or decompound, diffuse: spilielets 2-ranlicd, com. pressed, many-foucered, 3-10 in a cluster at the summit of the general and par. tial rays: scales closely imbreated, 3-7-nerced, decurrent on the rachis: sta mens 3 .

* Culms tercte, lnotted, leafless : involucre very short: nut oblong.

16. C. articulatus, L Umbel compound, many-rayed, spreading or re. curved; involuere of three bract-like pungent leaves; spikelets long $\left(\frac{1}{2}{ }^{\prime}-1 \frac{1}{2}{ }^{\prime}\right.$ long), linear, spreading, $30-40$-flowered; scales whitish, oblong, obtuse, 7 -nerved 
on the back, thrice the length of the linear-oblong dnll nut; ritizoma creeping, bearing tubar-like buds; enlms stout $\left(3^{\circ}-5^{\circ}\right.$ higlı), tumid at the sheathed base. - Marshes near the coast, Florida to South Carolina. Aug.-Sept. 4Flowers mostly abortive.

* * Culms 3-engled, hnotliss : incoluire leofy : nut otrovute.

17. C. Haspan, L. Umbel many-rayed, decompound, spreading, the filiform rays mostly longer than the 2-leaved involucre; spikelets small ( $t^{\prime \prime}-5^{\prime \prime}$ long), 3-5 in a cluster, linear, acute, 20-40-flowered; seales light reddishbrown, very sinall, oblong, mucronate, 3-nerved, free at the apex; nut white, round-ohorate, granular-roughened; culms tender, sharply angled; leaves linear, smooth, shorter than the eulms $\left(1^{\circ}-1 \frac{1}{2}^{\circ}\right)$, often reduced to membranaccous sheaths. (C. gracilis, Mulll. C. leptos, Schultes.) - Ponds and ditches, Florida to North Carolina, and westward. July - Sept.

18. C. dentatus, Torr. Umbel compound, erect, 4-7-raved, shorter than the 3-4-leared involncre; spikelets $3-5$ in a cluster $\left(3^{\prime \prime}-7^{\prime \prime}\right.$ long $)$, ovate-oblong, obtuse, flat, 12 -30-flowered; scales orate, acute, compressed, 7-nerved on the green keel, membranaceous on the reddish brown sides, spreading at the apex; nut minute, round-obovate, whitish; rhizoma creeping, bearing tubers; culms slender $\left(1^{\circ}\right.$ high $)$, obtuse-angled, longer than the rigid keeled leaves. Sandy swamps and banks, South Carolina, Torrey, and nortliward. Sept. I - Rays 1'-2' long.

19. C. Lecontii, Torr. Umbel compounl, erect, 6-12-rayed, slorter than the 3-leaved involucre; spikelets commonly three in a cluster, oblong or linear-oblong, obtuse, flat, $30-7\left(0\right.$-flowered $\left(3^{\prime}-1^{\prime}\right.$ long) ; seales closely imbrieated, ovate, obtuse, compressed, yellowish, faintly 7-nerved, appressed at the apex; nut minute, round-oborate, blackish; culms rigil, obtuse-angled, as long as the rigid leaves. - Low sandy places along the coast, East and West Florida. July - Sept. $\quad$ \& - Rhizoma creeping Culms $6^{\prime}-12^{\prime}$ high. Rays $2^{\prime}-6^{\prime}$ long. Rachis with very short joints. Whole plant pale straw-color.

4. Glow ERatr. l'mbel srmple or compound: spilielets many-flowered, compressed, numerous in a rluster, forming more or less dense hrads at the summit of the common and partial rays: raclus wingless: stamen solitary.

* Uinuel compound: spikelets ovate or oblong, fat : scales 3-nerved, concave on the buck, acute: nut minute, lanceolate or oblong.

20 C. virens, Michx. Umbel spreading, compound, many-rayed; involucre 4-6-leaved, many times longer than the umbel; spikelets $\left(4^{\prime \prime}-6^{\prime \prime}\right.$ long, and about 20 in a cluster) oblong, 30-40-flowered, pale green ; seales oblonglanceolate, straiglit; nut lanceolate. aente at each end; culins stout $\left(2^{\circ}-4^{\circ}\right.$ high), rough-anglerl ahove; leaves broad, elongated, reticulated, rough on the margins. Miry places, Florida to North Carolina July-Sept. \&-Plant pale green. Rays $3^{\prime}-4^{\prime}$ long. Spikelets turning yellowish.

21 C. vegetus, Willd. Umbel often decompound, many-rayed, widely spreading; involucre 4-leaved, many times longer than the umbel; spikelets short $\left(1 \frac{1}{2} \prime-2^{\prime \prime}\right.$ long), ovate, $10-15$-flowered, very numerous in the heads ; scales 
laneolate, incuverl, sprealing at the apex, nut minute, linear-lanceolate, slen-

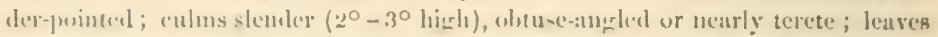

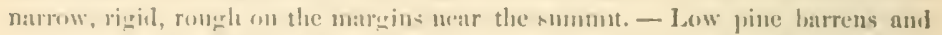

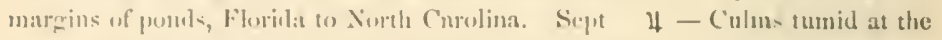

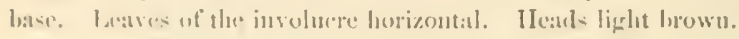

22. C. Drummondii, Torr. Limlel impouml, of $4-6$ primary rays, and ns many smaller ones, slunter than the 4-leswal in rolnere; spikelets $(10-20$ in a cluster) oblung or (blowg-linear, 40-50-flowered; senles rellowish, ovate, Ftratight, free at the apex; nut oblong, pointed, abruptly contracted at the laske,

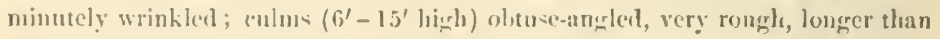
the narrow leares. - Simly swamps, Midlle Florida, and westward. Seqtember. (1)

* Limlu simple or sessile: spilirlets lanceolete or linear, compressed: scales 8-10nerecd, tapering into a long spreading or recurved point: nut obocuteablong: low tufled anmuls.

23. C. inflexus, Muhl. Uinbel of 1-2 short rays or sessile, much slorter than the 2-3-leaven involucre; spikelets very mumerous in the clusters (green), obloner-linear (2" long), 10-20-flowered; seales thin, oblong, 8-nerved, gradually pointerl; culms weak, acute-angled $\left(2^{\prime}-6^{\prime}\right.$ ligh), as long as the "smooth narrowly linear leaves. - Low sandy places, A palachicola, Florida, (apparently introducel;) to North Carolina, and northward. July - Sept. - Slieaths of the leaves green.

24. C. confertus, Swartz. Uinbel of 1-2 short rays or sessile, shorter than the 2-leated involucre; spikelets $8-20$ in a cluster, lanceolate, 12-20-flowered, reddish lorown ( 3 "long); scales rigrid, oblong, 10-nerved, abruptly pointed; culms acute-anerferl ( $1^{\prime}-4^{\prime}$ lighh), as longr as the linear smooth leares; slucuths dark brown. - South Florida. Norember. Spikelets less erowded than in the precerling.

5. Canitatr. Iintrel simple or sessile: spikelets inserted on all sidrs of the common rachis, forming clusters or heads: joints of the ruclus mostly uinged: scules rigid, 5-11-nerved: stamens 3 .

\section{* Spikelets few in loose clusters.}

25. C. filiformis, Swartz. Clusters sessile; spikelets 6-12, erect, terete, subulate, 6-12-flowered; scales seattered, appressed, oblong, mucronate, finely nerver; rachis very slender, flexuous; nut oblong, acute; eulms tufted, filiform, acute-angled, longev than the bristle-like leaves; involucre 2-leaved, the lower one elongated and erect. - Key West. Norember \& - Culms $4^{\prime}-10^{\prime}$ high, tumid at the hatse. Spikelets $4^{\prime \prime}-6^{\prime \prime}$ long.

26. C. complessus, L. Umbel simple or compound, often sessile, shorter than the 4-6-Icaverl involucre; spikelets sprealing, linear, flat, 12-30-flowered; scales orate, acuminate, elosely imbricated, keeled, nut broadly obovate, acutcangled, black and shining; culms ohtuse-angled, longer than the pale green leares. - Cultirated grounds, Florida to North Carolina, and westward. July Sept. (1-Culms $4^{\prime}-12^{\prime}$ ligh. Umbel spreading, sometimes reduced to few 
spikatets or a single one. Spike'ets somewhat glancons, $4^{\prime \prime}-6^{\prime \prime}$ long, serrated by the projecting points of the seales.

27. C. trachynotus, Torr. Umbel simple, of 3-5 short erect rays; in volucre elougrated, 3-leavel ; spikelets several in a eluster, laneeolate, compressed, 12-20-flowered; scales whitish, ovate, aeuminate, loosely imbricated in fruit, hispid-serrulate on the keel, the broad margins embracing the pear-shaped acutely angled nut; culm flattened on one side, rounded on the other, as long as the slender keeled leaves. - Dry sandy soil, South Florida. May-Nor, - Culms $y^{\prime}-15^{\prime}$ high, straw-color, like the leares. Spikelets $\frac{1}{2}$ long.

\section{* * Spikelets numerous in rompact globular or oblong heads. \\ - Peremials: culms tumid or tuberous at the base.}

28. C. fuligineus, n. s]. Head solitary, globose, shorter than the 2-leaved involucre; spikes lanceolate, acute, compresserl, 8-12-flowered; scales (black) ovate, obtuse or emarginate, mucronate; nut oblong-obovate; ('ulms filiform, obtuse-angled, thrice the length of the narrow rigid leaves. - Key West. November. - Culms $\frac{10}{2}-1^{\circ}$ high. Sheaths of the leaves blackish. Head $5^{\prime \prime}$ in diameter. Scales 9-nerved.

29. C. filiculmis, Vahl. Umbel of 1-2 spreading rays or none; involucre 3-4-leaved; spikelets $15-20$, in a dense globose head, linear-lanceolate, 6-10-flowered; joints of the rachis barely margined; scales (greenish) ovate, obtuse or emarginate, short-ıncronate, loosely imbricated ; nut obovate ; culms $\left(10^{\prime}-15^{\prime}\right.$ high $)$, slender, wiry, longer than the linear leaves. (C. marisenides, Ell.) - Dry sandy soil, Florida, and northward. July - Sept. - Heads $\frac{1}{2}$ in diameter.

30. C. Grayii, Torr. Umbet of 4-6 erect rays, shorter than the 3-4leared inrolucre; spikelets $6-9$ in a rather loose liead, linear or linear-lanceolate, 5 - 7-flowered; joints of the rachis winged; scales (brownish) closely imbricated (spreading in fruit), ovate or oblongr, obtuse; nut obovate; culms ( $8^{\prime}$ $12^{\prime}$ high) filiform, wiry, longer than the bristle-shaped leaves. - Dry sandy pine barrens, Florida, and northward. Aug. and Sept.

31. C. ovularis, Torr. Umbel 3-6-rayed, rarely wanting; heads small, clobose or oblong; spikelets (1 $\frac{1}{2}{ }^{\prime \prime}-2^{\prime \prime}$ long) angular, obtuse, 2-4-flowered ; scales ovate-oblong, obtuse, mucronate, closely imbricated; nut oblong; culms filiform, smooth; rather acute-angled, much longer than the rigid filiform leaves. (Mariscus ovularis, Fahl. M. cylindricus, Ell.) - Wet or dry soil, Florida, and northward. Aug. and Sept. - Culms $\frac{1}{2}{ }^{\circ}-2^{\circ}$ high. Heads $2^{\prime \prime}-3^{\prime \prime}$ in diameter.

32. C. retrofractus, Torr. Umbel of about 8 slenter $\left(2^{\prime}-6^{\prime}\right.$ long $)$ rays, longer than the involucre; heads obovite; spikelets subulate, reflexed, terete; scales 4-5, the two lower ones ovate and empty, the mper lanceolate, acute: nut linear-oblong: culm tall $\left(2^{\circ}-4^{\circ}\right)$, downy and roughish, like the broadly linear leaves. (Mariscus retroftactus, Vahl.) - Barren sandy soil, Florida, and northward. July - Sept. - Leaves much shorter than the culm.

$$
++ \text { Annuals: roots filrous. }
$$

33. C. Baldwinii, Torr. Uinbel 6-12-rayed, shorter than the involucre; heads globose or oblong; spikelets linear, somewhat compressed, acute, 6-12- 
flowered ; seales (erreenish or yollowish) ollong, altuse, muclonate, closely inbrieated; mut oblong; (alms $\left(1^{\circ} . .20\right.$ higrli) ohense-angled, longer than the linear leaves. (Mariserus echinatus, Ell.) - Cultivated ground, Floridat to Nortl Caro. lina, and westward. July - Sept. - Spikelets $3^{\prime \prime}-6^{\prime \prime}$ long.

34. C. divergens, Kimtl. Umbel none; heal grobore, slorter than the 4-leaved involucre; spikclets ovate-lanceolate, flat, acute, 5-7-flowered; scales ovate, mucronate, compressed-keeled, 7 -nerred, the searions silles hroally decurrent ; style decply 2-3-partel ; stunens 2-3; nut (immature) ohlomer, lenticular or 3-ingled; culms low $\left(2^{\prime}-3^{\prime}\right)$, tufted, obtuse-angled, shorter than the smooth kecked leaves. - Damp cultivated gromuls, (Quincy, Niddle Florida. Augu-t. - IIeal $3^{\prime \prime}-4^{\prime \prime}$ in diancter, composed of $3-4$ compact clusters; spilielets I" long, white.

\$3. PAPYLUS. Style 3-aleft: nut 3-angled: scals of the rachis at length free and decidious. Infiorescence us in No. 7 .

35. C. erythrorhizos, Mfuhl. Umbel 3-12-raycul, simple or compound, shorter than the 3 -lo-leavel involuce ; spikelcts very numerons, narow-linear, compressed, spreading, 12-50-flowered; scales mimue, oblong-ovate, obtuse, greenish and faintly neved on the back, yellowish and grlony on the sides; beales of the rachis lancelate, acute; nut oval, compressed-3-angled, smooth and shining; culms obtuse-angled; leaves rough on the margins, pale beneath: involucels leafy, longer thin the spikes. (C. tenuiflorus, E./l.) - Ponds and ditches, Forida, and northward. July - Sept. (1) - Culms $\frac{10}{2}-4^{\circ}$ high. Leaves $1^{\prime \prime}-14^{\prime \prime}$ wide. Spikelets $2^{\prime \prime}-8^{\prime \prime}$ lung.

\section{KYLLINGIA, I.}

Spikelets compressed, mostly 1-flowered. Seales commonly 4, inhrieated in two rows, the two lower ones small and empty, the thirl perfect, the fourth imperfect. P'erianth none. Stamens 1-3. Style elongated, 2-cleft. Nut lenticular. - Culms jointless, 3-angled, leafy at the base. Inrolucre 3-5-leaved. Spikelets collected in single or chustered sessile heals. Plants ollorous.

1. K. pumila, Michx. IIeals (green) mostly 3, globose or ovate ; spikelets 1 -fowered, ovate-lanceolate, acute at each end; seales 3 , the lowest minute, the middle one ovate, compressed, mucronate, mostly serrulate on the keel, enclosing the upper one; nut olwvate; stamens 2; culms weak, acute-angled; leaves and 3-4-leaved involucre linear. - Wet places, Florida to North Carolina. July-Sept. (1)-Culns tufted, $4^{\prime}-10^{\prime}$ high.

2. K. sesquiflora, Torr. Heads (white) $1-3$, ovate or oblong; spikelets ovate-oblong, achte, l-flowered, or imperfectly 2-flowered; scales $4-5$, the two lower ones minute, the third and form alike, ovate, acute, smooth, the tifth enclosed in the fonth; stamens 2 ; nut obovate; culns erect, obtuse-angled ; leares and 3-5-feaved involuere broadly linear. - Low exposed places and along roads, Mirlde Florirla. Aug.-Sept. \&-Culms 4'-12' high. Plant pale green, pleasant-scented. 
3. K. monocephala, L. "Heads single, globose, compact; spikelets 1-flowered, monandrons, ovate, acuminate, the 2 superior seales striate, nearly smooth on the silles, serrulate-ciliate on the keel, the 2 inferior minute; nut somewhat orbicular; involncre 3-leived, one of the leaves erect, the others horizontal." Torr. - Low moist places near Darien and Sumbury, Georgia - Rhizoma creeping Culms $1^{\circ}$ high. Head greenish, generally inclined. Leaves abruptly pointed.

\section{DULICHIUM, Richard.}

Spikelets linear, compressed, many-flowered. Scales imbricated in 2 rows, decurrent on the joints of the rachis. Perianth composed of $6-9$ downwardly hispid rigid bristles. Stamens 3. Style 2-cleft. Nut lanceolate, compressed, long-beaked. - Perennial. Culms terete, jointed, leafy. Iseaves numerous, 3-ranked, linear or lanceolate, short and sprealing. Spikes mumerous, solitary in the upper axils, simple or the lower compound. Spikelets 8-14, 2-ranked, spreading, 6-10-flowered. Scales lanceolate, many-nerved, closely imbricated. Bristles nearly twice as long as the compressed or coneave nut.

i. D. spathaceum, Richarl. - Ponds and ditches, Florida, and northward. Aug. - Sept. - Culms $1^{\circ}-2^{\circ}$ high. Leaves $1^{\prime}-3^{\prime}$ long. Spikelets $6^{\prime \prime}-$ 12" long. Peduncles of the lower spikes longer thin the sheaths.

\section{HEMICARPHA, Nees.}

Spikes many-flowered, orate, one or few in a terminal (apparently lateral) cluster. Scales inbricated in many rows, ovate or ohovate. Inner seale single, behinil the flower, very thin, minute. Perianth none. Stamens 1-2. Style 2-cleft. - Small tufted annuals with naked culns, narrow radical leaves, and an erect mostly 1-leared involncre.

1. H. subsquarrosa, Nees. Culms erect, nearly terete $\left(2^{\prime}-4^{\prime}\right.$ high $)$; leaf solitary, linear-subulate, concave, smooth, shorter than the culm; -involncre 1-2-leaved, the lower one erect and continuous with the culm, mucli longer than the spikes, the other short and reflexed or wanting; spikes 2 (rarely one), scemingly lateral; seales brown, orate-oblong, reticulated, the stont and greenish midrib prolonged into a thick and obtuse erect point; stamens 2; style deeply 2-parted, smooth; nut ohlong-oborate, minutely pitted in lines. - Low sandy places, Florida, and northward. Ang. - Sept. - Sheaths brown. Spikes $2^{\prime \prime}-3^{\prime \prime}$ long.

\section{LIPOCARPHA, R. Brown.}

Spikes many-flowered, terete. Scales spatulate, imbricated in many rows, deciduous, the lowest empty. Interior scales 2, parallel to the exterior ones, inenubanaceous, enclosing the flower and mut. Stamens 1-2. Style 2-3-cleft. Nut compressed, 3-angled. - Culms jointless, leafy at the base. Spikes in a terminal cluster. Irvolucre leafy.

1. L. maculata, Torr. Anmual; culms chrstered, terete; leaves much shorter than the culm, linear, concave, smooth ; involucre 2 -6-leaved, spreading 


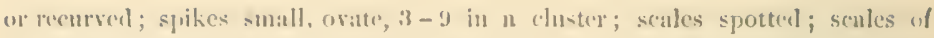
the perianth very thin, the nerves at length fore and bristle-likic belosv; nut oblongr, contracted into a short neek. (Ki yllingin unaculat:a, Jichex.) - Spriagy or miry places, Filorila to North Carolina. July-Sept. - Culms $4^{\prime}-8^{\prime}$ high. Spikes $1^{\prime \prime}-2^{\prime \prime}$ long, green.

\section{FUIRENA, Rotth.}

Spikes many-flowered. Seales imbricated in many rows, awned at the apex. Perianth consisting of three petal-like stalked scales alternating with as many hristles. Stamens 3. Style 3-cldeft. Nint 3-ingled, raised on a stalk, and pointed with the persistent base of the style. - Culms terete, jointel. Spikes single or clustered, latteral ant terminal. Seales hairy.

1. F. scirpoidea, Valıl. Rhizouna thick ant crepping; culms slender; leaves reducel to pointer sliesths, smootl, spikes $1-3$, termiulil, ovate, supported by a small linct-like involuere; scales obovate, 9-nerved, pointerl with a short erect awn; stalks of the oval barely pointed petal-like seales longer than the hispid bristles. - Wet sambly places, near the coast, Florida and Georgiit. May Scpt. $4-$ Culms $1^{\circ}$ high.

2. F. squarrosa, Michx. Culns clustered, smootl, or pubescent near the summit; leaves flat, linear or linear-lanceolate, the murgins, like the lower sheatls, hairy; spikes oblong, in lateril aml terminal clusters; seales oblongobovate, with the long pale awn reenred; petal-like scales ovate, acute; bristles ns long as the stalk of the oborate nut. - Var. mapms. (F. hispida, Ell.) Jeaves, sleaths, and upper portion of the culm bristy-hairy; petal-like seales acuminate; bristles nearly as long as the nut. - Swamps, Florida, and northward. Jnly - Sept. 4-Culms $\frac{10}{2}-2^{\circ}$ high. Leaves $2^{\prime}-5^{\prime}$ long. Terminal dinster occasionilly compound.

\section{ELEOCHARIS, R. Brown. Sriki-Rusir.}

Spikes many- (rarely 2-4-) flowered. Seales imbricated on all sides of the rachis, or somewhat 2-janked, the lowest nsually empty, loract-like, and persistent. l'erianth of $3-8$ hearded bristles, oceasionally wanting. Stamens $1-3$. Style 2 -3-clleft. Nut compressed, biconvex, or 3-angled, erowned with the persistent jointerl lasse of the style (tubereled). - Commonly peremials, with ereeping rootstocks. Culms jointless, leafless, sheathed at the base, bearing at the apex a single spike.

\$1. ELEOCHARIS Proper. Spikes many-fowered: scales imbricated in several rous.

* Spilies cyludrical, scatrely thesker than the soft rellular rulms: mut brconiex, pitted or urinkiled in longutudinal lines.

- Scales rounded, thick and fainely nerwed : style 3-cleft : brastles ti, sparingly bearded or smoothish, as long as the mut. (Limnochloa, Nees.)

1. E. equisetoides, Torr. Culms stout, terete, knotted by cross partitions, roughish; scales pale, round-svate, obtuse or the upper acute, searious on 
the margins; bristles hispid; nut pale brown, obseurely wrinkled, shining, crowned with a sessile conieal-beaked aeute tubercle. (Scirpus equisetoides, Ell.) - Ponds, Florida, and northward. July-Sept. 4-Culms $1^{\circ}-2^{\circ}$ high, $3^{\prime \prime}$ in liameter. Sheaths brown. Spikes $1^{\prime}$ long.

2. E. quadrangulata, R. Br. Culms unequally 4 -sided, with the angles acute; scales pale, roundish, very obtuse, searious on the margins; bristles slender, bearded, nnequal; nut broadly obovate, finely pitted, dull white; tuberele ovitte or eonical, free around the base, much shorter than the nut. (Scirpus quadrangulatus, Michx.) - Ponds and ditehes, Florida, and northward. July Sept. 4-Culm $2^{\circ}-3^{\circ}$ high $1^{\prime \prime}-2^{\prime \prime}$ in diameter. Sheaths purplish. Spikes $1^{\prime}$ long.

3. F. cellulosa, Torr. Culms obscurely 3-angled below, terete above; seales pale brown, round-obovate, white and scarious on the margins; bristles rather rigis, nearly or quite smooth; nut oblong-obovate, conspicuously pitted, narrowed into the eonical (at length flattened) tubercle. - Narshes, Apalachicola, Floridil, and westward, near the coast. Ang. and Sept. 4 -- Rootstocks creeping, slender. Culms $1^{\circ}-2^{\circ}$ high, $1 \frac{1}{2} \prime \prime$ in diancter. Lpper sheath elongated. Spikes $\frac{1}{2}-1^{\prime}$ long, spirally twisted.

+ + Scales oblong, nerved on the back, thin on the margins: style 2-3-cleft: bristles 7 , stronyly beardcd, longer than the nut.

4. E. Robbinsii, Oakes. Culms ereet, rather slender, acntely 3-angled, intermixed with laar-like abortive ones; spike 6-8-flowered, acute; scales greenish, obtusc, rather distant on the flattencel rachis, closely imbricated; style 2-cleft; bristles unequal, as long as the nut and tubercle; nut ( 1 "long) deeply pitted in lines, scarcely shorter than the subulate tubercle. - Shallow ponds, near Quiney, Florida, and in Now England, Oakes, Ohney; but not as yet detected at any intermediate point. Aug. - Rhizoma filiform. Culms $6^{\prime}-12^{\prime}$ high. Spikes $\frac{11}{2}$ long.

5. E. elongata, n. sp. Culms floating, slendes, terete, mingled with hairlike abortive ones; spike 12-20-flowered, acnte; seales rather distant on the compressed rachis, oblong-ovate, obtuse, green on the baek, dark brown on the sides; style 3-parted ; bristles rather longer than the obovate biconvex or somewhat 3-angled fantly pitted nut; tubercle minute. - In still watter, near A palachicola. July. 4 - Rootstocks filiform. Culms $2^{\circ}-3^{\circ}$ long, all but the summit immersed. Spikes $6^{\prime \prime}-9^{\prime \prime}$ long. Nut $\frac{1}{2}$ l long.

$$
\text { * * Spikes thicker than the culm: style 3-clcft: nut 3-angled. }
$$

+ Bristles 6, us long as the nut and tubercle: nut longitudinully furrowed and pitted.

6. E. tuberculosa, R. Br. Culms somewhat compresserl, touth :mal wiry; spikes pale, ovate or oblong, acute; s'ales oblong, rigid, 1-nerved; nut obovate, as large as the ovate compressed 3 -angled tubercle; bristles riginl, hispid. - Varies with larger spikes and pubeseent bristles. (Scirpus tubereulosus, Michx.) - Wet places, chicfy along the eonst, Florida, and northward. March - Sept. 4 -Culms $6^{\prime}-12^{\prime}$ high. Spikes $3^{\prime \prime}-4^{\prime \prime}$ long $\left(6^{\prime \prime}-8^{\prime \prime}\right.$ in the var. $)$. Nut shining. 
๖. E. simplex, Torr. Culms unęually 3-sicleıl, urutr-angled ; spikes slurt, ovate, an'ute; scales ovatte-oblong, whitish, with brownish side's; nut whorate, flat on the inner fine, twice as long ats the conical-benked compressed

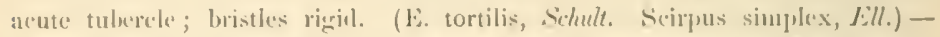
Miry places alone streams, Florida to North Camolina. May-Sept. If Culus $1^{\circ}-11^{\circ}$ high, very slemler, twisted when dry. Spikes $2^{\prime \prime}-3^{\prime \prime}$ long, angular, few-fluweresl.

8. E. prolifera, Torr. (Cyp. p. 315, not of p. 442). Culms filiform, diffuse or prostrate, compressed; spikes orate-lanceolate, acute, proliferous or rooting; scales whitish, thin, oval, obtuse; nut obovite, compressed-3-angled ; tulerele half as long as the nut, conical, 3-angled, free at the base; brintles stout. (E. vivipara, $I_{\text {ink }}$ ) - Marshy banks of ponds and streams, filoridlat to North Carolina. May-Sejt. $4-$ Culuns $10^{\prime}-20^{\prime}$ long, tough and wiry. Spikes $2^{\prime \prime}-4$ "long, very rarely fruiting.

$$
\text { + + Bristles 4-6, longer than the smooth nut. }
$$

9. E. intermedia, Torr. Culms bristleform, diflise, furrowel; spikes ohlong-ovate, acute, 8-10-flowered; scales ovate-lancelate, rather acnte, thin, brown on the sirk'; nut (yellowish) obovate, narrowerl at the base, flat on the inner face, beaked with the subulate tubercle; lristles 6 , stont, as long as the nut and tubercle. - Wet places and in shallow streams, Georgia, and northward. - Culms $\frac{10}{2}$ long. Spikes $2^{\prime \prime}-3^{\prime \prime}$ long. Nut minutely striate.

10. E. albida, Torr. Cuhus terete, spongy ; spikes pale, oval or ol,long, obtuse, many-flowered ; scales rigid, oval, whtnse, white or brownish ; nut brondly ohovate, whitish, flat on the inner face, smooth and shining; tulercle minute, free at the base; lnistles 6 , reddish, longrer than the nut. - W aloug the coast, Florida to South Carolina, and westward. May-Sept. 4 Khizoma filiform, creeping. Culus $2^{\prime}-6^{\prime}$ high. Spikes $2^{\prime \prime}-3^{\prime \prime}$ long.

11. E. rostellata, Torr. Culms compresserl, furrowerl, wiry ; spikes ovate-lauceolate, al'ute, 12 - 20-flowercel; sciales rigil, oval, obtuse, light brown; nut ohorate, flat on the imer face, tapering into the conical-benked tubercle; bristles 4-6, stunt, twice as long as the mut. - South Carolina, and northward. - Culms $1^{\circ}-1 \frac{1}{2} 0$ high. Splikes $3^{\prime \prime}-4^{\prime \prime}$ long.

$$
\text { + + + Bristles 2-6, not exceeding the mut, often wanting. }
$$

12. E. melanocarpa, Torr. Culms compressed, furrowed, tongh and wiry; spikes ovate or ovate oblong, obtase, many-flowered; seales thin, orate, oltuse, white on the broad margins; style 2-3-eleft; nut black, ohconical, 3angled or biconvex, trumcate at the apex, and capped with the triangular minutely pointel white tuberele; bristles 3 , as long as the mut, sometimes wanting. - Pine-burren swamps, Florida, and northwarl. June-Sept 4 -Culns $1^{\circ}-1 \frac{10}{2}$ high. Spikes $4^{\prime \prime}-5^{\prime \prime}$ long, $2^{\prime \prime}$ thick, occasionally proliferous.

13. E. arenicola, Torr. Rhizoma long and ereping; culms slender, slichtly (ompressed, striate, tough and wiry ; spikes ovate, or at length ohlong or erlindrical, obtuse, many-flowered ; scales thin, oblons, obtuse, brown at the summit, white on the margins; nut (yellowish) oborate, compressed-3-angled, 
contracted into a neck at the base of the short conical-beaked tuberele; bristles 4-6, realdish, not longer than the mut. - Sandy sea-shore, West Florida to South Carolina. May-Sept. \& - Thizoma and sheaths hlack. Culms $6^{\prime}-$ $15^{\prime}$ high. Spikes $3^{\prime \prime}-6^{\prime \prime}$ long, occasionally $2-3$-cleft. Nit minutely pitted.

14. E. tricostata, Torr. Rhizoma stout, creeping; eulms nearly terete, striate, wiry; spikes cylindrical-oblong, acutish, many-flowered; scales thin, oblong, green on the keel, dark lrown on the sides, white on the margins; mut ohovate, with strong and rib-like angles, contracted into the minute conical tuberele; bristles none. - Low pine barrens, Florida, and northward. MaySept. $\quad 4-$ Rhizoma and sheaths pale. Culms $1^{\circ}-1 \frac{10}{2}$ ligh. Spikes $2^{\prime \prime}-t^{\prime \prime}$ long. Nut very small, minutely wrinkled.

15. E. tenuis, Schultes. Culm; filiform, acntely 4-angled, the sheaths purple ; spikes elliptical, obtuse or acute, many-flowered ; scales oblong, obtuse, green on the keel, dark brown on the sides, white on the margins; nut olsovate, 3-angled, transversely wrinkled and pitted, erowned with the broat depressed short-pointerl tubercle; lristles $2-3$, mnels shorter than the nut, fugacious. Wet places, North Carolina, and northward. - Culus $8^{\prime}-12$ l high, almost bristle-form. Spikes $3^{\prime \prime}-4^{\prime \prime}$ long. Nut prale brown.

16. E. microcarpa, Torr. Culms bristle or hair-like, 4-angled; spikes ovate or oblong, obtuse, 10-many-flowered, often proliferons; scales oblong, obtuse or acutish, membranaceous, brownish, with white margins; nut very minute, white, olovate, rounded at the apex, and crowned with the depressed minntely pointed tuberele ; bristles $3-6$, rarely as long as the nut, occasionally wanting.

Var. ? filiculmis, Torr. Spikes many-flowered, dark brown ; nut obovateoblong, narrowed at the apex, and crowned with the conical 3-angled tubercle; bristles rigid, rather longer than the nut. - Low sandy places, Florida to North Carolina, and (the var.) northward, chiefly near the coist. May- Sept. Culms tufted, $3^{\prime}-9^{\prime}$ liggl. Spikes $1^{\prime \prime}-2^{\prime \prime}$ long. Lowest scale larger and persistent. Nut strongly 3-anglel.

$$
\begin{aligned}
& \text { *** Spikes thicker than the culm: style 2-3-cleft: nut lenticular. } \\
& \text { +- Culms t-angled, bristle-like. }
\end{aligned}
$$

17. E. bicolor, 11. sp. Culms erect or procumbent, 4 -angled or 4 -furrowed; spikes ovate, obtuse, 8-12-flowered ; scales thin, loosely imbricater, ovate, obtuse, white on the keel and margins, the sides dark brown; style 2-3-cleft ; nut very minnte, white, obovate, lenticular, smooth, twice as long as the three fugacious bristles; tubercle broally conical, compressed, one third as long as the nut. - Sandy margins of ponds, near Quiney, Florida. Aug ( - Cuhns tufted, $1^{\prime}-6^{\prime}$ long, when growing in water finely knotted. Spikes $1 \frac{1}{2}{ }^{\prime \prime}$ long.

18. E. multiflora, n. sp. Culms tufted, erect, 4 -furrowed, the sheaths dark brown; spikes ovate or oblong, obtuse, at length rery many- (70-100-) flowered; seales oval, very obtnse, thin, brown on the sides, white on the margius; stamens 2; style 2-eleft; nut very minute, pear-shaped, compressed, almost truncate at the apex, tipped with the somewhat peltate tuberele; bristles 
none. - Margins of pouds and strenms, Weint Florida. June-Aug. (1)Culus $3^{\prime}-5$ liph. Sprikes $1^{\prime \prime}-2^{\prime \prime}$ loner, the lower seales derilnous as new flowers are developed. Nut black, smooth and shining.

+ + Culms terete wi rompressid, wore or liss spmomy.

19. E. capitata, R. I3rown. lihizoma slenter, croping; enlons compressed; spikes slort, orute, 12-16-flowerel; seales menbranaceous, whitish, ollener, obtuse, deciluons; nut black and shinime, broally obovate, biconvex, tipened with the short conient tuherele; liristles 6 , as long as the nut. - Springy or miry places, Florida, Gorgria, and westwart. June-Sept. \&-Culus $1^{\prime}-4^{\prime}$ high. Spikes $1^{\prime \prime}-2$ "long. Scales often brown when young. Nint very small.

20. E. olivacea, Torr. Culms rompressed, furrowel, diffuse; spikes ovate, acntish, many-floweret; scales ovate, obtuse, thin, purplish on the sieles, green on the keel, the margins white; nut olovate, dull, dark olive; tulnerele distinct, conical-beaked; bristles $6-8$, about half as long as the nut. - Wet sandy places, North Carolini, and northward. Aug. aud Sept. - Culns 2'-5' long. Spikes $3^{\prime \prime}$ longr, 20-30-fluwered.

21. E. palustris, R. Brown. Rhizoma creeping; eulıns slender, terete, striate; spike's obloug-lanceolite, mostly acute, many-flowered; seales ol,long, membranaceous, brown on the silles, at Iength whitish, the upper ones acute; nut dull sellow, obovate, tmmid, minutely dotted; tuberele short, triangularovate, compressed ; bristles 4, slender, commonly as long as the nut. (Scirpus palnstris, L.) - Marshes and wet places, Florida, and northward. June-Sept. 4 - lilizoma black. Culms $1^{\circ}-3^{\circ}$ long. Spikes $3^{\prime \prime}-5^{\prime \prime}$ long.

22. E. obtusa, Schultes. Cnlms tufted, terete, thick and spongy; spikes orate or oblong, obtuse, many-flowered; scules thin, oblong, obtuse, commonly brown on the sides, green on the keel, with broad and white margins; style 2-3-cleft; nut (ligrlt hrown) obovate, lenticular, smooth amd shining, scarcely wider than the short compressed arute tuherele; bristles 6 , rigill, wice the length of the nut. (Scirpus capitatus, Ell.) - Muddy margins of ponds and streams, Florida, and northwarl. Common. June-Sept, - Culms $6^{\prime}-18^{\prime}$ high. Spikes $2^{\prime \prime}-4$ "long.

\$2. CHLATOCYPLRUS. Spilies few-flowered, compressed: scales memibranarcous, imbricated in 2-3 rous: style 3-cleft. C'ulms capllary.

23. E. acicularis, R. Br. Culms $\left(2^{\prime}-12^{\prime}\right.$ lighl $)$ angled; spikes ovate, 5-6-flowerell, aente; seales ohlong, with redlish sides; nut oblong, white, nearly tercte, longitmlinally ribled and pitted, pointed with the conieal or depressed tubcrcle; lorisiles $3-4$, shorter than the nut, sometımes wanting. (Scirpus trichodes, I/ull.) - Mingins of ponds, Florida, and northward. JuneSept.

24. E. pygmæa, Torr. Cnlms short $\left(1^{\prime}-2^{\prime}\right.$ high), grooved on one sile; spikes orate, 3-6-flowered; scales whitish, ovate; nut ovate, pale, prominently 3-angled, smooth and shining, varrowed above into the minute tubercle; bristles 6, longer than the nut, sometimes wanting. (Scirpus capillaceus, Ell.) - Mudely 
or sandy banks near the const, Florida, and northward. April-July. - Rhizoma very slender, bearing minute tuber-like buds. Spikes $1^{\prime \prime}-2$ "long.

25. E. Baldwinii, Torr. Culms $\left(4^{\prime}-6^{\prime} \operatorname{long}\right)$ grooved, diffuse, wiry ; spikes oblong, flat, 3 -5-flowered, proliferons and rooting; scales 4-6, 2-ranked, lanceolate, obtuse, finely nerved, the lower ones longer; nut smootls, oblong, strongly 3-angled, crowned with the conical 3-angled sessile tubercle; bristles $4-6$, unequal, the longest as long as the nut. - Swamps, Florida and Georgia. June-Sept. 4-Sheaths light brown. Spikes 2 "long.

\section{SCIRPUS, I. Bulrush.}

Spikes terete, single, or oftener in clusters or umbels, which are subterided by a 1 -many-leaved involucre. Scales imbricated in several rows. Nut obtuse, or pointed by the persistent jointless base of the style. Tubercle none. - Culms jointcd and leafy, or leafy or sheathed only at the base. Otherwise like Eleocharis. - All perennial except No. 2.

\section{\$1. Culms jointless: leaves or sheaths radicul. * Spike solitary, terminal.}

1. S. cæspitosus, L. Culms tufted $\left(6^{\prime}-10^{\prime}\right.$ high $)$, terete, wiry; sheaths numerons, rigid, imbricated, the uppermost ending in a short leaf; spike 3-8flowered; involnere 2-leaved, as long as the spike, pointed; nut oblong, compressed-3-angled, abruptly pointed, half as long as the smooth capillary bristles. - High mountains of North Carolina, and northward. July. - Rhizoma thick and creeping. Spike $1 "-2$ " long.

* Spikes 2-many, apparently lateral: the 1-leaved incolucre erect and continuous with the culm.

\section{+ Spikes in sessile clusters.}

2. S. debilis, Pursh. Culms terete, slender, commonly leafless; spikes $2-5$, oblongrovate or cylindrical; inrolucre elongated; scales round-ovate, obtuse mucronate; style 2-3-cleft; nut broadly obovate, plano-convex, smooth, shorter than the 4-6 strongly hispid bristles. - Borders of ponds and streans, South Carolina, and northward. (1) - Culms $\frac{1}{2}^{\circ}-1 \frac{1}{2}^{\circ}$ high. Spikes $3^{\prime \prime}-5^{\prime \prime}$ long.

3. S. pungens, Vahl. Culms stout, acutely 3-angled, two of the sides coneave, leafy at the base; leaves channelled, sharply keeled; involucre slender $\left(3^{\prime}-4^{\prime}\right.$ long $)$; spikes $3-6$, light brown, oblong; seales membranaceous, oval, 2-cleft, mucronate-awned, slightly ciliate; anthers slender-pointed; style 2-eleft; nut round-obovate, plano-convex or lenticular, as long as the $3-5$ hispid bristles. (S. Americanus, Pcrs.) - Sandy marslies along the eoast, West Florida, and northward. June-Sept. - Culm $2^{\circ}-3^{\circ}$ high. Leaves 2-3, mostly shorter than the culm. Spikes $4^{\prime \prime}-6^{\prime \prime}$ long.

4. S. Olneyi, Gray. Culms stout, with three-winged angles, and three deeply channelled sides, leafless, or the sheaths ending in short pointed leaves; involucre short $\left(\frac{t^{\prime}}{2}-1^{\prime}\right.$ long $)$ rigid; spikes $7-13$, short, orate, dark brown; scales 
smooth, orliconl:ur, 2-cleft, mueronate; anther's obtuse; style 2-eleft; nut rounel-

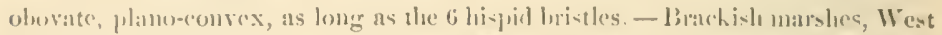

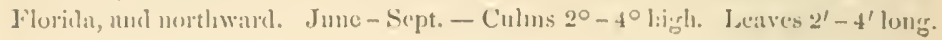
Spikes 2 "lunir.

$$
\text { + + Spritirs umbelled. }
$$

5. S. lacustris, I. Cuhn tall $\left(3^{\circ}-S^{\circ} h_{i}, y h\right)$, terete, leaffess, or the radical sheaths leafy-pointed; involuere 1 -fenverl, puntent, shorter than the decompound umbel; spikes ovate ur oblong, mostly cinstered; seales ovate, cmarginate, roughawned, ciliate on the margins, pubescent on the latck and green kecl; style 2-cleft ; mut obovate, pointerl. plano-convex, shorter than the 3-6 strongly hispicl bristles. (S. validus, J"ahl.) - Varies, with the broader keeled and fiunlriate brislles rather shorter than the romml-obovate nut. - Freh or Juackish marshes and ponds, Floricla, and northward. July-Sept.

6. S. leptolepis. Culms 3 -angled, leafy at the hase $\left(2^{\circ}-3^{\circ}\right.$ high $)$; leaves long, sharply kechel, triangnlar-compressed near the obtuse enred apex, the immerses ones flat and pellucirl; involncre slencler $(\vec{f}$ longr), leaf-like, with shorter ones at the divitions of the compound umbel; spilices single, oblong or evlincirical, many-flowered, acute; seales liphlit brown, lanceulate-oblong, acute, smooth, membranaceons, mucronate, and, like the three ohtuse anthers, fincly spotted; style 3-parted; nut whitish, 3-angled, oblong-oborate, long-pointed, shorter than the 5 slender and minutely denticulate bristles. (S. maritimus, var. cylindrieus, Torr.?) - Lakies and ponds, Middle Florida, and westward. Lr. IIale. September.

\section{\$2. Culms jointcd, leafy throughout: umbel terminal: involucre 2-several-leaved, spreading.}

\section{* Bristles hispid douncard.}

7. S. maritimus, L. Culm sharply 3-angled, rongh above; leaves longer than the culm, keeled; umbel simple, $1-3$-rayed, bearing single or $2-3$ spikes in a cluster, or the spikes all clustered and sessile; involuere $2-4$-leaved, much longer than the unbel; spikes large, ovate or oblong-ovate, dull brown; seales thin, ovate, pulsescent, tipped with a spreading awn; nut round-oborate, planoconvex or lenticular, smooth and shining, twice the length of the 4 weak bristles. - Saline marshes, Florida, and northward. Aug. and Sept. - Culms $2^{\circ}-3^{\circ}$ high. Spikes $6^{\prime \prime}-10^{\prime \prime}$ long, $4^{\prime \prime}$ in diameter.

6. S. polyphyllus, Vahl. Culm obtuse-angled, smooth; leaves long, rough on the margins; umbel dccompound, spreading; spikes small, $3-8$ in a cluster, orate, yellowish-brown; seales orate, mucronate, kecled; lristles 6 , slender, hispid near the summit, mostly tortuous, $2-3$ times as long as the pale compressed-3-angled pointed nut. (S. exaltatus, Pursh.) - Sharly swamps, North Carolina, and northward. July. - Culm $2^{\circ}-5^{\circ}$ high. Spikes $1 "$ long.

9. S. divaricatus, Ell. Culm round-angled, many-jointed; leaves flat, broadly linear; umbel large, widely spreading or drooping, decompound, longer than the 3-leaved involucre; spikes all single, ohlong-linear, scattered; scales ovate, obtuse, 3-nerved, brown on the sides; bristles hair-like, rather roughened than hispid, crisped at tho summit, longer than the obovate pointed equal-sided 
acute-augled nut. - Muddy lanks of the Chipola Rirer, and of Flat Creek, near Aspalaga, Florida, to South Carolina; not common. Aug. - Culm $2^{\circ}-4^{\circ}$ high, often proliferous at the joints. Umbel $6^{\prime}-12^{\prime}$ long. Spikes $2^{\prime \prime}-3^{\prime \prime}$ long.

* * Bristles 6, capillary, smooth, crisped and entangled. (Trichophorum.)

10. S. Eriophorum, Michx. Culm nearly terete, with the joints remote; leaves linear, elongated, keeled; nmbel terminal, decemponnd, spreading or recurved, shorter than the 3-5-leaved involucre; spikes single or elustered, orate; seales thin, lanceolate, obtnse; bristles many times longer than the oblong compressed-3-angled beak-pointed nut, at length exserted, and covering the spike with woolly down. (Trichophorum eyperinum, Pers.) - Swamps and low grounds, Florila, and northward. July - Sept. - Culm $2^{\circ}-4^{\circ}$ high.

11. S. lineatus, Michx. Culm 3-angled; leaves flat, linear-lanceolate; umbels lateral and terminal, longer than the 1-3-leaved involnere; spikes all single, eylindrieal; scales rigid, keeled, mneronate; bristles barely exserted; nut as in the preceding. Swamps, Georgia, and northward. June - Ang. - Culm $2^{\circ}-3^{\circ}$ high. Spikelets $3^{\prime \prime}-4^{\prime \prime}$ long.

\section{ERIOPHORUM, L. Cotton-Grass.}

Spikes many-flowered. Scales imbricated in many rows. Perianth composed of numerons (rarely 6) smooth and flat hairs, mnch longer than the scale, and forming a woolly or silky tuft. Stamens commonly 3. Style 3-cleft, deciduons. Nut 3 -angled or lenticular. - Perennials, witl leafy culms, in our species, and clustered or umbelled spikes.

1. E. Virginicum, L. Culm nearly terete, rigid; leaves narrowly linear, elongated ; spikes densely elustered, nearly sessile, erect; involucre 2-3-leaved; wool reddish, thrice the length of the brownish seales; nut compressed-3-angled, acute. - Bogs and swamps, Florida, and northward. June $-\mathrm{Aug}$. - Calm $2^{\circ}$ $3^{\circ}$ high. Leaves $10^{\prime}-18^{\prime}$ long.

2. E. polystachyon, L. Culm terete; leaves broadly linear, 3-angled at the summit; spikes umbelled, distinet, on slender at length nodding peduneles; involncre 2-leaved, shorter than the umbel; wool white, many times longer than the dark brown scales; nut obtuse. - Meadows and bogs in the upper distriers, Georgia, and northward. Aug. and Sept. - Culm $1^{\circ}-2^{\circ}$ high. Leaves $3^{\prime}-6^{\prime}$ long.

\section{FIMBRISTYLIS, Vahl.}

Spikes many-flowered. Scales imbricated in several rows. Perianth none. Stamens 1-3. Style 2-cleft, commonly flat and fringed on the margins, tumirl at the base, deciduous. Nut lenticular. - Culms jointless, leafy at the basc. Involucre 1 -several-leaved. Spikes terminal, umbellate or clustered.

\section{* Spikes umbelled.}

1. F. spadicea, Vahl. Perennial; culms clustered, nearly terete, rigid $\left(2^{\circ}-3^{\circ}\right.$ high $)$; leaves long, linear or filiform, concave, rough on the matrgins; umbel simple or compound, ereet; involucre 2-3-leaved; spikes ovate or ob- 
longr, dark bown; scales smooth, rigist, rounded; nut olovate, acwere, slightly

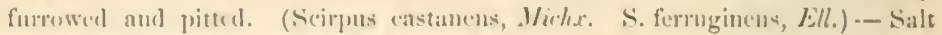
maxlues, Floricla, and nomtliwarl. Sug. - Oet.

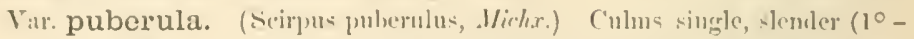
$2^{\circ}$ high); leares filiform, iurolute, and, like the spikes, densely pubescent and somcwhat hoary; nut round-obovate, obtuse. - Low pine barrens.

2. F. laxa, Valıl. Annual; culms $\left(6^{\prime}-18^{\prime}\right.$ lighlı) slenter, anıl, like the narrowly linear leaves, often puluescent; umbel mostly simple; involure $2-4$ leared; spikes oblong-ovate; scales orbicular, mucronate; nut obovate, strongly furrowed and pitted, warty on the edges. (Sciprins suldaus, Ell.) - I.ow grounds, in ficlds and waste places, Florida to North Carolina. Ang. and Sept. - Umbel occasionally reduced to a single spike.

* Spilics clustered, sessilc.

3. F. congesta, Torr. Annual ; eulıns densely tufteil $\left(3^{\prime}-6^{\prime}\right.$ lijgh $)$, bristle-like, like the rough leaves; spikes $5-10$ in a terminal cluster, oblong or cylindrical, pale, or at length yellowish brown; involucre 4-leaved, erect-spreading, longer than the cuim; scales lanceolate, tapering into a slender spreading point; nut ohlong-oborate, crossed with fiint lines. - Banks of the A palachicola River, Florida, and westward. Aug. and Sept. - Spikes $2^{\prime \prime}-3^{\prime \prime}$ long.

\section{TRICHELOSTYLIS, Lestib.}

Spikes terete, many-flowered. Scales imbricated in few $(4-8)$ rows. Periantl none. Style 3-cleft, tumid at the base, deciduous. Nut 3-angled. -- Culms jointless, leafy at the base. Spikes umbelled.

1. T. autumnalis. Culms slender, flat, 2-edged, $6^{\prime}-12^{\prime}$ high, tuftel ; involucre 2-leaved, mostly shorter than the simple componnd or decompound umbel ; spikes linear-lanceolate; scales oratc-lanceolate, mucronate, imbricated in 4 rows; stamens 2 ; nut white, obovate, obtuse, often warty. (Scirpus autum. nalis, L.) - Low grounds, Florida to Mississippi, and northward, very common. July-Oct, (1)

\section{ISOLEPIS, R. Brown.}

Spikes few-many-flowered. Seales imbricated in few-sereral rows. Perianth none. Style 3-cleft, the tumid base persistent at the apex of the 3-angled mut. - All anmuls (in our species), with filiform or bristle-form culms and leaves. Spikes umbelled or clustered. Leares radical.

\section{* Spikes umbelled. (Scales pubescent.)}

1. I. capillaris, R. \& S. Culm $\left(4^{\prime}-6^{\prime}\right.$ high $)$ smooth, furrowed, and, like the rough-edged leares, bristle-like; spikes $3-4$, in a simple umbel, oblong, $6-8$ flowered; scales oblong, obtusc, strongly keeled, brown on the sides, imbricated in 4 rows; nut obovatc, obtuse, nearly equal-sided, transversely wrinkled; stamens 2. (Scirpus capillaris, L.) - Moist sandy places, Florida, and northward. June-Sept. - Sheaths of the leares bearded at the throat. Involucre 2-3leaved, scarcely longer than the umbel. 
2. I. ciliatifolia, Torr. Culms tufted, filiform, angled $\left(6^{\prime}-12^{\prime}\right.$ ligh $)$; leares bristle-form, hispid on the edges, the sheaths bearded at the throat; umbel compound; spikes several ( $1^{\prime \prime}-2^{\prime \prime}$ long), 6-12-flowered, linear-oblong; sales oral, strongly keeled, brown on the sides; unt obovate, very obtuse, nearly equal-sided, obscurely wrinkled. (Scirpus ciliatifolins, Eli.) - Dry sandy places, Florida to North Carolina. Aug. and Sept.

3. I. coarctata, Torr. Culms $\left(1^{\circ} \mathrm{high}\right)$ terete, filiform; leaves bristleform, smooth, with the sheaths bearded; umbel compound, contracted; spikes ( $3^{\prime \prime}$ long) lincar-oblong, 10-15-flowered; scales ovate, acntish, imbricated in 4 rows; nut flat on the inner face, obtuse-angled in front, obscurely dotted. (Scirpus coarctatus, Ell.) - Dry sanily soil, Gcorgia and South Carolina, near the coast. Sept. and Oct. - Rays of the umbel $\frac{1}{2}$ long.

$$
\text { * Spiles clustered in a terminal head. }
$$

4. I. stenophylla, Torr. Culms $\left(2^{\prime}-4^{\prime}\right.$ ligh $)$ densely tufted, 3-angled, and, with the bristle-form leares and involucre, bristly-ciliate; involuere much longer than the head, 3-4-leared, dilated and ciliate at the base; spikes $4-6$, oblong-linear, 8-10-flowered; scales lance-ovate, slender-pointed, lispid on the 3-nerved keel; nut (bluish) obovate, ol,tuse, wrinkled. (Scirpns stenophyllus, Ell.) - Dry sandy soil, Florida to North Carolina. Augr. and Sept.

5. I. Warei, Torr. Culms filiform $\left(1^{\circ}-I_{\frac{2}{2}}^{\circ}\right.$ high $)$, smooth, 3-angler, much longer than the bristle-form hispid leares; sheaths bearded at the throat with long silky hairs; leares of the involucre rigid, twice as long as the head, orbicular and cut-fringed at the base; spikes $8-10$ in a head, ovate, many-flowered; scales ovate, mucronate, many-nerved; nut obovate, obtusely angled, obscurely wrinkled. - Dry sands near the eoast, West Florida. Sept. - Heads $\frac{11}{2}$ in diameter.

\section{ABILDGAARDIA, Vahl.}

Spikes many-flowered. Scales imbricated in 2 or (by the twisting of the rachis) 3 rows, keeled, decurrent on the rachis, deciduons. Perianth none. Stamens 1-3. Style 3-cleft, tumid at the base, deciduous. Nut 3-angled. Culms jointless, leafy at the base. Spikes solitary, clustered or umbelled.

1. A. monostachya, Vahl. Culms filiform, tufted $\left(6^{\prime}-10^{\prime}\right.$ high $)$; leaves shorter than the culm. filiform, obtuse, concave; spikes solitary (rarely by pairs), ovate, acute, compressed, 8-12-flowered, much longer than the bract-like mucronate 1-leaved inrolucre; scales broadly ovate, acute or mucronate, compressedkeeled, with broad and white margins; stamens 3 ; nut somewhat pear-shaped, 3-angled, warty, ycllowish-white. - South Florida, Dr. Blodyett.

\section{RHYNCHOSPORA, Vahl. BeAK-Resir.}

Spikes 1 -several-flowered. Scales imbricated in few rows, the lowest empty, the upper usually bearing imperfect flowers. Perianth of 3-6 (rarely 12-20) hispid or plumose bristles, occasionally wanting. Stamens mostly 3. Style 2-eleft. Nut lenticular or globose, crowned with the dilated and persistent base 
of the style (tuloceled). Pereminals, with jointerl and leafy culuns. Spikes small, disposid in axillary and terminal coryuls or clu-ters.

\section{Elisucll.Elle. Bristles of the periunth fi, plumose.}

1. R. plumosa, lill. Culms $\left(6^{\prime}-12^{\prime}\right.$ lijerh) aum leaves filiform ; spikes f.w, in alsout three small chusters at the summit of the rohn; nut ne:uly wholunlar, strongly wrinkled, pointerl with the short ovate smooth tuberele; lovistes rather longer than the nut, plumose throughout or nearly to the summit. - Low jine harrens, Florida to North Carolina. June and July.

Var intermedia. Culms taller $\left(1^{\circ}-2^{\circ}\right.$ ligh $)$; leaves narowly linear; clnsters 4-6, forming an interrupted spike at the smmonit of the culm; nut ohovate, pointed with the conieal-beaked pubescent tuberele; lristles plumose only at the base, or below the middle. - Sandy pine barrens, often dry places, Florilit.

2. R. semiplumosa, Gray. Culms erect, rigril $\left(1^{\circ}-2^{\circ}\right.$ high $)$; leaves narrowly linear; spikes olulonrrovate, dark brown, croweled in a terminal leasl, or rarely in a remote axillary one; nut globose-obovate, faintly wrinkled, pointed with the short lonodly conical smooth tuberele; hristles excedinir the tuberele, plunose below the milldle. - Iry sandy rideres, near the coast, West Florida. July and Aug. - The leaves, like those of the preceding species, have a jointlike contraction near the mildle.

3. R. oligantha, Gray. Culms $\left(6^{\prime}-12^{\prime}\right.$ high $)$ and smooth leaves bristlelike, reclining; corymb terminal, of $3-6$ large ( 4 "long) orate-lanceolate whitis/s stalkerl spikes; nut oral, lentienlar, faintly wrinkler; tuberele dilated at the base, conical, fiat; bristles longer or shorter than the nut, plumose loclow the midlle. - Low open pine harens, Florida to North Carolina. June and July.

\$2. RHYXCHOSPORA Proper. Bristles of the perianth 3-20, smooth, scabrous, or hispirl.

* Nut transversely urinkled or uneven : bristles denticnlate or hispid upuard.

\section{+ Bristles shorter than the nut.}

4. R. rariflora, Eill. Culms and leaves bristle-form: corrmbs $2-3$, remote, sprealing; spikes few and scattered, ovate; nut liroally olorate, biconrex, strongly wrinkled, twice as long as the 6 fragile bristles; tuherele flat, broadly conical, $\frac{1}{3}$ as long as the nut. - Low grassy pine barrens, Florida to North Carolina. June and July. - Culms $1^{\circ}-1 \frac{1}{2} 0$ long, commonly reclining. Spities pedicelled.

5. R. Torreyana, Gray. Culuns erect, slender, nearly terete; leaves narrowly linear or bristle-form; corymbs $1-3$, remote, erect; nut obovate, flat, about twice as long as the 6 bristles; tubercle compressed-conical. dilated at the hase, 3 the length of the nut. - Wet gromnd, South Carolina, and northward. July. - Culm $1^{\circ}-3^{\circ}$ high. Corymbs many-flowered and somewhat spreading, or few-flowered and capitate.

6 R. cymosa, Nutt. Culms $\left(2^{\circ}-3^{\circ}\right.$ high) 3 -anglel; leaves narrowly linear ; corymhs mostly 3 , distant, open or contracted ; spikes orate, clustered, light brown; seales mucronate; nut broadly ohorate, biconvex, faintly wrinkled, twice as long as the $3-6$ bristles; tubercle broally conical, eompressed, $\frac{1}{4}$ as 
long as the nut. - Var. GLonularis Smaller $\left(6^{\prime}-15^{\prime}\right.$ high $)$; corymbs rednced to few ghobose-ovate dark brown elustered spikes; nuts smaller, and deeper furrowed. - Low ground, Florida, and northward. June ant July.

7. R. compressa, Carey. Culms stont, 3 -angled ( $2^{\circ}-3^{\circ}$ high $)$; leaves linear, rigid; corymbs $3-5$, remote, spreading; spikes orate, numerons, in dense bracted clusters; seales acute; mut obovate; the flat or somewhat depressed sides strongly wrinkled and pitted, twice as long as the 6 bristles; tubercle conical-beaked, with the dilated base wider than the nut. - Margins of pinebarren ponds, West Florida. June and July, - Radical leaves nmmerous, $1^{\circ}$ long.

\section{+ + Bristles equalling or longer than the nut (in No. 9 variuble).}

8. R. stenophylla, n. sp. Culms and leaves setaceous; corymbs 1-2, small, erect; spikes $5-7$, distinet, lanceolate-oblong; mut obovate, biconvex, strongly wrinkled, twice as long as the conical-beaked tubercle; bristles 6 , slender, nearly as long as the nut and tubercle. - Low grassy pine barrens, A palaehicola. June aud July. - Culms tufted, $1^{\circ}$ long.

9. R. microcarpa, Baldw. Culms (20 higl $)$ erect, slender, nearly terete; leaves narrowly lincar; corymbs $4-6$, slender, spreading, compound; spikes small, roumd-ovate, scattered; nut round-obovate, lenticular, strongly wrinkled, tipped with the very short and broad tuberele; bristles 5-6, as long as the mut.Varies with the spikes elusterel, and the 3 bristles not half the length of the nut. - Margins of ponds, Florida to North Carolina. Jnly and Ang.

10. R. inexpansa, Vahl. Culms nearly terete, slender $\left(2^{\circ}-3^{\circ}\right.$ high $)$; leares narrowly linear; corymhs 4-5, narrow, remote, compounl, drooping; spikes scattered, lanceolate; nut lanceolate-oblong, compressed, twice as long as the conical-beaked tuberele; bristles 6, very slender, twice the length of the nut.Swamps and banks of streams, Georgia, and northward. July and Aug.

11. R. decurrens, n. sp. Culms $\left(2^{\circ}-3^{\circ}\right.$ high $)$ erect, nearly terete, very slender and bending near the top; leaves linear, elongater, flat and somewhat glaucous; corymbs 5-6, remote, compound, the bristle-like branches spreading or drooping; spikes ( 1 "long) ovate, scattered, pedicelled; nut obovate, lenticular, slightly wrinkled and pitted ; tubercle compressed, crescent-shaped, with the edges decurrent, $\frac{1}{3}$ the length of the nut; bristles 6 , as long as the nut. Marshy bauks of lakes and rivers, West Florida. June and July.

12. R. patula, Gray. Culms 3 -angled $\left(2^{\circ}-3^{\circ}\right.$ high $)$, slender above; leares linear; corymbs 3-5, remote, compound, widely spreadling; spikes scattered, ovate, on slender stalks; nut round-obovate, Ienticular; tubercle flat, conical, half the length of the mut, ciliate on the edges; bristles 6 , rather longer than the nut. - Varies with the spikes laneeolate, the narrower nut contracted at the base, and the bristles twice the length of the nut. - Banks of pine-baren streams, Florida and Georgia. Jume and July.

13. R. Elliottii, Dietr. Culn $\left(2^{\circ}-3^{\circ}\right.$ high) 3-angled; leaves linear ( $1^{\prime \prime}-$ 2 "wide) ; corymbs $3-5$, compound, the lower ones remote; spikes small, ovate, erowded; nut obovate, flattened, strongly wrinkled ; tuberele broadly conieal, flat, $\frac{1}{4}$ as long as the nut; bristles 6 , strongly lispid, as long as the nut and 


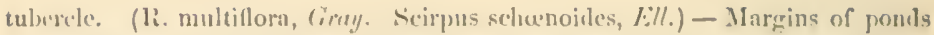
in the pinc barrens, (icorgia, Florida, and westward. June and July. - Nuts $\frac{1}{2} "$ lonin, several on a spike.

1.. R. caduca, kll. ('ulms stou ( $3^{\circ}-4^{\circ}$ high), 3-anglell ; leaves loroadly lincar ( $3^{\prime \prime}-4^{\prime \prime}$ wide) ; corymbs 4-6, compunul, remote, the branches and short perlicels ereet; spikes very numerous, approximate, ovate; scales caducous ; nuts $4-8$ on the spike, olovate, biconvex, faint! wrinkled; tubercle flat, conical, ciliate, 3 as long as the nut ; bristles 6 , slender twice ns long as the nut. Swamps and wet banks of streams, Florida to North Carolina. Ang. - Sipikes 2 "long. Nut twice as large as in No. 13

15. R. miliacea, Gray. C'ulms tall $\left(3^{\circ}-4^{\circ}\right.$ high $), 3$-angled ; leaves flat $\left(3^{\prime \prime}-\right.$ $4^{\prime \prime}$ wide); corymls $6-8$, distant, compound ; the lrandes and slender pedicels spreading horizontally; spikes ovate; scales calncone; muts $4-8$ on the spike, round-obovate, biconvex; tuberele compressed, conical; bristles 6 , slender, as long as the mut and tubercle. (1R. spatrsa, Ell.) - Bougs and deep miry places, Florida to North Carolina. June and July. - The nuts of this and the preeceling species remain on the spike after the scales have fallen away.

16. R. punctata, lill. Culms $\left(1^{\circ}-2^{\circ}\right.$ lijgh) slemeler, 3 -nugled; leares short, linear-lanceolate; corymbs $3-4$, cluster-like, the lateral ones simple, distant, and long-pedumeled ; spikes wate ; nut obovite, compressed, witl transverse pitted furrows, rather shorter than the 6 slightly hispid bristes; tuberele conieal, compressed, shorter than the nut. - Near Sayamals and St. Mary's, Georgia, Elliott. May aud June.

17. R. Grayii, Inunth. Culm solitary, 3 -angled $\left(2^{\circ}-3^{\circ}\right.$ highl $)$; leaves linear, rigitl, shining; corymbs $3-4$, distant, capitate; spikes few, larre, orate; nut roumd-obovate, tumicl, sligelhtly pitted, dull; tubercle short-conical, dilatel at the base; bristles 6 , as long as the nut and tubercle; stamens $3-6$. (1R. distans, Ell. R. Elliottii, (iray.) - 1)ry pine barrens, Florilat to North Carolina June and July.

* * Nut smooth and exen: bristles hispid upurard.

18. R. megalocarpa, Gray. Culms stout $\left(2^{\circ}-3^{\circ}\right.$ ligh 1$), 3$-angled; leaves rigid, linear, shining; corymbs $4-6$, distunt, spreading or somewhat contracted ; spikes ( $3^{\prime \prime}$ long orate, single; mut large (2" long), orlbicular-obovate, biconvex, light brown, turning blackish ; tuberele slort-conical from a spreading base; bristles 6-10, commonly shorter than the nut; stamens 12 . (R. dodecandra, Buldu.) - Dry sands along the coast of West and East Florida, and Wilmington, Nortlı Carolina. May-Augr.

19. R. Baldwinii, Gray. Culms $\left(2^{\circ}-3^{\circ}\right.$ high $)$ sharply 3 -angled, rough ; leaves short, glaucous, smooth, very acute ; corymbs 1-3, contracted or nearly capitate; spikes ovate, dark cliestnut; nut ovate, lenticular, twice as long as the flat conical tuhercle; bristles 12-14, longer than the nut; stamens $6 .-$ Wet pine barrens, Georgia and Floricla. June and July.

20. R. ciliata, Vahl. Culms blunt-angled $\left(1^{\circ}-2^{\circ}\right.$ high $)$; leaves short, glau cous, linear-lanceolate, oltuse, fringed on the margins; corymbs mostly solitary, capitate; spikes light brown, ovate; nut oval, lenticular, minutely roughened; 
tuberele flat, conical; bristles $6, \frac{3}{3}$ the length of the nut ; stamens $3 .-$ Wet pine barrens, Florida to North Carolina. June $-\Lambda$ ug. - Leaves $2^{\prime}-4^{\prime}$ long. Lateral corymb (when present) remote.

21. R. fascicularis, Nutt. Culms obscurely 3-angled, commonly slender, $\left(2^{\circ}-3^{\circ}\right.$ high $)$; leaves pale, narrowly linear ; corymbs $2-3$, distant, capitate, or sometimes compound; bracts conspicnous; spikes light brown, oblong-ovate, densely elustered; scales mucronate-awned; nut oval or orbieular, lenticular, dark brown, usually pale in the middle and on the prominent edges; tubercle white, broadly or narrowly conical, obtuse, compressed, $\frac{1}{3}-\frac{1}{2}$ the length of the nut; bristles $4-6$, varying from one half to nearly twice the length of the nut. - Low pine barrens, Florida to North Carolina. June and July.

Var. distans. (R. distans, Nutt) Every way smaller; culms $\left(6^{\prime}-18^{\prime}\right.$ high) erect; corymbs capitate, by pairs at the summit of the culn, and often with a third rather distant lateral one; spikes orate; bristles 6 , as long as the nut, rarely twice as long. - Low pine barrens, Florida to North Carolina. Ang. and Sept.

Var. trichoides. Culms $\left(6^{\prime}-12^{\prime}\right.$ long $)$ prostrate, and, like the leaves, bristleform ; corymb solitary, capitate; spikes few ; nut orbicular, three times as long as the $3-6$ bristles. - Open pine barrens, West Florida.

22. R. filifolia, Gray. Culms $\left(1^{\circ}-2^{\circ}\right.$ ligh $)$ filiform, erect; leaves setaceous; corymbs 2-4, distant, capitate; spikes densely clustered, lanceolate ; nut minute, obovate, lenticular, smooth and shining, twice as long as the compressed triangular-ovate ciliate tubercle; bristles 6 , rigit, nearly as long as the nut and tubercle. - Margins of pine-harren ponds, Florida to North Carolina. July and Aur. - Culm nearly terete. Spikes brown. Nut pale, with thickened edges.

23. R. pallida, M. A. Curtis. Culms rigid, acutely 3-angled, glaucousgreen, rough above; leaves erect, ciliate-serulite; corymb terminal, eapitate, compact; spikes very pale-firruginons, lanceolate, I-flowered; nut obovate, smooth, compressed, reddish brown, with a paler disk; tuberele very short, depressed, apiculate; bristles 3 , one fifth the length of the nut; stamens 3 ; style 2-cleft. - Wilmington, North Carolina. Curtis. June. - Culm 12'-20' high. Nut I"long.

24. R. gracilenta, Gray. Culms and leaves filiform or setaceous ; corymbs 2-3, distant, capitate, brown; spikes densely clustered, ovate-lanceolate; nut oval, dull, as long as the slender subulate tuberele; bristles 6 , twice as long as the nut. - Wet pine barrens, Florida, and northward. July and Aug. - Culms $1^{\circ}-2^{\circ}$ high.

*** Nut smooth and even : bristles hispid dounuord.

25. R. alba, Vahl. Culms $\left(1^{\circ}-2^{\circ}\right.$ high $)$ slender, 3 -angled above; leaves narrowly linear or setaceous; corymbs mostly 2, capitate, white, turning brownish, the lower one long-peduncled; spikes ovate-lanceolate, 1-flowered; nut obovate, lenticular, twice as long as the compressed subulate tubercle; bristles $10-20$, rigid, as long as the nut and tubercle, ciliate at the base.Wet springy places, Florida, and northward. $\Lambda$ ug. and Sept.

26 R. glomerata, Vahl. Culms $\left(2^{\circ}-3^{\circ}\right.$ high $)$ 3-anglerl ; leaves narrowly lincar; corymbs 4-12, often by pairs, capitate, dark brown; spikes ovate-lanceo 
late; unt olowate frem a stulk-like hase, lenticular: tubercle sululate, as long as the mut, with its dilated batse "ynalling it in widsh ; loristles 6 , stont, nearly a- long

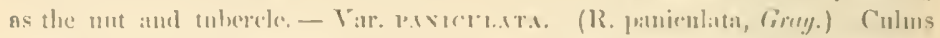
stent $\left(3^{\circ}-4^{\circ}\right.$ highl) ; leaves flat $\left(2^{\prime \prime}-3^{\prime \prime}\right.$ wille) ; corymbs compentul, panirnlate,

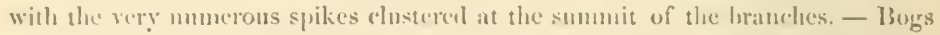
and spriney plates, Florital to North ('arolima, and westward. July - Scept.

27. R. cephalantha, Gray. Culuns $\left(2^{\circ}-3^{\circ}\right.$ high $\left.h\right)$ nearly terefo ; leaves nurrowly lincar; corymlis 4-8, mostly ly patirs, glohose, compact; spikes numer-

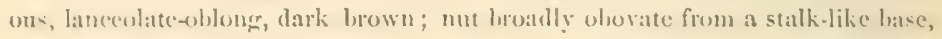
compresicel, almost truncate at the apex, and much wider than the hane of the subulate tuluerele; bristles 6 , as loner as the nut and tuberele. - Bogs and slaty swam [ıs, Florid:ı, and northward. July and Ang.

\section{\$3. IIALOSCIICENES. Periunth none.}

2s. R. pusilla, n. sp. ('mms $\left(6^{\prime}-12^{\prime}\right.$ high) and leaves lristle-form; corrmbs 2-3, distint, crect-sprtanling, the upper one compound; spikes mimte, ovate, mostly scatterel on the branches, 3-flowered; seales ovate, brown; nut white, oblong-oborate, compressed-lenticular, contracted at the base, tran-rersely wrinkled; tuberele depresed-enieal, free at the base. - Margins of pine-barren pond:, Midille and West Florida. Jume.

29. R. divergens, $n$ sp. Culms $\left\langle 6^{\prime}-12^{\prime}\right.$ lighl $)$ aml luares filiform or bristleform; corymls 2-3, distant, spreading; spikes small, scattered, pedieclled, 3flowererl; scalles brown, ovate; nut olsovate, biconvex, minutely pitserl ; tubercle depressed, sessile, mimntely pointed in the centre. - Low pine barrens, Filorida to Soutl, Carolina. June.

30. R. Chapmanii, M. A. Curtis. Culms $\left(12^{\prime}-20^{\prime}\right.$ hichl) (lensely tufted, erect, setaceous or filiform, like the short and flat leaves; ('oryml, solitary, terminal, capitate; spikes whitish, lanceolate, densely clu-tered, 1-flowered; seales 5, the np) pernos fertile; nut oval, lentienlar, smooth and shining; tulsercle slort, sessile, Inoatlly conical; stamens $1-2$. - Flat pine barrens, Florida to Suutl Carolina. July and Augr.

\section{CERATOSCHCENUS, Nees. Howint.Resu.}

Spikes few-flowered. Scales loosely imbricated, the lower ones enupty, the upper with staminate or alortive flowers. Peliamb of $4-6$ loristes, which are dilated and connate at the base. Stanens 3. Style clonsated, entire or slightly 2-cleft at the apex. Nint compressed, crowned with the persistent and hispid lower half of the style. - P'eremnials. Culms jointed, leafy. Spiles scattered in an open corymh, or clustered in a grjobose hear.

1. C. corniculatus, Nees. Culms stout $\left(3^{\circ}-4^{\circ}\right.$ ligh $), 3$-anclel ; leaves flat, scabrous on the erlges $\left(6^{\prime \prime}-10^{\prime \prime}\right.$ wide $)$; corymls.3-5), ereet, compund; spikes brown, ovate-lanceolate; style very long, the lower and persistent portion upwarlly seabrous; nut narrowly olovate, smooth, the sides coneave and nimutely dotted ; bristles $5-6$, rigrit, smoothish, half as long as the nut ; tubercle subulate, 3-4 times the length of the nut. (Rhynchospora longirostris, Ell ) - I'onds 
ant ditches, Florida, and northward. Ju!y-Sept. - Leares $1^{\circ}-2^{\circ} \operatorname{long}$. Nut and tubercle nearly l' long.

2. C. macrostachyus, Gray, rar, patulus. Cormbs rery large, decompound, diffinse; style minutely 2-cleft; uut broadly ohovate; bristies slenIer, twice as long as the nut; otherwise like No. I. - Ponds and ditches, Florida, and northward. Angust. - Culms $3^{\circ}-4^{\circ}$ high. Terminal corymbs often $1^{\circ}$ in dianeter.

3. C. capitatus, n. $\mathrm{sp}$. Culms $\left(2^{\circ}-3^{\circ}\right.$ high $)$ nearly terete, straight, like the long narow erect and channelled leares; spikes densely clustered in I-6; globular heals, the lateral heals long peduncled and somewhat corymbuse; scales about 9 (the fourth fertile), whitish; style very long, minutely 2-cleft; nut obovate, lenticular, obsenrely wrinkled, hispid on the margins above, shorter than the 6 slender bristles; tubercle bristle-awl shaped, twice as long as the nut. - Pine-barren jon Is, Middle and West Florida June - Aug. - Leaves $2^{\prime \prime}-4^{\prime \prime}$ wide, as long as the culn. Head composed of 30 or more spilies. Nut and tubercle $3^{\prime \prime}$ long.

\section{CHATOSPORA, R. Brown.}

Spikes few- (1 -8-) flowered. Scales imbricatch in two rows; the lower ones empty, the npper bearing perfect flowers. Perianth of $3-6$ scabrous or plumose bristles. Stamens 3. Style 3-eleft, not dilated at the base, nearly deciduous. Nut triangnlar, mostly pointed hy the persistent base of the style. - Leaves radical, narrow. Spikes in a terminal cluster, subtended by a 1 -2-leaved involucre.

1. C. nigricans, Kunth. Culms tufted, ereet, slightly compressed, smooth and rigid, jointed near the summit; leaves rigill, erect, seni-terete, rongh on the margins, shorter than the eulms; sheaths black; involncre 2-leaved, the lowest longer than the ovoid dark brown hend; spikcs ovate-lanceolate, conpressed, 6-8-flowerel; scales orate, compressed-keeled, the lowest mucronate; rachis zigzag; bristles 6 , unequal, compressed, dilated at the base, lispicl upwarl, longer than the glohose-3-ingled white and polished nut. (Schoums nigricans, L.) - Damp soil, near Marianna, We.t Florida, and salt marnes, near St. Mark, Middle Florida. May. 4-Culms $1^{\circ}-1 \frac{1}{2}{ }^{\circ}$ ligh. Althongh differing in some particulars, the Florida plant is probably not distinet from that of the eastern hemisphere.

\section{PSILOCARYA, Torr.}

Spikes many-flowered, terete. Scules inbricated in several rows, membranaceous, all bearing perfect flowers. Perianth none. Stamens 2. Style 2-eleft. Xut biconvex, transwersely wrinkled, erowned with the persistent base of the style. - Culms leufy. Spikes orate, disposed in spreading lateral and terminal corymbs.

1. P. rhynchosporoides, Torr. Culms nearly terete $\left(\frac{1}{2}{ }^{\circ}-20 h_{i}, h_{1}\right)$; leaves narrowly linear, longer than the eulm; corvmbs 2-3, widely spreading, the terminal one mostly compound; spikes pedicelled; seales ovate, acute; nut 


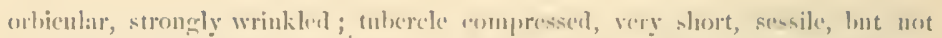

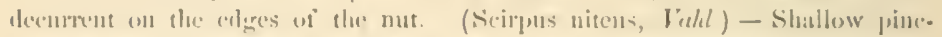

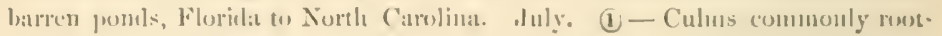
inge at the lower joints.

P. sc114011.s, Torr., if within our limits, may be known ly its neurly smouth nut, and slender beak-like decurrent tuberele.

\section{DICHROMENA, Richard.}

Spikes compressed, few-1howeret, nggregaterl in a teminal head, and surromeded bo an inolucre of several leares, which are commonly white at the base. Seales inbrienterl in few rows, most of them leariug abortive flowers. Stamens 3. Style 2-cleft. Nut lenticular, crowned with the hroal and persistrnt lase of the style. l'erianth none, l'erennials. Culns jointless, leafy at the base. Seale's white, menlranaceous.

1. D. leucocephala, Michx. Culms $\left(1^{\circ}-1 \frac{10}{2}\right.$ ligh $)$ slender, 3-angled ; leaves nurrowly linear; involucre of $4-7$ narrow leaves; nut ordicular, wrinkled ; tubercle flat, broally conical, sessile, but not decurrent. - 1)amp suil, Florida is North Carolina. Ang. and Sept. - Involucre mehanged in drying.

2. D. Iatifolia, Baldw. Culms stont $\left(2^{\circ}-3^{\circ}\right.$ high $)$, weurly terete; leaves broadly linear, clongated; leaves of the involuere 8-9, tapering from the broul $\left(3^{\prime \prime}-4^{\prime \prime}\right.$ wide) base to the slender summit, leceming rectlists; nut romd-obovate, faintly wrinkled; tubercle flat, conical, obtuse, the sides decurrent on the celgers of the nut. - Low pine barrens, Florida to North Carolina. May - July. Heads larger than those of the preceding.

\section{CLADIUM, Browne.}

Spikes orate, 1-2-flowered. Seales loosely imbricated, the lower ones enpty. Jerimth none. Stamens 2 . Style 2-3-eleft, the divisions often 2-3-eleft, deciduons. Nut grohose-ovate, the pericarp thickened and corky near the apex. 'Tulerele none, - Culms tall. Spikes disposed $m$ axillayy and terminal cymelike panicles.

1. C. effusum, Torr. (SAw-Gmss.) Culms $\left(4^{\circ}-8^{\circ}\right.$ highl $)$ nearly treec; leaves linear, elungated, saw-edged, panicles numerons, diffuse ; spukes small, 3-4 in al cluster, deep brown; seales abont 6 , the nppermo-t bearing a perfert flower, the next below staminilerous, the others empty; nut ovate, pointed, wrinkled. (Schuenus cffusus, Sucartz.) - Fresh or brackish marshes along the coast, Florida to North Carolina, and westward. July and 1 ugr.

\section{SCLERIA, I. Nirr.liısu.}

Flowers moncecions. Sterile spike few - many-flowered. Seales loosely imbricater in 2-3 rows. Fertile flowers solitary, separate or at the base of the sterile spike. Stanens l-3. Style 3-cleft. Nut glohose or ovate, stony or bony. - Chiefly perennials, with creeping rootstocks, aud triangular leafy culms. Spikes clustered, lateral and terminal. 


\section{\$1. SCLERIA Proper. Yut supported by an annular or 3-6-lobed disk.}

* Nut smooth: stamens 3 .

1. S. triglomerata, Michx. Culms stout, rough, sharply angled $\left(2^{\circ}-3^{\circ}\right.$ high); leares broadly linear, smooth or hairy; spikes disposed in $3-6$ clusters at the summit of the eulm, and $1-2$ distant lateral ones on long and drooping peduneles; disk forming a complete narrow ring at the base of the globoseovate yellowish white nut. - Low grounds, Florida, and northward. JuneAngust.

2. S. oligantha, Ell., Michx.? Culms $\left(1^{\circ}-2^{\circ}\right.$ high $)$ slender, smooth, sharply angled, often glancous, like the smooth linear leaves; spikes $3-5$, single, scattered, forming a terminal interrupted compound spike, and $1-2$ distant lateral ones, on long drooping peduneles; bracts leafy ; disk of 9 minute globular lobes at the base of the white and polished ovate nut. - Thickets and margins of ficlds, Florida to South Carolina. July.

\section{* * Nut reticulated: disk of 3 flattened lobes : stamens 2.}

3. S. reticularis, Michx. Culms slender $\left(1^{\circ}-1 \frac{1}{2} 0\right.$ high $)$, seabrous below; leaves narrowly linear ; spikes clustered, axillary and terminal, the lateral ones on a short erect peduncle; nut grlobose, small, retienlated and pitted; lobes of the disk appressed to the base of the nut. - Margins of ponds, Florida, and northward. Aug. and Sept.

4. S. laxa, Torr. Culms weak, rongh on the angles; leaves linear, obtuse; spikes separate, the axillary ones on a long and drooping peduncle; nut globose, wrinkled and somewhat hairy, obscurcly pitted; lobes of the disk appressed to the nut. (S. reticularis, Ell.) - Damp pine barrens, Florida, and northward. Aug. - Oct. - Culms $1^{\circ}-1 \frac{1}{2}{ }^{\circ}$ long. Nut $1 \frac{11 \prime}{2}-2^{\prime \prime}$ in dianeter.

$$
\text { *** Nut warty: disli bearing 3-6 globular lobes: stumens } 3 \text {. }
$$

5. S. ciliata, Michx. Culms slender, rigid $\left(1 \frac{10}{2}-2^{\circ}\right.$ high $)$, smooth below, sparingly fringed on the angles above; leaves 2 , narrowly linear ( $\mathrm{I}^{\prime \prime}$ wide), rigid, smooth, or with scattered hitirs on the margins; sheaths pubescent; clusters terminal; sterile spikes large, many-flowered ; nut glohose, pointed, closely beset with unequal warts, these corresponding to the angles of the nut and at the base larger thin the rest; lobes of the disk 3, globular, entire. - Dry pine barrens. Florida to Sonth Carolina. Jume-Ang. - Rhizoma thick and creeping.

6. S. Elliottii. Culms stout $\left(\frac{10}{3}-1^{\circ}\right.$ high), densely rough-fringed on the angles throughont ; leaves $3-4$, broadly linear $\left(2^{\prime \prime}-3\right.$ " wide), closely fringed on the margins and midrib beneath; sheaths pubescent; clusters 2, the lateral one remote, on a short erect peduncle; sterile spike small, few-flowerel; unt grlobose, deeply wrinkled or pitted, and with slender warty projections at the base; lobes of the disk 3, globose, 2-lobed. (S. hirtella, Ell., Whelux.? not of Sertz.) Low pine barrens, Florida to North Carolina. July.

7. S. pauciflora, Muhl. Smoothish or hairy or villons throughont; culms $\left(6^{\prime}-1.2{ }^{\prime}\right.$ ligh $)$ slender; leaves narrowly linear; clusters small, of 1 - few spikes, terminal, and also a remote axillary one on a short crect peduncle; sterile spike few-flowered; nut globose (small), pointed, closely beset with minute 
warts, those at the hase rlonerated, lubes of the di-k 6 , distinct, gloloses. (S (arolinimu, Hilld, the villous form)

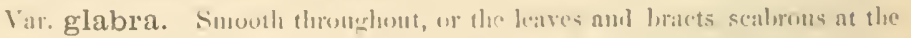

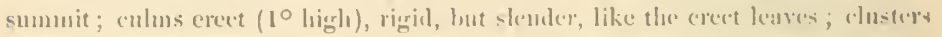
terminal; spikes mamy-fowerd, lubes of the di-k 3, cath 2-loled. This alow varies, with longer (20-210) diflue culms, and with 1 - 2 distant axiltary clusters on long $\left(5^{\prime}-10^{\prime}\right)$ drooping preluncles. - Low sandy pine barrens, florida, and northwarl; the varieties dhiefly suthward. May - Aug.

\$2. HYPOPORLM. Ihsk none: nut roncuve and often pitted at the sides of the triangular base.

* Clusters of spulies terminal, leafy-bracted.

8. S. Baldwinii, Torr. Cuhus rongh ahove $\left(2^{\circ}-3^{\circ}\right.$ highl) ; leaves mo-tly 2, linear, rigrd ; nut large $\left(2^{\prime \prime}\right.$ lougr dull white, eloluse-ovate, obscmely angled, longitudinally furrowert, conceave at the sides of the ahruptly contracted base, slighty gointed. - l'me-bamen swampss, Florida and Georgia, near the coast Junc and July.

9. S. gracilis, EIt. CuIms slender (10 high), smooth, like the filiform leaves; unt small (1"lone), ovate, dull white, fiurowed lemptlowion, the sirles at the base concave and pitterl. - Low pine barrens, Floridia to South Carolina June and fuly. - I'lant brownish, tufted.

* * Clusters of spilies (small) mumerous, scattred noar the snmmt of the culm, forming an interrupted compround spilie: bracts mostly stiort.

10. S. filiformis, Swart\%. (ilaucons; (culms slender $\left(1 \frac{1}{2}{ }^{\circ}-2^{\circ}\right.$ higlı), smooth; leaves narrowly linear, rough on the margins and keel, ciliate at the throat; clusters 3-4, erect, few-flowered, the lowest remote, leafy-lnarted ; scales lausecolate, rongh-pointed; stamens 3 ; nut obovate, olscurely 3-angled, smooth and glas sy, concave at the batse, not pitted. - South Florida. Oet.

11. S. verticillata, Mhhl. Culms very slender $\left(6^{\prime}-12^{\prime}\right.$ highli), smooth, like the marrowly linear or filiform leaves and sleaths; clusters $3-5$, erect; scales smooth; mut very small, ghlohose-3-angled, pointed, rongh with raised wavy ridges, not pitted at the base. - Varies with hairy slieaths, more mumerons $(6-9)$ clnsters, and reticulated nuts. - Danp soil, Florida, and northward. June and July.

12. S. Michauxii. Culıns $\left(6^{\prime}-12^{\prime}\right.$ high $)$ smootll; leaves linear, and, like the sheatls, hairy; chusters 4-6, nodding; scales bristle-awned; nut glohose3-angled, very minute, pointed, sinooth, not pitted at the hase. I. intermpta, Miche., not of Rachard) - Low pine barrens, Floridin to South Carolina. July and $A$ ug.

\section{CAREX, I. SHDG.}

Flowers monocious, rarely dicecions, spiked. Sterile and fertile flowers in the same spike (androynons), or in separate spikes. Scales imbricated in fewmany rows. Stamens 2-3. Style 2 -3-cleft, exserted from a sac (perigynium) which encloses the ovary and the lenticular biconvex or 3-angled nut. - Peren 
nials, witl grass-like leares. Splikes from the axils of scale-like or leaf-like bracts, simple or compound.

1. VIGNEA. Stigmas tuo: nut lenticular, or more or less compressed.

A. Spikes bearing both sterile and jintile flourers.

* Spikes with the sterile and fertile flowers variously disposed.

1. C. bromoides, Schk. Spikes 4-6, distinet, oblong-lanceolate, compressed ; perigynia lanceolate, erect, finely nerved, ending in a long flat roughmargined 2-cleft beak, longer than the ovate-lanceolate mucronate scale. Swamps and bogs, Florida, and northward. March and April.-Culms tufted, weak and slender, $1^{\circ}-1 \frac{1}{2}$ high. Leaves narrowly linear Spikes occasionally wholly sterile or furtile. Perigynia somewhat 2-ranked

* * Spikes with the upper flowers sterile, the loucer fertile.

- Spikes indefinite, disposed in a close panicle.

+ Perigynia sessile.

2. C. decomposita, Mull. Panicle long, drooping, the upper spike-like branches densely elustered, the lower elongated, distinct, and spreading; perigyniat obovate, biconvex, nerved, abru!tly shortbeaked, about the length of the ovate pointed white-margined scalc. - Wet margins of ponds and streams, Florida, and northwarl. May - Culms erect, stout, $2^{\circ}-3^{\circ}$ high. Panicle $4^{\prime}-6^{\prime}$ long. Bracts of the lower spikes bristle-form. Perigynia dark brown at maturity.

3. C. vulpinoidea, Michx. Panicle spike-like, erect; clusters of spikes 8-12, hlort, oval, the upper ones densely crowded; perigynia small, ovate, compressed, slort-beaked, 2-cleft at the orifice, faintly nerved at the broad base; scales yellowish, mucronate. (C. multiflora, Mhlh.) - Swamps, Sontlı Carolina, and northwarl. May. - Culms $1 \frac{10}{2}-2^{\circ}$ high. Panicle $2^{\prime}-3^{\prime}$ long, cylindiveal. Braets of the lower spikes setaceous or leaflike, often excecding the panicle. Perigynin yellowish at maturity.

\section{++ Perigynia short-stulked, truncate at the base.}

4. C. crus-corvi, Shuttleworth. Panicle very large, the lower branches long and distinct, the upper short and erowded; perigynia plano-convex, ovate, strongly nerved, dilated at the base, tapering into a long and slemeler rough-edged deeply 2-cleft beak, thrice the length of the orate mucronate scale. - Riverswamps, West Florida, and westward. MLay - Culms thick and spongy, sharpandlerl, and, like the broad $\left(\frac{1}{2}{ }^{\prime}-34^{\prime}\right.$ wirle) leaves, glaucons. Panicle $4^{\prime}-9^{\prime}$ long, oblong or spike-like. Perigyina widely spreading, brown at maturity.

5. C. stipata, Muhl. Panicle oblong; the short orate lranches densely clustered; perigynia ovate-lanceolate, stronerly nerved, tapering into a stout rough-edged erect-spreading 2-eleft beak, 2-3 times the length of the scale. Swamps, Florida to Missisippi, and northward. April and May. - Plant yellowisl. Culm; $1^{\circ}-2^{\circ}$ highl, sharp-angled, thick and spongy. Lcaves $4^{\prime \prime}-9$ broad. 


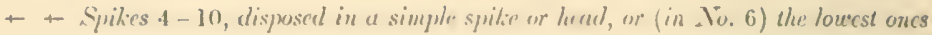 compouml.}

6. C. sparganioides, Muhl. Spikes 6-10, ovvil, the upper ones crowdcil, the lower scattered amel often componml; perizyia flattened, ovate, acnte at

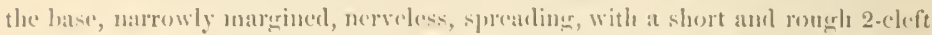
beak, twiee as long us the thin osute scalc. - Leper districts of Georgia, smol northward. - Culus stout, $2^{\circ}$ high. Lowes broally linear, as long as the cuhn. Conmon spike 2' $-4^{\prime}$ long. Perigrnia yellowish.

7. C. Muhlenbergii, Schkr. Spikes 5-8, ovoil, approximate, or crowil(d) in an ollong heal; perigynia romel-osate, plano-consex, strongly nerverl, with a short and hroat rongh-edged 2-cleft beak, barely longer than the ovate short-pointed scale. - Dry sterile soil, South Carolina, and uorthward. - Culms $12^{\prime}-1 s^{\prime}$ hight, rigicl, rough above, twice as long as the nurrow leaves. Head or spike 1' long. l'raets bristle-form, longer than the spikes.

8. C. cephalophora, Mulıl. Spikes 5-6, small, (cowded in a compart ovoill head ; periegnia lnoadly ovate, few-nerved, short and rongli-beaked, as long as the ovate long-pointed scale. - Dry soil, Florita, amb northward. - Cums $9^{\prime}-15^{\prime}$ lrigh, naked ahove, rough on the angles, tongh and wiry. Leaves narrow. Ilead $\frac{1}{2}$ 'long. Bracts bristle-like.

9 C. rosea, Schk. Spikes $4-6,8-10$-flowered, the two upper ones approximate, the otliers scattered, perigrnia oblong, plano-eonvex, rougli-beaked, spreading at matmity, twice as long as the broally owate obtuse or slort-mucronate scale. (C. raliata, Dew, a form with nore slenler culns, amel 3 -4-flowerew sprkes.) - Upper districts, Georgia, and northward. - Culms $1^{\circ}$ hight, smooth, longer than the narrow leaves. Common spike $2^{\prime}-3^{\prime}$ long. Bract of the lowest spike commonly excecding the culm.

10. C. retroflexa, Mubl. Spikes 4-5, crowled, or the lower ones distinet, ovoid, the lowest short-bracted ; perigrnia ovite-lane eolate, smouth-beaked, 2.rleft, at length widely spreating or retlexed, barely longer than the ovate longpointed seale. - Open wouds, Florida, and northwarl. - Culms slemler, 10 high, rough-angled above. Leaves narrow, shorter than the culm. Common spike about 1' long.

*** Spikes with the lower flowers sterile, the upper fertile.

11. C. stellulata, Good. Spikes $3-5$, ohovoil, distmet, the uppermost club-shaped at the base, perigynia ovate, rounded at the base, tapering into a short and rough 2-cleft heak, finely nerved, spreading and finally recurved, rather longer than the orate pointed scalc. (C. scirpoides, sichk.) - Shady river-swamps, Florida, and northward. - Culms $6^{\prime}-12^{\prime}$ high, weak. Leares narrow amd tender. Spikes small.

Var sterilis. Sterile and furtile spikes on separate enlms, nl :ome of them either sterile or fertile on the same eulm, otherwise like the preceding, and growing in sinilar places. (C. sterilis, II illd.)

V:ur. conferta. Culms taller $\left(2^{\circ}\right.$ high $)$ and stouter ; spikes larger and more erowded; periognia romulovate, twice as long as the broadly ovate barely pointed scale. - Pine-barren swamps. 
12. C. canescens, L, var. vitilis, Cary. Spikes $5-7$, small, scattered, roundish, 6-10-flowered; perigynia ovate, plano-convex, short and roughbeaked, spreading and tawny at maturity, rather longer than the ovate acute white scalc. (C. spharostachya, Dew.) - High mountains of North Carolina, and northwarl. - Culms weak and slender, $10^{\prime}-15^{\prime}$ ligh, longer than the narrow and tender leaves.

13. C. scoparia, Schk. Spikes 6-8, approximate, ovate or oblong, manyflowered; perigyila oblong-lanceolate, narrowly margined, acute at the base, tapering into a long 2-cleft rongh beak, longer than the ovate-lanceolate pointed scale, turning light brown at maturity. - Swamps, South Carolina, and northward - Culms $1^{\circ}-2^{\circ}$ high, rough above, longer than the narrow leaves.

Var. lagopodioides. Spikes 10-15, obovoid; perigynia lanceolate, remaining pale green at maturity, ncarly twice as long as the rather oltuse scale. (C. lagopodioides, Schk:) - Mountains of North Carolina, and northward. Culms commonly taller than the preceling.

14. C. straminea, Sclık. Spikes 3-6, listinct, ovoid; perigrnia ovate or round-ovate, broadly winged, abruptly narrowed into a slort 2-cleft beak, somewhat tawny and spreading at maturity, longer than the ovate-lanceolate scale.

Var. festucacea. Spikes 6-8, pale, oboroid or somewhat club-shaped, scattered; perigynia ovate, less broadly marginch, tapering into a more slender beak, ereet and pale green at maturity. (C. festneacea, Schk. C. feenen, Torr., \&c., a form with more rigid culms, and more crowded and glancous spikes.) Swamps, very common. - Culms $1^{\circ}-2^{\circ}$ high. Leaves narrowly lincar, shorter than the culin.

15. C. fœnea, Muhl. Spikes 6-10, large $\left(6^{\prime \prime}-8^{\prime \prime}\right.$ long), ovoirl, approximate; perigruia flat, broadly obovate, wing-marginch, abruptly contracted into a very short beak, longer than the lanccolate scale; nnt oval, stalked. (C. alata, Torr.) - Marslies, Florida to North Carolina. - Culms $2^{\circ}-3^{\circ}$ high, leafy below the middle. Spikes brownish at maturity. Perigynia $2 \frac{1}{2}$ "long.

B. Terminal spities sterile: the others fertile or with few sterile flowers at the summit: perigynia beakless.

* Scales awnless, biack or brown: bracts searcely exeeeding the culm: leaves narrouly linear, glaucous.

16. C. torta, Boott. Sterile spike solitary, pedıncled ; fertile spikes mostly 3, linear-elub-shaped, loosely flowered below, sprearling, the lowest peduncled; perigynia clliptical, tapering and at length spreading or reeurved at the apex, nerveless or nearly so, as long as the oblong black seale; culms smooth ( $1^{\circ}$ high): leares narrowly linear. (C. verrucosa, Schw., not of Ell.) - Mountain swanps, North Carolina, and northward.

17. C. stricta, Good. Sterile spikes 1-2; fertile spikes 2-4, linear-cylindrical, sessile or the lowest short-peduncled, erect, dense-flowered; perigynia elliptical, crect, nerveless, commonly shorter than the narrow obtuse reddishbrown scalc ; culms ( $2^{\circ}$ high) rough-angled; leaves linear. (C. acuta, Ell., \&c., not of Linnceus.) - Swamps in the upper districts, and north ward. 


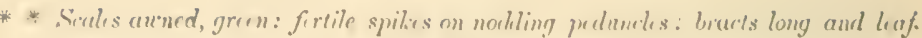
like: leares bremelly limer.

1s. C. crinita, Iam. Sterile spikes mo-tly 2, uften with fercile flowers

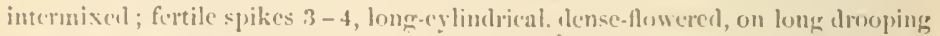
pedusedes; perigynia rouml-ovate or obovate, somewhat inflated, 2 nerverl, at)ruptly short-pointed, shorter than the long and rounh-allned scald ; culms ronghanted alone $\left(2^{\circ}-3^{\circ}\right.$ highlı). - Swamps in the upjer districts, and northward. Spikes $1 \frac{1}{2}-3$ ' long.

19. C. Mitchelliana, M. A Curtis. "Spikes in threes, peduncled, somewhat distant, oblong, slightly nodding; terminal spike staminate at the base am summit; the lowest peduncle searcely shoathed; perigynia ovate, aente, glabrons; seales oblong, the lowest with a long cnsp much excecting the fruit, the mpper ahout equalling it, - Wet places, Chatham County, North Carolina." Curtis. - Cuhn stender, 18' high, rough above. Spikes 1' long.

\section{\$ CAREX Proper. Sligmas 3: mut 3-angled.}

A. Spike solitary.

\section{* Diexcious.}

20. C. Boottiana, Benth. Culms slender, naked, rough, shorter than the linear Iright-green raclical leaves; spikes (rarely 2) many-flowered, purplish, cylindriral, erect; fertile spike dense-flowered; perigrnium olıvate, obtuse or abruptly short-beaked, ciliate and 2-toothed at the orifice, nerved, pmbesent, ciliate-toothed on the angles, shorter and narrower than the oblong-acute or ahruptly pointed purple scale. - North Alabama, Peters, and westward. - Culms 6'-8' long. Spikes $1^{\prime}-2^{\prime}$ long.

* Monccious. Spike sterile above, fertile below.

21. C. polytrichoides, Muhl. Spike linear, few-flowered; perigynia lanceolate-oblong, many-nerved, obtuse and entire at the apex, twiec as long as the oblong mueronate scale; bract scale-like or occasionally leafy and exceeding the spike; culms tufted, filiform, wenk $\left(6^{\prime}-12^{\prime}\right.$ high $)$, rongh abore, longer than the very narrow leaves - Bogs and swamps, Florida, and northward.

22. C. Fraseri, Sims. Spike oblong, many-flowered, the fertile portion chlobose; perigynia ovoid, inflated, abruptly short-pointed, longer than the oblong obtuse lyvaline seale; leaves very wide ( $I^{\prime}$ or more), obtuse, serrulate and wavy on the margins, conrolute below, and sheathing the base of the naked smooth culm. - Sharly banks of streams on the mountains of North Carolina. - Leaves $6^{\prime}-12^{\prime}$ long, longer than the culm.

23. C. Steudelii, Iiunth. Spike linear $\left(6^{\prime \prime}-10^{\prime \prime}\right.$ long); sterile flowers $20-25$; jerigyuia $1-4$, ovoid, smooth, 3-newed, abruptly contracted into a slender compressed rougl-edged beak, longer than the ovate white green-keeled scale; leaves linear, flat, abruptly pointed, longer than the bristle-like prostrate culms, - Shady banks, Florida, and westward. - Culms $3^{\prime}-6^{\prime}$ long. Plant whitish.

24. C. Willdenovii, Schk. Sterile flowers $4-8$, forming a minute linear spike; perigynia $6-9$, oblong, with 3 rough angles; lower seales longer than 
the spike, often leafy; otherwise like the last. - Shady woods, North Carolina, and northward. - Plant deep green.

B. Spikes tuto or more. (In No. 25 oftener solitary.)

* Terminal spike sterile below (often wholly so in 1 Wos 26 and 35), fertile above, the others chiefly fertile.

- Perigynia influted, contrarted into a long and slender beak.

25. C. squarrosa, L. Spikes $1-4$, oral, thick $\left(\frac{1}{2}^{\prime}-3^{\prime}\right)$, ereet, peduneled ; perigynia horizontal, obovate, smooth, 3-nerved, abruptly contracted into a long subulate smooth 2-cleft beak, longer than the lanceolate acnte scale. - Swamps and meadows, near the mountains, Georgia, and northward. - Culms $8^{\prime}-16^{\prime}$ high, shorter than the linear leaves and bracts.

26. C. Stenolepis, Torr. Spikes $4-7$, the terminal one small, often wholly sterile or fertile, the others cylindrieal, erect, dense-flowered, the upper ones approximate and nearly sessile, the lower seattered, on exserted peduneles; perigynia horizontal, contracted into a long and slender 2-eleft beak, shorter than the awn-like scales. - Swamps and meadows, upper districts of Georgia to Mississippi, and northward.-Culms $1^{\circ}-1 \frac{1}{2}^{\circ}$ high, flexuous above, shorter than the broad leaves and braets.

$$
\text { + + Perigynia bealiless. }
$$

- Spilies approximate, ovoid or cylindrical, dense-flowered, sessile, or on short and erect peduncles : bracts short.

27. C. Buxbaumii, Wahl. Spikes $3-4$, oblong, the upper one peduncled, the others sessile or nearly so; perigynia whitish, smooth, elliptical, compressed-3-angled, obtuse and emarginate at the apex, commonly shorter than the ovate acute or awn-pointed blackish scale. - Mountains of Georgia, and northward - Culms $1^{\circ}-1 \frac{1}{2}{ }^{\circ}$ high, rough above, longer than the narrow glaucous leaves.

28. C. hirsuta, Willd. Spikes $2-4$ (mostly 3 ), sessile or nearly so, ovoil or oblong, many-flowered; perigynia pubescent or at length smoothish, ovate, compressed-3-angled, strongly nerved, obtuse and emarginate at the apex, about as long as the oblong mneronate white seale. - Damp soil, Florida to Mississippi, and northward. - Culms ereet, $1^{\circ}-1 \frac{1}{2}$ high, rougli-angled, and, like the narrow leaves and sheaths, more or less pubesent.

29. C. triceps, Michx.? Spikes 3-4, oroid or oblong, sessile, few-flowered; perigynia smooth, round-pear-shaped, obscurely angled, faintly nerved, contracted into a short and entire point, as long as the oblong obtuse or barely pointed white scale. - North Carolina (Curtıs), Tennessec, and northward.Culms $1^{\circ}$ high, very slender. Leaves and sheaths smooth.

30. C. virescens, Muhl. Spikes 2-3, cylindrical, short-peduncled, densely many-flowered ; perigynia small, pubescent, oroid, strongly nerved, 3-angled, neute and entire at the apex, as long as the ovate mucronate white scale. - Low grassy meadows, North Carolina, and northward. - Culms $1^{\circ}-2^{\circ}$ high, rongh. Leaves and sheaths hairy. 


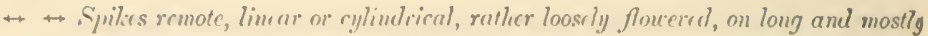

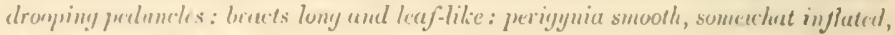
fiw and fivinlly urevel.

31. C. oxylepis, Torr. \& Ilook. Syikes $4-5$, linear, all on long bristlelike partly included nodding peduncles, distaut ; perigyia oblong, acute-megled, emarginate at the pointed apex, longer than the lanceolute rongh-pointerl white seale. - Low ground, Florida, aud westward. - Culus slender, $1 \frac{1}{2}{ }^{\circ}-2^{\circ}$ high, the lower part, like the leaves and slueuths, pubesent.

32. C. æstivalis, M. A. Curtis. Spilics $3-5$, linear or filiform, looscly flowered, erect, the lowest on nearly exserted peduncles, the upper al/nost sessile; perigyia oblong, ohtuse-angled, obtuse and entire at the apex, twice as long as the orate ubtuse or emarginate scale. - Mountains of North Camolina, and northward. - Culms $1^{\circ}-1 \frac{1}{2} 0$ high, smooth. Lowest sheaths puhescent.

33. C. gracillima, Schw. Spikes 3-5, distant, linear, on slender and nodding peduncles; perigrnia oblong, obtuse, entire assd oblique at the orifiec, about twiec as long as the oblong obtuse short-awnerl scale. - Wet neadows, North Carolina, and northward. - CuIm $1^{\circ}-2^{\circ}$ higgls. Spjik's $1^{\prime}-1_{2}^{\prime \prime}$ long, thicker than those of the preceling. Sheaths smooth.

34. C. Davisii, Schw. \& Torr. Spikes $3-4$, remote, olblong-cylindrical, all on slender nearly exserted peduncles, nodding; perigynia ovate-ohlong, inflated, round-angled, emarginate at the pointed apex, longer than the oblong awner scale. - Mountains of Georgia, and northwad - Culms $1 \frac{10}{2}-2^{\circ}$ high. Leares and sheath more or less pubeseent. Spikes rather dense-flowered.

35. C. miliacea, Muhl. Spikes 4, linear, all on exserted nodding peduncles, the terminal one often wholly sterile; perigrnia yellowish, ovate, compressed3-angled, nerveless or nearly so, tapering into a spreading slightly emarginate point, as long as the oblong mueronate scale. - Mountains of Gcorgia, and zorthward. - Culms weak, $1^{\circ}-1 \frac{1}{2}{ }^{\circ}$ high. Sheaths sinooth. Lower perigynia seattered.

* * Terminal spikes sterile, the others fertile, or with few sterile flouers at the summit.

- Perigynia small ( $1^{\prime \prime}-3^{\prime \prime}$ long), slightly or not at all inflated, obtuse or short-beaked.

- Fertile spikes sessile, oroid or oblong, dense-flowercd; perigynia pubescent, shortbeaked or pointed.

36. C. filiformis, I. Sterile spikes 2 or more, slender, longr-peduncled; fertile spikes 1-3, distant, oblong; perigrnia oroid, obtuse, 3-ingled, densely pubescent, obseurcly nerved, alsuptly contracted into a sliort emarginate point, longer than the oblong mucronate brown scalc. - Bogss and swamps, South Carolina, and northward. - Culms $2^{\circ}$ ligh, smooth. Leaves filiforn, clongated. Bracts lcafy, many times longer than the spikes.

37. C. vestita, Willd. Sterile spikes 1-2, thick, short-peduncled; fertilo spikes $1-2$, approximate, ovoid or oblong ; perigynia oblong-orate, 3 -angled, densely pubescent, strongly nerved, tapering into a distinct beak, with a white membranaccous 2-cleft orifice, longer than the oblong mucronate biown scale. Sandy swamps in the upper districts, and northward. - Culms rigid, acute- 
angled, $1^{\circ}-2$ high. Leaves short, linear. Bracts short, the upper one slorter than the spikes.

38. C. dasycarpa, Muhl. Sterile spike single, short-pedmeled, ferile spikes 2-3, approximate, oblong; perigynia woolly, oblong, 3-angled, striate, scarcely beaked, with the orifice entire, twice the length of the ovate barely pointed pale scale; nut stalked. - Sliady woods, Florida to South Carolina Culms $6^{\prime}-12^{\prime}$ high, rough-angled. Leaves pubescent.

39. C. tenax, Chapm. Culms $\left(10^{\prime}-15^{\prime}\right.$ lighl $)$ and rigid channelled leaves rough, but not pubescent; spikes and orate beaked and less pubescent perigynia larger; nut sessile; otherwise like the preceding, and possibly a stouter form of it. - Dry sand-ridges, Middle Florida.

40. C. Pennsylvanica, Lam. Sterile spike single; fertile spikes mostly 2 , ovoid, approximate, $4-6$-flowered, the lower one with a short or scale-like colored bract; perigynia ncarly globose, pubescent, abruptly contracted iuto a short 2-cleft beak, longer than the ohlong-ovate dark brown scale. (C. marginata, Muhl.) - Var. Munlexbergir, Torr. \&. Gray. Fertile spikes mostly 3, 6-10-flowered, distinct, the lowest leafy-bracted; perigynia ovate, tapering into a short beak; scales light hrown. (C. varia, Muhl.) - I)ry woods, in the upper districts, Georgia, and northward - Culms $4^{\prime}-8^{\prime}$ high, longer than the leares.

41. C. lucorum, Willd. Sterile spike single; fertile spikes $3-4$, ovoil, few-flowered, approximate, or the lowest remote and usually leafy-bracted; perigrynia ovoid, more or less pubescent, acute at the base, tapering into a slender rollyh 2-clcft beak, about the length of the ovate-oblong acute scale; leaves narrowly linear. - Var. xigro-MARgINATA. (C. nigro-marginata, Schw) Perigynia 3-angled; scales with brown or black sides; culms $1^{\prime}-2^{\prime}$ high. - Var. Flonidixd. (C. Floridana, Schw.) Perigynia compressed-3-angled or lenticular (but the stiginas 3); scales white or margined with black; cuhms $2^{\prime}-12^{\prime}$ long, prostrate or erect. - Var. Eusoxsir. (C. Emmonsii, Dew) Perigyni: 3-angled, acuminate at each cud, nearly smooth; scales white; culms bristleform, prostrate. - Dry sandy soil, Florida to North Carolina.

\section{+ Fertile spikes lineur or cylindrical, remote, all, or the lourest, on distinct and commonly elongated peduncles.}

$=$ Perigynia striated with numerous fine nerves: sterile spike aluays single.

† Perigynia smonth, nearly terete, obtuse or lurely pointed: bracts long and leuf-like: spikes erect.

42. C. grisea, Wahl. Sterile spike short, sessile; fertile spikes 3-4, linear-oblong, rather loosely-flowered $\left(4^{\prime \prime}-8^{\prime \prime}\right.$ long), the upper one nearly sessile; perigynia ohlong-oroid, pointless, somewhat inflated, twice as long as the white ovate rough-awned scale. - Varies (C. flaccosperma, Dew.), with longer (1'or more) cylindrical spikes, and nearly awnless seales. - Low gronud, Florida to Mississippi, and northward. - Culms smooth, $1^{\circ}-1 \frac{1}{2}^{\circ}$ high. Leaves and bracts broally linear. Upper spikes commonly approximate, the lowest very remote, on a long creet peduncle. Perigynia often indented near the apex. 
Var. angustifolia, Boott. Strrile spike loug-perlunclesl; fertile spikea montly 3, linest, few-flowered, wry romote, the lowe at the bate of the culm;

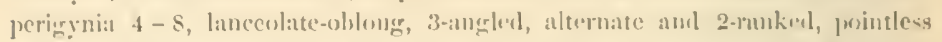
and contire at the apex, longer than the wate rongh-awnerl seale. - Iry open wools, Florida. - Culns filiform, $8^{\prime}-12^{\prime}$ high. Leaves and bracts linear. J.owert she:ath: lark-brown.

43. C. granularis, Muhl. Sterile spike short, sessile; fertile spikes $3-4$, linear-eylindrieal, densely many-flowered, yellowish, the upper one neatly sessile, the lowest distant and long-peduncled ; perygynia small, glohose-ovate, contracted into a minute mostly recurved entire or emarginate point, longer than the orate obtusc or batrely printed scale. - Meadows and banks of stremis, Florida, and nortlaward. - Culms $6^{\prime}-12^{\prime}$ high. Lcares and bracts broally lincar, 3-nervel.

44. C. conoidea, Schk. Sterile spike longr-perlunclerl; fertile spikes 2-3, oblong or cylindrical, denscly many-flowered, remote; perigynia snall, oblongovoill, oltuse, striate with impressed nerves, smonth and shinine, ecpualling or the lower shorter than the ovate pointed or short-awned seale. - Mommans of North Carolina, and northward. - Culuns $6^{\prime}-12^{\prime}$ highl. Leares and bracts linear. Spikes $\frac{11}{2}-3_{4}^{3}$ long, the lowest long-peduncled.

45. C. tetanica, Schk Sterile spike short-perluneled ; fertile spikes $1-3$, linear-cylindrical, remote, loosely flowerel; perigynia obovate, narowed at the base, contracted into a short hent point, longer than the ovate acnte or shortawned seale. - Mountains of North Carolisu, and northward. - Culns 10 high. Lcaves and bracts marrowly linear.

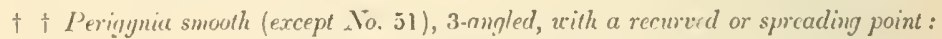
lourest peduncles clonyuted and often recured.

\section{Bracts leafy: scales white.}

46. C. laxiflora, Lam. Sterile spike peluneled, execeding the bracts; fertile spikes 2-3, remote, linear, loosely 8-12-flowerel; perimyia oblongolsovate, tapering into a smooth spreading entire beak, longer than the oblong mucronate scale. (C. anceps, I'illd C. plantaginea, Ell. C. ignota, Lew.) Plant more or less glaucons. Culm $10^{\prime}-15^{\prime}$ high, usually compressed-3-angled above. Leares linear or lanceolate, tender. Sheaths smooth.

Var. striatula. Culms, leaves, and especially the shenths, rough ; sterile spike scssile or nearly so, shorter than the bracts; fertile spikes $3-5$, raller elosely 12-20-flowered, the $2-3$ upper ones commonly approximate; perigynia obovate, abruptly short and bent-pointed. (C. striatula, M/chr. C. blanda, Dew. C. conoidea and C. tetaniea, Ell.) - 1) open woods and margins of fields, Florida, and northward ; common, and rarging greatly in the form of the perigynia and wilth of the leares.

47. C. styloflexa, Buckley. Sterile spike short-perluncler ; fertile spikes 3, oblong, few-flowered, very remote, the lowest on a long and mostly nodding peduncle; perigynia lanceolate or oblone, narowed at the base, tapering into a spreading rough-angled mo-tly enarginate heak, longer tham the ob'oug mucronate scale. - Shady swamps, Middle Floridi, to the mountains of North Caro- 
lina. - Culms filiform, $1^{\circ}-1 \frac{1}{2}$ high, and, like the sheaths of the linear leares, loughened downward.

48. C. digitalis, Willd. Sterile spike small, sessile, or nearly so; fertile spikes commonly 3, remote, very slenter, loosety 5 -8-flowered, all on long bristle-like peduncles, the lowest near the base of the eulm aml generally reclining; perigynia alternate, ovoid, with a short and spreading entire point, twice the length of the ovate arcute green-keeled scale; leaves linear, green; culms $6^{\prime}-12^{\prime}$ high. - Var. ci LALCA. Leaves and bracts wider $\left(4^{\prime \prime}-6^{\prime \prime}\right)$, glaucons, 3-nerved ; fertile spikes thicker, the two upper ones approximate and shortpeduncled; perigrnia larger, thrice the length of the barely-pointed seale. Low grounds, Florida, and northward.

Bracts sheathing, leafless or nearly so: scales brown or bluck.

49. C. plantaginea, Lam. Fertile spikes 3-4, remote, the lowest at the base of the enlin, linear, erect, loosely few-flowered, the peduncles mostly incluted in the brown leafless sheaths; perigrnia oblong-obovate, short-pointed, longer than the orate acute black seale. - Mountains of North Carolina, and northward. - Leaves all radical, $\mathrm{l}^{\prime}$ or more wide, about as long as the slender culm.

50. C. Caroliniana, Buckley. Fertile spikes 3, loosely 3-6-flowered, remote, all on long bristle-like drooping peduncles, which are partly ineluded in the sheaths of the short bracts; the lowest near the hase of the culm ; perigynia ovoil, short pointed, rather longer than the oblong mucronate dark-brown seale. - Table Mountain, South Carolina, Buckley. - Radical leaves $4^{\prime \prime}-6$ " wide, 3-nerved, cxceeding the tufted culms.

51. C. Baltzellii, Chapm. Sterile șpike rigid, often with a few fertile flowers at the base; fertile spikes $3-6$, linear-cylindrital, elosely many-flowered, one (rarely two) on an erect pelunele which is included in a leafless sheath at the base of the sterile spike, the others on long recurved or spreading radical peduncles, commonly sterile at the summit ; perigynia obovate-oblong, pubescent, abruptly short-pointetl, as long as the obovate obtuse mucronate redlish-brown scale. - Dry sandy soil, Middle Florida. - Leaves all radieal, $2^{\prime \prime}-4^{\prime \prime}$ wide, glaucous, very rourh above, longer than the culm.

$==$ Perigynia with feu and scattered nerres, commonly a little infated, straightbeaked or pointed: spikes all, or the lourest, on long and mostly nodding peduncles: bracts leofy.

$\dagger$ Spities linear or filiform, lonsely flovered: perigynia lancentate or oblong.

52. C. venusta, Dew. Fertile spikes $3-5$, linear $\left(1^{\prime}-1 \frac{1}{2}\right.$ long), remote, or the two upper ones approximate and erect; perigynia oblong, acute at each end, rongl-hairy, notehed at the orifiec, twice as long as the oblong obtuse scale - Low banks of streams, Florida to North Carolina. Culms $2^{\circ}-3^{\circ}$ high. Sheaths of the linear leaves very rough.

53. C. debilis, Michx. Fertile spikes $3-5$, remote, filiform, drooping; perigynia alternate, lancelate, smootl, aeute at the hase, tapering into a 2 -cleft beak, twice as long as the oblong obtuse one-nerved scale; shenths smooth. - 


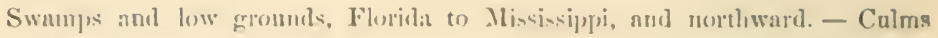
very slender, $1^{\circ}-2^{\circ}$ litirh.

54. C. juncea, Willd. "spikes $2-4$, slender, (rect, hrowni-h prople, the sterile one tiliform, the fertile loosely-floweres, somewhat remote, the lowert on

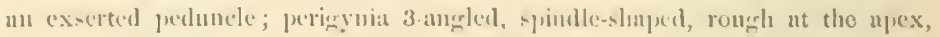
with the orilice entire; seales orate, ohtu-e, and longer than the perigynia, or lanceolate, nueronate, and about equalling them." Boolt. (C. miser, Bueklcy.) - Summit of lioan Monntain, North Carolina, Buckley. - Leaves somewhat bristle-form, shorter thim the culm.

I $\uparrow$ Spilies cylindricul or oblong, densely many-flowered: periyynio orate or roundish.

55. C. scabrata, Scliw. Sterile sp,ike sliort, single; fertile spikes $4-5$, rather distant, on erect exserted pedumeles; perigyuia ovate, roughl, sprending, with few rather prominent nerves, tapering into a 2 -cleft beak, longer than the oblong acute brownish scale. - Shady swamps, North Carolini, and northwarl. - Culms $\left(1^{\circ}-1 \frac{10}{2}\right.$ high $)$ and broadly linear thin leaves very rough. Bracts leaflike, destitute of slieatlis.

56. C. flacea, Schreb. Sterile spikes 1-2, long and rigil ; fertile spikes $2-3$, eylindrieal, all on drooping peduncles, commonly sterile at the summit; perigynia yellowish, compresicel-3-angled, rounil-elliptical, slightly roughened, emarginate or entire at the orifice, longer than the ohlongry olituse or pointerl black seale. - Marvies, Alabama to Nortlı Carolina (Curtis): and northward._Culms $1^{\circ}-2^{\circ}$ high, rough-angled, longer than the rigid glancous leaves.

57. C. glaucescens, Ell. Sterile spike single, long-peduncled; fertile spikes 4-10, eylindrical ( $\left.1^{\prime}-2^{\prime} \mathrm{long}\right)$, all on long and drooping peduncles, mostly sterile at the summit; lowest bract exceding the culm, the others shorter and lristle-like; perigynia glancons, ovate, compressent-3-angled, nerveless, except at the angles, narrowed into an emarginate point, longer than the brown rough. awned scalc. - Pinc-barren pouds, Florida to Nortlı Carolina. - Culms $2{ }^{\circ}-4^{\circ}$ high, rongh-angled above. Leaves glaucons, as long as the culms, bristle-like at the simmuit.

58. C. verrucosa, Ell. Sterile spikes 1-3, sessile or short-peduncled, often with fertile flowers varionsly intermixed; fertile spikes 4-10, cylindrical or oblong, the upper ones sessile ani erect, the lower long-peduncled and drooping; perieyuia glancous, globose-obovate, 3-angled, strongly nerved, abruptly: contracterl into a short and entire point, alout as long ats the hrown roughawned scalc. - Marrins of ponds and rivers, Fiorida to North Carolina, Culms, leaves, and bracts as in the preceding.

59. C. Cherokeensis, Schk, Sterile spikes 2-4, slender; fertile spikes $5-15$, often $2-3$ from the same sheath, oblong or cylindrical, sterile at the summit, all on long and nodding peduncles ; perigynia whitish, olslong, compressed3-angled, sliort-beaked, with the orifice membranaceous and obliquely 2-cleft, longer than the oblong acute scale; stigmas elongated. - Banks of the A palachicola liver, Florida, to the mountains of Georgia, and westward. - Plant whitish. Culms $1^{\circ}-2^{\circ}$ high, smooth, like the linear leares. 
- + Perigynia large $\left(3^{\prime \prime}-6\right.$ "long), and commonly much inflated (excopt Nos. 60 and 61), conspicuously nerved, tupering into a conıcul or long and subulute 2-cleft beculi.

$\rightarrow$ Sterile spile single: styles persistent, contorted: perigynia smooth: spilies many. flovered (except No.66).

60. C. comosa, Boott. Fertile spikes 4, cylindrical, approxinate, on exsertel nodling peduncles ( $1 \frac{1}{2}-2 \frac{1}{2} i$ long $)$ : perigynia ( 2 "long) oblong, spreading or reflexed, tapering into a long subulate deeply 2-cleft heak, with bristly, spread. ing tecth, longer than the awned scile. (C. furcata, Ell.) - Swamps, Georgia, and northwarl. - Culms stout, $2^{\circ}-3^{\circ}$ high, rough-angled above. Leaves broadly linear, and, like the bracts, cxceeding the culm.

61. C. hystricina, Muhl. Fertile spikes 3, oblong or eylindrieal, on nording peluncles; perigynia oblong-ovate, many-nerved, spreading, tapering iuto a minutely 2-cleft beak, twice as long as the oblong awned scale; nut obovate, smooth. - Swamps, Georgia, and northward. - Culns $1^{\circ}-1 \frac{1}{2}$ high, rough above, shorter than the leaves and bracts. Spikes $1^{\prime}-1 \frac{1}{2}^{\prime}$ long.

62. C. tentaculata, Muhl. Sterile spike nearly sessile; fertile spikes l3 , sessile, approximate, or the lowe-t remote and short-peduncled, orate or cylindrieal-oblong; perigynia ovate, sprealing, few-nerved, the long subulate beak cleft on the inner side, and minutely 2-toothed, twiee as long as the lanceolate awned scale; nut ovoid, roughish. - Mulows and low grounds, Florida, and northward. - Culms $1^{\circ}-1 \frac{1}{2}$ high. Leares and bracts elongated.

63. C. gigantea, Rulge. Fertile spikes 3-4, oblong or eylinclrical; the upper approximate and nealy sessile, the lowest di-tant and short-peduncled, erect; perigynia ( $6^{\prime \prime}-7^{\prime \prime}$ long) widely spreading, strongly many-nerved, tapering from an ovate and obtuse base into a long subulate rough 2-eleft beak, with lispid teeth, twice as long as the oblong awm-pointed scale; nut depressed, 3angled. - Pine-barren ponds, Floridia to South Carolina, and westward. - Culms $2^{\circ}$ high, smooth, shorter than the broad lincar leaves and hracts.

64. C. lupulina, Muhl. Fertile spikes 3-4, approximate, sessile, or the lowest short-peluncted, ereet, oblong, thick ( $1^{\prime}$ in diameter); perigynia $\left(6^{\prime}-7^{\prime \prime}\right.$ long erect-spreatling, tilyering fiom the oroid acutish liase into a subulate smooth or slightly roughened beak, with smooth and spreading teeth, twice as long as the oblong awn-pointel scale; nut thombic-oblong. - Deep river-swamps, Fluridit, and northward. - Culms and leaves as in the preceding.

65. C. Halei, Carey. Sterile spike slender, long-peduncled; fertile spikes 2-3, remote, ovoil or ollong ( $l^{\prime}$ in diameter), erect, the lowest commonly on a partly exsertect peeluncle, the others nearly sessile; ferigynia large ( $6^{\prime \prime}$ long), tapering from a greatly inflated and rounded base into a snooth and slenler 2 cleft beak, with smooth and sprealing teeth, more than twice as long as the ob. long acuminate seale ; nut rhomboirl. - Banks of the Apalachicola River, Florilil. and westward. - Culns $1^{\circ}$ high, smooth and slender, as long as the narrow smooth leaves. Spikes whitish, 1'-1 $\frac{1}{2}$ long.

66. C. subulata, Michx. Sterile spike small ; fertile spikes 3-4, remote, few-flowered, the lowest on a partly exserted peduncle, erect; perigynia 4-6. 


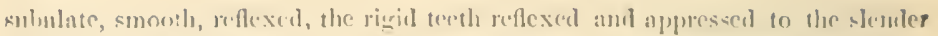

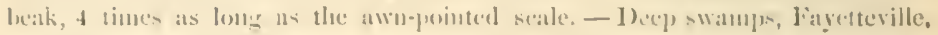

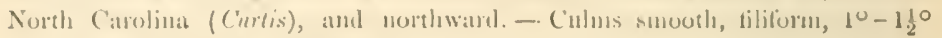
high, longer than the linear leaves.

- Stcrile spilie single: style deciduous, struight or marly so: frrtile spilis fiw. floureted.

67. C. folliculata, L. Fertile sprikes 3-4, oroil, resnote, 8-10 flowered,

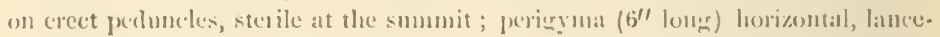

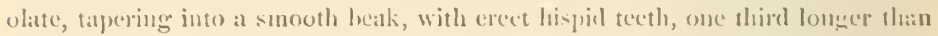
the lanceolate rough-pointed scale. - Wet matrins of streame, Florilia, anul northward. - Culms smooth, yo high, commonly execeding $2^{\circ}$ lincat and that leares.

68. C. turgescens, Torr. Fertile epilies 2, near or remote, on slort in-

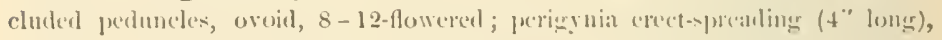

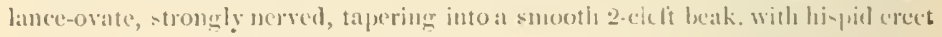
teeth, iwiec as long as the ovate ohtuse scale. - P'ine-haren swamps, Florila to Notth Carolina. - Culms smooth, $2^{\circ}-3^{\circ}$ high, longer than the narrow riginl and chanmelled leaves.

63. C. Elliottii, Seluw. \& Torr. Fertile spilies mostly 3, approximate and

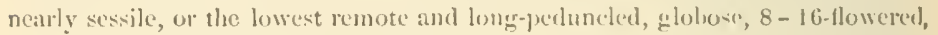
sterile at the apex; perigynia small ( $3^{\prime \prime}$ longr), oblong-orate, compresied, spreal. jug, few-nerved, tajering into a short smooth beak, with erect hispill teeth, wice ns long as the ovate olutuse scile. (C Catstane:a, Ell.) - Borgry mains of pinebarren streams, Florilat to North Carolina. - Culms $1^{\circ}-2^{\circ}$ ligh h, rughl above, longer that the narrowly linear leaves.

70. C. intumescens, Rumge. Fertile spikes 2-4, approximate, the up.

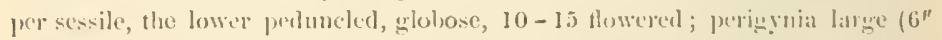
long), spreading, tapering from a rombled amel greatly buflated lase inte al short and sinootl 2-cleft beak with lispid tecth, twice as long as the ovate acuninate seale. (C. folliculata, Ell.) - Slady swanıjs, Florida, and uorthwarl. - Culuns $1^{\circ}-1$ lo high, rough above, shorter than the broally linear deep-grecen leaves and bracts.

+++ Sterile spilies 2 or more: frrile spilies many-flonered.

$=$ Perigymia pubsesent.

71. C. trichocarpa, Mnhl. Sterile spikes ahout three, linear, long-peduncled ; fertile spikes 2, cylindrical, on short and mostly included peduncles; perigrunia thin, rough-hairy, tapering from a romded ovate base into ạ rather slender romgh beak, with long and spiny teeth, longer than the oblong arute awnlexs seale. - Deep marses, Georgia, and northward. - Cuhus $2^{\circ}-3^{\circ}$ high, rough above. Leaves linear, elongated.

i2 C. Striata, Michx Sterile spikes $2-4$, long-peduncled : fertile spilies 1-4 (mostly 2), remote, sessile, or the lowest long-peduncled, oblong or rylindrical; perigynia thick, ovate, muleseent above the middle, contracted iuto a short and whitish 2-cleft or emarginate beak, longer than the oblong acute scale. 
(C. bullata, lill.) - Pine-barren swamps, Florida, and northward. - Cnlms $1 \frac{10}{2}-2^{\circ}$ high. Leaves narrowly linear, kecled, rather rigid. Perigynia occasionally nearly smooth.

$$
==\text { Perigyma smooth. }
$$

73. C. riparia, Curtis. Stcrile spikes 4-6, dark brown; fertile spikes $2-$ 3 , oblong eylindrical, sterile at the summit $\left(1 \frac{1}{2}{ }^{\prime}-2^{\prime}\right.$ long $)$, on erect peluneles. perigynia ovate-oblong, obscurely nerved, tapering into a smootl 2-cleft heak, longer than the obloug brown awned scale. - Deep marslies, Florila to Sionth ('arolina. - Culms stont, $2^{\circ}-3^{\circ}$ hight, rongh above, shorter than the broad $\left(\frac{1}{2}\right)$ sinoothish and glaucons leaves and bracts.

74. C. bullata, Schk. Sterile spikes 2-3, loner-perhuncled; fertile spikes 1-2, ohlong or oval (I' long), sessile, or on very short exserted peduncles : perigynia globove-ovate, moch inflated, strongry yered, smooth aul shining, slemerbeaked, longer than the oblong acnte scale. - Swamps, South Carolina, and northward. - Culms $1^{\circ}-1 \frac{1}{2}{ }^{\circ}$ high, shorter than the linear leaves and bracts.

\section{Order 160. GRAMINAAE. (Grass Fayily.)}

Chiefly herbs. Stem (culm) mostly hollow and with closed joints. Leaves alternate, 2-ranked, narrow and entire. Sheaths open or split on one side, and usually prolonged into a membranaceous or fringed appendage (ligula) at the base of the blade. Flower's in spiked or panicled spikelets, consisting of 2-ranked inibricated bracts or scales; of which the exterior or lower ones, subtending one or more flowers, are called glumes, and the two inner ones, enclosing the 1-celled 1-ovuled ovary, and 1-11 (commonly 3) hypogynous stamens, are called palex. Perianth none, or composed of $1-3$ minute lypogynous scales (squamulef). Anthers versatile, 2-celled. Styles $2-3$, with hairy or plumose stigmas. Fruit a caryopsis (grain). Embryo placed on the outside and near the base of mealy albumen. - Root fibrous.

\section{Synopsis.}

TRIBE I. ORYZEAE. - Spikelets 1 flowered, moslly imperfeet. Glunes none. Paleac 2. Stimens $1-11$.

1 LEEBSIA. Flowers perfect, eompreseed, panicled. Paler unerjual, ciliate.

2. ZIZAYIA. Flowers monocious; the pistillate and staminate ones in the same panicle.

59. LUZ101.1 Flowers monocious; the pistillate and staminate ones in separate panicles

3. HYD:R 'HI, I. Flowers monnecious; the pistillate and staminate ones in separntespikes. 60. MONAXTHOCHLOE Flowers dinecious, in terminal spikes.

TRIBE II. AGROSTIDEA. - Spikelets 1-flowered, or with the pedicel of a second fower above. Flumes 2. Pulen mostly 2, the lower one often awned. Stamens 1-3. Spikelets in open or closely spiked panicles

* Cilumes united at the hase, strongly compressed-keeled.

4. ALOPECURLS. Lower palen awned on the back, the upper wanting. Flowers spiked. 
- Glunes distinet, conceve or kueled. Patere membranaccoug. Grain free. Spikelets In open or contracted panicles.

5. Sponobolits. Flowers awnless. Sued lonse in the globose or obovojd pericarp.

(i. VILFA. Howers awnless. Seed atliering to the closely investing perinarp.

7. Achosiss. Palese shorter than the wearly equal glumes, the lower awned on the back, the njper sometimes wanting.

8. POLPOCiox. Iatexe much shorter than the long-awned glumes, the lower one truneated and tontlued. Stamens 3. L'anicle spikinalike.

9. C'XX. Jules rather longer than the acule glumes, the fower one awned unier the alex. St:amen 1. Pinicle loose.

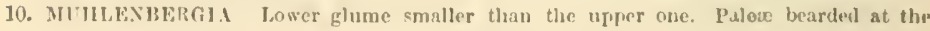
base, the lower one mueronate or awn pointed. Stamens 3.

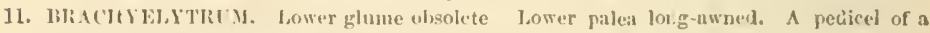
second llower at the back of the upper palege. Stamens 2.

12. CALAMAGROSTIS. Palea surrounded with a tult of long bairs, the lower awued on the bitck.

- * Palese raised on a hairy stalk; the lower one amned, indurated, aud involute, closely in resting the grain.

13. STIPA Lower palea with a single contorted awn jointed witlt its apex Panicle short.

14. STREPTIIINE Lower palea with a single straight or curved awn continuous with its apex. Panicle elongated.

15. ARISTIDA. Lower pulea triple-awned. Panicle elongated.

THmE 111. CHI,OH I DEA. - Spikelets 2 -several-flowered (in No. If one-flowered), in 1-siled spilies. Rachis jointless. Upper llowers imperfuct. Glnmes and palew 2. Spikes racemed or digitate, rarely single.

* Spikelets strietly 1 fowered. (See Paspalum.)

16. SPARTIXI. Spikelets lat, inbricated in alternate spikes.

* * Sjikelets 2-3-flowered, only the lowest flower perfect.

17. Gумуом0G0x. Spikelets lincar, scattered. Lower palea and rudiment awned. Spikes macemel.

18. EUSTA(IIS. Spikelets rounlish, crowdel. Jower pilea mucronate. Spilies digitate.

19. ('YxoLOX. Lower palea awnless. Culus creepiog. Spikes digitate.

** Spikelets $4 \cdot$.. 5-Howered, one of the midule ones only perfect.

20. 'TEXIUM. Lower palea stout-awned on tlue back. Spike solitary.

* * * Spikelets mostly several-flowered, the lower flowers perfeet.

21. DACтуLot"Гexily. Spikes divitate. Upper glume awned. Palexp pointed.

20. ELLUSIXE. Spikes digitate. Glume's and palece awnless.

23. LEPTOCILOA. Spikes racemel, leng and sleuder. Glumes amnless.

Trube IV. FESTC ICE.A. - Spikelets panicled, few-many flowered ; the upper and (in $\mathrm{Xo.35}$ and 37 ) the lower flowers also imperfect. (itumes 2. I'alere 2, membruaceous or moly indurated, awnless, or the lower one with a straight awn at or near the apex. Stamens $1-3$

* Grain smooth, free from the palex. Lower llowers perfect.

- Lower palea : 5 -toothed or asrned.

24. TRICLSPIS. Spikelets 5-7 Howered. Lower palea slightly 2-rleft, the 3 bairy nerves percurrent.

25. ThIPLASIs. Spikelets 3.Howered, the lower pacted deeply 2-cleft, aud with a plumoso awn between the teeth. 
+ + Lower palea entire, awnless or (in No 3i3) awn-pointed.

*- Glumes unlike, the lower one linear, the upper obovate.

26. EATONIA. Spilielets 1-5́-flowered. Culms slender, tufted.

+* +t Glumes alike. Lower palea rounded on the back, not keeled.

27. MELICA. Spikelets 3-5-flowered. Lower palea many-nerved.

28. GLYClili. Epikelets 5-many-flowered. Lower palea strongly 7-nerverl.

29. ARLAdidariA. Spikelets loosely many-flowered. Cnlms woody.

30. LRIZOPYrLil. Spikelets diecious. Lower palea rigid.

+* +* Glumes alike. Lower palea keeled.

31. P0.1. I'alese filling away together, the lower one 5-nersed, and with cobwebby hairs at the base. Spikelets $3-6$-flowered.

32. ERAGliosts. Lower palen falling before the upper one, 3-nerved, not hairy.

33. D.ICTYLJS. Lower palea awn-pointed. Punicle eontracted, eomposed of 1-sided clusters. * * Grain adherent to the upper palea, downy at the apex.

34. FESTCCA. Lower palea entire, aeute or awn-pointed.

35. BROMUS. Lower palea 2 eleft, awned between the teeth

*** Grain free, smooth. Lowest flowers of the spikelet imperfect.

36. CXIOLA. Spikelets broad and flut, many-flowered. Palere coriaceous.

37 PIIIAGJITES. Spikelets 3-6 flowered, silky bearded on the raehis. Paleæ thin.

TRIBE V. HOR DEA C E AE. - Spikelets 2 -several-flowered. sessile, on opposite sides of the jointed rachis, spiked. Glumes $1-2$, rarely wanting. Paleæ 2.

39. ELYyUS. Spikelets $2-4$ at each joint of the raehis. Glumes 2 , placed side by side before the spikelets.

39. GYunosticIlyI. Spikelets $2-3$ at each joint of the rachis. Glumes none.

40. LOLIUII. Spikelet solitary at each joint of the rachis. Glume 1.

Trabe V1. AVEN I CEF. - Spikelets panieled, 2 - several-flowered, the termiual flowers mostly imperfect. Iachiz or base of the flowers often bearded. Lower palea with a twisted, bent, or straight awn on the back, or below the apex

41. AIRA. Spikelets 2-flowered. Lower palea thin, $r$ unded on the baek, awned below the midule.

42. TRISETU3. Spikelets 2 - several-flowered. Lower palea thin, compressed-keeled, bearing a bent awn below the 2-cleft apex.

43. DANTIIOXIA. Spikelets 2 -several-flowered. Lower palea rigid, nany-nerved, bearing a flattened and twisted awn at the 2 -cleft apex.

44. ARIRILNATHERCI. Syikelets 2-flowered, the lower flower staminate, and bearing a long bent awn below the uiddle.

TRibe VII. PIILA RIDEA. - Spikelets in spike-like panieles 3 flowered, the upper or mildle flower perfeet, the two lateral ones imperfeet or mere rudiments. Gluuses 2 Palex 2, indurated in fruit.

45. ANTIIOXAXтіLI. Lateral flowers neutral, each of one awned palea. Perfect flower diandrous.

46. PIIALARls Lateral flowers rudimentary. Perfect flower triandrous.

TRIB VIII. PA NICEF.-Spikelets 2-flowered. Glumes 2, or the lower wanting. Lower flower inperfect, either staminate or neutral, with the lower palea membranaceous and similar to the upper glume, the upper one mostly wanting. Pillen of the perfert tlower coriaceous. Grain mostly grooved or flattened on the outside. Flowers in spikes or panicles.

* Lower glume and upper palea of the sterile flower wanting (the spikelet appearing like a single flower, with 2 glumes and 2 palea).

47 PASPAluM. Spikelets alike plano-rourex, in 1 sided spikes. 


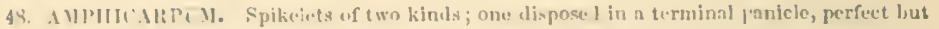
seldom fruiting ; the of her fruitful, on leng solitury ratienal peedumeles.

- Glumes 2, tla. Inwer one often uninute, rarely wanting.

49. P.I.ICI:M. Spikelets single, "Itlout a bristly or spiug involuere.

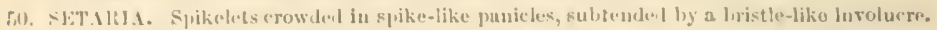

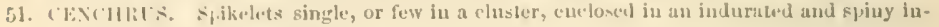
volucre. spilicelets spiket.

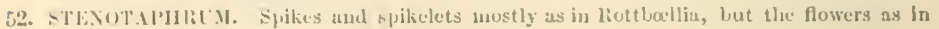
l':tuie'um.

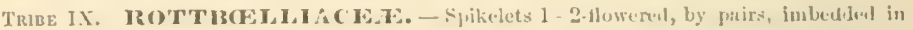

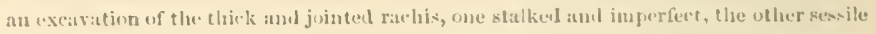
and perfect; or the upper nuikelets all staminate and the lower pistillate. Lower glunis enriaceous or cartilaginums. Palex awnless.

E3. ROTTHELLIA. Spikelets 2 on each joint, one stalked and sterile, the other sessile und perfect.

54. M.1.islias. Spikelets 2 on each joint, the one at the top of the joint sterile, the other at the base globose and ferlie.

55. Tlil'slCLII Upuer spikelets by pairs, all staminate; the lower ones single, and pistillate.

Tribe X. ANDROPOGONEA. - Spikelets 2-3 on each juint of the slender hatiry or plumose rachis. Cilumes more rigid than the thin-atwed palta.

5t). ANDliopo(iON. Spikelets 2 on ench joint of the plumose or hairy rachis, one sessile and perfect, the other stalked and imperfect or rudimenliry.

57. Jilistuls. Spikelets 2 on eneh joint of the rachis, both fertile and sarrounded by a hairy involucre.

58. Soligilu. Spikelets panieled, $2-3$ together, the lateral ones rudimentary.

\section{LEERSIA, Swartz. False Rice,}

Peremnial aquatic or marsh grasses, with the leares and sheaths roughened with minute recurved points, the 1-flowered (whitish) spikelets rowed in 1-sided panicled racemes. l'edicels jointed. Glumes none. Palca 2, chartaceons, strongly compresied, finged on the keel, the lower one much witer. Stamens 1-6. Stigmas 2. (irain compressed.

1. L. oryzoides, Swartz. Panicle large, diffuse; spikelets oblong, fat, loosely imbricated; stamens 3. - Ditches and swamps, Florida, and norliward. July and $\mathrm{Aug}$. - Cnlm $3^{\circ}-4^{\circ}$ long, commonly prostrate at the base. Leares spreating. Base of the panicle mostly enclosed in the sheath of the subtending Ieaf. Sprikelets strongly fringed, abont $3^{\prime \prime}$ long.

2. L. Virginica, Willd. Panjele nearly simple, the lower branches spreadiner ; spikelets small, coneave, sparingly fringed, closely imbricatcd; stamens 1 - 2. (1. imlureati. Letm.?) — Swamps and minrins of streams, Florida, aud northward July and Ang. - More stender than the lasr, and with spikelets half as liuge.

3. L. lenticularis, Michx. Panicle diffuse; spikelets oval, flat, strongly fringed, closely imbricated ; stamens 2. - Pourls and swamps, Florida to North Carolina, and westward. Ang - Culm $2^{\circ}-3^{\circ}$ long. Leaves widely spreading, somewhat glaucous. Spikelets 3 "long. 
4. L. hexandra, Swartz. Panicle contracted, erert, simple; spikelets lanceolate or oblong; stamens 6. - In lakes and ponds, often in deep water, Florida, and westwarl. July and Aug. - Culms slender, $1^{\circ}-6^{\circ} \mathrm{long}$, mostly branching. Leaves narrow, rather rigid. Panicle $2^{\prime}-3^{\prime}$ long, exserted. Spikelets short-fringed, $2^{\prime \prime}$ long, loosely imbricated.

\section{ZIZANIA, Gronov. With Rice.}

Rank water grasses, with broad flat leaves, and large diffuse panicles of monœcious 1-flowered spikelets, on club-shaped jointed pedicels. Glumes none, or reduced to a cup-shaped ring at the base of the spikelet. Palee 2, membranaceous, the lower one rough-awned in the pistillate spikelet. Stannens 6 . Stigmas elongated, brush-shaped. Grain cylindrical, free.

1. Z. aquatica, L Lower portion of the panicle staminate and wilely spreading, the upper pistillate and erect, with straight branches; awn strilight, elongated; styles 2; grain linear. - Deep marshes and ponds, Florida, and northward. July, - Culms $4^{\circ}-8^{\circ}$ high. Leaves rough beneath. Panicle $1^{\circ}-$ $2 \circ$ long.

2. Z. miliacea, Wichx. Panicle diffuse; staminate and pistillate spikelets intermixed; awns short; strles united, elongated; leaves smooth, with rough edges; grain oval. - With the preceding. April and May. - Culms $4^{\circ}-6^{\circ}$ high. Leares somewhat glaucous.

\section{HYDROCHLOA, Beauv.}

A small floating or creeping grass, with short oblong-linear flat leaves, and simple spikes of small monocious $\mathbf{I}$-flowered (white) spikelets, mostly included in the sheaths of the upper leares. Spikelets $3-4$ in a spike, the upper one staminate and exserted. Glumes none. Palea 2, lyvaline, the lower one emasginate, the upper acute. Stamens 6. Styles 2: stigmas elongated. Grain ovoid, free.

1. H. Carolinensis, Beary. (Zizania fluitans, Mirh.x.) - Floating in still water or creeping on muldy banks, Florida to North Carolina. July and Aug. - Culm filiform, branching, $\frac{1}{2}^{\circ}-2^{\circ}$ long. Leaves $1^{\prime}-2^{\prime}$ long.

\section{ALOPECURUS, L. Foxtul Grass.}

Flat-leaved grasses, with the I-flowered spikelets clusely crowiled in a simple spike-hke cylindrical paniele. Glumes 2, compresied, boat-shipen, sharply keeled, united below, awnless. Lower palea compressed, awned on the hack below the middle, the upper wanting. Stamens 3. Styles 2, rarely united below. Grain free, smooth and lenticular.

1. A. geniculatus, L Low; culms ascending, bent at the lower joints ; awn longer than the obtuse hairy glune. - Wet cultivated grounds, Florila and northw:ard. A pril. - Culms $6^{\prime}-12^{6}$ high. Leaves $2^{\prime}-4^{\prime}$ long, with the sheaths shorter than the joints. Spikes $1^{1}-1 \frac{1}{2}+$ long. 
Thr Mrınw Foxтыц (A. pratensis, L.), a tuller species $\left(2^{\circ}-3^{\circ}\right.$ high), with alute ghumes, is scarcely spoutancons at the South. 'Tle same olservation applies to the 'lusermy or Lleno's-gus.s. (l'hleum pratense, L.), which diflers from Alopecoms in labing two palea and awned grlumes.

\section{SPOROBOLUS, Hrown. 1)mop-strn (inss.,}

Tongh wiry and tufted or creeping peremnial gritsits, with narrow leaves, and 1-flowered awnless spikelets, desposed in open, or crowled in spiked panicles. Giunce: 2, membranaceous, unequal, the lower one shorter. Palea 2. mosty longere than the glumes, and of the sane texture. Stamens 3. Sityles 2. Crain oval or globose, loose in the thin nembranaceuts periearp, decidnons. Panieles exserted.

\section{* I'anicles open.}

1. S. junceus, Kinnth. (Wuk-(isiss.) Panicle narrow, the short and spreading loranches whorled; spikelets on one side of the branches, short-stalked ; grlumes smooth, the upper one acnte, $2-3$ times lonerer than the lower, and about cenal to the obtuse palex ; culms $\left(1^{\circ}-2^{\circ}\right.$ high $)$ erect; leaves chicfly ratical, filiform and elongated, involute, tho.e of the culm slort and remote. (Agrostis junceal, Michx.) - Dry pine barrens, conmon. April and May, and often in Ortober.

2. S. Floridanus, 11. sp. P'anicle cliffuse, large; spikelets (pupplish) on long laair-like stalks; grlunes acute, the lower one barely shorter than the oltuse palex, the upper one a third longer; leaves rather rigid, fatt, pungent, verg roughlt on the elges. - Low pine barrens, Mislde and Wext filorida. September. Culm $2^{\circ}-4^{\circ}$ lighth. Leares $1^{\circ}-2^{\circ}$ long. I'anicle $1^{\circ}-1 \frac{1}{2}$ long.

$$
\text { * * P'unicles spilied. }
$$

3. S. Indicus, Brown. Culms ereet; panicle elongated, linear; leaves lone, flat ; palea twice as long as the grlumes, the upper one trumeaterl. (Agrostis Indica, L.) - Waste places, Florida to North Carolina. May - Sejt. - Cinims $2^{\circ}-3^{\circ}$ lriglı. Leaves with bristle-like summits. P'anicle $6^{\prime}-18^{\prime}$ long, tuming blackish. Spikelets crowded on the short appressed brinches.

4. S. Virginicus, Kunth. Culms creepiug, shert-jointed, the short and mostly clustered luanches erect; leares 2-rankenl, soon convolute, short and rigid; panicle small, lanceolate; glumes nearly equal, acute, rather longer tham the paleas. (Agrostis Virginiea, L.) - Saline marshes and hanks along the const, Jilurida to North Carolina. July and Aug. - Flowering stems $60^{\prime}-12^{\prime}$ highlı. Lcaves $2^{\prime}-4^{\prime}$ loug. I'anicle $1^{\prime}-2^{\prime}$ longr, pale or purple.

\section{VILFA, Adans. Ri-su-Grass.}

l'anicles contracted or spriked. more or less included in the shenths of the leaves. Grain oblong or linear, adherent to the elosely investing pericarp. Otherwise as in Sporobolus.

1. V. aspera, Beanv. Perennial; culıns tall and slender; leaves elongated, rough above, bristle-like at the summit; panicles partly included in the 
upper sheaths; palex rough-hairy, unequal, aw]-pointed, $2 \cdot 3$ times as long as the rough-kecled glumes and linear grain. (Agrostis aspera, Mich.e. A. clandestina, Spreng.) - Dry santly soil, Florida, and northward. July and Ang. Culms $2^{\circ}-3^{\circ}$ high. Sheaths hiary at the throat.

2. V. vaginæflora, Torr. Annual; culms low, clustered, bearing concealed panicles at every joint, the terminal one partly exserter; leaves short, smoothish; palex orate, smooth, one third longer than the smooth glumes and oral grain. (Agrostis Virginica, Mhhl. Crypsis Virginica, Nutt.) - Dry basren soil, North Carolina, and northward. September. - Culms $6^{\prime}-12^{\prime}$ hitgh. Leaves $2^{\prime}-4^{\prime}$ long.

\section{Agrostis, L. Bent-Grass.}

Tufied usually tender grasses, with flat and narrow leaves; the small 1-flowered spikelets racemose on the hair-like clustered branches of the open pranicle, on thickened perlicels. Glumes 2, nearly equal, longer than the palex. Palex 2, the lower one commonly awned on the back, 3-5-nerved, the upper 2-nerved, occasionally minute or wanting. Stamens 1-3. Styles or stignats 2. Grain free.

\$1. TRICHODIUM. L Tper pulea minute or unting, the lower aunless, shorter than the unequal acute rough-keeled glumes.

1. A. elata, Trin. Culms stout, erect; leaves flat (1" $-2^{\prime \prime}$ wille); branches of the panicle flower-bearing above the middle. (A. llispar, Mich.x.?) - Swamps, North Carolina, Curtis. September. $4-$ Culms $2^{\circ}-3^{\circ}$ high. Panicles large and diffuse.

2. A. perennans, Gray. Culms slender, idenmbent at the base; leaves flat $\left(1^{\prime \prime}-2^{\prime \prime}\right.$ wide); branches of the panicle short, flower-bearing fiom below the midlle; spikelets whitish. (T. perennans, Ell.) - Swamps and river-banks, Florilat, and northwarl. July and Ang. If - Culms $1^{\circ}-2^{\circ}$ high.

3. A. scabra, Wrill. Culms slender, ereet; leaves short; branches of the panicle long, hair-like, hispiol, hearing the purple spikelets near their summits. (T. laxiforum, Ell.) - Sterile soil, Florida, and rorthward. June and July. (1) - Panicle usually as long as the culm.

\$2. AGROSTIS Proper. Liper pralet manifest: the lower commonly auned on the back.

4. A. alba, I. Culms ascending from a creeping base; panicle spreading in flower, contrated in fruit; glumes (whitish) nearly equal, rougl-keeled ; pale $x$ hairy at the base, the lower twice as long as the upper one, awnless or shortawned. - Dump soil, Florida, and northwart. Introduced. - Culms $1^{\circ}-3^{\circ}$ long.

5. A. rupestris, All. Culms slender, erect; panicle small, ollong, with erect smooth branches; glumes lanceolate, nearly equal, rongh-kecled; lower palea one third shorter than the glumes, short-awnel below the midalle, the upper one minute. - High mountains of North Carolina, and northward. July. Culms $1^{\circ}$ high. 


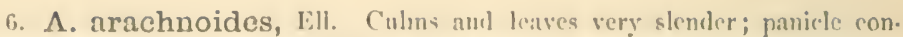

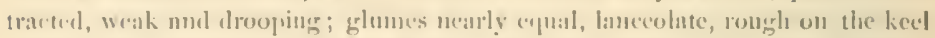

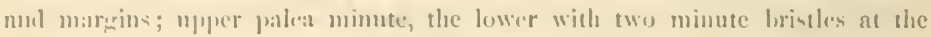

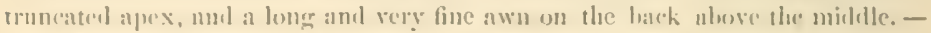

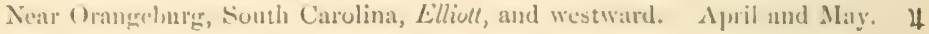
- Culms 10 highls.

\section{POLYPOGON, Inesf. Brimi-Griss.}

I'latt-leaved chichy annual grasses, with the 1-flowered spikelets stalkexl. and crowiled in elose clusters into a terminul spiked parnicle. Glumes 2, equal, alwued, and much longer than the palex, of whel the lower one is truneated and tooblect at the apex, and often short-awned. Stamens 3. Stigmas 2. Grain clliptical, free.

1. P. maritimus, Willel. Culms simple $\left(6^{\prime}-8^{\prime}\right.$ high $)$; ghlumes pmliescent, hispid on the keel, one third as long as the slender awns; lower prilea 4-torthed, mawnch. (Phleum pratense, Ell., Herb) - Sea-shore of North und South Carolina. Introdnced.

\section{CINNA, L.}

Tall perennial grasses, with broad leave, bearing the $]$-flowered compressed spikelets in a large compound terminal panicle. Glumes unequal, lanceolate, aeute, the sharp keel hispid-scrruhate. Palea 2, raised on a stalk, sinooth, the lower one short-awned on the back below the apex. Stamen 1. Grain linearoblong, frec.

1. C. arundinacea, L. Culms $\left(2^{\circ}-7^{\circ}\right.$ high $)$ simple; leares linearlanceolate $\left(\frac{1}{2}\right.$ wide); lranches of the panicle in fours or fives, erect in finit; spiliclets often purplish $\left(2 \frac{1}{2} "-3^{\prime \prime}\right.$ long $)$. - Shaded swamps, Georeria, and northwarl. - Panicle $6^{\prime}-15^{\prime}$ long, rather dense. - Var. rexurta, Gray. Culmw and hrandhes of the drooping panicle more slender; jedicels very rough; spikelets smaller; glumes and palex thinner. - Mountains of North Carolina, Curfis.

\section{MUHLENBERGIA, Sthreb. Drop-seed Griss.}

Spikelets 1-flowered. Glumes persistent, pointed or awned, equal, or the lower one smaller. Palex 2, sessile in the glumes, commonly hairy at the base, deciduous with the enclosed grain; the lower one 3-nerved and mueronate or awned at the apex. Stamens 3.

\$I. MUtiliniblirgid Proper. - Spititets commonly much crouded, in lateval and trminal panicles, short-stalked: culms branching: leares flut.

1. M. Mexicana, Trin. Panicles oblong, dense; glumes unequal, lanceolate, ending in slender lispid awn-like points, the upper one as long as the awnless paleap. (Agrostis lateriflori, Michx.) - Damp soil, North Carolina, and northward. June and July. - Culms aseending, much branched.

2. M. Willdenovii, Trim. Culms sparingly branchel, erect; panicles linear; spikelets scatterel; palex twice as long as the nearly equal short-pointed 
glumes, the lower one with an awn $3-4$ times as long as the spikelet. (Agros* tis tenuiflora, Willd.) - Dry rocky soil in the upper distriets. July and Aur. Culms $3^{\circ}$ ligh.

3. M. diffusa, Schreb. Culms diffusely branched, low ; panicles long and slender: glumes very small, the upper one truncaterl; awn of the palea twice as long as the spikelet. - Shaded waste places, Florida, and northward. Aug. and Sept. - Culms $1^{\circ}-1 \frac{1}{2}{ }^{\circ}$ high.

\$2. TRICHOCHLOA.-Panicle terminal, diffuse: spikelets on long and hair. like stalks: culms tall and simple.

4. M. capillaris, Kunnth. I.eaves rigirl, elongated, convolute; panicle erect, the long and purple glossy branches and spikelets drooping; glumes ncarly equal, half as long as the palex, the lower one awned; palca unequal, the upper one barely awned, the lower 3-awned, with the middle awn many times longer than the spikelet. - Varies with both glumes long-awned. (M. filipes, Curtis.) - Sandy soil along the coast, and sparingly in the interior, Florida, and northwarl. Aug. and Sept. - Culms $2^{\circ}-4^{\circ}$ high.

5. M. trichopodes. Culms and leaves filiform, elongated; panicle erect, oblong; spikelets linear, on spreading stalks; palea twice as long as the nearly equal awnless glumes, ribbed; the lower one tipped with a short awn. and with the two lateral nerres slightly perenrent, hairy at the base. (Agrostis trichopodes. Ell. - Low pine barrens, Florida to Nortl Carolina. Sept. $4-\mathrm{Culms}$ $2^{\circ}-3^{\circ}$ high. Panicle rarely purplish. Leares tlat.

\section{BRACHYELYTRUM, Beauv.}

A perennial erect grass, with a simple slender culm, flat lanceolate leares, and a loose lanceolate simple panicle of large ( $\frac{1}{2}$ long) 1 -flowerel spikelets. Lower glume obsolete, the wpper minute, persistent and awnless. Palea rigid, rough with short bristly hairs, the lower one concare, 5 -ribhed, tapering into a long straight awn, and cnelosing the shorter 2-pointed upper one. An awn-like pedicel of a second flower is applied to the back of the upper palea. Stamens and long stigmas 2. Gruin linear.

1. B. aristatum, Beauv. (Muhlenhergia crecta, Schreb.) - Dry roeky places, Florida, and northward. July. - Culms solitary, $2^{\circ}-3^{\circ}$ high.

\section{CALAMagrostis, Alans. Reed Bext-Grass.}

Perennial grasses, with rigicl erect simple culms, bearing a loose or contracted panicle of 1-flowered spikelets, with the hairy perlicel of a second flower at the hack of the upper palea. Glumes 2, nearly equal, kecled, longer than the palex. Palex 2, hearled at the base with long hairs, the lower one awned on the back. Stamens 3. Grain free.

\$1. CALA.MAGROSTIS Proper. - Glumes and palere membranacrous, the former boat-shiped: panicle open or loose.

1. C. coarctata, Torr. Punicle contracted, lanceolate; glumes lanceolate, awl-pointed, rongh-keeled, with a purple stripe near the margins; lower 


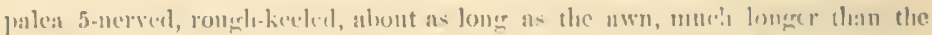

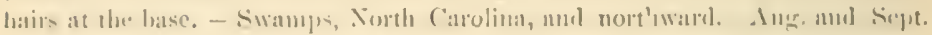

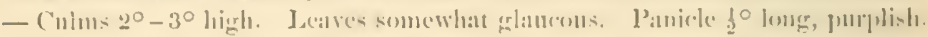

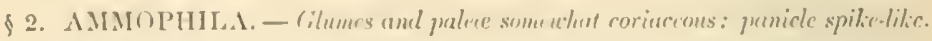

2. C. arenaria, Roth. (ubus amt clongated courolute leatres rigid; punicle long $\left(5^{\prime}-9^{\prime}\right)$, eylimbical; lower palea 5-nerverl, chlscurely awned, is timea as longr as the latirs at the base. - Saudy sea-shore, Nortl Carolina, amel morllward. Aug. - Ruotstock crecpines. Cum $2^{\circ}-3^{\circ}$ higrl. Spikclets, like the whole plant, whitish, $\frac{1}{2}$ long.

\section{STIPA, I. Fi:itner-Grass.}

Perennial grasses, with convolute leaves, and loose panicles of 1-fowered spikelets, with very long awns. Glumes 2, membranaccons, nearly equal, awnless and persistent. Palex coriaccons, involute, raised on an ohronical bented stalk, the lower one witl a twisted or contorted awn jointed with its apex. Stamens 3. Grain terete, cuclosed in the palear.

1. S. avenacea, I. Cuhms $\left(1^{\circ}-2^{\circ}\right.$ high $)$ chstered ; leares narrowly linear: rough, the lowest elongated; awn pubesecnt, hent in the milldle, many times longer than the dark-brown palea. - Dry soil, Florida, and northward. April.

\section{STREPTACHNE, R. Brown.}

Grasses with the habit of Aristida. Spikelet l-flowered; flower stalked. Glumes 2, loose, awnless. Palex 2; the exterior eylindrical-involute. Iwn terminal, simple, jointless, twisted below; the inner palea included, awnless. St:unens 3. Styles 2. Stigmas plumose.

1. S.? Floridana, n. sp. Culm: (20 high $)$ simple, slender, erect; leaves loner. filiform, conrolute, smooth; sheaths hairy at the thront; panicle ( 10 long) narrow, erect, the rough hranches by pairs, seattered ; spikelets short-stalked; glumes equal, linear, purple, 1-nerved, the lower one awn-pointed, hispid-serrulate on the back, the upper smooth, truncated, mucronate-awned; palere raised on a slender bearded stalk, smooth, shorter than the glumes; the lower one linear-subulate, gradually tapering into the long compressed curved awn, conrolute, and enclosing the capillary inner one. - South Florida, Dr. Blodyett.

\section{ARISTIDA, L. WIRE-Grass.}

Dry and harsh percnnial grasses, growing in barren soil, with narrow leaves, racemose or spiked-panicled l-flowered spikelets nearly as in Stipa, but the lower palea ending in a triple awn, which is continuous with its apex (cxcept in No. 9). Upper palea minute. Grain linear.

* Glumes unequal, the upper one shortcr.

1. A. lanata, Poir. Culms stout $\left(2^{\circ}-3^{\circ}\right.$ highl $)$, simple; leaves flat, rough on the upper side, the sheaths, like the axils of the loose panicle, woolly; lower palea ( $4^{\prime \prime}$ long) as long as the upper glume and lateral awns, and one half as 
loug as the middle one. - Dry pine barrens, Florida to North Caroliua. July and Aug. - Lower palea spotted with purple.

2. A. purpurascens, Poir. Culms $\left(1 \frac{1}{2}^{\circ}-2^{\circ}\right.$ high $)$ slender, sparingly Iranched; sheaths sinootlı; glumes sometines nearly equal, purple; lower palea ( $3^{\prime \prime}$ long) $\frac{1}{2}-\frac{1}{3}$ as long as the nearly equal awns. - Dry soil, Florida, aud nortluward. Ang. - Paniele slender, $1^{\circ}$ longr, with the branches appressed.

$$
\text { * * Glumes equal, or the upper one longer. }
$$

3. A. gracilis, Ell. Culms much branched at the base, very slender; leaves flat; panicle very narrow, with distant appressed branches; mildle awn rather longer than the rough and spotted lower palea, the lateral ones much shorter; glumes nearly equal. - Dry gravelly soil, Florida to North Carolinia. Aug. - Culms (with the panicle) $6^{\prime}-12^{\prime}$ high. Spikelets purple.

4. A. virgata, Trin. Culms $\left(2^{\circ}-3^{\circ}\right.$ high $)$ branched near the hase; leaves flat, rigid; panicles ( $1^{\circ}$ long) loose; glumes nearly equal; middle awn spreading, twice as long as the erect lateral ones, and four times the length of the short ( 2 "long) lower palea. - J)ry soil, Florida to North Carolina.

Var? palustris. Every way larger $\left(3^{\circ}-5^{\circ}\right.$ high $)$, with the paniele $1 \frac{1}{2}{ }^{\circ}-$ $2 \frac{1}{2}^{\circ} \mathrm{long}$, and the straight awns nearly equal. - Margins of pine-barren ponds, West Florida. Aug. and Scpt.

5. A. stricta, Michx. Culnıs $\left(2^{\circ}-3^{\circ}\right.$ high $)$ tufterl, simple, straight; leaves chiefly radical, filiform, involute, rigid, hairy at the base; panicle (10 longr) spiked; lateral awns as long as the lower palea, the midlle one one third longer. - Dry sandy ridges in the pine barrens, very common. June and July.

6. A. dichotoma, Michx. Culms low, fork-hranched; leaves filiform, erect; panicle $\left(2^{\prime}-3^{\prime}\right.$ long) spiked; glumes purple, longer than the palea and the very short and erect lateral awns, the middle awn shorter than the palex, spreading. - Dry soil in the upper distriets. Aug. and Sept. - Culus 6'-12' high.

7. A. spiciformis, Ell. Culms simple, rigid, ereet $\left(1^{\circ}-1 \frac{10}{2} \operatorname{high}\right)$; leaves rigid, erect, convolute, smooth; panicle spiked; glumes much slorter than the long (1') very slender palex, the upper one twice as long as the lower; awns nearly equal, widely spreading, the middle one as long as the palex. - Low pine barrens, Florida to South Carolina. Aug. and Sept. Panicles $2^{\prime}-4^{\prime}$ long, at length twisted.

8. A. oligantha, Michx. Culns $\left(1^{\circ}-2^{\circ}\right.$ high $)$ branched, slender; leaves filiform, convolnte; spikclets seattered, single or by pairs, in a simple terminal raceme; glumes nearly equal, longer than the palex; middle awn very long $\left(2^{\prime}\right)$, rather longer than the lateral ones, and 2-3 times the length of the palex. - South Carolina or Georeria, Nutull. Sept.

9. A. tuberculosa, Nutt. Culms rigid, branching $\left(1^{\circ}-1 \frac{1}{2}^{\circ}\right.$ high $)$; Icaves flat; glumes nearly equal, longer than the palex, bristle-awned; awns ( $2^{\prime}$ long) equal, jointed with the palex, twisted below, then widely spreading, several times longer than the palea. - Dry ridges, in the middle districts of Georgia. Sept. - Panicle simple. 


\section{SPARTINA, Sclireh. Musi-Gusss.}

ligid perennial grasses, growing chicfly in saline marslers, with simple culms,

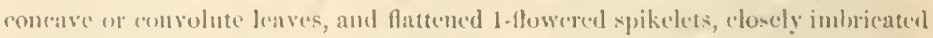
in two pows on one side of the trianghlar rachis, forming appressed or spreading altermite spikes. (ilumes 2, une pusl, arute or shom-inwerl, rommenly bristly. serrulate on the keal; the upper mostly louger than the muegual awnless palea. Stamens 1-3. Styles long, united below, or nearly distinet. Grain free.

\section{* Leaves concolute, rush-like.}

1. S. juncea, Willı. Spikes 3-9, remote, ereet; glumes hispill-serrulate on the keel, the upper $2-3$ times longer than the lower one; lower palea, aud sometimes the mper also, routh above. - Sandy or marshy places along the co:st, Floridla, aul northward. July and $\Lambda$ ug. - Culms $1^{\circ}-3^{\circ}$ high. Leaves pungent. Spikes 1 '-2' long. Stumens $1-3$.

2. S. gracilis, Hook. Spikes $15-30$, closely imbricated in a cylindrical spike, the lowest rather distinct; glumes hispied on the latek, the upuer one third longer than the lower one, ohtuse, numeronate; palea obtuse, the lower rough on the back, the upper smonth. - Sandy saline swamps, West Florila. July and Aug. - Culms $\left(1^{\circ}-2^{\circ}\right.$ high $)$ and rush-like leaves very rigid. Common spike $4^{\prime}-6^{\prime}$ long. Proper spikes $4^{\prime \prime}-6^{\prime \prime}$ long.

\section{* * Leaves concare or flal.}

3. S. polystachya, Willd. Spikes numerous, spreading; upper glume aud nearly equal palex slightiy ronghened, $2-3$ times longrer than the lower one; leaves broad $\left(\frac{1}{2}^{\prime}-1 \frac{1}{2}^{\prime}\right)$, concave, very rough on the margins. - Brackish marshes, Florida to North Carolina. Aug. and Sept. - Culms stout, $4^{\circ}-8^{\circ}$ liggh. Spikes $2^{\prime}-3^{\prime}$ long, racemed.

4. S. glabra, Muhl. Spikes numerous, appressed to the common raclis; upper glume linear, obtuse, 3 times the length of the lower one, and, like the palex, very smooth; leaves concave, smooth on the margins. - Salt marshes, Florila, and northwarl. Aug. and Sept. - Culms $2^{\circ}-4^{\circ}$ high. Lraves narrower than the last, elongated.

\section{GYMNOPOGON, Beanr.}

Low perenuial grasses, with short and crowder distichous spreading leaves. Spikelets appressed, scattered on the straight and at length reflexed branches of the simple panicle, consisting of one perfect flower, and the awn-like pediecl of a second flower above. Glumes 2, subulate, hispid-serrulate. l'alex 2, shorter than the glumes, the lower one awned under the apex. Stamens 3.

1. G. racemosus, Beaur. Culms (10 ligh) rigid; leaves laneeolate $\left(1 \frac{1}{2}{ }^{\prime}-2^{\prime}\right.$ long); branches of the panicle bearing the linear spikelets from the base to the summit; awn $2-3$ times the length of the palea and the pedicel of the sterile flower. (Andropogon ambiguns, Michr.) - Var. Filuformis has narrower leaves, the spikelets borne ahove the nirldle of the hranehes, and the awns and sterile pedicel shorter than the palex. - Dry sandy soil, Florida, and northward. Sept, and Oct. 


\section{EUSTACHYS, Desv.}

Chiefly trcpical grasses, with compressed culms and sheatls, distichous flat or folded obtuse leaves, and digitate rarely single spikes. Spikelets 2 -3-flowered, jmbricated or crowded in 2 rows on one side of the triangular rachis ; the lowest flower perfect and sessile, the upper ones staminate or neutral, and stalked. Glumes 2, membranaceons, persistent, the upper (exterior) one short-awned. Palex coriaccous, the lower one boat-shaped, mucronate-awned under the apex, the upper (mostly wanting in the sterile flowers) unawned. Stamens 3. Grain free.

1. E. petræa, Desv. Culms $\left(1^{\circ}-2^{\circ}\right.$ high) clusterel, erect ; leaves glaucous; spikes 3-5; spikelets 2-flowered; glumes hispid, the npper oblong, deeply emarginate; lower palea dark brown, hairy on the keel and margins, bearded at the base; sterile flower neutral, club-shaped, awnless. - Damp soil along the coast, Florida to North Carolina. May-Aug. 4 -Leaves $3^{\prime}-5^{\prime}$ long. Spikes erect. Spikelets roundish.

2. E. glauca, n. sp. Culms stont $\left(3^{\circ}-5^{\circ}\right.$ high $)$, and, like the broal $\left(6^{\prime \prime}-8^{\prime \prime}\right.$ long) leaves, smooth and glaucous; spikes about 20 ; spikelets roundish, 2-flowered; glumes hispid, the upper laneeolate, entire; palese tark brown, smootls; upper flower obovate, short-awned. - Brackish m irshes, West Florida, Ang. and Sept. (1) - Culms $\frac{1}{2}^{\prime}$ wide at the base. Leaves $1 \frac{10}{2}-2^{\circ}$ long.

3. E. Floridana, n. sp. Cnlms slender ( $2^{\circ}$ high $)$; leaves $\left(2^{\prime}-t^{\prime}\right.$ long $)$ glaucous; spikes single or by pairs; spikelets light brown, 3-flowered, the middle flower staminate; glumes smoothish, truncate, oblong; lower palea of the perfeet flower hairy on the keel and margins, distinctly awned; sterile flowers oborate, smooth, the lower one short-awned. - Dry pine barrens, Middle Florida. July-Sept. I - Spikelets larger than in the two preeding.

\section{CYNODON, Richard. Bermuda-Grass.}

Diffusely creeping grasses, with short and erect flowering stems, and flat leaves. Spikes digitate, 1-sided. Spikelets crowded, awnless, 2-flowered; the lower flower perfect, the upper an awn-like pedicel. Glumes 2, membranaceous, nearly equal. Paleæ 2, membranaceous, the lower one larger and keeled. Stamens 3. Grain free.

1. C. Dactylon, Pers. Spikes 3-5, filiform, purple; glumes roughkeeled; paleæ longer than the glumes, the lower one boat-shaped, and hairy on the keel; anthers and stigmas purple. (Digitaria Dactylon, Ell.) - Watste 1)laces. Introduced. - Culins perennial. Leaves $2^{\prime}-4^{\prime}$ long. Spikes $1^{\prime}-2^{\prime}$ long, filiform.

\section{CTENIUM, Panz.}

Flat-leaved grasses, with the erect culms terminated by a single falcate spike. Spikelets 4-5-flowererl, crowded in two rows on the lower side of the flattened rachis; the two lower sterile, of $1-2$ palea which are awned under the apex, and similar to the third perfect one; the upper ones $(1-2)$ abortive and awn. 
less. Glumes 2, membranacens, very unequal; the larger upper one with a sprealine awn or tulerele on the lack. l'alea of the perfect flower membranareous; the bower one awned Induw the apex, and dersely viliate on the margins. Stamens 3. () vary smooth. Styles terminal: stigmus clongated, plumose, with simple hairs. Grain free.

1. C. Americanum, Spreng. Tirst jumgent; culur $\left(2^{\circ}-3^{\circ}\right.$ highl $)$ rongh, like the narrow leaves; spike at length recurved or coilen $\left(3^{\prime}-4^{\prime}\right.$ long $)$; upper enlume crranular on the back ; the stont awn spremling horizontally. (Monocera aromatica, Ell ) - Low pine barens, Florida to North Carolina. July und Ang. 4 .

\section{DACTYLOCTENIUM, Wilk. Crowfoot-Grass.}

Annual crepping or spreading branching grasses, with flat leaves and digitate rarely single spikes. Spikelets 2 -several-flowered, crowded on one sirle of the flattened rachis; the uppermost flower imperfect. Filumes 2, compressed-kecled, membranaceons; the npper (exterior) awn-jointell. Pallea 2, hoat-shaped, pointed. Stanens 3. Stigmas plumose, with branching hairs. Grain roundish, rugrose, free.

1. D. Egyptiacum, Willı. Culms asernding from a reeping base; leaves fringell; spikes commonly 4, awn-pointed ; spikelets 3-flowerel. (Elcusine? cruciata, Ell.) - Cnltivated gronnd, common. Introduced. - Culnıs numerous, $1^{\circ}$ high. Spikes $1^{\prime}-2^{\prime}$ long.

\section{ELEUSINE, Girt.}

Characters chicfly of Dactylocteninm, but the narrower glumes and palca obtuse and awnless. Stignas plumose, with simple hairs. Spikelets closely imbricated. - Low anmuals.

1. E. Indica, Grert. - Cultivated ground, very common. Introiluced. Cu!us $\left(6^{\prime}-18^{\prime}\right.$ high) flattened ; letwes that ; spikes $2-$ sercral, the lower ones sometimes seattered $\left(2^{\prime}-4^{\prime}\right.$ long $)$; spikelets 6 -flowered.

\section{LEPTOCHLOA, Beaur.}

Flat-leaved grasses, witl the numerous spikes disposed in a terminal raceme. Spikctets sessile, loose on one site of the elongated filiform rachis, 3-manyflowered. Glumes 2, membranaceon; mequal, keelerl. Palex 2, membranaceous; the lower one longer than the upper, 3-nerved, awned or unawned. Stamens 3. Grain oblong, free.

\section{\$1. LEPTOCHLOA P'ROPER. - Lourer pulfa unawned.}

1. L. mucronata, Kuntl. Culms $2^{\circ}-3^{\circ}$ high; sheaths of the broad (4" $6^{\prime \prime}$ wide) rough leaves hairy; spikes numerous, in an elongated meeme, $2^{\prime}-4^{\prime}$ long, spreading; spikelets mintute, 3 -4-flowered; glumes mucronate, longer or shorter than the flowers: lower palea smooth, emarginate. (Elensine mucronata, Miclix.) - Cultivated fields, Florida, and northward. Aug. - Sept. (1) 
2. L. dubia, Nees. Culms $2^{\circ}$ high, slender; leaves elongated, fliform, with smooth sheaths; spikes $6-10$, somewhat corymbose; spikelets distant on the filiform rachis, 6 -flowered; glumes laneeolate, nearly equal, serrulate on the keel, shorter than the awnless soon spreading flowers; palex fringed on the mas. gins, the lower one truncate or emarginate. - South Florida.

\section{\$2. DIPLACHNE. - Lower palea 2-cleft, 1-3-auned.}

3. L. polystachya, Kunth. Culms $\frac{10}{2}-4^{\circ}$ long, mostly prostrate and rooting at the lower joints, much branched; raceme partly included in the sheaths of the elongated leaves; spikes numerous, approximate, erect, $3^{\prime}-5^{\prime}$ long; spikelets lanceolate, 8 -10-flowered; glumes unequal, shorter than the flowers; lower palea hairy on the margins below, 3-awned; the lateral awns minute, the middle one about as long as the palea. (Festuea polystachya, Michx.) - Brackish swamps along the coast, Florida, and northward. Sept. (1)

4. I. Domingensis, Link.? Culms erect, simple, straight and slender: leaves narrowly lincar or filiform, shorter than the rulm; spikes 6-12, seattered, exserted; spikelets lanceolate, 6-8-fowered; glumes unequal, acute, roughkeeled; lower palea hairy on the margins, much longer than the single rougls awn. - South Florida. Oct. - Culıns $1^{\circ}-1 \frac{10}{2}$ ligh.

\section{TRICUSPIS, Beauv.}

Perennial grasses, with tall, erect, simple culms, from a thick and sealy rootstock, elongated rigid leaves, and ovate or lanceolate 5 - 7-flowered stalked spikelets, disposed in a simple or compround open panicle. Glumes 2, smooth, emargirate, shorter than the crowled flowers. Palex 2, 2-cleft, the lower one shortly 3-awned by the percurtent hairy nerves, bearded at the base. Stamens 3. Grain obovate-oblong, free.

I. T. sesslerioides, Torr. Panicle ample and diffuse, or contracted and erect, bearded in the axils; spikelets terete, lanceolate, mostly purple; lower palea with two awn-like teeth sinilar to the three short awns. (Poa quinquitictit. Pursh.) - Dry soil, Florida, and northward. Aug. and Sept. - Cnlms $3^{\circ}-5^{\circ}$ lighl. Sheaths often hairy.

2. T. ambigua. Panicle short, nearly simple, spreading, smooth in the axils, clammy; spikes ovate or roundisl, compressed; teeth of the lower palea obtuse, wider than the three short awns. (Poa ambigua, Cll.) - Low pine barrens, Florida to South Carolina. August. - Culms $2^{\circ}-3^{\circ}$ high.

\section{TRIPLASIS, Beauv.}

Low tufted fihrous-rooted grasses, with branching culm.s, linear-subulate leaves. and few 4 -flowered purple spikelets, disposed in reduced lateral and terminal panicles. Flowers seattered on the slender rachis. Ghumes 2, lanceolate, smooth. Palere 2, hairy on the margins; the lower one 2-eleft, with a hearled or plumose awn between the teeth; the upjer concave, 3-toothed. Stamens 3. Grain free.

1. T. Americana, Beauv. Culms erect, $1^{\circ}-1 \frac{1}{2} 0$ high ; leaves and sheathe hairy; lateral panicles included ; awn of the lower palea plumose, much longer 


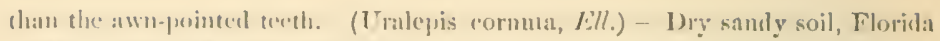
to North Carolinat. Aneg. and Sept. 4.

2. T. purpurea. Cnlms procmulent or ascending, $1^{\circ}-1 \frac{10}{2}$ long; leaves and sheaths smeoth or roughish; lateral panicles inchuldel; awn of the lower

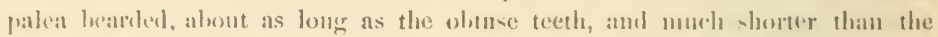

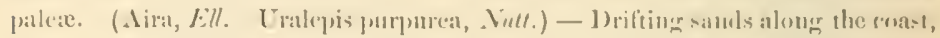
Florida, and northward. Aug. -Uct. - Leaves $1^{\prime}-4^{\prime}$ longr. Spikclets brights purple.

\section{EATONIA, Raf.}

Slender crect and tufted grasses, will narrow leares, and small smooth (not hairy) spikelets of pale howers in a racemose or spicate panicle. Spikelets awnless, 2-5-flowererl, the uppermost flower nsually an awn-like perlicel. Ghmes membranareous, shorter than the flowers; the lower one linear and 1-nerverl; the upper olovite, 3-nerved. l'alex unequal, the lower one obtuse. Stamens 3. Grain lincar-oblong.

1. E. obtusata, Gray. Panicle dense, spike-like, the 2-flowered spikelets much crowided on the short erect loranches; grlumes rongh on the bask, the uprer one ronnd-obovate, somewhat truneate, rather rigid; lower patea lanceshateoblong, olhtuse, rougli-keeled. (A ira obtusata, Michx.) - Dry soil, Florida, aurl northwarl. April and May. I and - Culus $10-20$ high.

2. E. Pennsylvanica, Gray. Panicle slender, loo:e, the 2-3-flowered spikelcts scattered on the slender branches; glumes slightly roughened on the back, the mpecr one olovate, obtuse, or abruptly short-pointed ; lower palea ob. tuse; laraves flat, with the sheaths smooth, rongh, or soft-towny. (Aira mollis, Ell.) - Upper di-triets. April. \& - Culms $1^{\circ}-2^{\circ}$ high.

Var.? filiformis. Culms 10 highl, very stender, barely longer than the filiform involute leaves; panicle linear, loose ; spikelets seattered, mostly 3-fluwercd, the fowers distant on the rachis, the lowest one and glumes nearly suooth. (Aira mollis, var. Ell.) - Jry pine barrens, Florida to South Carolina. March.

\section{MELICA, L.}

I'erennial grasses, with flat leaves, and 3-5-flowered spikelets of large flowers in at simple paniele. Flowers awnkes, the upper ones imperfert. Glumes menbranacens, meegual, convex, obtuse, scarious on the maryins, many-nerved. Palex sinilar to the glumes; the upper one smaller, concave on the back. Stamens 3. Grain free.

1. M. mutica, Walt. Culms $11^{\circ}-20$ high ; leaves and sheaths smooth or rongh-pubescent ; panicle loose, of few nodding racemose spikelets; upper flowers imperfeet, truncate-obovate; palea roughish. (M. glabra, Michx.) - Dry open woods, Florida, and northward. April.

\section{GLYCERIA, Brown.}

Smooth perennial marsh or water grasses, with flat leaves, nearly entire sheatls, and terete or tumid many-flowered spikelets disposed in a simple or compound 
panicle. Rachis jointed. Glunes membranaceous, obtuse, persistent Paleæ nearly equal, somewhat chartaceous, obtuse, early falling away with the separating joints of the rachis; the lower one naked, convex, 7-nerved. Stamens 2-3. Grain free, oblong.

1. G. nervata, Trin. Culms erect; panicle diffuse, the capillary branches at length drooping; spikelets purplish, very mumerous, ovate-oblong, 5-6-flowered, nearly terete; lower palea oblong, obtuse, 7-nerved. (Poa parviflora, Pursh.) -Wet swamps, West Florida, and northward. July. - Culms $2^{\circ}-3^{\circ}$ high. Spikelets 2" long.

2. G. pallida, Trin. Culms erect or ascending; panicle narrow, nearly simple, with the capillary branches erect ; spikelets pale, oblong-linear, 5-9-flowered, nearly terete; lower palca oblong, minutely 5-toothed, 7 -nerved. - Shallow water, North Carolina, and northward. July. - Culus $1^{\circ}-3^{\circ}$ long. Spikelets $\frac{1}{2}^{\prime}$ long.

3. G. fluitans, R. Brown. Culms thick, ascending from a creeping base; leaves long, broadly linear; panicle long, narrow, racemose; spikelets linear, terete, pale, loosely 7 -13-flowered ( $l^{\prime}$ long); lower palea obtuse, ol slightly 3lobed at the scarions apex, roughish. i-nerved. (Poa fluitans, Ell.) - Shallow water in the upper districts, and northward. Jume and Jnly. - Culms $1^{\circ}-5^{\circ}$ long. Panicle $1^{\circ}$ long.

4. G. rigida, Snith. Culms low $\left(2^{\prime}-4^{\prime}\right.$ high), ascending, rigid; Jeaves subulate, $\frac{1}{2}-1 \frac{1}{2}$ long, involute and rigid when dry ; panicle $1^{\prime}-1 \frac{1}{2}$ long, lanceolate, dense, 1-sided; spikelets linear, acute, 5-11-flowered, short-pedicelled; grlumes serrulate on the keel; paleæ obtuse, emarginate or mucronate. (Poa rigida, L.) - Dry soils, around Beaufort, South Carolina, Elliott. April and May.

\section{ARUNDinaria, Michx. Cane or Reed.}

Tall woody grasses, with elustered spreading branches, broad and flat persistent leaves, and racemose or panicled many-flowered spikelets. Glmmes unequal, concave, memhranaceons, awn-pointed. Palea rather loosely imbricated on the bearded and jointed rachis, nearly equal ; the lowest one orate-lanceolate, concave, many-nerved, awn-pointed; the upper strongly 2-kecled. Stamens 3. Stigmas 3. Grain oblong, free.

1. A. gigantea. (C.ıxE.) Cnlms arborescent, $10^{\circ}-20^{\circ}$ high, rigid, simple the first year, branching the second, afterwards at indefinite periods fruiting, and soon after decaying; leaves lanceolate $\left(1^{\prime}-2^{\prime}\right.$ wde), acuminate. smonthish; panicles lateral, composed of few simple racemes: spikelets purple, ereet; lower palea lanceolater-ovate, pulescent, fringred ( $8^{\prime \prime}$ lon $(\underline{)})$, awn-pointed (Armolinaria macrosperma, Michx.) - Banks of the larger vivers, Florida to North Carolina. February.

2. A. tecta, Muhl. (Reed.) Culms slender, $2^{\circ}-10^{\circ}$ high, loranehing; leaves linear-lanceolate, acuminate, ronghish, the sheaths bearded at the throat; spikelets solitary, or in a simple raceme at the summit of the branclies, or frequently 


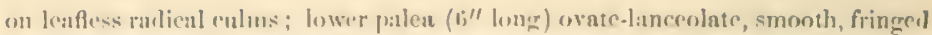
on the matrins, awn-pointerl. (Arumle tect:1, Walt.) - Swamps, Florida to North Curolina. Feb. unl March.

\section{BRIZOPYRUM, Iink.}

A low aud rigid peremial licerions grass, growing in saline manhes, with linear-sulsulate involute distichous leares, sud many-fowered compressed spikelets, crowled in a nearly simple spike. (ilumes am pralea smorth, somewhat coriaceous, obtuse, rompressed, not kereled; the lower ones several-nerved. Stamens 3. Stigmas 2. Giain oblong, frer.

1. B. spicatum, Hook. Routstorks long and crecping; culm: 10 high ; leaves sprealling, rigirl, 2'-4' loner, smooth, like the imbricuted sheatlss; fppikelets oblung, 7 -15-flowcreal. (Tniolit spicata, Ell.) - Low sandy sliores and matrshes, Went Florida, amd northward. Aug. and Sept.

\section{POA, L. Mramow-Grass.}

Grasces with tufted eulms, smooth fat and temter leaves, and compressed fewfowered rpikelets in loose or contracted panicles. (ilumes unequal, shorter than the flowers. Lower palea nearly membranacens, keeled, scarions on the marcins, awniess, 5-nerved, the three more prominent nerves mostly hatiry or woolly below; nper palea 2-toother, falling at maturity with the lower one. Staurens 2-3. Stigmats plunose. Grain free.

\section{* Bronches of the panicle single, or by pairs.}

1. P. annua, L. Aunual; culms tender, spreading, 6-10' high; leaves linear, $3^{\prime}-6^{\prime}$ long, $12_{2}^{\prime \prime}$ widc ; panicle ovate, the smooth branches at length reflexed spikclets ovate, ahout 5-flowered; glumes obtuse or emarginate, lalf as long as the sparsely hary obuse flowers. - Yards and gardens, Florida, and northwarl. Feb, and March. Introduced.

2. P. cristata, Walt. ? Aunual; culms ereet, $6^{\prime}-10^{\prime}$ higrlı ; leaves linear, subulate, I' lung, $\frac{1}{2} "$ wide; panicle linear or lancenlate, dense, the lowest of the rough branches sprealing; spikelets $3-5$-flowered ; lower palea with in prominent crest-like fringe on the back, harely longer than the acute glumes. - J)ry soil around Quinsy, Millle Florila. April.

3. P. flexuosa, Mulhl. Perennial; (ulms weak, mostly crect, $10-11_{2}^{\circ}$ high; leaves narrowly linear; lranches of the panicle by pairs $\left(1 \frac{1}{2}^{\prime}-2^{\prime}\right.$ long), eapillary, widely spreading; spikelets $2-4$ near the summit of each branch, pale, oblong, 3-4-flowered; glumes acute; lower palea conpressed and very ohtuse at the apex, hairy on the nerres. (P. autumnalis, E/ll.) - Rich shaded soil, Florida, and nortluward. May.

* * Branches of the panirle 3 - 6 in a cluster: perennials.

4. P. pratensis, I. Culnis terete, ascending from a creejing base; leaves mostly abruptly pointerd branclies of the panicle expanding, about 5 in a cluster; spikelets ovate, $3-5$-flowered, crowded ; flowers elosely imbricated; lower 
palea acutish, strongly nerved, hairy. (P. viridis and P. angustifolia, Ell.) Rich soil, mostly around dwellings. Introduced. May. $-\mathrm{Culm} 1^{\circ}-2^{\circ}$ high.

5. P. compressa, L. Culms ascending from a creeping base, geniculate, and, like the sheaths, compressed; panicle contracted, 1-sided, the slort erect branches $2 \cdots 4$ in a cluster; spikelets $4-8$-flowered; lower palea rather obtuse, halry below, faintly nerved. - With the preceding. May. - Culms 10 high. Leaves bluish green.

\section{ERAGROSTIS, Beaur.}

Spikelets few-many-flowered, compressed. Lower palea 3-nerved, not hairy nor woolly; the upper one remaining after the rest of the flower has fallen. Otherwise as in Poa. - Culms often branched. Leaves and sheaths smooth or hairy.

\section{* Culms prostrate and creeping, diffusely brumched.}

1. E. reptans, Nees. Culns filiform, the tlowering branches erect $\left(4^{\prime}-6^{\prime}\right.$ high), leaves short ( $1^{\prime}$-- $2^{\prime}$ long), linear; sheaths downy at the base; panicle small (2'-3' long), ovate or oblong, often contracterl; spikelets linear, 10-30-flowererl, nearly sessile, imperfectly dicecions; palex acute. (Poa reptans, Michx.) - Low sandy places, Florida, and northwarl. Ang. and Sept. (1)-Plant pale green.

* *ulms branching, erect or ascendiny: annuals.

2. E. megastachya, Link. Culms prostrate and genirulate at the base, ascendingr; leaves linear; sleaths smooth; panicle oblong or pyramidal, contricted or spreading; spikelets oblongr or at length linear $\left(3^{\prime \prime}-5^{\prime \prime}\right.$ long $), 10-30$ flowered, often lead-color; lower palea ovate, obtıse. (Briza Eragrostis, L.) Cultivated or waste grounds, Florida, and northward. July and Aug.

3. E. ciliaris, Link. Culms slender, prostrate or ascending, geniculate; leaves $\left(2^{\prime}-3^{\prime}\right.$ long) linear, smooth; sheaths smootl, learded at the throat; panicle spiked, cylindrical, the minute $\left(\frac{1}{2}\right.$ " long) ovate spikelets densely crowedel on the short appresserl branches, 5 - 7-flowered ; lower palea obtuse, mucronate, rough or ciliate on tle back; the upper one fringed on the margins with long bristly hairs. - Varies with the culms nearly erect, open lanceolate or oblong janicle, distinct pale spikelets, and flowers more seattered on the smooth rachis. - Waste places and along roads, Florida to South Carolina; the var. at Key West. Culms $6^{\prime}-12^{\prime}$ long. Spikelets purple.

4. E. Purshii, Schrad. Culms slencter, ascending, genieulate near the base, $6^{\prime}-1 \cdot 2$ ' long; leaves narrowly linear, with the sheaths bearled at the throat ; panicle $3^{\prime}-6^{\prime}$ long, the lowest of the widely spreading branches whorled; spikelets linear, $5-10$-flowererl, purple or pale, the lateral ones alppressed, and mostly longer thatn their pedicels; lower palea ovate, 3-nerved. (Poa peetinata, and $\mathbf{P}$. tenella, of authors.) - Waste places and cultivated grounds, common. June - Sept.

5. E. conferta, Trin. Culms ereet, stout, $2^{\circ}-3^{\circ}$ high; leaves linear; sheaths smooth ; panicle elongated $\left(1^{\circ}-2^{\circ} \mathrm{long}\right)$, linear or lanceolate, the very numerons elustered branches and sinall oblong $8-10$-flowered spikelets ereet or 
appressed, flowers minute, membramenecus, rather distant on the rarhlis; lower

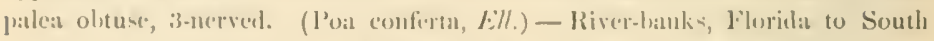

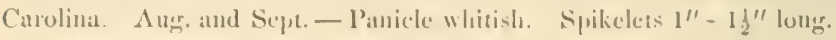

* * * Culms simple, erret, shorter them the lerige aud spmouling jumide.

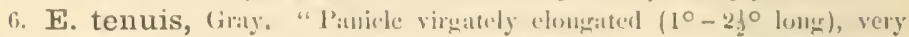
loose, the spreading branches learded in some of the lower asils, their monte

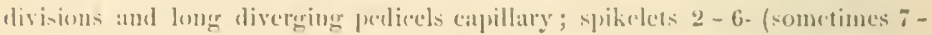
12-) flowercel, palc or greenish; grlumes lanceolate or awl-shaped, wry ardute $\left(1 \frac{1}{2} " 2^{\prime \prime}\right.$ long $)$, membranaceoss, as are the oblong-lanceolate atute flowers;

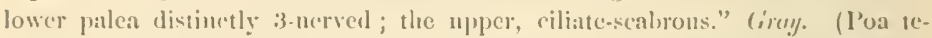
nuis, Ell.) - Greensille, South Carolina, Elliott; North Carolina, Curtis. Ang. and sicpt. 4 ? - Leaves $\left(1 \frac{1}{2}{ }^{\circ}-20\right.$ long $)$ and sheaths smooth or hatiry.

7. E. capillaris, Nees. P'anicle wirlcly expandine, the lower axils mostly bearderl ; spikelets very small (1" - $1 \frac{1}{2} "$ long), $2-4$-llowered, mostly purple, on long diverging capillary pedicels ; glumes and flowers ovate, arnte; lower palea

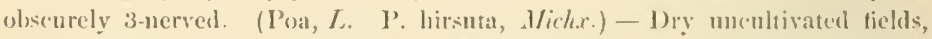
Florida, and northward. Ang. and Sept. - Leaves and sheaths smooth or hairy. l'anicle $1^{\circ}-2^{\circ}$ long.

8. E. nitida. Pinicle $\left(1 \frac{1}{2}^{\circ}-3^{\circ} \mathrm{long}\right)$ reclining, the loristle-like or capillary blanehes crect-sprealing, naked in the axils ; sprtielets linear, flat (3" -4 " long), 8-12-flowered, on erect-spreading pedicels $1^{\prime}-2^{\prime}$ loner; lower palea ar'ute, 3-nerved, nearly smooth on the keel ; leaves and sheaths very smooth and shining. (P'oa nitida, Eill.) - Low grassy places along the coast, West Floridat to South Carolina. Aug. and sept. \& - Leaves narrowly linear, longer than the short $\left(6^{\prime}-9^{\prime}\right.$ high) ('ulm.

9. E. pectinacea, (iray, Panicle erect, widely sprealing, or the rather righil and hitiry hranches at length reflexed; spikelets purple, flat, ahout 8 -flowered, shorter than the ereet or slightly spreading pedicels; lower palea ovate, acute, strongly 3-iserved, rongh-keeled. (Poa pectinacea, Mich.x. P'. hirsuta, Ell., \&c., not of Mich.x.) - Dry sterile soil, lilorida, and northward. Aug. and Sept. - Panicle $1^{\circ}-1 \frac{1}{2}$ long. Leaves and sheatlis mostly clothed with long soft hairs.

Vir. refracta. Smooth thronghont, or the sheaths of the short and rigid Jeaves bearded at the throat; panicle $\left(6^{\prime}-12^{\prime}\right.$ lone with the hranches rellexed ; spikelets sessile or nearly so, 15-20-flowered; lower paleat faintly 3-nerved (Poa refracti, Ell.) - Damp soil, Florida to North Carolina. - Spikelcts about 5 "long.

\section{DACTYLIS, L. Orchamb-Grase.}

Perennial grasses, with simple culns, keeled leaves, and $2-7$-flowered spikelets crowded in a 1 -sided grlomerate panicle. Glumes and lower palea lichaceous, kecled, awn-pointed, rough-ciliate on the keel, the latter 5-nerved. Stamens 3. Grain free.

1. D. glomerata, L. - Near Charleston, Ellioll, and northward. Introdueed. May and June. - Culms $2^{\circ}-3^{\circ}$ high. Leaves and slieatlis scabrous. 
Spikelets in close clusters at the end of the short branches, 2-4-flowered. Glumes and flowers lanccolate.

\section{FESTUCA, L. Fescue-Grass.}

Grasses with flat or setaceons leaves, and panicled 3-many-flowered mostly awnel spikelets. Rachis jointed as in Glyceria. Glumes nnequal, mostly keeled. Palca nearly coriaceuss; the lower one naked, rouncled on the hack, 3-5-nerved, acute or bristle-awned the upper commonly alhering at maturity to the enclosed grain. Stamens $1 \mathbf{- 3}$.

* Flowers auned: panicle contracted: annuals.

1. F. Myurus, I. Culms ereet, very slender, concealed in the sheaths of the bristle-like leaves; panicle elongated, lincar, 1 -sided, partly included in the sheath of the uppermost leaf, the stattered branches appressed; spikelets compressed, 6-flowered; awn 3-4 times the length of the subulate sparsely hairy palea. Stamen 1. - Dry sandy soil, Florida to North Carolina. Mareh and April. - Culms $6^{\prime}-12^{\prime}$ high. Panicle pale, $4^{\prime}-6^{\prime}$ long.

2. F. tenella, Willd. Culms $\left(2^{\prime}-12^{\prime}\right.$ high $)$ erect or ascending; leaves narrowly linear or filiform; panicle long-peduncled, simple, spiked, or the branches slightly spreading, mostly purple; spikelets crowded, compressed, oblong, 8-12-flowered; awn not longer than the subulate hispid palea. - Dry sandy soil, Florida, and northward. Feb.-April.

3. F. duriuscula, L. Cnlms erect, $1^{\circ}-1 \frac{10}{2}$ high ; leares filiform; panicle simple, 1-siled, mostly bending, spreading; spikelets oblong, about 6 -flowered, awn slorter than the smooth lanceolite palea. - Around dwellings, Florida, and northward. Introduced. April-May.

4. F. parviflora, Ell. "Panicle equal, slender, appressel ; spikelets terete, subulate, 5-flowered, awned ; calyx (glumcs) unawned." Ell. - Near Orangeburg, South Carolina. April. 4?-Culms 12'-18 high. Awn as long as the palea. (*)

$$
\text { * * Flowers awnless : panicle spreuding: perennials. }
$$

5. F. elatior, L. Culms $1^{\circ}-2^{\circ}$ high ; leaves linear, smooth; panicle long, narrow, erect, the erect branches bearing the loosely 5 -10-flowered spikelets throughout; palea oblong-laneeolate, barely pointed. - North Carolina, and northward. Introdnced.

6. F. nutans, Willd. Culms $2^{\circ}-4^{\circ}$ high, and, like the broadly linear leaves, rough, or the latter hairy; panicle I-sided, simple, erect or bending, the branches mostly by pairs, remote, bearing few ovate $5-6$-flowered spikelets near their summits, at length reflexerl ; glumes rough on the back, acnte; lower palea ovate, barely pointed. - Rich woods and banks, Florida, and nortliward. Aug.

7. F. grandiflora, Lam. "Panicle simple, erect; spikelets very few, generally i-flowered ; flowers aente, distant." - Carolina, Frazer. (*)

8. F. unioloides, Willd. Panicle contractel ; spikelets compressed, 8-flowerel, awnless; sheaths of the leaves bearded at the summit. - Carolina, Willd. - Panicle nodding, expandling. Spikes oblong-lanecolate. Root fibrous. (*) 


\section{BROMUS, I. Jиоме-firiss.}

Girasses with flat l'aves, umd long-stalkerl spikelefs in loose panieles. Spike let; larger, 3 - many-flowerel. Ginmes membranacens, uncyual, commonly keeled. Lower palea mianlly awned muler the apex, convex on the lack, about 7-nerved at the bate. Stamens 3. Grain flattened and grooved on the inner fise, and allherent to the upper palea.

1. B. ciliatus, L., var, purgans, Gray. Percnnitil; panicle diffuse, the slender drooping luanehes mustly hy pairs; spikelets lancolate after flowering, 10-12-fowered; lower glume 1-nerved, the ujper 3-newed; lower patea convex on the back, 7 -nerved, hairy, about as long as the awm; cnlms $2^{\circ}-4^{\circ}$ high; leaves and sheaths smooth or downy. - River-banks and rich soil, Florida, and northwart. June.

2. B. secalinus, L. (Cunat or Cusss.) Annual; panicle spreading, with elustered, at length drooping branches; spikelets ( $\frac{1}{2}^{\prime}-1^{\prime}$ long) $8-10$-flowared, oblong-ovate; lower glume 5-nerved, the mpper 7 -nerved; jalese smooth, the lower one eonvex, 7-nerved, awnless or short-awned; culms $1^{\circ}-2^{\circ}$ high; leaves and sheaths smootl or downy. - Grain-fields, \&e. Introdueed.

\section{UNIOLA, L.}

Tough peremial grasses, with ereet eulms, from creeping rootstoeks, and mostly broad, flat many-flowered spikelets, in erect or drooping panicles, with one or more of the lower flowers ghme-like amd neutral, and the upper imperfect. Glumes lanceolate, eompressed-keeled. Lower palea rather rigril. strongly compressed-keeted, nerved, awnless, much larger than the 2-keeled upper one. Grain free. Stamens 1-3.

\section{* Spikelets long-pedicelled, dronping : fiowers appressed.}

1. U. latifolia, Michx. Culms $2^{\circ}-3^{\circ}$ high ; leaves Hat, laneeolate $\left(\frac{1}{2}^{\prime}-\right.$ l'wile); panicle loose, drooping; spikelets green, oblong, acute, 10 - 15-flowered ; lower palca one third longer than the upper, fringed on the keel, aentish ; stamen 1. - Banks of rivers, Florida, and northward. July and Ang. - Spikelets $12^{\prime i}-15^{\prime \prime}$ long.

2. U. paniculata, L. Culns stout, $3^{\circ}-5^{\circ}$ high ; leaves very long, rigid, soon convolute; panicle crowded, drooping; spikelets whitish, ohlong-ovate, about 12-flowered; palea equal, the lower one notehed at the apex, sermlate on the keel; stamens 3. - Driftine sands along the coast, West Florjdit, and northward. July and Aug. - Plant pale. Leaves $2^{\circ}-4^{\circ}$ long.

$$
\text { * * Splielets sessile or nearly so, rect: Alowers at length spreading. }
$$

3. U. gracilis, Michx. Panicle long and slender, with the branches appressed : spikelets sntall (2" $\left.-3^{\prime \prime}\right)$, wedge-shaped, 1-6-flowered; lower palea longer than the upper one, smooth on the keel, obtuse; stamen 1. - Rich damp soil, Florida, and northward. July and $\Lambda u g$. - Culms slender, mostly ereet, $2^{\circ}-4^{\circ}$ long. Leaves $2^{\prime \prime}-6^{\prime \prime}$ wide. Sheaths smooth or downy. 
4. U. nitida, Baldw. Panicle short, of few rigid spreading branches; spikelets $\left(6^{\prime \prime}-8^{\prime \prime}\right.$ long) oblong, 6-8-flowered; palex equal, the lower acute, serrulate near the apcx ; stamen 1. - Swamps, Florida, Georgia, and westward. Aug. - Culms slender, $1^{\circ}-2^{\circ}$ high. Leaves linear, smooth.

\section{PHRAGMITES, Trin. REeD.}

Large perennial marsh grasses, with broal and flat leaves and panicled spikelets. Spikelets 3-6-flowererl, with the rachis bearded with long and silky hairs. Lowest flower with a single stamen and imperfect ovary, the others triandrous and perfect. Glumes uncqual, pointerl. Lower palea narrowly awl-shaped, 2-3 times as long as the 2-cleft upper one. Stigmas 2. Grain free.

1. P. communis, Trin. Cnlms $5^{\circ}-8^{\circ}$ high; leaves numerous, $1^{\prime}-2^{\prime}$ wide; panicle diffuse, nodding; spikelets $3-5$-flowercd, about as long as the white hairs of the rachis. - Deep river marshes near the coast, Florida, and northward. Sept.

\section{ELYMUS, L. LYME-Grass.}

Coarse flat-leaved perennial grasses, with rigid erect culms, bearing a single spike of $2-7$-flowered spikelets, arranged $2-4$ in a eluster at each joint of the zigzag rachis. Glumes 2, placed sille by side before the spikclets, coriaceous, unequal-sided, mostly awned. Palea of the same texture as the glumes, the lower eonvex on the back, tapering into a rigil awn; the upper enclosing the linear hairy-tipped grain. Stamens 3. Stigmas 2.

1. E. Virginicus, L. Spike rlense, erect $\left(3^{\prime}\right.$ long $)$, the base usually included in the dilated sheath of the nppermost leaf; spikelets $2-3$ in a eluster, 2-3-flowcred, smoothish, short-awned; glumes lanceolate, strongly nerved. Rirer-banks, Florida, and northward. July and Aug. - Culms $2^{\circ}-3^{\circ}$ high. Leares rough. Sheaths smooth.

2. E. striatus, Willd. Spike dense, ereet or slightly nodding $\left(3^{\prime}-5^{\prime}\right.$ long $)$, long-peduncled; spikelets $2-3$ in a elnster, 1-3-flowercl, hairy, long-awned; glumes linear-subulate, long-awned, much longer than the flowers. - Rocky woods and banks in the upper districts, and northward. July - Sept. - Culms slender, $2^{\circ}$ high. Leares and sheaths smooth or pubescent.

\section{GYMNOSTICHUM, Schreb.}

Spikelets 2-3 on each joint of the rachis, raised on a short and thick stalk. Glumes none, or a single awn-like rudiment. Otherwise as in Elymus.

1. G. Hystrix, Schreb Spike erect, $3^{\prime}-6^{\prime}$ long, lax-flowered; spikelets yellowish, 3-4-flowered, smooth or rough-hairy, long-awned; leaves and sheaths smoothish. (Elymus IIystrix, L.) - Upper districts, Georgia, and northward. July. - Culms $2^{\circ}-3^{\circ}$ high. Rachis 2-edgred. 


\section{LOLIUM, I. I):Rพi:.}

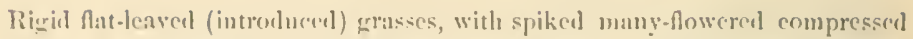
spikelets, with one edge spplied to the jointless rachis. (ilume 1, rigrid, uwnless.

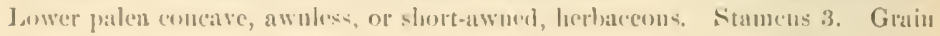
adlerent to the upper palea - Spikelets distant on the elongated rachis.

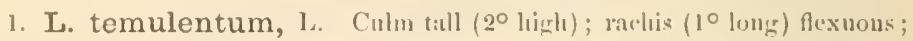
glume righil, many-nervell, longer thin the 5-fowered sprikelet, hwer palea nwned under the scarions ohtuse npex. - G rain-ficlis, North Carolina.

2 L. arvense, Withering. Culms low $\left(6^{\prime}-12^{\prime}\right)$; rachis $\left(6^{\prime}-8^{\prime}\right.$ long $)$ struight; glume rigil, many-nerved, shorter than the 8-10-flowered spikelet; lower palea awnless or short-awned at the searious emarginate apex. - Strects of Apalachicola. July.

\section{AIRA, I.}

Low and slender tnfted grasses, with the small 2-flowered stalked spikelets in a lonse panicle. Glumes membranaceons, keeled, longer than the flowers. I'alea hairy at the base; the lower one $3-5$-nerved, and awned on the back. Stamens 3. Grain ollongr, smooth.

1. A. flexuosa, I. Culms nearly naked, $1^{\circ}-1 \frac{1}{2} 0$ ligh ; leaves short, bristle-like; panicle small, capillary, spreading; lower palea toothed at the apex, much shorter than the slender awn; grain free. - Mountains of Georgia, and northward. July. 4 .

\section{TRISETUM, Pers.}

Spikelets 2-several-flowered. Lower palea compressed-keeled, usually bearing a bent awn below the 2-eleft or 2-pointed apex. Otherwise as in Aira. Spikelets in open or spiked panicles.

1. T. palustre, Torr. Smoosh; culms weak $\left(1^{\circ}-1 \frac{1}{2} 0 \mathrm{long}\right)$; leaves flat, linear; panicle long and narrow, loose; spikelets 2-3-flowered; the lower flower awnless, the upper with a spreading awn and an awn-like rudiment at the base, or rarely both flowers awnless. (Aira pallens, Muhl. A. triflora, Ell. ?) Swamps, West Florida to Mississippi, and northward. March and April. Panicle pale, $4^{\prime}-8^{\prime}$ long.

2. T. molle, kinnth. Soft downy; culms short $\left(6^{\prime}-8^{\prime}\right)$; panicle $\left(2^{\prime}-3^{\prime}\right.$ long) contracted, dense and spike-like; spikelets 2-flowered, the lower palea of both flowers with a spreading awn. - Mountains of North Carolina, and nortl. ward.

\section{DANTHONIA, DC.}

Tufted grasses, with racemose or panicled spikelets, and rough or hearded flowers. Spikelets 3-many-flowered. Glumes nearly equal, membranaceous, longer than the flowers, awnless. Lower palea rigid, concave, many-nerved, bearded below, sharply 2 -toothed at the apex, bearing an intermediate awn, which is flattencd and twisted near the base. Stamens 3. Grain oblong, free 
1. D. spicata, Beanr. Spikelets $4-8$, racemose, 7 -fowered; lower palea rough with short rigid hairs, much longer than the lanceolate-subulate teeth; culms $\left(10^{\prime}-18^{\prime}\right.$ lighl) slender; leaves short and narrow, soon involute. (Arena spicata, L.) - Dry barren soil, Florida, and northward. June and July. - Raceme $1^{\prime}-2^{\prime}$ long.

2. D. sericea, Nutt. Spikelets numerous, panicled, 7 -flowered; lower palea white with long silky hairs, as long as the slender, awn-pointed teeth; culms $2^{\circ}$ bigh ; sheaths of the linear leaves woolly above. (Avena spieata, Ell.) - Upper districts of Georgia, and northward. April.

\section{ARRHENATHERUM, Beauv.}

Tall grasses, with flat leaves, and spreading panicles with clustererl or whorled branches. Spikelets 2-flowered, with the awn-like rudiment of a third flower; the lower one staminate, the upper perfect. Glumes membranaceous, concare, the upper one as long as the flowers. Palex herbaceous; the lower one of the perfect flowers slightly awned near the apex, that of the staninate flower hearing a long bent awn below the middle. Stamens 3 .

1. A. avenaceum, Beauv. Culms smooth, $2^{\circ}-3^{\circ}$ high; leaves broadly lincar; panicle narrow, whitish, $8^{\prime}-10^{\prime}$ long; glumes scarious. - North Carolina, Curtis. Introduced. May. 4.

\section{ANThoXANTHUM, L. Swfet-scexten Grass.}

Grasses with flat leaves and 3-flowered spikelets, crowrled in a spiked panicle; the two lower flowers neutral, and consisting of a single hairy palea awned on the back; the upper flower perfect, of two smooth awnless palex, and two very thin glumes, the upper one 3-nerved, longer than the flower, and twice as long as the 1-rerved lower one. Stamens 2. Grain enclosed in the palex.

1. A. odoratum, L. Culms $1^{\circ}$ high ; leares linear, hairy ; panicle $1^{\prime}-3^{\prime}$ long. - Low grounds around the larger cities, Savannah, Charleston, \&e. Introduced. April and May.

\section{PHALARIS, L.}

Spikelets crowded in a densely spiked panicle, 3-flowered; the two lower flowers reduced to hairy scales; the upper perfect, consisting of 2 boat-shaped awnless, at length coriaceous palex, the lower one longer and enclosing the upper, and two nearly equal broadly keeled glumes which are longer than the flower. Stamens 3. Styles elongated. Grain enclosed in the palex.

1. P. intermedia, Bose. Culms ascending, slender, $6^{\prime}-12^{\prime}$ higl ; leaves short, with the uppermost sheath inflated; spike $\left(\frac{1^{\prime}}{2}-l^{\prime}\right.$ long) oral, compact; glumes lanceolate, slender-pointed, broally keeled, twice as long as the hairy ovate flower. (P. Americana, Ell. P. microstachy'a, DC.) - Sandy places along the coast, Florida to North Carolina. April and May. - Leaves broadly linear, $1^{\prime}-2^{\prime}$ long, somewhat glaucous. Spike white or purplish.

Var. angusta. (P. angusta, Nees.) Culm stout $\left(2^{\circ}-3^{\circ}\right.$ high $)$; spike cy. 
limbrienl $\left(2^{\prime}-4^{\prime}\right.$ long), somewhat interrupted at the buse; glumes short-pointed,

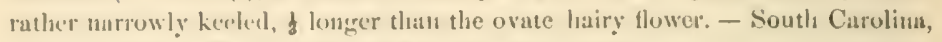
and westward. (1) - Lanves not glnucous, $4^{\prime}-10^{\prime}$ long.

\section{PASPALUM, I.}

Spikelets spikerl or somewlint racemed, apparently 1 -Howered, awnless, horne in $1-4$ rows on one side of the flatened or triangulur jointless rachis. Glumes 2, membranaceons, nearly equal. Palca 2, ovate or roundish, coriaccons; the lower one latrger, coneave, and partly enclosing the flattened upper one. Stumens 3. Grain inchuled in the induraterl palea. Such is the ajparent structure of the spikelet, but theoretically it is 2-flowered, as in P'anicum, with the lower grlune and upper palca of the lower flower andeveloped.

* Sprities racemed: spiketets partly enclosed by the recurced margins of the broadly uinged membranaceous ruchis.

1. P. fluitans, Kuntl. Spikes very nunerons; spikelets in two rows, minute $\left(\frac{1}{2} "\right.$ long $)$, oblong, pubescent ; grlunes pointed ; culm branehing, ascending from a ereeping or flouting base; leaves flat, broadly linear $\left(4^{\prime \prime}-8^{\prime \prime}\right.$ wide $)$. (Ceresia flutans, Ell.) - River-swanps, Florida, and northward. Sept. and Oct. (1) - Culms smooth, $1^{\circ}-33^{\circ}$ long.

2. P. Walteri, Schnltes. Smooth; spikes $3-7$, the lowest ones includer in the sheath of the uppermost leaf; spikelets in two rows, ovate, smooth; glumes obtuse, 5-nerved. (P. vacrinatum, lill.) - Low cultivnted grounds, Florida to North Carolina, and wentwarl. July and Aug. - Culms decumbent, creeping, $1^{\circ}-3^{\circ}$ long. Leaves linear, slsort.

* * Spikes mostly by purirs, divaricute: spikelets onate-fanceolate, acute, 2-roued on the slcnder wingless rachis: glumes smooth, lunger than the puleo.

3. P. Digitaria, Poir. Peduncles elongated, lateral and terminal, often $2-3$ together from the upper sheath; spikes $\left(3^{\prime}-4^{\prime}\right.$ long) filiform, spreading liorizontally; glumes even, 7 -nerved, $\frac{1}{3}$ longer than the obtuse perfect flower; culns aseending from a creeping and branching base; leaves linceolate, obtuse, flat, mostly fringed on the mareins, the sheaths compressed. (Milium puspalodes, Ell) - Open swamps, Florida to Nortl Carolina, and westward. July Sept. $\quad 4-\mathrm{Culms} 1^{\circ}-2^{\circ}$ high.

4. P. vaginatum, Swartz. Peluncles single, terminal, spikes (rarely 3 or 4) short (1'-1 $1^{\prime}$ long), erect or horizontal; glumes rugose, 5-nervell, rather longer than the acute flower; culns diffusely creeping, short-jointed; the flowering branches $\left(4^{\prime}-10^{\prime}\right.$ longe erect; leaves $\left(1^{\prime}-3^{\prime}\right.$ long $)$ sululate-(onvolute, their dilated imbricated sheatls persistent. (I'. furcatun, Fluegge.) - Saline swamps, West Florila, ami soutlwarl. Aug. und Sept. 4-Culms $29^{\circ}-4^{\circ}$ long. Sheaths compressed, bearded at the throat.

* * * Spikes solitary, or few and racemose: spiketets orate or roundish, in 2-4 rous: rachis mostly fattened and flexuous: glumes and palea nearly equal.

5. P. distichum, L. Spikes 2 , rarely 3 or 4 , spreading $\left(1^{\prime}-1 \frac{1^{\prime}}{2}\right.$ long $)$; spikelets in 2 rows, single, orate, acute, as wide as the straight rachis; glumes 
3-nerved, more or less pubescent; culms diffuse, creeping; leaves flat, glaueous, rough above, and, like the sheaths, smooth or hairy. (P. tristachyum, Leconte?) - Swamps and low grounds, Florida to North Carolina, and westward. Ang. and Sept. 4 - Flowering stems $1^{\circ}$ high.

6. P. præcox, Wralt. Spikes 3-6; spikelets by pairs, in 3 rows, orbicular, compressed, as wide as the stright and flat rachis; glumes smooth, 3-nerved, often discolored; cuims erect $\left(3^{\circ}-4^{\circ}\right.$ high $)$, simple; leaves long and narrow; sheaths purple, smooth or hairy. - Pine-barren swamps, May and June. 4 .

7. P. læve, Michx. Spikes $3-5$, long $\left(3^{\prime}-4^{\prime}\right)$ and slender; spikelets single, in 2 rows, orbicular, wider than the flexuons raehis; glumes smooth and even, 5-nerved; culms simple, erect $\left(3^{\circ}-4^{\circ}\right.$ high); leaves (deep green) and sheaths smooth, or the latter lairy. - Dry woods and margins of fields, Florida, and northward. July and Aug. 4 - Spikelets $1 \frac{1}{2}$ " long, larger and thicker than the last.

8. P. Floridanum, Miehx. Spikes $2-3$, thiek, erect; spikelets large (2" long), mostly in 3 rows, broadly oval, tumid, wider than the flexuous rachis; glumes smooth, 5-nerved, more or less rugose; culms rigid, ereet $\left(2^{\circ}\right.$ ligh $)$; leaves narrow, rigid, and, like the sheaths, rough-hairy. (P. maerospermum, Fluegge.) - Damp soil, near the coast, Florida. Aug. and Sept. 4-I'lant glancous.

9. P. racemulosum, Nutt. Spikes $2-3$, slender, ereet $\left(4^{\prime}\right.$ long $)$; spikelets single or by pairs, oborate, distant on the filiform and somewhat flexuous rachis, distinetly pedicelled; glumes smooth, obtuse, 7 -nerved; culms simple, ereet $\left(2^{\circ}-3^{\circ}\right.$ high $)$; leaves long, linear, keeled, glancous, and, like the sheaths, sprinkled with long white hairs. (Panieum Alahamense, Trin.) - Dry sandy soil, Florida to North Carolina, and westward. Ang. and Sept. If.

10. P. undulatum, Poir. Spikes $2-12$, spreading $\left(2^{\prime}-3^{\prime}\right.$ long $)$; spikelets small (1"long), oral or roundish, crowded in 3-4 rows under the broad and flat rachis; glumes smooth, 5-nerved; paleæ of the neutral flower often rngose; enlms ereet or ascending, mostly branching; leaves deep green, broally linear, flat, mostly fringed on the margins or near the base, and, like the smooth or bairy sheatlss, often purple. (P. purpuraseens, Ell. P. plicatulum, Wichx. P. confertum, Leconte. P. Boscianum, Fluegge.) - Low cultivated grounds, Florida to North Carolina. Sept. (1) - Culms $\frac{10}{2}-3^{\circ}$ high.

11. P. Blodgettii, n. sp. Spikes 4, filiform; spikelets minute ( $\left(33^{\prime \prime}\right.$ long), in 3 rows, elliptical, as wide as the straight rachis; glumes 3-nerved, minutely pubescent and granular; culms tufted, simple, ereet $\left(1^{\circ}-1 \frac{1}{2} \circ \mathrm{high}\right)$; leaves flat, fringed on the margins. - Key West, Lr. Blodgett. 4 -Spikes I' long.

12. P. ciliatifolium, Michx. Spikes slender, mostly solitary, rarely 23 , on long lateral and terninal peduncles, of which $2-3$ often project from the upper sheatls; spikelets orbicular, in $2-3$ rows, wider than the narrow flexuous rachis; glume 3 -nerved, commonly pubescent; culms tufted $\left(1^{\circ}-2^{\circ}\right.$ long), ereet or spreading, simple or branched; leaves $2^{\prime \prime}-9^{\prime \prime}$ wide, flat, wavy and fringed on the margins, or, like the sheaths, hairy all over. (P. sctaceum, and P. debile, Michx. P. dasyphyllum, Elll, \&c.) - Wet or dry soil, very common. JunoSept. (1) and 4 . 


\section{AMPHICARPUM, Kinth.}

I'erennial flat-leared grasses, with the spikelets nearly as in Panicum, but of two kinds; one perfect, but rarely fruitful, dicpoced in a simple terminal panicle or raceme; the other largere, pistillate or perfect, aud borme st the sumnit of long runner-like ralieal peduncles. L.ower glume minute or wanting.

1. A. Purshii, limnth. Culms tufterl, erect from filrous roots, naked ahove; leares lanceolate, rather thin, clothed, like the sheatls, with spreading rigid hairs; upper flowers in a strict panicle; those at base of the ruln perfert; grain ovoid or ublone, terete. (Milium amplicarpon, Pursh.) - Low sandy pine barrens, Georgia, and northward. Sept. - Cuhms $1^{\circ}-3^{\circ}$ hight. Glunes of the "upper flowers 5-nerved, of the lower one white, many-nerverl.

2. A. Floridanum, n. sp. Culms subterrancous, diffusely creeping; flowering branches erect $\left(1^{\circ}-3^{\circ}\right.$ high), branching; leaves linear-lanceolate, rigid, smootlı; sheaths fringed on the margins; upper flower abortive, panicled or racemel, oblong ( $3^{\prime \prime}$ long), acute; glumes 5 -nerved; anthers of the radieal flowers imperfeet ; grain compressed-globose, pointed. - Banks of the Apalachicola River, Florila. Sept, and Oct. - Plant pale green. Palex of the radical flowers crustaccous at maturity.

\section{PANICUM, I. Panic-Grass.}

Inflorescence spiked, racemose or panieled. Spikelets 2-flowered, naked (no involuere). Glumes 2, herbaccous; the upper one usually as long as the flowers, the lower smaller, often minute, or oceasionally wanting. Lower flower staminate or neutral, of $1-2$ palex; the upper palea, when present, small and lyyaline, the lower herbaccons and resembling the upper glume. Upper flower perfect, coriaceous, awnless, enclosing the free grain. Stancns 3.

\$1. DIGITARIA. - Inflorescence spiked: sprikelets 2-3 together, imbricated on one side of a filiform rachis: lower flouer of one palca, and neutral: glumes shorter than the flowers: ammals.

1. P. sanguinale, L. (Cran-Grass.) Culms asecnding from a diffusely ereeping base; leaves thin, spreading, the lower part, like the sheaths, hairy; spikes 5-10, spreading; spikclets oblong, pointed; glumes hairy on the margins, the upper half as long as the flowers, the lower minute, or in var. villosum (Digitaria villosa, Ell., a smaller and more hairy form) wanting. - Cultivated grounds and waste places everywhere. May-Oet.

2. P. filiforme, L. Culms erect, sparingly branched $\left(2^{\circ}-3^{\circ}\right.$ high $)$; leaves linear, erect, and, like the sheaths, hairy; spikes 2-5, alternate, crect, filiform ; spikelets oblong, acute, scattered; upper glume half as long as the acute blackish palca, the lower wanting. - Dry sandy soil, common. Aug. and Sept.

\$2. PANICUM Proper. - Cilumes 2, unequal, awnless: spilielets in panicles or racemes.

* Spikelets crouded in simple or panicled racemes.

- Sterile flouer of one palea, neutral.

3. P. tenuiculmum, Meyer. Culm filiform, ereet, simple; leaves chicfly radical, linear ( 2 "wide); racemes $8-12$, remote, $3-6$-flowered, forming a long 
narrow and simple panicle; rachis flexuous, naked and bristle-like at the apex; spikelets orate ( $l^{\prime \prime}$ long) ; upper glume 9 -nerved, twice as long as the obtuse lower one. - South Florida. - Culıns $1 \frac{1}{2}^{\circ}-2^{\circ}$ high. Racemes distant on the common rachis, $\frac{1}{2}^{\prime}$ long.

\section{+ + Stcrile flower of tuo palece, staminate or neutral.}

4. P. gibbum, Ell. Panicle spiked, cylindrical, $3^{\prime}-5^{\prime}$ long; spikelets oblong, obtuse; upper glume oval, strongly Il-nerved, tumid at the base, twice as long as the smooth fertile flower, the lower one minute; sterile flower 3-androus; culms branched, slender, reclining; leaves linear-lanceolate, smooth or hairy. - Swamps, Florida to North Carolina. July - Sept. - Plant deep green. Spikelets cadncous.

5. P. Curtisii. Panicle slender, spike-like $\left(6^{\prime}-8^{\prime}\right.$ long $)$, the appressed lower branches remote; spikelets ovate-lanceolate; glumes slightly keeled, the upper 5-nerved, twice as long as the lower one, and rather shorter than the acutish flower; sterile flower 3-androus; culms and smooth linear-lanceolate leaves rigicl; sheaths smooth or hairy. (P. Walteri, Ell., not of Poiret nor Pursh. P. earinatum, Torr, in Curtis's Plants, Wilmington, not of Presl.) Ponds and swamps, Florida to North Carolina. - Culms $3^{\circ}-4^{\circ}$ high, often rooting at the lower joints.

6. P. hians, Ell. Panicle small, the few scattered and spreading branches naked below; spikelets in small distinct clusters, ovate; upper glume 5-nerved, $3-4$ times longer than the lower; sterile flowers neutral, longer than the perfect flower, the upper palea rigid, obovate, involute, gaping at the apex; culms slender $\left(6^{\prime}-18^{\prime}\right.$ high $)$, simple; leaves linear, smooth. - Low grounds in fields and along roads, Florida to North Carolina.

7. P. gymnocarpum, Ell. Panicle large, pyramidal, the rigid expanding branches mostly clustered or whorled; spikelets $3-6$ in seattered clusters (2" long), lanceolate; glumes lanceolate-subulate, rough-kecled, $2-3$ times longer than the perfect flower; sterile flower neutral ; the lower palea as long as the lower glume, and much longer than the upper palea; culms rigil, ereet; leaves (I' or more wide) lanceolate, cordate, smooth. - Muddy banks of rivers, Florida, Georgia, and westward. Sept. $4-$ Culms $2^{\circ}-3^{\circ}$ high. Sheaths imbricated.

8. P. anceps, L. Panicles lateral and terminal, diffuse; spikelets $3-10$ in mostly scattered clusters, ovate-lanceolate, acute; glumes smooth, keeled, compressed at the apex, the upper $i$-nerved, twice as long as the lower one, and one third longer than the fertile flower; culms flattened. - Var. sтuıcum. Culms strict aud rigid, like the erect leaves; panicle filiform, of few appressed branches, $2^{\prime}-3^{\prime}$ long. - Damp sterile soil, Florida, and northward. Common and very rariable. Aug. and Sept. $4-1$ lant mostly pale. Spikelets often purple.

* * Spikelets mostly ly pairs, on short appressed pedicels (except Nas. 13 and 14), scattered on the ultimate branches of the usually ample open panicle.

- Sterile flower consisting of turo palere.

9. P. virgatum, L. Culms tall $\left(2^{\circ}-4^{\circ}\right.$ high $)$; branches of the large diffuse panicle whorled or clustered; spikelets ( $I^{\prime \prime}$ long) on rough pedicels, ovate; 
glumes lons-pointed, the upper 7-nerved, one third lonirer than the obtuse per. teet flower; sterile flower 3-anthons. - Sindy soil, Florirla, and nortliwarl. Angr. and sippt. I - Culms several in a cluster. Leaves smooth, flat (green), 10 or more lomer. Cilumes pmplisls.

10. P. amarum, lill. Glancons; culms stont ; loranches of the slender contracteil panicle smooth, appressed; leaves long and rivil, soon convolute; spikelets ovate-lanceolate ( 2 "loner), slinrt-stalked ; upper glume pointerl, strongly 7-nerved, one third longer than the oblong obluse perfect flower, and equalliner the 3-androns sterile flower. - I rifting sands along the coast, Florida, and northward. Sept. \&-Plant salt and hitter to the taste.

11. P. fasciculatum, Swartz. Smooth; culms erect (10 ligh), branching; leaves membranaceons, lincar-linceolate; panicle contracted, $3^{\prime}-t^{\prime}$ long, with the mostly simple branches erect; spikelets deep green, obovate, acute; flumes smooth, the upper one strongly 7 -nerved and reticnlated, $2-3$ times as long as the lower one, barely longer than the tumid rugose perfeet flower; sterile flower neutral. (I'. fuscorubens, Lam.) - South Florida. Oct. 4

+- +- Sterilc flower of one palea, neutral.

12. P. proliferum, Lam. Smooth; eulms thick and succulent, ascending, branched, geniculate; panicles lateral and terminal, diffuse; spikelets lanecolateovate, acute, somewhat crowded on the straight branclies; upper glume $i$-nerved, $3-4$ times as long as the lower; perfect flower pointed. (P. greniculatum, M/uhl.) - Wet places near the coast, Florida, and northward. Sept. (1) - Culns $1^{\circ}-$ $3^{\circ}$ long.

13. P. capillare, I. Culms erect, simple or lranclied ; leaves and sheaths hirsute; panicles lateral and terminal, the very slender branelies at length reflexed; apikelets lanceolate-ovate, scattered on long and eapillary pedicels; upper glume 5-nerverl, pointed, twice as long as the lower; perfect flower obtuse. (1'. strigosum, Ell. ?) - Sandy ticlds, Florida, and northward. Sept. (1 Culms $1^{\circ}-2^{\circ}$ high.

14. P. divergens, M[uhl. Culms slender, fragile, sparingly branched; leaves sululate, rough on the upper surfice and margins; the smooth sheaths longer than the joints; panicle diffinse, bearded at the axils; spikelets small, spindle-shaped, solitary at the summit of very long $\left(2^{\prime}-4^{\prime}\right)$ and rough peduncles; lower glume minute; perfect flower lanceolate-oblong, acute, nearly as long as the upper glume and nentral palea. (P. autummale, Bose.) - Dry sandy soil, South Carolina, and northward. Aug. I - Culms $1^{\circ}$ high. Leares $2^{\prime}-$ $4^{\prime}$ long.

15. P. verrucosum, Muhl. Smooth; culms rely slender, branched; leaves linear-lanceolate; pamcles terminal, prranidal, the slender seattered and often simple branches spreading; spikelets obovate, obtuse; glumes obtuse, ronghened with fine warts, the upper one at length shorter than the perfect flower, the lower minute. - Swamps, Florida, and northward. Sept. 4 Culms $2^{\circ}-4^{\circ}$ long. Spikelets $\frac{1}{2} "$ long.

16. P. angustifolium, Fll. ? Culms weak, diffusely hranched; leaves linear; panicle simple, the few elongated and scattered branches bearing $2-4$ 
oblong-obovatu acute spikelets near the summit; glumes papillose-hispid, the upper one 5-nerved, longer than the pointed gramular-roughened perfect tlower; the lower minute, obtuse. - Dry soil, Elorida to South Carolina, - Culms $1^{\circ}$ $2^{\circ}$ long. Spikelets $1 \frac{1}{2}$ llong.

* * * Spikelets single, on a spreading pedicel, disposed in open panicles: sterile flower consisting of turo unequal palece, neutral (except No. 17) : perennials: culms at length much branched.

17. P. latifolium, L. Culms smooth, erect; leaves ovate-lanccolate, mostly smooth, the sheatls, especially at the joints, villous; panicle nearly simple; spikelets large ( 2 "l long), obovate; glnmes pubescent, obtuse, the upper $2-3$ times longer than the lower one; sterile flower 3 -androus. - Dry rich soil, Florida, and northward. May. - Culms $10.1 \frac{1}{2}{ }^{\circ}$ high. Leaves and panicles $3^{\prime}-4^{\prime}$ long, the latter exserted.

18. P. clandestinum, L. Cnlms rigid (10 high), branched, naked at the joints; leares lanceolate, acuminate, the sheaths papillose-hirsute; panicles small, lateral and terninal, more or less included in the sheaths; spikelets oblong, pubesent ( $1 \frac{1}{2}$ "long); lower glume half the length of the 7 -nerved upper one. - Dry sterile soil, North Carolina, and northward. Sept. 4-Varies with the sheaths smooth, or merely pubescent, and the terminal panicle sometimes exserted.

19. P. scoparium, L. Hairy or woolly all over, except the upper surface of the somewhat rigid lanceolate leaves; culms stout $\left(1^{\circ}-1 \frac{1}{2}{ }^{\circ}\right.$ high $)$, mostly simple ; panicle terminal, exserted ; spikelets obovate ( $1 \frac{1}{2}^{\prime \prime}$ long), obtuse, pubeseent; upper glume 9-nerved, three times the length of the lower one; sterile flower neutral. - Open woods and margins of fields, in dry soil, Florida to Nortl Carolina. May.

20. P. pauciflorum, Ell. "Panicle expanding, few-flosvered; flowers very large ; leaves narrow-lanceolate, ciliate at the base; sheaths hairy." Ell.In close damp soils, Georgia, Elliott. May. - Culm 12'-18' high, roughish and branching at the joints. Leaves $3^{\prime}-4^{\prime}$ long, $3^{\prime \prime}-4^{\prime \prime}$ wide, smooth above. Spikelets oval, the lower glume very small. Resembles $P$. scoparium in fruit, and $P$. villosum somewhat in habit. (*)

21. P. divaricatum, L. Shrubby, smooth; culms reclining, witl short and spreading branches; leaves lanceolate, faintly nerved, decidnons from the persistent sheaths; panicles small, simple, few-flowered, terminating the branches ; spikelets ( $2^{\prime \prime}$ long) obovate, tumid, nodding; grlumes smooth, many-nerved, and, like the lower palea of the sterile flower, tipped with a tuft of down; palea of the sterile flower nearly equal. - South Florila, Dro. Blodgett. - Leaves $1 \frac{1}{2}{ }^{\prime}-2^{\prime}$ long. Branches of the paniele short and diverging.

22. P. viscidum, Ell. Soft-hairy or downy all over, except a narrow ring below cach joint of the culm; leaves lanceolate ; sheaths viseid ; panicle $\left(4^{\prime}-6^{\prime}\right.$ long) compound, diffuse ; spikelets ( $1^{\prime \prime}$ long) orate, pubescent ; upper glume 9-nerved, many times longer than the minute lower one. - Varies witl the leaves, sheatls, and purple spikelets smooth. - Wet swamps and bogs, near the 
roast, Floridla, and northwarl. May. - Culnus $3^{\circ}-4^{\circ}$ high, soon much hranched. Iataves $6^{\prime}-10^{\prime}$ long. Branclies of the panicle smooth. - In the smooth form of this species I notice a remarkahle deviation from the generic chanctr. The two grlumes and lower palca of the sterile flower are as ubnal in the genus, while the upper palea of the latter is developed into mu npparently perfect flower, in all resprets similar to tlac uper one.

23. P. scabriusculum, Ell. Culm $\left(3^{\circ}-4^{\circ}\right.$ long $)$, sheaths, unl lower surfice of the linear-lancelate leaves rough and more or less pubescent; panicle ample, eompound, difluse, pubescent below, the divi-ions smooth; spikelets small, ovate, rough, but not puhescent; upper glume 9-nerved, the lower uninute. - l'ine-larren swamps, Flurida to North Carolina. May. - l'robably a form of the last.

24. P. microcarpon, Muhl. Culm and leares smooth; the latter lanceolate, tapering from a lroad cordate hase, strongly nerved, fringed on the margins near the base; panicte compound, diffuse; spikelets very numerous, small ( $\frac{1}{2}$ "long), oval, puheseent; upper glume 5-nerved, 3 times the length of the minute lower one. (P. multiflorum, Ell., not of P'oir. P. ovale, Ell.?) - Dry soil, South Carolina, and northward. May. - Culms $2^{\circ}-2 \frac{1}{2}$ high. Leares $4^{\prime}-6^{\prime}$ long, $8^{\prime \prime}-10^{\prime \prime}$ wiric.

25. P. dichotomum, I. Culms at length mnch branched; paniele nearly sinple, few-flowered ; leaves linear-lanceolate, lenrded at the hase, or villons all over. (Y. villosum, Ell.) - Var. 1. P'anicles compound, diflisse; spikelets small; leaves lineal-lanceolate, and, like culm, sheaths, and panicle, soft hairy (l'. lanuginosum, Ell.), or only at the joints of the culm (l'. harbulatum, Michx.), or smooth throughout (P. nitidum, Ell., spikclets purple and very minute). - Var. 2. Culms weak; panicle loose, componnd; sheaths and pale-green thin leaves soft hairy ( $\mathrm{I}^{\prime}$. pubeseens, Ell.), or the margins of the otherwise smooth leaves fringed with long hairs (P. eiliatm, Ell.). - Var. 3. Culms ( $2^{\circ}$ ligh) smooth; leaves latge $\left(6^{\prime}-8^{\prime}\right.$ long), lanceolate, rough or downy above, margins near the base and sheaths fringed; panicle large, diffuse; spikelets (1" long) oblone, nearly smooth. (P. nerrosum, Ell.?) - Var. ? 4. Culms smooth and rigid $\left(1^{\circ}-1 \frac{1}{2}{ }^{\circ}\right.$ high $)$; learcs pale, rigid, lanceolate, fringed; panicle ohlong, diffuse; spikelets minute, oval, very lairy. (P. splæarocurpon, Ell.) Woods, fields, and swamps, everywhere, in some one of its numerous forms. Mareh - May.

26. P. depauperatum, Muhl. Culms low $\left(2^{\prime}-12^{\prime}\right.$ high $)$, simple, ereet, like the linear lenves; panicle simple, few-flowered, with the branches ereet, often shorter than the subtending leaf; spikelets oval-obovate ( $l^{\prime \prime}$ long), mostly acute; upper frlume 9-nerved, smoothish, three times the length of the ovate lower one. (P. strictum, Pursh.) - D)ry sandy soil, North Carolina, and northward. Junc. - Leaves rigid, $2^{\prime}-6^{\prime}$ long, smoothish or hairy.

27. P. melicarium, Michx. "Culm weak; leaves narrow; panicle contracted; glumes menıhranaceons, lanecolate, nearly equal ; rudiment of a flower stalked. - In Carolina and Georgia. Very smooth. Leaves long. I'aniele slender, long, with few branches." Michx. (*) 
- \$3. AULAXANTIUUS. - Spikelets uwnless, single, loosely racemose on the erect branches of the compound contracted panicle: lower glume wanting, the upper one 5-ribled, very hairy: perenials.

28. P. ignoratum, liunth. Cuhns ereet, simple, smooth; leaves linearlanceolate, pungent, strongly nerved, fringed on the margins, the lower ones widely spreading; panicle racemose; spikelets obovate; sterile flower 3 -androns; anthers and stigmas yellow. (Aulaxanthus ciliatus, Ell.) - Dry gravelly soil, Florida to North Carolina. July and Aug. - Culns $2^{\circ}-3^{\circ}$ high. Leaves and spikelets pale.

29. P. rufum, Kunth. Leares erect, linear, smooth, elongated; sterile Hower neutral; anthers and stigmas purple; otherwise like the preceding. (Aulaxanthus rufus, Ell.) - Pine-barren swamps, Florida to North Carolina. Sept. - Leaves and spikelets purplish.

\$4. ECHINOCHLOA. - Spikelets crouded on one side of the racemed or panicled spikes: glumes and lower palea of the sterile flower hispid-pointed or awned.

30. P. Crus-galli, L. Culm stout $\left(2^{\circ}-4^{\circ}\right.$ high $)$, branching; leaves very long, broadly linear, rough; sheatlss smooth, rongh, or hispid; spikes $\left(1^{\prime}-2^{\prime}\right.$ long) very numerous, crowded in a long raceme; spikelets clustered; glumes and lower palea of the sterile flower strongly hispid on the nerves, awn-pointed or longr-awned; firtile flower rough-pointed. - Wet places, Florida, and northward. Ang. and Sept. (1) - I wns pale or purple.

31. P. Walteri, Ell. Culms $\left(1^{\circ}-2^{\circ}\right.$ high) branehing; leaves linear, smooth, like the sheaths; spikes 5-12, distant, erect or appressed $\left(\frac{1}{2}{ }^{\prime}-1^{\prime}\right.$ long), bearded at the base; spikelets in 3 rows, awnless; glumes and lower palea hispill on the nerves, pointel; fertile flower harely pointed ; rachis rough. - Damp soil, Florida to North Carolina. July-Sept. (1) - Spikelets purplisl.

32. P.? molle, Michx. "Spikes panicled, alternate, expanding, flowerjng on one side; spikelets approximate, pedicillate, on one side, awnless," Ell. - Sea islands of Sonth Carolina, Ellott. Ang. and Sept. 4-Culm $4^{\circ}-6^{\circ}$ high, smooth below, downy above. Leaves $12^{\prime}-18^{\prime}$ long, smooth, fringed at the throat. Spikelets 2-3 together on a villous rachis, hairy. Plant salt and bitter.

\$ 5. OR'THOPOGON. - Panicle simple, spiked: spikes few-floweral, distant: ylumes equal, hairy, the lower one long-auned: upper and lower palea of the sterile flower shortaund.

33. P. hirtellum, L. Culms slender, ascending from a creeping base; leaves $\left(1^{\prime}-2^{\prime}\right.$ long) orate-lanceolate, thin; sheaths hairy; spikes about 5 , distant, 5-8-flowered; awns (often purple) clammy. - Shady woods, Florida to North Carolina. Aug. and Sept. $\quad 4-$ Culms $1^{\circ}-2^{\circ}$ long, branched, the erect portion $6^{\prime}-12^{\prime}$ high.

\section{SETARIA, Beauv.}

Erect annual grasses, with flat leaves and the spikelets of Panicum proper, but crowded in cylindrical spike-like panicles; the short pedicels bearing one or more bristles, which usually exceed the spikelets. 


\section{* Bristles roughened dournucerd.}

1. S. verticillata, Busuv. ('ulns sparingly branclıcl; leaves linear-

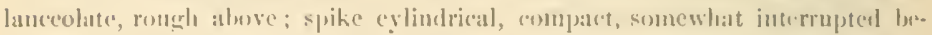
low $\left(2^{\prime}-3^{\prime}\right.$ long); bristles short, single or hy pairs. - Aromul dwellings, Sorth Carolina, and nortliward. Introluced. - Culm $2^{\circ}$ hight.

$$
\text { * Bristles roughened upuerd. }
$$

2. S. glauca, Benuv. Culms smooth, slightly compressed; leaves linearlanceolate, rongh above; spike nearly simple, eylindrical; hristes 6-10, in 2 clusters, longer thim the spikelets; perfect flower transversely wrinkled. - Var.

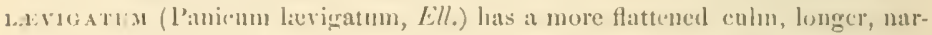
rower and smooth leaves, and the perfect fluwer olsenrely wrinklerl. - Cultivated gromm, the rar. in damp soil along the const, Florida to North Carolina. - Culms $1^{\circ}-3^{\circ}$ high. Spikes $2^{\prime}-3^{\prime}$ long, pale or purplish.

3. S. viridis, Beanv. Culms smooth, terete; leaves l:uceolate or linearlanceolate, rourhl ; spikes compound, eylindriral, deuse; bri-tles $1-3$ to each spilielet; perfect flower finely striate and lofted lengthwise. - Around dwellings, Introduced. June-Sept. - Culms $1^{\circ}-20$ highl. Spikes $1^{\prime}-2^{\prime}$ long.

4. S. corrugata, Sehult. Culms, narrow (2" wide) leares, and sheaths rough: spikes componnd, cylindrical, dense, erect or bending; spiticlets $6-10$ in a cluster; bristes one to each spilielet, elongated; perfect flower ubtuse, strongly wrinkled. (l'anieum corrugatum, Ell.) - Dry soil, Florida and Georgia. July and Aug. - Culms $2^{\circ}-3^{\circ}$ high. Spikes $3^{\prime}-6^{\prime}$ longr, purple.

5. S. composita, Kunth. Cuhns smooth; leares linear-lanecolate, the fringed sheatlis rough-latiry at the thront; spikes loose, compound, the lower elnsters seattered ; bristles single or by pairs, many times longer than the spikelets; perfect flower acute, with faint transverse lines. - 1)ry sancly soil along the west coast of Florila, Apalarlicolar to Key West. June-Aug. - Culns $2^{\circ}-4^{\circ}$ long. Leaves $1^{\circ}$ or more long. Suikes $6^{\prime}-12^{\prime}$ long.

6. S. Italica, Kunth. Culms tall $\left(4^{\circ}-8^{\circ}\right.$ high $)$, smootl, branthel; leaves $\left(\frac{1}{2}{ }^{\prime}-1^{\prime}\right.$ wide) rery rough ; spikes compound $\left(6^{\prime}-18^{\prime}\right.$ long $)$, cylindrical, dense, the lower clusters scattered; bristles $1-2$ to each spikelet, elongated; fertile flower smooth and even. - Swamps atong the coast, Florida to Nurth Carolina. July - Sept. - This, and P'enicillaria spicata, Willd, are commonly cultivated, usder the name of MilLer, as green food for cattle. The latter seems to be the Panieum cenchroides, Ell.

\section{CENCHRUS, L. Cock-sprir.}

Prostrate or creeping grasses, with the spikelets of P'anicun proper, but enclosed, l -several together, in spiny or bristly, at length indurated and decidnous involueres; the latter burr-like, and arranged in a terminal spike. Stamens 3. Styles united below.

1. C. echinatus, L. Spikes cylindrical, composed of 20 or more globular involueres $\left(3^{\prime}-4^{\prime}\right.$ long $)$; involuere downy, spiny above, and with a row of rigid larbed bristles above the base, $3-5$-flowered; eulns ascending. - Fields and 
waste grounds, Florida to North Carolina. July - Sept. (1)-Culms $1^{\circ}-2^{\circ}$ long. Involuere purplish.

2. C. tribuloides, L. Inrolucres whirish, 10-15 in a spike, wedge-shaped at the base, armed above with stout compressed broally snbulate ereet or spreading spines; bristles none; spikelets mostly by pairs. - Sands along the coast, Florida, and northward. July - Oct. (1) - Culns prostrate, $1^{\circ}-2^{\circ}$ long. Leaves linear. Spikes $1^{\prime}-2$ ' long.

\section{STENOTAPHRUM, Trin.}

A creeping and branching grass, with the awnless spikelets sunk in excavations of the continuous flattened rachis. Spikelets by pairs, one pedicelied and imperfect, the other sessile, and with the structure of Panicum.

1. S. Americanum, Schrank. (Rotthoulia dimidiata, Ell.)-Danp sandy places along the coast, Florida to South Carolina. June-Sept. \& Smooth throughout. Culms flattened, creeping, the branches nearly opposite; Howering culms crect, $6^{\prime}-12^{\prime}$ high. Leaves $2^{\prime}-6^{\prime}$ long, linear, obtuse, flat or folded, contracted at the base. Spikes lateral and terminal, peduncled, $2^{\prime}-55^{\prime}$ long. Sterile spikelet neutral or rudimentary. Fertile spikelet sessile; the upper glume 7 -nerved, 3 times the length of the lower one. Palea of the sterile flower coriaceous, like those of the perfect one.

\section{ROTTBCELIIA, Brown.}

Erect perennial mostly tall grasses, with flat or channelled leaves and spiked inflorescence. Spikes nearly terete, jointed. Spikelets awnless, horne by pairs at the base of each joint; one imperfect, on a coriaceons and closely appressed pedicel ; the other sessile, embedded in an excavation of the joint, 2-flowered. Glumes 2, the exterior one flat, coriaccons, with a hinge-like depression at the hase, the interior boat-shaped, membranaceons. Palce hyaline, $1-2$ in the staminate or neutral lower flower, and 2 in the upper and perfect flower. Stamens 3. Styles 2. Grain compressed, free. - Spikes solitary on lateral and terminal peduncles or brinches.

1. R. rugosa, Nutt. Culms compressed; peduncles or branches clustered, short, included in the sheaths of the clongated npper leaves; spikes spreading, slightly compressed; sessile spikelet shorter than the joint; lower glume lanceolate, transwersely rugose; sterile flower neutral. - Pine-barren swanps and ponds, Florida to North Carolinis. Scpt. - Culms $2^{\circ}-4^{\circ}$ high. Spikes green, $1 \frac{1{ }^{\prime}}{2}-2^{\prime} \operatorname{long}, 1^{\prime \prime}$ in diumeter.

2. R. corrugata, Balilw.? Culm stout, compressed; peduncles mostly single, elongated; spikes slightly compressel, ereet; spikelets longer than the joint; lower glume longitudinally grooved and somerhat reticulated, ovate; sterile flower staminate. - Low pine barrens, Georgia and Florida, near the coast. Sept. and Oct. - Culm $2^{\circ}-4^{\circ}$ high. Spikcs $4^{\prime}-6^{\prime}$ long, $2^{\prime \prime}$ in dianeter, purplisl.

3. R. cylindrica. Culm slender, tercte; leaves narrowly linear; perluncles single, clongated; spikes slender, terete, mostly curved; spikelets as long as 
the joint; lower ghume ovate, obtuse, obsemely pitted in lines; sterile spikelet

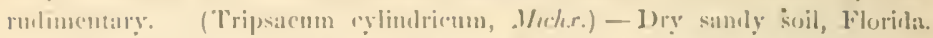
July - Sipt. - Culms $1^{\circ}-2^{\circ}$ highl. Sppikes $2^{\prime}-6^{\prime}$ long, $1^{\prime \prime}$ in diameter, purplish.

\section{MANISURIS, I.}

Annual grasses, witl branclingrg culus, flat lenves, mud spikerl inflorescence. Spikes lateral and terminal, chustered, jointerl, the short preluncles enclosed in spatle-like shentlss. Spikelets l-flowered, placed one at eatele end of the joints of the spike; the npper neutral, compressed, of two nearly equal hispird membranaceone glumes; the lower perfect, globose. Glunes coriaceus, concare, the lower reticulated, the upper smooth. Palea 2, lyaline. Stamens 3. Grain included.

1. M. granularis, Swart\%. Leav's linenr-lancelate, aul, like the sheaths, hairy; spikes $6^{\prime \prime}-10^{\prime \prime}$ long; spikelets minute, turning hlack - Fieltls and pastures, Florida to South Carolina. Aug. and Sept. Introduced. - Culms $1^{\circ}-$ $2^{\circ}$ light.

\section{TRIPSACUM, I. Gimi-Grıss.}

A tall perennial grass, with solil eulms, broad and flat leares, and spiked inflorescence. Spikelets awnless, monocions, in jointerl spikes, the upper ones staminate, the lower fertile, 2-flowered. Staminate llowers ly pairs on cach slort triangular joint of the slender mhis, 3-androns; crlmmes 2, eoriaceous; palea hyaline. l'istillate spikelets single, cmberded in a deep excavation of the thick and polished joints; the outer grlume eartilaginous, concave, the inner membranaceous, boat-shaped; lower flower nentral, the upper pistillate, both with hyaline palex. Anthers opening by terminal pores. Stigmas elongated. (i)ain free.

I. T. dactyloides, I. - Rich soil, Florila, and northwarl. Aug. and Scpt. - Culms erect, from tufted ereeping root-torks, $3^{\circ}-5^{\circ}$ high. Leaves $1^{\prime}$ wille. Spikes $4^{\prime}-8^{\prime}$ long, on long lateril amil terminil peluneles, $2-4$ in a cluster or sometimes solitary. ('T. monostachyum, Willd.)

\section{ANDROPOGON, L. Brum-Grass.}

Coarse perennial grasses, with branching erect culms, long and harsh leares, and spiked inflorescence. Spikes lateral and terminal, jointed. Spikclets ly jairs on each joint of the slender commonly hairy or plumose rachis ; one of them pedicelled and staminate, neutral, or rudimentary ; the other sessile, 2flowered, the lower flower consisting of one palea, and nentral ; the npper of 2 palex, mostly perfect, shorter than the herbaceous or chartaceons glnmes, the lower one mostly awned at the apex (except No. 1). Stamens 1-3. Grain free.

\$1. ANDROPOGON PROPli. - L Pper flower perfuct.

* Prduncle solitary, baring a single spike.

1. A. Nuttallii. Culms $\left(3^{\circ}-4^{\circ}\right.$ high $)$ straight, smooth, like the long linear leaves; spikes rigid, long-peduncled, the rachis atud pedicel of the sterile 
flower fringed with closely appressed white hairs; spikelets awnless; glumes hispid above; sterile flower of 2 palex, 3-androus. (Rottbocllit (iliata, Natt.) Low pine barrens, Florida and the lower districts of Georgia. Sept. - Spikes $3^{\prime}-6^{\prime}$ long.

2. A. oligostachyus. Culms rigid, erect; leaves linear, smooth, glaucous ; spikes $3-4$, on short mostly inclnded peduncles, hoary with short spreading hairs; lower glume pubeseent, $\frac{1}{2}-\frac{1}{3}$ as long as the contorted awn; sterile flower nentral, short-awned. - Dry saml-ridges, Middle Florida. Aug. and Sept. - Culn $2^{\circ}-3^{\circ}$ high. Spikes $2^{\prime}-3^{\prime}$ long.

3. A. tener, Kunth. Culns filiform, like the smooth soon involute leares; spikes terete, with the joints bearled at the base, otherwise smooth; spikelets appressed, half as long as the bent awn; glumes rough above; upper palea minute; pedicel of the awnless neutral fower bearded at the apex. - Dry grassy pine barrens, Georgia, Florida, and northward. Sept. - Culms $2^{\circ}-3^{\circ}$ long. Spikes slender, $I^{\prime}-2^{\prime}$ long. Upper leaves short, hearded at the throat.

* Peduncles clustered, each bearing a single spilie.

4. A. scoparius, Michx. Leares snooth or rough-hairy; spikes numerous, on exserted peduneles, the slender flexnous rachis, and pedicel of the awned or awnless staminate or neutral sterile flower fringerl with spreading hairs; perfect flower half as long as the awn, the glumes often ronghened with elevated points. - Dry sterile soil, Florida, and northward. Aug. and Sept. - Culms $2^{\circ}-3^{\circ}$ high. Spikes $1^{\prime}-2^{\prime}$ long.

* * Peduncles or brunches mostly clustered, bearing 2-4 rigid (qreen) digitate spikes: rachis and pedicel of the triandrous uunless sterile flower fringed with scattered hairs, and short-beurded at the base.

5. A. furcatus, Mull. Culm stout, rigill, $3^{\circ}-5^{\circ}$ high; leaves rongh, fringed at the base; peduncles or branches commonly several at each upper joint; spikelets appressed; glumes hispid on the nerves, half as long as the bent awn. - Open woods and margins of fields, Florida, and northward. Sept. Spikes compressed, $2^{\prime}-3^{\prime}$ long.

* * * Peduncles or branches I-sereral from each npper joint, often included in the dilated sheaths: spilielets slender, hoary with lony silky spreading huirs: sterile flower reduced to an awn-lile glume at the apex of the very slender pedicel, or obsolete: stamen 1 .

6. A. tetrastachyus, Ell. Culms $3^{\circ}-4^{\circ}$ high ; leaves and sheaths very hairy; branches short. the lower ones by pairs, the upper single; spikes 4; yhumes bristly-serrulate, one fourth as long as the straight awn; pedicel of the awn-like sterile flower barely exceeling the fertile flower. - Var. Distachy us. Leaves and sheaths less hairy or smoothish; spikes by pairs, more rigid, on long-exserted branches; pedicel of the sterile flower mueh longer than the smoother glumes. - Low pine barrens, Florida to North Curolina. Sept.

7. A. Elliottii. Culms $1^{\circ}-2^{\circ}$ high, bearded at the upper joints; leaves purplish, narrow, hairy at the base; sheaths hairy, the upper oues inflated and often crowded or imbricated ; branches single or by pairs; spikes by pairs (rarely 
$3-4)$, exserted, or included in the upper sheaths; awn $3-4$ times the length of the erlumes; hates of the very slender rachis long and glossy. (A. argentens,

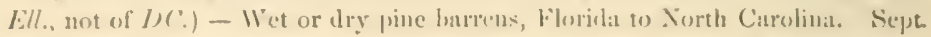
and oct. - Sumewhat variable, hut distinguished ly the dilated clustered sheaths, unel by the silvery hatirs of the spikes.

8. A. Virginicus, I. Culms nostiy tall, erect or bending, with the joints

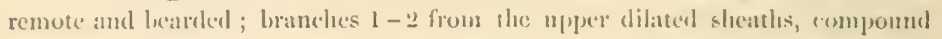
and forming a long and loose panicle; spikes ly pairs (marely by fours), shorter than the sheaths; awn strairht, four timen the lengtlu of the grlumes; sterile flower none. (A. vaginatus, Ell, the slort branches or peduncles includerl in the more inflated shenths. A. dissitiflurna, Michx.? A. gracilic, Curpenter, the spikes borne at the summit of elongated simple hranclies.) - Jianen sobl, Florida to Mississippi, and northward. Sept. and Oet.

9. A. macrourus, Mlielı. Spikes by pairs, execelingly numerous, (rowded in a linge and close panicle; awns $3-4$ times the lengrth of the glumes; sterile flower an awn-like glune. - Varies with the whole plant glancons and more slender, branches and spikes more seattered. - Low barren soils, Floridil, and northwarl. Sippt. - Culns $2^{\circ}-50$ high.

10. A. ternarius, Miclix. "Branches remote, alternate, solitary, simple, bearing mostly three distant alternate 2-cleft spikes; hatirs of the involncre shorter than the glume; flowers 3-atmdrous; palex somewhat villous; awn long, contortedi." Mich.x. In Carolina. (*)

\section{\$2. HETEROPOGON. - Upper flower staminate or pistillate.}

11. A. melanocalpus, Ell. Culms tall $\left(t^{\circ}-8^{\circ}\right.$ high) panicled above; leares elongated; spikes numerous, approximate, 1-sided, shorter than their slender filiform-pointed shenths; spikelets large, the two lowest pairs grlume-like, persistent, sterile, the others deciduous; sterile flower 3 -androns, with the lower glune lanceolate, membranaceous, twistel, much louger than the fortile spikelet and the smooth and short pedicel; fertile spikelet rusty bearded ; the coriaceons glunes olutuse, many times slorter than the very long $\left(t^{\prime}\right)$ contorted and hairy awn. - Indian old fields, Florida and Georgit. Introdued? - Ghume of the sterile spikelet, like the sheaths, rugose on the back. Perhaps identical with A. polystichyus, Roxb.

\section{ERIANTHUS, Michx,}

Tall rect-like grasses, with long and flat leaves, and panieled infloresenee. Spikelets lyy pairs on the slender branches, alike, one pedicelled, the other sessile, hoth with a hairy involucre at the base. Lower Hower of one palea, nentral; the upper of two palea, perfect, shorter than the membranaeeous nearly equal glumes, the lower one awned. Stanens 2-3.

1. E. alopecuroides, Ell Culms $4^{\circ}-10^{\circ}$ high; sheaths of the broad $\left(6^{\prime \prime}-12^{\prime \prime}\right)$ very rough leares woolly ahove, rough below; paniele $\left(1^{\circ}-2^{\circ}\right.$ long $)$ woolly, expanding, prramilal; hairs of the involnere copions, twice as long as the sparsely hairy glunes; awn straiglut. - Var. costontes. (E. contortus, Ell.) 
Smaller ( $2^{\circ}-4^{\circ}$ high $)$; leaves and sheaths smonth ; panicle $\left(6^{\prime}-12^{\prime} \operatorname{long}\right)$ oblong; awns slort and twisted. - Var. Brevun russ. (E. brevibarbis, Michx.) Smootl or nearly so; rachis of the oblong paniele rongh (not woolly); hairs of the involncre shorter than the glumes. - Dry or wet soil, Florida to North Carolina. Sept. and Oct.

2. E. strictus, Baldw. Culms, leaves, and sheaths smooth or slightly roughened; panicle $\left(10^{\prime}-15^{\prime}\right.$ long) spiked; involnere very short or none; glumes rough; awns straight. - River-banks, Florida and the lower distriets of Georgia, and westward. Sept. - Culms $4^{\circ}-8^{\circ}$ high. Leaves $3^{\prime \prime}-6^{\prime \prime}$ wide. Spikelets twice the size of the preceding.

\section{SORGHUM, Pers.}

Spikelets 2-3 together on the slender branches of the loose panicle; the lateral ones sterile or a mere pedicel; the middle or terminal one fertile. Glumes coriaceons or indurated, closely bearded, sometimes awnless. Otherwise like Andropogon.

1. S. avenaceum. Panicle erect; glumes yellowish, lanceolate, the lower one hairy; one palea to each flower, linear, ciliate; awn rough, slender, twice as long as the glumes; sterile flowers rednced to one or two slender hairy pedicels. (Andropogon arenaceus, Michx. A (iliatıs, Ell.) - Dry sandy soil, Florida to North Carolina. Sept. 4-Culms $\left(2^{\circ}-4^{\circ}\right.$ high $)$ and leaves smooth Panicle oblong, 6' - 12' long.

2. S. nutans, Gray. Panicle long and narrow, nodding; glumes dark brown, the upper sparingly, the lower densely hairy ; palea of the upper flower 2 , unequal; awn 4 times the length of the glumes, bent in the middle, rough above, twisted and hairy below; sterile spikelets mostly rudiments. (A. nutans, L.) - Dry barren soil, Florida and northward. Sept. $4-$ Culms $2^{\circ}-4^{\circ}$ high. Panicle $1^{\circ}-2^{\circ}$ long.

3. S. secundum. Panicle erect, contracted, l-sided; spikelets nodding; glumes light brown, very hairy all over; otherwise like the last, and probally a variety of it. (Andropogon secundns, Ell.) - Dry sand-rirlges in the pine barrens, Georgia and Florida. Sept. and Oct. - Culms $2^{\circ}-3^{\circ}$ high.

S. velgare, Pers, is the Durra Corn: S saccuaratym, the Broom Cors; S. cersucu, Willd, the Grivea Cors. S. halapexse, Pers., is sometimes cultivated under the name of Cerba Grass.

\section{IUZIOLA, Juss.}

Perennial aquatic or marsh grasses, with narrow elongated leaves, and panicled monœcions flowers; the pistillate and snualler staminate spikelets borne on separate panicles. - Spikclets scattered, on jointed peclicels, nearly terete, 1-flowered. Glumes none. Paler 2, nearly equal, membranaceous, coneave, obtuse, strongly nerred. Squamula 2. Stamens 5-11: anther's linear, 2-lobed at the base, much longer than the short filaments. Styles 2, short: stigmas plumose. Grain free, ovoid. Pericarp crustilreous. 
1. L. Alabamensis, n. sp. Smooth throughout; ("ulms low ( $t^{\prime}-6^{\prime}$ lighh), simple, jointed near the hase; leaves mostly two; the lowest one $3-4$ times the length of the rulm; the elongated purple slarath enelosing the short membrunaeeons njper one, and the stalk of the simple few-flowered paniele; spikclets pale, orate-lanceolate, shorter than the erect or appressced capillney perlicels; the staniuate aud pistillate ones horne on separate rulms; pulcate of staminate spikelet lanceolate, 7 -nerved ; those of the pistillate ovate-lanceolate, $11-13$ nerved, macls longer than the smooth grain. - Brooklyn, Conceula County, Alabama, J. F. Beceumont.

\section{MONANTHOCHLOË, Engelm.}

A low maritime branching grass, with rery short rigid crowiled leaves, and diocious flowers in solitary terminal sessile spikes. Glunes none. - Spikes short, 3-5-flowerel; the lowest flower, or the two lower ones, neutral, of $1-2$ palear; the nppermost alortive; the intermediate ones, composed of two palex, triandrous in the staminate, digynous in the pistillate spike. P'aleac convolute, searious and olstuse at the apex; the lower one rigid, ovate-lanecolate, 9-12nerved alsove; the npper rather longer, 2-kecled or 2-wingerl on the back. Squamula nore. Anthers longer than the short filaments, 2-loled at each end. Ovary lancelate-linear, 3-angled. Styles 2 : stigmas elongated, plumose with simple laairs. Grain 3-angrled, fice.

1. M. littoralis, Engelm. - Low sandy slores, Sonth Florida, and westward. - Culms much branched, $5^{\prime}-8^{\prime}$ high, smooth and somewhat woody, erect, or at length prostrate and rooting. Leaves $3^{\prime \prime}$ long, very rigid, obtuse, many-nerved, rough on the margins, mostly erowded at the summit of the short branches, and enclosing the short $\left(3^{\prime \prime}-4^{\prime \prime}\right)$ sessile spikes. Flowers pedicelled. 


\section{SERIES II.}

\section{CRYPTOGAMOUS OR FLOWERLESS PLANTS.}

VEGETables destitute of proper flowers, and producing, in the place of seeds, minute homogencous bodies (spores) containing 110 embryo.

\section{Class III. ACROGENS.}

Plants with a distinct stem, growing from the apex only, containing woody fibre and ressels.

\section{Order 161. EQUiset ACEA. (Iorsetail Fanily.)}

Comprises only the genus

\section{EQUISETUM, L. Scourixg Resh.}

Fructification terminal, spiked or cone-like. Spore-cases (sporangia) 6-7, borne on the lower surface of the peltate scales, 1-celled, opening on the inner side. Spores loose, furnished at the base with 4 club-shaped elastic filaments (elaters). - Stems leafless, grooved, hollow and jointed, bearing at the closed joints a toothed sheath.

1. E. lævigatum, Braun. Stems perennial, mostly simple, the obtuse ridges smooth, or ronghened with minute tubereles; sheaths appressed, with numerous bristle-like caducous black teeth. - Stiff clay soil, North Carolina, and northward. - Stem $1 \frac{1}{2}^{\circ}-4^{\circ}$ high.

\section{Order 162. FILICES. (Fervs.*)}

Leafy plants, mostly with perennial rootstocks (caudex), which in this climate are ereeping and slender, or stouter and sometimes ascending, but in the tropics often grow many fect high, with a diancter of several inches, giving the plants an arborescent appearance (Tree-ferns). Leaves (fronds) eircinately rolled up in vernation (except the last suborler), and raised on a stalk or petiole (stipe). Spore-eases (sprrangia) one- 


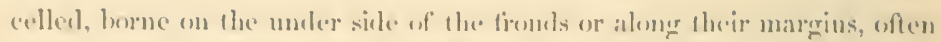

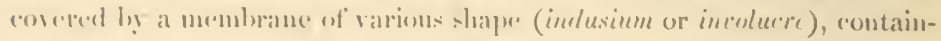
inger munerous excecelingly minute sfores.

\section{Syonopis.}

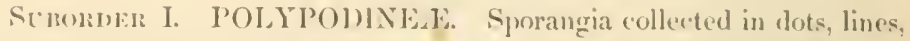
or varionsly shaped clusters (sori or fivit-fots), or in indefinite masses, relludar-reticulated, mostly pedicelled: the stalk rmunge into a vertieal incomplete elastic ring, the straightening of which ruptures the ripe sporangium on the imer side, discharging the spores. - Fronds simple or variously clivided.

Trine I. ACIROSTICHE.E. - Sporangla collected in large or indefinite masses on the back of the frond : indusium none.

1. ACliosticiluy. Sporangia covering the lower surfuce of the upper pinna. Veins reticulated.

Tribe II. POLY PODIE.E. - Fruit-dots roundish, distiuct, destitute of indusium, borne on the back of the frond.

2. POLYPODICM. Fruit-dots scattered variously on the back of the frond, borne at or near the ends of the veins.

TRIBE III. - VITTARIEAE. - Sporangia borne in a continuous elongated marginal or sub-marginal furrow.

3. VITTARiA. Fronds simple, narrowly linear.

Tribe IV. PTERIDEAE. - Fruit-dots marginal, scparate or continuous. Indusium forued by the reflexed margin of the frond or its lobes, opening toward the midrib.

* Indusium thin and membranaceous, continuous around the margin of the fertile pinnæ.

4. PTERIS. Sporangia borne on a transterse intramarginal veinlet.

5. PELL.EA. Sporangla borne on the ends of the reins, at length confluent.

* * Indusium rarely continuous, mostly formed of the reflexed ends of the lobes or divisions of the pinnæ or pinnules.

6. CIIEILANTHES. Sporangia borne on the reins beneath the reflexed margin of the frond. PInnules with a nidrib.

7. ADIANTII. Sporangia borne on the under Eide of the indusium. Midrib none or eccentric.

Tribe Y. BLECHNEA. - Fruit-dots dorsal, linear or oblong, borne on trankverse reine parallel to the midrib. Indusium fixed by its outer margin, and opening at the inner one.

8. BLEChivy. Fruit-dots linear, elnngated, corered hy a continuous induslum.

9. WOODWARDIA Fruit-dots lineur-oblong, in a keries bear the midrib, covered by separate Indusia.

Tribe VI. A SPI.FNIE F. - Fruit-dots dorsal, linear or objong, oblique or at right angles to the midrib. Indusium fixed by one margin to the veinlet, opening at the other.

10. CANPTOSORES. Fruit-dots straight or curred, seattered irregularly on the more or less retlculated veins, or facing each other in pairs. Frond simple.

11. ASPLENIUY. Fruit-dote oblique, on the upper side of the reins, rarely on both sldes of them. Vins free. 
TRIBE TII. ASPIDIEAE. - Pruit-ulots at or helow the ends of the vtirs, rount, or somewhat oblong and then placed across the vein. Indusium round or nearly so, fixed in the middle and opening at the margin, or reniform and fixer at the sinus.

* Fertile and sterile fronds alike.

12. CYSTOPTEliS. Indusium on the back of the reinlet, hood-shaped, fixed at the base partly under the fruit-dot, opening toward the apex of the segment

13. ASPIDIUM. Indusium mostiy on the back of the veins, orbirular or round-reniform, fixed in the niddle or at the sinus, opening all round the margin.

14. NEPIROLEPIS Indusium at the end of a free rein, reniform, fixed at the sinus or by the arcuate base, opening toward the margin of the frond.

** Fertile and sterile fronds different.

15. ONOCLEA. Fertile fronds contracted, the dirisions rolled up and berry-like.

TRIBE VIII. IVOODSIEAE. - Fruit-dots round, borue on the back of a free rein. Indusium fixed beneath the fruit-dot, sancer-shaped, or globose and bursting at the lop.

16. WOODSIA. Indnsium divided into irregular lobes, or a capillary fringe.

TRIBE IX. DICKSONIEA. - Frnit-dots marginal, roundish, borne at the ends of the free veins. Indusium cup-shaped or two-valved, its outer part composed of a reflexed lobe of the frond, or more or less united with it.

17. DICKSOXIA. Indusium (in our species) small, nearly glohular, membranaceous.

Suborder II. HYMENOPHYLLE. Sporangia borne on a setiform or slender reeeptacle, cellular-retieulated, surrounded by a complete transverse ring. Involueres marginal, at the ents of the veins, cup-slaped or two-ralved. Fronds delicately membranaceous and pellucid.

18. TRICIIOMANES. Involucre cup-shaped or funnel-shaped, sometimes 2-lipped.

Suborder III. SCIIIZ EINEiL. Sporangia large. borne on narrow segments of the frond, oval, cellular-reticnlated, erowned by the converging strix of a complete apical ring, opening longitudinally.

19. LYGODIUY. Sporangia attached laterally in two rows to the narrow divisions of the pinnæ, each one covered by a scale-like indusium.

20. ANEIMIA. Sporangia attached by their bases to the narrow dirisions of the panicled fertile branches of the frond. Indusium none.

Strorder IV. OSMICNDINEA. Sporangia large, nearly sessile on the back or margins of the mostly contracterl fertile fronds, twovalved, opening vertically at the apex. Ring rudimentary or none.

21. OSIIUDA. Sporangia globular, covering the contracted fronds or portious of fronds.

Suborder T. OPIIIOGLOSSE. Sporangia very large, sessile, spiked or panicled, eoriaceous, not reticulated, on narrow divisions of the frond, destitute of a ring, transversely two-ralred. Fronds not circinate in vernation.

22. BotrychIUM. Sporangia in panicled spikes. Sterile part of the frond pinnately divided.

23. OPHIOGLOSSUM. Sporangia in a simple spike. Sterile part of the frond simple in our species. 


\section{ACROSTICHUM, J.}

Sporangia entirely covering the lower surface of the upper pinna. Veins finely reticulated with oblong hexagomnl meshes. - Tall Ferne, with pinnate fronds.

1. A. aureum, I. Fronils coriaccons; pinux short-stalkel, lanceolnteoblong, entire. - Coast of South Florida. - Fromds $4^{\circ}-8^{\circ}$ liggh, dark green, shining.

\section{POLYPODIUM, I. PolYPODY.}

Fruit-dots round, naked, mostly at the ends of the free or reticulated veins. liootstocks erecping. Sterile and fertile fronds alike.

\section{\$1. POLYPODIUM Propir. - Veins free.}

1. P. vulgare, L. Fronds cvergreen, smooth on both sides, oblong, simply and decply pinnatific; the divisions linear-oblong, obtuse, slightly tootled; fruit-dots large. - Mossy rocks, \&c., in shady woods, in the upper districts of Alabama, and northward. - Fronds $4^{\prime}-10^{\prime}$ high.

2. P. Plumula, Wille. Fronds linear-lanceolate, narrowed at both ends, pinnatifit to the black and somewhat ehaffy milrib; the divisions very numerous, narrowly linear, entire, wider at the base; fruit-dots small. - Tampa Bay, Dr. Leavenuorth. - Fronds $12^{\prime}-18^{\prime}$ ligh, $18^{\prime \prime}-24^{\prime \prime}$ wide.

3. P. hexagonopterum, Michx. Frontis annual, broally triangular, bipinnatifid; pinnæ lanecolate, acuminate, sprealing, the lower pair erect; pinnules oblong, mostly obtuse, erenately trothed or entire; fruit-dots numerous, minute. - Shady woods, Florida to Mis-isippi, westward and northward $\Lambda$ foot or more high from an clongated (recping rootstock. I'innx decurrent, forming irregular hexagonal wings on the rachis.

\$ 2. MARGINARIA, Bory- - Veins obscure, sometimes reticulating near the margin. Stipe and lover surface of the frond covercd with chaffy scules.

4. P. incanum, Swartz. Fronds evergreen, coriaceous, beneath thickly beset with peltate chaffy seales, smooth and green above, pinnately parted; the divisions ohlong, obtuse, entire; fruit-dots near the margin. - On trunks of trecs, Florida to Mississippi, westward and northward. - Rootstock chaffy, crecping. Fronds $3^{\prime}-8^{\prime}$ high.

\$3. CAMPYLONEURUM, Presl. - Veins paralle, pimate from the midrit: veinlets reticulated, forming a series of parullel angular arcs with short veinlets pro. ceeding from their angles. Fronds simple.

5. P. Phyllitidis, L. Fronds lincar-lanecolate, entire, acuminate, of a thin chartaceous texture, semi-pellueid; frnit-lots rather large, in two rows between the veins. - South Florida. - Fronds $1^{\circ}-2^{\circ}$ high.

\$ 4. PHLEBODIUM, R. Br. - Veins pinnate from the midrib, furrate: veinlets reticulated in mostly elongated meshes. Fruit-dots larye, commonly at the extremities of two converging veinlets.

6. P. aureum, L. Fronds smooth and glaucous, broarly ovate, pinnatcly 
parted; the livisions lanceolate, acuminate, entire; f:uit-dots mostly in a doulle series in each lobe of the frond, near the midrib. - South Florida. - Rootstock large, crecping, copiously beset with lanceolate brown chaffy scales. Stipe smooth, $8^{\prime}-10^{\prime}$ long. Fronds $10^{\prime}-15^{\prime}$ long, two thirds as wide.

\section{VITTARIA, Smith.}

Sporangia on a continuous receptacle immersed in a furrow open outwardly at or near the margin of the frond. Veins obseure, simple, connected at their extremitics by the receptacle. Fronds simple, linear, elongated.

1. V. lineata, Swartz. Fronds nearly sessile, narrowly linear, elongated; midrib inconspicuous, lines of fructification near the margin. (V. angustifrons, Mich. .) - On trees, South Florida. Fronds many from the short sealy rootstock, $1^{\circ}-2^{\circ}$ long.

\section{PTERIS, L.}

Sporangia borne on a transverse marginal receptacle connecting the ends of the veins. Indusinm continuous, formed of the membranaceous margin of the frond, at first reflexed, at length pushed back and disclosing the ripened fructification. Fronds 1-3-pinnate or decompound.

1. P. longifolia, L. Fronds lanceolate, pinnate; pinnse numerous, narrowly linear, acuninate, obtuse at the base, the terminal one elongated, the lower ones gradually smaller. - Key West. - Fronds $1^{\circ}-2^{\circ}$ ligh, smooth. Stipe more or less chafty.

2. P. Cretica, L. Fronds smooth, ovate, ternate or pinuate; the lower pinnæ 2-3-parted, sessile, the upper ones decurrent; sterile ones lanceolate, or linear-lanceolate, finely serrate; fertile ones narrower, entire, or spinulosescrrate at the acuminate apex; veins straight, simple or forked, close together, almost at right angles to the midrib. - Shady woods, Middle and East Florida. - Frond $6^{\prime}-10^{\prime}$ long. Stipe smooth, very long and slender.

3. P. aquilina, L. (Brake.) Fronds large, glabrous or somewhat hairy beneatl, broadly triangular, tripinnate; pinnules oblong or linear, entire or hastate or pinnately parted; ultimate segments obtuse, oblong or linear, the terminal ones often elongated, the margin reflexed or revolute; veins simple or forked; indusium narrow, ciliated. - Common cverywhere. - Stipe stout, $6^{\prime}-2^{\circ}$ high. Frond $1^{\circ}-2^{\circ}$ long.

Viur. caudata (P. caudata, $L_{\text {. }}$ ), with very narrow segments, the terminal ones elongated, and both surfaces of the frond glabrous or even glaucous, occurs in South Florida and along the Gulf coast.

\section{PELI再A, Link.}

Fruit-dots oblong or linear at the ends of the veins, confluent in a broad marginal line of fructification. Indusium as in Pteris. Veins free, forked or pinnate. Fronds mostly I-3-pinnate, smooth, mostly coriaccous.

1. P. atropurpurea, Link. Fronds tufted, coriacenıs, ovate-lanceolate, pinnate or below bipinnate; pinnæ opposite, rather distant, the lower ones 
stalked ; pinnules sessile, oblunger or linear-oblong, trumeate or sulerordite nt the

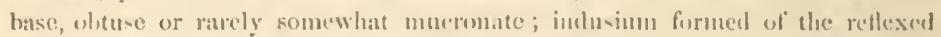

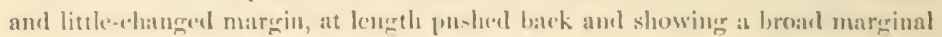

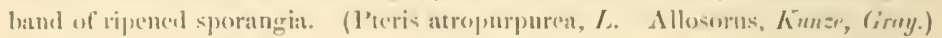

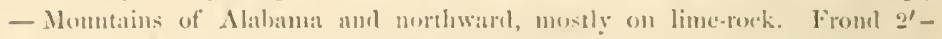
$12^{\prime}$ high. Stipe and rachis blike and shining, snooth or somewhiat rustypubescent.

\section{CHEILANTHES, Swart\%.}

Fruit-lots at the thickened ends of the veins, distinct or at length conflnent, covered ly the continnons or interrupted reflexed matrin of the lobes. Veins free. Fronds 1-3-pinnate; pinnules with a midrib, often liairy or woolly.

1. C. Alabamensis, Kimze. Fronts broadly lanecolate, subeoriareous, pinnate; pinne ovate-lanceolate, deeply pinnatifit, or the luwer ones again pinnate; pinnules orate-olilong, rather obtunc, often anriculate at the upper side of the base, glabrous, the margin reflexed and forming a mosty continuous membranaceuns involucre. (I'teris Alabamensis, Buchley.) - Limestune clitts on the 'Tennessee and French Broat likers, Alabama, \&e., Bucklyg. - Fronds $4^{\prime}-6^{\prime}$ long, on slender black and polished stupes $2^{\prime}-4^{\prime}$ long, pulverulem along the upper side, and somewhat chaffy at the base.

2. C. vestita, Swartz. Fronds loroadly lanccolate, like the stalks lirsute with rusty hairs, hipinnate; pinne triangular-ovate; pinnules oblongr, oltuse, more or less inciecl; the ends of the lobes retlexed to furm separate herhacons involucres, - Near Angusta, Georgia, Kunze, and northward. - Fronds $4-8^{\prime}$ long, hecoming smooth above.

3. C. tomentosa, Link. Fronds broally lanceolate, tripinnate, above clothed with white deciduons hatrs, beneath densely fomentose with brownishwhite wool; primary pinne ovute-oblong; ultimate segments minute, roundobovate, sessife or adnate-decurrent, the margin reflexed forming a continuous somewhat membranaceon involucre. (C. Bradburii, I/ook, at least as to Limsheiner's plant.) - French Broad River, North Carolina and Tennessee, and sonthwestward - Fromd $6^{\prime}-12^{\prime}$ long. Stije and rachis whitish with long paleaceous hairs.

\section{ADIANTUM, L. ManENhitr.}

Indusinm orbicular or transversely elongated, formed of a reflexed and aitered portion of the margin of the frond, bearing the sporangria on its miler side at the ends of the veins. Midrib none or eccentric: veins forking, mostly frec. Stipe and rachis commonly hlack and shining.

1. A. pedatum, I. Stipe long and slender, forked, the spreading and recurved branches bearing on the onter side several sleuder horizontal pinnate divisions; pinnules munerous, alternate, short stalked, ohlong, entire on the lower sitle, the upper margin eleft and frnit-bearing. - Sharly woorls, North Carolina, and northward. - Stipe $8^{\prime}-12^{\prime}$ ligh. The most graceful of all our Ferns. 
2. A. Capillus-Veneris, L. Frond ovate-lanceolate, 2-3-pinnate; pinnules very delicate, oblique, broadly wedge-shaped or sometimes rhomboid, rather long-stalked, the upper margin deeply ineised and fruit-bearing or sterile and dentate; stipe slender, ebeneous ; raehis aimost eapillary, flexuous. - Mostly pendent from Limestone cliff's, Florida, Alabama, and westward. - Fronds $1^{\circ}-$ $3^{\circ}$ long.

\section{BLECHNUM, L.}

Sporangia on a transrerse elongated receptacle parallel to the midrib, combining the veius near their bases. Indusium fixed by its outer margin, opening inward. Veins of the sterile fronds frec. Fronds simple or pinnate.

1. B. serrulatum, Michx. Fronds ereet, rigid, pinnate; pinnæ artieulated with the rachis; fertile ones linear-lanceolate, acute, finely and sharply serrate; fruit close to the midrib; sterile ones broader, bearing a few ehaffy seales along the midrib. (B. angustifolium, Willd.) - Florida, Michaux, Buckley!

\section{WOODWARDIA, Smith.}

Fruit-dots linear-oblong, in one or two series on transverse anastomosing veinlets parallel and near to the mixlrib. Indusium attached by its outer margin to the veinlet, opening inward. Teins more or less retieulated, free toward the margin of the frond. Fronds mostly pinnatifid or pinnate.

1. W. angustifolia, Smith. Fronds smooth, pinnatifid; the sterile ones ovate, with broadly-lanceolate finely serrate divisions, unitcd at the base and deeurrent on the stipe, the reins reticulated in several series of areoles; fertile fronds taller, with narrowly linear entire divisions, and a single series of clongated arcoles, each containing an oblong fruit-dot with a rauled indusium. (Acrostichum areolatum, L. W. onoeleoides, Willd.) - Bogs and shady banks, Florida, and northward. - Rootstock ereeping, elongated, as thiek as a goose'quill. Stipe $6^{\prime}-12^{\prime}$ high, about the length of the froud.

2. W. Virginica, Willd. Fertile and sterile fronds alike, orate, smooth, pinnate; pimn limecolate, narrowed at both ends, pinnatifit ; segnents oblong, obtuse; veins forked, forming a single series of areoles along the midrib both of the pinne and of the segments; areoles fruit-bearing in the fertile frond. - Shallow ponds, Floridat to Mississippi, and nortluward. - Rootstock as thick as one's fincer, creeping, elongated, with a tough black exterior, the interior soft and white. Fronds $1^{\circ}-4^{\circ}$ high; stipe smooth.

\section{CAMPTOSORUS, Link. WALKING-LEAF.}

Fruit-dots linear or oblong, straight or curved, scattered irregularly on the baek of the frond, often opposite in pairs, or converging and united. Indusium linear, attached by one margin to the retieulated veins of the simple frond.

1. C. rhizophyllus, Link. Fronds evergreen, lanceolate, cordate or lastate at the base, longracuminate, often rooting at the extremity and giring 
rise to new plants. ( $\Lambda$ splenium dhizoplyyllum, I..) - Slakled rocks on the mountains of Georgia, and northwaral. - Fronds $t^{\prime}-10^{\prime}$ long.

\section{ASPLENIUM, I.}

Fruit-dots oblong or linear, olyligue to the milrib, the imlusium attaches by one marain to the mostly fiee veins, rarely curved, or double and attuched to both silles of the rein.

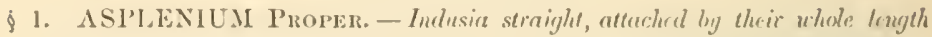
to the upper side of the vein; rarely some of them double, and placed back to buck.

* Fronds pinnutifid or simply pinnute.

1. A. pinnatifidum, Nutt. Fronds lancenlate, acuminate, corlate at the base, pinnatifil, or below sometimes pinnate, the roumli-h divisions obtuse, erenate or servite; frnit-lots scattered. - Alleglanies of Alabama, and northward. - Frouds $3^{\prime}-6^{\prime}$ long. $\Lambda$ form with the lowest secrment on each siclo elongated horizontally and aeminate, las been found in Mlabana by Mr. Braumont.

2. A. dentatum, L. Fronds linear-oblong, obtuse, pinnate; pinnac mostly opposite, $8-12$ jairs on sliort but distinct stalks, roundish ovate $\left(3^{\prime \prime}-4^{\prime \prime}\right.$ long), (nneate at the lower side of the base, and truncate at the upper side, erenate or serrate, obtuse; fruit-dots $6-8$ on each pima, clongated, the one next the rachis often donble. - Carolinil, Th. 1 Hoore, Florida, Binney. - Fertile fronds $4^{\prime}-6^{\prime}$ hight, the stipe as long as the sterile fronds.

3. A. Trichomanes, L. Stipe and rachis slemier, purplish black and shining; fronds many from the short rootstock, linear, pinnate; pima nunerous, minute $\left(2^{\prime \prime}-3^{\prime \prime}\right.$ long), roundish oblong, narrowed at the lase and attached to a raicel point on the rachis; fruit-dots $4-8$ on a pinna. (A. melanocaulum, Willd.) - Rocks along the Alleghanies, and northward - Fronds $q^{\prime}-$ $8^{\prime}$ lighh.

4. A. ebeneum, Aiton. Stipe and rachis purplish black and shining; fronds linear-lanceolate or spatulate, acuminate: pinnate; pimse nunerous, sessile, linear-oblong, auricled on one or both sides of the base, serrate or nearly entire, those below the mitdle of the frond gradually shorter and deflexed ; frutdots 10-13 on a pinna. - Florila to Mississippi, and northward. - Fronds $6^{\prime}-$ $18^{\prime}$ lighh, $1^{\prime}-3^{\prime}$ wide; stipe very slsort.

5. A. angustifolium, Michx. Fronds tall, lanceolate, pinnate; pinna numerous; the sterile ones linceolate from a truncate hase; the fertile ones narrower, and bearing 60-80 cursed finit-ilots on the upper branches of the pinuate forking veins; inclu-ia thickish, strongly convex. - Kich soil along the mountains, and northward. - Fronds $1^{\circ}-3^{\circ}$ high, annual. I'inna $2^{\prime}-4^{\prime}$ long, $4^{\prime \prime}-8^{\prime \prime}$ wide.

\section{* Fronds 2-3-pinnate or pinnatifid.}

6. A. montanum, Willd. Frouds small, orate-lanceolate, pinnate; pinna few, petioled, ovate or triangular; the lewer ones pinmatifid; the upper ones incised; divisions toothed or serrate; fruit-dots very short, the basal ones often 
wilh a double indusium. - Mountains of Alabama, and northward. - Fronds $2^{\prime}-5^{\prime}$ higl, with a winged greenish rachis, and a stipe nearly as long as the frond.

7. A. Ruta-muraria, L. Fronds small, ovate, pinnate ahove, hipinnate bolow, the divisions stalked, obovate-cuneate, toothed at the apex; vens forked from the base ; fruit-dots $\mathrm{few}$, indusia laciniate at the margin. - Rocks along the mountains, and northward. - Fronds $2^{\prime}-4^{\prime}$ high.

8. A. myriophyllum, Presl. Fronds delicately membranaceous, lanceolate, narrowed below, 2-3-pinnate; ultimate segunents oborate-oblong, entire or 2-3-lobed; veins single in each segment or lobe, bearing below the middle a solitary oblong fruit-dot. (A. Anchoriti, Chupm. MS.) - On the walls of a limestone cave at Schurlock's Spring, Jackson Co, Florida, Chapm.Fronds $3^{\prime}-10^{\prime}$ ligh, with short stipes and narrowly winged rachises.

9. A. thelypteroides, Michx. Fronds ample, oblong-orate, pinnate; the deeply pinnatifil pinnæ lanecolate-acuminate from a broad sessile base; the lower ones smaller, distant, and deflexed; the lohes oblong, obtuse, crenately serrate; fruit-dots $8-12$ to a lobe, at length confluent, those next the midrib toward the ends of the pinnæ nostly double; indusium convex, thickish. Rich woods in the npper part of Georgia, and northward. - Fronds $1^{\circ}-3^{\circ}$ lighl.

\$2. ATHYRIUM, Roth. - Indusium thin, attached to the upper side of the vein; or recurt d and crossing the vein, attached to both sides of $i t$, thus becoming renifirm or shaped like a horseshoe.

10. A. Filix-fœmina, Bernh. Fronds ample, ovate-nhlong; pinnæe lan. ceolate, numerons; pinnules oblong or lanceolate, doubly serrate or variously incised ; fruit-dots short, at length confluent. (Aspidium Filix-fomina, Swartz.) - Low shady woods, Florida to Mississippi, and northward. - Fronds $1^{\circ}-3^{\circ}$ high. - A. asplenoides (Aspidium asplenoides, Swartz?) is said to differ in having a creeping caudex.

\section{CYSTOPTERIS, Bernhardi.}

Fruit-dots round, on the back of the free forking veins, covered when young by a thin ovate or roundish hood-shaped indusium attached by the lower side rather beneath the fruit-dot, its apex pointing toward the end of the vein, at length reflexed or falling away. - Delicate Ferns with 2-3-pinnate fronds, and short creeping rootstoeks.

1. C. fragilis, Bernl. Fronds ovate-oblong, bipinnate; the orate-lanceolate pinnac mostly opposite, the lowest pair distant, smaller; pinmules oblong or obovate, cuneate at the bise and decurrent on the winged secontlary rachis, variously toothed or incised; indusium ovate, acuminate. (Aspidium tenue, Swartz.) - Moist rocks on the mountains of North Carolina, aud northward. Fronds $4^{\prime}-8^{\prime}$ long, on slender brownish stipes as long as the frond. Pinnules varying greatly in shape and size. 
2. C. bulbifera, Beml. Fromds lanceolate, very long and aftenuated at the apex, often bentugr bulblets beneath, hipinuate; pimua triangular-lanecolate; the lewest pair langest, distant; pimules oblong, menately incised or toothed, obtuse; indusimu romblish, truncate. (Aspidimm bullifermu, Sururtz) - Rocks on the monntains of North Carolina, and northward. - Fonds $1^{\circ}-3^{\circ}$ long. The lubblets fall to the gromel, and form new plants, which are about two years in coming to maturity.

\section{ASPIDIUM, Swart. Sun:L1)-Fer.}

Fruit-dots roumd, horne on the veins mostly below their apices. Indusium round-reniform and fixed at the sinus, or orhenalar and fixed by the deprensed centre. Veins with acute or attenuated apices. Our species have fiee veins and 1-3-pinuate fronds.

1. LASTRliA, Bory. Indusium round-kidney-shaped, fixed at the sinus.

* Fronds thin and delicate, deerying in autumn; ultimate segments entire or nuarly so; veins simple or once forlicd.

1. A. Thelypteris, Swartz. Fronds smooth, ovate-lanecolate. pinnate; pinnæ lanecolate, often recurved, deeply pinnatitid; the lowest 1 - 2 pairs rather smaller; segments oblong, obtuse, nearly entire, the fertile ones with a strongly revolute margin; veins mostly forked; indusium minute, smooth. - Swamps and logs, Florida, and northward. - Fronds $10^{\prime}-18^{\prime}$ long, with an clongated stipe. This species and the next one have slender, nearly naked rootstocks, which creep several inches in alvance of the fronds.

2. A. Noveboracense, Willd. Fronds lanceolate, tapering botll ways from the middle, pinnate; pinne lanceolate, hairy beneatlo along the inidrib; the lowest $4-6$ jairs gradually smaller, distant and deflexed ; seginents oblong, obtuse, nearly entire ; reins simple ; indusinm ninute, sinooth. - Low grounds, North Carolina, and northward. - Fronels $1^{\circ}-2^{\circ}$ loner, on rather slort stipes.

3. A. patens, Swartz. Fronds ovate or oblong-ovate, pulescent, especially on the reins beneath, pinnate; pinne lanee-linear from a broad base, deeply pinnatifid; the lowest pair a little smaller and reflexed; segments oblong, often fiteate, entire, or the upper basal one cularged and pimnatilid; veins simple, free, or the basal ones meeting at the sinus between the segments;

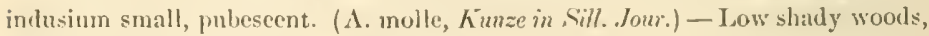
Florida to South Carolina, and westward. - Fronds $1^{\circ}-3^{\circ}$ high.

* * Fronds thicker; ultimate segments more or less serrute or toothed; the lowest veins more than once forkel.

4. A. spinulosum, Swart\%. Fronds ovate-oblong, tlin, smooth; hipinnate or below tripinnate; pinne oblong-lanecolate; the lower ones broader, triamgulat-ovate; ultimate seguents oblong, or linear-oblong, closely set on a narrowly winged partial rachis, varionsly ineised or serrate with spinulose tecth; fruit-dots small; indusium deciduons, sparingly glandular at the margin. (A. intermedium, Muhl.) - Shady woods in the upper distriets of North Carolina, Tennessee, and northward. - Fronds $1^{\circ}-2^{\circ}$ long, $5^{\prime}-9^{\prime}$ wide, varying greatly in outline, and in the sliape of the segments. 
Var. dilatatum, Gray. Fronds wirler in outline, of a rather firmer texture; the pinne fewer and set firther apart, the lowest pair largest, with the $2-3$ lower basal pinuules elongated; segments larger and more distant; fruit-ilots larger; indusium smooth. (A. dilatatum, Suartz. A campylopterum, Kunze.) - Summits of the Black Mountains, North Caroliua, Rugel. - Fronds $1^{\circ}-2^{\circ}$ long, $10^{\prime}-16^{\prime}$ wide.

5. A. Ludovicianum, Kunze. "Fronds membranaceons, rather rigid, finely glandular-pubescent beneatl on the midribs, orate, aemunate, bipinnate; pinna distant, petioled, ovate or oblong, acuminate; pinnules ovate, decply pinnatifid; the lowest divisions sessile with a narrowed base; the upper ones adnate, oblong, obtuse, crenately appressed-serrate; serratures acute, sometimes denticulate; fruit-dots half-way between the midrib and mare, on the upper branches of the forked veins; indusium reniform, thickish, entire, smooth, persistent." Mettenius. - Florida to Louisiana, hunze. - "liootstock oblique; fronds $2^{\circ}-3^{\circ} \operatorname{long}$; stipe straw-rolor, sparsely chaffy" - I have not seen this Feru, which has more recently been referred by Mettenius to $A$. Canaricnse, Al. Br.

6. A. Floridanum. Fronds thiekish, broadly lanceolate, pinnate; lower pinnæ sterile, triangnlar-lanceolate, deeply pinnatifid, with closely set oblong, obtuse divisions; upper pinne fertile, narrower and longer, again pinnate, with obloug obtuse pinnules, distant on the narrowly winged secondary rachis; fruitdots large, half-way between the midrib and margin; indusium ronnd-reniform, snooth. (Nephrodium Floridanum, Hook.) - Wet woods, Florida to Lonisiana. - Fronds $1^{\circ}-2^{\circ}$ hight, the sterile ones shorter, growing in a erown from a thick and scaly rootitock. - The plant has much the appearance of large forms of $\Lambda$. cristatum, Sicurtz, and may prove to be an extreme state of that species.

7. A. marginale, Swartz. Fronds evergreen, smooth, thickish and almost coriaccous, ovatc-lanceolate, bipinnate; piuns lanecolate from a broad base; pimules oblong or linear-oblong, attached by a broad base to the narrowly winged secondary rachis, entire or crenately toothed; frnit-dots large, very near the margin; indusium round-reniform, convex, thickisl, smooth. Mountains of North Carolina, and northward. - Fronds bluish-green, $1^{\circ}-2^{\circ}$ long, on a short stipe, which, like the short thick rootstock, is shaggy with large brown chaffy seales.

\section{\$2. POLYSTICIIUM, Roth, Schott. Indusium orbiculur, fixed by the de- pressed centre.}

8. A. acrostichoides, Swartz. Fronds evergreen, thickish, smooth and shining, lanceolate, the fertile ones tallest, pinuate; pinne numerous, shortstalked, oblong-lanceolate, auriculate at the base on the upper side, cmeate at the lower, obtuse or acute, fineły serrate or incised witl spinulose-pointed teeth; the upper pinne of the fertile frond contracted and covered with the copions fruit dots; indusium roumd, peltate, smoorh and entire. - Sharly and rocky woods, Florida to Mi<sissippi, and northward. - Fronds $1^{\circ}-2^{\circ}$ high. Rootstock and stipe very chilfy. 


\section{NEPHROLEPIS, Sihot.}

Fruitellots at the ents of the veins, in a scries near the margin of the pinnas. Imlusimm reniform, often brotdly so, tixed by the sinus, or by the urenate base, open oblipuely towal the mnrgin of the pinne. Fronds pinme, clongated; the pinne articulated to the rachis. Veins free, forked from the milrib, their apices thickencel.

1. N. exaltata, Schott. Fromls linear, imlehinitcly clongaterl, unfulling numerous pinua, which are oblong-lanceolate, antienlate on the upper side of the base, ronnded on the lower side, falcate, crenately serrate ; fruit-chts large; indusinm reniform or eresent-shaped, the oblipue sinns narrow and deep or broad and shallow on the same pinnax. - South klorida, Dr. Cooper. - Fronds $1^{\circ}-6^{\circ}$ long, $2^{\prime}-3^{\prime}$ wide, usually pendent from the trunks of trees.

\section{ONOCLEA, L.}

Fertile fronds eontraeted, the pinnules strongly revolute and herry-like; fruitdots on the hack of the free veins, with an elevaterl receptacle; inclusinm attiched partly to the receptacle and partly to the intervenular surface. Sterile fronds foliaceous, much taller than the fertile ones.

1. O. sensibilis, L. Sterile fronds on a long smooth stipe, broadly deltoid-ovate, pinnatilid almost or quite to the rachis; the divisions lanceolate, entire or arenately incised; reins finely reticnlated with oblong-hexilgonal arcoles; fertile fromds shorter, bipinnate; pinne erect, appresserl to the rachis; the pinnules crowded. - Meadows and wet places, Florida to Missisippi, and northward. - Rootstock nearly naked, creeping. Fronds varying from four inches to three feet in height.

\section{WOODSIA, R. Brown.}

Frnit-dots on the back of the reins; the inrolueres placed leneath the fruitdot, saucer-shaped or cup-shaped, divided into irregular lobes or a delicate fringe, or sub-globose and contracted at the mouth. Sull Ferns with many fronds from a short scaly rootstock.

* Involucre fringed, the hair-like divisions incuresel on the sporangia.

1. W. Ilvensis, R. Brown. Fronds sparingly hairy ahove, villous beneath and on the stipe and rachis with brown hairs and narrow cluff, lanecolate, piunate; pinne orate-ollong, deeply pinnatifid, the divisions oblong, obtuse, entire or erenate. Fruit-lots emeloped in the fringe of the involnere. - Rocks along the Alleglany Mountains, and northward. - Fronds $3^{\prime}-8^{\prime}$ light.

* * Incolucre divided into a few irregular lubes.

2 W. obtusa, Torr. Fronds nearly smooth, broadly laneeolate, pinnate, or near the rachis bipinnate; pinnae triangular-ovate, the lower ones distant, pinnately parted; segments oblong, oltuse, the upper ones toothed, the lower ones pinnatifid with tootherl lobes; veins forked, the tips whitish on the upper surface of the frond; fruit-dots on the lobules; involucre delicate, the lobes 
hidden by the ripened sporangia. - Rocky places, North Carolina, Tennessee, and northward. - Fronds $6^{\prime}-16^{\prime}$ high.

\section{DICKSONIA, L'Her. § SI'TOLOBIUM, Desv.}

Fruit-dots small, globular, terminal on the free reins; sporangia on an elevated reeptacle in a thin cup-shaped involuere which is partly adherent to a reflexed lobule of the frond. Fronds large, 2-3-pinnate, from a crepping rootstock. - Dicksosid proper lias large two-lipped involucres, of a firmer texture, and several species lave an arboresent caudex.

1. D. punctilobula, Kunze. Fronds delicate, slightly glandular-pubescent, as is the rachis, lanceolate-acuminate, 2-3-pinnate; pinux numerous; pinnules oblong-ovate, closely placed, obtuse, pinnately incised or pinnatifid; the divisions obtusely serrate, each one bearing a minute fruit-dot at the upper margin. - Moist shaty woods in the upper part of North Carolina, Tennessec, and nortliward. - Rootstoek slender, cxtensively creeping. Fronds $2^{\circ}-3^{\circ}$ ligh, when cruslied returning a pleasant odor.

\section{TRICHOMANES, L.}

Sporangia witl a transverse entire ring, arrangel on the lower part of a cylindrical, filiform, often clongated recepticle: involucres maryinal, funnelshaped, or bell-shiaped, entire or two-lipped at the moutl. Fronds delicate, very thin and pellucid.

1. T. Petersii, Gray. Very small, with entangled filiform tomentose rootstocks; fronds oblong-lancecolate or obovate, entire or variously pinnatifid, narrowed into a slender stipe nearly as long as the frond, the younger ones with a few black forked hairs along the margin; veius forked, pinnate from the midrib; involucre solitary, terminal, funnel-shaped, the mouth expanded and slightly two-lipped, receptacle included.-On the face of a sandstone rock, sprinkled from a waterfill, Hancock Co., Alabama, T. M. Peters. Also among some Mosses sent from Pensacola, Florida. - Fronds less than an inch high.

2. T. radicans, Swartz? Fronds pellueid, with a loose roundish arcolation, on a short broadly wiuged stipe, lanceolate or orate-lanceolate, bipinnatifid; pinnæ ovate or deltoid-ovate, obtuse, the upper side of the hase parallel and appressed to the winged rachis, the lower side cuncate; divisious toothed or diviled into linear lobes; involucres terminal on short lobes of the piunx, tulular-funnel-shaped, margined, at the moutl truncate and slightly two-lipped; receptacle exserted a little or very much. (T. Boschianum, Sturm.) - Hancoek County, Alabama, Peters, Beammont. Cumberland Mountains, Eastern Teunessee, Rev. Dr. Curtis. - Rootstock slender, creeping, tomentose with black hairs. Fronds $4^{\prime}-8^{\prime}$ light, 12" $-18^{\prime \prime}$ wide.

\section{LYGODIUM, Swart\%. Climbivg Fern.}

Sporangia beneath ovate hood-shaped imbrieated indusia, in a double row on narrow divisions of tho fronds, attached laterally, ovate, witl a many-rayed api- 
("al ring. Fronds clongated, climbing, the branches usually in pairs with a short common foot-stalk.

1. L. palmatum, Swart\%. Fronds slender, pimut deeply corilate at the base, pahnitely $4-7$-lohed, the lobess oblong, obtu-c, chitire; the ulper pintes decompoum and bearing the frut an the very narrow segrnents. - Low shaty woods, llorida, and northwarl; not common. - liootstock very slender, crep. ing. Fronds $2^{\circ}-5^{\circ}$ high, climbing on weeds and bnshes.

\section{ANEIMIA, Swarz.}

Sporangia ovate, many-rayed at the apex, attached by the base in a double row to the narrow one-sided paniculate divisions of the two lower branches of the frond, or on separate fronds. Indusinm none. Fronds erect, commonly threc-lranched, the middle branch sterile and $1-3-p$ innate.

1. A. adiantifolia, Swartz. Fronds sparingly puleseent, erect on a slender stipe; the two lower branches elongated, pimately decompouml, fertile; sterile part of the frond leltoirl-ovate, 2-3-jinnate; ultimate semments obovate, cumeate, entire or lobed, strinte ahove with mumcrons flabcllate veins. - lícy West, \&e., South Florida. - Fronds $6^{\prime}-12^{\prime}$ high, rather rigid. Rootstock creeping, slender, corered with a black tomentum.

\section{OSMUNDA, I. Flowerisg Fer.}

Sporangia globular, short-pedicelled, having an incomplete transwerse ring, represented by a few parallel strix near the apex, opening by a vertical elink into two nearly equal valves, paniculately arrauged on contracted parts of the froul or on separate fronds. Fronds tall, erect, several from a stout rootstock, 1-2-pinnate. Veins forking, free.

$$
\text { * Fronds bipinnate, fertile at the top: sterile pime few. }
$$

1. O. regalis, L. Fronds orate, smooth ; sterile pinue distant ; the fincly serulate pinmules distinet, oblong-lanceolate, eordate or truncate at the nearly sessile lase, sometimes anricled at the lower side of the hase; the npper pinne erect, panicled and thickly evered with light brown sporangia. ((). spectalilis, Willd.) - Swamps, Florida to Mississippi, and northward. - Fronds $1^{\circ}-5^{\circ}$ high ; pinnules $1^{\prime}-2^{\prime}$ long, $3^{\prime \prime}-4^{\prime \prime}$ wide.

* * Sterile fronds pinnate: the pinne numerons, deeply pimatifid, with oblong entire segments.

2. O. Claytoniana, L. Fronds broadly lancenlate, woolly when young, at length uearly smooth: sterile pinnx sessile, oblongr-lanceolatc, deeply pinnatifid; the segments crowled; fertile piunx few; between the milldle and the base of the frond, contracted, the sporangria decpening in eolor as the sterile pinnse expand. (O. interrupta, M/ichx.) - Low grounds in the upper districts, and northward. - Fronds $2^{\circ}-3^{\circ}$ high.

3. O. cinnamomea, I. Sterile fronds corered with rusty wool when young, at length smooth; pinna sessile, lanceolate; segments broally oblong, 
obtuse ; the lower basal ones in large fionds often elongated and pinnatifid ; fertile frond distinet, contraeted, bipinnate, very woolly, densely covered with einnamon-eolored sporangia, withering before the sterile fronds are expanded. Low grounds, Florida, and northward. - Fronds $1^{\circ}-3^{\circ}$ high.

\section{BOTRYCHIUM, Swartz. Moowwort.}

Fronds mostly solitary, erect from a root of thickened fleshy fibres; the terminal branch fertile, pinnately decompound, bearing on its narrow divisions the large coriaceous, transversely 2-ralved sporangia; the lateral branch sterile, with forking free reins.

1. B. Virginicum, Swartz. Stem tall; sterile part of the frond sessile, broadly triangular, ternately $3-4$-pinnate; ultimate segments oblong-lanceolate, thin and delicate, toothed and incised ; fertile part long-stalked, 2-3-pinnate. Shady woods, Florida, and northward. - Fronds $t^{\prime}-2^{\circ}$ high.

2. B. lunarioides, Swartz. Stem low ; sterile part of the frond mostly long-stalked, broadly trlangular, 2-4-pinnate; ultimate segments of a thick and fleshy texture, romdish, ovate, oblong or lanceolate, entire, toothed, incised, or even dissected into very narrow lobes; fertile part taller than the sterile, ovate, 2-3-pinnate. (B. fumarioides, Willd. B. obliqunm and B. dissectum, MUhl.) - Low shady woods and pastures, rarely in open pine-barrens, Florida, and northward. - Fronds $3^{\prime}-10^{\prime}$ high, the succulent stem divided down to the surfice of the ground, or even lower.

\section{OPHIOGLOSSUM, L. AdDer's-toxgue.}

Fronds mostly solitary, with short and often thickened rootstocks, and fleshy fibrous roots ; sporangia large, cori:tceous, opening transversely, connate, arranged in compaet simple 2-ranked spikes, proceeding variously from the mostly simple sterile part of the frond. Veins reticulated.

1. O. vulgatum, L. Sterile part of the frond ovate or oblong-oval, obtuse, sessile near the middle of the stem, without a unidrib ; fertile spike terminal, long-peduncled; rootstock short, ereet; roots fibrous, spreading horizontally. In sphagnous meadows and pastures, Tennessee, and northward. - Fronds $4^{\prime}$ $10^{\prime}$ high. - The following are probably but forms of this widely diffused and variable species.

Var. crotalophoroides. Smaller; sterile part of the frond near the base of the stem, ovate, abruptly contracted at the base and slightly petioled; spike short and thick; rootstock bulbous; roots slender. (O. erotalophoroirles, IValter. O. bulbosum, Michx.) - Low grounds, Florida to Louisiana. - Fronds $3^{\prime}$ $6^{\prime}$ high.

Var. nudicaule. Small, sterile part of the frond near the base of the stem, ovate or oblong, acute, narrowed into a short petiole; spike linear acuminate; rootstock bulbous; roots coarse. (O. nudicaule, L.f. O. ellipticum, Hook. $\oint^{\circ}$ Grev.) - Low sandy places or occasionally in dry soil, Florida and Georgia. Fronds $1^{\prime}-4^{\prime}$ high. 


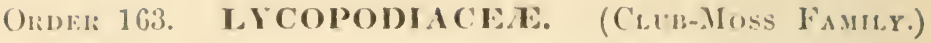

Peremuial plants, with solid branching and mostly creceping stens, Eparingly on thickly elothed with small, simple, sessile, awl-shaperl or linear leaves. Finctification consisting of 1-3-celled solitary spore-eases, axillary, eitluer along the main strm, or only in the axils of the ujper and mostly changed (bract-like) leares.

\section{LYCOPODIUM, I. Curn-Moss.}

Sporangia of one kind, coriacens, commonly kilney-sluaped, openiug transveriely into two valves and containing minute powdery spores. Perennial, mostly evergreen plants; the leaves imbrieated in several or mauy rows along the stem and branches.

\section{\$1. Sporangia borne along the stem, in the axils of uniforn leares.}

1. L. lucidulum, Michx. Stems ascending, forking, somewhat eninpressed; leaves (deep green) in several rows, linear-linceolate, very acute, spalingly denticulate, sprealing or reffexed. - Shady woods on the mountains of North Carolina, and northward. - Sten $66^{\prime}-12^{\prime}$ long. Leaves glosir.

2. L. Selago, I. Stems short and thick, terete, elustered, erect or ascending, forking; leaves in several rows, deep green, lanceolate, acute, entire, the upper erect, the lower spreading. - High mountains of North Carolina, and northward. - Stems $3^{\prime}-6^{\prime}$ high, rigid. Leaves crowded.

\$2. Spurangia in the axils of the upper leates, forming a terminal tercte bractcd spike.

* Bractcal and stem leares alitie, spreading.

3. L. alopecuroides, L. Stem thick, terete, forking near the hase, recurvel, and rooting at the apex, very leafy; leares in many rows, spreading, subulate, bristly-fringed below the middle; peduncles erect, $6^{\prime}-12^{\prime}$ high, sinilat to the stem; spike thick, cylindrical, bristly from the sfreading or recurved bracteal leaves. - Open pine-barren swamps, Florida to Mississippi, and nortlward. - Stems $10-1 \frac{1}{2}$ long, pale green.

4. L. inundatum, L. var pinnatum. Stem rather slender, prostrate, creeping, pinnately branched; leaves linear-subulate, bristly-fringed below tho middle, unequal, the upper and lower ones shorter and somewhat appressed, the lateral ones widely spreading; peduncle mostly solitary, erect $(1 \circ \mathrm{high})$, very leafy; spike thick, cylindrical, $2^{\prime}-3^{\prime}$ long. - Low pine barrens, near the coast, West Florida. - Stem $6^{\prime}-15^{\prime}$ long, and, with the spreading leares, $\frac{1}{2}{ }^{\prime}$ wide.

* Bracteal leaves wider than those of the stem.

- Leaves of the stem equal and alike.

5. L. clavatum, I. Stem very long, terete, ereeping, with numerous short and ereet leafy branches; peduncles with seattered leaves, each bearing 23 linear-cylindrical spikes; leaves in several rows, subulate, entire, incurved, pointed, like the orate crosely-denticulate bracts, with a spreading bristle. Mnuutains of North Carolina, and northward, - Peduncles $4^{\prime}-6^{\prime}$ long. 


\section{+- + Leaves of the fluttened stem and branches unequal.}

6. L. dendroideum, Michx. Stem erect $\left(6^{\prime}-12^{\prime}\right)$, clothed with seattered appressed subulate and entire leaves, simple below, bearing above numerous forking and spreading fan-like mostly compressed branches; lower row of leaves, and sometimes the upper, shorter, the lateral ones spreading; pednncles short, bearing one or more cylindrical spikes; bracts sprending, ovate, acute, erenate on the margins. (L. obscurum, L.). - High mountains of North Carolina, and northward.

7. L. Carolinianum, L. Stem creeping, pinnately branched, naked and rooting beneat's; upper leaves short appressed, the lateral ones widely spreading, lanceolate, acute, entire; peduncle slender $\left(6^{\prime}-12^{\prime}\right.$ higll $)$, clothed with seattercd subulate leaves, and bearing a single linear spike; bracts ovate, acuminate, spreading. - Low pine barrens, Florida, and northward. - Stem $2^{\prime}$ 8 ' long.

8. L. complanatum, L. Stem long and creeping, the nnmerous erect branches successively forking into many linear crowded flattencel branchlets; leaves minnte, snbulate, imbricated in 4 rows, the lateral ones slightly spreading; peduncles with minute scattered leaves, slender, bearing 2-4 erect cylindrical spikes. - Woods along the Alleghanies, and northward. - Stem $2^{\circ}-10^{\circ}$ long.

\section{SELAGINELLA, Beauv.}

Fructification of two kinds, either in the same or separate axils; one kind as in Lycopodium, the other with sporangia containing few (mostly 3-4) larger spores. Spikes 4-angled.

1. S. rupestris, Spring. Stems rigid, densely clnstered, erect or spreading, much brancher; leaves (grayish) subulate, rigid, rough-fringed on the margins, bristle-pointed, closely imbricated in many rows; spikes linear, nearly sessilc. - Dry sand rirlges in the pine barrens, and on dry rocks, Florida, and northward. - Stems $2^{\prime}-3^{\prime}$ high.

2. S. apus, Spring. Stems prostrate, creeping, slender, branclied; leaves scattered, unequal, the lateral ones larger and widely spreading, 2-ranked, ovate, acnte or obtuse, membranaceous, denticulate on the margins; the others smaller, acuminate, and appressed; bracts of the short sessile spike similar to the leaves. - Low shady woods, Florida, and northward. - Plant whitish. Stems $3^{\prime}-9^{\prime}$ long.

\section{PSILOTUM, R. Brown.}

Sporangia of one kind sessile, globular, opening at the apex into $2-3$ valves, and filled with very minute powdery spores.

1. P. triquetrum, Swartz. Stem forking, compressed, the branclies 3angled; leaves very minute, bristle-like; sporangia spiked, 3-celled, the cells imperfectly 2-valved. - East Florida. 


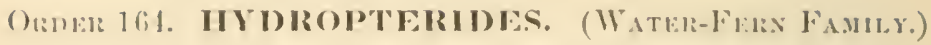

Ayuatie herbs. with the spomengia of two forms, borme at the base of the leaves and bursting irregenlarly.

\section{ISOETES, I.}

l'lants composed of fibrous roots and filiform cellular leaves, without any apparent stem. Sprorangia sunk in an excavation of the dilated base of the lenves, plano-convex, membranaceous, filled with transverse threads and minute powdery spores; those of the central leares filled witl lurger spores.

1. I. flaccida, Shuttlw. Immersed; leaves very long $\left(1 \frac{1}{2}-2^{\circ}\right)$, slender, flaceid, yellowish-erreen; spores very small, minutely pulverulent, not reticulated. - In lakes and clear streams, Middle and West Florida.

\section{AZOLLA, Lam.}

Minute floating plants, with pendent roots, piunately brancluing stems, and thick imbricated cellular leaves. Sporangia of two kinds, ovoit, sessile on the under side of the hranches, and covered with a thin membrane; the smaller kind opening transtersely, containing several angular grains, attached to a central column, the larger bursting irregularly and containing numerous globular stalked spores.

1. A. Caroliniana, Willd. - On still water, chiefly near the coast, Florida, and northward. - Plant reddish, circular in ontline, $\frac{1}{2}-1^{\prime}$ in diameter Leaves orate, oltuse, rounded and roughened on the back. 


\section{SUPPLEMENT.}

\section{Order RanUNCULACE}

\section{ADONIS, L.}

Sepals 5, deciduous. Petals 5-15, orate without seale or spot on the narrowed base within. Stamens uumerous. Ovaries numerous, 1-celled, 1oruled. Style straight or hookell: achenia spiked or capitate. Seed suspended. - Herbs with many-parted leaves, and solitary red or yellow flowers.

A. autumnalis, L. (PıEAsaxt's Ere.) Stem branching; leaves pimnately dissected; petals $6-8$, deep red; achenia capitate. - New ()rleans. Introduced. (1)

\section{RANUNCULUS, L.}

R. oblongifolius, Ell. Stem branching; leaves oblong, renticulate, the upper ones linear-lanceolate; petals 5 , longer than the calyx; stamens numerous; seeds globular, pointless. - Ditches and wet places, South Carolina, and westward. May-July - Stem $11^{\circ}$ higl. Flowers $3^{\prime \prime}-5^{\prime \prime}$ in diameter.

\section{Order anoNace E.}

\section{ASIMINA, Adans.}

A. reticulata, Shuttlw. Leaves coriacenus, lanceolate-oblong, obtuse, abruptly short-petioled, smooth above, paler and pubescent beneath; flowers single, the short peluncle and caly $\mathrm{x}$ rusty-tomentose; sepals ovate, acute; outer petals oblong, twice as long as the thick ovate inner ones. - Soutl Florida (liugel, Feay) - A low shrub. Leaves $3^{\prime}-4^{\prime}$ long. Outer petals $10^{\prime \prime}$ long.

\section{anona, L. Custard Apple.}

Ovaries numerous, with a single erect ovule, forming in fruit a compound many-seeded pulpy berry. Otherwise like Asimina.- Tropieal trees or shrubs.

A. laurifolia, Dunal. Smooth; leaves oblong, acute; peduncles short, 1-flowered; petals thick, whitish, the outer ones larger, broad-ovate, acute; fruit conical, smooth; seeds oblong, compressed. - Banks of the Caloosa River, and Miami (Garber). - A small tree. Leares $3^{\prime}-5^{\prime}$ long. Flowers $1 \frac{y^{\prime}}{2}$ wide. 


\section{Order NYMPHALCEA.}

NYMPHAEA, Tиแrn.

N. flava, Leitner. Rhizoma short, oblong ; leaves broally oval, nore or less way on the margins, with the lobes acute or obtuse; flowers yel. low ; stigma 7-rayed. - St. John's River (Curtiss), Miami (Garber). - Leaves $8^{\prime}-5^{\prime}$ wide. Flowers $3^{\prime}-4^{\prime}$ wide.

\section{Order PAPAVERACEAs. STYLOPHORUM, Nutt.}

Sepals 2, rounded, concave, hairy. Petals 4, orlicular. Ovary ovoid. Style long; stigma 3-4-lobed, spreading. Capsule ornid, loristly, with 3-4 parietal placenta. Seels globular, erested; albumen fleshy, - Perennial herbs, witls yellow juice, 1-2-pinnatifid leaves, and showy long-peduneled flowers.

S. diphyllum, Nutt. (Ýl, Low Porpy.) Leaves petiolel, divided into 5-7 oblong sinuate lobes, the upper pair opposite; perluncles terminal, single or elustered; flowers bright yellow. (Meconopsis, DC.) - Shadly woods, Tenuessee, and northwarl. May. - Stems $1^{\circ}-1 \frac{1}{2} 0$ ligh. Flowers $r^{\prime}$ wide.

\section{Order FUMARIACEA.}

\section{FUMARIA, L. Fintory.}

Posterior petal spurred, united below with the two imer ones. Stamens mited in two sets of three each. Style deciluous. Fruit globular, 1-seeded, indehiscent; sceds crestless, - Tender branching anmuals, with finely dissected leaves, and small flowers in lateral or terminal racemes.

F. officinalis, L. Leaves hipinnately divided, the narrow lobes widening upwarls; racemes many-flowered; sepals sharply tonthed; petals fleshcolor, tipped with crimson. - Waste places, sparingly introduced.

\section{CORYDALIS, Tent.}

C. aurea, Wiild., var. australis. Stem ronghish; racemes stout, many-flowered, mueh longer than the leaves; corolla ( $\frac{1^{\prime}}{2}$ long) three times as long as the pedicel and straight spur, loright yellow; outer petals crested ; capsule erect, even; seerls smooth am shining, the nargins obtuse. - Waste grounds in early spring.

C. flavidula, Raf. - Stem smooth; racemes few-flowered, barely longer than the leaves; corolli $\left(\xi^{\prime \prime}-t^{\prime \prime}\right.$ long) as long as the perlicel, pale yellow, crested; spur very short; capsule spreading or drooping, slightly knotted: seeds rugose-reticulated, the margins acute.-Tennessee (Dr. Gattinger), and northward. 


\section{Order CRUCIFERA.}

\section{NASTURTIUM, R. Br.}

N. sylvestre, R. Br. Stem ascending; leaves pinnately divided into narrow toothed lobes; silique linear, mostly shorter than the slender pedicel; style very short; petals yellow, longer than the calyx. - New Orleans. Introducerl.

N. obtusum, Nutt. Stem short, widely branched; leaves oblong, pin. natifil, the oblong or roundish lohes sparingly toothed; racemes barely as long as the leaves, mintely many-flowered; silique oblong, obtuse, or pointed by the short style, twice as long as the slender pedicel; petals minute, yellowish. - Banks of the Mississippi.

N. limosum, Nutt. "Very smootlı; leaves :anceolate, laciniately pin. natifil towards the base, nearly entire above, or angularly toothed, the lobes serrate or entire; perlicels much shorter than the short silique; stigina nearly sessile." - New Orleans (Nutlall).

\section{CARDAMINE，L.}

C. Clematitis, Sluttlw. Smooth; earliest leaves reniform, nearly entire; lower stem leaves broadly 3-lobed, the middle Jobe larger, reniform-cordate, or angularly 3-lobed; upper ones oblong, 3-lobel; petioles with an arrowslaped appendage at the base; racemes slort, loose; petals white, twice as long as the calyx; silique narrow-linear, eompressed, tipped with the long style. - Moist hanks, Mountains of Nortli Carolina and Tennessee. June. Stem $6^{\prime}-12^{\prime}$ high.

C. curvisiliqua, Shuttlw. Stem aseending from a creeping base $\left(\frac{1}{2}^{\circ}-\right.$ $1 \frac{1}{2} 0$ highs), smooth, soon branching; leaves pinnately divided into $3-8$ oval or obovate wavy-margined lobes, rarely entire, the lobes of the upper ones narrower anil sometimes toothed; petals white, spatulate-obovate, twice as long as the sepals; style short; silique filiform, terete, incurved; seerls oval or roundish. - Margins of ponds, \&c., St. Marks (Rugel). Fast Florida (Garber).

\section{LEAVENWORTHIA, Torr.}

L. torulosa, Gray. Silique linear, torose; style fully equalling the brealth of the silique; sceds broally oval, narrowly winged; radicle nearly transverse, strictly applied to the edges of the cotyledons at the base on one sile; petals purplish with a yellow base. - Cedar barrens, Temnessee $(L)$. Galling(r).

L. stylosa, Gray. Slender, strictly stemless; silique oval or broadly oblong (4" long), plane, surmounted by a slenter style of fully 2 lines in length ; seeds only $3-6$, orbicular, distinetly winger:; embryo as in the pre. cerling; petals pure golden yellow. - With the preceeding.

'The above-describer species, submitted hy Dr. Gray for future determination, appear to me to be quite distinct. 
BARBAREA, R. Br.

Silique long, linear, terete or d-sirlerl, the valves keeled. Seerla in a single row in each eell, marginless. Cotyledon thick, accumbent. - biemuial or perennial lerbs, with pinnatifil clasping leaves, and yellow flowers.

B. præcox, R. Br. (Secmy Guase) Lower leaves lyrate, with the termial lolve obovate, the upper ones pinnatifil, witls olblong-linear lobes; silique compressed, barely thicker than its pedicel ; style short and thick. Waste places, Nortl Carolina. Introduced.

\section{ERYSIMUM, L.}

Silique linear, 4-angular, the valves keeled. Seeds in a single row in each cell, oblong, marginless. Cotyledon that, incumbent. - Chicfly biennial herbs, with narrow leaves, and yellow tlowers.

E. cheiranthoides, L. (WORusevo MustaRu.) Stem erect, branching above, closely pubescent; leaves thin, laneexlate, acute, ('ntire or slightly toothed, ronghish; flowers small; silique ascending, rather longer than the slender pedicel, the angles rommded. - North Carolina (Curtis). July. Stem $1^{\circ}-2 \circ$ high. Silique $8^{\prime \prime}-10^{\prime \prime}$ long.

CAKILE, Tourn.

C. maritima, Scop., var. Cubensis. Stem and branches erect; leaves linear, obtuse, dentate-serate, tapering into a petiole; loment obovate. (C. Americana, var. Cubensis, DC.) - Keys of South Florida.

\section{Orier CAPPARIDACE E.}

\section{POLANISIA, Raf.}

P. trachysperma, Torr. \& Gray? Glandular-pubeseent ; leaflets and bracts ovite or oblong; raceme loosely many-flowered ; petals bright-yellow ( $\frac{1}{2}$ long), the obovate notched limb as long as the eapillary claw; stamens $20-30,2-3$ times as long as the petals; style longer than the orary ; capsule stipitate. - Roadsides, Dadeville, Alabama (Charles Mohr).

\section{Orner VIOLACEA}

\section{VIOLA, Tourn.}

V. rostrata, l'ursh. Stcms numerous, ascending $\left(3^{\prime}-f^{\prime}\right.$ long $)$; leaves corlate, strrnlite; stipules large, fringerl; spur straight, slender, longer than the pale-purp'c beariless petals; stigma beakless. - Mountains of Georgia and Alabama, and nortliward. 


\section{Order HYPERICACEA.}

\section{HYPERICUM，L.}

H. sphærocarpum, Michx. Stem woody at base, simple, or branching above, obscurely 4-ingled; leaves oblong-linear, obtuse, sessile; cyme compound, nıany-flowered; sepals nearly equal, ovate, much shorter than the petals; styles united; capsule coriaceous, globose. - Rocky hills, Northern Alabama (Molv) and Tennessee (Dr. Gattinger).

H. Colabriforme, Vent. Stem woody at base, ascending, 2-erlgerl above; leaves linear-lanceolate, sessile, spreading; cyme few-flowered; sepals unequal, ovate-lanceolate, about the length of the very oblique petals; cipsule broadly conical, acuminate. (11. procumbens, Michx.) - Dry hills, 'Tennessee. July. - Stem 6 ' $-20^{\prime}$ high. Leaves $I^{\prime}-1{ }^{\prime}$ long.

\section{Order PORTULACACEA.}

\section{PORTULACA, Adans.}

P. halimoides, L. Stem thick, erect $\left(3^{\prime}-6^{\prime}\right.$ high $)$, branching ; leaves terete, woolly in the axils; flowers few, in a terminal cluster, immersed in wool, and surrounded by a whorl of short subulate bracts; petals 4-6, yellow ; stamens 8-12. - Shell-Hummocks at Sarasota Bay (Gaiber).

\section{TRIANTHEMA, Sauvages.}

Sepals 3. Stigmas 1 or 2. Capsule 1- or 2-celled, 1- or few-seeded. Otherwise, with the characters and habit of Sesuvium.

T. monogyna, L. Perennial ; stem dichotomous, diffuse $\left(2^{\circ}-3^{\circ}\right.$ long $)$; leaves opposite, obovate, subconnate by their dilated petioles; flowers axillary, sessile, purple within ; stamens 5; stigma single; capsule 1-celled, 48-seeded. - Kieys of South Florida (Garber, Curtiss).

\section{CYPSELEA, Turp.}

Calyx 5-parted. Petals none. Stamens $1-3$, alternate with the calyxlobes. Styles 2. Cavsule circumscissile.

C. humifusa, Turp. Small, annual, decumbent, glabrous, branching; leaves nearly opposite, obovate or oval, dotted ( $1 \frac{1}{2}{ }^{\prime \prime}-2^{\prime \prime}$ long), the petiole dilated and with membranous margins at the base; stipules laciniate; flowers axillary, small, greenish. - South Florida (Blodyett).

\section{Older CARYOPHYLLACEA.}

\section{PARONYCHIA, Tourn.}

P. riparia, Chapm. Smooth or nearly so; perennial; stems several, spreading, brancherl; leaves ovatelanceulate, acute; stipules very short; sepals smonthish; otherwise like I'. Baldwinii. - Banks of Flint River, Georgia. - Stems $1 \frac{1}{2} \circ-3^{\circ}$ long. Leaves $\frac{1^{\prime}}{2}$ long. 
ALSINE, Tourn.

A. Pitcheri. Stems erect $(:)^{\prime}-6 f^{\prime}$ lighl $)$; leaves narrow linear, olutuse; cyme perluncled, setaceons, sprealling; petals oblong, longer than the :" -5 nerved lamceolate-subulate sepals. (Arenaria, Nuth.) - bastern slowe of Mobile Bay $(1 / \%)$.

\section{STELLARIA, I.}

S. crassifolia, Elırhart. Stenı wenk, diffuse $\left(6^{\prime}-12^{\prime}\right.$ long $)$; loaves linear-spatulate or oblong, spreading; peluncles axillary, longer than the leaves; flowers very snall, mostly 4 -androus; petals longer tlan the calyx, or none; sepass i-nerved, acute (Sagrina fontinalis, short f Prters). Springy places, 'Tennessee ( $D_{i}$. Guttinger). April. - Flowers apetalous.

\section{Order MALVACEA.}

\section{MALVASTRUM, Gray.}

M. Rugelii, Watson. Stems erect, much branched, stehate-hairy; leaves ovate, coilrsely serrate, slender-petioled; flowers axillary, small, single, or the upper ones densely spiked; involucel :-leaverl, as long as the very lairy calyx; petals yellow, oblique; carpels l2, even, awnless. (Malope, Ell. Malva, L.) - South Florila. - Stems $20-40$ high. Flowers $\frac{1^{\prime}}{2}$ wide.

\section{SIDA, I.}

S. cordifolia, I. Annual, villous; stem tall, much brancherl; leaves ovate, cortate, entire or angularly :-fobed, crenate-serrate; flowers suall, yellow, nostly erowded in axillary and terminal racemes; carpels $10-12$, shorter than the slender retrorsely scabrous awns. (S. althæifulia, var. aristosa, $l\left(C^{\circ}\right.$.) - Cedar lieys, Florila. Introduced. November. - Stem $3^{\circ}-5^{\circ}$ high. Leaves $2^{\prime}-3$ ' long.

\section{PAVONIA, Cav.}

P. racemosa, Swartz. Slırublyy, tomentose, sparingly branched; leaves petioled, cordate-ovate, acuminate, sliglitly serrate, 3-ncrved; stipules subulate, deciduous; racenes terminal, leafless, few-Howered; involucel 8-leaved; petals twice as long as the calyx, convolute, "dull white tinged with yellow"; stigmas sessile, "carpels unarmed." - Miami and licy Biscayne (Garber, Cutiss). - Stem $6^{\circ}-8^{\circ}$ high.

P. spinifex, Will. Shrubby, hirsute; leaves long-petioled, oblongovate or cordate, coarsely serrate; flowers long-peduncled; involucel 8. leaved, longer than the calyx, shorter than the yellow corolla; carpels armed with three stout retrorsely bearled spines. - Charleston (Rer. Dr. Bachman). Mayport, Florida (Curtiss). Introduced. - Stem $3^{\circ}-5^{\circ}$ high. Corolla $1^{\prime}$ wide. 


\section{MALACHRA, L.}

Flowers capitate, surrounded by a $3-5$-leaved involucre. Leaves of the involucel 8-12, linear or setaceous. Stigmas 10, capitate. Capsule separating into fire 1-seeded carpels. - Herbs or shrubs, rough with rigid, of ten stinging hairs. Flowers white or yellow.

M. capitata, L. Bristly, and tomentose in lines; stem much branched; leaves cordate, obscurely lobed and toothed; peduncles single or $2-3$ in a cluster, axillary, 7-flowered; involnere 3-leaved, cordate; petals twice as long as the calyx, yellow; capsule glabrous. - Key in Chuckolusky Bay (Curtiss). - Stem $3^{\circ}-5^{\circ}$ ligh.

\section{URENA，L.}

Involucel deeply 5-cleft. Calyx 5 parted. Petals oblique. Column short; anthers few, terminal. Stigmas 10 , capitate, capsule separating into 5 bristlybarbed 1-seeded carpels. - Branching shrubs.

U. lobata, L. Stem stont, tomentose; leaves roundish, slightly corlate, entire or obscurely $3-5$-lobed, canescent beneath ; flowers small, axillary, and crowded in a terminal raceme; leaves of the involucel 5-7, subulate; petals pale rose-color; carpels densely bristly. - Waste places. Flurida. Introduced.

\section{ABUTILON, Tourn.}

A. pedunculare, HBK. Shrubhy, velvety.tomentose; leaves longpetioled, round-cordate, acmminate, crenate, canescent beneath; peduncles axillary, as long as the petioles; calyx-tube plicate; petals "rose-color," reflexed, twice as long as the calyx ; carpels about 20, mucronate, villous, 3 9 seeded, - South Florida (Miss Reynolds). - Stem $2^{\circ}-6^{\circ}$ higl.. Petals $10^{\prime \prime}$ long.

A. permolle, Don. Shrubby, velvety-tomentose ; leaves round.cordate, acute, crenate; peduncles twice as long as the flowers, the upper ones racemose; calyx-tube not plicate; petals yellow, twice as long as the calyx; carpels 7-10, villous, 3-seeded. - South Florilla (Grisebach).

\section{FUGOSIA, Juss.}

Involucel 6-9-leaved. Column of stamens naked above. Stigmas 3 or 4 . separate or united. Capsule 3- or 4-celled, 3- or 4-valved, few-or manyseederl. Seeds woolly. - Shrubby tropical plants, with solitary axillary yellow flowers.

F. heterophylla, Vent. Smootl, ercet; stem angular, branching; leaves linceolate, obovate, or :3-lobed, :-nerved; peduncles long, dilated under the flower; leaves of the involncel minute, subulate; ealyx dotted with Wack, the acute sepals 3-ribbed, nuch shorter than the showy petals; stigmas 3, united ; capsule 3-celled, 12-20-seeded. - Keys of South Florida. - Stem $12^{\prime}-18^{\prime}$ high. Corolla $1 \frac{1^{\prime}}{2}-2^{\prime}$ wide. 


\section{KOSTELETZKYA, l'resl.}

K. smilacifolia. Stcm slender, the lower branclies long $\left(20-3^{\circ}\right)$ and trailing; leaves small, the lowest ovate, the others hastate-3-loherl, witl, the midlle lobe lanceolate, serrate; racemes loosely few-flowered; corolla rose-color, 2' wide; colmmn interrupterly antheriferous; capsule lirsute. (llibiscus, shullw.) - Low pine woods, South Florida.

\section{HIBISCUS, I.}

H. coccineus, var. integrifolius. Leaves smaller $\left(t^{\prime}-6^{\prime}\right.$ long), ovate, undivided, or the lowest angularly :?lobed; jetals broaler, - Deep marsles. East Floricla.

H. furcellatus, Desrons. Slirubly ; stem tall, branching, tomentose ; leaves cordate, entire, finely serrate, rough above, tomentose beneath; leaves of the involucel 10, forkerl; c:alyx hispid ; corolla ycllow ( 8 ' long); capsule strigose; seeds smooth. - Listern shore of South Florida (C'urtiss).

\section{Orneli BYTTNERIACEA.}

\section{MELOCHIA, L.}

Inrolucel 3-leaved, or none. Calyx 5-cleft. Petals 5, convolute. Stamens 5 , the filaments more or less uniterl near the base. Cells of the ovary 1-2. ovuled; styles 5, separate, or partly united; stigmas (lub-shaped. Cajsule 5-celled, few-seeded. - Ilerbs or shrubs, with stellate pubescence, and clustered white or purple flowers.

§ Riedizia. Capsule septicidal or loculicidal. Involucel 3-leared. Flowers purple.

M. serrata, Benth. Shrubby, pilose; stem slender, brancling $\left(2 \circ-4^{\circ}\right.$ high); leaves ovate, acute, unequally serrate; stipuies linear, longer than the petioles; flower-clusters axillary, globose, the upper ones spiked; corolla showy, purple (1' wide). - P'ine wouls, South Floritli. October.

M. hirsuta, Cav. IIerbacenns, pubescent and slightly lispid; leares ovate, subcordate, erenate-serrate; stipules subulinte, shorter thin the petioles; flower-cluster terminal; corollat pale purple, yellowish within. - Streets of Savannah (Feay). East Florida (Curliss). - Sten $1^{\circ}-2^{\circ}$ high. Corolla $\frac{1^{\prime}}{2}$ wide.

\section{Orner TILIACE E.}

\section{TRIUMFETTA, I.}

Sepals 5, linear. Petals 5, convolute. Stamens $10-30$, separate. Cells of the ovary 2-5, 2-ovuled. Capsule uncinate-hispid, 2-5-cellerl, mostly scparable into as many 1 - "-sceded carpels. - Chiefly shrubs, with lobed leares, and small clustered yellow flowers. 
T. semitriloba, L. Hirsute, much branched; leaves round-ovate, entire, or angnlarly 3-lobed; peduncles 3-fluwered, clustered in the axils; sepals pointed, as long as the yellow wedge-shaped petals; stamens $10-15$; capsule globose. - Manatee, Florida. Introduced. - Stem $3^{\circ}-4^{\circ}$ high.

\section{Order OLACACEA.}

\section{SCHCEPFIA, Wallich.}

Calyx truncate, calyculate. Petals united into a 4 -5-cleft tube, smooth within. Stamens 4 or 5, opposite the lobes. Ovary 3-celled, the cells 1 ovuled. Style 3-furrowed; stigma 3-lobed. Drupe 1-3-seeded. - Slırubs or trees. Flowers small, on axillary peduncles.

S. arborescens, R. \& S. Branches smootlı, brittle; leaves ovate-lanceolate, short-petioled ; pelluncles short, single or clustered, 3-flowered; corolla bell-shaped, red. - Sonth Florida. A small tree.

\section{Order SIMARUBACEA.}

\section{PICRAMNIA, Swartz.}

Flowers dinecions. Calyx 3-5-parted. Petals 3-5, oblong. Stamens 3-5, exserted. Stigmas 2, sessile. Frnit a 2-celled, 2-seeded drupe. — Small trees, with unequally-pinnate leaves, and small flowers in teminal racemes or panicles.

P. pentandra, Swartz. Leaflets 5-7, alternately distant, ovate-oblong, obtuse; panicle simple, drooping; flowers greenish; stamens 5. - Miami, South Florida (Garber).

\section{Order VITACEA.}

\section{VITIS, L.}

V. (Cissus) sicyoides, L. Pubescent, climbing high ; leaves entire, ovate, cordate, finely and sharply serrate, longer than the small cymes; berry small, globose. - Banks of the Caloosa River, South Florida. October. - Branchlets and leaves somewhat succulent, detaclied in drying.

V. rupestris, Scheele. Stem low, mostly erect; leaves pale, snootl, round-cordate, or truncate at the base, rarely divided, coarsely and broadly serrate, abruptly acuminate; berries middle-sized, in small clusters. - Tennessee (Dr. Gattinger), and westward.

\section{Order LINACE $A$.}

\section{LINUM, L.}

L. Berlandieri, Ilook. ? Stem simple or sparingly branched $\left(\theta^{\prime}-12^{\prime}\right.$ high) ; leaves narrow-linear; flowers few, racenose, yellow; sepals acute, glandular on the margins; styles united to the top; capsule globose. Niami, South Floricla (Garber). 


\section{ORDE: RHAMNACEA.}

CONDALIA, Civ.

Calyx 4-5-eleft, alherent to the base of the orary, the lobes decilnous. l'etals none. Stamens 4 or 5 , alternate with the calyx-lobes. Ovary $2-3$ celled, with a single erect ovule in each cell. Style short; stigma 2-3-loherl. 1)rupe l-celled, 1-sected, the seed not grooved. - Mostly spiny trees or slurubs, with short-petioled leaves, and small clustered axillary flowers.

C. ferrea, Griseb. Lnarmel; branchlets puberulent; leaves oval or oblong, obtuse or emarginate, entire, smooth; umbel-like clusters few-flowered, sessile or short-peduncled; calyx-lobes 4, ovate, acote; stamens 4; stigma 2-lobed; drupe globose. (Scutia ferrea, Brongu.) - Coast and lieys of South Florida. - $\Lambda$ small tree. Leaves thick, $1^{\prime}-2^{\prime}$ long.

\section{REYNOSIA, Griseb.}

Calyx urceolate, 5-cleft. Stamens 5. Ovary free, l-celled, 1-ovulal. Drupe baccate. Seed large, with ruminated alhumen. Otherwise like Condialia.

R. latifolia, Griseb. Leaves pale, coriaceons, alteruate or opposite, elliptical or obovate, emarginate; flowers axillary, short-pedicelled ; calyxtube 5-angled, the lobe's ovate; stigma 2-lobed; drupe ovoid. (Scutia ferrea, 1st elition.) - South Florida. - A small tree, or shrub. Leaves $\mathrm{l}^{\prime}$, or less, long. Drupe $\frac{1^{\prime}}{2}$ long.

\section{RHAMNIDIUM, Reiss.}

Calyx 5-cleft, the lohes keeled within, deciluous. Petals 5, elawed. Stamens 5, enclosed in the petals. Ovary free, 2-cellerl. Siyle short; stigma 2-lobed. Berry elliptical, dry, 1-2-celled. Secd compressed. Albumen none. - Trees or shrubs. Leaves opposite. Flowers white, in axillary cymes. Seeds bony.

R. revolutum, Wright. Branclies puberulous; leaves smonth, thick, oval-ohlong, rounded or notched and mucronate at the tip, the margins revolute; clusters as long as the petioles; (alyx lobes deltoill ; petals olucordate; berry globose. - South Florida (Curtiss). - Leaves $\mathrm{I}^{\prime}-2^{\prime}$ long. Berry $6^{\prime \prime}$ in diameter.

\section{Orner CELASTRACEA.}

\section{MYGINDA, Jiaq.}

M. pallens, Smitl. Branches 4-angled; leaves elliptical or obovate, obtuse, crenate, smooth, nearly sessile; perluncles few-flowered, forking, $\frac{1^{\prime}}{2}$ or less long, shorter than the leaves; style distinet, 4lobed : Irupe obovate. - P'ine Ley, South Florida (Curtiss). - Slırub $10^{\circ}-15^{\circ}$ high. Leaves l' 2' long Flowers and drupe red. 
PACHYSTIMA, Raf.

Calyx 4-lobed. Petals and stamens 4, inserted on the edge of the disk that fills the throat of the calyx. Style very short; stigma obscurely 2 lobed. Capsule 2-celled, loculicidally 2 -valved, $2-4$-seeded, the seed arillate. - Low slurubs, with opposite persistent leaves, and minute axillary flowers.

P. Canbyi, Gray. Leaves oblong-linear, denticulate near the tip; flowers single, or clusterel on the common peduncle; petals oblong-ovate. - Rocky cliffs on the mountains of North Carolina and Virginia (Curtiss). Shrub $1^{\circ}$ or more hight.

Tribe HiPPOCRATEA. Calyx 5-cleft. Petals 5. Stamens 3, inserted within the large disk. Ovary 3-celled; styles uniled below. Ovules ascending. Albumen none.

\section{HIPPOCRATEA, L.}

Calyx small, 5-paried. Petals spreading, valvate or imbricate. Filaments recurved; anthers 2- or 4-celled. Disk expanded. Ovary free or confluent. Style sliort, subulate, 3 cleft. Ovules 2-6 in each ecll. Carpels 3, united at the base, 2-valved, or indehiscent, few-seeded. Seeds mostly winged. Climbing shrubs. Cymes or panicles dichotomous.

H. ovata, Lam. Leaves elliptical-oblong, serrulate; panicles rustypubescent, mostly longer than the leaves; petals oblong; carpels oval or roundish. - Borders of the Everglades (Curtiss).

\section{Order SAPINDACEA.}

\section{SAPINDUS, I.}

S. Saponaria, L. Petioles broadly winged ; leaflets 6 or 8 , nearly opposite, rather rigid, oblong, obtuse, mostly equal siled, pubescent beneath ; panicle tomentose, canescent; fruit globose. - Coast of South Florida. A small tree.

\section{Order POLYGALACE $A$.}

\section{POLYGALA, L.}

P. Rugelii, Shuttlw. Stem mostly branching; leaves alternate, lanceolate, acute, sessile, the lowest ones clustered and narrowed into a petiole; spikes globose; wings oblong-obovate, euspidlate; seeds and caruncle as in $P$. lutea. - Flat pine barrens, East Florida. May - Augnst. - Stem $1^{\circ}-2^{\circ}$ ligh. Flowers bright yellow, drying brown.

P. Reynoldsæ, n. sp. Stems stout, at lengtlı branching above $\left\{1^{\circ}\right.$ or more ligh); leaves lanceolate, mucronate, punctate ( $\left.1^{\prime} \operatorname{long}\right)$; the lowest ones clustered, spatulate; flowers large, yellow, scattered in a long $\left(6^{\prime}\right.$ or more) stout terminal raceme; wings elliptical, mucronate, 4 times as long as the capsule; keel crested; pedicels as long as the subulate bracts; caruncle 
as long as the hairy ovil seed. - St. Augustine, Filst Flurida (.1/iss . Veryy E. lieynolds). - Anomalous amoug the yellow-tlowered species, but may prove to be a form of the preeceling.

P. Curtissii, Gray. Stem slender; leaves altermate, narrow-lincar; racences long, loosely flowered; wings narrowly oblong, erect, twice as long as the eapsule; seeds and earuncle is in P. Chapmernii. - North Carolina (Prof. Porter), 'Temessee (Lr. Guttinger), - Stem $y$ ' high. Flowers rosecolor. Bracts persistent.

P. ambigua, Nutt. Very elosely allied to $P$. verticillata, but taller $\left(0^{\prime}-1 \tilde{J}^{\prime}\right.$ ligh $)$, the branches ereet; leaves usually hroader, mly the lower ones verticillate; spikes more slender, more loosely flowered; wings white. Gravelly liills, mountains of Georgli, and northward. May.

\section{Order tegUMTNOSH.}

\section{CROTALARIA, L.}

C. maritima, Chapm Low, muel, hranched, appressed-pubeseent ; leaves simple, ohlong, sessile, very thick and succulent; stipules minute or none; raceme 2-flowered; legmme oblong, smooth. - Saudy beach at I Palm Cape, Soutl Flurila. - Sten G' higlı. Leares 1' long. Flowers not seen.

C. pumila, Ortega. Shrubby or perenniul; stem sleuler, recumbent ; leaves trifoliolate; leaflets small, euneate, emarinate, longer than the petiole; pedmoles longer than the leaves, few-flowered; corolla small; legume oral, pubescent, tew seeded. (C. littoralis, $/ /$ /SK) - Sandy beach at Casey's Pass, South Florislit. October. - Stem $2^{\circ}-5^{\circ}$ lung.

C. incana, L. Annual, tall, much branclied, pubescent ; leaves trifoliolite, long-petioled; leaflets round.obrvate; racemes stout, many-flowered; keel of the corolla tomentose on the margins; legune oblong, hairy.South Florida, near the coast.

\section{MEDICAGO, L.}

M. denticulata, Willd. Stems prostrate; leaflets obovate or obeordate, denticulate; stipules ciliate-toothed; spoikes "- 5 -flowered, the flowers purplish; legume flat, coiled, the thin margin fringed with at double row of curved hooked hristles. - Charleston and New Orleans. Introduced.

M. maculata, Willd. Like the preeding, but the leaflets mostly purplish in the centre, the stipules more strongly toothed, and the margins of the legume thicker. - New Orleans. Introrlucell.

\section{MELILOTUS, 'Tourn.}

M. parviflora, Desf. Annual; stems ascending; leaflets of the lower leaves roundislı entire, of the upper ones oblong, denticulate; flowers very small, densely spiked, sellow; legume orate, rugose 1-seeded. - New Orleans. Introduced. 
PETALOSTEMON, Michx.

P. violaceus, Michx. Sten erect, corymbose above, very leafy; leaf. lets $3-5$, narrow-linear; spikes oblong or eylindrical ; calyx silky, the short tekth obtuse, as long as the lanceolate acuminate silky bracts. - West Tennessee, and westward. - Stem $2 \circ$ high. Flowers violet-purple.

P. roseus, Nutt. Leaflets narrower; calyx smooth, the teeth as long as the tube, shorter than the setaceous bracts ; petals obovate, rose-color; otherwise like the preceding. - Low pine barrens, East Florida.

P. candidus, Michx. Smoothish; stem erect, branching abore; leaflets $5-7$, lanceolate; spikes oblong; bracts lanceolate, acuminate, twice as long as the calyx ; flowers white. - West Tennessee, and westward. - Stem $1{ }^{\circ}$ $2^{\circ}$ high.

P. foliosus, Gray. Smontl, very leafy; leaflets $16-29$, linear-oblong, mucronate, the glands few and smaL; spikes cylindrical, short-peduncled; bracts slender-awned from a lancenlate base, exceeling the rose-purple flowers; calyx glabrous, the tceth abont half the length of the cylindraceous tube (Gray). - Near Nashville, Tennessee, and northward.

P. decumbens, Nutt. Stems decumbent, branching from the base; leaflets 6 or 8 , linear-oblong, mucronate; spikes ovate-oblong; calyx shorter than the acuminate bracts, the teeth longer than the smonth tube; petals deep violet-purple, linear-oblong, obtuse at the base, vexillum cordate. North Alabama, Tennessee, and westward. - Stems 10 long. Leaflets $6^{\prime \prime}-8^{\prime \prime}$ long.

P. Feayi, n. sp. Smooth; stems several, decumbent, much branched; leaves long-petioled, the $t-8$ leaflets soon involute-filiform, obtuse or truncate ; heads globular, corymbose, long-peduncled; calyx-tube smonth, twice the length of the orate acute pubescent tecth, and smo;th bracts; petals briglit rose-color; stamens long-exserted. - Bartow, South Florida (Feay). Stems $1^{\circ}-1 \frac{1}{2}$ long. Leaflets $5^{\prime \prime}-8^{\prime \prime}$ long. Heads $3^{\prime \prime}-4^{\prime \prime}$ broad.

\section{DALEA, L.}

D. Domingensis, $D C$. Erect, velvety-pubescent; leaflets 12 or $\mathbf{1 4}$, obovate; spikes capitate, short-peduncled ; calyx villous, the lobes subulate. - Key Biscayne, South Florida (Curtiss).

\section{TEPHROSIA, Pers.}

T. onobrychoides, Nutt. Softly pubcscent ; stem erect, mostly simple ; leaves petioled ; leaflets numerous, narrowly oblong, truncate or emarginate at the apex, mucronate, soon smootl nbove; racemes very long, erect, many-flowered; petals white, turning red; legume nearly straight. - 1'ine barrens near Mobile (Wohr), and westward. - Sten $2^{\circ}$ high. Leaflets $1^{\prime}$ long. Racemes $1^{\circ}-2^{\circ}$ long. 
T. leptostachya, 1)C. Stem erect, branching, slightly pubescent ; leaflets $8-12$, weildenblong, when young silky beneath; stipules subulate; racemes long and slemler; flowers distant, purple; legume erect. - Sandhills at Cape Camaveral (Curliss). July. - Stem $1^{\circ}-2^{\circ}$ high.

\section{INDIGOFERA, I.}

I. subulata, Vahl. Somewhat slımbly, sparsely pubescent with appressell laxirs; stem filiform, decumbent; Javes distant ; leaflets 5 , oblong, mucronate; racemes loosely many-flowered, in fruit many times longer than the leaves; calyx-teetl, subulate; legume filiform, reflexed, nearly terete, 6-8-seeded. - Miami, South Florida ( ('arber). - Stem 2'-8' long. Legume 2 ' 2 ' long.

\section{ASTRAGALUS, I.}

A. caryocarpus, lier. Stems prostrate or ascending, appressed.pubes cent; leaflets $16-24$, oblong; stipules ovate; perluncles as long as the leaves; racemes rather loosely flowered; the flowers violet-purple; legmue ovate, acute, smooth, thick and sucenlent, corky when dry. - Near Nashville, Tennessce (Dr. Guttinger), and westward.

Diubextoxia pexicea, DC., a Brazilian slırub, with showy bright.red flowers and 4-winged legumes, was introluced into the gardens of $A$ palachicola many years ago, and is now permanently established in the lower part of the city.

\section{VICIA, Tourn.}

V. Ludoviciana, Nutt. Smoothish; lenflets $10-15$, elliptical, rounderl or emarginate at the tip; peduncles mostly 2-flowered, flowers small, pale blue; calyx hairy ; legume broadly sibbre-shaped, 5 - 6-seerled. - New Orleans (Cinpenter). - Stem stout, $2 \circ-3^{\circ}$ long. Leaflets $6^{\prime \prime}-8^{\prime \prime}$ loug. Peiluncles-in fruit longer thim the leaves.

V. Floridana, Watson. Leaflets oblong or obovate, mucronate, thin

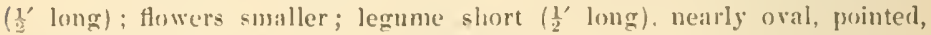
2-4-seeded; otherwise like $V$. acutifolia. - Low humnocks, East Florida (Gurber, Curtiss).

\section{LESPEDEZA, Michx.}

L. striata, IIonk. \& Armott. Annmal, ereet or prostrate, appresserl-pubescent ; leaflets oblong-obovate; stipules thin, strongly veined, twice as long as the petioles, persistent; racemes shorter than the leaves, 1 -5-flowered; caly $x$ veiny, the ovate teeth shorter than the round ovate reticulate legume; flowers purple. - Fields and waste ground. Introduced from $\Delta$ sia. - Stems $6^{\prime}-12^{\prime}$ Iong.

\section{DESMODIUM, DC.}

D. triflorum, DC. Creeping, pubescent; leaflets obcorilate ; peduncles axillary, single, or $2-3$ together, 1 -flowered; legume curved, $3-4$-jointed. Manatee, South Florida. - Stem $6^{\prime}-12^{\prime}$ long. 
D. incanum, DC. Stems erect or spreading, rongh above $\left(2 \circ-3^{\circ}\right.$ high $)$; leaflets varying from roundish or oval to lanceulate, acute or obtuse, smoothish above, canescent-tomentose beneath; stipules partly united; fiowers small ; legume nearly sessile, straight on one ellge, with 2-8 semi-oval joints. - Soutl Flurida (C'urtiss).

An arborescent ERYturiva occurs sparingly in South Florida, with the characters, so far as these are known, of E. herbacea, and it has been suggested that it may be that species growing in a climate more suited to its full development.

\section{CENTROSEMA, DC.}

C. Plumieri, Turp. Smooth or scabrous; leaflets ovate; peduncles 2-6-fowered; bracts twice as long as the ealy $x$; corolla very large, whitish, the middle of the vexillum and tip of the wings bright purple; legume con pressel-4-sider. - New Orleans. Introduced.

\section{GALACTIA, P. Browne.}

G. filiformis, Bentl. Stem long, twining, villous; leaflets oval or oblong, silky beneath, shorter than the many-flowered enrved racemes; flowers rather large, purple, the vexillum finely and obliquely striate; legume silky, falcate, compressed, 10-seeded. (G. spiciformis, var., 1st edit.) - Keys of South Florida. November.

\section{CANAVAL'A, DC.}

C. altissima, Macfadyen. Stem climbing; leaflets oblong, mucronateawned; racenes many-flowered, the petals large, purple; legume slightly curved, 11 -seeded, the seeds whitish. - South Florida (Feay), climbing over the tallest trees. - Legume $8-10^{\prime}$ long, $1^{\prime}-1 \frac{1}{2}^{\prime}$ wide.

\section{ECASTAPHYLLUM, P. Browne.}

Calyx campanulate, unequally 5-tootlsed. Vexillum orbicular. Stamens 8 or 10, diadelphous. Ovary stipitate, 2 -ovuled. Style slort anı slender. Legume orbicular, compressed, mostly 1-seeded. - Tropicil shrubs, with pinnate leaves, and small flowers in short axillary panicles.

E. Brownei, Pers. Stem branching; leaf reduced to a single ovate acute leaflet, pubescent above, pale and velvety beneath; panicles clusterlike, shorter than the petiole; corolla white; legume 1-seeded. - Banks of rivers, South Florida. Novenber. - Shrub $4^{\circ}-8^{\circ}$ high. Leaflet $3^{\prime}-5^{\prime}$ long.

\section{BAPTISIA, Vent.}

B. calycosa, Canby. Smoothish, much branched; leaflets wedge-obovate; stipules and bracts lancenlate, persistent; racemes numerous, terminal, the long $\left(1^{\prime}-2^{\prime}\right)$ pedicels bibracteolate; lobes of the caly $\mathrm{x}$ lanceolate, leaf $\mathrm{y}$, 4 times as long as the tube, and barely shorter than the yellow petals; legume ovate, acuminate, as long as the ealyx. - Near St. Augustine, East Florida (1/iss Reynolds). 
GYMNOCLADUS, lam. Compr:-lin:k.

Flowers polygamo dimcims, tomentose. Calyx narrowly fumbl-shaped, i-cleft. Petals 5. Stamens 10, s'parate. Sigle long, exsertell. Legume wooly, pulpy within, few-seculed, the seeds large, compressed. - $\Lambda$ slember tree, with thick thomless lranches, very large bipinnate leaves, and small whitish flowers in axillary racemes.

G. Canadensis, Lam. - Rich woods, Tennessee, and northward. Mily. - Leaves $: 20$-30 long. Leaflets ovate, the lowest pair borne on the common petiole, and larger. Legmue $\sigma^{\prime}-10$ ' long, ' 2 ' wide, 6 -8-seeded.

\section{C.FSALPINIA, ז。}

Sepals unequal, united into a cup-shaped base. Petals 5, mequal, clawed. Stamens 10, all fertile, the long filaments ascending, and hairy at the base. Style filiform. Legmme unarmed, compressel, wingless, 1-many-seeded. 'lrees or shrubs, with abruptly bipinmate leaves, and racemose mostly yollow Howers.

C. pauciflora, Benth. \& Ifonk. Glabrous, armed with rather stont stipular and stipellate recurved spines; pimne $2-4$ pairs; leaflets $3-5$ pairs, obovite, rombled at each end $\left(t^{\prime \prime}-5^{\prime \prime}\right.$ long); racemes simple, lonsely fewflowered; sepals obovate-oblong, little shorter than the yellow corolla and the slightly exserted stamens; legumes short, short-stipitate, oblicjucly acuminate, 1-few-seeded. - IBig I'ine liey, South Florida (C'utiss). $-\Lambda$ low shrub.

C. Bonduc, Benth. \& Hook. Leaflets $5-8$ pairs, obliquely oval, mueronate, the stipular thorns $2-3$; racemes long, densely flowered; calyx-lobes downy within, shorter than the long recurved deciduous bracts. (Guilandina, .Juss.). - South Flerida. - A tall shrub. Leaflets $\frac{1^{\prime}}{2}-1^{\prime}$ long. liacemes $1^{\circ}$ long. Flowers yellow.

PARKINSONIA, P'ım.

Sepals 5, equal, recurved. P'etals 5, ovate, the upper one roundish, long. clawed. Stamens 10. Style filiform. Legume linear-oblong, compressedmoniliform, several-scederl. - I spiny shrub. Leaves pinnate, with the petiole broadly winged, the numerous leaflets small, often deciduous or abortive. Flowers showy, yellow, in terminal racenes.

P. aculeata, L. - Key West, escapel from cultivation.

\section{DESMANTHUS, Will.}

D. brachylobus, Benth. Smooth; stem erect; pinnæ 6-14 pairs, each with a minute gland at the base; leaflets numerous, linear; heads globose; stamens 5; legumes oblong, curved, 4-6 seedeu. (Darlingtonia, DC.) Mississippi (Carpenter), and northward. 


\section{ACACIA, Necker.}

Flowers polygamous. Calyx $4-5$-toothed. Petals $4-5$, separate or united in a tube. Stamens numerous, inserted on the base of the corolla. Legume 2-valved, many-seederl. - Mostly trees or slırubs, with pimuately compound leaves, and small flowers in spikes or heads.

A. filicina, Willd. llerbaceous, unarmed, lirsute; stem erect; leaves bipinnate ; le:1flets $50-60$, very small, oblong-linear ; stipules deciduous ; licads peduncled, axillary and terminal; flowers white; "legume flit, fewseeted." - Gaiusville, Florida (Garber). - Stem simple, 20 - 30 higli.

A. Farnesiana, Willı. (Opopoxıx.) Slırubby, spiny, glabrous; pinna about 6 pairs; leaflcts $12-18$ pairs, oblong-linear; stipular spines long, straight; heads globose, on axillary single or clustered peduncles; flowers yellow, fragrant; legume terete, torulose. - Waste places. Introluced.

A. Julibrissin, Willd. Arborescent, nuarnel, glabrous; ninnæ 8-12 pairs; leaflets about 30 pairs, ol,long, oblique; heads in a terminal panicle; flowers flesh-color ; staniens long-exserterl ; legume flat, oblong, few-seeded. Roadsides. Introilnced.

\section{LEUC止NA, Bentll.}

Calyx 5-toothed. Stamens 10; anthers ovoid-oblong. Legume stipitate, broadly linear, flit. 2-valved; seeds compressed, transverse to the valves. Shrubs or trees. Leaves bipiunate. Flowers white, in glohose heals.

I. glauca, Bentlı. Unarmed, glabrous; pinnæ $4-5$ pairs; leaflets $12-$ 15 pairs, linear, distant, acute, glaucons beneath; heads single or by pairs on axillary peduncles; flowers white; legume linear, flat. - Keys of South Florida (Curtiss). $-\Lambda$ small tree.

\section{LYSILOMA, Bentl.}

Flowers polygamous. Calyx 5-cleft. Corolla broadly funnel-shaped, the lobes valvate. Stamens mostly $12-30$, united at base, exserted; anthers minute, globose. Orary sessile or nearly so, many.oruled. Legume linear, nearly straight, compressed, the valves at maturity separating from the persistent margin. Seels compressed, transverse. - Trees or shrubs.

L. latisiliqua, Benth. Unarmed, glabrons; piunæ 5 pairs; leaflets 10 pairs, elliptical; heads panicled; flowers white; legume flat, strap-slsaped, stipitate, many-seeded. - South Florida (Garber, Curtiss). - A shrub or small tree. Legume 6' long.

\section{Order ROSACE'A.}

\section{SPIR妮A，I.}

S. corymbosa, Raf. Leaves undivided, ovate, unequally serrate near the tip, whitish leneatlı; corymb large, smootlı, compouml; flowers white; follicle smootl. - Momntains of Nortl Carolina and Georgia. June. - Shrub $1^{\circ}-2^{\circ}$ high. Leaves $2^{\prime}-3^{\prime}$ long. 


\section{PRUNUS, L.}

P. (Laurocerasus) sphærocarpa, Swartz. Riccemes small, erect, shorter thau the leat; leaves entire, shiubing; flowers scattered; drupe subglobose. - Key 13iscityne (Curtiss), South Florida. $-\Lambda$ small tree, $10^{\circ}-15^{\circ}$ ligh, flowering in winter.

FRAGARIA, 'Tourn.

F. (Duchesnea) Indica, Andr. (Striwarry Ger.num.) Creeping; leaves trifoliate or 3 -lobed, the lobes rouml-obovate, crenate; peduncles 1-flowered; petals yellow; fruit inelible. - Waste places, escajed from cultivation.

\section{OHDER MYRTACEA.}

EUGENIA, Micheli.

E. longipes, Berg. Smootlı; loranchlets very slender; leaves ( $1^{\prime}$ or less long) oblong-oval or obovate, short-petioled, obtuse ; thowers large, single, or by pairs, lateral or at the base of the branchlets, on long $\left(1^{\prime}-1 \frac{1^{\prime}}{2}\right)$ bibracteolate peduncles; petals oblong, spreading, as long as the slamens and slender style; berry large. - No Name liey, South Florida (Curtiss). - $\Lambda$ shruh or small tree.

The Guara-Tree (Psinium) is cultivated at Manatee, and occurs along the west coast of Florila.

\section{Olener týthraCEAs.}

\section{A MMANNIA, Houston.}

A. latifolia, L. Stem erect, branching; leaves linear-lanceolate, sessile, dilated at the base; flowers single or elustered; style long and slender. Banks of the Mississippi. August. - Stem $\frac{10}{2}-2^{\circ}$ high.

\section{LYTHRUM, L.}

L. flagellare, Sluttlw. Perennial, creeping, smooth; the branches erect, terete; leaves opposite, nearly sessile, rigil, oblong; flowers single, shorter than the leaves, the short pedicel bibracteolate; caly $x$ club-sliaped, 6 -toothed, the teeth broad and shorter than the subulate appendages; petals 6 , spatulate, bright purple; stamens and style exserted. - Margins of ponds. Sarasota, South Florida (Garber). - Branches $6^{\prime}-12^{\prime}$ high. Leaves $4^{\prime \prime}-6^{\prime \prime}$ long.

The Tamarisk (Tamarix Gallica, L.) has been found by Mr. C. E. Smitl permanently established on James Island, near Charleston. 


\section{Order ONAGRACEAE.}

\section{CENOTHERA, L.}

C. triloba, Nutt. Perennial, nearly stemless, easpitose; leaves pinnatifil, smoothislı; calyx-tube very long $\left(3^{\prime}-5^{\prime}\right)$, filiform, the lobes longer than the somewhat 3 -lobed pale yellow petals; capsule sessile, 3-winged. Naslıville, Temessee (Dr. Gattinger).

JUSSI 仺A, L。

J. repens, C. Smooth, creeping or floating; leaves oblong, obtuse, tapering into a slender petiole; flowers large; calyx-lobes 5 , shorter than the petals; capsule eylindrical, much shorter than the long $\left(2^{\prime}\right)$ peduncle.Pouds and ditclies. New Orieans. August.

J. Peruviana, L.? Shrubby, hirsute; branches terete; leaves broally lanceolite, acute at each eul; ovary clavate, as long as the 2-bracted pedieel; caly-lobes 4 , ovate-lanceolate, acuminate, longer than the tube, shorter than the roundisl petals; capsule clavite-oblong, obscurely 4 -sided, longer than the bracts. - Mudity banks of rivers. South Florida. - Slırub $5^{\circ}-10^{\circ}$ ligh.

\section{LUDWIGIA, L.}

L. Curtissii, Chapm. in Curtiss's Fasc. III. Smooth ; stem rigidly ereet, simple, terete; upper leaves linear-lanceolate, tapering at the base; flowers single, sessile, apetalous, bibracteolate; calyx turbinate, terete, the triangular lobes as long as the tube. - Shallow ponds, East Florida (Curtiss). July and August. - Stem $1^{\circ}-1 \frac{1}{2}$ high.

\section{Order PASSIFLORACE $\mathrm{E}$.}

\section{PASSIFLORA, L.}

P. multiflora, L. Stem elimbing high; leaves relvety-pubescent, orateollong, entire, slort-petioled; flowers small, in axillary clusters: involuere none. - Niami (Gurbrr). Umbrella Key (Curtiss), Soutl Florida. - Stem woody, elimbing over the tallest trees. Leaves $2^{\prime}-3$ long.

\section{CARICA, L. Custand-Appte.}

Flowers dinecious. Corolla of the staminate flower salver-shaped, 5-lobed. Stamens 10, inserted on the throat of the corolla. Corolla of the pistillate flower 5-petalled. Lobes of the stigma lacerate. Fruit pulpy, many-seeded. - Trees, with simple stems, large long-petioled lobed leaves, and axillary flowers.

C. Papaya, L. Trunk simple, leafy at the top $\left(10^{\circ}-20^{\circ}\right.$ lighlı $)$ leaves mostly 7 -lobed, broadly sinuate; staminate Howers panicled; pistillate flowers single or 2-3 together, and larger. - South Flurida. - Flowers jellow. 


\section{OrDER CUCURBIT $\Lambda$ CEA.}

The common Gourd or Calamsu (Iagranta vulgams, Seringe.), originally from the tropies, is generally diffused over the Southern States, in waste places and around dwellings.

\section{Order CRASSULACEA.}

\section{SEDUM, I.}

S. pusillum, Michx. "Pale glancons; leaves alternate, nearly terete, oblong; fluwers tetramerous, jn a loose terminal cyme, white; stamens 8; carpels oblong, abruptly pointed by the short style." - Flat Rock, South Carolina (1/ichaux). Stone Mountain, Georgia (Gray). - Stem 1'-3' high. Leares 2" 2 "

S. Rhodiola, DC. Stem simple, erect, very leafy ( $6^{\prime}$ high) ; leaves alternate, lanceolate, serrate; flowers diceions, greenish yellow, crowled in a suall nearly sessile corymbose eyme; stamens 8 . - Jountains of North Carolina (Canly), and nortlıward.

\section{TILLÆA, L.}

Sepals, petals, stamens, and carpels :, or 4 ; the carpels mostly with a minute scale at the base, 2-many-secded. - Snall annuals, with opposite leaves, and minute axillary flowers.

T. simplex, Nutt. Stems mostly simple (2'-8' ligh), ascending, rooting near the base; leaves comate, broally linear, sprealing; flowers nearly sessile; petals and 8-10-seeler] capsule twice as long as the sepals. - Wet places, Mobile (.Mohr), and northward.

T. Drummondi, Torr. \& Gray. Stems tufted, dichotomous ( $1^{\prime}$ high) ; leaves oblong-linear, somewhat connate; flowers pedicelled; petals reddish; carpels obtuse, 12 - 20-seeded. - East Feliciana, Lonisiana (Carpenter).

\section{Oruer: SAXIFRAGACEA.}

\section{HEUCHERA, L.}

H. Rugelii, Shuttw. Glandular-hirsute, and somewhat viscirl; scape slender $\left(8^{\prime}-15^{\prime}\right.$ high), often leafy ; panicie small $\left(2^{\prime}-5^{\prime}\right.$ long $)$, the slender pedicels nodling; flowers small; petals lincar-spatulate, twice as long as the calyx-lobes; filaments exsertel ; leaves thin, obicular-corlate $\left(3^{\prime}-6^{\prime}\right.$ Lroad), shortly and broally 7 -9.jolsed, with rounded mucronate teeth, pubescent on the nerves beneath: petinles filiform. - Shaded rocks on the nountains of Alabama and North Carolina (1/ohr, Ringrl). 


\section{Order UMBELLIFER E.}

LEPTOCAULIS, Nutt.

L. echinatus, Nutt. Leaves, \&e. as in L. divaricatus, but the fruit beset witls rigid spreading hooked bristles. - Mobile (Muhr) and westward.

\section{HELOSCIADIUM, Koch.}

H. leptophyllum, DC. Stem erect or diffuse; leaves ternately or biternately divided, the divisions linear or setaceous; umbels nearly sessite, 1 -3-1ayed; involucre and involucel none; fruit ovate. - East Florida, and westward. Introduced. - Stem $\frac{1}{2}^{\circ}-2^{\circ}$ ligh. Fruit very small.

\section{CYNOSCIADIUM, DC.}

Calyx-teeth subulate. Fruit ovate, terete. Carpels with 5 obtuse ribs, the two lateral ribs united with the thick corky margin. Intervals with single vittæ. - Smooth annuals, with finely divided leaves, and rery small white flowers. Leaves of the involucre few or none.

C. pinnatum, DC. Leaves pinnately divided into few long linear segments; petals roundish, obtuse; fruit ovate-oblong, the ribs not prominent. Alabama (Prof. E. A. Smith), and westward. August. - Stem $6{ }^{\prime}-12^{\prime}$ ligh. Low est leaves of ten entire.

\section{POLYTANIA, DC.}

Calyx 5-toothed. Fruit oval, compressed, the margins thickened; carpels obscurely ribbed, with two vittre in the intervas, and six on the commissure - A smooth biemnial? herb, with pinnately divided leaves, and yellow flowers.

P. Nuttallii, DC. - St. Tammany Parish, Louisiana (Molr), Tennessee (Di. Guttinger). April. -Stem $1^{\circ}-2^{\circ}$ high. Upper leaves opposite.

\section{TREPOCARPUS, Nutt.}

Calyx-teetlı subulate, deciduons. Fruit linear-oblong, acute, nearly terete, 8-angled; carpels 4-ribbed, each rib corering a single vitta. Commissure spongy, grooved in the middle, with two minute vitta next the seed - A smootlı annual, with 3 -pinnately finely dissected leaves, and 3-5-rayed longpeduncled umbels.

T. Æthusa, Nutt. - Low banks near Mobile (11ohr). - Stem $2 \circ$ ligh. Peduncles longer than the leaves. Flowers white.

\section{ERIGENIA, Nutt.}

Calyx-teeth obsolete. Petals obovate. Fruit didymous, the carpels kidney-shaped, incurved at eael end, with 5 slender ribs; intervals with several vittæ. $-\Lambda$ low $\left(i^{\prime}-10^{\prime}\right.$ high $)$ smooth herb from a deep round tuber; the 
simple stem bearing $2-3$-ternately fincly dissected leaves, and a small leafybracted compound umbel of white flowers.

E. bulbosa, Nutt. - Liatse of Lookout Mountain, Temessee, and northward. April.

\section{Orner CAPRIFOLIACEA.}

\section{VIBURNUM，L.}

V. densiflorum. Stem slenter, branching; leaves small, downy beneatli, varyiug from oblong to brually ovate, entire, irregularly serrate or slightly $2-3$-luberl, acute at each (1ud, or rounded at the base; cymes downy, small, compact, the batse and ramifications involucrate with a whorl of linear bracts. (V. involucratum, Chapm., not of Wall.) - Wooded hillsides, West Florida. April. - Stems $2^{\circ}-4^{\circ}$ high. Leaves $1^{\prime}-2^{\prime}$ long.

V. nudum, I., val. angustifolium, Torr. \& Gray. Smoolher; leaves thinner and narrower, obscurely serrulate or entire. - Margius of swamps, Florida to Nortlı Carolina

Var. serotinum, Ravenel. Sinooth, or nearly so, punctate; leaves oblong-ovate, attenuate alove the millle, cremate-serrate, abruptly shortpetioled; eyme long-perluncled, mostly leafy and corymbose, the divisions very slender, flowers very small, the filaments slightly exserted. - Low pine barreus near Daricu, Georgia. Uctober and November.

\section{Order RUBIACEA.}

\section{GALIUM, I.}

G. Aparine, L. (Chesvers.) Amual ; stems weak, retrorsely hispid; leaves $6-8$ in a whorl, lanceolate, hispid on the margins and midrib; peduncles long, 1-2-flowered; fruit bristly. - Waste places, sparingly introduced.

G. pilosum, var. puncticulosum, Gray. (G. puncticulosum, Michx.) Stem, leaves, Se. smooth or nearly so; fruit often much larger. - Dry, ricla soil, Florida, and northwarl.

G. virgatum, Nutt. Low $\left(6^{\prime}-10^{\prime}\right.$ bigh $)$, simple or branching at the base, smooth or hispid; leaves 4 in a whorl, short $\left(4^{\prime \prime}\right.$ or $\left.5^{\prime \prime}\right)$, oblong-lanceolate, lispirl-ciliate; perluncles axillary, short, bracteolate, 1-fluwered; fruit hispid. - Barreus of Temessee (Dr. Gattinger), and westward.

RICHARDSONIA, liunth. Fatse IPECac.

Calyx 4-7-parted, the lobes deciluous. Corolla funnel-shaped, 3-6-Jobed. Stamens 3-6, exserterl. Style 3-or 4-cleft. Capsule separating into 2-4 one-seeded indehiscent nutlets. - Ilairy branching herbs. Leaves united by bristly stipnles. Flowers white, in terminal sessile clusters.

R. scabra, St. Hilaire. Anmul, hirsute, forking; leaves ovate, acute, the two upper pairs involucre-like; calyx-lobes subulate; nutlets $2-3$, oblong. - Alabama, Georgia, and Florida. Introduced. 
OLDENLANDIA, Plum.

O. patens. Radical leaves acute; flowers erect in the bud, seldom (if ever) dimorphous; calyx-lobes acute; corolla $3^{\prime \prime}$ broad, deep blue, its tube three times as long as the cullyx; otherwise like $O$. corulca, Gray. (Houstonia, Eil.) - lioadsides, \&c., Florida to South Carolina.

\section{CATESB正A，L。}

Calyx 4-toothed or 4-parted Corolla funnel-shaped, 4-lobed. Stamens 4, inserted on the base of the corolla. Stigma 2-lobed. Berry 2-celled, many seeded, the placenta at the top of the partition. Seeds Hat, imbricated. Spiny shrubs, with small thick opposite leaves, and axillary whitish flowers.

C. parviflora, Swartz. Glabrous; leaves oval or obovate, mostly shorter than the spines, the margins revolute; flowers sessile ; corolla small ( $t^{\prime \prime}$ long), the tube 4-angled; berry globose. - Bahia Honda, South Florida (Curtiss). - Shrub $4^{\circ}-8^{\circ}$ lighl.

\section{Order VALERIANACE}

FEDIA, Moncl.

F. olitoria, Vahl. Flowers pale blue; fruit compressed, oblique, with a corky mass at the back of the fertile cell, the empty cells large and sometimes confluent; stem and leaves as in F. radiata. - New Orleans. Introduced.

F. patellaria, Sulliv. Flowers white; fruit circular, notched at both ends, the empty cells concave, broader than the fertile one, and forming a wing around it. - Nashville (Dr. Gattinger).

\section{Order composita.}

VERNONIA, Schreb.

V. angustifolia, var. pumila, Chapm. Low $\left(6^{\prime}-12^{\prime}\right)$, smoothish ; leaves short; heads $3-7$, loosely corymbose; involncre smooth ; pappus yellowish; achenium smooth. - Wet pine woods, South Florida. November.

\section{ELEPHANTOPUS, I.}

E. nudatus, Gray? Sparsely lirsute, and dotted with minute resinous atoms : stem $\left(6^{\prime}-18^{\prime}\right.$ high) with 3 or 4 slort obovate leaves at the base, and a smaller one below the branches of the eyme; floral leaves broad-ovate, barely acute, rather shorter than the heads; scales of the involucre smooth, cuspidate; scales of the pappus abruptly dilated at the base. - Damp ground near the coast, Florida. 


\section{PECTIS, J.}

P. ciliaris, L. Stem erect, smooth; leaves lincar, bristly-fringel below the millle; heals nearly sessile; rays 3 ; patppus of the disk-ftowers of 5 lanceolate acuminate seales, of the rays only :3. - Keys of Caximbas Bay, South Florida. - Stem $6^{\prime}-12^{\prime}$ high.

\section{LIATRIS, Schreb.}

L. Garberi, Gray. Hirsute, the rigid leaves at length smooth; heads closely spiked, 6-7-flowered; scales of the bell-shined involucre orate or oblong, cuspidate, glandular-hirste; pappus barbellate. - 'lampa, Florida (Gurber).

L. tenuifolia, var. quadriflora. Leaves involute filiform, rigid, those of the stem setaceous; heads 4 flowered; seales of the involucre 8 , half as long as the disk, of ten cuspidate - Banks of the Caloosa River, south Florida.

\section{EUPATORIUM, 'Tourn.}

E. conyzoides, Vahl. Shrubhy, stem much branched $\left(4^{\circ}-6^{\circ}\right.$ high $)$, leaves opposite, ovate or ovate-lanceolate, acuminate, "y-nerved, serrate or nearly cutire; corymb trichotomous; heads 10 - 2)-flowered, receptacle flat; seales of the involucre rounded at the tip, striate; achenium scabrous on the angles. - Coast of South Florila (Curtiss).

E. heteroclinium, Griseb.? Pubescent; stem branclung above (20 highi); leaves opposite, ovate, crenate-serrate, short-petioled ; pedicels $1-8$ in the forks of the branches, longer than the cylindrical many-flowered heals; scales of the involucre smooth, oblong, obtuse, strinte, deciluons; receptacle globular, maked; flowers pale blue ; achenimu smooth. - Leys or South Florida.

E. aromaticum, var. gracile. Smoothish; stem long and slender; leaves thin, acuminate, coarsely serrate; corymbs loose; achenium slightly pubescent. - Dry sandy pine wools, Clear Water IIarbor, South Florida.

\section{CONOCLINIUM, IC.}

C. dichotomum, Chapm. Stem dichotomously branched $\left(1^{\circ}-2^{\circ}\right.$ high) ; leaves deltoill, barely acute, crenate-serrate, twice as long as the short petiole; corymbs numerous, mostly in the forks of the branches, shortpeduncled: heads few $(3-10)$, short-pedicelled; flowers blue. - South Florida.

\section{ASTER, 'l'ourn.}

A. ptarmacoides, 'Torr. \& Gray. Smootl or scabrous ; stems $\left(6^{\prime}-15^{\prime}\right.$ high) simple; leaves linear-lancenlate, 1 - 3 -nerved; heads small, in a flat corymb; seales of the involucre imbricated in 3 or 4 rows, short; rays white. - Northern States. 
Var. Georgianus, Gray. Tailer $\left(11^{\circ}-2^{\circ}\right.$ ligh $)$, and more slender, corymbosely branclied above; lower leaves lanceolate, sparingly serrate; corymb larger and more loosely flowered; ray-flowers sterile, the style short or abortive. - Muuntains of Georgia. September.

\section{ERIGERON, L.}

E. divaricatum, Michx. Annual, deeumbent, hirsute; leaves narrowlinear; heads loosely corymbose; rays purple, not longer than the simple pappus; achenium nearly smooth. - Mississippi, Tennessee, and northward.

E. annuum, l'ers. Annual, hirsute, erect ( $2 \circ-4^{\circ}$ high) ; lowest leaves oblong, petioled, toothed, the others lanceolate, sessile, mostly entire; lieachs corymbose; rays numerous, white, not twice the length of the sparsely hirsute involucre; inner pappus of the ray-flowers scanty or none. - Waste places, Florida, and northward. May and June.

\section{BELLIS, Tourn. DatsT.}

Heads many-flowered. Rays pistillate, in a single row. Seales of the involucre mostly in two rows, rather thin, equal. lieceptacle contical, naked. Achenia obovate, compressed, wingless. 1'appus none. - Low herbs, with alternate leaves, and solitary terminai heads of white or purple flowers.

B. integrifolia, Michx. Amual, branching, smoo(h $\left(0^{\prime}-12^{\prime} h_{1} \operatorname{igh}_{2}\right)$; leaves obovate, entire, the upper ones lanceolate, sessile, healls peduncled; rays pale purple; achenia rough. - Tennessee (Lr. Guttinger), March.

\section{GRINDELIA, Wiild.}

Heads many-flowered. Rays pistillate. Scales of the hemispherical involuere imbricated in several rows. lieceptacle flat. Achenia oval or obovate, glabrous. Pappus of 2-8 rigid decidnons awns or bristles. - Perennial herbs, witl alternate leares, and single heads of yellow flowers terminating the brauches.

G. Ianceolata, Nutt. Glabrous, corymbosely branching $\left(1^{\circ}-2^{\circ}\right.$ high $)$ : leaves lanceolate, sessile, sharply serrate; involucre glutinous, the scales nearly equal, ending in a filiform point; bristles of the pappus mostly 2. Celar barrens, Tennessee (Lr. Galtinger), and westward.

Arlopaypes rebigixosus, Torr. \&. (xay, a branching herl $2^{\circ}-3^{\circ}$ high, the leaves with sharp sprealing hristle-pointed teeth, the single heals of yellow flowers terminating the leafy branches, ind the villous top-sliaped achenium crowned witl a copious scabrous pappus, is spontaneous at Punta Rassa, South Florida, doubtless introduced from Texas.

\section{SOLIDAGO, I.}

S. Missouriensis, Nutt., var. pumila. Low ( $1^{\circ}$ high $)$, simple, glabıons; lower leaves lanceolate, rather obtuse, tapering into a petiole, entire, or ob- 
scurcly denticulate near the apex, the others much smaller, the upper oues (f' or less long) passing into the oblong-lunear obtuse bracts of the widely spreading flat panicle; involuere ovoil, bi-2t) flowered, the oblong scales obtuse; rays few, notclietl pappus coatse, bltorter than the flowers; ovary smooth. - liocky barrens of Tennessee (Dr. Ciattinger).

S. rupestris, Rat: Smootl throughout; stem slemder $(2 \circ-80$ high); leaves linear-lanceolute, entire, or the lowest ones slightly serrulate; panicle narrow, often simple; heads small with very slort rays ; aclicuia pubescent. - liocky banks, Tennessee.

\section{LINDHEIMERIA, Giay \& Engelm.}

Ray-flowers 4-5. Scales of the involucre in two rows, the onter ones linear, the imner ones oblong, allherent to tl:e hase of the fertile achenia, and to the aljacent scales of the receptacle. Achenim oval, fhat, the uarrow wings frolonged into a 2 -toothed pappus. Otherwise like lierlandiera.

L. Texana, Gray \& lingelnı. - Alabama (Mohr), and westward. - Annual, hirsute, erect, $10-20$ high. Leaves oblong, dentate. Heads in a dicliotomous panicle, nodling. Flowers yelluw.

\section{IVA, L:}

I. ciīiata, Willd. Anmual, hispid; stem branching; leaves ovate, acuminate, cuar:ely serrate; spikes dense, the bracts elongated; scales of the involure $3-4$, roundislt, ciliate; fertile flowers mostly 3.-Nlississippi (Carpenter), and westward. September. - Stem $20-3^{\circ}$ high. Leaves $3^{\prime}-4^{\prime}$ long.

\section{AMBROSIA, 'Tourn.}

* * Heads of sterile flowers denseiy apiked, the top-shaped involucre prodiced on one side into a lony recurced appendige. Fiertile hearls axillary, 4-angled.

A. bidentata, Michx. Anmual, hirsute. very leafy; leaves mostly alternate, lanceolate, sessile or clasping, entire or with 2 short basal lobes; fruit acute, with 4 short spines. - Northern Mississippi, and westward. - Stem $10-2 \circ$ high.

\section{ACANTHOSPERMUM, Schrank.}

Heats monocioms, ratiate, many-flowered; the rays pistillate, in a single row; disk-flowers staminate, tubular, 5-toothed. Involnere of 5 elliptical scales. Receptacle flat. Achenia compressed, armed on the back with rigid hooked prickles, anl enclosed in the outer scales of the chaffy receptacle. 1)iffusely branching lierbs, with upposite leaves, and solitary lieads of yellow flowers.

A. xanthioides, DC. I'rostrate, pubescent ; leaves petioled, oval or obovate, toothed or entire; elatf of the receptacle which encloses the achenium unarmed. - Introduced from South Amcrica several years ago, and now widely disseminated. 


\section{WEDELIA, Jacq.}

Heads many-flowered, radiate. Flowers of the ray pistillate, of the disk perfect, tubular, 5-toothed. Scales of the involucre in $2-3$ rows, the outer ones leafy, the inmer ones membranaceous. Receptacle convex, chaffy. Achenia obovate or compressed. Pappus calyx-like, composed of united dentate and ciliate scales. - Herbs or undershrubs, with opposite serrate leaves, and mostly solitary yellow Howers.

W. carnosa, Rich. Herbaceous, smooth, creeping; leaves sessile, thick, obovate, slightly 3-lobed; heads axillary, peduncled; outer scales of the involucre oblong, as long as the disk, the inner ones smaller; achenia wingless. - Springy places, Key Biseayne (Curtiss).

\section{DRACOPIS, Cass.}

Scales of the involuere very small, the inner row linear, mucronate. Achenia terete, finely striate and glandular. Pappus none. Otherwise like Rudbeckia.

D. amplexicaulis, Cass. - New Orleans (Dr. Hale), and westward. Annual, smooth, branching, $1^{\circ}-3^{\circ}$ higls; leaves oblong, mostly serrate, clisping; heads terminating the peduncle-like branches; rays yellow; disk brown.

\section{RUDBECKIA, L.}

R. rupestris, Chickering. Stem and leaves sparingly hairy ; lower stemleaves 3 -parted, with deep rounded sinuses, the lateral loles sprearling; heads large ( $\frac{g^{\prime}}{4}$ witle), globular; rays $10-13$, orange-yellow; otherwise like $R$. triloba. - Rocky slopes of Little Roan Mountain, North Carolina (Prof. J. $W$. Chickering).

R. bupleuroides, Shuttlw. Smootls thronghont; stem sometimes flexuous below ; leaves broadly linear, 3-nerved, entire, the lowest ones tapering into a more or less elongated petiole, the upper ones distant, short, linearsubulate; heads long-pedunclerl, glolose ; rays yellow, longer than the darkbrown disk ; aelıenia slightly curved ; pappus eup-shaped. (R. Molırii, Gray.) - Wet pine barrens, St. Mark's and Iola, Florida (Rurjel, IJohr). - Stem $2^{\circ}$ $3^{\circ}$ ligh. Lower leaves $6^{\prime}-12^{\prime}$ long.

\section{HELIANTHUS, I.}

H. Floridanus, Gray. Stem tall ( $4^{\circ}-6^{\circ}$ high $)$, smooth ; leaves lanceolate or ovate-lanceolate, acute at both ends, sparingly denticulate, short-petioled ( $2^{\prime}-4^{\prime}$ long) ; involucre smootl, the leaves lanceolate, acuminate; disk dark purple ; rays long, oblong. - East Florilla (Palmer, Garber).

H. cinereus, Torr. \& Gray. Rouglı with rigid white hairs; stem sinple; leaves ovate-lanceolate, slightly serrate, nearly sessile, paler beneath, the upper ones small and distant; heads $1-3$ at the summit of the stem, shortpeduncled; scales of the involucre ovate-lanceolate, canescent. - Mountains of Georgia, and westward. September. - Stem $2^{\circ}-3^{\circ}$ high. Leaves $3^{\prime}-$ 5 ' long. 


\section{ACTINOMERIS, Nutt.}

A. heterophylla, ('hapm. Stem mustly simple, liirsute, terete above, winged below ; leaves rough, the lower ones oppesite, deenrrent, obleng, tho upper ones small, linear, remote; leads simgle or loosely corymbose; scales

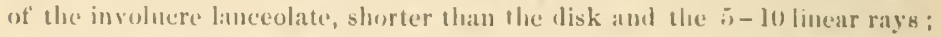
clunf of the receptacle rigit, acute, longer than the obovate narrowly winged 1-2-awnel achenia. - low pine barrens, bast Florida. - Stem $20-80$ high. Lower leares ' $2^{\prime}-3$ ' long.

\section{COREOPSIS, I.}

C. auriculata, I. Stem shore $\left(f^{\prime}-\delta^{\prime}\right.$ lighl $)$, smootl or sparsely villons, 1 -2-forking; lower leaves osate or roundish (1 $y_{2}^{\prime}-2^{\prime}$ long $)$, entire, or with $2-4$ small lateral lobes, $\frac{1}{8}-\frac{1}{2}$ the length of the slemler petiole, the others small and remote; heals few; elaff of the receptacle setacens, twice as long as the flowers ; achenia oblong, incurver, wingless, even, or olscurely papillose. (C. auriculitti, var. diversifolia, Ell.) - Wouds in the ujper districts. April and May.

C. pubescens, lill. Stem tall ( $2^{\circ}$ high), densely villous, at length much branched; lower leaves lanceolite or oblong (3'- $t^{\prime}$ long), montly 3-lobed, as long as the stont petiole, the uppermost ones only entire ; heals very ummerous; chaff of the reeptacle as long as the flowers; achenia broally winged, cireular, slightly 2 tootlecl, plainly papillose on both sisles. (C. anriculata, var., Torr $\&$ Gruy.) - Mountains of Georgia and Carolina. Nhay to September.

\section{VERBESINA, I.}

V. encelioides, Benth. Amnual, cauescent; stem crect; leaves ovate or oblong, conrsely scrrate, the broadly winged petioles auriculate at the base; hearls somewhat eorymbose; achenia of the disk winged, 2-awned, of the rays wingless, ?-toothed. (Ximenesia encelioides, Car.) - Niddle and South Florida. Introduced from Mexico, - Stem $2^{\circ}-3^{\circ}$ high. Flowers yellow.

\section{FLAVERIA, Juss.}

F. angustifolia, Pers. Stem woody and much branched at the base, erect ; leases thick, narrowly lanceolate, acute, remotely serrulate, comnte; corymbs very numerous, compact; heads 10-15-tlowerel, angular, discoid, or with a single oblong entire ray. - Sandy beach at Clear Water Ilarbor, South Florida. October. - Stems $2^{\circ}-4$ high.

\section{PALAFOXIA, Lag.}

P. Feayi, Gray. Stem woody, slender, widely bratıched, rough with short rigid hairs; leave orate or lanceolate, opposite or alternate, shortpetioled; corymbs loose; heads discoid; achenium sparsely hispid, many times longer than the ohtuse denticulate scales of the pappus. - South Florida $(F \mathrm{Fay})$. - Stem $3^{\circ}-5^{\circ}$ high. 


\section{ARTEMISIA, L.}

A. vulgaris, L. (MUGworr.) Stem branching; leaves white-downy beneath, pinnatificl, with the lobes lanceolate; leads lowny, in slender terminal spicate panicles; flowers all perfect. - Waste grounds, North Carolina. Introduced.

A. biennis, Willd. Biennial, smooth ; stem simple $\left(1^{\circ}-3^{\circ}\right.$ high $)$; leaves 1-2-pinnatifid, the linear lobes sharply toothed ; heads crowded in terminal and axillary spikes, which form a long narrow leafy panicle; flowers all perfect. - West Tennessee.

\section{FILAGO, L. Cudwed.}

Heads discoid, many-flowered; the central flowers perfect, but of ten abortive, the outer ones very slender and pistillate. Involucre of few woolly scales. Lower part of the long or top-shaped receptacle chaffy, the upper part naked. Pappus of the perfect flowers capillary, of the pistillate flowers none. - Low woolly annuals.

F. Germanica, L. Stem forking; leaves lanceolate, entire; scales of the involucre and chaff cuspidate. - Waste ground. Introduced.

\section{CNICUS, Vahl.}

IIeads many-flowered, the central fluwers sterile. Scales of the involucre produced into a long pinnate spine. Receptacle bristly. Achenium terete. Pappus in 3 rows; the onter row consisting of 10 lorny teeth; the middle row of 10 longer bristles alternating with the inner row of 10 bristles. $-\mathrm{A}$ prostrate villous annual herb, with pinnatifid-toothed clasping leaves, and large bracted heads of yellow flowers.

C. Benedictus, L. - Coast of Sonth Carolina (Elliott). Montgomery, Alalsama $\left(1 / h^{\circ}\right)$. New Orleans (Riddtll). Introduced.

\section{NABALUS, Cass.}

N. asper, Torr. \& Gray. Rougl-pubescent ; stem simple; leaves ovaloblong, sharply-toothed; heads erect, clustered, forming a compound villous terminal raceme; involucre of 8 or 9 hirsute scales, 12-14-flowered ; pappus straw-color. - Barrens of Tennessee, and northward. - Stem $2 \circ-4^{\circ}$ high. Leaves small. Flowers cream-color.

N. Roanensis, Chickering. Hirsute; stem low ( $\Re^{\prime}-12^{\prime}$ high) simple; leaves hastate, acuminate, coarsely toothed, the lower ones petioled; raceme compound; involucre 10-13 flowered; pappus straw-color. Summit of Roan Mountain (Chickering).

\section{ORDER LOBELTACE $\not E$.}

\section{LOBELIA, I.}

L. Canbyi, Gray. Stem simple, or branching above $\left(10-2^{\circ}\right.$ high); leaves numerous, linear, glandular-denticulate; racemes long, loosely flow- 
ered : bracts longer than the pedicels; calyx-tube top-sliaped, lialf the length of the denticulate lobes, in fruit oblong, covering the capsile; corolln deep blue, more or less beardeal in the throat. - Wet places, South Carolina (Ciriy). August.

L. Cliffortiana, L. Amumal; stem branching $\left(1^{\circ}-1 \frac{1}{2} \circ\right.$ ligh $)$; leaves ovate, petioled, tentate, the upper onc's narrower and sessile; racemes louscly many-flowered, the pedicels longer than the bracts and flowers; calyx-tube obconical, enclosing the lower half of the ovoid eapsule, the lobes subulate. - siouthern States (cimy). Introuluced.

Vir. Xalapensis, Gray. Stem weaker; leaves thinner; tube of the calyx enclosing mly the base of the capsule; seeds smooth. (L. Xalapensis, II.B.K.) - Manalice, South Florida (Gurber). East Florida (M/iss Lifynolds).

L. Feayana, Gray. Amuual, smootlı $\left(t^{\prime}-8^{\prime}\right.$ lighl); stem simple or brancherl; leares few, the lowest orthicular, crenate, petioled, the others narrower, nearly sessile; racemes lonsely $t-10$-flowered; calyx-tube ol)conical, in fruit enclosing the lower half of the capsule, the lobes subulate; seeds rough. - 1)imp places. East Florida.

L. Gattingeri, Gray. Smooth; stem weak, branching; leaves thin, sessile, oblong-ovite, obtuse, serrate, the fowest obovate; racemes peduncled, very slemler, many-flowered; calyx-tube ovoil, longer than its pedicel, shorter than the linear-subulate entire lobes, thic sinuses not appendaged; corolla $\left(t^{\prime \prime}-\sigma^{\prime \prime}\right.$ long) deep blue. - Barrens of Temessee (D). Gultinger). April. Stem $10^{\prime}-20^{\prime}$ ligh. Leares $2^{\prime}$ or less long.

L. Floridana, Chapm. Stem stout (, $0^{\circ}-50$ highli); lowest leaves thick, lanceolate or strap-shaped, sessile by a broal base, denticulate $\left(6^{\prime}-9^{\prime}\right.$ long); the others small ( $1^{\prime}$ long) and distant; raceme rigidly erect, closely flowered, the stout appressed pedicels as long as the linear lenticulate bracts; calyxtube obconical, in fiuit enclosing the lower half of the oroid capsule, the ovate-lanceolate fobes mostly denticulate, the acute sinuses rarely appendiaged; corolla (8" $-9^{\prime \prime}$ long) blue, the tube longer than the lohes, almost villons within, the upper lobes reflexed. - Wet pine-barrens. Florida. JuneSeptember.

\section{Order: CAMPANULACEA.}

CAMPANULA, L.

C. Floridana, Watson. Smooth; stem filiform, angular, simple or brinchell nbove $\left(6^{\prime}-12^{\prime}\right.$ long $)$; leaves lanceolate, entire $\left(\delta^{\prime}-12^{\prime}\right.$ long $)$, the upper nues linear; peduncles terminal; calyx-lobes subulate, bidentate, spreading, longer than the 5-parted blue corolla; stigmas recurved. - Tampa, Florith (Feay).

\section{SPECULARIA, Heister.}

S. biflora, Gray. Stem rough, simple or branching at the base; leaves ovate or oblong, sessile, crenate, the upper ones bract-like; fowers single or by pairs, mostly apetalous. - Waste places and fields, Florida to South Carolina. 


\section{Order ERICACEA.}

VACCINIUM, L.

V. formosum, Andr. Stem smooth; leaves thickish (partly perennial), ovate or oblong, entire, smooth, or pubescent beneath; racenes axillary; corolla cylindrical, red. - Florida (Herb. Durand). - Stem $2^{\circ}-3^{\circ}$ high. Leaves $1^{\prime}-2^{\prime}$ long.

V. virgatum, Ait. Stem smooth, the branches and young leaves duwny; leaves thickish, ovate or ovate-lanceolate, acute, entire; racemes mostly on naked branches; corolla cylindrical, white, or red like the bracts; berry black. - Low pine barrens, Florida to South Carolina. March. - Stem $2^{\circ}-4^{\circ}$ ligh. Leaves $1^{\prime}$ or less long.

V. vacillans, Solander. Stem smooth, with yellowish shining branches; leaves ovate or ohovate, nearly entire, pale and glancous ; corolla oblongbell-shaped, white, berry blue.-Mountains of Georgia and North Carolina, and northward. April. - Stem $1^{\circ}-2^{\circ}$ high. Leaves $1^{\prime}-2^{\prime}$ long.

\section{CHIOGENES, Salisb. Creeping Sxowberry.}

Calyx 4-parted. Corolla bell-shaped, 4-cleft. Stamens 8: anther-cells unawned, opening from the tip to the middle. Berry white, globular, 4-celler, many-seeded. - A small crecping evergreen. Leaves ovate, acute, the margins revolute, the lower surface, like the margins, bristly. Flowers small, axillary, white, nodding.

G. hispidula, Torr. \& Gray, - Damp woods, Mountaius of North Carolina, and northward.

\section{RHODODENDRON, L.}

R. Vaseyi, Gray. Low and bushy; branches smooth : leaves thin, ovateoblong, acuminate, acute at base; pedicels glandular, at length recurverl; caly $\mathrm{x}$ short, truncate; corolla smooth, rose-color, rotate-campanulate, nearly equally 5-parted, the lobes obnvate; stamens and style slightly exserted; capsule oblong, smootl. (Gruy.) - Balsa Mountain, North Carolina ( $R$. Vusey).

\section{Order AQUIfOLIACEAE.}

\section{ILEX, L。}

I. mollis, Gray. Leaves thin. oval or oblong, acuminate, sharply serrulate, downy; sterile flowers very numerous, in nmbel-like clusters, the pedicels shorter than the petiole, soft-lowny, like the calyx; fertile peduncles very short. - Mountains of North Carolina and Tennessee.

I. monticola, Gray. Leaves thin, ovate or lance-oblong, acuminate, smooth, sliarply serrate; fertile flowers very short-peduncled; calyx ciliate. (I. ambigua, Torr.) - Mountains of Nortl Carolina (Gray). - Leaves $3^{\prime}-5^{\prime}$ long. 


\section{Orine: SAPOTACEA.}

\section{CHRYSOPHYLLUM, I.}

Calyx 5-parted. Corolla 5parted, without appendages. Stamens 5. Oviary 5-10-celled, the ovules ascending. Berry inosily 1-celled, 1-secterl. Albumen scanty. - Tropical trees. Leaves thick, silky beneatl. Flowe:s small, in axillary clusters.

C. oliviforme, Lam. Branclılets, \&r. witl copper-colored pulescence; leaves oblong-ovate, acute, entire; pedicels shorter than the petiole; corolla white; "herry black, 1-seeded." - South Floridi. - I small tree. Leaves $2 t^{\prime}-t^{\prime}$ long.

\section{Order PLAN'TAgINaCEA.}

\section{PLANTAGO, I.}

P. Patagonica, Jac'q. Annual, villous, or sometimes smoothish; leaves lanceolate or linear, shorter than the scape; spike oblong or capitate; bracts slorter than the flower; lobes of the corolla rounted; eapsule 2 seeded. Nashrille, Tenmessee ( $D_{r}$. Cialtinger), and westwarl.

Var. aristata, Gray. Leaves linear-lanceolate; sjike linear, the filiform bracts $3-6$ times the length of the flower. - Alabima, Temessee, and westwarl. - Stem $I^{\circ}$ or less liigh.

P. pusilla, Nutt. Small ( $I^{\prime}-2^{\prime}$ ligh $)$, slightly pubescent; leaves narrowlinear, entire; capsule ovoid, rather longer than the calyx, 4 -seeded. - Tennessce and northward.

\section{Order PLUMbaginace}

\section{STATICE, L.}

S. Brasiliensis, Boissier. Leaves ollong, rounded or emarginate at the apex, thin; scape and spreading panicle slender $\left(1^{\circ}-2^{\circ}\right.$ high $)$; spikelets 1 3 -flowerel, more or less distant; braci!ets very unequal: calyx smooth, the ovate lobes acute; corolla white. - Const of Florida to Nortl Carolina.

\section{Order PRIMULACEA. CENTUNCULUS, I.}

C. pentandrus, R. Br. Stems erect, simple $\left(t^{\prime}-8^{\prime}\right.$ high $)$; leaves oval or roundish, mucronate; perluncles $2-3$ times the length of the pentandrous flower; lobes of the calyx and corolla 4 or 5. - Low ground along the Caloosa River, South Florida. October. 


\title{
Order LENTIBULACEA.
}

\author{
UTRICULARIA, L.
}

U. longeciliata, A.DC. Scape 3-7-fiowered ( $\sigma^{\prime}$ high), the pedicels shorter than the calyx; upper lip of the small (5" long) yellow corolla obovate, the lower one nearly entire, with reflexed margin, as long as the hornshaped spur; leaves numerous, linear; scales and bracts long-eiliate-dentate. - Miami, South Florida (Garber).

\section{PINGUICULA, Tourn.}

P. Floridensis, n. sp. Leaves short ( $\frac{1^{\prime}}{2}$ long), obovate-oblong; scape filiform ; ealyx-lobes oblong-linear, acutish, dowry ; eorolla $\left(4^{\prime \prime}-5^{\prime \prime}\right.$ long $)$ violet-purple, deeply 5-cleft; the broad lobes notched or entire, the tube short; spur depending, subulate, acute, as long as the tube of the corolla. Low ground along the Homosassee River, Florida (Mr. Benj. Miller).Scape $4^{\prime}-6^{\prime}$ ligh.

\section{Orner SCROPHULARIACEA.}

\section{HERPESTIS, Gært.}

H. repens, Chan). \& Sclilect. Smooth, or the summit of the creeping stems pubescent; leaves oval, clasping; perlicels about as long as the flower; outer sepals oval or slightly cordate, reticulate-veiny, nearly as long as the white corolla. (H. micrantha, Ell.) - Banks of the Ogeechee River, Georgia (Ellioll).

H. rotundifolia, Pursh. Stem smoothish, creeping; leaves roundobovate, clasping $\left(\frac{\frac{1}{2}^{\prime}}{2}-\mathrm{I}^{\prime} \mathrm{long}\right)$; peduncle longer than the flower; exterior sepal ovate. - Nashville, Tennessee (Dr. (ialtinger).

\section{HYDRANTHELIUM, II.B.K.}

Calyx 4-parted. Corolla short-funnel-shaped, 3-cleft. Stamens 3, inserted on the throat of the eorolla. Style 2-lobed. Capsule many-seeded. Aquatic herbs, with the habit of Callitriche. Leaves opposite. Peduncles axillary, 1-flowered.

H. Egense, Poepp. Floating; stem filiform, branching; lower leaves small ( $2^{\prime \prime}$ or $3^{\prime \prime}$ long), distant, oblong, the upper ones crowded, obovate; caly $\mathrm{x}$-lobes ovate-lanceolate. - New Orleans (Dr. Male). Introduced?

\section{MICRANTHEMUM, Michx}

M. Nuttallii, Gray. Stem erect or ereeping $\left(1^{\prime}-2^{\prime}\right.$ long); leaves obovate; pedicels equalling or longer than the flowers, upper lip of the corolla obsolete. - Wet banks, Florida, and northward. 
CONOBEA, Aublet.

Calyx 5-parted. Corolla obscurely 2-lipped, the upper lip 2-lobed, the lower one 3-parted. Stamens 4, all fertile; anthers approximate in pairs, the (ells parallel. Sityle 2-lobed. Capsule ovoid or globular, many-seeded.Low herbs, with opposite leaves, and small axillary flowers.

C. multifida, Benth. Annual, muclı branched, pubescent $\left(3^{\prime}-8^{\prime}\right.$ higl 1$)$; leaves pinnately divided into linear toothed lobes; corolla pale purple, harcly longer than the calyx; capsule ovoid. (Capraria, Michx.) - Valley of the Coosa liver, Georgia, and westward. July.

\section{DASYSTOMA, Raf.}

D. Drummondii, Benth. Closely pubescent; stem branching; lower leaves ovate-lanceolate, pinnatifid, the upper ones dentate or serrate; calyx mostly longer than the pedicel, the broally lanceolate lobes as long as the top-shaped tube. (Gerardia grandiflora, Benth.) - Nountains of Georgia, Tennessee, and westward. - Stem $20-30$ high. Corolla $1 \frac{1}{2}$ ' long.

D. lævigata, Raf. Smooth, or nearly so, slender, sparingly branched; lowest leaves mostly pinnately lobed and toothed, the others lanceolate, entire; caly x longer than the pedicel, the lobes shorter than the tube; corolla funnel-shaped ( $1^{\prime}$ long). - Mountains of Georgia, and nortliward.

D. patula, Chapm. Stem tall $\left(3^{\circ}-4^{\circ}\right)$ and slender, widely branched; lower leares pinnately lobed and toothed, the upper ones oblong, entire; pedicels long $\left(1^{\prime}-1 \frac{1}{2}\right)$, spreading or recurved; caly $x$-lobes rather longer than the tube, entire; corolla ( $\left.1 \frac{1^{\prime}}{2} \mathrm{long}\right)$ tubular-funnel-shaped. - Mountains of Georgia and Tennessee. August.

\section{SEYMERIA, Pursh.}

S. macrophylla, Nutt. Tall and stout $\left(4^{\circ}-5^{\circ}\right.$ high $)$, more or less pubescent, branching; leaves large $\left(6^{\prime}-8^{\prime}\right.$ long $)$, deeply pinnatifid, the ovate or lanceolate lobes toothed or pinnatifid, the floral ones entire; racemes short, dense; tube of the corolla longer than the lobes of the calyx, woolly within. - Mountains of Georgia? Tennessee, and northward.

\section{Order VERBENACEA.}

\section{VERBENA, L.}

V. stricta, Vent. Softly pubescent; stem mostly simple; leaves sessile, oblong, serrate; spikes thick, densely flowered; flowers rather large, blue. - Barrens of Tennessee, and nortliward. - Stem $1^{\circ}-2^{\circ}$ ligh.

V. Bonariensis, L. Pubescent and scabrous; stem much branched $\left(2^{\circ}-3^{\circ}\right.$ high $)$; leaves lanceolate, serrate, auriculate-clasping; pauicle dense, cymose, the spikes sliort; tube of the purple corolla twice as long as the calyx. - Roadsides near Charleston (Curtiss). Introduced. 


\section{Order LABIATAE.}

HYPTIS, Jacq.

H. spicata, Poit. Anuual, closely pubescent; stem obtusely 4-angled, muricate; leaves ovate, acute, coarsely serrate, long-petioled; whorls shortpeduncled, 3-6-flowered, interruptedly racemose; calyx-teeth spine-like, spreadiug ; corolla small, purple. - Tampa and Jacksonville, Florida. - Stem $2 \circ-5 \circ$ high.

H. pectinata, Poit. Anunal ? pubescent; stem often muricate; leaves ovate, acute, serrate, pale beneath, twice as long as the petiole, the uppermost ones bract-like; whorls packed in dense one-sided pectinate spikes; calyx villous at the throat; corolla minute, pale purple. (H. spicigera, Chapm., not of Lam.) - South Florida. - Stems $2^{\circ}-6^{\circ}$ high.

\section{MENTHA, L.}

M. arvensis, L. (Cons Mixt.) Downy and somewhat canescent; leaves oblong or ovate; whorls axillary, dense, globose; calyx-teeth lanceolate. Georgia. Introluced.

M. aquatica, L., var. glabrata, Benth. (Berganot Mint.) Smooth; leaves ovate, sharply serrate; whorls loose, peduncled, single or racemose; calyx-teeth subulate. - Manatee, South Florida (Garber). Introduced.

\section{PYCNANTHEMUM, Michx.}

P. Torreyi, Benth. Stem more or less pubescent, nearly simple; leaves (not whitened) linear-lanceolate, acute at both ends, nearly sessile and entire ; caly $x$-teeth subulate. - Nashville, Tennessee (Dr. Guttinger), and northward. - Stem $2^{\circ}-3^{\circ}$ high. Leaves $2^{\prime}$ long.

SATUREIA, L. SAYORY.

Calyx bell-shaped, 10-nerved, 5-toothed. Corolla 2-lipped, the lower lip 3-lobed. Stamens 4, spreading or connivent; anthers 2-celled. Style unequally 2-cleft.

S. (Pycnothymus) rigida, Bartram. Shrubby, villous; stem assurgent $\left(1^{\circ}-1 \frac{1}{2}^{\circ}\right.$ long); leaves rigill, lanceolate, entire; spikes capitate, oblong; calyx minute; corolla pale purple. - Low sandy pine barrens, South Florida.

\section{HEDEOMA, Pers.}

H. graveolens, Chapm. Stems chistered, woody at the base, mostly simple, pubescent $\left(1^{\circ}-1 \frac{1}{2}^{\circ}\right.$ high); leaves ovate, cordate, the lowest shortpetioled, sparingly serrate; flowers single, opposite, racemose; the bracts and 2 opposite bractlets oblong, nearly equal; calyx-teetl ciliate; sterile anther manifest; seeds ovoid. - Low pine barrens near Apalachicola, Florida. July. 


\section{CALAMINTHA, Benth.}

C. glabella, Bentl.. Herbaceous, smootlı; stems slender $\left(1^{\circ}-2^{\circ}\right.$ ligh $)$; leaves ovate-lanceolate, obtuse, sparingly serrate, short-petioled; whorls mostly 6-fowered, sessile, the spreading pedicels twice as long as the caly $x$, and commonly longer than the lanceolate acute bracts; corolla pale purple. (Cunila glalıella, Michx.) - Rocky bunks, Tenuessec.

\section{SALVIA, L.}

S. lanceolata, Willu. Stem low $\left(6^{\prime}-12^{\prime}\right.$ high $)$, smonth, the branches pubescent ; leaves lanceolate-linear, obtuse, obscurcly serrate (1 $\frac{1}{2}^{\prime}-2^{\prime}$ long), narrowed to a petiole, the floral ones subulate; whorls distant, mostly 2 . flowered; corolla blue, scarcely longer than the smooth calyx. - East Florida ( $G(t) y)$, and far west.

S. occidentalis, Swartz. Stem long $\left(2^{\circ}-6^{\circ}\right)$, creeping, retrorsely pubescent, the internorles swollen; leaves short-petioled, ovate, acnte, serrate; racemes spike-like, many-flowered; whorls distant, mostly 6-flowered, ats long as the ovate acuminate bracts; calyx glandular-villous, half as long as the blue corolla, the teeth obtuse; lobes of the style flat, rounded. - Miami, Soutl, Florida (Garber).

S. privoides, Benth., var. Garberi. Chiefly like the preceding, but the whorls less crowded and more listant, the calyx larger in fruit ( $3^{\prime \prime}-4^{\prime \prime}$ long), the broad teeth aloruptly contracted into an a wn-like point, and both lobes of the style rounded. (S. oecidentalis, var. Garberi, Chapm.) Manatee, South Florida (Garber).

\section{SCUTELLARIA, L.}

S. saxatilis, Riddell. Smooth, or nearly so; leaves thinner, obtuse, less strongly erenate-toothed; otherwise like S. mgutu, Bnckley, which appears to be scarcely a variety of it. - Slialy woods, 'Tennessee, ant northward.

S. montana, Chapm. Softly puheseent; stem mostly simple (110 $-2^{\circ}$ high) ; leaves of the stem, and lowest fioral ones, ovate or oblong-ovate, coarsely serrate, acute at each end, or the lowest ones cordate; racemes fewflowered ; corolla large $\left(1^{\prime}-1 \frac{1}{2}^{\prime}\right.$ long $)$, blue, the ample lower lip nearly as long as the upper one.- Dry woods, and margins of fields, on the mountains of Georgia.

S. Canescexs, Nutt, is nearly like the var. punctata of the first edition, but is taller $\left(3^{\circ}-4^{\circ}\right.$ high), smooth or canescent, and leaves generally longer and narrower. - Mountains of Georgial, Tennesseee, and northward.

\section{SYNANDRA, Nutt.}

Calyx inflated, bell-sliaped, 4-toothed. Corolla 2-lipped, the upper lip entire, the lower broadly 3 -lobed, spreading. Stamens 4, ascending under the upper lip, hairy; anthers smooth, the contiguous cells of the upper pair smaller, sterile, and comnate. Nutlets large, smooth, angular. 
S. grandiflora, Nutt. Biennial; sten simple, hairy $\left(1^{\circ}-I_{\frac{2}{2}}^{\circ}\right.$ high $)$; leaves thin, long-petioled, cordate, crenate-serrate, obtuse, the floral ones narrower, acuminate, sessile; corolla large ( $1 \frac{1^{\prime}}{2}$ long), yellowish-white ; caly $x$-teeth acute. - Shady woods, Tennessee, and northward. June.

\section{STACHYS, L.}

S. cordata, Riddell. Stem slender, more or less hirsute; leaves thin, oblong-cordate, crenate, acuminate, long-petioled, the floral ones minute; calyx-teeth broadly subulate. - Banks of streams, mountains of Georgia and Tennessee. August.

\section{Order BORRAGINACE $\mathrm{E}$.}

CORDIA, Plum.

C. Sebestena, L. (Geiger-Tree.) Rough-pubescent ; leaves large $\left(4^{\prime}-8^{\prime}\right.$ long), ovate; cyme loose, many-flowered; calyx cylindrical, $2-5$ toothed, half as long as the tube of the large red corolla; stamens $5-8$. Keys of Soutl Florida. - A large shrub.

\section{HELIOTROPIUM, Tourn.}

H. polyphyllum, Lelım. Rough, with short appressed white hairs; stems (10 long) spreading from a woody root, very leafy; leaves nearly sessile, lanceolate; spikes leafy; nutlets 4, hairy; corolla white, or, in var. Leavenworthii, Gray (H. Leavenworthii, Torr.), bright yellow. - South Florida, the varicty near Miami (Garber).

H. tenellum, Torr. Annual, rough-hairy; stenı erect $\left(6^{\prime}-12^{\prime}\right.$ high $)$, slender, branching; leaves linear; racemes leafy or naked, remotely fewflowered, calyx-lobes linear, unequal ; corolla white. - Alabama, West Tennessee, and westward.

H. anchusæfolium, Poir. Stem villous, simple; leaves lanceolate ; cyme compact, at length spreading; flowers violet-blue. - East Florida; Augusta, Georgia ; Montgomery, Alabama. Introduced.

\section{IITHOSPERMUM, L.}

L. latifolium, Michx. Softly pubescent; leaves broadly lancenlate, acnte or acuninate; root fibrous; otherwise like L. tuberosum. - Tennessee, and northward. - Stem $1^{\circ}-2^{\circ}$ high.

\section{Order HYDROPHYLLACE $A$.}

\section{HYDROPHYLIUIM, Tourn.}

H. macrophyllum, Nutt. Hirsute; stem stout $\left(1^{\circ}-2^{\circ}\right.$ high $)$; leaves long $\left(0^{\prime}-10^{\prime}\right)$, pinnatifid, with distinct oval toothed lobes, the upper lobes 
coufluent; peluncle shorter thin the petiole; eyse compact; caly $x$-lubes lanceulate-subulate; corolla white. - Rich woods, Northern Alabaua and Mississippi, and nortlıwarl.

H. appendiculatum, Michx. Ilirsute, erect, brinching (10 high I), lowest leaves pinnately divided, with toothed lobes, the others palmatcly 5 -lobed; peduncles longer than the leaves, the cyme bosely flowered; calyx with short reflexed appendages between the subulate lobes; corolla blue.Damp woods, mountilins of North Carolina, 'Tennessee, and northward. May.

\section{ORDER HYDROLEACEA.}

HYDROLEA, L.

H. ovata, Nutt. Spiny, closely pubescent; stem hranching near the summit; leaves sloort $\left(1^{\prime}-1 \frac{1^{\prime}}{2}\right.$ long $)$, ovate; flowers crowled at the end of the branches; calyx-lobes lanceolate, villuus, sliorter than the corolla; stamens exserted. - Central Alabama (Prof. E. A. Simith), and westwaru. Stem $1^{\circ}-2^{\circ}$ lighl. Corolla $1^{\prime}$ wide.

\section{Order polemoniace $A$ e.}

\section{PHLOX, L.}

P. stellaria, Gray. Low ( $6^{\prime}$ higl $)$, smonth, branching; leaves linear $\left(1^{\prime}-2^{\prime}\right.$ long); lobes of the pale blue corolla welge.shaped, rleeply notched. Near Nashville, Tennessee $(G r a y)$. Kentucky (Short), on rocky cliffs.

\section{Order convolvulace}

IPOMCEA, I.

I. trifida, Don., var. Torreyana, Gray. I'erennial, smoothish; peduncles longer than the leaves, $3-10$-flowered; sepals glahrous; capsules as long as the calyx; otherwise like $/$. commutata, which it greatly resembles. - Cultivated ground, Apalaclicola. Introduced.

\section{CONVOLVULUS, L.}

Sepals, corolla, ovary, \&e. of Ipomœa. Style single; stigmas 2, filiform or subulate, or broarler and flat. Capsule 2-9-valvel.

C. Havanensis, Jaeq. Stems very long, wootly, jrostrate, eanescenttomentose; leaves small, oblong, obtuse, short-petiolell peduncles stout, single or by pairs, 1 -3-flowered ; outer sepals obovate, twice as long as the roundish inner ones; corolla white, sharply 5-lobed; valves of the capsule 6-9. (C. Garberi, Chapm.) - Sandy const at Cape Florida (Garber). - Stem $15^{\circ}-20^{\circ}$ or more long. Leaves $6^{\prime \prime}-10^{\prime \prime}$ long. Corolla $9^{\prime \prime}$ long. 
C. nodiflorus, Desr. Stem twining, woody, pubeseent; leaves cordateovate, tomentose, short-petioled; peduncles as long as the petioles, nuostly many-flowerell; sepals ovate, obtuse, equal ; corolla small; capsule 8-valved. - Bahlia Honda Key, South Floridit (Cutiss). - Stems climbing over low bushes. Leaves $1^{\prime}$ long. Corolla $5^{\prime \prime}$ long.

\section{BREWERIA, R. Br. (Strlisma, 1st edit.)}

B. grandiflora, Gray. Stem prostrate, tomentose ( $2 \circ$ or more long); leaves oval, obtuse or emarginate, short-petioled ( $\left.1 \frac{1}{2}^{\prime} \mathrm{long}\right)$; peduncle mostly shorter than the leaf, I-flowered; caly $x$ large, the sepals acute; corolla very large $\left(2 \frac{1}{2}^{\prime}-3^{\prime} \mathrm{long}\right)$, purple; capsule 4 -seeded. - Sandy coast at Sarasota Bay, South Florida (Gurber).

\section{EVOLVULUS, L.}

E. argenteus, Pursh. Silky-villous throughout ; stem rigid (6' high), very leafy; leaves linear-lanceolate or spatulate; sepals lance-subnlate; corolla blise or purple. - Pine Key, South Florida (Blodgett, ex Gray), Tennessee, and westward.

\section{CUSCUTA, Tourn.}

C. obtusiflora, H.B.K, var. glandulosa, Engelm. Stems widely spreading, bright orange; flowers short-pedicelled, glandular; lobes of the calyx and corolla obtuse; scales ineurved, deeply fringed; eapsule large, depressed; styles short and thick. - Georgia, Florida, and westward, on Polygonum.

C. inflexa, Engelm. Flowers in umbellate cymes; sepals acute, keeled; corolla fleshy, eylindrical, mostly 4-cleft, the ovate aeute lobes as long as the tube; seales minute, slightly tootlied; capsule depressed, enclosed or crowned with the withered corolla. (C. umbrosa, Beyrich.) - Georgia, and northwarl, mostly on shrubs.

C. chlorocarpa, Engeln. Stems eoarse, yellow; lobes of the calyx and corolla mostly acute, ofien longer than the tube; sciles small, 2-cleft; capsule tlsin, pale greenish-yellow. - Around ponds and in wet places, Tennessee, and westward, mostly on Polygonum.

C. glomerata, Choisy. Stems coarse, the dense elusters of flowers forming rope-like masses; bracts and sepals recurved-spreading; lobes of the corolla oblong, obtuse, much shorter than the tube; styles longer than the ovary. - Tennessee, and westward, mostly on tall Compositæ.

\section{Order SOLANACEA.}

\section{SOLANUM, L.}

S. sisymbriifolium, Lam. Glandular-villons and prickly; leaves large, deeply pinnatifid, the oblong divisions lobed and tootherl; racemes

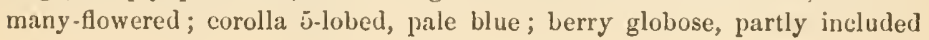


in the hispijd calyx. - Waste places, Georgia and Florida. Introduced. Stem $3^{\circ}-5^{\circ}$ high. Leares $t^{\prime}-y^{\prime}$ long.

$\$$ Axdrocera. - Fruit included in the calyx; stamens and style declined; anthers topering upwards, the lowest one longer and incured.

S. rostratum, 1)unal. Stellate-pubescent and prickly; leaves 1-2. pinnatifid, the lolies obtuse; corolla yellow, its lobes short, ovate; caly $\mathrm{x}$

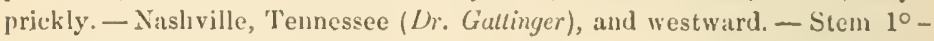
'20 light. Corolla $1^{\prime}$ in diameter.

PETUNIA, Juss.

Calyx 5-parted. Corolla funnel-sliaped, plicate. Stamens 5, unequal ; anther-cells separate. Stigma capitate. Capsule 2-valved, many-seeded.Clammy pubescent herbs.

P. parviflora, Juss. Anuual, diffuse, leaves oblong-linear or spatulate ; corolla small, pale bluish-purple. - South Florida, and New Orleans. Introduced.

\section{Order GENTIANACEAE.}

VOYRIA, A ubl.

Calyx 5-cleft. Corolla salver-form. Stamens included: anthers erect. Style persistent: stigma capitate. Capsule 2-celled. Seeds on the margin of the introflexed valves, usually tailed at each end.-Colorless lierbs, growing on rotten wood. Leaves scale-like. Flowers terminal.

V. Mexicana, Griseb. Sten simple; scales opposite; cymes few. flowered; ealyx-lobes lanceolate, acute; corolla small, the lobes slorter than the tube; seeds tailed. - Keys of South Florida (Curtiss). - Stem 4'-6' higlı. Corolla $3^{\prime \prime}-4^{\prime \prime}$ long.

\section{Order APOCYNACEA.}

\section{ECHITES, P. Browne.}

E. paludosa, Vahl. Smootl, twining or floating; leaves oblong or lanceolate, thick, short-petioled; peduncles as long as the leaves, $1-3$-flowered ; calyx-lobes oblong, acute; corolla large $\left(2^{\prime}-3^{\prime}\right.$ long), funnel-shaped, white; follicles fusiform; seeds linear, plumose. - Mudily islets of the Caloosa River, South Florida. Oetober. - Stem long. Leaves $3^{\prime}-4^{\prime}$ long.

E. Sagræi, A.I)C. Smooth, ereet, very leafy; leaves varying from oval to linear-lanceolate, acute, rigid, the margins revolute; peduncles much longer than the leaves, racemosely several-flowered, the long perlicels single or by pairs; calyx-lobes acuminate; corolla yellow, bell-slaped, witl spreading lobes; anthers obtuse; seeds plumose. - Rocky places, Miami, South Florida (Garber). - Stem $1^{\circ}$ high. Leaves and corolla $1^{\prime}$ long. 


\section{Order ASCLEPIADACEA.}

\section{ASCLEPIAS, L.}

A. Curtissii, Gray. Stem puberulous ( $1^{\circ}-3^{\circ}$ high $)$; leaves smooth, oval, acuminate or obtuse ( $1 \frac{1^{\prime}}{2}$ long) ; umbel solitary, terminal, short-peduncled, loosely few-flowered; Howers yellowish-green; pedicels twice as long; leaves of the crown somewhat hastate-lanceolate, erect, more than twice as long as the gynostegium and the ineurved horn; anther-wings very broad; column short. - Eastern part of South Florida (C'urtiss).

\section{ENSLENIA, Nutt.}

Calyx 5-parted. Corolla bell-shaped, 5-parted: crown inserted on the base of the gynostegium, 5-leaved, each leaf deeply cleft, with the lobes prolonged into a slender flexuous point. Stigma subconical. Follicle fusiform. Seeds comose, flit. - A perennial twining vine, with opposite cordateovate aeuminate leaves, and small white fragrant flowers in axillary umbels or corymbs.

E. albida, Nutt. - River-banks, Georgia, Alabama, and northward. July.

\section{GONOLOBUS, Michx.}

G. hirsutus, Michx. Pubescent and hirsute; leaves ovate, cordate, acuminate; peduncle of the 6 -8-flowered umbel equalling or shorter than the petiole; corolla dark purple, ovate in the bud, the oval or oblong lobes smooth within; margins of the crown 10-crenate; "follicle muricate." Woods, Florida, and northward.

G. obliquus, R. Br. Leaves broadly cordaten short-acuminate, or mucronate-pointed; umbel simple or compound, long-peduncled; corolla crimson purple, long-conical in the bud, the linear lobes smoothish within; margins of the crown 10-crenate; folliele terete, muricate. - Banks of the Coosa River, North Georgia, and northward. July.

G. Carolinensis, Ir. Br. Leares cordate, acuminate; peduncle rather longer than the petiole; corolla brownish purple, oblong in the bud, the oblong lobes smooth within; crown obtnsely 5-lobed, and with a longer bifid process in the sinuses. - South Carolina, and westward.

G. Baldwinianus, Sweet. Stem and cordate leaves pubescent and hairy; peduncles mostly longer than the petioles; umbel simple or compound; flowers oblong-oval in the bud, white, the lobes somewhat spatulate; crown 5-crenate, with a pair of subulate processes in the sinuses. - Calcareous soil, Florida and Alabama. 
G. suberosus, R. I3r. Leaves eorlate, acuminate, minutely pubescent or smoothish; mmbels :3-1)-1lowered, much slorter than the petiole; corolla broadly conical in the but, twisted, the lobes triangular-lanceolate, dusky, minutely pulescent within, but sometimes smooth, lardly double the length of the calyx-lobes; crown 10-crenate (Gray). - Near the coast, Virginia to Florida (Gray).

\section{Order OLEACEA.}

FORESTIERA, Poir.

F. pubescens, Nutt. Leaves pubescent; drupe shert-pedicelled, with the nut striate; otherwise like $F$. ligustrina. - Floridi, and westward.

\section{ORDER ARISTOLOCHIACE $A$.}

\section{ARISTOLOCHIA, Tourn.}

A. pentandra, L. lerennial, herbaceous, smoothish; stem prostrate or twining ( $2^{\circ}-3^{\circ}$ long); leaves ovate, cordate; flowers axillary; limb of the caly $\mathrm{x}$ linceolate, acuminate, deep green, much longer than the 5-angled tube; stamens 5. - Miami, South Floridis (Garber).

\section{Order NYCTAGINACE E.}

OXYBAPHUS, Vahl.

O. nyctagineus, Sweet. Stem smoothish, 4-anglel, forking; leaves petioled, deltuid-ovate; flowers clustered, terminal ; involucre 3 -5-flowered, becoming large and reiny. - West Tennessee, and westward. July and August. - Stem $1^{\circ}-2^{\circ}$ high.

\section{PISONIA, Plum.}

P. rotundata, Griseb. Spineless; leaves obovate, rounded at the base, short-petioled ( $l^{\prime}$ long); cymes divaricite, sessile or short-peduncled; flowers clustered; sterile calyx 5-toothed, the fertile one clavate-oblong, obtuseangled, glandular above the middle, the glands stipitate. - Keys of South Florida (Curtiss).

\section{Order AMARANTACEA.}

ACNIDA, Mitchel.

A. Floridana, Watson. Stem branching from the base, erect or ascending; leaves lanceolate; flowers in clusters along the upper part of the stem, the fertile ones often in distant heads; utricle thin, rugulose, indehis- 
cent, as long as the cuspidate bracts; stigmas slender, liairy. - Sandy coast of South Florida. August to October. - Stems $3^{\circ}-5^{\circ}$ long.

A. rusocarpa, Michx. Stem tall; leaves ovate-lanceolate, acuminate; fertile flowers crowded in a continuons spike; utricle fleshy, more than twice as long as the bracts, the angles often punctate-rugose; stigma rather short, slender-subulate. - Salt marshes, Georgia, and northward. - Stem $3^{\circ}-6^{\circ}$ high.

A. cannabina, L. Stem and leaves as in the precerling: fertile spikes less densely flowered; utricle less flesliy, smooth, sharply angled, much longer than the linear-subulate bracts; stigma very long and hairy.Brackish marshes and river-banks, Georgia, and northward.

\section{Order POLYGONACE}

\section{FOLYGONUM, I.}

P. Hydropiper, L. (Common Suartweed.) Annual, smooth; leaves lanceolate, punctate, acrid; spikes slender, interrupted, nodding; flowers greenish ; stamens 6 ; style 2-3-parted ; aclienium flat or triangular. - Roadsides, Northern Georgia, and northward. - Stem $1^{\circ}-2^{\circ}$ high.

\section{Order PIPERACEA.}

Chiefly like Saururacex, but with a simple one-celled ovary containing a single erect ovule. - Herbs or slirubs.

\section{PEPEROMIA, Ruiz \& Pavon.}

Bracts free. Flowers hermaphrodite. Stamens 2, lateral; anthers 2valved, extrorse. Stigma solitary.

P. magnoliæfolia, C. DC. Leaves mostly alternate, rigid, petioled, obovate, pellucid-punctate; spikes terminal, densely flowererl, longer than the leaves; peduncles as long as the petiole; bracts rounded, peltate. - East Florida (Garber). - Leaves $1 \frac{1^{\prime}}{2}-S^{\prime}$ long.

P. leptostachya. Leaves opposite or whorled, very thin, smaller ( 1 ' or less long), 3-nerved; spikes very slender, rather loosely flowered; otherwise much like the precerling. (Piper leptostachyon, Nutt.) - lslands at the mouth of the St. John's (Curtiss).

\section{ORder CALLITRICHACE E.}

\section{CALLITRICHE, L.}

C. peploides, Nutt. Annual; stems creeping; leaves uniform, obovate or spatulate; fruit nearly sessile, circular, notched at the apex, the sides 
gibbous, grooved around the wingless margin, as long as the widely spreading stigmas. - Florida and westward, on damp earth. Februay and March.

C. Austinii, lingelm. Smaller ( $I^{\prime}$ or less long); fruit short-jedicelled, fattened, wider than long, notched at both ends, with narrow denticulate wings, longer than the spreading stigmas; otherwise like the preceding.Temessee (Dir. Gallinger), and nortluward. $\Lambda$ pril.

\section{Order EUPHORBIACE $\mathrm{E}$.}

\section{EUPHORBIA, L.}

E. mercurialina, Michx. I'erennial, smooth; stem erect, simple or branching; leares opposite, or three in a whorl, thin, oval, obtuse, entire, nearly sessile; tlowers single, terninal, or in the forks of the stem, the setaceous pedicels mostly longer than the leaves; lobes of the involucre bifid, the glands broadly margined with white (fruit not seen). - Crevices of rocks on Lookout Mountain, 'Tennessee. April. - Stem 4'-6' high. Leaves $4^{\prime \prime}-$ 8 'long.

E. tetrapora, Engelm. Stem erect, umbellately branched; leaves wedge-shaped, obtuse or emarginate, the upper ones roundish; glands 2 horned; capsule smooth, obtuse-angled; inner face of the seed only 4-pitted. - Georgia, and westward.

E. dictyosperma, Fisch. \& Meyer. Snuooth; stem umbellately branched, slender, the branches forking; leaves spatulate-obovate, serrulate near the apex, of the branches cordate; glands round ; eapsule warty ; seeds reticulate. (E. Arkansana, Engelm.) - Alabama (Buchiey), and westward. Stem 8'-12' high.

E. Garberi, Engelm. (ined.). Peremial, sof tly villous throughout; stems widely branching; leaves oval or obovate, oblique, entire, short-petioled; stipules ciliate-laciniate; flowers single in the upper axils; glands narrowly margined; capsule acutely angled; seeds redlish-brown, transversely 2 ribbed. - Sandy coast, South Florida. - Stem $1^{\circ}$ or more long.

E. serpens, H.B.K. Smooth, small $\left(t^{\prime}-8^{\prime}\right.$ long $)$; leaves round-ovate, entire ( $\frac{1}{2} "{ }^{\prime \prime} 2^{\prime \prime}$ long) ; stipules triangular, toothed ; peduncles single; appeniages of the gland minute or none; capsule smootl, acutely angled; seeds smooth and even, obtusely 4-angled. (E. herniarioides, Nutt.) - Soutlı Florida, Mississippi, and westwarl.

E. ammannioides, H.13.K. Smooth throughout; stems long $\left(2^{\circ}-3^{c}\right)$, filiform, prostrate, alternately branched ; leaves oblong ( $2^{\prime \prime}-3^{\prime \prime}$ long), entire ; rounded and mucronate at the apex, short-petioled; stipules 2-parted; flowers single, terminal, and in the forks of the branches; glands margined with white; capsule obtusely iriangular; seels ovate, obseurely triangular, smooth and even. - Roberts's Key in Caximbas Bay, South Florida.

E. humistrata, Engelm. Prostrate, pubescent; leaves elliptical or obovate, oblique at the base, serrulate near the apex $\left(4^{\prime \prime}-9^{\prime \prime} l o n g\right)$; stipules 
fimbriate; flowers in dense lateral elusters; involucre cleft on the back; appendages of the gland red or white, truncate or crenate; capsule acutely 3 -angled; seeds ovate, obtusely angled, minutely roughened. - Rich soil, Nashville, Tennessee (Dr. Gattiager), and westward.

E. dentata, Michx. Annual, erect ( $1^{\circ}$ ligh $)$, irregularly hranching ; leaves distant, petioled, ovate, lanceolate, or linear, coarsely toothed, the lower ones alternate, the uppermost ones opposite; in volucres nearly sessile, with five toothed lobes, and mostly a single stalked gland; seeds nearly globular, slightly tubercled. - Rich soil, Tennessee, and nortlıward. JulySeptember.

E. deltoidea, Engelm. (ined.). Small, perennial; stems $\left(\mathscr{L}^{\prime}-4^{\prime}\right.$ long) diffuse, glabrous; leaves ( $1 \frac{1}{2}^{\prime \prime} \mathrm{long}$ or less) petioled, obliquely deltoid, cordate, or reniform, sprinkled with short hairs, the margins narrowly revolute; stipules minute, entire; involucre single, terminal (always?) turbinate, pedicelled, with downy lobes, and transrersely oblong glands without appendages; styles very short; capsule (immature) acutely 3-augled, glabrous. - South Floridal (Curtiss).

E. prostrata, Ait. Prostrate, more or less pubeseent $\left(4^{\prime}-6^{\prime}\right.$ long) ; leaves oval, sliglitly serrulate, smooth above $\left(2^{\prime \prime}-3^{\prime \prime} \operatorname{long}\right)$; flowers in lateral clusters; involucre top-shaped; appendages narrow; capsule long-ciliate on the angles; seeds 4 angled, strongly rugose. - Waste places, Florida, and westward.

E. adenoptera, Bertolini. Prostrate; stems shortly villous; leaves obliquely oblong, denticulate; stipules subulate, ciliate; involucre topshaped, hirsute, deeply cleft withont, the ciliate lobes lanceolate; appendages rosy; capsule hirsute, acute-angled, seeds oblong, 4-angled, transversely furrowed. - South Florida (Curtiss)

\section{ACALYPHA, L.}

A. Lindheimeri, Müller. Stem ( $1^{\circ}$ high) branching, hirsute; leaves rhornbic-ovate, serrate, short-petioled ( $l^{\prime}$ long) ; spikes very slender; hracts of the numerous pistillate flowers ovate, deeply 5 -7-toothed, 1-2-flowered ; ovary hirsute; styles long, setaceously 4-6-cleft; seeds minutely pitted.Key West (Riddell in Merb. Mohr).

\section{MERCURIALIS, Tourn.}

Flowers diœcious, apetalous, in axillary spikes or clusters. Calyx 3 -parted. Stamens 8-20, distinct. Styles 2, simple, united at base. Capsule 2-celled, 2 -seeded.

M. annua, L. Smooth, branching (10 high) ; leaves ovate-lanceolate, crenate-toothed; sterile spike longer than the leaves; fertile flowers clustered ; capsule hispid. - Waste places, sparingly naturalized. 


\section{TRAGIA, Plum.}

T. macrocarpa, Willd. Hirsute; stem twining $\left(2^{\circ}-4^{\circ}\right.$ long $)$; leaves anple, thin, cortate, eoarsely and sharply serrate, long-petioled; racemes shorter than the leaves; capsule large. $-\Lambda$ labana, 'T'ennessee, and westwarl.

\section{CROTON, L.}

C. Texensis, Müller. Amunal, diøcions, stellate-tomentose; stem dichotomons $\left(1^{\circ}-2^{\circ}\right.$ high); leaves lanceolate, short-petioled; sterile racemes short; petals none; fertile flowers axillary, solitary; stigmas 18-24; capsule nearly globose, covered with tufts of deciduous down; seed biconvex. Alabama (Molr), and westwart.

C. capitatus, Miclix. Amunal, monøcious, woolly; stem umbellately branched; leaves long-petioled, lance-oblong, rounded at the base; sterile flowers unmerous, the petals fimbriate; fertile flowers crowided ; caly $x$ 7-10parted, with the lobes obtuse; seed smooth. - Georgia, along railroats, and westward. - Stem $2^{\circ}-4^{\circ}$ highl.

C. humilis, L. Low (10 high), shrubby, stellate-tomentose; leaves longpetioled, cordate-ovate, acuminate; racemes densely 10 - 15-flowered ; calyx woolly, 5-parted; petals of the sterile flower oblong; stamens 20 - 30 ; petils of the fertile flower narrow-linear; styles twice 2-parted; (apsule downy. (C. Berlandieri, Torr.) - Florila (Cubunis).

C. linearis, Jacq. Slırubby, canescent-tomentose, monocions or dixcious; stem slender, branching $\left(3^{\circ}-4^{\circ}\right.$ high) ; leaves short-petioled, linearJanceolate, obtuse; sterile racemes slender, longer than the leaves, minutely many-ilowered, the fertile ones short, few-flowered; styles 2-parted; capsule roundish. - Miami, South Florida (Garber).

C. Alabamensis, E. A. Smith (ined.). Stem tall, woody, much branclied; leaves thin, short-petioled, oblong-lanceolate, mostly obtuse, smooth or nearly so above, the lower surface, like the branchle? 3 and racemes, coated with silvery scales: racenes often unizexual, few-or manyflowered; calyx-lobes 5 , acute petals of hoth sexes scarcely shorter than the calyx, woolly-margined; stamens 20 or more; styles simple, truncate or emarginate; capsule much longer than the calyx; seeds glabrous. - Central Alabaina, flowering throughout the year. - Stem $6^{\circ}-10^{\circ}$ ligh. Leaves $2^{\prime}-3^{\prime}$ long.

C. Betulinus, Vahl. Stellate-tomentose ; stem low $\left(1^{\circ}-1 \frac{1}{2}\right.$ high $)$, with slender branches; leaves small ( $1^{\prime}$ or less long), triangular-ovate, truncate at the base, coarsely toothed, rough above, twice as long as the petiole; racemes bisexual; stamens $10-11$; styles twice 2-cleft; capsule subglobose. - Rocky pine woods, South Florida (Curtiss).

\section{JATROPHA, I.}

Flowers monœcions. Sepals 5, mostly united. Petals 5, or none. Glands of the disk 5, opposite the calyx-lobes. Stamens monadelphous. Styles 3 
or 4, 2-3-cleft, capsule 2-4-seeded. - Herbs or slirubs. Leaves mostly palmately lobed.

J. gossypiifolia, I. Slrubby ( $2^{\circ}$ high) ; leaves roundish, $3-5$-lobed, serrate, the petiole bristly, glandular; bracts and caly $\mathrm{x}$ bristly-ciliate; petals 5, dark red. - Key West (Curtiss), introduced.

\section{Order ULMACE $\not$ E.}

\section{ULMUS, L.}

U. racemosa, Thomas. Branches often corky; leaves oblong-ovate, smooth above, downy beneath; racemes slender; fruit large. - River-banks, Tennessee, and northward.

\section{TREMA, Lour.}

Chiefly like Celtis, but with fleshy albumen, and thick narrow incurved cotyledons. - Trees or slirubs.

T. micrantha, Benth. \& Hook. Shrub very leafy $\left(10^{\circ}-15^{\circ}\right.$ high $)$, the branchlets, \&c. canescent; leaves ( $l^{\prime}$ long) rigid, oval, serrate; flowers minute, in dense axillary cymose chusters; drupe small, yellow, globose. (Celtis pallida, Torr.) - Shell-mounds in Lastero Bay, South Florida (Garber).

\section{Order CUPULIFER A.}

\section{QUERCUS, L.}

Q. palustris, Du Roi. (PIN OAs.) Leaves long-petioled, oval, truncate or abruptly acute at base, with broad and rounded sinuses, aind 5- ; sparingly-toothed lobes, snooth on both sides; cup shallow, with appressed scales, enclosing the base of the nearly globular nut. - Mutntains of Georgia, and northward. - A middle-sized tree. Nut $\frac{y^{\prime}}{2}$ long.

\section{Order SALICACEAE.}

\section{SALIX, Tourn.}

S. fragilis, L. Leaves broadly lanceolate, acuminate, fincly serrate, white silky when young, glaucous beneath; aments long, cylindrical; bracts hairy ; stamens mostly 2 ; capsule short-pedicelled. - Tennessee, and northwarl. - A small tree.

\section{POPULUS, Tourn.}

F. monilifera, Ait. Branchlets obtusely angular ; leaves deltoid-ovate, acuminate, serrate $\left(3^{\prime}-10^{\prime}\right.$ long); fertile aments long and slender; stigma large. tootherl; capsule ohlong-ovate. (P. Canadensis, Michx. P'. lævigata, Willd.) - River-banks, Florida, and northward. - A large tree. 


\section{Order CasUARINACEAE.}

Trees or slırubs, with leafless jointed furrowed branches, like Equisetum. Flowers in spikes, monocious or diacious, the staminate ones in whorls at the joints, monandrous, 4-bracted, the pistillate flowers capitate, without floral envelopes. Ovary l-celled, with $1-2$ orthotropous orules, forming in fruit a winged achenium. Styles 2. Albumen none. Radicle superior.

CASUARINA, Rumpl.

Characters of the Order.

C. equisetifolia, Forst. Branclies filiform, simple; furrows 6-8; teeth of the sheaths, as many, keeled on the back; staminate spike terminal, the pistillate lateral, short-peduncled. - Iicys of South Florida (Curtiss).

\section{Order CONIFERAE.}

PINUS, Tourn.

P. Elliottii, Engelm. Leaves $2-3$ in a sheath, $7^{\prime}-12^{\prime}$ long; bracts longfringed; male aments purple, female aments peduncled, $t$ wo or more together; cones recurved, oval or cylindric-conical $\left(3^{\prime}-6^{\prime}\right.$ long); wings $4-5$ times longer than the seed. (P. tæda, var., Ell.) - Low ground, Florida to South Carolina. A large tree.

P. inops, var. clausa, Engelm. Leaves Ionger and finer ; cones nearly sessile, spreading or reflexed, mostly persistent for years; bracts 8 or 9 ; cotyledons mostly 4. - Barren sandy ridges near the coast, Florida. - Tree $10^{\circ}-40^{\circ}$ high. Wood valueless.

\section{ABIES, Tourn.}

A. Caroliniana, Engelm. (as Tsuga). Leaves larger than in A. Canadensis, $6^{\prime \prime}-8^{\prime \prime}$ long, deeper green and more glossy, notched at the tip; cones larger (12" - $14^{\prime \prime}$ long), the oblong scales widely spreading at maturity. Mountains of North and South Carolina, on dry lills. $-A$ small tree.

\section{JUNIPERUS, L.}

J. communis, L. (Comson Juxiper.) Shrubby, widely spreading; leaves 3 in a whorl, spreading, linear-lanceolate, white on the upper surface, the margins involute; drupes large. - Aiken, South Carolina (Ravenel), and northward.

\section{Order PALMIE.}

\section{OREODOXA, Willd.}

Flowers monœeious, sessile, bracted. Sepals 3 , imbricated, at length united. Petals 3 , valvate. Stamens 6,9 , or 12 . Ovary 3-celled, with six 
united rudimentary stamens at the base. Stigmas?, sessile. Drupe baccate. Enbryo at the base of horny albumen. - Tall Palms, with long pectinatepinnate long-sheathing leaves. Spadix enclosed in the 2-leaved spathe.

O. regia, H.13.K. (Royal Palm.) Stem $60^{\circ}-100^{\circ}$ high; leaves $10^{\circ}-$ $15^{\circ}$ long, the narrowly lanceolate divisions acmunate, $1^{\circ}$ long; drupe oblong, dark blue. - On lioger's River, east of Caximbas Bay, and sparingly near the mouth of Little River, South Florida (Garber).

\section{SABAL, Adanson.}

S. Adansoni, Guerns, var. ? megacarpa. Leaves grayish green, the divisions parted nearly to the sinuses; spadix ( $2^{\circ}$ long) ascending, prostrate in fruit; drupe ( $\frac{1}{2}$ in diameter) globose, black; flowers unknown. - Dry rocky pine woods, Miami, South Florida (Garber).

\section{THRINAX, L. f.}

Stameus 6-12, connate at the base : anthers oblong. Ovary 1-celled, 1-ovuled. Style dilated upwards. Stigma concave, - Otluerwise like Sabal.

T. parviflora, Sivartz. Stem tall $\left(10^{\circ}-30^{\circ}\right.$ ligh $)$, smoothish; leaves fansliaped, soon smooth, the numerous lanceolate divisions tapering to the deeply cleft apex, the lower third connate; ligule triangnlar, acute; spadix paniculate, nearly as long as the leaves, the branches bracted; flowers very small; drupe globose. - Coast and Kieys of South Florida.

T. argentea, Loddiges. Stem rather low $\left(12^{\circ}-15^{\circ}\right.$ high); leaves shorter than their petiole, silvery-sericeous beneath; divisions united at the base ; ligule semi-lunar; spadix sparingly branched; drupe small. - Keys of South Florida (Curtiss). - Leaves $1 \frac{1}{2}^{\circ}-2^{\circ}$ long. Spadix $1^{\circ}$ long.

T. Garberi, Chapm. Stem very short; leaves smooth, parted nearly to the base into several strap-shaped entire divisions, sparingly filamentous; ligule rounded; spadix very small $\left(6^{\prime}-8^{\prime}\right.$ high $)$, bractless ; stamens $6-10$; drupe globose, deep purple. - Rocky pine woods, Miami, South Florida (Garber).

\section{COCOS, L.}

Flowers monœcious. Sepals and petals 3. Stanens of the sterile flower 6, the filaments subulate. Sepals and petils of the fertile flower roundish. Ovary 1-celled. Stigmas 3. Nut bony, with 3 pores at the base, enclosed in a thick fibrous husk. Albumen hard or flesly, hollow. Embryo basal. Tall palms, with pinnate leaves, and smill greenish or yellowish flowers.

C. nucifera, I. (Cocos.) Stem $40^{\circ}-60^{\circ}$ high ; leaves very long, the divisions narrowly lanceolate; spathe rleeply gronverl; spallix long, branching; nut very large, ovate. - South Florida. Introduced. 


\title{
Order NATADACEA.
}

\author{
INAIAS, L.
}

N. major, All. Stem muricate; leaves broadly linear, serrate-dentate, with muricae teeth, the sheaths cutire; flowers diocions; anthers 4-valved; style very short; stigmas 3 ; achenium elliptical, obscurely reticulate. South Florida.

\section{HALOPHILA, Thouars.}

Flowers diœcious, axillary, solitary. Perianth 2-leaved. Stanens ?, monadelphous; anthers 1-celled. Oviry 1-celled, with numerous parietal ovules. Style long, filiform ; stigmas $3-5$, penicillate. Capsule indehiscent. Seeds globnlar. Embryo in copious albumen. - Marine herbs, with creeping stems, and $n p$ posite pellucid stipulate leaves.

H. Engelmannii, Ascherson. Stem filiform, much branched; leaves, seemingly whorled at the end of the branches, linear-olilong, 3-nerved, sharply serrulate ( $1^{\prime}$ or less long); flowers and fruit unknown. - Muddy coves along the west coast of Florida.

\section{POTAMOGETON, Tour:}

P. amplifolius, Tuck. Stem simple; leaves large, oblong or ovallanceolate, ac'utish, long-petioled; the submergerl ones lanceolate, undulate; stipules very long, pointed; peduncles stout, fruit obliquely obovate, bluntly keeled. - Ponds on the mountains of Georgia, and northward.

P. pulcher, Tuck. Closely resembles the preceding, but the stipules short and obtuse, and the fruit sharply 3 -keeled on the back when dry. Georgia (Leconte).

\section{Order ORCHIDACEA.}

\section{EPIDENDRUM, L.}

E. cochleatum, L. Stem tuber-like, ovate-lanecolate, 2-erlged, sealy, 2 -leaved; leaves oblong-linceolate, acute, as long as the few-flowered scape; flowers racemose, short-bracted; sepals and petals greenish, broadly linear, recurved ; lip much shorter, purple, entire, cordate-roundish, eochleate, acute, 2-callous at the base. - South Florida (Garber). - Stem $1^{\circ}$ high. Leaves 1' wide. Flowers $1^{\prime}-1 \frac{1}{2}^{\prime}$ long.

E. umbellatum, Swartz. Stem leafy ; leaves oblong, obtuse $\left(2^{\prime}-3^{\prime}\right.$ long); flowers nubellate, greenish; bracts ovate; sepals oblong; petals linear; lip reniform-roundish, obseurely 3-lobed, veiny, 2-eallous at the base ; column denticulate. - Miami, South Florida (Garber). - Stem $6^{\prime}-12^{\prime}$ high. Flowers $6^{\prime \prime}-8^{\prime \prime}$ long.

E. nocturnum, L. Stem leafy ; leaves oblong or oval, obtuse ; flowers 1-2, terminal, white or yellowish, long-peduncled; petals large, linear, acu- 
minate; lip 3-cleft, the lateral lobes ovate-oblong, the middle lobe longer, linear-setaceous. - With the preceding. - Stem $1^{\circ}-2^{\circ}$ high. Leaves $2^{\prime}-5^{\prime}$ long. Flowers $1 \frac{1}{2}{ }^{\prime}-2 \frac{1}{2}^{\prime}$ long.

POLYSTACHYA, Hook.

Two upper sepals broad, gibbous, connivent. Petals small. Lip jointed, sessile, 3-lobed. Anthers lid-like, free. Pollen-masses 4 , hemispherical, waxy: - Epiphytes. Sten leafy near the base. Flowers small, in simple or compound racemes.

P. luteola, Hook. Stem $\left(1^{\circ}-2^{\circ}\right.$ high $)$ tuberous at base, longer than the few lance-oblong rigid leaves; raceme compound ; flowers greenish yellow; the lip obovate, oblong, downy within, the lateral lobes small, the middle one broad and recurved. - On various trees, South Florida.

\section{DENDROPHYLAX, Reichenbach, f.}

Sepals and petals spreading. Lip erect, 3-lobed, the lateral lobes small angular, the middle one with 2 widely spreading lobes. Spur very long, filiform. Column short. Pollen-masses 2. - Epiphytes. Scape leatless, in ours bearing a single large white flower.

D. Lindenii, Reichenbach, f. Scape filiform $\left(3^{\prime}-4^{\prime}\right.$ long) ; sepals and petals lanceulate; segments of the midule lohe of the lip lanceolate curved, attenuate; eapsule stipitate, oval, snrooth. - On Oreodoxa regia, South Florida (Curtis).

VANILLA, Swartz.

Lip adnate to the column, convolute; perianth jointed at the base, spreading. Column naked. Pollen-masses 2 . - Stem climbing by rootlets. Leaves jointed at the base. Flowers lirge, in axillary racemes. Capsule pulpy within.

V. planifolia, Andr. Stem cylindrieal ; leaves fleshy, oblong, acute, contracted at the base $\left(5^{\prime}-7^{\prime}\right.$ long $)$; bracts leafy; flowers $\left(2^{\prime}\right.$ long) green, the sepals and petals lance-oblong; lip serrate at the apex, thickened helow, slightly crested in the middle ; capsule cylindrical ( $6^{\prime}$ long). - Borders of the Everglades (Curtiss).

\section{CYRTOPODIUM, R. Br.}

Sepals and petals alike, spreading. Lip clawed, continnous with the base of the column, incurved, 3-lobed. Pollen-masses 2, the short stalk linear. Gland ovate. - Terrestrial. Scape sheathed, separate from the leaves. Flowers racemose or panicled.

C. punctatum, Lindl. Scape tall; leaves broadly lanceolate, strongly S-ribbed ( $1 \frac{1^{\prime}}{2}$ wide) ; flowers in a simple panicle $\left(6^{\prime \prime}-8^{\prime \prime}\right.$ long) ; bracts leafy, lanceolate, undulate, spreading; sepals and petals greenish white, spotted; middle lobe of the lip emarginate. - Miami, South Florida (Garber). 
C. Woodfordii, Lindl.! Scape more slendor $(20-30$ liglı); leaves rigid, linear-lanceolate (1- long); racemes rather closely thowered (' $z^{\prime}-4^{\prime}$ long); flowers small, shorter than the linear bracts; sepals and petals green; lip crestlens, the mihlde lohe cuncate-obhong; capsule erect. (Bletia verecunda, lst edit. in part.) - Low sancly pine barrens, Florida.

\section{HABENARIA, Willd.}

H. Garberi, Porter. Rout a globulatr tuber; stem erect $\left(1^{\circ}\right.$ or more high); leav's oblong-lanceolate, widely spreathng; spike loosely manyHowered; perianth greenish yellow, lateral sepals broadly ovate; petals unequally - -parted, the upper lobe wedge-shaped, truncate; the lower filiform; lip linear, obtuse, entire; spur as long as the ovary, - 1)amp shady woods; Manatee, South Florida (Gurber).

H. distans, (iriseb. Stem leafy at base (10 high); leaves ellipticaloblong, acute ( $t^{\prime}-6^{\prime}$ long); racemes few-flowered; bracts oblong-lanceolate, shorter than the ovary ; flowers distant ( $t^{\prime \prime}$ long); petals 2-parted, the upper lobe oblong, the lower linear; lip 3-parted, the segments linear, spreading; spur as long as the ovary. - Soutl Florida (C'urtiss).

\section{SPIRANTHES, Richard.}

S. simplex, Gray. Ront a single tuber: stenı short $\left(\sigma^{\prime}\right.$ high), with withered leaves at the base; spike not twisted; flowers very small, white, the lip obovate-oblong, crenulate, with slender prominences at the base. Nasluville, Tennessee (Dr. Gattinger), and northward.

\section{Order AMARYLLIDACEA.}

\section{AMARYLLIS, I,}

A. (Zephyranthes) Traatiæ, Watson. Bulb small; leares very narrow ( $1 \frac{1}{2}$ "wide), thick, semiterete with rounded margins, not shining; scape 4 '-12' ligh; flowers :' long, white, the segments rather obtuse; capsule broader tlian long, its peifuncle $3^{\prime \prime}-9^{\prime \prime}$ long. - Low ground, East Florida (Mrs. Mary Treat). April and May.

\section{HYMENOCALLIS, Salisb. (PAxcratiun, 1st edit.)}

H. Caribæa, Herb. Bulb large, with slort runners; leaves broadly lanceolate, erect-spreading $\left(1 \frac{1}{2}{ }^{2}-2^{\circ}\right.$ long); scape many-flowered; tube of the perianth $\left(5^{\prime} \mathrm{long}\right)$ usually longer than the recurved white divisions; crown short-funnel-shaped, entire, or with few teeth between the filaments. Sandy coast of South Florida. July.

H. crassiflora, Herb. Bulb large, with runners; leaves erect, strapshaped $\left(2^{\circ} \mathrm{long}\right)$; scape thick, glaucous, rather longer than the leaves, 2-flowered; tube of the perianth $\left(3^{\prime}-4^{\prime}\right.$ long) thick, shorter than the yellow- 
ish-white broadly linear spreading divisions; crown large, funnel-shaped, one third as long as the divisions, variously toothed between the filaments. - Wet pine barrens, West Florida. May.

H. Palmeri, Watson. Bulb small; leaves very narrow ( $3^{\prime \prime}$ wide); scape slender $\left(8^{\prime}-10^{\prime}\right.$ long $)$, 1-flowered; tube of the perianth as long as the narrow divisions; crown tubular-fumnel-shaped, sharply toothed between the stamens. - Biscayne Bay, South Florida (Palmer).

H. humilis, Watson. Bulb larger; leaves broader; scape 1-flowered, nearly as long as the leaves; perianth greenish, the tube much shorter than the narrow divisions; crown broadly fumnel-shaped ( $8^{\prime \prime}$ long), truncate between the stamens. - Indian River, South Florida (Palmer).

\section{AGAVE, I.}

A. rigida, Miller, var. Sisalana, Engelm. Caulescent; leaves $\left(4^{\circ}-6^{\circ}\right.$ long) linear-lanceolate, unarmed, the terminal spine not decurrent; scape leafy-bracted $\left(15^{\circ}-20^{\circ}\right.$ high $)$; panicle horizontal, the clustered flowers often viviparous; corolla funnel-shaped; stamens and style exserted. - Sandy coast of South Florida.

\section{Order BROMELIACEA.}

\section{TILLANDSIA, L.}

T. Houzeavi, Morren (ined.). Scurfy $\left(10^{\prime}-20^{\prime}\right.$ high $)$; leaves rather tender, lanceolate-subulate, concave, spreading $\left(S^{\prime}-12^{\prime}\right.$ long $)$, the upper ones passing into the oblong acnte bracts; stem mostly simple; spikes linear, closely many-Howered; capsule linear, thrice the length of the lanceolate sepals; petals pale blue. - Slady river-banks, South Florida. October.

T. flexuosa, Swartz. Scurfy $\left(11^{\circ}-2^{\circ}\right.$ high $)$; leaves rigid $\left(1^{\circ} \mathrm{long}\right)$, very broad and spirally imbricated below the middle, and crossed with lines of gray and red, abruptly attenuate above, the upper ones oblong, acute; stem dark red, branching, the spikes flexnous, few-flowered; capsule twice the length of the bright red sepals; petals pale red.-Miami, South Florida (Garber). September-October.

\section{CATOPSIS, Griseb.}

Mostly like Tillandsia, but the stigmas nearly sessile, the stipe incurved, and dissolved into flexuous hairs from the base, the pappus spreading from the hilum, and the pendulous seed euding in a blunt coma.

C. nutans, Griseb. Not scurfy; stem usually nordding $\left(2^{\circ}-3^{\circ}\right.$ long); leaves thin, smonth, ovate-lanceolate, attenuate, pale $\left(10^{\prime}-15^{\prime} \mathrm{long}\right)$; caly $\mathbf{x}$ ovate, sessile on the flexuous branches of the simple pauicle, longer thin the ovate bracts; sepals oblong-oval, obtuse, enclosing the white spatulate petals ; capsule ovate. (Tillandsia, Swartz., Pogospermum, Brongn.) - Miami, South Florida (Garber), mostly on low trees. 


\section{OrDEI SMILACER.}

\section{SMILAX, 'Tourn.}

S. Havanensis, Jacq. I'rickly; leaves rigid, ovate or roundisl, emarginate, 5-nerved (3'- $4^{\prime}$ longr), the margins prickly. - Keys of South Florida (Curtiss).

\section{TRILLIUM, I.}

T. recurvatum, Beck. Stem (10 ligh) erect from a lorizontal tuber, leaves oblong-ovate, acute, contracted into a short petiole, faintly mottled; petals purplish brown, erect $\left(1 \frac{1^{\prime}}{2}\right.$ longr), linear-spatulate, twice as long as the lanceolate reflexed sepals; filanients as long as the incurverl anthers and the spreading stigmas. - lich valleys of the mountains of Georgia. April.

Var.? lanceolatum, Watson. Leaves sessile, more narrowly lanceolate; sepals less strictly reflexed; petals almost linear; filaments longer. (T. lanceolatum, Boykin.) - Georgia and Alabama.

\section{Order LtLIACE E.}

\section{POLYGONATUM, Tomn.}

P. giganteum, Dietrich. Smooth; stem tall (30-80 high), curving; leaves ovate, partly clasping, many-nerved; peduncles $3-5$-flowered, the lower ones half as long as the leaves; filaments smootlı. (P. canalieulatum, Pursh.) - Rocky cliffs of the mountains of Georgia, and northward. Flowers $\frac{8^{\prime}}{4}$ long.

\section{CAMASSIA, Lindl.}

Perianth bell-shaped, 6-leaved, deciduous. Stamens 6, inserted on the base of the perianth. Style filiform. Capsule 3-angled, 3-celled, loculicidally 3-valved, several-seeded. - Scape from a coated bulb. Leaves radical. Flowers racemose, blue or purple.

C. Fraseri, Torr. (Wrld IIracintr.) Leaves linear; seape $1^{\circ}$ high; raceme many-flowered; flowers showy, pale blue; cells of the ovary 6-9ovuled. - Rich valleys of the mountains of Georgia, and northward. April.

\section{ALLIUM, L.}

A. vineale, L. Seape leafy at base $\left(1^{\circ}-2^{\circ}\right.$ high $)$; leaves terete, hollow ; umbel often bulb-bearing; alternate filaments 3-cleft. - North Carolina (Curtis). Introduced.

\section{SCHCENOLIRION, Torr.}

S. Elliottii, Feay. Scape often sparingly branched $\left(1^{\circ}-2^{\circ}\right.$ high $)$; leaves linear, concave, the upper ones small and distant; racemes loosely 
many-flowered, bracts thiek, subulate, appressed; leaves of the perianth ublong-oval, 5-nerved, whitish ; filaments subulate. (S. Michauxii, 1st edit.) - Wet pine barrens, Georgia and Florida. May and June.

S. croceum, Gray. Scape simple (12' $-15^{\prime}$ high), leafless; leaves dry, narrow-linear, Hat, as loug as the scape; raceme ${ }^{\prime}-t^{\prime}$ long; bracts thin and scarious, oval, obtuse; leaves of the perianth saffron-yellow, lance-oblong, 3-nerved. (Phalangium croceum, Michx.) - Low ground, Southern Georgia to Tennessee. June.

\section{LILIUM, L.}

L. Grayi, Watson. Leaves lanceolate ( $2^{\prime}$ or less long), in whorls of $4-8$, not ac:uminate; flowers of ten solitary, horizontal $\left(1 \frac{1}{2}^{\prime}-2 \frac{y^{\prime}}{2}\right.$ long), the segments oblanceolate, spreading but not recurved, deep reckdish orange, purple-spotted. - Summit of Roan Mountain, North Carolina (Gray, \&c.).

\section{ERYTHRONIUM, L.}

E. albidum, Nutt. Leaves not spotted; flowers bluish white; style slender, the three stigmas distinct, spreading. - Summit of Roan Mountain, North Carolina (Cunby).

\section{ORDER JUNCACE $\boldsymbol{A}$.}

\section{LUZULA, DC.}

L. Carolinæ, Watson? Villous; lowest leaves broadly linear, as long as the stem; stem-leaves 3 , short ( $I^{\prime}$ lon $\left.q\right)$, distant ; umbel nearly simple, the setaceous branches spreading or drooping, 1-flowered; sepals ovate-lanceolate, very acute, as long as the ovate-acute capsule; seed not appendaged. - Shaded roeks on the mountains of Georgia and North Carolina. April.

\section{JUNCUS, I.}

J. Gerardi, Loisel. Stem terete $\left(1^{\circ}-2^{\circ}\right.$ high $)$; leaves linear; panicle contracted; flowers single; sepals oval-oblong, obtuse, the margins brown, rather longer than the oval light brown capsule. (J.bulbosus of Authors, not of L.) - Salt marshes, Florida, and northward.

J. leptocaulis, Torr. \& Gray. Stems low $\left(6^{\prime}-12^{\prime}\right.$ high $)$, caspitose, slender; leaves flat, few, shorter than the stem; heads 1-5, 3-6-flowered; sepals ovate-lanceolate, nearly equal, awn-pointed, longer than the $3-6$ stamens, and obovate capsule; seed obovate, apiculate. - Nashville, Tennessee ( $D r$. Guttinger), and westward.

J. diffusissimus, Buekley. Stems leafy ( $\left(\frac{1}{2}{ }^{\circ}-3^{\circ} \mathrm{long}\right)$, weak; leaves eompressed, knotted; panicle decompound, widely spreading, the clusters 5 -7-flowered ; sepals equal, lanceolate, acute ; capsule ( $t^{\prime \prime}$ long) oblonglinear, barely acute, twice as long as the sepals ; seed ovoid, obtuse. $\rightarrow$ New Orleans, 'Tennessec, and westward. 
J. militaris, Bigel. Stout $\left(2^{\circ}-4^{\circ}\right.$ high $), 1$-leared; hends pranicled, 510-1lowered; sepals lanceolate, acnte, as loug as the ovate, taper-beaked, 1. celled cansule; stamens 6 ; seeds globose-orate, abruptly pointed. -1 water, Alabama, and northward.

J. brachycarpus, lingelm. Stem erect $\left(1^{\circ}-2^{\circ}\right.$ high $)$, mostly 2 leaved, heals :-10, globular, closely many-flowered, pate green; sepals linear-subulate, unequal, the outer ones longer; capsule ovoid, acute, 1-celled, shorter than the sepals; style very short. - South Carolina (Bryrich), mountains of Georgia?, and northward.

J. asper, Engelm. Rigid, erect $\left(20-3^{\circ}\right.$ high $)$; leaves terete; panicle erect; hearls : -6 -Howered; sepals ovate-lanceolate, strongly nervel, very acute, the inner ones longer, and barely shorter than the beak-pointed capsule; seeds oblong, finely ribbed. - Swamps, IIenderson County, North Carolina (Canby), and nortliward.

\section{ORDER COMMELYNACEA.}

\section{TRADESCANTIA, L.}

T. Floridana, Watson. Stem $\left(4^{\prime}-8^{\prime}\right.$ long) tender, aseending from a creeping base, branching; leaves ovate or ovate-lanceolate, acute, eiliate at the base (䭪 or less long), the floral ones bract-like; flowers very small ( $Z^{\prime \prime}-$ $3^{\prime \prime}$ wide), terminal, shorter than their pedicels; sepals pubeseent. - Coast of East Florida (Curtiss).

\section{Order XYRIDACEA.}

XYRIS, L.

X. setacea, n. sp. Scape setaceous (10 ligh) like the terete leares, these $Z^{\prime}-5^{\prime}$ long; spikes ovoid ( ${ }^{\prime \prime}$ long); lateral sepals included, comnivent at the tips, the narrowly winged keel serrulate above the middle. - Margins of ponds near Mobile (Mohr).

\section{Order ERIOCAULONACEAE.}

\section{ERIOCAULON, L.}

E. septangulare, Withering. Leaves slıort $\left(1^{\prime}-2^{\prime}\right.$ long), subulatelinear, pellucid; scape weak and slender; heal small, hemispherical, densely white-bearded; scales of the involuere rounded; bracts spatulate. F. pellucidum, Michx.) - Wet pine barrens, Southern Mississippi (Prof. Milgard). 


\section{Order CYPERACE}

\section{CYPERUS, L.}

C. ligularis, L. (not of 1st edit.). Unbel many-rayed; spikes compact, cylindrical, compound, pale: spikelets slort $\left(2^{\prime \prime}-3^{\prime \prime}\right.$ long $)$, spreacling, nearly terete, 7 -flowered; scales thin, ovate, acute, 7 -nerved, twice the length of the obovate triangular acute nut; rachis broadly winged; culms stout, nearly terete $\left(2^{\circ}-3^{\circ}\right.$ high $)$, glaucous, like the broadly linear rough-edged leaves. Wet sandy places, Punta Rassa, South Florida. - The C. liguluris of the 1st edition is C. brunneus and $\because$. purpurascens, Vahl.

C. dissitiflorus, Torr. Unbel simple, 3-4-rayed; spikelets scattered along the upper portion of the slender rays, lanceolate, compressed, acute, 5 -i-flowered; scales oblong-lanceolate, acute; nut oblong-obovate, compressed-triangular; culms filiform $\left(1^{\circ}-2^{\circ}\right.$ high $)$; leaves narrow-linear. Mississippi, Tennessee, and westward.

C. acuminatus, Torr. Spikelets (whitish) numerous in a compact cluster, oblong, compressed, 20-30-flowered ; scales thin, keeled, oblong, tapering into a spreading point, faintly :-nerved; nut minute, narrowly obovate ; culms clustered; leaves one or two, very narrow, like the 3-leared involucre. - Low ground, Tennessee, and westward. - Culms $4^{\prime}-8^{\prime}$ high.

C. Lancastriensis, T. C. Porter. Culms triangular $\left(1^{\circ}-2^{\circ}\right.$ high), leaves rather broadly linear; umbel 6-9-rayed; spikelets subulate, numerous in an oval or globular 'sead, soon reflexed, 3-6-flowered; scales oblong, obtuse, twice the length of the linear-oblong nut; rachis broadly winged. Alabama (Porter), and northward. - The spikelets are like those of C. retrofiactus, Torr.

C. cylindricus. Umbel 3-6-rayed, simple, erect; heads oblong or cylindrical ; spikelets very numerous, lanceolate, 7 -9-Howered; scales oblong, 7-9-nerved, pale, twice the length of the oblong triangular nut; rachis very slender, narrowly winged; culms $\left(1^{\circ}-2^{\circ}\right.$ high $)$ triangular, smooth; leaves broadly linear, as long as the culm. (Mariscus cylindricus, Ell. ?) Saudy Keys of Caximbas Bay, South Florida.

C. retroversus, Chapm. Umbel simple, 8-rayed; spikes clavate-obovate; spikelets lanceolate, acute, reflexed, 2-3-flowered, the lowest flower fertile; scales oblong, 7 -nerved, scarcely longer than the oblong triangular nut; rachis very slender, broally winged; culm smooth $\left(2^{\circ}\right.$ high); leaves linear, involucre longer than the umbel. - Robert's Key, Caximbas Bay, South Florida.

\section{ELEOCHARIS, R. Br.}

E. compressa, Sulliv. Culms flat, from a creeping rootstock $\left(1^{\circ}-2^{\circ}\right.$ high) ; spikes ovate-oblong, many-flowered ; scales oblong, acute, dark purple, the margins white; nut obovate, conıpressed, the small tubercle acute; bristhes 1-4, very slender, about the length of the nut, often wanting. - Wet places, mountains of Georgia, Tennessee, and north ward. 


\section{SCIRPUS, I.}

S. (Oxycaryum) Cubensis, l'oepp. \& liuntl. Culms aentely 3 angular, leafy at base $\left(8^{\prime}-12^{\prime}\right.$ light ), slowrter than the leaves and the involuere; spikes obovate, compressecl, 12-tlowered, closely packed in a terminal glolualar lheal; scales rigid, oblong-obovate, tapering into a stout spreading point, 1:3nerved; stamens :3; style deeply 2-parted; nut ovate-lanceolate, acmminate, concavo-convex; bristles none. - Marshes, New Urleans (Lr. Male), Mobile (Hohr).

\section{TRICHELOSTYLIS, Lestib.}

T. miliacea, Nees. Culm weik, compressed-4-angled $\left(6^{\prime}-12^{\prime}\right.$ high $)$; leaves ensiform, straight, erect; umbel decompound, spreading; spikes small

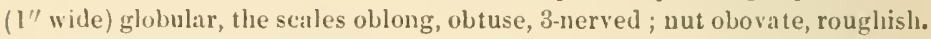
- Bogs and ditches, Apalachicola.

\section{ISOLEPIS, R. Br.}

I. carinata, Hook. \& Arn. Culms setaceous, with a single setaceous leaf at the base, caspitose; spike solitary, apparently lateral, ovate, 6 -8-flowered; seales ovate, acute, strongly keeled, twice as long as the acutely 3 -angled rouglish nut. - New Urleans (Dr. Male), and northward.

\section{RHYNCHOSPORA, Vah!}

R. stipitata, n. sp. Culms tall $\left(3^{\circ}-5^{\circ}\right.$ high $)$, triangular, bending; leaves linear; corymbs 4-5, compomd, drooping; spikes ( $4^{\prime \prime}$ long) ovate-lanceolit te, the scales persistent; nuts stipitate, $1-3$ in a spike, roundish, biconvex, finely wrinkled, twice as long as the compressed-conical tubercle; bristles 6 , more than twice the length of the nut; stamens :3. - River-banks, South Florida.

\section{CLADIUM, P. Browne.}

C. mariscoides, Torr. Culms nearly terete; leaves narrow-linear, suoothish; panicles $2-3$, the few branches erect; spikes $3-8$ in a cluster; mut ovate, aeute, faintly wrinkled. (Schœnus, Mull.) - Grassy ponds, West Florida, North Carolina, and northward.

\section{CAREX, L.}

C. trisperma, Dew. Spikes very small, distant, mostly with 3 fertile flowers, the lowest one leafy-bracted ; perigynia oblong, plano-convex, acute, finely nerved, longer than the thin white scale; culms very slemler, spreading or prostrate, $10^{\prime}-20^{\prime}$ long. - Cold shady swamps, mountains of Nortl Carolina (Dr. Gattinger), and northward.

C. gynandra, Sehw. Perigynium ovate or elliptical, aeute, obscurely nerved at the base, the upper ones crowded, and as long as the acute scale, the lower ones scattered, and shorter than the awned scales, sheaths retrorsely seabrous; otherwise like C. crinita. - Damp woods, Florida and northward. 
C. Meadii, Dew. Sterile spike mostly long-peduncled, slender; fertile spikes $1-3$, oblong ( $t^{\prime \prime}-8^{\prime \prime}$ long), elosely flowered ; perigynia obovate, abruptly contracted into the entire orifice, barely longer than the oblong acute broadly margined scale; culm $6^{\prime}-12^{\prime}$ high; leaves narrow-linear, slorter than the culm. - Mountains of Georgia, and northward.

C. oligocarpa, Sehk. Sterile spike short-peduncled; fertile spikes mostly 8 , loosely $4-8$-flowered; perigynia thick, finely striate, oblong, with a straiglit or slightly spreading point, shorter than the ovate long-awned white seale ; style very short ; culms $10^{\prime}-15^{\prime}$ higl ; leaves narrow-linear. North Carolina (Curtis), and northward.

C. polymorpha, Mulıl. Sterile spikes 1 or 2, slıort, long-peduncled; fertile spikes 1 or 2 , remote, erect ; perigynia oblong-ovate, minutely granular, entire at the white oblique orifice, longer than the ovate, mostly obtuse, brownislı-purple scale; culms $1^{\circ}-1_{2}^{\circ}{ }^{\circ}$ high ; leaves short, erect. - Low grassy meadows, North Carolina (Curtis), and northward.

C. Grayii, Carey. Fertile spikes 2, globose, elosely 15-30-flowered; perigynia sparsely pubescent (in ours), reflexed; culms tall $\left(2^{\circ}-3^{\circ}\right.$ ligh); otherwise like C. intumescens. - Swamps near Rome, Georgia, and nortlward.

\section{ORdER GRAMINER.}

\section{LEERSIA, Swartz.}

I. monandra, Swartz. Panicle nearly simple, exserted, spreading; spikelets ( $1^{\prime \prime}$ long) ovate, acute, flat, smootl ; stamen 1 ; culms $\left(2^{\circ}-3^{\circ} \mathrm{long}\right)$ smooth; leaves hroadly linear, rough above and along the margins. - South Florida (Herb. Thurber).

\section{PHARUS, P. Browne.}

Aquatic grasses, witl broad flat leaves, petiole-like sleaths, and monœcious flowers disposed in a simple terminal panicle. - Spikelets by pairs, unequal, the smaller one pedicelled, hexandrous, the larger one pistillate, with the lower palea indurated, involute. Glumes 2, thin. Style long; stigmas 2. Grain linear, jncluded.

P. latifolia, L.? Floating; leaves oblong, rough beneath, longer than the sheath; lower palea of the pistillate flower pointed, downy on the back, twice as long as the lanceolate glumes. - Orange Lake, Florida (Herb. Thurber).

\section{SPOROBOLUS, R. Br.}

S. Domingensis, Swartz. Culms braneling near the base, $2^{\circ}$ long; leaves narrow.linear, roughish above, mostly hairy at the base; panicle simple, narrow, the short spreading branches loosely whorled; spikelets shortpedicelled, smootlı; upper glume as long as the palea, twice as long as the lower one; upper palea truncate. - Wet sandy places on the Keys along the Reefs of South Florida. 


\section{MUHLENBERGIA, Schreber.}

M. arenicola, Buckley. (ulus tuftel, simple ( $2 \circ$ high); leaves short, flat, natrow-linear; panicie terminal, long-peduncled, simple, spreading; palear :-1servel, hearled at the hase, four times as loug as the oval obtuse or acute glumes, and equalling the rough awn. (M. cespitosa, (Kapm.) - I)ry pine barrens, Florida, and westwatel.

M. sylvatica, 'T. \& Fr. Culms diffuse, branched $\left(2^{\circ}-3^{\circ}\right.$ high $)$; panicles contrated ; palea as long as the nearly equal short-awned glumes, the lower one with its awn $2-3$ times the length of the spikelet. - North Carolina, Temuessee, and northward.

\section{CALAMAGROSTIS, Adans.}

C. brevipilis, Gray. Culıns tufted, simple $\left(2^{\circ}-3^{\circ}\right.$ high); leaves linear, setaceously attenuate; panicle long, narrow; glumes ovate-lanceolate, the upper one basely shorter thin the palea, the lower one half as long; palea bearded on the hack, twice as long as the hatirs at their base, awnless; rudi. ment of a second flower none. - East Florida, and northward.

\section{THURBERIA, Benth.}

Low tufted annual grasses, with ereet branching culms, soft-hairy leaves, and 2 -flowered spikelets in an ereet narrow terminal panicle. - Glumes 2, unequal, 3.nerved, hispid. Palea 2, included, the lower one smooth, coriaceous, armed below the apex with a stout bent dorsal awn; the upper one thin, witl an awn-like pedicel at its base. Stamens 2. Grain free.

T. Arkansana, Benth. Culms $6^{\prime}-12^{\prime}$ high. Leaves shorter than the culm ; panicle 2' -3 ' long. - On a shell mound near Apalachicola. A pril.

\section{ARISTIDA, L.}

A. simpliciflora, Chapm. Culms filiform $\left(2^{\circ}\right.$ high $)$, forking; leaves flat, smoothish; racemes simple, straight $\left(6^{\prime}-9^{\prime} \mathrm{long}\right)$, loosely flowered; glumes nearly equal, awn-pointed, the lower one rough on the keel, longer than the palea; midlle awn circular-curved near the base. - Damp pine barrens, West Florida.

A. gyrans, Chapm. Culms simple ( $1^{\circ}$ high), purple; leaves convolutefiliform ; panicle simple, with the branches appressed ; lower glume truncate, short-awned, as long as the palea, the upper one a third longer, attenuate; paleæ long-stipitate, the awns nearly equal, curved. - Keys of Caximbas Bay, South Floricla.

A. condensata, Chapm. Culms stout, simple $\left(2^{\circ}\right.$ high $)$; leaves rigid, flat or concave, soon convolute; panicle $\left(1^{\circ}-1 \frac{1}{2}^{\circ} \mathrm{long}\right)$, long-peduncled, contracted, densely many-flowered; glumes equal, awn-pointed, longer than the palex; awns straight, longer than the glumes. - Dry sandy pine barrens, West Florida. 
A. scabra, Kunth. Culm scarcely any, the long $\left(1 \frac{1}{2}^{\circ}-3^{\circ}\right)$ peduncle arising from a creeping rootstock; leaves radical, setaceously attenuate; panicle large, patulous, the branclies $2-5$ in a cluster; spikelets appressed; glumes awn-pointed, the lower one longer; awns straight, the lateral ones very short ; stamens 2. - Sandy coast, Florida.

\section{CYNODON, Richard.}

C. Dactylon, Pers., var. maritimus, Nees. Culms stouter (6' high); leaves shorter and broader, distichous, the sheaths imbricated; spikes 6-8. - Sandy coast, South Florida. - Leaves 1' long.

\section{BOUTELOUA, Lag.}

Spikelets crowded in two rows on one side of the flattened rachis, 1-3flowered, the lower flower perfect, the upper ones sterile or rudimentary. Glumes keeled, the lower one shorter. Lower palea 3 -nerved and :-toothed; the upper one 2-nerverl, 2-toothed. Stamens :3. Sterile flower awnell.

B. gracilis, H.B.K.? Annual ; culms filiform ; leaves narrow-linear, flat, papillose-ciliate; spikes 1 or 2, purplish, many-flowered, the smooth rachis awn-pointed; keel of the upper ghume papillose-bristly; teeth of the smonthish lower palea setaceons; awns of the sterile flower as long as the spikelet. - Dry pine woods, South Florida (Garber).

B. curtipendula, Gray. 1'erennial; culms simple $\left(1^{\circ}-2^{\circ}\right.$ high $)$; spikes sereral, distant, sprearling or reflexed, 4-12-flowered; flowers scabrous; teeth of the lower palea subulate; awns of the sterile flowers shorter than the spikelet. - Banks of the Flint River, Georgia (Feay). - A small form with 4 -flowered spikelets.

TRIPLASIS, Beauv.

T. sparsiflora, Chapm. Anmmal; culms rigid $\left(6^{\prime}-12^{\prime}\right.$ high); leaves short, linear-subulate; racemes axillary and terminal, simple, appressed, few-flowered; spikelets 2-4-flowered, the flowers distant; glumes nearly equal, the lower one 2-toothed, the upper acute; lower palea oblong, 3 nerved, ciliate, 2 -toothed, twice the length of its awn, the upper one villous above the middle. - Sandy coast at I'unta Rassa, South Florida.

\section{POA, L.}

P. brevifolia, Muhl. Culms erect $(2 \circ$ high); leaves broally linear, abruptly acute, those of the culm few and short; branches of the panicle few, mostly by pairs, bearing the 3-flowered spikelets near the end ; lower palea obtuse, faintly nerved, slightly hairy on the back. - Rich soil, Florida, and northward. April.

P. sylvestris, Gray. Culms compressed ( $2^{\circ}$ high); leaves thin; panicle long-pedmeled, ovate, the branches $5-6$ in a cluster, roughish; spikelets ovate, loosely 3 -flowered, the lower palea villous on the margins and keel. Mountains of Georgia and Tennessee. June. 
P. alsodes, Gray. Culms weak ( 20 high) ; leaves narrow-linear; panicle lonse, the setaceous branches mostly by fonrs; spikelets 2-4-flowered; glumes and palea acute, the lower palea hairy near the base. - Summit of I3lack Mountain, Nortlı Carolina (C'anby).

\section{ERAGROSTIS, Beauv.}

E. Brownei, Kuntlı. Low ( $6^{\prime}-12^{\prime}$ high), annual, tufted; leaves linear, attenuate; panicle sinple, racemose, the short brinches sprealing; spikes linear-lanceolate, nearly sessile, 20 -30-flowered ; lower palea ovate, acutisl, i-nerved, the "pper one ciliate. - Last Florida (Garber), Tennessee (Dr. Guttinger). - Probably a form of E. megastachya.

\section{BROMUS, L.}

B. racemosus, L. Panicle erect; flowers larger, the lower palea longer than the upper one, not longer than its awn; otherwise like $B$. secalinus, L. - Mountains of Georgia, Tennessee. Introduced.

B. sterilis, L. Annual; (ulms ascending ( $1^{\circ}-2^{\circ}$ long); leaves downy; panicle ample, drooping; spikelets thin, lonsely 5 -9-flowered, the long-awned flowers linear-subulate. - Tennessee, and northward. Introduced.

\section{ELYMUS, I.}

E. Canadensis, L. Spike long ( $6^{\prime}$ or more), erect or nodding, exserted; spikelets by pairs, 5-6-flowered; glımes and palex more or less rough-hairy, long-awned. - liver-banks, mountains of Georgia, and nortliward. - Culms $3^{\circ}-4^{\circ}$ high. Leares broadly linear.

\section{HORDEUM, I. BARLEY.}

Spikelets 3 at each joint of the terminal spike, the lateral ones imperfect, the midlde one 1-flowered, with a rudiment at the base of the upper palea. Glumes 2 before each spikelet, unequal, awned. Palex 2, the lower one awned. Stamens 3. Grain adhering to the palex.

H. pratense, Huds. Annual, 6'-18' high; upper sheath dilated ; lateral spikelets short-pedicelled, awnless, the middle one long-awned. - Road-sides and waste ground. Introduced.

\section{AIRA, L.}

A. crespitosa, I. Perennial; culms tufted $\left(2^{\circ}-4^{\circ}\right.$ high); leaves flat, linear; panicle oblong, with ereet clustered branclies; spikelets 2-flowered, with a bristle-like rudiment; lower palea denticulate at the tip, as long as the appressed awn. - Georgia (Leconte in Herb. Durand). Introduced.

A. caryophyllea, L. Annual, low $\left(5^{\prime}-10^{\prime}\right.$ high $)$; leaves setaceous; panicle widely spreading; spikelets 2 -flowered, purplish; lower palea 2-cleft, awned on the back. - Waste places. Introduced. 
DANTHONIA, DC.

D. compressa, Austin. Like D. spicata, but taller; leaves longer; panicle larger and more open; teeth of the lower palea longer and more slender. - Summit of Roan Mountain, North Carolina (Chickering), and northward.

\section{HOLCUS, L. SoFt Grass.}

Spikelets 2-flowered, the flowers short-pedicelled, the lower one perfect and unawner, the upper one triandrous and awned. Glumes 2, thin, keeled, enclosing the flowers. Palex 2, thin, equal, the lower one keeled. Grain free.

H. lanatus, L. Soft-downy, erect ( $2^{\circ}$ ligh $)$; panicle oblong $\left(2^{\prime}-t^{\prime}\right.$ long); awns recurved. - Low ground, North Carolina. Introduced.

\section{REIMARIA, Fluegge.}

Like Paspalum, but the spikelets ghmeless, and the sterile flower of one palea. - Culms creeping, spikelets appressed to the flexuous rachis in two rows.

R. oligostachya, Munro. Culms branching, leaves linear, attenuate, the sheatlis mostly longer than the internorles; spikes $3-4$, filiform, at length reflexed; spikelets sunk in the flexures of the rachis. - Banks of the St. John's, East Florida (Curtiss).

\section{PASPALUM, L.}

P. monostachyum, Vasey (ined.). Very smooth throughont; culm strictly erect ( $3^{\circ} \mathrm{high}$ ), simple; leaves erect, very narrow, striate-nerved, the lower ones $1^{\circ}-1 \frac{1}{2}^{\circ}$ long, the uppermost one short, pointing the elongated sheath ; spike solitary, long-peduncled, nearly straight, $6^{\prime}-7^{\prime}$ long ; spikelets in two rows beneath the filiform rachis, oblong-oval, obtuse ( $1 \frac{1}{2}{ }^{\prime \prime}$ long); lower palea slightly keeled; perfect flower smooth. - South Florida (Garber).

P. Reimarioides, n. sp. Culms long, ascending from a creeping base, branching; leaves narrow-linear, attenuate, the sheaths as long as the internodes; spikes mostly 3 , subterminal ( 2 ' long); spikelets in 2 rows under the straight triangular rachis, ovate-lanceolate, acute, the glume and undulate sterile palea equal, thin, 3-nerved, longer than the acute perfect flower.Brackish marshes along the coast, West Florida.

P. obtusifolium, Raddi. Creeping; flowering branches ( $\left.1{ }^{\circ} \mathrm{high}\right)$ singlejointed; leaves $\left(1^{\prime}-2^{\prime}\right.$ long) broadly linear, obtuse ; peduncles $2-4$ from the long sheath; spikes $2-4$, filiform; spikelets in 2 rows, ovate, acute; sparse. hairy, 3-nerved. (P. barbatum, Schulles.) - Damp waste ground, Georgia and Florida.

P. Boscianum, Fluegge. Perennial ; eulms simple $(2 \circ$ ligh $)$; leaves long, linear ; spikes several, distant, spreading ( 2 ' long); spikelets in 3 rows under the narrow flexuous rachis; upper glume more or less rugose within the pale thickened margins. (P. plicatulum, Wich $x$.) - South Carolina, and westward. 
P. conjugatum, lierg. Smonth and branching ( $2^{\circ}$ long); leaves thin, linear ; spikes $2-3)$, flat, the two terminal ones conjugate; spikelets mimute, in (wo ruws, ovate, long-tringed. - New Urleans (I/r. I/ale). Introduced.

P. dilatatum, l'oir. ('nluss stout ( $3^{\circ}-4^{\circ}$ ligh); leives flat, linear lancenlate, smootlı; spikes 4-6, racemose; spikclets in 4 rows, wrate, acute, villous, much wider than the flat rachis; glumes and sterile palea th-nerved, longer than the roundish perfect flower. - Nlabama, New Urleans, and westward.

\section{PANICUM, I.}

P. serotinum, Michx. Peremial, creeping, much lranched; leaves short (I' long), linceolate, villous, like the sheaths; spikes mostly $\bar{b}$, digitate; spikelets minute; ylume laali as long as the palee. (Digituria villosa, Ell.) - Fields and road-sides, Florida to Nortlı Carolina.

P. prostratum, L. Creeping, branching; leaves slort $\left(1^{\prime}-2^{\prime}\right.$ long $)$, ovate-lanceulate, ciliate; panicle short, composed of $5-10$ simple racenues; spikelets ovate-oblong, acute, short-pedicelled; npper glune and lower patea of the triandrous sterile flower 5nerved. (P. Aurelianum, Ilale.) - Mobile and New Orleans.

P. paspaloides, I'ers. Culms erect; leaves long, acuminate; panicle narrow, the branclies appressed; spikelets in two rows, ovate; glume 5nervert; sterile flower triandrous, much shorter than the fertile one. - South Florida (Blodgett, Garbler).

P. repens, L. Culms erect from ereeping rootstocks (10 high), very leafy; leaves rigid, lanceolate, distichous, beconing conrolute; panicle loose (1'-2' long); spikelets suooth, the upper glume and lower palea of the staminate sterile flower strongly 7-nerved. - Sandy coast, Mobile (Mohr).

P. agrostoides, spreng. Very near some forms of $P$. anceps, but the fanicle more branched and contracted, the purplish spikelets smaller, and not clustered, and the upper glume 5-nerved. - Ditclies, \&e., Florida, and northward.

P. striatum, Lam. Culms sparingly lranclied ( $2^{\circ}-3^{\circ}$ high) ; leaves lanceolate, with scabrons margins $\left(6^{\prime}-8^{\prime}\right.$ long); panicle somewlat corymbose, consisting of several erect simple racemes; spikelets oljong, ncute; the upper ghme and sterile palea strongly 7 -nerved ; perfect flower rugulose. Banks of the Caloosa River, South Florida.

P. leucophæum, 11.13 K. Culms tall, branching; leaves broadly linear, rough above, hearicel at the throat $\left(1^{\circ} \mathrm{long}\right)$; panicle contracted, racemose $\left(10^{\prime}-1 .\right)^{\prime}$ long), the simple branches erect; spikelets stattered on one side of the slender rachis, lancecolate, silky-pilose; lower glume minute or wanting, the upper one linear, 3 -nerved, shorter than the perfect flower; lower palea of' the nentral flower longer than the fertile one, 5 -nerved. - Chuckolisky Niey, South Florida (Garber).

P. maximum, Jaq. Culms $\left(4^{\circ}-5^{\circ}\right.$ high $)$ smooth; leaves linear; panicle very large, composed of long $\left(6^{\prime}-12^{\prime}\right)$ straight clustered branches ; spikelets 
smootl, oblong, faintly nerved; lower glume nearly half as long as the abruptly pointed upper one; palex of the triandrous sterile flower nearly equal. - South Florida.

P. commutatum, Schultes. Culm smooth ( $2^{\circ}$ high); leaves $\left(3^{\prime}-6^{\prime}\right.$ long) ovate-lanceolate, the margins and sheath ciliate ; panicle diffuse ; spikelets oblong, sparsely pubescent; the upper glume and lower palea of the neutral flower 7 -nerved; perfect flower acute. (P. nervosum, Ell.) - Dry woods and margins of fields, Florida to North Carolina.

P. sphærocarpon, Ell. Culms rigidly erect $\left(1 \frac{1}{2}{ }^{\circ}-2^{\circ}\right.$ high $)$; leaves rigid, lanceolate, smooth, the rough margins near the base, and sheaths, ciliate; panicle oval, diffuse; spikelets small, oval, almost villous; upper glume 7-nerved; upper palea of the neutral flower minute or wanting. Shallow grassy ponds, Georgia and Florida.

P. consanguineum, Kunth. Smooth or villons; culms $\left(1^{\circ}-1 \frac{10}{2}\right.$ high $)$ at length excessively branched; leaves linear, erect; panicle long-peduncled, the flexuous widely spreading branches few-flowered; spikelets obovate, pale, pubescent; upper glume 7-nerved; upper palea of the neutral flower none; perfect flower acute. (P. villosum and angustifolium, Ell. P. setaceum, Mull. P. subuniflorum, Bosc.) - Woods and borders of fields, Florida to North Carolina, and westward.

P. laxiflorum, Lam. Culms tufted, smooth $\left(1^{\circ}\right.$ high); leaves lanceolate, acuminate, ciliate, mostly pale yellowish green $\left(2^{\prime}-3^{\prime}\right.$ long $)$, the villous sheaths shorter than the internodes; panicle diffuse, plumose-bearded, rather few-flowered; spikelets scattered, oval, densely pubescent, the upper glume 7-nerved; neutral flower bipaleaceons; fertile flower acute. (P. pubescens, Vichx., the culms pubescent, and the panicle more dense.) - Damp soil, Florida, and northward.

P. ramulosum, Michx. (in part). Low $\left(6^{\prime}-8^{\prime}\right.$ ligh), tufted, very smooth and shining; culm mostly purple; leaves linear; panicle diffusely branched, many-flowered ( $1 \frac{1}{2}^{\prime}-2^{\prime}$ long); spikelets minute, purple, very smooth, the upper glume and neutral palea 5-nerved.-Low sandy pine barrens, Florida and Georgia.

\section{CENCHRUS, L.}

C. incertus, M. A. Curtis. Smonth, strict, nearly simple, erect or ascending $\left(2^{\circ}-3^{\circ}\right.$ long $)$; leaves linear, folded, the lower sheaths longer than the internodes; spike cylindrical, many-flowered; involucre naked and acute at base, the 10 or 11 stout spines ciliate; spikelets geminate, smooth; sterile flower triandrous. (C. strictus, Chapm.) - Sandy coast, Florida to North Carolina.

C. myosuroides, H.B.K. Tall $\left(4^{\circ}-6^{\circ}\right.$ high $)$; leaves long, rigid, convolute; spikes cylindrical, densely many-flowered; involuere small, 1-flowered, armed with 20 , or more, slender spines, as long as its strongly nerved spikelet. (Panicum cenchroides, Ell.) - South Florida (Blodgett), Georgia (Elliott). 


\section{ANDROPOGON, I.}

A. arctatus, Cliapm. Culms single $\left(2^{3}-30\right.$ high), the appressed branches narrowly paniculate; leares and sheaths shaggy with long white, mostly deciduous hairs; spikes by pairs $\left(I^{\prime}-1 l^{\prime}\right.$ long), ratler stout; ctosely $15-20$ flowered; glumes rough, twice as long as the joints of the rachis; perdicel of the neutral flower tipped with two slender glumes; lairs of the rachis few aud short; stamen 1. (A. tetrastaclyus, var., 1st edit.) - Low pine barrens, Florida.

A. brachystachyus, Chapm. (in Curtiss's Fascic.). Culms $\left(2^{\circ}-4^{\circ}\right.$ high) compressel, branching from all the upper joints, narrowly paniculate; leaves linear, not hairy, rough on the margins; spikes very numerous, by pairs, short ( $6^{\prime \prime}-8^{\prime \prime}$ long) ; spikelets, \&c., as in A. macrouras, of which it is probably a marked form. - East Florida (IIerb. Durand, Curtiss).

A. maritimus, n. sp. Smooth and glaucous; culms ascending from creeping rootstocks $\left(1^{\circ}-1 \frac{1}{2}^{\circ}\right.$ ligh $)$; leaves $\left(2^{\prime}-5^{\prime}\right.$ long) widely spreading, their eompressed sheaths distichous, imbricated; panicle sinple, racemose ( $t^{\prime}-8^{\prime}$ long); spikes single, 8-10-flowered, very silky; glumes equal, twice as long as the stout joints, and lialf as long as the twisted awn; sterile flower triandrous. - Sandy coast, West Florida.

A. argenteus, Ell. (not of 1 st edition). Smooth; culms branching (2 ${ }^{\circ}$ high); leaves long, linear; branches $1-2$ from each upler joint, simple, long-exserted; spikes by pairs on the long $\left(3^{\prime}-8^{\prime}\right)$ stout peduncle, white with dense silky hairs; joints of the rachis rigid, as long as the hispid-serrulate spikelet; palex unequal; stamens 3.-Old fields and open woods, Florida, and northward.

\section{IMPERATA, Cyrill.}

Spikelets by pairs on the slender branches of the spike-like panicle, one sessile, the other pedicelled, both fertile and 2-flowerel, the lower flower neutral. Glumes 2, thin, nearly equal, woolly; lower flower of one palea, the upper one perfect. Stamens 2.

I. caudata, Cyr. Culm simple ( $2^{\circ}$ high) from long creeping rootstoeks; leaves broadly linear $\left(2^{\circ} \mathrm{long}\right)$, those of the culn few and short; panicle white-woolly, oblong ( $4^{\prime}-5^{\prime}$ long); flowers minute. - South Florida.

\section{SORGHUM, Pers.}

S. pauciflorum, Chapm. Annual ; culms branched near the base (20$3 \circ$ high); leaves long, broadly linear, flat, ciliate; spikelets few $(6-12)$, racemose, the long $\left(2^{\prime}-3^{\prime}\right)$ setaceous pedieels in whorls of $2-6$; glumes equal, linear, rigid, convolute, the lower one bifid, the upper one truncate; awn very long $\left(5^{\prime}-6^{\prime}\right)$, geniculate, $t$ wisted and tortuous below the middle; sterile flower triandrous, linear, acute, or reduced to two setaceous spirally twisted pedicels. - Sandy pine barrens, East Florida. 


\section{Order EQUISETACEAE.}

\section{EQUISETUM, L.}

E. robustum, A. Braun. Stem tall $\left(2^{3}-4^{\circ}\right.$ high $)$, stout, simple; the ridges roughenel by a single row of tubercles; sheaths short, appressed, with a black girdle above the base, and about forty :3-keeled ovate-subulate deciduous teetl. - Banks of the Chattahoochee River, Georgia, and westward.

\section{Order FILICES.}

\section{POLYPODIUM, L.}

P. pectinatum, L. Stipe erect from a stout rootstock, smoothish $(2$ $6^{\prime}$ long); frond $1^{\circ}-2^{\circ}$ long, broadly lanceolate, attenuate at eacli end, deeply pinnatifid; pimnæ very numerous, alternate, linear-lanceolate, obtuse, mostly entire; sori in two rows. - On trees, East Florida (Miss Reynolds, Gurber).

P. Swartzii, Baker. Rootstock very slender, long and climbing; fronds single, or ' $z-3$ together, $4^{\prime}$ or 5 ' long, lanceolate, mostly obtuse, narrowed at base into the short stipe, the margins wavy, entire; sori in a single row on the free reinlets. (P. serpens, Swartz.) - Key Largo, South Florida (Curtiss), climbing on low buslies.

\section{T止NITIS, Swartz.}

Sori linear, continuous or interrupted, central or intramarginal. - Veins reticulate.

T. lanceolata, R.Br. Rootstock thick, creeping; frond $6^{\prime}-12^{\prime}$ long, lanceolate, entire, narrowed at base into the short smooth stipe; sori intramarginal along the upper part of the frond.-On trees, Rhoda Key, South Florida (Curtiss).

\section{PTERIS, L.}

P. serrulata, I. f. Like $P$. Cretica, L., but the frond bipinnatifid, the numerous divisions narrower, and the rachis broadly winged. - On walls, Charleston. Probably introduced.

\section{CERATOPTERIS, Brongn.}

Sori on 2 or 3 veins which are parallel with the midrib and margins of the frond, the fruit-dots sessile, roundish, the involucre formed by the inflexed margins of the frond which meet at the midrib.

C. thalictroides, Brongn. Floating; stipes thick, witlı large air-cells ; fronds tender, the sterile ones ovate in outline, broally 3-lobed or 3-parted, or at length bipinnatifil, the margins wary or bluntly lobed; the fertile ones '2-3 pinnate, with linear livisions. - Heal-waters of the St. Joln's (Curtiss). 


\section{CHEILANTHES, Swartz.}

C. microphylla, Swartz. Stipe dark brown, from a short rootstock, smoothish; fromd smooth, broally lanceolate, $2-3$ pimatifil, 3 ' $-y^{\prime}$ long; pima lancentate from a broaler base; pimmles linear-oblong, obtuse, entire, or the lower ones pinsatifid; involncre pale, narrow. - Islands near the mouth of the St. John's (C'urtiss). - Frond $1^{\circ}$ or less long.

\section{ADIANTUM, I.}

A. tenerum, Swartz. Frond deltoid, ?-4-pinnate; pinnules stalkel, obliquely rhombic, the wedge-shaped base and lower edge entire, the upper edge broadly and shortly lobel, bearing the transverse sori at their tips. East Floricla (Feay, \&c.). - Fern $10-30$ ligh, the black stipe and rachis sinooth aud glossy.

\section{SCOLOPENDRIUM, I.}

Sori as in Asplenium, but the involucres arrangel in pairs, and opening towards each otlier.

S. vulgare, Smith. Stipe smoothisl, $2^{\prime}-3^{\prime}$ long from a thick rootstock; frond lanceolate-oblong, acute, slightly serrulate, cordate at the base, $\sigma^{\prime}-9$ long, the upper lialf frnit-bearing. - Shaded rocks, 'Tennessee, and nortlward.

\section{ASPLENIUM, I.}

A. Bradleyi, Eaton. Frond tlin, pinnate below, pinnatifid abore, lanceolate-oblong, barely acute, $8^{\prime}-7^{\prime}$ long; pinne sloort-stalked, oblong-ovate, the lowest ones lobed or pinnatifid. - Eist Tennessee (Euton). - Rootstock slrort. Stipe smooth, black.

A. ebenoides, R. R. Scott. Fronl thin, broally lanceolate, pinnate below, pinnatifia above, long-attenuate and often rooting at the apex, $4^{\prime}-9^{\prime}$ long; pinne lanceslate from a broader base, $3^{\prime \prime}-9^{\prime \prime}$ long. - Shady ravines, Central Alabama, and northward. Rare.

A. parvulum, Mart. \& Galeotti. Frond rigid, lanceolate, pinnate, $2^{\prime}-8^{\prime}$ Iong; pinnw nearly opposite and sessile, oblong, entire or crenulate, auricled on one or botll sides at the base, $2^{\prime \prime}-6^{\prime \prime}$ long; sori half-way between the margins and midrib. - Calcareous rocks, Florida to Tennessce.

A. cicutarium, Swartz. Tufted from a slort rootstock, $y^{\prime}-12$ ' high, smootl, ; stipe blackish; frond thin, ovate or oblong, pinnate or nearly bipinnate; pinnæ lanceolate, obtuse; pinnules oblique, entire on the lower edge, toother on the upper, with the teeth 2 -i-cleft; sori in two rows. - Sumpter County, S. Florida (C. F. Adams).

A. firmum, liunze. Rontstocks short; frond ovate or oblong, pinnate, ratler longer thin the pale smooth stipe, $12^{\prime}$ or less long; pinnæ (about 12) lanceolate or oblong, obtuse, serrate, the terminal one attenuate; sori in two rows. - Marion County, Florida (.J. D. Smith). 
A. serratum, L. Frond entire, acute, long-tapering at the base, $1^{\circ}-2^{\circ}$ long, the margins wavy and serrate; sori linear, on the lower third of the veins. - Eastern coast of South Florida (Garber, Curtiss). - Stipe short and rigid.

\section{ASPIDIUM, L.}

A. conterminum, Willd, var. strigosum, Eaton. Rootstock thick, erect; stipe short and scaly ; frond $1 \frac{1}{2}^{\circ}-3^{\circ}$ high, oblong-lanceolate, attenuate at each end, pinnate; pinnæ very numerous, lanceolate, acuminate, sessile, pinnatifid, the lower ones gradually reduced, the segnents obliquely acute, the lowest ones often elongated; sori small, in a single marginal row. - Polk County, Florida (J. D. Smith).

A. unitum, var. glabrum, Mettenius. Stipe long and slender, from a slender creeping rootsiock; frond rather rigid, smooth, ovate-lanceolate, pinnate, $1 \frac{10}{2}-2^{\circ}$ long; pinnæ lanceolate, pinnatifid-lobed, the lobes rounded; lower veins of contiguous lobes united; sori forming a eontinuous zigzag intramarginal line. - Boggy places, South Florida.

A. trifoliatum, Swartz. Frond thin, cordate-ovate in outline, 3-lobed, or 3 -foliate, the ovate pinnæentire or 3 -lobed, acuminate, the margins nndulate; sori scattered; involucre peltate, orbicular. - Hernando County, Florida (Curtiss). - Frond $1^{\circ}$ or less long, barely longer than the slender stipe.

\section{OPHIOGLOSSUM, L.}

O. palmatum, Plnm. Frond thick and succulent, drooping, $4^{\prime}-10^{\prime}$ long, stipitate from a short woolly rootstock; sterile ones cuneate at base, simple, or palmately 2-6-lobed, the lobes tongue-shaped, rarely forking; fertile fronds 1 -several at the top of the stipe, or along the basal margins of the sterile frond, short-stalked, 1' long. - In the axils of the leaves of the Palmetto. South Florida.

\section{Order LYCOPODIACEA.}

\section{LYCOPODIUM, L.}

L. inundatum, I. Var. adpressum, Clıapm. Size and habit of var. pinnatum, but leaves thinner, entire, those of the spike, which is barely thicker than its peduncle, closely appressed. - Damp pine barrens.

Var. elongatum, Cliapn. Sparingly branched $\left(1 \frac{1}{2}-2^{\circ} \mathrm{long}\right)$; leaves subulate-attenuate, entire, spreading; peduncle slender, erect or leaning $\left(10^{\prime}-15^{\prime}\right.$ long), the leaves scattered, those of the spike longer, spreading. Wet or overflowed banks, Apalachicola.

L. cernuum, I. Stem forking near the base $\left(6^{\prime}-12^{\prime}\right.$ long $)$, the divis. ions arcuate-recurved, and rooting at the tip, the short alternate branches 
torking, and terminated by the short $\left(4^{\prime \prime}-6^{\prime \prime}\right)$ nodiling spike; leaves ubout G-rowed, linear-subulate, entire, spreading or recurved; those of the spike ovate, acuminate, with bristly margins. - Springy sandy places, latst Florida (Curtiss), and Alabama (Molir).

\section{ORDER HYDROP'TERIDES.}

MARSILIA, L.

Plants with filiform creeping stems, a whorl of 4 werlge-shaped leaves at the summit of a long ereet petiole, and one or more globular sporangia borue on a slender stalk at the bise of the pelioles, each divitled into sev. eral partitions, which continu the larger and smaller spores.

S. uncinata, A. Bram. Stem long; leaves smooth or hairy ; sporangia oval, compressed, half as long as the peluncle. - Banks of the Mississippi below Vicksburg.

\section{ISOETES, Is.}

I. melanospora, Engelm. Small, mostly monюcious; leaves few (510), distichous ( $z^{\prime}-2 \frac{1}{2}^{\prime}$ long) ; spore cases coveret by the thin ertges of the cavity (velum); larger spores blackish, very minntely warty, the smaller ones dull, papillose. (Engelmann.) - In shallow depressions on the simmit Stone Mountain, Georgia (Engelmann, \&॰c.).

I. Engelmanni, A. Braun, var. Georgiana, Engelur. Leaves 10'-12' long, rather slemder, stomatose; spore-cases oval, with marrow velum : lirger spores and smaller spores smooth. - Slow-flowing water in IIorseleg Creek, mountains of Georgia.

I. Butleri, Engelm. Diœcious; trunk nearly globose; leaves 8-12, briglit green, $z^{\prime}-7^{\prime}$ long; spore-cases usually oblong, spotted, the velum very narrow, or none; ligule subulate, from a triangular base; larger spores warty, smaller spores dark brown, papillose. (Engelmam.) - Barrens of Tennessee ( $D r$. Guttinger), and westward. 


\section{Order ACANTHACEAE.}

[Omitted on p. 636.]

\section{HYGROPHILA, R. Br.}

Calyx equally 4-cleft. Corolla 2-lipped, the lower lip 3-lobed. Stamens 4, didynamous: anther cells parallel, spreading at the base. Stigma simple. Capsule narrow, nearly terete, bearing the mumerous orbicular seeds at its base. - Aquatic herbs. Flowers axillary, in cymose clusters.

H. lacustris, Nees. Stem long $\left(2^{\circ}-4^{\circ}\right)$, erect from a procumbent base, 4-angled; leaves sessile, lanceolate; cymes opposite, few-flowered; calyx smooth; flowers white. - Muddy banks of the Apalachicola River ( $D r$. Saurman), and westward.

\section{STENANDRIUM, Nees.}

Calyx 5-parted. Corolla salver-form, equally 5-lobed. Stamens 4 : anthers 1-celled. Stigma truncate. Cells of the ovary 2-ovuled. - Low perennial herbs, with a scupe-like stem, clustered radical leaves, and purplish flowers in a terminal spike.

S. dulce, Nees, var. Floridanum, Gray. Smooth; leaves oval or oblong, long-petioled, as long as the scape; spike capitate, few-Howered, the bracts ciliate; tube of the corolla longer than the calyx; capsule clubshaped. - Indian River and Key Biscayne, South Florida (Curtiss). - Leaves $1^{\prime}$ long. Corolla $\frac{1^{\prime}}{2}$ wide. 



\section{N D E X .}

Abies,

Abietines,

Abildgaardia,

Abutilon,

Acalypha,

ACANTHACEE,

Aeanthus Family,

Acer,

Acer,

$\triangle$ CERACER,

Acerates,

Achillea,

ACIrravilie.e,

Acmella,

Acnida,

Aconitum,

Acorus,

ACROGENS,

Acrostiche.z,

Acrostichum,

Actæa,

Actinomeris,

Actinospermum,

Adder's mouth,

Adder's tongue,

Adelia,

Adiantum,

Adlumia,

Eschynomene,

Asculus,

Agave,

Ageratum,

Agrimonia,

Agrimony,

Agrostemma,

Ag rostidede,

Agrostis,

Igrostis,

Aira,

Lira,

Air-Plant,

AJUGEe,

Alchemilla,

\begin{tabular}{|c|c|c|}
\hline Page & & Page \\
\hline 434 & Alder, & 429 \\
\hline 432 & Aletris, & 470 \\
\hline 523 & Alisma, & 447 \\
\hline 55 & Alisma, & 448 \\
\hline 405 & ALISIIACE E, & 447 \\
\hline 302 & ALISHE.E, & 447 \\
\hline 302 & Allionia, & 373 \\
\hline 80 & Allium, & 482 \\
\hline 81 & Allspiee, & 130 \\
\hline 80 & Almond, & 129 \\
\hline 365 & Alnus, & 429 \\
\hline 242 & Alopecurus, & 549 \\
\hline 379 & Allosones, & 590 \\
\hline 237 & Alsine, & 48 \\
\hline 381 & Alsinefe, & 45 \\
\hline 10 & Alternanthera, & 382 \\
\hline 442 & Althiea, & 58 \\
\hline 585 & Alum-root, & 152 \\
\hline 586 & AMARANTACEE, & 378 \\
\hline 588 & Amaranth, & 379 \\
\hline 11 & Amaranth Family, & 378 \\
\hline 232 & Amarantus, & 379 \\
\hline 241 & Amarantus. & 380 \\
\hline 453 & AMARYLLIDACEA, & 466 \\
\hline 599 & Amaryllis, & 466 \\
\hline 370 & Amaryllis Family, & 466 \\
\hline 590 & Amblogyna, & 381 \\
\hline 22 & Amblygonon, & 388 \\
\hline 99 & Ambrosia, & 223 \\
\hline 79 & Amelanchier, & 129 \\
\hline 468 & American Barberry, & 17 \\
\hline 189 & Amcrican Cowslip, & 281 \\
\hline 122 & Amianthinm, & 490 \\
\hline 122 & Ammannia, & 134 \\
\hline 52 & Ammi, & 162 \\
\hline 545 & Amorpha, & 93 \\
\hline 551 & Ammophila, & 554 \\
\hline $55: 3$ & Ampelopsis, & 71 \\
\hline 568 & Amphianthus, & 295 \\
\hline 568 & Amphicarpaa, & 107 \\
\hline 470 & Amphicarpum, & 572 \\
\hline 311 & Amsonia, & 360 \\
\hline & & \\
\hline
\end{tabular}

Page 
ANACARIIACEA,

Anacharis,

Anatuallis,

Amiromeda,

Indiomeda,

AXIROMEDEA,

Andropogon,

Indropayon,

AxmRoperones,

Ancimiar,

Anemone,

AXEMUXEA,

Angrelica,

ANGIOSPERME,

Anise-tree,

ANUNACEA,

Antennaria,

Autirrlimun,

Anthemis,

Anthoxanthum,

Anvelia,

Amishire,

A petalous Exogenous Plants,

Apios,

Aphora,

Aphyllon,

Aplectrim,

Al'OCYNACELE,

Apoeymum,

Apogon,

Apple,

A pricot,

Aliteria,

AQITFOLIACEA,

Aquifolium,

Aquilegia,

Arabis,

ARACER,

Aralia,

A RALIACE E,

Arbor-Vita,

Archangelic'a,

Areliemora,

Arrlisia,

Arenaria,

Arenaria,

Arethusa,

ARLTHUSE.E,

Argemone,

Arisama,

Aristida,

Aristoloclia.

$\triangle R I S T O L O C H I A C E$ E.

Arnica,

Aronia,

Arrhonatherum,

Arrow-Arum,

A rrow-orrass,

Artemisia,

Arum,

Arum Fumily,
68 Arumdinaria, $\quad 56 ;$

45 () Arumdo, 562

281 A-amaluacear,

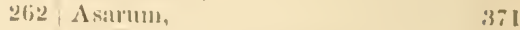

261, 262, 263 ASCILIIIADACEA;

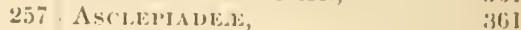

581) 1 inclepins, 362

$5.56,583$ Ascyrmm,

5fR Asi, 369

598 Aximina, 15

4 Asm.tRAGE.R, 4 \&O

$2 \Lambda$ spen, 431

164 ASTHIELE.V, 480

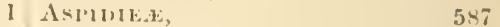

12 Aspoidium, 594

14 A-IPLEXIE.E,

243 Isplenimm, 592

290 A.ter, 198

241 Aster, 197, 198, 207, 208

569 ASTRKOIDE.E, $\quad 197$

46 Astilbe, 154

46 Astrigialus, 97

371 Atamasco Lily, 466

105 Athyrium, 593

408 Atragene,

287 Atriplex, 377

455 Atriplex, $\quad 377$

358 Atropk, 3.51

358 Aulaxanthus, 577

249 AURAN'TIACEA,

128 ferna, 569

129 AVEXACEA, 547

452 Areus, 123

268 Avicentia, 309

269 Avickxites, 306

9 Avicularia, 390

27 Ayenia, 59

439 Aralea, 265

166 Azolia, 602

166 Baccharis

164 Bachelor's Button 217

165 Bald Cypress, $\quad 435$

277 Ballwinia, $\quad 240$

49 Balduinia, 241

49 Bahm, 318

4.58 Balsam Family, 6.5

453 BALA

21 Balsam-trec Family, 42

439 Baneberry, 11

554 Baptisia, 110

371 Baptisia, 113

371 Barberry, 17

246 Barberry Family, $\quad 16$

128,129 Bartonia, 356

$\begin{array}{ll}569 \text { Basil, } & 312\end{array}$

440 Bascwood, 59

448 BАTII $\triangle \mathrm{CE}$ E, 411

242 Batis, 411

440 Batis Family, 411

439 Batodendron, $\quad 259$ 
Batschia,

Batatas,

Bayberry,

Beak-Rush,

Bean-Caper Family,

Beard-grass,

Bear-grass,

Beech,

Beceh-drops,

Beggal-ticks,

Bejaria,

Bellflower,

Bellwort,

Bellwort Family,

Bent-yrass,

Benzoin,

BERBERID ACE E,

Berberis,

Berchemia,

Berlantliera,

Bermuda grass,

Betula,

BETULACEA,

Birlens,

Bigelovia,

Bimonia,

Bimponice,

BIGNONLACEE,

BIGNONIEE,

Bignonia Family,

Biotia,

Bireh,

Birch Family,

Birthwort,

Birthwort Fumily,

Black-Jack,

Black Snakeroot,

Bladdler-Nat,

Bladder-Nut Family,

Bladilerwort,

Bladderwort Family,

BLECIXNEA,

13lechuum,

Blephilia,

Bletia,

Blood-root,

Bloodwort Family,

Blueberry,

Blue Cohosh,

Blue Curls,

Blue-eyed grass,

Blue Flag,

Bluets,

Buehmeria,

Boerhaaria,

Boltonia,

Bonnets,

Borage l'amily,

Borlihuusia,

BORRAGINACE $A$.

Burrages,
332 Borreria, $\quad 175$

341 Borrichia, 224

426 Botrychium, $\quad 599$

523 Borkinia, 153

63 Brachychceta, 213

552 Bracliyelytrum, $\quad \mathbf{5 5 3}$

485 Brake, $\quad 589$

424 Bramble, 124

286 Brasenia, 19

236 Brasiletto Family, 114

266 Brier, 124

256 Brickellia, 193

486 Brizu, 563

486 Bryzopyrum, $56 \div$

551 Brome-grass, $\quad 5.56$

394 BROMELIACE $\mathrm{E}_{2}$

16 Broom-Corn, 583

17 Broom-grass, $\quad 580$

73 Broom-rape Family, $\quad 286$

221 Bronssonetia, 415

557 Brunella, 322

428 Brunnichia, 392

428 BRUNNICHIEE,

236 Bryonia, 148

215 Buchnera, 296

285 Buckeye, 79

285 Buckleya, 397

284 Buckthorn, 73

284 Buckthorn Family,

284 Buckwheat Fimily, 384

198 Bugbane, 11

428 Bullace,

428 Bumelia, 274

371 Buphthalmum, 224

371 Bupleurum, $\quad 162$

421 Burdock, 248

11 Burmannia, 451

77 BURMANNIACEA,

77 Bumamia Family, 451

282 Burr-reed, $\quad 443$

282 Bursera, 68

586 BURSERACEA, 67

591 Busli-Clover, 100

321 Butter-Cup, 7

456 Butter-mut, 419

2. Butter-weed, 245

469 Butterwort, 283

259 Button-bush, $\quad 176$

17 Buttoli-Snakeroot, $\quad 159,190$

327 Byrsonima, 82

473 BYTTNERIACEA,

472 Byttneria Fanily; 58

180
414
Cabomba,

373 CAMOMBACEA, 18

207 Caealia, 244

20 CACTACEN, 144

328 Cactus Family, 144

252 CISALXNAER, 88

328 Cakile, 30

328 Calaunagrostis, $\quad 553$ 
Calamintlaa,

Calamms,

('ulico-bush,

Callinstrum,

Callicarpar,

Callirrbü,

CAlIIRICIACEA,

Callitriche,

Culonelisisa,

Calomyrtion,

Calophanes,

Calopogou,

Caltia,

CAI,YCANTHACEA,

Calveantums,

Calycocarpum,

Calyptranthes,

Calystegia,

Camelina,

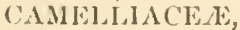

Camellia Fanily,

Campanula,

Campremula,

Campanula Family,

C.MMANULACEA,

Camptosorus,

Campylonenrum,

Canavalia,

Canse,

Canellat,

CANNABINACE.F,

Camna,

Canna Family,

CANNACLA:

Cantua,

Caper Family,

Caper-tree,

CAI'I'ARIDACEA,

Capparis,

Capraria,

CAIRIFOLIACEA,

Caprifolium,

Capsellit,

Capsicum,

Cardamine,

Cardamine,

Cardinal-flower,

Cardiospermum,

Carex,

Carices,

Carolina Allifuice Family,

Carphepliorus,

Carpinus,

Carva.

CAKYOPIIYLLACEA,

Cashew Family,

Cassandi*a,

Cassia,

Cassyta,

Cassitea,

Castanea,
317 Castillein, 300

442 Custor-oil I'lant, 409

264 Cutulpu, 285

198 Catchifly, 51

309 Catnip, 321

5.3 Cat-tuil, $X$

398 Cat-tail Family,

399 Cimlinia, 444

317 Canloplivllim, 17

344 C'mothis, 74

303 CEI)lilil, ACli.ti,

456 Cidronella, 322

9 CELAS'TRACLA,

129 Celastrus, $\quad 76$

130 Celosial, 379

16 Cleosike, $\quad 379$

131 Celtis, 417

344 Cenchrns, $\quad 578$

30 Centanrea, 246

60 Centaurella, $\quad 356$

60 Centrosema, 107

256 Centunculns, 281

257 Ceplaalantlus, $\quad 176$

256 Ceplialoxys, 495

256 Ceruntheri, 318

591 Cerastiun, $\quad 50$

588 Cerasus, 120

109 Ceratiola, 411

$56 \mathrm{I}$ CERATUPIIYLACEA, $\quad 398$

43 Ceritopliflum, $\quad 398$

414 Ceraturcliarms, $\quad 528$

465 Cereis, 114

465 Ceresia, 570

465 Cercus, 144

339 Cestrum, 352

31 Charophyllum, 165

32 Chcerophiyllum, 161

31 Chatoevperus, 518

32 Chatosjora, 529

296 Chanxlirinm, 49!

169 Chamarojs, 438

170 Chameropss, 438

30 Chapmannia, $\quad 100$

350 Chaptalia, $\quad 248$

25 Chawstick, 74

27, 28 Cheilantlies, $\quad 500$

254 Chelone, 259

79 CHINUIPODIACEE, 375

532 Chenopodina, 378

50.5 Chenopodium, $\quad 376$

129 Cherry, 119

190 Chestmut, $\quad 424$

425 Chickwced, 49

418 Chimaplila, $\quad 267$

45. China Brier, 475

68 China-tree, 62

262 Chinquapin, $\quad 424$

114 Chiococea, 177

395 Chionanthus, $\quad 369$

393 Chlorilea, $\quad 5 \$ 6$

424 Chrysunthemum, 242

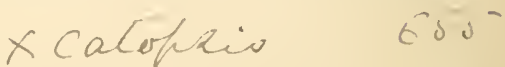


Chrysastrum,

Chrysobalaxee,

Chrysobilanus,

Chrysocoma,

Chrysogonum,

Chrysoma,

Chrysopsis,

Chrysopsis,

Chrysosplenium,

Crchoraces,

Cicuta,

Cimicifuga,

CIMICIFUGe.e,

Cinchosese,

Cinna.

Cinquefoil,

Circea.

Cirsium,

CISTACE $\mathbb{E}$,

Crtharexylum,

Citrus,

Cladastris,

Cladium,

Cliytonia,

Clematidez,

Clematis,

Cleome,

Clethra,

Cliftonia.

Climbing-Fern,

Clintonia,

Clitoria,

Clitoria,

Clover,

Club-moss,

Club-moss Family,

Clusia,

CLUSIACEN,

Cuicus,

Cnidoscolts,

Coecoloba,

Cocculus,

Cocklebur,

Cockspur,

Cocoa Plum,

Coelestina,

Coelostylis,

COFFEE.E,

Colchicum Family,

Colicodendron,

Collinsonia,

Colubrina,

Columbine,

Comandia,

COMBRETACE E,

Combretum Family,

Commelyna.

COMMEIYNACEA, COMPOSIT E,

Composite Family,

Comptonia,
208 CONIFER Æ,

118 Conioselinum, 164

119 Conocarpus, 136

215 Conoclinjum, 197

219 Conopholis, $\quad 286$

214 Conostylis, 470

215 Convallaria, 481

215 CONVOLVULACE

$15+$ Convolyulea, $\quad 340$

¿49 Concolvulus, $341,342,344,346$

161 Convolvulus Family, 340

11 Conyza, 217

2 Conyza, 218

173 Coontie, 437

552 Copro:manthus, 477

124 Corallorhizil, $\quad 454$

14.3 Corallorhiza, 455

246 Coral-root, $\quad 454$

35 Corchorus, 60

309 Cordia, 329

61 CORDLE:,

113 Coreopsis, 233

5:30 CORNACE.E, 167

4.3 Corn-Cocklc, $\quad 52$

2 Cornel, 167

3 Corn.Poppy, $\quad 22$

31 Cornus, 167

264 Corrdalis, 23

273 Corydulis, 22

597 Corylus, $\quad 425$

481 Cosmanthus, 335

107 Cosmos, 236

107 Cotton-grass, 521

90 Cotton-Plint, $\quad 59$

600 Cotton-wood, 431

600 Crab-grass, 521

42 Cranesbill, 6.5

4.) Cruniclis, 285

247 Crantzia, 159

409 Crape-Mvrtle.

391 CRASSULACEA, 149

16 Cratæens, 126

223 Crinm, 468

578 Croomia, 479

119 Cross-vine, $\quad 285$

189 Crotalaria, 89

18.2 Crotonopsis, 408

172 Croton, $40 \tau$

185, 186 Crowherry Family, $\quad 410$

32 Crowfoot, 7

315 Crowfoot Family,

it Crowfoot-grass, 558

9 CRECIFERE, 23

396 CRYPTOGAMOUS PLANTS, 585

136 Crvptotænia, 161

136 Ctenium, 557

497 Cuba-crass, $\quad 58: 3$

497 Cucumber-tree, 13

184 CUCURBITACE $\mathrm{E}, \quad 14 \%$

184 Cunila, 313

427 Cuphe:a, 135 
Cupresista,

('in)

Cinjerssus,

CIPUIFEREA,

Cumaut,

('uraut Funily,

Cinscuta,

Ci'scutere,

Custard-Apple,

Cu-tari-Apule Family,

Crimococciss,

CYCAIACEA,

Creas family,

Cyclolones,

Cynanchum,

Cristerti,

Cinoctonum,

Cinodon,

Crmoglosium,

Cintliai,

CYPRRACEA,

CrPEREA,

('урети,

Crpress,

Cypress-vine,

('Yl'RIPlEIEL,

Cvpripedium,

Civilla,

Crrilla Family,

CYRILLACEE,

Cystopteris,

Dactylis,

Dactiloctenium,

D)ALIBERGIEA,

1):aleal,

Maliturda,

Dandelion,

1)anthonia,

1):mbya,

Dalriel,

1)asystoma,

1)atiura,

I) aucus,

1):y-flower,

Dearl Nettle,

Decorlon,

I)ecumaria,

Deer-erriss,

1) Iphinium,

I)entaria,

1)esinanthus,

J)esmodium,

Diamorplaa,

1)ianthera,

Dirupensia,

IIAPLNSHEE,

Dicentra,

D)iccrandra,

Dichondira,

DICHONDREA,
432 Diclıromena, $\quad 530$

4:35 Dicks(r)ilal, $5: 97$

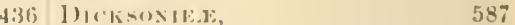

42() Dicliptria. 305

145 1)I(T'TLEI)ONOUS PLANTS, 1

145 Diervilla, 169

346 1)iritaria, 572

$3+1$ lligiteriue, 550

15 l)iodial, 175

14 Dionter, 37

259 J)ioscoreal, $47+$

437 DIOSCORLACLE, 474

4:37 1)iosuros, 273

375 bipholis, 2it

367 Diphylleial, 17

246. Diplarline, 559

367 Diplopappus, 206

5.57 Dipteracautlus, $\quad 303$

33.3 Dirca, 395

249 1)iscopleura, $\quad 162$

504 Dittany, 313

504 l)ock, 385

505 1)orlder, 346

4:35 Dexleciatheon, 281

$3: 1$ l)orloniea, is

45.3 Dowositi, is

464 Doe's-tuoth Violet, $4 \& 3$

27: Dowhine, 358

272 Dowword 167

272 Howwoul Family 167

593 Holichos, 109

Julichos, 106

$56+$ Driba, $\quad 29$

558 Dicurephalum, 322, 325

88 1)ropseed-grass, 350,352

93 1)rosera, 36

124 1)R(SERACE.E, 36

251 J Jryetes, 410

568 1)rickweril, 442

396 1)nckweed Family. 442

568 Dulichium, 513

298 1)ura-Corn, 583

352 Duranta, 309

161 1)utchman's Breeches 22

497
3.5

135 EBENACEA,

155 Ebony Fumily, 273

132 Echinacea, 206

9 Echinochlon, $\quad 577$

26 Echinocaulon, $\quad 390$

117 Echinodorus, 448

101 Edhites, $\quad 359$

150 Echites, $\quad 359$

304 Echium, 331

340 Eclipta, 224

337 lel-rrass, 444

22 Egr-Plant, 349

318 Eglantine, $\quad 126$

346 Ehretia, 329

341 EHRETIEÆ, 328 
Elder,

Elecampane,

Eleocharis,

Elephantopus,

Elephant's foot,

Eleusine,

Eleusine,

Elliottia,

EIm,

Elm Family,

Elodea,

Elymus,

Elymus,

Elytraria,

ENIPE'TRACEA,

Endogenous Plants,

Enemion,

EPIDENDRE.E,

Epidendrum,

Epigaa,

Epilotium,

Epiphegus,

EQUISETACEA,

Equisetum,

Eragrostis,

Erechthites,

Eriantluus,

ERICACEA,

ERICINEA,

Erigeron,

Eriocaulon,

Eriocuulon,

ERIOCAULONACE王,

Eriochate,

ERIOGONEA,

Eriogronum,

Eriophorum,

Eritlalis,

Eroodia,

Ervum,

Ervngium,

Erythrina,

Erythronium,

ESCA LLONIE.E,

Eugrenia,

Euonvmus,

Fupitortace.e,

Eupatoriun,

Eupatorium,

Euphorbia,

EUPHORBIACER,

Eupolygonella,

EUS,IIACE.

Eustachys,

Enstomi,

Euthamia,

Eutoea,

Euxolus

Evening-Primrose,

Eveniug-Primrose Family,

Everlasting,
171 Evolvulus, $\quad 345$

217 Exececaria, 405

$51+$ Exogenons Plants,

188 Exostemma, 179

188

558 Fagus,

416 False Ileliebore, 48

416 False Mitrewort, 154

42 False Nettle, 41

567 False Rice, $5+8$

567 Feather-grass, $\quad \mathbf{5 5}+$

302 Fedia, $18: 3$

410 Ferns, $\quad 585$

437 Ferula, 164

9 Fescue-grass, $\quad \mathbf{5 6 5}$

453 Festucia, 565

455 Festuca, 559

261 FESTCACE.E, 546

139 Feverwort, 170

286 Ficus, +15

585 Figwort. 288

585 Figwort Fanily, 28-

563 Fir, 415

244 FILICES, 585

582 Fimbristylis, 521

257 Fir, 434

257 Fireweed, 244

206 Elaveria, 238

502 Flax, 62

503, 504 Flax Family, 6 ?

502 Fleabane, 206

524 Hlower de Luce, 472

385 Flowering Fern, 598

392 FLOWEILESS PLANTS, 58.5

521 Fly-Poison, $\quad 490$

178 Fly-Trap,

176 Foresticra,

93 Forestiere.e, $\quad 369$

159 Forget-me-11ot, 332

106 Forsteronia, 359

483 Fothereilla, $\quad 157$

151 Four-o'elock Family, 372

130 Foxtail-grass, $5+9$

76. Fragaria, 124

189 Frangula,

193 Franklinia, 60

197 Frasera, 357

400 Fraxines,

399 Fraxinus, 369

386 Fringe-tree, 369

475 Frolichia, 383

557 Frocr's-bit Family, $\quad 450$

355 Fuirena, 514

214 FUMARIACEA, 22

335 Fumitory Family, 22

380 (138)

138 Gaillarlia, 238

137 G

243 | Galactiı, 108 
Gialax,

(jalnx family,

Cialeya,

Galium,

(ianua-rriass,

Gurdenia,

(iaultleria,

Gaura,

Gaylussacia,

(ielsemium,

Gentium,

Geutiana,

GINTHANACEA,

Gentian Family,

Georria Bark,

GLRANIACER,

Geraniurn,

Geranimu Family,

Gerardia,

Gerardia,

Germander,

Gellm,

Gilia,

Gillenia,

Gillseng,

Giuseng Family,

Gleditschia,

Glottidium,

Gliceria,

Glycine,

Gnaphalium,

Goat's Rue,

Golden Club,

Golden Osier,

Golden Rod,

Golden Saxifrage,

GoMpll RENEE,

Gonolobus,

Gonopvrum,

GOODENIACEA,

Goodenia Family,

Goodvera,

Gooseberry,

Goosefoot,

Goosefoot Family,

Gordonia,

Gossypium,

Gouania,

Gourd Family,

GRAMINEA,

Grape,

Grass Family,

Grass of Painassus,

Gratiola,

Gratiola,

Gromwell,

GROSSULACE E,

Ground Cherry,

Ground Laurel,

Groundsel,

Guaiacum,

268 | Finctiarla, $\quad 178$

268 (;uine: Corn, $\quad 583$

95) (immundenia, 458

173 (ivmmojouron, 556

580 (IIMNOSIERMTi,

179 Gymmosticlum, 567

261 Giymnostylis, 243

137 Gynandropsis, $\quad 32$

258

183 Hnbenaria, 46]

355 H.EMOIORACE.T, $\quad 469$

355 Halesia, 271

352 HALOHAGEN, 137

352 Haloschormus, 528

$17911 \mathrm{AMMELACEA,} 156$

64 Hamamelis, 156

65 Ilamelia, 178

64 Homiltonia, 396

299 Haw, 171

298 Hawthorm, 126

327 Hazel-nut, 425

123 Heart's-ease, 33

339 Ileath Fumily, 257, 261

121 Herleoma, 316

166 Hedge-Iyssop, 292

$166^{\circ}$ Iledge-Nlustard, 28

115 Hedige-Nettle, $\quad 326$

97 Iledyotis, 181

560 HEUYSARLA,

104, 10.5 Hedysarum, 101

24.3 Heleninm. 239

95. Heliauthella, 232

441 Itelianthemum, 35

431 Helianthus, 228

208 Helianthus, 223

$15+$ Heliopliytum, 330

379 Heliopsis, 225

368 HELIOTROPLE, 328

387 Heliotropium, 330

255 HELLEHORIXEX,

25.5 Helonias, 489, 490, 491

463 Heloseiadium, 162

145 Hemianthus,

376 Hemicarpha, 513

375 Hemp Fanily, 414

60 Hepatica,

58 Heracleum, 165

74 Herd's grass, $\quad 550$

148 Lermiaria, 47

545 Herpestis, 291

70 Merpestis, 295

545 Ilesperis,

38 Heteropogon, 582

292 Heterotheca, 215

291, 294 Heterotropa, 371

331 Henchera, 152

145 HiBISCE 2 , 53

350 Hibiscus, 57

261 Hibiscus, $\quad 57$

245 Hickory, 418

64. Hicracium, 250 
Hippocastanez,

Hippomane,

Holly,

Holly Family,

Honey-Locust,

Honeysuckle,

Honeysuckle Family,

Hop,

Hop-Hornbearn,

Hop-tree,

HoRdElCER,

Horehoumd,

H rrubeam,

Horned Rush,

Hornwort,

Hornwort Famils,

Horse-Balm,

Horse-Chestmut,

Horse-Mint,

Horsetail Eamily,

Hosackia,

IIottonia,

Hound's Tongue,

Iloustonia,

Hucklelserry,

Hndsuniat,

Humults,

Huntsman's Cup,

Hylrangea,

HydraxgIEA,

Hydrastis,

HYDROCHARIDACEA,

Hydrocharis,

Hydiochlon,

Hydrocotrle,

Hydrocotyle,

Hydioleat,

HYDROLEACEA,

Hydrolea Family,

Hydropeltis,

HYDROPHYLLACER,

Hvilrophrllum,

Hydropterides,

Hvmenocallis,

Hymenopappus,

HYMEXOPUY LLEA,

IIyoseris,

IIrpelate,

IIYPERICACE.E,

Hyperienm,

Hypobryehia,

Hypopitys,

Hуророгты,

Hypoxys,

Hyptis,

Ilex,

ILLECEBREA,

Illicium,

Ilysanthes,
78 ' Impatiens,

404 Indian Hemp, 358

269 Indian Mallows, 55

268 Indian Plissic, $\quad \mathbf{1 2 5}$

115 Indian Pive, 268

170, 265 Indian Pipe Family, $\quad 267$

169 Indian Sliot, 465

414 Indian Turnip, 439

426 Indigo, $\quad 96$

66 Indigofera, 96

547 lnga, $\quad 116,117$

325 Inula, 217

425 Iodanthus, $\quad 25$

528 I Iomrea, 342

39s Ipomac, 341

398 Iresilastrum, 38.2

315 Iresine, 381

79 IRII ACEE,

314,320 Iris, $\quad 472$

58.5 Iris Family, $\quad 472$

91 Irish Putato, $\quad 349$

279 Iron-weed, 187

192, $3: 33$ Isanthus, $\quad 32 i$

180,181 lsmene, $46 \hat{\imath}$

258,259 Isoetes, 60.2

36 Isolepis, 522

414 Isopappis, $\quad 215$

20 Isopyrum, 9

155 Itea, 155

151 Iva, 222

11 Lxia, 474

450 Jamaica Dogwood, 110

451 Jamestown-IVeed, 352

549 . Jacquemontia, 344

159 Jaquinia, $\quad 276$

336 Jatropha, 409

336 Jeffersonia, 18

336 Jersey Tea, 74

19 Jerusalem Artichoke, 232

19 Jerusalem Cherry, 349

333 Jewel-weed, 65

334 JUGLAND ACE.T, $\quad 418$

602 Juglans, 419

467 JUNCACE $\mathrm{E}, \quad 492$

238 JNCAGINEA,

587 Jineus, 493

250 . Junc:us, 93,495

Juniper, 435

38 Juniperus, $\quad \mathbf{4 3 5}$

39 Jussian, 140

268 Justiciu, 304, 305

532 Kiallströmia, 64

468 Kílmia, 264

312 Kidney-Beau, $\quad 106$

Kinotweed, 388

269 Kosteletzkya, $\quad 57$

45 Krameria, 86

12 KRAMERI CEN, 86

294 Krigial, 9 
Kulınia,

Kyllingin,

Siyllingir,

I.IBIATE,

I.ABIATIFLOR.AE,

I alchinatuthe:,

Lachnocanlon,

Lactuca,

lakly's slipper,

I sigerstrwemia,

Larruncularia,

Lamb-Lettuce,

Latuinm,

l.antulla,

laportea,

Lappa,

Larkspur,

Lastrea,

Jathyrus,

LALRACEA,

Laurel,

Laurel Family,

Laurocerasus,

Laurus,

Lavcutera,

Iseadwort,

Leadwort Family,

Leatherwood,

Leavenworthia,

Lechea,

Leersia

I.EGUMINOSE,

Acimeria,

lemma,

LEMNACEE,

J.emon

LENTIBULACEA,

Leonotis,

Leontice,

Leonurus,

Lepacliys,

Lepidium,

Leplandra,

Leptunthus,

Leptocaulis,

I. ptochloa,

Jejtopoda,

Lepuropetalon,

Iespedezal,

Letiuce,

Lencanthemum,

Leucothoё,

Liatris,

Jicutris,

LIGILIFLORA,

Limsticum.

LILIACE $\mathbb{E}$,

Lilium,

Lily,
INDEX.

193 | Lily Family, 480

51: Lili of the Valley, 481

514 Jinuc, 61

Limn:mthemum, $\quad 357$

310 Linnolium, $\quad 451$

187 Limmorhloai, 514

469 Limortorum,

$503 \mathrm{JIN} \triangle \mathrm{Cl}$ Li, $\quad 62$

252 Linaria, 290

464 Linden, $\quad 59$

135 Linden Family, 59

136 Lindemic, 294

183 Linnm, 62

32.5 Lipilris, 454

308 Lipocalphla, 513

413 LIPOCARPHE.E,

248 lippiti, 308

9 Liquilambar, $\quad 157$

594 Liriodendron, 14

99 Listera, 463

393 Lithospermum, 331

264 Liver-leif, 5

393 Lizard's 'T'ail, 398

120 Jizard's 'Tail Family, $\quad 397$

393,394 LOASACEL, $\quad 1+6$

56 Loasa Fimily, 146

279 Lobelia, 253

278 Lobelia Family, 253

395 LOBELJ \CE

27 Ioblolly Bily, 60

36 Locust, 94

548 LOGANIEA, $\quad 173$

86 Lolium, 568

427 LONEXTACE.E, 24

442 Lone Moss, $\quad \mathbf{4 7 0 , 4 7 2}$

442 Lonicelia, 170

61 Loosestrife, 134, 280

282 Loosestrife Family, 133

326 Lophanthus, 321

17 Lophiola, $\quad 469$

326 Lopsecel, 310

228 LORANTHACEA,

30 LOTLA,

295 Jurdwigia, 140

497 Ludecigie, $\quad 140$

161 Lupine, 89

558 Lapinus, 89

239 ldiriola, 583

15] Luzula, 492

100 Lrcium, 351

2.52 IXCOPODIACE $A, \quad 600$

242 Lycopodium, 600

261 Licopus, 313

190 Lirgodesmia, 25I

190 Livgodium, 597

187 Lime-grass, $\quad 567$

16.3 Lyonin, 367

480 Trsimichia, 280

484 LYTHRACEN, 133

484 Lythrum, 134 
Machirlea,

Macranthera,

Marliker Family,

Maernolia,

Maunolia Familv,

MAGNOLI A CEA,

MAGrolie.e,

Mahogany,

Mahogany Fanily,

Maianthemum,

Marilen-Hair,

Malachodendron,

MIL.AXIDE.E,

Mulaxis,

Mallow,

Mallow Family,

MALPIGHIAEA,

Malpighia Family,

Malva,

Aialea,

M.IL $V$ ACE.E,

Malvastrum,

Muleuviscus,

MILVEE,

Mandrake,

Mangrove,

Mangrove Family,

Manisuris,

Maple,

Maple Family,

Marginaria,

Marrubium,

Maruta,

Marshallia,

Marsli-grass,

Maush Marigold,

Marsh Pennywort,

Mar-h Rosemary,

Matrinia,

Mavac'a,

MAYACACEA,

Maraca Family,

May-Apple,

Maypop,

Maytenus,

Marweed,

Mearlow-grass,

Meadow-Rue,

Meadow-sweet,

Mecleola,

Medicano,

Melampyrum,

MELA XTHACEA,

Melinthera,

Melanthinn,

Mclastoma Family,

MELAS'TOMACEA,

Melia,

MELIACE E,

Melica,

Melicocca,
324 ' Melilot, 90

297 Melilotus, $\quad 90$

172 Melica, $\quad 318$

13 Melothia, 148

12 MENISI'ERMACEA, 15

12 Menispermum, 16

12 Menispermum, 16

62 Mentha, 312

62 Mentzelia, 146

481 Menziesia, 265

590 Mercurialis, $\quad 410$

61 Mertensia, 332

452 Metastelma, 366

453, 45t Mexican I’oppy, 21

53 Mezereum Fanily, $\quad 395$

52 Micranthemum, 294

81 Micromeria, 317

81 Micropetalon, 49

53 Micro-tylis, 453

53,56 Mikania, 197

52 Hilium, 570,572

54 Milk-Tetch,

59 Milkweed, 362

52 Milkweed Family, 361

18 Milkwort, $\quad 82$

135 Milkwort Family, 82

135 Millet, 578

580 Mimosa, 115

80 Mimosa Family, 115

80 MIMOSE.

588 Mimulns, $\quad 291$

325 Mimusops, $\mathbf{2 7 5}$

$2+1$ Mint, 312

241 Mint Family, 310

556 . Mistletoe, 397

9 Mistletoe Family, 397

$15 \mathrm{~s}$ Mitehella, 176

278 Mitella, 154

285 Mitreola, 182

498 Mitrewort, 154, 182

498 Mock Orange, 120

498 Modiola, 56

I8 Mollugixex,

147 Mollugo, 48

7 Monanthochloë, 584

241 Monaria, $\quad 320$

562 Montercla, 321

5 MONARDE.E, 311

120) Monkey-Flower, 291

479 Monk's lood, 10

90 Mowocert, 558

301 Monocotyledonous Plants, 437

485 Monopetalous Exogenous Plants, 169

225 Monotropa, 268

488 MoxuTROPE,

131 M(

131 Mommort, 599

62 MORACLA, 414

62 Morinda, 177

560 Mroming-Glory, $\quad 342$

79 Morus, 415 
IIotherwort,

Jlousceear,

Mlousce-tail,

Inhlenhergia,

Mulienluigum,

Mlullerry,

Mullerry Family,

Blulgedium,

Mlullein,

Muscaline,

Mustarl Fumily,

Mutisiseces,

Myrindal

Mylocurium,

MIrosotis,

Myosotis,

IIrosuris,

Mirries,

MYRICACER,

Myriephyllam,

MYRSIN $\triangle C E E_{\text {, }}$

Mrrsine,

Myrsiue Family,

MYRTACEZ,

Iyrtle Family,

Nabalits,

NAIADACE.E,

Naias,

Namr,

Nistiutimn,

Netris,

1 Negunda,

NELUIBLACEE,

Nelumbiam,

Nelnmbo,

Nelmbo Family,

Nemastrlis,

Nemoptila,

Neotrues,

Nepeta,

NEPETE

Nephrolepis,

Neptanias,

Nesxa,

Nettle,

Nettle-tree,

Neuropluyllum,

Nerinsia,

Nicandra,

Nicotiana,

Night-hlooming Jessamine,

Nightsharle,

Nightsharle Family,

Nolina,

Nondo,

Nuphar,

Nut-rush,

NYCTAGINACEE,

Nrmphra,

NYMPHEACEE,

\begin{tabular}{|c|c|c|}
\hline $\begin{array}{r}326 \\
50\end{array}$ & Nyssa, & 168 \\
\hline 6 & O:ik, & 42 \\
\hline 552 & Oak Family, & 42 \\
\hline 5.53 & Obione, & 37 \\
\hline 415 & Otoularia, & 35 \\
\hline 414 & OCIMUINEA, & 311 \\
\hline 252 & Ocinuแn, & 31: \\
\hline 288 & Enothera, & 138 \\
\hline 71 & Oreechee Lime, & 168 \\
\hline 23 & Oil-nut, & 396 \\
\hline 248 & (1kial, & 58 \\
\hline 75 & $U L A C \triangle C E N$ & 61 \\
\hline 273 & Ohlculandia, & 180 \\
\hline 332 & Olea, & 369 \\
\hline 333 & OLFACEE, & 368 \\
\hline 6 & OLEIXEe, & 368 \\
\hline 426 & Olive, & 369 \\
\hline 426 & Olive Family, & 368 \\
\hline 143 & ONAGRACEEE, & 137 \\
\hline 276 & OXIARICEX, & $13 \pi$ \\
\hline 276 & Onion, & 482 \\
\hline 276 & Onoclea, & 596 \\
\hline 130 & Onosmodium, & 331 \\
\hline 130 & OPHIOGI,OSSEL, & 587 \\
\hline & (1)hioglossum, & 599 \\
\hline 250 & Ophiortiza, & 182 \\
\hline 444 & UPUIRDEE, & 45.3 \\
\hline 444 & Oplerys, & 464 \\
\hline 336 & Oplotheca, & 384 \\
\hline 24 & Opuntia, & 144 \\
\hline 19 & Oraclie, & $3 \pi \pi$ \\
\hline 81 & Orange, & 61 \\
\hline 18 & Orange Family, & 61 \\
\hline 18 & Orchind-crass, & 564 \\
\hline 18 & ORCHIDACEA, & 452 \\
\hline 18 & Orchis, & 458 \\
\hline 474 & Orchis, & 459,460 \\
\hline 334 & Orchis Family, & 452 \\
\hline 455 & Oinithexgulmin, & 483 \\
\hline 321 & OROBANCHACEA, & 286 \\
\hline 311 & Orobanche, & 286,287 \\
\hline 596 & Oroutium, & 441 \\
\hline 117 & ()rpine, & 150 \\
\hline 134 & Orpine Family, & 149 \\
\hline 412 & Orthomeris, & 205 \\
\hline 417 & Orthopogron, & 577 \\
\hline 165 & ORYZE.E, & 545 \\
\hline 121 & Osmorrliza, & 166 \\
\hline 351 & Osmunda, & 598 \\
\hline 352 & OSMUNDINEA, & 587 \\
\hline 35 & Ostrya, & 426 \\
\hline 348 & Otophylla, & 298 \\
\hline 347 & OXALIIACE,E, & 63 \\
\hline 483 & Oxalis, & 63 \\
\hline 163 & Ox-eye Daisy, & 242 \\
\hline 20 & Oxybaplus, & 372 \\
\hline 530 & Oxyeoceus, & 259 \\
\hline 372 & Oxydendrum, & $2 f 3$ \\
\hline $\begin{array}{l}19 \\
19\end{array}$ & Oxytripolium, & $20 \overline{-}$ \\
\hline
\end{tabular}




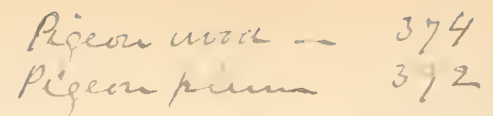

INDEX.

Pachrsandra,

Preàlanthus,

410 'Philoxerus,

382

503 Phlebodium,

238 Phleum,

437 Phlox,

438 Phoradendron,

437 Phragmites,

166. Pliryma,

467 PhRYMEA,

547 Plyllanthus,

572 Physalis,

572 Pliysostegia,

571, 578 Pliftolacea,

21 PHYTOLACCACEE,

15 Phytolicce.e,

415 Pickerel-weed,

86 Pickerel-sweed Family,

512 Pig-nut,

413 Pig-weed,

38 Pilea,

37 Pimpernel,

37 Pinckucya,

46 Pine,

47 Pine Family,

157 Pine-Apple Family,

222 Pinguicula,

570 Pink Family,

147 Pink-1oot,

147 Pinus,

147 Pipewort,

147 Pipewort Family, $\quad 502$

79 Piriqueta, $\quad 146$

56 Piscidia, 110

129 Pisonia, 373

128 Pistia, 441

418 Pitcheria, 105

189 Pitcher-Plant Family, $\quad 20$

301 Pithecolobium, $\quad 116$

589 Planera, $\quad 417$

413 Planer-tree, $\quad 417$

440 Plane-tree, 418

578 Plane-tree Family, 417

151 P'LAN'TAGINACEA, 277

289 'Plantago, 277

30 Plantain, $\quad 277$

393 Plantain Fanily, $\quad 277$

388 PLAN'I'ANACEA, 417

273 Platanthera, $\quad 459$

93 Platanus, 418

374 Pleea, $49 \mathrm{I}$

374 Plucher, 218

352 Plum, 119

98 PLUIIIAGINACE $\mathrm{E}, \quad 278$

335 Plumbagro, $\quad 279$

1 Poi, $\quad 562$

48.3 Pou, 559, 561, 563, 564

547. I'odophyllum, 18

569 PODOSTEMIACEZ, $\quad 399$

342 I'odlostemon, $\quad 399$

88 Podostigma, $\quad 366$

106 Pogonis, 457

156 Hoison Elder, 69 
Poindil Oalk,

Poke-mind.

Poke-weed Family,

I'ulanisia,

PIIEMONIACER,

JOLWMONILE,

Polemoniunz,

Polemonimu Fatuly,

l'olvearion,

lobligalia,

I'UIYGALACLE,

POI,YGNACEA,

Polvenolatmu,

POIXONE,

Polygonella,

Polygonum,

Polyyonuin,

Polymuia,

I'olyjetalous Exogrenous Plants,

PULYPDIE.

Pormporisex,

Polypodium,

Polyjurly,

Polviogron,

Polypremum,

Polypteris,

Polysticham,

I'one.x,

Poniegranate,

l'onr-Lily,

Pond-wred,

Pond-weed Family,

Ponterleria,

PONTLDERIACE E

'onthieva,

l'oplar.

l'oppy Family,

'opuliss,

l'ortirlaciar,

J')R'TULACACEA,

lotamogreton,

Potentilla,

I'othos,

Prenumities,

Prickly Ash,

Prickly Pear,

Pride of India,

Primrone Family,

PRIMLLACEA

Prince's Pine,

Prinoides,

Prinos,

Prinos,

Priva,

Prosartes,

Proserpinaca,

Prunus,

Psilocarya,

P'silotum,

I'soralea,

Psychotria,
69) Prelen,

375 P'TEHUE.E,

374 l'mis,

31 l'teris,

337 J'erociulour,

3337 I'urce(c)ll,

340) I'ulmanarior,

337 l'ule Family,

48 P'unica,

\&. J'tritime,

8.2 P'ur:lane Family,

384 l'utty-rent,

4ㅇ) P'renauthemum,

384 Prerents,

386 I'vrola,

38.8 Pyrola Fumily,

387, 388, 391 P' ROLEA:,

219 Pyrrhopily'us,

1 Pyrnlaria,

586 Pyrm,

5*6 P'rxilathera,

588

588 Quamoclit,

552 (2uassia,

182 Qnassia Family,

238 | Queen's Delightit,

595 Quercus,

118 (kneria,

130 Qnillwort,

19 (2uince,

445

444 Randia,

496 RANUNCTIACE.E,

496 Raxungele,

464 Ranmeulus,

431 Rattle-box,

21 Rattlesnake-Plantain, 463

431 Red Bay, 393

44 Riri-buil, 114

43 Rod P'pper, 350

445 Reed, 561, 567

124 Reed Bent-grass, 55.3

441 RIIANINACEN, i2

251 Rlammus,

66 Rhamms, $\quad 72,73,74$

144 Rhatamy Family, 86

62 Rhexia, 132

279 Rhizopliora, 135

279 RHIZOPIORACE

267 Rhotodendron, 265

269 RHODURE.E, $\quad 257$

270 Rhus, 68

270 Rhymchosia, 104

306 Rhivichospora, $\quad 52.3$

$1+3$ RHYYCHOSPOREX, 505

119 Ribes, 145

509 Ricinus, 409

601 River-weed, 399

9I Rirer-weed Family, $\quad 399$

177 Rivina, 375

\section{6}

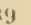

(1) 32

\section{5} (1) 66 52

96

40

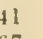
. 46 29

(1)

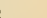

4

3

2

5


Robinia,

Rock-Rose,

liock-Rose Family,

Rosa,

ROSACE.E,

ROSACE.E,

Rose,

Rose-Bay,

Rose Family,

Rose-Mallow

Rottbollia,

Rottballia,

RotTbELlea,

Roxburghia Family,

ROXBURGHIACEA,

Rubia,

RUBIACEE,

Rubus,

Rudbeckia,

Rudbeckia,

Ruellia,

Rue Family,

Rugelia,

Rumex,

Ruppia,

Rush,

Rush Family,

liush-grass,

RUTACEA,

Sabal,

Sabbatia,

Sage,

Sagreretia,

Sarina,

Sagittaria,

St. Jolın's-wort,

St. John's-wort Family,

St. Peter's-wort,

SALICACEÆ,

Salicornia,

Salix,

Salsola,

Saltwort,

Salvia,

Sambircus,

Samolus,

Simphire,

Sandialwood Family,

Siand wort,

Sanguinaria,

Singruisurbat,

Simicula,

SANTALACEA,

SAPINDACEA,

SAI'INEA,

Sixpindus,

Saporlilla Family,

Siponaria.

SAIOTACEA,

Sarcostcmma,
94 ' Sarracenia,

20

35 SARRACLNIACE.E,

35 Sarsaparilla,

125 Sissatras,

117 Satin-wood,

166

394

118 SATLREIE.E,

125 SALRLRACET,

66

311

265 Samrurus,

117 Saxifraga,

397

398

153

151

579 SAXIFRAGEA,

579, 58l Saxifrage, $\quad 153$

548 Saxifrare Family, 151

479 Seærola, 255

479 Schatieria, $\quad 76$

173 Schizandra, 13

172 Schizaxulits, $\quad 12$

124 SCHIZ.EIX.

226 Schonolirion, 483

2:38 Schoenoeaulon, $\quad 490$

303,304 Sichenus, $\quad 529,530$

66 Schollera, 496

246 Schrankia, - 116

385 Schwalbea, 301

445 Schweinitzia, 267

49.3 SCIRl'E, $\quad 504$

492 Seirpus, 519

550 Scupus, $\quad 515,518,522,523,526,530$

66 Seleria, 530

SCLERIE⿺, $\quad 505$

438 Selerolepis, $\quad 190$

353 Scleropus, $\quad 381$

318 Scoparia, $\quad 296$

73 Scouring Rush, $\quad 585$

48 Serophularia, $2 \times 8$

448 SCROPHLLARIACEA, 287

39 Scutellaria, 322

38 Scutia,

38 Sea-Grape, 391

429 Sea-I'urslane, 44

377 Sedre, $\quad 532$

429 Sedwe Family, $\quad 504$

378 Sedum, $\quad 150$

378 Seed-box, 140

318 Selavimella, 601

171 Self-heal, $\quad 322$

281 Senelicra, 30

377 Seneca-Snakeloot, 85

395 Senceio, 245

49 Senecio, 244

22 SENECIONIDEE, 219

122 Senna, 114

159 Sensitive-Plant, $\quad 115$

395 Sericocarpus, $\quad 197$

78 SESAME.E, 281

78 Seshania, 97

79 sesbania, 97

274 Sesluvinm, 44

52 Setaria, 577

274 Seutera, $36 \pi$

367 Seymeria, 297 
Slicplueril's Pursc,

Shichl-Fern,

slurtia,

Sireves,

Sirlit,

Sïlu,

sideroxron,

sirle-siadlle Flower,

Silene.

Silentex,

SILICLLOSA.E,

Siligeose,

silplium,

silphim,

Simarnba,

SIMLIRUBACEA,

siphomychia,

sison,

Sis ymilsium,

Sisinulitium,

Sismlinchium,

Situlobium,

Simm,

simm,

skulleare,

Skunk-Cabbage,

slue,

SMUACEA,

smilacina,

similacina,

Smilax,

similax,

Smilax Family,

simyrnizm,

sinake-hearl,

Snowberry,

Snowdroj-tree,

Sivalulerry,

Soipbery Family,

Soapwort,

SOL $\triangle N A C E$ E,

sol:mum,

Solen,

Soliditgro,

Soliva,

Solumon's Seal,

Sourlins,

Sophora,

SOPIIURE.E,

Sorbus,

Sorechum,

Sorrcl-tree,

Som Ginm,

Sollwoorl.

Spanish Iatyonet,

Spurgnenopliorus,

Sparganium,

Spartina.

Spatter Dock,

Specularia,

Speedwell,
30 Spergula, 48

594 simerylu, 48

267 Sipereularia, 47

$1+9$ sperintuoc, 174

54 vimomaroce, 176

54,56 sive.bush, 394

$27+$ Sinderwort, 498

20) Sijderwort Family, $\quad 497$

51 Spirulia, 181

45 Sijukikerosis, $51+$

24 Silanthe's, 237

24 Simble-trec,

220 Sirata, 120

221 Sirituntles, 461

6i SiLILOLOHEA,

67 Sporobolus, 550

46 Springr-lieauty,

161 Spruce, 434

28 Spmrer,

24 Spmrere Family, $\quad 399$

473 Sprirey, 48

597 Syluiw root, 286

162 STICIYUE.E,

162, 165 Stueliys, 326

322 Situch 308

441 Stafl-ilec, 76

171 Situpliylea,

475 S'IPHLLACE $\lambda$,

481 Star-grass, 468,470

482 Star-'Tlistle, $\quad 246$

475 Stillwort, 49, 198

477 Statice, 278

475 Steliuria, 49

163 Stellariu, 49

289 Stemanthimm, 489

169 Stenotaplirum, $\quad \mathbf{5 7 9}$

27 Stillingia, 404

79 Stipa, $55+$

78 Stipulicila, $\quad 47$

52 Stokesia, 188

347 Stonecrop, 150

348 Storix, 271

34 Storax Family, 270

208 Striwherry, 124

242 Streptachne, 554

481 Streptopus, 487

25.3. Streplojus, $\quad 487$

113 Strumfia, $\quad 177$

88 Stuartia, 61

129 Stylisma, $\quad 346$

58:3 Strlosanthes, 100

26:3 S'IYRACACEA, 270

168 STYRACFA, 270

263 Styrax, 271

485 Simach, 68

190 Sundew, 36

44.3 Sundew Family, $\quad 36$

556 Sunflower, 228

20 Supple-Jack, 73

256 Surania, 149

295 SURANIACE.E, 149 
Surania Fanily,

Sweet Bay,

Sweet Clover,

Sweet Fern,

Sweet Flag,

Siveet Gum,

Sweet Potato,

Sweet-scented Grass,

Sweet-scented Shrub,

Swietenia,

Sreanore,

Siyena,

Symphoria,

Symphoricaruus,

Symplocarpus,

SYMPLOCINE.E,

Symplocos,

Siringa,

Talinum,

Tanacetum,

Tausy,

Tape-grass,

Taraxacum,

Tare,

TAXINEA,

Taxodium,

Taxus,

Tecoma,

Telanthera,

Tephrosia,

Terminalia,

Tetragonotheca,

Tetranthera,

Teuerium,

Thalia,

Thalictrum,

Thaspium,

Theoplurata Family,

THEOPHRASTACE.E,

Thermopsis,

Thesium,

Thistle,

'Tloru-Apple,

'Thoroughwort,

'Thuja,

THI MELEACEAE,

Thyrsanthus,

Thysanella,

Tiarella,

Tiedemannia,

Tilia,

THLI CE,E

+ lillandsia,

'Timothy,

'Tiniaria,

Tipularia,

'Titi,

Toad-Flax,

Tobacco.

Toficldia,
149 | Tomato, $\quad 349$

13 'Torcliwood, 68

90 Torchwood Family, $\quad 67$

$\mathbf{4 2 7}$ Torreya, $\mathbf{4 3 6}$

442 Tooth-ache Tree, $\quad 66$

157 Toothwort, $\quad 26$

341 Tournefortia. 329

569 Touch-me-not, 6.5

130 Tovaria, $\quad 390$

62 Tradescantia, 493

418 Tragia, 406

499 Trantvetteria, 6

169 Tree-Orehis, $\quad 455$

169 'Triantha, 492

441 Tribulus, 64

271 Trichelostylis, $\quad 522$

272 Trichochlon, 553

156 Trichodeum, 551

Trichophorum, 521

44 Triclomanes, 597

242 Trichostema, 327

242 Trienspis, $\quad 559$

450 Trifolium, 90

251 Triglochin, 447

98 TRILLIACEE, 475

432 Trillium, 477

435 Trillium Family, 475

436 Triosteum, 170

285 Triphora, $\quad 457$

383. Triplasis, $\mathbf{5 5 9}$

95 Tripsacum, $\quad \mathbf{5 8 0}$

137 Tripsacum, $\quad 580$

225 Tripterellu, 451,452

394 'Trisetum, $\quad 568$

327 Trumpet-Flower, 285

465 Trumpet-Leaf, 20

5 TUBULIFLOR.E, 184

163 TILIPACE.£, 480

276 'Tulip-tree, 14

276 Turnera, 147

113 Turnera Family, 146

396 TURNERACEA, 146

246 Twin-Leaf, 18

352 Twisted Orchis, $\quad 461$

193 'Typha, 443

436 TIPHACEE, 443

395 T)

95 Udora, 450

391 UI, I ACE, $\quad 416$

154 Ulmus, 416

164 UMBEILIFERA,

59 Unubella-Tree, 13

59 Unicorn-Plant, 285

470 Uniola, 556

550 Uniola 562

390 Tralepis, $\quad 560$

456 U'

273 Urtica, 412

290 Urtire, 413

352 [RTICACE.E, 411

491 Utricularia, 282 
Cearies,

Uvuluria,

UYILAIIE.T,

V.ce'rix.te,

Vacoinium,

levinimm,

VALERIANACET,

Valcrianat,

$\mathrm{V}$ alcrian Fanily,

Vallexia,

Villisneria,

Veratrium,

lerutrum,

Terlaseun,

Verlien:

VEIRIFNACER,

Veisulesex,

Verbesina,

Vernonia,

VEl:NONIACEE,

Veroniea,

Vervain,

Vervain lamily,

Veseicaria,

reteli,

Tiburnum,

Vicia,

VICIEN,

Vigraa,

Tionnea,

Vilta,

Vinca,

Vine,

Vine Family,

Viola,

Tiole,

VIOI,ACEA,

Violet,

Violet Family,

Virgaurea,

Firgilia,

Virginian Creeper,

Virrin's Bower,

Iiscum,

VITACIA,

TITE.E,

Vitis,

Vitis-Idiea,

Vittaria,

VITTALEX,

Wallsteinia,

WValking Leaf,

Walnut,

Walnut Family,

$\mathrm{TH}^{\mathrm{r}}$ altheria,

TV ampee,

IV area,

IV atches,

Water-Chinquapin,
15) Water-Cross, 24

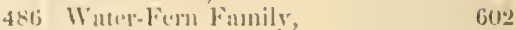

450 Writer-Homlork, 161 Wuter-I.c口il, 334

25) Watrer-I,al' Family,

259 Wuter-Iily, 19

258 Water-Lily Fimily, 19

183 Watcr-Militoil, 143

183 Watce-l'latuin, $\quad 447$

183 Watcr-Plantain Family, 447

360 Watcr-silncld. 19

450 Water-sluield Family, 18

489 Wrater-Sitarwort, 399

484 Water-Starwort Family, 398

288 Wrax-Myrtle, 426

306 Wax-Mirtle Family, $\quad 426$

30.5 IVlabori, $\quad 417$

306 White J'uplar. 14

237 Whortleberry Family, 258

I\&7 Wicki, 264

187 Wilk Flax, 62

295 Wild lírer,

306 Willow, 423

30.5 Willow Family, $\quad 429$

29 Willow-Lerl), 139

98 Wjul-Flower, 4

171 WIXTEUE.

98 Wintergreen, 261

S7 Wire-crass, $\quad 550,554$

106 W istaria.

533 Witel-Hazel, 156

550 Witch-1Iazel Family, 156

360 Wultisane, $\quad 10$

70 Woodline, $\quad 170$

70 Worrl-Rnsh, $\quad 492$

33. Woorkia, 596

35 WOONSLE,

32 Wool-sorrel, 63

33 Wood-Sorrel Family, $6: 3$

32 Woodwardia, 591

208 Womsect, 377

113 Wommood, $\quad \cdot 242$

72 Tanthium, 223

397 Xinthesmia, $\quad 440$

70 X(roplivllum, 490

306 Ximenia, 61

70 Ximenia Family, 61

259 XYRII $\triangle$ CEA,

589 Xyris, 499

586 Yam,

123 Yam Family 474

591 Yarrow, 242

419 Yellow-eyed grass, 499

418 Yellow-red grass Family, $\quad 499$

59 Yellow, Jessamine, 183

496 Yellow Water-Lily, $\quad 20$

28 Yellow Wood, 113

21 Tew, 436

18 Tucca, 485 
INDEX.

Zamia,

Zannichellia,

Zanthorhiza,

Zanthoxylum,

Zapania,

Zigadenus,

Zinnia,
437 Zizania,

445 Zizania,

11 Zizia,

66 Zizyphus,

308 Zornia,

488 Zostera,

225 ZYGOPHILLACEA,
549

$5+9$

163

72,73

99

444

63 



\section{INDEX TO SUPPLEMENT.}

Abies,

Abutilon,

Acacia,

Acalypha.

ACANTIACEE,

Acanthospermum,

$\Lambda$ cnida,

Actinomeris,

Adiantum,

Adonis,

Agave,

Aira,

Allium,

Alsine,

AMARANTACEF,

AMARYLLIDACEA,

Amaryllis,

$\Lambda$ mbrosia,

Ammannia,

Andropogon,

Anona,

ANONACEA,

Aplopappus,

$\triangle P O C Y N A C E E$,

$\triangle Q U I F O L A C E F$,

Aristida,

Aristolochia,

ARISTOLOCHIACEA,

Artemisia,

ASCLEPIADACEE,

Asclepias,

Asimina,

$\Lambda$ spidium,

Asplenium,

Aster,

Astragalus,

\section{Baptisia,}

Barbarea,

Bellis,

BORRAGINACEE,

Bouteloua,

Breweria,

\begin{tabular}{|c|c|}
\hline 650 & BROMELLACE $A$, \\
\hline 609 & Bromus \\
\hline 619 & BYTTNERIACE $A$, \\
\hline 678 & Cæsalpinia, \\
\hline 628 & Cakile, \\
\hline 644 & Calamagrostis, \\
\hline 630 & Calamintha, \\
\hline 670 & $\begin{array}{l}\text { CALLITRICHACE E, } \\
\text { Callitriche }\end{array}$ \\
\hline 655 & Camassia, \\
\hline 664 & CAIIPANULACEA, \\
\hline 656 & Campanula, \\
\hline 608 & Canavalia, \\
\hline $6 \pm 4$ & CAPPARIDACEA, \\
\hline 654 & Cardamine, \\
\hline 654 & Carex, \\
\hline $\begin{array}{l}628 \\
620\end{array}$ & $\begin{array}{l}\text { Carica, } \\
\text { CARIOPHYLLACE } A \text {, }\end{array}$ \\
\hline 668 & Casuarina, \\
\hline 6 & CASUARINACEE, \\
\hline & Catesbæa, \\
\hline 627 & Catopsis, \\
\hline $\begin{array}{l}642 \\
633\end{array}$ & CELASTRACEA, \\
\hline 6 & $\begin{array}{l}\text { Cenchrus, } \\
\text { Centrosema, }\end{array}$ \\
\hline 644 & Centunculss, \\
\hline 644 & Ceratopteris, \\
\hline 6 & Cheilanthes, \\
\hline & Chiogenes, \\
\hline $\begin{array}{l}613 \\
603\end{array}$ & $\begin{array}{l}\text { Chrysopliyllum, } \\
\text { Cladium, }\end{array}$ \\
\hline & $\begin{array}{l}\text { Cricus, } \\
\text { Cus, }\end{array}$ \\
\hline & Cocos, \\
\hline 626 & COMAELYNACEA, \\
\hline & $\begin{array}{l}\text { COMI'OSITA, } \\
\text { Condalia, }\end{array}$ \\
\hline 617 & CONIFERA, \\
\hline 16 & Conobeal, \\
\hline & Conoclinium, \\
\hline & $\begin{array}{l}\text { CONVULVULACEA, } \\
\text { Convolvulus, }\end{array}$ \\
\hline & Cordia, \\
\hline
\end{tabular}


Cureopsis,

C'urvilalis,

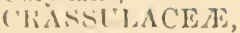

Crutilarin,

("intori,

Clicelflist,

Cryptoposium,

CLCLTRITAC Clisis,

CLI'LlarElid,

Cirscuta,

Cynorlon,

Cynoscialium,

CY'liAClis,

('yperus,

Cypselea,

1): Jea,

J):uthonia,

Dasystomla,

Ditubertonia,

Dendropliylax,

Desurntlius,

Desmodium,

1)racopis,

Ecastaphyllum,

Eclites,

Eleoclaris,

Elephantopus,

Elymus,

jinslenia,

Epidendrum

EUUISLTACEL,

Equisetum,

Eracrostis,

ERICICEA,

Frigenia,

Erigeroli,

Eriocaulon,

ETIOC $\triangle U L O N \triangle C E A$,

Erysimmm,

Erytlırima,

Frytlironium,

Eivenia,

Eupatorium,

EUI'H()IBIACEA,

Einpliorhia,

Evolvulus,

Fedia,

Filago,

FILICES,

Flaveria,

Forestiera,

Fragaria,

Fugosia,

FUIARIACEA,

Funaria

Galactia,

Galium,

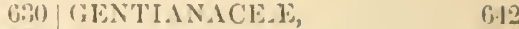

601 (immolulus,

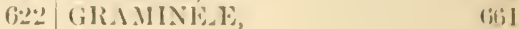

614 Cirinlelia,

6.18 Gigmnocladus, 618

(i5:) Habenaria,

6.2.2 Inploplila,

(iI9) Hedenmu, 637

6.41 lleliantlus,

663 Heliosciarlium, $\quad 623$

623 Helistrupium,

65!) Ilerpestis,

6es!) Heucliera,

607 llibiscus, $\quad 610$

Ilippocratea, $\quad 613$

615 Holcus, 66.5

605 Horlenm, 6 (i)

686 Ilrilrantlıeliam, 635

616 HYI)liOLACEN, 640

653 Hytrolea, fifo

618 HY1)R(OIIYLL,ICF, I, $6: 39$

616 Hydroplı]lu, 63!)

629 Hygroplita. 67:3

IIYJRII'TIRII)LS,

617 Irmenomallis, 654

642 HYPlilCACEA, 607

659 Ilypericum, $\quad 607$

625 I]yltis, $\quad 637$

664

643 Ilex, 630

652 Imperata, 668

669 Indigofer: $\quad 616$

669 Ipomoa, $\quad 640$

664 Isoctes, $67^{\circ}$

633 Ira, 628

6:33

$\begin{array}{ll}627 & \text { Jatroplia, } \\ 658 & 618\end{array}$

658 Juncis, 657

606 Juniperus, $\quad 650$

617 Jussixa, 621

657 Kónteletzkya, $\quad 610$

626

$6+6$ LABIAT2E, 637

646 Lagenaria, 622

611 Leavenworthia, 605

leersia, 661

I.LGLIIINOSA, $\quad 614$

631 LENTIBULACEL, $\quad 635$

6.20 Lespedeza, 616

644 Leuerena, 619

$6: 20$ Liatris, 626

609 Lilium, 657

604 I.INACE.E, 611

604 Lindlueimeria, 628

Linum, 611

617 Lithospermum, 639

624 Lobelia, 631 
LOBELIACEA,

Ludwigia,

Luzula,

LYCOPODI $\triangle \mathrm{CE}$ E,

Lycopodium,

Lisiloma,

LITHRACEA,

Lythrum,

Malachra,

i. $\triangle \mathrm{L} \backslash \mathrm{C}$ CEE,

Malvastrum,

Marsilia,

Medicago,

Melilotus,

Melocliia,

Mentha,

Mercurialis,

Iicrantliemum,

Muhlenbergia,

Myginda,

MYRTACEA,

Nabalus,

Najas

NAIADACEA,

Nasturtium,

NYCTAGINACEA,

Nrmpluae,

NYMPHAACEA,

Enothera,

OL $\backslash$ C $\backslash$ CE.E,

Oldenlandia,

OLEACEA,

ON.IGRACE.E,

Ophioglossum,

ORCHII) ACEA,

Oreodoxa,

Oxybaplius,

Pachystima,

Palafoxia,

P.IL.MLE,

Panicum,

PAP I VERACE.E,

l'arkinsonia,

Taronyclia,

P'aspalum,

P'assiflora,

'ASSIFLORACEA,

Invonia,

Pectis,

Peperomia,

Petalostemon,

Petunia,

Pharus,

Plilox,

Picramnia,

P'inguicula,

Pinus,
681 PIPERACE.E, 645

621 Pisoniat, 644

657 PLANTAGINACEA,

671 Plantago, 634

671 PLUMBAGINACE,E,

619 Poa, 663

620 Polanisia, 606

620 HOLENUNIACE.E, 640

Polygala, 613

609 POLYGALACE.

608 POLYGUNACE,

608 Polygonatun, 656

672 Polygonum, 645

614 Polypodium, 669

614 Polystachya, 658

610 Polytania, 6:3

637 Populus, $\quad 649$

$6 \pm 7$ Portulaca, 607

635 PUR'TULACACEA, 607

662 Potamogeton, 652

612 PRIMULACEA,

6:0 Prunus, 620

P'sidium, $\quad 620$

6.31 Pteris, 66!

65: Pycnanthemum, 637

$65)^{2}$

60.

Quercus, $\quad 649$

644

604 RANUXCUIACEA,

604 Ranunculus, 603

lieimaria, $\quad 665$

621 Regnosia, 612

611 RHAMNACEE, 612

6:5 Rhamnirlium, 612

644 Rhodotendron, 633

621 Rhyncliospora, $\quad 660$

671 Richardsonia, $\quad 624$

65.2 ROS ACE .

650 RUBI C E E,

$6 \pm 4$ Rudbeckia, $\quad 629$

613 Sabal, 651

630 SALICACEE,

650 Silix, 649

666 Salvia, 638

604 S.SPIND.ACE.E,

618 Sapindus, $\quad 613$

607 SAP('l'ACE.E,

6365 Satureia, 6327

621 SAXIFRAGACEA,

621 Schnenolirion, $\quad 656$

608 Scliopfia,

626 Scirpus, $\quad 660$

645 Scolopendrium,

615. SCROPHULARIACE.E,

642 Scutellaria, 6.38

6(iI Sedum, 622

640 Seymeria, 630

(ill Silla, 608

(i:) SIMARLBACEN, 611

6.50 S.IILACE正, 656 
Suilax,

Sil.ANACLA,

fiolanum,

Sulislagno,

Siorglımı,

Nipecularia,

Nipirana,

Sirirantlies,

sipurobolus,

Stachys,

Statice,

Stellaria,

Stellandrium,

Stylisma,

Stylophorum,

Synandra,

Tanitis,

Tamarix,

Tephrosia,

'I'lirinax,

Thurberia,

'TI,I A CEE,

'Tillae:

Tillanclsia,

Tradescantia

Tragia,

Trema,

Trejocarpus,

Trianthema,

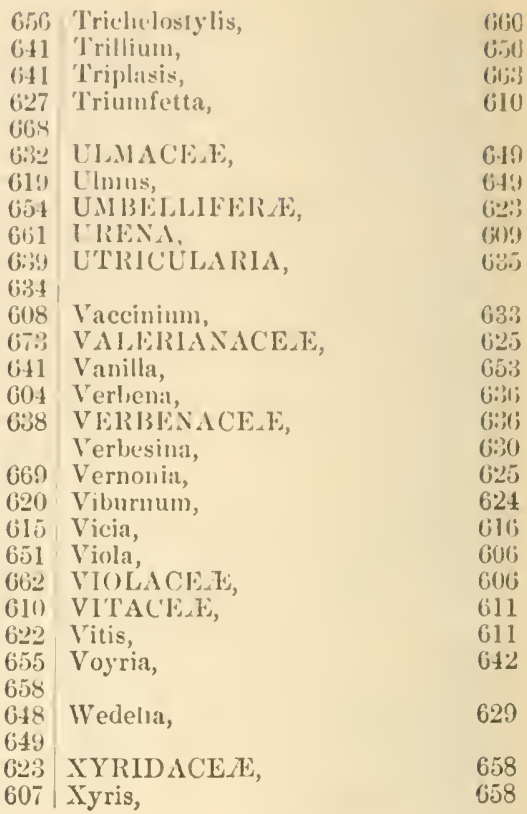

Unicersity Press: John Wilson \& Son, Cambridge. 




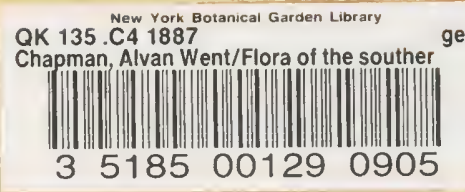


